LINGUA MONTENEGRINA

časopis za jezikoslovna, književna i kulturna pitanja

LINGUA MONTENEGRINA

the magazine of linguistic, literature and cultural issues

God. III, br. 5

Izdavač

INSTITUT ZA CRNOGORSKI JEZIK I JEZIKOSLOVLJE „VOJISLAV P. NIKČEVIĆ“،

\title{
Redakcijski odbor
}

Radoslav Rotković (Herceg Novi)

Josip Silić (Zagreb)

Vukić Pulević (Podgorica)

Milorad Nikčević (Osijek)

Žarko L. Đurović (Cetinje)

Amira Turbić-Hadžagić (Tuzla)

Aleksandra Nikčević-Batrićević (Podgorica)

Przemyslaw Brom (Katowice)

Milica Lukić (Osijek)

Aleksandra Banjević (Podgorica)

Jakov Sabljić (Osijek)

Ljudmila Vasiljeva (Lavov)

Čedomir Drašković (Cetinje)

Aleksandar Radoman (Podgorica)

Glavni i odgovorni urednik

Adnan Čirgić

Sekretar Redakcije

Jelena Šušanj

Cetinje, 2010. 

LINGUA MONTENEGRINA, god. III, br. 5, Cetinje, 2010.

Institut za crnogorski jezik i jezikoslovlje „Vojislav P. Nikčević“

UDK 811.163.4'373.613(497.16)

811.163.4'276(497.16)

Izvorni naučni rad

\section{Jelena ŠUŠANJ (Podgorica)}

Institut za crnogorski jezik i jezikoslovlje „Vojislav P. Nikčević“

\section{DEKOMPONOVANJE LEKSEMA I BIROKRATIZACIJA JEZIKA NA PRIMJERIMA IZ CRNOGORSKIH DNEVNIH NOVINA}

Cilj nam je da u radu izložimo načine dekomponovanja leksema u jeziku, funkciju dekomponovanja i karakteristike upotrebe, te da na primjerima prikažemo dobre i loše strane primjene toga postupka u publicističkome stilu, odnosno da preko njih ukažemo na uticaj administrativnoga stila na publicistički. Premda ćemo se kretati u okviru funkcionalne stilistike, osobenosti stilova pojedinačno, s obzirom na ograničenost obima rada, neće biti predmet analize.

U radu ćemo se prevashodno baviti dekomponovanjem glagola, manje imenica. Kod glagola ćemo nešto više pažnje posvetiti karakteristikama dekomponovanja, što nam kod imenica neće biti cilj, budući da je taj proces znatno jednostavniji. Osnovu rada činiće sintaksičko-semantičke analize i transformacije.

Ključne riječi: dekomponovanje, birokratizacija, publicistički stil, administrativni stil, deverbativna imenica, deadjektivna imenica, kopula, semikopulativni glagol

\section{Uvod}

1.0. Jezik je polifunkcionalna kategorija; karakteristike jezika zavise od sfera njegove upotrebe. Time se bavi funkcionalna stilistika. Nema jedinstvene podjele funkcionalnih stilova, ali se uglavnom prihvata podjela na pet stilova: administrativni, naučni, publicistički (tj. publicističko-novinarski), razgovorni i književnoumjetnički (beletristički). Funkcionalni stilovi mogli bi se razvrstati na apstraktne i konkretne, tj. deskriptivne i pripovjedačke. U apstraktne spadaju administrativni, publicistički i naučni, a u konkretne beletristički i razgovorni. ${ }^{1}$ Razlike među stilovima prvenstveno su sintaksičko-se-

${ }^{1}$ Viđeti: Ivo Pranjković, „Funkcionalni stilovi i sintaksa“, Suvremena lingvistika (elektronički časopis: http://suvlin.ffzg.hr/index.php/suvlin/article/view/106/44), 41/42, 1996, str. 519; Josip Silić, „Administrativni stil hrvatskoga standardnog jezika“, Kolo, 4 , Zagreb, 1996, str. 351. 
Jelena ŠUŠANJ

mantičke i leksičke (naročito u upotrebi termina). Tako je za prvu skupinu, koja je od značaja za ovaj rad, na gramatičkom planu karakterističan nominalni stil, a za drugu verbalni. Ono što je u jednom stilu prihvatljivo, u drugome ne mora biti, ponekad i ne treba.

1.1. Pod birokratizacijom jezika podrazumijeva se proces širenja izraza specifičnih za jezik administracije i politike na ostale segmente upotrebe jezika, prije svega u publicistički stil. Kako kaže I. Klajn, ,[u] štampi, na radiju i na televiziji ustalila se navika da se žargon političara doslovce prenosi - što je za izveštače i urednike najbezbednije, ma kako se protivilo i razumljivosti, i tradicionalnoj sažetosti novinarskog stila, i zdravom jezičkom instinktu“.2 U odlike birokratskog stila bilježe se: preopširnost, komplikovanost, neodređenost i nominalni stil te stereotipnost. Iz toga vidimo da je jedno od obilježja birokratizacije (samim tim i administrativnoga stila, kao njezina izvorišta) nominalizacija, koja se definiše kao upotreba nominalnih sredstava umjesto verbalnih. $^{3}$

1.2. I. Pranjković ukazuje na četiri tipa nominalizacija. To su: kondenzacija, dekompozicija, prepozicionalizacija i intenzifikacija. Nas ovđe zanimaju dekompozicija i intenzifikacija. Dekompozicija je postupak kojim se predikacija rastavlja na glagolski (kopulativni ili semikopulativni) i imenski dio, dok intenzifikacija podrazumijeva proširivanje imenskih konstrukcija novim imenskim riječima pleonastičnog karaktera, $s$ ciljem da se precizira ili istakne sadržaj poruke. ${ }^{4}$

1.3. Da bismo jasnije prikazali te procese, potrudićemo se da za svaki navedeni primjer sa dekomponovanom jezičkom jedinicom u površinskoj strukturi iskaza damo njen denominalizovani ekvivalent. U tu svrhu primjenjivaćemo transformacioni test, odnosno rekonstrukciju dubinske strukture. Rečenice u kojima se javljaju kopulativni i semikopulativni glagoli sa deverbativnom odnosno deadjektivnom imenicom ili prijedloško-padežnom konstrukcijom analiziraćemo s obzirom na njihove semantičko-sintaksičke odlike. Rekonstruisane dubinske rečenične strukture obilježavaćemo na sljedeći način: $[\leftarrow \ldots]$.

1.4. Za korpus smo uzeli dnevne novine koje su u Crnoj Gori izlazile 1-4. jula 2008. godine: Pobjeda, Vijesti, Dan, Republika. Da bismo primjere učinili preglednijima, izdanja smo poređali hronološki i obilježili indeksnim oznakama ${ }^{1},{ }^{2},{ }^{3} \mathrm{i}^{4}$ za svako izdanje, kao što slijedi:

Pobjeda $^{1}=$ Pobjeda, 1. jula 2008; Pobjeda ${ }^{2}=$ Pobjeda, 2. jula 2008 ..;

${ }^{2}$ Pavle Ivić, Ivan Klajn, Mitar Pešikan, Branislav Brborić, Srpski jezički priručnik, Beogradska knjiga, Beograd, 2006, str. 185.

${ }^{3}$ Milorad Radovanović, Stari i novi spisi (Ogledi o jeziku i umu), Izdavačka knjižarnica Zorana Stojanovića, Sremski Karlovci - Novi Sad, 2007, 78.

${ }^{4}$ Ivo Pranjković, op. cit., 520-521. 
Dekomponovanje leksema i birokratizacija jezika...

Vijesti $^{3}=$ Vijesti, 3. jula 2008; Vijesti ${ }^{1}=$ Vijesti, 1. jula 2008...;

Dan $^{4}=$ Dan, 4. jula 2008; $\operatorname{Dan}^{3}=$ Dan, 3. jula 2008...;

Republika $^{2}=$ Republika, 2. jula 2008; Republika ${ }^{4}=$ Republika, 4. jula 2008.

1.5. U radu se koriste međunarodni simboli za obilježavanje vrsta riječi, sintaksičkih jedinica i odnosa:
$\mathrm{N} \quad=$ imenica
$\mathrm{N}_{\text {Dev }}=$ deverbativna imenica
$\mathrm{N}_{\text {Deadj }}=$ deadjektivna imenica
Cop = glagolska kopula
Lex = leksema
Nom = nominativ
Gen = genitiv
Dat $=$ dativ
Acc = akuzativ
Loc = lokativ
$[\leftarrow \ldots]=$ rekonstruisana semantička baza na dubinskom nivou

\section{Dekompozicija glagola}

2.0. Pojam dekomponovanja glagolskih leksema u srpskohrvatskom jeziku prvi je opisao i protumačio Milorad Radovanović u doktorskoj disertaciji Imenica u funkciji kondenzatora, 1977. godine. ${ }^{5}$ On je tada taj postupak nazvao dekomponovanjem predikata, no smatramo da je dekomponovanje glagola, kako je sugerisao Sreto Tanasić, ${ }^{6}$ nešto precizniji termin, jer se dekomponuju i glagolske lekseme koje nijesu u funkciji predikata, poput glagolskih priloga sadašnjega i prošloga:

Bulatović je bez povoda napao Rackovića, dva puta ga udario pesnicom u glavu, nanoseći mu teške povrede. $[\leftarrow$...teško ga povređujući] (Republika ${ }^{3}, 11$ ); I moji kolege bili su ugrožene pružajući mi pomoć jer je prijetila opasnost od daljeg obrušavanja. [ moje kolege bile su ugrožene pomažući mi...] (Republika $\left.{ }^{4}, 10\right)$; Moneta će nastaviti sa unapređenjem svojega poslovanja i usluga, dajući kroz njih kao i do sada doprinos razvoju tržišta kapitala. [ $\leftarrow$ Moneta će nastaviti sa unapređenjem svojega poslovanja i usluga, doprinoseći kroz njih kao i do sada razvoju tržišta kapitala] (Vijesti $\left.{ }^{3}, 17\right)$; Vlada RS se dajući garancije obavezala da će ispošto-

${ }^{5}$ Viđeti: Milorad Radovanović, „Imenica u funkciji kondenzatora“, Zbornik za filologiju i lingvistiku, XX/1-2, Matica srpska, Novi Sad, 1977.

${ }^{6}$ Navedeno prema: M. Radovanović, op. cit., str. 148, fusnota 4. 
vati sve naloge Pretresnog vijeća haškog tribunala... [ $\leftarrow$ Vlada RS se garantujući obavezala...] ( $\left.\operatorname{Dan}^{4}, 4\right)$.

Džez avantura je potom odvela i do Japana, Indonezije te Dalekog istoka, dostigavši kulminaciju njenim dvanaestogodišnjim boravkom u Evropi. $\left[\leftarrow\right.$...kulminiravši ${ }^{7}$ njenim dvanaestogodišnjim boravkom u Evropi] (Vijesti², 16); Nalog za ovo ekspresno rušenje krsta dao je lično i javno Gzim Hajdinaga, predsjednik opštine, učinivši zajedno sa svojim saučesnicima brojne povrede u svom histerično brzopletom postupku... $[\leftarrow$...povrijedivši sa saučesnicima brojne (zakone) u svom histerično brzopletom postupku] (Dan $\left.{ }^{1}, 8\right)$.

Dekomponovanje je derivacioni postupak koji ima dvije faze. Prvo se nominalizuje predikacija, a potom se iz nominalizovane predikacije izdvaja verbalni elemenat (pretiče $\rightarrow$ preticanje $\rightarrow$ vrši preticanje). ${ }^{8}$ Tu pojavu odlikuje dvočlani izraz u površinskoj strukturi, koji čine glagol nepotpunoga značenja (kopulativni ili semikopulativni), što nosi gramatička obilježja vremena, vida i modalnosti, i deverbativna imenica, kao nosilac značenja, umjesto glagola. Uz nepunoznačni glagol, kao rezultat dekomponovanja, može se javiti i deadjektivna imenica, ali jedino kad je u semantičkoj vezi s odgovarajućim glagolom, poput: mogućnost ( $\leftrightarrow$ moći), vrijednost ( $\leftrightarrow$ vrijeđeti), saglasnost ( $\leftrightarrow$ saglasiti se), zapanjenost ( $\leftrightarrow$ zapanjiti se), savršenstvo ( $\leftrightarrow$ usavršavati), hrabrost ( $\leftrightarrow$ hrabriti). ${ }^{9}$

2.1. Milorad Radovanović navodi da se dekomponuju glagoli izrazito apstraktnoga značenja: procjenjujem $\rightarrow$ vršim procjenu, analiziram $\rightarrow$ vršim analizu, ali ne i: kopam $\rightarrow *_{\text {vršim kopanje. }}^{10}$

2.1.1. Ipak, u pregledanom korpusu primijetili smo da je distinkcija konkretno : apstraktno pomjerena. Naime, zabilježili smo nekoliko primjera u kojima se po istovjetnoj shemi dekomponuju glagoli veoma konkretnoga značenja. Kod tih se glagola može govoriti o dvama stepenima dekomponovanja. Prvo se punoznačni glagol nominalizuje uz ekstrakciju verbalnog dijela u vidu glagola raditi, tako da dobijamo sintagmu nepunoznačni glagol raditi + glagolska imenica (često u prijedloško-padežnom izrazu - raditi + $\left.n a+N_{\operatorname{Dev}(\operatorname{Loc})}\right)$ :

\footnotetext{
${ }^{7} \mathrm{Na}$ ovom stupnju analize nije nam cilj vrednovati upotrebu dekomponovanoga ili jednočlanoga glagolskog oblika. Želja nam je, zasad, rekonstruisati (mogući) glagolski oblik u dubinskoj strukturi i ukazati na njega. O valjanosti upotrebe jedne ili druge forme (i stilskoj i inoj) govoriće se u nastavku rada.

${ }^{8}$ M. Radovanović, op. cit., str. 58.

${ }^{9}$ Nataša Bugarski, „Deadjektivna imenica kao sredstvo nominalizacije (u publicističkom stilu standardnog srpskog jezika)“, Zbornik Matice srpske za filologiju i lingvistiku, XLVII/1-2, Novi Sad, 2004, str. 343.

${ }^{10}$ M. Radovanović, op. cit., str. 57.
} 
Dekomponovanje leksema i birokratizacija jezika...

Sredinom ovog mjeseca najavili su dolazak investitori iz Slovačke koji su spremni da izgradnju puta urade u okviru donacije... [ $\leftarrow$ da put izgrade u okviru donacije] $\left(\mathrm{Dan}^{4}, 15\right)$; Mogu se graditi od kamena, betona, cigle, drva, plastičnih ili aluminijskih profila, gredica koje imaju vrlo dobru imitaciju drva ili se, pak, rade kombinacije jednoga s drugim ili više materijala. [ $\leftarrow$ ili se, pak, kombinuje...] (Pobjeda ${ }^{2}$, XII); Dio žitelja Glavice (...) dohvatili su se krampa i lopate i rade na asfaltiranju jedne trase puta u njihovom naselju. $\left[\leftarrow\right.$ asfaltiraju jednu trasu puta] ( $\left.\operatorname{Dan}^{2}, 17\right)$; Radnici Elektrodistribucije Podgorica radiće na podizanju dva stuba na pružnom prelazu... [ $\leftarrow$ podići će dva stuba...] (Republika $\left.{ }^{4}, 19\right)$; ...naveo je Radović, dodajući da treba intenzivno i koordinirano raditi na naplati svih državnih prihoda od turističke privrede... [ $\leftarrow$ treba intenzivno i koordinirano naplaćivati sve državne prihode od turističke privrede / turizma...] (Vijesti², 21).

$\mathrm{Na}$ narednom nivou nominalizuje se i sam glagol raditi, a konstrukcija se proširuje novim glagolom, izrazito nekonkretizovanoga značenja: vršiti / obavljati / izvoditi... radove na пес̌ети:

...na kojoj su stručnjaci Regionalnog zavoda za zaštitu spomenika kulture iz Kotora vršili radove na njenoj rekonstrukciji i valorizaciji. [ $\leftarrow$ radili na rekonstrukciji i valorizaciji $\leftarrow$ rekonstruisali i valorizovali...] (Dan $\left.{ }^{1}, 13\right)$; Prema riječima šefa gradilišta iz preduzeća Putevi Sabahudina Kozice, radovi se izvode na izgradnji puta, gdje je inače bilo zaposleno 30 radnika. [ $\leftarrow$ radi se na izgradnji puta $\leftarrow$ gradi se put] $\left(\right.$ Dan $\left.^{4}, 8\right)$.

Zanimljiv je i primjer:

Direktorka CNB Jelena Đurović podsjetila je da je donacija Norveške od preko 400.000 eura omogućila da se urade najznačajniji radovi na restauraciji zgrade biblioteke i zaštite njeni bogati fondovi... [ $\leftarrow$ da se uradi najznačajnije na restauraciji... $\leftarrow$ da se restaurira najznačajnije...] ( $\left.\operatorname{Dan}^{3}, \mathrm{XVI}\right)$,

u kojem glagol raditi nalazimo u vezi s istoznačnom imenicom rad, čime dobijamo tautološku konstrukciju, koja u datom kontekstu nije stilski obilježena, tj. nema za cilj stilski efekat - đe bi navedena sintagma bila opravdana, već prije svega ukazuje na nemar novinara (i lektora), ali i na to da značenje toga glagola postaje sve manje konkretno.

2.1.2. Vratimo se dekomponovanju kao sintaksičkom postupku. Kad se kao glagolski dio dekomponovanoga glagola nađe kopula (glagol biti u finitnom obliku), leksičko jezgro izraza čini deverbativna ili deadjektivna imenica u različitim prijedloško-padežnim konstrukcijama. Navešćemo ih redom, 
pri čemu se u ovom dijelu rada nećemo zadržavati na odlikama njihove upotrebe, no jedino na derivacionim mogućnostima.

\section{Cop $+\mathbf{N}_{\operatorname{Dev}(\mathrm{Nom})}$}

U funkciji dekomponovanoga predikata đe se u površinskoj strukturi nalazi glagol biti u ličnom obliku i imenica derivirana iz punoznačne riječi, u navedenom korpusu našli smo samo primjere upotrebe deverbativnih imenica, u službi imenskoga dijela predikata:

Očekivanja su da će time u $\mathrm{BiH}$ početi stizati jeftiniji proizvodi široke potrošnje iz zemalja Evropske unije [ $\leftarrow$ Očekuje se da će...] $\left(\operatorname{Dan}^{1}, 4\right) ;$...a ova bivša jugoslovenska republika je već dugo vremena uvoznik hrane $[\leftarrow$ a ova bivša jugoslovenska republika već dugo uvozi hranu] $\left(\operatorname{Dan}^{3}, 4\right)$; Dobitnici diplome Luča su... [ $\leftarrow$ Diplomu Luča dobili su...] (Pobjeda $\left.{ }^{1}, 9\right)$; Procjene su da Herceg-Novi u svim vrstama smještaja ima oko 30000 ležajeva... [ $\leftarrow$ Procjenjuje se da Herceg Novi...] (Pobjeda $\left.{ }^{3}, 16\right)$; Namjera osiguravajuće kuće Delta lajf, kao predstavnika srbijanskog Delta holdinga, je da postane regionalni lider u toj oblasti. [ $\leftarrow$ Osiguravajuća kuća Delta lajf... namjerava da postane regionalni lider u toj oblasti] (Vijesti $\left.{ }^{3}, 19\right)$.

\section{$\mathbf{N}_{\text {Dev/Deadj(Nom) }}+$ Cop + Lex}

M. Radovanović ${ }^{11}$ ističe konstrukcije toga tipa kao sasvim specifičan oblik dekomponovanoga predikata. Konstituent Lex po pravilu je neki kvantifikator ili kvalifikator i sa kopulom čini složeni predikat, pri čemu nominalizovana predikacija izražena deverbativnom (ili deadjektivnom) imenicom ima funkciju rečeničnoga subjekta, a ne imenskog dijela predikata:

Procentualno povećanje broja gostiju u 2007. godini u odnosu na 2000. je 74,8 odsto. [ $\leftarrow$ Broj gostiju procentualno se povećao...] (Republika $\left.^{3}, 19\right)$; Međutim, kako smatraju u Ministarstvu, kroz ostala uvećanja - dežurstvo, prekovremeni i noćni rad, primanja će biti znatno veća. $\left[\leftarrow\right.$...primaće znatno više] $\left(\right.$ Republika $\left.^{4}, 7\right)$; Njegova primjena je jednostavna $\left[\leftarrow\right.$ Primjenjuje se jednostavno] (Pobjeda $\left.{ }^{1}, 19\right)$; Očekivanja regiona su ogromna... [ $\leftarrow$ Region očekuje veoma mnogo...] (Pobjeda $\left.{ }^{1}, 13\right)$; Prijavljivanje studenata biće 7. jula... [ $\leftarrow$ Studenti će se prijavljivati 7. jula...] (Pobjeda $\left.{ }^{3}, 3\right)$; Bežična povezivost je nemoguća, s obzirom na nedostatak kako Bluetootha, tako i infracrvenog porta. [ $\leftarrow$ Nemoguće je bežično se povezati...] (Vijesti², 35).

${ }^{11}$ Milorad Radovanović, Spisi iz sintakse i semantike, Izdavačka knjižarnica Zorana Stojanovića, Sremski Karlovci - Novi Sad, 1990, str. 59. 
Dekomponovanje leksema i birokratizacija jezika...

Navodno, dva do tri miliona eura koštaće uklanjanje betonskog džina, ali je vrijednost gradskog građevinskog zemljišta na tom kvartu, od 10.000 kvadrata, oko osam miliona. $[\leftarrow$...ali gradsko građevinsko zemljište na tom kvartu vrijedi...] (Vijesti $\left.{ }^{3}, 5\right)$; Vrijednost radova je 1.200.000 eura... [ $\leftarrow$ Radovi vrijede...] (Dan $\left.{ }^{4}, \mathrm{XV}\right)$.

\section{Cop $+\mathbf{N}_{\text {Dev/Deadj(Gen) }}$}

Deverbativna ili deadjektivna imenica u genitivu u takvoj konstrukciji u funkciji predikata javlja se u slobodnoj upotrebi ili s prijedlogom od:

Opozicioni odbornici mišljenja su da je informacija neozbiljna...

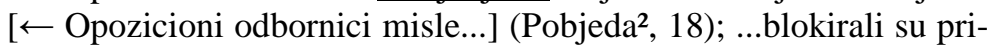
laz i ulaz na deponiju tako da danas nije bilo odlaganja ogromnih količina otpada. $[\leftarrow$ tako da danas nijesu odlagane ogromne količine otpada...] (Pobjeda ${ }^{2}$, 9); Bilo je dosta polemike oko zemljišta. [ $\leftarrow$ Dosta se polemisalo...] ( Dan $\left.^{2}, \mathrm{XII}\right)$; Dosad su podaci čuvani u fiskalnoj memoriji i pošto u praksi nije bilo nikakvih zloupotreba, uvođenje terminala je bespotrebno. $[\leftarrow \ldots$... pošto se u praksi ništa nije zloupotrebljavalo...] (Dan $\left.{ }^{3}, 6\right)$; Predsjednik Upravnog odbora KK Crvena zvezda Mirko Petrović rekao je da je prvi sastanak radne grupe protekao bez konkretnih zaključaka, ali da će rješenja biti u roku od desetak dana. $[\leftarrow$...ali će se (to) riješiti u roku od desetak dana] (Dan 4 , VI); Bilo je oscilacija u igri, što je i normalno u ovom periodu priprema... [ $\leftarrow$ Osciliralo se u igri...] (Republika $\left.{ }^{4}, 28\right)$.

Na našem razvojnom putu od izuzetnog je značaja prepoznavanje pozitivnih stremljenja naučnih postignuća i njihove primjene... [ $\leftarrow$ Na našem putu izuzetno je značajno prepoznavanje...] ( $\left.\operatorname{Dan}^{3}, 13\right)$.

\section{Cop $+\mathbf{N}_{\text {Dev/Deadj(Loc) }}$}

U korpusu koji smo odabrali brojni su primjeri upotrebe lokativne konstrukcije deadjektivne ili deverbativne imenice s prijedlogom $u$ i na uz kopulu (glagol biti u finitnom obliku), đe se u dubinskoj strukturi rekonstruiše punoznačni glagol. Primjetno je da su mnogi takvi slučajevi, preuzeti iz administrativnoga stila, postali frazeologizmi novinarskoga stila.

Suhih je, vidno izrevoltiran, istakao da je u saznanju da ta tačka nije procesuirana i nije proslijeđena odbornicima... $[\leftarrow$ Suhih je, vidno izrevoltiran, istakao da je saznao da...] (Pobjeda $\left.{ }^{3}, 19\right) ;$...kazao je Mugoša, dodajući da je u planu i nastavak radova na vodosnabdijevaju u Tuzima i Zeti... [ $\leftarrow$...dodajući da se planira i nastavak radova na vodosnabdijevanju / nastavak vodosnabdijevanja...] (Vijesti², 25); Osjećaj nečijeg zadovoljstva platom u velikoj je zavisnosti od toga koliko njegove kolege zarađuju. [ $\leftarrow$ Ośećaj nečijeg 
Jelena ŠUŠANJ

zadovoljstva / Nečije zadovoljstvo platom uveliko zavisi od toga...] (Vijesti ${ }^{2}$, III); Kad platim prevoz i ovaj prostor, ja sam u gubitku. $\left[\leftarrow \ldots\right.$ ja gubim] $\left(\operatorname{Dan}^{1}, 16\right)$; Gradonačelnik je juče najavio da je u pripremi novi tender za izgradnju Milenijum siti centra. [ $\leftarrow$ Gradonačelnik je juče najavio da se priprema novi tender...] (Dan ${ }^{2}$, XII); ...a povjerenje u ovu državnu valutu je u porastu u području bankarskog sektora. [ $\leftarrow$ a povjerenje u ovu državnu valutu raste...] $\left(\operatorname{Dan}^{3}, 4\right)$; Perović je istakao da je Institut u obavezi da put tranzicije skrati što je moguće više... [ $\leftarrow$ Perović je istakao da se Institut obavezao da...] (Republika $\left.{ }^{3}, 6\right)$; Ipak, ne smijemo dozvoliti da nas zavara to što smo bili i bolji u igri protiv jedne takve ekipe kao što je Mađarska... [ $\leftarrow$ Ipak, ne smijemo dozvoliti da nas zavara to što smo igrali bolje protiv...] (Republika $\left.{ }^{4}, 31\right)$.

Ukoliko zagađivač nije u mogućnosti da bez odlaganja hitno sprovede sve mjere za sprečavanje i ograničavanje nastanka štete $u$ životnoj sredini... [ $\leftarrow$ Ukoliko zagađivač ne može da bez odlaganja sprovede...] (Vijesti $\left.{ }^{3}, 8\right)$; Kao ministar prosvjete gledaću da budem pri ruci tim ljudima, da im pomognem, koliko država bude u mogućnosti. [ $\leftarrow$...koliko država bude mogla] $\left(\operatorname{Dan}^{2}, 5\right)$; TVCG je ranije saopštila da, iz finansijskih razloga, nije u mogućnosti da prenosi sva zasjedanja, već samo ona od posebnog značaja. [ $\leftarrow$ TVCG je ranije saopštila da, iz finansijskih razloga, ne može da prenosi sva zasijedanja...] (Republika $\left.{ }^{3}, 3\right)$.

U cilju prevencije protiv požara tokom ljeta, Ministarstvu unutrašnjih poslova će, pored helikoptera i dva dromadera, na raspolaganju biti još pet aviona aero-klubova za izviđanje prostora. [ $\leftarrow$ ...Ministarstvo unutrašnjih poslova će, pored helikoptera i dva dromadera, raspolagati i sa još pet aviona...] ( $\left.\operatorname{Dan}^{3}, 18\right)$.

2.1.3. U površinskoj strukturi na isti način može stajati i semikopulativni glagol i deverbativna ili deadjektivna imenica. Semikopulativni glagoli nijesu konkretizovani i uza se imaju imenicu deriviranu iz nekoga punoznačnog glagola ili pridjeva, koja je nosilac značenja u sintagmi. Deadjektivne imenice uz glagole ovoga tipa znatno su rjeđe od imenica deriviranih iz glagola. Stoga ćemo u ovom odjeljku uglavnom navoditi primjere deverbativnih imenica u dekomponovanom glagolu, bez napomene o njihovoj derivaciji. Ako smo pronašli primjer sa deadjektivnom imenicom kao dopunom, navodimo ga zasebno, ali bez dodatnih pojašnjenja.

Najčešći semikopulativni glagoli u dekomponovanoj glagolskoj leksemi jesu: vršiti, voditi, obavljati, imati/nemati, dati, raditi... Za svaki od njih navodimo primjere. 
Dekomponovanje leksema i birokratizacija jezika...

\section{Vršiti}

Glagol vršiti i njegov vidski par izvršiti traži dopunu u akuzativu, izuzev kad je u pasivnom obliku, đe imenica o kojoj govorimo uzima funkciju gramatičkog subjekta i shodno tome stoji u nominativu.

Shodno dozvoli za arheološka istraživanja, izdatoj od strane Republičkog zavoda za zaštitu spomenika kulture Cetinje, nadzor nad istraživanjima vrši Dejan Gazivoda, arheolog te ustanove. [ $\leftarrow$ ...istraživanja nadzire Dejan Gazivoda...] $\left(\right.$ Pobjeda $\left.^{2}, 12\right)$; Vujović smatra da je dobro što se rasprava o reformi izbornog sistema otvorila i što sve više subjekata smatra da je potrebno izvršiti korekciju u postojećem izbornom sistemu. [ $\leftarrow$...da je potrebno korigovati postojeći izborni sistem] (Republika², 4); Pojedini dosadašnji članovi uprave smatraju da je Vlada, odnosno njeno Ministarstvo za ekonomski razvoj, vršilo opstrukciju realizacije ključnih projekata da bi pokazali da ne valjaju... [ $\leftarrow$...Ministarstvo za ekonomski razvoj, opstruiralo realizaciju ključnih projekata...] (Vijesti $\left.{ }^{1}, 6\right)$; Sporni član važećeg Zakona o krivičnom postupku (...) predviđa i ovlašćenje policije da takođe bez kontrole oduzme kompjuter i izvrši pregled njegovog sadržaja. [ $\leftarrow$ da bez kontrole oduzme kompjuter i pregleda njegov sadržaj] (Vijesti $\left.{ }^{3}, 5\right)$; Autobusi preduzeća „Olimpija ekspres“ iz Budve već deset mjeseci uspješno vrše prevoz putnika na području opštine Bar. [ $\leftarrow$...uspješno prevoze putnike...] $\left(\operatorname{Dan}^{3}, 18\right)$.

Ona je podsjetila na izjavu predsjednika Francuske Nikolasa Sarkozija koji je „odlučno saopštio da neće biti daljeg proširivanja“ dok se ne izvrši potpuna ratifikacija Lisabonskog sporazuma. [ $\leftarrow$ ...dok se potpuno ne ratifikuje Lisabonski sporazum] (Pobjeda ${ }^{1}, 3$ ); Dostava listinga se vrši na zahtjev suda, kada se protiv korisnika vodi krivični postupak, u cilju istrage. [ $\leftarrow$ Listinzi se dostavljaju na zahtjev suda...] (Vijesti², 9); Samo možemo da nagađamo kako su mine tu dospjele, jer do unazad dvije godine na tom dijelu korita rijeke Gračanice vršena je eksploatacija pijeska i niko nije primijetio bilo kakve eksplozivne naprave. $[\leftarrow \ldots$ na tom dijelu korita rijeke Gračanice eksploatisan je pijesak...] ( $\left.\operatorname{Dan}^{3}, 11\right)$.

\section{Raditi}

Već smo govorili o glagolu raditi u vezi s dekomponovanjem punoznačnih glagola kojima se označavaju apstraktne ili konkretne radnje. Ovđe se, uz napomenu da taj glagol unosi značenje procesualnosti i dugotrajnosti vršenja imenicom označene radnje, osvrćemo na njega kao na produktivan glagol u sintaksičkom postupku dekomponovanja.

Glagolska rekcija mijenja se s promjenom glagolskoga vida. Ako je glagol nesvršen, uz njega se najčešće nalazi imenica u lokativu s prijedlogom 
$n a$, mada se javlja i dopuna u akuzativu. Uz glagole te osnove svršenoga vida (uraditi, izraditi, odraditi...) stoji imenica u akuzativu, odnosno u nominativu ako je rečenica pasivna:

Radiće na kontroli ostavljanja smeća i otpada i upozoravati nesavjesne da ne ugrožavaju i zagađuju životnu sredinu. [ $\leftarrow$ Kontrolisaće ostavljanje smeća...] (Dan $\left.{ }^{1}, 17\right)$; Ministarstvo ekonomije već duže vremena radi na osmišljavanju, pripremi, realizaciji i praćenju brojnih aktivnosti na unapređenju energetske efikasnosti u Crnoj Gori. [ $\leftarrow$ osmišljava, priprema, realizuje i prati brojne aktivnosti....] $\left(\operatorname{Dan}^{3}, 8\right)$.

Mogu se graditi od kamena, betona, cigle, drva, plastičnih ili aluminijskih profila, gredica koje imaju vlo dobru imitaciju drva ili $\underline{\text { se, }}$ pak, rade kombinacije jednoga s drugim ili više materijala. [ $\leftarrow$ ili se, pak, kombinuje...] (Pobjeda², XII); Profesor Pravnog fakulteta Miomir Dragačević, koji je radio transformaciju kompanije, u prvoj fazi nova društva će preuzeti sve obaveze i dio imovine dosadašnje Željeznice. [ $\leftarrow$...koji je transformisao kompaniju...] $\left(\operatorname{Dan}^{3}, 7\right)$.

Uradićemo pripremu projektne dokumentacije za novi most u zoni Kombinata aluminijuma... [ $\leftarrow$ Pripremićemo projektnu dokumentaciju / projekat...] (Republika², 21); Bivša direktorka Doma zdravlja Bar Ana Kalamperović kazala je „Danu“ da je raspodjela stanova urađena zakonito... [ $\leftarrow$ da su stanovi zakonito raspodijeljeni] $\left(\mathrm{Dan}^{3}\right.$, 12); Odradili smo dobre pripreme, učestvovali na svim prestižnim takmičenjima. [ $\leftarrow$ Dobro smo se pripremili] (Vijesti $\left.{ }^{3}, 29\right)$.

\section{Činiti / Ostvariti / Praviti}

Navedeni glagoli upotrebljavaju se kao sintaksički i semantički sinonimi. Veoma su frekventni u građenju dekomponovanih glagola. Tranzitivni su (i oni i njihovi vidski parovi) i traže dopunu u akuzativu bez prijedloga:

Na marginama okruglog stola, u razgovoru za „Dan“, Plaks je ocijenila da je u odnosu na prošlu deceniju učinjen značajan napredak. $[\leftarrow$...Plaks je ocijenila da se u odnosu na prošlu deceniju značajno napredovalo] $\left(\operatorname{Dan}^{1}, 3\right)$; Treba se upitati zašto nas baš ono čini tako uznemirenima i kada taj razlog osvijestimo lakše će se biti s njim suočiti. [ $\leftarrow$ Treba se upitati zašto nas baš ono tako uznemirava...] (Republika $\left.{ }^{1}, 23\right)$.

HLT je u prošloj godini ostvario 50,2 miliona eura dobiti, od kojih je 27 miliona eura raspoređeno na pokrivanje gubitka iz prethodnih godina... [ $\leftarrow$ HLT je u prošloj godini dobio 50,2 miliona eura...] (Pobjeda $\left.{ }^{1}, 5\right)$; Crnogorski studenti su svoje školovanje ostvarili posredstvom Univerziteta „Mediteran“... [ $\leftarrow$ Crnogorski 
Dekomponovanje leksema i birokratizacija jezika...

studenti školovali su se posredstvom Univerziteta „Mediteran“] (Pobjeda ${ }^{1}$, III); On smatra da je naša država ostvarila izuzetan napredak na putu integracija... [ $\leftarrow$ On smatra da je naša država izuzetno napredovala na putu integracija / u integracijama] (Republika ${ }^{1}$, 6); Uprava Elektroprivrede odbila je optužbe Regulatorne agencije za energetiku (RAE) da su propustili da ostvare dobitak od deset do 14 miliona eura... [ $\leftarrow$...da su propustili da dobiju deset do 14 miliona eura] (Vijesti $\left.{ }^{3}, 14\right)$; Tu taktiku uvijek koriste i pokazala im se uspješna pošto su prošle sezone ostvarili 23 pobjede... [ $\leftarrow$...pošto su prošle sezone pobijedili 23 puta] $\left(V_{i j e s t i}^{3}, 30\right)$.

Izbor najboljih banaka napravljen je na osnovu poslovnih rezultata, glasanja, ocjena novinara i dopisnika Juromanija. [ $\leftarrow$ Najbolje banke izabrane su na osnovu...] (Republika $\left.{ }^{3}, 5\right)$; On smatra da je u pitanju nečija avantura, organizovana da se napravi opstrukcija. [ organizovana da se opstruira (nešto)...] (Republika $\left.{ }^{4}, 19\right)$.

\section{Obaviti}

Vidski par obaviti / obavljati traži dopunu u akuzativu. Izrazito je produktivan u procesu dekomponovanja glagola, naročito kad je rečenica pasivna (đe deverbativna imenica u nominativu ima funkciju subjekta):

Testiranja kandidata obavlja tim stručnjaka, što je opet stvar dogovora sa klijentom. [ $\leftarrow$ Kandidate testira tim stručnjaka...] (Vije-

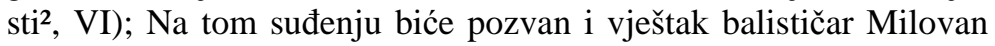
Mihailović koji će obaviti upoređivanje projektila čaura. [ $\leftarrow \mathrm{Na}$ to suđenje biće pozvan i vještak balističar Milovan Mihailović, koji će uporediti projektile čaura] (Pobjeda $\left.{ }^{1}, 8\right)$; Upozoravamo sve građane da će naše ekipe svakodnevno obavljati kontrolu. $[\leftarrow$ da će naše ekipe svakodnevno kontrolisati (to)] (Pobjeda², 9); Zidanje crkve su obavili domaći majstori iz ovog kraja... [ $\leftarrow$ Crkvu su zidali domaći majstori...] (Pobjeda $\left.{ }^{3}, 10\right)$; Što je ranije moguće, klub planira da obavi razgovore sa Bartonom i njegovim zastupnicima... $[\leftarrow$...klub planira da razgovara sa Bartonom i njegovim zastupnicima...] (Pobjeda/Arena ${ }^{2}, 6$ ); Ocijenjeno je da je Tivat opština koja je odlično obavila pripreme za sezonu. [ $\leftarrow$ Ocijenjeno je da je Tivat opština koja se odlično pripremila za sezonu...] (Republika², 7).

Zato je besmisleno da se upravljanje tim znanjem obavlja stihijski. [ $\leftarrow$...da se tim znanjem upravlja stihijski] (Vijesti ${ }^{2}$, VI); Da bi se mogao obavljati prevoz, po evropskim standardima, autobusi moraju biti stari nekoliko godina... [ $\leftarrow$ Da bi se moglo prevoziti] (Dan ${ }^{1}$, XIII); Poreski obveznici će morati da donesu kasu u servis u Podgorici ili nekom drugom gradu kako bi bila obavljena popravka. [ $\leftarrow$ ...kako bi bila popravljena] $\left(\operatorname{Dan}^{3}, 6\right)$; On ističe da je, nakon što su 
Jelena ŠUŠANJ

nadležni dozvolili vlasnicima privremenih objekata da rade i ovog ljeta, dogovoreno da uklanjanje tih objekata bude obavljeno od 15 . septembra do 15. oktobra... [ $\leftarrow$...da ti objekti budu uklonjeni] (Dan ${ }^{3}$, 18); Pavićević je bio kategoričan da Štrajkački odbor neće dozvoliti ni da se raspodjela stanova obavlja mimo njih. $[\leftarrow$...da se stanovi raspodjeljuju mimo njih] (Republika $\left.{ }^{3}, 9\right)$; Sahrana Ljubomira Tomića obaviće se danas u 16 časova na Starom groblju u Nikšiću. [ $\leftarrow$ Ljubomir Tomić biće sahranjen danas...] (Republika $\left.{ }^{4}, 28\right)$; Na dijelu Ulice 4. jula, koji se rekonstruiše od raskrsnice sa Ulicom Vojislavljevića do Bulevara 40, oko 280 metara, radi se atmosferska kanalizacija i obavljaju pripreme za postavljanje ivičnjaka. $[\leftarrow$...i priprema se postavljanje ivičnjaka] (Pobjeda $\left.{ }^{1}, 16\right)$; Svi građevinski radovi na raskrsnici kod „Radoja Dakića“ završeni su juče, a obavljeno je i postavljanje horizontalne i vertikalne signalizacije... $[\leftarrow$...a postavljena je $\mathrm{i}$ horizontalna i vertikalna signalizacija] $\left(\right.$ Pobjeda $\left.^{3}, 18\right)$.

\section{Voditi}

Ovđe ćemo navesti primjere i za glagole derivirane iz glagola voditi: izvoditi, provoditi, sprovoditi. Uza sve njih, ako nijesu pasivni, deverbativna imenica kao nosilac značenja dekomponovanog glagola stoji u akuzativu bez prijedloga:

Poljski parlament je ratifikovao Lisabonski ugovor, poljski predsjednik sam je vodio pregovore o njemu... $[\leftarrow$...poljski predśednik sam je pregovarao o njemu] (Republika $\left.{ }^{3}, 13\right)$; On je podsjetio da se radi o rezoluciji koju je predložio PZP i kojom se zahtijeva od nadležnih organa da provedu efikasnu i djelotvornu istragu u cilju otkrivanja kako neposrednih izvršilaca tako i nalogodavaca sve učestalijih napada na poslenike javne riječi. $[\leftarrow$...kojom se zahtijeva da nadležni organi efikasno i djelotvorno istraže (to)...] (Republika $^{4}, 3$ ); Odbornici će polemiku voditi i o Predlogu odluke o završnom računu GO za prethodnu godinu. [ $\leftarrow$ Odbornici se polemisati i o Prijedlogu odluke...] (Vijesti $\left.{ }^{1}, 25\right)$; ...najavljujući teške dane Jelisejskoj palati u trenutku kada Pariz preuzima šestomjesečno predsjedavanje Unijom s ambicijama da sprovede reformu evropskih institucija u skladu sa tim sporazumom. [ $\leftarrow$...s ambicijama da reformiše evropske institucije...] (Pobjeda $\left.{ }^{3}, 12\right)$.

Obilježavanje se provodi saglasno planu Martija Ahtisarija prema kojem se demarkacija izvodi prema dogovoru o državnoj granici koji je Makedonija 2001. godine potpisala s vlastima tadašnje SR Jugoslavije. [ $\leftarrow$ Obilježava se saglasno planu Martija Ahtisarija prema kojem se demarkira (granica) prema dogovoru...] (Republi$\left.\mathrm{ka}^{1}, 12\right)$; Zato se o svakom članu konstantno vodi posebna briga... 
Dekomponovanje leksema i birokratizacija jezika...

[ $\leftarrow$ Zato se o svakom članu konstantno posebno brine] (Vijesti², VII); Novinarka Mila Milosavljević zabilježila je da je razgovor vođen u njegovom stanu u Krunskoj ulici u Beogradu, na Svetog Nikolu. [ $\leftarrow$...zabilježila je da su razgovarali u njegovom stanu...] (Dan $\left.{ }^{3}, \mathrm{XVIII}\right)$.

\section{Imati / Nemati}

Glagol imati (i njegova odrična varijanta) izuzetno je čest u dekomponovanim glagolima. To je prelazni glagol, koji zahtijeva dopunu u akuzativu bez prijedloga:

Zanimljivo je da je Žarko Vukčević u Nionu imao i razgovor sa predstavnicima slovačke ekipe Artmedija Petržalka... [ $\leftarrow$ Zanimljivo je da je Žarko Vukčević u Nionu razgovarao sa predstavnicima...] (Republika², 29); U okruženju imaju odličnu saradnju sa hrvatskim lukama. [ $\leftarrow$ U okruženju odlično sarađuju sa hrvatskim lukama] (Republika $\left.{ }^{3}, 5\right)$; Ipak, ljudi iz kluba imali su drugačije mišljenje... [ $\leftarrow$ Ipak, ljudi iz kluba mislili su drugačije] (Republika ${ }^{4}$, 29); Pred žrijeb smo imali samo želju da izbjegnemo timove iz okruženja, što nam se ispunilo. [ $\leftarrow$ Pred žrijeb smo samo željeli da izbjegnemo...] (Vijesti ${ }^{2}, 30$ ); Razvoj Interneta unaprijedio je i djelatnost državnih službi za nezaposlene, kao i privatnih firmi koje pod različitim uslovima povezuju one koji imaju potrebu za novim ljudi-

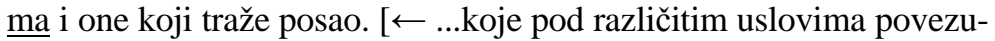
ju one kojima trebaju novi ljudi i one koji traže posao] (Vijesti², II).

Društveni položaj i gubitak posla nema jednak uticaj na sve osobe. [ $\leftarrow$ Društveni položaj i gubitak posla ne utiču jednako na sve osobe] (Vijesti ${ }^{2}$, III); ...pa zaposleni često nemaju ni osjećaj da su konkurentniji i da su njihova kompanija i proizvodi/usluge kvalitetniji. [ $\leftarrow$ ...pa zapošljeni često i ne ośećaju da su konkurentniji...] (Vijesti², VII); Možda nećemo ni imati potrebu da to radimo. [ $\leftarrow$ Možda nećemo ni trebati to da radimo] (Vijesti ${ }^{3}, 3$ ); Uprava Bajerna saopštila je da nema namjeru da pusti Lukasa Podolskog iz kluba... [ $\leftarrow$ Uprava Bajerna saopštila je da ne namjerava da pusti...] (Vijesti $\left.{ }^{3}, 31\right)$.

U naredna dva meča imaćemo mogućnost da vidimo kako igraju Turci, ali od nas sve zavisi. [ $\leftarrow$ U naredna dva meča moći ćemo da vidimo] (Dan $\left.{ }^{3}, \mathrm{II}\right)$; Predsjednik Vlade ima dodatnu mogućnost da u slučaju neriješenog ishoda glasanja istog broja za i protiv njegov glas vrijedi dvostruko. [ $\leftarrow$ Predśednik Vlade dodatno može da...] $\left(\operatorname{Dan}^{3}, 5\right)$. 
Kao dopuna ovom glagolu može se naći i imenica u lokativu s prijedlogom na (npr. imati na uти $\leftarrow$ naumiti), ali primjere takve upotrebe u izučenom korpusu nijesmo pronašli.

\section{Dati / Dobiti}

Sintaksički, glagoli dati i dobiti zahtijevaju dopunu u akuzativu (u funkciji pravog objekta). Zanimljiviji su sa semantičke strane jer dekomponovani glagoli čiji su oni verbalni članovi iskazuju odnos aktivnosti i pasivnosti radnje označene imenicom (vidi tačku 2.2.11).

Na kraju je pobjednik na aukciji bio čovjek koji je dao ponudu od 399.300 dolara... [ $\leftarrow$...čovjek koji je ponudio 399.300 dolara...] (Republika1 ${ }^{1}$ 32); Kroz Sporazum o saradnji bićemo u prilici da se bavimo važnim pitanjima i za jednu i za drugu stranu, kao i za region, u kojem želimo da damo zajednički doprinos miru i stabilnosti. $[\leftarrow$...kao i za region, u kojem želimo da zajedno doprinesemo miru i stabilnosti] (Republika $\left.{ }^{4}, 4\right)$; On je u stabilnom stanju, ali je još nezahvalno davati bilo kakve prognoze... $[\leftarrow$...ali je još nezahvalno bilo što prognozirati] (Vijesti ${ }^{1}, 32$ ); Veoma su direktni i ponekad ih ponese žar razgovora, te može da se desi da neka obećanja olako daju. [ $\leftarrow$...te može da se desi da nešto olako obećaju] (Vijesti² $\left.{ }^{2}, \mathrm{XI}\right)$; A zašto im dati 45 odsto povećanja kad oni i to, i mnogo više od toga uzimaju svaki dan od pacijenata... [ $\leftarrow$ A zašto im povećati (platu) 45 odsto...] ( $\left.\operatorname{Dan}^{4}, 17\right)$.

Prošle godine bilo je predloženo da zastava bude crveno-plavobijele boje, ali na taj predlog Vlada nije dala saglasnost. [ $\leftarrow$...ali sa tim prijedlogom Vlada se nije saglasila] (Dan $\left.{ }^{1}, 14\right)$; Saglasnost na Ugovor dali su Odbor direktora EPCG i Savjet ARD-a. [ $\leftarrow$ S Ugovorom su se saglasili Odbor direktora EPCG i Savjet ARD-a] (Pobjeda $\left.^{1}, 4\right)$; Ekonomski fakultet je dao mogućnost kandidatima koji nijesu primljeni na studijskom programu ekonomija da se upišu na primijenjene studije menadžmenta. [ $\leftarrow$ Ekonomski fakultet omogućio je kandidatima...] ( $\left.\operatorname{Dan}^{3}, 13\right)$.

Nakon procjene, dobijali su ocjenu tačnosti njihovog odgovora. [ $\leftarrow$ Nakon procjene, ocjenjivana je tačnost njihova odgovora...] (Vijesti², III); Predsjednik Skupštine Kosova Jakup Krasnići kaže da su na Kosovu dobili obećanje od najviših zvaničnika Crne Gore da će Crna Gora donijeti odluku o priznanju? $[\leftarrow \ldots$ kaže da su im na Kosovu najviši državnici Crne Gore obećali...] (Vijesti $\left.{ }^{3}, 2\right)$; U kasnim popodnevnim satima, Služba zaštite i spasavanja dobila je poziv iz sjedišta ruske korporacije da im je u kancelarije ušla otrovna šarka dugačka pola metra. $[\leftarrow$...Služba zaštite i spasavanja pozvana je iz 
Dekomponovanje leksema i birokratizacija jezika...

śedišta...] (Vijesti $\left.{ }^{3}, 21\right)$; Na početku samita, 84-godišnji Mugabe je iskoristio priliku da dobije regionalno priznanje svoje pobjede, dan nakon što je položio zakletvu za šesti mandat. $[\leftarrow$...Mugabe je iskoristio priliku da se njegova pobjeda regionalno prizna...] (Republika ${ }^{1}$, 12); Jedan od tri informatičara zloupotrebljava administrativne lozinke kako bi dobio pristup u tajne podatke kao što su visina plate kolege i lične e-poruke, pokazalo je nedavno istraživanje. $[\leftarrow$...kako bi pristupio u tajne podatke...] (Republika $\left.{ }^{3}, 24\right)$.

\section{Nositi}

Navodimo primjere upotrebe svih zabilježenih glagola (oba vida) izvedenih iz glagola nositi. Svi se javljaju u konstrukciji s akuzativom bez prijedloga:

Cvetković je ranije saslušan pred istražnim sudijom, koji je poslije toga donio rješenje o proširenju istrage protiv obojice... $[\leftarrow$...koji je poslije toga riješio da se proširi istraga protiv obojice...] ( $\operatorname{Dan}^{2}$, III); Vlada Hrvatske je nedavno donijela odluku za povećanje kapaciteta na plinovodnom sistemu od Bosiljeva prema Splitu... [ $\leftarrow$ Vlada Hrvatske je nedavno odlučila da poveća kapacitet...] $\left(\operatorname{Dan}^{2}, 6\right)$; Etički savjet Udruženja novinara Hrvatske donio je jednoglasnu odluku da se vlasnik nedjeljnika Nacional Ivo Pukanić isključi iz Udruženja. [ $\leftarrow$ Etički savjet Udruženja novinara Hrvatske jednoglasno je odlučio da se...] (Pobjeda $\left.{ }^{1}, 13\right)$; Iz HLT-a su najavili i da će u narednim danima podnijeti i tužbu Privrednom sudu... [ $\leftarrow$ Iz HLT-a su najavili i da će u narednim danima tužiti Privrednom sudu (nekoga)...] (Republi$\mathrm{ka}^{4}, 5$ ); Predsjednik Vlade i šef DPS-a Milo Đukanović juče je u Atini izdejstvovao „razumijevanje“ Grčke da Crna Gora ove godine podnese aplikaciju za članstvo u EU, a za svoju partiju članstvo u Socijalističkoj internacionali. [ $\leftarrow$...da Crna Gora ove godine aplicira za članstvo u EU...] (Vijesti' $\left.{ }^{1}, 3\right)$.

\section{Doći do}

U posljednje vrijeme konstrukcija doći do $+N_{\text {Dev/Deadj(Gen) }}$ postaje sve frekventnija: zbog obezličenoga karaktera pogodna je za izricanje predikacije bez imenovanja agensa, tj. vršioca radnje:

Dužim odležavanjem vina na ovom talogu došlo bi do oslobađanja neprijatnih i nepoželjnih jedinjenja. [ $\leftarrow$ Dužim odležavanjem vina na ovom talogu oslobodila bi se neprijatna i nepoželjna jedinjenja] (Pobjeda $\left.{ }^{2}, \mathrm{X}\right)$; Do sukoba je došlo i u Darhanu, drugom po veličini industrijskom gradu u Mongoliji. $[\leftarrow$ Sukobili su se i u Darhanu...] (Pobjeda $\left.{ }^{3}, 11\right)$; Škola koju pohađa neimenovani dječak smatra da je došlo do diskriminacije, jer je slavljenik dijelio poziv- 
nice u učionici. [ $\leftarrow$ Škola koju pohađa neimenovani dječak smatra da je diskriminisan...] (Republika $\left.{ }^{2}, 32\right)$; U sudaru došlo je do prevrtanja prikolice, zbog čega je nesrećni farmer ostao bez 25 tona krompira. [ $\leftarrow \mathrm{U}$ sudaru se prevrnula prikolica...] (Republika $\left.{ }^{4}, 32\right)$; ...koja štiti podatke ukoliko dođe do pada računara. $[\leftarrow$...koja štiti podatke ukoliko padne računar] (Vijesti² $\left.{ }^{2} 35\right)$; Do hapšenja renomiranih vojnih oficira došlo je nekoliko sati prije nego što je pred Ustavnim sudom počelo saslušanje u slučaju protiv partije AK.. [ $\leftarrow$ Renomirani vojni oficiri uhapšeni su nekoliko sati prije...] (Vijesti ${ }^{3}$, 10); On je rekao da u odboru manjinskih akcionara Rivijere vjeruju u Vladu kao i u to da je možda došlo do neke greške. [ $\leftarrow$...kao i u to da je možda neko pogriješio] (Vijesti $\left.{ }^{3}, 17\right)$.

\section{Ići}

Ovaj glagol nalazimo u vezi sa dvjema prijedloško-padežnim konstrukcijama: s glagolskom imenicom u lokativu s prijedlogom $u$ (što je češća upotreba) i sa deverbativnom imenicom u instrumentalu s prijedlogom $s(a)$ (rjeđe). Konstrukcijom se izražava cilj, težnja, namjera, opredjeljenje da se neka radnja (iz)vrši:

On je rekao da su u zakon uvrštena samo ovlašćenja koja idu u korist poslodavaca. [ $\leftarrow$...koja koriste poslodavcima / kojima je cilj korist poslodavaca] (Vijesti $\left.{ }^{2}, 8\right)$; Što se tiče gradskog prevoza, naše opredjeljenje je da kroz privatno i javno partnerstvo na planski uređenim lokacijama idemo sa pouzdanim partnerom u formiranje firme koja treba da podstakne bolji javni prigradski i gradski prevoz. $[\leftarrow \ldots$ opredijelili smo se da ... formiramo firmu sa pouzdanim partnerom...] (Republika $\left.{ }^{2}, 21\right)$.

Instrumentalna sintagma s prijedlogom $s(a)$ uz ovaj glagol nema navedenu značenjsku nijansu i, zapravo, stilski je ,,neprikladna“:

Uskoro treba da pošaljemo ambasadora u Grčku, a vrlo brzo ćemo ići i sa donošenjem odluke o otvaranju ambasada u Turskoj i Mađarskoj. [ $\leftarrow$...a vrlo brzo ćemo donijeti odluku o otvaranju ambasada...] (Vijesti $\left.{ }^{3}, 2\right)$.

2.2. Kad se govori o dekomponovanju leksema, nabrojati konstrukcije koje se prepoznaju kao manje ili više frekventne u površinskoj strukturi, navesti primjere i rekonstruisati njihove jednočlane glagolske ekvivalente na dubinskom nivou spada u lakši dio posla. Najzanimljivije pitanje u vezi s tim procesom jeste otkriti zašto je dekomponovanje tako produktivno i, na kraju krajeva, koliko je i đe opravdano. 
Dekomponovanje leksema i birokratizacija jezika...

U vezi s time prenosimo zaključak M. Radovanovića: ,,...nije slučajna situacija da jezici sa razvijenim nominalizacionim procesima, kao prateću osobinu, pokazuju i visok stepen produktivnosti sintaksičkih modela sa dekomponovanim predikatom, a istom pravcu razmišljanja, kao argument, skladno se pridružuje i konstatacija da su nominalizacioni procesi, kao i procesi dekomponovanja predikata, u srpskohrvatskom jeziku, barem, posebno frekventno zastupljeni primerima u tzv. specijalnim funkcionalnim stilovima jezičkog standar$d a$, tj. u onim njegovim ulogama kada ovaj funkcioniše kao instrument intelektualizovanih, a, po tematici, relativno uopštenih i apstraktnih domena jezičke upotrebe (podvukla J. Š.), kao što su npr. pravo, nauka, novinarstvo, politika, administracija itd.“12 Kako je predmet našeg interesovanja publicistički (i administrativni) stil, u ovom dijelu rada analiziraćemo paradigmatične primjere valjane upotrebe dekomponovanih leksema u jeziku crnogorskih novina, ali i slučajeve đe dolazi do miješanja kodova, pa se elementi karakteristični za administrativni stil neosnovano javljaju u publicističkome.

Načinima upotrebe, karakteristikama i razlikama u značenju punoznačnih i dekomponovanih glagola, uz Radovanovića, ${ }^{13}$ više od drugih bavila se Milka Ivić, ${ }^{14}$ pa ćemo se kretati u granicama njihovih nalaza i zaključaka.

2.2.1. Dekomponovani glagol u funkciji predikata spada u takozvane analitičke predikate. Premda višečlan (podrazumijeva konstrukciju glagol + imenica naspram jedne punoznačne glagolske riječi u dubinskoj strukturi), on je ekonomičan na semantičkom nivou: ne mora davati informaciju o vršiocu radnje, o objektu na kojem se radnja vrši, ni o okolnostima pod kojima se vrši. Te se informacije mogu smatrati redundantnima, nebitnim, pa se i ne moraju iznositi, ili se, pak, može željeti namjerno izbjeći navođenje koje od njih.

U maloj svemirskoj letilici koja će doseći visinu od oko $100 \mathrm{~km}$ biće obavljeno vjenčanje, kažu organizatori. [ $\leftarrow U$ maloj svemirskoj letilici koja će doseći visinu od oko $100 \mathrm{~km}$ vjenčaće se (mladenci)...] (Pobjeda $\left.{ }^{3}, 20\right)$; Na današnjem zasjedanju biće podnijet i predlog o davanju saglasnosti na Ugovor o transportu vode iz sistema Plat i

\footnotetext{
${ }^{12}$ Milorad Radovanović, Spisi iz sintakse i semantike, str. 53-54.

${ }^{13}$ Uz već pominjana djela Milorada Radovanovića viđeti i sljedeće knjige: Sociolingvistika, Izdavačka knjižarnica Zorana Stojanovića, Sremski Karlovci - Novi Sad, 2003; Planiranje jezika i drugi spisi, Izdavačka knjižarnica Zorana Stojanovića, Sremski Karlovci - Novi Sad, 2004; te radove: „Još o pojavi dekomponovanja jezičkih jedinica“, Zbornik Matice srpske za filologiju i lingvistiku, XLV/1-2, Novi Sad, 2002; ,Dekompozicija i univerbizacija“, Zbornik Matice srpske za filologiju i lingvistiku, XLVII/1-2, Novi Sad, 2004.

${ }^{14}$ Milka Ivić, O zelenom konju (novi lingvistički ogledi), Slovograf, XX vek, Beograd, 1995, str. 180-187.
} 
Jelena ŠUŠANJ

održavanje tog vodovoda. [ $\leftarrow \mathrm{Na}$ današnjem zasijedanju predložiće se i da se saglase s Ugovorom o transportu vode...] $\left(\mathrm{Dan}^{3}, 19\right)$.

U voćnjacima obavezno treba uraditi zimsko prskanje preparatima na bazi mineralnih ulja... [ $\leftarrow$ treba obavezno zimi prskati (voće)] (Pobjeda ${ }^{2}$, VIII); Berba se obavlja svaki dan ili svaki drugi dan, ako nije vrijeme previše toplo i suvo. $[\leftarrow$ Bere se (grožđe) svaki dan...] (Pobjeda ${ }^{2}$, VIII); Proces razlaganja obavljaju bakterije mliječne kisjeline tokom burne fermentacije. [ $\leftarrow$ Bakterije mliječne kiśeline razlažu (to) tokom burne fermentacije] (Pobjeda ${ }^{2}, \mathrm{X}$ ); Nakon zakazivanja sjednice gradonačelnik Kankaraš dao je kratko saopštenje. [ $\leftarrow$ Nakon zakazivanja śednice gradonačelnik Kankaraš kratko je saopštio] $\left(\operatorname{Dan}^{3}, 20\right)$; Iako smo napravili manje promjene, novi sistem nije toliko strog koliko se misli. [ $\leftarrow$ Iako smo malo izmijenili (sistem), novi sistem...] ( $\mathrm{Dan}^{4}$, VII).

$\mathrm{U}$ istom periodu građani su putem telefona podnijeli 28 prijava... [ $\leftarrow$ U istom periodu građani su putem telefona prijavili 28 (komunalnih prekršaja)] (Pobjeda $\left.{ }^{1}, 16\right) ;$...crnogorski kik-bokseri ostvarili su veliki uspjeh, ocijenjeno je iz Kik boks saveza Crne Gore. [ $\leftarrow$ crnogorski kik-bokseri veoma su uspjeli (na takmičenju)] (Republika $\left.{ }^{4}, 28\right)$; ...dok Baćović nije saslušan jer je u bjekstvu. $[\leftarrow$ jer bježi / je pobjegao (od nekoga/nečega)] (Pobjeda' $\left.{ }^{1}, 8\right)$.

Dekomponovani glagol, vidimo u prvoj grupi primjera, izuzetno je pogodan za situaciju s anonimnim odnosno uopštenim agensom. Ako uporedimo prvi i drugi primjer, zapažamo da je u prvome informacija o vršiocu radnje redundantna (agens je uopšten, vjenčava se dvoje ljudi), a u drugom, pak, primjeru možemo samo da naslućujemo ko je podnio prijedlog i ko treba da se saglasi s Ugovorom, što su informacije neophodne za razumijevanje vijesti.

U navedenim primjerima druge skupine upotrebljava se dekomponovani glagol kad se želi neutralisati tranzitivnost predikacije. Kao što se vidi iz rekonstruisanih dubinskih struktura, kod tranzitivnih predikacija iskaz ostaje nedovršen bez navođenja objekta ili okolnosti, a ta se nedovršenost ne ośeća kad se upotrijebi dekomponovana glagolska struktura.

Treću grupu čine primjeri u kojima se pri rekonstrukciji punoznačnoga glagola rečenica javlja kao nepotpuna.

Moramo priznati da analiza koju smo ovđe sproveli ima bitan nedostatak - izvlačenje rečenica iz konteksta. Dekomponovani oblik efikasan je i poželjan kad su bitne informacije već iznešene, te ih je suvišno ponavljati. Ipak, u novinarskome diskursu (đe, da bi se valjano prenijela vijest, treba precizno odgovoriti na pitanja: ko, šta, đe, kad, kako i zašto) upotrebom dekomponovanoga predikata često se maskiraju značajni podaci, naročito pri prenošenju političkih novosti. 
Dekomponovanje leksema i birokratizacija jezika...

Slikovit je primjer:

Ne smiju se davati izjave u kojima gradonačelnik Mugoša kaže da će KAP-u dati placeve za stanove, sindikatu plac za izgradnju Doma sindikata (Vijesti $\left.{ }^{3}, 24\right)$,

đe se upotrebom dekomponovanoga glagola u predikatu i refleksivnoga pasiva pokušava uopštiti agens. Kažemo pokušava jer se iz nastavka rečenice vidi ko je u zapravo vršilac radnje, tj. ko je dao izjavu (gradonačelnik Mugoša). Takvim postupkom, prije svega pasivnom konstrukcijom, izvršena je i specifična eufemizacija, ublažavanje iznešenoga stava time što se ono što se odnosi na konkretnu osobu prenosi na neimenovano, anonimno mnoštvo ljudi.

2.2.2. Upotrebom dekomponovanoga glagola saopštava se prethodna društvena institucionalizovanost, tj. organizovanost i strukturiranost aktivnosti koja se obavlja.

Iz tog suda „Vijestima“ je juče potvrđeno da je optužnica, podignuta 20. juna, stigla u sud krajem prošle sedmice i da je Gvozdenoviću upućen poziv kako bi mu akt bio uručen. $[\leftarrow$...da je Gvozdenović pozvan kako bi mu akt bio uručen] (Vijesti² 11$)$; Odradili smo dobre pripreme, učestvovali na svim prestižnim takmičenjima. [ $\leftarrow$ Dobro smo se pripremili...] (Vijesti $\left.{ }^{3}, 29\right)$; Početkom nedjelje

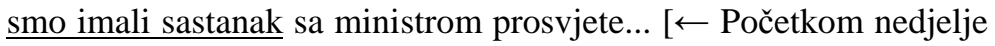
sastali smo se sa ministrom prosvjete] (Dan $\left.{ }^{1}, 11\right)$; Pored gradonačelnika Milovana Jankovića, $\underline{u}$ razgovoru sa ministrom Simovićem učestvovali su i potpredsjednici... [ $\leftarrow$...sa ministrom Simovićem razgovarali su i potpredśednici...] (Dan $\left.{ }^{1}, 15\right)$; Bistricu namjeravamo da u naredne dvije godine zaštitimo i stavimo zabran ribolova. [ $\leftarrow$ Bistricu namjeravamo da u naredne dvije godine zaštitimo i zabranimo ribolov] (Dan $\left.{ }^{1}, 17\right)$; Saša Božović, direktorica, naglasila je da je čast što se dodjela nagrada svake godine održava u biblioteci „Njegoš“. [ $\leftarrow$...naglasila je da je čast što se nagrade svake godine dodjeljuju u biblioteci „Njegoš“] $\left(\operatorname{Dan}^{3}, 20\right)$; Prije početka sjednice gradonačelnik Tivta Miodrag Kankaraš održao je kratke konsultacije sa predsjednicima partija... [ $\leftarrow$...Miodrag Kankaraš kratko se konsultovao sa predśednicima partija...] $\left(\mathrm{Dan}^{4}, 14\right)$; Novi šef stručnog štaba Saša Petrović izvršio je juče prozivku u Komu, na kojoj su mu se javila 39 fudbalera, a odmah nakon toga uz asistenciju svog pomoćnika Zlatka Kostića su i odradili prvi trening. $[\leftarrow$...Saša Petrović prozvao je juče (fudbalere) u Komu..., a odmah nakon toga uz asistenciju svog pomoćnika Zlatka Kostića su i prvi put trenirali] (Pobjeda/Arena $\left.{ }^{1}, 4\right)$. 
Postignuta je saglasnost i sa generalnim sekretarom SSCG Veselinom Vujanovićem... [ $\leftarrow$ Usaglašeno je i sa generalnim sekretarom SSCG Veselinom Vujanovićem...] ( $\left.\operatorname{Dan}^{4}, 10\right)$.

Dekomponovani glagol unosi značenje oficijelnosti, koje glagol iz koga se izvodi ova konstrukcija ne sadrži. Ribolov može biti zabranjen i zato što je voda zatrovana ili iz nekih drugih razloga, ali kad se stavi zabran ribolova, to znači da je kakvim aktom propisano da se u tim vodama ne smije ribati i da se svako oglušenje o tu zabranu zakonom kažnjava. Kad se u sportu kaže da su odrađene pripreme, to podrazumijeva organizovane i dobro planirane pripreme. Vode se zvanični razgovori, a razgovara se neformalno.

Ta razlika karakteristična je za apstraktne stilove (u koje spadaju i publicistički i administrativni). Upotreba dekomponovanih oblika glagola u tom slučaju postaje odlika lošega stila jedino kad se prečesto upotrebljava. Negativni uticaj može imati kad preko medija uđe u razgovorni stil i u njemu se ustali.

2.2.3. Jednočlani i višečlani dekomponovani glagol s istom osnovom ne moraju imati isto značenje, nijesu obavezno sinonimi:

Ne ulazeći u zasnovanost argumenata koje je iznio, uočavamo da je Fejt ovakvim izjavama napravio ozbiljan diplomatski prestup. $[\neq$...uočavamo da je Fejt ovakvim izjavama ozbiljno diplomatski prestupio] $\left(\mathrm{Dan}^{2}, 11\right)$; Ustavni sud je dao primjedbu da kreditor ne može biti Dom zdravlja već banka i to smo otklonili. [ $\neq$ Ustavni sud je primijetio...] (Dan $\left.{ }^{3}, 12\right)$; Valjda bi se tada već jednom uvela rasvjeta od mosta do mlinova. $[\neq$ Valjda bi se tada već jednom rasvijetlilo od mosta do mlinova] $\left(\operatorname{Dan}^{3}, 16\right)$.

U primjeru:

Uviđaj je obavila dežurna ekipa podgoričke policije, a okolnosti nezgode se ispituju. [ $\leftarrow$ Dežurna ekipa podgoričke policije uvidjela je...] (Republika $\left.{ }^{3}, 2\right)$

dekomponovanim glagolom obilježava se institucionalizovanost radnje. Ujedno, punoznačni glagol uviđeti ne može biti upotrijebljen kao njegov sinonim.

2.2.4. Nepotpunu sinonimnost zabilježili smo i u primjerima kad se dekomponovanim glagolom izražava apstraktna radnja, dok njegov jednočlani ekvivalent nosi obilježje konkretnosti iskazane radnje:

On je dodao da su SAD fokusirane na iransku diplomatiju i međunarodne organizacije koje mogu da izvrše pritisak da se iranska nuklearna situacija riješi. (Republika², 12) [upor. Uzeo je čašu i pritisnuo papir. (razg.)]; Drago mi je što sam ostvario i kontakt s publikom, što su osjetili emociju u pjesmi... (Vijesti², 40) [upor. Kontaktirao sam sa Savom telefonom. (razg.)]. 
Dekomponovanje leksema i birokratizacija jezika...

2.2.5. Dekomponovani glagol može biti izuzetno podoban za determinisanje radnje. Naime, u nekim slučajevima radnja izražena punoznačnim glagolom ne može se lako kvalifikovati (odrediti prilogom za način ili nekom drugom determinantom). Ta se prepreka prevazilazi dekomponovanjem, pri čemu se determinator veže za imenicu deriviranu iz toga glagola (ili pridjeva), te umjesto priloške odredbe na sintaksičkom planu nalazimo atribut.

Očevici su zadobili slabe opekotine, čak i oni udaljeni nekoliko stotina kilometara od epicentra eksplozije. $[\neq$ Očevici su se slabo opekli...] (Republika $\left.{ }^{1}, 13\right)$; Vujanović je kazao da je tokom njegovog susreta sa Kostom iskazano očekivanje da će Crna Gora preko svog sudije Nebojše Vučinića, dati puni doprinos kvalitetu rada ove institucije. $[\neq$...da će Crna Gora preko svog sudije Nebojše Vučinića puno doprinijeti kvalitetu rada ove institucije] (Pobjeda $\left.{ }^{1}, 2\right)$; Ne mislim da smo imali nekih propusta, sem to što prvo veče nijesmo imali direktnog prenosa... $[\neq \mathrm{Ne}$ mislim da smo nešto propustili, sem što prvo veče nije direktno prenošeno...] (Vijesti $\left.{ }^{1}, 42\right)$; Imali smo tri jake provjere, igrali smo odlično protiv najjače reprezentacije na svijetu i mislim da smo na pravom putu da dođemo do igre kakvu svi priželjkujemo... [₹ Triput smo se jako provjerili...] (Vijesti², 28); Prošle sezone Zeta je napravila istorijski uspjeh plasmanom u drugo kolo kvalifikacija za Ligu šampiona... [ $\neq$ Prošle sezone Zeta je istorijski uspjela plasmanom...] (Vijesti², 30).

Pekarska industrija nema materijalnih mogućnosti da to preuzme, već će morati nadoknaditi to kroz cjenovni rast svojih proizvoda koje će plasirati potrošačima, smatra Blečić. [ $[\neq$ Pekarska industrija materijalno ne može da to preuzme...] (Pobjeda ${ }^{1}, 7$ ); Hercegnovski gradonačelnik Dejan Mandić zahvalio se Agenciji za prestrukturiranje privrede i strana ulaganja, Savjetu za privatizaciju i Vladi Crne Gore koja je dala konačnu saglasnost... $[\neq$...zahvalio je Agenciji za prestrukturiranje privrede i strana ulaganja, Savjetu za privatizaciju i Vladi Crne Gore koja se konačno saglasila...] (Pobjeda $\left.{ }^{2}, 9\right)$.

Posebnu pažnju posvetićemo prvom primjeru, jer je najeksplicitniji. Kad se kaže da su očevici zadobili slabe opekotine, atributom je obilježen kvalitet, stepen opekotina. Ako se prilog istoga značenja upotrijebi uz glagol opeći, kao što je urađeno u zagradi, promijeniće se značenje, a rečenica lako može dobiti ironičan prizvuk (slabo su se opekli - mogli su i bolje). Zamijenimo li prilog slabo kakvim drugim, npr. malo, opet nećemo dobiti željeno značenje. Taj prilog u rečenicu donosi kvantitet umjesto kvaliteta, pa će se pomisliti da su opekotine bile male po veličini, a ne po intenzitetu. Stoga je najprikladniji način za determinisanje toga tipa upravo dekomponovani oblik glagola. 
Jelena ŠUŠANJ

2.2.6. Još jedan, s aspekta birokratizacije jezika neutralan ali na sintaksičko-semantičkom nivou produktivan, momenat u dekomponovanju glagola predstavlja pluralizacija predikacije. Jednočlanim glagolom ne može se lako iskazati kvantitet predikacije, stoga se poseže za dekomponovanjem, pri čemu se izvedena imenica javlja u množini:

Udario ga je njome po glavi i nanio mu teške povrede mozga i prelom lobanje, te oštećenje živaca. [ $\leftarrow$ Udario ga je njome po glavi i teško mu povrijedio mozak, prolomio lobanju i oštetio živce.] (Republika $^{3}, 11$ ); Do glavnog turnira stigla je iz kvalifikacija, a na putu do polufinala napravila je nekoliko iznenađenja i jednu senzaciju, kada je savladala najbolju teniserku svijeta Anu Ivanović. $[\leftarrow \ldots a$ na putu do polufinala iznenadila je nekoliko puta i napravila jednu senzaciju...] (Republika $\left.{ }^{4}, 30\right)$; Dobijali smo i nezaslužene javne opomene i kaznene poene. [ $\leftarrow$ I nezasluženo smo javno opominjani i kažnjavani u poenima] (Republika ${ }^{4}, 28$ ); Osim što je sa umišljajem izvršio dvostruko ubistvo, Bulajić je optužen i da je doveo u opasnost živote Dragana Kostića, Jelene Marković, Uglješe Šarića, Nenada Buzića i prisutnih gostiju u lokalu. [ $\leftarrow$ Osim što je sa umišljajem dvaput ubio...] (Vijesti² $\left.{ }^{2}, 10\right)$; Dok je hauba otvorena, provjerite kaiševe, kablove i crijeva, koje treba promijeniti ako postoje oštećenja ili pukotine. $[\leftarrow$...koje treba promijeniti ako su oštećeni ili pukli] (Vijesti ${ }^{1}$, IX); Koliko će mladom vaterpolisti trebati snage da se izbori za život, najbolje svjedoči podatak da trenutno nije poznato ni kada će ljekari početi da daju prve prognoze o njegovom stanju. $[\leftarrow$...da trenutno nije poznato ni kada će ljekari početi da prognoziraju njegovo stanje] (Pobjeda/Arena ${ }^{1}, 8$ ).

2.2.7. Već smo iz prethodnih analiza uočili da je dekomponovanje nekad nužno sredstvo za semantičko diferenciranje, za iskazivanje nijansi značenja. Ono, viđećemo, može imati i prosto stilski efekat, razbijati jednoličnost izraza i unositi slikovitost:

Prema nekim informacijama, Ministarstvo će izaći s prijedlogom da se za najugroženije kategorije, odnosno srednji medicinski kadar plate povećaju oko 40 odsto, a za nekvalifikovane oko 50 odsto. [ $\leftarrow$...Ministarstvo će predložiti da se...] $\left(\right.$ Republika $\left.^{3}, 9\right)$; Predsjednik Francuske Nikola Sarkozi spreman je da dođe u Varšavu i lično ubijedi poljskog predsjednika Leha Kačinjskog da ipak stavi potpis na Lisabonski ugovor... [ $\leftarrow$...da ipak potpiše Lisabonski ugovor...] (Republika $\left.{ }^{3}, 13\right)$; Vrtoglavi uspon Sivaspora počeo je 2005. godine, kada je prvi put izborio plasman u elitni rang. [ $\leftarrow$ ...kada se prvi put plasirao u elitni rang] (Vijesti $\left.{ }^{3}, 30\right)$. 
Dekomponovanje leksema i birokratizacija jezika...

U vezi s obilježjima stila mogao bi biti i sljedeći primjer (koji svakako nije usamljen), đe se dekomponovani glagol upotrebljava da se u dvjema uzastopnim klauzama ne bi javio isti oblik:

Ubrzo se protiv njega pobunio cezar Galije, Julijan Apostata, a uz to izbila je pobuna u Aziji. $[\leftarrow \ldots a$ uz to se pobunio (narod protiv Rimljana) u Aziji] (Dan ${ }^{1}$, XVII).

2.2.8. Naspram jednoga glagola stoji više njegovih dekomponovanih varijanti, sa različitim semikopulativnim verbalnim elementima. Takvo semantičko razrađivanje doprinosi bogatstvu rječnika i nijansiranju značenja.

Povrijediti (se):

Činjenica da Ikodinović može da pomjera noge i reaguje na spoljne nadražaje pokazuje da nije pretrpio teške neurološke povrede... (Vijesti², 29); Od ispaljenih hitaca, lake tjelesne povrede su zadobili Jelena Marković, Dragan Kostić i Uglješa Šarić. (Vijesti², 10); On je iz pištolja ispalio hitac u njega, nanoseći mu tešku tjelesnu povredu. (Vijesti ${ }^{2}, 10$ ); U madridsku bolnicu je primljeno 125 povrijeđenih, od čega je jedan u kritičnom stanju zbog povreda glave, a većina je zaradila posjekotine ili se otrovala alkoholom. (Pobjeda/Arena $\left.{ }^{1}, 6\right)$.

\section{Pobijediti:}

Potpuno zasluženo, osporavani sastav Luisa Aragonjesa odnio (je) konačnu pobjedu u Austriji i Švajcarskoj. (Pobjeda/Arena ${ }^{1}, 6$ ); Prvog dana nijesmo bili kompletni, pa $\underline{s u}$ Bugari lakše došli do pobjede nego drugog, kada je u skoro svim setovima do pred kraj vladala rezultatska ravnoteža i neizvjesnost. (Pobjeda/Arena ${ }^{3}, 9$ ); Neizvjesnost na ovom meču viđena je samo u prvom setu, dok je pobjeda zasluženo pripala mlađoj sestri Vilijams... (Pobjeda/Arena $\left.{ }^{2}, 12\right)$.

\section{Zahtijevati:}

U međuvremenu, Štrajkački odbor Kliničkog centra uputio je zahtjev menadžmentu ove ustanove da se sastanu kako bi precizirali detalje o načinu rješavanja stambenih problema zaposlenih u ovoj ustanovi. (Republika², 9); Socijalistička partija Srbije podnijela je juče zvaničan zahtjev za prijem u Socijalističku internacionalu... (Vijesti $\left.{ }^{3}, 11\right)$; Danas sam generalnom sekretaru SI Luisu Ajali predao zvaničan zahtjev SPS-a za prijem u članstvo. (Vijesti ${ }^{3}, 11$ ).

\section{Dogovoriti:}

Oni su ogorčeni što nijesu postigli nikakav dogovor s nadležnim ministarstvima... (Republika $\left.{ }^{2}, 7\right)$; Najveći sportski dnevnici 
„As““ i „Marka“ slažu se u ocjeni da ję Fudbalski savez Španije već napravio dogovor sa del Boskeom, koji bi tako na klupi trebalo da naslijedi Luisa Aragonjesa. (Pobjeda/Arena², 6).

\section{Omogućiti / Onemogućiti:}

Crnogorski poslodavci stiču mogućnost stvaranja poslovnih kontakata na međunarodnom nivou.... (Pobjeda $\left.{ }^{1}, 6\right)$ Donacija je usmjerena toj djeci, radi pružanja mogućnosti za njihov napredak i bolji život. (Pobjeda $\left.{ }^{3}, 9\right)$; Nad njima je vršena vasektomija „,da $\underline{\text { bi se }}$ izbjegla mogućnost rađanja mutanata u široj populaciji“. ( $\left(\mathrm{Dan}^{2}, 19\right)$.

2.2.9. Postoje i slučajevi kad se od dekomponovanoga glagola ne može rekonstruisati jednočlani glagolski ekvivalent. To se dešava kad u jeziku uz imenicu ne postoji odgovarajući glagol s istim značenjem:

Imam kontakte sa OFK Beogradom, a juče sam razgovarao i sa menadžerom koji me je upoznao sa mogućnošću da napravim ino transfer. $[\leftarrow *$...koji me je upoznao sa mogućnošću da se ino transferišem] (Pobjeda/Arena ${ }^{3}$, 2); Kako ne bi dolazilo do konflikata u vaspitanju, prije svake odluke konsultujte se sa partnerom. [ $\leftarrow$ *Kako se ne bi konfliktovalo u vaspitanju...] (Pobjeda ${ }^{1}$, III).

Važno je napomenuti da ovđe ne govorimo tek o riječima stranoga porijekla:

Vlada je učinila napor i obezbijedila sredstva. [ $\leftarrow *$ Vlada se naporila i obezbijedila sredstva.] $\left(\mathrm{Dan}^{4}, 10\right)$.

2.2.10. Eufemizam se definiše kao upotreba blaže riječi ili izraza umjesto pravoga naziva za kakvu neprijatnu pojavu. ${ }^{15}$ I u funkciji ublažavanja značenja dekomponovanje je produktivan postupak:

Otjerao je isto toliko Njemaca iz Vojvodine da bi mogao, u „Osmoj ofanzivi““ da protjera Srbe krajišnike iz BiH i Hrvatske u Vojvodinu (koja će biti budući problem i zato što mnogi folksdojčeri i dalje imaju tapije na svoja imanja) i napravi etničko čišćenje u korist Hrvata. [ $\leftarrow$...i etnički očisti u korist Hrvata...] $\left(\mathrm{Dan}^{3}, 13\right)$; On je iskoristio trenutak kada su ostali pritvorenici bili u krugu zatvora i izvršio samoubistvo vješanjem u kupatilu zatvora... [ $\leftarrow$...i objesio se u kupatilu zatvora...] ( $\left.\operatorname{Dan}^{3}, 28\right)$; Prema njegovim riječima, nakon ove presude je očigledno da ubijanja Srba izvršena u proteklom ratu mogu proći nekažnjeno. $[\leftarrow$...nakon ove presude je očigledno da to što su ubijeni Srbi u proteklom ratu može da prođe nekažnje-

${ }^{15}$ Ivan Klajn u: Pavle Ivić, Ivan Klajn, Mitar Pešikan, Branislav Brborić, Srpski jezički priručnik, Beogradska knjiga, Beograd, 2006, str. 215. 
Dekomponovanje leksema i birokratizacija jezika...

no] ( $\left.\operatorname{Dan}^{4}, 4\right)$; Kako stanovništvo u narednih 25 godina bude sve starije u zemljama sa srednjim ili niskim primanjima, doći će do znatnog povećanja udjela smrtnih slučajeva, koji su posljedica nezaraznih bolesti. $[\leftarrow$...povećaće se broj smrtnih slučajeva, koji su posljedica nezaraznih bolesti. / $\leftarrow$ umiraće više ljudi od nezaraznih bolesti] (Pobjeda ${ }^{1}$, IV); Poljoprivrednik Vukajlo Brković (73) i njegov sin Branko (44), službenik plavske Ispostave policije, smrtno su stradali juče oko 13 sati u selu Brezojevica kod Plava... [ $\leftarrow$ ...poginuli su juče oko 13 sati...] (Republika $\left.{ }^{4}, 2\right)$.

Iako na Skupštini akcionara niko nije želio da to javno komentariše, Radomir Milović je, po svemu sudeći, prva žrtva najava da će neko snositi odgovornost što nije privatizovan pljevaljski energetski kompleks. [ $\leftarrow$...prva žrtva najava da će neko odgovarati što nije privatizovan pljevaljski energetski kompleks] (Republika $\left.{ }^{1}, 5\right)$; Došlo je i do svađe između Vlade i drugog Saveza sindikata, prvi put. [ $\leftarrow$ Posvađali su se Vlada i drugi Savez sindikata, prvi put] (Republika ${ }^{1}$, 9); Opšta je konstatacija da ima dosta nekorektnosti i nerealnosti u cjenovniku koji nam je dostavljen. [ $\leftarrow$ Opšta je konstatacija da je cjenovnik koji nam je dostavljen dosta nekorektan i nerealan] (Vijesti $\left.{ }^{3}, 2\right)$.

Eufemizam u prvoj grupi primjera razumljiv je i, ako se može tako reći, opravdan. Mnogo će blaže djelovati kad se pročita da je neko izvršio samoubistvo vješanjem no ako pročitamo da se neko objesio. Drugu grupu već karakteriše veća birokratizovanost izraza. Eufemizam se, naime, tu ne koristi zbog čitalaca, da bi se umanjio utisak, izazvale slabije emocije, već da bi se zatamnio smisao i umanjio značaj onoga što se govori. To je karakteristično za jezik politike, ali u novinarstvu (koje bi trebalo da teži preciznosti i jasnoći) teško da može imati osnova i opravdanja.

2.2.11. Pasiv se sintaksički obilježava na dva načina - trpnim glagolskim pridjevom uz pomoćni glagol (participski pasiv) ili aktivnim glagolom $\mathrm{s}$ povratnom rječcom se (refleksivni pasiv). Semantički (leksički) pasivizacija se može izraziti i dekomponovanim punoznačnim glagolom. O tome smo govorili u vezi s glagolima dobiti i dati. Navodimo primjere đe se radnja označena imenicom deverbativnoga porijekla uz različite glagole nekonkretizovanoga značenja u okviru dekomponovanoga predikata upotrebljava u aktivu i pasivu i đe upravo nekonkretizovani glagol nosi značenje aktivnosti ili pasivnosti:

poraziti / biti poražen ...nevjerovatni Švajcarac će izaći na megdan Mariju Ančiću, koji mu je u prvom kolu Vimbldona 2002. godine nanio posljednji poraz na najbržoj podlozi. (Vijesti $\left.{ }^{2}, 29\right)$; Kadetska reprezentacija 
Jelena ŠUŠANJ

Crne Gore doživjela je dva poraza prvog dana otvorenog prvenstva Evrope u Geteborgu. (Vijesti², 29).

2.2.12. Svi elementi i efekti dekomponovanja što smo ih dosad naveli, viđeli smo, ne javljaju se i ne djeluju uvijek izolovano jedan od drugoga. Ovđe ćemo obratiti pažnju na svega jedan primjer:

Pod rukovodstvom DPS-a dogodio se i proces privatizacije. $\left(\operatorname{Dan}^{3}, 2\right)$.

Interesantan je iz više razloga. Subjekat rečenice - proces privatizacije - nalazi se na kraju: sintagma pleonastičnoga karaktera ${ }^{16}$ koju čini dekomponovana imenica. Ovako razgrađena imenica ne traži nikakvu dalju dopunu, nije potrebno precizirati što se privatizuje (objekat). Taj se proces ne sprovodi, ne realizuje, ne vrši, ne obavlja (što su sve, viđeli smo, potencijalni semikopulativni glagoli u funkciji verbalnog konstituenta dekomponovanoga predikata): on se, naprotiv, događa. Odabir toga glagola, sa specifičnom eufemističkom funkcijom u datome kontekstu, ukazuje nam na medijalno stanje, aktiva nema, pa time ni vršioca radnje. To nije čak ni anonimni agens: privatizacija se događa, sama od sebe. Istu obezličenost imala bi i konstrukcija (takođe česta u publicističkom stilu): došlo je do privatizacije. Priloška odredba s početka rečenice pod rukovodstvom DPS-a određuje tek vrijeme ili okolnost vršenja radnje.

Dakle, datom formulacijom rečenice čitaoci nijesu saznali ni vršioca ni objekat privatizacije, a vrlo je teško odrediti i način privatizovanja. Prenešena vijest nejasna je, nepotpuna i neprecizna i odličan je primjer uticaja birokratizacije na jezik novina.

\section{Dekompozicija imenica}

3.0. Pažnju lingvista i stilističara dugo je privlačio samo dekomponovani predikat, naravno kad je riječ o ovoj oblasti. Ipak, sve se više govori i o dekomponovanju ostalih vrsta riječi, prvenstveno imenica. Mogu se dekomponovati i poimeničavati i prilozi i pridjevi (pri čemu nastaju prijedloškopadežne konstrukcije: veoma brzo - pri velikoj brzini - Pranjković tu pojavu naziva prepozicionalizacijom; ${ }^{17}$ ili pak imenske sintagme tipa: borben - borbenoga karaktera...), pa čak i veznici (radi - u cilju, s ciljem), ali se time zbog ograničenosti obima rada nećemo detaljnije baviti.

3.1. Duška Klikovac na dekomponovanje imenica gleda kao na odraz eksplicitne kategorizacije: „od svih nivoa apstrakcije na kojima se može

${ }^{16} \mathrm{O}$ pleonastičnosti konstrukcija toga tipa biće govora u poglavlju o dekompoziciji imenica.

${ }^{17}$ Ivo Pranjković, op. cit., 521. 
Dekomponovanje leksema i birokratizacija jezika...

kategorizovati neka stvar, postoji jedan na kojem čovek dobija najviše informacija sa najmanje kognitivnog napora - to je osnovni nivo kategorizacije". ${ }^{18}$ U odnosu na taj osnovni nivo, postoje i viši i niži nivoi.

U potonje vrijeme sve je češći sljedeći postupak: iz jednog imeničkog pojma izvodi se njemu nadređen (viši) pojam i imenuje imenicom, a prvobitna imenica postaje njena odredba: ${ }^{19}$ tako ljeto postaje ljetnji period ili ljetnji mjeseci, škola prerasta u školski objekat, hrana u prehrambeni proizvod:

Na Cetinju je 1.648 nezaposlenih i za njihov rad se traži šansa na seoskom području. [ $\leftarrow$ u selima] (Pobjeda $\left.{ }^{1}, 7\right)$; On je, govoreći o završnom računu budžeta za prošlu godinu, kazao da realizacija finansijskog plana u prvoj godini funkcionisanja GO nije na zadovoljavajućem nivou. [ $\leftarrow$ nije zadovoljavajuća $\leftarrow$ ne zadovoljava] (Republika ${ }^{2}$, 19); Statistike na državnom nivou su ograničenog dometa... [ $\leftarrow$ u državi...] $\left(\operatorname{Dan}^{3}, 4\right){ }^{20}$

Svaki stil, odnosno svaki tekst bira oblike kategorizovanja koji najviše odgovaraju potrebnom nivou saznajnosti, odnosno informativnosti. Pranjković upotrebu imenica apstraktnijega značenja u navedenim i sličnim sintagmama naziva intenzifikacijom, ističući da takve riječi, koje u datim slučajevima gotovo da bivaju obeznačene, često postaju riječi-paraziti: ${ }^{21}$

Postupak javne rasprave je neprihvatljivo skraćen... [ $\leftarrow$ Javna rasprava je neprihvatljivo skraćena] $\left(\operatorname{Dan}^{1}, 11\right)$ Kao prioritete Pariz je najavio rješavanje pitanja u oblasti energetike i klimatskih promjena, inicijativu za sklapanje sporazuma o imigrantima na nivou EU i ponovno pokretanje pitanja zajedničke politike u oblasti odbrane i poljoprivrede. $[\leftarrow$ u energetici i klimatskim promjenama; $\mathrm{u}$ odbrani i poljoprivredi] (Dan $\left.{ }^{1}, \mathrm{X}\right)$; Državni sekretar SAD, Kondoliza Rajs, saopštila je u svom godišnjem izvještaju da Crna Gora, na neki način, nije dovoljno uradila na polju borbe protiv korupcije i organizovanog kriminala... [ $\leftarrow$ u borbi protiv...] $\left(\right.$ Pobjeda $\left.^{2}, 3\right)$; Danas ste $\underline{u}$ fazi potrošačke groznice. [ $\leftarrow$ u potrošačkoj groznici] (Republika $^{1}, 24$ ); Pripremamo se za 2009. u kojoj će se definisati dalja politika na planu visokog obrazovanja. [ $\leftarrow$ u visokom obrazovanju] (Republika $\left.{ }^{3}, 9\right)$; Akcija spasavanja trajala je do kasno sinoć. [ $\leftarrow$ Spasavanje je trajalo] (Republika $\left.{ }^{4}, 12\right)$; ...i ocijenio da irsko „ne“ Lisabonskom ugovoru neće zaustaviti proces proširenja. $[\leftarrow$ proširenje] (Vijesti $\left.{ }^{1}, 3\right)$; ...kazao je na jučerašnjoj sjednici Skupštine

${ }^{18}$ Duška Klikovac, „O javnom jeziku. (Eksplicitna kategorizacija imeničkih pojmova)“. Jezik danas, br. 8, Matica srpska, Novi Sad, 1998, str. 17.

${ }^{19}$ Ibidem.

${ }^{20} \mathrm{Za}$ više primjera ovoga tipa pogledati tačku 3.1.3.

${ }^{21}$ Ivo Pranjković, op. cit., 521-522. 
Jelena ŠUŠANJ

Gradske opštine Golubovci Čedo Dobrović, raspravljajući o informacijama oko aktivnosti na podsticanju otkupa... [ $\leftarrow$ oko podsticanja otkupa] (Vijesti², 24); Potočnik u intervjuu "Vijestima" ističe ulogu naučno-istraživačke djelatnosti u procesu pridruživanja Crne Gore Evropskoj uniji... [ $\leftarrow$ naučnog istraživanja u pridruživanju] (Vijesti ${ }^{3}, 6$ ); U okviru simpozijuma, koji je bio posvećen profesionalnoj orijentaciji i na kome uglavnom Nacionalna služba za zapošljavanje Srbije predstavlja svoja istraživanja i iskustva u radu sa nezaposlenima... [ $\leftarrow \mathrm{Na}$ simpozijumu] (Pobjeda ${ }^{1}, 20$ ); Simović je rekao da ima još mnogo prostora gdje će se preduzetništvo iskazati u sektoru poljoprivrede, a posebno da će nova kreditna linija koja se priprema na nivou Vlade u jednoj združenoj akciji resornih ministarstava... [ $\leftarrow$ u poljoprivredi; u Vladi] (Pobjeda ${ }^{1}, 7$ ).

Značenje svake od boldom istaknutih imenica obuhvaćeno je značenjem imenice uz koju stoje. Informativnost se ne bi umanjila i kad bi se one uklonile iz rečenice, no njihova upotreba u granicama intelektualizovanih stilova nije greška. Kodifikacijom svakoga stila posebno trebalo bi ograničiti njihovu upotrebu, jer im svakako nema mjesta u razgovornom jeziku.

3.1.1. Navedeni primjeri mogli bi se smatrati pleonastičnim. Pleonazam podrazumijeva gomilanje istoznačnih riječi i može biti namjerni i nenamjerni. ${ }^{22}$ Oba se tipa iz administrativnoga stila (koji im je zbog svoje analitičnosti najpodložniji) lako prenose prije svega u publicističke tekstove (a odatle i u razgovorni stil).

Namjerni pleonazam bio bi stilogen, dakle, izražajni specifikum specijalnih (apstraktnih) stilova. Karakteriše ga korišćenje imenica oblast, područje, akcija, polje, nivo, stanje, sfera, proces, faza, okvir, milje, domen, sektor, plan, pitanje, postupak i sl. Neki od ovih intenzifikatora unose novu nijansu značenja u sintagmu. Tako na primjer, akcija ,implicira odlučnog i efikasnog organizatora, ponekad uz masovan odziv građana“, dok imenica proces „može implicirati dugotrajnost radnje, ako ne sa neizvesnim ishodom, a ono svakako uz mnoštvo prepreka““: ${ }^{23}$

Akcija spasavanja trajala je do kasno sinoć. [ $\leftarrow$ spašavanje je trajalo] (Republika $\left.{ }^{4}, 12\right)$; Proces upoznavanja sa realnom statistikom biće dug, ali je to jedino pravo rješenje. [ $\leftarrow$ Upoznavanje $s$ realnom statistikom biće dugo...] ( $\left.\operatorname{Dan}^{2}, 14\right)$; Proces paljenja olimpijske vatre na samom stadionu, Nacionalnom stadionu, poznatom kao „Ptičje gnijezdo“, već je osmišljen... [ $\leftarrow$ Paljenje olimpijske vatre...] (Pobjeda/Arena $\left.{ }^{3}, 5\right)$.

${ }^{22} \mathrm{O}$ tome više viđeti u: Josip Silić, Funkcionalni stilovi hrvatskoga jezika, Disput, Zagreb, 2006, 68.

${ }^{23}$ Duška Klikovac, op. cit., str. 19. 
Dekomponovanje leksema i birokratizacija jezika...

Prva dva primjera potvrđuju rečeno o upotrebi imenica akcija (organizovanost i učešće više ljudi) i proces (ovđe je dugotrajnost procesa data i eksplicite), dok treći primjer ima nešto drugačije značenje od navedenoga. U njemu se imenicom proces izražava isplaniranost, odnosno organizacija aktivnosti koja se vrši (paljenja vatre).

Upotreba imenica opštijeg značenja može imati i funkciju eufemizacije:

Policijski izvori iz Madrida kažu da je nesrećni navijač vjerovatno bio u teškom alkoholisanom stanju i da je zbog toga izgubio kontrolu i pao. [ $\leftarrow$...bio teško alkoholisan / pijan...] (Vijesti $\left.{ }^{1}, 31\right)$.

S druge strane, odlika je birokratizovanoga stila stihijska upotreba takvih izraza, kad se u rečenici gomilaju jedan za drugim:

Od sredine prošle godine i početka sprovođenja akcije separatnog odlaganja otpada, na području opštine zapaljena su 33, za tu svrhu namijenjena, plastična kontejnera... [ $\leftarrow$ (sprovođenja) separatnog odlaganja otpada, u opštini...] ( Dan $\left.^{2}, 14\right)$.

U tom smislu rečenica koja slijedi mogla bi se okarakterisati kao alarmantna:

...kazao je odbornik DPS-a Haris Krupa i pozvao odbornike opozicije da sa svojim radom pomognu u pravcu zaštite životne sredine. $\left(\operatorname{Dan}^{1}, 15\right)$.

Naime, imenica pravac upotrijebljena je bez stvarnoga osnova, kao manir u izražavanju, čime se pokazuje da ona u datom idiomu nema značenja, da je tzv. riječ-parazit.

Može se shvatiti i drukčije: davno je primijećeno da se u padežnom sistemu crnogorskoga jezika gubi razlika u označavaju pravca (Dat.) i cilja, tj. mjesta završetka kretanja (Acc.). Moguće je da se u našem primjeru to poistovjećivanje reflektovalo i na imenicu, pa se umjesto cilja javio pravac. U navedenome kontekstu cilj bi bio sasvim prihvatljiv, mada informativno redundantan:

...i pozvao odbornike da svojim radom pomognu u zaštiti životne sredine / pomognu u cilju zaštite životne sredine / pomognu da se zaštiti životna sredina.

3.1.2. Nenamjerni, pak, pleonazmi najčešće nastaju usljed nedovoljnoga poznavanja termina, tj. jezika. Oni su mana svakoga stila, pa i specijalnih. Navodimo neke što smo ih pronašli u crnogorskim dnevnim novinama koje smo uzeli za uzorak, ali treba naglasiti da su oni podjednako česti i u razgovornome stilu i da bi im trebalo posvetiti znatno više pažnje:

Narednih dana ćemo uputiti i zahtjev Tenderskoj komisiji tako da očekujemo da će $u$ toku jula mjeseca biti raspisan tender, kazao 
Jelena ŠUŠANJ

je Boro Vučinić. $\left[\leftarrow u\right.$ julu: $u$ toku $=u$; jul $=$ mjesec] $\left(\right.$ Pobjeda $\left.^{1}, 4\right)$; ...Bošković je rekao da je na zboru sa radnicima dogovoreno da se svakodnevno u vremenskom intervalu od 11 do 12 okupljaju ispred Opštine... [ $\leftarrow$ intervalu: interval $=$ vrijeme $]\left(\right.$ Vijesti $\left.^{2}, 23\right) ; \mathrm{Na} d a-$ našnji dan cijena koštanja vekne hljeba o kojoj smo već govorili prevazilazi i 85 centi... [ $\leftarrow$ danas cijena vekne hljeba: cijena hljeba = hljeb košta] $\left(\right.$ Pobjeda $\left.^{1}, 7\right)$; Posebno mi se dopada što su knjige štampane ćiriličnim pismom što doprinosi očuvanju srpske kulture i tradicije. [ $\leftarrow$ ćirilicom] (Dan $\left.{ }^{1}, \mathrm{XIV}\right)$; Obrazlažući optužnicu, tužilac Vukčević je navela da je tokom istražnog postupka ustvrđeno da su optuženi počinili krivično djelo na način kako je to predstavljeno. [ $\leftarrow$ tokom istrage...; kako je predstavljeno / na predstavljeni način: kako $=$ način $]\left(\operatorname{Dan}^{2}, 8\right)$; Nadam se da će ovo biti primjer drugim festivalima, kako treba i na koji način raditi. [ $\leftarrow$ kako treba raditi / na koji način treba raditi: kako = način] (Vijesti² $\left.{ }^{2}, 17\right)$.

3.1.3. Eksplicitnost je jedna od bitnih karakteristika administrativnog stila, težnja da izraz bude što precizniji i tačniji. Umjesto implicitnih gramatičkih sredstava, koriste se eksplicitna leksičko-gramatička obilježja. To, rekli smo, često uzrokuje pojavu i korišćenje pleonastičkih konstrukcija. Neke od tako nastalih sintagmi prerastaju u idiome, ustaljene konstrukcije:

Imao sam uslove da dobijem vajld kartu, jer sam ispunio minimalne kvote za streljački sport. [ $\leftarrow$ streljaštvo] (Pobjeda/Arena ${ }^{3}, 9$ ); Sa druge strane, mislimo da Crna Gora ima veliki potencijal za razvoj turističke privrede. [ $\leftarrow$ turizma] $\left(\mathrm{Dan}^{2}, 14\right)$; ...tako da smo odlučili da u avgustu počnemo sa radovima ne bi li sve pripremili za zimski period kada je grijanje neophodno... [ $\leftarrow$ zimu] $\left(\operatorname{Dan}^{2}, \mathrm{XIII}\right)$; ...posljednji je put nastupio u pulskoj Areni prije šest godina kada je koncert pred oko osam hiljada gledalaca prekinulo olujno nevrijeme. [ $\leftarrow$ prekinula oluja] $\left(\mathrm{Dan}^{3}, \mathrm{XXI}\right)$; da će izrada planske dokumentacije biti usmjerena u tom pravcu. [ $\leftarrow$ planova] (Pobjeda $\left.{ }^{1}, 4\right)$; $\mathrm{Na}$ afričkom kontinentu ima mnogo takvih primjera... [ $\leftarrow$ U Africi] (Pobjeda ${ }^{1}, 12$ ); Hrvatska državna nagrada Red Danice Hrvatske s lentom i likom Katarine Zrinske je najviše priznanje za civilne osobe... [ $\leftarrow$ civile] $\left(\right.$ Pobjeda $\left.^{3}, 6\right)$; To je, prije svega, cijena benzina, zatim cijene parkinga, plažnih rekvizita, prehrambenih proizvoda i napitaka... [ $\leftarrow$ hrane] (Pobjeda $\left.{ }^{3}, 17\right)$; Postavlja se pitanje, sasvim bezazleno i dobronamjerno: Dokle će SDP, kao koalicioni partner DPS-a, da stvara incidentne situacije u crnogorskom parlamentu... [ $\leftarrow$ incidente] (Vijesti $\left.{ }^{2}, 2\right)$; Traženi kandidati su uglavnom starosnog doba između 30 i 40 godina. [ $\leftarrow$ starosti] (Vijesti $\left.{ }^{2}, \mathrm{VI}\right)$; On je obećao materijalnu pomoć, te najavio sanaciju stanova na drugom spratu, odnosno izgradnju novog potkrovlja i stavljanje krovnog po- 
Dekomponovanje leksema i birokratizacija jezika...

krivača. [ $\leftarrow$ krova] (Pobjeda $\left.{ }^{2}, 17\right)$; Obratio sam se ministru prosvjete i nauke prof. dr Sretenu Škuletiću da provjeri da li je odabran odgovarajući metod za obezbjeđenje klimatizacije školskog objekta.

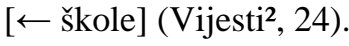

Naveli smo veći broj primjera prije svega da bismo ukazali na njihovu učestalost. Frekventnost ovih i sličnih frazeologizama tolika je da su neki od njih već postali uobičajeni u svakodnevnome govoru.

3.2. Radi cjelovitijeg uvida u problematiku, navodimo i nekoliko primjera pleonazama pri dekomponovanju pridjeva, tj. priloga:

a) stilogeni izrazi: Nikšićki gigant od juče ima i novi logo na kojem je predstavljen metalni krug podijeljen na dva dijela, crno-crvene boje. [ $\leftarrow$ crno-crven] (Dan $\left.{ }^{1}, 19\right)$; Ako su plodovi namijenjeni za prodaju u svježem stanju, proizvodnju kompota i za zamrzavanje, beru se dan do dva prije potpune zrelosti. [ $\leftarrow$ svježe] (Pobjeda ${ }^{2}$, VIII); U saopštenju se navodi da su sjednici prisustvovali svi članovi odbora direktora osim Nikole Martinovića koji je glasao elektronskim putem. [ $\leftarrow$ elektronički] $\left(\right.$ Pobjeda $\left.^{3}, 5\right)$.

b) pleonazmi: Tokom perioda od 5 godina carinske stope na uvoz $\mathrm{u}$ $\mathrm{BiH}$ biće postepeno smanjivane... [ $\leftarrow \mathrm{U} 5$ godina: tokom $=$ period $=5$ godina $\left(\operatorname{Dan}^{1}, 4\right)$; Skup povreda koje je pretrpio mogu i u kasnijem periodu da izazovu komplikacije. [ $\leftarrow$ kasnije] (Republika $^{2}, 31$ ); Danas, kao i u ranijem vremenu, uvijek je bio i ostao aktuelan. [ $\leftarrow$ ranije] (Dan ${ }^{1}$, XIV); Tokom jučerašnjeg dana organizatori budvanskog festivala priredili su završnu konferenciju za novinare... [ $\leftarrow$ juče] $\left(\right.$ Republika $\left.^{1}, 16\right)$.

\section{Analiza primjera birokratizacije jezika u crnogorskim dnevnim novinama}

4.0. Pošto smo objasnili kako se vrši dekomponovanje leksema, teorijski obrazložili birokratizaciju jezika, u ovom dijelu rada analiziraćemo nekoliko primjera različite tematike iz izučavanoga korpusa a u kojima je vidan uticaj administrativnoga stila na publicistički.

4.1. Dnevni listovi Pobjeda i Republika 1. jula 2008. godine donose ovu vijest:

Potrošači sa područja Zete: Bijelo Polje, Bistrice, Ponari, Vukovci, Berislavci, Plavnica, željeznička stanica Zeta, radio-predajnik i Dom zdravlja Golubovci danas će od 9 do 11 sati ostati bez napajanja električnom energijom.

Do prekida u napajanju doći će zbog radova na zamjeni prekidača u TS 35/10 kV „Ponari“. (Pobjeda ${ }^{1}, 17$; Republika $\left.{ }^{1}, 19\right)$ 
U Pobjedi se još dodaje: $U$ slučaju lošeg vremena radovi će biti odloženi.

I. Klajn, rekosmo u Uvodu, navodi četiri bitne osobine birokratskoga stila: preopširnost, komplikovanost, neodređenost i stereotipnost. Primjer koji smo naveli kratak je sam po sebi, pa na osnovu njega ne možemo komentarisati preopširnost, ali ostale karakteristike mogu se lako identifikovati.

Komplikovanost i neodređenost nalaze se $u$ tome što se $u$ ovako kratkome tekstu upotrebljavaju brojne obezličene konstrukcije s dekomponovanim leksemama. $\mathrm{U}$ tom nedostatku glagola te u monotonosti nominalizovanih i dekomponovanih oblika ogleda se i stereotipnost datoga teksta.

Znamo da je administrativnome stilu svojstven visok stepen shematizovanosti, da poštuje stroga pravila, razvijene obrasce. ${ }^{24} \mathrm{Ti}$ se obrasci jasno primjećuju u navedenome tekstu, koji su novinari proslijedili čitaocima onako kako su ga dobili, bez ikakvih, a neophodnih, novinarskih (i lektorskih) intervencija. Prije svega, ponavljaju se iste ili slične fraze: ostati bez napajanja, prekid u napajanju; radovi na zamjeni, radovi će biti odloženi. No, idemo redom.

Treba imati na umu da je vijest objavljena u novinama upućena upravo potrošačima struje koji žive u pomenutim mjestima, ne nekoj instituciji koja se bavi distribucijom struje ili čime sličnim. Stoga treba jasno da ukaže na to što će se desiti, kad će se desiti, zašto će se to desiti, ko će biti odgovoran...

U prvoj rečenici saznajemo da potrošači (žitelji se nazivaju potrošačima, sasvim u skladu s terminologijom administracije, tj. elektroprivrednoga preduzeća) iz dijela Zete jedno vrijeme neće imati struju. Umjesto imenice struja upotrebljava se stručni termin električna energija. Administrativna praksa uslovila je da se umjesto sintagme imati/nemati struju upotrijebi znatno duža i komplikovanija sintagma: ostati bez napajanja električnom energijom.

Druga rečenica pravo je oličenje birokratizovanoga stila: u šesnaest riječi sadrži čak dvije višečlane dekomponovane jedinice. Bezličnom konstrukcijom doći do prekida u napajanju zaobilazi se imenovanje agensa, ne otkriva se ko će to stanovnicima dijela Zete isključiti struju, tj. da upotrijebimo terminologiju iz teksta, da prekine napajanje električnom energijom. Najavljuje se nešto što će se sigurno desiti, ali očito bez ičije intervencije (upor. Iz seizmološke službe javiše da može doći do zemljotresa (razg.)). Iz nastavka rečenice vidimo da će neko ipak intervenisati, tj. raditi na zamjeni prekidača. Upotrebom nominalizovanog oblika zbog radova na zamjeni... u funkciji uzročne rečenice nanovo je izbjegnuto imenovanje vršioca radnje ( $\mathrm{tj}$. radova na zamjeni prekidača).

${ }^{24}$ Marina Katnić-Bakaršić, Lingvistička stilistika, Open Society Institute, Center for Publishing Development, Electronic Publishing Program, Budimpešta (elektroničko izdanje), 1999, 31. 
Dekomponovanje leksema i birokratizacija jezika...

Impersonalizovana je i posljednja rečenica toga kratkog saopštenja (koju objavljuje samo Pobjeda). Ona donosi nove formule birokratizovanoga jezika. Umjesto precizne uslovne rečenice (Ako bude padala kiša), čitamo frazu: U slučaju lošeg vremena, đe se ne definiše ni što bi to loše vrijeme moglo da bude (oblačnost, kiša - slabija ili jača, pljuskovi, grmljavina...). Na kraju, sasvim dosljedno, pasivna konstrukcija još jednom uklanja vršioca radnje iz fokusa, on postaje redundantan, irelevantan, pa se i ne navodi. Radovi će biti odloženi, a ko će ih odložiti, kao i ko će ih obavljati, iz citiranoga se teksta ne može saznati.

Istina, zna se da se distribucijom struje u Crnoj Gori bavi Elektroprivreda Crne Gore, tj. lokalne elektrodistribucije, i da je saopštenje došlo iz neke od tih institucija. No to ne mijenja mnogo stvar kad govorimo o stilu kojim je tekst pisan i načinu na koji je vijest prezentovana čitaocima.

Tekst koji smo naveli odlikuju sve osobine administrativnoga stila. Nema ništa neobično, ništa negativno kad na taj način komuniciraju institucije međusobno ili institucija i pojedinac. Ipak, kad se takav tekst nađe u novinama, postaje primjer lošega novinarskog stila, jer u njemu dolazi do tzv. zamjene koda (code confusing). U novinskom tekstu, naime, neprimjereno se, neadekvatno primjenjuju karakteristike drugoga koda, tj. drugoga funkcionalnoga stila. ${ }^{25}$

Primjer tzv. promjene koda (code switching), kad se s jednog načina izražavanja, adekvatnog u određenim nejezičkim situacijama, prelazi na drugi, tj. izražavanje se prilagođava novonastalim, drugačijim nejezičkim momentima, nalazimo u istome obavještenju koje čitamo u Vijestima od 1. jula 2008. godine, str. 25:

Potrošači sa područja Zete, sela Bijelo Polje, Bistrica, Ponara, Vukovaca, Berislavaca, Plavnice, željeznička stanica Zeta, radiopredajnik i Dom zdravlja neće imati struje od 9 do 11 časova. U tom vremenu radnici Elektrodistribucije mijenjaće prekidač u TS 35/10 kV Ponari.

Tako sročena vijest sasvim je precizna, jasna i, za razliku od prethodnoga njezina vida, potpuna i zamjerke joj po pitanju informativnosti ne može biti, premda se i ovđe domaćinstva nazivaju potrošačima a prilog tada dekomponuje u imensku sintagmu $u$ tom vremenu.

4.2. Uticaj birokratskoga izražavanja izrazit je u sljedećem primjeru:

Nalozi za odvoz vode, kako se navodi u saopštenju, izdaju se $\underline{u}$ cilju blagovremenog i organizovanog preduzimanja potrebnih mjera

${ }^{25}$ O zamjeni i promjeni koda više viđeti u: Radovanović, Milorad, Sociolingvistika, Izdavačka knjižarnica Zorana Stojanovića, Sremski Karlovci - Novi Sad, 2003, str. 168. 
oko obezbjeđenja vode za bezvodna područja i sprječavanja suše u Glavnom gradu. (Pobjeda $\left.{ }^{2}, 17\right)$

Novinar se, istina, ogradio napominjući da je u pitanju dio saopštenja jedne institucije, ali kako je već intervenisao u saopštenju, nije ga prenio cijelo, valjalo bi da je izmijenio i način na koji se u njemu govori. Brojne nominalizacije i dekomponovanja uslovili su da izraz bude dug i nejasan. Dio preduzimanje potrebnih mjera frazem je preuzet iz administrativnih šablona koji ne nosi nikakvu novu informaciju: sve što bi on mogao da znači obuhvaćeno je pridjevom organizovanog. Rečenica bi, stoga, bila jasnija kad bi glasila:

Nalozi za odvoz vode, kako se navodi u saopštenju, izdaju se radi blagovremenog i organizovanog obezbjeđenja vode za bezvodna područja i sprečavanja suše u Glavnom gradu -

ako bi se novinar odlučio da zadrži nominalni stil. Ako bi pak nominalni stil zamijenio verbalnim, jedna od mogućnosti bila bi:

Nalozi za odvoz vode, kako se navodi u saopštenju, izdaju se da bi se blagovremeno i organizovano obezbijedila voda za područja u kojima je nema $i$ spriječila suša u Glavnom gradu.

4.3.1. Sljedeća rečenica preuzeta je iz reportaže o selu u Andrijevici. Novinar razgovara s čovjekom u kafani i bilježi sljedeću njegovu rečenicu:

Često mi ovdje imamo naše seoske „okrugle stolove“ gdje uz obavezne i neobavezne razgovore vršimo degustaciju i ,piskavice“ $i$ „,debelice“. [ $\leftarrow$ degustiramo i ,piskavicu“ i „debelicu“] (Dan $\left.{ }^{4}, 17\right)$.

Iz konteksta se vidi da je rečenica primjer razgovornoga stila. Nije uobičajeno da seljani isprobavanje i konzumiranje rakije i hrane nazivaju degustiranjem, ali mi ovđe nećemo ulaziti u karakteristike rječnika. Uostalom, može biti da je riječ upotrijebljena u šali ili čak ironično. Nas interesuje nešto drugo.

Rekli smo da se dekomponovani glagol često upotrebljava da bi se radnji dao karakter institucionalizovanosti, organizovanosti. Tako bi se u nekom saopštenju, uputstvu, pa i reportaži iz kakve vinarije moglo govoriti o vršenju degustacije prije nego se piće pusti u promet.

Dekomponovanje, koje nosi izraz apstraktnosti, intelektualizovanosti označene radnje, nije postupak koji karakteriše, niti treba da karakteriše razgovorni stil. I ova rečenica, dakle, predstavlja primjer zamjene koda, a ovđe je navodimo da ukažemo na to da se birokratizacija jezika ne očitava samo u jeziku masovnih medija, već da je njen opseg mnogo veći.

Pri tom, poznato je da novinar ne prenosi uvijek doslovan iskaz sagovornika, već stilski interveniše. Stoga je moguće da i u toj rečenici dekomponovani izraz nije izvoran, već rezultat naknadne intervencije novinara. 
Dekomponovanje leksema i birokratizacija jezika...

\subsubsection{Rečenica koja slijedi dio je reportaže o Plavu:}

Sunce ovih dana sija punim kapacitetom, što je neuobičajeno za krajeve sa planinskom prepoznatljivošću. $\left(\operatorname{Dan}^{1}, 16\right)$

Reportaže su podstil publicističkoga stila i karakteriše ih jača veza $\mathrm{s}$ književnoumjetničkim izrazom. Slikovitost i metaforičnost njegova su obilježja. Ipak, reklo bi se da se novinar izgubio između težnje za slikovitošću i birokratske frazeologizacije.

U novinama se sve češće izvještava o punim smještajnim kapacitetima, o proširenju kapaciteta neke institucije, o poboljšanju infrastrukturnih kapaciteta... Imenica kapacitet zauzela je siguran položaj u nizu birokratskih izraza. Ipak, govoriti o kapacitetu sunčeva sjaja zaista nadilazi horizont čitaočevih očekivanja. Moglo se reći da sunce jako sija, da je izuzetno vruće, da je vrijeme pravo ljetnje, da je toplo, da je sunčano, vedro..., ali novinaru to očito nije bilo dovoljno izražajno, pa se odlučio da kancelarijski rječnik iznese u polje i progovori o kapacitetima Sunca, kao da podnosi izvještaj nadzornom organu o situaciji koju je zatekao na Zemlji. Ostaje pitanje: koliko bi sunce sijalo sa $47 \%$ kapaciteta?!

Odnosna rečenica donosi nove birokratski stilizovane ekspresije: planinska regija oko Plava opisuje se kao krajevi sa planinskom prepoznatljivoš́u. Istina je: krajevi na śeveru Crne Gore prepoznatljivi su po planinama, pa i cijela Crna Gora. No nije jasno zašto se prepoznatljivost ističe u tome kontekstu. Na sunčev sjaj ne utiče je li neki predio prepoznat kao ravan, brdovit ili planinski. Prepoznatljivost je informacijski (i logički) irelevantna, a i stilski je neprikladno upotrijebljena riječ. sija?!

Konačno, zašto bi bilo neuobičajeno da sunce ljeti u planinama jako

Rečenica u navedenome obliku nema vrijednost (evo primjera eufemističke upotrebe dekomponovanja) ni stilsku, ni informativnu, pa ni logičku. Vrijedna je, s druge strane, kao izvanredan primjer kapaciteta birokratskog izražavanja, đe se komplikovanim spletovima riječi kazuju opštepoznate stvari.

4.4. U tzv. crnim hronikama u novinama najčešće se donose vijesti vezane za saobraćajne nesreće, za krađe, zloupotrebe droga i sl. Sasvim je jasno da se takve novosti ne mogu plasirati bez saradnje sa policijom. A iz policije se obično šalju saopštenja i obavještenja koja su rađena po utvrđenom obrascu. To podrazumijeva brojne frazeologizme, dekomponovanja i slične postupke.

\subsubsection{Rečenica:}

B. M. je, kako se sumnja, oštećenom izvršio predaju vozila sa dokumentima, iako je znao ili morao znati da je saobraćajna dozvola falsifikovana i da vozilo nije uredno registrovano $\left(\operatorname{Dan}^{2}, 9\right)$, 
ne iskače iz pravilā i shemā kojima se rukovodi policijski administrativni diskurs. No, ni takvom dekomponovanju nema mjesta u stilovima van administrativnoga. Izvršenje predaje vozila u tome slučaju nije institucionalizovani čin, da bi se dekomponovanjem iskazao taj element značenja. Njime se ne uklanja tranzitivnost, ne unosi se slikovitost, posebna determinacija ili što slično. Dakle, razloga za dekomponovanje nema. Moglo se jednostavno napisati:

B. M. je, kako se sumnja, oštećenom predao vozilo s dokumentima...

\subsubsection{U istoj rubrici i s istim obilježjima čitamo:}

Pretresom stana Dž. B., pronađen je i oduzet pištolj marke „CZ“ 99 cal. 9 mm - luger, koji je ovo lice držalo u ilegalnom posjedu $\left(\operatorname{Dan}^{2}, 8\right)$.

Često se u takvim tekstovima citiraju djelovi saopštenjā koja su iz uprave policije ili centra bezbjednosti upućena uredništvu novina. No za tim nema potrebe, jer se i preko toga šablonizovanog postupka kod primalaca informacije (u datome slučaju čitalaca dnevnih novina) zadržavaju određene konstrukcije, kojima se tako olakšava put ka razgovornome jeziku.

Nominalizovana sintagma s početka rečenice ima funkciju ekvivalentnu vremenskoj rečenici: Kad je pretresan stan $D \check{z}$. B. Bez promjene značenja može se upotrijebiti i glagolski prilog sadašnji (Pretresajući stan Dž. B.), ali bi to u nastavku rečenice zahtijevalo imenovanje vršioca radnje, tj. onoga ko je pretresao stan (policajci), što je ovđe (u pasivnoj rečenici) zaobiđeno.

Zanimljiva je i upotreba imenice lice. Umjesto imenice osoba (ili u datom kontekstu $D \check{z}$. B., tj. zamjenice on/ona, pri čemu se, istina, izriče pol), javlja se imenica lice, specifična za policijski žargon, kojom se takođe vrši depersonalizacija (korišćenjem te imenice, srednjega roda, izbjegava se prvenstveno izricanje i isticanje pola osobe o kojoj je riječ). To „lice“ $d r z ̌ i$ pištolj, i to $u$ ilegalnome pośedu. Frazem držati pištolj u pośedu može se zamijeniti prikladnijom sintagmom ,,pośedovati pištolj“. Nije potrebno ni prilog ilegalno razlagati na tročlanu imensku sintagmu u ilegalnom pośedu.

Dakle, rečenica bi čitaocima bila pregledanija i jasnija da je glasila:

Pretresajući stan Dž. B., policajci su pronašli i oduzeli pištolj marke „CZ“ 99 cal. $9 \mathrm{~mm}$ - luger, koji je on pośedovao ilegalno.

4.4.3. Rečenica koja slijedi vjerovatno je najočigledniji prikaz birokratizovanoga diskursa. U njoj je dekomponovano sve što se moglo razložiti:

U trajanju do šest sati, zadržana su 42 lica, od kojih je, kod 38 tokom kontrole konstatovano prisustvo alkohola u krvi u većoj mjeri od dozvoljene za vrijeme dok su upravljali motornim vozilom, dok su četiri lica odbila alkotestiranje. (Pobjeda $\left.{ }^{1}, 8\right)$ 
Dekomponovanje leksema i birokratizacija jezika...

Prvi istaknuti dio rečenice ima opravdanje, premda je pleonastičan. Ako bi se napisalo: Četrdeset dva lica zadržana su do šest sati, stvorila bi se nedoumica jesu li oni zadržani do šest sati prije tj. poslije podne ili najviše šest sati.

Druga sintagma najzanimljivija je za interpretaciju: kod 38 lica konstatovano je prisustvo alkohola u krvi - u većoj mjeri od dozvoljene. Što to znači? - Trideset osam ljudi, od zadržanih 42 , bilo je pijano. No, u administrativnom diskursu pijan nije adekvatna riječ. Ona ima mnoštvo sinonima, uglavnom višečlanih. Pijan čovjek je lice pod dejstvom alkohola, lice u alkoholisanom stanju, lice kod koga je utvrđeno prisustvo alkohola u organizmu ili, pak, lice koje pokazuje znake alkoholne poremećenosti. Navodimo stav 2 iz člana 200 crnogorskoga Zakona o bezbjednosti saobraćaja na putevima (Službeni list RCG, br. 72/2005):

Pod dejstvom alkohola je lice za koje se analizom krvi ili krvi i urina ili drugom metodom mjerenja količine alkohola u organizmu utvrdi da sadržina alkohola u krvi iznosi više od $0,5 \mathrm{~g} / \mathrm{kg}$ ili ako je prisustvo alkohola u organizmu utvrđeno odgovarajućim sredstvima ili aparatima (alkometrom i dr.) za mjerenje alkoholisanosti, što odgovara količinama većim od $0,5 \mathrm{~g} / \mathrm{kg}$ ili kod koga se, bez obzira na sadržinu alkohola u krvi, stručnim pregledom utvrdi da pokazuje znake alkoholne poremećenosti.

Frazemi koje primjećujemo u citatu iz Zakona često se koriste i u drugim stilovima, publicističkome naročito, u kome pri tom dobijaju eufemističko značenje, koje u administrativnom diskursu nemaju. U težnji za analitičnošću u birokratskim obrascima sve se iznosi raščlanjeno, u vidu definicija. Tako se i u navedenome tekstu iz novina pijana osoba naziva licem kod koga je konstatovano prisustvo alkohola u krvi - u većoj mjeri od dozvoljene.

Imenica prisustvo upotrebljava se da uz apstraktne pojmove i pojmove koji označavaju neživo, što je prepoznatljiva osobina birokratskoga jezika. ${ }^{26}$

Vozači, pretpostavlja se, znaju koliko alkohola smiju popiti kad voze, ali ne znaju svi čitaoci novina u kojima je ta informacija objavljena koliko je alkohola u krvi pri vožnji u Crnoj Gori Zakonom dozvoljeno (te odredbe nijesu iste u zakonima svih zemalja). Stoga je umjesto cijele petočlane imenske sintagme niskog informativnoga potencijala ( $u$ većoj mjeri od dozvoljene) bolje bilo napisati: više od 0,5 promila. Vijest bi bila potpunija, preciznija i jasnija.

U uobičajene namjerne pleonazme spada i naredna konstrukcija u rečenici: za vrijeme dok. Veznik dok svrstava se u veznike kojima se obilježava vrijeme (bilo u vremenskim rečenicama, bilo u suprotnim rečenicama pseu-

${ }^{26}$ Upor. Klajn u: Ivić et al., op. cit., str. 190. 
dozavisnoga karaktera). Nema potrebe, dakle, dodatno ukazivati na ono što se podrazumijeva. I to je posljedica težnje za raščlanjivanjem u administrativnim tekstovima.

U skladu sa svime rečenim, u navedenoj rečenici glagol voziti dekomponuje se na sintagmu upravljati vozilom, s tim što je ovo raščlanjivanje opravdano potrebom da se determiniše tip vožnje (dakle, ono što je kazano odnosi se na one koji voze motorna vozila, ne bicikl ili trotinet).

Da zaključimo, rečenica bi bila jasnija i informativnija u obliku:

Četrdeset dvije osobe zadržane su na najviše šest sati. Kod 38 njih kontrolom je konstatovano da su imali više od 0,5 promila alkohola u krvi dok su upravljali motornim vozilom, a četiri lica odbila su alkotestiranje.

4.5. S crne hronike prelazimo na sportske stranice. Reklo bi se da su formulacije birokratskoga tipa u izvještavanju o sportu neočekivane. Ipak, i na tim stranicama mnoštvo primjera nepotrebno dekomponovanih izraza ukazuje na to da je birokratizacija zaista uzela maha. Analiziraćemo tri primjera.

4.5.1. Na 8. strani Arene, sportskog dodatka Pobjede, u broju od 1. jula 2008. godine, čitamo:

Iz crnogorske vaterpolo kuće su nam javili kako od organizatora nijesu dobili traženu kvotu karata, pa su preko interneta obavili kupovinu ulaznica.

Kupovina ulaznica, premda je obavlja institucija - Vaterpolo savez Crne Gore, nije apstraktan čin. Tekst u kojem se govori o trgovini ulaznica za neku utakmicu (ili više njih) ne (treba da) karakteriše intelektualizovanost. Nijedan od u prethodnim poglavljima navedenih uzroka dekomponovanja ne postoji da bi se ovđe koristio raščlanjeni predikat.

Nećemo govoriti o upotrebi termina „tražena kvota“, umjesto čitljivijeg „koliko su tražili“. Osvrnućemo se ipak na informativnu aktualizaciju rečenice. ${ }^{27}$ Složena rečenica u primjeru sadrži dvije naporedne sastavne rečenice. U prvoj od njih saznajemo da Vaterpolo savez Crne Gore od organizatora nije dobio karata koliko je tražio. Druga rečenica, pseudozavisnoga posljedičnog karaktera, treba da iskaže kako su do karata na kraju došli. Stoga bi valjan redosljed rečeničnih konstituenata u drugoj rečenici bio: objekat (kao ono što je poznato iz prethodnog konteksta) + predikat (kao djelimično nova informacija: karte nijesu dobijene, kupljene su) + priloška odredba (kao sasvim nova, samim tim najbitnija, informacija).

27 Živojin Stanojčić, Ljubomir Popović, Gramatika srpskoga jezika, Udžbenik za I, II, III i IV razred srednje škole, Zavod za udžbenike i nastavna sredstva Beograd Zavod za izdavanje udžbenika Novi Sad, Beograd - Novi Sad, 1992², str. 354. 
Dekomponovanje leksema i birokratizacija jezika...

Informativnost je, dakle, u citiranome primjeru umanjena rasporedom rečeničnih djelova, tj. time što se umjesto odredbe načina u rečeničnome fokusu našao dekomponovani predikat s informacijski redundantnim sadržajem.

Sve opisano, a prije svega nepotrebno dekomponovanje predikata, rečenicu čini paradigmatičnim primjerom zamjene koda. U publicističkom stilu ona bi trebalo da glasi:

Iz crnogorske vaterpolo kuće javili su nam kako od organizatora nijesu dobili karata koliko su tražili, pa su ih kupili preko interneta.

\subsubsection{Sljedeći primjer tiče se dvostruke pasivizacije:}

Tim je, kao uostalom i stadion pod Malim brdom, u odnosu na prošlogodišnji pretrpio renoviranje. ( $\left.\mathrm{Dan}^{2}, \mathrm{III}\right)$

Govorili smo u tački 2.2.11. o sredstvima pasivizacije - sintaksičkim i semantičkim - u jeziku. U ovom primjeru rečenica je „pretrpjela“ dvostruku pasivizaciju: i sintaksičku i leksičku. Glagol renovirati razložen je na tranzitivni glagol pretrpjeti i deverbativnu imenicu renoviranje, sa značenjem glagola iz kojeg je derivirana. Trpni glagolski pridjev nosi ime po tome što označava da je na nekome/nečemu vršena radnja, tj. da neko/nešto trpi radnju. Uz takav pasiv eksplicitno izražavanje trpljenja nije potrebno. Uz to, glagol pretrpjeti unosi određeni emocionalni naboj u rečenicu, te se pretrpljeno renoviranje tima može shvatiti kao mučan proces.

Dvostruka pasivizacija u beletrističkome stilu bila bi vjerovatno efektna i upečatljiva. U izvještavanju o promjenama u Fudbalskom klubu Petrovac nije tako.

Neka dalja analiza mogla bi se ticati i upotrebe glagola renovirati $(\mathrm{t} j$. imenice renoviranje) u vezi s imenicom koja označava živo.

4.5.3. U izvještavanju o sportu statistika zauzima posebno mjesto. U svim sportovima prave se tabele sa svim podacima, na njima se jasno prikazuje ko je ostvario kakav rezultat, ko je bio prvi, ko posljednji, ko je dao najviše golova / skočio najdalje ili najviše / trčao ili plivao najbrže... I tu varanja nema. Do varanja, ili zavaravanja, ipak može doći kad novinar komentariše ono što je sportista ili klub postigao. Razlozi su brojni, najčešće subjektivni (lični ili nacionalni), no o njima ovđe nećemo govoriti.

Da bi se neki loš rezultat prikazao u, u najmanju ruku, manje lošem svijetlu, dekomponovanje leksema može se pokazati kao vrlo svrsishodno.

Početkom juna učestvovali su i na svjetskom prvenstvu u Francuskoj, ali tamo nijesu postigli značajniji uspjeh. U konkurenciji 25 ekipa zauzeli su posljednje mjesto. $\left(\operatorname{Dan}^{1}, 17\right)$ 
U prvoj rečenici saznajemo da se ekipa takmičila na svjetskom prvenstvu. Ostvareni rezultat predstavlja se dekomponovanim predikatom nijesu postigli uspjeh uz imenički determinator značajniji. Zadržaćemo se za trenutak na atributu. U pitanju je pridjev u komparativu. Novinar nas informiše da značajniji uspjeh nije postignut, ali znači li to da značajan uspjeh jeste?!

U birokratizovanim izrazima komparativ se često upotrebljava van pravoga značenja i može da bude činilac ublažavanja smisla. Eufemističku notu u citiranu rečenicu unosi i sam pridjev svojim značenjem, bez obzira na stepen komparacije. Druga rečenica obavještava nas da je ekipa o kojoj je riječ bila posljednja na tom takmičenju. Sportisti koji uđu u finale nekog takmičenja i ne pobijede znaju da kažu: Nijesmo osvojili srebro, izgubili smo zlato. U skladu s tim, je li u našem primjeru postignut ikakav (a kamoli značajan) uspjeh?! Nije osvojeno posljednje, izgubljeno je i pretposljednje mjesto.

Iz toga se vidi da prva navedena rečenica ima funkciju ublažavanja značenja druge rečenice. To se realizuje dekomponovanim glagolom u funkciji predikata i pridjevom sa značenjem pozitivne osobine u komparativu.

4.6. Za kraj ove analize ostavili smo primjer:

Pun stadion i pjevač zvučali su kao jedan glas, dok je štimung pravio i vatromet pirotehničkih efekata. $\left(\right.$ Pobjeda $\left.^{2}, 28\right)$

Dekomponovani predikat ,pravio je štimung“ frazeologizam je koji smo obilježili kao primjer kad se iz imenice ne može izvesti glagol (ne postoji glagol štimungovati, štimungirati, štimungati...). Napomenuli bismo jedino da glagol praviti podrazumijeva „svjesnu“ aktivnost, čega kod vatrometa biti ne može. Za interpretaciju je zanimljiv subjekat te rečenice, sintagma vatromet pirotehničkih efekata. Imenica efekat plodna je u konstrukcijama administrativnoga stila i birokratizovanoga jezika reklama: kreme imaju blagotvoran efekat, sirena ostvaruje zvučni efekat...

Ako znamo da je vatromet jedno od pirotehničkih sredstava, vidimo da sintagma zapravo označava pirotehničko sredstvo pirotehničkih efekata. Imenica i njena odredba imaju ekvivalentno značenje, što sintagmu čini pleonastičnom. Prema svemu navedenome, ispravno bi bilo reći: ...dok je štimungu doprinosio i efektan vatromet.

Tu konstrukciju ostavili smo za kraj više simbolično: kao primjer pirotehničkih efekata birokratizacije jezika.

\section{Zaključak}

5.0. Cilj rada bio je da se prikaže dekomponovanje leksema u funkciji birokratizacije jezika. Na osnovu 248 izloženih i analiziranih primjera preuzetih iz dnevnih novina koje su izlazile u Crnoj Gori 1-4. jula 2008. godine, pokušali smo da ukažemo na osnovne karakteristike dekomponovanja glago- 
Dekomponovanje leksema i birokratizacija jezika...

la i imenica. Nakon takve teorijske interpretacije procesa dekompozicije, jedanaest primjera iz novinskih tekstova različitog karaktera detaljno smo analizirali s aspekta birokratizacije jezika i mogućnosti promjene koda koja bi uslovila jasnije i potpunije informisanje.

U teorijskom dijelu (poglavlja II i III) primjere smo analizirali rekonstruišući dubinsku strukturu, pri čemu smo koristili transformacioni test. Umjesto dekomponovanih leksema koje prepoznajemo u površinskoj strukturi, u dubinskoj strukturi javljaju se punoznačni glagoli ili imenice.

5.1. Uticaj administrativnoga stila na ostale funkcionalne stilove izrazit je jer se mnoge oblasti čovjekove djelatnosti normiraju, propisuju i kodifikuju administrativnim sredstvima. U tom smislu donose se rješenja, odluke, instrukcije, propisi, statuti, zakoni..., a svi imaju ustaljeni obrazac, shemu, stereotipni su. Kako shema lako upada u oči, lako se pamti, otuda se lako i primjenjuje u drugim situacijama (i jezičkim i izvanjezičkim) đe nije prikladna. $\mathrm{Na}$ taj način dolazi do zamjene kodova (code confusing), kad elementi administrativnoga (najčešće, ali može i bilo kog drugog) izraza zalaze u sferu drugih stilova i onamo se ustaljuju.

5.2. Dekomponovanje je, viđeli smo, izuzetno produktivan proces. Našu analizu zadržali smo u granicama raščlanjivanja glagola i imenica zbog obima rada, premda i dekomponovanje pridjeva, priloga i veznika ne treba zanemarivati.

a) Punoznačni glagol raščlanjuje se na višečlanu konstrukciju koju čine kopulativni ili semikopulativni glagol i deverbativna imenica kao nosilac značenja. Kao dio takvoga glagola u površinskoj strukturi može se naći i deadjektivna imenica, tj. imenica koja je izvedena iz pridjeva, ali jedino ako je u semantički čvrstoj vezi sa istoznačnim glagolom (vrijednost, mogućnost, saglasnost, hrabrost...). Premda u nauci stoji mišljenje da se dekomponuju glagoli apstraktnoga značenja, pokazali smo da se mogu raščlanjivati i glagoli koji označavaju neku konkretnu radnju: graditi put $\rightarrow$ raditi na izgradnji puta $\rightarrow$ vršiti / izvoditi / obavljati radove na izgradnji puta

Kad se kao verbalni dio dekomponovane konstrukcije nađe kopulativni glagol, imenski dio čini deverbativna ili deadjektivna imenica u nominativu (Očekivanja su $\leftarrow$ Očekuje se), genitivu (slobodnom - biti mišljenja $\leftarrow$ misliti - ili vezanom: s prijedlogom od - biti od koristi $\leftarrow$ koristiti) ili lokativu s prijedlozima $u$ ili na (biti u planu $\leftarrow$ planirati, biti u mogućnosti $\leftarrow$ moći, biti na raspolaganju $\leftarrow$ raspolagati). Može se javiti i specifična konstrukcija u kojoj je deverbativna ili deadjektivna imenica u nominativu (i vrši funkciju subjekta rečenice), a u predikatu se javlja kopula (glagol biti u finitnom obliku) i neki kvantifikator ili kvalifikator (primanja će biti znatno veća $\leftarrow$ primiće se znatno više; vrijednost radova je 1.200 .000 eura $\leftarrow$ radovi vrijede 1.200.000 eura). 
Kao verbalni dio dekomponovane glagolske lekseme može se upotrijebiti i semikopulativni glagol, koji najčešće zahtijeva dopunu u akuzativu bez prijedloga. Takvi su glagoli vršiti (uslugu $\leftarrow$ usluživati), raditi (kombinaciju $\leftarrow$ kombinovati), činiti (prekršaj $\leftarrow$ prekršiti), ostvariti (pobjedu $\leftarrow$ pobijediti), praviti (prestup $\leftarrow$ prestupati), obaviti (razmjenu $\leftarrow$ razmijeniti), voditi (razgovor $\leftarrow$ razgovarati), imati/nemati (mogućnost $\leftarrow$ moći / ne moći), dati / dobiti (poziv $\leftarrow$ pozvati / biti pozvan), nositi (nalog $\leftarrow$ naložiti). Ne moraju svi glagoli biti tranzitivni, tj. ne moraju svi imati dopunu u akuzativu bez prijedloga. Na primjer, raditi na naplati ( $\leftarrow$ naplaćivati), raditi na usavršavanju ( $\leftarrow$ usavršavati), ili, pak, ići sa odlukom ( $\leftarrow$ odlučiti), ili u ići na dogovor $(\leftarrow$ dogovarati), te obezličena konstrukcija doći do, koja traži imenicu u genitivu: doći do zaključka ( $\leftarrow$ zaključiti).

b) Pri dekomponovanju imenica vrši se ekstrakcija opšteg pojma koji imenica obuhvata, tj. podrazumijeva, i to tako da punoznačna imenica postaje odredba opštoj. Taj se proces naziva intenzifikacijom. Najfrekventnije imenice opštega karaktera su: proces, postupak, faza, oblast, nivo, polje, oblast, akcija... Kako često ne unose nikakvo novo značenje u imenicu uz koju stoje ove se imenice mogu nazvati riječima-parazitima.

Opasnost koja vreba u procesu dekomponovanja imenica jeste pleonastičnost tako nastalih izraza. Ona može biti namjerna (akcija prikupljanja $\leftarrow$ prikupljanje) ili nenamjerna (mjesec jun $\leftarrow$ jun). Namjerni pleonazmi odlika su specijalnih stilova, apstraktnoga i intelektualizovanoga karaktera (a to su administrativni, publicistički i naučni), samim tim su stilogeni, dok nenamjerni pleonazmi nastaju kao posljedica nedovoljnoga poznavanja značenja riječi i mana su svakoga stila.

5.3. Lekseme se dekomponuju iz različitih razloga: za neutralizaciju tranzitivnosti (vršiti analizu $\leftarrow$ analizirati nešto), za iskazivanje anonimnog ili uopštenog agensa (bilo je polemika $\leftarrow$ polemisalo se), za obilježavanje institucionalizovanosti radnje (voditi pregovore $\leftarrow$ pregovarati). Jednočlani glagol i njegov višečlani derivat ne moraju biti sinonimi (vršiti uviđaj $\leftarrow$ uviđati). Dekomponovanom se leksemom može napraviti razlika između konkretnosti i apstraktnosti radnje (izvršiti pritisak $\leftarrow$ pritisnuti), a može se i izvršiti leksička pasivizacija, umjesto sintaksičke (nanijeti poraz / pretrpjeti poraz $\leftarrow$ poraziti / biti poražen). To je pogodno sintaksičko sredstvo za determinisanje radnje (zadobiti slabe opekotine $\leftarrow$ slabo se opeći), kao i za izražavanje pluralizacije predikacije (zadobiti povrede $\leftarrow$ povrijediti se).

U vezi s birokratskim izražavanjem najvažniji momenat dekomponovanja leksema jeste eufemizacija koja se na taj način vrši (izvršiti ubistvo $\leftarrow$ ubiti).

5.4. Analizirani primjeri poslužili su nam da pokažemo koliko je zaista česta upotreba dekomponovanih izraza, kakve efekte može imati i koliko utiče na informativnost, kao nužnu i najbitniju osobinu publicističkoga stila. 
Dekomponovanje leksema i birokratizacija jezika...

Dekomponovanje, dakle, nije negativna pojava per se. Naprotiv, može služiti i kao sredstvo bogaćenja rječnika i za slikovito izražavanje. Mana stila postaje kad se upotrebljava stihijski i kad se koristi u cilju manipulisanja i mistifikacije - da se njime neke informacije zataje ili im se umanji značaj.

\section{Literatura}

- Bugarski, Nataša, Deadjektivna imenica kao sredstvo nominalizacije (u publicističkom stilu standardnog srpskog jezika), Zbornik Matice srpske za filologiju i lingvistiku, XLVII/1-2, Novi Sad, 2004, 297-404.

- Čomski, Noam, Gramatika i um, Nolit, Beograd, 1972.

- Ivić, Milka, O zelenom konju (novi lingvistički ogledi), Slovograf, XX vek, Beograd, 1995.

- Ivić, Pavle, Ivan Klajn, Mitar Pešikan, Branislav Brborić, Srpski jezički priručnik, Beogradska knjiga, Beograd, 2006.

- Jezik politike (istraživanja i rasprave), ur. Sanja Vrhovec-Vučemilović, Zagreb, 1987.

- Katnić-Bakaršić, Marina, Lingvistička stilistika, Open Society Institute, Center for Publishing Development, Electronic Publishing Program, Budimpešta (elektroničko izdanje), 1999.

- Klikovac, Duška, Jedna stilska vežba - govorite li birokratski?, Jezik danas, br. 3, Matica srpska, Novi Sad, 1997, 2-7.

- Klikovac, Duška, O javnom jeziku (Eksplicitna kategorizacija imeničkih pojmova), Jezik danas, br. 8, Matica srpska, Novi Sad, 1998, 17-21.

- Pranjković, Ivo, Funkcionalni stilovi i sintaksa, Suvremena lingvistika, 41/42, 1996, 519-527, elektronički časopis:

http://suvlin.ffzg.hr/index.php/suvlin/article/view/106/44.

- Radovanović, Milorad, Imenica u funkciji kondenzatora (I), Zbornik za filologiju i lingvistiku, XX/1, Matica srpska, Novi Sad, 1977, 63-144.

- Radovanović, Milorad, Imenica u funkciji kondenzatora (II), Zbornik za filologiju i lingvistiku, XX/2, Matica srpska, Novi Sad, 1977, 81-160.

- Radovanović, Milorad, Spisi iz sintakse i semantike, Izdavačka knjižarnica Zorana Stojanovića, Sremski Karlovci - Novi Sad, 1990.

- Radovanović, Milorad (red.), Srpski jezik na kraju veka, Institut za srpski jezik SANU, Službeni glasnik, Beograd, 1996.

- Radovanović, Milorad, Još o pojavi dekomponovanja jezičkih jedinica, Zbornik Matice srpske za filologiju i lingvistiku, XLV/12, Novi Sad, 2002, 21-28. 
- Radovanović, Milorad, Sociolingvistika, Izdavačka knjižarnica Zorana Stojanovića, Sremski Karlovci - Novi Sad, 2003.

- Radovanović, Milorad, Planiranje jezika i drugi spisi, Izdavačka knjižarnica Zorana Stojanovića, Sremski Karlovci - Novi Sad, 2004.

- Radovanović, Milorad, Dekompozicija i univerbizacija, Zbornik Matice srpske za filologiju i lingvistiku, XLVII/1-2, Novi Sad, 2004, 43-49.

- Radovanović, Milorad, Stari i novi spisi (Ogledi o jeziku i umu), Izdavačka knjižarnica Zorana Stojanovića, Sremski Karlovci - Novi Sad, 2007.

- Silić, Josip, „Administrativni stil hrvatskoga standardnog jezika“, Kolo, 4, Zagreb, 1996, 349-358.

- Silić, Josip, Funkcionalni stilovi hrvatskoga jezika, Disput, Zagreb, 2006.

- Službeni list RCG, br. 72/2005, 1. 12. 2005. god.

- Stanojčić, Živojin, Ljubomir Popović, Gramatika srpskoga jezika, Udžbenik za I, II, III i IV razred srednje škole, Zavod za udžbenike i nastavna sredstva Beograd - Zavod za izdavanje udžbenika Novi Sad, Beograd - Novi Sad, $1992^{2}$.

- Tošović, Branko, Funkcionalni stilovi, Beogradska knjiga, Beograd, 2002.

\section{Jelena ŠUŠANJ}

\section{LEXICAL DECOMPOSITION AND LANGUAGE BUREAUCRATIZATION ON EXAMPLES TAKEN FROM THE MONTENEGRIN NEWSPAPERS}

The purpose of this paper is to describe the ways of lexical decomposing, its functions and characteristics of its use, to present examples of its good and bad usage in publicistic style and thereby to show the influence of the administrative style on the publicistic. Although we are dealing with the functional stylistics, due to the limited scope of this paper characteristics of each functional style will not be explained separately.

Since decomposition of nouns is a significantly simpler derivational process, in this paper we will deal with decomposition of verbs in more detail, and approach it on the morphological basis. The analysis will primarily be done on syntactic/semantic and transformational basis.

Key words: decomposition, bureaucratization, publicistic style, administrative style, deverbative noun, deadjective noun, copula, semi-copulative verb 
LINGUA MONTENEGRINA, god. III, br. 5, Cetinje, 2010.

Institut za crnogorski jezik i jezikoslovlje „Vojislav P. Nikčević“

UDK 811.163.4'367.634

Izvorni naučni rad

Miomir ABOVIĆ (Tivat)

Univerzitet Mediteran - Podgorica

\title{
O PRIRODI VEZNIKA $A$ \\ I MOGUĆNOSTI KOMUTABILNE UPOTREBE VEZNIKA A I I
}

\begin{abstract}
U radu se razmatraju pitanja koja se odnose na veznik $a$, njegov status u normativnim priručnicima i gramatikama srpskohrvatskoga, srpskog i hrvatskoga jezika, smisaone odnose među klauzama koje se njime povezuju i mogućnosti komutabilnosti veznika $a$ i $i$ u određenim semantičko-gramatičkim kontekstima koji ukazuju na posebnost značenja klauza (ili nekih drugih jezičkih formi) što se vezuju tim veznikom. Konstatovali smo da, pored povezivanja klauza suprotnih/kontrarnih/nepodudarnih po smislu ili povezivanja klauza nepodudarnih rečeničkih konstituenata, veznik $a$ ima i značenje intenzifikacije/isticanja/naglašavanja sadržaja druge klauze (ili neke druge jezičke forme), a to značenje treba snažnije naglasiti u novim normativnim priručnicima i gramatikama bosanskoga, crnogorskog, srpskoga i hrvatskog jezika.
\end{abstract}

Ključne riječi: veznik a, veznik $i$, suprotne rečenice, komutabilnost veznikā, književnojezička norma, BHSCG jezici

Problem na koji ćemo ukazati u ovom radu tiče se određenih aspekata upotrebe veznika $a$, prije svega kontekstā u kojima je moguća komutabilnost njegove upotrebe sa veznikom $i$. Pažnju ćemo pokloniti i tretmanu ove pojave (mogućnosti komutabilne upotrebe veznika $a$ i $i$ u određenim kontekstima) u serbokroatističkoj gramatičkoj literaturi i normativnim priručnicima. Primjere smo ekscerpirali iz korpusa savremene dnevne štampe.

Na mogućnost komutabilnosti upotrebe suprotnih i sastavnih veznika u određenim kontekstima ukazivano je u serbokroatističkoj literaturi. Definišući suprotne rečenice u svom radu o nezavisnosloženim rečenicama i govoreći o odnosu prostih rečenica u njima, M. Ajanović kaže sljedeće: „Za karakteristične suprotne rečenice najbolje je reći, po mom osjećanju, da iskazuju vrstu radnje (stanja ili zbivanja) ili uopće nešto što je suprotno, sasvim drukčije od onoga što je izneseno u rečenici za koju su vezane (jedan je marljiv, iskren, 
pažljiv, a drugi lijen, lažljiv, nepažljiv); a mogu označavati i nejednakost, kao u primjeru: Ti nosiš jednoga, a ja troje. “1 Dalje konstatuje da se ,...tipično suprotno značenje ne iskazuje sa svezom ali, nego svezom $a^{\prime \prime} .{ }^{2}$ Isti autor, međutim, u nastavku svoga rada, pišući o vezniku $a$, konstatuje ,...da je njeno karakteristično značenje ovo: upotrebljava se onda kad u složenoj rečenici treba da se iznese naporedno isticanje, uzajamnost, poređenje, da se o nekom rekne jedno, a o drugom drugo... i sl. - nekad sa suprotnim značenjem“. ${ }^{3}$ Iako M. Ajanović ne govori direktno o slučajevima moguće komutabilnosti upotrebe veznika $a$ i $i$ u određenim semantičko-gramatičkim kontekstima, upotreba priloga nekad od strane tog autora, pored toga što posljednju tvrdnju dovodi u izvjesnu protivurječnost sa ranije iznesenim konstatacijama, kao da na neki način relativizuje apsolutnu suprotnost klauza povezanih veznikom $a$.

I M. Stevanović konstatuje da su ,...najizrazitije suprotne rečenice $\mathrm{s}$ veznikom $a^{64} \mathrm{i}$ da ,....sve suprotnosti ... nisu istovetne, već suprotnost, odnosno nepodudarnost, može se reći, pored toga što iskazuje pravu suprotnost..., sadrži se i u nepodudarnosti pojedinih rečeničnih delova, u nepodudarnosti predikatskih odredaba ili dopuna, u nepodudarnosti objekata - između ostalih rečeničnih delova“. ${ }^{5}$ Nakon navođenja primjera u funkciji dokaza za rečeno, Stevanović navodi primjere tipa Sedi u bašti i oštri brijače, a pevuca kroz zube, To već prilično dugo traje, a postaje sve teže $i$ sve zamornije, ${ }^{6}$ za koje konstatuje da u njima ,...imamo približno slične odnose među naporednim rečenicama u složenoj kakve smo prikazali i u nekolika prethodna stava ... ali je u ovima poslednjim istomernost smisla - sastavni karakter rečenice mnogo izrazitiji“". Naglasak, dakle, sa nepodudarnosti funkcionalnih elemenata rečenicā premješta na smisaoni odnos među rečenicama, pa zaključuje da ,...istinska suprotnost nije samo u nepodudarnosti pojedinih delova posebnih rečenica u naporedno-složenoj rečenici, nego više u smislu onoga što se tim rečenicama iznosi““. ${ }^{8}$ Kao primjer nezavisnosložene rečenice u okviru koje se naporedne rečenice odlikuju nepodudarnošću njihovih subjekata i predikata, ali ne i suprotnošću po smislu Stevanović navodi Ćosićeve rečenice iz Korena: Aćim dobi unuka a Srbija se oslobodi, konstatujući da „,...ove dve naporedne rečenice u složenoj i nasuprot nepodudarnosti njihovih subjekata i pre-

${ }^{1}$ M. Ajanović - ,'Nezavisno' složena rečenica i odnos prostih rečenica u njoj“, Naš jezik, knj. 5, sv. 3-4, Beograd, 1953, 141.

${ }^{2}$ Isto, 142.

${ }^{3}$ Isto, 141.

${ }^{4}$ M. Stevanović - Savremeni srpskohrvatski jezik II, Beograd, 1974, 799.

${ }^{5}$ Isto, 799 .

${ }^{6}$ Isto, 802.

${ }^{7}$ Isto, 803 .

${ }^{8}$ Isto, 804. 
O prirodi veznika $a$ i mogućnosti komutabilne upotrebe veznika $a$ i $i$

dikata, po smislu nisu suprotne jedna drugoj, koliko što se nikakva suprotnost ne bi osetila kada bi ta rečenica bila upotrebljena u obliku s veznikom a... “9 Zbog postojanja ovakvih smisaonih odnosa među klauzama poveznih veznikom $a$ u okviru nezavisnosloženih rečenica, nije čudo što Stevanović donosi unekoliko protivurječne zaključke pa na jednoj strani kaže da se ,...u svakome slučaju vezniku $a$ koji ide među one reči (veznike) svoje vrste koje imaju i svoja značenja, pored suprotnih daje i sastavno značenje“, ${ }^{10}$ a dvije strane poslije toga da ,...ne možemo poricati da se suprotnim veznikom $a$ uvek označava neka vrsta suprotnosti““. ${ }^{11}$

$\mathrm{Na}$ fenomen upotrebe određenih veznika u, da tako kažemo, kontekstu ne baš očekivanome za njih, a riječ je ponovo o upotrebi veznika $i$ i $a$, ukazuje i I. Pranjković, s tim što on problemu prilazi govoreći o vezniku $i$. Konstatujući da ,...možemo pronaći relativno veliki broj rečenica u kojima su kopulativni veznik $i$ i adverzativni $a$ međusobno komutabilni“, ${ }^{12}$ Pranjković naglašava da ,...kad veznik $i$ dolazi na ono mjesto na kojem bismo s obzirom na odnos među klauzama prije očekivali $a$ (tj. kad povezuje neskladne ili suprotne elemente) onda on može imati dvovrsnu ulogu“. ${ }^{13}$ Sa jedne strane, ,,...ako se radi samo o neskladnosti (subjekatskoj, predikatskoj, vremenskoj i sl.) ili o djelomičnoj smisaonoj suprotnosti, veznik $i$ često ublažava te neskladnosti i suprotnosti: No, psi su lajali kao i svakog dana $i$ (a) njihov je lavež jače $i$ veselije odjekivao“ ${ }^{14}$ Sa druge strane, ,...obično kad se radi o potpunoj smisaonoj suprotnosti veznik $i$ ne samo da ne pomiruje neskladnosti i suprotnosti nego ih povećava: Bio sam žedan, (a, ali) ne napojiste me“. ${ }^{15}$ Uzimajući u obzir ove činjenice, Pranjković konstatuje da je u primjerima kao što su upravo navedeni veznik $i$ vrlo često stilski obilježen te da je stilska obilježenost dokaz da taj veznik, i pored svoje izuzetne učestalosti, ipak ima manje-više određeno značenje te da nije tačno da je njegovo značenje uslovljeno prirodom odnosa među elementima koje povezuje. Zaokružujući taj segment, Pranjković zaključuje: „Ne mislim, dakle, da se može govoriti o suprotnom $i$ ili o kopulativnom $a^{\text {“ }} .{ }^{16}$

Dodirivanje suprotnog i sastavnog odnosa, bez zalaženja u detaljnije eksplikacije, uočavaju i Ž. Stanojičić i Lj. Popović: „Veznik $a$ najčešće obeležava kontrast ili pokazuje da situacija u drugoj rečenici predstavlja nešto razli-

\footnotetext{
${ }^{9}$ M. Stevanović, $n . d ., 804$.

${ }^{10}$ Isto, 799.

${ }^{11}$ Isto, 805.

${ }^{12}$ I. Pranjković - Koordinacija u hrvatskom književnom jeziku, Zagreb, 1984, 55.

13 Isto.

${ }^{14}$ Isto.

${ }^{15}$ Isto, 56.

${ }^{16}$ Isto.
} 
čito u odnosu na prethodnu rečenicu. U ovom drugom slučaju suprotni i sastavni odnos se ponekad dodiruju. Up: Zoran je najpre prihvatio poziv, a onda se predomislio; Zoran je najpre prihvatio poziv $i$ onda se predomislio". ${ }^{17}$

O međusobnoj supstituentnosti kopulativnog veznika $i$, sa jedne strane, i adverzativnog $a$ (ali), sa druge, govori i M. Kovačević, i to u okviru postupka komunikativno-stilske intenzifikacije. ,Intenziviranjem smatramo takav jezički postupak preuređenja sintaksičke konstrukcije kojim se upotrebom posebnih formalno-gramatičkih sredstava jedan ili više rečeničnih članova ističe (naglašava) i smisaono i emfatički" ${ }^{18}$ Upravo jedan od načina intenzifikacije vezan samo za kopulativne sintagme ,...postiže se supstitucijom kopulativnog veznika $i$ adverzativnim veznikom $a$ ili ali. Pri tome adverzativni konektor preuzima gramatičko značenje kopulativnosti, a svoje adverzativno značenje preobraća u intenzifikatorsko. Tako je supstitucijom kopulativnog adverzativnim veznikom osložnjeno značenje ovog posljednjeg: on ujedinjuje gramatičku sa stilističkom funkcijom, postajući konektivno-intenzifikatorska riječ“ “, ${ }^{19}$ navodeći primjere tipa: ... ali je stih postepeno a stalno $(\leftarrow$ postepeno i stalno) istiskivan iz mnogih oblasti.

Rezimirajući navedena mišljenja, možemo zaključiti da jedni autori (Stevanović) mogućnost komutabilne upotrebe kopulativnoga veznika $i$, adverzativnog veznika $a$ i upotrebe prvog umjesto drugog vide prije svega $\mathrm{u}$ istosmjernosti smisla klauza koje konstituišu nezavisnosloženu rečenicu. Drugi autori (Pranjković, Kovačević) naglašavaju stilske efekte mogućnosti komutabilne upotrebe veznika $i$ i veznika $a$ - prvi tvrdi, donekle nasuprot Stevanoviću, da je ta stilska obilježenost dokaz da veznik (u tom slučaju $i$ ) ima određeno značenje i da smisaoni odnos među elementima koje povezuje ne utiče na njegovo značenje, dok drugi naglašava činjenicu intenzifikacije postupkom supstitucije kopulativnoga veznika adverzativnim.

I jezik crnogorske dnevne štampe obiluje primjerima u kojima je moguća komutabilnost kopulativnog veznika $i$ i adverzativnog veznika $a$. Navodimo veći broj primjera, najprije onih u kojima je upotrijebljen veznik $a$ komutabilan sa veznikom $i$, a onda obrnuto, onih u kojima je upotrijebljen veznik $i$ komutabilan sa veznikom $a$ :

Holivudska filmska zvijezda ... gitaru svira od dvanaeste godine, a dvosmjernu turneju po gradovima i mjestima Velike Britanije počinje koncertom $u$ „Tyne Theatreu“ u Njukaslu. (Vijesti, 19. 1. 2007, 39. str.); Haški optuženik Radovan Karadžić krije se u Rusiji, a tom informacijom odnedavno se bavi javnosti dosad nepoznata ...

${ }^{17}$ Ž. Stanojčić, L. Popović - Gramatika srpskog jezika, Beograd, 1999, 356.

${ }^{18}$ M. Kovačević - Stilstika i gramatika stilskih figura, Nikšić, 1995, 169.

${ }^{19}$ Isto, 171. 
O prirodi veznika $a$ i mogućnosti komutabilne upotrebe veznika $a$ i $i$

Grupa za praćenje ratnih zločinaca... (Vijesti, 2. 2. 2007, 11 str.); Grupom rukovodi državni tužilac B i $H$, osnovana je na predlog visokog predstavnika međunarodne zajednice, a u njoj su predstavnici svih policijskih agencija u B i H. (Vijesti, 2. 2. 2007, 11. str.); On je istakao da će radnici redovno dobijati plate, a da je briga poslovodstva kako će ih obezbijediti. (Vijesti, 3. 2. 2007, 5. str.); Sekretar ... saopštio je da će se licenca izdavati na pet godina, a za nju će taksisti plaćati 400 eura. (Dan, 15. 3. 2007, 6. str.); Leskovački trubači sviraju po dogovoru, a prosječno za svirku na svadbi traže oko 500 eura. (Republika, 12. 2. 2007, 9. str.); Prema njegovim riječima, u istom dijelu MZ oko dvadeset kuća priključeno je na gradsku kanalizaciju, a još toliko na septičke jame. (Republika, 12. 2. 2007, 19. str.); On očekuje da će prostor kod GSP-a biti ozelenjen, a nova rasvjeta biti postavljena. (Republika, 12. 2. 2007, 19. str.); PN-26 "Sipa“ je jedan od najmladih brodova u floti MCG, izgraden je 1989. u Kraljevici, a puni deplasman mu je oko 1600 tona. (Vijesti, 20. 1. 2007, 7. str.); Duizburg je neporažen već 14 kola..., a kod kuće još nije izgubio ove sezone. (Start, 12. 2. 2007, 26. str.); Prema najavama, treća generacija „Renoovog “ „megana“ će stići tokom 2008. godine, a svojim kvalitetima bi trebalo da francusku kuću dovede na sam vrh prodaje. (Dan, 24. 2. 2007. g., 21. str.); Deklaracija bi se ... predočila građanima, a zatim bi se usvojila na lokalnom parlamentu. (Dan, 24. 2. 2007. g., 17. str.); ...jer je u noći između osmog i devetog januara nožem izbo svog dugogodišnjeg prijatelja ... a zatim ga bacio u jedan kanal rijeke Nekar... (Dan, 24. 2. 2007, 12. str.); To je drugi po redu automobil koji je napravljen za seriju, a koristio se od šeste do posljednje epizode. (Pobjeda, 2. 3. 2007, 17. str.); Parada je izrasla iz masovne demonstracije održane 1989. kod Brandenburške kapije, a prerasla u veliku svečanost klupske kulture na otvorenom. (Vijesti, 23. 2. 2007, 40. str.); ...da učine daleko više u smanjenju emisije gasova koji proizvode efekat staklene bašte, a koji nastaju sagorijevanjem fosilnog goriva u termoelektranama... (Vijesti, 3. 2. 2007, 10. str.); Predsjednik sindikata ... kazala je da su radnici u veoma teškom materijalnom položaju, da među njima ima supružnika i samohranih majki..., a da ih je većina u starosnoj dobi kada u drugim firmama ne mogu naći posao. (Vijesti, 20. 1. 2007, 12. str.)

Aktuelni šef ... je miljenik bogatih saveza i u predizbornoj kampanji igrao je na kartu iskustva... (Vijesti, 26. 1. 2007, 30. str.); Amerikanci su akcije u crnogorskoj telekomunikacionoj kompaniji kupovali po cijenama ispod 2,5 eura, i očigledno je da su imali ogromnu zaradu po akciji. (Republika, 30. 1. 2007, 5. str.); Svi sadržaji nalaze se na platformi i naplaćuju se po cijeni koja je usvoje- 
Miomir ABOVIĆ

na za dati tip sadržaja. (Dan, 1. 2. 2007, 12. str.); Kamene kuće u tom bloku izgrađene su 1957. godine $i$ od tada niko nije ulagao $u$ razvoj tog dijela grada. (Republika, 12. 2. 2007, 18. str.); Mediji su prenijeli i izjave očevidaca da je napadač imao oko 20 godina i da je bježeći s mjesta zločina uzviknuo „ubio sam nemuslimana“. (Vijesti, 20. 1. 2007, 8. str.); Načelnik pljevaljskog CB Milivoje Tomčić rekao je juče da je bezbjedonosna situacija u Pljevljima stabilna $i$ da ta opština spada u najmirniju sredinu u Crnoj Gori. (Vijesti, 20. 1. 2007, 8. str.); Teške godine izolacije ... dovele su ne do saradnje nego do sjedinjavanja države i kriminala ... $i$ bez krupnih rezova ... nemoguće je nastaviti dalje. (Dan, 24. 2. 2007, 2. str.); Na prvom mjestu, svakako, ističu dotrajale vozove, prugu i uopšte željezničku infrastrukturu i pri tome opominju na tešku saobraćajnu nesreću... (Dan, 24. 2. 2007, 15. str.)

Za navedene primjere sa veznikom $a$ karakteristična je tzv. istosmjernost smisla klauza konstituenata nezavisnosloženih (višestrukosloženih) rečenica, a za većinu i identičnost subjekta povezanih klauza ili identičnost pojma nosioca sadržaja cjelokupne nezavisnosložene (višestrukosložene) rečenice (treći, peti, deveti primjer rečenica povezanih veznikom $a$ u našem slučaju, recimo) te bi se u svima mogao upotrijebiti veznik $i$ pa da dobijemo potpuno smislene i gramatične rečenice. Mogli bismo se složiti sa mišljenjem M. Kovačevića da je upotreba veznika $a$ u ovim slučajevima vezana za postupak komunikativno-stilske intenzifikacije kojim se naglašava, ističe sadržaj druge klauze, informacije koju ona nosi. Zanimljiva je njegova tvrdnja da ,....adverzativni konektor preuzima gramatičko značenje kopulativnosti, a svoje adverzativno značenje preobraća u intenzifikatorsko“. ${ }^{20}$ Znači li to da, uprkos Pranjkovićevim tvrdnjama da se ne može govoriti o kopulativnom $a$ i tradicionalnoj podjeli veznikā nezavisnosloženih rečenica, taj autor ipak na neki način dozvoljava, sa jedne strane, poput Stevanovića, postojanje i sastavnog značenja ovoga veznika, a, sa druge, makar i indirektno, ukazuje na mogućnost izdvajanja posebne podvrste nezavisnosloženih rečenica u okviru postojeće podjele? ${ }^{21}$

\footnotetext{
${ }^{20}$ M. Kovačević, n. d., 171. str.

21 Navodeći Pranjkovićeve riječi da se ,...posebnom vrstom koordiniranih rečenica mogu ... smatrati samo one rečenice kod kojih određenom značenjskom odnosu odgovara određen skup izražajnih sredstava“ (I. Pranjković - Koordinacija u hrvatskom književnom jeziku, Zagreb, 1984. g., 38. str.), M. Kovačević zaključuje da ,...sintaksički relevantna klasifikacija nezavisnosloženih rečenica prioritetno mora uvažiti suodnos izražajnih sredstava i smisaonih odnosa koji se njima iskazuju“. (M. Kovačević, Sintaksa složene rečenice u srpskom jeziku, Beograd, 1998. g., 12. str.) Polazeći od stavova tih lingvista, čini se da, uz odsustvo naglašene posebnosti izražajnih sredstava, ali na osnovu određene
} 
O prirodi veznika $a$ i mogućnosti komutabilne upotrebe veznika $a$ i $i$

Do značajnih i upotrebljivih uvida u konstrukcije sa veznikom $a$ dolaze R. Simić i J. Jovanović u Srpskoj sintaksi. „Uviđamo“, kažu ti autori, „da je veznik 'a ' upotrebljiv u konstrukcijama čiji se sadržaj delom podudara, a delom razlikuje.“22 „Najbolje je reći da se veznikom 'a' obeležava izuzimanje izvesnih grupa fakata iz celine, i to na taj način što se među njima stvara disparitet po nekom svojstvu, funkciji ili odnosu, ali uz zadržavanje osećaja pripadnosti celini u opštem smislu, van istaknute perspektive. Važno je dodati da je objedinjavajuća perspektiva samo stvar 'osećaja' i da je u semantičkoj pozadini, kao neka opšta perspektiva. A da je disparitet u prvom planu. Na jednoj strani, prema tome, činjenice su konjuktne, uključene u zajedničku celinu po opštim osobinama svojim, a na drugoj su u izvesnom disparitetu međusobno i sa celinom, isključuju se iz nje po nekom posebnom svojstvu svaka na svoju stranu. Veznikom 'a' može se reći, označava se delimičan unutrašnji disparitet neke globalno jedinstvene celine.“23 Simić i Jovanović dalje primjećuju da veznik $a, \ldots$,..nije prost sinonim ni veznika ' $i$ ' ni veznika 'ali', iako mu se polje upotrebe delimično preklapa i sa jednim i sa drugim već ima i sopstveni krug upotrebe, distinktan od susednih ili semantički srodnih vezničkih reči“. ${ }^{24}$ Veznik $a, \ldots . . n$ nije varijanta ni veznika 'i' a ni 'a' već ima sopstveni krug funkcija - insistira istovremeno na delimičnom podudaranju sadržaja povezanih formi, i na delimičnom razilaženju, disparitetu. Razilaženje može ići do suprotnosti, ali može ostati na nivou prostog 'variranja'. Svešćemo analizu na zaključak da veznik 'a' obeležava izuzimanje dela sadržaja dvaju članova obuhvaćenih zajedničkim smislom, i to na taj način

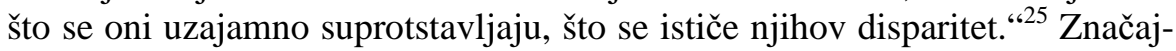
no je Simićevo zapažanje da veznik $a, \ldots$,..insistira istovremeno na delimičnom podudaranju sadržaja povezanih formi, i na delimičnom razilaženju, disparitetu. ${ }^{\text {26 }}$ Upravo je taj djelimični disparitet, naglašavanje sadržaja, u našim primjerima, druge klauze distinktivna crta koja uslovljava i omogućava povezivanje ovih klauza veznikom $a$ dok se upotrebom veznika $i$ naglašava sastavnost, ,istosmjernost smisla“ klauzā nezavisnosložene rečenice. Na mogućnost komutabilnosti veznika $a$, sa jedne strane, i $i$, sa druge, nesumnjivo direktno utiče stepen istosmjernosti smisla klauzā konstituenata nezavisnosložene rečenice. U primjerima koje smo upravo naveli sadržaj klauzā konstituenata nezavisnosložene rečenice karakteriše visoki stepen istosmjernosti,

posebnosti smisaonih odnosa među klauzama povezanim veznikom $a$ o kojima smo upravo govorili, ima smisla govoriti o podvrsti određene vrste nezavisnosloženih rečenica.

22 R. Simić, J. Jovanović - Srpska sintaksa I, II, Beograd, 2002. g., 431.

23 Isto.

24 Isto, 432.

25 Isto.

${ }^{26}$ Isto. 
naporednosti te je u njma sasvim moguća upotreba sastavnog veznika dok se upotrebom veznika $a$ naglašava, ističe sadržaj druge klauze. Već u sljedećim primjerima upotreba sastavnog veznika $i$ umjesto veznika $a$ bila bi mnogo manje prihvatljiva iako moguća:

Nacrtom prostornog plana Crne Gore predviđena je izgradnja 49 hidrocentrala, a svaka sedma bi se gradila na rijeci Tari. (Dan, 22. 1. 2007, 6. str.); BBM ... je u ponudi navela da će cijena mjesečne pretplate za osnovni paket programa iznositi šest eura, a svaki dodatni bi se plaćao dva. (Dan, 22. 1. 2007, 7. str.); Da bi potpuno bili u toj funkciji potrebno je učiniti dodatne napore u stvaranju uslova za rad suda, a sada je pravi trenutak. (Vijesti, 3. 2. 2007, 6. str.); Mnoge kuće širom države su uništene i oštećene, a hiljade ljudi su ostale bez struje. (Vijesti, 3. 2. 2007, 11. str.); Postoje naznake da bi mogao biti izabran i treći potpredsjednik stranke, a u jednom dijelu stranke na toj funkciji vide premijera Željka Šturanovića. (Vijesti, 10. 2. 2007, 21. str.); ...plavima trebaju četiri pobjede, a prva žrtva na tom putu trebalo bi da bude fenjeraš Slovan. (Vijesti, 17. 2. 2007, 21. str.); Nigdje u operativnom i investicionom budžetu Opštine ne stoji koliko mora da se plati za prošlu godinu, a koliko je planirano za ovu godinu... (Vijesti, 17. 2. 2007, 14. str.); Od 305 podnijetih krivičnih prijava tužioci su odbacili 14, a među njima najbrojnija su bila krivična djela nasilje u porodici. (Vijesti, 20. 1. 2007, 8. str.); ,Zebre“ nemaju problema sa povredama, a na svakom meču kod kuće imaju podršku više od 30000 navijača. (Start, 12. 2. 2007, 26. str.); Džejms Braun je preminuo 25-og decembra u 73-oj godini, a njegova smrt je izazvala pravi rat između nasljednika. (Vijesti, 23. 2. 2007, 40. str.); Nekada se to naselje zvalo „male kuće“, a nalazi se između Bulevara Save Kovačevića i Ulice Bracana Bracanovića. (Republika, 12. 2. 2007, 19. str.); Ono što će, takođe, biti karakteristično za prednji dio je to da će tradicionalni znak kompanije biti veći, a cio prednji dio će biti zatvoreniji. (Dan, 21. 2. 2007, 11. str.); PzP je priznanje Mesiću ocijenio kao kompenzacijski odnos između crnogorske vlasti i Hrvatske, a svoju uzdržanost povodom ovog predloga objasnili su time da ne žele da se manipuliše o tome da se ta partija ne zalaže za dobrosusjedske odnose. (Pobjeda, 2. 3. 2007, 15. str.); Prije nepunih mjesec dana DOO „Univerzitates“ podnijelo je Savjetu zahtjev za akreditaciju, a jedan od osnivača Milo Đukanović najavio da će privatni univerzitet na jesen početi da radi. (Vijesti, 10. 5. 2007, 5 str.)

Za primjere netom navedene, za razliku od onih prvonavedenih, već je karakteristična nepodudarnost, disparitet sadržaja klauza povezanih veznikom $a$, ali disparitet koji ne ide do potpunog razilaženja sadržaja povezanih 
O prirodi veznika $a$ i mogućnosti komutabilne upotrebe veznika $a$ i $i$

klauza. Možemo se složiti sa mišljenjem I. Pranjkovića da bi eventualna upotreba veznika $i$ u tim slučajevima ublažila odnos određenoga smisaonog dispariteta među povezanim klauzama, te je veznik $a$ upotrijebljen u značenju intenzificiranja, isticanja dispariteta, posebnosti sadržaja druge klauze. Možemo zaključiti iz navedenoga da u slučajevima kada postoji snažniji disparitet u smisaonom pogledu među klauzama koje se povezuju, smisaoni odnos među klauzama svakako utiče na izbor koordinativnoga veznika $a$, ali da taj uticaj nema karakter apsolutnoga kriterijuma za izbor datoga veznika, jer i veznik svojim značenjem može uticati na karakter i smisao cjelokupne nezavisnosložene rečenice, što se dokazuje i mogućnošću makar djelimične komutabilnosti upotrebe veznika $a$ i $i$ u upravo navedenim primjerima. Zanimljiv je sljedeći primjer đe se može opažati suodnos smisaonog odnosa između klauzā nezavisnosložene rečenice, sa jedne strane, i značenja veznika, sa druge:

Uostalom neblagovremeno postupanje suda „stimulišse“ nezakonit rad javne uprave, a građani takvim odnosom prema tužbi gube povjerenje u institucije sistema... (Vijesti, 3. 2. 2007. g., 6. str.)

Među klauzama navedene nezavisnosložene rečenice postoji nesumnjiva „,istosmjernost smisla“, naime sadržaj druge klauze javlja se kao posljedica situacije na koju referiše prva klauza. Ako bi izbor veznika bio uslovljen samo smisaonim odnosom među klauzama, onda bi u tom slučaju bila logična upotreba sastavnoga veznika (veznika $i$ ). Međutim, veznik $a$ svojim značenjem datoj nezavisnosloženoj rečenici daje specifičnu smisaonu nijansu umjesto da se drugom klauzom i činjenicom koju ona iznosi samo konstatuje logična posljedica sadržaja i situacije na koju se referiše prvom klauzom, upotrebom toga veznika (veznika $a$ ) ističe se i naglašava značaj te činjenice u odnosu na ono što se saopštava prvom klauzom.

Stepen nepodudarnosti, dispariteta sadržaja klauza ili nepodudarnosti određenih njihovih konstituenata može biti potpun, kao u sljedećim primjerima:

Decembarski računi za štedljive potrošače iznosili su 66,92 eura, a januarski u prosjeku 82,98 eura. (Vijesti, 9. 2. 2007, 20. str.); ...saznali su da se radi o prevari jer je, po tom socijalnom programu, ... radnicima andrijevičkog pogona izmireno po 150 eura, a radnicima u Beogradu i Ljuboviji po 400 eura. (Vijesti, 9. 2. 2007, 20. str.); Pljevlja imaju tolika prirodna bogatstva, a najsporije se razvijaju. (Vijesti, 20. 1. 2007. g., 13. str.); Ona je kazala da se spor zbog likvidacije štamparije vodi pred Privrednim sudom, a pred Osnovnim sudom u Nikšiću se vodi spor u vezi krivične prijave protiv izvršnog direktora „Svetigore“... (Vijesti, 20. 1. 2007. g., 12. str.); Sinoć sam saznao za reagovanja pojedinih autora, a danas slučajno da su termin izbora promijenili. (Vijesti, 23. 2. 2007. g., 41. str.); Iskreno se nadam da će se na kraju svi dogovoriti, a ja ću 
Miomir ABOVIĆ

se u međuvremenu posvetiti svom nastupu. (Vijesti, 23. 2. 2007. g., 41. str.); Bolest se pojavila na individualnim domaćinstvima, a vlasnici svinja ... nijesu imali uvjerenja o njihovom porijeklu $i$ zdravstvenom stanju... (Dan, 6. 3. 2007, 10. str.); Problem je u tome što je predsjednik Ramon Kalderon pregovore povjerio generalnom direktoru Hoze Anhelu Sančezu, a ne Predragu Mijatoviću i Franku Baldiniju... (Vijesti, 11. 5. 2007. g., 30. str.); Izvođač radova bila je austrijska firma ,Štrabag“, a podizvođač nikšićki „Boksiti“. (Vijesti, 10. 5. 2007, 6. str.).

$\mathrm{U}$ tim primjerima komutabilnost veznika $a$ veznikom $i$ nije moguća i primjeri tipa upravo navedenih i najprije i najčešće se navode u gramatikama i normativnim priručnicima srpskohrvatskoga, srpskog i hrvatskoga jezika kada se govori o $a$ kao vezniku suprotnih rečenica. Tako se, npr., u Gramatici hrvatskoga jezika J. Silića i I. Pranjkovića, uz konstataciju da „,...veznik a ima značenje kontrasta u najširem smislu“, ${ }^{27}$ uopšte ne spominju slučajevi moguće komutabilnosti veznika $a$ i $i$ u određenim semantičkim kontekstima. Slično tome i R. Katičić konstatuje samo da veznik $a, \ldots .$. izriče vezu među sklopljenim rečenicama, a označuje i suprotnost sadržaja tih sklopljenih rečenica...“, ${ }^{28}$ dok pomena o mogućoj komutabilnosti veznika $a$ i $i$ u određenim kontekstima nema ni u Priručnoj gramatici hrvatskoga književnoga jezika. ${ }^{29}$ A upravo brojnost primjera ekscerpiranih iz samo jednoga funkcionalnog stila srpskog i hrvatskoga jezika, u kontekstima u kojima je veznik $a$ komutabilan sa veznikom $i$ i u kojima ti veznici funkcionišu kao opozitne jezičke jedinice koje razlikom u svom značenju uslovljavaju i pojavu različitih nijansi smisaonih odnosa među klauzama koje povezuju, nalaže da se to značenje isticanja, naglašavanja, intenzificiranja sadržaja jedne od povezanih klauza mnogo više istakne kada se govori o tom vezniku i klauzama njime povezanim. Ovđe se možemo vratiti zapažanju R. Simića i J. Jovanović da „ovaj veznik ima sopstveni krug funkcija - insistira istovremeno na delimičnom podudaranju sadržaja povezanih formi, i na delimičnom razilaženju, disparitetu“. ${ }^{30}$ Činjenica djelimičnoga podudaranja sadržaja povezanih formi približava taj veznik značenju sastavnosti i mogućnosti njegove komutabilnosti sa veznikom $i$, uz distinktivnu crtu isticanja, naglašavanja sadržaja (u našim primjerima) druge navedene klauze. Upravo u stupnju dispariteta i naglašavanja sadržaja druge klauze leži i razlika u mogućnosti komutabilnosti veznika $a$ i $i$ - što je stepen isticanja posebnosti i dispariteta sadržaja druge klauze veći, to

27 J. Silić, I. Pranjković - Gramatika hrvatskog jezika, Zagreb, 2005. g., 325.

28 R. Katičić - Sintaksa hrvatskoga književnog jezika, Zagreb, 1991. g., 167.

29 E. Barić, M. Lončarević, D. Malić et al. - Priručna gramatika hrvatskoga književnog jezika, Zagreb, 1979. g., 385-386.

30 R. Simić, J. Jovanović, n. d., 432. 
O prirodi veznika $a$ i mogućnosti komutabilne upotrebe veznika $a$ i $i$

je manja mogućnost komutabilnosti veznika $a$ veznikom $i$, i obrnuto, što je istosmjernost smisla klauzā nezavisnosložene rečenice veća, to je komutabilnost veznika $a$ i $i$ sasvim moguća, a rečenične strukture dobijene umetanjem jednog umjesto drugog veznika sasvim gramatičke i smislene.

Međutim, ovđe se moramo podśetiti činjenice da smisaoni suodnos klauzā nezavisnosložene rečenice ne može biti i nije jedini i apsolutni parametar i kriterijum koji diktira upotrebu određenog veznika i mogućnost njegove komutabilnosti. Ako pogledamo sljedeće primjere: Ranko troši, a ne pravda. (Dan, 23. 5. 2007, 4. str.); ...mi usvajamo sve što nam se kaže, a ne primjenjujemo ništa. (Dan, 24. 2. 2007, 2. str.), svakako ćemo konstatovati odnos potpune smisaone nepodudarnosti među klauzama tih nezavisnosloženih rečenica. Međutim, drugi jedan lingvistički faktor - identičnost subjekta - vršioca radnji označenih glagolima u predikatu klauzā konstituenata datih nezavisnosloženh rečenica omogućava ovđe komutabilnost veznika $a$ sastavnim veznikom $i$, s tim što bi u tom slučaju došlo do promjene značenja cjelokupne nezavisnosložene rečenice - umjesto da se subjekat percipira kao entitet koji je podvojen u određenom pogledu, eventualnom upotrebom sastavnog veznika percepcija subjekta bila bi percepcija entiteta kojega karakteriše jedinstvo u pogledu obavljanja određenih aktivnosti.

Ispostavlja se da su prava suprotnost odnosno potpuna nepodudarnost sadržaja klauzā nezavisnosložene rečenice ili nepodudarnost određenih njihovih gramatičkih konstituenata samo jedan od slučajeva upotrebe veznika $a$, mada naravno veoma markantan. Time se relativizuju konstatacije lingvistā kao što su Ajanović i Stevanović da je $a$ najizrazitiji suprotni veznik, premda su već i oni sami na neki način tu tvrdnju doveli u pitanje.

Zanimljiva su sljedeća dva primjera višestrukosloženih rečenica sa različitim značenjima veznika $a$ :

U petom kolu Podgoričanke uzvraćaju posjetu mađarskom rivalu, a poslije četiri uzastopna poraza, cilj pred početak sezone zvuči kao san nekog nerealnog navijača, a ne očekivanje ozbiljnih ljudi koji vode ekipu. (Vijesti, 17. 2. 2007, 20. str.); On je cigare ... rasporedio na nekoliko punktova po planini, a dogovor je bio da iste prevezu sa petnaestak automobila u BiH gdje su namjeravali da ih prodaju, a aršin podijele. (Dan, 24. 2. 2007, 12. str.)

U prvom primjeru prvi veznik $a$ djelimično je komutabilan sa veznikom $i$ jer se fokus u razumijevanju sadržaja druge klauze može staviti na semantičku komponentu kontinuuma onoga što se saopštava prvom klauzom, mada je u tom slučaju sasvim moguća i transformacija u zavisnosloženu rečenicu $(\rightarrow U$ petom kolu Podgoričanke uzvraćaju posjetu mađarskom rivalu mada poslije četiri uzastopna poraza, cilj pred početak sezone zvuči kao san nekog nerealnog navijača...). Za razliku od značenja prvog veznika $a$, drugi veznik $a$ ima 
pravo suprotno značenje jer povezuje jezičke forme - poredbene dopune kontrarne po značenju. U drugoj rečenici oba veznika $a$ u principu su komutabilna sa veznikom $i$, s tim što je, kad je u pitanju prvi veznik $a$, uz disparitet sadržaja dvaju klauzā, i komponenta naglašavanja sadržaja druge klauze istaknutija pa je tu i komutabilnost veznika $a$ sa veznikom $i$ manje prihvatljiva, dok u slučaju drugog veznika $a$, i pored nepodudarnosti leksičkoga značenja objekata i glagolā u predikatu dvaju klauzā, faktor koji smo (slijedeći Stevanovića) nazvali istomjernošću smisla doprinosi većoj mogućnosti komutabilnosti tih dvaju veznikā.

U pojedinim primjerima ekscerpiranim iz jezika crnogorske dnevne štampe, opet, faktor istomjernosti smisla i logičnost proishođenja sadržaja druge klauze iz sadržaja prve toliko su naglašeni da se čak može dovesti u pitanje opravdanost upotrebe veznika $a$ :

...nijesam sve ovo očekivao jer smo se tek bili okupili, a nijesmo imali prilike da se uhvatimo u klinč sa bilo kim... (Vijesti, 19. 1. 2007, 32. str.); Izabranice Tanje Jeraminok nijesu uspjele da upišu prve bodove, a po drugi put zasluženo su poražene od ekipe Lada Toljati... (Republika, 12. 2. 2007, 29. str.)

Uvažavajući činjenicu (povodom preskripcije u jeziku) da je ,,...dominantan stav modernih lingvista da, u čisto lingvističkom smislu, ništa što prirodno kažete u svom maternjem jeziku ili dijalektu, slijedeći svoje intimno jezičko osjećanje, ne može biti nepravilno“, ${ }^{31}$ a donekle protivurječeći i samom sebi i onome što smo dosad kazali, ipak smatramo da bi u ovakvim i sličnim primjerima, s obzirom na visok stepen logičnosti proishođenja sadržaja druge klauze iz sadržaja prve, tj. visok stepen istosmjernosti smisla, primjerenija bila upotreba sastavnoga veznika $i$ nego veznika $a$ iako se upotreba tog drugog uvijek može pravdati potrebom isticanja sadržaja druge klauze. Sličnoga karaktera je i sljedeći primjer ekscerpiran iz dnevnog lista Republika:

Pozitivno je što su, evidentno, preskočene lokalne barijere u svakom segmentu, a kriminalci su $i$ te kako dobro povezani. (Republika, 12. 2. 2007, 18. str.)

Među klauzama navedene nezavisnosložene rečenice nesumnjivo postoji odnos smisaone nepodudarnosti, ali mnogo markantniji odnos među datim klauzama jeste uzročnost pa bi sa normativnoga gledišta ovđe bila mnogo primjerenija upotreba uzročnoga veznika jer i transformacija takve forme rečenice u zavisnosloženu uzročnu rečenicu $\rightarrow$ Pozitivno je što su, evidentno, preskočene lokalne barijere u svakom segmentu jer su kriminalci i te kako dobro povezani.

\footnotetext{
${ }^{31}$ M. Riđanović - Jezik i njegova struktura, Sarajevo, 1998, 15.
} 
O prirodi veznika $a$ i mogućnosti komutabilne upotrebe veznika $a$ i $i$

Konačno, u jeziku crnogorske dnevne štampe nailazimo i na primjere potpuno nepotrebne upotrebe veznika $a$ :

Kurtagić je podsjetio da je to jedan od zaključaka sa sastanka održanog u Podgorici a čija glavna tema je bila ponuda za kupovinu Gir-a i Špad-a... (Dan, 24. 2. 2007, 14. str.)

Pojava takvih primjera može se objasniti pominjanim intenzifikatorskim značenjem veznika $a$ koje se manifestuje u naglašavanju sadržaja druge klauze, ali činjenica je da je, makar sa stilskog aspekta, ta upotreba u tom i sličnim primjerima sasvim suvišna, štoviše rezultira rogobatnošću izraza datih rečenica.

Može se reći da se intencija ovoga rada iscrpljuje u nekoj vrsti ukazivanja na relativizam i limite postupka književnojezičkoga normiranja. Nije sporno, naime, da je $a$ veznik koji povezuje klauze suprotnoga, nepodudarnog, kontrarnoga sadržaja odnosno klauze nepodudarnih pojedinih rečeničnih konstituenata i da se stoga može svrstati u veznike suprotnih rečnica. Međutim, isto tako viđeli smo da postoje i semantički konteksti u kojima se ovaj veznik upotrebljava, a koji nemaju bilo kakve veze sa suprotnošću, kontrarnošću ili nepodudarnošću bilo kakve vrste. Sa druge strane, viđeli smo da smisaoni odnosi među klauzama daleko od toga da mogu biti jedini ili čak najvažniji faktor i kriterij upotrebe određenoga veznika mada se njihov uticaj pri tome ne može negirati. Na upotrebu određenoga veznika utiču i drugi lingvistički faktori tipa podudarnosti odnosno nepodudarnosti određenih konstituenata klauzā nezavisnosloženih rečenica. Konačno, i značenje samoga veznika bitan je faktor koji utiče na odnos među klauzama nezavisnosložene rečenice, značenje cjelokupne te rečenice i komunikativne namjere pošiljaoca poruke. Vraćajući se na problematiku što se odnosi na veznik $a$, možemo reći da je svaka klasifikacija više-manje uslovna i nesavršena te da je i ovaj veznik u krajnjoj liniji, respektujući gramatičku tradiciju, opravdano svrstavati i proučavati u okviru suprotnih nezavisnosloženih rečenica, uz napomenu da bi u normativnim priručnicima i gramatikama više pažnje trebalo posvetiti njegovom značenju intenzifikacije, isticanja, naglašavanja sadržaja druge klauze, značenju koje se upravo i manifestuje u opoziciji prema vezni$\mathrm{ku} i$, u kontekstima u kojima su ovi veznici međusobno komutabilni.

\section{Izvori}

- Vijesti - dnevne novine iz Podgorice

- Dan - dnevne novine iz Podgorice

- Pobjeda - dnevne novine iz Podgorice

- Republika - dnevne novine iz Podgorice

- Start-dnevne novine iz Podgorice 


\section{Literatura}

- M. Ajanović - „'Nezavisno“ složena rečenica i odnos prostih rečenica u njoj“, Naš jezik, knjiga 5, sv. 3-4, sv. 5-6, Beograd, 1953-54.

- E. Barić, M. Lončarić, D. Malić et alt. - Priručna gramatika hrvatskoga književnog jezika, Školska knjiga, Zagreb, 1979.

- M. Kovačević - Stilistika i gramatika stilskih figura, Unireks, Nikšić, 1995.

- M. Kovačević - Sintaksa složene rečenice u srpskom jeziku, Raška škola, Beograd, 1998.

- I. Pranjković - Koordinacija u hrvatskom književnom jeziku, HFD, Zagreb, 1984.

- R. Katičić - Sintaksa hrvatskoga književnog jezika, HAZU, Zagreb, 1991.

- M. Riđanović - Jezik i njegova struktura, Šahinpašić, Sarajevo, 1998.

- J. Silić, I Pranjković - Gramatika hrvatskoga jezika, Školska knjiga, Zagreb, 2005.

- R. Simić, J. Jovanović - Srpska sintaksa I. - II., Jasen, Beograd, 2002.

- Ž. Stanojčić, Lj. Popović - Gramatika srpskoga jezika, Zavod za udžbenike i nastavna sredstva, Beograd, 1999.

- M. Stevanović - Savremeni srpskohrvatski jezik II, Naučna knjiga, Beograd, 1974.

\section{Miomir ABOVIĆ}

\section{ON THE NATURE OF THE CONNECTIVE $A$ AND COMMUTATION POSSIBILITIES OF THE CONNECTIVES $A$ AND I}

This work deals with a corpus taken from Montenegrin daily papers and focuses on the problems which concern the nature of the conective $a$, and explores grammatical contexts in which this connective is interchangeable with the connective $i$. It is concluded that this connective was justly classified and researched as a member of opposite coordinate connectives, though it should be noted that the Serbian/Croatian reference and grammar books should give more attention to the meaning of stress, emphasis and intensification that this connective gives to the second clause (or some other language form).

Key words: connective a, connective $i$, adversative clauses, commutability of connectivies, standard BCMS languages 
LINGUA MONTENEGRINA, god. III, br. 5, Cetinje, 2010.

Institut za crnogorski jezik i jezikoslovlje „Vojislav P. Nikčević“

UDK 821.163.4'367.625

Stručni rad

\section{Miloš KRIVOKAPIĆ (Podgorica) \\ Filozofski fakultet - Nikšić}

\section{FREKVENCIJA GLAGOLSKIH OBLIKA U LJUBIŠINU JEZIKU}

Stefan Mitrov Ljubiša, darovit pripovjedač i vrstan stilista, postigao je potpun sklad motivike i tematike s oblikom pripovijedanja. Pored vertikalnog sklada, ostvario je i horizontalni sklad između oznake (zvuka) i značenja riječi. Uspostavljanju oba sklada dali su nezamjenljiv doprinos glagolski oblici i njihovi sinonimi, odnosno velike mogućnosti njihove izražajnosti. Visok je i raznovrstan stilematski potencijal glagolskih oblika u jeziku Ljubišinom. Mnogoznačnost i slojevitost glagolskih oblika izviru iz afektivnog stava govornog lica, iz težnje pripovjedača da pri izboru glagolskih oblika i njihovih sinonima angažuje onu varijantu (glagolski oblik i njegov sinonim) koja njegovu poruku, informaciju čini značenjski i zvukovno najizražajnijim. Suptilno nijansiranje gramatičko-logičkih i stilističkih funkcija glagolskih oblika stvara snažnu ekspresiju, skladnu ritmičnost.

Ključne riječi: frekvencija, sinonimija, transpozicija, glagolski oblici, jezik

Stefan Mitrov Ljubiša (Budva, 1824 - Beč, 1878), političar, prevodilac, pjesnik, darovit pripovjedač, vrstan stilista, jedan od najdosljednijih pristalica narodnoga jezika, svojom osobenom prozom označio je prijelaz iz romantizma u realizam, dao izuzetan doprinos crnogorskoj literarnoj baštini. Njegova proza, koja predstavlja značajnu etapu u razvoju našega jezika, osvaja čitaoce ljepotom i mudrošću i prkosi vremenu. Vremenu prkosi ne samo ljepota i moć Ljubišina jezika, njegov neponovljivi jezički vez, nego i etička načela koja se uklapaju u savremenu etičku misao, duh i karakter patrijarhalnoga svijeta antičkih vrlina, što potvrđuju Pripovijesti crnogorske i primorske i Pričanja Vuka Dojčevića.

Pripovijesti crnogorske i primorske, reprezentativno djelo Ljubišino, obuhvata dug period, od petnaestoga do devetnaestog vijeka. Neke pripovijesti u ovoj zbirci vraćaju čitaoce u petnaesti vijek („Kanjoš Macedonovićc“, 
„Skočidjevojka“, „Prokleti kam“), druge u osamnaesto stoljeće (,Prodaja patrijare Brkića“, „Pop Andrović, novi Obilić“, „Šćepan Mali“, „Gorde, ili kako Crnogorka ljubi“). Pripovijest „Krađa i prekrađa zvona“ ima temu iz savremenoga života. Bliske životu naroda, čije su pripovjedne niti Ljubišu inspirisale, ove pripovijesti nose snažan pečat piščeve mašte. Bitne odlike ove Ljubišine zbirke jesu: dinamičnost, sadržajnost, uvjerljivost, sažetost izraza, bogatstvo jezičkog nijansiranja.

Pričanja Vuka Dojčevića sadrže trideset i sedam umjetnički stilizovanih šaljivih priča sa dośetkom. Priče izviru iz usta Vuka Dojčevića, a vremenski su vezane za petnaesti vijek i vladavinu Ivana Crnojevića. Dojčević, koji je narator i učesnik događaja, pričanje i smisao priče podvrgava naslovljenoj gnomi.

Priče se temelje na narodnoj anegdoti, ali i bogate piščevom maštom. Najbitnija značajka ovih priča ipak je jezik. Jezik je najčešće isticani kvalitet u proučavanjima Ljubišina književnog djela. Ljubišin jezik i njegov odnos prema narodnome jeziku bili su preokupacija ne samo lingvista, nego i književnih kritičara. Jedan od bitnih razloga Ljubišina insistiranja na jeziku nalazi se u njegovoj težnji ,da pruži slikovit dokaz da naš jezik ni po čemu ne zaostaje za talijanskim i drugim velikim jezicima“. ${ }^{1}$

Dok su književni kritičari uzgred govorili o Ljubišinu jeziku, lingvisti su pokušali da prodru u srž njegova jezičkog izraza, tražili i stavljali na uvid argumente za svoje konstatacije. Došli su, pored ostaloga, do saznanja ,da se Ljubišin jezik razlikuje od vukovsko-hercegovačkog u dva pravca: a) u sintagmatskom strukturiranju fraza sa kvantifikatorom ima više mogućnosti, b) u organizaciji struktura S-P ima skromniji inventar mogućnosti $(. ..) ;^{2}$ da je Ljubišin obrazac nastao odabirom iz različitih krajeva naše jezičke oblasti i njihovim sjedinjavanjem u jedinstveni jezički tip." ${ }^{3}$ Ljubišin jezik je uzdignut, dakle, iznad dijalekatskog materijala, što se, prema mišljenju Radoja Simića i Branislava Ostojića, očituje u fonetsko-morfološkim osobinama, u leksici i sintaksi. Jezik Stefana Mitrova Ljubiše obiluje arhaičnim riječima poznatim dijalekatskoj leksici piščeva kraja (kao i svim crnogorskim govorima). Malo je u Ljubišinu jeziku riječi iz crkvenoslovenskoga jezika. Narodne riječi, koje su stavljene u nove suodnose i iznijansirane, ne daju mnogo maha bremenu crkvenoslovenskoga nasljeđa i pozajmljenicama, odnose prevagu i slivaju se u snažnu maticu pripovijedanja.

${ }^{1}$ Novo Vuković: „Neke stilske karakteristike Dojčevićevog pričanja“, Stvaranje, br. 12, Titograd, 1974.

${ }^{2}$ Radoje Simić i Branislav Ostojić: „Neki slučajevi kongruencije u jeziku Stefana Mitrova Ljubiše“, CANU: Stefan Mitrov Ljubiša, Titograd, 1976, str. 228.

${ }^{3}$ Asim Peco: ,Jedan pogled na pisanu reč Stefana Mitrova Ljubiše“, CANU: Stefan Mitrov Ljubiša, Titograd, 1976. str. 211.

62 
Frekvencija glagolskih oblika u Ljubišinu jeziku

Posebna draž Ljubišina stila i jezika jeste izvjesna arhaičnost u sklopu rečeničnom (u odnosu na savremeni jezik). Ne libi se Ljubiša crnogorske narodne sintakse, rečenica bez razvijenih djelova, što će naći mjesto u kasnijim gramatikama, uzeti maha u književnim djelima. Najčešće je Ljubišina rečenica razgranata, obogaćena umetnutim riječima, rijetko glomazna. Ponekad se u sastavu složenih rečenica nađe poetski obojeno prozno kazivanje, nađu se deseterci, koji ne remete prozni način kazivanja.

Cilj ovoga rada je sagledavanje i utvrđivanje u književnom djelu Stefana Mitrova Ljubiše (Pripovijestima crnogorskim i primorskim, Pričanjima Vuka Dojčevića, Napisima) ${ }^{4}$ učestalosti glagolskih oblika.

Da bi se dobili relevantni podaci o frekvenciji upotrebe glagolskih oblika, njihovim međusobnim odnosima, transponovanju značenja i ekspresivno-impresivnim vrijednostima u jeziku Stefana Mitrova Ljubiše, neophodno je bilo angažovati, pored ostalih, i statističku metodu. Ova egzaktna metoda, koju je prvi u našoj lingvistici upotrijebio krajem devetnaestoga vijeka Tomo Maretić, a koja se afirmisala sredinom dvadesetoga vijeka, danas je nezamjenljiva pri ispitivanju i utvrđivanju učestalosti jezičkih jedinica u književnim djelima. Njeni rezultati zavise od upornosti, istrajnosti, preciznosti proučavaoca, od provjere više puta, što iziskuje maksimalan napor i strpljenje. „Koliko je ovaki posao mučan i koliko se hoće za nj velike strpljivosti, to može ocijeniti samo onaj ko ga je pokušao raditi; tu se čovjek u brojanju vrlo lako zabuni, a najmanja pogreška remeti račun, zato treba po nekoliko puta isto mjesto brojati, dok se čovjek ne uvjeri, da nema u brojanju pogreške“, kaže, pored ostaloga, T. Maretić. Stoga su i u ovom radu moguća manja statistička odstupanja kada su u pitanju najfrekventniji glagolski oblici (prezent, perfekat, aorist). Ovo će biti shvatljivo ako se ima u vidu da je Stefan Mitrov Ljubiša upotrijebio u svome književnom djelu (tri knjige, sedamsto i četrnaest stranica) ${ }^{6}$ dvadeset i sedam hiljada i dvjesta devedeset puta glagolske oblike i njihove sinonime. ${ }^{7}$

${ }^{4}$ Stefan Mitrov Ljubiša: Djela; Obod - Cetinje, Kulturni centar - Budva, 1974.

${ }^{5}$ Tomo Maretić: Gramatika sa stilistikom, Zagreb, 1899, 1931.

${ }^{6}$ Stefan Mitrov Ljubiša: Djela, Obod - Cetinje, Kulturni centar - Budva, 1974.

${ }^{7}$ Sinonimija - termin za lingvističku pojavu, uslovljenu spletom različitih okolnosti semantičke i sintaksičke prirode, koja se ispoljava u mogućnosti međusobne zamjene jezičkih sredstava uz očuvanje nepromijenjenog smisla onoga što se njima kazuje. Sinonimi - termin za jezička sredstva (riječi, sintagme, rečenice i rečenične skupine), oblički različna, a po cjelokupnoj značenjskoj vrijednosti identična ili krajnje bliska. Sinonimika - nauka koja proučava sinonime. Sintaksička transpozicija - termin za pojavu pri kojoj jedna gramatička kategorija preuzima sintaksičke funkcije druge gramatičke kategorije; transpozicija sintaksičke funkcije koja izaziva promjenu značenja date kategorije. Sintaksička sinonimika - termin za označavanje oblasti sinonimike koja se bavi proučavanjem 
Na osnovu dobijenih podataka utvrđeno je sljedeće:

Stefan Mitrov Ljubiša je u svome književnom djelu upotrebljavao sve glagolske oblike u primarnom i sekundarnom značenju. Najveću frekvenciju imaju prezent, perfekat i aorist, a najmanju futur II, glagolski prilog prošli i pluskvamperfekat. Svi glagolski oblici češći su u primarnome nego u sekundarnom značenju. Različite su njihove ekspresivno-impresivne mogućnosti, obilježja u sekundarnom značenju osobena.

Transpozicija značenja glagolskih oblika, pri kojoj jedni glagolski oblici pod određenim uslovima preuzimaju funkciju i značenje drugih oblika, veoma je rasprostranjena u jeziku Ljubišinu. Novo značenje glagolskog oblika ima određenu frekvenciju upotrebe i stepen ekspesivnosti. Stilistička vrijednost glagolskog oblika u sekundarnom značenju uslovljena je frekvencijom upotrebe i stepenom ekspresivnosti. Ekspresivnost najčešće gube glagolski oblici čija je frekvencija upotrebe neuporedivo veća od učestalosti drugih glagolskih oblika, a čuvaju je oni oblici čija je učestalost manja. ${ }^{8}$

Ljubiša naporedo upotrebljava u istoj funkciji i značenju ne samo glagolska vremena nego i druge glagolske oblike (moduse, glagolske pridjeve i priloge, infinitiv). Otuda u njegovu jeziku načini (potencijal, imperativ, futur II) u funkciji i značenju glagolskih vremena, glagolska vremena u funkciji modusa, futurska značenja nefuturskih vremena (prezenta, aorista, perfekta), glagolska vremena u funkciji i značenju drugih glagolskih vremena (aorist i prezent perfektivnih glagola, prezent imperfektivnih glagola i imperfekat, perfekat i pluskvamperfekat. Podudarnost i mogućnost naporedne upotrebe, odnosno njihova sinonimnost dovela je do potiskivanja pojedinih glagolskih oblika na marginu, znatno smanjila radijus njihove upotrebe (futur II, pluskvamperfekat, glagolski prilog prošli, imperfekat).

Pojedina glagolska vremena preuzela su značenja drugih glagolskih oblika u Ljubišinom jeziku. Prezent se često nalazi u funkciji i značenju aorista, imperfekta, futura I, futura II, infinitiva, imperativa, a perfekat u funkciji i značenju pluskvamperfekta, imperativa, futura I. Zahvaljujući mogućnostima transpozicije, ,koja nastaje transferom semantičkog i sintaksičkog osnovnog elementa gramatičke kategorije“, ${ }^{9}$ Ljubiša je sačinio bogat i skladan mozaik sinonima. Njegov bistrotok razliva se u brojne prezentske, futurske, preteritalne i druge rukavce indikativnog, modalnog i relativnog značenja. Sinonimi su u Ljubišinu jeziku raskošno bogatstvo, ali nikako ne izlišna raskoš. ${ }^{10}$

sinonimije na sintaksičkom nivou; proučavanje sinonima i sinonimije na sintaksičkom nivou (u sistemu rečenica, u sistemu glagolskih oblika).

8 Milorad Ćorac: Stilistika srpskohrvatskog književnog jezika, Naučna knjiga, Beograd, 1974, str. 79-80.

${ }^{9}$ Ibidem, 36.

${ }^{10}$ Mihailo Stevanović: „Sintaksička sinonimika“, Književnost i jezik, god. X, br. 2, Beograd, 1963, str. 81. 
Frekvencija glagolskih oblika u Ljubišinu jeziku

Među glagolskim oblicima u Ljubišinu jeziku ima i onih koji su u koliziji sa važećom književnojezičkom normom: šćene, šćah, šćaše bit, sklonu se, koračeći, gledeć, siplju, piplju, pozivljući, plackati, pohmiliti, šnjelo, pane i dr. Upotreba glagolskih oblika i njihovih sinonima u jeziku Stefana Mitrova Ljubiše u skladu sa piščevim motivsko-tematskim opredjeljenjima, njegovim afektivnim stavom i težnjom da angažuje, upotrijebi onaj glagolski oblik ili njegov sinonim koji informaciju, naraciju čini najizražajnijom. Dakle, transpozicija značenja glagolskih oblika, pri kojoj je svaki glagolski oblik postao stilogen, i to manje ili više, usklađena je sa sadržajem i smjerom konteksta. Ona je uzdigla Ljubišinu naraciju na visok nivo, učinila njegov jezik i stil neponovljivim.

Tab. 1: Frekvencija glagolskih oblika u jeziku Stefana Mitrova Ljubiše

\begin{tabular}{|l|c|}
\hline Prezent & 14256 \\
\hline Perfekat & 4870 \\
\hline Aorist & 2493 \\
\hline Futur I & 1088 \\
\hline Imperativ & 1130 \\
\hline Infinitiv & 1085 \\
\hline Potencijal & 694 \\
\hline Radni glagolski pridjev & 663 \\
\hline Impefekat & 288 \\
\hline Glagolski prilog sadašnji & 246 \\
\hline Trpni glagolski pridjev & 227 \\
\hline Pluskvamperfekat & 149 \\
\hline Glagolski prilog prošli & 60 \\
\hline Futur II & 47 \\
\hline
\end{tabular}

\section{Literatura}

- Milorad Ćorac: Stilistika srpskohrvatskog književnog jezika, Naučna knjiga, Beograd, 1974, str. 79-80.

- Tomo Maretić: Gramatika sa stilistikom, Zagreb, 1899, 1931.

- Asim Peco: „Jedan pogled na pisanu reč Stefana Mitrova Ljubiše“, CANU: Stefan Mitrov Ljubiša, Titograd, 1976. str. 211. 
- Stefan Mitrov Ljubiša: Djela; Obod - Cetinje, Kulturni centar Budva, 1974.

- Mihailo Stevanović: „Sintaksička sinonimika“, Književnost i jezik, god. X, br. 2, Beograd, 1963, str. 81.

- Novo Vuković: „Neke stilske karakteristike Dojčevićevog pričanja“, Stvaranje, br. 12, Titograd, 1974.

Miloš KRIVOKAPIĆ

\section{FREQUENCY OF THE VERB FORMS IN THE LANGUAGE OF STEFAN MITROV LJUBIŠA}

Stefan Mitrov Ljubiša, a talented narrator and stylist, has achieved a complete harmony between motifs, themes and the manner of narration. He has achieved not only a vertical harmony, but also a horizontal one which relates between the sound and the meaning of a word. Various verb forms, their synonyms as well as great possibilities of their combining have significantly enabled creation of this harmony. The language of Stefan Mitrov Ljubiša has a very significant stylistic potential. The various meanings and multi-layered structures of the verb forms are the product of the affective attitude of the narrator which stems from the aspiration of the narrator to use the most expressive verb form (the verb form and its synonym). The subtle shading of the logical and grammatical and stylistic functions of the verb forms creates a very strong expression and rhythmicity.

Key words: frequency, synonymy, transposition, verb forms, language 
LINGUA MONTENEGRINA, god. III, br. 5, Cetinje, 2010.

Institut za crnogorski jezik i jezikoslovlje „Vojislav P. Nikčević“

UDK 811.163.42'366.543

Izvorni naučni rad

\section{Branko KUNA (Osijek)}

Filozofski fakultet Sveučilišta J. J. Strossmayera

\section{KVALITATIVNI GENITIV U HRVATSKOME JEZIKU ${ }^{1}$}

Kategoriju kvalitativnoga genitiva odlikuju jasna sintaktička i semantička obilježja koje ga čine bitno drukčijim od ostalih genitivnih atributa. U sintaktičkom pogledu obilježen je čvrstim ustrojstvom koji čini obvezna odredba, u semantičkom - izdvajanje izvjesne osobine, svojstva dijela ili cjeline određenog referenta. U članku se raspravlja o obvezatnosti odredbe kvalitativnoga genitiva i njezinoj morfološkoj naravi, a također i o gramatičkim opisima koji se odnose na uporabu te konkurentnost s drugim sredstvima za izražavanje kategorije kvalitete.

Ključne riječi: kategorije, kvalitativni genitiv, semantički padež, posvojni genitiv, pridjevne složenice, instrumental karakteristične pojedinosti

\section{Uvod - o kategori(zaci)ji}

Iskustva i impresije koje prije negoli postanu spoznajom, prema Immanuelu Kantu, ,moraju se nekako organizirati ili ujediniti putem djelatnosti razuma“, što je uvjet njihova prenošenja (Russel, 2005: 240). Univerzalni način organiziranja spomenutih činjenica jest kategorizacija. Pristupi u kategorizaciji jesu ona ključna točka u jezikoslovlju oko koje se pojedine teorije i metodologije razilaze. Klasični pristup, naslanjajući se na Aristotela, podrazumijeva dovoljnu količinu zajedničkih svojstava članova svake kategorije između kojih postoje jasne, diskretne i čvrste granice. Suvremeni, kognitivno usmjereni pristupi tumače da među kategorijama postoje sličnosti koje se u određenom dijelu međusobno prožimaju. Prema Lakoffu (1987) svaka se kategorija odlikuje unutrašnjom organizacijom u čijem se središtu nalaze reprezentativni članovi s prototipičnim obilježjima, a na njezinoj se periferiji

\footnotetext{
${ }^{1}$ Ovaj rad do sada nije objavljen, a izložen je na znanstvenome kolokviju u povodu 60. rođendana prof. dr. sc. Ive Pranjkovića 16. 12. 2007. na Filozofskome fakultetu u Zagrebu.
} 
nalaze manje reprezentativni članovi koji sadržavaju u različitim omjerima obilježja susjednih kategorija. Međutim, pojam prototipa ne veže se uz pojavu kognitivnog jezikoslovlja jer se njime operira već dulje vrijeme još od praškoga kružoka, a nastao je kako bi se razriješilo razgraničenje, odnosno stupnjevitosti među sintaktičkim i semantičkim kategorijama. ${ }^{2}$

Stvarnost, u koju smo uronjeni, raznolika je i dinamična. Komunikacija bi izazivala veliki napor, nadilazila bi ili pojačano trošila naše kognitivne sposobnosti i mogućnosti ukoliko bi se svaki segment izvanjezične stvarnosti označavao posebnim imenom. Svako navođenje pojavnog obilježja prema kojem se neki referent izdvaja od ostalih naziva se aktualizacija (Crystal, 1988: 21), a drugi autori njome označuju proces u kojem jezične jedinice iz leksika određenog jezika, koje označuju koncepte izvanjezične zbilje, poprimaju značenja konkretnih fenomena u jeziku. Izdvajanje imenice prema nekom svojstvu, veličini, boji, pripadnosti i sl. navođenjem kakve odredbe naziva se kvalifikacija, za razliku od kvantifikacije koja podrazumijeva izdvajanje imenice po brojivoj ili nebrojivoj količini. Jedna od bitnih uloga kvalifikacije jest sužavanje kruga mogućih denotata. Vrlo je srodna kategorija i način koji je prema Paliću (2007: 17) u semantičkom smislu samo svojevrsna potkategorija kvalitete. Pranjković (2007: 191) tvrdi kako se u sintaktičkom smislu kvaliteta proteže i na predmete (označene imenicama) i na radnje (označene glagolima), no tada se govori o načinu vršenja glagolske radnje koja se izražava adverbijalima (priložnim oznakama). Tako hrvatski jezikoslovac iz 19. stoljeća A. Veber Tkalčević (1859: 33-4) odvaja genitiv kojim se „naznačuje svojstvo koje osobe ili stvari“", a koji se pojavljuje s glagolom biti: ${ }^{3}$," Puškin je bio kundrave cèrnjušaste kose, široka nosa, sivih očijuh", od genitiva načina koji vežu svi drugi glagoli: „Naša slava proći će praznih ruku“ ili „draga sèrca priznajem“.

Ponekad nije jasno i razlučivo je li kvalitativni izraz određuje referenta ili radnju, posebice ako se nalazi u izravnom dodiru s imenicom:

(1) a. Čovjek pognute glave izlazi iz prostorije.

b. Čovjek izlazi iz prostorije pognute glave.

Međutim, u oba prethodna primjera riječ je o adverbijalima: kao prvo, dio referenta izdvojen je na temelju povezanosti s poimeničenom glagolskom riječi. Svi takvi primjeri imaju particip (pridjev trpni) kao odredbu imenske rije-

\footnotetext{
${ }^{2}$ Tako je Roman Jakobson pomoću obilježja: [ \pm rubni] (periferijnyj); [ \pm obuhvatnost] (obъemnostb) i [ \pm upravljeni] (napravlennyj) primijenio teoriju prototipa u kategorizaciju ruskoga padežnog sustava (Franks, 1995: 42-3).

${ }^{3}$ Veber je takvim stavom zapravo blizak preobličnoj gramatici (Katičić, Znika) jer nastanak atributa dovodi u vezu s preobličenim imenskim predikatom.
} 
Kvalitativni genitiv u hrvatskome jeziku

či. ${ }^{4}$ No glagolski način mogu izricati i genitivni izrazi kojima je odredbeni pridjev neglagolskog podrijetla.

Prema Pranjkoviću (2007) kakvoću predmeta primarno označuju kvalitativni pridjevi (odnosno kvalitativni atributi), no to vrijedi samo ako se misli na kakvoću cijelog referenta: plavi automobil, žuta kuća, pametna misao, strog profesor. Kada je riječ o kakvoći koja se odnosi na stvarni ili mišljeni dio određenog referenta, tada se ona izriče nizom sintaktičkih načina: kvalitativnim genitivom, složenim pridjevima, prijedložnim izrazom, imeničnim skupinama ili relativnim rečenicama. U tom slučaju riječ je isključivo o priimeničnoj (adnominalnoj) ulozi takvih izraza:

(1) a. djevojka crne kose

b. crnokosa djevojka

c. djevojka s crnom kosom ${ }^{5}$

d. djevojka kose poput ugljena (kao ugljen)

e. djevojka koja ima crnu kosu

f. djevojka kojoj je kosa crna.

\section{Gramatičke odredbe i teorijski pristupi}

U tradiciji hrvatske gramatike na tu se kategoriju odnose sljedeći nazivi koji su podudarni ili su rezultat dodatne diobe: genitiv svojstva (Veber, Katičić, Silić/Pranjković), genitiv reda i gradiva (Veber); genitiv oznake (Maretić) te genitiv dobi (Silić/Pranjković).

Kvalitativni genitiv odlikuje se postojanim sintaktičkim i semantičkim obilježjima koji ga čine jasno prepoznatljivim u odnosu na druge atributne kategorije. Ta je kategorija poslijeimenični modifikator, koji uključuje svezu najmanje dviju imenskih riječi, od kojih je najmanje jedna imenica. Ta je sveza riječi sintaktički zavisna o imenici, a semantička joj je uloga izricati kakvo svojstvo, osobinu, determinanta, glavne imenice, jezgre nominalne skupine, ili regensa, kako se u različitim teorijama naziva kvalificirani član. Izdvajanje nekog entiteta kvalitativnim genitivom može biti trenutačno, vezano za određenu situaciju: čovjek ozbiljna lica; djevojka mokre kose ili izdvajanje kakva trajnog obilježja: mladić snažne građe; računalo snažne memorije. Česta poraba kvalitativnoga genitiva dâ se objasniti paradigmatskom ekonomijom, odnosno izbjegavanjem stvaranja nove jedinice u sustavu tako što se kombinacijom postojećih i aktualizacijom pojavnog obilježja izdvaja od-

${ }^{4}$ I. Palić (2007: 649) u tim slučajevima govori o distinkciji između načinskoga i popratnookolnosnog značenja. Načinsko se značenje ,padežnog izraza aktualizira samo onda kada se odredbom... ...obilježava neka osobina koja je relevantna za sudjelovanje onog što je njime obilježeno u ostvarivanju glagolske radnje“.

${ }^{5}$ Nestandardni oblik u hrvatskome jeziku. 
ređeni referent (žena crne kose) između mnoštva istovrsnih entiteta. Kada se izdvojeni referent često spominje, tada kombinacija više jezičnih jedinica postaje neekonomična te nastupa sintagmatska ekonomija, odnosno tvorba riječi koja će u svojoj strukturi sadržavati i spomenuto svojstvo crnka ili garavuša.

U hrvatskom je jeziku kvalitativni genitiv iznimno česta atributna vrsta, nije ograničen na pojedine funkcionalne stilove, iako je nešto rjeđi u razgovornom stilu. Može se govoriti o uzvišenosti i zastarjelosti pojedinih sintagmi u kojima se nalazi kvalitativni genitiv, poput čovjek staroga kova, ali sintaktički obrazac prema kojem takve sintagme nastaju nikako nije arhaičan, već je iznimno produktivan i živ. U usporedbi s drugim slavenskim jezicima u kojima se u genitivnom obliku pojavljuju imenice samo općega značenja: boja, vrsta ili oblik, K. Feleszko (1995: 43-5) uočava znatno veću rasprostranjenost takvoga genitiva u hrvatskom jeziku, a što objašnjava činjenicom da genitivno označene sastavnice mogu biti i imenice općeg, ali i veoma uskog značenja, kojih je u jeziku znatno više, te je stoga broj kombinacija s određenom imenicom znatno veći. S druge pak strane u njemačkom su jeziku konstrukcije s kvalitativnim genitivom neplodne i danas teško prihvatljive (Engel, 1991: 612) jer u najmanju ruku vrijede kao zastarjele, iako su nekada bile veoma plodne, a danas se upotrebljavaju kao idiosinkratički izrazi ili listemi: ein Jüngling edlen Wuchses - 'mladić plemenita podrijetla'; Leute beliebigen Alters - 'ljudi različite dobi ${ }^{`}{ }^{6}$

\subsection{O obvezatnosti (pridjevne) odredbe}

Kao glavna strukturno obilježje u svim gramatičkim opisima te kategorije navodi se činjenica kako se imenica u tom obliku ne pojavljuje samostalno, već mora biti ,združena s kojom pokretnom riječi“", odnosno uz nju je „obvezatno uvršten atribut" ${ }^{8}$ D. Stolac (1992: 171) daje i restriktivnije određenje o pojavnosti te navodi kako kvalitativni genitiv uvijek dolazi s obveznom pridjevnom odredbom - determinantom. Međutim, takvo određenje nije potpuno, odnosno vrijedi u najvećem broju slučajeva, ali ne i u svim, budući da postoje sklopovi gdje taj atribut može biti i imenica u genitivu:

${ }^{6}$ Ulrich Engel (1991) u sklopu svog teorijskog pristupa gramatike zavisnosti ne govori posebno o toj genitivnoj atributnoj vrsti svjestan kako potreba za izražavanjem značenja kvalitete koji je on nekada predstavljao, nije nestala iz jezika već samo može imati različite ostvaraje, stoga govori o kvalitativnom dodatku (Qualitativangabe). U Dudenovoj (1995: 645) se Gramatici samo napominje kako se u današnjem njemačkom „Genitivus qualitatis“ uglavnom zamjenjuje prepozicionalnim izrazima s von ili aus. Tako se kazuje: Ein Mann von mittlerem Alte, ali i ein Mann mitleren Alters - 'čovjek srednjih godina'.

${ }^{7}$ Maretić, 1963: 572-3.

${ }^{8}$ Katičić, 1991: 435. 
Kvalitativni genitiv u hrvatskome jeziku

(2) a. Noći boje borovnice. ${ }^{9}$

b. ? Noći borovničine boje.

c. Noći boje kao borovnica.

(3) a. Posjetili smo i Regensburg, grad veličine Osijeka.

b. ? Obišli smo i Regensburg, grad osječke veličine.

c. Obišli smo i Regensburg, grad veličine kao Osijek.

Genitive u primjerima ( 2 a i 3a) bilo bi sporno zamijeniti relacijskim pridjevima koji bi bili izvedeni od imenica jer bi tada oni nametali prvotno posvojni odnos ( $2 \mathrm{~b}$ i $3 \mathrm{~b}$ ). U tim je izrazima u prvom planu izricanje vrste boje očiju i veličine grada na temelju usporedbe s referentima koji su poznati sugovorniku ili primatelju poruke, zato je i moguće načiniti atribut s vezničkim kao-izrazom u (2c i 3c). Takvi primjeri dokaz su srodnosti kategorije kvalitativnosti s kategorijom poredbenosti (komparativnosti), ali isto tako da se i danas u takvim konstrukcijama imenica u genitivu i pridjev nalaze u konkurentnom odnosu kao i u dopovijesnim jezičnim stanjima. M. Ivić (1983: 191) razloge obvezatnosti atributa (determinatora) objašnjava činjenicom da zavisna imenica, kojom je označen (sastavni) dio onoga što imenuje glavna imenica, može biti u determinativnoj ulozi pod uvjetom ,,da se i sama ostvari u konstrukciji s determinatorom“, jer isticati da se nešto sastoji od poznatog dijela ili sadržava opću osobinu *oči boje značilo bi lišiti jezik njegove glavne uloge - obavješćivanja - i ukloniti semantičke regulatore koji upravljaju sintaktičkim odnosima. Postojanje pridjevne odredbe uz genitiv ipak nije svojstveno samo za kvalitativni genitiv, odnosno to ne može biti jedini kriterij, jer svaki atributni genitiv može imati odredbu:

(4) a. znak dobre volje

b. znak volje

c. znak je (dobre) volje

(5) a. čovjek dobre volje

b. *čovjek volje

c. čovjek je dobre volje

Silić-Pranjković (2005: 202) izraz u (4a) određuju kao objasnidbeni (eksplikativni) genitiv, a kriterij za takvu kategorizaciju jest mogućnost ispuštanja pridjeva bez utjecaja na gramatičnost dobivenog izraza (4b). Suprotno je $s$ primjerom u (5a), postojanje ili nepostojanje volje dijelom je čovjekova integriteta, stoga izostanak odredbe uz nju čini izraz besmislenim (5b). Osim semantičke sličnosti s objasnidbenim genitivom te dvije kategorije pokazuju određenu podudarnost i u sintaktičkom ponašanju. Naime, između glavne i atributne imenice moguće je načiniti preobliku (4c i 5c), uspostaviti predikatni odnos s pomoćnim glagolom biti, pri čemu atribut postaje predikatno ime.

\footnotetext{
${ }^{9}$ Ime filma.
} 
Razlika je u tome što su izrazi, u kojima je kvalitativni genitiv dijelom imenskog predikata, sasvim uobičajeni u upotrebi te ne postoje samo kao dio teorijskog morfosintaktičkog modela.

\section{2. O sličnosti s posvojnim genitivom}

Kvalitativni genitiv dijeli određenu konceptualnu sličnost s onim vrstama posvojnoga genitiva u temelju kojih je odnos između dijela i cjeline (dijelovi tijela i predmeti). ${ }^{10}$ Taj se odnos u Langackerovu (1993: 2-4) kognitivnom pristupu uvrštava u jednu od predodžbenih shema kao bazičnih kognitivnih sposobnosti urođenih svakomu čovjeku koje imaju mogućnost apstraktnoga proširenja pri tjelesnom iskustvu spoznavanja svijeta koji nas okružuje. Predodžbena se shema podjednako odnosi na konkretne i apstraktne pojmove, a osim dijela i cjeline Langacker navodi i odnose: kontejner - sadržaj; izvor - staza (put) - cilj; središte - periferija i sl. Odnos između dijela i cjeline prepoznatljiv je ne samo kada je riječ o izricanju posvojnosti i kvalitativnosti (osim genitiva to su i druga kvalitativna sredstva: crnokosa žena; automobil s pretincima) već i drugih značenja kao što je odnos između vršitelja i predmeta radnje: Ona pere kosu ili u značenju dijelnosti: većina prozora, neki od studenata.

Na semantičkom je planu uloga kvalitativnoga genitiva (čiji se leksički sadržaj odnosi na dio ili kakvo imanentno svojstvo) da služi kao mentalna adresa, identifikacijsko obilježje za entitet koji predstavlja njegovu cjelinu. Kada je riječ o sličnosti između dvaju atributnih kategorija, može se reći kako je sintagma s kvalitativnim genitivom zrcalna strukturna projekcija posvojne sintagme:

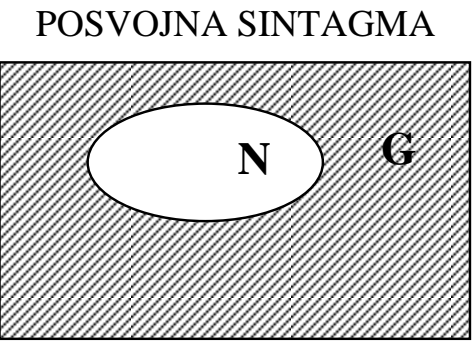

KVALITATIVNA SINTAGMA

U posvojnoj sintagmi dio označen imenicom u nominativu glava je skupine, a aktualizira ju imenica u genitivu koja označuje cjelinu. U kvalitativnoj je sintagmi obrnuto, cjelina kao semantička i sintaktička jezgra (glava)

${ }^{10} \mathrm{U}$ taj odnos ne ulaze prototipična značenja posvojnosti kao što su vlasništvo i rodbinski odnosi. 
Kvalitativni genitiv u hrvatskome jeziku

obilježena je imenicom u nominativu, a aktualizira ju imenica u genitivu s odredbom kojom se imenuje dio. Tako je u sljedećim primjerima:

(6) a. spretne noge nogometaša

b. nogometaševe spretne noge

c. njegove noge

(7) a. nogometaš spretnih nogu

b. *njihov nogometaš.

U oba slučaja riječ je izdvajanju dijela u odnosu na svoju cjelinu, pri čemu je posvojnim genitivom označena cjelina (6a) kojoj pripada dio koji imenuje glava imenične skupine. Dio označen kvalitativnim genitivom (7a) pripisan je kao svojstvo cjeline. Cinjenica je kako se oba izraza mogu podvesti pod oznaku izricanja neotuđive posvojnosti (Fillmore 1968: 61-3). No, kvalitativni je genitiv (7b) sa svojom jezgrenom imenicom u posebnom tematskom odnosu jer ne može biti zamijenjen posvojnim oblicima: pridjevom ili zamjenicom kao posvojni (6b i 6c) ili subjektni i objektni genitiv, iako je tematski označen. U slučaju te kategorije postoji zapreka u NP-pomicanju jer se pomicati može samo slobodna leksička glava, a on bez odrednika ne može biti gramatičan. Ali ako se kvalitativnom genitivu dodjeljuje tematska uloga, postavlja se pitanje zašto onda ne mogu biti zamijenjeni posvojnim zamjenicama. U skladu s teorijom upravljanja i teorijom tematskih uloga uzroci sintaktičko-semantičkom neskladu mogli bi se protumačiti činjenicom što je kvalitativni genitiv semantički (inherentni) padež. On jest tematski označen, ali ne zauzima A-položaj, dakle nije pravi argument, tada on i ne može biti pomican jer pomicanje imenične skupine podrazumijeva pomicanje s jednog Apoložaja na drugi (Mihaljević 1998: 200), a subjekt NP, kamo bi atributni genitiv trebao biti pomaknut, jest A-položaj (argument glave). Uzrok takvom položaju kvalitativnoga genitiva leži u semantičkim relacijama među imenicama. Dakle, može se reći da je kvalitativna sintagma zrcalna strukturna projekcija posvojne sintagme, samo bez A-položaja.

\section{Konkurentnost s drugim sredstvima}

\subsection{Pridjevi}

Uporaba se kvalitativnoga genitiva veoma često isprepliće s pridjevima, to je stoga što je pridjevima „obilježavanje svojstva“ (Pranjković 1993: 50) značenjski primarno. No, ne može se govoriti o ekvivalentno vrijednim izrazima jer postoje leksičko-semantička i tvorbena ograničenja pri uporabi pojedinog oblika koji nose različite sintaktičke i pragmatičke obavijesti. Naime, kvalitativni je genitiv jedini atributni padežni izraz koji može alternirati s pravim (nemotiviranim) te izvedenim pridjevima. Tako dijelni genitiv uopće ne alternira s pridjevima čaša mlijeka - *mliječna čaša, a takozvani tematski genitivi (posvojni, subjektni i objektni) alterniraju u odnosu slobodnih i kom- 
binatoričnih varijanata s motiviranim pridjevima: načelnik općine - općinski načelnik; knjiga moga brata - bratova knjiga.

Promatrajući upotrebu različitih sintaktičkih oblika za izricanje kvalifikacije, daju se otkriti sljedeće zakonomjernosti:

1. Ako je riječ o isticanju kakve osobine koja je sastavnim, neodvojivim dijelom kvalificiranog referenta i koja ga prožima u cijelosti, tada je kvalificirajuća imenica zališna, odnosno može biti ispuštena, a sročni pridjev može biti suprotstavljen nesročnom kvalitativnom genitivu. Ideja odvojivosti, dijelnosti te osobine nije zamisliva u konceptualizaciji određenog referenta, budući da se podrazumijeva kako svaki (konkretan) predmet ima boju, građu, okus, visinu, moguće je samo istaknuti obilježje tog svojstva. Stoga supostoji:

brod bijele boje i bijeli brod; igrač snažne građe - snažan igrač; čokolada gorka okusa - gorka čokolada; vino slatka okusa - slatko vino; dječak visoka rasta - visok dječak

U tim primjerima ne može se govoriti o potpunoj istoznačnosti jer je kvalificirana sintagma s pridjevom znatno šireg značenja, tako pridjev u izrazu snažan igrač može označivati i tjelesnu i psihološku snagu; stoga je izraz s kvalitativnim genitivom jasniji, određeniji jer ima specificirajući element - građu. Vino slatka okusa nije jakošću ili stupnjem osobine u tolikoj mjeri prevladavajuće kao u izrazu slatko vino koje je zbog (pragmatičkog) isticanja, odnosno topikalizacije (stavljanjem u prvi plan) svoje kakvoće, oznakom vrste vine.

2. Pridjevne složenice (složeno-sufiksalne tvorbe) javljaju se u onom slučaju kada je riječ o izdvajanju trajnog ili trenutačnog svojstva dijela referenta, a čija obilježja nisu razlikovna, tipična za predodžbu nekog referenta, dakle ne podrazumijevaju se, stoga trebaju biti i spomenuta. Svojstva dijelova nekog referenta izraženo sredstvima kvalifikacije odražava njegovu promjenjivost u stvarnom svijetu i nisu značenjski ključna za shematsku predodžbu njegova tipičnog uzorka koji čini središte određene kategorije ili prototipa (Taylor 1989: 59). Ideja je odvojivosti dijela referenta naglašenija:

mačka kratke dlake - kratkodlaka mačka; pas dugih ušiju - dugouhi pas; svinja kratka vrata - kratkovrata svinja; korovi široka lista širokolisni korovi; žena duge kose - dugokosa žena; dječak brzih nogu - brzonog dječak...

Pridjevna složenica može se odnositi i na svojstva koja se odnose na cijeli kvalificirani predmet, ali njegova obilježja također nisu značenjski relevantna za određenje nekog entiteta

uređaji niska napona - niskonaponski uređaji; mlijeko kratka trajanja - kratkotrajno mlijeko; kulen visoke kvalitete - visokokvalitetni 
kulen; djevojka tamne puti - tamnoputa djevojka; mladić bistra uma - bistroumni mladić...

Da bi se pridjevna složenica mogla načiniti, pridjev mora biti dvosložan, u najčešćem broju slučajeva, to su nemotivirani pridjevi. Ako je pridjev trosložan, tvorba pridjevne složenice nije moguća:

(8) a. čovjek dobrih namjera - dobronamjeran čovjek

b. čovjek nečasnih namjera - *nečasnonamjeran čovjek

c. stranka opasnih namjera - *opasnonamjerna stranka.

Drugi razlog nemogućnosti zamjene kvalitativnoga genitiva može biti zauzetost značenja koju već ima pridjevna složenica, poput karta prvog razreda *prvorazredna karta. ${ }^{11}$

3. Konkurentan izraz može biti i pridjev izveden od imenice kvalitativnoga genitiva koji je modificiran popriloženim pridjevom kao njegovom odredbom. U pravilu je riječ o unutarnjim značajkama karaktera, inteligencije ili tjelesne građe:

učenik natprosječne inteligencije - natprosječno inteligentni učenik; profesor solidne elokvencije - solidno elokventni profesor; atletičar izrazite brzine - izrazito brz atletičar; planinar zadivljujuće snage - zadivljujuće snažan planinar...

Takva se ustrojstva ne mogu uspostaviti ako se izriče osobina dijela entiteta: boksač smirenih živaca - *smireno živčan boksač.

\subsection{Instrumental karakteristične pojedinosti}

Odnos tih dvaju sredstava za izražavanje kakvoće čestim je mjestom normativnih uputa u gramatikama i jezičnosavjetničkoj literaturi. Tako Brabec-Hraste-Živković (1970: 223) tvrde kako ne valja upotrebljavati instrumental s prijedlogom $s$ umjesto kvalitativnoga genitiva. Jonke (1964: 128) također spominje kako kvalitativnomu genitivu treba uvijek dati prednost: „Instrumental s prijedlogom može se podnijeti samo u rijetkim slučajevima koji su uvjetovani stilskim potrebama.“ U „Hrvatskom jezičnom savjetniku“ ističe se da je kvalitativni genitiv odlika biranijeg stila tamo gdje su zamjenjivi te da on ima prednost kada označuje dio živoga bića (djevojka plavih očiju) ili kada se njime kvalificira cijela osoba (čovjek visoka rasta). Tamo gdje su oba sredstva zamjenjiva ,genitivom se izriče tješnja veza, a instrumentalom manje tijesna veza“" (Barić 1999: 254). Izbor određenih jezičnih sredstava odlučuju ne samo pravila koja su strukturno uvjetovana već i brojni se-

${ }^{11}$ Prvorazredan u hrvatskom označuje da je nešto 'najbolje', 'izvanredno'. Tako se i u njemačkom kvalitativni genitiv, koji se sačuvao u idiosinkratičkom izrazu Eine Fahrkarte erster Klasse, ne može zamijeniti složenim pridjevom *erstklassige Fahrkarte. 
mantički i pragmatički razlozi. I najmanja promjena na planu izraza izaziva promjenu na semantičkom planu, a ona je opet rezultat promjene perspektive iz koje se promatra situacija. Gramatički opis ako isključi kontekstualnu ovisnost postaje necjelovit i manjkav. Jezik je složen, ali ujedno i ekonomičan sustav te je stoga svaka takozvana sintaktička sinonimija upitna (v. Stolac, 2007). Brojni semantički, situacijski pa i formalno logički odnosi utječu na način kvalifikacije:

(9) Kopf mit dem struppigen weißen Haar

(10) a. Glava s čupavom bijelom kosom

b. *Glava čupave bijele kose

(11) Starac čupave bijele kose.

Njemačka rečenica iz Kafkina djela na hrvatski jezik može biti prevedena samo prijedložnim instrumentalom (10a) jer je riječ o kvalifikaciji dijela ljudskog tijela (glave) svojstvima njegova manjeg dijela (čupava, bijela kosa), a ne cijele osobe ili njezina duhovnog bića. Kvalitativni genitiv uporabit će se kada se njime označuje svojstvo dijela osobe (11).

Kada je riječ o izdvajanju bolesti ili tjelesnog nedostatka živog bića kao njegova obilježja, tada ne može biti upotrijebljen genitiv, dakle: dječak $s$ upalom pluća, ali ne i *dječak upale pluća; bolesnik $s$ jednom nogom, a ne *bolesnik jedne noge. Isto vrijedi i za nadomjestke ili zamjene čovjekovih dijelova tijela ili organa: i u tom slučaju prijedložni instrumental jedino je moguć: pacijentica s umjetnim kukom a ne *pacijentica umjetnoga kuka; osoba $s$ umjetnim zubalom, a ne *osoba umjetnog zubala.

Tvrdnja kako se instrumental karakteristične pojedinosti s atributom može upotrebljavati u svim slučajevima, a kvalitativni genitiv samo kad on označuje dio živog bića (Barić, 1999: 253; M. Ivić, 1954: 204) ne odgovara današnjem stanju. U tome bi slučaju i naziv atributne vrste - instrumental karakteristične pojedinosti - odstupao od toga pravila jer je instrumental imenica koja označuje nešto neživo okvalificirana genitivnim izrazom karakteristične pojedinosti. Dakle, i imenice koje imaju oznaku neživog mogu biti određene genitivnim dopunama, potvrda su tomu nazivi iz naše svakodnevice:

automobili luksuzne klase; kuća visoke mode; košulje kratkih rukava; ruž visokog sjaja; regenerator nove generacije; sprej neodoljiva mirisa; maslac prve klase; knjiga gorke istine; proizvodi jednostavne izrade; motor izvrsnih performansi...

\section{Zaključak}

Kvalitativni je genitiv atribut koji označuje kakvo svojstvo ili sastavni dio imenice koju određuje. Osim atributne uloge može biti u rečenici i dio imenskog predikata (Majka je uvijek bila nasmijana lica), a nju opet valja lučiti od priložne (načinske) uloge. U gramatičkim se opisima ističe kako ime- 
Kvalitativni genitiv u hrvatskome jeziku

nica u kvalitativnom genitivu nikada ne dolazi samostalno, već mora imati sročnu pridjevnu odredbu, to vrijedi u najvećem dijelu primjera, ali odredba može biti i imenica u genitivu (oči boje Dunava, grad veličine Osijeka). Kvalitativni je genitiv, unutar modela generativne gramatike, semantički (inherentni) padež koji je tematski obilježen (od glavne imenice dobiva padež i s njom je u odnosu zavisnosti) te je stoga na neki način srodan s tematskim genitivima (posvojni, subjektni, objektni). Ali za razliku od njih, kvalitativni $G$ ne predstavlja argument te stoga ne može biti zamijenjen s posesivima: dolazak starog prijatelja - njegov dolazak, ali ne i čovjek vedre naravi - *njegov čovjek. Strukturno se ponaša jednako kao i dijelni i objasnidbeni genitivi koji također ne zauzimaju položaj argumenta (A-položaj). S određenim vrstama posvojnoga genitiva u temelju kojih je odnos između dijela i cjeline, dijeli konceptualnu sličnost, a usporedbom skupina u kojima se ti genitivni atributu pojavljuju, može se reći kako se nalaze u odnosu zrcalne strukturne projekcije - glava posvojne sintagme jest zavisni dio (atribut) kvalitativne sintagme: nasmijano lice manekenke - manekenka nasmijana lica. U izražavanju kvalitativnosti može biti zamijenjen pravim pridjevima, pridjevnim složenicama ili pridjevima s priložnim modifikatorima, ovisno o leksičko-semantičkim obilježjima, tj. odnosi li se svojstvo na cjelinu ili dio te koliko su obilježja tih svojstava značenjski relevantna ili prototipična za poimanje određenog entiteta. Također, ta kategorija alternira i s (prijedložnim) instrumentalom karakteristične pojedinosti, ali primjeri pokazuju kako je područje njihove uporabe također ograničeno situacijskim okvirom i semantičkim značajkama izdvojenog referenta.

Budući da se odnosi na imenice općeg, ali i veoma uskoga značenjskog polja, u hrvatskome je jeziku kvalitativni genitiv veoma proširen i plodan način izricanja kvalitete ili kakvoće, pogodan za uzvišenu, stilski obilježenu, ali i kolokvijalnu uporabu. Sredstvo je to opće i posebne namjene.

\section{Literatura}

- Barić, E. / Hudeček, L. / Koharević, N. / Lončarić, M. / Lukenda, M. / Mamić, M. / Mihaljević, M. / Šarić, Lj. / Švaćko, V. / Vukojević, L. / Zečević, V. / Žagar, M.: 1999. Hrvatski jezični savjetnik. Institut za hrvatski jezik i jezikoslovlje, Pergamena, Školske novine: Zagreb.

- Brabec, Ivan/Hraste, Mate/Živković, Sreten 1970. ${ }^{9}$ Gramatika hrvatskosrpskoga jezika, Školska knjiga: Zagreb.

- Crystal, David 1988. Enciklopedijski rečnik moderne lingvistike, Nolit: Beograd.

- Drosdowski, Günther (ur.) 1995. ${ }^{5}$ Grammatik der deutschen Gegenwartssprache, Band 4, Dudenverlag. 
- Engel, Ulrich 1991. ${ }^{2}$ Deutsche Grammatik, Julius Groos Verlag: Heidelberg.

- Feleszko, Kazimierz 1970. Skladnia genetiwu $i$ wyražen przyimkowych z genetiwem w jezyku serbsko-chorwackim, /prijev. Značenja i sintaksa srpskohrvatskog genitiva, Beograd 1995./

- Fillmore, Charles J. 1968. „The Case for Case“, u: Universals in Linguistic Theory (ur. Beach E. i Harms R.) New York.

- Franks, Steven 1995. Parameters of Slavic Morphosyntax, Oxford University Press: Oxford - New York.

- Helbig, Gerhard/Buscha, Joakim 1994. ${ }^{16}$ Deutsche Grammatik (Ein Handbuch für den Ausländerunterricht), Verlag Enzyklopädie: Leipzig.

- Ivić, Milka 1954. Značenja srpskohrvatskog instrumentala i njihov razvoj, Naučna knjiga: Beograd.

- Ivić, Milka 1983. Lingvistički ogledi, Prosveta: Beograd.

- Katičić, Radoslav 1991. ${ }^{2}$ Sintaksa hrvatskoga književnog jezika, Hrvatska akademija znanosti i umjetnosti i Globus: Zagreb.

- Lakoff, George 1987. Women, Fire and Dangerous Things: What Categories Reveal about the Mind. The University of Chicago press: Chicago.

- Langacker, Ronald 1993. „Reference-point constructions“, Cognitive Linguistics, 4-1, str. 1-38.

- Maretić, Tomo 1963. ${ }^{3}$ Gramatika Hrvatskoga ili srpskoga književnog jezika, Matica hrvatska: Zagreb.

- Mihaljević, Milan 1998. Generativna sintaksa i semantika, Hrvatsko filološko društvo: Zagreb.

- Palić, Ismail 2007. Sintaksa i semantika načina, Bookline: Sarajevo.

- Pranjković, Ivo 1993. Prva hrvatska skladnja, Hrvatska sveučilišna naklada: Zagreb.

- Pranjković, Ivo 2001. Druga hrvatska skladnja, Hrvatska sveučilišna naklada: Zagreb.

- Pranjković, Ivo 2007. „Načini izražavanja načina“, Sintaktičke kategorije (zbornik znanstvenoga skupa I. hrvatski sintaktički dani, ur. B. Kuna), Filozofski fakultet: Osijek, Institut za hrvatski jezik i jezikoslovlje: Zagreb, str. 189-198.

- Russell, Bertrand 2005. Mudrost zapada, Marjan tisak: Split.

- Taylor, John R. 1989. Linguistic Categorization: Prototypes in Linguistic Theory. Clarendon Press: Oxford.

- Silić, Josip / Pranjković, Ivo 2005. Gramatika hrvatskoga jezika za gimnazije i visoka učilišta, Školska knjiga: Zagreb. 
Kvalitativni genitiv u hrvatskome jeziku

- Stolac, Dijana 1992. „Sintaktičke funkcije genitiva u jeziku Tituša Brezovačkog“, Rasprave Zavoda za hrvatski jezik, sv. 18., Zagreb, str. 165-176.

- Stolac, Dijana 2007. „Sintaktička sinonimija“, Sintaktičke kategorije (zbornik znanstvenoga skupa I. hrvatski sintaktički dani, ur. B. Kuna), Filozofski fakultet: Osijek, Institut za hrvatski jezik i jezikoslovlje: Zagreb, str. 241-252.

- Znika, Marija 1988. Odnos atribucije i predikacije, Hrvatsko filološko društvo: Zagreb.

- Veber Tkalčević, Adolfo 1859. Skladnja ilirskoga jezika za niže gimnazije, /sastavio Adolfo Weber, Beč/, pretisak Instituta za hrvatski jezik i jezikoslovlje: Zagreb, 2005.

\section{Branko KUNA}

\section{THE QUESTION OF THE QUALITATIVE GENITIVE IN THE CROATIAN LANGUAGE}

The author claims that the qualitative genitive consists of the clear syntactic and semantic features, different from other qualities related to the genitive case. In terms of the syntactic features it is defined by the necessary disposition and in the semantic ones it refers to the pointing out some important feature of the part or the object as a whole. The paper deals with the necessity of the qualitative genitive and its morphological structure as well as the grammatical descriptions related to its usage and its competitiveness to other means of the expressing of the same quality.

Key words: categories, qualitative genitive, semantic case, possessive genitive, instrumental of the characteristic feature 

LINGUA MONTENEGRINA, god. III, br. 5, Cetinje, 2010.

Institut za crnogorski jezik i jezikoslovlje „Vojislav P. Nikčević“

UDK 930.85:003.349.1

Izvorni naučni rad

\author{
Milica LUKIĆ (Osijek) \\ Filozofski fakultet Sveučilišta J. J. Strossmayera
}

\title{
USUSRET NOVIJOJ POVIJESTI GLAGOLIZMA
}

U članku se razmatra društveno-politički kontekst u kojemu se ćirilometodska ideja u 19. st., dakle u novijoj povijesti glagolizma, ponovno afirmira nakon punih deset stoljeća među slavenskim narodima, potaknuta velikim obljetnicama: tisućnicom moravske misije 1863. godine, tisućnicom smrti Sv. Ćirila 1869. godine, tisućnicom enciklike pape Ivana VIII. Industriae tuae 1880. te tisućnicom smrti Sv. Metoda 1885. godine i djelovanjem đakovačkoga i srijemskog biskupa Josipa Jurja Strossmayera. Razmatraju se također inicijalni poticaji razvoja hrvatske cyrillomethodiane pod vodstvom Franje Račkoga, a u okviru slavenske ćirilometodske znanosti, kao i prvi, u hrvatskoj periodici zabilježeni, koraci kojima je ćirilometodska ideja počela stupati u kulturni, znanstveni, a onda i politički život hrvatskoga nacionalnog prostora u 19. stoljeću.

Ključne riječi: glagolizam, ${ }^{1}$ cyrillomethodiana, 19. stoljeće

\section{Društveno-politički kontekst obnove ćirilometodske ideje u 19. st.}

Do sada sam već u nekoliko navrata u svojim radovima naglašavala kako ćirilometodsku problematiku u 19. st. oblikuju sastavnice čije silnice zasijecaju u tkivo mnogih stoljeća povijesti te da je baština koju su nam povjerili tvorci prvoga slavenskoga književnog jezika, Konstantin-Ćiril i Metod, i koja zato nosi naziv ćirilometodska, u okvirima je 19. stoljeća bremenita nanosima vremena - povijesnim, političkim i kulturološkim okolnostima

\footnotetext{
${ }^{1}$ Pojam glagolizam razumijevam u smislu definicija E. Hercigonje i J. Bratulića kao idejno usmjerenje - ideologem, pokret koji ima političke i vjerske konotacije i koji je simbol hrvatskoga/slavenskoga nacionalnog bića te simbol otpora rimskome crkvenom (latinskom) univerzalizmu. Usp. Josip Bratulić, Glagolizam i glagoljaštvo, u: Stjepan Damjanović (ur.), Drugi Hercigonjin zbornik, Hrvatska sveučilišna naklada, Zagreb, 2005, str. 53-57. Vidi i: Eduard Hercigonja, Glagoljaštvo i glagolizam, Zbornik Hrvatska i Europa. Kultura, znanost i umjetnost, sv. 1, Zagreb, 1997.
} 
naroda kojima je služila. ${ }^{2}$ Vrijeme je to prije svega obilježeno velikim ćirilometodskim obljetnicama: tisućnicom moravske misije 1863. godine, tisućnicom smrti Sv. Ćirila 1869. godine, tisućnicom enciklike pape Ivana VIII. Industriae tuae 1880. te tisućnicom smrti Sv. Metoda 1885. Te su velike obljetnice između ostaloga potakle borbu za ponovnu uspostavu staroslavenskoga bogoslužja i oživjele znanstveni i stručni rad u kojima se dokazivao legitimitet staroslavenskoga bogoslužja na hrvatskim prostorima, a i u širim, slavenskim okvirima, a preko toga temeljnoga prijenosnika i ostale sastavnice bez kojih njezino tumačenje u 19. stoljeću ne može biti potpuno: ekumenske ideje sjedinjenja Istočne i Zapadne crkve, jedinstva svih slavenskih naroda u jednoj Crkvi, jedinstva južnoslavenskih naroda, ideje ravnopravnosti s ostalim kršćanskim narodima Europe, i u hrvatskim okvirima - ideje ravnopravnosti i samostalnosti hrvatskoga naroda. Povjerenje slavenskih naroda u rješavanje navedenih problema naraslo je dolaskom na papinsku stolicu Lava XIII. 1879/1880. godine, a još više njegovim potezom proglašavanja Ćirila i Metoda svecima Katoličke crkve kroz okružnicu Grande munus 1880. godine, upravo tisuću godina poslije pisma Ivana VIII. moravskom knezu Svatopluku u kojemu se potvrđuje staroslavenska liturgija.

Ponovno probuđena ćirilometodska ideja u 19. stoljeću neće međutim biti puno povoljnija za slavenske narode od one u stoljećima njezina nastanka i razvoja. Francuska revolucija na samome kraju 18. stoljeća narednom stoljeću u nasljeđe ostavlja nemir. Ideja slobodarskoga preobražaja državnih struktura u demokratskome duhu i preobražaja staroeuropskoga društva u novo građansko društvo u 19. stoljeću živi u liberalno-demokratskim i nacionalnim pokretima čiji se osnovni zahtjev ogleda u nacionalnoj slobodi koja

${ }^{2}$ Usp. Ćirilometodske okružnice biskupa J. J. Strossmayera u Glasniku Biskupija Bosanske i Sriemske od 1873. do 1900. godine. U: Muka kao nepresušno nadahnuće kulture - Vukovar kao paradigma muke, Zbornik radova 4. međunarodnog znanstvenog simpozija / Jozo Čikeš (ur.), Vukovar, 2004, str. 146-161. Rad je objavljen i u časopisu Republika, mjesečniku za književnost, umjetnost i društvo br. 11, Zagreb, god. LX, studeni 2004, str. 97-107; Crtice o sveslavenskom hodočašću u Rim 1881. (Prilog za noviju povijest glagolizma). U: Zavičajnik, Zbornik Stanislava Marijanovića / Milovan Tatarin (ur.), Osijek, 2004, str. 233-251; Strossmayerova ćirilometodska djelatnost pretočena u pjesmu i priču, Zbornik 1. i 2. Strossmayerovih dana / Mirko Ćurić (ur.), Đakovo, 2005, str. 51-69; Šimun Milinović - bokokotorski biskup-glagoljaš i njegova uloga u oživljavanju ćirilometodske ideje u drugoj polovici 19. stoljeća, u: Stoljetni hrvatski i crnogorski književni i jezični identiteti - izborni pregled - Vojislavu P. Nikčeviću u spomen (19352007), str. 325-334; O glagoljaštvu i glagolizmu u zagrebačkome Katoličkom listu od 1849. do 1900. godine, Lingua montenegrina, Časopis za jezikoslovna, književna i kulturna pitanja, br. 3, Cetinje, 2009, str. 149-195; Popularizacija ćirilometodske ideje u drugoj polovici 19. stoljeća na hrvatskom nacionalnom prostoru, Lingua montenegrina, Časopis za jezikoslovna, književna i kulturna pitanja, br. 4, Cetinje, 2009, str. 85-125. 
Ususret novijoj povijesti glagolizma

će biti osigurana državom nacionalnoga jedinstva. Na zapadu Europe moderne se novointegrirane nacije uklapaju u postojeće državne okvire i tako kao nacionalne države nastavljaju svoj razvoj. U srednjoj se i istočnoj Europi takvu procesu ispriječila stara višenarodna monarhija nespremna na popuštanje novom dobu.

Ideja nacionalnoga jedinstva razvija se i kod naroda srednje i istočne Europe, ali ona ovdje ne može pronaći oslonac u državnom okviru. Zbog specifičnog načina integracije ovih nacija, mađarski ih povjesničar I. Bibo naziva ,jezičnim nacijama“. One su, prema onomu što iznosi Bibo, prisiljene etničkim činiteljima poduprijeti neizvjesnost političkoga bića, pa se oslonac traži u jeziku, narodnoj i državnoj tradiciji. ${ }^{3}$ Glavnu ulogu u „buđenju“ hrvatske nacije u prvoj polovici 19. stoljeća odigrat će hrvatski narodni preporod kao pokret građanstva i osviještenoga dijela plemstva čiji je cilj konstituiranje moderne hrvatske nacije. Takvi su narodni pokreti bili karakteristični za gotovo sve male narode srednje i jugoistočne Europe, gdje su ih obično vodili isti društveni slojevi kao i na hrvatskome nacionalnom prostoru s istim ili sličnim ciljem, ovisno o političkoj i društvenoj situaciji u kojoj se pojedini narod nalazio. S obzirom na političku nesamostalnost Hrvatske obilježenu sve manjim ovlastima bana i Sabora i sve većim ugarskim pritiskom te upravnom odvojenosti Dalmacije i Istre od Hrvatske (one su pod izravnom upravom Austrije), pojačava se djelovanje na području znanosti i kulture. To je vrijeme kada se intenzivno razvijaju filologija i historiografija, koje u 19. stoljeću traže temelje koji bi izdržali nacionalnu nadgradnju. Poseže se za prošlošću, povijesnim veličinama, tradicijom, posebice jezikom, kako bi se dokazala posebnost, samosvojnost i različitost. Kako su slavenski narodi unutar Habsburške Monarhije bili u gotovo istom položaju, a svaki pojedinačno podjednako slab, javlja se i ideja zajedničkoga djelovanja. U Hrvatskoj je ta ideja bila izražena u tzv. ilirskom pokretu, koji se tako nazivao jer se pozivao na zajedničko ilirsko podrijetlo južnoslavenskih naroda. Još je u vrijeme ilirizma naglašavano kako to nije politički već kulturni program (Ljudevit Vukotinović u članku Ilirizam i kroatizam) i kako smjera kulturnom, književnom i jezičnom, a ne političkom jedinstvu Južnih Slavena, iako je bilo i takvih zamisli u hrvatskoj politici 19. stoljeća, posebice kada je riječ o đakovačkome biskupu Josipu Jurju Strossmayeru. U takvu je povijesnom trenutku ćirilometodska ideja opet postala iskoristiva. Spomenuti biskup Strossmayer, kao središnja osobnost javnoga, kulturnog, a neko vrijeme i političkog života Hrvatske, obnavlja ovu ideju, a potporu mu pružaju istomišljenici iz područja

\footnotetext{
${ }^{3}$ Vidi: I. Bibo, Raspad teritorijalnog statusa Srednje i Istočne Evrope i nastanak jezičnoga nacionalizma - u: I. Bibo - T. Huszar - J. Szucs, Regije europske povijesti, Zagreb, 1995, str. 18-24.
} 
historiografije i filologije: Franjo Rački, Ivan Kukuljević Sakcinski, Šime Ljubić, Radoslav Lopašić, Tade Smičiklas, Vjekoslav Klaić, Ivan Krstitelj Tkalčić, Natko Nodilo, Frane Bulić, Matija Mesić, Ivan Berčić, Dragutin Parčić, Vatroslav Jagić, Ivan Crnčić, Fran Kurelac, Ivan Broz - samo su neki od njih. ${ }^{4}$

U osnovi ćirilometodske ideje su jezik i pismo. Već je spomenuto da se nacije u nastanku u srednjoj, istočnoj i jugoistočnoj Europi najviše oslanjaju na jezik kao na osnovni integrativni element. Dakle, jezik je ono što povezuje sve pripadnike istoga naroda odnosno nacije. Uostalom, još u srednjem vijeku narod se doživljava i objašnjava kao zajednica jednakogovorećih. Ćirilometodska se ideja uklapa i u viđenja tadašnje slavistike predvođene Šafařikom i Kollarom, koja se intenzivno razvija s ciljem povezivanja slavenstva, jer upravo su Ćiril i Metod Slavenima donijeli jezik i pismo. Tako desetstoljetna ideja Sv. Braće ponovno brani jezik Slavena, ali sada u smislu prava na opstanak među drugim jezicima odnosno nacijama. Hrvatski teolog i paleoslavist Josip Tandarić naglašava u svome članku Ćiril i Metodije - novi pristup evangelizaciji da su se Slaveni počeli osjećati kao narod tek kad su ,,progovorili pred Bogom svoju riječ u liturgiji“ te da „Sveta braća su pomogla da se u već uspostavljenom zapadnom svijetu, ili pak u koliko - toliko jasnoj podjeli Europe na Istok $i$ Zapad, na povijesnoj pozornici ravnopravno uspostavi i novi narod - Slaveni““. (istaknuo L. T.) $)^{5} \mathrm{U}$ istome smjeru idu i promišljanja Josipa Bratulića, posebice zanimljivo oblikovana u tekstu Glagoljica: Pismo, znak, slovo, koja se oslanjaju na tumačenje da se slavenski narodi prepoznaju u jedinstvu jezika. „Oni slove 'govore', i govorom se razumiju, skupljaju, postaju ethnos, narod“", kaže Bratulić. ${ }^{6}$ Ćirilometodska je ideja Slavenima u 9. stoljeću pomogla da se stave uz bok drugim europskim narodima, a njezin je zadatak deset stoljeća kasnije bio pomoći im da se konstituiraju kao moderne nacije u otporu pritiscima susjednih, vladajućih nacija. Međutim, u 19. stoljeću slavenski svijet nije više onako jedinstven kao što je to bio u 9. stoljeću - od 1054. podijeljen je crkvenim raskolom. Ideja se crkvenoga pomirenja javljala u više navrata kroz povijest. Sada je njezin obnovitelj biskup Strossmayer, koji sve vrijeme ima na umu prvenstveno prevladavanje ,zida“ između Slavena katolika i Slavena pravoslavaca, pa je u tome smislu isticao

${ }^{4}$ I. Esih, Hrvatska historiografija u posljednjih 75 godina. - u: Obzor, Spomenknjiga 1860-1935, Tisak i naklada „Tipografije“ d.d. Zagreb MCMXXXVI, str. 192-195.

${ }^{5}$ Leonard Tandarić, Sveti Ćiril i Metodije - novi pristup evangelizaciji, Bogoslovska smotra, 1985, br. 3-4, str. 369-375.

${ }^{6}$ Vidi: Leksikon hrvatske glagoljice, Minerva, Zagreb, 1995, str. 10. Bratulić naglašava da je takvo prepoznavanje sebe kao ethnosa u ideji jezika karakteristično samo za Slavene, dok se primjerice povijesni narodi, poput Grka i Rimljana kojima je država bila više od ethnosa, naroda ili jezika, prepoznaju u ideji carstva. 
misao da Slaveni nisu uzrokovali raskol, ali su ga najteže platili. I ta se ideja može podržati obnavljanjem ćirilometodske baštine jer su Ćiril i Metod apostoli jedinstvenoga slavenskog svijeta. Njihovo je djelo još u 9. stoljeću na Slavenima gradilo most između Istoka i Zapada. Franc Grivec, jedan od uopće najvećih proučavatelja života i djela Sv. Braće, ističe kako su oni ,pravovjerni i u istočnom i u zapadnom smislu, posrednici između istočnog kršćanstva i zapadnog kršćanstva, apostoli općeg kršćanskog jedinstva““. ${ }^{7}$ U 19. stoljeću u staroslavenskom liturgijskom jeziku i glagoljskom pismu pronalaze se zajednički korijeni Slavena. Glagoljska kultura pojačava svijest o zajedništvu i time dobiva i političku konotaciju. Tako prestaje biti samo pitanje crkve i povlastice pojedinih biskupija i postaje sinonim za nacionalno jedinstvo, pa onda i prijetnja postojećem državnom okviru, što je posebno dobro opisao povjesničar Mario Strecha u tekstu Sve za vjeru i domovinu podastirući brojne potvrde u prilog tvrdnji da je ćirilometodska ideja za slavenske narode imala osim vjersko-crkvenog i kulturno-političko, napose političko značenje. ${ }^{8}$ Monarhijski su austrijski i ugarski krugovi te dvor nastojali na sve načine spriječiti slavensko povezivanje koje bi omogućilo da Slaveni postanu odlučujući čimbenik u Monarhiji, a onda i politički subjekt s kojim bi bili prisiljeni dijeliti povlašteni položaj i vlast. Jednako veliku opasnost predstavljalo je i eventualno povezivanje monarhijskih Slavena sa Slavenima izvan Monarhije, s Rusijom i Srbijom, što je upravo bilo temeljnom sastavnicom politike pape Lava XIII. prema Slavenima. Takva je vrsta saveza prijetila da Monarhiju ugrozi i izvana. Tako ćirilometodska baština stječe neprijatelje u vladajućim krugovima i postaje i političko pitanje. Druga strana, dakle Slaveni, baštinu uvodi u znanost koja joj treba potvrditi vjerodostojnost. U nastojanju da potvrdi i povijesno opravda baštinu, mlada je hrvatska znanost često padala u zablude, anakrono prenoseći odnose i pojmove svoje suvremenosti desetak stoljeća unatrag i tako stvarala mitove od kojih će neki živjeti do duboko u prošlo stoljeće. Tražeći potvrdu za suvremena nastojanja oko obnavljanja ćirilometodske baštine, hrvatska će historiografija u prošlosti pronalaziti primjere koji će ohrabrivati i ukazivati na to da su slična nastojanja već doživljavala uspjeh usprkos zabranama i progonima. Često se tako spominju crkveni sabori iz 10. stoljeća na kojima je, navodno, hrvatska strana glasno branila svoje pravo na staroslavensko bogoslužje i glagoljicu. Tkalčić se slaže s Jagićem da već tada to nije bio samo „prijepor religiozne naravi“, nego pitanje „narodnosti i narodne prosvjete“. U Dalmaciji 10. stoljeća oni vide preneseno suvremeno stanje: „,narodni dualizam“ koji je nastao onog trena

${ }^{7}$ Franc Grivec, Sveti Ćiril i Metod, slavenski blagovjesnici, Kršćanska sadašnjost, Zagreb, 1985, str. 6.

${ }^{8}$ Vidi: Katoličko hrvatstvo. Počeci političkog katolicizma u banskoj Hrvatskoj (1897.-1904.), Barabat, Zagreb, 1997, str. 103. 
Milica LUKIĆ

„(...) kada (Hrvati) doznaše za slovjensku riječ božju i za slovjensko pismo“ te ,tada probudi se i njihova religiozno-narodna svijest, i oni se oslobodiše, te se zapodjede borba, koja je vijekove i vijekove trajala, dapače, nije se ni do dana današnjega utišala, van što se njezin oblik izmijenio“.9 Iako povijesni izvori ne upućuju na to da je kler hrvatske biskupije bio glagoljaški niti nam daju zaključiti da je ninski biskup Grgur bio glagoljaš, on ipak u 19. stoljeću postaje mitski branitelj prava na staroslavenski jezik u liturgiji i na glagoljicu. Čini se da u tome ima udjela i literatura na kojoj su se historiografi odgajali, posebice oni usmjereni na ćirilometodska istraživanja, među kojom je i često citirani Daniele Farlatti, ni kod koga zaobiđeni, i njegovo djelo Illyricum sacrum iz 1765. Taj se talijanski povjesničar bavio pitanjima slavenske liturgije, stanjem dalmatinsko-hrvatske crkve na kraju 9. i u prvim desetljećima 10. stoljeća, objavio pisma pape Ivana X. splitskom nadbiskupu Ivanu i hrvatskom kralju Tomislavu, pa je u taj kontekst smjestio i susret Hrvata s ćirilometodskim djelovanjem. Zastupao je tezu da su slavensko bogoslužje i druge kulturne tekovine ćirilometodskoga djela među Hrvate u Dalmaciju došli još u vrijeme kada su Solunska braća preko Dalmacije 867. putovala u Rim, a glavni je zagovornik toga staroslavenskoga bogoslužja i borac za glagoljanje u hrvatsko-dalmatinskoj crkvi na Splitskom saboru 925. bio Grgur Ninski. Uopće, o ovome ninskom biskupu povijesni izvori daju vrlo šture podatke. Spominje se u djelu Historia Salonitana Maior u zaključcima splitskih crkvenih sabora i pismima pape Ivana X. i Lava VI. te u kronici splitskog arhiđakona Tome iz 13. stoljeća, koji opisujući obnovu Ninske biskupije u 11. stoljeću kratko napominje kako je njezin nekadašnji biskup Grgur pravio poteškoće splitskom nadbiskupu. ${ }^{10}$ Nadgradnja te davne ličnosti o kojoj malo znamo počinje upravo kada je ugroženom hrvatskom narodu potreban suvremeni borac za njegova prava. ${ }^{11} \mathrm{U}$ drugoj polovici 19 . stoljeća pojačana su nastojanja za obnovom slavenskoga bogoslužja. Kao što je već spomenuto, podrška je došla i od pape Lava XIII. u obliku enciklike Grande munus kojom se izjednačuje slavensko bogoslužje s latinskim. Otpor odrednicama enciklike javlja se među talijanskim svećenstvom u Dalmaciji i monarhijskim vladajućim krugovima u Hrvatskoj koji ne žele zbližavanje Hrvata s njihovim pravoslavnim susjedima Srbima. Budak skreće pozornost da takva situacija podsjeća na konflikt iz 10. stoljeća te da su se u takvu sudaru ideologija ,nužno rađali simboli nacionalnosti pod kojima bi se okupljali njihovi sljedbenici“. ${ }^{12}$ Osni-

\footnotetext{
${ }^{9}$ Ivan Tkalčić, Slavensko bogoslužje u Hrvatskoj, Zagreb, 1904, str. 40.

${ }^{10}$ Neven Budak, Prva stoljeća Hrvatske, Zagreb, 1994, str. 162-165.

${ }^{11}$ Vidi: J. Bratulić, Predavanje o Grguru Ninskome. - u: Aleja glagoljaša, Zagreb - Pazin - Roč, 1994, str. 42.

${ }^{12}$ Budak, o. c., str. 168.
} 
vač suvremene hrvatske historiografije Ivan Kukuljević Sakcinski 1872. godine u pjesmi Grgur Ninski progovorit će kao književnik i političar:

$$
\begin{gathered}
\text { „Kralj Tomislav na čelu tog sbora } \\
\text { Tužno gleda dvije stranke ljute: } \\
\text { Jedna papi rimskom ljubi skute, } \\
\text { Druga brani narod bez odmora. } \\
\text { Uz tu drugu puk je i boljari, } \\
\text { S njima biskup Ninski Grgur stari.“13 }
\end{gathered}
$$

U svojoj Povijesti Hrvata Tade Smičiklas 1882. prvi put u znanosti vidi Grgura ovako: „Na to je dakle ustao srčani biskup ninski, Grgur Dobre, rođeni Zadranin, da brani pravo jezika hrvatskoga u crkvi (...).“14 Takvo je viđenje Grgura Ninskoga razradio i Vjekoslav Klaić u svojoj Povijesti Hrvata objavljenoj 1899. Ivan Tkalčić podržava mit te vidi Grgura kao hrvatskoga biskupa „koji bijaše za sloveštinu gorljiviji od oba svoja predšasnika“. Tkalčić zna i da je Grgur, uvijek nastojeći nadmašiti latinštinu, zaređivao u svećenike i Hrvate koji su živjeli u dalmatinskim biskupijama, a da su „hrvatski popovi kao pravi sinovi svoga naroda zajedno sa svojim ocima i braćom borili se za slavensku službu božju“. Donoseći ove zaključke, Tkalčić ima pred sobom papinska pisma i zaključke sabora, ali ih čita s unaprijed zadanim ciljem. On povezuje X. zaključak sabora koji govori o slavenskom bogoslužju i XI. koji upozorava Grgura da se u svemu pokorava Splitskoj metropoliji. ${ }^{15}$ Suvremena se politička i društvena situacija u potpunosti nametnula znanstvenom rasuđivanju. Može se primijetiti da se na srednjovjekovnu pozornicu događaja ne prenosi samo devetnaeststoljetna situacija i odnosi, nego i suvremena terminologija tadašnjih političkih borbi. Baveći se istom ovom problematikom, Svetozar Ritig 1910. zaključuje da je pitanje slavenskoga bogoslužja na splitskim crkvenim saborima u 10. stoljeću bilo sporedno, ali Grgura još uvijek ne oslobađa u 19. stoljeću nametnute mu uloge. On utvrđuje da je „Grgur tek nastojao sebe i svoju biskupiju osloboditi vrhovničtva splitske metropolije, nipošto pako ni u snu, nije mu palo na um, da sebe učini metropolitom i nad dalmatinskim biskupima“. Odluku sabora da splitski biskup postane metropolit tumači time ,što je latinska metropolija u Hrvatskoj bila rimskoj stolici pouzdanija hijerarhijska tvorba nego li hrvatska narodna crkva s nerazumljivim jezikom slavenskim. I rimska stolica i latinski kler nadao se da će uslijed potvrde prijepornih kanona na II. splitskom saboru po vremenu

\footnotetext{
${ }^{13}$ Budak, o. c., str. 169.

${ }^{14}$ Budak, o. c., str. 167.

${ }^{15}$ Ivan Tkalčić, Slavensko bogoslǔ̌je u Hrvatskoj, Zagreb, 1904, str. 40-46.
} 
iščeznuti glagoljica u narodu hrvatskom, nu nada ih je prevarila, jer iako bi poražen ninski biskup Grgur, ono ipak glagoljica preživi sve nedaće i bure, i održa se u XI. i u XIII. i u XIX. vijek. " ${ }^{\text {16 }}$ Kao što ga je u 19. stoljeću opjevao Sakcinski, tako to u 20. st. čini Vladimir Nazor pjesmom Grgur Ninski u zbirci Hrvatski kraljevi 1931. godine, u kojoj promiče upravo ono gledanje koje je zastupala historiografija XIX. stoljeća - u Grguru Ninskom vidi hrvatski pandan Ćirilu i Metodu, borca za slavensko bogoslužje i glagoljicu. ${ }^{17}$

\section{Historia est magistra vitae}

Kako je 19. stoljeće vrijeme intenzivnoga razvoja znanosti, u sagledavanju je ćirilometodske problematike osobito važno uzeti u obzir korespondiranje dviju od njih, povijesne i filološke (u 19. stoljeću su čak u istome Akademijinu razredu), koje se možda više nego ostale međusobno podupiru i dopunjuju svojim spoznajama. Uz to, istaknuti su filolozi toga vremena ujedno i povjesničari, kako smo to već prethodno spomenuli, a to ovomu postupku daje dodatan legitimitet. Kod Hrvata je osjećaj historizma živ i neobično razvijen u 19. stoljeću tako da je gotovo identičan s hrvatskom kulturom i civilizacijom toga vremena. ${ }^{18}$ Već je Vatroslav Jagić toga svjestan kada definira filologiju kao interdisciplinarnu znanost koja je ,složeni organizam različitih predmeta spojenih u jednu cjelinu“", ${ }^{19}$ a neizostavna je među njima i povijest. Prema mišljenju Radoslava Katičića, ona je baš u to vrijeme kao znanost postigla izvanredno značajne rezultate, a njezine spoznaje iz toga vremena nesumnjivo pripadaju među najveća djela ljudskoga duha. ${ }^{20} \mathrm{Na}$ tu se misao, a na tragu povjesničarke Mirjane Gross, nadovezuje i razmišljanje Stjepana Damjanovića koje vrlo precizno objašnjava odnos povijesti i filologije u 19. stoljeću: povjesničarima 19. stoljeća od izuzetne su važnosti bila filološka znanja, a filolozi toga vremena u obilnoj su se mjeri koristili poviješću da bi

\footnotetext{
${ }^{16}$ Svetozar Ritig, Povijest i pravo slovenštine u crkvenom bogoslužju, s osobitim obzirom na Hrvatsku, Zagreb, 1910, str. 139-151.

${ }^{17}$ Vidi: Josip Bratulić, Aleja glagoljaša, Zagreb-Pazin-Roč, 1994, str. 43.

${ }^{18} \mathrm{U}$ prilog tomu navodimo riječi bana Josipa Jelačića: „Povjesnicu svakoga naroda možemo smatrati njezinim krsnim listom. Kao što krsni list služi pojedinom čovjeku na biljegu čovječjeg društva, u koje spada, tako je i svakom narodu povjesnica obilježje njegovog mjesta u velikom krugu čovječanstva. Bez nje ne zna narod, što je bio i kamo spada“. Vidi: Franjo Rački, Nacrt hrvatske historiografije od g. 1835. do 1885, Rad 80, str. 257 i dalje. Cit. prema: Dr. Ivan Esih, Hrvatska historiografija u posljednjih 75 godina, Obzor, Spomen-knjiga 1860-1935, Tisak i naklada „Tipografije“ d.d. Zagreb, MCMXXXVI.

${ }^{19}$ Cit. prema: E. Hercigonja, Nad iskonom hrvatske knjige, Rasprave o hrvatskom glagoljskom srednjovjekovlju, Zagreb, 1983, str. 8.

${ }^{20}$ Radoslav Katičić, Što nam znači povijest. - u: Jezikoslovni ogledi, Zagreb, 1971, str. 259.
} 
Ususret novijoj povijesti glagolizma

bili što precizniji u svojim opisima i zaključcima. ${ }^{21}$ I ključna će ličnost, koja je označila novo razdoblje u borbi za uspostavu ćirilometodske baštine na području cijeloga hrvatskoga nacionalnoga prostora, posebice matične biskupije, poznati đakovački biskup Josip Juraj Strossmayer, vjerovati u sudbinsku povezanost s poviješću pa u svojim zalaganjima stalno poseže za njezinim potvrdama i najnovijim dostignućima, angažirajući u tome poslu i mnoge znanstvenike svoga vremena, napose već spomenutoga Franju Račkoga, što je još 1986. u svojim istraživanjima ćirilometodske baštine u korespondenciji između Račkoga i biskupa Strossmayera potvrdio S. Damjanović. Takva se situacija u kojoj povijest i filologija jedna drugu podržavaju i dopunjuju ocrtava u gotovo svim ćirilometodskim napisima, žanrovski različitima, iz periodike (i ne samo nje!) 19. stoljeća, udovoljavajući pritom dvama zadacima, koje također apostrofira Damjanović: jačanju nacionalne svijesti i podupiranju tradicionalne hrvatske autonomije preko ćirilometodske baštine kao prijenosnika na putu do moderne autonomije.

Ćirilometodska se znanost počinje razvijati u krilu povijesnih znanosti i slavenske filologije potkraj 18. i u prvim desetljećima 19. stoljeća pa u skladu s tim slavenskoj filologiji daje obilježja povijesne znanosti, a prema tumačenjima Ivanke Petrović, i temeljne razloge života i postojanja. ${ }^{22}$ Već sam naglasila da Slaveni u ćirilometodskoj baštini traže, a sada uz pomoć znanosti otkrivaju i dokazuju kamen temeljac slavenske kulture i književne povijesti i vide u njoj veliku slavensku prošlost $s$ kulturnim i društveno-političkim tekovinama koje su prije tisuću godina slavenske narode stavile u ravnopravan položaj s vodećim europskim narodima i značajno obogatile europsku kulturu i civilizaciju. Unutrašnja snaga i veličina same ćirilometodske ideje ujedinjuje slavenske znanstvenike, ali i popularizatore njihove znanosti.

Nakon što je 1843. moskovski profesor crkvene povijesti i rektor moskovske Duhovne akademije Aleksandar Vasiljevič Gorski znanstveno otkrio Žitije Konstantinovo i Žitije Metodovo, nastaje novo razdoblje u ćirilometodskoj znanosti za koje će V. Jagić prilikom tisućgodišnjice Metodove smrti u ocjeni dotadašnjih znanstvenih istraživanja o Sv. Ćirilu i Metodu reći: „Taj

${ }^{21}$ S. Damjanović, Filološki razgovori, Hrvatska sveučilišna naklada, Zagreb, 2000, str. 100 .

${ }^{22}$ Ivanka Petrović, Franjo Rački - otac hrvatske Cyrillo-Methodiane, Zbornik zavoda za povijesne znanosti Istraživačkog centra JAZU, vol. 9, Zagreb, 1979, str. 47. Upravo je I. Petrović napisala najbolju sintezu ćirilometodske problematike 19. stoljeća u nas, od koje bi trebalo započeti svako daljnje promišljanje toga područja, kroz znanstveno djelo Franje Račkoga (navedeni tekst) i studiju Prvi susreti Hrvata s ćirilometodskim izvorištem svoje srednjovjekovne kulture iz 1988 (Slovo, br. 38, str. 5-54). 
razmjerno kratak članak znači epohu u povijesti o sv. Ćirilu i Metodu.“23 Rasprava u kojoj je Gorski znanstveno ocijenio povijesni sadržaj Žitija kao prvorazredni izvor za život i djelatnost Konstantina-Ćirila i Metodija objavljena je 1843. u časopisu M. Pogodina Moskovitjanin, III, str. 405-434 u raspravi koja je kasnije preštampana u Pogodinovu Ćirilo-Metodskom Zborniku, Moskva, 1865, str. 5-42, odakle će ju prihvatiti ćirilometodski znanstvenici širom svijeta, pretiskavati ju i prevoditi, a poseban će odjek rasprava imati među ruskim znanstvenicima (Filaret, 1846), ali i kod Čeha Hanke i Šafařika, koji je istovremeno kad i Gorski došao do spoznaje da je Žitije Konstantinovo dragocjen povijesni izvor, ali je Žitije Metodovo upoznao tek iz rasprave Gorskoga. Oba se žitija u kritičkome izdanju nalaze kod Šafařika 1851. godine, a zapadni svijet za njih saznaje već 1846. iz Hankina češkog prijevoda. ${ }^{24}$ Hrvatska je ćirilometodijana izrasla na tekovinama europske, prvenstveno češke i slovačke ćirilometodske znanosti, ali se od njih razlikuje po tomu što najprije pozornost posvećuje proučavanju ćirilometodske povijest (putovi, tokovi, ideje i namjere njezinih nositelja na relaciji ciljeva i interesa tadašnje Europe), a potom svoje spoznaje predaje slavenskim filolozima. Slavistička je znanost 19. stoljeća u životu, misiji i djelu braće Konstantina Ćirila i Metoda gledala prvenstveno misionarski i prosvjetiteljski rad namijenjen ponajprije slavenskim narodima u Moravskoj. Za mladu slavističku znanost, kako su joj temelje postavljali Franz Miklošič i Vatroslav Jagić, zanimljivi su bili temeljni ćirilometodski izvori koje smo spomenuli - Žitja (Vitae), a potom i njihovo djelo koje se ogledalo u pismu, jeziku, tekstovima Evanđelja, potom ostaci Biblije koji su se sačuvali u prijepisima do kraja 12. stoljeća. ${ }^{25}$ Filološki je problem, dakle pitanja jezika, potom i pisma - glagoljice, zasjenio njihovu društvenu i političku, organizacijsku i diplomatsku djelatnost. Djelo je Sv. Braće zanimljivo u 19. stoljeću između ostaloga i zato što je smješteno u vrijeme kada se, kako kaže Bratulić, Europa počela tragično lomiti na Istok i Zapad, a u crkvenom smislu na pravoslavlje i katolicizam, zrcaleći tako 1000-godišnju, novom vremenu iskoristivu, matricu. U oba su slučaja na snazi bile imperijalističke tendencije koje su svoj izraz pronašle u porobljavanju malih naroda koji svoju politiku moraju podrediti ili Bizantu ili Francima, ili Istočnom ili Zapadnom Rimskom

${ }^{23}$ Cit. prema: F. Grivec, Izvori o svetom Ćirilu i Metodu. - u: Slavenski blagovjesnici - Sveti Ćiril i Metod, Kršćanska sadašnjost, Zagreb, 1985, str. 202.

${ }^{24} \mathrm{Na}$ Zapadu Žitija promovira njemački povjesnik Wilhelm Wattenbach 1849, čiji rad postaje povod izdanjima Žitija Konstantinova i Žitija Metodova Ernsta Dummlera i Franca Miklošiča 1854, 1861. i 1870. godine.

${ }^{25}$ Vatroslav Jagić je o tisućnici smrti Sv. Metoda u svom kritičkom pregledu skupljao i kritički ocjenjivao radove o Ćirilu i Metodu u slavenskoj filologiji (Sanktpeterburg 1885). 
Carstvu, pravoslavlju ili katolicizmu. U tom kritičnom trenutku europske povijesti uloga Sv. Braće izrasta u ulogu pomiritelja, moderatora, štoviše mosta koji želi i hoće dva svijeta ujediniti na temelju onih zajedničkih istina na koje se pozivaju i jedni i drugi, ali koje ni jedni ni drugi ne žele do kraja usvojiti.

$\mathrm{S}$ toga aspekta gledana - misija Braće dobiva još jednu dimenziju, koja našem vremenu govori jezikom koji nam je blizak i razumljiv, jer u njihovu vremenu prepoznajemo i naše vrijeme, u njihovim rješenjima, ili bar pokušajima rješenja, možemo nazreti i neka rješenja koja bi i nama danas bila potrebna i dobrodošla. ${ }^{26}$

Dvije su se velike ličnosti 9. stoljeća, Konstantin Ćiril i Metod, izdigle iznad svoga vremena, iznad općeg shvaćanja, iznad kratkovidne politike razjedinjenosti, sukoba i tlačenja. Budući da su bili iznad i ispred svog vremena, postali su suvremeni i prilikama 19. stoljeća.

\section{Ususret hrvatskoj cyrillomethodiani}

Početak se ozbiljnoga uključivanja Hrvata u, nazovimo ga tako, ćirilometodski pokret druge polovice 19. stoljeća među Slavenima može povezati s programatskim tekstom Franje Račkoga u Pozoru br. 183 od 9. kolovoza 1862. Imamo li i mi slaviti tisuć-godišnjicu slovjenskih apoštolah sv. Cirila $i$ Metoda ${ }^{27}$ Taj je tekst sročen kao poziv na obilježavanje prve u nizu ćirilometodskih obljetnica koje će dati jak poticaj razvitku ćirilometodske znanosti i koje nitko tko će u 19. st. pisati o ćirilometodskoj problematici neće zaobići; štoviše, to je poziv kojim slavenski narodi pod tuđinskom supremacijom pozivaju sami sebe na slavlje. On pokazuje dvoje - Račkijevo temeljno životno i znanstveno opredjeljenje te početak ozbiljnoga promišljanja u krugo-

\footnotetext{
${ }^{26}$ Josip Bratulić, Konstantin-Ćiril i Metod i njihova baština kod Južnih Slavena. u: Sjaj baštine, Književni krug Split, Split, 1990, str. 6.

${ }^{27} \mathrm{Na}$ taj će se Račkijev tekst i stotinu godina kasnije, prilikom proslave 1100 . obljetnice Metodove smrti znanstvenim skupom „Tisuću i sto godina od smrti Metodijeve ćirilometodsko kulturno-književno nasljeđe u Hrvata“, u svom pozdravnom govoru na otvaranju Skupa 16. listopada 1985. pozvati i Jakov Sirotković, ali u duhu ,jugoslavenskome" koji stotinu godina poslije nema više ništa zajedničko s jugoslavenstvom iz Račkijeva teksta, a u smislu na koji upozorava S. Damjanović kada kaže da je ,ćirilometodska ideja tu i tamo mogla dobro doći i komunističkim ideolozima za dnevnopolitičke svrhe (...)“. Vidi: Umjesto predgovora - O filologiji i rodoljublju - u: Jazik otačaski, Matica hrvatska, Zagreb, 1995, str. 12. Slovenci već 1857, predvođeni biskupom Slomšekom koji Sv. Braću drži za ,prve najznačajnije učitelje slovenskog naroda“ pa 1851. osniva Bratovštinu sv. Ćirila i Metoda, dokazuju kako imaju razloga, štoviše, kako su dužni častiti sv. Ćirila i Metoda (pisac Davorin Trstenjak u časopisu „Novice“). Vidi: Štovanje sv. Ćirila i Metoda među Slovencima. - u: Slavenski blagovjesnici - Sveti Ćiril i Metod, Kršćanska sadašnjost, Zagreb, 1985, str. 198.
} 
Milica LUKIĆ

vima hrvatskih intelektualaca (povjesničara, filologa, pa i političara) o ćirilometodskoj baštini i njezinu udjelu kod slavenskih naroda, posebice Hrvata, što je već jasan znak da je obnova kulta Sv. Braće uzela ozbiljnoga maha na hrvatskome nacionalnom prostoru. Kako hrvatska znanost $\mathrm{u}$ to vrijeme nije imala tradiciju češke, slovačke ili ruske historiografije i slavistike na ćirilometodskom polju, a rezultati su drugih znanstvenika sporo dopirali do nas, prijetila je opasnost da se i taj veliki datum slavenske kulturne i književne povijesti i znanosti dočeka nespremno i neobaviješteno. Ovaj je tekst to značajniji što ga piše utemeljitelj, otac hrvatske cyrillomethodiane, koji gotovo sam obilježava cijelu hrvatsku ćirilometodsku znanost u najpresudnijem razdoblju njezina života, koji je svojim znanstvenim radom i zalaganjem morao popuniti i prazninu koju je ostavio rani odlazak filologa Vatroslava Jagića iz Hrvatske. Rački zastupa stav da su i Južni Slaveni iako ne slave tisućitu godišnjicu svoga pokrštenja, jer bijahu pokršteni prije ćirilometodske misije u 9. stoljeću, dužni slaviti tisućitu obljetnicu misije Sv. Braće u Moravsku jer su dionici svih ostalih plodova ćirilometodskoga djela: pisma, jezika i književnosti te staroslavenske liturgije. ${ }^{28}$ Račkijev je prvenstveni cilj u ovome članku ojačati svijest hrvatskoga naroda o važnosti ćirilometodskoga djela, posebice na razvoj hrvatskoga jezika i književnosti, koje se upravo na hrvatskome tlu najduže održalo u svome izvornom obliku. Zato, iako popularnim diskurzom kako i zahtijeva novinska publikacija, te romantičarskim oduševljenjem koje će dijeliti sa svojim prijateljem i mecenom Strossmayerom, a što će im se u znanosti često spočitavati, čini ono što će i u svakoj budućoj prilici činiti pišući o ćirilometodskoj baštini - podučava, razlaže misli o staroslavenskome jeziku i pismu, sada već kao vrstan poznavatelj ćirilometodske baštine iza kojega su djela antologijske vrijednosti za hrvatsku i svjetsku ćirilometodijanu - knjiga u dva sveska Viek $i$ djelovanje sv. Cirilla i Metoda slovjenskih apostolov (I, 1857, I-XII, 1-77; II, 1859, 79-420) te knjiga Pismo slovjensko iz 1861, niz ćirilometodskih članaka u Katoličkome listu, Viencu i ostalim časopisima 19. st.:

Doista tkogod je samo površno obazreo se na naše stare pismene spomenike, grudi mu se od ponosa šire što govori jezikom, komu najstariji brat bijaše tako bogat, tako nakićen već u ono doba, kada sadašnji europejski jezici još u djetinjih povojih bijahu. I za to slava ide sv. Cirilu i Metodu. Oni su glasove slovjenskoga jezika umnimi pismeni prikovali; oni su mu slovnične oblike divnom točnošću

${ }^{28}$ Takav se njegov stav može pročitati još nekoliko godina ranije (1857) u uvodnome dijelu teksta Nacrt jugoslovjenskieh povjestij do IX. stoljetja: „Nedvojim, da će svaki Slovjen uvjeren biti o tom, da su sv. Cyrill i Method početnici duhovnog života u njegovom narodu, te da oni svakoga Slovjena, bilo koje mu drago grane, zanimat imaju." Vidi: Arkiv za povjestnicu jugoslavensku, knjiga IV, Zagreb, 1857, str. 235. 
ustanovili; oni i njihovi učenici obogatiše ga prievodi sv. pisma, prievodi sv. otacah i kanoničkih knjigah, prievodi najznamenitijih grčkih pisacah. Tim jezik slovenski postade tako bogat, tako gibak, da se već IX. i X. vieka s klasičkimi takmiti može. ${ }^{29}$

Rački smatra da Hrvati imaju još jedan razlog koji bi ih morao nukati da se pridruže proslavi tisućgodišnjice, a koji će od tada i on i Strossmayer prizivati u svakoj novoj prilici koja bude zahtijevala obranu pozicija hrvatske cyrillomethodiane: Metodovo stolovanje na drevnoj srijemskoj biskupskoj stolici koju je još u IV. stoljeću osnovao Sv. Andronik, a koja je imala jurisdikciju nad čitavom Panonijom. Sada, u okvirima 19. stoljeća, nasljednikom je Metodovim biskup đakovački i srijemski Josip Juraj Strossmayer. Račkijev je plan da se proslavi uz hrvatski episkopat pridruže i istaknute ličnosti iz javnoga i kulturnoga života toga vremena jer se karakter ćirilometodskoga djela ogleda i u tim područjima. Na koncu, on želi da iz toga događaja izađe i praktična korist, odnosno da on bude poticaj i povod znanstvenim istraživanjima na različitim područjima: povijesti, književnosti, jezikoslovlja, teologije i dr. U tom smislu predlaže:

Da se čim prije u Zagrebu sastavi odbor književni, koji sazvav sve bolje jugoslovjenske jezikoslovce i povjestnike nastojao bi buduće godine na svietlo izdati spomenik, album, koji bi sadržavao znanstvene razprave o pismenih slovjenskih, o jeziku staroslovjenskom, o knjizi staroslovjenskoj, o slovjenskoj literaturi, jednom riečju: o onih strukah iz književne i liturgičke povjesti slovjenske, kojim slaviše temelj naši slovjenski spoštoli (... $)^{30}$

Taj je Račkijev prijedlog zaživio u, kako ga suvremena paleoslavistička znanost naziva, najznačajnijem znanstvenom izdanju u Hrvatskoj koje je bilo posvećeno ćirilometodskoj obljetnici 1863. - Tisućnici slovjenskih apostolah sv. Cirila i Metoda. Ta je knjižica u izdanju Društva za jugoslavensku povjestnicu i starinu sastavljena od studija Ivana Kukuljevića Sakcinskoga (Uvod), Franje Račkoga (Književni rad sv. Cirila i Methoda. Izvadak iz većega rukopisa), Vatroslava Jagića (Evangjelije u slovênskom prievodu. Historičko-filologički nacrt), Matije Mesića (Služba sv. Cirila i Metoda) ${ }^{31}$ te pjesničkih uradaka Ivana Trnskog ${ }^{32}$ (Sveta priča o solunskoj braći, slovjenskim'

\footnotetext{
${ }^{29}$ Pozor, 9. kolovoza 1862, god. III, br. 183, str. 1.

${ }^{30}$ Isto.

${ }^{31}$ Posebnu će pozornost ovomu Mesićevu radu posvetiti S. Damjanović u tekstu Mesićeve filološke teme u knjizi Filološki razgovori, Hrvatska sveučilišna naklada, Zagreb, 2000, str. 93-101.

${ }^{32}$ Kako su pjesnički uradci potpisani samo inicijalima, Sveta se priča neko vrijeme pogrešno pripisivala Janku Tomboru. Naime, osamdesetih je godina 20. stoljeća Div-
} 
Milica LUKIĆ

apostolima sv. Cirilu i Metodu) i Petra Preradovića (Slovjenski Dioskuri). Iz navedenoga se vidi kako je riječ o uratku koji sjedinjuje znanstvena i književna ostvarenja kojima je temeljni cilj popularizacija ćirilometodske ideje.

Prvi, u hrvatskoj periodici zabilježeni, koraci kojima je ćirilometodska ideja počela stupati u kulturni, znanstveni, a onda i politički život hrvatskoga nacionalnog prostora u 19. stoljeću, i prije Strossmayerovih poticaja, i prije programatskoga teksta F. Račkoga u Obzoru, započinju peticijom u trideset točaka upućenom kralju, poznatom pod nazivom Zahtievanja naroda, koja je prihvaćena na Narodnoj skupštini Trojedne kraljevine Hrvatske, Slavonije i Dalmacije 25. ožujka 1848, a koja između ostaloga u jednoj svojoj točki govori i o uvođenju narodnog jezika (ovdje se misli, kako ćemo to kasnije pokazati, na crkvenoslavenski jezik, op. M. L.) u Crkvu ,polag starinskog hrvatskog prava i običaja““. ${ }^{33}$ Slijede zahtjevi korone Stubičkoga kotara od 25. svibnja 1848. da se latinski liturgijski jezik zamijeni staroslavenskim, koje autor teksta naziva narodnim, iznikli na temelju Proglasa izišloga u Gajevoj tiskari u travnju iste godine, koje je potaknuo i organizirao svećenik u Bistrici Ivan Krizmanić, a koji se tiču i slavenskoga bogoslužja. U 6. točki navedenoga Proglasa stoji:

Budući da sve duhovne svečanosti moradu smjerat na podučavanje puka, na utvrđivanje u vjeri, na obodjelanje ponašanja, iskustvom pako jest potvrđeno da razumljiva disciplina dublje u srce dira i više na dobro vabi, nego ikakve forme, koje se samo vide a nerazume, i da se tim načinom isto obučavanje puka olakša budući od opetovanog čuvenja mnoga ostanu u glavi, koja kroz podučavanje težkim trudom moći je usaditi: za to je od potrebe, da se dosadanji jezik liturgički zamijeni narodnim.

Da je riječ o staroslavenskome jeziku pojašnjava nam točka br. 9. zapisnika spomenute korone, gdje stoji:

Dosadašnji liturgički jezik neka se zamijeni s našim narodnim jezikom. To je lasnije postići, što je naš narodni jezik već od rimske stolice za sveti i liturgički pripoznat; što se u pograničnoj biskupiji senjskoj sva svetootajstva u ovom jeziku obavljaju; da što u prvašnjih vremenih i u našoj biskupiji liturgički bijaše, dakle po ne-

na Zečević iznijela tezu da uopće nije riječ o inicijalima I. T. nego J. T. koji se odnose na pjesnika Janka Tombora, koji se iste, 1863. godine, javlja u kalendaru Dragoljub napisima ćirilometodskoga sadržaja te pjesmom posvećenom Svetoj Braći.

${ }^{33}$ Zagrebački biskupi, Školska knjiga, Zagreb, 1995, str. 463. 
hajstvu predšasnika naših moćniem svom takmacu latinskom mjesto ustupiti morade. $^{34}$

Ovaj je zahtjev, iznikao još na odjecima oduševljenja ilirskim pokretom, utoliko zanimljiviji što nam svoga autora/e pokazuje kao dobre poznavatelje povijesti staroslavenske liturgije na području Zagrebačke biskupije. Držim kako je navedeni podatak doista zanimljiv budući da se sustavnim proučavanjem staroslavenskoga bogoslužja na području Zagrebačke biskupije počinje baviti tek Ivan Krstitelj Tkalčić 1861. kada u Katoličkome listu objavljuje prvu seriju članaka (šest nastavaka) o toj tematici pod naslovom Slovjensko bogoslužje. On će se tim problemom na stranicama Katoličkoga lista baviti dvadesetak godina; još 1871. u tekstovima Utemeljenje biskupije zagrebačke (br. 27-29, god. XXII, str. 217-235), Prinos za poviest biskupije zagrebačke (br. 50, god. XXII, str. 412-413), 1873. u seriji tekstova Iz domaće crkvene poviesti - stope glagoljaške po zagrebačkoj biskupiji (br. 9-11, god. XXIV, str. 65-83) te 1883. u tekstu Još jedna o slavenskoj liturgiji u nadbiskupiji zagrebačkoj (br. 33, god. XXXIV, str. 257-259), a najsustavnije 1904. u knjizi Slavensko bogoslužje u Hrvatskoj, posebice nakon što je istraživanjima Ivana Kukuljevića Sakcinskog 1863. uspostavljena slavenska teza knjigom Tisućnica slovjenskih apostola Cirila i Metoda.

Zaključke te korone Stubičkoga kotara prihvatilo je svećenstvo cijeloga kotara, čemu se oštro suprotstavio zagrebački nadbiskup Josip Haulik, ${ }^{35}$ kao i kasnijim akcijama koje su afirmirale ćirilometodsku ideju u njegovoj nadbiskupiji. Među takvim je događajima bilo i svečano ustoličenje bana Josipa Jelačića 5. lipnja 1848. u crkvi Sv. Marka, kada je senjski biskup Mirko

${ }^{34}$ Ivan Krstitelj Tkalčić, Slavensko bogoslužje u Hrvatskoj, Tisak i naklada Dioničke tiskare Zagreb, Zagreb, 1904, str. 96.

${ }^{35}$ Olga Maruševski zagrebačkoga nadbiskupa Jurja Haulika (1837-1869) vidi kao realista u odnosu spram druge jake ličnosti toga doba, biskupa Strossmayera, kojega zbog njegovih sveslavenskih i južnoslavenskih ideala vidi kao „pravog romantičara“. Ona toga bečkoga čovjeka i pouzdanika Dvora i apsolutizma te s druge strane zagovornika pred Krunom koji se nije mogao mjeriti ni s jednim drugim biskupom prije ni poslije njega, kako ga uglavnom vidi hrvatska historiografija, ocjenjuje kao vrsnog diplomata koji je kao Slovak i poznavatelj politike Bečkoga dvora znao iskoristiti trenutačne okolnosti da bi se stavio na stranu hrvatskoga nacionalnog pokreta koliko mu je dopuštala njegova crkvena funkcija i uvelike omogućavala politička kao namjesnika banske časti i zastupnika hrvatskih interesa na zajedničkim saborima. U svjetlu takvih promišljanja njegovi bi se javni stavovi glede staroslavenske liturgije također mogli promatrati kao diplomatski potez, to više što je u svome prvom pastirskom govoru 1838. godine javno iskazao lojalnost hrvatskome narodu rečenicom: „Vas molim i zaklinjem da me smatrate svojim i onim koji domovinu vašu smatra svojom domovinom." Vidi: Nadbiskup Juraj Haulik 1837-1869. - u: Zagrebački biskupi i nadbiskupi, Školska knjiga, Zagreb, 1995, str. 461-473. 
Ožegović poslije „,dvjesta godina opet jedanput u Zagrebu sv. misu u narodnom milom jeziku odpojio“. ${ }^{36}$ Nakon što je u listopadu 1861. Hrvatskoj vraćen Ustav, želja za uspostavom staroslavenskoga bogoslužja u hrvatskoj javnosti postaje sve glasnijom. Sisački se kotar prvi u Zagrebačkoj nadbiskupiji oglašava na svojoj jesenskoj kotarskoj skupštini 1862. u povodu proslave nastupajućega ćirilometodskoga jubileja 1863. - tisućnice moravske misije, i upućuje svoju molbu Duhovnom stolu, što nailazi na oštar otpor nadbiskupa Haulika. Vrijeme je to kada mnogi na hrvatskome nacionalnom prostoru traže uspostavu staroslavenskoga bogoslužja. Na adresu nadbiskupa Haulika stigla su još dva takva zahtjeva prije nego se on 19. svibnja 1863. oglasio svojom okružnicom. Prvi je zahtjev podnijelo Društvo za povijest i starine Jugoslavena 27. veljače 1863, a drugi građani i Poglavarstvo grada Karlovca 9. i 11. svibnja iste godine. Iz Tkalčićevih bilježaka doznajemo da je nadbiskup Haulik, vjerojatno ponukan reskriptom pape Pija IX. o premještanju blagdana Sv. Apostola s 9. ožujka na 5. srpnja, koji je uvelike potaknut zalaganjem biskupa Strossmayera, ublažio svoje stavove i odobrio oba zahtjeva. ${ }^{37}$ Međutim, situacija se ubrzo mijenja kada zahtjeve za uspostavu staroslavenskoga bogoslužja uz Poglavarstvo trgovišta Siska postavljaju i glavne hrvatske županije - Virovitička, koja svoje zahtjeve donosi na skupštini održanoj u Osijeku u srpnju 1863. godine, te Požeška i Zagrebačka koje o pitanjima staroslavenskoga bogoslužja raspravljaju u siječnju 1864. Zahtjevi su Virovitičke županije bili najopširniji i usmjereni ne samo na zagrebačkoga nadbiskupa nego i na đakovačkoga te pečuškog biskupa, i kako se doznaje iz Katoličkoga lista koji u cijelosti donosi tekst predstavke, imala je velikoga utjecaja na oblikovanje javnoga mišljenja o pitanjima staroslavenske liturgije i bila povod mnogim raspravama. Sastavljači predstavke želju za uvođenjem staroslavenske liturgije povezuju s buđenjem nacionalne svijesti u Slavena:

Za cielo bi bilježio narod slovinski u svojoj povjestnici medju najradosnije i najsretnije dane žića svoga onaj željno očekivani dan, kad bi opet u svojim rimokatoličkim crkvama svuda mogao božju istinu onim jezikom slušati, kojim mu ju sveti njegovi apoštoli navještivahu. ${ }^{38}$

${ }^{36}$ Ivan Krstitelj Tkalčić, Slavensko bogoslužje u Hrvatskoj, Tisak i naklada Dioničke tiskare Zagreb, Zagreb, 1904, str. 95.

${ }^{37}$ U 11. broju Katoličkoga lista od 12. ožujka 1863, str. 83-85, u tekstu K tisućnici sv. apoštolah Cirila i Metoda kao potpora cijeloj proslavi u hrvatskome narodu donosi se reskript pape Pija IX. praškome nadbiskupu Miroslavu o izmjeni datuma blagdana Sv. Apostola s 9. ožujka na 5. srpnja, što je potom Strossmayerovim zalaganjem dopušteno i hrvatskoj Crkvi.

${ }^{38}$ Katolički list, god. XV (1863), br. 9, str. 66. 
U svom odgovoru Požeškoj županiji, za koji bi Rački rekao da je „historička neistina“" ${ }^{39}$ nadbiskup Haulik u svezi sa staroslavenskim liturgijskim jezikom između ostaloga kaže: ,(...) jer ponajprije jezik glagolski, koji bi trebalo po rečenom rabiti za službu božju, nije više, pače pravo se reći može, da je još manje poznat viernim našim, nego li jezik latinski! ‘40

Međutim, kardinal se Haulik više nije mogao u otporu protiv staroslavenskoga bogoslužja osloniti na svoje sufragane, jer utjecaj zauzimanja biskupa Strossmayera, posebice nakon spomenutoga reskripta pape Pija IX, postaje nadmoćnim. Tomu u prilog Tkalčić bilježi kako je obrana latinskoga jezika u bogoslužju u Katoličkome listu pala na leđa njegova tadašnjeg urednika i profesora na nadbiskupskom liceju Nikole Horvata, koji je 1864. godine službene stavove zagrebačkoga Kaptola iznio pod naslovom Slavenska liturgija i bogoslužni jezik biskupije zagrebačke od 9. do 16. broja. U prilog navedenomu ide još jedna Tkalčićeva bilješka koja kaže da „,biskupi senjski i križevački i sami slavenski liturgisahu, a domaće svećenstvo malom iznimkom prionulo uz taj pokret"“. ${ }^{41}$ Ćirilometodska se ideja, iako ometana, od toga vremena nezaustavljivo širila popularnim i znanstvenim člancima i književnim prilozima i osvajala prostor legalnoga kulturnoga, nacionalnoga i crkvenoga pokreta na hrvatskome nacionalnom prostoru, a tomu je zasigurno pripomogla i tradicija liturgijskoga čašćenja Slavenskih Apostola Ćirila i Metoda posvjedočena u Hrvata mnogo prije nego su oni uvršteni u katalog svetaca Katoličke crkve 1880. godine. Njihova se imena, kako to saznajemo iz istraživanja Biserke Grabar, od 14. stoljeća pojavljuju u hrvatskoglagoljskim kalendarima. ${ }^{42}$ Od 70 -ih godina 19 . stoljeća kult se Svete Braće, potpomognut slavenskom znanošću, ponovno širi i među pravoslavnima, osobito Bugarima i Makedoncima. ${ }^{43}$ C̆ak se i kult Sv. Metoda kao panonskoga arhiepi-

${ }^{39}$ Iako nisu išle u prilog zagovarateljima staroslavenskoga bogoslužja, Haulikove riječi o nepoznavanju staroslavenskoga jezika među pukom i svećenstvom nisu bez osnove. I Parčić će u svojim Opazkama (1882) govoriti o istom problemu, Š. Milinović u Slovjenskoj liturgiji (1881) također piše o tome, I. Prodan u Katoličkoj Dalmaciji i još mnogi drugi..

${ }^{40}$ Odgovor uzoritoga stožernika i nadbiskupa Zagrebačkoga sl. županiji požeškoj u poslu slovenske liturgije. - u: Katolički list, god. XV (1864), br. 17, str. 129-134.

${ }^{41}$ Isto, str. 104.

${ }^{42}$ Vidi njezin tekst Kult Ćirila i Metodija u Hrvata, Slovo, Zagreb, 1986, br. 36, str. 141.

${ }^{43}$ Bratulić navodi kako je kao znak kulta Sv. Braće i tradicije koja se održala unatoč nepovoljnim prilikama na samom početku 19. stoljeća na jednoj fresci u manastiru Sv. Nauma Metod prikazan među svojim učenicima, tzv. sedmoricom, ispred svoga brata Ćirila kako drži model svoje crkve, simbolizirajući tako osnivača slavenske Crkve. Vidi: Josip Bratulić, Konstantin-Ćiril i Metod i njihova baština kod Južnih Slavena. - u: Sjaj baštine, Književni krug Split, Split, 1990, str. 11. 
skopa, kako nas obavješćuje Josip Bratulić na temelju tvrdnji najboljega poznavatelja srijemske heortologije i hagiografije Mitra Dragutinca, zadržao u Srijemskoj Mitrovici, gdje ju u katoličkoj crkvi postojala slika Sv. Metoda, sve do nove, službene obnove kulta Svete Braće u 19. stoljeću. ${ }^{44}$ Kada se prihvaćao goleme zadaće poticatelja obnove ćirilometodske baštine na hrvatskome nacionalnom prostoru biskup je Strossmayer zasigurno raspolagao podacima o postojanju kulta Sv. Braće u svojoj matičnoj biskupiji, koji je zabilježen u proprijima prije 1807. godine na dan 14. veljače. On će s brojnim istaknutim obnoviteljima ćirilometodske baštine u 19. stoljeću pred sebe postaviti zadatke koji se mogu podijeliti u četiri velike skupine, od kojih svaka pojedinačno implicira još niz podtema:

1. Obnavljanje staroslavenske liturgije u njezinu izvornom obliku, tj. u hrvatskoj njezinoj inačici;

2. Obnavljanje staroslavenske liturgije tamo gdje je bila povijesno ovjerena i proširivanje na krajeve koji nisu imali povlasticu obavljanja staroslavenske liturgije (na hrvatskome nacionalnom prostoru to se odnosi posebice na Đakovačku i srijemsku biskupiju);

3. Sjedinjenje Istočne i Zapadne crkve;

4. U slavenskoj svijesti živu izjednačenost pojmova jezik i narod iskoristiti za ostvarivanje uvjeta političke i kulturne samostalnosti te jačanje hrvatske i slavenske nacionalne svijesti, a kroz to za put do ravnopravnosti s ostalim europskim narodima.

Riječi Ivana Kukuljevića Sakcinskoga zapisane u Zagrebu 24. lipnja 1863. u uvodnome tekstu Tisućnice slovjenskih apostolah sv. Cirila i Metoda poetiziranim diskursom opisuju zatečeno stanje staroslavenske liturgije na hrvatskome tlu kao i raspoloženje naspram novonastale situacije, te ujedno obilježuju nastojanja koja će se, kada je riječ o promicanju ćirilometodske baštine, nastaviti na hrvatskome nacionalnom prostoru, u različitim oblicima, sve do naših dana:

$\mathrm{Nu}$ blagotvorno sieme svetih apostolah slovenskih Cirila i Metoda nije ipak sve do danas usahlo na zemljištu hrvatskom, navlastito u senjskoj, krčkoj i spljetskoj biskupiji; tu uprav ove godine, kad slavimo tisućljetnicu na uspomenu svetih naših apoštolah, ori se opet sveti njihov jezik od oltara i pjevališta prvostolne crkve glavnoga grada hrvatskoga, te spasonosni njihov nauk, s nova odobren po istoj svetoj rimskoj stolici, nalazi odziv u svih nepokvarenih srd-

${ }^{44}$ Josip Bratulić, Konstantin-Ćiril i Metod i njihova baština kod Južnih Slavena. u: Sjaj baštine, Književni krug Split, Split, 1990, str. 11. 
cih naroda hrvatskoga, i spaja duševno ujedno sve pobožne ćuti i glasove ogromnoga slavenstva. ${ }^{45}$



Naslovnica knjige Sveti Kiril i Metodij slavenski apostoli objelodanjene u povodu tisućite godišnjice smrti Sv. Metoda u Petrogradu 6. travnja 1885. i otisnute u Sinodalnoj tiskari. Knjižica je bila namijenjena besplatnoj razdiobi.

${ }^{45}$ I. Kukuljević Sakcinski, Uvod - u: Tisućnica slovjenskih apostolah sv. Cirila i Metoda. U Zagrebu. Tiskom Dragutina Albrechta, 1863, str. 11-12. 


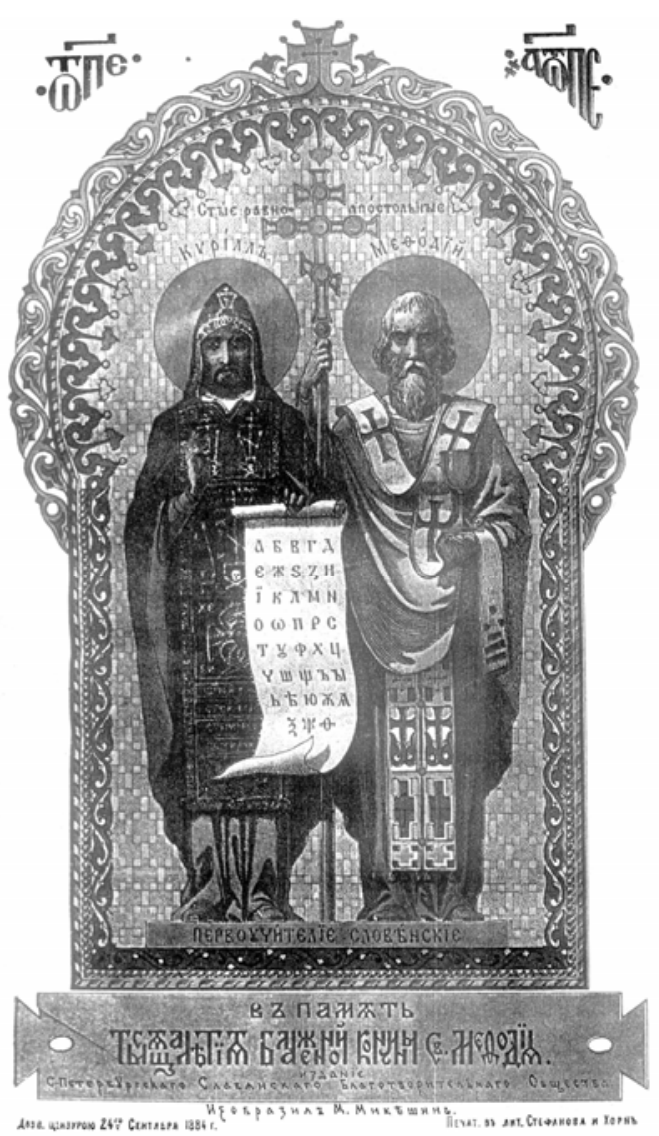

Sveti Kiril i Metodij, prvoučitelji slovjenski - slika posvećena tusućgodišnjici smrti Sv. Metoda, otisnuta na 1. stranici knjige Sveti Kiril i Metodije slavenski apostoli, Petrograd 1885.

\section{Literatura}

- Bibo, I., Raspad teritorijalnog statusa Srednje i Istočne Europe $i$ nastanak jezičnoga nacionalizma - u: I. Bibo - T. Huszar - J. Szucs, Regije europske povijesti, Zagreb, 1995, str. 18-24.

- Bratulić, Josip, Sjaj baštine, Književni krug Split, Split, 1990.

- Bratulić, Josip, Aleja glagoljaša, Zagreb-Pazin-Roč, 1994.

- Bratulić, Josip, Leksikon hrvatske glagoljice, Minerva, Zagreb, 1995.

- Bratulić, Josip, Glagolizam i glagoljaštvo, u: Stjepan Damjanović (ur.), Drugi Hercigonjin zbornik, Hrvatska sveučilišna naklada, Zagreb, 2005, str. 53-57. 
- Budak, Neven, Prva stoljeća Hrvatske, Zagreb, 1994.

- Damjanović, Stjepan, Filološki razgovori, Hrvatska sveučilišna naklada, Zagreb, 2000.

- Esih, Ivan, Hrvatska historiografija u posljednjih 75 godina. - u: Obzor, Spomen-knjiga 1860-1935, Tisak i naklada „Tipografije“ d.d. Zagreb, MCMXXXVI, str. 192-195.

- Grivec, Franc, Sveti Ćiril i Metod, slavenski blagovjesnici, Kršćanska sadašnjost, Zagreb, 1985.

- Hercigonja, Eduard, Nad iskonom hrvatske knjige, Rasprave o hrvatskom glagoljskom srednjovjekovlju, Zagreb, 1983.

- Hercigonja, Eduard, Glagoljaštvo i glagolizam, Zbornik Hrvatska i Europa. Kultura, znanost i umjetnost, sv. 1, Zagreb, 1997.

- Katičić, Radoslav, Jezikoslovni ogledi, Zagreb, 1971.

- Katolički list, god. XV (1863), br. 9.

- Katolički list, god. XV (1864), br. 17.

- Kukuljević Sakcinski Ivan, Uvod - u: Tisućnica slovjenskih apostolah sv. Cirila i Metoda. U Zagrebu. Tiskom Dragutina Albrechta, 1863.

- Maruševski, Olga, Nadbiskup Juraj Haulik 1837-1869. - u: Zagrebački biskupi i nadbiskupi, Školska knjiga, Zagreb, 1995, str. 461-473.

- Petrović, Ivanka, Franjo Rački - otac hrvatske Cyrillo-Methodiane, Zbornik zavoda za povijesne znanosti Istraživačkog centra JAZU, vol. 9, Zagreb, 1979.

- Rački, Franjo, Pozor, 9. kolovoza 1862, god. III, br. 183, str. 1.

- Ritig, Svetozar, Povijest i pravo slovenštine u crkvenom bogoslužju, s osobitim obzirom na Hrvatsku, Zagreb, 1910.

- Strecha, Mario, Katoličko hrvatstvo. Počeci političkog katolicizma u banskoj Hrvatskoj (1897.-1904.), Barabat, Zagreb, 1997.

- Tandarić, Leonard, Sveti Ćiril i Metodije - novi pristup evangelizaciji, Bogoslovska smotra, 1985, br. 3-4, str. 369-375.

- Tkalčić, Ivan Krstitelj, Slavensko bogoslužje u Hrvatskoj, Tisak i naklada Dioničke tiskare Zagreb, Zagreb, 1904. 
Milica LUKIĆ

Milica LUKIĆ

\section{TOWARDS RECENT HISTORY OF GLAGOLITISM}

This article considers socio-political context in which the Cyrillo-Methodian concept in $19^{\text {th }}$ century, ie. recent history of glagolitism, is affirmed again amongst the Slavonic people after ten whole centuries. This affirmation is initiated by activities of the Bishop of Đakovo and Srijem - Josip Juraj Strossmayer and for millenial anniversaries: the thousandth anniversary of Moravian Mission in 1863, the thousandth anniversary of death of St Cyrill in 1869, the thousandth anniversary of encyclical by pope John VIII Industriae tuae in 1880, and thousandth anniversary of death of St Method in 1885. The initial incentive of development of the Croatian Cyrillomethodiana within the framework of Slavic Cyrillo-Methodian science under the lead of Franjo Rački is considered, with the first steps, recorded in Croatian periodicals, of Cyrillo-Methodian concept in cultural, scientific and subsequently political life of Croatian national area of $19^{\text {th }}$ century.

Key words: glagolitism, Croatian Cyrillomethodiana, $19^{\text {th }}$ century 
LINGUA MONTENEGRINA, god. III, br. 5, Cetinje, 2010.

Institut za crnogorski jezik i jezikoslovlje „Vojislav P. Nikčević“

UDK 811.163.42’26

Pregledni rad

\title{
Loretana FARKAŠ (Osijek)
}

Filozofski fakultet Sveučilišta J. J. Strossmayera

\section{OBLIKOVANJE STRUČNOGA NAZIVLJA U HRVATSKOM JEZIKU 18. STOLJEĆA}

\begin{abstract}
U 18. stoljeću u hrvatskom se jezikoslovlju očituje intenziviranje standardizacijskih procesa. Posebice se takva strujanja očituju u Slavoniji, gdje u nekoliko desetljeća izlazi veći broj normativnih priručnika, gramatika, rječnika i pravopisa. Budući da definicije standardnoga jezika upućuju kako je riječ o jeziku koji je normiran, svakako valja u obzir uzeti i dio definicija koje naglašavaju da je standardni jezik uvijek i funkcionalno polivalentan. $U$ prilog toj tvrdnji rad opisuje pokušaje izgradnje stručnoga nazivlja u Slavoniji 18. stoljeća, kako u normativnim priručnicima tako i u djelima nejezične problematike, tiskanima i rukopisima.
\end{abstract}

Ključne riječi: hrvatski jezik, standardizacijski procesi, stručno nazivlje, 18. stoljeće, Slavonija

Hrvatski jezikoslovac Dalibor Brozović standardni jezik definira kao ,autonoman vid jezika, uvijek normiran i funkcionalno polivalentan, koji nastaje pošto se jedna etnička ili nacionalna formacija, uključivši se u internacionalnu civilizaciju, počne u njoj služiti svojim idiomom, koji je dotad funkcionirao samo za potrebe etničke civilizacije“. ${ }^{1}$ Budući da definicije standardnoga jezika upućuju kako je riječ o jeziku koji je normiran, svakako valja u obzir uzeti i dio definicija koje naglašavaju da je standardni jezik uvijek i funkcionalno polivalentan. U prilog toj tvrdnji opisat ćemo pokušaje izgradnje stručnoga nazivlja u Slavoniji 18. stoljeća, kako u normativnim priručnicima tako i u djelima nejezične problematike, tiskanima i rukopisima. Više će riječi biti o stvaranju jezikoslovnoga nazivlja u tadašnjim normativnim priručnicima (Tadijanović, Reljković, Mandić). Kada je riječ o poetičkom, filozofijskom i prirodoznanstvenom nazivlju (geodetsko, matematičko, fizikalno, medicin-

${ }^{1}$ D. Brozović, Standardni jezik. Teorija / usporedbe / geneza / povijest / suvremena zbivanja, MH, Zagreb 1970., str. 28. 
sko, botaničko i dr.) kao izvori će nam poslužiti rukopisna i malo obrađivana građa starih slavonskih pisaca, Matije Petra Katančića i Marijana Lanosovića.

\section{Jezikoslovno nazivlje}

Razdoblje 19. stoljeća uobičajeno je označeno i razdobljem stvaranja jezikoslovnoga nazivlja. No, višedesetljetna su istraživanja pokazala kako stvaranje jezikoslovnoga nazivlja zapravo započinje s nastajanjem prvih normativnih priručnika (gramatika i rječnika).

U tim pokušajima ne zaostaju niti jezikoslovci koji stvaraju na području Slavonije. Iako su Tadijanovićeva, Reljkovićeva i Lanosovićeva gramatika tiskana normativna djela koja su obilježila 18. stoljeće, i to posebice njegovu drugu polovicu, pokušaji oblikovanja jezikoslovne terminologije naziru se i u drugih slavonskih pisaca i jezikoslovaca.

Pogledajmo usporedni abecedni prikaz jezikoslovnih termina koji se pojavljuju u Tadijanovićevoj ${ }^{2}$ i Reljkovićevoj $^{3}$ gramatici te u Mandićevu ${ }^{4}$ pravopisu:

Tadijanović, $\quad$ Reljković, 1767. Mandić, 1779.

1761 .

\begin{tabular}{|c|c|c|c|}
\hline aorist & & $\begin{array}{l}\text { vrime prošasto } \\
\text { samostavno }\end{array}$ & $\begin{array}{l}\text { navi }\{\text { tujuchi } \\
\text { nac in }\end{array}$ \\
\hline apostrof & & $\begin{array}{l}\text { zlamenje } \\
\text { ostavljenja }\end{array}$ & okratenje \\
\hline $\begin{array}{l}\text { buduće } \\
\text { vrijeme }\end{array}$ & vrime doschalto & vrime došasto & \\
\hline crtica & & $\begin{array}{l}\text { zlamenja } \\
\text { svezanja }\end{array}$ & $\begin{array}{l}\text { zlamenje } \\
\text { pri|tajanja }\end{array}$ \\
\hline glagoli & & & riec $\{i$ vrimenite \\
\hline $\begin{array}{l}\text { gramatički } \\
\text { morfem }\end{array}$ & & pridavak & \\
\hline imenica & & imena & \\
\hline imperfekt & vrime & vrime polak & \\
\hline jednina & $\begin{array}{l}\text { Nesverscheno } \\
\text { broj } \\
\text { jedno }\{\text { truki }\end{array}$ & $\begin{array}{l}\text { prošasto } \\
\text { jedno }\{\text { tavni } \\
\text { broj }\end{array}$ & \\
\hline
\end{tabular}

${ }^{2}$ Svashta pomallo illiti kratko sloxenje immenah i ricsih u illyrski i nyemacski je$z i k$, koje sloxi otacz Blax Thadianovich franciscan thaborski, $i$ suxanyah cze farskih duhovni sluxbenik, Magdeburg, 1761.

${ }^{3}$ Nova slavonska i nimacska grammatika, Zagreb, 1767.

${ }^{4}$ Uputjenje $k^{\prime}$ slavonskom Pravopisanju za potrebu narodnieh ucsionicah и Kraljestvu Slavonie, Budim, 1779.

104 
Oblikovanje stručnoga nazivlja u hrvatskom jeziku 18. stoljeća

\begin{tabular}{|c|c|c|c|}
\hline \multicolumn{3}{|l|}{ konjugacija } & \multirow[t]{2}{*}{ sprezanje } \\
\hline kratica & & $\begin{array}{l}\text { zlamenje } \\
\text { okratjenja }\end{array}$ & \\
\hline množina & $\begin{array}{l}\text { broj } \\
\text { mlogo truki }\end{array}$ & $\begin{array}{l}\text { vechje \tavni } \\
\text { broj }\end{array}$ & uzmloxani broj \\
\hline naglasak & & $\begin{array}{l}\text { nadslovak illiti } \\
\text { zlamenje glasa }\end{array}$ & nadslovak \\
\hline ortoepija & & & dobrogovorenje \\
\hline ortografija & & slovosloxnost & slovosloxno $\{t$ \\
\hline perfekt & vrime & vrime prošasto & \\
\hline & Sver]cheno & sastavljeno & \\
\hline pravopisni & & zlamenjah & \\
\hline znakovi & & razdiljenja & \\
\hline pridjev & & & pridavno ime \\
\hline prijedlog & & priddstavak & \\
\hline prilog & & priricsak & \\
\hline prošlo vrijeme & $\begin{array}{l}\text { vrime } \\
\text { pro/cha /to }\end{array}$ & & prosha to vrime \\
\hline rod & kollinno, pleme & pokolenje & \\
\hline samoglasnik & & glasovito slovo & glasovito slovo \\
\hline sklonidba & $\begin{array}{l}\text { prigibanye } \\
\text { immenah, } \\
\text { prignutje }\end{array}$ & pregibanje & prigibanje \\
\hline slog & syllaba & silaba & \\
\hline suglasnik & & $\begin{array}{l}\text { neglasovito } \\
\text { slovo }\end{array}$ & neglasovito slovo \\
\hline sadašnje & vrime & vrime sadašnje & \\
\hline vrijeme & Sada |chnye & & \\
\hline točka & dover 「enye & & dioka \\
\hline $\begin{array}{l}\text { upitnik } \\
\text { uskličnik }\end{array}$ & $\begin{array}{l}\text { govorenja } \\
\text { upitanye }\end{array}$ & $\begin{array}{l}\text { zlamenje pitanja } \\
\text { zlamenje } \\
\text { podvikanja, illi } \\
\text { zach \udjenja }\end{array}$ & $\begin{array}{l}\text { zlamenje pitanja } \\
\text { zlamenje } \\
\text { izvikanja }\end{array}$ \\
\hline uzvik & & medjumetak & \\
\hline veznik & & sa tavak & \\
\hline zagrada & & zlamenje & zlamenje \\
\hline & & umishanja & umishanja \\
\hline zamjenica & & & pridime \\
\hline zarez & razdilenje & & zarezak \\
\hline & govorenja & & \\
\hline
\end{tabular}


Oblikujući jezikoslovno nazivlje, slavonski su jezikoslovci nasljedovali višestoljetnu hrvatsku jezikoslovnu tradiciju.

Za „glagol“ Antun Mandić bilježi termin riječ koju preuzima od Belostenca, Della Belle i Mikalje.

Reljković za „,imenice“ rabi naziv imena, čije se inačice pojavljuju već u Habdelića (ime stoječe), Belostenca (ime stoječe/samostojna, samobitna reč) i Jambrešića (ime).

„Jedninu“ Tadijanović označuje kao broj jednostruki, a tako je i u Ljubušaka i Babića.

Termin pridstavak (prijedlog), koji bilježi Reljković, kajkavski leksikografi bilježe kao prepostavak (Belostenec) i predstavje/predrečje (Jambrešić). U Ljubušaka se pojavljuje pristavak.

Reljković „prilog“ zapisuje kao priricsak dok je u Habdelića pridanjel pridavek, a u Ljubušaka također priričak.

Tadijanović „rod“ označuje kao pleme i kollinno, a tako je i u Ljubušaka i Babića.

$\mathrm{Za}$ „samoglasnik“ Slavonci rabe naziv glasovito slovo kako je i u Vrančića, Kašića, Della Belle, Jambrešića, Mikalje, Ljubušaka, Babića), a neglasovito slovo (suglasnik) preuzimaju od Belostenca, Della Belle, Mikalje, Kašića, Ljubušaka, Babića.

Termin prigibanje (sklonidba) je zabilježen i u Ljubušaka i Babića.

Reljković terminom medjumetak označava „uzvik“, Della Bella ima medmetak, Belostenec medmetek, a Ljubušak meumetak.

Reljković „veznik“ bilježi kao sastavak, a tako je i u Ljubušaka i Babića.

Mandić „zarez“ označuje kao zarezak, kao što je i u Della Belle (Belostenec piše zarez).

\section{Poetičko nazivlje}

Katančićeva poetika De poesi Illyrica libellus ad lege aestheticae exactus, cum Rosaleide Kanixlichii emandata (Knjižica o ilirskom pjesništvu, izvedena po zakonima estetike, s ispravljenom Kanižlićevom Rožalijom) ležala je u rukopisu od 1817. godine, kada je u Budimu napisana, sve do 1984. godine, kada je u Osijeku prevedena i objelodanjena u dvojezičnom izdanju. O njezinoj je namjeni Katančić pisao u predgovoru. Imao je pred očima ne samo učenike, učitelje i studente, već i filologe kojima ilirsko (hrvatsko) pjesništvo nije dovoljno poznato: za njih je Katančić sve hrvatske tekstove preveo na jezik europske znanosti - latinski kako bi ih učinio dostupnim. Hrvatski jezik i pisce Katančić naziva iliričkim, ali i slavno-iliričkim i slavino-iliričkim bosanskoga izgovora, upućujući na povezanost hrvatske književne baštine 18. stoljeća sa zajedničkom bosanskom, pisanom na štokavsko-ikavskoj podlozi. U vrijeme pisanja De poesi, Katančić je okrenut hrvatskoj tematici, 
Oblikovanje stručnoga nazivlja u hrvatskom jeziku 18. stoljeća

jezičnoj i književnoj, svjesno se opredjeljujući pisanju upravo o hrvatskom pjesništvu s estetskog gledišta, prikazujući ne opću, nego nacionalnu poetiku. Pokušaja sličnoga Katančićevu, da se napiše poetika hrvatskoga pjesništva, do De poesi nije bilo.

Slijedi popis riječi koje je Katančić stvorio u Knjižici o ilirskom pjesništvu 1817. godine. Većina je riječi i vezana uz stvaranje poetičkoga nazivlja:

$\begin{array}{ll}\text { Katančićev naziv } & \text { Suvremeni naziv } \\ \text { cslankobolan } & \text { kostobolan } \\ \text { dugokrak } & \text { horej } \\ \text { dvodug } & \text { spondej } \\ \text { dvokrak } & \text { dibrah } \\ \text { glasomirje } & \text { prozodija } \\ \text { godnopis } & \text { komedija } \\ \text { hiljadnica } & \text { milja } \\ \text { kratkodug } & \text { jamb } \\ \text { ljuboznanac } & \text { estetičar } \\ \text { obratno } & \text { anapes } \\ \text { palac } & \text { daktil } \\ \text { pivalica } & \text { kantorica } \\ \text { pivaoc } & \text { kantor } \\ \text { polglasno } & \text { pastorala } \\ \text { poljeslov } & \text { ekloga } \\ \text { popivje } & \text { pjesma } \\ \text { popivnik } & \text { pjesnik } \\ \text { popivnost } & \text { pjesništvo } \\ \text { pravoslovnik } & \text { filolog } \\ \text { protres } & \text { disertacija } \\ \text { redosloxac } & \text { stihotvorac } \\ \text { rugopis } & \text { satira } \\ \text { rukogonet } & \text { hiromantija } \\ \text { skladnomirje } & \text { harmonija } \\ \text { skladnopis } & \text { ortografija } \\ \text { skladnoricsje } & \text { versifikacija } \\ \text { slavni opis } & \text { epopeja } \\ \text { slovoljubje } & \text { literatura } \\ \text { slovosloxje } & \text { ortografija } \\ \text { shestonog } & \text { stih od šest stopa } \\ \text { tiholjubac } & \text { filolog } \\ \text { tiholjubno znanje } & \text { filologija } \\ \text { trokrak } & \\ & \end{array}$


Loretana FARKA ̌̌

$\begin{array}{ll}\text { tugoslov } & \text { elegija } \\ \text { tugopis } & \text { tragedija } \\ \text { vixbaoc } & \text { matematik } \\ \text { vixbopis } & \text { didaktička pjesma }\end{array}$

Taj je Katančićev popis riječi izuzetno vrijedan i sustavan opis i doprinos u oblikovanju hrvatskoga poetičkog nazivlja te ga i danas valja iščitavati i eventualno preuzimati pokoji Katančićev prijedlog.

\section{Filozofijsko nazivlje}

U oblikovanju stručnoga nazivlja posebno je zanimljiv i Njemačkohrvatsko-latinsko-talijanski rječnik Marijana Lanosovića, na kojem je započeo raditi 1788. godine i izradio ga je samo do slova $f$. Njegov rječnik nema izvorni naziv, sačuvan je u rukopisu u Franjevačkom samostanu u Slavonskom Brodu. U njemu Lanosović bilježi nazivlje koje obuhvaća gotovo sve filozofijske discipline: logiku, ontologiju, racionalnu teologiju, etiku, psihologiju, hermeneutiku, estetiku i dr. Pogledajmo neke prijedloge:

Njemački naziv

Allezeti

Allgemein - allem gemein, alle betrefend, allen gehöring

Allgemeinheit

Angeboren

Auschannung

Ausdruch

Bestimmt

Vorsetzlich
Lanosovićev naziv vazda, navik, nepristance, sveg, svegjer, usvigdar, u svako vrime opchinski, opchen, inokupni, veselen, veselenski opchenost, opchenstvo, svescstvenost, svecsinost uvodjen, uvexen, urodstven, naravan, narodjen, naravski gled, pogled, ugled, sgledanje, gledanje, pazenje, razmishljanje, promishljanje, visoko mishljenje izgovor, izvod, odsik, zasjecsenje, odsjecsenje, riecsi, izustje, izrecsenje, prikazanje, osnovanje, osnova, obsjena, bistrina, prikaza, izgovornost, blagoricsnost, sladost, jakost, krepkost, izslovnost csist, ocsit, razboran, razabran, bistar, znan, razumljiv, razumiv znanno, svisno, naumno, smishljeno, smislito, namjenjeno 
Oblikovanje stručnoga nazivlja u hrvatskom jeziku 18. stoljeća

Ausfürung

Ausklügeln

bedeutung

die Anzeige einer kunftigen Sache

der Sinn, oder Begriff in dem

Worte

Begehren izvod, razlog, pokaza, potverda, nadrazloxenje, ukazanje, potverdjenje, ugodjanje izmudriti, izmudrovati, izmisliti, iznaći, tenkovito izmishljavati, hitrovati

naucsenje, nauk, uputjenje, ubavistjenje, ukazanje, odvratjenje od zla

kob, slutnja, slutjenje, gonetanje, zlamenje

zlamen, izgovor, zlamenak, zlamenje, zvanje voljenje, hotjenje, xeljenje, poxeljenje, xudjenje, hlepenje, posvedjenje

das Vermögen der Seele, der um, razum, razumak, razumjenje Vertand

Besonnenheit

mudrost, umjetnost, obertnost, svijest, smishljenost, domishljenost, oshtroum nost, prizriteljnost, svidljivost, opaznost, opaza, ostroxnost, um

Bewusst

die Existenz znanje, poznanje, spoznanje, svjed, vjed, povjed bitnost, jestost, postanak, bivanje, postanje, bivstvo, sushetstvo

\section{Nazivlje prirodnih znanosti}

Slavonski pisci i jezikoslovci druge polovice 18. stoljeća izgrađuju i stručno nazivlje prirodnih znanosti (geometrijsko, matematičko, fizikalno, medicinsko i dr.). Nažalost, ta je građa uglavnom ostala u rukopisima i nije mogla značajnije utjecati na daljnje oblikovanje prirodoznanstvenoga nazivlja.

a) Geodetsko-geometrijsko nazivlje

Nekoliko desetljeća prije sustavnoga prikupljanja rječničke građe, Katančić s latinskoga za potrebe školske nastave na hrvatski jezik prevodi školski udžbenik iz geometrije. Riječ je o 37 stranica rukopisa ${ }^{5}$ koje je u arhivu

\footnotetext{
${ }^{5}$ Hamm smatra da je prijevod bio namijenjen fakultativnom učenju geometrije $u$ drugom i trećem razredu niže gimnazije. Hamm je utvrdio da je Katančićev prijevod na-
} 
Franjevačkoga samostana u Budimu pronašao Josip Hamm i o tome više objavio u radu „Najstarija hrvatska geometrija“. ${ }^{6}$ Kao predložak je Katančiću poslužilo prvo izdanje udžbenika Elementa Geometriae Practicae in Usum Gymnasiorum, et Scholarum Grammaticarum per regnum Hungarie et Provincias eidem adnexas (Elementi praktične geometrije/zemljomjerstva za potrebe gimnazija $i$ gramatičkih škola u Kraljevini Ugarskoj $i$ pripojenim joj pokrajinama) iz 1778. godine, kojega je autor jedan od tadašnjih ponajboljih mađarskih matematičara Pál Makó. Rukopis nema naslova, ali je na stranici ispred prve stranice rukopisa Nandor Krausz napisao Zemljomirje (geometria) P. Petri Katančić ord. Min. Prov. Capistr. ${ }^{7}$ Katančićev rukopis počinje naslovom koji se odnosi samo na prve tri stranice i predstavlja uvod u djelo koje se sastoji iz tri dijela: Pridhodna Bilixenja od Dilloredneg Zemlyomirja (str. 1-3), potom slijedi Dio pervi od mirenja nitakah (str. 3-32) i Dio drugi od mirenja skorupah (str. 33-37). Na kraju se nalazi još jedanaest praznih stranica i pretpostavka je da je taj tekst bio samo uredan i sređen prijepis cjelokupnoga Katančićeva prijevoda, dakle riječ je o čistopisu izvornoga teksta koji je Katančiću služio kao predložak prijepisu. Katančić je preveo 48 stranica originala.

Prevodeći s latinskoga udžbenik Elementa geometriae practicae, Katančić donosi sljedeće geodetsko-geometrijsko nazivlje:

\begin{tabular}{|c|c|c|}
\hline $\begin{array}{l}\text { Katančićev naziv } \\
\text { bitevo }\end{array}$ & $\begin{array}{l}\text { Latinski naziv } \\
\text { solidum }\end{array}$ & $\begin{array}{l}\text { Suvremeni naziv } \\
\text { tijelo, obujam, }\end{array}$ \\
\hline bitevomirje & stereometria & $\begin{array}{l}\text { stereometrija, } \\
\text { mjerenje tijela, } \\
\text { geometrija prostora }\end{array}$ \\
\hline bodak & punctum & točka \\
\hline bok & latus & stranica \\
\hline broj & numerus & broj \\
\hline cilomir & diameter & promjer \\
\hline cletirje & $\begin{array}{l}\text { trapezium (figura } \\
\text { quadrilatera) }\end{array}$ & četverokut, trapez \\
\hline cletverobocsan & quadrilaterus & $\begin{array}{l}\text { četverostran, } \\
\text { četverobočan }\end{array}$ \\
\hline
\end{tabular}

stao u Osijeku krajem 1786. i početkom 1787. godine. Preveo je dvije trećine teksta, a pretpostavka je da je uvođenje njemačkoga jezika kao nastavnoga u niže razrede gimnazije (1787./1788.) razlogom zašto rukopis nije i dovršen.

${ }^{6}$ Hamm 1936./1937. : 97-123.

${ }^{7}$ Hamm 1936./1937. : 104.

${ }^{8}$ Riječi su pisane izvornom Katančićevom grafijom. 
Oblikovanje stručnoga nazivlja u hrvatskom jeziku 18. stoljeća

\begin{tabular}{|c|c|c|}
\hline cletvert & quadrans & četvrtina \\
\hline cletvoredno & quadratum & kvadrat \\
\hline $\begin{array}{l}\text { dalyina, odltupaj, } \\
\text { uzmaknutje, razjtupaj, } \\
\text { razltajak }\end{array}$ & distantia & razmak \\
\hline da $\int_{\text {csica }}$ & tabella & tablica \\
\hline defetina & decas & desetina \\
\hline dilloredan & practicus & praktičan \\
\hline dlan & palmus & dlan (mjera) \\
\hline dometak & corollarium & zaključak, izvod \\
\hline doticsan & contiguus & $\begin{array}{l}\text { susjedni, bliz, } \\
\text { dohvatljiv }\end{array}$ \\
\hline drobi & minutum & djelić \\
\hline drobil pervi & minutum primum & djelić prvi, minuta \\
\hline drobi $\int_{\text {drugi }}$ & minutum secundum & djelić drugi, sekunda \\
\hline dugomirje & longimetria & $\begin{array}{l}\text { geometrija dužina, } \\
\text { longimetrija, mjerenje } \\
\text { dužina }\end{array}$ \\
\hline fat & orgia & $\begin{array}{l}\text { orgija, hvat (duljina } \\
\text { obje raširene ruke) }\end{array}$ \\
\hline ganutiv & mobilis & pomičan \\
\hline gnat, golen, krak & crus & krak \\
\hline gerba & curva & $\begin{array}{l}\text { krivulja, zakrivljena } \\
\text { crta }\end{array}$ \\
\hline gumno & area & ravnina \\
\hline hirotvoran & artificiosus & umjetan \\
\hline jednak, prilic」an & aequalis & jednak \\
\hline jednobocfan & aequilaterus & $\begin{array}{l}\text { jednostran, } \\
\text { jednobočan }\end{array}$ \\
\hline jednokrac「an & aequicrurus & istokračan \\
\hline jednoltruk & simplex & jednostruk \\
\hline kalamir & perpendiculum & okomica \\
\hline kalamiran & perpendicularis & okomit \\
\hline kolicfina & quantitas & količina \\
\hline kolomir & perimetrum & $\begin{array}{l}\text { perimetar, obujam, } \\
\text { opseg }\end{array}$ \\
\hline korak & passus & korak (mjera duljine) \\
\hline lakat & ulna & lakat (mjerilo) \\
\hline $\operatorname{li} \iint a$ & scala & ljestvica \\
\hline luk & arcus & luk \\
\hline mira & mensura & mjera \\
\hline
\end{tabular}




\begin{tabular}{|c|c|c|}
\hline mirioka & libella & vaga \\
\hline milhica & brachium & $\begin{array}{l}\text { podlaktica, krajevi u } \\
\text { luka }\end{array}$ \\
\hline mlogokutje & polygonum & $\begin{array}{l}\text { višekutnik, mnogokut, } \\
\text { poligon }\end{array}$ \\
\hline naslic $\int a n$ & homologus & $\begin{array}{l}\text { homologan, istoimen, } \\
\text { istosmislen }\end{array}$ \\
\hline $\begin{array}{l}\text { nedokonclan, } \\
\text { nedomiran }\end{array}$ & indefinitus & neodređen \\
\hline neganutiv & immobilis & nepomičan \\
\hline neuredan & irregularis & nepravilan \\
\hline nitclica & lineola & crtica \\
\hline nitka & linea & crta, linija \\
\hline nitkoprav & rectilineus & pravocrtan \\
\hline noga & pes & stopa (mjera) \\
\hline nugao, kut & angulus & kut \\
\hline nuglomiran & goniometricus & goniometričan \\
\hline oblifh, oblifhje & rombus & romb \\
\hline obruा & mappa & karta, crtež \\
\hline $\begin{array}{l}\text { odkuclenje, odlucfje, } \\
\text { otvor, razlucfenye }\end{array}$ & apertura & otvor \\
\hline okolica & peripheria & kružnica \\
\hline okrug, krug & circulus & kružnica, krug \\
\hline osnova & delineatio & skiciranje, ocrtavanje \\
\hline olhtrokutan & acutangulus & oštri kut \\
\hline palac & pollex & palac (mjera) \\
\hline pedaly & spithama & $\begin{array}{l}\text { mali pedalj (oko 17,5 } \\
\mathrm{cm} \text { ) }\end{array}$ \\
\hline peterokutje & pentagonum & peterokut \\
\hline podltup & basis & osnova \\
\hline pokrajak & horizon & horizont \\
\hline pokrajan & horizontalis & horizontalan \\
\hline polla, polovica & dimidia & polovica \\
\hline polovan & dimidius & polovica \\
\hline polukolica & semiperipheria & polukrug \\
\hline polukrug & semicirculus & $\begin{array}{l}\text { polukružnica, } \\
\text { polukrug }\end{array}$ \\
\hline polumir & semidiameter & polumjer \\
\hline po〕ad & situs & položaj, mjesto \\
\hline prava, pravac & recta & pravac \\
\hline pravokutan & rectangulus & pravokutan \\
\hline
\end{tabular}


Oblikovanje stručnoga nazivlja u hrvatskom jeziku 18. stoljeća

\begin{tabular}{|c|c|}
\hline pravokutno & rectangulum \\
\hline prilic $\int a n$ & aequalis \\
\hline prilika & figura \\
\hline prinel & transportatorius \\
\hline pro@tor & spatium \\
\hline $\operatorname{per} \int t$ & digitus \\
\hline ravnomirje & planimetria \\
\hline ralbiran & theoreticus \\
\hline razlic $\int a n$ & scalenus \\
\hline razkrenutje, & divaricatio \\
\hline redka & regula \\
\hline Jedmerokutje & heptagonum \\
\hline $\int k l a d n o m i r j e$ & proportio \\
\hline 〔kladnomiran & proportionalis \\
\hline $\int k o r u p$ & superficies \\
\hline $\int l i c \int a n$ & similis \\
\hline $\int \operatorname{lic} \int \mathrm{n} o \int t$ & similitudo \\
\hline $\int m i r k a$ & dioptra \\
\hline $\int p o m e n a k$ & scholion \\
\hline $\int p o r e d a n$ & parallelus \\
\hline $\int p o r e d n i t j e$ & parallelogrammum \\
\hline Sranka & capsula \\
\hline $\int r i d n i$ & medius \\
\hline $\int$ ridobod & centrum \\
\hline Sridokutan & diagonalis \\
\hline $\int t a j$ & situs \\
\hline $\int$ tajali $\int h t e, \int t a j a n y e$, & statio \\
\hline Jtan, Jtanak, Jtanye & \\
\hline $\int$ tota & centena \\
\hline Stupaj & gradus \\
\hline 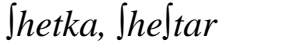 & circinus \\
\hline tilo & corpus \\
\hline trikutje, trokutje & triangulum \\
\hline tupokutan & obtusangulus \\
\hline tverdiโhte & munimentum \\
\hline tverdoftajan & fixus \\
\hline
\end{tabular}

pravokutnik

jednak

lik, figura

prijenosan, prenosiv

prostor

prst (mjera)

planimetrija

teorijski

raznostraničan

razmaknutost

pravilo

sedmerokut

razmjer

proporcionalan

površina, ploha,

oplošje, dio ravnine

sličan

sličnost

diopter

kratko tumačenje,

napomena

usporedan, koji ima

svojstva paralele

paralelogram

kapsula

središnji

središte, centar

dijagonala

položen, postavljen

stajalište

stoput

stupanj

šestar

tijelo

trokut

tupi kut

utvrda

čvrst, stalan,

nepomičan, učvršćen 


\begin{tabular}{|c|c|c|}
\hline uprava & regula & ravnalo, letva, mjerilo \\
\hline upravan & rectus & ravno \\
\hline uredan & regularis & pravilan \\
\hline velicfina, velikoft & magnitudo & veličina, jakost, sila \\
\hline $\begin{array}{l}\text { vodoranilhche } \\
\text { verh }\end{array}$ & $\begin{array}{l}\text { hydrophylacium } \\
\text { vertex }\end{array}$ & $\begin{array}{l}\text { vodospremište, bunar } \\
\text { vrh, vršak }\end{array}$ \\
\hline verhovan & verticalis & okomit, uspravan \\
\hline zajmen & mutuus & recipročan \\
\hline zbica & radius & polumjer, radijus \\
\hline zemlyomirje & geometria & geometrija \\
\hline zgradja & machina & sprava \\
\hline zrno razluto & bomba dissilieus & $\begin{array}{l}\text { komadić pale granate } \\
\text { ili bombe }\end{array}$ \\
\hline zvizdnik & astrolabium & $\begin{array}{l}\text { astrolab, gonio- } \\
\text { metrijski instrument }\end{array}$ \\
\hline xica & chorda & tetiva \\
\hline
\end{tabular}

Uzimajući u obzir današnje geometrijsko nazivlje, zanimljivo je da se i danas zadržala Katančićeva podjela kutova na pravi kut, oštri kut i tupi kut, kao i vrste poligona ili mnogokuta (peterokuti, šesterokuti, sedmerokuti). Danas se u suvremenoj geometriji zadržala gotovo trećina Katančićevih naziva iz Zemlyomirya: bok, broj, četverobočan, četvrt, daljina, desetina, dlan, fat 'hvat', golijen 'krak', jednak, jednobočan, jednostruk, količina, korak, lakat, luk, mjera, mnogokut, noga, kut, otvor, krug, oštrokutan, palac, pedalj, peterokut, polovica, polumjer, pravac, pravokutan, prostor, prst, sedmerokut, sličan, sličnost, stajalište, stupanj, šestar, tijelo, trokut, tupokutan, veličina, vrh, zemljomirje.

Budući da se stručna terminologija prirodnih znanosti uvelike razvila od vremena s kraja 18. stoljeća, razumljivo je da se dio nazivlja koje je predložio Katančić nije zadržalo u suvremenoj uporabi. Problem je veći i što je Katančićev prijevod Zemlyomirja ostao u rukopisu i nije bio dostupan široj znanstvenoj javnosti, koja bi vjerojatno i preuzela više od Katančićevih prijedloga. No, Katančićevo je oblikovanje geometrijskoga nazivlja zanimljiv predložak za današnje stručnjake, kako bi eventualno u posvemašnjoj poplavi tuđica u Katančićevim prijedlozima mogli pronaći i nazivlje koje bi moglo svoju svrhu imati i danas.

Za jezikoslovlje je pak ova Katančićeva knjižica još jedan vrijedan pokazatelj kako hrvatsko stručno nazivlje ne nastaje tek u 19. stoljeću, već zapravo započinje s nastajanjem prvih normativnih priručnika. A Katančić u tom vremenskom slijedu predstavlja tek jednu od poveznica hrvatske jezične prošlosti i sadašnjosti. 
b) Matematičko i fizikalno nazivlje

Stara hrvatska leksikografska djela do danas su slabo istražena za upoznavanje prirodnoznanstvenih gledišta. Jedan od takvih pokušaja je već spomenuti Lanosovićev rukopisni njemačko-hrvatsko-latinsko-talijanski rječnik na kojem je počeo raditi 1788. godine. Iako je Lanosovićev rječnik nepotpun, u njemu se nalazi određeni broj prirodoznanstvenih pojmova. Izdvajamo Lanosovićeve prijedloge za matematičko i fizikalno nazivlje:

Latinski naziv
arcus
astrologia
astrologus
alchimia
astrolabium
computatio
diameter
divisio
divisor
elementum
focus
fulmen
ecliptica
materia
parabola
reflexio
speculum ustorium
sphaeroides
triangulum
vitrum ustorium

Lanosovićev naziv gib, naklonak, zavertak

zvizdonauk, zvizdoznanje, zvizdoslovje, zvizdogatanje

zvizdoznanac, zvizdogatalac

zlatotvorstvo, zlatotvorje

zvizdogled

racsun, razbroj, racsunanje

prirezaj, prisjek

dilenje, razdilenje

dilitelj, razdilitelj

istocsalo

ognjishte

munja, strila, trisak, grom

suncokolish, suncotek

gradja, japia, gradivo

pricha, prichica

odbijanje, odzivanje zrakah

zercalo zaxigatelno, ogledalo paliteljno

nakriva okruglina

trokutje, trouglenik

ognjishte

c) Medicinsko nazivlje

Lanosovićev rukopisni četverojezični rječnik čuva i stručno nazivlje iz medicine, farmakologije i farmacije:

Njemački naziv der Arzt

die Arzeney
Lanosovićev naziv

likar, vracsar, licsnik, vidnik, ozdravitelj, gohitelj, balstvenik, balstvenica, cjelitelj lik, likaria, licsba, pomoch, vracsba, vracstvo, vrashtvo, balstvje, balstvo, 
der Apotheker

die Apotheke

der Augenarzt

die Badefrau

der Bruchartz

der Chirurgus

der Afterdam

das Beinmark

die Blutader

die Fallsucht

der Backenzahn

das Blut

die Engbrüstigkeit

das Fieber

die Chirurgie

der Blutsturz

der Beinbruch

das Brustgeschwür

das Augenpulver

die Brusttropfen

die Brecharzney licsenje, vrashtvo, vracsbanje, cjelba, cjelenie, vracsestvo, lekartvoj, likarenje, likarstvo, medicina

likarnik, likovnik, likospravac,

likoprodalac, likodiljnik

likarnica, likovnica, vracsarnica,

likoprodalnica, vracsevnica

ocsni likar, ocsnik, okovracs

babica, primalja, stiskulja, puporiza

kilolikar, kilorizac, proterxnik,

pridornik

rannolicsnik, rannolikar,

rannovracsnik, rannovracsar,

rukoljekar, rukoljecsnik

guzicsnjak, guzno crivo, csrevo jednako, kayti raven iz sebe izleva

mozg, mozag

xilla kervna, dushnik, vena

padavica

kutnji zub, kutnjak

kerv, krev, rigati, bljuvati, kervju, izraknuti kerv, kerv bacati, pustiti,

pushtati, izvaditi kerv

dihavicsnost, tisnodushnost, sipotina,

sipljivost, zadahnutost, odishka,

grudnaa bolezen

groznica, zimnica, zimlica, ognjic, oganj, ognjica, vatrushtina, horka zymnice, trechodanica, trechacsa, grozna treshnja, poshalina, treshljavica, tresavica, ledena, studena,

silna, xestoga groznica

rannolikaria, rannolikarstvo,

rannovrashtvo, rukolikarstvo

kervi riganje, veli kervotok

kostolom, kostolomljenje, nogolom

csir, otek persni illi jetrei

prah ocsni

kapi persne, perstokapi

bljuvilo, rigalo, lik bljuvljiv, bljucsa

bljucsica 
d) Botaničko nazivlje

Lanosovićeva rukopisna građa upotpunjena je i botaničkim nazivljem. Iako je obrađeno tek oko 400 vrsta i rodova, rad je vrijedan zbog suvremeno obrađene i danas upotrebljive građe koja uz već ranije poznate nazive sadržava i veći broj novih vrsta i rodova te oko pedesetak novih hrvatskih imena biljaka:

$\begin{array}{ll}\text { Lanosovićev naziv } & \text { Latinski naziv } \\ \text { Blidvica } & \text { Hieracium pilosella } \\ \text { Bljuvacsnik } & \text { Jatropha } \\ \text { Bobovac, bobovnja, krupnik, } & \text { Anagallis } \\ \text { jurje oko } & \\ \text { Bodiljak } & \text { Poterium sanguisorba } \\ \text { Crjevatica } & \text { Nummularia } \\ \text { Csecsek kozji } & \text { Cichorium intybus } \\ \text { Csekanka } & \text { Cichorium intyvux } \\ \text { Cservenika } & \text { Haematoxylon } \\ \text { Dablik } & \text { Dracontium, Dracunculus } \\ \text { Davon } & \text { Cupressus } \\ \text { Dlanak-dervo } & \text { Cocos } \\ \text { Gorcsinjak } & \text { Menyanthes trifoliata } \\ \text { Guljez } & \text { Asphodelus } \\ \text { Gusenjak } & \text { Chenopodium } \\ \text { Jablanak } & \text { Marrubium } \\ \text { Jagoresak } & \text { Saxifraga } \\ \text { Kostrish, csepcseg, mlicsac, } & \text { Sonchus arvensis } \\ \text { zajcsa trava } & \\ \text { Kozlik } & \\ \text { Mahovitac } & \text { Valeriana celtica } \\ \text { Puspan } & \text { Hieracium alpinum } \\ \text { Striljan } & \text { Buxus } \\ \text { Xabnjak, stopa, vraxja, xabica, } & \text { Ononis arvensis } \\ \text { xabokiek } & \text { Ranunculus arvensis }\end{array}$
xabokrek

Uvodeći nove domaće i strane rodove i vrste, Lanosović je obogatio hrvatsku botaničku građu. Poslu je pristupao studiozno, a služio se i nekim suvremenim botaničkim djelima.

Slavonski se jezikoslovci i izgrađivači ondašnjega stručnog nazivlja ugledaju u latinske, njemačke, talijanske i mađarske uzore, no nastoje nazivlje oblikovati u okviru hrvatskoga jezičnog sustava. Pri oblikovanju stručnoga nazivlja pokazuju se i kao dobri poznavatelji leksikografske 
tradicije koju uglavnom i nasljeđuju, ali je zamjetno kako donose i vlastita, samostalna rješenja. Izgrađujući stručno nazivlje, slavonski jezikoslovci i književnici samo potvrđuju tvrdnje kako ozbiljnije zamahe standardizaciji hrvatskoga jezika valja tražiti već u 18. stoljeću, i to posebice u Slavoniji, bez obzira na to što stručno nazivlje nisu izgrađivali, dotjerivali $\mathrm{i}$ usustavljivali već je ono nastajalo više usput, iz pragmatičnih razloga.

Valja stoga sa zadrškom uzimati tvrdnje kako hrvatsko stručno nazivlje nastaje tek u 19. stoljeću, upravo stoga što se ono oblikovalo već u starijim razdobljima i utjecalo je na oblikovanje stručnoga nazivlja u drugoj polovici 19. stoljeća. Većina primjera navedena je iz stare i teško dostupne rukopisne građe koja nije u većem značaju mogla utjecati na daljnji razvitak hrvatskoga stručnog nazivlja. No, ta nastojanja pokazuju da su već u 18. stoljeću postojale težnje i napori za stvaranjem hrvatskoga stručnog nazivlja.

\section{Literatura}

- Babić, Stjepan. 1968. „Jezik starih hrvatskih pisaca u Slavoniji“, Godišnjak Matice hrvatske 6, Vinkovci, str. 7-84.

- Belostenec, Ivan. 1740. Gazophylacium, seu latino-illyricorum onomatum aerarium, Gazophylacium illyrico-latinum, Zagreb: pretisak Liber - Mladost, 1972. i 1973.; Gazophylacium, seu LatinoIllyricorum onomatum aerarium: selectioribus synonimis, phraseologiis verborum constructionibus, metaphoris, adagiis, abundantissime locupletatum..., Zagreb: pretisak Stari grad, 1998.

- Brozović Dalibor. 1970. Standardni jezik. Teorija / usporedbe / geneza / povijest / suvremena zbivanja, Zagreb, MH

- Brozović, Dalibor. 1978. „Hrvatski jezik, njegovo mjesto unutar južnoslavenskih i drugih slavenskih jezika, njegove povijesne mijene kao jezika hrvatske književnosti“", Hrvatska književnost u evropskom kontekstu, Zagreb : Zavod za znanost o književnosti Filozofskog fakulteta Sveučilišta u Zagrebu - Sveučilišna naklada Liber, str. 9-83.

- Della Bella, Ardelio. 1728. Dizionario italiano, latino, illirico (Avv.) : Mleci, $785+177$ str.

- Habdelić, Juraj. 1670. Dictionar ili reči slovenske, Graz: pretisak Kršćanska sadašnjost, Zagreb 1989. (pogovori Josipa Bratulića i Vladimira Horvata)

- Hamm, Josip. 1936./1937. „Najstarija hrvatska geometrija“, $\mathrm{Na}$ stavni viestnik, knj. XLV., sv. 1-3, Zagreb, str. 97-123.

- Jonke, Ljudevit. 1966. „Hrvatsko-njemački jezični priručnik Blaža Tadijanovića iz 1761“, Kolo IV, br. 3-4, Zagreb 
Oblikovanje stručnoga nazivlja u hrvatskom jeziku 18. stoljeća

- Katančić, Matija Petar. 1815. Etymologicon Illyricum, Budimpešta: rukopis Sveučilišne knjižnice u Budimpešti, sign. H 13, Catal., 1473 str.

- Katančić, Matija Petar. 1817. De poesi Illyrica libellus ad lege aestheticae exactus, cum Rosaleide Kanixlichii emandata (Knjižica o ilirskom pjesništvu, izvedena po zakonima estetike, s ispravljenom Kanižlićevom Rožalijom), rukopis

- Katančić, Matija Petar. 1820. Index Latino-Illyricus, Budimpešta: rukopis Arhiva Franjevačkog samostana u Budimpešti, sign. K VI 4, 676 str.

- Katančić, Matija Petar. 1786./1787. Pridhodna Bilixenya od Dillorednog Zemlyomirja, Uvodne bilješke iz praktične geometrije Previae notiones de geometria practica, rukopis, Franjevački samostan u Budimu, 37 str.

- Kolenić, Ljiljana. 1998. Riječ o riječima : iz hrvatske leksikologije $i$ frazeologije 17. i 18. stoljeća, Osijek: Pedagoški fakultet, 196 str.

- Lanosović, Marijan. 1778. Neue Einleitung zur slavonischen Sprache, Osijek, 272 str.

- Lanosović, Marijan. 1789.-1791. Njemačko-hrvatsko-latinsko-talijanski rječnik, rukopis, 1. i 2. dio Franjevački samostan, Slavonski Brod

- Lanosović, Marijan. 1789.-1791. Njemačko-latinsko-hrvatsko-mađarski rječnik, rukopis, Franjevački samostan, Slavonski Brod

- Mandić, Antun, 1779. Uputjenje k' slavonskom Pravopisanju za potrebu narodnieh ucsionicah u Kraljestvu Slavonie, Budim, 32 str.

- Maretić, Tomo. 1889. Istorija hrvatskoga pravopisa latinskijem slovima, Zagreb: Djela JAZU, XIII + 406 str.

- Maretić, Tomo. 1910. Jezik slavonskijeh pisaca, prilog istoričkoj gramatici hrvatskoj ili srpskoj, Zagreb: Rad JAZU 180., str. 146-233.

- Matić, Tomo. 1945. Prosvjetni i književni rad u Slavoniji prije preporoda, Zagreb: Djela HAZU XLI, 169 str.

- Mikalja, Jakov. 1649. Blago jezika slovinskoga, Loretto

- Moguš, M. - Vončina, J. 1969. „Latinica u Hrvata“, Radovi Zavoda za slavensku filologiju 11, Zagreb, str. 61-81.

- Moguš, Milan. 1993. Povijest hrvatskoga književnoga jezika, Zagreb: Globus, 205 str.; drugo prošireno izdanje, Zagreb: Globus 1995., 234 str.

- Pavić, Emerik. 1808. Epistole i Evangjelja priko sviu godishnji nediljah i svetkovinah... U Budimu, Sa slovima Kraljevske Magjarske Mudroskupshtine, Budim, 436 str. 


\section{Loretana FARKAŠ}

- Reljković, Matija Antun. 1767. Nova slavonska i nimacska grammatika, Zagreb, 560 str.

- Samardžija, Marko. 1996. Leksikologija hrvatskoga jezika, Zagreb: Školska knjiga

- Tadijanović, Blaž. 1761. Svashta pomallo illiti kratko sloxenje immenah $i$ ricsih $u$ illyrski $i$ nyemacski jezik, koje sloxi otacz Blax Thadianovich franciscan thaborski, $i$ suxanyah cze farskih duhovni sluxbenik, Magdeburg, 214 str.

- Tanocki, Franjo. 1996. Slavonska jezikoslovna baština, Osijek: Matica Hrvatska, 242 str.

- Vince, Zlatko. 1990. Putovima hrvatskoga književnog jezika, Zagreb: Matica hrvatska, 695 str.

- Vončina, Josip.1988. Jezična baština, Split: Književni krug, 390 str.

- Vrančić, Faust. 1595. Dictionarium quinque nobilissimarum Europae linguarum, latinae, italice, germanicae, dalmaticae et ungaricae, Venecija: pretisak Novi Liber, Zagreb 1992.

- Zbornik. 1981. Zbornik o Vidu Došenu i Blažu Tadijanoviću, JAZU - Centar za znanstveni rad Osijek, 174 str.

- Zbornik. 1985. Zbornik o Marijanu Lanosoviću, JAZU - Zavod za znanstveni rad Osijek, 276 str.

\section{Loretana FARKA $\check{S}$}

\section{DEVELOPING TEHNICAL VOCABULARY IN THE CROATIAN LANGUAGE IN THE $18^{\text {TH }}$ CENTURY}

The intensification of standardization processes in Croatian linguistics was felt during the $18^{\text {th }}$ century. These tendencies were particularly evident in Slavonia where a large number of normative handbooks, grammar books, dictionaries and orthography handbooks had been published in a few decades. Since definitions of a standard language imply that it is a normed language, we should also consider those definitions which emphasise that a standard language is always functionally polyvalent. With reference to the above mentioned this paper deals with the attempts to develop technical vocabulary in $18^{\text {th }}$ century-Slavonia in the normative handbooks and nonlinguistic works, both printed and manuscripts.

Key words: Croatian language, standardization processes, technical vocabulary, $18^{\text {th }}$ century, Slavonia 
LINGUA MONTENEGRINA, god. III, br. 5, Cetinje, 2010.

Institut za crnogorski jezik i jezikoslovlje „Vojislav P. Nikčević“

UDK 811.163.41'26

Pregledni rad

\section{Lilianna MIODONSKA (Bielsko-Biala)}

Akademia Techniczno-Humanistyczna Bielsko-Biała

\section{CZY OBECNA SERBSKA POLITYKA JEZYKOWA TO JUŻ JEZZYKOWY LAPOT?}

U konfrontaciji sa postupajućom globalizacijom srpski lingvisti već odavno razmišljaju o sudbini njihovog maternjeg jezika. U savremenoj teškoj ekonomskoj situaciji koju je prouzrokovala svetska privredna kriza, problemi nauke i kulture ostali su odloženi u drugi plan, a da ne spominjemo već jezičku politiku zemlje i finansijska sredstva koje bi trebalo za nju da budu predviđena.

U Srbiji su u poslednje vreme ponovo počele diskusije na ovu temu, a mišljenja - kao se obično događa u takvim situacijama podeljena su. Ipak svi se slažu u jednom: treba više brinuti o sudbini srpskog jezika i neprekidno raditi na problemima razvitka jezičke kulture i na očuvanju tradicije.

Svesni ozbiljnih promena u okviru srpskog jezičkog standarda prouzrokovanih posebno uticajem engleskog jezika, lingvisti preuzimaju intenzivne napore u oblasti normativistike. Osim toga započeli su diskusiju na temu kompetencije određenih državnih ustanova, odgovornih za standardizaciju jezika i jezičku kulturu.

Ostaje samo imati nadu da će veoma radikalni koraci preduzeti 2009. god. stvoriti odgovarajuću, prijateljsku klimu u kojoj će se odvijati dalji razvitak jezika, a njegovi korisnici biće svesni značaja svog maternjeg jezika za srpsku kulturu.

Ključne reči: Srbija, jezička politika, globalizacija, normativistika, jezičko planiranje, standardizacija

Jezik je hranitelj naroda. Dokle god živi narod, dokle ga ljubimo i počitujemo, njim govorimo $i$ pišemo, prečišćavamo ga, umnožavamo ga i ukrašavamo, dotle i živi narod.

Vuk Stefanović Karadžić ${ }^{1}$

${ }^{1}$ V. Karadžić, cyt. za: Z. Spasojević, Govor i mišljenje su dar, (2009-10-07), http://www.politika.rs/rubrike/Tema-nedelje/putevi-i-stranputice-srpskog-jezika/Govori-mishljenje-su-dar.lt.html. 
Polski mistrz reportażu R. Kapuściński w swym Lapidarium II skomentował otaczającą nas, ogarniętą globalizacją rzeczywistość w następujący sposób: Trudno jest pisać w świecie tak gwattownej i gruntownej przemiany. Wszystko osuwa sie spod nóg, zmieniaja się symbole, przestawiaja znaki, punkty orientacyjne nie maja juz miejsc stałych. Wzrok piszqcego btaka się po coraz to nowych i nieznanych krajobrazach, a jego glos ginie w huku pedzacej lawiny historii. ${ }^{2}$ Czytając przytoczony fragment, pozostaje zastanowić się, czy nie można go odnieść także do sfery językowej?

Do niedawna zjawisko globalizacji wiązano nierozłącznie z zagadnieniami li tylko natury przemysłowo - ekonomicznej. Obecnie już nikt nie ma wątpliwości, iż dotyczy ona również sfery językowej. Dotknęła zwłaszcza języków mniej popularnych, którymi posługuje się stosunkowo niewielka liczba rozmówców. Do takich należy między innymi język serbski.

W świecie zapanowała nowa sytuacja językowa sprowadzająca się do tego, iż większość populacji posługuje się kilkoma najbardziej popularnymi językami, wśród których pierwszeństwo przypadło angielskiemu. Pełni on rolę międzynarodowego lingua franca, wywierając równocześnie wpływ na inne, małe języki, modyfikując je i przekształcając obowiązujące w nich dotychczas standardy. Tymi właśnie relacjami pomiędzy małymi a wielkimi językami i ich otoczeniem zajmuje się stosunkowo młoda dziedzina nauki, którą jest lingwistyczna ekologia. To właśnie przez nią zostało ukute pojęcie glottofagii jako kolektywnego kulturowego i duchowego kanibalizmu, dotykającego w warstwie kulturowej najważniejszego jej elementu, którym jest język.

Serbscy językoznawcy już od pewnego czasu bardzo poważnie podchodzą do wspomnianego zagadnienia, zastanawiając się nad przyszłością ich ojczystego języka. Zdania - jak zwykle w takich przypadkach - są podzielone. Część z nich, m. in. prof. Ivan Klajn uważa, iż serbski jest zagrożony w tym samym stopniu, co pozostałe języki, włączając $w$ tę grupę również te o wielkiej tradycji, do których zaliczył: francuski, włoski czy niemiecki. Smatram da nije verovatno da ćemo doći do jednojezične civilizacije. Równocześnie twierdzi, iż angielski pozostanie językiem międzynarodowej komunikacji i nie wyprze poszczególnych języków narodowych. ${ }^{3}$

Całkowicie odmienne stanowisko reprezentuje drugi znany serbski lingwista, profesor Filološkog fakulteta w Belgradzie, Ranko Bugarski. Twierdzi, iż język serbski należy do grupy języków zagrożonych wymarciem. U svetu ima 12 miliona ljudi koji govore srpski, uključujući naravno $i$ Srbiju, naš jezik je standarizovan, sa gramatikom, rečnicima, institucional-

${ }^{2}$ R. Kapuściński, Lapidaria I - III, Biblioteka Gazety Wyborczej, Warszawa 2008, s. 156.

${ }^{3}$ I. Klajn, Čuvajmo srpski jezik, (2009-10-06), http://www.mtsmondo.com/news/ world/text.php?vest=125354 
Czy obecna serbska polityka językowa to już językowy lapot?

nom podrškom (...) drugo je pitanje da li se dovoljno vodi briga o jezičkoj kulturi onih koji govore srpski jezik. ${ }^{4}$

Trudno się dziwić niepokojom, gdyż badania nad losem poszczególnych języków wskazują, iż co dwa tygodnie ginie w świecie jeden z około 6000 języków, a największa ich liczba zaniknie do końca bieżącego stulecia - ponad połowa czy nawet dwie trzecie. Będzie to związane z naturalnym odejściem - śmiercią użytkowników poszczególnych języków jak również z rezygnacją porozumiewania się danej grupy językowej własnym językiem i wyborem języka prestiżowego w środowisku, w którym przyszło im żyć, co odnosi się zwłaszcza do grup imigrantów. ${ }^{5}$

Wszyscy jednak pozostają zgodni co do tego, iż trzeba bardziej troszczyć się o los języka serbskiego, pracować nieustannie nad rozwojem językowej kultury oraz nad zachowaniem tradycji. Pravilan govor zahteva više pažnje i napora, pre svega jezičku kulturu i svest o sopstvenom izrazu koji se stiču dugo i mukotrpno, učenjem, čitanjem dela dobrih pisaca $i$ vežbama pisanja i govorenja. ${ }^{6}$

\section{Kryzys w gospodarce, kryzys w nauce}

O kryzysie, który ogarnął gospodarkę światową i daje się we znaki poszczególnym krajom, słyszymy nieustannie. Upadają przedsiębiorstwa, likwidowane są kolejne miejsca pracy, niebezpiecznie wzrasta bezrobocie. Któż w tak trudnej rzeczywistości myśli o kondycji nauki i kultury, w tym również o polityce językowej, nie wspominając już o nakładach finansowych, które powinny być na nie przeznaczone. Sytuację najlepiej komentuje następująca wypowiedź: Sigurno je da nema druge delatnosti koja je toliko suvoparna i nekomercijalna a toliko bitna za nacionalnu kulturu kao što je izrada osnovnih jezičkih priručnika. Da li i koliko država treba da finansira pozorište, filmove, muziku itd., o tome bi se moglo dugo raspravljati, kaže za NIN profesor Ivan Klajn, predsednik Odbora za standardizaciju srpskog jezika, ali jedno je sigurno: „Nikad nijedan višetomni rečnik, gramatika, istorija jezika, etimološki ili dijalektološki atlas neće postati knjižarski bestseller. Zato bi država morala ne samo da finansira takva izdanja nego da organizuje $i$ podstiče njihovu izradu. Nažalost, ni jedno od tri nadležna ministarstva ne smatra da mu je to dužnost i obaveza. ${ }^{7}$

\footnotetext{
${ }^{4}$ I. Klajn, Loco cit.

${ }^{5}$ Por. Loco cit.

${ }^{6}$ Z. Spasojević, Govor i mišljenje su dar, (2009-10-07), http://www.politika.rs/ rubrike/Tema-nedelje/putevi-i-stranputice-srpskog-jezika/Govor-i-mishljenje-sudar.lt.html

${ }^{7}$ Z. Latinović, U stanju tihog odumiranja, NIN, br. 3068, Belgrad, 15. 10. 2009, 46.
} 
Sytuacja finansowa serbskiej nauki jest zastraszająca. Państwo przeznacza na tę dziedzinę mniej niż 0,3\% swego budżetu, co lokuje Republikę Serbii na jednym z ostatnich miejsc pomiędzy rozwiniętymi krajami świata. Te, będące w nieco lepszej kondycji gospodarczej, wydzielają na ten cel około $3-4 \%$. Wszystko to sprawia, że Ministerstwo Nauki boryka się z ciagłymi problemami.

Według oficjalnych danych na sfinansowanie podstawowych badań w zakresie języka serbskiego i literatury państwo przeznacza $290 \mathrm{mln}$ dinarów (ok. 30 mln euro). Stanowi to zaledwie 6,5\% przewidzianych na nie środków - 4.534.700.000 din., co jest połową budżetu przeznaczonego na naukę. Ponadto nakłady państwa nie przekraczają $10 \mathrm{mln}$ euro rocznie na żadną $\mathrm{z}$ dziedzin badań podstawowych. Znacznie większe kwoty przeznaczane są na projekty badawcze w zakresie chemii, nauk społecznych, biologii, fizyki, historii, archeologii, etnologii oraz medycyny, aniżeli te dla języka i literatury. Iza jezika, prema kojem se svaka pristojna država ophodi kao prema temelju nacionalne svesti, što jezik nesumnjivo i jeste, samo su matematika i geo-nauke (sa oko 4,5 odsto). Treći zanimljiv detalj kad je reč o „,brojkama $i$ slovima" jeste da su ove godine samo za Rečnik srpskohrvatskog književnog i narodnog jezika SANU poreski obveznici Srbije dali 28.894 .338 dinara. A to je desetak odsto budžeta Ministarstva nauke za jezička istraživanja. ${ }^{8}$ Niestety, rewizja budżetu sprawiła, iż środki będące w gestii Ministerstwa Nauki zostały zmniejszone o kwotę 918 mln dinarów ${ }^{9}$, co wymogło konieczność ograniczenia zakresu prac nad poszczególnymi projektami.

\section{Problemy serbskiej normatywistyki}

W Serbii w ostatnim czasie odżyły dyskusje na temat polityki językowej państwa, a zwłaszcza w zakresie normatywistyki, co było związane z zapowiedzią wydania pod koniec bieżącego roku lub na początku następnego Pravopisnog rečnika, mającego się ukazać w Wydawnictwie Prometej oraz poprawionego wydania Pravopisa srpskog jezika - wydania Matice srpske $\mathrm{z}$ 1993 r.

Procesom kodyfikacyjnym serbskiej i chorwackiej normy językowej oba narody poświęciły wiele uwagi, a problemy z nimi związane zaprzątały językoznawców, a także polityków zarówno w okresie międzywojennym, jak i w trakcie trwania II wojny światowej.

W powstałym w 1918 r. Królestwie SHS posługiwano się językiem serbsko-chorwackim, a najwięcej problemów dla jego użytkowników wynikało z nieunormowanej ortografii. W związku z tym okres międzywojenny

\footnotetext{
${ }^{8}$ Z. Latinović, Loco cit.

${ }^{9}$ Loco cit.
} 
Czy obecna serbska polityka językowa to już językowy lapot?

wypełniły starania, mające na celu wyeliminowanie rozbieżności ortograficznych pomiędzy poszczególnymi zasadami pisowni i ich finalne ujednolicenie. ${ }^{10}$ Wojna tylko pozornie przerwała toczący się proces, gdyż obie strony kontynuowały rozpoczęte reformowanie pisowni, jednak już oddzielnie - języka serbskiego i chorwackiego. To wtedy Serbowie podjęli odważną próbę uproszczenia obowiązującej ortografii, publikując w 1942 r. Novo pravopisno uputstvo srpskog književnog jezika. W latach powojennych, kiedy oba narody stanęły wobec konieczności funkcjonowania w obrębie federacyjnego państwa, unormowanie sytuacji ortograficznej przyniosło podpisanie Novosadskog dogovora i wydanie w 1960 r. równoczesnym staraniem Matice srpske i Matice hrvatske ujednoliconych zasad pisowni, obowiązujących na terytorium czterech republik posługujących się językiem serbsko-chorwackim. Jednak ze względu na stanowisko strony chorwackiej, po pewnym czasie trzeba było podjąc starania nad zmodyfikowaniem dotychczasowej pisowni. ${ }^{11}$ W 1989 r. ukazały się opublikowane przez Matice srpska Prilozi Pravopisu, będące opracowanymi w 1987 r. przez lingwistów z ośrodków: w Belgradzie, Nowym Sadzie, Nikšiciu i Sarajewie poprawkami i innowacjami w zakresie dotychczasowych zasad pisowni. Podjęte starania były kontynuowane przez tzw. Međuakademijski odbor za ortografiju i ortoepiju (MO, 19891990). Niebawem jednak wydarzenia polityczne wyprzedziły publikację efektów działań naukowców, którzy stanęli wobec faktu rozpadu nie tylko politycznego dotychczasowego państwa, ale również wyodrębnienia się dwóch oddzielnych standardów językowych - serbskiego i chorwackiego.

W nowych realiach grupa trzech językoznawców: M. Pešikan, J. Jerković oraz M. Pižurica, biorąc pod uwagę dotychczasowe wyniki badań i poczynione ustalenia, ukończyła podjęte wcześniej prace, co zaowocowało wydaniem w 1993 r. przez Maticę srpska Pravopisa srpskoga jezika wraz z jego wersją szkolną (Matica srpska i Zavod za udžbenike i nastavna sredstva, 1995).

W tym czasie ukazały się również inne opracowania ortograficzne. Tegoż roku pojawił się kolejny Pravopis - efekt pracy pięciu lingwistów uniwersytetów w Belgradzie i Nikšiciu, negujący ustalenia normy opracowanej we wcześniej wspomnianej publikacji. W 1994 r. na półki księgarskie trafił następny Pravopis pióra M. Dešicia, przeznaczony głównie do użytku szkolnego, a w 1998 r. pojawił się nowy Pravopis autorstwa R. Simicia, znacznie różniący się od wersji z 1993 r.

Wobec wielości opracowań, by uniknąć ortograficznej anarchii, Ministerstwo Oświaty i Kultury Republiki Serbii w 1996 r. uznało za obowiązują-

${ }^{10}$ Zob. L. Miodońska, Język Serbów i Chorwatów w latach 1929-1945 (z problematyki ortoepicznej), Wyd. ATH, Bielsko-Biała 2007, s. 44-47.

${ }^{11}$ Zob. Loco cit. 
Lilianna MIODOŃSKA

cy Pravopis Matice srpske z 1993 r., który mimo wielu innowacji wkrótce okazał się również niespełniającym wymogów serbskiej ortografii ze względu na niejasność zaprezentowanych w nim reguł i wynikającą stąd możliwość dezorientacji posługujących się nim użytkowników. O mającym się niebawem ukazać, a oczekiwanym od pięciu lat drugim wydaniu wspomnianej publikacji, kierujący grupą redakcyjną (M. Pižurica, M. Dešić, Ž. Stanojčić, B. Ostojić) prof. M. Pižurica wypowiedział się następująco: Pravopis će biti završen do kraja ove godine i neće biti nesporan. Za velike pravopisne reforme nema prostora u srpskom jeziku, ima prostora za fina podeřavanja, Pravopis 1993. nije pisan da prekine vukovsku tradiciju. Vukovska tradicija je srpska i ne treba od nje bežati. Interpunkcija je centralna tema Pravopisa. ${ }^{12}$

Jednakże zarzuty dotyczące serbskiej polityki językowej nie ograniczają się wyłącznie do kwestii związanych z pisownią. Brak także podstawowych podręczników językowych, a zwłaszcza najnowszych opracowań gramatyki języka serbskiego. W dalszym ciagu najbardziej reprezentatywny w tej dziedzinie jest napisany przez M. Stevanovicia Savremeni sprskohrvatski jezik oraz opracowana na potrzeby szkół średnich Gramatika srpskog jezika Ž. Stanojčicia i Lj. Popovicia, która ukazała się przed dwudziestu laty. Ponadto w 2005 r. została opublikowana mała Gramatika srpskog jezika I. Klajna. Jednotomowy Rečnik srpskog jezika Matice srpske ujrzał światło dzienne po 17 latach trwających nad nim prac - w 2007 r.

Część lingwistów, m. in. I. Klajn ${ }^{13}$, jest zdania, iż Serbowie nie posiadają w ogóle sprecyzowanej polityki językowej, a wszelkie lingwistyczne instytucje znajdują się $w$ fazie zamierania. Przyczyn takiego stanu rzeczy należy poszukiwać w stosunku samych Serbów do ich ojczystego języka, którego nigdy nie uważali - w przeciwieństwie do Chorwatów - za zagrożony, a serbska tolerancja zarówno w stosunku do innych wariantów, jak i obcych wpływów była zawsze stawiana za wzór. Nie oznacza to jednak braku wrażliwości językowej oraz troski o język. Wszak w 1997 r. z inicjatywy członków SANU powstał Odbor za standardizaciju srpskog jezika, a jego założycielami były: Akademie Nauk Serbii, Czarnogóry i Republiki Serbskiej, Institut za srpski jezik w Belgradzie, Matica srpska oraz większość wydziałów filologicznych. Niestety, organ ten, mający służyć systematycznemu normowaniu języka serbskiego, znajduje się w tej chwili w stanie zupełnej stagnacji, co nastąpiło po przedwczesnej śmierci jego sekretarza - wszechstronnego lingwisty B. Brboricia.

${ }^{12}$ Z. Latinović, U stanju tihog odumiranja, NIN, broj 3068, Belgrad, 15. 10. 2009, s. 47.

${ }^{13}$ Zob. Loco cit. 
Czy obecna serbska polityka językowa to już językowy lapot?

Funkcję popularnego magazynu językowego miało pełnić powstałe $\mathrm{z}$ inicjatywy B. Petrovicia, a znajdujące się w pieczy Matice srpske czasopismo Jezik danas. W założeniu miał być powszechnie dostępnym kwartalnikiem. Niestety, w związku z brakiem współpracowników zainteresowanych zamieszczaniem w nim artykułów, tytuł ten ukazał się jedynie dwudziestokrotnie, a przed czterema laty zaprzestano jego publikacji.

Istotnie, sytuacja jest trudna. Odebranie Ministerstwu Nauki i Rozwoju Technologicznego wspomnianych $918 \mathrm{mln}$ din. spowodowało ograniczenie ilości nakładów na już rozpoczęte przedsięwzięcia, wśród których znalazły się m. in.: Srpski biografski rečnik, Srpska enciklopedija (prvi tom još nije izašao, u 2009. je izostalo finansiranje, ali je 10 miliona dinara duga od prošle godine refundirano), izmenjeno i dopunjeno izdanje jednotomnog Pravopisa Matice srpske, dopunjeno izdanje jednotomnog Rečnika srpskog književnog jezika, višetomni Rečnik srpskog književnog jezika, Dijalekatski rečnik Vojvodine, Normativna gramatika srpskog jezika. ${ }^{14}$

Biorąc jednak pod uwagę zagadnienia związane z planowaniem języ$\mathrm{ka},{ }^{15}$ muszą być brane pod uwagę procesy, a nie stan faktyczny, wyrażający się - w tym wypadku - gotowymi publikacjami. Właśnie w trakcie realizacji znajduje się kilka zakrojonych na dużą skalę projektów. Należą do nich m. in.: opracowywana przez I. Klajna i P. Pipera, pod patronatem Matice srpske i Odbora za standardizaciju, Normativna gramatika srpskog jezika oraz Prilozi gramatici srpskoga jezika. W obrębie tego ostatniego ukazały się: dwutomowa Tvorba reči u savremenom srpskom jeziku autorstwa I. Klajna oraz Sintaksa savremenoga srpskog jezika. Do tej pory została opublikowana pozycja Prosta rečenica w redakcji M. Ivić, a będąca efektem pracy zespołowej kilku autorów, pracujących pod kierunkiem P. Pipera. W przygotowaniu znajduje się ciąg dalszy, dotyczący problematyki zdania złożonego. Ponadto została już napisana i w tej chwili jest recenzowana Fonologija i Morfologi$j a$, a także trwają nieprzerwanie prace nad zagadnieniami dotyczącymi wymienionych dziedzin. Los zaś sześciotomowego słownika Matice srpske i prac nad jego innowacją zależy wyłącznie od przewidzianych na ten cel nakładów finansowych.

Pozostaje jeszcze jedna, wzbudzająca spore kontrowersje pozycja, którą jest Rečnik srpskohrvatskog književnog i narodnog jezika SANU. Chodzi oczywiście o tytuł, który w nowej sytuacji politycznej i językowej powinien ulec modyfikacji. Jednak mocą Zakona o Rečniku SANU przyjętego przez Parlament Republiki Serbii w 2005 r. jest kontynuowana realizacja projektu:

14 Z. Latinović, U stanju tihog odumiranja, NIN, broj 3068, Belgrad, 15. 10. 2009, s. 46.

${ }^{15}$ Zob. M. Radovanović, Predgovor. [w:] Najnowsze dzieje języków słowiańskich. Srpski jezik. Opole 1996, s. 6. 
Lingvistička istraživanja savremenog srpskog jezika i izrada Rečnika srpskohrvatskog književnog i narodnog jezika SANU. ${ }^{16}$ Wspomniana ustawa reguluje również pewne kompetencje. Otóż realizacją projektu zajmuje się Instytut Języka Serbskiego $S A N U$, zaś publikacją $S A N U$. Aktualnie został opracowany tekst 18 . tomu (litera $O$ ), który w gotowej już, elektronicznej wersji oddano do druku w grudniu 2008 r.

\section{Normatywistyka wobec aktualnych wyzwań}

Wszechobecna globalizacja spowodowała bardzo poważne zmiany w obrębie serbskiego standardu językowego. Przenikają do niego nie tylko angielskie słowa, często całe syntagmy, a nawet zdania. Ponadto coraz częściej język angielski bywa używany paralelnie z językiem serbskim bądź całkowicie go wypiera. Serbscy językoznawcy zdają sobie sprawę z powagi sytuacji, o czym świadczą ukazujące się systematycznie opracowania z zakresu lingwistyki normatywnej. Jednakże codzienność zdaje się wyprzedzać starania i prace naukowców.

\subsection{Porady językowe}

Częstokroć stajemy wobec słów i sformułowań wymagających dokładnego wyjaśnienia, które umożliwi nam ich zrozumienie i ewentualne stosowanie. W tej dziedzinie prym wiedzie zwłaszcza język polityków, w którym neologizmy są napotykane coraz częściej. W tym zakresie ratunkiem wydają się rubryki językowe prowadzone przez poszczególne czasopisma.

Okazuje się, że podobne problemy nie są tylko domeną przedstawicieli tzw. małych języków. Dotyczą one również użytkowników języka angielskiego. Niech przykładem będzie bijąca rekordy popularności rubryka, nazywana potocznie słownikiem politycznym, zamieszczana regularnie $\mathrm{w}$ amerykańskim dzienniku New York Times. Jej autorem był zmarly niedawno lingwista William Safire, który wprost z Białego Domu przeszedł do redakcji wspomnianej gazety. Komentując bieżące wydarzenia polityczne, niestrudzenie tłumaczył i przybliżał nierzadko kuriozalne sformułowania. Częstokroć dostarczała mu ich obecna Sekretarz Stanu Hilary Clinton. Przykładowo: objaśniał użyte przez nią słowo kanalisati - prenositi nečije misli i stavove, služiti nekome kao glasnogovornik. Również sam bywał źródłem nowych syntagm: „,senatorka Klinton je urodjena lažljivica”, nikako da kaže nešto što je istina. Gdzie indziej zaś objaśniał gradację izmedju greške, teške greške i neoprostive greške. W swym ostatnim tekście przedmiotem rozważań uczynił wyrażenie: saviti krivulju grafikona nadole - szczególnie popularną

${ }^{16}$ T. Sabo, pomoćnik ministra nauke, cyt za: Z. Latinović, U stanju tihog odumiranja, NIN, broj 3068, Belgrad, 15. 10. 2009, s. 47. 
Czy obecna serbska polityka językowa to już językowy lapot?

zarówno w prasie, jak i w świecie polityki i finansów. Imao je teoriju da reči i fraze samo prividno nestaju, zapravo odlaze i vraćaju se u recikliranom vi$d u$. Recikliranje je još jedna pomodna $i$ višeznačna reč, tipična za naše doba - što višeznačnija, to plića i nejasnija, kao implementacija, elita, operacionalizacija, prioritizacija (Zašto ne onda $i$ anonimizacija, pita se u jednom tekstu iz septembra 2006, u odeljku pod naslovom Nacija-izacija). ${ }^{17}$

Podobną rolę na gruncie serbskim odgrywa internetowy poradnik językowy Politike oraz niemal cotygodniowa, prowadzona przez prof. I. Klajna rubryka Jezik, zamieszczona w NIN-e. Wprawdzie nie dominuje w nich język polityki i polityków, ale dzięki temu, że o ich kształcie decydują sami czytelnicy, piszący do autorów obu poradników, upowszechnia się szeroko wiedza lingwistyczna. Inicjatywa to tym cenniejsza, iż częstokroć tylko tu można uzyskać kompetentną informację w pewnych kwestiach lingwistycznych, zwłaszcza jeśli nie dysponuje się dostępem do odpowiednich materiałów źródłowych. Przykładem tegoroczny problem dotyczący transkrypcji nazw pochodzących z małych i nieznanych języków: (...) naša reprezentacija je igrala na Farskim ostrvima, u gradu Torshavn, koji su naši novinari pisali manje-više kao u originalu. (...) Kako saznati bilo šta o izgovoru farskog, najmanjeg od svih germanskih jezika, izgubljenog na ostrvcima usred Atlantskog okeana, sa pedesetak hiljada govornika? Tu je, doduše, Vikipedija, iz koje možete saznati da Farani izgovaraju „Tošhaun”. Ali pravila o transkripciji moraju se zasnivati na dobrom poznavanju stranog jezika, ne na Vikipediji. ${ }^{18}$

\subsection{Jezik političke korektnosti}

A jak ustosunkować się wobec wprowadzonego przez TV pojęcia $P K$ jezika (jezika političke korektnosti)? Wiąże się ono z narastającą lawinowo ilością nowych wyrazów, będących nazwami profesji wykonywanych przez kobiety. Temu zaś towarzyszy zagadnienie równouprawnienia językowego, które znacznie komplikuje sytuację.

W społeczeństwie serbskim, a zwłaszcza w świecie językoznawczym, prawdziwą sensację wzbudziła publikacja Rod i jezik, będąca wynikiem pracy czterech autorek: S. Savić, M. Čanak, V. Mitro oraz G. Štasni. Zawarte w niej wyrazy, np.: akupunkturistkinja, ekspeditorka, etičarka, koncertistkinja, kongresmenka, meteorologinja, monitorka, nobelovka, operaterka itd. ${ }^{19}$ stały

${ }^{17}$ Global Village: Sefajerov politički rečnik, NIN, broj 3068, Belgrad, 15. 10. 2009, s. 67.

${ }^{18}$ I. Klajn, Nemuzikalni naslov, Ibidem, s. 51.

19 Z. Latinović, Antievropejke su krive za sve! NIN, broj 3059, Belgrad, 13.08. 2009, s. 44. 
się przedmiotem żartów, głównie blogerów TV B92, jakkolwiek właśnie ten kanał jest promotorem rodzajowo równoprawnego języka.

Opracowanie to zostało wydane przez Organizację Pozarządową $N V O$ Ženske studije i istraživanja (ŽSI) - Fundację Friedrich Ebert, działającą na rzecz podstawowych wartości demokracji społecznej i gospodarki rynkowej, a więc $\mathrm{w}$ zgodzie $\mathrm{z}$ zaleceniami prowadzącymi do integracji europejskiej. Trudno się dziwić, że sprzeciw nim wywołany został odebrany jako krytyka polityki i orientacji proeuropejskiej kraju. Otworzył równocześnie szeroką dyskusję na temat społecznej pozycji kobiet widzianej w szerokim socjologicznym kontekście, której najlepszym komentarzem jest następujące stwierdzenie: Dobar je svaki povod koji će među lingvistima (pocepanim, očito, na „patrijarhalne" $i$,feminističke”) iznova otvoriti raspravu o politici i gramatici, feminizmu i jeziku, diskriminaciji, mizoginiji i mizandriji u jeziku. Dobro bi bilo i da se rasprave vode u institucijama koje već brinu o standardizaciji srpskog jezika. Da li je međutim, dobro da se „izmišljanje”novih reči prepusti medijima, donatorima i nevladinim organizacijama koji brinu više o trendovima i društveno-političkoj klimi nego o prirodi srpskog jezika? ${ }^{20}$

\section{Uwagi końcowe}

Zwykle każdy kolejny rząd posiada własną wizję polityki językowej państwa. W poprzednim gabinecie V. Koštunicy, na szczeblu premiera, działała specjalnie wyznaczona grupa, której zadaniem była troska o język serbski. Niestety, zmiana władzy nie przyniosła kontynuacji tej bardzo pozytywnej rządowej inicjatywy. Problem pravopisa, gramatike, i rečnika srpskog jezika, ili opštije, pitanje jezičke politike u Srbiji, u ovom trenutku kao da se nalazi na ničijoj zemlji. ${ }^{21}$

W istocie kwestie te leżą w kompetencji trzech Ministerstw: Nauki, Kultury oraz Oświaty, które zgodnie z literą prawa uchwalonego w 1991 r. są odpowiedzialne za kształtowanie polityki językowej w Serbii. Dotychczasowa praktyka wskazywała, iż starały się one przerzucać wzajem na siebie ciążącą na nich wspólnie odpowiedzialność.

Jednak wszczęte w kraju dyskusje na temat prowadzonej w nim polityki językowej spowodowały, iż przedstawiciele poszczególnych ministerstw spotkali się we wrześniu 2009 r. w Vukovej zadužbinie z zamiarem ustalenia wspólnej strategii działania. Postanowiono, że: (...) srpski jezik treba da se nađe u prvom planu strategije delatnosti ministarstava za kulturu, prosvetu $i$ nauku i tehnološki razvoj, a u ovome treba da se priključe Ministarstvo spolj-

\footnotetext{
${ }^{20}$ Z. Latinović, Loco cit., s. 47.

${ }^{21}$ M. Graf, Jezik ničiji, bruka i nerad svačiji, (2009-10-07), http://www.blic.rs/ Kultura/98635/Jezik-niciji-bruka-i-nerad-svaciji
} 
Czy obecna serbska polityka językowa to już językowy lapot?

nih poslova i Ministarstvo za dijasporu Republike Srbije. ${ }^{22}$ Ponadto Rada Vukove zadužbinie wystąpiła $\mathrm{z}$ inicjatywa, by rok 2010 ogłosić Rokiem serbskiego jezzyka i ksiązki.

Do wspierania podjętych decyzji zostały zobowiązane wszystkie instytucje zajmujące się sprawami standaryzacji języka oraz kultury słowa, a wśród nich: Matica srpska, SANU wraz z Institutom za srpski jezik, Zavod za udžbenike, wydawnictwa oraz media. Ponadto obowiązek realizacji przyjętej strategii działania spoczął na wszystkich instytucjach realizujących programy nauczania języka serbskiego zarówno w ojczyźnie, jak i w diasporze.

Pozostaje mieć nadzieję, że podjęte bardzo radykalne kroki okażą się sprzyjające klimatowi, w jakim będzie następował dalszy rozwój języka, zaś jego użytkownicy będą świadomi znaczenia swego języka ojczystego dla serbskiej kultury.

\section{Literatura}

- Global Village: Sefajerov politički rečnik, NIN Broj 3068, Belgrad, 15.10. 2009.

- Graf, M., Jezik ničiji, bruka i nerad svačiji, (2009-10-07), http://www.blic.rs/Kultura/98635/Jezik-niciji-bruka-i-nerad-svaciji

- Kapuściński, R., Lapidaria I - III, Biblioteka Gazety Wyborczej, Warszawa 2008.

- Klajn, I., Čuvajmo srpski jezik, (2009-10-06),

- http://www.mtsmondo.com/news/world/text.php?vest=125354

- Klajn, I., Nemuzikalni naslov, NIN Broj 3068, Belgrad, 15.10. 2009.

- Latinović, Z., Antievropejke su krive za sve! NIN Broj 3059, Belgrad, 13.08. 2009.

- Latinović, Z., U stanju tihog odumiranja, NIN Broj 3068, Belgrad, 15.10. 2009.

- Miodońska, L., Język Serbów i Chorwatów w latach 1929 - 1945 (z problematyki ortoepicznej), Wyd. ATH, Bielsko-Biała 2007.

- Radovanović, M., Predgovor. [w:] Najnowsze dzieje języków stowiańskich. Srpski jezik. Opole 1996.

- Spasojević, Z., Govor i mišljenje su dar, (2009-10-07), http://www.politika.rs/rubrike/Tema-nedelje/putevi-i-stranputicesrpskog-jezika/Govor-i-mishljenje-su-dar.lt.html

${ }^{22}$ T. Sabo, pomoćnik ministra nauke, cyt za: Z. Latinović, U stanju tihog odumiranja, NIN, broj 3068, Belgrad, 15. 10. 2009, s. 46. 


\section{Lilianna MIODOŃSKA}

\section{HAS THE CURRENT SERBIAN LANGUAGE POLITICS ALREADY BECOME A LANGUAGE LAPOT?}

Under the progress of globalisation, Serbian linguists have pondered over the fate of their native language for a long time. In the present difficult economic situation, triggered by the world economic crisis, the problems of science and culture have been pushed into the background, not to mention the language politics of the country and the financial outlays that should be allotted to it.

Discussions on that topic have recently returned in Serbia, and views on this matter are divided - that's the way it goes in such situations. Nonetheless, everybody agrees on this that it is essential that the fate of the Serbian language be cared about, that the language culture be incessantly developed and tradition preserved.

Linguists are made to undertake intensive efforts within the scope of normative linguistics by being aware of very serious changes that are taking place in the Standard Serbian language. Moreover, they have launched discussions on the competences of particular national institutions that are responsible for the issues of regularising the language and language standards.

There is hope that the radical steps taken in 2009 will be favourable to the climate in which the further development of the language will take place, and that its users will be aware of the significance of their native language for the Serbian culture.

Key words: Serbian language politics, globalisation, normativisation, language planning, standardisation 
LINGUA MONTENEGRINA, god. III, br. 5, Cetinje, 2010.

Institut za crnogorski jezik i jezikoslovlje „Vojislav P. Nikčević“

UDK 811.111'27

Izvorni naučni rad

Sandra VUJOVIĆ (Nikšić)

Filozofski fakultet - Nikšić

\title{
FUNKCIJA PROZODIJSKIH ELEMENATA U TELEVIZIJSKIM EMISIJAMA RAZGOVORNOGA TIPA NA ENGLESKOM JEZIKU
}

\begin{abstract}
Rad predstavlja dio magistarske teze pod naslovom „Prozodija u televizijskim emisijama razgovornog tipa (na materijalu engleskog jezika)“. Bavi se ulogom koju prozodija ima u ostvarivanju kohezije i vezom prozodije sa leksičko-gramatičkom strukturom u okviru istoga polja.
\end{abstract}

Ključne riječi: prozodija, televizijska emisija razgovornog tipa, kohezija, mentalna slika

Ovim radom pokušaćemo dati doprinos rasvjetljavanju odnosa između prozodije i njenih elemenata, s jedne, i kohezije, sa druge strane. Prije nego pređemo na razmatranje tog odnosa, smatramo važnim iznijeti nekoliko uvodnih napomena o korpusu, teorijskom pristupu koji se u radu koristi i sredstvu instrumentalne analize.

Materijal na kom se proučava prozodija u ovom radu uzet je iz američke televizijske emisije razgovornog tipa The Oprah Winfrey Talk Show. Sakupljeno je nešto više od deset sati intervjua. Primjeri se nalaze na šest diskova koji su objavljeni povodom obilježavanja 20 godina rada voditeljke (The Oprah Winfrey Show: $20^{\text {th }}$ Anniversary Collection).

Analiza navednih primjera i njihovih intonacionih obilježja zasniva se na modelu Janet Pierrehumbert (autosegmentalna - metrička fonologija). Pod autosegmentalnom - metričkom fonologijom podrazumijevamo teorijski pristup u čijoj je osnovi intonaciona fraza sa sljedećim elementima: tonskim akcentom (povezan sa prominentnim leksičkim jedinicama, tj. sa onim jedinicama za koje govornik smatra da su relevantne u informacijskoj strukturi diskursa), fraznim tonom (ukazuje na stepen povezanosti dviju međufraza) i graničnim tonom (ukazuje na stepen zavisnosti dviju intonacionih fraza). Kao dopunu ovom pristupu koristićemo i modifikovani model Pierrehumber- 
tove koji primjenjuje Ann Wennerstrom. U ovom modelu bitnu ulogu igraju početni ton (govornikov izbor visine na početku jednog iskaza koji ukazuje na njegov/njen stav ili odnos prema prethodnom iskazu) i govorni paragraf (karakteriše organizacioni nivo diskursa i ukazuje na promjenu teme u govorenom diskursu). Ovđe ćemo iznijeti kratak opis i značenje intonacionih elemenata korišćenih u radu:

$\mathrm{H}^{*}$ - visoki tonski akcenat (ukazuje na novu informaciju u tekstu);

$\mathrm{L}^{*}$ - niski tonski akcenat (ukazuje na staru, poznatu informaciju u tekstu);

$\mathrm{L}+\mathrm{H}^{*}$ - uzlazni visoki tonski akcenat (ukazuje na kontrast između dvije jedinice u tekstu);

$\uparrow$ - visokouzlazni krajnji ton (ukazuje da je red na drugog govornika u komunikaciji);

$\nearrow$ - niskouzlazni krajnji ton (ukazuje na nastavak reda govorenja govornika radi upotpunjavanja iskaza);

$\rightarrow$ - ravni krajnji ton (isti govornik nastavlja svoj red - nabrajanje, oklijevanje);

$\searrow$-djelimično silazni krajnji ton (ukazuje na visok stepen zavisnosti između fraze na čijem se kraju nalazi i naredne, i to obično unutar iskaza jednog istog govornika);

$\downarrow$ - niski krajnji ton (ukazuje na kraj niza međuzavisnih konstituenata u iskazu);

$\Uparrow$ - visoki govorni paragraf (ukazuje na novu organizacionu jedinicu u tekstu);

$\Downarrow$ - niski govorni paragraf (ukazuje na jedinice koje su umetnute ili sporedne u diskursu);

$\Gamma-$ visoki početni ton iskaza (ukazuje na kontrast u stavu s obzirom na prethodni iskaz);

$\hookrightarrow$ - niski početni ton iskaza (ukazuje na početak iskaza koji ne pruža ništa novo, već predstavlja drugačiju formulaciju nečega što je poznato i jasno);

VELIKA SLOVA visoki tonski akcenat $\left(\mathrm{H}^{*}\right)$;

VELIKA SLOVA

niski tonski akcenat $\left(\mathrm{L}^{*}\right)$;

PODVUČENA VELIKA SLOVA uzlazni visoki tonski akcenat $\left(\mathrm{L}+\mathrm{H}^{*}\right)$.

Od paralingvističkih elemenata navešćemo sljedeće:

((laughs))

(xxx)

Ho:::w

speech

speech

$>>$

$<<$

134 informacija o vrsti interakcije dio koji se ne može transkribovati produžen izgovor sloga

preklapanje u govoru

ubrzani tempo govora

usporeni tempo govora 
Funkcija prozodijskih elemenata u televizijskim emisijama razgovornoga tipa...

Na kraju da pomenemo da će intonacione konture u radu biti analizirane instrumentalno. Za potrebe takve analize koristićemo kompjuterski program za analizu, sintezu i manipulaciju govora - Praat.

\section{Prozodija, kohezija, mentalna slika}

Kohezija je važna komponenta diskursa koja predstavlja ,,jedinstvo delova nekog teksta“" (Savić, 1993: 31). Halliday i Hasan u djelu Cohesion in English definišu ovaj pojam na sljedeći način:

„Kohezija je semantička veza između jednog elementa u tekstu i nekog drugog elementa koji je važan za interpretaciju prvog. Ovaj drugi elemenat nalazi se u tekstu, ali njegovo mjesto nije određeno gramatičkom strukturom.“ (1976: 9)

Povezivanje lingvističkih jedinica tako da data cjelina ima smisla ostvaruje se leksičkim i gramatičkim sredstvima. Međutim, veza se ostvaruje i drugim lingvističkim elementima, npr. prozodijskim. Zajedničkim djelovanjem leksičko-gramatičkog i prozodijskog nivoa (u okviru kog se najviše ističe intonacija) postiže se kohezivni odnos, a pretpostavlja se da u nekim situacijama prozodija može pružiti mnogo više od same leksičko-gramatičke strukture.

Definisanje kohezije zahtijeva osvrtanje na mentalnu sliku. Wennerstrom navodi da je riječ o ,sistemu kratkoročne memorije, izgrađenom za potrebe komunikacije, koji je u interakciji sa drugim kognitivnim sistemima, kao što su percepcija i dugoročna memorija“" (2001: 70). Upravo je mentalna slika važna za interpretaciju svakog novog iskaza jer sagovornici vode računa o već izgovorenom dijelu, podrazumijevanom znanju, zajedničkom iskustvu, odgovoru slušalaca u vezi sa govornikovim izlaganjem (da li su razumjeli ili im je potrebno dalje objašnjenje). Tako učesnici u konverzaciji mogu definisati određenu jedinicu kao „novu“, a zatim je uključiti u mentalnu sliku na kohezivan način. Ili je, pak, definišu kao nešto što pripada tzv. podrazumijevanom znanju. Formiranje mentalne slike zavisi od leksičko-gramatičke strukture, ali i od drugih elemenata.

Kako su kohezija i mentalna slika sistemi koji karakterišu diskurs i tipove diskursa te koji omogućavaju njegovu interpretaciju, pitanje je da li i kako prozodija doprinosi ostvarivanju kohezije diskursa; da li prozodija na tom putu djeluje samostalno ili se udružuje sa drugim lingvističkim elementima; koja je uloga prozodije u formiranju mentalne slike u procesu komunikacije; koji elementi prozodije posebno pomažu koheziju razgovora.

\section{Počećemo od primjera 1.}

1 Oprah: $\Uparrow$ Let's GET to the SPECIFICS, вов \

2 What's FIRST STEP in The BEST LIFE DIET PLAN $\downarrow$ 
Sandra VUJOVIĆ

3 Bob: Well the FIRST thing you REALLY wanna do $>$ um (0.39)

4 I BELIEVE in GRADUALLY MAKING CHANGES $>$ The WORST thing

5 you can do is $\searrow$ DRASTICALLY CUT CALORIES $\rightarrow$

6 we KNOW THAT doesn't work $\nearrow$

7 Oprah: Yeah

8 Bob: Your body

9 Oprah: $\Downarrow_{\text {IT }}$ makes you MISERABLE $\searrow$ and then you $\searrow(0.2)$

$10 \quad \overline{L I} E$ to YOURSELF $\downarrow$

11 Bob: $\Uparrow$ So the FIRST PHASE of MY PROGRAM I want you

12 EATING BREAKFAST $\downarrow$ (1.15)

13 FIRST PHASE is ALL about REVVING up your METABOLISM $\rightarrow$

14 INCREASING your EXERCISE $\rightarrow(0.4)$ BREAKFAST INCREASES

15 your METABOLISM $\rightarrow$ and causes you to $>$

16 eat ON AVERAGE \ a HUNDRED calories LESS per day

17 PEOPLE WHO EAT BREAKFAST So it's VERY important $>$

18 It NEEDS to BE a HEALTHY BREAKFAST $\boldsymbol{\nearrow}(0.78)$

19 The REST of your day $\nearrow$ you can STRAY in the FIRST PHASE $\rightarrow$ but EAT a

20 HEALTHY BREAKFAST $\downarrow$

21 Oprah: $\Uparrow$ So let's LOOK at what do you call HEALTHY $\downarrow$

Navedeni primjer dio je razgovora u kom voditeljka talk show-a (Oprah Winfrey) promoviše novu knjigu svog gosta (Bob Greene), The Best Life Diet Plan. Oni razgovaraju o novoj dijeti i o novom planu detaljno opisanom u knjizi, kog bi se trebalo pridržavati kako bismo održali dobru formu, izbjegli gomilanje viška kilograma i vodili zdrav život. Na osnovu tonskih akcenata i drugih tonova možemo viđeti na koji se način povezuju ideje u ovom razgovoru i kako se postiže jedinstvo među jedinicama.

a) U drugom redu Opra pominje Grinovu knjigu, a tonski akcenat koji karakteriše njen izgovor je L* (BEST LIFE DIET PLAN). Na osnovu prisustva $\mathrm{L}^{*}$ akcenta (koji ukazuje na već poznatu ili „staru“ informaciju) zaključuje se da voditeljka pretpostavlja da je taj naslov svima dobro poznat, tj. da je on već uključen u mentalnu sliku gledalaca i slušalaca, pa nema potrebe naglašavati ga.

b) U redovima 11, 13 i 19 javlja se ista sintagma - first phase. Međutim, razlika je primjetna jer prvi izgovor obilježava visoki ton $\left(\mathrm{H}^{*}\right)$, a izgovor po drugi i treći put niski ton $\left(\mathrm{L}^{*}\right)$. $\mathrm{H}^{*}$ akcenat u redu 11 pokazuje da govornik smatra važnim istaći sintagmu koja predstavlja polaznu tačku njegova plana. Budući da je izgovara prvi put i da o njoj želi dalje govoriti, neophodno ju je uključiti u mentalnu sliku svih prisutnih. 
Funkcija prozodijskih elemenata u televizijskim emisijama razgovornoga tipa...

Posmatrajući sintagmu kao novu informaciju, govornik je uvodi u proces razgovora pomoću $\mathrm{H}^{*}$ akcenta. U redovima 13 i 19 ista fraza izgovorena je $\mathrm{L}^{*}$ akcentom. Govornik sada procjenjuje da je to stari podatak, usvojen od strane publike, i da nema potrebe posebno ga isticati.

c) Sličnu situaciju imamo u redovima 12, 14, 17, 18 i 20. Govornik u 12. redu pruža novu informaciju koja čini osnovu prve faze njegova plana, a to je eating breakfast, i zbog toga imamo $\mathrm{H}^{*}$ akcenat (sl. 1). Duga pauza $(1,15$ sek.) takođe ukazuje na značaj upravo pomenute sintagme. Čini se da govornik daje vremena publici da ideju uvrsti u mentalnu sliku, pa nakon toga nastavlja o temi. U 14. redu akcenat je i dalje isti, pošto govornik daje još jedan podatak: razlog - zbog čega je doručak tako važan.

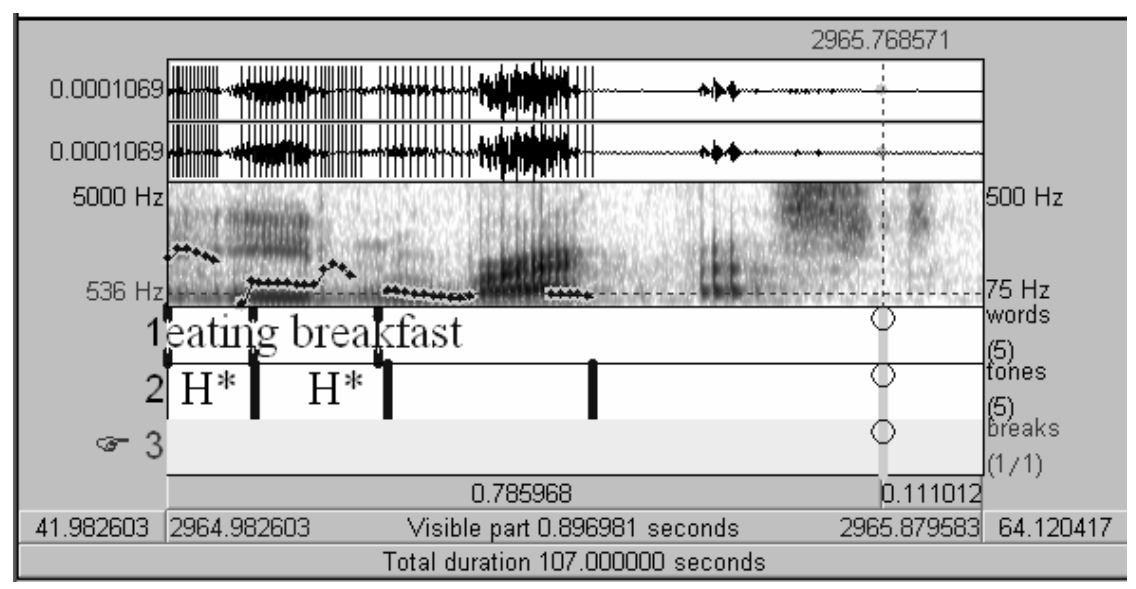

Slika 1

$\mathrm{U}$ 17. redu akcenat se mijenja: sa $\mathrm{H}^{*}$ prelazi se na $\mathrm{L}^{*}$ akcenat (people who eat breakfast) jer govornik pretpostavlja da je publika usvojila taj podatak i shvatila njegov značaj (sl. 2). Na slikama 1 i 2 jasno se može viđeti razlika u osnovnoj frekvenciji glasa $(\mathrm{Fo})$ prilikom izgovora riječi breakfast: u prvom slučaju Fo iznosi $219.6 \mathrm{~Hz}$, a u drugom svega 102 Hz. Naravno, L* akcenat u 18. i u 20. redu (breakfast) očekivan je. 


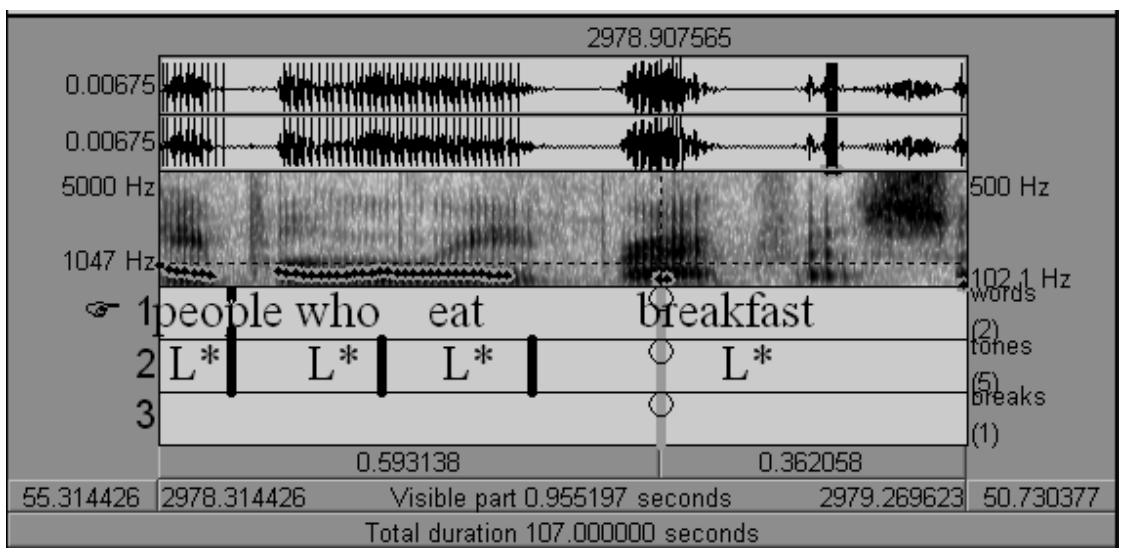

Slika 2

d) $\mathrm{U}$ redovima 4 i 5 govornik objašnjava razliku između postepene i drastične promjene $u$ procesu ishrane i kaže da je najgora stvar za jedan organizam ,drastično smanjenje unosa kalorija“. Tu frazu karakteriše $\mathrm{H}^{*}$ akcenat. $\mathrm{U} 6$. redu on, umjesto ponavljanja cijele fraze, koristi poseban stepen referencijalnosti (pronominalni) i upotrebljava zamjenicu that koja nosi $\mathrm{L}^{*}$ akcenat. Voditeljka prekida njegovo izlaganje (7. red) s ciljem da izrazi slaganje sa njegovom izjavom i upotpuni sliku. Međutim, ona tim iskazom ne dodaje ništa novo, već samo umeće opštepoznatu ideju i time se malo udaljava od teme. Dokaz za to je niski govorni paragraf $(\downarrow)$ na početku njena iskaza. Ona, takođe, ne ponavlja cijelu frazu, ali za razliku od Grina, koristi ličnu zamjenicu it, sa L* akcentom. Kraj njezina iskaza obilježava niski ton $(\downarrow)$ koji predstavlja nezavisnost tog iskaza prema sljedećem. Kako se ne bi narušila kohezija, Grin ne komentariše Oprinu izjavu, već se vraća prvobitnoj temi, što pokazuje i visoki govorni paragraf na početku njegova izlaganja (11. red).

e) Na kraju ovog izvoda (red 21) Opra započinje novu organizacionu jedinicu. Nakon niskog graničnog tona $(\downarrow)$ na kraju reda 20, koji ukazuje na Grinovu pretpostavku da je odgovorio na Oprino pitanje (2. red), tj. opisao prvu fazu i ukazao na važnost doručka, Opra postavlja naredno pitanje, koje se tiče definisanja zdravog doručka. Taj prijelaz označen je visokim govornim paragrafom na početku Oprina reda (red 21). Na ovaj način zaokružuje se jedna diskursna cjelina i počinje druga.

Pored $\mathrm{H}^{*}$ i L* akcenata, koji ukazuju na međusobnu povezanost ideja u diskursu, kao i na jedinice koje treba uključiti ili koje su već uključene u mentalnu sliku, važan je kohezivni element i $\mathrm{L}+\mathrm{H}^{*}$ akcenat. Riječ je o ton- 
Funkcija prozodijskih elemenata u televizijskim emisijama razgovornoga tipa...

skom akcentu kojim pravimo kontrast između dvaju iskaza ili dvije jedinice u diskursu, odnosno između iskaza govornika i onoga što slušalac pretpostavlja da će govornik reći. Pomoću kontrasta govornik želi da isključi sve pretpostavke slušalaca u vezi s aktuelnom temom i tako utiče na modifikovanje njihove mentalne slike. Modifikacija podrazumijeva uključivanje novih ideja koje govornik izlaže. Kako ovaj akcenat funkcioniše, pokazaćemo na narednom primjeru. Primjer 2 predstavlja dio razgovora između Opre Vinfri i slavnog glumca Džonija Depa (Johnny Depp). Voditeljka želi saznati kakav je ośećaj biti jedan od najpoželjnijih muškaraca na svijetu i pokazuje publici veliki broj magazina na čijoj se naslovnoj strani nalaze fotografije ovoga glumca.

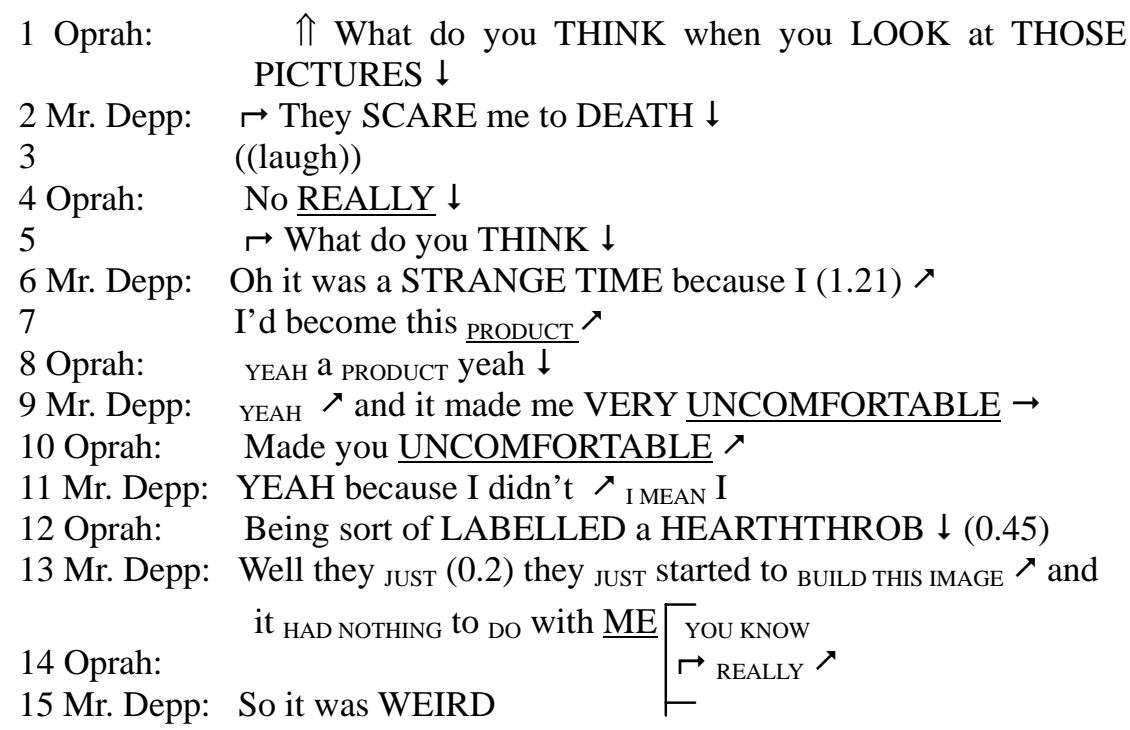

Na samom početku izvoda Džoni Dep kaže da ga plaši činjenica da je na naslovnim stranama gotovo svih časopisa i da mu sve to uopšte ne prija. On je siguran da publika, pa i sama voditeljka, misle suprotno, što pokazuje visoki početni ton $(\mapsto)$ u 2 . redu, a koji služi za iskazivanje drugačijeg stava. Upravo takvim tonom, glumac pokušava da ih uvjeri u suprotno. Informaciju da li je publika prihvatila taj odgovor dobijamo odmah: smijeh koji traje gotovo 2 sekunde. Naravno, ni voditeljka ga ne prihvata. $\mathrm{L}+\mathrm{H}^{*}$ akcenat na riječi really u 4. redu pokazuje kotrast između Oprina poimanja cijele situacije i Depova odgovora, a niski granični ton $(\downarrow)$ ukazuje na kraj takvog toka razgovora i želju voditeljke da od glumca čuje drugi odgovor. Ova dva prozodijska elementa u 4. redu kao da saopštavaju: „Ok, dosta je bilo šale. Naravno, svi znamo da je to bila šala! Hajde sada da govorimo ozbiljno!“ Stoga Opra ponavlja pitanje u 5. redu, na čijem je početku visoki ton $(\sqcap)($ sl. 3). 


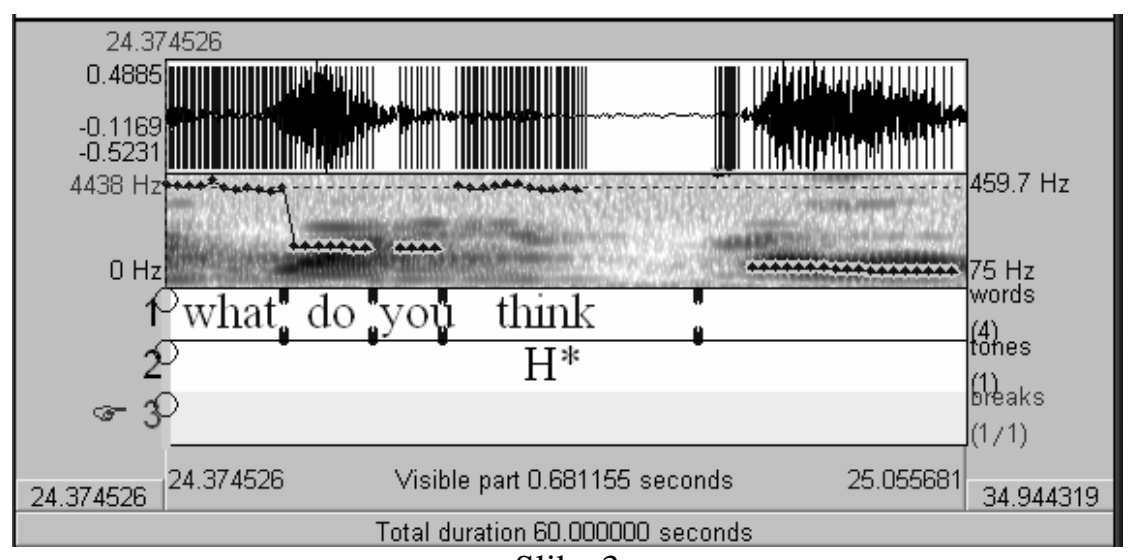

Slika 3

I taj je ton još jedan dokaz da Opra nije povjerovala u Depov odgovor i traži od njega drugačiji. Međutim, Džoni Dep nastavlja na isti način pokušavajući da izgradi valjani argument i ubijedi sve u studiju u tačnost njegove izjave. On naglašava da je sve to samo jedan ,proizvod“ iza kog stoji cijeli tim i da taj ,proizvod“ nema nikakve veze sa njim, čak sve to čini da se ośeća neprijatno. Objašnjavajući taj ośećaj, Dep izgovara riječ uncomfortable sa $\mathrm{L}+\mathrm{H}^{*}$ akcentom i na taj način svoj stav suprotstavlja ideji, koju je gotovo nemoguće zamijeniti drugom, u mentalnoj slici publike (sl. 4).

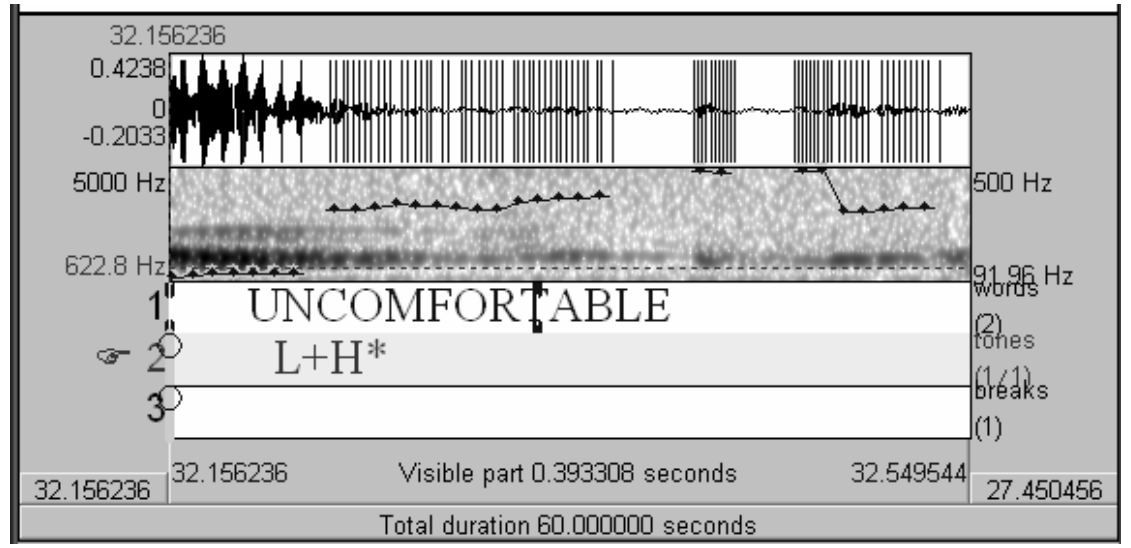

Slika 4

U 10. redu Opra ponavlja njegovu izjavu, a niskouzlazni granični ton na kraju pokazuje da voditeljka željno iščekuje nastavak objašnjenja. Kako bi upotpunio svoj odgovor i konačno svima djelovao uvjerljivo, Dep pravi razli- 
Funkcija prozodijskih elemenata u televizijskim emisijama razgovornoga tipa...

ku između slike koju stvaraju mediji i sebe kao individue, naglašavajući da nema ništa zajedničko sa takvom slikom. Kontrastiranje je očigledno, na što ukazuje i L+H* akcenat na riječi me (sl. 5). Zahvaljujući pomenutom akcentu, Dep pokazuje da je on čovjek kao i bilo ko u publici, a ne neka ,tvorevina" za kojom uzdiše ženska populacija. Da li je uspio ubijediti publiku ili ne, pitanje je na koje nije lako dati odgovor. Ali jedno je sigurno: to je pokušao konstantno suprotstavljajući svoje stavove pretpostavkama i idejama nepokolebljive publike i voditeljke i ukazujući na veliki jaz između onoga što je realnost i onoga što drugi stvaraju i nameću kao istinu.

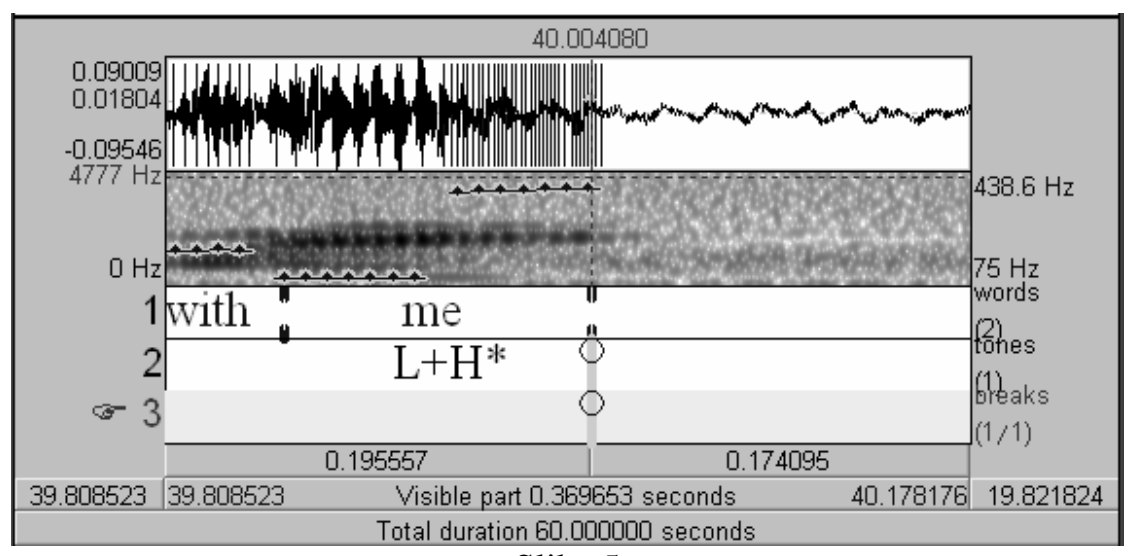

Slika 5

Koliki je značaj ovog akcenta, pokazuje još jedna činjenica. Već smo viđeli značenje riječi really koju izgovara voditeljka u 4. redu. Ako bi riječ bila izgovorena na drugi način njeno značenje bi se svakako promijenilo. Ova reakcija na Depovu izjavu mogla bi se tumačiti kao pravo iznenađenje, nevjerica i kao nešto potpuno neočekivano, zatim kao ironija, kao nezainteresovanost itd. Međutim, u svim tim slučajevima glavnu ulogu odigrao bi tonski akcenat, tj. pomoću određenog tonskog akcenta lako bismo odredili značenje riječi u kontekstu, a samim tim i njenu gramatičku funkciju. Tako, na primjer, $\mathrm{H}^{*}$ akcenat na really i visokouzlazni granični ton $(\uparrow)$ ukazali bi na to da je Opra iznenađena i da takav odgovor nije očekivala, a zatim i to da voditeljka očekuje pojašnjenje. Takva kombinacija prozodijskih jedinica svakako ne bi značila odbacivanje prvog odgovora glumca.

Svi navedeni primjeri pokazuju kako prozodija pomaže u interpretaciji datog diskursa. Naravno, i leksičko-gramatička struktura u tom je smislu relevantna, ali nekada se dešava da taj nivo, kao u prethodnom primjeru, ne može funkcionisati samostalno i da se mora udružiti sa prozodijskim nivoom. Ovo potvrđuju i veznici (and, or, but), koji su neizostavne leksičke jedinice u 
talk show-u, a koje Halliday i Hasan (1976) definišu kao posebnu kategoriju čija je osnovna uloga obezbjeđivanje kohezije, tj. povezivanje konstituenata u iskazu i utvrđivanje semantičkog odnosa među njima. Da veznici ne mogu djelovati samostalno i da su nekada prozodijski elementi od važnosti za njihovo tumačenje, pokazuje primjer 3 .

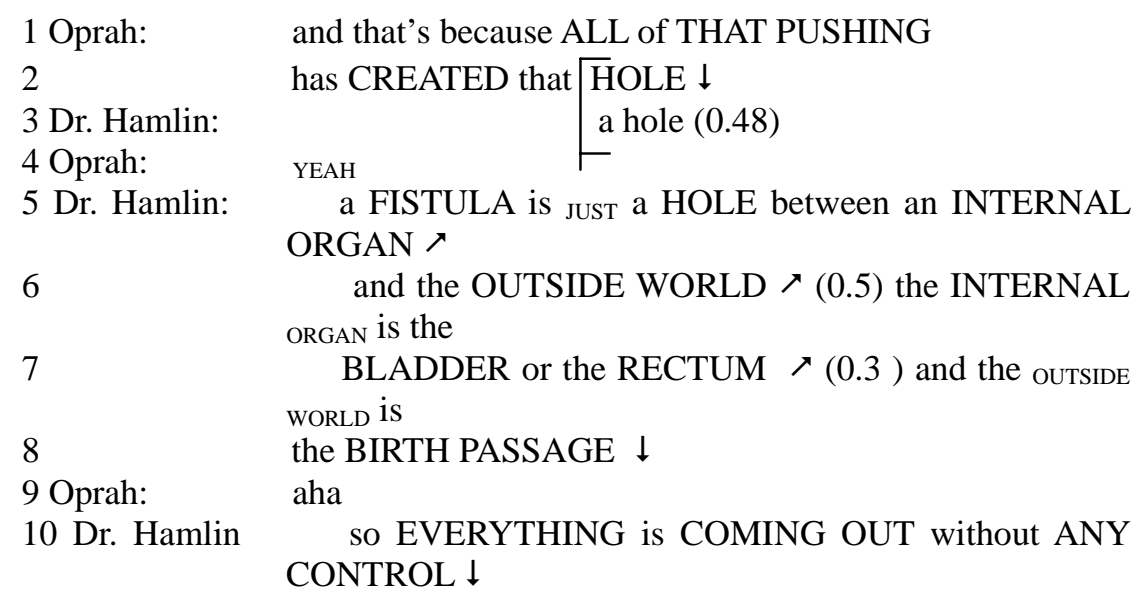

Opra Vinfri i doktorka Ketrin Hamlin razgovaraju o teškom položaju žena u Etiopiji, o njihovoj ranoj udaji, trudnoći, problemima koji se javljaju, kao i o njihovoj odbačenosti od strane porodice, muža i čitavog društva nakon svih pretrpljenih nevolja. Dr Hamlin provela je 50 godina u takvoj sredini radeći kao ginekolog i pokušavajući da na neki način pomogne svim ženama. U ovom izvodu doktorka govori o najvećem problemu žena u Etiopiji, a to su fistule. Sve žene udaju se još dok su đevojčice (9-12 godina) i ubrzo ostanu u drugom stanju. Zbog veoma dugog, iscrpljujućeg porođaja i nedostatka stručne pomoći, kao i zbog nerazvijenog organizma, kod njih se javljaju fistule. Primjećujemo da doktorka koristi veznike and i or kako bi objasnila samu riječ i ukazala na kontrast između: a) unutrašnjeg organa i spoljašnjeg svijeta i b) bešike i rektuma. Svrha kontrasta jeste ukazati na veliki problem sa kojim se žene suočavaju nakon stvaranja te „šupljine“. U vezi sa funkcijom pomenutih veznika postavlja se pitanje: da li i na koji način djeluju prozodijski elementi i veznici da bi se postigla kohezija i da li prozodija doprinosi tačnijoj interpretaciji značenja veznika?

U pokušaju da odgovorimo na ovo pitanje osvrnućemo se na primjer 3, i to posebno na redove 5-8.

Veznik and javlja se u 6. i 7. redu, i u oba slučaja ukazuje na „rupu“ koja odvaja unutrašnji organ od spoljašnjeg svijeta. Veznik or javlja se samo u 7. redu, da pokaže o kojim unutrašnjim organima je riječ. Wennerstrom (2001) naglašava da, pogledamo li da li i koje intonacione morfeme okružuju 
Funkcija prozodijskih elemenata u televizijskim emisijama razgovornoga tipa...

veznike u nekom kontekstu, dolazimo do njihova polja djelovanja. Konkretno u ovom primjeru, vidimo niskouzlazni krajnji ton $(\nearrow)$ ispred veznika and u oba slučaja (sl. 6), te pauzu ispred drugog and. Ton ukazuje da postoje dvje intonacione fraze, tj. kraj jedne i početak druge, i to od istog govornika, koji zapravo upotpunjuje svoj iskaz.

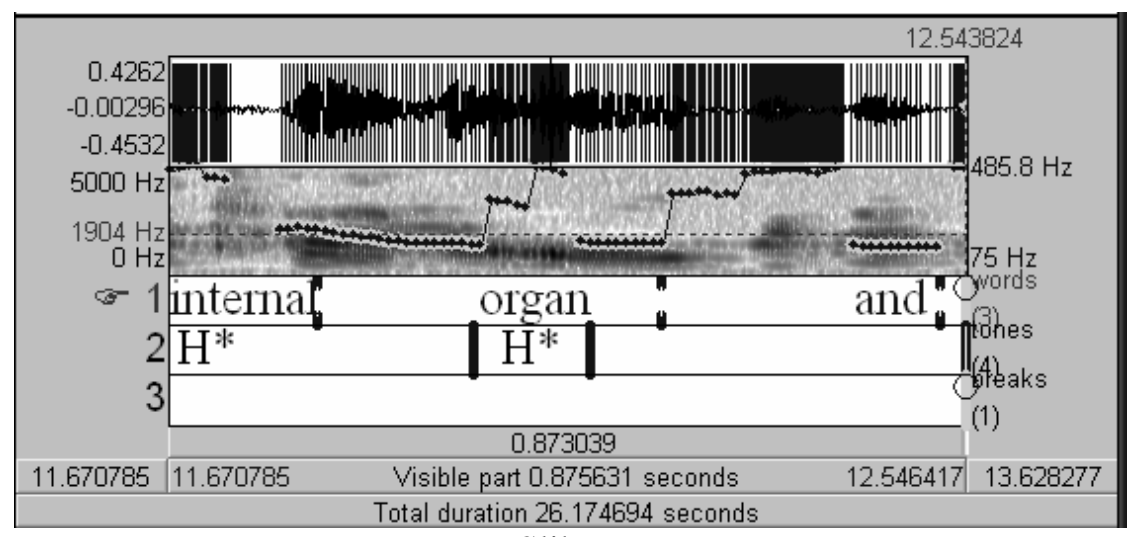

Slika 6

Nasuprot ovome, u slučaju veznika or nemamo ni krajnji ton niti pauzu (sl. 7). Upravo ovi podaci govore da je polje djelovanja dvaju veznika u ovom kontekstu različito. Or djeluje na nižem nivou povezujući dvije leksičke jedinice u okviru iste intonacione fraze. And djeluje na višem nivou jer ukazuje na dvije odvojene intonacione fraze, ali opet međusobno povezane (pokazatelj je niskouzlazni ton).

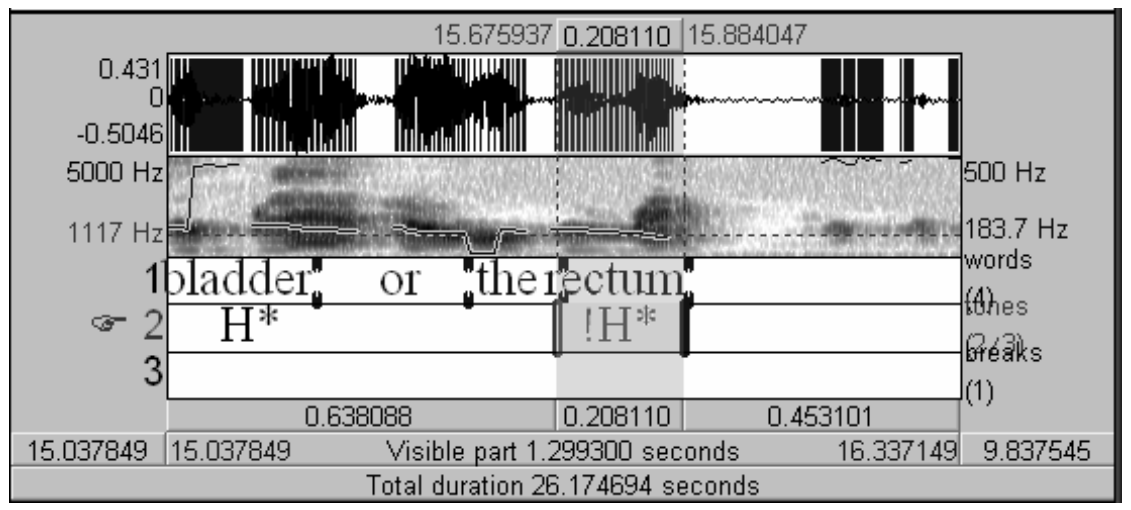

Slika 7 
Naravno, i veznik or može povezivati dvije odvojene, a opet međusobno povezane intonacione fraze, baš kao i and. Primjer 4 to pokazuje.

1 Dr. Hamlin: the TWO GREAT CAUSES of OBSTRUCTED LABOR

2 are SMALL PELVIS $\nearrow(0.2)$ or a MALPOSITION

3 of the BABY inside the MOTHER'S UTERUS $\downarrow$

4 in ETHIOPIA she can't GET any HELP \(0.3) she's got NOBODY

$5 \quad$ in the VILLAGE $\rightarrow(0.41)$ NO ANTI-NATAL CARE $\rightarrow(0.54)$

$6 \quad$ NO MIDWIFE to HELP her $\downarrow(0.55)$

U 2. redu doktorka koristi veznik or kako bi povezala dva glavna uzroka teškog porođaja. Za razliku od njegove upotrebe u primjeru 3, ovđe vidimo da veznik ne djeluje u okviru jedne intonacione fraze, već ukazuje na dvije različite fraze, budući da mu prethodi niskouzlazni ton i pauza.

Svi navedeni primjeri pokazuju da u govorenom jeziku leksičko-gramatička struktura ne može funkcionisati samostalno kako bi se ostvarilo jedinstvo elemenata diskursa i održala tema razgovora. Zaključuje se da prozodija u tom procesu igra važnu ulogu: njeni elementi utiču na organizaciju razgovora u ovim emisijama, pokazuju razliku između ,stare“ i ,nove“ informacije, suprotstavljaju različite ideje sagovornika i tako obavljaju diskursnu funkciju. Isto tako viđeli smo da prozodija ističe pojedine informacije i samim tim ukazuje na veliki stepen prominentnosti jedinica u diskursu. U tom smislu prozodija obavlja akcenatsku ulogu.

\section{Literatura}

- Brown, G., K.L. Currie and J. Kenworthy (1980), Questions of Intonation, London: Croom Helm

- Brown, G. and G. Yule (1983), Discourse Analysis, Cambridge: Cambridge University Press

- Chun, D. M. (2002), Discourse Intonation in L2: From Theory and Research to Practice, Amsterdam/Philadelphia: John Benjamins Publishing Company

- Couper-Kuhlen, E. (1986), An Introduction to English Prosody, London: Edward Arnold Ltd

- Couper-Kuhlen, E. (2003), "Intonation and Discourse: Current Views from Within“, in: The Handbook of Discourse Analysis, Schiffrin, D., D. Tannen and H.E. Hamilton (eds.), Blackwell Publishing 
Funkcija prozodijskih elemenata u televizijskim emisijama razgovornoga tipa...

- Cruttenden, A. (1997), Intonation, $2^{\text {nd }}$ edition, New York: Cambridge University Press

- Fox, A. (2000), Prosodic Features and Prosodic Structure. The Phonology of Suprasemnetals, New York: Oxford University Press

- Halliday, M.A.K. and R. Hassan (1976), Cohesion in English, London: Longman

- Hirschberg, J. and G. Ward (1995), "The interpretation of the highrise question contour in English", Journal of Pragmatics 24, 407412

- Liberman, M. (1975), The Intonation System of English, Ph.D. Dissertation, Massachusetts Institute of Technology. Reproduced by the University of Indiana Linguistics Club, Bloomington

- Pierrehumbert, J. (1980), The phonology and phonetics of English intonation, Ph.D. Dissertation, MIT

- Pierrehumbert, J. and J. Hirschberg (1990), "The meaning of intonational contours in the interpretation of discourse“", in: Intentions in Communication, Cohen, P.R., J. Morgan and M. Pollack (eds.), Cambridge: MIT Press, 271-311

- Roach, P. (2000), English Phonetics and Phonology: A Practical Course, $3^{\text {rd }}$ Edition, Cambridge: Cambridge University Press

- Savić, S. (1993), Diskurs analiza, Univerzitet u Novom Sadu, Filozofski fakultet

- Wells, J. C. (2006), English Intonation, Cambridge: Cambridge University Press

- Wennerstrom, A. (2001), The Music of Everyday Speech: Prosody and Discourse Analysis, New York: Oxford University Press

\section{Sandra VUJOVIĆ}

\section{THE FUNCTIONS OF PROSODIC ELEMENTS IN TV TALK SHOWS IN ENGLISH}

This paper is a part of the MA thesis "Prosody in TV Talk Shows (analysed material is in English)". It explores the role of prosody in achieving the cohesion of a text, as well as the connection of prosody with the lexicogrammatical structure within the same field.

Key words: prosody, talk show, cohesion, mental representation 

LINGUA MONTENEGRINA, god. III, br. 5, Cetinje, 2010.

Institut za crnogorski jezik i jezikoslovlje „Vojislav P. Nikčević“

UDK $811.111^{\prime} 243$

$811.134 .2 ' 243$

Pregledni rad

\author{
Ireneusz KIDA (Bielsko-Biala) \\ The University of Silesia in Katowice \\ The University of Bielsko-Biała
}

\title{
METALANGUAGE IN ENGLISH AND SPANISH CLASSROOM INSTRUCTION - HOW MUCH OF TRANSPARENCY?
}

Razlike u terminologiji u gramatičkome sistemu engleskoga i španskoga jezika često uzrokuju probleme onima koji ta dva jezika - španski i engleski - uče simultano. Standardna nomenklatura korišćena u gramatikama ta dva jezika ponekad (reklo bi se) traži različite pojmove da bi prikazala slične, često identične gramatičke pojave. Dovoljno je, na primjer, baciti pogled na sistem vremena u dvama jezicima. U standardnoj engleskoj gramatici nazivom ,present perfect" imenovano je gramatičko vrijeme koje se, među ostalim funkcijama, koristi za akcije koje su nedavno okončane i čiji je rezultat vidan do trenutka govorenja. U španskome, s druge strane, gramatičko vrijeme koje se koristi za slične akcije naziva se ,pretérito perfecto" (preterit perfekta ili perfekat prošli). Još jedan problem predstavlja upotreba tzv. „gerunda”. Premda termini ,gerund” i ,gerundio" postoje i u engleskome i u španskom, oni predstavljaju dvije različite stvari: dok se u engleskome pod terminom ,gerund” podrazumijeva element imeničkoga tipa koji se ponaša kao imenica (npr. to može biti i rečenični subjekat), u španskome je „gerundio” glagolski elemenat koji čini sastavni dio složenih trajnih vremena i zapravo je ekvivalentan engleskome participu prezenta. Problem nastaje i usljed zastarjele podjele na prosta i složena vremena. $\mathrm{Na}$ primjer, engleski ,simple present” je prosto vrijeme samo u potvrdnim rečenicama, dok u većini upitnih i odričnih rečenica postaje složeno vrijeme. U španskome, pak, taj problem ne postoji. Stoga je cilj našega rada da pokažemo kako se baviti pomenutim problemima, kako učiniti predavanje jezika u učionicama transparentnijim i zabavnijim i, konačno, kako upravljati učenjem učenika.

Ključne riječi: metajezik, gerund/gerundio, prezent, preterit, prosta vremena, složena vremena 


\section{Introduction}

We are living in times when more and more people decide to learn a foreign language, or even two or more foreign languages at the same time. While doing so, a number of difficulties may arise. The difficulties do not only concern the process of language learning/acquisition, like for example problems connected with negative transfer, but they very often have to do with the terminology that is used in the discription of the linguistic system in grammar books or in classroom instruction. Since it is often the case that the native language grammar terminology in some areas does not match the linguistic terminology used in a target language, or the terminology of target language 1 does not match the terminology employed to describe target language 2 or 3 or more, the learning/acquisition process can be obscured and thus the life of the student/teacher can be made more difficult. It is such differences between English and Spanish that will be of our concern in this paper. We will concentrate upon three problem areas that we think important in drawing attention to in the process of teaching/learning of English and Spanish. They are: the gerund, the present perfect tense and simple/complex tenses. The aim of our discussion is not only to facilitate the students' learning process and solve their problems but also to make one aware that language is changing all the time and that perhaps it would be a good idea to keep the terminology used to describe grammatical systems up to date.

\subsection{Gerundium vs. gerundivum}

Before we turn into discussing the English and Spanish gerundival forms, let us first have a look at their etymology. In Latin there are two related verbal forms that sometimes cause confusion in students of this language. The forms that we have in mind are gerundium (gerund) and gerundivum (gerundival). Although they are related, and in many cases can be used interchangeably, there are some points of formal difference between the two verbal particles. Let us start with gerundium. As Jurewicz et al. 1998 state, the Latin gerundium is a verbal neuter noun and it expresses a general activity or an activity that is not yet finished. It is formed on the basis of the simple present tence base form and the feature $-(e) n d$ - plus the case endings of the second declension (only in the singular). Let us take the verb laudare 'to praise' to see how gerundium declines in its declension paradigme: 
Metalanguage In English And Spanish Classroom Instruction...

\begin{tabular}{|l|l|l|}
\hline & Latin example & English translation \\
\hline N. & Lauda-re & Praising \\
\hline G. & Lauda- $n d-i$ & Of praising \\
\hline D. & Lauda- $n d-o$ & For praising \\
\hline Acc. & Ad lauda- $n d-u m$ & With the aim of praising \\
\hline Abl. & Lauda- $n d-o$ & By means of praising \\
\hline
\end{tabular}

It needs to me mentioned that gerundium has not got any form in the nominative case. However, the empty space has been filled with the infinitive form that is translated as a verbal noun in the nominative case. To give an example, let us take a well-known saying: Errare humanum est - 'to err is human' (or literally 'erring is human'). The other cases can also be exemplified as is shown in the table below:

\begin{tabular}{|l|l|l|}
\hline & Latin example & English translation \\
\hline N. & Errare humanum est & To err is human \\
\hline G. & Ars amandi & The art of loving \\
\hline D. & Pares amando sumus & We all are equal for loving \\
\hline Acc. & Ad amandum vivimus & We live in order to love \\
\hline Abl. & Docendo discimus & We learn from teaching others \\
\hline
\end{tabular}

Gerundivum, on the other hand, as difined in Jurewicz et al. 1998, is a participle. To be more precise, it is a future passive participle and it is derived from gerundium, hence the name gerundivum 'gerundival'. It is sometimes refferred to as a verbal adjective. It is formed by adding the suffix - $(e) n d$ - to the present tence base form of the verb plus adjectival endings. Moreover, it declines together with the noun like a corresponding adjective. It's form is demonstrated in the table below:

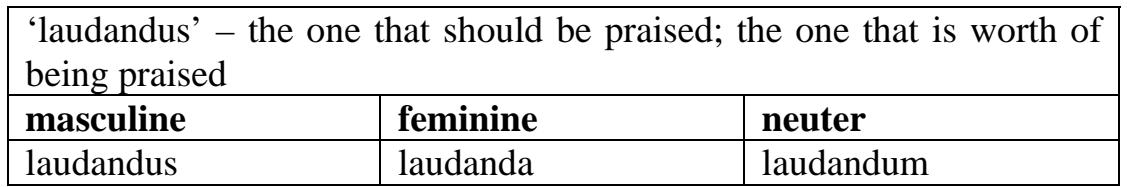

Gerundivum has a number of functions, namely:

- attributive function. In this function it relates what a given object or person is worth of, for example: mulier laudanda - a woman worth of praising; - complement function. In this case it is accompanied by the link verb esse 'to be', for example: mulier amanda est - a woman must be loved; 
- present or future passive participle. In this case it relates what will/is going to happen with something/somebody, for example: Caesar pontem faciendum curavit - Caesar ordered that a bridge be constructed.

The two verbal forms, gerundium and gerundivum, may be formally different but, being genetically related, they have quite a lot in common and they can often be used interchangeably in a number of contexts. The basic characteristics that the two verbal forms have in common are the following: both can be translated in the same way; both can take the same prepositions; both can have the same cases; both can have same functions

\subsection{Gerund vs. gerundio}

Students who learn English and Spanish simultaneuosly often have problems with the following terms: gerund (in English) and gerundio (in Spanish). Both terms are genetically related but they describe two different situations. The English gerund is a verbal noun and it has many nominal features. For example, it can function as the subject (eg. swimming is healthy), as the object (eg. Susan likes swimming), and also as the complement of a verb eg. (what is swimming?). Moreover, it can be modified by an adjective as in Peter likes long-distance swimming; the Spanish equivalent of the English 'gerund' is the infinitive itself. As far as the Spanish gerundio is concerned, it behaves like the present participle in English, so it is more like a verbal adjective. It is for example used in the Spanish present continuous tense: estoy hablando contigo ahora 'I am speaking with you now'. In other words, the Spanish present continuous tense has the structure 'be + gerund' (Span. estar + gerundio), so in this case it is identical with to the English present participle, and not with the gerund, because the English present continuous, which is used for continuous actions taking place at the moment of speaking like in Spanish, has the structure 'be + present participle'. In the description of present continuous, then, due to the application of two different linguistic terms describing the same linguistic phenomenon, students of English and Spanish are unnecessarily confused. They often comment upon the situation: 'wouldn't it be better just to use equivalent terminology items to equivalent linguistic phenomena?' They are certainly right. And there is a solution to the problem. What we do, for example, is we treat the Spanish 'gerundio' as if it were a present active participle, and in fact we call it like that in order to avoid calling it a gerund. At the same time, it is necessary to tell the students that in Spanish the function of the English gerund is fulfilled by the infinitive. As a matter of fact, the Spanish 'gerundio' has the form of the original dative and ablative case of the Latin 'gerundium' but it's use is 
Metalanguage In English And Spanish Classroom Instruction...

not compatible with what we said about 'gerundium' above. The problem is that the Latin 'gerundium' seemed to have been the best candidate for something like the present continuous tense in Valgar Latin that later on developed into Spanish. It needs to be mentioned that Latin itself did not have the present continuous tense but it had the present participle. The present participle, however, was not used the way it is used in English nowadays. It was much more like an adjective and not like a verb; in fact, if one wanted to, one could produce an artificial present continuous statement in Latin but it would sound very awkward, like for example in modern German or modern Polish. Only later in the history did the present participle start to function as part of continuous tences in some Indo-European languages. Moreover, since the Latin gerundium and present participle had very similar forms (gerundium had the feature -nd-, whereas the present participle had the feature $-n s$ in the nominative case and - $n t$ - in the oblique cases), it was very easy for the speakers to confuse them, merge them and use interchangeably, especially after during the mediaeval period of Latin where numerous simplifications took place when it was turning into Vulgar Latin and later on into Spanish. At that time new grammatical systems developed on the basis of the indigenous substrate languages; present continuous, for example, can be found in Celtic languages.

\subsection{Praesens vs. praeteritum}

Another problem area for students learning English and Spanish again lies in the temporal system. This time it concernes the present perfect tense. The present perfect tense, however, can be called 'present' only in English but in Spanish it is called 'preterite'. Before we start the comparison proper, a few words explaining the etymology of some words are necessary. Etymologically, the term 'present' derives from prae- 'pre-, ahead of' + esse 'to be'. The term 'preterite', on the other hand, derives from praeter 'by, past, aside' + ire 'to go'. As can be seen, the two terms refer to two totally different things: the term 'present' refers to what is present, whereas the term 'preterite' refers to what has past, gone by.

\subsection{Present perfect vs. pretérito perfecto}

Both in English and Spanish there is a grammatical tense that tells us about an action that took place in the resent past and whose result can be seen in the present. However, in English this tense is called 'present perfect'. It is formed according to the pattern have + past participle where the auxiliary verb have is a tensed personal verb and the past participle is an element that does not carry tense but simply serves as an aspect marker. To give an 
example let us take the following sentence: Sasan has bought a car. As far as Spanish is concerned, here the tense is called 'pretérito perfecto' (Eng. preterite perfect, past perfect). It is built exactly according to the same pattern, that is haber + participio pasado (Eng. have + past participle). As an example, let us take the following sentence, which is a translation of the English example given right above: Susana ha comprado un coche. What is confusing for students about the tense in question is that in Spanish and English the terminology does not overlap, although one and the same event is being described. The terms 'present perfect' and 'pretérito perfecto' distort the whole picture and one is likely to get the impression that two distinct tenses are being spoken about. The problem is that in English the word 'present' refers to the result of the action, whereas in Spanish the word 'pretérito' refers to when the action took place. As regards the past participle, it is not problematic at all because in both languages it tells us about the aspect, namely, the perfective aspect of the action. To a student not familiar with the historical development of the two languages it may seem an utter nonsense that such a misunderstanding should ever take place. The problem becomes clearer when one has a look at the formal structure of the tense in question. In English, the verb have apart from having the function of an auxiliary, also denotes possession. The fact that it is still used as a verb of possession, places the speaker more in the present when they mention the verb in the present perfect tense. For example, whe the speaker says Susan has bought a car they state that Susan is in the state of having/possessing something in the present. In Spanish it is not that obvious because the auxiliary haber does no longer denote possession. In the past by all means it did when it still was Latin, but nowadays it does not. In the history of the Spanish language the verb haber lost its semantic force and stopped to be used as a verb denoting possession, and in its time was substituted by the verb tener which from then on fullfilled the function of expressing possession. Nevertheless, although in the process of language development many elements are lost, some tend to be preserved to fulfill other functions, very often semantically related ones, as if they were regarded as the best candidates to do so. It so happened that the verb haber according to the process of grammaticalisation became part of the grammatical system and now has the function of an auxiliary, or to be more general, is now a function word. It no longer expresses possession but the context in which it occurs still has a shade of possession whether the speakers realises it or not. Because it is grammaticalised, it is more abstract now and the speakers cannot associate it with any concrete notion. It in fact is only a marker of recent past. If one looks at the whole 
Metalanguage In English And Spanish Classroom Instruction...

problem from this perspective, one will come to terms with the existing terminology more easily perhaps.

\subsection{Sequence of tenses}

As regards the Spanish pretérito perfecto (present perfect) the situation is further complicated when it comes to the notion of the sequence of tences in Spanish. On the one hand, grammar books, for example CybulskaJanczew et al. (2001), tell the student that when there is the requirement to use the subjunctive mood, the present subjunctive mood (presente de subjuntivo) should be used in the dependent clause when the indicative main clause introducing the subjunctive mood is in the following tenses: presente simple (present simple), pretérito perfecto (present perfect) or futuro simple (future simple). On the other hand, as regards the use of the past subjunctive mood (imperfecto de subjuntivo), it should be used in the dependent clause when the indicative main clause introducing the subjunctive mood is in the following tenses: pretérito imperfecto (simple past), pretérito pluscuamperfecto (pluperfect), pretérito de indefinido (indefinite preterite), pretérito anterior (a type of pluperfect) or condicional (conditional, or future in the past). The former group of indicative tenses offers the student an unnecessary difficulty, namely, the pretérito perfecto (present perfect) seems to belong to the past group rather than to the present one. Although it is a present tense, it is called a preterite tense and thus misleads the student, who thinks that the preterito perfecto should be the odd one out.

\subsection{Simplex vs. complex}

On the basis of what has so far been said in this article the reader might get the impression that the terminology used to describe the grammar is more transparent in English than in Spanish and that it should be looked up to as the better one. It is in fact not so. It is true that the Spanish terminology should in some areas learn from the English terminology in order to make the life of the students less complicated, but we have also found areas where the English terminology could learn a lot from the Spanish one. What we have in mind still concernes the Spanish-English temporal system but this time we will concentrate upon whether a given tense is simplex or complex. To give a somewhat simplified definition of what is a simplex tense we can say that a sentence is written in a simplex tense if it contains only one verbal form that is tensed and personal, and moreover it does not need any additional verbal form to convey the meaning. An example of such a sentence would be John eats apples every day(Eng.) /Juan come manzanas todos los dias (Span.). As far as the definition of a complex tense is concerned, it would more or less 
Ireneusz KIDA

sound as follows. A sentence is written in a complex tense when it contains only one verbal form that is tensed and personal. This tensed and personal verbal form, however, usually has the function of an auxiliary and cannot stand alone and thus it requires some other verbal form to complete its meaning.

\subsection{Simplex or complex?}

If we look at the English simple present tense, we will see that it is a simplex tense in positive statements, eg.: Peter reads books twice a week. However, if we turn this statement into an interrogative one, we will automatically obtain a complex tense, as in does Peter read books twice a week? The same happens when we turn the sentence into a negative statement Peter does not read books twice a week. Does this mean that the so called simple present tense should on the one hand be called 'simple present' and on the other 'complex/composite present'? Perhaps it would be a good idea to do a review of the terminology used to describe the tense in question. Nevertheless, there are a number of verbs in the English language that are still capable of forming simplex tenses in all the three kinds of statements (positive, negative and interrogative). For example the verbs 'be' and 'have' do not need to form complex tenses in interrogative and negative statements but they are only the few ones that still work according to the old system. In Old English, the majority of the verbs preserved the simplex tense structure not only in positive statements but also in interrogative and negative ones. As far as Spanish is concerned, a similar problem does not exist there, as the simplex tense pattern is preserved all the way. If we translate the above English example about Peter reading books into English, we will obtain the following results: Positive - Pedro lee libros dos veces a la semana, Interrogative - ¿lee Pedro libros dos veces a la semana? Negative - Pedro no lee libros dos veces a la semana. In Spanish when a tense is simplex it is simplex all the way, but when it is complex it is complex all the way too. So in this respect English should learn from Spanish, namely the terminology used to describe the English grammar should be more transparent in order that students learning this language cuold get a clearer picture of the temporal system of the language.

\section{Conclusions}

In the grammatical system of English and Spanish there are a number of areas where the two systems do not agree with each other. The lack of correspondence arises from the fact that the two languages were developing independently of each other and one simply cannot expect one-to-one corre- 
Metalanguage In English And Spanish Classroom Instruction...

spondence in all of the areas of their grammars. Such situation is often a source of misunderstandings and misinterpretations on the part of the student learning the two languages simultaneously. We have described particularly three areas where the English and Spanish terminology items do not correspond very well. The areas are: the gerund/gerundio, the present perfect tense /preterito perfecto and simplex/complex tenses. The solution of the problems is not an easy tusk because the nomenclature cannot be changed at once. Moreover, it is part of national heritage and perhaps it should be left intact. What we aim at in our paper, however, is that we would like to make the teacher and their students aware of the problem areas because if one is aware of such things, one can see grammatical systems much more transparently. And if one sees the systems more transparently, one can teach them more transparently in order that one could learn them more transparently

\section{References}

- Cybulska-Janczew, M. and Perlin, J. 2001. Gramatyka języka hiszpańskiego z ćwiczeniami. Warszawa 2001: Wydawnictwo Naukowe PWN.

- Jurewicz O., Winniczuk L., Żuławska J. Język łaciński - Podręcznik dla lektoratów szkót wyższych. Warszawa 2000: Wydawnictwo Naukowe PWN.

\section{Irineusz KIDA}

\section{METALANGUAGE IN ENGLISH AND SPANISH CLASSROOM INSTRUCTION - HOW MUCH OF TRANSPARENCY?}

Differences in the descriptive apparatus of the English and Spanish grammar system often pose problems to students of Spanish and English, who learn the two languages simultaneously. The standard nomenclature used to describe the grammars of the two languages sometimes employs (seemingly) unrelated notions to describe similar, and often identical grammatical phenomena. It is enough to have a look at the temporal system of the two languages, for example. In the standard grammar of English the name 'present perfect' has been given to a grammatical tense that, among other functions, is used for recent completed actions whose result can be seen in the present. In Spanish, on the other hand, the grammatical tense that is used for similar actions is called 'pretérito perfecto' (English: preterite perfect or 
Ireneusz KIDA

past perfect). Another problem area is the use of the so called 'gerund'. Although the terms 'gerund' and 'gerundio' exist in English and Spanish respectively, they describe two different phenomena: whereas in English the term 'gerund' is a noun-like element and behaves like a noun (for example it can be the subject of a clause), in Spanish the term 'gerundio' is a verb-like element that forms an integral part of complex continuous tenses, and in fact is equivalent to the English present participle. Problems also arise due to the outdated division into simplex and complex tenses. For example, the English 'simple present' is a simplex tense only in positive statements, whereas in the majority of interrogative and negative statements it becomes a complex tense. In Spanish this problem does not exist, however. Therefore, the purpose of my presentation is to demonstrate how to deal with the above mentioned problems, how to make the language of classroom instruction more transparent and fun, and consequently how to facilitate students' learning.

Key words: metalanguage, gerund/gerundio, praesent, praeteritum, simplex tenses, complex tenses 
LINGUA MONTENEGRINA, god. III, br. 5, Cetinje, 2010.

Institut za crnogorski jezik i jezikoslovlje „Vojislav P. Nikčević“

UDK 811.134.2'27

Stručni rad

Ivana KOVAČ-BARETT (Nikšić)

Univerzitet Crne Gore

\section{ISTORIJSKI, PRAVNI I SOCIOLINGVISTIČKI KONTEKST JEZIČKE SITUACIJE U ŠPANIJI}

Višejezičnost na prostoru današnje Španije ima veoma dugu istoriju. Ipak, pravnu osnovu dobila je tek 1978. godine, kad je konačno donešen Ustav Španije koji je ujedno prestavljao i najvažniji dokument za očuvanje jezičke različitosti na tom jezičkom prostoru. Kastiljanski jezik je, iz različitih razloga, nametan i kao lingua franca i kao simbol Kraljevine Španije dok su se ostali jezici sve manje govorili. Danas se, na teritoriji Španije, u ukupno šest autonomnih regija govore jezici tih regija u statusu kooficijalnih jezika a to su galicijski, valensijski, katalonski i baskijski. Budući da je autonomnim regijama omogućeno da same sprovode svoje regionalne jezičke politike, očito je da se sama jezička situacija i rezultati sprovedenih jezičkih politika razlikuju od regije do regije, a na njih utiču demografski pokazatelji regije, opšta jezička situacija, prestiž regionalnog jezika, sličnost između regionalnog i službenog, odnosno španskog jezika itd.

Detaljne jezičke studije i statistička istraživanja koja se sprovode vezano za jezičku situaciju na ovim prostorima pokazuju da je svakim danom sve više onih koji govore i onih koji razumiju regionalne jezike a da bi jezička situacija na teritoriji Španije mogla i dalje da nastavi da se razvija u smjeru proliferacije regionalnih jezika. Fenomen proliferacije jezika na ovom prostoru, po svemu sudeći, još uvijek nije završen.

Ključne riječi: regionalni / manjinski jezici, kooficijalni jezici, jezička politika, jezička situacija, višejezičnost, bilingvizam, jezička proliferacija

\section{Uvod}

Namjera nam je da predstavimo jezičku situaciju u Španiji i sistem funkcionisanja kooficijalnih jezika u onim regijama u kojima ta kooficijalnost postoji - kroz istorijski, pravni i sociopolitički kontekst. U tome okviru višejezičnost na tome prostoru vjekovima predstavlja jednu od najznačajnijih 
osobenosti. Ipak u ustavnoj istoriji te države prvi put se na osnovu Ustava iz 1978. godine zaista i prepoznaje i prihvata postojanje višejezičnosti u njoj. Ta višejezičnost oslikana je prvjenstveno u sistemu kooficijalnosti jezika, što je potvrđeno članom 3 Ustava, koji glasi: ${ }^{1}$

\section{Artículo 3.}

El castellano es la lengua española oficial del Estado. Todos los españoles tienen el deber de conocerla y el derecho a usarla.

Las demás lenguas españolas serán también oficiales en las respectivas Comunidades Autónomas de acuerdo con sus Estatutos.

La riqueza de las distintas modalidades lingüísticas de España es un patrimonio cultural que será objeto de especial respeto y protección. $^{2}$

Regionalni jezici su, dakle, kulturna baština države koja je danas podijeljena na 19 autonomnih regija, od kojih je svakoj ustavno omogućena široka autonomija, dok je u šest pokrajina koje imaju svoje vlastite jezike omogućeno da se oni upotrebljavaju i promovišu paralelno s kastiljanskim. U skladu s nivoom pravne zaštite koju nude Ustav odnosno statuti autonomnih regija, kao i na osnovu usklađenosti s Evropskom poveljom o regionalnim ili manjinskim jezicima, moguće je napraviti razliku između dvije grupe jezika koji se govore u Španiji. To su:

1. Jezici koji nemaju kooficijalan status, ali figuriraju u statutima autonomnih regija kao zaštićeni jezici:

- u Statutu Autonomne regije Asturijas: bable/asturijski

- u Statutu Autonomne regije Aragon: ,različiti jezički varijeteti koji se govore u Aragonu”. ${ }^{3}$ Ti „varijeteti“ su kasnije imenovani kao katalonski i aragonski u Aktu 3/1999.

\footnotetext{
${ }^{1}$ Član 3 Ustava predmet je brojnih analiza i tumačenja. Po jednima, tim se ustavom prepoznaje višejezičnost u Španiji. Po drugima, Ustav priznaje samo španski jezik kao jedini koji se u njemu imenuje. Za ostale jezike upotrebljava se izraz ,jezički modaliteti Španije“ ili „ostali španski jezici“.

${ }^{2}$ Član 3

Kastiljanski je službeni jezik španske države. Svi Španci imaju obavezu da ga poznaju i pravo da ga koriste.

Ostali španski jezici biće takođe službeni u određenim autonomnim regijama u skladu s njihovim statutima.

Bogatstvo različitih jezičkih modaliteta Španije je kulturna baština i biće predmet posebnoga poštovanja i zaštite. (Prev: I. K.)

Izvor: Boletín Oficial del Estado

http://www.boe.es/datos_iberlex/normativa/TL/ConstitucionCASTELLANO.pdf

3 "Las diversas modalidades lingüísticas de Aragón..." (cit. u: Siguan, 1992: 86)
} 
Istorijski, pravni i sociolingvistički kontekst jezičke situacije u Španiji

- u Statutu Autonomne regije Katalonije: aranski (jezik karakterističan za oblast doline Aran)

2. Jezici koji imaju kooficijalni status na teritoriji datih regija:

- na teritoriji Katalonije: katalonski

- na teritoriji Balearskih ostrva: katalonski

- na teritoriji Valensije: valensijski

- na teritoriji Galisije: galisijski

- na teritoriji Baskije: baskijski/euskera

- na dijelu teritorije Navare: baskijski/euskera

U daljem tekstu ćemo predstaviti jezičku situaciju u onim regijama u kojima je prisutna kooficijalnost katalonskoga, galisijskoga, valensijskoga, baskijskoga i kastiljanskoga jezika, kao i podatke koji ukazuju na porast poznavanja i upotrebe regionalnih jezika koji se, međutim, na tome prostoru i dalje proliferišu mijenjajući tako jezičku situaciju.

\section{Prikaz jezika koji imaju status kooficijalnosti}

\subsection{Istorijski kontekst}

Današnja Španija nastala je kao rezultat spajanja različitih kraljevstava i principata. Tokom XVIII i naročito XIX vijeka usvojeni su različiti modeli centralizacije političke strukture. Može se reći da je sve do 1978. godine Španija bila država koja je imala veoma centralizovanu teritorijalnu organizaciju. Razlog za to se može naći, jednim dijelom, u autoritarnome političkom sistemu kojem je ta zemlja bila izložena od 1939. do 1975. godine. S druge strane, razlog je upravo tradicija započeta dolaskom dinastije Borbon na vlast, odnosno prihvatanjem apsolutistički i jezički ujedinjenoga modela kao modela koji je tada vladao u velikom broju evropskih država.

Proces centralizacije, dakle, započet na osnovu francuskoga modela, ustanovljen je Ustavom iz 1812. godine, a trajao je tokom XIX vijeka i odvijao se uporedo s romantizmom, kulturnim a zatim i političkim pokretom koji je naročito obilježio jezičku situaciju u onim regijama koje su imale svoje „vlastite“ jezike. Upravo te jezičke manjine su u svojim prvim zahtjevima državi često tražile priznavanje njihova prava da im se omogući obrazovanje na vlastitome jeziku. Uz te zahtjeve naglašavano je da su oni isključivo regionalnoga karaktera, da neće uključivati drugu vrstu političkih zahtjeva (autonomiju itd.) te da se njima ne želi oslabiti autoritet države. Ukratko, tim se zahtjevima insistiralo na promjenama u strukturi državne organizacije koja je bila zapala u duboku krizu nakon gubitka kolonija 1898. godine. 
Na osnovu već pomenutoga modela francuskoga sistema, Španija je bila podijeljena na 50 regija koje su i u političkome i u administrativnome smislu bile veoma zavisne od države, a, osim toga, regije nijesu bile priznate.

Društveno i kulturno priznavanje specifičnih identiteta i teritorija pokrenulo je proces koji je vodio ka novoj i različitoj teritorijalnoj organizaciji. Politički sukobi i građanski ratovi u XIX i XX vijeku spriječili su da se taj prelazak iz dva međusobno sasvim različita sistema - iz centralističkoga u alternativni model decentralizovane države, odvije mirnim putem. Godine 1978. konflikt još uvijek nije bio riješen, a to je rješenje predstavljalo glavni cilj ustava koji će biti usvojen te godine.

Tokom Druge Republike (1931-1936) Parlament je, naime, bio odobrio autonomne statute za Kataloniju 1931. godine i za Baskiju 1936. U Galisiji taj proces nije bio završen zbog dramatičnih događaja tokom Građanskoga rata 1936-1939.

Ipak, Frankov režim značio je brutalan prekid procesa priznavanja i upotrebe tradicionalnih regionalnih ili manjinskih jezika koji je bio započet. Javna upotreba tih jezika je zabranjivana, knjige napisane na njima su javno spaljivane dok su regionalna imena bila izbrisana iz spiska toponima i građanskih registara. Ukratko, bilo je zabranjeno govoriti tim jezicima. Izdavačke kuće koje su štampale djela na tim jezicima bile su izložene brutalnoj cenzuri. Jedini službeni jezik bio je kastiljanski ili španski, dok su se regionalni jezici koristili u veoma ograničenome porodičnom i društvenome kontekstu. Uprkos tome, javna upotreba tih jezika bila je u porastu od početka 1970-ih.

Prevlast kastiljanskoga u odnosu na ostale jezike bila je rezultat istorijskoga razvoja započetoga početkom XVI vijeka kad je kastiljanski postao glavni jezik ujedinjenog kraljevstva kao i, postepeno, jedan od simbola njenog ujedinjenja. Od tog vremena mu je dodijeljen naziv španski jezik, a u XVIII vijeku je osnovana i Španska kraljevska akademija čiji je glavni zadatak upravo bila briga o tome jeziku.

Prvi slobodni izbori nakon 1936. godine održani su 1977. Rezultati izbora ukazali su na prevlast nacionalističkih i regionalnih političkih partija, naročito u Kataloniji i Baskiji. Nakon takvih rezultata započelo je regionalno strukturisanje Španije, a u isto vrijeme su započele i brojne debate oko Ustava. Takvo političko ponašanje bilo je praćeno i bilo je rezultat očitoga društvenog pritiska da se brzo priznaju regije, naročito Katalonija i Baskija. To će se i desiti tako što će se najprije priznati vlade u tim oblastima. Drugim riječima, započeto je uspostavljanje jednoga sistema koji je prethodio priznavanju autonomija posredstvom brojnih pravnih dekreta donešenih tokom 1977. i 1978. godine. Bio je to prvi stupanj u zvaničnome priznavanju regionalnih jezika. 
Kad je konačno usvojen Ustav 1978. godine, mapa regija je bila u velikoj mjeri već nacrtana a regionalnim jedinicama već bile dodijeljene izvjesne moći. Zapravo, regije su se već nalazile u samome procesu formiranja, a put ka priznavanju regionalnih jezika već je bio započet. Težnja da se državna teritorija organizuje na regionalnom nivou reflektovala je želju društva kao i izabranih poslanika koji su ga predstavljali. Ona se sasvim iskristalisala u Ustavu iz 1978. članom 2, u kome se kaže:

La Constitución se fundamenta en la indisoluble unidad de la Nación española, patria común e indivisible de todos los españoles y reconoce y garantiza el derecho a la autonomía de las nacionalidades y regiones que la integran y la solidaridad entre todas ellas. ${ }^{4}$

Usvojeni su statuti 17 regija: Baskije i Katalonije (1979), Galisije, Andaluzije, Asturijasa i Kantabrije (1981), Riohe, Mursije, Valensije, Aragona, Kastilje-La Manće, Kanarskih ostrva i Navare (1982) i Ekstremadure, Balerskih ostrva, Madrida i Kastilje-Leona (1983) i svakoj od tih regija je dodijeljena široka autonomija koja uključuje regionalnu vladu i parlament. Statuti Seute i Melilje usvojeni su 1995. Iako te dvije regije nemaju pravni kapacitet, one uživaju veliku organizacionu i izvršnu autonomiju u onim okvirima u kojima im nivo dodijeljene vlasti to dozvoljava.

Na taj način je, nakon Frankove smrti, javna upotreba regionalnih jezika postala realnost. Proces je već bio započet. Sedamanaest autonomnih regija dobilo je svoje autonomne statute, a šest od njih su dobile i zvanično priznavanje regionalnih ili manjinskih jezika koji se govore na njihovim teritorijama. Dakle, autonomne regije su zadobile političku i administrativnu moć kao i odgovornost za promociju svojih sopstvenih jezika.

\subsection{Pravni i sociolingvistički kontekst}

Ispunjavajući svoja zakonska prava, svih šest autonomnih zajednica su između 1982. i 1986. godine donijele zakon kojim definišu svoju jezičku politiku i većina njih je taj zakon nazvala Zakon o političkoj normalizaciji (Ley de la Normalización Política). ${ }^{5}$ Svi ti zakoni imaju sličnu strukturu, osim za-

${ }^{4}$ „Ustav se zasniva na neraskidivom jedinstvu španske nacije, zajedničke i nedjeljive otadžbine za sve Špance, njime se priznaje i garantuje pravo na autonomiju onim nacionalnostima i regijama koje ulaze u njen sastav kao i solidarnost među svima njima." (Prev. I. K.)

Izvor: Boletín Oficial del Estado

http://www.boe.es/datos_iberlex/normativa/TL/ConstitucionCASTELLANO.pdf

${ }^{5}$ Termin ,normalizacija“ tradicionalno se odnosi na interne jezičke norme: gramatiku, leksiku, ortografiju... Međutim, u konkretnom slučaju se pod tim terminom pod- 
kona u Navari koji se ograničava samo na onu oblast svoje teritorije na kojoj se govori baskijski jezik.

U uvodnome dijelu Zakona o političkoj normalizaciji ističe se potreba da se zaštite ti jezici kako bi se kompenzirala dugogodišnja marginalizacija kojoj su bili izloženi. U svim zakonima se ističe da se prihvata kooficijalnost kastiljanskog/španskog i onog jezika koji se govori na teritoriji date regije, a samim tim se daje pravna vrijednost dokumentima koja mogu biti sačinjena na bilo kom od dva pomenuta zvanična jezika. Takođe se tim zakonom garantuje jednaka upotreba jezika u državnoj, regionalnoj i lokalnoj administraciji i sasvim se konkretno potvrđuje da građani mogu da koriste podjednako ma koji od dva kooficijalna jezika. Na sličan način se reguliše i prisustvo tih jezika u školskome sistemu tako što svi učenici imaju obavezu da poznaju oba službena jezika. Tim zakonom se potvrđuje pravo vlastima u autonomnim regijama da odobre otvaranje medija na regionalnome jeziku (novine, radio, televizija), kao i to da one snose odgovornost za promociju kulturnih dešavanja na svome jeziku (objavljene knjige, pozorište, bioskop, književne nagrade itd.)

Svi ti zakoni bili su prihvaćeni jednoglasno (ili skoro jednoglasno) u regionalnim parlamentima i većina njih nije imala kasnijih modifikacija.

U Navari je donešen još jedan zakon kojim se proširuje zaštita baskijskoga jezika, a u Kataloniji zakon kojim se proširuje zaštita katalonskoga.

U svakoj od pomenutih regija ustanovljen je specifičan administrativni organ koji je zadužen za primjenu tih zakona i u većini on nosi naziv Direkcija za jezičku politiku (Dirección de Política Lingüística). Taj organ je odgovoran za jezičku politiku, nezavisno od toga što takođe postoje i institucije i organi specijalizovani za različite sektore (prosvjeta, zakonodavstvo, administarcija i javne usluge, mediji, kultura, ekonomski i društveni sektor i granične razmjene).

Tako je, recimo, jedna od funkcija Direkcije za jezičku politiku da osigura da se korektno upotrebljavaju pravila koja donose akademske jezičke institucije kao i da garantuje njihovu primjenu. Naime, zbog statusa „vlastitih jezika" ${ }^{6}$ koji imaju regionalni jezici na svojoj teritoriji, statuti tih regija kao i zakoni koji se odnose na jezičku standardizaciju obično nameću autonomnim zajednicama neke specifične obaveze i odgovornosti vezane za zaštitu regionalnih jezika, uključujući i jezičko-akademsku oblast. Stoga su, iz akademskih namjera, sve autonomne regije s kooficijalnom jezičkom situacijom for-

razumijeva „normalnost u upotrebi“. Naime, termin u tome značenju je najprije počeo da se upotrebljava u Kataloniji kad je taj jezik, koji je bio potisnut neko vrijeme, povratio svoju društvenu vitalnost, prestiž i upotrebu.

${ }^{6}$ Lengua propia (Prev. I. K.) 
malno priznale jedan akademski jezički autoritet koji ima funkciju da sačuva jezik te regije i da brine o njemu.

U slučaju konflikata vezanih za kompetenciju ili interpretaciju jezičkih pitanja, odluke donešene od strane Vlade Španije kao i odluke regionalnih vlasti mogu biti preispitane pred Konstitucionalnim sudom.

Iako su struktura i sadržaj pomenutih zakona slični, u praksi su postignuti veoma različiti rezultati. Neki od razloga kojima se objašnjava takva situacija su:

- polazna sociolingvistička situacija

- prestiž samoga regionalnog jezika

- nivo znanja jezika koji imaju govornici date regije

- demografski pokazatelji

- značaj imigracije itd.

Ti faktori uslovljavaju ili utiču na primjenu jezičke politike, kao i na postignute rezultate.

Prilikom popisa stanovništva obavljenog 1975. godine u Barseloni, prvi put je popis sadržao i neka pitanja vezana za nivo poznavanja katalonskoga jezika. Pet godina kasnije, 1981. godine, kad se već ustanovila i Vlada Katalonije, ta su se pitanja proširila na cijelo stanovništvo Katalonije. Kasnije su i ostale autonomne regije usvojile tu inicijativu i danas se u svim regijama koje imaju jezike kooficijalne s kastiljanskim sprovode popisi koji sadrže i pitanja o jeziku (Siguan, 2001).

Na tim opštim popisima, međutim, bilo je moguće postaviti ograničen broj veoma konkretnih pitanja o jeziku. Da bi se dobile preciznije informacije o ponašanju i stavovima o jeziku, pristupilo se anketama koje nude manje ili više reprezentativne pokazatelje. Najstarija anketa je sprovedena 1981. godine na teritoriji grada Barselone, a ista anketa sprovedena je 1986. Nakon toga, 1991. godine, sprovedena je u Galisiji jedna anketa koja je po obuhvatnosti (blizu 40000 anketiranih) i po reprezentativnosti vjerovatno jedna od najreprezentativnijih sociolingvističkih anketa. I u Baskiji je takođe 1991. godine sprovedena anketa koja je pored Baskije (na teritoriji Španije) obuhvatala i Navaru i Baskiju na dijelu francuske teritorije. Ta anketa, ovoga puta mnogo obimnija, ponovljena je 1996, a zatim 2001. godine.

Međutim, sve te ankete sprovođene tako da se odnose samo na jedan jezik i jednu teritoriju karakteriše vlastiti pristup, što čini poređenja među njima prilično teškim. Stoga smo u ovom radu, osim podataka s posljednjih popisa u autonomnim regijama (2001. godine) koristili podatke najobimnije ankete načinjene za sve jezike (osim španskoga) i teritorije na kojima se govore a koju je realizovao Centar za sociolingvistička istraživanja (Centro de Investigaciones Sociolingüísticas) 1993. i 1998. godine pod koordinacijom Migela Siguana. 
Novina u tim anketama jeste to što se ispitanici ne ispituju samo o njihovoj jezičkoj kompetenciji, već o jeziku koji obično koriste i koji smatraju svojim glavnim jezikom. To omogućava da se razlikuju sljedeće kategorije:

1. oni kojima je maternji jezik jedan od regionalnih jezika, ali govore i kastiljanski;

2. oni koji se smatraju bilingvalnima;

3. oni kojima je kastiljanski glavni jezik, ali govore i regionalni jezik;

4. oni kojima je kastiljanski glavni jezik, a razumiju ali ne govore regionalni jezik;

5. oni kojima je kastiljanski glavni jezik, a niti govore niti razumiju regionalni jezik.

Evo nekih rezultata toga istraživanja (Podaci preuzeti iz: Siguan, 1999):

Tabela 1. Poznavanje i upotreba kastiljanskoga jezika

\begin{tabular}{|l|r|r|r|r|r|r|}
\hline & $\begin{array}{r}\text { BASKI- } \\
\text { JA (\%) }\end{array}$ & $\begin{array}{r}\text { KATA- } \\
\text { LONIJA } \\
(\%)\end{array}$ & $\begin{array}{r}\text { GALI- } \\
\text { SIJA (\%) }\end{array}$ & $\begin{array}{r}\text { VALEN- } \\
\text { SIJA (\%) }\end{array}$ & $\begin{array}{r}\text { NAVA- } \\
\text { RA (\%) }\end{array}$ & $\begin{array}{r}\text { BALE- } \\
\text { ARO } \\
(\%)\end{array}$ \\
\hline $\begin{array}{l}\text { Razumije, } \\
\text { govori, } \\
\text { čita i piše }\end{array}$ & 98.2 & 96.7 & 92.5 & 95.8 & 98.7 & 94.9 \\
\hline $\begin{array}{l}\text { Razumije, } \\
\text { govori i } \\
\text { čita }\end{array}$ & 0.7 & 0.9 & 2.4 & 1.4 & 0.0 & 0.4 \\
\hline $\begin{array}{l}\text { Razumije i } \\
\text { govori }\end{array}$ & 0.7 & 2.4 & 2.5 & 2.3 & 1.1 & 3.0 \\
\hline Razumije & 0.0 & 0.0 & 2.4 & 0.4 & 0.2 & 1.3 \\
\hline $\begin{array}{l}\text { Ne } \\
\text { razumije }\end{array}$ & 0.0 & 0.0 & 0.3 & 0.0 & 0.0 & 0.4 \\
\hline $\begin{array}{l}\text { Bez } \\
\text { odgovora }\end{array}$ & 0.5 & 0.0 & 0.0 & 0.0 & 0.0 & 0.0 \\
\hline
\end{tabular}


Istorijski, pravni i sociolingvistički kontekst jezičke situacije u Španiji

Tabela 2. Poznavanje kooficijalnih jezika u datim pokrajinama

\begin{tabular}{|l|r|r|r|r|r|r|}
\hline & $\begin{array}{r}\text { BASKI- } \\
\text { JA } \\
(\%)\end{array}$ & $\begin{array}{r}\text { KATA- } \\
\text { LONIJA } \\
(\%)\end{array}$ & $\begin{array}{r}\text { GALI- } \\
\text { SIJA } \\
(\%)\end{array}$ & $\begin{array}{r}\text { VALEN- } \\
\text { SIJA } \\
(\%)\end{array}$ & $\begin{array}{r}\text { NAVA- } \\
\text { RA } \\
(\%)\end{array}$ & $\begin{array}{r}\text { BALE- } \\
\text { ARO } \\
(\%)\end{array}$ \\
\hline $\begin{array}{l}\text { Razumije, } \\
\text { govori, } \\
\text { čita i piše }\end{array}$ & 16.5 & 48.1 & 52.9 & 19.3 & 7.1 & 31.1 \\
\hline $\begin{array}{l}\text { Razumije, } \\
\text { govori i } \\
\text { čita }\end{array}$ & 3.6 & 23.2 & 15.5 & 19.6 & 3.8 & 24.7 \\
\hline $\begin{array}{l}\text { Razumije i } \\
\text { govori }\end{array}$ & 8.5 & 7.8 & 20.8 & 16.7 & 4.7 & 15.9 \\
\hline Razumije & 14.7 & 18.3 & 9.7 & 33.6 & 7.1 & 20.7 \\
\hline $\begin{array}{l}\text { Ne } \\
\text { razumije }\end{array}$ & 56.6 & 2.7 & 1.2 & 10.8 & 77.3 & 7.6 \\
\hline $\begin{array}{l}\text { Bez } \\
\text { odgovora }\end{array}$ & 0.2 & 0.0 & 0.0 & 0.0 & 0.0 & 0.0 \\
\hline
\end{tabular}

Kako bismo te odgovore stavili u širi vremenski konteks, poređenje s rezultatima dobijenim 1993. godine na osnovu istoga istraživanja dala su sljedeće rezultate ${ }^{7}$ :

Tabela 3. Poređenje podataka o poznavanju kastiljanskoga jezika u 1993. i 1998.

\begin{tabular}{|c|c|c|c|c|c|c|c|c|c|c|c|c|}
\hline & \multicolumn{2}{|c|}{$\begin{array}{r}\text { BASKI- } \\
\text { JA } \\
(\%) \\
\end{array}$} & \multicolumn{2}{|c|}{$\begin{array}{r}\text { KATALO- } \\
\text { NIJA } \\
(\%) \\
\end{array}$} & \multicolumn{2}{|c|}{$\begin{array}{r}\text { GALI- } \\
\text { SIJA } \\
(\%) \\
\end{array}$} & \multicolumn{2}{|c|}{$\begin{array}{r}\text { VALEN- } \\
\text { SIJA } \\
(\%) \\
\end{array}$} & \multicolumn{2}{|c|}{$\begin{array}{r}\text { NAVA- } \\
\text { RA } \\
(\%) \\
\end{array}$} & \multicolumn{2}{|c|}{$\begin{array}{r}\text { BALE- } \\
\text { ARO } \\
(\%) \\
\end{array}$} \\
\hline & 9 & '9 & & & '9 & '9 & & & 9 & '9 & 9 & '9 \\
\hline & 3 & 8 & '93 & '98 & 3 & 8 & '93 & '98 & 3 & 8 & 3 & 8 \\
\hline $\begin{array}{l}\text { Razu- } \\
\text { mije, } \\
\text { govori, } \\
\text { čita i } \\
\text { piše }\end{array}$ & 92 & 98 & 93 & 97 & 90 & 92 & 95 & 95 & 97 & 98 & 0 & 95 \\
\hline $\begin{array}{l}\text { Razu- } \\
\text { mije, } \\
\text { govori } \\
\text { i čita }\end{array}$ & 2 & 17 & 2 & 1 & 3 & 2 & 2 & 1 & 1 & 0 & 0 & 0 \\
\hline
\end{tabular}

${ }^{7}$ Podaci preuzeti iz: Siguan, 1999. 
Ivana KOVAČ-BARETT

\begin{tabular}{|l|r|r|r|r|r|r|r|r|r|r|r|r|}
\hline $\begin{array}{l}\text { Razu- } \\
\text { mije i } \\
\text { govori }\end{array}$ & 2 & 1 & 4 & 2 & 4 & 2 & 2 & 2 & 1 & 1 & 0 & 3 \\
\hline $\begin{array}{l}\text { Razu- } \\
\text { mije }\end{array}$ & 0 & 0 & 0 & 0 & 2 & 2 & 0 & 0 & 0 & 0 & 0 & 1 \\
\hline $\begin{array}{l}\text { Ne } \\
\text { razu- } \\
\text { mije }\end{array}$ & 0 & 0 & 0 & 0 & 0 & 0 & 0 & 0 & 0 & 0 & 0 & 0 \\
\hline $\begin{array}{l}\text { Bez } \\
\text { odgo- } \\
\text { vora }\end{array}$ & 4 & 0 & 1 & 0 & 1 & 0 & 2 & 0 & 1 & 0 & 0 & 0 \\
\hline
\end{tabular}

Tabela 4. Poređenje podataka o poznavanju regionalnih jezika u 1993. i 1998.

\begin{tabular}{|c|c|c|c|c|c|c|c|c|c|c|c|c|}
\hline & \multicolumn{2}{|c|}{$\begin{array}{r}\text { BASKIJA } \\
(\%)\end{array}$} & \multicolumn{2}{|c|}{$\begin{array}{r}\text { KATA- } \\
\text { LONIA } \\
(\%)\end{array}$} & \multicolumn{2}{|c|}{$\begin{array}{r}\text { GALI- } \\
\text { SIJA } \\
(\%)\end{array}$} & \multicolumn{2}{|c|}{$\begin{array}{r}\text { VALEN- } \\
\text { SIJA } \\
(\%)\end{array}$} & \multicolumn{2}{|c|}{$\begin{array}{r}\text { NAVA- } \\
\text { RA } \\
(\%)\end{array}$} & \multicolumn{2}{|c|}{$\begin{array}{r}\text { BALE- } \\
\text { ARO } \\
(\%)\end{array}$} \\
\hline & '9 & & 9 & & 9 & '9 & & & '9 & 9 & '9 & 9 \\
\hline & 3 & '98 & 3 & '98 & 3 & 8 & '93 & '98 & 3 & 8 & 3 & 8 \\
\hline $\begin{array}{l}\text { Razu- } \\
\text { mije, } \\
\text { govori, } \\
\text { čita i } \\
\text { piše }\end{array}$ & 20 & 17 & 41 & 48 & 32 & 53 & 12 & 19 & 3 & 7 & 0 & 31 \\
\hline $\begin{array}{l}\text { Razu- } \\
\text { mije, } \\
\text { govori } \\
\text { i čita }\end{array}$ & 6 & 4 & 24 & 23 & 26 & 15 & 19 & 20 & 3 & 4 & 0 & 25 \\
\hline $\begin{array}{l}\text { Razu- } \\
\text { mije i } \\
\text { govori }\end{array}$ & 5 & 8 & 9 & 8 & 30 & 21 & 24 & 17 & 4 & 5 & 0 & 16 \\
\hline $\begin{array}{l}\text { Razu- } \\
\text { mije }\end{array}$ & 15 & 15 & 22 & 18 & 10 & 10 & 35 & 34 & 8 & 7 & 0 & 21 \\
\hline $\begin{array}{l}\mathrm{Ne} \\
\text { razu- } \\
\text { mije }\end{array}$ & 53 & 57 & 4 & 3 & 1 & 1 & 10 & 11 & 82 & 77 & 0 & 8 \\
\hline $\begin{array}{l}\text { Bez } \\
\text { odgo- } \\
\text { vora }\end{array}$ & 1 & 0 & 0 & 0 & 1 & 0 & 0 & 0 & 0 & 0 & 0 & 0 \\
\hline
\end{tabular}


Iako se većina pomenutih jezika govori samo na prostoru pomenutih regija, sociolingvistička situacija u Španiji se može definisati kao „bilingvalna“ s obzirom na to da većina stanovnika na tim teritorijama govori kastiljanski/ španski i jedan od regionalnih jezika. Veliki procenat stanovništva je, dakle, u stanju da koristi jedan ili drugi jezik u manjem ili većem stepenu, a u velikome broju slučajeva poznavanje dva službena jezika je na jednakom nivou.

U skladu s aktuelnom situacijom bilingvizma, u cilju određivanja stepena bilingvizma, tim podacima je dodato pitanje koje je postavljeno samo onim ispitanicima koji su rekli da barem razumiju i govore jezik autonomne regije. Postavljeno pitanje je glasilo: „Ukoliko bi Vas neko pitao, da li biste sebe opisali kao govornika kastiljanskog/španskog ili kao govornika nekog od regionalnih jezika?" Odgovori na to pitanje, na osnovu sociolingvističkoga istraživanja iz 1998. godine, dali su sljedeće podatke: (Podaci preuzeti iz: Siguan, 1999)

Tabela 5. Podaci o govornicima kastiljanskoga i govornicima regionalnih jezika

\begin{tabular}{|l|r|r|r|r|r|r|}
\hline & $\begin{array}{r}\text { BASKI- } \\
\text { JA } \\
(\%)\end{array}$ & $\begin{array}{r}\text { KATA- } \\
\text { LONIA } \\
(\%)\end{array}$ & $\begin{array}{r}\text { GALI- } \\
\text { SIJA } \\
(\%)\end{array}$ & $\begin{array}{r}\text { VALEN } \\
\text { SIJA } \\
(\%)\end{array}$ & $\begin{array}{r}\text { NAVA- } \\
\text { RA } \\
(\%)\end{array}$ & $\begin{array}{r}\text { BALE- } \\
\text { ARO } \\
(\%)\end{array}$ \\
\hline $\begin{array}{l}\text { Govornik } \\
\text { španskoga }\end{array}$ & 41.0 & 27.6 & 29.7 & 32.9 & 36.2 & 25.4 \\
\hline $\begin{array}{l}\text { Govornik } \\
\text { regionalnog } \\
\text { jezika }\end{array}$ & 41.0 & 51.5 & 51.7 & 52.0 & 40.6 & 57.5 \\
\hline $\begin{array}{l}\text { I jednoga i } \\
\text { drugog }\end{array}$ & 17.3 & 20.7 & 18.6 & 14.9 & 23.2 & 16.2 \\
\hline $\begin{array}{l}\text { Bez } \\
\text { odgovora }\end{array}$ & 0.6 & 0.3 & 0 & 0.2 & 0 & 0.9 \\
\hline
\end{tabular}

Još jedan faktor veoma bitan za uspješnu primjenu jezičke politike koja se sprovodi u autonomnim regijama, a koja za cilj ima promociju vlastitoga jezika jeste i bliskost regionalnih jezika s jedne, i kastiljanskoga s druge strane. Kastiljanski, katalonski i galisijski pripadaju romanskoj porodici jezika, tako da je govornicima tih jezika njihovo međusobno usvajanje znatno lakše u odnosu na baskijski, čija je sličnost s kastiljanskim veoma mala pa je i međusobno usvajanje tih jezika zbog toga znatno otežano.

Pored pomenutoga, politička volja regionalnih vlasti svakako je uticala na način na koji su se primjenjivali ti zakoni. Siguan, recimo, navodi, kao jedan od razloga za uspješnost primjene jezičke politike i činjenicu da je npr. u Kataloniji ili Baskiji, za razliku od drugih regija, od dobijanja autonomije na 
vlasti nacionalistička struja, što svakako doprinosi boljem poznavanju i upotrebi tih jezika.

$\mathrm{Na}$ osnovu rezultata istraživanja koja su sprovođena u autonomnim regijama moguće je uočiti da su jezici koji nemaju kooficijalan status (aranski, aragonski, bable) manje zaštićeni i da je čak prisutan pad njihova poznavanja, a da je poznavanje regionalnih, kooficijalnih jezika, zakonom zaštićenih, u stalnom porastu ali da su i dalje veoma male varijacije u odnosu na to koji jezik ispitanici smatraju glavnim jezikom.

\section{Zaključak}

Jezička politika, kao aktivnost koja ima za cilj promovisanje sistematske jezičke promjene u jednoj govornoj zajednici i njeno usmjerenje ka onome što se smatra „,dobro“ “ili „,korisno“, u Španiji vodi ka jezičkome pluralitetu. To pokazuje da se španska jezička situacija neprekidno mijenja kako u pravnome tako i u sociolingvističkome kontekstu, da će ona nastaviti da se mijenja ali da će ti jezici, kako se to i kroz njihov istorijski kontekst jasno vidi, nastaviti da koegzistiraju kao jezici u neprekidnome međusobnom kontaktu.

Takva proliferacija jezika svakako dodatno komplikuje funkcionisanje jezičke politike na državnome nivou. Uprkos tome, državna jezička politika, na osnovu Ustava iz 1978. definisana kao instrument za zaštitu svoje kulturne baštine (odnosno svoje višejezičnosti), svakako će nastaviti da štiti svoje jezike i time će doprinijeti pomenutoj jezičkoj proliferaciji usmjeravajući govornu zajednicu ka onome što se smatra „dobro“ i „korisno“.

\section{Bibliografija}

- Balboni, Paolo. 2003. La politica linguistica in Europa. Journal of American Association of Teachers of Italian. 10 str.

- Bargueño, Jesús. 2002. El mapa escondido: las lenguas de España. U: Boletín de la A.G.E.N. ${ }^{\circ}$ 34. Universitat de Lleida. str. 171-192.

- Bastardas Albert\&Emil Boix (eds). 1994. ¿Un estado una lengua? La organización política de la diversidad lingüística. Barcelona: Octaedro Universidad 167 str.

- Bossong Georg, de Aguilar González\& Francisco Báez (eds). 2000. Identidades lingüísticas en la España autonómica. Madrid: Iberoamericana. 189 str.

- Bratt Poulston, Christina. 2003.(a) Language Policies and Language Rights. U: Christina Bratt Poulston \& G. Richard Tucker (eds.) Sociolinguistics. The Essential Readings. Blackwell Publishing. str. 472-483. 
Istorijski, pravni i sociolingvistički kontekst jezičke situacije u Španiji

- Bratt Poulston, Christina. 2003. Linguistic Minorities and Language Policies. U: Christina Bratt Poulston \& G. Richard Tucker (eds.) Sociolinguistics. The Essential Readings. Blackwell Publishing. str. 395-407.

- Bugarski, Ranko. 1996. Jezik u društvu. Beograd: XX vek. 259 str.

- Bugarski, Ranko. 2001. Lica jezika. Sociolingvističke teme. Beograd: Biblioteka XX vek. 246 str.

- Bugarski, Ranko. 2005. Jezik u kontekstu. Beograd: Čigoja. 298 str.

- Calvet, Jean Louis. 1998. Language wars and linguistic politics. Oxford: Oxford University Press. 212 str.

- Climent-Ferrando, Vincent. 2005. L'origen i l'evolució argumentativa del secessionisme lingüístic valencià. Una anàlisi des de la transició fins a l'actualitat. Documents de treball 18. [www.ciemen.org/ mercator/pdf] (stranici pristupljeno u oktobru 2008.)

- Cooper, Robrt Leon. 1989. Language Planning and Social Change. Cambridge: Cambridge University Press. 216 str.

- Coucil of Europe. 2001.Common European Framework of Reference for Languages: Learning, teaching, assessment. Cambridge: Cambridge University Press.

- Council of Europe. 2006. Catalan in Spain (Catalonia) through the lenses of the European Charter for Regional or Minority Languages. Public Foundation for European Comparative Minority Research. 84 str.

- Crystal David. 1987. The Cambridge Encyclopedia of Language. Cambridge: Cambridge University Press.

- De Varennes, Fernand. 1997. To speak or not to speak. The Rights of Persons Belonging to Linguistic Minorities. Working Paper prepared for the UN Sub-Committee on the rights of minorities. [www.unesco.org/shs/most] (stranici pristupljeno u avgustu 2008.)

- Echenique Elizondo, María Teresa \&Juan Sánchez Méndez. 2005. Las lenguas de un Reino. Historia lingüística hispánica. Madrid: Gredos. 535 str.

- Euskeraren jarraipena III. 2001. La continuidad del euskera III Encuesta Sociolingüística de Euskal Herria. Publicación del Gobierno Vasco. 55 str.

- Filipović, Jelena. 2009. Moć reči. Ogledi iz kritičke sociolingvistike. Beograd: Zadužbina Andrejević. 173 str.

- García Mouton, Pilar. 2002. Lenguas y dialectos de España. Madrid: Arco. 61 str.

- Garrote Bernal, Gaspar. 1998. El conflicto lingüístico en España. Madrid: Universidad Europea de Madrid-CEES. 20 str. 
- Hornberger, Nancy H. 1998. Bilingual Education and EnglishOnly: A Language-Planning Framework. U: International Communication Gazette: 60 (1): 27-46.

- House, Juliane. 2003. English as a lingua franca: A threat to multilingualism. Journal of Sociolinguistics 7(4): 556-578.

- Kaplan, Robert B.\& Richard B. Baldauf. 1997. Language Planning: From Theory to Practice : Clevedon: Multilingual Matters Series. 394 str.

- Kloss, Heinz. 1966. Types of Multilingual Communities:A Discussion of ten variables.U: Sociological Inquiry. 36:135-145.

- Koeing, Matthias. 1999. Democratic governance in multicultural societies. Social conditions for the implementation of international human rights through multicultural policies. [www.unesco.org/shs/ most] (stranici pristupljeno u avgustu 2008.)

- Lodares, Juan Ramon. 2002. Lengua y Patria. Sobre el nacionalismo lingüístico en España. Madrid: Santillana Ediciones Generales. 214 str.

- López García. Angel. 1997. Tres actitudes ante un mismo problema: Cataluña, Galicia, País Vasco. U: Revista de antropología social. Madrid: Servicio de publicaciones Universidad Complutense. str. 87-104.

- Mackey, William F. 1994. La ecología de las sociedades plurilingües. U: Bastardas, Albert \& Emili Boix (eds.) ¿Un estado, una lengua? La organización política de la diversidad lingüística. str. 25-54. Barcelona: Octaedro.

- Marcos-Marín, Francisco A. 2004. Política Linguística y lenguas iberoeuropeas. U: Razón y Fe. 331, febrero 1995,139-159. [http://www.ucm.es/info/circulo/no18/marcos.htm] (stranici pristupljeno decembra 2005.)

- Moreno, Elda. 2001. La Charte Européenne des Langues Regionales ou Minoritaires: un instrument juridique au service du patrimoine linguistique européen. U: International Journal on Multicultural Societies (IJMS). UNESCO. 3 (1): 26-32.

- Nahir, Moshe.1984. Language Planning Goals: A Classification. U: Language Problems and Language Planning. 8.3: 294-327.

- Núñez Seixas, Xosé M. 1997. Idioma y nacionalismo en Galicia en el siglo XX: Un desencuentro histórico y algunos dilemas en el futuro. U: Revista de antropología social. Madrid: Servicio de publicaciones Universidad Complutense. str. 159-184.

- Petschen Verdaguer, Santiago. 1997. Los principios reguladores de las lenguas en la Europa Contemporánea. U: Revista de antropolo- 
Istorijski, pravni i sociolingvistički kontekst jezičke situacije u Španiji

gía social. Madrid: Servicio de publicaciones Universidad Complutense. str. 71-86.

- Ricento, Tomas. 2002. Historical and theoretical perspectives in language policy and planning. U: Journal of Sociolinguistics 4, (2): 196-213.

- Romeo, Joseph. 2003. Aplicación de la Carta Europea de Lenguas Regionales o Minoritarias en España. U: Año europeo de las lenguas. Situación jurídica del euskera en Navarra. Pamplona: Euskara Kultur Elkargoa. str. 33-51.

- Siguán, Miguel. 1988. Bilingual Education in Spain. U: Christina Bratt Paulston. International Handbook of Bilingualism and Bilingual Education. Greenwood Publishing Group. str. 449-473.

- Siguán, Miguel. 1992. España plurilingüe. Madrid: Alianza Universidad. 355 str.

- Siguán, Miguel. 1999. Conocimiento y uso de las lenguas en Espana: investigación sobre el conocimiento y uso de las lenguas cooficiales en las Comunidades Autónomas bilingües. Madrid: CIS. 78 str.

- Siguán, Miguel.2001. El español como lengua en contacto en España. II Congreso Internacional de la lengua española. Valladolid 2001. [http://congresosdelalengua.es/valladolid/default.htm], (stranici pristupljeno u oktobru 2006.)

- Siguan, Miquel. 2004. Jezici u Europi. Prevod: Janja Kelava. Zagreb: Školska knjiga. 217 str.

- Skutnabb-Kangas, Tove. 2002. Language policies and education: The role of education in destroying or supporting the world's linguistic diversity. Izlaganje na Svjetskom kongresu o jezičkoj politici, 16-20 aprila, 2002, organizator Linguapax Institute u saradnji sa Vladom Katalonije, Barselona, Španija. [http://www.linguapax. org/congres/plenaries/skutnabb.html.] (stranici pristupljeno u oktobru 2006.)

- Skutnabb-Kangas, Tove. 2005.Eangered linguistic and cultural diversity and endangered biodiversity:The role of educational linguistic human rights in diversity maintenance. Diyanrbair/Amed, 2025 march 2005. [www.pen-kurd.org/Diyarbakir-seminar/tove-endangered-linguistic-and-cultural-diversities.html.] (stranici prostupljeno u oktobru 2006.)

- Spolsky, Bernard. 1998. Sociolinguistics. Oxford: Oxford University Press. 128 str.

- Trudgill Peter. 2004. Glocalisation and the Ausbau sociolinguistics of modern Europe. U: Duszak, Anna \& Urszula Okulska (eds.). Speaking from the Margin: Global English from a European Per- 
spective. Polish Studies in English Language and Literature. Vol.11. Frankfurt, New York, Oxford: Peter Lang.

- Vernet i Llobet, Jaume. 1994. ¿Un estado, una lengua? La organización política de la diversidad lingüística. Barcelona: Octaedro universidad. 167 str.

- Vila Pujol, M. Rosa. 2005. El español en las comunidades de habla catalana. Curso del Instituto Cervantes: La influencia de lenguas en el ámbito hispano.

- Yule, George. 1998. El lenguaje. Cambridge: Cambridge University Press. 354 str.

- Zabaltza, Xabier. 2006. Una historia de las lenguas y los nacionalismos. Barcelona: Ed. Gedisa, S.A. 282 str

\section{Ivana KOVAČ-BARETT}

\section{HISTORICAL, LEGAL AND SOCIOLINGUISTIC CONTEXT OF THE LANGUAGE SITUATION IN SPAIN}

Multilingualism in the Spanish territory has rather a large story. Despite this fact, legal acknowledge of Multilingualism occurred in the year 1978, when the Spanish Constitution was established as the most important legal document for the protection of the different languages in Spain. Through history, and mainly due to circumstantial reasons, Castilian was imposed as the language of the Kingdom of Spain and as the very symbol of it, while other languages began to fall in disuse. Moreover, during some periods in their chronology, those regional or minority languages were forbidden and their usage limited to the family scope. In Spain, politics and linguistic situation are basically an inseparable tandem, therefore the legal acknowledge of the languages preceded that of the autonomous provinces to whom a specific power was transferred in order to promote and protect their own languages. A total of six provinces, in which territories languages such as Galician, Catalan, Basque, and Valencian are spoken, were allowed to protect their language by means of legal documents and acts.

This linguistic situation reflects a language policy focused in a strong protection of the languages which are considered a cultural patrimony of the State. Obviously the linguistic situation differs from one province to another. Such depends on many factors, among which some can be remarked: demographic indicators, main linguistic situation, the prestige of the regional language, similarity between the official language and the regional one, etc. 
Istorijski, pravni i sociolingvistički kontekst jezičke situacije u Španiji

Linguistic in-depth studies and statistics actually show that each day that pass, more and more persons understand and speak the regional languages, and that the situation in the Spanish territory could keep developing into a proliferation of the regional languages, a phenomenon that to this day is yet to be finished.

Key words: regional or minority language, cooficial language, language policy, language situation, multilingualism, bilinguism, language proliferation 

LINGUA MONTENEGRINA, god. III, br. 5, Cetinje, 2010.

Institut za crnogorski jezik i jezikoslovlje „Vojislav P. Nikčević“

UDK 811.163.4.09"18/19"

Izvorni naučni rad

\title{
Milorad NIKČEVIĆ (Osijek)
}

Filozofski fakultet Sveučilišta J. J. Strossmayera

Institut za crnogorski jezik i jezikoslovlje „Vojislav P. Nikčević“

\section{POEZIJA DRUGE POLOVINE XIX I POČETKA XX VIJEKA*}

\begin{abstract}
U ovome radu dat je sintetički pregled crnogorske poezije druge polovine XIX i početkom XX vijeka. Autor ukazuje na ključne poetičke, tipološke i žanrovske karakteristike epohe koja je nastupila nakon grandiozne pojave Petra II Petrovića Njegoša. Ovaj period obilježava snažan uticaj narodne književnosti a dominiraju pjesme prigodnog, rodoljubivog i didaktičkog karaktera, te epske junačke pjesme, javljaju se i drame u stihu, da bi se u sam smiraj ove epohe javili i prvi nagovještaji modernističkih tendencija. Najznačajnija i najuticajnija pjesnička figura ovog perioda je crnogorski knjaz/kralj Nikola I Petrović, dok se kao zanimljive pojave izdvajaju Stefan Perović Cuca i Jovan Sundečić.

Ključne riječi: istorija književnosti, romantizam, lirska poezija, epska poezija, drama u stihu, Stefan Perović Cuca, Jovan Sundečić, Nikola I Petrović
\end{abstract}

Pojava Petra II Petrovića Njegoša u crnogorskoj književnosti u prvoj polovini XIX vijeka nije značajna samo po tome što se slučajno poklapa $\mathrm{s}$ početkom novoga i neobično interesantnoga književnog razdoblja u našem stvaralaštvu, poznatoga pod imenom predromantizam i romantizam, već prije svega zato što je Njegoš predstavljao od samoga početka karakterističnu, snažnu i zaokruženu umjetničku personalnost. Gotovo je teško odrediti: je li se to Njegoš pojavio baš u najpogodnije istorijsko vrijeme koje je od njega, kao izuzetne i snažne poetske ličnosti, stvorilo vrhunskoga pisca i državnika, izbačilo ga na površinu, ili se on sâm kao stvaralac nametnuo tome burnom istorijskome vremenu, dao mu svoj specifični pečat, pjesnički univerzalni

* Ovaj rad odlomak je Istorije crnogorske književnosti od sredine XIX vijeka do 1918. godine. Priredio ga je i strukturi časopisa prilagodio Aleksandar Radoman. 
ram i postao tumačem i nosiocem novijeh umjetničkih tendencija koje su značile početak direktnoga povezivanja crnogorske književnosti s procesima evropske kulture. Njegoš je za kratko vrijeme prešao ubrzanim razvitkom književnosti sve etape opštega književnog razvoja što su prethodile trenutku kad se crnogorska književnost uključuje u svjetsku. ${ }^{1}$ No, bez obzira na takav svoj razvoj, on nikada nije kidao vezu s crnogorskom književnom tradicijom i narodnom poezijom. Ona je rodno tle njegovog genija, izvor njegove antejske snage. Iz nje je crpio građu $i$ u svom najvećem delu Gorski vijenac (1847). Njegošev stvaralački razvitak sa stanovišta odnosa prema narodnoj poeziji možemo označiti kao put od narodne pesme kao forme izraza do narodne pesme kao riznice tema i motiva $i$ umetničkih sredstava za izgrađivanje samostalnih pesničkih tvorevina. ${ }^{2}$

Njegovi poetski sljedbenici u drugoj polovini XIX vijeka pa sve do kraja toga stoljeća, a i kasnije do 1918. godine nijesu, nažalost, pošli tijem putevima: refleksivne, misaone, opšteljudske i intuitivne poetike, već su uveliko ostali zarobljenici mita crnogorske tradicije, usmene književnosti epskijeh narodnih pjesama i pjesama na narodnu, tvorevina koje je, i prije i poslije njega, ponajviše njegovala dinastija Petrovića u cijelom trajanju crnogorske državnosti. Takva poezija je bila i ostala, zajedno sa onom koja je prikupljana iz usmenoga narodnog areala, osnovni literarni žanr knjaza/kralja Nikole I i njegovijeh savremenika. Ona se prethodno snažno produkovala u ondašnjijem periodičnim i serijskijem publikacijama tokom XIX pa i u osvitu XX vijeka. U stvari, ona je predstavljala sponu između književnih publikacija koje pokazuju, pored ostalog, i njegovu u osnovi jedinstvenu idejno-estetsku umjetnost. Ona se javlja ne samo kao nit koja povezuje časopisnu periodiku u toku cijelog razdoblja, već i kao nedjeljivi dio ukupne umjetničke pjesničke riječi u Crnoj Gori - poezije objavljene u posebnim izdanjima i u političkim listovima. ${ }^{3}$ I po brojnosti pjesnika i po širini i zamahu književne produkcije, poezija je u tome razdoblju bila kvantativno veoma bogata. Stiče se utisak da su skoro svi školovani i pismeni ljudi u klasičnoj Crnoj Gori nastojali da se izraze različitijem poetskim formama, epskijem deseteračkim pjesmama, pjesmama na narodnu, te drugijem sadržajima i oblicima poetskog osmeračkog izraza kako bi putem njih saopštili javnosti svoja programska i ideološka opredjeljenja; kako bi opjevali svoje prigodne, pretežno dvorske trenutke, ali

\footnotetext{
${ }^{1}$ Г. Д. Гачов, Ускоренное развитие литературы, Москва, 1964.

2 Jovan Deretić, Kompozicija Gorskog vijenca, Zavod za izdavanje udžbenika SRS, Beograd, 1969, 28.

${ }^{3}$ Radivoje Šuković, „Umjetnička poezija u književnim publikacijama“, u: Književna periodika u Crnoj Gori (1835-1914). Književnoistorijska monografija, NIO Univerzitetska riječ, Titograd, 1986, 263.
} 
Poezija druge polovine XIX i početka XX vijeka

i vrijeme stalnijeh borbi u lancu neprekidnih ratova i pogibija; kako bi ostavili spomene dobra i zla, ocrtali crnogorske junake, njihove borbene podvige i viteška pregnuća. I u pjesmama na narodnu oni su ponekad nastojali da izraze sebe, svoje bujne romantične emocije, preokupacije, poglede i zgode, polete, ushićenja i zanose prema slobodi, a osobito pohvale slovenstvu koje je sve više dobijalo konture osmišljenijeh ideoloških i poetskijeh planova, koncepcija i programa. Takav poetski senzibilitet osobito je prisutan 60-ijeh i 70-ih godina XIX vijeka, pa je od svijeh književnih vrsta u tome vremenu ponajviše njegovana lirska i lirsko-epska pjesma, a tu i tamo su ponekad stvarane klasične deseteračke pjesme i one poetske vrste iz Njegoševa ranog perioda. Tek pod kraj XIX vijeka u periodičnijem publikacijama i u posebnim izdanjima, javljaju se stihovane epske strukture u kojijema se opjevava prošlost $\mathrm{Cr}$ ne Gore, njezina istorijska perspektiva koju stvaraoci pretaču u posebno epsko ruho, u epske pjesme, razvučene epove i narativne spjevove, te ponekad u specifične stihovane drame - dakle, u reprezentativne pjesničke žanrove koji su izražavali osnovno poetsko raspoloženje crnogorske sredine onoga vremena. Stoga cjelokupnu lirsku produkciju crnogorske poezije u XIX i XX vijeku možemo tematski razvrstati u nekoliko poetsko-tematskijeh ciklusa.

Prvi poetski ciklus je najopsežniji i obuhvata prigodnu tematiku. Takva je lirska produkcija objavljivana pretežno u periodičnijem publikacijama, a samo su pojedini stvaroci uspjeli pripremiti i izdati svoja zasebna uknjižena izdanja poezije. Već 70-ijeh godina XIX stoljeća pojavilo se na Cetinju nekoliko zbirki rodoljubnijeh pjesama. Prva je zbirka Rista Milića pod naslovom Serbobranke (1870), a 1889. godine omiljeni izvanjac, Simo Matavulj, sakupio je u posebnome izboru lirsko pjesništvo knjaza Nikole I Petrovića. ${ }^{4}$ Iste godine i pjesnik Đuro T. Perović objavljuje na Cetinju zbirku poezije pod nazivom Hercegovka. Sredinom 90-ijeh godina, tačnije 1894, objavljena je i zbirka didaktično-poučne, prigodne i primijenjene poezije knjaza Nikole, pod naslovom Nova kola, a te godine pojavilo se i njegovo drugo izdanje Skupljenijeh pjesama. Svega dvije godine nakon toga javiće se i intimnom poezijom nikšićki pjesnik Novica Nikolić sa zbirkom Uzdisaji (1896). Tako je lirska poezija prigodnoga i rodoljubnog karaktera u Crnoj Gori sve do kraja 80-ijeh godina XIX vijeka bila dominantna poetska vrsta, dok su socijalne, ljubave, misaone, humorističke, satiričke pjesme, kao i đečija poezija, bile sporadične i veoma usamljene. Prema obimu, prvo mjesto u periodici i u zasebnijem zbirkama, zauzimale su prigodne i patriotske lirske pjesme, a iza njih usputno se afirmisala i intimna lirska poezija: elegija i samo nekoliko usamljenijeh ljubavnih pjesama. Prema širokome arsenalu svoga motivskoga, jezičkog i

\footnotetext{
${ }^{4}$ Pjesme Knjaza Nikole. Sakupio Simo Matavulj. Na Cetinju. U Državnoj štampa-
} riji 1889, 91 str. + 5 strana „Primjedbe“. 
formalnog izraza, cijelo to pjesništvo pripadalo je stilskoj formaciji predromantizma i romantizma, a samo su usamljeni primjeri bili vezani za pjesnički realizam i novije poetske sfere i tendencije.

Prigodno pjesništvo je poniklo u krilu same cetinjske književne škole, poetskoj klimi koju je diktirao ne samo knjaz/kralj Nikola već i cijela dvorska svita oko njega. Ono je i svojijem sadržajem usmjereno pretežno na cetinjski Dvor, na kultivisanje dvorske svite. Dakle, svojijem je sadržajem, tematikom i motivikom ta poezija vezana za sve prigodne i svečane trenutke dinastije Petrović. U užem smislu i žanrovskom određenju, to su stihovane prigodnice koje su objavljivane u središnjijem periodičnim publikacijama, a zatijem preštampavane u zasebne zbirke poezije kako bi i tim putem receptivno što jače prodrle do širokijeh narodnih masa. Pjevalo se u slavu imendana i rođendana Nikole I Petrovića, jubilarnim godišnjicama njegove vladavine, godišnjicama bračnog života knjaževskog bračnog para, rođendanima knjaževih sinova i kćeri, vjeridbama i vjenčanjima crnogorskih princeza, rođendanima i značajnim godišnjicama crnogorskog prestolonasljednika Danila, zatim svečanim danima, blagdanima na crnogorskom dvoru $u^{5}$ i slično. I sami naslovi takvijeh pjesama zbore o kakvoj poeziji i tematici je riječ. Uz sve te poetski pompezno udešene prigodne i intimne ushite, prigodno-pohvalne emocije, stihovane tirade i tugovanke, prigodnice su pratile i svakodnevna zbivanja radosti, ali i tužne dnevi koje su potresale iznenadne smrti Knjaževe uže porodice kao i one ličnosti koje su bile bliske sa Dvorom. Nerijetko su se javljale pjesme istoga sadržaja koje su bile usmjerene na ličnosti iz kulturnoga i političkog života crnogorske prijestonice i širega crnogorskog miljea. Bili su to najčešće stihovi onijeh stvaralaca što su tokom cijeloga svog stvaralačkog puta ostali na marginama tekućega ideološkog stvaralaštva, upravo onih pjesnika kojijema je poezija bila samo romantični mladalački krik, uvod u kasnija mnogo bolja ostvarenja i iz drugijeh žanrovskih oblika (Stefan Perović-Cuca, knjaz/kralj Nikola, Jovan Sundečić, Marko Miljanov, Borislav Sl. Minić i drugi); ili pak pjesništvo onijeh upornih stvaralaca koji su u svome dugom životu i aktivnome pisanju ostajali do kraja na literarnijem pozicijama s kojih su i krenuli: kao neumorni propagatori ideologije slovenstva ili nekijeh drugih političkijeh i ideoloških opcija.

Udaljivši se tematski od usmene narodne pjesme, oživljavajući moralno-prigodnu atmosferu, unoseći u pjesme osmerce i standardnu epitetoniku, mršavu refleksiju i metaforiku, pjesnici su se u svojijem tvorevinama očitovali kao stvaraoci stila i izraza tzv. objektivne lirike. Dakle, vratili su se onoj istoj tematici koju je ranije njegovao Njegoš u svojoj ranoj razvojnoj i drugoj stvaralačkoj fazi, kao i neki srpski i ruski pjesnici neoklasicističke i prosvjeti-

\footnotetext{
${ }^{5}$ Radivoje Šuković, Isto, 265.
} 
Poezija druge polovine XIX i početka XX vijeka

teljske orijentacije. Udaljivši se na planu jezika i stila od epske narodne pjesme, oni su sve više naglašenom tematikom ponirali u didaktiku, pouku, retoriku i razgovornu intonaciju. Te su tvorevine po svojoj estetskoj vrijednosti veoma slabe, ponekad i beznačajne. One se ne nameću ni estetskijem učinkom, niti funkcionalnim sredstvima pjesničkog jezika, već samo motivskijem i tematskim raznovrsnijem repertoarom. Glavni cilj takvih pjesnika bio je onaj isti kao i svojevremeno kod Njegoša kad je pjevao Odu Knjazu Aleksandru Nikolajeveću Galicinu i mnogobrojnijem drugim vladarima i dostojanstvenicima $^{6}$ - dakle, da se privuče pažnja knjaza/kralja Nikole i njegovijeh uglednika. Crnogorski pjesnici 60-ijeh godina XIX vijeka, u već uveliko izmijenjenim okolnostima od onijeh u kojima je svojevremeno Njegoš kao pustinjak cetinjski pjevao ode u slavu visokijeh evropskih ličnosti političkoga i kulturnog života, u pjesništvu ove vrste ostajali su u uskijem okvirima svoje svakodnevne zbilje, vezivali ih za dvorski život, pa je pjesništvo i u tom smislu ostalo nepromijenjeno pola vijeka kasnije. ${ }^{7}$

Reprezentativni predstavnik takve poezije bio je Jovan Sundečić. On je svojom uredničkom politikom u Orliću i Crnogorki pjevao i kultivisao ponajviše naznačenu prigodnu poeziju. Bio je Knjažev sekretar, pa je u svoje prigodno pjesništvo nastojao pretočiti sva zbivanja i događaje oko crnogorskoga Dvora. Uz to, on je ideloški oblikovao i pjesništvo i književnu periodiku i čitalaštvo, odgajao ga onako kako je diktiralo vrijeme, a u tome mu se pridružuje i sâm knjaz/kralj Nikola. Iako se svojijem prvim stihovima Sundečić javio veoma rano, on je neumorno pisao tradicionalističke stihove skoro sve do smrti (1900). No, ipak, po idejnosti i sadržajnom tkivu svoje poezije, ostao je tipični predstavnik zakašnjeloga klasiciste i romantičara kojega je prevladalo vrijeme, bez obzira na to što je sve do kraja XIX vijeka ostao upornijem pjesnikom pišući pretežno prigodnu, rodoljubnu i ljubavnu poeziji, a ponekad i intimnu liriku. U svome dugogodišnjem pjesnikovanju nije ni motivima ni formom otišao dalje od svojijeh uzora - Njegoša iz rane stvaralačke faze i pjesnika srpskog klasicizma Lukijana Mušickog i nekijeh srpskih i ruskijeh pjesnika te samoga knjaza/kralja Nikole. Dovoljno je navesti samo dvije njegove pjesme kako bi se već po naslovima ośetila Sundečićeva idejna orijentacija: „Prilikom presrećnog rođenja knježevne Zorke Petrović Njegoš, prvorodne kćeri knjaza Nikole i knjeginje Milene“; „O svečanom krštenju knježevne Marije Petrović Njegoš na Cetinju dne 17. marta 1869 g.“. Ove pjesme, kao i sve druge Sundečićeve tvorevine u Orliću i drugijem periodičnim publikacijama, bile su neka vrsta hvalospjeva i žalopojki u stihovima, pisanih

${ }^{6}$ Dr Vojislav Nikčević, Mladi Njegoš. Pjesnikovi putevi ka sintezi, Obod, Cetinje, 391.

${ }^{7}$ Radivoje Šuković, Isto, 265. 
u duhu i stilu ondašnjih crnogorskih zdravica, napojnica ili pak tužbalica. ${ }^{8}$ Prigodničarstvo je u Crnoj Gori ostalo kao najistaknutiji pjesnički manir i trajalo je znatno duže nego kod kontaktnijeh naroda. Ostalo je kao dominantna poetska vrsta sve do početka XX vijeka kad će ga potisnuti urednici Književnog lista i osobito školovani urednici i senzibilniji stvaraoci modernoga časopisa Dan.

Slične pjesme po romantičarskoj tematici i tonu pisao je u istome periodu i knjaz/kralj Nikola te gotovo svi drugi pjesnici, saradnici cetinjskijeh časopisa. Od tih saradnika treba posebno istaći Živka Dragovića koji piše pjesmu: „Pozdrav njegovom visočanstvu knjazu našljedniku prilikom smrtnog prelaska u novi dvor" u Luči, 1895. godine, i srpskoga romantičarskog pjesnika Laza Kostića koji se javio pjesmom: „Njegovom carskom visočanstvu Stani Nikolajevnoj, vojvodkinji lajhtenberškoj, knjeginji romanovskoj u spomenicu“" u Novoj Zeti, 1891, kojom je odstupio od ustaljenijeh pjesničkih rekvizita, te prožeo tvorevinu poetskijem vizijama o snazi suprotnosti: kontrastom vjeridbe i vjenčanja Knjaževe šćeri sa ruskim plemićem. U njoj se srio srećan spoj sjevera i juga, sokola sa sjevernih gora $i$ sunčane južnjačke odive. ${ }^{9} \mathrm{Uz}$ ovu pjesmu možemo pribrojiti i Kostićevu „Tužbalicu Crnogorku prilikom smrti njene svjetlosti knjaginjice Marije“ u Crnogorki za 1885. godinu. Sadržajem, tonom i dikcijom naše tužbalice, on je ovđe isticao moralne vrline i ljepote đevojačke: E ti para neimaše / Oh, od boga! / Tvoga oka i pogleda / Naš uglede.

Drugi poetsko-tematski ciklus ovoga vremena čine epske junačke pjesme nastale u predasima bitaka ili neposreno poslije njih. Te pjesme nastaju pod presijom ratnijeh zbivanja i uzavrelih emocija, ali ovoga puta u duhu narodnog pjesništva. U njima je prevlast stihotvorstva po obrascima guslarskog deseterca i osmerca. Ujedno je takvo pjesništvo bilo usmjereno tendencijom i ciljem na širenje istine: svjedočilo je o pojedinijem događajima, pobjedama i istorijskim trenucima i zbivanjima. Takav je epski spjev vojvode Mirka Petrovića Njegoša Junački spomenik kojega je ovaj politički strateg i poetski bard objavio na Cetinju 1895. godine. Ovome ciklusu pripadaju i lirske pjesme koje su motivisane tijem istim trenucima. Iz njih se probija duh borbenoga raspoloženja, nepobjedive i nepokorene Crne Gore. Po ugledu na zmajovanke, pjesme snažnoga iskrenog ośećanja i novoga poetskog izraza, pjevao je i knjaz/kralj Nikola o Grahovskoj bici u epskom desetercu „Boj na Grahovcu 1858. godine“, tvorevini koju je objavio u novosadskoj Danici (1863). Pjesma je tipičan primjer versifikacije hronike o jednom događaju u kojoj se

\footnotetext{
${ }^{8}$ Radivoje Šuković, Isto, 266.

${ }^{9}$ Isto, 269.
} 
Poezija druge polovine XIX i početka XX vijeka

nadahnuto emocionalno i poetski toplo iskazuje vizija bitke, u trenutku kad se njen hod prenosi u srce mladog pjesnika. ${ }^{10}$

Početkom 90-ijeh godina u crnogorskom pjesništvu se stidljivo mijenja ne samo tematika, već i poetski izraz, a i sama forma i struktura pjesme. U taj treći poetsko-tematski ciklus naše poezije ubrajaju se novi sastavi u formi poema, drama u stihu i onijeh mikro i makrostruktura koje se označavaju kao jednostavni oblici, poput legendi, patriotskijeh pokličnica i zvaničnih pohvalnica. U formi usmene pjesme probijaju se neki novi disonantni tonovi, a mijenja se i motivika u koju se sve više unosi funkcionalnija refleksija i pokušava se odgovoriti na pitanje: koji je smisao poezije? Ti su tonovi, izgleda, nastali pod uplivom modernijeh poetskih strujanja srpskoga i ruskog pjesništva, prije svega Vojislava Ilića i veoma omiljenoga ruskog pjesnika Nadsona. To su, u stvari, prvi proplamsaji i začeci moderne, te nagovještaji parnasovske, impresionističke i simbolističke poetike. Stoga nije čudno da se u to vrijeme u crnogorskoj periodici probijaju pjesnici mostarskoga književnog kruga koji su vatreno zagovarali u svojijem pjesmama srpstvo i misiju Crne Gore na Balkanu. Upravo su se oni u najvažnijem dijelu svoga pjesništva nalazili $u$ procesu traganja za smislom poezije, iskazujući te svoje dileme $i$ nevjerice $u$ cetinjskoj Luči. ${ }^{11}$ Refleksi takvijeh poetskih ośećaja dolazili su prije svega iz kruga pjesnika koji su bili saradnici sarajevske Nade, ponajprije Alekse Šantića koji je u pjesmama „Pjesniku“ i „Zarobljeni pjesnik“ (objavljene u Luči) zagovarao dalekosežnu i avangardnu, modernističku misao da je pjesnik mesija i prorok, a pjesma je stanje duha i poetska ekstaza stvaraoca. Upravo u to vrijeme cetinjska Luča sve više objavljuje retoričke i programske stihove Vojislava Ilića i crnogorskoga pjesnika Novice Nikolića koji pod uplivom Ilićevijeh stihova piše perifrastičnu pjesmu „Na umrlom polju uvenula trava“.

Da ovo nijesu usamljeni slučajevi nove modernističke poetike domalo će posvjedočiti i drugi crnogorski pjesnici: Simo Šobajić, Nikola St. Ljubiša i Radomir Krivokapić Orlinski. Nikola St. Ljubiša upravo tada prevodi i ruske moderniste, osobito ruske pripovjedače i pjesnika Nadsona koji je izražavao rezignirane, sumorne, jesenske teme, teme smrti i rastanka sa životom. To su, u stvari, bili pjesnici koji su u crnogorskoj književnosti krajem XIX i u osvitu $\mathrm{XX}$ vijeka stidljivo utirali modernističke pravce, a svoje su predstavnike našli u misaonijem tvorevinama Filipa Kovačevića, Trifuna Đukića, Čedomira Pavića (Nestora Žučnog) i drugijeh. Tek s pojavom časopisa Dan, pred same Balkanske ratove, ovaj isti ton crnogorske modernističke poezije će se nastaviti u misaonijem, pejzažnim i senzibilnijem pjesmama Dušana S. Đukića, Nikole Škerovića, Pera Šoća i Milorada Petrovića. Upravo će toj novoj gene-

${ }^{10}$ Radivoje Šuković, Isto.

${ }^{11}$ Isto, 273. 
raciji uspjeti da donekle uhvati korak s modernom: bliskijem dodirima i strujanjima naših pjesnika s evropskijem impresionizmom i simbolizmom. Razdoblje realizma koje u crnogorskoj književnosti traje veoma kratko, dalo je samo skromna poetska dostignuća jer je ta stilska formacija bila mnogo više okrenuta narodnjaštvu i pripovjednoj folklornoj prozi. Svi ovi tokovi i pojave biće dodatno osvijetljeni u panoramskom pregledu crnogorskijeh pjesnika druge polovine XIX i u prvim decenijama XX vijeka.

\section{PJESNIŠTVO EPSKOGA NARODNOG RUHA}

U dijahroniji crnogorske književnosti ne mogu se zaobići ni oni stvaraoci koji su čvrsto ostali ukorijenjeni u usmenu epsku tradiciju u postnjegoševskom razdoblju. Njihovo pjesništvo, kao i kulturno i političko djelovanje, može poslužiti samo kao model za uočavanje polivalentnosti i višeslojnosti književnog razvoja u nacionalnoj crnogorskoj književnosti, i to na dva nivoa: u okviru pojedinačne, izdvojene matične tradicije i u njihovu sučeljavanju s ostalijem nacionalnim i evropskijem književnim pojavama toga vremena. $\mathrm{U}$ crnogorskoj književnosti, to jest njezinome sinhronijskom razvoju, pojava ovakvijeh pisaca značajna je samo po tome što svjedoči o neujednačenome stupnju razvoja unutar crnogorske literature u drugoj polovini XIX i u prvijem decenijama XX vijeka. Do sada su takve književne pojave najčešće prećutkivane; prelazilo se preko njih kao preko nečega što treba potisnuti, ,sakriti“, te je književnoistorijski mozaik našega poznavanja vlastite književnosti i kulturne istorije i za mnoge današnje književne znalce ostao s puno bijelijeh mjesta, neispunjen i prekriven velom zaborava. Neke od njih su prvi put sintetički obradili, u opštim naznakama i književnoistorijskijem obrisima, Petar M. Božović, ${ }^{12}$ Radoslav Rotković ${ }^{13}$ i Branko Banjević. ${ }^{14} \mathrm{U}$ tekstovima ovijeh autora prvi je put odmjereno i koncizno u znatnoj mjeri kritički valorizovano i pjesništvo ove epohe.

\section{Savo M. Martinović (1808-1896)}

Savo Martinović nije bio sistematski školovan, ali je bio čovjek velikoga životnog iskustva koje je sticao u blizini Petra II Petrovića Njegoša jer je pripadao njegovoj gvardiji, a u vrijeme knjaza Danila bio je starješina njego-

\footnotetext{
${ }^{12}$ Petar M. Božović, Antologija crnogorskih pjesnika i pripovjedača, Štamparija Ujedinjenje, Podgorica 1927.

${ }_{13}$ Dr Radoslav Rotković, „Pregled crnogorske literature. Od najstarijih vremena do 1918“, Stvaranje, br. 4, Titograd, 1979.

${ }^{14}$ Pleme za oblakom (Crnogorska poezija druge polovine XIX vijeka), izbor, predgovor i pogovor: Branko Banjević, Grafički zavod, Biblioteka Luča, Titograd, 1973. 
Poezija druge polovine XIX i početka XX vijeka

ve garde. Zbog nemilosti knjaza Nikole I Petrovića otputovao je u Austriju, te je potom boravio i u Zadru i Zagrebu. Potonje dane svoje starosti proživio je u Podgorici. Iako nesistematski školovan, Savo Martinović je bio marljivi skupljač narodne usmene poezije. Iza njega je ostalo preko četrdeset pjesama koje su uvrštene u IX knjigu Vukovih Srpskih narodnih pjesama 1902. godine. Bez obzira na to što su te pjesme po svojoj strukturi i sadržaju epske tvorevine, one su dijelom impersonalne $\mathrm{i}$ ispjevane $\mathrm{u}$ duhu i tonalitetu narodnijeh pjesma. Vuk Karadžić je S. Martinovića smatrao jednijem od svojih marljivijeh sakupljača i pomagača iz južnih krajeva. U svojijem pjesmama se najviše dodirivao novijih crnogorskih ratovanja s Turcima te u njima ima mnogo više prepričane istorije, fakata i detalja nego prave poezije. Svojom epskom naracijom i jezikom ističe se pjesma „Pogibija Bega Mušovića“ koju je i Petar M. Božović uvrstio u svoju Antologiju kao uspjeliji epski poetski sastav. $^{15}$

\section{Mirko Petrović \\ (1820-1867)}

Po poetskoj vokaciji i ukupnome stvaralačkom učinku u crnogorskoj književnosti, Mirko Petrović i nije bio pravi pjesnik. On je u svojem dobu bio više vodeći politički i društveni čelnik iz znamenite dinastije Petrovića. Bio je brat knjaza Danila, a otac Nikole I Petrovića Njegoša, kasnijeg knjaza i kralja Crne Gore i svestranog književnika. Nosio je laskavu titulu zetskog vojvode i bio glavni vojni strateg u crnogorskijem oslobodilačkim okršajima od 1852. do 1863. godišta. Zvali su ga laskavo i veliki vojvoda, jer je uz svoga brata, bio glavni vojni pregalac svijeh bitaka i pobjeda u znamenitijem istorijskim prekretnicama i događajima u Crnoj Gori, naročito na Grahovu 1858. Sa knjazom Danilom bio je ideolog, strateg, sudionik i izvršitelj i u ratovima 1877-1888. godine.

Stekao je u svoje vrijeme afirmaciju kao narodni pjesnik, ali ne pjesnik anonimus već daroviti pjesnički stvaralac tipa narodnijeh pjesnika-pjevača: Starca Milije, Filipa Višnjića, Starca Raška, Tešana (Gavrilovića) Podrugovića i Stojana Lomovića, koji takođe potiču sa istoga dinarskog areala Crne Gore. Iz njihovijeh pjesama izbija talent za dramsku kompoziciju i psihološko modeliranje likova, pa je Starca Miliju Vladan Nedić upravo zbog toga nazvao pjesnikom tragične ljudske usamljenosti. ${ }^{16}$ Oni pripadaju pjesnicima usamljenijeh istorijskih predjela u kojima porodične (istorijske - M. N.) drame dobijaju neobične psihološke razmjere. ${ }^{17} \mathrm{Na}$ tragu toga i takvog usmeno-

\footnotetext{
${ }^{15}$ Petar M. Božović, Isto.

${ }^{16}$ Vladan Nedić, Vukovi pevači, Rad, Beograd, 1984, 105.

${ }^{17}$ Vojislav P. Nikčević, „Filip Višnjić je etnički i jezički Crnogorac“, Lučindan,
} 
ga pjesništva sačinio je i Mirko Petrović svoju zbirku pjesama Junački spomenik 1864. godine. Uklopljen u sivilo tadašnjega epskog guslarskoga deseterca, na početku 60-ijeh godina XIX vijeka, Mirko Petrović je iznenadio ciklusom od šesnaest pjesničkijeh cjelina. To su pjesme o ratovanju Crnogoraca i Turaka počevši od 1852. godine. One su najčešće u epsko-lirskome i donekle refleksivnom opisu fiksirale detalje crnogorskijeh bojeva i junaka, ispreplićući istorijske sudbine tih ljudi sa slikama crnogorskoga podneblja. Po ugledu na Njegoševu ranu poeziju i poetiku usmene epske pjesme, Mirko Petrović ređa asocijativne nizove ratnika ističući njihove podvige i moralna pregnuća. On se deklamatorskijem izricanjem svojih patriotskijeh ośećaja i njihovom patetičnom stihovanom intonacijom, ipak nije uspio dublje odvojiti od naracije i versifikacije usmene epske poezije. U potpunosti se može prihvatiti estetski sud Branka Banjevića koji kaže da je pjesnik M. Petrović značajan jer je jedan od posljednjih takozvanih narodnih pjesnika u vrijeme kad već imamo individualnu poeziju... Vojvoda Mirko je bio višestruko obdaren čovjek, ali kao pjesnik nije izrastao u neku individualnost (...) Njegovo djelo je (...) svjedok sporog kretanja Crne Gore u nove oblike, sporog opšteg prevazilaženja tradicije. ${ }^{18}$

I drugi pjesnici pjevali su u istom narodnom ruhu i versifikaciji usmene epske pjesme. Oni slijede sličnu guslarsku tradiciju. Ovo ponajviše što su bili bliski saradnici i prijatelji sakupljača usmenoga blaga, Vuka StefanovićaKaradžića. Nihov površni deseterac nije više mogao da dâ one umjetničke vrijednosti kakve nam je sačuvala narodna poezija, glačana i dorađivana decenijama i stoljećima. ${ }^{19}$

\section{Đuko Sredanović (1813-1864), Nikola Bastać (oko 1848-1898), Ilija Hajduković (1858-1916), Maksim Šobajić (1836-1917)}

$\mathrm{Na}$ tradicionalističku poeziju, tek kao saputnicu glavnijeh crnogorskih poetskih obilježja 70-ijeh i 80-ih godina XIX vijeka, nastavljaju se i neki pjesnici čije stvaralaštvo ne prelazi prag književnoistorijskoga podatka. Takvi su Đuko Sredanović, Nikola Bastać, Ilija Hajduković i donekle Maksim Šobajić. Ostavši zaprepašćeni i uznemireni pod presijom oslobodilačkijeh ratova javili su se pjesničkim tvorevinama kao tipični predstavnici tradicionalnoga epskog pjesništva (koje je kod drugih naroda već uveliko bilo prevladalo vrijeme). Oni su još uvijek uporno i monotono pjevali shematizovane desetera-

br. 16, na Petrovdan, Cetinje, 2005, 118-120.

${ }^{18}$ Branko Banjević, „Crnogorska poezija druge polovine XIX vijeka“, predgovor knjizi Pleme za oblakom. Crnogorska poezija druge polovine XIX vijeka, Grafički zavod, Biblioteka Luča, Titograd, 1973, 18.

${ }^{19}$ Dr Radoslav Rotković, Isto, 629. 
Poezija druge polovine XIX i početka XX vijeka

čke stihove. Takve su dijelom i pjesme Maksima Šobajića u zbirci Slavenska sloga (1880). Tu su unešene pjesme o ratovanju Rusa i Turaka 1875-1878. godine. Dovoljno je iz te zbirke navesti prve stihove iz pjesme „Zauzeće planine" kako bi se naslutio njegov tradicionalni i epski poetski nerv: Procvilio sužanj u tamnici/ U Plijevni u zemlji bugarskoj./ Ko je sužanj, čija li tamnica? / Carev sužanj, careva tamnica, / Sužanj jedan mušir Osman paša/ A tamnica krvava Plijevna,/ Jera su ga Rusi opkolili... U istome takvom žanru i tonu ispjevane su sve pjesme Maksima Šobajića. U Novom Sadu štampana mu je i zbirka Osveta kosovska (1879). Njegovi saputnici i prijatelji A. Luburić i I. Kavaja štampali su mu zbirku Nevesinjski ustanak 1925. godine, nakon pjesnikove smrti. Iako je Šobajić pjevao o savremenijem zbivanjima i događajima, njegova je poetika ostala u stilskim i jezičkijem obrascima epske usmene poezije. Otuda ona ima istorijske vrijednosti, a malo pravijeh poetskih uzleta. On je pjesnik sa svim vrlinama i manama svog vremena zaključuje njegov antologičar Petar Božović. ${ }^{20}$

\section{Jovan Magovčević (1876-1941) Mićun Pavićević (1879-1949)}

$\mathrm{Na}$ istoj poetskoj okomici našli su se i Jovan Magovčević i Mićun Pavićević. Oni su bili deklamatorski, guslarski pjesnici, koji su događaje i zbivanja opjevali deseteračkijem stihovima i patetičnom epskom intonacijom. O Jovanu Magovčeviću se zna da je bio iz Pješivaca, da je pohađao pravo u Beogradu, da je po okončanju Prvog svjetskog rata bio narodni poslanik i da je potonju deceniju svoga života proveo u Prištini kao advokat. Njegov poetski opus nije veliki. Napisao je svega nekoliko epskijeh pjesama koje je prilagođavao guslarskom načinu pjevanja, tonu i izrazu. Petar M. Božović u svoju Antologiju crnogorskih pjesnika i pripovjedača uvrstio je samo jedan insert iz njegove pjesme „Boj na Kumanovu“.

Krajem prve i početkom druge decenije XX vijeka, uz Sundečića kao najplodnijega pjesnika, najviše objavljuje poeziju, anegdotsku prozu i političke spise Mićun M. Pavićević. U to vrijeme objavljuje prigodnu i didaktičku liriku u brojnijem zbirkama: Brđanke (1907), Gorske ruže (1909), Crnogorcu (1910), Oslobođenje (1912), Pjesme krvi i slobode (1913), Srpsko-Bugarski rat (1913), Kroz život (1913), Stari motivi, knj. I-III (1912. i 1913), Od Cetinja do Njujorka (1916), Krvavim poljanama (1917), Iz memljivih dana (1917), Razmišljanja o Božiću (1917), Apoteoza besmrtnicima (1917), Srbija i Crna Gora (1917), Što ko sanja (1917), Portret Banovca Milana (1917), Planinske ruže (1918) (na engleskom), Prekomorke, Pogrebna zvona (1918), Pjesma besmrtnicima (1918) (na engleskom), Nejski vijenac (1918), Novi

${ }^{20}$ Petar M. Božović, Isto, 36. 
motivi knj. I-II, Karađorđe (1918), Svjetski rat (1922), Naši dani i megdani (1922), Božić u tuđini (1923), Ognjenim stazama (1924), Jedno pismo (politički memorandum) (1924), Kralj-Nikolini kaprisi (memoari) (1927). Neki ga kritičari smatraju najplodnijim i najboljijem crnogorskim pjesnikom poslije Njegoša čije je djelo od književnoistorijske kritike ostalo sve do danas neproučeno i nevalorizovano. Razlog takvome zaobilaženju je bio dvojak: prvo, što je Mićun Pavićević od 1910. bio jedan od žestokijeh oponenata knjaza/kralja Nikole I Petrovića i to prema njegovoj politici i prema njegovom književnom djelu; i drugo, što je on svoje brojne poetske i anegdotske tvorevine objavljivao u domaćijem dnevnim i periodičnijem publikacijama na cijelome prostoru bivše Jugoslavije i u mnogijem stranim publikacijama. Dovoljno je bačiti pogled na bibliografiju radova Mićuna Pavićevića, pa se sa lakoćom može utvrditi da se radi o čovjeku čiji je opus ostao razasut, neproučen i receptivno nepribližen savremenoj književnoj istoriografiji. ${ }^{21} \mathrm{Nje}-$ gov prvi antoligičar, prof. Petar M. Božović, se čudio: zašto se poetski i anegdotski opus Mićuna Pavićevića u njegovo vrijeme prećutkivao? Na svoje pitanje implicite je odgovorio: Strana je kritika o njemu nešto i progovorila, a to je nešto objektvno i valja zapamtiti, sve je to u korist g. Pavićevića. A što je s nama iz Pavićevićeve okoline?! I mi smo ga kritikovali, ali kako?! U najviše slučajeva napamet, bez čitanja a kamo li poznavanja njegova djela. Takvom su kritikom negativni duhovi osuđivali njegov rad mnogih njegovih pjesama, on je kroz sve vreme visoko stajao iznad takve kritike. ${ }^{22}$

Premda njegovo književno raznovrsno djelo nije zaista iščitano u cjelosti, interpretativno raščlanjeno i vrednovano, ipak možemo utvrditi da je on pjesnik, anegdotičar i pripovjedač koji je snagom svoga lirskog talenta i širinom poetskijeh tema potpuno iskočio iz crnogorskijeh matičnih tokova književnosti svoga vremena. Pjesme su mu prevođene na mnoge evropske jezike: engleski, francuski, ruski, češki, rumunski, bugarski, esperanto itd. Uvid u njegovo cjelokupno djelo otežava i to što mu je izvorna građa razasuta po brojnijem časopisima Crne Gore i kontaktnijeh naroda: u Brankovom kolu, Bosanskoj vili, Letopisu Matice srpske, Savremeniku, Srđu, Delu i brojnijem dnevnim i periodičnijem publikacijama.

U svojoj lirskoj poeziji on je sljedbenik u izrazu kasnoromantičarske poetike. Dakle, poeziju doživljava najviše kao potrebu da u idiličnome tonu i ljubavnom zanosu glorifikuje ljudske ośećaje i svoj vlastiti emocionalni intenzitet. Takve su mu uspjele lirske pjesme „Ispovijest“, „Sonet“, „Hajdmo dušo!“, „Opraštaj“”, „Sutonska pjesma“ i dr. Pavićević je vješt versifikator, u svoju poeziju unosi različite metričke sheme (od osmerca do jampskog dese-

\footnotetext{
${ }^{21}$ Književna bibliografija Leksikografskog zavoda Miroslava Krleže, Zagreb, s. a.

${ }^{22}$ Petar M. Božović, Isto, 108.
} 
Poezija druge polovine XIX i početka XX vijeka

terca). S prilično istančanijem ośećajem za igru i ritam uspio je izbjeći monotonost pjesnika deseteračkog uticaja postnjegoševskog razdoblja. Možda je ocjenu Pavićevićeva pjesništva nabolje sintetizovao hrvatski modernistički pjesnik, putopisac i feljtonist Antun Gustav Matoš kad je napisao: U Mićunovićevim stihovima, ima prave poezije; ima riječi, koje idu od srca $k$ srcu, ima i neke surove snage, što podsjeća na iskrenu prostotu snažne Vladičine patriotske lirike. ${ }^{23}$ Stoga ne iznenađuje da su neke Pavićevićeve pjesme bile muzički obrađene. Inače, uspješan je bio i kao lirsko-epski pjesnik, naročito u onijem stihovima koje posvećuje kulturno-istorijskim spomenicima i lokalitetima, poput „Skadru“, „Beogradu“ i slično. U njima progovara pjesnik rodoljub, a stihovi su mu narativno usmjereni, izdignuti do patosa i simbola opstojnosti crnogorske slobode. Ni Pavićević se, egzaltiranijem izricanjem svojih rodoljubivijeh ośećanja, u rimovanim stihovima patetične intonacije, nije sasvim uspio osloboditi versifikacije usmene poezije, ali ni srpskijeh i hrvatskih pjesnika romantičara: Đ. Jakšića i B. Radičevića, P. Preradovića, te Kostićeve sentimentalnosti i etičkih poruka. Sasvim je u pravu Petar M. Božović koji u krajnjoj ocjeni Pavićevićeve poezije piše: Pavićević je epsko-lirski pesnik, ali u njegovim delima preovlađuje lirika. On je u pesmi nacionalni optimista, prorok propasti neprijatelja svog naroda (...) i oštar satiričar svakoga onoga ko se drzne u budućnost našeg plemena. Većim delom njegove pesme su prožete dubljim osećanjima. Karakteristične su tom pogledu ljubavne i patriotske pesme (...). Uticaj narodne poezije očigledan je na njegove pesme. Pod tim uticajem on se pesnički sam razvijao, pretvorio se u originalnog pesnika kako sadržinom tako i pesničkom formom. ${ }^{24}$

Više od jedne decenije Pavićević je sistematski i marljivo sakupljao crnogorska anegdotska zrnca. Za vrijeme boravka u Zagrebu on je dijelom realizovao svoj projekt izdajući anegdote pod naslovom Crnogorci u pričama $i$ anegdotama, knj. I (Beograd, 1928), knj. II (Podgorica, 1928), knj. III (Herceg-Novi, 1928) i knj. IV (Heceg-Novi, 1928). Pod istijem naslovom izdao je 1929. godine i petu knjigu u Zagrebu. U rukopisu mu je ostala i druga opsežna građa pod istoimenijem naslovom te Lovćenske elegije. U zagrebačkom izdanju Crnogorci u pričama i anegdotama, u autorskoj riječi, Pavićević objašnjava svoj odnos prema toj sabranoj građi. U stvari, to i nijesu tvorevine njegova duha, već zapisi koje je on skupljao na cijelome crnogorskom arealu. On to eksplicite i kaže: Skupljeni materijal, što ga izdajem u ovoj petoj knjizi narodnih priča iz Crne Gore i Brda, podoban je da prikaže dušu Crnogoraca, njegove osobine, život, koji je težak u onom kršu - i snagu, koja

${ }^{23}$ Dr Nikola Andrić, „Mićun M. Pavićević“”, predgovor u: Mićun M. Pavićević, Crnogorci u pričama i anegdotama, knj. V, Zagreb, 1929, 5.

${ }^{24}$ Petar M. Božović, Isto, 109. 
je nastala u tim goletima. ${ }^{25}$ Anegdota je inače bila omiljena forma iskaza Crnogoraca jer su se u njoj zgušnjavali prostor i vrijeme i karakterološke osobine crnogorskog čovjeka, koji svojim značajem i filozofskim shvaćanjem mogu da dadu primjer poštenja, čojstva i pravde, koje su nam u današnjim danima najpotrebniji. Nigdje se naime na prostranom području našeg naroda nije shvaćanje o svim problemima, koji se dotiču narodne duše, iskristaliziralo, kao u onim Crnim Brdima. Iz Pavićevićevih anegdota ocrtava se njegovijem sirovim crnogorskijem narodnim jezikom mozaik od stotine različitih kamenčića, koji mogu da posluže kao produženje Čojstva i junaštva od Marka Miljanova ili još bolje - kao stostruka ilustracija vječnim herojima klasičnog Vladičinog Gorskog vijenca. ${ }^{26}$

\section{Jovan Sundečić (1825-1900)}

\section{Pjesnik integracionog slavjanstva}

Već je odavno poznato u književnoj istoriji i kritici da je Jovan Sundečić proslavljeni pjesnik, kulturni poslenik i političar svoga vremena. Oko četrdeset godina živio je i radio kao izvanjac ${ }^{27}$ u Crnoj Gori. Uz svakodnevne sekretarske poslove koje je obavljao kod knjaza/kralja Nikole, on je razvio živu i bogatu prosvjetno-kulturnu i književnu aktivnost na Cetinju. ${ }^{28}$ Vatreno zadojen panslavističkijem i prosvjetiteljskim idejama Josipa Jurja Štrosmajera (Strossmayer) i svoga bliskog idejnoga saradnika, pobratima i prijatelja, don Mihovila Pavlinovića, Sundečić je u svojoj prigodnoj i rodoljubno-panegiričkoj poeziji razvio i jačao nacionalnu misiju slavjanstva. Uz to, kao već iskusni kulturni radnik, pokretač je crnogorske periodike, godišnjaka Orlić, ${ }^{29}$ osnivač i suvlasnik poznate Crnogorke koja je izlazila kao prilog listu Crnogorac, a služila je za zabavu, književnost $i$ pouku. ${ }^{30}$ Inicijator je i učesnik gotovo svijeh književno-kulturnih zbivanja na Cetinju do kraja XIX stoljeća. ${ }^{31}$

\footnotetext{
${ }^{25}$ Mićun M. Pavićević, „Autorova riječ““, u: Crnogorci u pričama i anegdotama, knj. V, Zagreb, 1929, 11-12.

${ }^{26}$ Dr Nikola Andrić, Isto, 9.

${ }^{27}$ Milorad Nikčević, „Doprinos, značaj i podsticaj izvanjaca i inozemaca crnogorskom književno-kulturnom razvoju u drugoj polovni XIX i početkom XX vijeka“, Stvaranje, br. 5, Titograd, 1984, 665-680.

${ }_{28}$ Živorad Jovanović, „Bio-bibliografska građa o Jovanu Sundečiću“, Stvaranje, br. 9, Titograd, 1953.

29 Radivoje Šuković, Crnogorski almanasi i kalendari (1835-1914), Cetinje, 1980, 55-86.

${ }^{30}$ Dr Miroslav Luketić, Crnogorski književni časopisi 1871-1891, Bibliografija, Cetinje, 1978, 4-10.

${ }^{31}$ Branko Banjević, Isto, 22-25.
} 
Poezija druge polovine XIX i početka XX vijeka

Posebno se angažovao na osnivanju Bogoslovije koja je ubrzo prerasla u Bogoslovsko-učiteljsku školu iz koje su ponikli svještenici Crnogorske pravoslavne crkve i domaća inteligencija. Uz to, bio je angažovan u brojnijem kulturnim, diplomatskijem i političkim aktivnostima i misijama. Nastupao je u ime knjaza Nikole: putovao u Rim radi potpisivanja ugovorâ i ratifikacije čuvenoga Konkordata sa Sv. stolicom (1866); uspostavljao je i izglađivao zategnute odnose s Kneževinom Srbijom, putovao u Prag (1865) zbog opremanja Cetinjske štamparije i slično. ${ }^{32}$

Osim Sundečićeva rada na organizatorskijem poslovima i na kulturno-prosvjetiteljskome polju, on je, zajedno sa knjazom/kraljem Nikolom, bio jedan od afirmisanijeh i najhvaljenijih pjesnika svoga vremena. Jovan Skerlić ga je uvrstio, zajedno sa Brankom Radičevićem, Ljubomirom Nenadovićem i Jovanom Ilićem, u Istoriju nove srpske književnosti (1914), svrstavši ga u pjesnike romantičarskoga književnog korpusa. Okarakterisao ga je, istina, kao pjesnika bez dubine i talenta, ali mu je priznao veliku popularnost i uticaj u svome vremenu, a to se može, prema njegovome sudu, objasniti narodnijem duhom Sundečićeve poezije i patriotskim ośećanjem koje je prelazilo konfesionalne granice i obuhvatalo podjednako i Srbe i Hrvate. ${ }^{33}$ Srpski književni istoričar Jovan Deretić je u novijim naučnijem radovima revidirao Skerlićeve ocjene o Sundečićevim poetskijem tvorevinama i utvrdio (bar što se tiče njegove poezije u Srpsko-dalmatinskom magazinu) da je on pjesnik poznih izdanaka objektivne lirike. Kod njega nema klasicističkog rimskog razmera kao kod Mušičkog, osnovno stilsko ishodište njegovog pesničkog rada je podražavanje narodne poezije. Narodni duh, narodni stih, narodni jezik - to su bitna obeležja njegovog pevanja. ${ }^{34}$

S književnoistorijskoga gledišta, danas ime Jovana Sundečića zauzima sasvijem sporadično i marginalno mjesto u poeziji druge polovine XIX vijeka, bar kada je riječ o estetskijem vrijednostima njegova književnog opusa u srpskoj, hrvatskoj i u crnogorskoj književnosti - korpusima u kojijema se profilisao i kao književno-kulturni i politički pregalac. Naime, njegovo književno djelo, gledano s estetskijeh pozicija i odmjeravano s onim što je u tom trenutku bilo estetski vrijedno i živo u evropskijem književnim razmjerama,

\footnotetext{
${ }^{32}$ Milorad Nikčević, „Prinosi J. J. Strossmayera i Nikole I. Petrovića Njegoša na uspostavljanju Konkordata (1886)“, u: Hrvatski i crnogorski književni obzori. Povijesni književno-kulturni kontekst, Zagreb, 1995, 143-159; Milorad Nikčević, „Kulturno-povijesna scena i izvori korespondencije J. J. Strossmayera i Nikole Petrovića Njegoša“, u: Hrvatski i crnogorski književni obzori. Povijesni književno-kulturni kontekst, Zagreb, 1995, 117-141.

${ }^{33}$ Jovan Skerlić, Istorija nove srpske književnosti, Beograd, 1967, 290-291.

${ }^{34}$ Jovan Deretić, Almanasi Vukovog doba, Institut za književnost i umetnost Vuk Karadžić, Beograd, 1979, 319.
} 
predstavlja poetski anahronizam svoga vremena, pa i samijeh strujanja koja su bila izražena i afirmisana u drugim nacionalnijem književnostima: hrvatskoj, srpskoj i crnogorskoj literaturi. No, ono što je Sundečićevo ime čvrsto vezivalo, podjednako spajalo i duboko prožimalo kontaktne narode u tome burnom vremenu, jeste njegovo izuzetno političko i kulturno djelovanje $\mathrm{s}$ težnjama ka sjedinjavanju i integrisanju južnoslovenskijeh književnosti u jedinstvo sveslovenskoga integralizma.

Životna putanja Jovana Sundečića i kao društveno-političkog poslenika i kao književnika započela je u zadarskoj pravoslavnoj bogosloviji od 1843. do 1864. godine (s kraćijem izbivanjem 1848-1854), a zatim nastavljena dvije godine u crnogorskoj enklavi njegovijeh predaka u Peroju (Istra ${ }^{35}$ od 1848, te na kraju produžena na Cetinju u Crnoj Gori đe će književno djelovati i ostati aktivan sve do smrti u Kotoru (1900). U svijem tim sredinama bio je ne samo jedan od najaktivnijih pjesnika, već i personifikator i istaknuti sudionik društveno-političkijeh gibanja svoga vremena.

Već u mladalačkijem danima u zadarskoj seminariji ističe se kao pregalac u širenju narodnjačkijeh slavjanskih ideja i zagovornik ilirskoga pokreta. Naročito je radio na stvaranju duhovne i idejne klime oko izlaženja Srpsko-dalmatinskog magazina $(1836)^{36}$ i Zore dalmatinske (1844). I u početničkoj poeziji i u javnome djelovanju u toj fazi svoga rada Sundečić se zalaže za jedinstvo Srba i Hrvata. Tu je orijentaciju nastavio cijeloga života, osobito u crnogorskoj enklavi u Peroju, đe je službovao kao pravoslavni učitelj i svještenik. ${ }^{37}$ Takva orijentacija duboko ga je povezala sa slovenskijem krugom i naraslim narodnjačkijem snagama u Trstu. Revolucionarne 1848. godine u tome gradu je osnovano Slavjansko društvo koje je ubrzo pokrenulo i svoja glasila Slavjanski rodoljub, a nešto kasnije i Jadranski Slavjan. ${ }^{38}$

U presudnijem godištima od 1848. do 1850. godine Sundečić je izbliza aktivno pratio opšteslovenski polet koji je bio veoma izražen u Trstu, a koji

${ }^{35}$ Zbornik radova s IV. međunarodnoga znanstvenog skupa Jezici i kulture $u$ doticajima: Peroj/Istra u proslošti $i$ sadašnjosti, Tabula, časopis Filozofskog fakulteta u Puli, uredio prof. dr. sc. Milorad Nikčević, Pula, 1999; Milorad Nikčević, „Prilog bibliografiji o Peroju“, Nova Istra, br. 4, Pula, 1999, 265-278.

36 Srpsko-dalmatinski magazin pojavio se prvi put 1836. godine u Karlovcu (Karlštat) i do 1873. godine izašlo je trideset godišnjih svezaka. Pod naslovom Srpskodalmatinski magazin analizirao ga je Jovan Deretić u knjizi Almanasi Vukova doba, Institut za književnost i umetnost Vuk Karadžić, Beograd, s.a., 247-349.

${ }^{37}$ Mirjana Strčić, „Prilog poznavanju života i rada Jovana Sundečića“, u: Prlozi o zavičaju, knj. 6, Pula, 1990.

38 Ivo Mihovilović, „Jedna tršćanska godišnjica. Slavljansko društvo“, Kolo, I, Zagreb, 1948, 727-744. (Isti je rad uvršten kao predgovor uz prilog Sama Pahora, u reprint-izdanju Slavjanskog rodoljuba, Založništvo tržaškega tiska, Trst, 1971.) 
Poezija druge polovine XIX i početka XX vijeka

se idejno dovodi u vezu sa identičnijem stremljenjima i patriotskim pobudama i orijentacijama ilirskoga pokreta u Hrvatskoj. Hrvatske preporodne novine Naša sloga 1871. objavljuju Sundečićeve stihove u kojima žestoko brani narodni jezik pred importovanom talijanskom jezičkom dominacijom. Da je Sundečić bio jedan od idejnijeh i aktivnih čelnika preporodnog duha u Dalmaciji i Hrvatskom primorju/Istri govori i podatak što je on tu saradnju kasnije živo prenio i u svome cetinjskom godišnjaku Orliću. U njemu su nastavili sarađivati osim brojnijeh srpskih predstavnika preporodnoga doba iz Hrvatskog primorja i hrvatski biskup Dobrilo i Mate Bastian, najznačajniji narodni preporoditelji toga vremena u Istri. Istina 1848-1850. još nema organiziranog djelovanja u okviru preporoda, ali se upravo u to doba oko Trsta i J. Dobrile uobličavaju osnovne konture nadolazećeg preporodnog snaženja $i$ organiziranja. ${ }^{39}$ Iz toga istarskog duhovnoga okružja iznjedrena je i prva Sundečićeva pjesnička zbirka Sreća (1850), sa kojom je počeo sticati već tada glas javnosti te je nakon povratka u Zadar ubzo mogao postati jednim od najznačajnijih sudionika preporodnih borbi u Dalmaciji. ${ }^{40}$

I nakon ponovnoga povratka u Zadar, đe obavlja dužnost profesora u bogoslovskoj školi, Sundečić svom žestinom radi na učvršćenju slovenstva u Dalmaciji. Pod Kazalijevijem imenom, Sundečić uređuje Glasnik dalmatinski (1855) kojega će uređivati i u prelomnijem godinama u Dalmaciji - 1860/ /1861, dok ga zbog svoje eksponirane narodnjačke orijentacije nijesu vlasti potisnule s toga položaja. No, ni tada se ne miri s političkijem stanjem u Dalmaciji, već pokreće svoj časopis Zvijezdu, a revnosno sarađuje u Narodnom listu (Il nazinale) - časopisu u kojem se snažno razračunavaju narodnjaci, pristalice Pavlinovića i Štrosmajera, i autonomaši, odnosno talijanaši. Ujedno je Sundečić svoj idejni pravac sve više inaugurisao i u Lukšićevom Glasonoši đe je bio jedan od vatrenijeh saradika. Tih godina on je saradnik i u Matici dalmatinskoj (1862) i urednik Matičinog Koledara (1863. i 1864), a čak mu i Ljudevit Gaj nudi uređivanje njegove Danice. Sve to samo sobom govori da je bio ne samo vatreni rodoljub već i idejni zagovornik sveslovenstva, a žestoki protivnik prodora talijanaša i njihove dominantne kulture u arealu Dalmacije. Svoju popularnost Sundečić sve više stiče među slovenskijem narodima, pa će zbog takvih svojijeh ideja putovati kao narodni misionar sa svojim pobratimom i popularnijem liderom i zastupnikom u Dalmatinskom saboru i Carevinskom vijeću u Beču, don Mihom Pavlinovićem, prvo za Trst, a potom na relaciji - Ljubljana, Zagreb, Štrosmajerovo Đakovo, do Sremskijeh Karlovaca, Novog Sada, Beograda i Cetinja. Na Cetinju se susreo s crnogor-

${ }^{39}$ Mirjana Strčić, ,Jovan Sundečić u kontekstu hrvatske, srpske i crnogorske književnosti“, Gesta, br. 29-30-31, Varaždin, 1988, 218.

${ }^{40}$ Isto. 
skim knjazom Nikolom koji ga je vjerovatno tom prilikom i pozvao da se preseli u Crnu Goru, đe se nastanio već 1864. godine.

Jovan Sundečić je jedan od najplodnijih i najistaknutijih pjesnika svog vremena. Njegov je opus veoma raznolik i brojan, pa je postao pjesnikom velike reputacije u drugoj polovini XIX vijeka. Njemu su još za života izašle Izabrane pjesme (1889) u izboru i opremi hrvatskog književnika Huga Badalića, a neposredno nakon smrti štampaju se o njegovom životu i književnom radu integralne književnoistorijske monografije i naučne studije. U svome dugom životu objelodanio je na stotine različitijeh stihova, pretežno u periodici, ali i u zasebnim zbirkama poezije. Po svojijem pjesmama ostao je do smrti nacionalno-preporodni tradicionalni pjesnik i po idejnom poetskom konceptu - apologeta zajedništva slovenskijeh naroda. Kao pjesnik, tipični je predstavnik stvaralaštva zakašnjeloga neoklasicizma. Sa L. Mušickim ga veže objektivnost, prigodnost, didaktičnost, impersonalnost u poeziji, ali je generacijski Sundečić pripadao ranoj romantici, pjesničkoj generaciji B. Radičevića, J. Ilića, J. Subotića, Đ. Daničića, Zmaja, Lj. Nenadovića i knjaza/ /kralja Nikole. On je, putem svoga žanrovski raznovrsnog pjesništva, nastojao u razdoblju preporodnijeh težnji poetski izraziti pluralitet gibanja i političke težnje svoga vremena.

Po tematskoj i žanrovskoj usmjerenosti Sundečićeva se poezija razvrstava na moralno-poučnu (didaktičnu) liriku, rodoljubivu i ljubavnu, pejzažnu, refleksivnu i duhovno-poučnu poeziju. Oblikovana na proklamovanijem konceptima kulture Vuka Stefanovića-Karadžića i njegove monogenetske teorije o jeziku, te široko zadojen idejama srpstva i ilirskog pokreta, osobito narodnjaštvom J. J. Štrosmajera i idejama don Mihovila Pavlinovića, Sundečić se oslanja na sve modele poetika toga vremena, osobito na poetiku usmene književnosti. Uzdižući i kultivišući tokom cijeloga svog dugog poetskoga rada, slovenstvo i jedinstvo južnoslovenskijeh naroda, Sundečić je dominantno isticao slobodarstvo, jedinstvo naroda, jedinstvo i otpor prema dominaciji tuđijeh kultura, a posebno talijanske u Dalmaciji, Boki i cijelome Hrvatskom primorju. Iako idejno Sundečićeva poezija nosi sve tragove ideologema onoga vremena, ona ipak u svojoj poetskoj niti vrši objektivno uzvišenu pjesničku misiju. Ta ideja opredjeljuje Sundečića kao nacionalnog borca, apologetu i barda; daje mu onu misiju i duhovnu snagu koju mu je nametao istorijski trenutak i sudbina slovenskijeh narodā u tim povijesnim čeljustima istorije.

U svojem cetinjskom poetskom ciklusu, Sundečić je bio idejni misionar i tumač politike knjaza Nikole. Tu je svoju poetsku fazu baštinio od rane mladosti, iz duhovnog okružja koje se snažno ispoljavalo 50-ijeh i 60-ih godina XIX vijeka u Dalmaciji, osobito preko Srpsko-dalmatinskog magazina. U njemu je Sundečić objavio cijeli ciklus svoje poezije. To su pjesme po tematskoj i žanrovskoj orjentaciji prigodnice, poučne (didaktičke) tvorevine i u 
Poezija druge polovine XIX i početka XX vijeka

najvećem dijelu pjesme rodoljubivoga i ljubavnog karaktera. U njima se iznose vizije političkijeh trenutaka i izdiže slovenstvo kao dominantna poetska opsesija. Te pjesme su bez veće umjetničke vrijednosti, snažno opterećene detaljima, naracijom, tendencijom, didaktikom i idejnom porukom. Iz cjelokupnoga tog ciklusa u Srpsko-dalmatinskom magazinu, kao zrnce uspjele poezije ističe se Sundečićeva prigodnica posvećena ,Sočinitelju Gorskog vijenca“. Taj Sundečićev sonet predstavlja, u stvari, prvu tvorevinu ispjevanu Njegošu u slavu. Sazdan je na simbolima preuzetijem iz Njegoševe poezije. Ova pjesma misaonom i izražajnom složenošću i gustinom metaforike izdvaja se ne samo među Sundečićevim pesmama nego i među svim drugim pesmama objavljenim u Magazinu. ${ }^{41}$ Njegove prigodnice u Magazinu ispjevane su najčešće u pohvalu istaknutijeh savremenika, a po tonu i žanru bliske su odama Mušickog i Njegoša. Takve su i njegove brojne pjesme didaktičkog karaktera objavljene u Magazinu, pisane pretežno da zadovolje poetski ukus đece. Didaktičnost kao osnovno obilježje njegove poezije u tom vremenu dobilo je u njima osnovni ton i izraz. S estetskog gledišta nemaju veće vrijednosti, mada se ističu lakoćom poetskoga izraza pa su zbog toga bile pamtljive, umilne i lako su se prenosile na narodne slojeve.

Nešto veći značaj imale su Sundečićeve rodoljubive pjesme i to ne samo one iz Magazina već i one koje čine njegov većinski poetski opus. Takve su pjesme: „Pjesma k braći Slavjanima“ (1848), „Na obranu slavenskog imena“"(1850) u kojima izbija ośećanje slavjanstva karakteristično za period revolucionarnijeh gibanja od 1848. do 60-ijeh godina. U tijem je pjesmama Sundečić direktno pod uticajem poezije Petra Preradovića, mada sa daleko nižom poetskom vokacijom i refleksijom. I njegove pjesme sabrane u zbirci Kosovske davorije ispjevane su pod idejnijem uticajem Sterije Popovića. U njima se lirsko-didaktički razmatra sudbina srpskog naroda poslije Kosova. One su svojijem uzvišenim rodoljubljem plijenile pažnju brojnijeh Sundečićevih čitalaca, ali su imale i pozitivnoga odjeka u onovremenijem periodičnim glasilima. Svoje zrelije trenutke poetskog izraza Sundečić je postigao u tvorevini Krvava košulja, spjevu koji je posvećen knjazu Nikoli. S osloncem na usmenu predaju, Sundečić razvija crnogorske motive u čijim je poetskijem odjecima uočljiva bajronsko-romantičarska idealizacija prošlosti Crne Gore i borbe Crnogoraca za slobodu; teme su najčešce iz usmene predaje, a i po duhu i po stilskom značajkama bliske narodnoj pjesmi, s uvijek idealnim i nedostignutim uzorom u P. P. Njegošu. ${ }^{42} \mathrm{Na}$ istoj tematskoj i estetskoj vertikali mogu se posmatrati i Sundenčićeve pjesme „Majka Crnogorka“, „Knjaz Danilo“, pjesma „Ubavoj nam Crnoj Gori“, koja je po invokaciji i uzvišenom

${ }^{41}$ Jovan Deretić, Isto, 320.

${ }^{42}$ Mirjana Strčić, Isto, 221. 
svečanom tonu postala crnogorskom himnom, i mnogo hvaljeni prozni narativni izrazi - pripovijetke „Anđelija Kosorića“ i „Kula Baja Pivljanina“.

Uz Sundečićeve pjesme s rodoljubivijem motivima, najviše su plijenile pažnju čitalaca i njegove ljubavne pjesme. Premda pripadaju poznom periodu njegova života, one su nastale iz autorovoga dubokog emocionalnoga izvorišta, inspirativno su vezane za njegovu suprugu i đecu i nalaze se u zbirci cjelokupnijeh Sundečićevih ljubavnijeh pjesama Milje i Omilje ili Milica i Nevenka (1893). Iz toga kanconijera posebno se izdvaja pjesma „Jednoj majci prigodom preminulog joj sina“, koja je ušla u antologijski izbor Pleme za oblakom. U njoj Smrt ... nije samo patnja već i povod za razmišljanje o smrti. ${ }^{43}$ Književna ih je kritika proglasila, zbog izliva intime i neposrednosti, najlošijim dijelom Sundečićeve poezije. Na njih se nadovezuju i one pjesme u kojima fiksira smrt dvojice sinova u zbirci Tužna knjiga (1885). Iako su nastale pod uticajem Zmajevih Đulića uvelaka, one nijesu ni svojom emocijom, a ni poetskijem skladom i estetskim učinkom dosegnule dubinu i iskrenu emociju Zmajevijeh tugovanki. Kod Sundečića je sve razblaženo naivnom neposrednošću i utiskom o dnevničkoj, porodičnoj ispovijesti. ${ }^{44} \mathrm{Uz}$ ovaj tematski krug ljubavnijeh pjesama i prigodnica idu i one iz zbirke Niz dragocjenih bisera, namijenjene mladeži, đe pedagoško-moralistički ton nadvladava estetski sklad i ljepotu pjesme. Nad njima se izdižu pjesme iz zbirke „Vršidba“ čija tematika je svojevremeno upoređivana sa Šilerovijem „Zvonom“.

Svoje najdublje refleksije Sundečić je izrazio u zbirci Sjetva, mada je još uvijek njegova poetska tekstura opterećena didaktizmom, poukom i rodoljubnijem motivima. Po svojoj prirodnoj darovitosti Sundečić je imao velike sklonosti za likovne umjetnosti. Ta senzibilna komponenta došla je do izražaja i u pejzažnijem pjesmama. Premda je njegov pejzaž još uvijek nedovoljno personalan, on je često nesamostalan i čini samo tematski okvir njegove poezije s naglašenijem vizuelnim doživljajem života i svijeta. Motiv pejzaža je naročito inkorporiran u fabularne pjesme, lirsko-epske strukture s crnogorskijem motivima. Sundečićeva satirična poezija ostala je u śenci njegova cjelokupnog pjesnišstva.

Sundečić nije bio pjesnik poetskijeh eksperimenata i mijena stiha. Tokom cijeloga svog pjesništva ostao je vjeran tradicionalnijem modelima stvaralaštva. Iako se ponekad znao približiti poetici Preradovića, Radičevića i Zmaja, i utkati svježinu Njegoševe misli i refleksije usmene književnosti, Sundečićeva se poezija odavno svela na razinu toposa $i$ steriotipa pjesničkog umijeća. ${ }^{45}$ On se služio manje desetercem, a više osmercem te promijenjeni-

\footnotetext{
${ }^{43}$ Dr Radoslav Rotković, Isto, 633.

${ }^{44}$ Mirjana Strčić, Isto, 220.

${ }^{45}$ Isto, 221.
} 
Poezija druge polovine XIX i početka XX vijeka

jem metrom po modelu kakav je upotrebljavao knjaz Nikola I i B. Radičević u „Đačkom rastanku“. Iako je pjesnik Sundečić ostao zarobljenikom tradicionalnijeh oblika pjesništva, bez većega poetskog obrazovanja (u mladosti je poznavao ponešto talijanskijeh romantičara i prevodio ih), on je bio vas okrenut zbivanjima svoje savremenosti. Prema tome, Sundečić se skoro nikako nije mijenjao kao pjesnik cijelog života. Ostao je vjeran poetici umilne liričnosti, arsenalu rima, deminutiva, često tipičnijeh epiteta narodne pjesme, ponekad i nasilja nad jezikom kada to zahtijeva nategnuta rima. Sve to opterećuje njegovu poeziju i gubi se impresija o bogatoj leksici, o plastičnosti slike u najnadahnutijim trenucima. Njegovo pjesništvo nije, dakle, izašlo, po tematici i motivici a niti po jeziku, izvan poetskoga horizonta pjesništva prve polovine XIX vijeka.

I u zaključku ovoga pregleda ističemo sasvijem opravdani sintetički sud književnika Branka Banjevića: No i pored svega (svih nedostataka i mana - M. N.), obimno Sundečićevo djelo zaslužuje da se prouči, da se iz njega izvuku sve vrijednosti kojih još ima i pored naivnosti, neke lakoće u pripovijedanju koja nečim podsjeća na Puškinove skaske u stihu. Njegovo djelo je mješavina romantičarskog načina pjevanja iz Zmajevih pjevanija i političke propagande ovog vremena. Za našu istoriju književnosti važno je da se pokaže, na njegovom primjeru, kako se od Njegoša, čije je djelo politički angažovano u najpoetskijem smislu, angažovanost poezije snizila do gole politike, da se objasni: otkud to da u jedno književno razuđenije i kulturno bogatije vrijeme dolazi do devalvacije poetske vrijednosti riječi, do pada umjetničkog zahtjeva kojega pjesniku postavlja vrijeme. ${ }^{46}$

\section{Stefan Perović Cuca (1830-1857)}

Stefan Perović Cuca bio je od onijeh naših književnika i javnijeh radnika kojemu je prerana smrt uskratila da ostvari punu stvaralačku zrelost i sreću da dočeka oživotvorenje svojijeh mladalačkih ideala, za koje je nesebično radio i prerano svoje iluzije platio glavom. Potekao je iz cucke porodice, od oca serdara i senatora Andrije Perovića i Njegoševe starije sestre Marije. Takvijem predodređenjem bilo je usmjereno Stefanovo đetinstvo, mladost i njegova prerana tragična smrt. Poslije osnovne škole na Cetinju do 1845, odlazi na preporuku svoga ujaka Njegoša kod njegova učitelja Sima Milutinovića radi produženja školovanja i proširenja svojijeh duhovnih vidika. Imao je nesistematsko školovanje: prvo u Beogradu, đe uči gimnaziju koju prekida, potom mu Njegoš osigurava školovanje talijanskog jezika u Dubrovniku kod svoga prijatelja, ruskog konzula Jeremije Gagića. Neko vrijeme provodi u

\footnotetext{
${ }^{46}$ Branko Banjević, Isto, 25.
} 
Beču, đe je studirao filologiju koju nije nikada okončao. Na prijedlog Ilije Garašanina, upisuje vojnu akademiju u Beogradu, ali ni nju nije završio jer se nakon smrti svoga ujaka, Njegoša, vratio u Crnu Goru. Po stupanju na vladarski tron, knjaz Danilo mu prenosi očeve počasti i postaje cucki senator i serdar. U tome svojstvu je učestvovao kao komandant u bici na Grahovu 1853. godine protiv Omer-paše. Zbog održavanja pismenijeh veza s turskim komandantom Grahova, Derviš-pašom, koga je konačno 1853. godine pozvao na javni dvoboj ${ }^{47}$, zamjerio se knjazu Danilu. Nesporazumi s Knjazom, a u vezi s neizvršenom voljom Njegoševa Testamenta u raspodjeli sredstava koje mu je ujak namijenio za školovanje, doveli su do vidnog zahlađenja. Takvi ośećaji poduprti su aspiracijama oko preuzimanja vlasti: crnogorski čelnici - Njegošev brat Pero Tomov, predśednik Senata, senator i serdar Milo Marinović, te Cucin otac Andrija, kovali su zavjeru kako bi se domogli crnogorskoga trona. Zbog toga su bili osuđeni, proćerani iz zemlje, a i sâm je Cuca učestvovao u tijem kobnim planovima, pa je 1854. kao izgnanik stupio u vojnu školu u Klosternojburgu kraj Beča. I kao pitomac, i kasnije kao oficir, uživao je posebne privilegije i blagonaklonosti cara Franja Josifa. Na jednom proputovanju kroz Carigrad, 10. juna (29. maja) 1857. godišta, poginuo je od ruke popa Joka Kusovca i Andrije Smokovca Ljubotinjanina, koje je bio najmio knjaz Danilo, ili njegova najbliža okolina. ${ }^{48}$

Izrastao i odgojen na izvorima usmene književnosti i programima poezije svojijeh savremenika Sima Milutinovića Sarajlije, Vuka Karadžića, Branka Radičevića, Đura Jakšića, a osobito na misaonoj, emocionalnoj i refleksivnoj poeziji svoga ujaka Petra II Petrovića Njegoša, Stefan Perović Cuca nosio je u sebi od rane mladosti nerv pjesnika. To nam potvrđuju njegove početničke pjesme koje piše još kao učenik četvrtog razreda gimanzije u Beogradu. Prvu pjesmu „Glas usrdija“ objavio je u Podunavci (1847) kad je

\footnotetext{
${ }^{47}$ Maksim Todorović, Stevan Cuca. Prvi književni dvoboj u Crnoj Gori, Beograd, 1938.

${ }^{48} \mathrm{O}$ tragičnom ubistvu Stefana Perovića Cuce, na osnovu dokumentacione građe i prepiske ondašnjijeh srpskih kulturnijeh i političkih radnika, detaljno piše u svojoj doktorskoj disertaciji Ilija M. Petrović (Ilija M. Petrović, „Stevan Perović Cuca“, u: Lord Bajron kod Jugoslavena, Beograd - Požarevac, 1989, 177-182). Njegovi podaci umnogome se podudaraju s rukopisnom monografijom Ljubice Klančić (čitaj: Savić Marković Štedimlija), (Ljubica Klančić, Život i smrt Stefana Perovića Cuce (1831-1857), rukopisna monografija) koju nam je na uvid, neposredno pred smrt, dao Blažo Kilibarda iz Zagreba, na čemu smo mu iskreno zahvalni. Za razliku od drugijeh autora koji kao godinu Cucine smrti navode 1857, Ilija M. Petrović na osnovu istorijskijeh izvora tvrdi da je $\mathrm{Cu}-$ ca poginuo 29. maja po starom kalendaru (10. juna po novom) 1855. godine što se može pouzdano prihvatiti i iščitati iz ondašnje dokumentacione prepiske. Ovo je veoma važno utvrditi zbog toga što bi pjesnik živio samo 27 godina, odnosno 25 prema Petroviću!
} 
imao sedamnaest godina. Kasnije su njegove pjesme štampane u Srpskim novinama, Neven-slogu, Nevenu, Svetovidu, Svetozaru, Šumandinki, Srpskoj zori i Godišnjici. Zbirka Cucinijeh Pjesama izašla je tek 1953. na Cetinju i u javnosti s razlogom ostala nezapažena jer je štampana s mnogo pogrešaka, uredničkijeh propusta i ispuštenih stihova i strofa. ${ }^{49} \mathrm{U}$ njoj je ukupno sabrano 39 pjesama, dok se u rukopisnoj zbirci Ljubice Klančić (Savića Markovića Štedimlije) nalazi njegovijeh 55 sabranih pjesama. U cjelokupnom opusu ostalo je i nekoliko integralnijeh članaka i pisama koje je slao raznim poznatijem i istaknutim ličnostima svoga vremena. Štedimlija u svojoj rukopisnoj monografiji ukazuje na to da se Cuca bavio i sakupljanjem narodnijeh epskih pjesama koje je slao Vuku St. Karadziću. Sâm je Vuk o tome zasvjedočio kad eksplicite ističe: Osim ove imenovate gospode i prijatelja meni su još $i$ drugi gdjekoji, kao na primjer ... i pokojni Stefan Cuca slali i davali različitijeh pjesama. ${ }^{50}$

U književnoj kritici onoga vremena često se isticalo da je Cuca pjesnik koji se ugledao po misaonosti na svoga ujaka Njegoša, da je oponašao njegovu poeziju, da je bio naš prvi pravi pjesnik romantizma, vrsni bajronista kojega on u stihovima i pominje. Takve sudove davali su Svetislav Vulović, Jakov Ignjatović, Andro Gavrilović, a Stefan M. Ljubiša o njemu i njegovom djelu kaže: Bio je lep, gizdav i uzgojen, a pesnički duhom naturio je na ujaka (...). Iz ovo malo pesama vidi se da je bio naravi utuljene $i$ melankolične jer mu u svim pesmama vlada i diše isti motiv, očajanje o čovečijoj sudbi. Da je više živeo i učio valjda bi sa sebe stresao patetične (!) osećaje ili s njima dopro do pesničkog lovora Italijanca Leopardija.$^{51}$ I Isidora Sekulić, spisateljica impresivne knjige - Njegošu knjiga duboke odanosti (1951), ističe da je Cuca imao pjesničkoga dara. Ostale su dve-tri Stefanove pesme, naravno mladenačke i početničke, ali koje nisu na odmet. Pokazuju da je Stefan išao ozbiljno i iskreno u refleksiju, vodio, valjda preko matere, krv baš od svog ujaka. ${ }^{52}$ Ovakav sud Isidora je izrekla na osnovu Cucinijeh ranih pjesama: prva je izašla bez naslova nakon izgnanstva iz Crne Gore. Napisana je 16. decembra 1853. u Kotoru i te iste godine objelodanjena u zagrebačkom Nevenu. Ona je programska i deklarativna: $U$ vrijeme po svijetu / Ljubio sam $i$ grlio, / A udaljen od svijeta / Sve sam za rod pregorio / Izvan roda i u rodu / Za rodom sam uzdisao, / U mladosti iz svijeta / U njemu sam pohitao / Al' ža-

${ }^{49}$ Ljubica Klančić (= Savić Marković Štedimlija), Život i smrt Stefana Perovića Cuce (1831-1857) - rukopisna monografija, 7.

XLV.

${ }^{50}$ Vuk Karadžić, Srpske narodne pjesme, knjiga IV, drž. izdanje, Beograd, 1896,

${ }^{51}$ S. M. Ljubiša, „Pesme Stefana Cuce Crnogorca“, Srpska zora, 1878, br. 34, 7.

${ }^{52}$ Isidora Sekulić, Njegošu knjiga duboke odanosti, Srpska književna zadruga, Beograd, 1951, 40-41. 
lost! Želje moje / Nemila mi ruka uze, - / Da za rodom po svijetu / Neopravdano lijem suze... Iako smo naveli samo dvije kitice, uočljivo je da pjesma ima sve odlike kasnijega Perovićeva pjesništva: emociju, čežnju, bol i rodoljublje. U drugoj pjesmi „Čuvstvovanje u vrijeme bolesti crnogorskog vladike P. P. Njegoša" koja je napisana dvije godine ranije, 25. juna 1851, putujući iz Beograda brodom uz Dunav, Perović je iskrenijem emocionalnim i misaonijem tonom oplakivao nestanak i gubitak velikoga pjesnika. Zaokupljen njegovom smrću, gubitkom i samijem sobom, traumom i tregedijom, Cuca je još jače izrazio svoje intimne preokupacije u pjesmi „Prahu Petra II Petrovića Njegoša“. U objema pjesmama posvećenijem Njegošu, on usmjerava svoju duboku emociju i asocijativno niže stihovane refleksije o životu i smrti, ali i o svome poetskom subjektu. Obje ove pjesme, zajedno sa trećom, „Tuga“, koja se po motivici i ośećaju na njih nadovezuje, uvrstio je Branko Banjević u svoj antologijski izbor Pleme za oblakom. Ovo ponajprije jer je u njima ośetio damar pjesnika, njegovu poetsku senzibilnost i varijaciju na temu života, smrti i, uopšte, sudbine čovjeka kojoj se ne može oduprijeti. To je poezija opšteljudskijeh tema, koje Perović zaogrće u romantičarsko ruho i u kojijema misao preovladava spontanost stihova kakve je Cuca stvarao jasnije pišući ponajbolje svoju autobiografsku poetsku ispovijest.

Nakon uvida u cjelokupni Perovićev poetski opus može se bez prećerivanja kazati da je njegovo pjesništvo izraz lirskoga senzibilnog subjekta koji će, prolazeći kroz uzvišenja i padove svoje životne biografije, od privatnoga života do vojničke odore i društveno-rodoljubne angažovanosti, do kraja uspjeti svojoj poeziji nametnuti vlastiti personalitet i svoj ego. Pobliže, pronaći će najbliži način za pronalaženje i razotkrivanje sebe kao poetskoga subjekta, svojijeh dubokih emocionalnijeh intenziteta u stalnome sukobu s iracionalnim ograničenjima koja mu je nametala životna stvarnost. Stoga, bilo kakva stroža podjela na razvojne faze ili tematske cjeline u Cucinom stvaralaštvu može biti samo formalna. Izuzmemo li samo Perovićevu pjesmu „Viteški podvizi“", koju je napisao po ugledu na narodnu poeziju u 535 stihova, sve druge pjesme Stefana Perovića Cuce su lirske strukture. Kako se odvajao od usmene književnosti prema zrelijem dobu, tako je i njegova poezija sve više od tematizovanja probuđenijeh rodoljubnih ośećanja i obuzetosti vlastitom intimom, prelazila u lirske ekstaze, opšteljudske teme, u razmišljanja o enigmi života kao univerzalnoj ljudskoj sudbini, u refleksivno poniranje o smislu života i smrti koje je opjevao u nekoliko pjesama. Poetsko rano stvaralaštvo Perovićevo obilježeno je posebnošću njegova shvatanja rodoljublja, različitijeg od onoga koje su izražavali pjesnici postnjegoševskoga epskog romantizma. Kod Cuce nema dubokijeh tematskih oscilacija. Preovlađuju teme ljubavi i rodoljublja, besmisla te u manjoj mjeri tematika tugovanki i žalopojki. Sâm je pjesnik u uvodnijem stihovima i naslovima naglasio takve 
Poezija druge polovine XIX i početka XX vijeka

poetske raspone: „Vječna žalost“, „Nada“, „,Smrt“, „Dan“, „Priziv u bijedi“, „Čežnja“, „Vijenac juga“, „Izraz čuvstva“, „Orepak bića“ i sl. Ponajviše zaokupljen pitanjima misterije ljubavi, rodoljublja, čežnje, tuge, njega zanima kako preživjeti doživljene ośećaje, kako istovremeno svoje erupcije emocija obuzdati razumom? Drugijem riječima, na koji način uskladiti vlastita ośećajna stanja - poetski izražena sentimentalističko-romantičnom epitetonikom i metaforikom sa grubom realnošću, realnošću života kojom je okružen. U pravu je Branko Banjević kad ističe da se u Peroviću nazire liričar sklon lirskoj meditaciji, pod jakim uticajem Njegořevih pjesama u šesnaestercu, jedna prava tuga kojoj odgovara to dugo talasanje ritma. Cuca nije bio književno obrazovan u onoj mjeri koja zahtijeva talent. On nije bio u toku književnih zbivanja i strujanja u Evropi, iako je tamo proveo dosta vremena. On pominje Bajrona i to pokazuje da je bio izvan evropske književne mode, jer je Bajronovo vrijeme bilo već prošlo. ${ }^{53}$

Zaokupljen samijem sobom, svojim traumama i nedaćama, ljubavnim radostima, ali još više bolima, tugama i žalostima, kao i rodoljubnijem zanosima i ushitima, najčešćim motivima svoje poezije, Perović krajem 50-ijeh godina XIX vijeka svoje intimne preokupacije usmjerava prema novijem temama. Variranje rodoljubnijeh stihova, vezanih za pjesnikov povratak svojoj domovini Crnoj Gori, zamijeniće, u romantičarskome maniru, misaonijem vizijama o životu i smrti; okreće se bitnim pitanjima ljudske egzistencije, ośećajući svoju sudbinu kao fatalnu i nesavladivu realnost, a život kao neumitnost prolaženja. Perović se ponekad miri sa sudbinom i bez borbe se prepušta svom udesu.

Ogledao se Cuca i u pjesmama širokoga metra (šesnaestercu), nalik na pjesme u prozi, ali s mnogo manje uspjeha no u poetskijem zaletima intimne senzibilinosti. Lirike ima i u njegovijem pismima Derviš-paši (1853) kad mu je nuđen visoki turski položaj, a on ga je odbio dostojanstveno i pozvao pašu na dvoboj. Dovijek su se klali moji đedovi s tvojijema, pa i ja i ti da se okušamo jesmo li sinovi onih otaca slavnih. Paša nije izašao na dvoboj, a Cuca je poginuo od ruke pobratima. Njegov život je njegova najveća Pjesma zaključuje svoj kratki tekst o Peroviću Radoslav Rotković. ${ }^{54}$

\section{Filip Radičević (1839-1917)}

Po godini rođenja Filip Radičević je mlađi skoro deceniju od Stefana Perovića-Cuce, a svega dvije godine stariji od Nikole I Petrovića-Njegoša. On se generacijski i stvaralački uklapa u krug pjesnika epskoga narodnog ru-

\footnotetext{
${ }^{53}$ Branko Banjević, Isto, 13.

${ }^{54}$ Dr Radoslav Rotković, Isto, 629.
} 
ha. Naime, cetinjski arhiđakon Filip Radičević porijeklom je, kao i njegov mlađi prezimenjak, najliričniji i najsublimniji pjesnik srpske romantike, Branko Radičević (1824-1853), iz Berislavaca u Zeti. ${ }^{55}$ Filip nije originalni pjesnik, već pripada onoj skupini stvaralaca koji su skupljali, zapisivali i donekle prerađivali modele usmene književnosti dajući im ponekad i svoj osobeni stvaralački pečat. Poput njegova savremenika Stefana Popovića, Radičević objavljuje u Beogradu 1872. godišta zbirku usmenijeh pjesama koje su i jedan i drugi nazvali Gusle crnogorske, samo što je Popovićeva zbirka objelodanjena nešto ranije, 1858. godine. Gusle su bile omiljeni instrumenat Crne Gore preko kojega su se transponovale od pojedinca do naroda misli, rodoljubni ośećaji i uzvišeni mitski junaci crnogorskoga i srpskog podneblja. Takvu poeziju zagovarao je donekle knjaz/kralj Nikola I Petrović, a i sâm je tvorio pjesništvo takvoga ruha i ośećaja. Potrebu da izda zbirku usmenijeh pjesama ośetio je i Filip Radičević. O toj potrebi istoričar Trifun Đukić u Pregledu književnog rada Crne Gore kaže: Gusle Filipa Radičevića su postale iz težnje da se iz onoga kraja, gdje ima još mnogo narodnih umotvorina koje žive u narodu (...) prikupe i sačuvaju od zaborava, a malo dalje naglašava njihovu istorijsku vrijednost jer imaju više istine nego poezije, pa prema tome one mogu služiti više kao istorijske crtice, jer su u njima vrijeme, događaji i sama lica vjerno opisani. ${ }^{56}$ Dakle, izraziti sljedbenik Vuka Stefanovića Karadžića, Radičević je skupljao usmenu poeziju, bilježio je, ali je izgleda pod uticajem individualnoga stvaralačkog procédéa, svoje pjesme bogatio i nekijem elementima vlastitoga poetskog duha. Zbog toga se pojedine Radičevićeve pjesme mogu označiti kao pjesme na narodnu. U tu nas misao učvršćuju, ne samo pojedini poetski motivi i slikovne posvete, već i to što je književni istoričar Ljubomir Stojanović u trenutku objelodanjivanja Vukove IX knjige usmenijeh pjesama (1902), objašnjavajući od koga ih je Vuk dobio, naznačio da su usmene pjesme pod brojevima 7, 12 i 18 Filipa Radičevića $i$ da je možda sve tri sam on napisao. ${ }^{57}$ A o kakvoj se poeziji radi? To je ono isto usmeno pjesništvo koje je cvjetalo mnogo ranije u slobodnome dijelu Crne Gore, ali i u primorskome pojasu. Uz tvorevine epskoga sadržaja, pjesme koje su dosta vjerno opjévale istorijske događaje i junake ovoga kraja, ${ }^{58}$

\footnotetext{
${ }^{55}$ Radičevići potiču iz Berislavaca u Zeti. Njihov potomak doselio se u 14. vijeku iz Lješa neko vrijeme (živjeli su - M.N.) u Draču... i Grudama (Tuzi). Od njih su (Radičevići - M.N.) u Podgorici, Dalmaciji i Todor Aleksin ode u Slavonski Brod i sin Branko u Beč, posmrtni ostaci na Stražilovo (Sremski Karlovci). Viđi: Vukota Miljanić \& Akim Miljanić, Prezimena u Crnoj Gori, Beograd, 2002, 380.

${ }^{56}$ Trifun Đukić, Pregled književnog rada Crne Gore od Vasilija Petrovića Njegoša do 1918. godine, Narodna knjiga, Cetinje, 1951, 322.

${ }^{57}$ Isto.

${ }^{58}$ Zbirka Crnogorske gusle Stefana Popovića sadrži pjesme bez naslova, ali su
} 
Poezija druge polovine XIX i početka XX vijeka

živjele su uporedo i druge književne vrste koje su ponekad umetnički $i$ realistički stajale iznad njih. ${ }^{59}$ Uz te vrste u Crnoj Gori stvarano je pjesništvo koje je svojim sadržajno-motivskijem i stilsko-izražajnim, tj. jezičkijem svijetom predstavljalo neku vrstu dodirnijeh prijelaznih formi između usmene narodne poezije i pisanoga pjesništva. Takav poetski žanr, koji je u teoriji književnosti poznat kao poezija na narodnu, stvarali su u Crnoj Gori literarno daroviti pojedinci koji su svoje spoznaje o svijetu i životu, o vremenu i društvu, nastojali da izraze u takvijem tvorevinama. Njih je, među prvima pisao, krajem prve polovine XVIII vijeka vladika Vasilije Petrović („Crna Gora“, „Simeone, Sveti Nemanja“ i „O Ismaili““ $)^{60}$; svoj je puni procvat to pjesništvo doživjelo u ličnosti Petra I Petrovića, a prisutno je i kod Njegoša i Ljubiše („Boj na Visu“, 1866) u njihovijem najranijim poetskijem sastavima. Spomenute tvorevine, u odnosu na epsku junačku pjesmu, i u sadržajno-motivskome svijetu, i u stilsko-izražajnome pogledu, predstavljale su vidnu novinu. U sadržajima su se te novine ogledale u određenijem političkim namjerama, tendencioznosti, tj. angažovanosti koju iskazuju njihovi tvorci, najčešće crnogorski političari, vladaoci iz porodice Petrovića, i veoma obrazovani ljudi. A novine u pogledu stila i izraza najviše su se ispoljile u elementima koje su pośedovale pisane pjesničke tvorevine. Pjesme na narodnu pisane su najčešće u dugome stihu, u većini strukturiranome iz dva kratka stiha, rime, melodije, i pjesničkoga jezika koji je u osnovi narodni, ali ponegđe s primjesama crkvenijeh jezičkih elemenata. ${ }^{61}$ Ako uz ovo dodamo idejnost - element koji je u većoj mjeri svojstven pisanoj poeziji, ${ }^{62}$ naglašenu moralističku tendenciju, onda smo približno naveli sve komponente pjesništva na narodnu koje su ga udaljavale od epske narodne književnosti. ${ }^{6}$

Prema gore izloženijem modelima poetike na narodnu, pisao je svoje pjesme Filip Radičević. Njegove pjesme imaju sklop koji odmah podsjeti na kompoziciju školovanog pjevača ${ }^{64}$ Takve su mu pjesme „Pop Crnogorac i kapetan Đulek“, „Began serdar“, „Boj na Kolašinu“ i druge. U njima se ośeti

obilježene rednijem brojevima. Među njima ima pjesama o crnogorskijem i srpskim junacima (Marku Kraljeviću, Sibinjanin Janku i sl.), no uz njih su ušle mnoge lirske pjesme, poskočice i pošalice.

${ }^{59}$ Jovan Deretić, Kompozicija Gorskog vijenca, Beograd, 1969, 26.

${ }^{60} \mathrm{U}$ književnoj se istoriji ističe da njihovo autorstvo nije do kraja rasvijetljeno.

${ }^{61}$ Prednjegoševsko doba, II izdanje, priredio dr Niko S. Martinović i dr., Grafički zavod, Biblioteka „Luča“, Titograd, 1966, 202-203.

62 Jovan Deretić, Isto, 27.

${ }^{63}$ Milorad Nikčević, „Duhovni zavičaj - ishodište književnog djela Njegoša i Ljubiše“, u knjizi Ideje i paralele (Književni ogledi $i$ studije), Izdavački centar „Revija“, Mala teorijska biblioteka 14, Osijek, 1984, 102-104.

64 Trifun Đukić, Isto, 322. 
konciznost, kratkoća, zbijenost, tipična crnogorska leksika, slikovni stihovi, što je obično odlika onijeh pjesnika koji se bave umjetničkom poezijom. ${ }^{65} \mathrm{Na}$ vodeći brojne osobine individualne poetike Filipa Radičevića, Trifun Đukić je utvrdio da su mnoge pjesme u njegovoj zbirci Gusle crnogorske njegove tvorevine poput njegove pjesme „Boj na Rasenoj glavici“ čiji je motiv isti kao u Dučićevoj pjesmi Ratovanje Omer-paše. Nadalje, on kaže da je pjesma ispjevana u čast vojvode Marka Miljanova Popovića i da ova pjesma ima iste stilske, ili stihovane osobine koje smo vidjeli kod onih u Vukovoj knjizi. I tamo je čest slik, kojim se (...) obilježava težnja da pjesma dobije izvjesne umjetničke odlike, pa navodi: Iz bijele crkve izidoše./ Sveštenici krsta iznesoše./ Sveti barjak u ruke nosiše./ Na kom obraz. Spasitelja bješe./ Sav s' od zlata čistoga blistaše ${ }^{66}$ Dodamo li ovoj pjesmi rodoljubnu tendenciju i realni uzročno-posljedični istorijski slijed prikazivanja događaja, onda smo iscrpili sve elemente pjesništva Filipa Radičevića koji je pjevao po uzoru poezije na narodnu.

\section{Nikola I Petrović Njegoš (1841-1921)}

Nikola I Petrović Njegoš proslavljeni je knjaz/kralj Crne Gore i veoma plodan i žanrovski raznovrstan književni pregalac. Imao je više sluha i uspjeha kao vojni strateg, dugovjeki gospodar Crne Gore, a manje je domete postigao u književnome stvaralaštvu. Dva su ga, dakle, životna poziva sudbonosno i presudno obilježila i zaokupljala kad je u pitanju njegovo emocionalno i racionalno dozrijevanje i ideološko opredjeljenje, a u krajnjem ishodu i prije svega, uticali su na njegovo cjelokupno literarno stvaralaštvo.

Prvi je poziv njegov bio snažni vladarski duh, temperamentni angažman i želja da kao vladar izvede Crnu Goru cjelovitu, suverenu i slobodnu zemlju, oslobođenu, u njenijem povijesnim granicama, od vjekovnih zavojevača. Kad se taj osnovni i vjekovima dosanjani cilj dijelom u njegovijem slavnim bitkama ostvario, knjaz/kralj Nikola je u slijepome zanosu i nestvarnijem iluzijama svoga dugog vladanja, otvoreno gajio nade, pa čak i određene političke pretenzije, da kao vladar Crne Gore postane suveren nekadašnjega srednjovjekovnog srpskoga i pravoslavnog carstva s ciljem da na toj osnovi objedini nekadašnje cjelokupno srednjovjekovno Dušanovo carstvo. Iluzionistički, maglovito i nerealno je gajio nade da će postati kraljem Balkana, a svakako su ga u tome njegovi najbliži saradnici podsticali, zavaravali i govorili mu da će u najmanju ruku biti kraljem Crne Gore i Srbije. Ka tom cilju on polako počinje da okreće ukupnu državnu politiku, pa u tome sklopu $i$

\footnotetext{
${ }^{65}$ Trifun Đukić, Isto, 323.

${ }^{66}$ Isto.
} 
Poezija druge polovine XIX i početka XX vijeka

prosvjetnu $i$ kulturnu politiku. ${ }^{67} \mathrm{Na}$ tijem osnovama gradio je svoju dugovjeku političku strategiju, kulturnu, pa i cjelokupnu književnu koncepciju. Težio je da postane glavni stub i prestižni personifikator i politike i književnosti. U toj nestvarnoj želji i pogrešnoj politici strastveno je izgarao i na kraju neslavno sagorio završivši u finalu svoje dinastičke vladavine kao prognanik od srpskijeh trupa, u egzilu u Francuskoj đe je skončao i svoju politiku i svoju književnu karijeru te zauvijek izgubio sve ono za što se cijeloga života žustro borio - državnost svoje domovine Crne Gore!

Drugi knjažev/kraljev životni poziv - književni - čvrsto je proistekao iz sagledavanja funkcije prvoga: književnost se takođe morala podrediti, kao što je to bilo i kod nekijeh njegovih prethodnika - crnogorskijeh vladara, svenacionalnoj velikosrpskoj (= štokavskoj i pravoslavnoj) i slovenskoj ideji; staviti crnogorsku ideološku perspektivu u njezinu najužu političku i pravoslavnu viziju srpstva. Pod očiglednijem uticajem svojih predaka iz dinastije Petrovića, posebno Njegoša i savremenijeh srpskih i crnogorskijeh ideologa i pjesnika, Nikola I Petrović se kao književnik od samoga početka pa do konca svojega dugog književnoga rada nije uopšte znatnije poetološki, književnoistorijski i književnoteorijski razvijao, nije evolutivno poetski napredovao, nije se bitno kao književnik mijenjao i transformisao; nije se upuštao u eksperimentisanje ni jezikom, ni stilskijem postupcima, već je ostao dosljedan zarobljenik crnogorske književne tradicije i pojedinijeh njegovih poetskijeh prethodnika. Glavno izvorište, opsesija i inspirativnost njegova cjelokupnoga djela proistekla je takođe iz njegova dvorskoga okruženja, njegove dinastičke dvorske slave, poleta i pogrešne prosrpske politike, društvene stvarnosti i vremena u kojem su se prelamala izuzetna istorijska, politička, pa i kulturna zbivanja i za crnogorski narod i za crnogorsko društvo uopšte i za koncepciju i perspektivu same crnogorske državnosti i njene cjelovite kulture. Ugroženost egzistencije narodnog $i$ nacionalnog bića prirodno je vodila literaturu $u$ društvene zadatke, u etičku inspiraciju. (...) Duhovne i fizičke snage naroda skoncentrisane za odbranu ulazile su u poetsku riječ koja je bila vid borbe, vid postojanja, odbrana postojanja. ${ }^{68} \mathrm{Uz}$ to, Nikola kao državnik i pjesnik je bio vas zanosno okrenut, kao što rekosmo, pravoslavlju i „srpstvu“, a dijelom kao pjesnik bio je okrenut crnogorskoj tradiciji, narodnoj epskoj i lirskoj poeziji, pa se nije mogao, iako je čitao i donekle poznavao talijansku, francusku i nešto površnije rusku literaturu, književno i poetski šire edukovati i posvojiti neke modernije literarne forme, poglede, tendencije i poetike evropske ili istočnoevropske literature koja je u onome trenutku kod drugijeh naroda i te

${ }^{67}$ Branko Banjević, ,Jedan vid 'primijenjene poezije'“, predgovor u knjizi: Nikola I Petrović, Rat crnogorski, Biblioteka „Luča“, NIP Pobjeda, Titograd, 1975, 11-12.

${ }^{68}$ Isto, 11. 
kako snažno pulsirala. On, upravo zbog te tradicionalne zarobljenosti stihom narodne poezije i svojijeh užih uzora, ne unosi nikakve revolucionarne novosti u crnogorsko pjesništvo svojega doba, ali se, ipak, u ponajboljijem svojim poetskijem, epskim i drugijem djelima, uspio donekle ophrvati i oteti stereotipima vladajućega epskog rimovanoga deseterca, izražajnoj konvencionalnosti svojih brojnijeh prethodnika i deseteračkijeh sljedbenika i epigona. Ponešen više neposrednošću, intenzitetom svoga emocionalnog bića i ośećanja, poetskoga senzibilnoga nagona, Nikola Petrović ostvaruje brojne poetske, epske i epsko-lirske tvorevine pisane osmeračkijem stihom, stihom koji se sve više afirmiše kod crnogorskijeh pjesnika oko njega.

Snažno zagledan u poetsku misiju svojijeh predaka, prije svega Petra I i Petra II Petrovića Njegoša, Nikola se dijelom ugledao i na generaciju pjesnika koji su bili sudionici njegove savremenosti, posebno na pjesništvo srpskijeh romantičara Branka Radičevića, Jovana Jovanovića Zmaja i donekle Laza Kostića. U biti, stvarajući patetično rodoljubivo i ljubavno stihotvorstvo, Petrović se neprestano nalazio u raskoraku i poetskoj dihotomiji sa stvarnijem inspiracijskim trenutkom iskrenoga, produbljenog doživljavanja, afirmacije rodoljublja i domovine Crne Gore i njezina herojskoga naroda i imperativnog ,zahtjeva“ da mora pisati angažovane stihove, rodoljubive $\mathrm{i}$ podsticajne pjesme, jer mu to nalaže patriotska dužnost i poziv agilnoga vladara svoje države. Riječju, Nikola I Petrović bio je stalno razapet između poziva istinskoga rodoljubivog pjesnika i književnika koji treba da služi narodu i domovini, s jedne, i prigodničara - stihotvorca „programskog“ praktičara i ideološkoga pjesnika, s druge strane, što je svakako rezultiralo i visokijem estetskim, sadržajnijem oscilacijama njegove poezije i neujednačenošću njegovijeh brojnih patriotskijeh, ljubavnih i prigodnijeh pjesama, pa i cjelokupnoga njegova književnoga opusa.

Književno djelo Nikole I Petrovića Njegoša tradicionalno se dijeli po tematskome, motivskom i žanrovskome kriterijumu upravo onako kako su ga njegovi priređivači Risto Dragićević, Savo Vukmanović i Niko S Martinović, kao priređivači i redaktori, uobličili u Cjelokupna književna djela. ${ }^{69}$ Podijelili su ga na: Pjesme, Spjevove, Drame, Govore, Autobiografiju, Memoare i putopise te Pisma. Dakle, uz državničke poslove Nikola Petrović je ostavio i žanrovski raznovrsne književne, diskurzivne i epistolarne forme; cijelijem svojim bićem bio je i vladar i svestrani književnik.

\footnotetext{
${ }^{69}$ Djela su izašla u izdavačkoj kući Obod na Cetinju 1969. godine, a u redakciji Rista Dragićević, Sava Vukmanovića i dr Nika S. Martinovića. Svi citati su prema tijem djelima.
} 
Poezija druge polovine XIX i početka XX vijeka

Književni istoričar Radoslav Rotković je precizno pobrojio da se u cjelokupnome poetskom korpusu Nikole I Petrovića nalazi, uz njegove lirskoepske spjevove i drame, 98 lirskijeh raznovrsnih pjesama. Tragajući za estetskijem vrijednostima Nikoline lirike, za onijem što je u njegovoj poeziji estetski esencijalno i poetski živo, iznjedreno istinskom emocijom, Branko Banjević je u svoje dvije knjige: $u$ antologijskome pregledu crnogorske poezije Pleme za oblakom (1973) i u Ratu crnogorskome (1975), takođe širemu antologijskom izboru Nikoline poezije, uveliko olakšao i omogućio budućijem čitaocima i prosuditeljima Nikolina djela da sadržajno i estetski pravilno na jednome mjestu nađu i iščitaju upravo sve one sadržaje što su zaista kod Nikole I Petrovića - pjesnika ostali vrijedni i pohranjeni u memoriju crnogorskoga pjesništva; sve ono što je ostalo, dakle, i danas svevremenski živo i aktuelno. I sasvijem smo sigurni da upravo taj Banjevićev izbor čini Nikolinu poetsku srž: kvalitativnu i kvantitativnu vrijednost njegova poetskoga opusa! Uz ovaj vidno uspjeli i nadasve kvantitavno neveliki estetski izbor u Banjevićevijem antologijama, svakako treba pridodati pohvale vrijedna još dva novija izdanja Nikolinijeh djela: prvi je izbor njegovijeh Političkih spisa koje je znalački priredio neprevaziđeni crnogorski istoričar Dragoje Živković 1989. godišta, a drugi je temat prvoga izdanja Cjelokupnijeh književnih djela kralja Nikole I u jednotomnoj knjizi koju je svojevremeno priredio istorijski i književni pregalac i izvanjac u Crnoj Gori Dušan Vuksan. Izdala ga je kao reprint izdanje tek u naše doba Univerzitetska riječ u Nikšiću 1989. godine s kraćijem predgovorom Novaka Kilibarde. Upravo je takvijem prezentiranjem i cjelovitim odabirima Nikolina izdanja, koja su ujedno opremljena predgovorima, pogovorima i drugom naučnom aparaturom, omogućila dovoljno solidan i svestran panoramski uvid u Nikolin raznovrsni i književnoistorijski vrijedan književni korpus.

Ocjenjujući u svome sintetičkome pregledu Nikolinu poeziju, Radoslav Rotković je s pravom istakao da su mu lirske pjesme mahom prigodne, da se u njima pominje više od 150 različitijeh ličnosti, pretežno savremenika i eksponenata političkoga, dvorskog i užega kulturnog života Dvora i zemlje iz vremena samoga pjesnika. Posebno su opjevane ličnosti iz njegove najuže dvorske okoline sa svijem svojim zvanjima, profesijama i funkcijama koje su na Dvoru obavljali. Veliki dio takvijeh prigodnih, personalno-intoniranijeh ushitnih i panegiričkijeh pjesama, Kralj je posvetio i svojoj užoj porodici, posebno đeci i supruzi, njenim čestim liječenjima, važnijim godišnjicama braka. Te omiljene prigodnice, kao i one ljubavne pjesme iz njegove rane mladosti, ne sadrže, kaže Rotković, ništa više emotivnosti nego druge posvete saborcima ili u zdravicâ(ma) prilikom domaćeg ručka. (...) Njegova poezija (je) familijarna, ođevena u kućne haljine, neočešljana. Osmerac u kome se najčešće slikuju samo parni stihovi u stvari je niz šestnaesteračkijeh distiha a 
distih je najlakši način pučke improvizacije, u prikazanjima, kolima, borbenijem pjesmama. ${ }^{70}$

Svakako ovome brojnom Nikolinome prigodničarskom pjesništvu, treba pridodati i njegove rane ljubavne i rodoljubive pjesme koje su Knjaževe početnice i nijesu imale „većeg estetskog učinka“. Pobliže, i jedne i druge tvorevine, promatrane i doživljene s estetskoga dojma i stajališta njegove poezije u cjelini, kao i one njegove najranije ljubavne pjesme za koje se tvrdi da su ,izgubljene“, odnosno da ih je sâm pjesnik odstranio kao emocionalno nedolične iz svoga opusa, ne ostavljaju nikakve dublje estetske učinke, a kamoli poetske poruke. Na ovom ih mjestu ipak apostrofiramo samo kao književnoistorijsku i dijahronijsku pojavu u Nikolinome cjelokupnom razvojnom opusu i crnogorskoj književnosti koju će uveliko potisnuti samo Kraljevo vrijeme i talas sadržajnijih i modernističkijih poetskijeh pojava prije i poslije njega.

Kao poseban ciklus iz nešto zrelijega Nikolina pjesništva svakako treba izdvojiti onaj korpus njegove poezije koji je na nešto višemu poetskome i estetskom nivou. To su pjesme koje Nikola naslovljava simbolično Iskrice $o$ čovjeku. Tek u tome opusu, kao i u nekijem njegovim drugijem poetskim ciklusima, nalazimo naznake uspjelije poetske tematike, motivike i metaforike. To su zaista poetske iskrice, trunci poetskijeh reflksija kojima je pjesnik, tu i tamo, prožeo svoj poetski ciklus kao i uopšte svoju cjelokupnu rodoljubivu i intimnu poeziju. A njezina se poetika i tematsko-motivska vrijednost može svesti na tri ključne odrednice, na tri poetske sintagme o kojima pjesnik uporno i varirano stalno pjeva: Crna Gora - njena sloboda - i njezin narodl Irod; slavjanski rod i slično. Ova poetska inspirativna žarišta su donekle odraz dubljijeh Nikolinih emotivnih stanja, obojene su poetskom i političkom opsesijom pjesnika i bitna su sastavnica pjesnikova zreloga doživljaja i shvatanja njegova rodoljublja. Ti motivi su svakako dublji stvaralački etimoni koji se lako iščitavaju gotovo u svijem njegovim brojnijem stihovima na naznačene teme. Više nego ijedan pjesnik do njega, Nikola je i kao državnik i kao rodoljubivi pjesnik otvoreno pjevao, zastupajući ideju snažnoga i impulsivnog života Crne Gore i Crnogoraca, njihova opstanka kako u savremenome životu, tako i u burnoj istoriji i prošlosti. On često poletno i energično, u emocionalnome ushitu pjeva apoteozu svojoj domovini - Crnoj Gori:

Još je živa Crna Gora!

u njoj ima još gorštaka!

u njoj ima i još ljudi,

vitezova i junaka!

Neće njena slava stara

popuznuti i nestati!

${ }^{70}$ Dr Radoslav Rotković, Isto, 630. 
Poezija druge polovine XIX i početka XX vijeka

Kao prije, kao vazda svijetu će ona sjati! i njen sin se ponositi kao soko među ptice! i pjesmu će pjevat staru na visove i litice! Čudotvornu, nepobjednu pjesmu, duše do potresa! I dalje će krepost, snagu on dobivat od nebesa! (,Crnoj Gori“)

Ističemo na prvom mjestu upravo ovu rodoljubivu i programsku Nikolinu pjesmu iz osnovnog razloga: ona najsnažnije ilustruje motiviku kojom je prožeta cjelokupna rodoljubiva poezija kralja Nikole I Petrovića. U takvijem brojnim stihovima i prigodnijem naslovima, koje ne trebamo posebno isticati, doći će do pravoga izražaja ne samo izvanredna pjenikova lakoća osmeračkoga stiha, pjesničkog jezika kojijem Nikola uspijeva graditi svoju liriku, već mnogo više jednostavnost i jasnoća ośećaja i misli, ali i poetski uspješno izražena pjesnikova ličnost, njegove izvorne i poletne misli i emocije. U takvijem se pjesmama Nikola Petrović upravo približio pjesnicima romantizma: Radičevićevoj i Zmajevoj emocionalnoj jasnoći i poetskoj razigranosti te ponekad i Njegoševoj asocijativnoj misaonoj snazi borbenoga metaforičnog izraza:

O nevoljo od nevolje, i od španje španjo stara, mojom sudbom ti ne vladaš dok je puške i handžara! Građani me puštit neće krvavci su, znam i zlice! al neka ih, junaci su čuvaće mi čat i lice! (,Na straževo stoje kolje“)

Iz ośećaja slave, apoteoze junačkijeh i etičkih pobuda i emocija te personalnoga Nikolina borbenog i snažnoga agona, njegova inspirativnoga izvora, nastaju njegove brojne borbene i rodoljubive pjesme. Njima dodajemo i poetsku tvorevinu koju je naslovio „Turčinu“ i koja je često isticana kao jedinstveni primjer pjesnikova objektivnog, tolerantnoga i etičkog stava. Naime, u njoj po principu etike, viteškoga agona, pjesnik slavi sablju i desnicu svoga vjekovnog protivnika Turčina, ali kao ravnopravnoga rivala i ratnika na bojnijem poljima; saputnika i viteza u okršajima i stalnijem borbama i satiranjima: 
Milorad NIKČEVIĆ

Što te ruže, lafe stari istočnoga care sv'jeta, Orle, koji sred zapada U pohode nam dol'jeta?

(...)

Što te ruže, o viteže, što te ruže, bojni grome, a pregnuća kavge - car si, ti stravični krunolome!

(...)

Borba strašna i velika

nastane li iznovice:

zadime li bojnom maglom

naša brda i ravnice,

kroz tu maglu zasjaju li

sabalja nam bistri zraci...

mi ćemo se iza toga

opet štovat ka junaci (...).

Iako se cjelokupno Nikolino pjesništvo umnogome otima krutoj imanentnoj podjeli po tematskijem vrstama i žanrovima, ipak možemo iz cjelokupnoga opusa, od pjesme do pjesme, uočiti kod njega, osim ljubavnijeh, prigodnih i rodoljubivijeh pjesama o kojima je bilo riječi, i poneku socijalnu, pejzažnu pa čak i refleksivnu pjesmu. Takva je uspjelija socijalna pjesma „Bol Crnogoraca u Americi“. U njoj se u narativnom stihu probija istančani emocionalni glas pjesnika, njegova žal nad sudbinom svojih zemljaka čiji životi izgaraju i skončavaju, ostavljajući svoju vitalnost i mladost širom Amerike u rudokopima „crnoga zlata“:

Čas prokleti onaj bio kad me talih zli navede, te za ruku nesrećnoga u ovaj me kraj dovede!

Bog pravedni prokleo je moga puta grešne stope da imuće tobož tečem u duboke rudokope (...)

Prevarih se u daljini, Amerika mišljah da je mnogo bliža - bog ubio predaleke njene kraje. (...) 
Poezija druge polovine XIX i početka XX vijeka

Nikola je u ovoj pjesmi, kao i u nekijem drugim tvorevinama sličnoga sadržaja, istupio glasom angažovanoga pjesnika, socijalnog pravednika. On je zasigurno preteča one struje pjesništva što će doći do izražaja u razdoblju crnogorske književnosti humanoga ili socijalnog realizma između dva svjetska rata, posebno transponovana u antologijskijem pjesmama Mirka Banjevića „Tužba svetom Vasiliju Ostroškom“ i još potresnijom socijalno angažovanom pjesmom Janka Đonovića „Crnci i Crnogorci“.

I poduža pjesma „More“ odaje pjesnika Nikolu Petrovića kao vrsnoga pejzažnog i perifrastičnoga stihotvorca. Ona je sva i ritmom i riječju u slici i gibanju, pokretu, sazdana poetskom slikom uzburkanosti mora: talasa se pjesnikovo osjećanje kao morska širevina. Glatko plovi stih kroz ushićenje vladaoca što je podlovćensku Crnu Goru izveo na državinu zetskih gospodara; što ga konačno zapljuskuje more koje je bilo i Dušanovo i Ivanovo, i duždevo i sultanovo. Treba ga pozdraviti kao živoga stvora što je Crnoj Gori pripalo po volji božjoj $i$ sablji britkoj ${ }^{71}$ :

Pozdravljam te, sinje more,

o livado tečna ravna,

ti velika prostorijo -

željo naša preodavna!

Nikola I Petrović je svakako značajniji pjesnik u onijem stihovima koji poprimaju himnički ton i nacionalno odražavaju njegovu uzvišenu poetsku viziju i političku iluziju. Bez obzira na to što nije skrivao u svojoj rodoljubivoj euforiji pogrešno uvjerenje da su Crnogorci izdanci „,srpskoga roda““ ${ }^{72}$ on je znao zapjevati svečanijem evokativnim ritmom, tonom i širinom dikcije is-

71 Novak Kilibarda, „Gospodar kao pjesnik“, predgovor u: Cjelokupna djela kralja Nikole I, Univerzitetska riječ, Nikšić, 1989, 9.

${ }^{72}$ Nikolino srpstvo podrobno je i naučno utemeljeno objasnio akademik Vojislav P. Nikčević u svojoj dvotomnoj istoriji crnogorskoga jezika (Nikčević, Vojislav P. Crnogorski jezik. Geneza, tipologija, razvoj, strukturne osobine, funkcije. Tom II, Matica crnogorska, Cetinje, 1997) pod sljedećijem naslovima: Nikolino „srpstvo“, Nikolino pravoslavno „srpstvo“, Nikoliko filološko i monogenetsko štokavsko „srpstvo“. U najkraćem, objašnjenje akademika Nikčevića sastoji se u sljedećem: $\mathrm{Na}$ temelju analize $\mathrm{Ni}$ kolina „srpstva“ i njegova upoređivanja s Karadžićevijem i Njegoševim „srpstvom“, dolazi se do saznanja da je Nikola I. Petrović Njegoš direktno od Petra II. Petrovića i posredno preko njega baštinio pravoslavno te filološko i monogenetsko štokavsko Vukovo „srpstvo“ za potrebe svoje ekspanzinističke politike. A ta je politika išla za tijem da proširi njegovu vlast kao „cara Balkana“ u granicama koje su nastanjivali pripadnici južnoslovjenskoga štokavskog dijalekatskog sistema triju balkanskijeh vjerozakona - pravoslavaca, rimokatolika i muslimana. (Vojislav P. Nikčević, Crnogorski jezik. Geneza, tipologija, razvoj, strukturne osobine, funkcije. Tom II, Matica crnogorska, Cetinje, 1997, 431-432.) 
krenoga pjesnika s uvjerenjem da su „Crnogorci potomci Dušanova carstva“. $\mathrm{U}$ tome duhu ispjevao je brojne pjesme, ali se posebno ističe tvorevina koja je himnično zazvučala jer je patetično uznesena i u njegovo je vrijeme predstavljala omiljenu, omamnu, cijenjenu i veoma popularnu pjesmu-himnu: „Onamo, onamo!“‘:

\section{(...)}

Onamo, onamo... za brda ona

Govore, da je razoren dvor,

Mojega cara, onamo vele,

Bio je negda junački dvor. -

Onamo, onamo... da viđu Prizren -

Ta to je moje - doma ću doć'. -

Starina mila tamo me zove,

Tu moram jednom oružan poć'. -

Onamo, onamo... sa razvalina

Dvorova carskih vragu ću reć':

„S ognjišta milog bježi mi, kugo,

Zajam ti moram vraćati već!“ -

\section{(...)}

Himničnošću, uzvišenošću, ritmičnošću aliteracija na početku stihova ova je rodoljubiva pjesnička emocija usaglasila (...) svečani ritam s tematikom, rodoljublje sa strašću vojskovođe (...), riječi s rimom, metaforiku s ritmom, dužinu teksta sa srećnim naslovom. ${ }^{73}$ Po njoj je Nikola I Petrović i kao pjesnik i kao državnik najviše hvaljen i slavljen ne samo u Crnoj Gori već i u cijelome slovenskom i pravoslavnom rodu.

Sve u svemu, Nikolina je rodoljubiva poezija kao i ona sličnoga žanra, emocionalno eruptivna, poletna, po poetskoj i emocionalnoj snazi i motivici raznorodna i u svoje je vrijeme predstavljala žive poetske obrasce koji su se receptivno lako prenosili do malo obrazovanoga čitaoca, ali i do školovanih ljudi; pamtile su se njegove pjesme kao svojina mase i usmenoga narodnog kolektiva. Nikolina poezija, iako se čini da je ponekad stvarana aljkavo, u grču, napetosti, tenziji i borbenom poletu, ostaće, ipak, i tematikom i motivikom osmeračkijeh stihova, te nekim drugijem novitetima, onaj vid ,primijenjene poezije“ koja je plijenila emocije crnogorskoga čovjeka, podneblja i naroda pa je kao takva određenijem slojevima i za današnje savremene čitaoce veoma prijemčiva i emocionalno dojmljiva.

Nikola je kontinuirano stvarao i spjevao i epsko-lirske tvorevine: „Ženidba bega Ljubovića“ (1868); „Selim begova kula“ (1879); „Na ponoći“ (1903); „Pjesma sv. Savi“ (1912). Posebno je ustihovao poetsku tvorevinu,

\footnotetext{
${ }^{73}$ Novak Kilibarda, Isto.
} 
Poezija druge polovine XIX i početka XX vijeka

cjelinu u strukturi od 32 kola sa „Posvetom muškoj mladeži crnogorskoj“, dok je u vremenu od 1888. do 1892. sačinio i tri opsežna epska spjeva: Potonji Abenseraž (1888), Hajdana (1889) i Pjesnik $i$ vila (1892). Svi ti poetski sastavi pisani su u romantičarskome duhu, ispjevani su u stilu i dikciji ondašnje domaće i evropske poezije; puni su slikovitih epskih opisa $i$ još više lirskih i patriotskih akcenata. ${ }^{74}$ Ženidba bega Ljubovića karakterizirana je kao zanimljiva i dramatična pjesnikova naracija. Predmet joj je uzet iz narodnoga predanja, a fabulom je vezana za osionoga bega Lakešića iz Mostara koji je preoteo vjerenicu mladome Alil-begu Ljuboviću iz Nevesinja. Složićemo se sa sudom da je ta epska pjesma zanimljiva sentimentalna istorija ... sa puno jakih dramatičnih scena. Radnja se u njoj izlaže prirodno, postupno, i logično, idejni smjer pjesme je da ukaže na neki viši etički zakon koji po pjesnikovom mišljenju vlada nad svim bićima i koji pobjeđuje zlo i nepravdu. ${ }^{75}$

Iako su naznačena djela ovoga žanra pisana pretežno pjesnikovijem omiljenim osmeračkijem stihom, u Nikolinoj književno-iskustvenoj razvojnoj fazi, ona ni svojom književnom zrelošću ni svojom epskom naracijom, ni svojijem poetskim jezikom ni metrikom, kompozicionijem skladom sadržaja, nijesu dosegla estetski ciklus njegovijeh najboljih rodoljubivih i intimnih pjesama koje smo maloprije raščlanjivali, interpretirali i vrednovali. Tako njegova Nova kola, posvećena crnogorskoj mladeži, a objavljena u osvitu XX vijeka, nijesu niti svojijem skladom, a još manje jezičkim učinkom, napravila poetske pomake i prodore epskoga iskaza u onovremenu klišeiranu poeziju, a niti pomake estetskoga učinka. Čak se u njima mogu iščitati pjesnikove ideološke opservacije, poruke koje su dijelom zastarjele, konzervativne, degradirajuće, porazne, upućene crnogorskoj mladeži kao pouke i opomene. Kralj je, eksplicite, veoma konzervativno želio da se mladež ne prepušta „mlakijem zvucima“" ljubavne nježnosti, već da se drži zavjeta njihovijeh đedova i crnogorske tradicije, predaka i vitezova, glasova epske tradicije i gusala; slave i opojne strasti junaštva. Zaokupljen tako epskom i opširnom naracijom u tom razvučenom spjevu, pjesnik je pjevao poetska kola posvećena svakome crnogorskom plemenu dozirajući plemenicima predviđenu količinu junačke časti iz obilja Gospodareve milosti. Ni manje ni više no koliko treba da se podanik usija od ratničkog elana i odanosti Nikoli I, „,caru junaku“. (...) Plemenu koje osjeća da je jače od Gospodareva kola ostavljena je šansa da se nadoknadi u novom ratničkom i podaničkom naprezanju, a pleme s prepunijem kolom časti moraće u takmičarskoj trci da ostane na nivou priznatog prestiža.

${ }^{74}$ Savo Vukmanović, „Dramski pisac“, predgovor u knjizi: Nikola I Petrović Njegoš, Drame, Cjelokupna djela Nikole I Petrovića Njegoša, knj. treća, Obod, Cetinje, 1969, 13.

${ }^{75}$ Isto, 18. 
Riječju, sve je „milosni knjaz Nikola“ predvidio, nema što da se misli... i doda. $^{76}$

Spjev Potonji Abenseraž i nije Nikolino originalno djelo. To je njegov narativni prepjev popularnoga francuskog romantičara Fransoa Rene de Šatobrijana Les aventures du dernijer Abencerage (1827). S tijem autorom Nikola se srio u svojoj ranoj mladosti, na školovanju u Parizu i ono je plod njegove rane lektire. Iako se pjesnik dosljedno držao originala, on je nastojao da ovom spjevu ostavi istu formu i zadrži romantični ton i osjećajnost i da ga začini što više lirizmom i emotivnošću. ${ }^{77} \mathrm{U}$ stvari, pjesnik nije u sadržaju i likovima ništa mijenjao i nadopunjavao. $\mathrm{S}$ težnjom da istakne patriotsku notu koja je eksponirana preko glavnoga junaka Aben Ameta, Nikola je u sadržaj djela inkorporirao kao dodatak pejzaže pune kolorita i reljefa, u kojima se prikazuje život nekadašnje slavne kuće Bobdila. To su elegične istorijske evokacije, popraćene sa refleksijama o prolaznosti ljudske sreće. (...) Sve je to činilo da je njegova pojava u jedno vrijeme u nerazvijenoj crnogorskoj kulturnoj sredini predstavljala pravi književni događaj. ${ }^{78}$

Za sadržaj svoga spjeva Hajdana Nikola Petrović je uzeo građu iz crnogorskoga narodnog života. Romantično je opjevao događaj iz XVIII vijeka, iz perioda vladike Vasilija Petrovića. U strukturi epskoga spjeva od 11 pjevanja prikazana je pobjeda dobra i pravde nad zlom i niskostima života i idealisan lik Hajdane Vukotića (Baletovića), sa Čeva od kojih je i knjaginja Milena. Glorifikujući čojstvo i junaštvo, kućiće i odžakoviće, pjesnik je principom kontrasta suprotstavio nikogoviće, prostake i odmetnike svoje domovine. Pjesnik je u romantičarskome ruhu prikazivao realne likove i stvarnu fabulu. Naime, travnički vezir lukavstvom i prijevarom kroti dva mlada Crnogorca: Perišu sa Ceklina i Sima sa Grahova. Obojica su bili lak plijen: prvi ozlojeđeni zbog osvete, drugi zbog uvrede što ga je vjerenica Hajdana napuštila. Vezir ih podstiče, pomaže im u napadima na crnogorske katune. No, ubrzo dolazi do zaokreta: za svoje nepromišljene postupke Simo se ubrzo pokajao, povukao i naselio ponovo na Grahovu. Tek tada je za Perišu nastalo teško stanje, zbog vezirovoga nepovjerenja. Slijepo odan veziru, Periša u jednom času skuplja Turke, upada u Crnu Goru, ubija Rada i Vukotu Baletovića, strica i oca Hajdanina, a nju zarobljava i vodi je u harem travničkome veziru koji se u nju zaljubi i zbog nje napušta porodicu, vjeru i domovinu. Da bi okajao grijeh izdajstva, Simo predvodi jednu crnogorsku četu i nastoji osloboditi Hajdanu. U tijem borbama vezir je bio ranjen, a njegovi protivnici poubijani. Poslije tijeh okršaja Crnogorci sa oslobođenom robinjom Hajdanom vraćaju se na Čevo.

\footnotetext{
${ }^{76}$ Savo Vukmanović, Isto, 8.

${ }^{77}$ Isto, 9.

${ }^{78}$ Isto.
} 
Poezija druge polovine XIX i početka XX vijeka

Ovakva se romantična fabula i danas se može čuti u narodnome predanju na Čevu, što znači da je Nikola Petrović tu fabulu koristio, modifikovao je, preradio i u nekim detaljima radi, efekta $i$ isticanja Hajdanina lika, izmijenio. ${ }^{79}$ Vodeći se moralnijem efektima, pjesniku Nikoli je bio cilj da Hajdanu moralno i fizički glorifikuje, da efektno ukaže da pred njezinijem vrijednostima mora da ustukne i sami travnički vezir. Iako je Hajdana u svoje vrijeme izuzetno hvaljena, nazivana prećeranijem epitetima, ocjenjivana i upoređivana s Gundulićevijem epom Osmanom, njena stvarna estetska vrijednost, ipak, nije velika. To je uglavnom stihovana proza s puno romantičnoga i monotonog pričanja.

Pored lirske i epske poezije, najveći književni uspjeh u svoje vrijeme Nikola I Petrović Njegoš je postigao istorijsko-političkijem spjevom Pjesnik $i$ vila. Sâm ga je hrvatski biskup i mecena Josip Juraj Štrosmajer kao takvoga vidio u jednome svom pismu:

Vaša pjesma „Pjesnik i vila“ divna je i dostojna genialnog pjesnika „Gorskog vijenca“. Dok je svi(j)eta i vi(j)eka ta će divna pjesma ostati slavni i neumrli spomenik Vašeg veluma i Vašega božanstvenoga srca. Sto puta sam je, kad sam na dvi(j)e prozne stranice te predivne pjesme naišao, zavapio: ah ne daj, bože, da desnica tog predivnog muža usahne prije nego sve ono izvede, što mu je bog i dušu i srce posadio. ${ }^{80}$

Istina, to djelo su hvalili u svoje vrijeme i mnogi drugi književni istoričari, ponajprije jer je predstavljalo istorijsko-politički spjev u dramskome i dijaloškom obliku. A daleko više što je pjesnik u njemu pjevao istorijsku sudbinu svoga crnogorskog, odnosno kako on kaže „srpskog naroda“, davao poetski preśek i istorijsku viziju od nastanka naroda do „njegove propasti na Kosovu“. Personifikujući razgovor s mitološkijem bićem - vilom, sa kojom se još i „bratimi“, pjesniku je taj lik poslužio da preko njega iznese svoje brojne refleksije o sebi i narodu koji vodi. U njegovom djelu ima puno razmišljanja o srpstvu, o društvu, o besmrtnosti $i$ slobodi ${ }^{81}$ Vila je povezni lik cijeloga spjeva. Ona pjesnika smišljeno vodi u daleku prošlost srednjovjekovnijeh vladara Duklje i nabraja sve važnije datume srpske i crnogorske istorije i tradicije. Spjev završava pohvalom Kosova i njegovih vitezova, čiji su potomci naselili Crnu Goru i čija je slava napajala srpska srca, podigla Karađorđa i toliko drugih čuvenih junaka. ${ }^{82}$ Opśednut srpstvom i ideološkom ge-

${ }^{79}$ Savo Vukmanović, Isto, 11.

${ }^{80}$ Zapisi, knj. XIII, sv. 1-6, Cetinje, 1935, knj. XXI, sv. 6, 1939, 239. Pismo je datirano „9. srpnja 1893“.

${ }^{81}$ Savo Vukmanović, Isto, 14.

${ }^{82}$ Isto, 13. 
nezom Crnogoraca, kralj Nikola i kao pjesnik kaže da su Crnogorci Srbi. On je u stalnome sukobu između svojijeh nacionalnih težnji i stvarnijeh političkih realnosti i okruženja.

No, bez obzira na sve brojne pohvale, ideološki neprihvatljive stavove, panegiričke i uzvišene osvrte mnogijeh Knjaževih savremenika, mi ćemo se ipak prikloniti sintetičkome sudu Sava Vukmanovića koji je kritički i realno utvrdio da Nikolin spjev Pjesnik $i$ vila (...) ima mana $i$ vrlina koji imaju $i$ ostali njegovi književni proizvodi. U njemu ima slabih stihova, naivnih refleksija, razbijene kompozicije, ograničene poetske slobode, odsustva nadahnuća. Samo mjestimično pjesnik je uspio u toplijim lirskim pasažama, u junačkim patriotskim osjećajima $i$ u širim epskim opisima. Lijepi su, živo $i$ vrlo snažno prikazani pojedini istorijski momenti (...). U spjevu ima $i$ opštih romantičarskih motiva i legendi kao i kod velikih evropskih pjesnika. Lijep mu je i završetak u poentiranoj patriotskoj himni Kosovu koje je nadahnulo Njegoševu liriku. ${ }^{83}$

I Nikolin spjev iz vremena pred/balkanskijeh okršaja Malisorski ustanak predstavlja rodoljubivu tvorevinu u kojoj je Kralj poetski transponovao poznatu pobunu Malisora 1910-1911. godine protiv Turgut-paše. S ciljem da glorifikuje junaštvo i prijateljske odnose Malisora s Crnom Gorom, kralj Nikola je u njihovoj pobuni vidio prave epske junake, veličajući njihov patriotski i oslobodilački duh i ističući njihovu ljubav i privrženost prema Crnoj Gori koja im je jedina bila nada spasenja od turskog ropstva. ${ }^{84} \mathrm{U}$ epskom žanru Nikola je opjévao i neke sporadične balkanske bitke. Pisao ih je za vrijeme Prvoga svjetskog rata u tuđini. Takav je i njegov spjev Balkanski ratovi, spjev koji hronološki registruje noviju istoriju, istorijska zbivanja i posvećen je vojskovođi i junaku, serdaru i generalu Janku Vukotiću. No, i ovi sporadični epski spjevovi ostali su, kao i oni njegovi raniji, u śenci njegovijeh izabranih poetskijeh sastava, poetsko-epski proizvodi koji donekle imaju samo književno-istorijsko značenje u dijahroniji cjelovite crnogorske književne produkcije.

Nikola I Petrović Njegoš poznat je i hvaljen kao uspješan dramski pisac. Njegov nedovršeni dramski prvijenac je Vukašin od kojega je sačuvan samo fragmenat djela. Ugledajući se na Njegošev Gorski vijenac, Nikola je u toj ranoj fazi dramskoga stvaralaštva napisao i odlomak drame Husein-beg Gardašević. Obje početničke drame plod su njegovijeh nevještih osmeračkijeh dramskih pokušaja, u kojima nema, u sadržajnom i jezikom dometu, većijeh scenskih i estetskijeh učinaka. U prvoj drami-tragediji Vukašin za predmet je uzeo narodno predanje. U središtu je opjevao gramzivoga kralja Vuka-

\footnotetext{
${ }^{83}$ Savo Vukmanović, Isto, 14.

${ }^{84}$ Isto, 16.
} 
Poezija druge polovine XIX i početka XX vijeka

šina i nejakoga srpskog cara Uroša. Iako je kasnije Simo Popović u Orliću (1867) prenio jedan njegov odlomak i o njemu napisao panegirik ističući ljepotu i lakoću sloga, jezgrovitost misli $i$ dobro obilježeni značaj lica, ${ }^{85}$ ovo Nikolino djelo je ostalo samo pokušaj dramskoga začetka. I sâm Knjaz nije njime bio zadovoljan, pa je isticao da mu je to bila zabava mladijeh dana. I njegovo drugo dramsko djelo vezano je za istorijske motive. Imajući pretenzije da dramu motiviše svojom državno-političkom koncepcijom, pjesnik je utrpao u njen sadržaj brojna lica (četrdeset i jedno), iz domaće i turske sredine, crtajući ih bez dubljijeh dramskih i psihološkijeh nijansi i karakterizacija. Pjesnik na jednostavan i dosta suhoparan način (...) priča o Huseinu Gardaševiću koji se obraća Njegošu radi organizovanja ustanka protiv turskih zavojevača i protiv sultana. ${ }^{86}$

Najznačajnije Nikolino dramsko djelo je svakako Balkanska carica (1884). Napisana je povodom izgradnje dvorske kapele, na temeljima manastira Ivana Crnojevića na Cetinju. Prvobitno je djelo Nikola I koncipirao u jednom činu, potom ga je brižljivo dorađivao, postepeno sadržajno širio, modelovao i oblikovao pa je na kraju dobilo pozamašan dramski oblik od tri dramska prizora (čina). U njegovom sastavu, od prvoga začetka, pa do konačnoga stvaralačkog oblika i finaliziranja, učestvovali su skoro svi kulturni i književni pregaoci Knjaževa ,pjesničkog savjeta“ te ostali njegovi „kritičari“ s noćnijeh sijela i dvorskih zabava na Cetinju. Otuda je djelo receptivno i munjevito lako usmeno prenošeno, primano i doživljavano u mnogo intenzivnijem žaru među slušaocima i gledaocima i prije nego što ga je kralj Nikola doveo do svojeg konačnog dramskoga uobličenja. Izvođači toga Knjaževa djela bili su prvobitno pozorišni diletanti, bolje reći daroviti cetinjski „dramski“" amateri, sudionici iz političkoga, kulturnog i književnoga života, koji su dobrovoljno i s ljubavlju izvodili Knjaževu dramu. Tijem popularnim predstavama izvođači su polagali temeljac pozorišnoj umjetnosti u Crnoj Gori. Zahuktalost i aktuelnost dramskoga života na Cetinju ubrzo je dovelo i do toga da je Cetinje dobilo i prvo pozorište, Zetski dom. O tome uznapredovalom kulturnome i pozorišnom zamahu, neslućenijem pozorišnim uspjesima, životu i događajima Savo Vukmanović piše: $S a$ „Balkanskom caricom “ nastavljen je i življi književno-kulturni život na Cetinju. Odlomke iz djela, koje su slušali na večernjim sijelima u dvorskoj Odžakliji, mnogi su prepisivali, učili ih napamet i poput njih i sami pjevali. Knjaz-pjesnik je u to vrijeme bio visoko cijenjen $i$ vrlo popularan. Njegovi stihovi su na svim stranama ,kipjeli“. Pod njegovim uticajem propjevalo je bilo skoro čitavo Cetinje. Knjaževom inicijativom pokrenut je list Crnogorka. Na prosvjetu se tada gledalo

${ }^{85}$ Orlić, Cetinje, 1867.

${ }^{86}$ Savo Vukmanović, Isto, 8. 
kao na „novo oružje“. I sami knjaz govorio je da je uvijek vjerovao da je „pero snažnije nego mač“. ${ }^{87}$

Pod ovakvom kulturnom presijom nalazila se i cijela književno-kritička svita onoga vremena. O dramskom djelu Balkanska carica pisali su brojni književni kritičari, stvaraoci i publicisti s najljepšijem riječima. Skoro svi istaknuti kulturni i književni pregaoci domaće i svjetske svite hvalili su Nikolinu Balkansku caricu. Ni o Gorskom vijencu, ni o Smail-agi ni o Mickijevićevim spjevovima, ni o Puškinovim i Ljermontovovim besmrtnim djelima nije se (...) toliko pisalo, kaže Simo Matavulj, koliko o Knjaževoj drami, pa nastavlja: ni jedno od tih umotvora nije toliko uzdizano, komentovano (i) prevođeno. ${ }^{88}$ A prema svjedočenju Pavla Rovinskog, o Balkanskoj carici pretresalo se od Beča do Londona, od varoši cijelog svijeta - Pariza do Petrovgrada i sjeverne Palmire. ${ }^{89} \mathrm{U}$ pohvalama, panegiričkijem i uzvišenim pozitivnijem ocjenama Nikoline drame svakako je najdalje otišao izvanjac u Crnoj Gori i jedan od najistaknutijih srpskijeh romantičara onog vremena - Lazo Kostić. On je u Novoj slobodnoj presi s divljenjem istako da je koliko rijetka toliko i zanimljiva pojava da se jedan vladar popeo na Parnas $i$ to na njegov najviši vrh koji nad svijetom vlada, na kome je dramska vila svoj prijesto namjestila (...). Suprotstavljajući čak Njegošev Gorski vijenac Nikolinoj drami, Kostić zaključuje: Njegov (Njegošev - M. N.) Gorski vijenac, sem dijaloškog oblika nema ničeg dramskog, a Balkanska carica knjaza Nikole pravi je dramat - prava tragedija. Dakle i prvjenstvo neosporno ostaje knjazu dramatičaru. ${ }^{90}$ Sve se to svjedočilo o drami iz perspektive pozorišnoga učinka na izvođenijem predstavama. Ujedno je to ubrzalo i štampanje toga djela. Drama je prvi put objavljena 1886. godišta i ubrzo nakon toga postala je i u domaćoj i u svjetskoj javnosti pravi dramski bestseler, omiljeno i izvođeno dramsko štivo ne samo kod nas već i na stranijem pozornicama. Tokom trideset godina Nikolino dramsko djelo prevedeno je petnaest puta na deset evropskijeh jezika, a izvođeno je na mnogijem značajnijim pozornicama svijeta, po više puta u novosadskome pozorištu i na ruskom jeziku na petrovgradskoj ljetnoj pozornici Ozerki. O njezinijem uspjesima i umjetničkim dramskijem dometima pisali su brojni književni i teatrološki stručnjaci, koji su osobito isticali pojedine dramske likove, a i sam sadržaj Balkanske carice. ${ }^{91}$

${ }^{87}$ Isto, 11-12.

${ }^{88}$ Simo Matavulj, Bilješke jednog pisca, u redakciji i s predgovorom Marka Cara, Srpska književna zadruga, Beograd, 1939, 246.

${ }^{89}$ P. A. Rovinski, ,'Balkanska carica' pred sudom ruske žurnalistike“, Javor, br. 27 i $28,1885,281$.

${ }^{90}$ Neue Freie Presse, Beč, 6. februara 1885.

${ }^{91}$ O tome detaljnije piše dr Savo Vukmanović: „O 'Balkanskoj carici' kod nas i na strani“, Balkanska carica (drama Nikole I Petrovića Njegoša), Cetinje, 1989, 3-23. 
Poezija druge polovine XIX i početka XX vijeka

Postavlja se pitanje: Što je to što je Balkansku caricu učinilo tako popularnom, snažno prestižnom i u svoje vrijeme nenadmašnijem dramskim djelom? Svakako se u tome ističe njezin romantičarski sadržaj i njezin lakonski osmerački stih. Pjesnik je, dakle, vezao dramski sadržaj za minulo vrijeme i burne istorijske događaje crnogorske države Zete. Riječju, radnju je pjesnik smjestio u vrijeme vladavine Ivana Crnojevića (1465-1490), pa je drama poprimila romantično-nacionalni karakter i po sadržaju i po istorijskijem likovima, Ivanovim sinovima - Stanku i Đorđiju koji se u drami ostvaruju i karakterizuju. U veoma razvučenoj i nekoherentnoj dramskoj kompoziciji u tri čina, pjesnik je naglasak stavio na Stankovo (Stanišino) primanje islama, a isticana je i tragična sudbina njegove vjerenice Danice - balkanske carice. U spletu i okolnosti svijeh tih burnijeh istorijskih zbivanja koji izazivaju i pokreću dramsku radnju ponajviše se ističu upravo karakteri. Prvi čin drame lociran je na Žabljaku, prijestonici Crnojevića i u tome se dijelu karakteriše lik Đorđija te njegov odnos prema svome mlađem bratu. Posebno je apostrofirano Stankovo junaštvo, njegovi tajni pregovori s izaslanikom turskoga cara Murata. On mu lukavstvom i mitom nudi potajno krunu Balkana, pod uslovom da primi islam. Drugi se čin odigrava u Berislavcima, Danilovome rodnom mjestu. Stanko se vraća iz borbe s Turcima ispod Kroje. Progonjen od Crnogoraca, Stanko bježi u Tursku. Sukobljava se s knezom Deanom koji ga kori zbog njegovijeh izdajničkih pobuda i na kraju ga ubija. Tada je smrtno stradala i Danica - balkanska carica. Treći čin se zbiva u Ivanovome dvoru, pod Đurđevijem šatorom, ali se dramska radnja prenosi i na bojno polje. Ocrtan je stari Ivan Crnojević, slomljena i skrhana srca od zla domaćega, a njegov sin Stanko, sada je u funkciji i ulozi poturčenjaka i paše. On podiže veliku vojsku i udara na svoju rodnu Crnu Goru. Dočekuju ga Crnogorci, s bratom Đorđijem, na Lješkopolju, ranjavaju ga i vojsku mu rasturaju. Na tome bojištu se kreće i Danica koja nailazi na ranjenoga Stanka i njegove saborce. Ona, poput ganute Kosovke đevojke, zaliva, previja i liječi ranjenike, a u susretu s vjerenikom Stankom, u njoj se bude jaki i kontrastni ośećaji: mržnja i ljubav. U duševnoj boli i uvjerenju da ostaje, ipak, vjerna svojoj čistoj ljubavi, bača se u valove rijeke Morače koja će je preko Skadarskog jezera odnijeti u Skadar, u novi dom njezina dragog vjerenika.

Koncipirajući Balkansku caricu kao romantičnu i dinamičnu tvorevinu, Nikola Petrović Njegoš, tada uspješni vladar Crne Gore, isticao je u drami rodoljubivu notu; utkivao ljubav prema svojoj domovini i svome narodu. Predmet joj je, dakle, istorijski i legendarni, oblikovan prema usmenoj predaji sa željom da cijelu građu i svoje istorijske likove svede u jednu harmoničnu cjelinu. Objašnjavajući njezinu pojavu i veliki dramski i književni uspjeh, Savo Vukmanović je u predgovoru Balkanske carice eksplicite istakao da ju je Knjaz napisao pod utiskom slavodobivenih ratova protiv Turaka se- 
damdesetih i osamdesetih godina prošloga (XIX) vijeka i u zanosu nacionalnih oslobodilačkih težnja. Njegove ideje su plemenite i uzvišene. One su potekle iz širokog pjesnikovog patriotskog osjećanja i istovremeno iz duše čitavog njegovog naroda. Zato je djelo ubrzo postalo vrlo popularno i dugo slavljeno kod nas i na strani, više nego i jedno te vrste u našoj književnosti. ${ }^{92}$

Posebno se među karakterima drame i dramskijem protagonistima ističu dvije ličnosti: Stanko kao poturčenjak i izdajnik Crne Gore i Danica. Danica je tip idealne patrijarhalne (treba tradicionalne - M. N.) Crnogorke, uzor-žene i patriotkinje, „male carice“, kojoj je najveća svetinja vjera i domovina. ${ }^{93}$ Nasuprot njoj, ističe se Stanko vjerolomnik i izdajnik. To je mladi čovjek, nestalan, temperamentan, slavoljubiv, lukav $i$ u isto vrijeme junačan $i$ sentimentalan. ${ }^{94} \mathrm{U}$ stvari, ova dva lika su cjelovito građena i karakterisana, psihološkom i vanjskom karakterizacijom su zaokružena i predstavljaju glavne nosioce radnje i srž cjelovite drame Balkanska carica. Svi se drugi likovi: knez Dean, Ibrahim-aga i dr. nalaze u śenci glavnijeh karaktera djela. I kolektivni likovi, poput Zetskog kola, bivaju u funkciji drame skladno i koherentno utkani u cjelinu, funkcionalno ukomponovani i scenski postavljeni. No, isti pisac predgovora drame Balkanska carica posebno je istakao i njezine krupnije nedostatke: događaji u tom Nikolinom dramskom djelu nijesu uvijek dovoljno scenski iskorišćeni i motivisani. Epizode su ponekad razvučene, psihologija je dosta naivna i ličnosti jednolike i jednoobrazne. Poetski i stilski u njemu ima neuspjelih strofa i neukusnih stihova. ${ }^{95} \mathrm{I}$ književni istoričar Trifun Đukić, koji je u svom Pregledu književnog rada Crne Gore posvetio opširno poglavlje Nikoli I Petroviću, detaljno raščlanio i interpretirao Nikolinu dramu Balkanska carica, istakao njene dobre strane, određen broj dramskijeh vrijednosti ovoga djela, ali je apostrofirao i njene krupne nedostatke i mane: Nikola I nije majstor za poetske ukrase. Naprotiv. Tu je on prozaičan, katkad posve štur, bez imaginacije. Prostota izraza, oskudica u poetskoj zamisli $i$ fantaziji, razvučenost u izvođenju pojedinih epizoda, sve to čini da ona mjesta Balkanske carice koja su u osnovi pjesnički lijepa gube od svoje emotivne i književne jačine. (...) Ima u Balkanskoj carici scena koje su sasvim izlišne (...) Zbog te narativne strane rastegla se drama u tri čina na četiri hiljade pedeset pet stihova, od kojih bi, is dramskog i poetskog gledišta, jedan veliki broj mogao da se odbaci. Ali to nije slučaj samo sa Balkanskom caricom ne-

92 Savo Vukmanović, „Dramski pisac“, predgovor u knjizi: Nikola I Petrović Njegoš, Drame, Cjelokupna djela Nikole I Petrovića Njegoša, knj. treća, Obod, Cetinje, 1969, 10.

${ }^{93}$ Isto, 18.

${ }^{94}$ Isto, 19.

${ }^{95}$ Isto, 20. 
Poezija druge polovine XIX i početka XX vijeka

go i sa ostalim njegovim djelima. Njemu je nedostajala sposobnost kritičkog odabiranja. Sa teorijom pjesništva stajao je rđavo, sa gramatikom još gore. ${ }^{96}$

Skoro iste takve mane Nikola je kao dramski pjesnik ispoljio i u svome posljednjemu dramskom djelu Kako se ko rodi, komediji koja je nastala na kraju XIX vijeka. Iako je napisana u prozi, ona se svojijem sadržajem i tematikom ne razlikuje od njegovijeh ranijih dramskih djela. Smatra se da je to tendenciozna pozorišna igra u tri čina $u$ kojoj se na osnovu jedne realne slike iz seoskog života dokazuje opravdanost postavljene teze u naslovu: čovjek po prirodi ostaje onakav kako se rodi. ${ }^{97}$

Dodamo li ovome i ono što je književni istoričar Trifun Đukić na kraju svoje studije izrekao - da su književna djela Nikole I Petrovića nekritički izdavana, u žurbi nedoćerana s puno pravopisnijeh i stilskih pogrešaka, onda smo istakli sve bitne i dobre strane njegova djela, ali i mane ovoga opsežnog romantičarskog pisca. Složićemo se i s najnovijim ocjenama poput onijeh koje je izrekao, iščitavajući pjesnikovo djelo, Novak Kilibarda u svome kratkom predgovoru „Gospodar kao pjesnik“. On je, između ostaloga, izveo sasvijem opravdan kritički sud o stvaralaštvu Nikole I Petrovića: $U$ Balkanskoj carici, jednako slaboj i slavnoj, proviruje zračak književno kazane ljubavi, zračak tragične gorčine, a našao bi se i lijek dramske radnje. Pronađe se tamo dobra riječ $i$ vješta sintagma, na više mjesta zgušnjava se po strofa književno uzrelih mjesta. U pravu je Kilibarda i u onome dijelu svoga sintetičkog suda kad poredbeno i metaforično sažima i odmjerava poetiku dvojice velikana književne riječi - književnika Petra II Petrovića Njegoša i Nikolu I Petrovića Njegoša, pa kaže: Pjesnik Gorskog vijenca uvrnuo je sve potoke ideologije i politike u široku maticu poezije, a pjesnik Balkanske carice ukapao je tanku struju poezije u talasavi huk svoje politike. I kod Kralja i kod Vladike sve pritoke - „, na uvoru svoje ime gube“. Nikola uz Njegoša izgleda kao ratni novac uz dukate. Ko pročita svega Kralja-zamoriće se, a ko ne pročita njegove najbolje stihove - kajaće se. ${ }^{98}$ Ovim je sudom sažeto i precizno rezimirana cijela problematika.

I na kraju ipak treba istaći da je književna kritika ponajviše zapazila da su Knjaževe/Kraljeve epistolarne forme, njegovi politički spisi i drugi diskurzivni žanrovi (proglasi i govori, memoari i putopisi, pa i njegova autobiografija), manje ili više uspjelo izlaganje njegovih taktičkih koncepata i političke strategije. ${ }^{99}$ Oni su veoma odmjereni, razborito pisani, stilski i jezički ujed-

${ }^{96}$ Trifun Đukić, Pregled književnog rada Crne Gore, Narodna knjiga, Cetinje, $1951,256$.

${ }^{97}$ Savo Vukmanović, Isto, 23-24.

${ }^{98}$ Novak Kilibarda, Isto, 8.

${ }^{99}$ Branko Banjević, Isto, 19. 
Milorad NIKČEVIĆ

načeni, doćerani, oslobođeni suvišnosti i mana koje je pokazivao Nikola I u svojijem pjesničkim, epskijem i dramskim tvorevinama. Budući da su i ti Nikolini žanrovi u više navrata analizirani, posebno u Cjelokupnim djelima, to nema potrebe da se na njima na ovome mjestu zadržavamo. Dodamo li tome i nedavno otkriveni istorijski roman Despa ${ }^{100}$, ostvaren u potpunosti u okvirima poetike romantizma sa izrazitom političko-ideološkom osnovom i tek književnoistorijskom vrijednošću, književni portret potonjega crnogorskog suverena biće zaokružen.

U konačnoj sintezi navodimo riječi književnog kritičara Radoja Radojevića koji u studiji „O Nikoli Prvom u crnogorskoj povijesti i književnosti“ tačno i suštinski zgusnuto ocrtao njegovo političko i pjesničko djelovanje: $Z a$ poeziju Nikole I možemo reći da je plod nesklada između više osnovnijeh činilaca pod čijim je djestvom nastajala, kao što je i njegova vladarska politika bila plod istorijskog nesklada. On je nesporni, ali osrerdnji pjesnički dar opteretio prevelikijem pretenzijama, nasuprot oskudnoj književnoj kulturi $i$ slabome vladanju versifikacijom $i$ uopšte poetskim jezikom. Umjesto da u svoje stvaralaštvo unosi, shodno vremenu, nove sadržaje i forme, ostao je do kraja vjeran romantičarskom pjevanju bliskom narodnoj poeziji.

Iako je malo znao o poetici, izgradio je sopstvenu poetiku koja je postala kanon za sve crnogorske pjesnike njegova vremena. (...) Čitajući njegove stihove zapažamo u nedoumici: da li je svoje pjesničke ideje oblačio u neodgovarajuće ruho, satkano od političkih pokliča i moralnih pridika, ili je političke i moralne ideje kazivao neadekvatnim umjetničkim sredstvima. I kao što je njegova knjaževsko-kraljevska politika imala strašnijeh posljedica za crnogorski narod, čiji je opstanak bio smrtno ugrožen, tako je i književna politika teško osakatila crnogorsku književnost, u doba kad je, po prirodi stvari, trebalo da doživi veliki uspon. Tako je nastao historijski apsurd da se, decenijama nakon štampanja Gorskog vijenca i Luče mikrokozma, na Njegoševu Cetinju prosiplju potoci nesuvislih pjevanja 'na narodnu', u desetercu $i$ osmercu; ali to sasvijem odgovara istorijskome apsurdu da, čitav vijek pošto je Njegoš onako izrazio crnogorsko nacionalno biće i proslavio ime crnogorsko, neki crnogorski intelektualci - 'ujedinitelji' čak i osobnu imenicu Crnogorac pišu malijem početnijem slovom „c“! Stoga nije čudno što mnogi stihovi Nikole I danas djeluju komično, jer su nastali kao plod mnogijeh nesklada koji daju komične rezultate. ${ }^{101}$

${ }^{100}$ Nikola I Petrović Njegoš, Despa, priređivači Aleksandar Radoman \& Adnan Čirgić, Matica crnogorska \& Institut za crnogorski jezik i jezikoslovlje „Vojislav P. Nikčević“", Cetinje, 2008.

${ }^{101}$ Radoje Radojević, Osporavana kultura, Kritike i polemike, priredio Danilo Radojević, Podgorica, 2006, 36. 
Poezija druge polovine XIX i početka XX vijeka

\section{Literatura}

- Andrić, dr. Nikola. - „Mićun M. Pavićević“, predgovor u knjizi: Mićun M. Pavićević, Crnogorci u pričama i anegdotama, knj. V, Zagreb, 1929.

- Banjević, Branko. - „Jedan vid 'primijenjene poezije““ u knjizi: Nikola I Petrović, Rat crnogorski, Biblioteka „Luča“, NIP Pobjeda, Titograd, 1975.

- Banjević, Branko. - „Crnogorska poezija druge polovine XIX vijeka“, u knjizi: Pleme za oblakom. Crnogorska poezija druge polovine XIX vijeka, Grafički zavod, Biblioteka „Luča“, Titograd, 1973.

- Božović, Petar M. - Antologija crnogorskih pjesnika i pripovjeda$\check{c} a$, Štamparija Ujedinjenje, Podgorica 1927.

- Гачов, Г. Д. - Ускоренное развитие литературы, Москва, 1964.

- Deretić, Jovan. - Almanasi Vukovog doba, Institut za književnost i umetnost Vuk Karadžić, Beograd, 1979.

- Deretić, Jovan. - Kompozicija Gorskog vijenca, Zavod za izdavanje udžbenika SRS, Beograd, 1969.

- Đukić, Trifun. - Pregled književnog rada Crne Gore od Vasilija Petrovića Njegoša do 1918. godine, Narodna knjiga, Cetinje, 1951.

- Jovanović, Živorad. - „Bio-bibliografska građa o Jovanu Sundečiću“, Stvaranje, br. 9, Titograd, 1953.

- Karadžić, Vuk. - Srpske narodne pjesme, knjiga IV, drž. izdanje, Beograd, 1896.

- Kilibarda, Novak. - „Gospodar kao pjesnik“, predgovor u knjizi: Cjelokupna djela kralja Nikole I, Univerzitetska riječ, Nikšić, 1989.

- Klančić, Ljubica (= Savić Marković Štedimlija). - Život i smrt Stefana Perovića Cuce (1831-1857) - rukopisna monografija

- Književna bibliografija, Leksikografskog zavoda Miroslava Krleže, Zagreb, s. a.

- Košćak, Vladimir. - Josip Juraj Strossmayer - političar i mecena, Izdavač Revija, Centar Otvorenog sveučilišta, Osijek, 1990.

- Košćak, Vladimir. - „Izvori, bibliografija i literatura o Josipu Juraju Strossmayeru“, u knjizi: Josip Juraj Strossmayer - Franjo Rački. Politički spisi, rasprave, članci, govori, memorandumi, Znanje, Zagreb, 1971.

- Luketić, dr Miroslav. - Crnogorski književni časopisi 1871-1891, Bibliografija, Cetinje, 1978.

- Ljubiša, S. M. - „Pesme Stefana Cuce Crnogorca“, Srpska zora, 1878, br. 34.

- Matavulj, Simo. - Bilješke jednog pisca, u redakciji i s predgovorom Marka Cara, Srpska književna zadruga, Beograd, 1939. 
- Mihovilović, Ivo. - „Jedna tršćanska godišnjica. Slavljansko društvo“, Kolo, I, Zagreb, 1948. /Isti je rad uvršten kao predgovor uz prilog Sama Pahora, u reprint-izdanju Slavjanskog rodoljuba, Založništvo tržaškega tiska, Trst, 1971./

- Miljanić, Vukota \& Miljanić, Akim. - Prezimena u Crnoj Gori, Beograd, 2002.

- Nedić, Vladan. - Vukovi pevači, Rad, Beograd, 1984.

- Neue Freie Presse, Beč, 6. februara 1885.

- Nikčević, dr. Vojislav. - Mladi Njegoš. Pjesnički putevi ka sintezi, Obod, Cetinje, 1978.

- Nikčević, Milorad. - „Doprinos, značaj i podsticaj izvanjaca i inozemaca crnogorskom književno-kulturnom razvoju u drugoj polovni XIX i početkom XX vijeka“, Stvaranje, br. 5, Titograd, 1984.

- Nikčević, Milorad. - „Duhovni zavičaj - ishodište književnog djela Njegoša i Ljubiše“, u knjizi: Ideje i paralele (Književni ogledi i studije), Izdavački centar Revija, Mala teorijska biblioteka 14, Osijek, 1984.

- Nikčević, Milorad. - „Kulturno-povijesna scena i izvori korespondencije J. J. Strossmayera i Nikole Petrovića Njegoša“, u knjizi: Hrvatski i crnogorski književni obzori. Povijesni književno-kulturni kontekst, Zagreb, 1995.

- Nikčević, Milorad. - „Prilog bibliografiji o Peroju“, Nova Istra, br. 4, Pula, 1999.

- Nikčević, Milorad. - „Prinosi J. J. Strossmayera i Nikole I. Petrovića Njegoša na uspostavljanju Konkordata (1886)“, u knjizi: Hrvatski i crnogorski književni obzori. Povijesni književno-kulturni kontekst, Zagreb, 1995.

- Nikčević, Milorad. - „Staroslavenski jezik u funkciji bogosluženja katolika Barske nadbiskupije i o ne/riješenom pitanju Parčićeva 'Misala' (1893.)“', Zbornik radova, Prvi hrvatski slavistički kongres, glavni urednik Stjepan Damjanović, Zagreb, 1997.

- Nikčević, Vojislav P. - Crnogorski jezik. Geneza, tipologija, razvoj, strukturne osobine, funkcije. Tom II, Matica crnogorska, Cetinje, 1997

- Nikčević, Vojislav P. - „Filip Višnjić je etnički i jezički Crnogorac", Lučindan, br. 16, na Petrovdan, Cetinje, 2005.

- Orlić, Cetinje, 1867.

- Pavićević, Mićun M. - Crnogorci u pričama i anegdotama, knj. V, Zagreb, 1929.

- Petrović, Ilija M. - Lord Bajron kod jugoslavena - Dodatak (Stevan Perović Cuca), Beograd - Požarevac, 1989. 
Poezija druge polovine XIX i početka XX vijeka

- Petrović Njegoš, Nikola I. - Despa, priredili Aleksandar Radoman \& Adnan Cirgić, Matica crnogorska \& Institut za crnogorski jezik i jezikoslovlje „Vojislav P. Nikčević“", Cetinje, 2008.

- Prednjegoševsko doba, II izdanje, priredio dr Niko S. martinović i dr., Grafički zavod, Biblioteka „Luča“, Titograd, 1966.

- Radojević, Radoje. - Osporavana kultura, Kritike i poelmike, priredio Danilo Radojević, Podgorica, 2006.

- Rotković, dr. Radoslav. - „Pregled crnogorske literature. Od najstarijih vremena do 1918.“, Stvaranje, br. 4, Titograd, 1979.

- Rovinski, P. A. - ,'Balkanska carica' pred sudom ruske žurnalistike“, Javor, br. 27 i 28, 1885.

- Sekulić, Isidora. - Njegošu knjiga duboke odanosti, Izdanje Srpske književne zadruge, Beograd, 1951.

- Skerlić, Jovan. - Istorija nove srpske književnosti, Beograd, 1967.

- Strčić, Mirjana. - „Jovan Sundečić u kontekstu hrvatske, srpske i crnogorske književnosti“, Gesta, br. 29-30-31, Varaždin, 1988.

- Strčić, Mirjana. - „Prilog poznavanju života i rada Jovana Sundečića“", u knjizi: Prlozi o zavičaju, knj. 6, Pula, 1990.

- Šuković, Radivoje. - Crnogorski almanasi i kalendari (18351914), Cetinje, 1980.

- Šuković, Radivoje. - „Umjetnička poezija u književnim publikacijama“, u knjizi: Književna periodika u Crnoj Gori (1835-1914). Književnoistorijska monografija, NIO Univerzitetska riječ, Titograd, 1986.

- Todorović, Maksim. - Stevan Cuca. Prvi književni dvoboj u Crnoj Gori, Beograd, 1938.

- Vukmanović, Savo. - „Dramski pisac“, predgovor u knjizi: Nikola I Petrović Njegoš, Drame, Cjelokupna djela Nikole I Petrovića Njegoša, knj. treća, Obod, Cetinje, 1969.

- Vukmanović, Savo. - „O 'Balkanskoj carici“ kod nas i na strani“, Balkanska carica (drama Nikole I Petrovića Njegoša), Cetinje, 1989.

- Zapisi, knj. XIII, sv. 1-6, Cetinje, 1935, knj. XXI, sv. 6, 1939.

- Zapisi, knj. XIV, sv. 1-6, Cetinje, 1935.

- Zbornik radova s IV. međunarodnoga znanstvenog skupa „Jezici i kulture u doticajima: Peroj/Istra u proslošti i sadašnjosti““, Tabula, časopis Filozofskog fakulteta u Puli, uredio prof. dr. sc. Milorad Nikčević, Pula, 1999. 


\section{Milorad NIKČEVIĆ}

\section{LATE $19^{\text {TH }}$ AND EARLY $20^{\text {TH }}$ CENTURY POETRY}

This work gives an overview of Montenegrin poetry from the second half of $19^{\text {th }}$ and early $20^{\text {th }}$ century. The Author stresses key poetic, typological, and genre characteristics of an epoch that followed Petar II Petrović Njegoš. The period is characterized by a strong influence of people's literature, and dominated by poems of patriotic and didactic character, as well as epic heroic poems, verse drama and, at the end of the epoch, first indications of modernist trends. The most significant and influential poet of this period is Montenegrin king Nikola I Petrović, while other interesting poets include Stefan Perović Cuca and Jovan Sundečić.

Key words: history of literature, romanticism, lyrical poetry, epic poetry, verse drama, Stefan Perović Cuca, Jovan Sundečić, Nikola I Petrović 
LINGUA MONTENEGRINA, god. III, br. 5, Cetinje, 2010.

Institut za crnogorski jezik i jezikoslovlje „Vojislav P. Nikčević“

UDK 821.163.4.09-6

Pregledni rad

\section{Marjana ĐUKIĆ (Podgorica) \\ Univerzitet Crne Gore}

\section{SENTIMENTALIZAM TURSKIH PISAMA STJEPANA ZANOVIĆA}

Turska pisma Stjepana Zanovića, djelo čija je žanrovska pripadnost aktualizovana recentnim određenjima, pripadaju glavnim tokovima evropske književnosti XVIII vijeka. Ovaj rad Zanovićev tekst posmatra prema različitim tipovima epistolarnog romana epohe. Sentimentalni roman kao hipotekst otkriva ne tako vidne slojeve djela, kao što su galantni diskurs, ali i drugi znaci i toposi koje je kanonizovao Ruso Novom Eloizom. Rezultat do kojeg se dolazi hipertekstualnom analizom jeste da je Zanovićeva ,knjiga“ nesumnjivo roman čija je pozicija prema sentimentalnom romanu dinamična i mnogostruka, od imitacije do transformacije i kritike. Isto tako, Turska pisma pokazuju kako jedan crnogorski autor koristi konvencije svog doba stvarajući djelo izuzetnog bogatstva registara i narativnih oblika.

Ključne riječi: Zanović, epistolarni roman, sentimentalizam, hipertekstualnost

Stjepan Zanović je Lettere Turche pisao na francuskom i italijanskom jeziku u skladu sa književnim tendencijama XVIII vijeka, kada su nakon Persijskih Evropu zapljusnula brojna pisma, bilo filozofsko-satirična, bilo književna. ${ }^{1}$ Priroda Zanovićevog teksta podstiče raznolike pristupe, uglavnom inspirisane uzbudljivim životom autora, od prve ozbiljne studije Mirka Breyera posvećene porodici Zanović, ${ }^{2}$ ali ostavlja mogućnost tekstualne i intertekstualne analize koja se pridružuje novom čitanju ovog, kako reče Bre-

${ }^{1} \mathrm{U}$ tim brojnim naslovima (Jevrejska pisma, Kineska pisma, Sijamska pisma), postoje Pisma jedne Turkinje iz Pariza sestri u saraju (Lettres d'une Turque à Paris écrites à sa soeur, 1730), ali je uobičajeno da se skraćeno nazivaju Lettres turques. Autor je Poullain de Saint-Foix. Navedeno prema: Henri Coulet, Le Roman jusqu' à la Révolution, Armand Colin, collection U, Paris, 1967.

${ }^{2}$ Mirko Breyer, Antun Conte Zanović i njegovi sinovi, Zagreb, Matica Hrvatska, 1928. 
yer, duhovitog, apstraktnog i zanimljivog teksta. Turska pisma Stjepana Zanovića upravo prolaze kroz značajnu žanrovsku reevaluaciju, što će nesumnjivo uticati na same početke romanesknog žanra u Crnoj Gori i mjesto koje će Zanović zauzeti u istoriji crnogorske književnosti.

Miroslavu Pantiću se duguje zahvalnost za izuzetno opremljeno prvo, kritičko izdanje Turskih pisama 1996. godine, ${ }^{3}$ iako je ova knjiga objavljena još 1776. godine u Drezdenu. Žanrovsko određenje ovog teksta priličan je problem pa Pantić, vidjevši elemente autobiografskog u likovima, ne ide dalje od određenja „knjiga“, mada ,ćudljivo sačinjena“, vjerujući da se radi o čestom obliku travestirane autobiografije. Radomir Ivanović određenjem „,epistolarna proza“, za razliku od Pantića, ostaje na nivou očigledne formalne oznake. Ivanović razlikuje, doduše, nekoliko tipova teksta u Turskim pismima, međutim ne vidi se jasna razlika između određenja epistolarna i narativna proza (jer i epistolarna proza je narativna), iako, pozivajući se na neimenovane teoretičare, Ivanović smatra da je narativna proza ,čista literarnost“; s druge strane, razlikuje „Priču o Felimi i Abderamenu“ kao novelu, a „Istoriju o Pizaniju“ kao ljubavnu priču, bez jasnog kriterijuma, jer obje su umetnute priče zapravo ljubavne. Značajno je što Ivanović otvara problem odnosa teksta i žanra, kako je to sâm naveo u svom radu, ali se pronalaženjem različitih nedovoljno jasnih određenja više diskursa nego žanra prije izbjegava žanrovski identitet nego što se on definiše. ${ }^{4} \mathrm{U}$ radu „Turska pisma Stjepana Zanovića kao prvi roman u crnogorskoj književnosti“ Aleksandar Radoman kritički polemiše sa prethodno pomenutim ocjenama i zasniva svoju analizu na fikcionalnosti Turskih pisama kao ključnom kvalitetu za žanrovsko određenje. ${ }^{5}$ Upravo je Radomanov rad prva smjela pretpostavka da se radi žanrovski o romanu, preciznije o epistolarnom romanu, iako autor pokazuje izvjesne rezerve prema „estetskim dometima“ Zanovićevih Pisama. Budući da je Zanović sâm odredio tip teksta naslovom i formom, čini se da je jedina nedoumica u stvari da li se radi o fikcionalnom ili nefikcionalnom književnom djelu, i u oba slučaja to treba dokazati.

Roman u pismima poznat je još od antike, ali zlatno doba je upravo XVIII vijek. Kada Zanović objavljuje Turska pisma 1776. godine, već su napisani i poznati veliki romani ovog žanra - Monteskjeova Persijska pisma 1721, Ričardsonovi romani Pamela 1742. i Klarisa Harlou 1751. u francu-

${ }^{3}$ Stjepan Zanović, Turska pisma, prevod s italijanskog i francuskog jezika Milica Popović, priređivač Miroslav Pantić, Cetinje, Obod, 1996.

4 Radomir Ivanović, „Emanacije 'divljeg genija“ u djelu Stjepana Zanovića (1751-1786)“, Hom [m]age Danilu Kišu, zbornik radova IV, Podgorica - Budva, 1998.

5 Aleksandar Radoman, ,Turska pisma Stjepana Zanovića kao prvi roman u crnogorskoj književnosti“, Lingua Montenegrina, br. 3, Cetinje, Institut za crnogorski jezik i jezikoslovlje „Vojislav P. Nikčević“", 2009, pp. 355-360. 
Sentimentalizam Turskih pisama Stjepana Zanovića

skom prevodu (na engleskom 1740. i 1747), Rusoova Nova Eloiza 1761. čak i Geteov Verter 1774. godine. Epistolarni roman, definisan formom, tematski ima nekoliko grana ali može se reći da su u francuskoj književnosti XVIII vijeka kanonizovane tri. U tradiciji Monteskjeovih Persijskih pisama postoji, uslovno rečeno, filozofski epistolarni roman kao kritika društva i njegovih institucija. Drugi vid, koji je najviše prepoznatljiv po obliku pisama, jeste sentimentalni roman kanonizovan Ričardsonovim i Rusoovim romanima, a treći, koji se rasplamsava krajem vijeka, pred Revoluciju, jeste libertenski roman, poput remek-djela Opasne veze.

Osamnaesti vijek je inače prevratnički period u istoriji književnosti poznat kao velika smjena rodova. Umjesto dotadašnjih vladajućih rodova epa i klasične tragedije pojavljuju se novi oblici, uglavnom nekanonizovani preskriptivnim poetikama - roman u raznim oblicima, građanska drama, plačljiva komedija, komična opera ali i mnoga žanrovski teško odrediva djela. Književnost ovog perioda stvoriće ipak neke konvencije kao što su pikarski roman, memoarski roman, roman u pismima, no mnogi danas priznati romani, prošli su brojne analize i provjere - Didroovi dijaloški oblici u Fatalisti Žaku na žanrovskoj su granici. Pored toga, roman XVIII vijeka je polemičan, $\mathrm{u}$ intertekstualnoj raspravi sa starim ali i sa savremenim konvencijama te je otud čest parodičan ton i ludički karakter kreacija. Upotreba prvog lica dominantna je i gotovo svi pisci ovog vijeka mu pribjegavaju - memoari, ispovijesti, romani u pismima.

U tom kontekstu treba posmatrati Zanovićeva Turska pisma. U Ženetovoj teoriji intertekstualni odnosi posmatraju se preko kategorije transtekstualnosti ili tekstualne transcedencije teksta koju Ženet definiše kao vidne ili nevidljive odnose teksta sa drugim tekstovima. ${ }^{6}$ Hipertekstualnost je samo jedan vid tih odnosa a hipotekst je prethodno postojeći tekst čijom transformacijom, a ovdje tu operaciju treba uzeti u najširem smislu, nastaje hipertekst. Zanović zasigurno poznaje glavne konvencije romana svog vremena, i u Turskim pismima ne može se uočiti nekakav jedinstven hipotekst koji bi inspirisao ovu ,istočnjačku“ korespondenciju. Prije bi se dalo zaključiti da u ovom slučaju imamo hipožanr, jer ulazi u transtekstualnu diskusiju ne sa tekstom, već sa čitavom vrstom epistolarnog romana književnosti XVIII vijeka.

U skladu sa konvencijom epistolarnog romana na početku je potvrđena klauzula priređivača - Stjepan Pastorvekjo, koji je sabrao i štampao prepisku, a zatim, pored isto tako uobičajene maksime, potvrda fikcionalnosti - mjesto izdanja Carigrad. Centralni lik je Osman, ,,jedan Turčin, pun vrline“, oko ko-

${ }^{6}$ G. Genette, Palimpsestes, Paris, Edition du Seuil, 1982, str. 7. Ženet transtekstualnost posmatra kroz pet tipova odnosa tekstova: arhitekstualnost, paratekstualnost, metatekstualnost, intertekstualnost i hipertekstualnost. 
jeg se u vidu korespondenata razvija niz likova vezanih za „turski svijet“" (sestra Zulima, Zamora, milosnica Fatima, Zizim kajmakam, Mahmud, veliki vezir...), zatim likovi koji bi pripadali evropskom svijetu (Geltruda, intradijegetički Zanović, kneginja Santa Kroče), kao i stvarne ličnosti koji su kao primaoci svedeni na unutrašnje naratere - Volter, kralj Pruske, Katarina II, ruska carica. Funkcionišući ne kao likovi već više kao tekstualne oznake, realne ličnosti političkog i književnog života predstavljaju kulturološke punktove intelektualne i mondenske Evrope što Zanović bira za svoj dijegetički svijet.

Sami naziv Turska pisma nedvosmisleno upućuje na transtekstualni odnos sa Monteskjeovim Persijskim pismima. Ne može se isključiti replika na filozofski aspekt u značenju kritike društva i civilizacije viđene „stranim pogledom“. No, ovaj aspekt Zanovićevog teksta nije samo monteskjeovski, već filozofski u značenju kritike prije svega religije, institucija, rušenja tabua i predrasuda u politici, filozofiji i moralu te je stoga u relaciji sa čitavom intelektualnom elitom sakupljenom oko Enciklopedije, među kojima najznačajnije mjesto, za Zanovića, ima Volter. Monteskje je u svom romanu satirično opisao agoniju sedamdesetogodišnje vladavine Luja XIV tako da je njegova slika društva bila napad na apsolutnu monarhiju i poziv na reformu francuskih institucija. Zanovićev tekst nije na taj način politički niti angažovan, više je opservacija postojećeg evropskog društva i oblika vladavina i ne poziva ni na kakvu reformu društva, osim unutar dijegeze, čime se suštinski razlikuje od Persijskih pisama i filozofskog epistolarnog romana generalno.

S druge strane, sentimentalni roman kao hipotekst otvara zanimljivije i mnogostruke diskusije. Dok danas osjećamo izvjestan prezir prema pridjevu sentimentalan, taj termin u XVIII vijeku nije imao negativno značenje, vezivao se za uzvišene osjećaje kojima su dorasli samo vrli i vaspitani ljudi izrazitog senzibiliteta za saosjećanje. Te profinjene duše imale su sposobnost da osjete ono što vulgarnim pojedincima izmiče i ostaje nepoznato. Zato su osjećanja često prenaglašena, patetika danas teško podnosiva. Cilj sentimenatalnog romana jeste da dâ moralnu pouku i da probudi saosjećanje čitalaca.

Sentimentalizam je u Francuskoj ishodište stare kurtoazne i preciozne tradicije koja postaje Zanovićev ne tako vidan izbor. Otmjen jezik, rafinirana osjećanja, galantan duh, prikladnost dominantan su ton u Turskim pismima, $\mathrm{s}$ tim što polifoni oblik epistolarnog romana nudi mnogostruke vidove: autentični sentimentalizam kod Geltrude, prihvatanje kod Zanovića lika ili njegovo obesmišljavanje kod Osmana.

Sentimentalizam je prisutan i eksplicitnim pominjanjem Rusoa (Sara Jevrejka evocira spaljivanje Emila, a dijegetički Zanović govori da mu je Ru- 
Sentimentalizam Turskih pisama Stjepana Zanovića

so postao u Parizu učitelj), čija je Nova Eloiza najveći best-seller XVIII vijeka i roman koji će konačno dati pravo građanstva romanesknom žanru, te umjesto brojnih avantura, memoara, ispovijesti i istorija, pisci od Julije počinju rado da koriste ime roman za svoja djela. Kod Rusoa ljubav je zasnovana na čistim i iskrenim osjećajima, gdje su junaci oličenja vrlina uz puno međusobno poštovanje zaljubljenih. Jednostavne radnje, bez mnogo epizoda i pustolovina, Nova Eloiza je slavna ljubavna priča Julije i njenog učitelja SenPrea. Opšte mjesto sentimentalne literature jeste i otac kao prepreka ljubavi jer je, u ovom slučaju, Julija već obećana Volmaru, koji je njenom ocu ranije spasio život. Ona prihvata brak i postaje uzorna supruga i majka, a Sen-Pre očajan odlazi u svijet. Prihvatajući norme društva, oboje se slažu da nastave da se vole ali da ne pripadaju jedno drugom. Prirodna, snažna, iskrena strast žrtvovana je u ime institucija društva.

U Turskim pismima Osmanov začuđen pogled na pozorište i operu, kao dio teksta koji bi olako mogao navesti na sličnost s Uzbekom i Rikom, svakako je rusoovski a ne monteskjeovski jer je opšte poznat Rusoov stav o moralnoj nekorisnosti pozorišta, zbog čega će, između ostalog, prekinuti saradnju sa Didroom i enciklopedistima. U XLVII pismu Osman kneginji Santa Kroče prepričava posjetu pozorištu sa gostom iz Turske, ali isto tako iznosi kritički stav prema evropskom pozorištu. Ovaj pogled je dakle dvostruko „turski“", Osmanov, već akomodiran na francusko pozorište, i drugi, potpuno naivno „turski““. Kritikujući otvoreno nemoralnost pozorišta - ljubav kao „gnijezdo svih zapleta“, likovi pomodara, koketa, bezbožnika, slobodoumnika - Osman ističe drugačiji tip predstava igranih u Carigradu, gdje je važna poučnost i sposobnost da obrazuje mladog čovjeka, a likovi posjeduju kvalitete koje drugi cijene. Na čuđenje njegovog gosta da ljudi dovode djecu da gledaju kako sinovi ismijavaju očeve, kako djevojke zakazuju sastanke i kako se govore „hiljadu bezobrazluka“, Osman krajnje ironičnim odnosom prema francuskom teatru staje u njegovu odbranu:

„Oh!, primijetih ja, oni predstavljaju ove poroke da bi time izazvali osjećanje gnušanja kod omladine. “7

Zanović na ovaj način obavlja imitaciju rusoovskog teksta, ali vrši transformaciju hipoteksta tako što ozbiljan registar transformiše u ludički, ironični pa često i humoristički. Takva transformacija režima sentimentalnog najbolje se uočava u ljubavnoj prepisci između Osmana i Geltrude, toposu sentimentalnog romana, i jedinoj pravoj razmjeni u Turskim pismima. Geltrudina pisma u potpunosti pripadaju sentimentalnoj konvenciji, u pitanju su iskrene emocije, rafinirano usklađene sa vrlinama uzvišenih duša, jezik je elegantan, razmišljanja lucidna, a suptilnom patetikom uspijeva da gane pu-

${ }^{7}$ Turska pisma, p. 212. 
bliku: „Pišeš mi da te ja ne volim. Nezahvalniče! Kako možeš to da kažeš ako pomisliš na patnje, koje mi ti svirepo priređuješ kada te ne vidim uvijek blizu mene..." ${ }^{8}$ Dok su njena pisma dostojna Nove Eloize, Osmanove ljubavne riječi pokazuju da on ne pripada toj tradiciji, da je „Turčin“ koji sentimentalnost ne prihvata potpuno ni kao diskurs, ni kao ponašanje. Od prvog Pisma Geltrudi (III) odbacuje ustaljene jezičke formule ljubavi koje se „odveć lako izgovaraju“, a najčešće se pokazuju kao lažne. Ne može se reći da njegova pisma nijesu u istoj mjeri iskrena, osjećajna i kreposna, čak i patetična - „Pišem Ti i odlazim a da Te ne vidim, jer bez plakanja ne mogu izgovoriti posljednje zbogom" (što evocira na Sen-Preova pismo kada odlazi u svijet i sva njegova adieux). No, da je sentimentalnost kod Osmana naučena, prihvaćena i ipak strana, potvrđuju mnogi iskazi koji probijaju sentimentalni diskurs:

„Dosta je više tako! Ti me voliš samo lažnim riječima, uvijek nekorisnim." (VI) ${ }^{9}$

„Nemam više vremena da se pretvaram. [...] Umoran sam da više čeznem. Moja duša se stidi da toliko moli pred jednom ženom. Moje srce se srdi što mu se još uvijek ne uzvraća."10

Kršenje konvencije odlično shvata i korespondentkinja - racionalan i kritičan nije mogao da komunicira sa njenim srcem.

„Turčin“ u Zanovićevom tekstu zapravo jeste oznaka kritičkog i stilskog otklona od sentimentalnog. U pismu u kojem Osman uvodi lik Zanovića u dijegezu, pored majstorskog portretisanja preko glasina, jedan ženski glas govori da je ,grof Zanović [...] svakako Turčin, vidi se po tome kako se obraća ženama nezainteresovano i prezirno". ${ }^{11} \mathrm{U}$ samom tekstu, umetnuta Zanovićeva prepiska to ne pokazuje, pisma su mu prigodna, uglađena i laskava, ali bi se moglo zaključiti da je čitav roman Turska pisma u stvari hipertekst nastao ne imitacijom Persijskih pisama, već transformacijom registra sentimentalnog romana, gdje pridjev turski znači upravo polemički u odnosu na sentimentalizam.

Sentimentalni roman ističe kao značajan problem i mjesto žene u društvu. Među junacima sentimentalnog romana značajan dio su ženski likovi, a i među autorkama XVIII vijeka ova konvencija je najprikladnija. Ženski likovi često su i u samim naslovima - Manon Lesko, Nova Eloiza, Pamela, Klarisa, Redovnica, Pisma jedne Peruanke, mnoge vojvotkinje od* i grofice od*. Kod Zanovića imamo petnaestak ženskih likova, od kojih neke pripadaju carigradskom svijetu, a neke evropskom. Uglavnom su primaoci, u najve-

${ }^{8}$ Turska pisma, p. 75.

${ }^{9}$ Ibid, p. 74.

${ }^{10}$ Ibid p. 80.

${ }^{11}$ Ibid, p. 90. 
Sentimentalizam Turskih pisama Stjepana Zanovića

ćem broju Osmanovih pisama, mada postoje tri potpuno ,ženske“ razmjene: Sara - Rozalinda, Despina - Zelinda i Fatima - Rosalinda, ${ }^{12}$ pri čemu u ovoj posljednjoj postoji zanimljiva komunikacija dviju žena iz različitih svjetova. Posebno mjesto zauzima, kao što smo vidjeli, Geltruda, a neobičan ženski lik je Sara Jevrejka koja usred rafiniranih sentimentalnih razmjena, vođena čistim interesom, predstavlja preduzetnicu i poslovnu ženu.

Interes me budi, otvara mi oči, bistri um, i upravlja moje korake. Kad se nadam dobroj zaradi, trčim kao lovački pas a nosim plijen kao pravi pas ptičar. Ali, ako gubim, ako se iznevjere moja očekivanja, moja mašta poludi, moj duh se pomrači, moje tijelo oboli. Patim kao zločudni Grk, ljutim se kao Jevrejin koji je bankrotirao, psujem kao neki lažljivi Hrišćanin. ${ }^{13}$

Njeno pismo Rozalindi potpuno je u skladu sa likom; to je zapravo repertoar njenih, ali i tuđih tajnih poslova za koji ironično tvrdi da bi, ako bi se štampao, gorio kao Emil Ž. Ž. Rusoa i donio zaradu koliko Enciklopedija izdavačima.

Ključno mjesto romana je umetnuta pripovijest „Priča o Felimi i Abderamenu“ koja u potpunosti podražava sentimentalno pisanje. Istorija dvoje napuštene djece koje odrastaju u prirodi kod mudraca Kajlaza reprezentacija su Rusoovih stavova o prirodnom i civilizovanom biću. Prvi dio priče je idilično odrastanje i razvijanje velike, čiste, iskrene i senzualne ljubavi između Felime i Abderamena. Ovaj dio sentimentalne književnosti tek nakon Zanovića stvoriće kanon Pol $i$ Viržini (1788) koji će, pod uticajem Rusoa, vrlinu vezivati za pastoralne slike u prirodi, a sve što je porok i tabu za civilizovani svijet. Takav je ton i Zanovićeve metadijegetičke pripovijesti, koja, za razliku od ostatka teksta, ne posjeduje ni kritički racionalizam niti ludičko tretiranje konvencija. Priča je cjelovita, nakon srećnog odrastanja, dvoje mladih dospijeva do „civilizovanih“ ljudi i u prvom susretu sa njima Felima umire. Abderamenova žalost i bijes kada okovan pokušava da je osveti, sa suzama, bolom, nepomičnošću i padanjem u nesvjest dostižu patos kakav ostatak teksta ne poznaje. Nakon toga, Abderamen kreće u susret civilizaciji opterećenoj religijskim koncepcijama, sukobima, ubistvima i ratovima.

Ova metanarativna enklava formalno izdvojena iz korespondencije Turskih pisama funkcioniše kao mise en abyme koji reflektuje ne samo ton, dominantno sentimentalan, teksta, već osvjetljava dijegetički svijet vidno la-

\footnotetext{
${ }^{12}$ Ovo ime se javlja u varijantama Rozalida, Rosalinda, Rosalida i Rozalinda, čak i u istom pismu. Nije jasno da li su propusti nenamjerni ili je to još jedna manifestacija nefiksiranosti ženskih likova u Zanovićevom tekstu.

${ }^{13}$ Turska pisma, p. 69.
} 
bavo organizovane fabule i dopušta drugačije čitanje dijelova teksta koji su zbunjujući i misteriozni.

Kraj „Priče“ završava Abderamenovom reformom kraljevine koja bi se zasnivala na regulisanju moći sveštenstva. Kralj saopštava projekat Savjetu, ali već narednog dana bivaju ubijeni i kralj i Abderamen. Kraj umetnute priče objašnjava kraj romana. Naime, u XLIX pismu Osman se obraća Velikom Državnom Savjetu svjestan moći i zloupotrebe crkvenih ljudi. Njegov projekat u četiri tačke, koji jeste proširena verzija Abderamenove reforme, nosi iste ideje i nagovještava njegov tragičan završetak. Posljednje pismo, prije Pisma javnosti koji funkcioniše kao epitaf, Osman završava Vergilijevim stihovima: „His Victor Cestus Artemque repono“ - ,Ja što pobijedih nikada više u borbu." Nepostojanje tradicionalnog naratora u epistolarnom romanu Zanović je vještim i prikladnim narativnim postupkom riješio.

Većina pisama u ovoj „turskoj“ korespondenciji pripada modelu koji Žan Ruse naziva epistolarna monodija i koji analizira upravo na jednom ro-

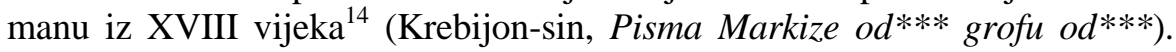
Iako postoji razmjena, čuje se samo jedan glas - Osmanov. (Izuzetak je razmjena sa Geltrudom, koja je duet, i tri ženske razmjene koje isto tako pripadaju monodijskom tipu. ${ }^{15}$ ) Dakle, monodijski roman nudi nam samo jednu stranu prepiske, primalac postoji kao znak, ali se ne čuje. Ta polovina, čitaocu nedostupne, prepiske ostaje tajna koju čitalac mora rekonstruisati. Ruse kaže: „Mi smo pozvani da pogađamo, da ponovo sastavljamo, da gradimo sve pomoću delova [...] U prirodi je ove knjige da nas ostavi u neizvesnosti.“16

Neizvjesnost i nesigurnost o kojima Ruse govori povodom Krebijona u potpunosti odgovaraju tumačenju pojedinih djelova Zanovićevog romana. „Priča o Felimi i Abderamenu“ mogla bi funkcionisati ne samo kao prospektivni mise ne abyme, koji nam osvjetljava kraj pripovijesti - Osmanovu smrt, već kao retro-prospektivni koji bi uključio i događaje koji prethode dijegezi (kao u Hamletu predstava u predstavi). Naime, glasovi Osmanovih sagovornika, a naročito sagovornica, čije priče za čitaoce ostaju misterija, preko refleksije umetnute pripovijesti skrivaju ljubavnu priču koja je prethodila Osmanovom putu u ,civilizaciju“.

Predgovor, pa dakle i roman, počinje pitanjem:

„Šta da čini muž kad neko voli njegovu ženu?

Ništa.“

14 Žan Ruse, Narcis romanopisac, prevod Jelena Novaković, Sremski Karlovci, Novi Sad, Izdavačka knjižarnica Zorana Stojanovića, 1995, pp. 146-162.

${ }^{15}$ I prepiska intradijegetičkog Zanovića pripada monodijskom tipu, s izuzetkom kratkog odgovora kralja Pruske.

${ }^{16}$ Ibid, pp. 149-150. 
Sentimentalizam Turskih pisama Stjepana Zanovića

Ovaj incipit kao tajni znak otkriva tu latentnu fabulatornu nit ljubavi između Osmana i vjerovatno neke od njegovih korespodentkinja. Enigmatični glas u Predgovoru (da li je Osman, ili priređivač Stjepan Pastorvekjo, Zanović autor romana ili Zanović lik?) onda bi svakako bio Osmanov.

U pitanju su četiri žene kojima Osman piše. Najprije, „sumnjiva“ je njegova prepisku sa sestrom. U pitanju su dva pisma u hronološkoj inverziji (dijegetičko prvo je zapravo kasnije pismo iz 1776. godine, a drugo iz 1774. godine) gdje je Zulima u jednom okarakterisana kao sestra, a u drugom kao Osmanova omiljena žena. U tom XXXVII pismu postoji neobičan završetak u kojoj pominjanje „muža“ ostavlja nedoumice. Ono kasnije napisano već otvoreno prikazuje Zulimu udatom, a Osman upravo razvija, u vidu savjeta sestri kako da sačuva muževljevu naklonost, koncepciju ljubavi kao taktike, koja pripada više libertenskom nego sentimentalnom romanu.

No, to nije jedina tajna ovog teksta. Tri Osmanova pisma Fatimi govore o odnosima muškaraca i žena, prevashodno negativno prema braku i muževima. Dva pisma Fatimi praćena su navodnim tuđim pismima, od kojih je prvo nekog „ovdašnjeg“, dakle pariskog ljubavnika, a u Pisamcetu, kako ga skromno imenuje, u sentimentalnom tonu izjavljuje se ljubav i, neobično, u pitanju je turska žena. Drugo, pak, umetnuto tuđe pismo Fatimi, prikazuje glasine o kojima bivši ljubavnik izvještava svoju prijateljicu zamjerajući joj izlazak na bal s mužem: „Reći ću Vam samo da ste Vi mladi i lijepi i da ja nikada ne bih očekivao takvog nasljednika kakvog ste mi dali. Možda ste ga samo zato izabrali da bi me spriječili da se uzoholim zbog mjesta koje sam dugo zauzimao u Vašem srcu." ${ }^{\text {"17 }}$ Dorimana i Zamora takođe dobijaju Osmanova pisma u kojima on prezirno govori o brakovima, odsustvu ljubavi i poštovanja. Pismo Zamori pripovijeda da u Parizu žena poništava svog muža, ne pominje ga i ,rijetko je posjećuje u njenim odajama“. Kraj pisma je opet enigmatičan: „Zbogom, moja lijepa, tako će biti jednog dana i gdje si ti.“"18 Nije baš vjerovatno da to kaže Turčin nekoj od svojih žena, niti da im uopšte otkriva naličja bračnog života osim ako, kao neki pobunjeni Sen-Pre, ne ustaje protiv licemjerja braka kao prepreke njegovoj strasti i ljubavi. Osmanova pobuna protiv braka jeste to „ništa“ što „čini muž kad neko voli njegovu ženu“.

Tajna koja ostaje jeste da li su četiri ženska lika u stvari jedna žena, ili se iza istih imena kriju različite žene, ili iza različitih imena iste. Načelno, primalac mijenja prirodu teksta, međutim Turska pisma ne nude tu vrstu pomoći u čitanju. U svakom slučaju, čini se ipak da ta ljubav, anteriorna u odnosu na Osmanova putovanja, pa dakle i u odnosu na dijegezu, jeste izvjesna i da Osmana čini, između ostalog, najnesrećnijim na svijetu (Predgovor) pa

\footnotetext{
${ }^{17}$ Turska pisma, p. 116.
}

${ }^{18}$ Ibid, p. 79. 
će na jednom mjestu uzviknuti: „Šteta što me je Venera umjesto ljubavi ranila!“"19 Iako postoje znaci razmjene - „Ti mi kažeš da je u Francuskoj žena slobodna da mijenja" - nepostojanje ijednog ženskog glasa iz turskog svijeta koji bi dopunio, osvijetlio ili razjasnio Osmanovu pripovijest, čini da se, kao Ruse, pitamo da li ćemo ikada imati ključ tajne.

U svakom slučaju, početne žanrovske revizije daju za pravo Radomanu da je u pitanju roman i kako on kaže, ,opravdanost ovakvog genološkog pozicioniranja pokazaće se nespornim“. Rezultat jedne interne analize zaista pokazuje da nema u to nikakve sumnje.

Zanovićeva Turska pisma jesu epistolarni roman potpuno impregniran u evropsku književnost XVIII vijeka, sa kojom razvija dinamičan i aktivan odnos. Ovaj rad je pokušao da predstavi odnos prema sentimentalnom, ali pretpostavlja mogućnost mnogobrojnih drugačijih čitanja. Radoslav Rotković je istakao dvostruk Zanovićev odnos prema Volteru, prihvatanje Volterove filozofske misli i parodiranje njegove poezije. ${ }^{20}$ Upravo u romanu Turska pisma diskusija sa književnim konvencijama bila bi zanimljiva ako bi se analizirao i odnos prema filozofskom diskursu velikog francuskog pisca.

Što se tiče sentimentalnog romana kao hipoteksta, ne može se reći da je Zanovićev roman parodija sentimentalnog, niti pastiš, nije ni antiroman, mada djelimično sve to jeste. Stjepan Zanović pripada savremenim tendencijama evropskog romana, ali ima i kritičan odnos prema njemu, pa njegov transtekstualni odnos dobija i metatekstualni karakter. Zanovićev je sentimentalizam bliži današnjem čitaocu. Neke scene izliva osjećanja Nove Eloize danas izgledaju smiješno, i baš taj „višak“ osjećajnosti Zanović eliminiše, zadržavajući pritom repertoar sentimentalnog romana.

Prividni nered i neodređena fabula više služe da zavaraju čitaoca ubjeđujući ga, kako to stari roman radi, da je u pitanju autentičan dokument, u ovom slučaju prepiska. Stoga su u Turskim pismima sakupljena i pisma bez adresata i adresanata, tuđa pisma, odlomci pisama, pismo u pismu, dvije priče, lakunae (,Ovdje nedostaju neki dijelovi koji nijesu mogli biti prevedeni jer su u rukopisu bili na tom mjestu izbrisani."), ${ }^{21}$ a u ime autentičnosti istočnjačkog identiteta glavnog lika umetnut je i govor iz džamije o Proviđenju. U igri fikcionalnosti i autentičnosti Zanović je izabrao, ne dramaturški razvijenu priču poput velikih predstavnika ovog žanra, već u skladu sa formom romana u pismima, rasutu, fragmentarnu, mozaičnu, prilično sinhronu fabulu. Tematski se tekst održava Osmanovim putovanjem i upoznavanjem mondenskog života, što ostavlja svjedočanstvo o Evropi XVIII vijeka. Od Pariza,

\footnotetext{
${ }^{19}$ Turska pisma, p. 161.

${ }^{20}$ Radoslav Rotković, ,Zanovićeva zaostavština“, predgovor u: Stjepan Zanović, Pakao ili nebo, Titograd, NIO Pobjeda, 1979, pp. 31-34.

${ }^{21}$ Turska pisma, p. 159.
} 
Sentimentalizam Turskih pisama Stjepana Zanovića

Venecije, Drezdena, Dubrovnika, Osman pripovijeda o navikama i običajima, ženama i muževima, ljekarima i advokatima, državnim uređenjima i zabavama. Ispod te prividne formalne i tematske ležernosti, Turska pisma su neobično strukturiran tekst, aktivan u odnosu na konvencije svog doba, bogat narativnim postupcima i oblicima i tek otvoren za ozbiljna tumačenja.

\section{Literatura}

- Beker Miroslav, Roman 18. stoljeća, Školska knjiga, Zagreb, 2002.

- Breyer Mirko, Antun Conte Zanović i njegovi sinovi, Zagreb, Matica Hrvatske, 1928.

- Coulet Henri, Le Roman jusqu' à la Révolution, Armand Colin, collection U, Paris, 1967.

- Gérard Genette, Palimpsestes, Paris, Edition du Seuil, 1982.

- Ivanović Radomir, „Emanacije ‘divljeg genija' u djelu Stjepana Zanovića (1751-1786)“, Hom[m]age Danilu Kišu, zbornik radova IV, Podgorica - Budva, 1998.

- Radoman Aleksandar, „Turska pisma Stjepana Zanovića kao prvi roman u crnogorskoj književnosti”, LINGUA Montenegrina, br. 3, Cetinje, Institut za crnogorski jezik i jezikoslovlje „Vojislav P. Nikčević“", 2009.

- Rotković Radoslav, "Zanovićeva zaostavština”, predgovor u: Stjepan Zanović, Pakao ili nebo, Titograd, NIO Pobjeda, 1979.

- Ruse Žan, Narcis romanopisac, prevod Jelena Novaković, Sremski Karlovci, Novi Sad, Izdavačka knjižarnica Zorana Stojanovića, 1995.

- Zanović Stjepan, Turska pisma, prevod s italijanskog i francuskog jezika Milica Popović, priređivač Miroslav Pantić, Cetinje, Obod, 1996.

\section{Marjana ĐUKIĆ}

\section{LE SENTIMENTALISME DES LETTERE TURCHE DE STJEPAN ZANOVIC}

Indéfinie et méprisée au niveau du genre littéraire, l'œuvre écrite en français et en italien Lettres Turques de Stjepan Zanović (1776) est examinée dans ce travail sous l'influences d'une hypothèse récente qu'il s'agit d'un roman. Acceptant ce point de départ, ce roman épistolaire est mis en relation avec les plus grands représentants français du genre et plus spécialement 
Marjana Đukić

avec le courant du sentimentalisme couronné par La Nouvelle Héloïse de Rousseau. Le résultat de cette analyse interne montre non seulement son identité romanesque incontestable, mais aussi que Lettres Turques appartient aux mouvements littéraires européens contemporains. Le sentimentalisme de Zanović n'est pas si évident, mais il apparaît sous diverses formes - de l'imitation à la transformation. La polémique hypotextuelle a dévoilé la richesse des registres et des formes narratives du roman de Zanović.

Mots-clés: Zanovic, roman épistolaire, sentimentalisme, hypertextualité 
LINGUA MONTENEGRINA, god. III, br. 5, Cetinje, 2010.

Institut za crnogorski jezik i jezikoslovlje „Vojislav P. Nikčević“

UDK 821.163.4.09-31 Radulović D. Izvorni naučni rad

\section{Jakov SABLJIĆ (Osijek)}

Filozofski fakultet Sveučilišta J. J. Strossmayera

\section{PRVA CRNOGORSKA KNJIŽEVNA ANTIUTOPIJA}

U radu se analizira roman Auschwitz Café (2003) suvremenog crnogorskog pisca Dragana Radulovića. Djelo je podnaslovljeno dystopia, što upućuje na specifičnu žanrovsku odrednicu kojom se podrazumijeva literarni oblik dosad kreativno neiscrpljen u crnogorskoj književnosti. Distopija ili antiutopija obično se odnosi na zamišljeni svijet u budućnosti u kojem se opresivan socijalni nadzor i iluzija savršenog društva održavaju uz pomoć korporacijske, tehnološke, moralne i totalitarne kontrole. Antiutopijom se pesimističkim slikama zapravo kritiziraju aktualna društvena pravila i politički sustavi. Osim antiutopijskog futurizma, roman je, među ostalim, obilježen i elementima postmodernog trilera pošasti. Zato se osobita važnost pridaje analizi metaforičkih konotacija virusa koji se upotrebljava kao biološko oružje u rukama neonacista. Dragan Radulović poslužio se propusnošću virusa kao označitelja (virulentno) prilagodljivog različitim metaforičkim kodiranjima. Njegovim rubnim statusom postojanja destabilizirane su granice između čovjeka i virusa te strogi binarizam standardnih znanstvenih klasifikacija zasnovanih na diferenciranju organskog i artificijelnog područja egzistencije.

Ključne riječi: književna antiutopija, virus kao metafora, zbilja, granica, identitet

Auschwitz Café roman je koji obilježuju prepletanja medijskih/fiktivnih sadržaja s onima iz projekcije autentične crnogorske zbilje, a ujedno se poigravački strukturira ukrižavanjem žanrova budući da je autoru roman vježbalište konvencija različitih literarnih izvorišta, primjerice: medicinskog trilera, horora, špijunskog, kriminalističkog i političkog romana, znanstvene fantastike, antiutopije, pastiša i cyberpunk romana. Djelo Dragana Radulovi- 
ća $^{1}$ po svojoj je žanrovskoj neodredivosti ili višepripadnosti značajno upravo zbog afirmiranja otvorenog modela pisanja. U okvirima takve hibridne strukture svoju su potvrdu prvi put našli dotad u crnogorskoj književnosti neiskušani pripovjedni postupci i formalna uobličenja narativa. Žanrovska „nediscipliniranost" signal je demokratizacije stvarateljskih konkretizacija književnoga teksta i njegove dekonzervativizacije u smislu pluralnosti pripovjednih tehnika i žanrovskih konvencija bez osvrtanja na isključivost ili kalupljenje monolitnih proznih oblika.

Specifičan odnos prema naraciji vidljiv je i u pogledu osobite pozicije autora. Budući da je književno djelo shvaćano poprištem stvaralačke slobode, javljala se u prozama mlađih crnogorskih pisaca, kojima pripada i Radulović, sumnja u unaprijed oblikovano sudioništvo autora i čitatelja na temelju zajedničkih shvaćanja i estetskih ili ideoloških potreba. Autor se više nije poimao ekskluzivistički pa je nerijetko postajao i objektom ironije - za to, primjerice, valja navesti tekstualnu smrt autora u romanu Andreja Nikolaidisa Zašto Mira Furlan (1996). No, usporedno s pomicanjem autoritetne i značenjske pozicije stvarateljske instancije događala se i naglašena deheroizacija pripovjedačā i junakā djela. Zato naratori u crnogorskim romanima nastalim od devedesetih do danas nisu bili isključivo nadređeni fikcionalnom svijetu, odnosno nisu imali ulogu tradicionalnog sveznajućeg pripovjedača, sveprisutnog obavjestitelja ili savjetnika uz pomoć poslovica ili moralke.

U Auschwitz Caféu primijenjena je poetika očuđenja budući da je glavni izvjestitelj o događajima pas Ždero, koji pripovijeda u prvom licu jednine. Time se uspostavlja stanje upitanosti u odnosu na društvene pojave koje su ljudima postale druga priroda, tj. same po sebi razumljive. Ždero preuzima ulogu naratora jer je on uglađen i civiliziran, kakvi bi trebali biti ljudi, a potonji se ponašaju posve suprotno od standardnog značenja „humanosti“ pa su uobičajene uloge zamijenjene: ,[Ljudi] su posljednja bića na koja bi jedan pas, što drži do sebe, trebalo da liči.“ (Radulović, 2003: 246) ${ }^{2}$ U takvom ustroju pripovjednog svijeta i likovi su neodređeni, upitni, krhki i neuračunljivi pa tako i glavni (anti)junak Seamus, koji se k tome odriče obitelji i prezimena odbacujući i negirajući time genealogičnu povezanost s ljudima oko njega te identitetnu pripadnost uvjetovanu područjem na kojem živi. Tom gestom distanciranja odbacuje se i crnogorski kult predaka pa je navedeno primjer subverzivnog, dekonstrukcijskog odnosa prema ukorijenjenoj epskoj svijesti. Zapravo, literarna činjenica koja se ne može dovoljno naglasiti sasto-

${ }^{1}$ D. Radulović rođen je na Cetinju 1969. Objavio je roman Auschwitz Café: dystopia (2003) te zbirke priča: Petrifikacija (2001), Vitezovi ništavila ili Đavo u tranzicionom Disneylandu (2005) i Splav Meduze (2007).

${ }^{2}$ U daljnjem tekstu svi citati iz Auschwitz Caféa označivat će se samo brojem stranice u zagradama. 
Prva crnogorska književna antiutopija

ji se u tom što se takvim likovima u suvremenoj crnogorskoj prozi općenito simbolički naznačuje prijelaz subjekta iz skupnog ili plemenskog uma u područje samopropitivanja individualnog identiteta redovito oprečnog kolektivnim mehanizmima društva. Zato je uzimanje ,neutralnog “ imena u Radulovićevoj distopiji ujedno postupak svjesnog distanciranja od ideologije. Naime, pod utjecajem njezinih praksi isključivanja u vrlo važnoj epizodi s muslimanima (poglavlje „Koje je doba noći, stražaru?“) u vlaku dolazi do njihove eliminacije jer su nositelji „,krivih“ imena vezanih uz ideološki tvorenu nepoželjnu „Drugost“.

\section{Antiutopizam}

Iako je napomenuto da je Auschwitz Café izgrađen na mješavini elemenata različitog žanrovskog podrijetla, on je podnaslovno ipak određen kao dystopia. Drugi je naziv za taj žanr antiutopija, koju su u svjetskoj književnosti kanonski utvrdili: Evgenij Zamjatin - Mi (My, 1924), Aldous Huxley Vrli novi svijet (Brave New World, 1932) i George Orwell - 1984 (Nineteen Eighty-Four, 1949). Unatoč miksturi žanrova i antiutopiji kao podnaslovnoj odrednici dominantnih generičkih parametara, roman odlikuje mimetičnost. Preciznije rečeno, likovi i fabula su fikcionalni, ali je povijesna/društvena pozadina, bez obzira na futurološke literarne prilagodbe, u bíti stvarna, a na realnom i mogućem zasnovani su i tematizirani znanstveni eksperimenti. Takva neočekivana mimetičnost rezultat je žanrovskih odrednica antiutopije, kojima svima udovoljava i Radulovićev roman. Svijet antiutopijske fikcije ponajprije se gradi u relaciji s totalitarnim diktaturama kao njihov prototip. Uobičajeno je da se distopijom reprezentira društvo uređeno po uzoru na koncentracijske logore pa se ozakonjenim nasiljem obespravljuje i eksploatira cjelokupno stanovništvo. Riječ antiutopija skovana je od riječi utopija i uglavnom se rabi kad se govori o naizgled fiktivnim društvima. ${ }^{3}$ Antiutopije su pretežno pisane kao upozorenja ili satire u kojima se krajnje negativno prikazuju aktualni društveni odnosi. Prema tome, u antiutopijskom djelu tematizira se imaginarno društvo čijom se radikalnom dehumanizacijom najčešće komentira piščeva šira ili uža okolina njezinim predstavljanjem u zastrašujućem svjetlu. ${ }^{4}$ Uvjetno rečeno, antiutopija ne „oslikava“, već „odražava“ suvremenu socijalnu zbilju.

\footnotetext{
${ }^{3}$ Utopija, prema grčkom: $u$ - ne + tópos - mjesto. Dakle, mjesto koje ne postoji jer je idealno (Klaić, 2002: 1398). Antiutopija, prema grčkom: anti-protu ili $d y s-n e+$ tópos - mjesto. Dakle, mjesto antipodno idealnom.

4 „Antiutopija je kritika budućnosti koju utopija prezentuje. Ona je izraz antinostalgije. Kako su utopisti često fanatici, antiutopiste bismo pre mogli nazvati lucidnim. Utopijski roman ističe se formom lažne savesti; antiutopijski - demistifikacijom." (Stojanović, 2004: 62)
} 
Dragan Radulović u svojoj distopiji predstavlja crnogorski Mediteranski Polis Budvu u zamišljenoj bliskoj budućnosti u kojoj se na Trgu od kazne (preimenovanom budvanskom Trgu pjesnika) vrše smaknuća politički nepodobnih pojedinaca i zakonskih prekršitelja za primjer domaćem stanovništvu. Sadržajno se Radulovićev roman djelomice nadovezuje na kritiku novije povijesti koju su pisci crnogorske historiografske proze realizirali aluzivnim odnosom fikcije i historije. Cirkularna koncepcija povijesti toliko karakteristična za Igora Đonovića (Ogledalo, 1996) i Predraga Sekulića (Made in Yugoslavia, 2002, Harem, 2004) svoje je ozbiljenje doživjela i u antiutopijskoj fantastici Auschwitz Caféa. Premda neposredna kritika osobitosti crnogorskog kulturnog identiteta, odnosno njegova neozbiljenja, nije glavni i isključivi cilj Radulovićeva romansijerstva, simbolički teret identitetne nezaokruženosti i neprestane agoničnosti pronalazi svoje mjesto i u tehnološki/ /medijski „osviještenom“ romanu kakav je Auschwitz Café. Seamusu, jednom od glavnih likova, njegov Đede u posmrtnoj poruci napominje:

Kakva je to kletva bačena na nas te se nikad dvije generacije sastaviti ne mogu, no razgrađuju jedna drugoj sve ono što su za života postigli. Nije tako svugdje. Posmatrao sam ja druge zemlje: i tamo se očevi sa djecom svađaju i progone, ali do jedne ure, jer i pored sve mržnje koja ih goni na zlo postoji mnogo toga što im je zajedničko i što im ne dopušta da se unište do kraja - domovina, barem! A ovdje kod nas? Ovdje su nam i domovine različite. [...] Crnogorci su rđava beskonačnost. Nihilizam koji ne uspijeva da pobijedi sebe, već neprekidno glođe vlastitu utrobu. A pored navedenih metafizičkih nedostataka: nečasni su još i lakomi na pare, nemilosrdni i bahati, kako ne posjeduju formu u kojoj bi čuvali svoj subjektivitet, oni subjektiviteta i nemaju. Neozbiljni su, te neozbiljno i postoje, ili preciznije: samo se igraju postojanja. (315-316)

Citat je dobar primjer načina na koji su mlađi crnogorski romanopisci promišljali povezanost i međusobnu uvjetovanost (svojih) koncepcija zbilje, granice i identiteta. Tako se razlikovnica najprije uspostavlja između mentaliteta „,nas“ (Crnogoraca) i ,drugih“ (inozemaca), potom na temelju izostanka jasne domovinske identifikacije, zatim na osnovi temporalnosti utopljene u frustrirajuću sinkronijsku istost društvene zbilje te, sukladno tome, na nepostojanju čvrsto izgrađenog nacionalnog identiteta. Također, jedan je od važnijih idejnih slojeva Radulovićeva romana vezan uz ciljano istrebljenje ljudi $\mathrm{u}$ impliciranom kontekstu politikā balkanskih ratova devedesetih godina XX. stoljeća. Valja napomenuti da je Seamusova nečista savjest uzrokovana prešutnim sudjelovanjem u faktografski provjerljivom odvođenju muslimana iz vlaka u Štrpcima 1993. godine. Time je ponovno aktualizirana (opetovana) tema vezana uz eksterminiranje muslimanske „Drugosti“" koja je toliko obi- 
Prva crnogorska književna antiutopija

lježila rasprave oko ideoloških tumačenja Njegoševe ,istrage poturica“ u Gorskom vijencu.

\section{Virus - simboličke vrijednosti}

Uništenje ljudskog života u Radulovićevu romanu također je pod značajnim utjecajem teorijskoga tereta investiranog provodnim motivom virusa te s njim povezane opasnosti zaraze. Općenito, motivi virusa, zaraze i bolesti nisu rijetkost u recentnoj crnogorskoj prozi. Osim za Radulovićevu antiutopiju, bolest i zaraza bitni su za semantički sloj romana poput Hansenove djece (2004) Ognjena Spahića, ali djelomice i za romane Mimesis (2003) i Sin (2006) Andreja Nikolaidisa. Izravan utjecaj na takav tematski odabir, poglavito Dragana Radulovića, moguće je izvorišno detektirati u stvaralaštvu Borislava Pekića, čiji romani imaju kultni status za nabrojane crnogorske pisce. Utjecaj je osobito vidljiv u relacioniranju Auschwitz Caféa i Pekićeva romana Besnilo (1983) u kojem je virus ne samo uzročnik karantene u londonskoj zračnoj luci Heathrow kao metonimiji svijeta nego je postao i jedan od glavnih likova tog romana. Besnilo je vrstovno odredivo kao spekulativna fikcija čije su žanrovske karakteristike djelomično značajne i za Radulovićev roman. Neke su od narativnih specifičnosti Besnila sljedeće: virusu se pripisuju osobine koje nisu (još) znanstveno dokazane; on je personaliziran te nije samo rekvizit naracije; virus je spekulativne prirode koja mu osigurava ulogu objekta podložnog teoretizaciji; on nadživljuje napadnuti subjekt; uvodi se pojam posthumaniteta budući da rekombinirani virus može dovesti do superiorne vrste čovjeka, što je utopijska vizija virusa jer stimulira evoluciju ljudske rase. ${ }^{5}$ Naravno, i kod Pekića su utvrdivi gotovo identični elementi različitog žanrovskog podrijetla kao što su: horor, znanstvena fantastika, medicinski triler i postmoderni triler pošasti. Takva poklapanja, pogotovo u pogledu tematskih preokupacija, pogodna su za analitička razmatranja fenomena virusa čije simboličke mogućnosti proizlaze iz međuprožimanja ideja popularne kulture, znanosti, medija i politike kao diskurzivnih arhiva, odnosno lingvističkih ili semantičkih rezervoara.

Motiv virusa poseban je po tom što se u označiteljskim praksama fikcije transcendira specifično materijalan aspekt virusa kao fenomena. Takva njegova upotreba pokazatelj je suvremene zaokupljenosti ,jastvom“ i ,,drugošću“ upravo na temelju liminalnosti virusa, odnosno njegova zauzimanja granične pozicije između (ne)živog. Uz to virus je kao literarna figura pogodan za preispitivanje tradicionalnih binarnih opreka budući da prelazi kulturno ustanovljene i u bíti artificijelne granice, destabilizira ih te dovodi do pre-

${ }^{5}$ Karakteristike spekulativne fikcije navedene su iz: Thomas, 2002: 18. Koje su razlike između Besnila i Auschwitz Caféa, pokazat će se u daljnjoj analizi. 
vrednovanja tradicionalne mreže odnosa ,jastva“ i ,drugosti“. U Auschwitz Caféu virus se javlja kao prijetnja cijelom čovječanstvu jer postaje biološko oružje tajne organizacije Naci-Baštovana, koji učinke rekombiniranih virusa eksperimentalno provjeravaju namjernim inficiranjem ilegalnih emigranata na Ostrvu u crnogorskom primorju.

Utopijski potencijal virusa kao teoretske kategorije u romanu je istaknut naglašavanjem problematičnog virusnog umnožavanja u tijelu domaćina. $\mathrm{Na}$ taj se način osporava jedinstvo subjekta poništenjem njegovih granica. No, u Radulovićevu djelu prisutno je i uobičajeno imaginiranje imunološkoga sustava kao područja obrane od „Drugoga“, tj. stranih uljeza. U skladu s navedenim, tijelo se shvaća kao vojni sustav uperen protiv okupatora koji uzurpira teritorij domaćina i uspostavlja novi red:

Jedan gen virusa sadrži dvije varijacije istog glikoproteina [...]. Oba su enkodirana iz istog gena Ebole, i doktor je utvrdio da napadaju različite ćelije: manji protein napada ćelije bijelih krvnih zrnaca, što koči imuni odgovor organizma koji bi trebalo da se bori protiv virusa, dok veći, transmembranski glikoprotein oblikuje površinu novih virusa koje proizvodi Ebolom inficirana ćelija, ugrađujući u te nove viruse izvjesnu sklonost ka receptorima endotelnih ćelija koje čine unutrašnjost krvnih sudova, srca i drugih organa. (58-59)

Vokabular moderne imunologije združen je s borbenom metaforikom ratnog sukoba, čime je zaraza definirana podvrstom informacijske neučinkovitosti ili komunikacijske patologije pa je zato ljudski organizam percipiran kao visoko militariziran strategijski sustav. Tijelo shvaćeno slikama bojnog polja, a infekcija u terminima rata visoke tehnologije, osim što su fabularni elementi znanstvene fantastike, također su mikrorazinski odslik vanjskog autoritarnog terora i represije ideologijom (torture i smaknuća u totalitarnoj državi-polisu, neonacistički eksperimenti na živim ljudima).

Iz prethodnog navoda (58-59) također je moguće utvrditi informacijsku metaforu o virusu s obzirom na to da su čovjekovo tijelo i virus svodivi na kodove. Osobitim spojem teorije informacije i molekularne biologije smrt subjekta u biomedicinskom diskursu romana analogna je poststrukturalističkoj smrti subjekta. Tijelo zbog toga nije samo konotirano kao vojni sustav već se promatra i kao konstrukt budući da je intenzivan fokus usmjeren na pojedine dijelove tijela, a ne na njegovu ukupnost. Stoga je logično što je u takvom mikroskopizirajućem diskursu virusu dano mjesto negativnog označitelja (,,ne-jastva“) suprotstavljenog genu (,,jastvu“).

U Auschwitz Caféu također su utvrdive jednadžbe identiteta čovjeka i virusa: „Parazitiranje je svaki oblik života koji prevrši mjeru, te ni čovjek nije daleko od toga. [...] Virus kao imuni odgovor planete na agresiju čovjeka koji se pretvorio u nemilosrdnog parazita, i ljudske vrste koja je izgubila 
Prva crnogorska književna antiutopija

smjernice i smisao svog postojanja te samo uništava svijet oko sebe pretvarajući ono čega se dotakne u pustoš.“ (53) Analogija između čovjeka i virusa uspostavljena je na općenitoj razini u skladu s toposom trilera pošasti u kojem je pošast, paradoksalno, ljudski život izjednačen s onim parazita. Iako se u i Radulovićevu romanu javlja svojevrsno personificiranje biološkog virusa, on ne postaje kao kod Pekića antropomorfizirani postmoderni patogen proizveden kao genetički bricolage koji može stimulirati evoluciju vrste upletanjem u genetski/metabolički ustroj domaćina.

Virus kao kodirani tekst i spremište informacija, podložan regulaciji i kontroli onoga što će doći do izražaja intervencijama u njegov genetski kôd, odraz je popularne fascinacije opasnostima ne više nuklearnih borbenih sredstava, već bionaoružanja. Radulovićev opis virusa kao utjelovljenja prijeteće stranosti tipična je strategija obračunavanja s uvriježenim kolektivnim strahovima. Pozicija liminalnosti samog virusa pri tom je poslužila kao polazište u procesu stvaranja „drugosti“ kao projekcije opasnoga i neugodnoga. Ujedno je znakovito da se eksperimentalno preobličen, ali i originalan Ebola virus žarišno locira u prostor središnje Afrike „odsječen od svake civilizacije“ (52). Radulović je time posegnuo za uobičajenim rekvizitom određenog broja medicinskih/znanstvenofantastičnih trilera u kojima je Afrika prikazana kao rezervoar virusa, a infektivnost „afrikanizirana“ i združena s metaforičkim konotacijama koje su djelomice posljedica imagološkog utjecaja romana Josepha Conrada Srce tame (Heart of Darkness, 1899). Primordijalnost, divljost i misterioznost nisu obilježja kojima bi „crni“ kontinent bio kontrastiran racionalizmu i superiornosti Europe, nego se te osobine pripisuju crnogorskom geografskom kontekstu kao negativne vrijednosne kvalitete mentaliteta određenog ozbiljenim metaforama kanibalizma, koncentracijskog logora i (balkanske) „kasapnice“. U takvom interpretacijskom kontekstu nije zanemarivo što je u romanu upotrijebljen conradovski leksik ,zemljopisne karakterizacije“. Na primjer, kod uvoda u razgovor o virusu: „da progovori iz same stvari, iz srca tame koja se pred njima otvara [...]“ (188) ili za potrebe metaforiziranja antropoloških svojstvenosti bivše Jugoslavije: ,zahvatiti u samo središte tame, jasno identifikovati čovjekovu životinjsku prirodu [...].“ (279)

Samim tim što je za područje eksperimentiranja s virusima na ljudima odabrano takozvano crnogorsko Ostrvo, negativne metageografske odrednice uglavljuju se za geoantropološko označavanje Crne Gore, napose na povijesnoj pozadini ratova na tlu bivše Jugoslavije. ${ }^{6}$ Također valja istaknuti da time taj prostor nije getoiziran jer bi bio rezerviran samo za antiutopijske vizije, nego je poslužio kao paradigma realiziranoga kanibalizma i perverzije suvre-

${ }^{6}$ Spomenutom Ostrvu zbiljski je pandan otok Sveti Nikola u okolici Budve. To se ime otoka u romanu napominje nekoliko puta. 
menih društava izvrnutih vrijednosti. Na tom tragu može se zaključiti kako virus u Auschwitz Caféu ima ulogu literarne figure u kojoj svoje utemeljenje metaforički pronalaze prijeteće „,drugosti“. Naravno, čudovišnu virusnu mješavinu koja nastaje „kanibalizacijskim“ utjecajem virusa Ebole moguće je analizirati njezinim asocijativnim povezivanjem s odredbama poput: primitivno, divlje, proždrljivo, životinjsko, afričko i, naposljetku, balkansko. Te odrednice funkcioniraju kao inkarnacije apokaliptične prijetnje bastionu „,prosvijetljene“ zapadne znanosti kojom bi se trebao spriječiti njihov kontakt $\mathrm{s}$,nepokvarenim“ tijelom Zapada, s tim da je, paradoksalno, u okvirima iste te ,znanosti“ i proizvedeno virusno bionaoružanje. Navedeno je čitanje i te kako moguće bez obzira na globaliziranje ili univerzaliziranje fenomena kanibalizma.

Posljedice globalizacije tema je koja se izravno nadovezuje na prethodne jer se od nekontroliranog širenja zaraze opasnijima čini amalgamiranje virusa i stvaranje virusne himere financijskim poticanjem multinacionalnih kompanija kakva je u romanu I. Gen. Pharmaceuticals. Amblematična hibridnost virusa (i njegove strukture i njegovih kulturnih funkcija) nesumnjivo se očituje u oblikovanju virusnog čudovišta kao konkretizaciji strahova od genetičkoga inženjeringa: ,'Pronašao', 'birao', 'stvorio', 'ukrstio“, 'povezao“ o čemu to govoriš!? [...] O genetičkom inženjeringu, dušo. Neko se ovdje odlično zabavio ukrštajući viruse i rješavajući njihove proteinske lavirinte.“ (112) Takvim i sličnim problemskim mjestima preispituje se inače neprijeporna kategorija organske autonomije čime se povratno utječe na shvaćanje pojma subjekta. Naime, ako i najmanji/krajnji oblik života kakav je virus može biti manipulativno spajan metodom doktora Frankensteina, onda je i subjektivitet podložan istim takvim transformacijama.

\section{(Epidem)ideologija}

Upletanje mitologije američkog televizijskog serijala Dosjei $X$ i njegova simboličkoga kapitala fabularnim uvođenjem lika agenta Foxa Muldera asocira na temeljne postavke toga filmskoga narativa. ${ }^{7}$ Prije svega na tezu da su ljudi tvorci vlastite apokalipse pa je naglasak ujedno stavljen na pogubnost virusa za njegove žrtve, na krhkost kao obilježje tjelesne konstrukcije te na proces raspada subjekta. Načela koja čine filozofsku potku serijala ugrađena su u svijet Radulovićeva romana, a mogu se sažeti ovako: istine su pomične; predstavnici vlasti su korumpirani negativci koji određuju što je istina, kakva će biti budućnost, a samim tim omogućeno im je upravljanje ljudskim životima; vlast se izjednačuje s virusom; um i tijelo podložni su mani-

${ }^{7}$ Dosjei $X$ žanrovski se mogu svrstati u naracije o virusima i biološkom oružju prema engl. virus and bioweapons narratives (Thomas, 2002: 83). S engleskog preveo J. S. 
Prva crnogorska književna antiutopija

pulaciji pa je za takvo podčinjavanje adekvatan pojam „zatvorskog društva“ Michela Foucaulta (Foucault, 1994: 242).

U Auschwitz Caféu Veliki Registrator koji nalaže javne egzekucije svojih protivnika metonimija je korumpirane vlasti Mediteranskog Polisa Budva, ali i prototip fašističkog diktatora. Budući da vlada rigidnim društvenim nadzorom i manipulacijama, Veliki Registrator predstavlja pomak od moći vladanja tjelesnom snagom prema disciplinirajućoj moći snagom misli. I u njegovu slučaju, kao i kod likova iz sfere vlasti u Dosjeima $X$, odlučivanje o smrti zamijenjeno je administracijom tijela i kalkuliranim menadžmentom života. Točnije, fizička sila nadomještena je ponajprije medijski artikuliranim znanjem kao tehnikom koju rabe službene vlasti, odnosno bio-znanjem kojim neonacisti nastoje zavladati u Radulovićevoj distopiji.

Valja reći da je u Auschwitz Caféu objekt moći um, a ne tijelo koje se tretira tek kao potrošna roba u komercijaliziranom svijetu prevladavajuće logike kapitalističke proizvodnje i potrošnje. Tako je tortura istodobno tehnika primjene sile, zabava i opomena za pučanstvo te dio turističke ponude „Gubilišta“ - Dioničarskog društva za proizvodnju i distribuciju agonije. Ovdje je ujedno riječ i o spektakularizaciji zločina i nasilja čime ubojstvo kao oblik kazne zadobiva status estetske kategorije, a ne nemoralnog čina. Kritika eksploatacije pornografije zla u romanu je usmjerena prema njezinoj medijskoj prezentaciji i tržišnom iskorištenju usred čega se moralna dimenzija povlači pred terorom - izvorom kolektivne fascinacije koja je istodobno najjači pokretač masa. Postupkom kojim se nasilje estetizira i kapitalizira naglašeno je i gubljenje razlike između sfera stvarnog i virtualnog budući da isti način vrjednovanja i konzumacije imaju filmski prikazi nasilja kao i oni stvarni Dželat tako postaje umjetnikom (performerom), Veliki Registrator producentom, masa publikom, a egzekucije se izjednačuju s umjetničkim činovima. Prema tome, ultimativnim trijumfom zatvorskog nadzora u romanu je izvršena invazija na tijelo u obliku ritualnih smaknuća, ali je istodobno destabilizirana koncepcija sveprisutnosti vlasti i njezina je kontrola prikazana kao mit jer genetički nadzor ipak ostaje izvan njezina domašaja.

Također je vidljivo da narativno oneobičenje nije postignuto samo perspektuiranjem pripovijedanja iz pozicije humaniziranog psa o animalnosti čovjeka, već i „kratkim spojem“ izazvanim integriranjem prošlosti u budućnost, i to posve srednjovjekovnim oblicima javnih smaknuća u kojima tijelo postaje predmet spektakla odvojeno od moralnih zakona i vrijednosti. Time se ponovno utvrdila temporalna reverzibilnost čija se posljedična tjeskobnost dosljedno pokušavala razriješiti ironijom u Radulovićevu „katalogu groteski“ 
Vitezovi ništavila ili Đavo u tranzicionom Disneylandu (2005). ${ }^{8} \mathrm{Na}$ tom tragu valja shvatiti i oksimoronski spoj u naslovu Radulovićeva romana kojim se signalizira prožimanje elemenata antiutopije i svakodnevlja ili kružna temporalizacija obilježena Auschwitzom kao povijesnom konstantom.

\section{Homo datum}

Po svemu sudeći virus je u Radulovićevu romanu konstruiran kao čovjekov neprijatelj izrazite letalnosti. No, upravo inzistiranjem na tom binarizmu dokazuje se konstruiranost opreke virus - čovjek jer ona ne bi morala imati takvo tekstualno utvrđivanje da je zaista fiksna. Njezinim oštrim naglašavanjem pokazano je kako se ona istodobno može i dekonstruirati oslikavanjem fluidnosti granice između sfera virusnog i humanog, što je vidljivo i u Dosjeima $X$ u kojima se opetovano dokazuje da je virus u čovjeku i da je virus čovjek. Narušavanje te granice zamjetno je i u onim dijelovima Auschwitz Caféa koji su inspirirani cyberpunk romanom inauguriranim Neuromancerom (1984) Williama Gibsona. ${ }^{9}$ U poglavljima pod utjecajem tog žanrovskog tipa („Na mjestu zločina“ i „Meduzina glava“) važan je lik gospođe Moris, koji u romanu ujedno predstavlja i pokušaj novog pogleda na ženskost u odnosu na tradiciju crnogorske književnosti. Ona je samosvjesna, odlučna i na sebe preuzima najvažniji dio posla vezan uz špijunsko ubacivanje u računalni sustav neonacistički instruirane korporacije. Rastakanje granice između biološkog i artificijelnog omogućeno je primjenom biomehanoidne konzole uz čije se posredovanje njezina svijest prekodira u elektronske čestice koje nesputano plutaju u virtualnom prostoru (cyberspaceu) u želji da poput virusa onemogući neprijateljski računalni sustav. U tom prostoru formira se i njezina digitalna dvojnica koja je dokaz da tehnološka domena spremno postaje vlastiti svijet, odvojen od zamršenosti i težine stvarnoga svijeta. O elektronički generiranom cyberspaceu misli se „kao o virtualnom kazalištu, u kojemu možemo zadovoljiti drevnu želju da svoje fantazije učinimo opipljivima. U

${ }^{8}$ Usp. citat iz navedene Radulovićeva „,kataloga groteski“: „Shvatio sam da budućnosti nema. [...] I to je moja najteža misao, moje vječno vraćanje istog. " (Radulović, 2005: 80) „Postaćemo predmet proučavanja studenata antropologije sa svjetskih univerziteta. Etno-park, prijatelju. [...] Perverzni amalgam kamenog i informatičkog doba, jer će naš poglavica uz sjekiru od kamena posjedovati i računar sa satelitskim priključkom na Internet." (81-82)

${ }^{9}$ Cyberpunk romani moralno su dvosmisleni. U njima se opisuju marginalci koji se bore za život u blijedim urbanim futurističkim svjetovima u kojima dominiraju korporacije ili vlade čija je kontrolna moć pojačana umjetnom inteligencijom. Cyberpunk priče ispričane su iz kriminalističke perspektive i prikazuju široko prisutnu uporabu biotehnologije, računala, droga te paranoidni stil života. One su zasnovane na distopijskoj vrsti znanstvene fantastike u kojoj se virtualna stvarnost promatra kao mjesto oslobođenja i područje istraživanja bez ikakvih ograničenja (Featherstone, Burrows, 2001: 15-16). 
Prva crnogorska književna antiutopija

tom kontekstu može se smatrati da virtualni svijet tvori zaštitni kovčeg [...]“ (Robins, 2001: 206) u kojem se rastjelovljenim, „lebdećim“ identitetima ispunjavaju sve želje:

Urlik zadovoljstva užasom koji je stvorila odliježe prazninom kiberprostora. Njen urlik izaziva na dvoboj, ali u Centralnoj mreži više ne postoji niko da joj se suprotstavi. Osvrće se oko sebe, bijesna zvijer u kavezu čiji očnjaci bjelasaju na sve što još postoji. Hiljadu smrtonosnih ruku virtuelne boginje Kali uzalud tragaju za neprijateljem. Nikoga nema ko bi joj izašao na megdan. [...] Amodeja ulazi u mozak glavnog računara, ulazi bez problema i to je za trenutak zbunjuje, očekivala je pobunu, bar nekakav otpor. Ali ona ulazi lako, jer središte glavnog računara je bez ikakvih sredstava za obranu. Glavni računar ne osjeća strano tijelo, ne osjeća neprijatelja. Kao ni ljudski mozak, misli Amodeja, tako ni memorija računara ne posjeduje receptore bola. (378)

Unatoč tome što je prikaz Amodeje, virtualne dvojnice gospođe Moris, moguće tumačiti kao konvenciju cyberpunk romanā u kojima junak/inja računalnim razbijanjem koda onemogućuje protudržavnu urotu, njezin je lik znakovit zbog toga što se inskribira kao virusni entitet budući da joj se pridaju osobitosti upravo primordijalnog, divljeg i misterioznog. Time Radulovićev pokušaj obrtanja crnogorskog patrijarhalnog kodiranja ženskosti rezultira samo utvrđivanjem njegovih postavki na isti način kojim se u romanu conradovski kvalificirala Afrika, i to bez prevelikog utjecaja kulturoloških konotacija feminističkog kiborga koji u romanu očito ostaje nefunkcionaliziran. ${ }^{10}$ No, s obzirom na to da gospođa Moris biva usmrćena ugradbenim aparatom za prebacivanje u kiberprostor, posredno se upleće i anticipacija „kibernetskog čovjeka“" (ovdje u nerodnom značenju pojma) koji umjesto gospodara tehnologije postaje njezin rob pa ,tehnika - nekada vitalni element stvaranja - pokazuje svoje naličje kao boginja destrukcije (kao indijska božica Kali) kojoj su ljudi voljni žrtvovati sebe“ (Fromm, 2004: 168).

Navedeni je lik indikativan i zbog (virulentne) prilagodljivosti, propusnosti virusa kao označitelja budući da je u romanu očito došlo do realizacije već napomenute metafore o čovjeku-virusu. Takvim transformacijama otkri-

${ }^{10}$ Lik feministički osviještene sudske patologinje Alise Čavor u Radulovićevu romanu nema značajniju ulogu da bi mogla biti metanarativno emblematična. U repozicioniranju ženskosti uspješniji je bio A. Nikolaidis, koji je u Mimesisu preoblikovao stereotipnu predodžbu o lutalačkom junaku homerske tradicije pridajući njegove osobine upravo ženskom liku, djevojci Tei. No, proces je i obratan - pripovjedač Konstantin Teofilis „feminizira“ se jer funkcionira poput Šeherezade. Nikolaidis je sam izjavio da je tijekom pisanja Mimesisa na umu imao Tisuću i jednu noć budući da njegov pripovjedač Konstantin, kao i Šeherezada, pokušava isposlovati odgodu (Senčar, 2007: www). 
vaju se analogije između diskursa o računalnom i onoga o biološkom virusu koji računalnom služi kao njegov referent. Biološki i računalni virus postaju problem jezika jer se komunikacijska i suvremena biološka znanost konstruiraju obratom, odnosno prijenosom svijeta u problem kodiranja. I ljudi i strojevi počinju funkcionirati poput kodiranih tekstova kroz koje se očituju manipulativne igre čitanja/preispisivanja svijeta, a biološka metafora za umjetno stvoreno dokaz je dvostruke prirode virusa kao a) jezičnog i b) informacijskog entiteta. ${ }^{11}$

Prethodno navedenim obrtanjima naznačuje se krhkost granice između „prirodne“ zaraze (biološke katastrofe) i ,artificijelne“ (intencionalno učinjene). U skladu s tim, računalni virus se naturalizira, a biološki artificijelizira. Navedeno je vidljivo po znanstvenom diskursu romana u kojem se podrobno elaborira o konstruiranim virusima za specifične ciljeve socijalne kontrole. Pri tom se zaraza ujedno poima i podvrstom informacijskog nefunkcioniranja ili komunikacijske patologije. ${ }^{12}$ Umjetni produžeci u obliku utičnih cerebralnih implanata doprinijeli su stvaranju čovjeka kao stanovnika mreže (homo datum), pri čemu je vrlo teško razlikovati stvarnu subjektivnost od one koja je računalno stvorena. Na taj se način binarizam opreke ,(ne)ja“ relativizira jer dolazi do sloma prirodnih i umjetnih granica te posljedično do svijesti o konstruiranosti i nestabilnosti kategorija zbilje (realnost - kiberprostor), granice (tijelo - računalo) i identiteta (realna egzistencija - virtualna egzistencija). Prikazom manipulacija računalnim podacima u svrhu utjecaja na važna zbivanja u stvarnom svijetu naglašava se performativna moć jezika u infosvijesti, a time se fokusiraju implikacije procesa konstruiranja ljudi kao računala. Takve identitetne jednadžbe moguće je izvesti iz semantičke strukture Radulovićeva romana jer se u djelu ljudska većina kvalificira kao „prosta materija koju po vlastitoj želji oblikuju ljudi od moći“ (172). Riječ i slika u službi ideologiziranih prikazivačkih praksi vrhovnika Mediteranskog Polisa Budva mogu se u tom analitičkom okviru izjednačiti s virusima budući da su ljudi konstituirani kulturnim informacijama kao kulturnim softverom koji pokreće „računala ljudskih mozgova“.

\section{Zaključak}

Na osnovi svega prethodno rečenog u Auschwitz Caféu utvrdive su dvije tehnike postmimetizma (Oraić Tolić, 2005: 222). Realno se pojavljuje kao imaginarno na temelju simulakralnog očuđenja brisanjem razlika između stvarnog i izmišljenog te mistifikacijom objektivnih činjenica po želji moćni-

\footnotetext{
${ }^{11}$ Usp. citat: „To je kreacija Amodejine fantazije (mnoštvo virusnih programa čije je djeliće skupljala na svojim putovanjima kroz matricu.“(376-377)

${ }^{12}$ Usp. citat: „Glavni računar ne osjeća strano tijelo, ne osjeća neprijatelja.“ (378) 
Prva crnogorska književna antiutopija

ka. S druge strane, imaginarno se pojavljuje kao realno budući da su virtualni svjetovi nadomjestili stvarnost: Đede je u radnju uveden kao hologramska projekcija, računalo određuje tko će se sve boriti protiv kriminalne korporacije, zamjetni su novi virtualni identiteti likova koji se bore u kiberprostoru, Fox Mulder iz serijala Dosjei $X$ deskribira se kao zbiljski (pojava filmskog mimetizma). Na osnovi nabrojanog zaključivo je da je upravo takvim pripovjednim strategijama i motivima ostvaren pionirski prodor u dosad netematizirane literarne svjetove unutar crnogorske književnosti. Kao ni u jednom drugom crnogorskom romanu s početka XXI. stoljeća u Auschwitz Caféu detektiran je poljuljan fenomen zbilje njezinim neposrednim apostrofiranjem kao proizvoda kulture, moći, politike i ideologije.

\section{Literatura}

- Conrad, Joseph. 2004. Srce tame. Preveo Vladimir Cvetković Sever. Zagreb: Globus Media.

- Đonović, Igor. 1996. Ogledalo. Cetinje: Dignitas.

- Featherstone, Mike i Roger Burrows. 2001. „Kulture tehnološke tjelesnosti. Uvod“. U: Kiberprostor, kibertijela, cyberpunk. Kulture tehnološke tjelesnosti. Uredili Mike Featherstone i Roger Burrows. Zagreb: Jesenski i Turk. Str. 13-38.

- Foucault, Michel. 1994. Nadzor i kazna. Rađanje zatvora. Prevela Divina Marion. Zagreb: Informator, Fakultet političkih znanosti.

- Fromm, Erich. 2004. Imati ili biti? Preveo Gvozden Flego. Zagreb: Izvori.

- Gibson, William. Neuromancer. 2001. Preveo Predrag Raos. Zagreb: Naklada Lukom.

- Huxley, Aldous Leonard. 1998. Vrli novi svijet. Preveo Stanislav Vidmar. Zagreb: Izvori.

- Klaić, Bratoljub. 2002. Rječnik stranih riječi. Zagreb: Nakladni zavod Matice hrvatske.

- Nikolaidis, Andrej. 1996. Zašto Mira Furlan. Ulcinj: Plima.

- Nikolaidis, Andrej. 2003. Mimesis. Cetinje, Zagreb: Otvoreni kulturni forum, Durieux.

- Nikolaidis, Andrej. 2006. Sin. Cetinje, Zagreb: Otvoreni kulturni forum, Durieux.

- Oraić Tolić, Dubravka. 2005. Muška moderna i ženska postmoderna. Rođenje virtualne kulture. Zagreb: Naklada Ljevak.

- Orwell, George. 2001. 1984. Preveo Antun Šoljan. Zagreb: Alfa.

- Pekić, Borislav. 1983. Besnilo. Zagreb: Sveučilišna naklada Liber.

- Radulović, Dragan. 2003. Auschwitz Café. Dystopia. Budva: Drakar. 
- Radulović, Dragan. 2005. Vitezovi ništavila ili Đavo u tranzicionom Disneylandu. Budva: Drakar.

- Robins, Kevin. 2001. „Kiberprostor i svijet u kojem živimo“. U: Kiberprostor, kibertijela, cyberpunk. Kulture tehnološke tjelesnosti. 2001. Uredili Mike Featherstone i Roger Burrows. Zagreb: Jesenski i Turk. Str. 195-224.

- Sekulić, Predrag. 2002. Made in Yugoslavia. Podgorica: Oktoih.

- Sekulić, Predrag. 2004. Harem. Podgorica: Oktoih.

- Senčar, Anela. 2007. „Andrej Nikolaidis“. Preuzeto s: http://www.booksa.hr/dossier/32 (23. travnja 2009).

- Spahić, Ognjen. 2004. Hansenova djeca. Cetinje, Zagreb: Otvoreni kulturni forum, Durieux.

- Stojanović, Milena. 2004. Književni vrt Borislava Pekića. Beograd, Pančevo: Institut za književnost i umetnost, Mali Nemo.

- Thomas, Anne Marie. 2002. It came from outer space. The virus, cultural anxiety, and speculative fiction. Baton Rouge: Louisiana State University.

- Zamjatin, Evgenij Ivanovič. 2003. Mi. Prevela Rafaela Božić Šejić. Zagreb: Naklada Breza.

\section{Jakov SABLJIĆ}

\section{FIRST MONTENEGRIN LITERARY DYSTOPIA}

The paper deals with the novel Auschwitz Café (2003) written by contemporary Montenegrin author Dragan Radulović. The novel is subtitled $d y$ stopia, which is a signal of specific genre that has never been used in Montenegrin literary tradition. Dystopia or antiutopia is related to some imaginary future world that is socially oppressive. It represents illusion of perfect society permeated with corporation, technological, moral and totalitarian control. That pesimistic images are in fact the way of critical approach to current social rules and political systems. Besides the dystopian futurism, the novel is also based on the elements of postmodern plague thrillers. Therefore the analysis of metaphorical connotations of the virus used by neonazis as a bioweapon is emphasized. Dragan Radulović made use of the protean nature of the virus adaptable to many metaphorical meanings. Its marginal status of existence destabilizes borders between man and virus and strict binarism of scientific classifications based on distinguishing organic and artificial field of existence.

Key words: literary dystopia, virus as a metaphor, reality, border, identity 
LINGUA MONTENEGRINA, god. III, br. 5, Cetinje, 2010.

Institut za crnogorski jezik i jezikoslovlje „Vojislav P. Nikčević“

UDK 821.131.1.035

Pregledni rad

Vesna KILIBARDA (Podgorica)

Filozofski fakultet - Nikšić

\section{LAZAR TOMANOVIĆ KAO ITALIJANISTA}

Tekst analizira ,italijanističku“ djelatnost Lazara Tomanovića, manje poznatu stranu njegova intelektualnoga profila, rasvjetljavajući u kontekstu privatnoga života i profesionalnog rada njegove prijevode italijanskih pjesnika i napise o italijanskoj književnosti nastale i prije i poslije Tomanovićeva dolaska u Crnu Goru. Upoznavanje s njegovim radom na učvršćivanju kulturnih i književnih veza i odnosa naroda koje razdvaja Jadransko more sagledano je kao prilog rekonstrukciji crnogorske kulturne stvarnosti krajem XIX i početkom XX vijeka.

Ključne riječi: Lazar Tomanović, italijansko-crnogorske književne i kulturne veze, vjenčanje Savoja-Petrović

Najveći dio i privatnoga i profesionalnog života Lazara Tomanovića (1845-1932), novinara, prevodioca i pisca, istoričara i političara, obilježen je neobično snažnim i dugotrajnim interesovanjem za italijansku književnost, kulturu i istoriju i gotovo opsesivnom željom za upoznavanjem i zbližavanjem italijanskoga i južnoslovenskih naroda. Podśećajući u ovome radu na najznačajnije etape ili segmente ove njegove strasti, otkrivamo ne samo jedan zaista specifični vid postojanja „Italije izvan Italije“ nego i jednu od manje poznatih strana tzv. ,jadranske“ kulturne istorije.

Vatreni pobornik kulturnih veza Italije i Crne Gore, ali i ostalih južnoslovenskih krajeva, Lazar Tomanović rođen je u Boki Kotorskoj, đe je od đetinjstva naučio italijanski jezik, s obzirom na to da je ovđe, kao i u ostalim bivšim pośedima Mletačke Republike poznavanje italijanskoga jezika, književnosti i kulture bilo tradicionalno odomaćeno, a tako je ostalo i nakon uspostavljanja vlasti Austrije, koja je italijanski u Boki i Dalmaciji zadržala kao jezik lokalne administracije. Školovao se u različitim slovenskim pokrajinama tadašnjega Habsburgškog carstva (Zadar, Novi Sad), potom studirao prava u Pešti i Gracu, đe je 1874. godine i promovisan za doktora pravnih nauka. Do dolaska u Crnu Goru 1888. godine živio je u rodnoj Boki, baveći 
se advokaturom. Ova mala balkanska država, koja je deset godina ranije na Berlinskome kongresu dobila zvanično priznanje svoje nezavisnosti, upravo je činila prve značajnije korake na unapređenju društvenoga, privrednog i kulturnoga života nerazvijene ratničke zemlje, između ostaloga okupljajući i angažujući na poslovima kulture i prosvjete obrazovane slovenske rodoljube iz okolnih država, tzv. ,izvanjce“. Na Cetinju, crnogorskoj prijestonici, Tomanović je prvo postavljan za urednika književnih časopisa i almanaha, da bi se od 1891. do 1903. prihvatio posla glavnoga urednika najpoznatijeg državnoga glasila, poluslužbenog lista „Glas Crnogorca“. Od 1903. do austrougarske okupacije Crne Gore 1916. godine obavljao je različite značajne političke dužnosti, među kojima i funkciju ministra inostranih poslova, ministra pravde i predśednika crnogorske vlade (1907-1912).

Prije nego što se posvetimo aktivnostima Tomanovića kao „italijaniste" neophodno je reći da se, zahvaljujući upravo njegovu trudu, italijanska književnost u Crnoj Gori krajem XIX i početkom XX vijeka, to jest sve do početka Prvoga svjetskog rata, po broju objavljenih prijevoda i napisa pozicionira odmah iza ruske koja je, zahvaljujući tradicionalnoj vezanosti i političkim interesima dviju slovenskih zemalja, bila najpoznatija i najprisutnija među svim stranim književnostima. Treba naglasiti i da prisustvo italijanske književnosti nije bilo plod ni osmišljenih programskih koncepcija književnoga razvoja kneževine ni uređivačke politike većine crnogorskih književnih glasila u kojima je, štaviše, u proklamovanome cilju očuvanja narodne i slovenske osnove nacionalne književnosti, postavljana čvrsta brana prodoru zapadnih kulturnih uticaja. Prisustvo italijanske književnosti u Crnoj Gori u naznačenome vremenskom razdoblju u najvećoj mjeri rezultat je ličnih književnih ,simpatija“ i književnog ukusa pojedinaca koji su različitim povodima, često i sasvim slučajno, svoju prevodilačku i kritičarsku aktivnost ostvarivali u ovoj zemlji. ${ }^{1}$ Među njima najistaknutije mjesto zauzima Lazar Tomanović, čija se italijanistička djelatnost vezuje ne samo za Crnu Goru nego i za druge krajeve tzv. Južne Slavije.

Široj čitalačkoj publici Tomanović se kao poklonik italijanske književnosti prvi put predstavio svojim prijevodom romana Frančeska Domenika Gveracija (Francesco Domenico Guerrazzi, 1804-1873) Obsada Fiorencije (Assedio di Firenze), koji je kao student prava u vlastitom izdanju u pet knjižica objavio u Pešti 1870. i 1871. godine. Troškovi izdanja pokriveni su uglavnom zahvaljujući unaprijed uplaćenoj pretplati oko 700 čitalaca koji su se odazvali pozivu objavljivanom u listovima koji su izlazili u slovenskim krajevima Austro-Ugarske, u Crnoj Gori i u Srbiji. Prijevod romana i izdanje

${ }^{1}$ O tome: Vesna Kilibarda, Italijanska književnost u Crnoj Gori do 1918. godine, Nikšić, Unireks, 1992, 156. 
Lazar Tomanović kao italijanista

na ,ilirskom“ jeziku imali su ogroman kulturni i politički odjek, posebno na istočnoj obali Jadranskoga mora, to jest u Boki Kotorskoj i Dalmaciji, đe su izazvali pravo oduševljenje. Tomanovićevo izdanje do danas je ostalo jedini prijevod ovoga djela italijanskog romantičara na jeziku čijim varijantama (crnogorski, srpski, hrvatski, bosanski) danas govori veliki dio južnoslovenskih naroda.

Odgovor na pitanje koji su razlozi uticali na ovaj prvi prevodilački izbor mladoga Tomanovića, tipični romantičarski roman F. D. Gueracija, pronalazimo u uticaju koji je pokret Ujedinjene omladine srpske, organizacija po modelu Macinijeve organizacije Mlada Italija (Giovine Italia), vršio na mladoga slovenskog patriotu. Tomanović je postao poklonik ideja i član ove organizacije, koja je među omladinom u slovenskim krajevima Austrougarske Carevine, u Crnoj Gori i u Srbiji širila i popularisala ideje oslobođenja od tuđinske vlasti i nacionalnoga ujedinjenja slovenskih naroda Balkana. Strasna i iskrena vezanost za ideje ovoga pokreta obilježiće čitav njegov život. Jasno je da je Gveraci, jedan od najvatrenijih pobornika italijanskoga Risordimenta, antiklerikalac, progonjeni i zatvarani patriota, saradnik slavnoga Đuzepea Macinija (Giuseppe Mazzini) koji je prvi usmjerio pažnju evropske demokratske javnosti na ,ilirsko buđenje“, morao ostaviti snažan utisak na Tomanovića, člana Ujedinjene omladine od srednjoškolskih dana u Zadru. Tako je, u stvari, i ovaj njegov rani prevodilački izbor podstaknut u prvom redu razlozima vanliterarne prirode. ${ }^{2}$

To se potvrđuje i kada povodom Gveracijeve smrti 1873. godine Tomanović piše prigodan nekrolog italijanskome piscu, objavljujući ga ovoga puta na Cetinju, u listu čiji je saradnik postao još kao student. ${ }^{3}$ Članak predstavlja jedan od prvih napisa italijanske tematike našeg autora. I ovđe se jasno pokazuje interesovanje Tomanovića ne toliko za djelo koliko za ličnost italijanskoga pisca, nesebičnog patriote, za koga kaže da „sav svoj život otačastvu posvećuje a od njega nikakve koristi ni časti ne traži, pače ih prezire“. Iz Gveracijeve biografije on bira samo činjenice koje se odnose na njegovu revolucionarnu aktivnost u italijanskome Risordimentu, to jest u borbi za oslobođenje i ujedinjenje Italije, što će za Tomanovića zauvijek ostati „najljepše i najviše djelo ovoga stoljeća“. ${ }^{4}$ Tomanović naglašava da je Gveraci kao „moćno sredstvo borbe“ koristio svoje pero, to jest svoje djelo, ističući da je za italijanskoga pisca književna „vještina“ bila „sporedna stvar“, dok je glavna bila žigosanje ,izdajica i tlačitelja Italije“. Tomanovićev prijevod Gveracijeva romana, kao i ovaj nekrolog, nastali su u društveno-istorijskom

\footnotetext{
${ }^{2}$ Mirka Zogović, Književna prožimanja, Beograd, Rad, 2000, 19.

3 „,Veliki patriota i spisatelj italijanski Gveraci“. Glas Crnogorca, I/1873, br. 24, 6.

${ }^{4}$ L. Tomanović, „Crna Gora i Italija“, Nova Evropa, 1929, br. 12, 361-363.
} 
trenutku borbe za nacionalno i političko oslobođenje južnoslovenskih naroda, odnosno u razdoblju koje, iako se vremenski tačno ne podudara, ima ista obilježja vremena u kome su u Italiji nastajala Gveracijeva djela. Obraćajući se u svome spisu posebno „najmlađim patriotima“, Tomanović podśeća na skromnost proganjanoga i zatvaranog italijanskoga književnika, ističući da je Gveraci, iako zaslužni rodoljub koji je za domovinu i slobodu puno stradao, kraj života proveo „,daleko od visokijeh zvanja i masnijeh plaća“ i ,gotovo zaboravljen“.

Kao prevodilac italijanske poezije, Tomanović nam je ostavio svoje verzije 13 soneta Frančeska Petrarke (Francesco Petrarca), 5 pjesama Đakoma Leopardija (Giacomo Leopardi), 2 Luiđija Karera (Luigi Carrer) i pjesme O grobovima (Dei Sepolcri) Uga Foskola (Ugo Foscolo). Svi ovi prijevodi sačinjeni su između 1881. i 1888. godine i objavljivani kako u crnogorskim tako i u časopisima koji su izlazili u drugim kulturnim centrima na Balkanu. Iako se ovi italijanski pjesnici međusobno razlikuju i po epohama kojima pripadaju i po glavnim obilježjima njihove poezije koja se, u svakom slučaju, pokazuje slabo primjerenom patriotskome raspoloženju Gveracijeva prevodioca, Tomanović stihove bira nalazeći u njima ono što ih objedinjuje, a to je tema prolaznosti života, smrti i śećanja, tuge i očaja. Sve to su ośećanja koja su njega lično snažno prožela poslije smrti njegove mlade supruge Petroslave, umrle 1880. u dobi od 23 godine. Tomanović je bio tako iznenađen ovim neočekivanim i teškim udarcem sudbine, tako pogođen bolom i skrhan da, prema uspomenama savremenika, a prvenstveno prema svjedočenju njegove ćerke Rosande, umalo nije pomjerio pameću. U prilog ovome govori i činjenica da je on ostao udovac svih 52 godine svoga daljeg života. Poznajući Tomanovića i njegove stavove, ne samo o „zadatku“" književnosti i pisca već i njegova ukupna životna i politička opredjeljenja, izbor iz ove lirike, kao što ćemo još viđeti, inače bi se teško uklopio u mjerila njegova književno-kritičkog ukusa.

Iz Petrarkina Kanconijera (Canzoniere) on, dakle, ne bira ni patriotske ni političke stihove koji bi mu kao poborniku Risorđimenta bili bliski, već one sa motivima ljubavi i smrti koji pripadaju drugome dijelu Rasutih rima (Rime sparse), onom naslovljenome In morte, koji je Petrarka posvetio mrtvoj dragoj. Na prvom mjestu nalazimo upravo sonet koji je Petrarka napisao pogođen viješću o smrti madone Laure 1348. godine: Oimè il bel viso, oimè il soave sguardo (CCLXVII). Ovaj i još pet Petrarkinih soneta pod zajedničkim naslovom Iz tužnijeg soneta Frančeska Petrarke (CCLXXV Occhi miei oscurato è 'l nostro sole; CCLXXVI - Poi che la vista angelica, serena; CCLXXXII - Alma felice che sovente torni; CCCLXXXIII - Discolorato ai, Morte, il più bel volto; CCLXXXIV - Sì breve è 'l tempo e 'l penser si veloce) Tomanović je objavio u novosadskome listu „Javor“ (1881, 
Lazar Tomanović kao italijanista

br. 15). Preostalih šest prijevoda pod naslovom Iz Petrarkinijeh soneta (CCLXXIX - Se lamentar augelli, o verdi fronde; CCCX - Zephiro torna, $e$ 'l bel tempo rimena; CCCXI - Quel rosignuol, che si soave piagne, CCCXXI - E questo 'l nido in che la mia fenice; CCCXXXIII - Ite, rime dolenti, al duro sasso; CCCXXXIV - S'onesto amor pò meritar mercede) objavio je nekoliko godina kasnije u listu „Stražilovo“ (1885, br. 22), dok je jedan sonet, pronađen u njegovoj rukopisnoj zaostavštini (CCCXIV - Mente mia, che presaga de' tuoi damni), objavljen tek u novije vrijeme. ${ }^{5}$ Takav Tomanovićev izbor Petrarkinih stihova, s kojima je očito mogao lako poistovjetiti iskaze svoga vlastitog bola, najvjerovatnije je odredila njegova porodična nesreća. O svojoj verziji Foskolove pjesme $O$ grobovima, objavljenoj 1883. godine u listu „Javor“, Tomanović u jednome pismu sačuvanom u njegovoj zaostavštini svjedoči da je i ovaj prijevod sačinio „sve više se prepuštajući očajanju i tražeći u tome utjehu“. ${ }^{6}$ Od 1884. godine naš autor prevodi Leopardija, prvo odlomak iz pjesme Le Ricordanze (od 136 stiha do kraja: O Nerina! e di te...), ${ }^{7}$ što prema bibliografskim podacima predstavlja prvi prijevod ove Leopardijeve pjesme na ,ilirski“ jezik i jedini u tri sljedeće decenije. ${ }^{8}$ Potom slijedi prijevod kancone La quiete dopo la tempesta. ${ }^{9}$ Oba ova prijevoda Tomanović objavljuje u Crnoj Gori dok ostale prijevode Leopardija (A Silvia, Il tramonto della luna, Canto notturno di un pastore errante dell'Asia i ponovo, prilično prerađen, prijevod pjesme La quiete dopo la tempesta) objavljuje četiri godine kasnije u časopisu „Stražilovo“ (1888, br. 32). Ovim svojim verzijama Leopardijeve poezije, obilježene motivima śećanja i prerane smrti nevinih mladih bića, Tomanović se uvrstio među prve prevodioce Leopardija na istočnoj obali Jadrana. ${ }^{10}$ Kao što u ovim Leopardijevim stihovima preo-

${ }^{5}$ Prijevod soneta objavljen u navedenom djelu Mirke Zogović, str. 31.

${ }^{6}$ Isto, 38

7 „Uspomena“. (Odlomak iz Leoparda). Crnogorka, I/1884, br. 17, 137.

${ }^{8}$ Mladen Machiedo, "Ancora sulla fortuna di Giacomo Leopardi in Jugoslavia", Studia romanica et anglica zagrabiensia, 13-14/1962, 129-141.

9 „Tišina po oluji“. (Leopardi). Crnogorka, I/1884, br. 29, 146.

${ }^{10} \mathrm{O}$ Tomanovićevim prijevodima Leopardija pisano je u više navrata a ono što im je najviše zamjerano bila je upotreba tzv. lokalizama iz govora Crne Gore i Boke i deseteračkoga stiha. Tomanovićev jezik na izvjestan način „opravdava“ Srđan Musić, pišući o grupi crnogorsko-bokeljskih prevodilaca italijanske poezije među kojima je Tomanović bio najplodniji. Musić ističe da se poznavanje italijanskoga jezika kod Tomanovića, kao i kod ostalih iz grupe (Niko Crnogorčević, Filip Kovačević), ne može dovoditi u pitanje, da upotreba deseterca ne treba da čudi, jer je to uzorni stih i prevodilaca i njegove čitalačke publike, te da upotreba lokalizama pada u oči samo savremenome čitaocu koji zaboravlja da su te riječi u ono vrijeme imale ,pravo građanstva, naročito u svakodnevnom govoru toga kraja“. Srđan Musić, „Nekoliko crnogorsko-bokeljskih prevodilaca Leopardija u XIX veku“. Boka, 12/1980, 257-262. 
vlađuju melanholični motivi i motivi neutješne tuge, tako u dvije pjesme Luiđija Karera, Epicedio ${ }^{11}$ i La Metamorfosi ${ }^{12}$ koje je Tomanović odabrao da prevede iz njegove zbirke Odi amorose dominira tema smrti vlastite drage. Prijevode Karerovih pjesama objavio je u Crnoj Gori, a moguće da ga je u njima privuklo i to što je kod ovoga italijanskog romantičara, u poređenju s izborom iz Leopardijeve lirike koja nosi pečat neke univerzalne tuge, pronašao više momenata $s$ kojima je mogao gotovo doslovno poistovjetiti odjeke svoga vlastitog bola.

Preselivši se u Goru Goru, Tomanović na Cetinju započinje aktivnost urednika književnoga časopisa „Nova Zeta“ (1889-1891), koji je prema svojoj programskoj koncepciji, usklađenoj sa zvaničnom kulturnom politikom, trebalo da bude otvoren samo za teme nacionalne i rodoljubive tematike i samo za slovenske a ne i zapadne književnosti. U tom smislu ni perspektiva prisustva italijanske književnosti nije djelovala obećavajuće. No, šta čini Tomanović: zaboravlja italijansku književnost? Svakako ne, mijenja samo polazište, birajući da ovoga puta svojoj publici predstavi neke nove i drukčije „italijanističke“" teme. Ti Tomanovićevi prilozi odnose se većinom na one pojave i protagoniste italijanskoga književnog svijeta koji su svojim djelom i aktivnošću italijansku javnost upoznavali ne samo sa svijetom slovenskoga Balkana nego i šire, sa slovenskim svijetom uopšte. On će od tad ubuduće uvijek pozdravljati sva djela na italijanskome jeziku u kojima su nalazili odjeka kulturna tradicija, istorija ili savremena stvarnost naroda s istočne obale Jadranskoga mora.

Tako Tomanović u svome časopisu, na primjer, piše o aktivnosti mladoga Dalmatinca Jakova Ćudine (Giacomo Chiudina), tada profesora ilirskoga jezika na Nautičkoj akademiji u Trstu, koji se pročuo po svojim prijevodima južnoslovenske narodne poezije i odlomaka iz Njegoševa Gorskoga vijenca na italijanski jezik, autora originalnih djela slovenske tematike na italijanskome jeziku, kao i prigodnih stihova od kojih su neki bili posvećeni i članovima tada vladajuće crnogorske dinastije Petrović-Njegoš. Ćudina se na južnoslovenskome prostoru proslavio kao autor istoriografskoga djela o Crnoj Gori (Storia del Montenegro), objavljenoga na italijanskome jeziku u Splitu 1882. godine. Tomanović u svome časopisu obavještava čitaoce o korespondenciji Ćudine sa italijanskim pjesnicima Đ. Kardučijem (G. Carducci) i F. Kavalotijem (F. Cavalotti), naglašavajući da su i oni mladome Dalmatincu čestitali na njegovu djelu i ističući da Ćudina svojom književnom aktivnošću doprinosi snaženju simpatija među narodima koje dijeli Jadransko mo-

${ }^{11}$ „Posmrtna“ (Karer). Crnogorka, I/1884, br. 3, 26-27.

12 „Metamorfozi“ (Karer). Crnogorka, I/1884, br. 4, 31. 
Lazar Tomanović kao italijanista

re. ${ }^{13}$ Jedna od omiljenih tema Lazara Tomanovića ostaće zauvijek ona posvećena piscima, prevodiocima i popularizatorima ,slovenskih tema“" na italijanskome jeziku. Obično se radilo o Damatincima bilingvistima, kao što je već pomenuti Jakov Ćudina, ili Ivan Nikolić iz Zadra, čijem prijevodu na italijanski Srpskih narodnih pjesama (Canti popolari serbi, Zadar, 1894) Tomanović nešto kasnije posvećuje širok prostor. ${ }^{14}$ On se, dakle, veoma zalaže da svoje čitaoce i sunarodnike upozna sa ličnostima koje su na najbolji način podsticale bolje poznavanje slovenskih naroda uopšte s italijanskim narodom. Tako Tomanović u svome časopisu objavljuje i članak posvećen aktivnosti Domenika Čampolija (Domenico Ciampoli), čija je dvotomna istorija slovenskih književnosti bila upravo izišla iz štampe (Letterature slave, Milano, 1889-1891), a koga predstavlja kao jedinoga italijanskog književnika koji ne samo da prati književnosti slovenskih naroda nego i poznaje slovenske jezike, čak i ruski. ${ }^{15}$

Ovo Tomanovićevo interesovanje za protagoniste međujadranskih kulturnih veza i dodira dobilo je najveći prostor u cetinjskome poluslužbenom listu „Glas Crnogorca“, uporištu crnogorske nacionalno-romantičarske književnosti, čiji je urednik bio više od jedne decenije, od 1889. do 1903. godine. To je i razdoblje njegova najplodnijega bavljenja kritičarskim i publicističkim radom koji se odnosi na italijansku književnost i Italiju uopšte. Gotovo svi prilozi o italijanskoj književnosti objavljeni u ovome listu nose potpis urednika Tomanovića koji neumorno piše, prevodi, komentariše, traži i prenosi iz raznovrsnih italijanskih izvora i publikacija informacije koje, po njegovu mišljenju, zaslužuju da budu poznate njegovoj čitalačkoj publici. ${ }^{16} \mathrm{Od}$ 1903. godine, posvećujući se isključivo državnim poslovima upravo u burnim godinama uoči balkanskih ratova (1912-1913), on prestaje da se bavi tom problematikom.

U aktivnosti Tomanovića koja se razvijala u godinama njegova uredničkog i autorskoga rada u "Glasu Crnogorca“ razlikuje se nekoliko pravaca. On je čitaocima svoga lista, koji je redovno čitan ne samo u Crnoj Gori nego i u pograničnim krajevima Austro-Ugarske (Bosna i Hercegovina, Boka Kotorska i Dalmacija), kroz raznovrsne napise kontinuirano predstavljao italijanske pisce i obavještavao o njihovim novim djelima koja su se pojavljivala

${ }^{13}$ Nova Zeta, I/1889, br. 5, 204.

${ }^{14} \mathrm{Na}$ primjeru Alberta Fortisa i njegova prijevoda Hasanaginice on u ovom prikazu ističe da su italijanski kulturni poslenici često bili posrednici u upoznavanju učenoga evropskog svijeta sa blagom južnoslovenske narodne poezije. Glas Crnogorca, XXIII/ /1894, br. 19, 1-2.

${ }^{15}$ Nova Zeta, II/1890, br. 6, 240.

16 Bibliografiju Tomanovićevih italijanističkih priloga vidi u navedenom djelu Vesne Kilibarde, str. 160-180. 
u izdanju raznih italijanskih izdavačkih kuća; pisao o prijevodima djela italijanskih pisaca, klasičnih i modernih, objavljivanim u to vrijeme u raznim južnoslovenskim centrima (na primjer: Bijesni Orlando u Beogradu, Dekameron u Sremskim Karlovcima, Božanstvena komedija u Zadru, Poslednja pisma Jakopa Ortisa u Nikšiću), a ponekad i u drugim krajevima slovenskoga svijeta uopšte; prenosio vijesti o najnovijim događajima u italijanskome književnom i izdavačkome svijetu, objavljujući nekrologe (Jakov Ćudina, Čezare Kantu, Ruđero Bongi) i vijesti o raznim godišnjicama i jubilejima, pozorišnim premijerama, pa i skandalima među kojima, na primjer, i o dvoboju sa tragičnim posljedicama u kome je izgubio život F. Kavaloti. Zanimljiv je podatak da je, pored italijanskih, on mnoge članke ove tematike pisao i prema izvorima iz ruske štampe koja je stizala u Crnu Goru. Sve u svemu, radi se o pedesetak njegovih priloga, među kojima je ipak manje obimnih studija a više kraćih radova na granici publicistike.

Tomanović je, nadalje, naročito pomno pratio izlazak knjiga italijanskih autora koji su pisali o Crnoj Gori. Na prvome mjestu on prati i prikazuje publikacije botaničara Antonija Baldačija (Antonio Baldacci) koji je upravo devedesetih godina XIX vijeka u Crnoj Gori učestano vršio botanička istraživanja i čiju je naučnu aktivnost finansijski pomagao aktuelni crnogorski vladar Nikola I, otac princeze Jelene, buduće kraljice Italije. Na vjenčanju princeze Petrović-Njegoš i italijanskoga princa Vitorija Emanuela III Savojskoga u oktobru 1896. godine u Rimu Tomanović je bio u sastavu crnogorske delegacije, a tom prilikom uručeno mu je visoko italijansko odlikovanje. Taj događaj podstakao je u Italiji nastanak prave lavine raznovrsnih publikacija i napisa o Crnoj Gori koja će mnogo kasnije biti opisana kao „veliki trijumf malene Crne Gore“. ${ }^{17}$ Lazar Tomanović u svome listu pažljivo i iscrpno obavještava čitaoce o ovim brojnim napisima iz pera novinara, istoričara, geografa i različitih znatiželjnika koji su dolazili da Crnu Goru upoznaju kao domovinu svoje buduće kraljice i prenesu svoje raznovrsne utiske italijanskim čitaocima. Bilo je među ovim spisima i na brzinu i bez dubljeg poznavanja pripremljenih tekstova koji su površno doticali različite teme, miješajući naučne činjenice s ličnim utiscima i iznoseći neosnovane sudove. Ipak, Tomanoviću se nije dešavalo da ova izdanja nekritički prihvata i hvali, on uvijek nepogrešivo prepoznaje među njima djela od prave i trajne vrijednosti. Mnogo je dobronamjernije Tomanović kao pasionirani istoričar prikazivao knjige nastale u Italiji, takođe povodom vjenčanja Savoja-Petrović, u kojima su kao svjedočanstva viševjekovnih kontakata Crnogoraca i Italijana objavljivani dokumenti iz italijanskih arhiva, posebno rukopisi iz venecijanskoga Držav-

17 Arturo Cronia, La conoscenza del mondo slavo in Italia. Bilancio storicobibliografico di un millenio, Padova, Istituto di studi adriatici, 1958, 501. 
Lazar Tomanović kao italijanista

nog arhiva, u kome su, između ostalog, sačuvani a sada u štampanome luksuznom izdanju u Rimu objavljeni izvještaji predstavnika mletačke vlasti u Kotoru (Relazioni dei Provveditori veneti 1687-1735, Rim 1896), puni podataka o Crnoj Gori iz njene dalje prošlosti. ${ }^{18}$ Tomanović ne zaboravlja da napomene da ovakve knjige može razumjeti i upotrijebiti „,na korist istorijske istine" samo stručnjak. Ili prikaz knjige o crnogorskoj dinastiji koja je njegovala odnose s Mletačkom Republikom, a zahvaljujući kojoj je 1494. iz Venecije u Crnu Goru donijeta i počela s radom prva štamparija kod Južnih Slovena. Riječ je o Crnojevićima, o kojima, na osnovu zapisa mletačkoga ljetopisca Marina Sanuda, piše Euđenio Barbarić. ${ }^{19} \mathrm{O}$ tim izdanjima, o njihovim temama i autorima Tomanović, i sam pisac istoriografskih djela, neprekidno informiše svoju čitalačku publiku. Njegovi brojni prilozi i komentari i danas su nezaobilazni u svakom proučavanju odnosa Italije i Crne Gore na razmeđu XIX i XX vijeka. Poznavalac italijanskoga, njemačkog i ruskoga jezika, ličnost od povjerenja crnogorskoga vladara, čovjek koji je neposredno poznavao gotovo čitav južnoslovenski prostor, Tomanović je imao mogućnosti i prilike da upozna dobro i djela i protagoniste italijansko-slovenske i italijansko-crnogorske kulturne razmjene.

U ovome razdoblju na italijanski jezik prevođena su i pjesnička djela aktuelnoga crnogorskog vladara Nikole I, koji je, na tragu porodične tradicije, bio i sâm pjesnik, a o njemu je i pisano. ${ }^{20}$ Prijevod knjaževih djela, prvenstveno najpoznatijeg, drame u stihu Balkanska carica, koja se pojavila u više italijanskih verzija (prvo izdanje: L'Imperatrice dei Balcani, Firenca, 1897), bilo je više posljedica rođačkih veza dviju vladajućih kuća nego umjetničke vrijednosti knjaževih stihova. U ovome slučaju, međutim, u skladu sa svojim književnokritičkim opredjeljenjima i iskreno uvjeren ne samo u državničku darovitost nego i u književnu vrijednost knjaževih djela, Tomanović izražava nadu da će i u „Danteovoj domovini“" ova poezija imati odgovarajući odjek. ${ }^{21}$ On u svom prikazu iskazuje duboko nezadovoljstvo zbog toga što su Manconijevi (Manzoni) horovi i patriotska poezija u Italiji postali ,prosti anahronizam“ i što uspjeha imaju samo moderni pisci koji se Tomanoviću nijesu do-

${ }^{18}$ „Nove knjige o Crnoj Gori“, Glas Crnogorca, XXV/1896, br. 46, 2.

${ }^{19}$ U osvrtu Tomanović ističe da autor ,novom svjetlosti obasjava potonjega nesrećnoga vladaoca iz kuće Crnojevića“ koji je namjeravao ,presaditi na Cetinje cvijet italijanske kulture i raširiti je po Crnoj Gori, /.../ ali ne nađe odziva u zemlji, ili prije ne ima postojanstva niti obećane pomoći Republike koja se kolebala između Istoka i Zapada“. „Crnojevići u Mlecima“, Glas Crnogorca, XXV/1896, br. 48, 2-3.

${ }^{20}$ Vesna Kilibarda, „Osvrt na italijanske prevode književnog djela Nikole I Petrovića Njegoša“. Kralj Nikola - ličnost, djelo i vrijeme. CANU, Podgorica, 1998, knj. 49, $135-147$.

21 „Nove knjige“, Glas Crnogorca, XXVI/1897, br. 22, 3. 
padali zbog nedovoljne sklonosti temama o herojskim podvizima za dobrobit otadžbine. U tome smislu, Tomanović je ostao vjeran svojim mladalačkim stavovima, zasnovanim na italijanskome ranom romantizmu, o isključivo utilitarnoj društvenoj ulozi književnosti, ostajući zauvijek protivnik djela koja nemaju za cilj da služe narodu i koja ne pružaju primjer i pouku. Našavši se na razmeđu XIX i XX vijeka, iako nezvanično, na mjestu crnogorskoga kulturnog ideologa, on se zalagao za sprečavanje zapadnih kulturnih i književnih uticaja na domaći književni razvoj, pravdajući ovaj svoj stav situacijom slovenskih naroda na Balkanu, još pod tuđinskom vlašću, otomanskom ili austrougarskom, iako su Crna Gora i Srbija od 1878. godine bile nezavisne i suverene evropske zemlje. Da bi osnažio ova svoja uvjerenja, Tomanović je nalazio primjere u književnosti koju najbolje poznaje i najviše voli - italijanskoj. Tako 1901. godine piše o Đ. Kardučiju, podstaknut člancima iz rimske „Tribune“ povodom četrdesete godišnjice pjesnikova rada na Univerzitetu u Bolonji i podśećajući da je „pjesnik nove Italije“” ujedno i „pjesnik istorije Italije“. ${ }^{22}$ Koristeći kao primjer figuru ovoga italijanskog pjesnika, Tomanović želi da podśeti i da utiče, uznemiren zbog gašenja interesovanja za patriotsku poeziju kod njegovih mladih sunarodnika. Ili drugi primjer. Obavještavajući svoje čitaoce kako i „najmoderniji italijanski pjesnik“ G. Danuncio (G. D'Anunzio) budi patriotsko oduševljenje čitajući svoju tek napisanu odu Garibaldiju (Ode a Garibaldi) u raznim italijanskim gradovima, Tomanović kazuje i da je razočaran što takve primjere ne nalazi u našim krajevima. ${ }^{23} \mathrm{Od}$ svojih prvih književnokritičkih priloga on je uvijek bio protivnik svake kulturne aktivnosti koja nema za svrhu da služi narodu. Razmatrajući neko djelo, Tomanović umjetničkim kvalitetima pretpostavlja njegovu društvenu i političku ulogu. U ovome smislu u svom listu on citira i odlomke o Risorđimentu iz knjige Moderna Italija (L'Italia moderna) Pjetra Orsija (Pietro Orsi), nastojeći posebno da istakne ulogu pjesnika i snagu poezije. ${ }^{24}$ Ili podśeća na dramskoga pisca Pjetra Kosu (Pietro Cossa), za koga navodi da je ostao po strani „od opšte struje svoje otačastvene književnosti“, ističući za uzor njegove teme vezane za antičku i srednjovjekovnu prošlost Italije. ${ }^{25}$

Među ličnostima koje su svojom književnom, prevodilačkom, naučnom i publicističkom djelatnošću nastojale da italijanskoj čitalačkoj publici približe istoriju, tradiciju, književnost i savremene društvene procese na tzv. Slovenskom jugu značajno mjesto u Tomanovićevim spisima pripada i Nikoli Tomazeu (Niccolò Tommaseo), o kome je pisao u više navrata i različitim

${ }^{22}$ „Karduči i istorija“.Glas Crnogorca, XXX/1901, br. 18, 2.

23 „D'Anuncio“. Glas Crnogorca, XXX/1901, br. 23, 2.

24 „Moderna Italija - knjiga Pjetra Orsija“. Glas Crnogorca, XXX/1901, br. 19, 2.

25 „Rus po savremenoj italijanskoj književnosti. Pjetro Kosa“, Glas Crnogorca, XXX/1901, br. 37, 2-3. 
Lazar Tomanović kao italijanista

povodima u razdoblju od 1896. do 1902. godine. O Tomazeovu odnosu s Njegošem, vladarem-mitropolitom i slavnim pjesnikom, Tomanović piše u jednoj svojoj istoriografskoj knjizi (Petar II Petrović Njegoš kao vladalac, Cetinje, 1896), a potom, upotpunivši svoje istraživanje novim podacima, i u prilozima koje je objavio u narednim godinama. ${ }^{26}$ Tomanović je jedan od prvih istoričara koji je pokušao da objasni poznanstvo i saradnju dva znamenita književnika i državnika, ${ }^{27}$ ali i njihovo docnije neprijateljstvo koje vezuje za burne istorijske događaje u Boki Kotorskoj i u Veneciji revolucionarne 1848. godine. $^{28}$

Da zaključimo. Intelektualni profil Lazara Tomanovića snažno je obilježen italijanskom književnošću i kulturom. Primjerima iz italijanske književnosti i istorije služio se da bi podupro svoje teze, osnažio svoje stavove, ilustrovao svoja mišljenja, u prvom redu ona o ulozi književnosti i književnika u istorijskim i društvenim događajima. Osim toga, u italijanskoj književnosti potražio je utočište u trenutku njegove porodične tragedije, našavši utjehu za svoj lični bol u stihovima čuvenih italijanskih pjesnika.

\section{Bibliografija}

- CRONIA, Arturo. 1958. La conoscenza del mondo slavo in Italia. Bilancio storico-bibliografico di un millenio. Padova: Instituto di studi adriatici.

- JERNEJ, Josip. 1957. „Foscolo presso i Croati e i Serbi“. Studia romanica et anglica zagrabiensia 4: 3-17.

- KILIBARDA, Vesna. 1992. Italijanska književnost u Crnoj Gori do 1918. godine. Nikšić: Unirex.

- KILIBARDA, Vesna. 1998. „Osvrt na italijanske prevode književnog djela Nikole I Petrovića Njegoša“. Kralj Nikola - ličnost, djelo i vrijeme, CANU, knj. 49, 135-147.

- KILIBARDA, Vesna. „Prilog proučavanju odnosa Njegoša i Tomazea“. Istorijski zapisi. LXXV/2002, br. 1-2, 81-91.

- KOSTIĆ, Milan. 1962. „Biografija Dr Lazara Tomanovića“. Stvaranje 9: 615-618.

- MACHIEDO, Mladen. 1962. „Ancora sulla fortuna di Giacomo Leopardi in Jugoslavia“. Studia romanica et anglica zagrabiensia 13-14: 129-141.

26 „U spomen Nikoli Tomazeu“. Glas Crnogorca, XXV/1896, br. 20, 2; 21, 2; 22, 3; ,Iskrice Nikole Tomazea, za štampu priredio i predgovor napisao Danilo Petranović“. Glas Crnogorca, XXVIII/1899, br.19, 2-3.

${ }^{27}$ Vesna Kilibarda, „Prilog proučavanju odnosa Njegoša i Tomazea“, Istorijski zapisi, LXXV/2002, br. 1-2, 81-91.

28 „Tomazeo i Njegoš“. Glas Crnogorca, XXXI/1902, br. 40, 2-3. 
Vesna KILIBARDA

- MAVER, Giovanni. 1929. „Leopardi presso i Croati e i Serbi“. $R i$ vista di letterature slave 2-3:100-163.

- MILUTINOVIĆ, Kosta. 1953. „Crna Gora i Primorje u Omladinskom pokretu“. Istorijski zapisi 9:1-46.

- MILUTINOVIĆ, Kosta. 1976. „O političkom liku Lazara Tomanovića“. Istorijski zapisi 33: 493-519.

- MILJANIĆ, Novak. 1973. „Bibliografija radova Dr Lazara Tomanovića“. Boka. 5: 123-140.

- MILJANIĆ, Novak. 1977. „Porijeklo i život Lazara Tomanovića“. Boka. 9: 219-234.

- MUSIĆ, Srđan. 1980. „Nekoliko crnogorsko-bokeljskih prevodilaca Leopardija u XIX vijeku“. Boka 12: 257-262.

- ROTKOVIĆ, Radoslav. 1979. „Pregled crnogorske literature od najstarijih vremena do 1918“. Stvaranje 4: 587-654.

- SKERLIĆ, Jovan. /1906/ 1966. Omladina $i$ njena književnost (1848-1871). Beograd: Prosveta.

- STIPČEVIĆ, Nikša. 1979. Dva preporoda. Studije o italijanskosrpskim kulturnim $i$ političkim vezama u XIX veku. Beograd: Prosveta.

- ZOGOVIĆ, Mirka. 1980, „Prilog bibliografiji Lazara Tomanovića“. Boka. 12: 345-349.

- ZOGOVIĆ, Mirka. 2000. Književna prožimanja. Beograd:Rad

\section{Vesna KILIBARDA}

\section{LAZAR TOMANOVIĆ AS AN ITALIANIST}

The paper deals with the "Italianistic" work of Lazar Tomanović, the less known sides of his intellectual profile enlightening his translations of the Italian poets and texts about Italian literature written before and after his coming to Montenegro, in the context of his private life and professional works at the same time. This introduction to his work on the strengthening of the cultural and literary relationships between two people, divided by the Adriatic sea is defined as a contribution to the reconstruction of the Montenegrin reality within the period between the end of the $19^{\text {th }}$ and the beginning of the $20^{\text {th }}$ century.

Key words: Lazar Tomanović, Italian and Montenegrin cultural relationships, the marriage of Savoia and Petrović 
LINGUA MONTENEGRINA, god. III, br. 5, Cetinje, 2010.

Institut za crnogorski jezik i jezikoslovlje „Vojislav P. Nikčević“

UDK 821.131.1 .09 Tomaseo N. 82.091

Pregledni rad

Nino RASPUDIĆ (Zagreb)

Filozofski fakultet Sveučilišta u Zagrebu

\title{
NICCOLO' TOMMASEO I ISTOČNA OBALA JADRANA - OD SENTIMENTALISTIČKOG PATERNALIZMA DO NEVOLJA S NJEGOŠEM
}

\begin{abstract}
Niccolò Tommaseo, veliki talijanski leksikograf i pisac iz 19. stoljeća, rođen u Šibeniku, jedna je od najznačajnijih figura za razumijevanje kulturnih i političkih odnosa između dvije jadranske obale. Analizirajući iz perspektive postkolonijalne kritike njegova djela u kojima se bavi Dalmacijom i slavenskim svijetom općenito (među kojima se ističu Scintille/Iskrice), otkrivamo da je njegov jadranski diskurs prožet orijentalizmom (u smislu kako ga poima E. Said). Tommaseovi prikazi Dalmacije obilježeni su izrazitim paternalističkim pristupom: promatra je sa simpatijom, ali uvijek iz pozicije spoznajne i kulturne nadmoći. U Iskricama je Dalmacija često metaforički prikazana kao mlada i nezaštićena žena, kojoj je potreban skrbnik, dok su Dalmatinci prikazani kao „dobri divljaci”, koji nipošto ne smiju dozvoliti da ih , iskvari” zapadna civilizacija. Tommaseo osuđuje modernizaciju, urbanizaciju, uvođenje općeg školstva, luksuz i ostale zapadne utjecaje kod Slavena (ne štedeći pri tome ni Njegoša, koji je kriv zato što čita francuske romane), koje „orijentalizira” pripisujući im neke urođene osobine, koje su na prvi pogled pozitivne, no koje impliciraju izvjesnu intelektualnu ograničenost i prevagu tjelesnog, strastvenog i fantastičnog elementa (na sličan način je ,klasična” kolonijalna književnost opisivala Afrikance). Ne čudi stoga što Tommaseo dijelom idealizira venecijansku vlast nad Dalmacijom. Paternalistički pristup, analiziran kod Tommasea, živ je i danas u birokratskom diskursu Europske unije o jugoistoku Europe.
\end{abstract}

Ključne riječi: Tommaseo, Dalmacija, Hrvati, Slaveni, paternalizam, orijentalizam, postkolonijalna kritika, Njegoš

Niccolò Tommaseo (Šibenik, 1802 - Firenca, 1874) najznačajniji je talijanski pisac rođen na istočnoj obali Jadrana. Autor je važnih djela talijanske književnosti i leksikografije 19. stoljeća, među kojima se ističe roman Vjera $i$ 
ljepota (Fede e bellezza, 1840), te kapitalni Rječnik sinonima (Dizionario dei sinonimi, 1830) $i$ Rječnik talijanskog jezika (Dizionario della lingua italiana, 1858-79). Pored toga, on je i ključna osoba za razumijevanje hrvatsko-talijanskih kulturnih odnosa u 19. stoljeću. Tommaseova djela u kojima se bavi istočnojadranskim i širim, općeslavenskim temama čine samo jedan, i to manji dio njegovog golemog opusa, što, pored njegove složene, često i kontradiktorne osobnosti, te javnog i političkog djelovanja, valja imati na umu prilikom parcijalnih analiza njegovog djela, kao što je nužno i ova, koja ga promatra iz perspektive ,prekojadranskog poluorijentalizma“, kako nazivamo, unutar talijanske kulture dominantnu, tradiciju gledanja na istočnu jadransku obalu kao na a priori civilizacijski inferiornu.

Rođen u Šibeniku 1802. godine, u potalijančenoj obitelji hrvatskog porijekla, Tommaseo kao mladić napušta rodni grad, kojeg se kasnije uglavnom sjeća s odbojnošću, i odlazi studirati u Italiju, gdje će u Padovi završiti pravo. Nakon studija posvećuje se novinarskom i književnom radu i seli najprije u Milano, a potom i u Firencu, grad u kojem se počinje potvrđivati kao književnik i leksikograf. Tommaseo, u tom životnom razdoblju, iskazuje snažnu potrebu za mletačkom identitetskom legitimacijom. Pitanje vlastite nacionalne pripadnosti pri tome promatra i etnički i kulturno - ističe kako je Talijan jer je rođen od venecijanskih podanika, jer mu je prvi jezik bio talijanski, jer mu je jedna baka Talijanka i jer je, po njemu, Dalmacija talijanska zemlja više od Torina, a to potkrepljuje činjenicom da jezik njegovog djetinjstva nije imao francuskih riječi. ${ }^{1}$ Kasnije će priznati i kako se u mladosti crvenio kada bi rekao da je Dalmatinac pa je, pošto je njegova baka s očeve strane bila Talijanka smatrao sebe Talijanom. ${ }^{2}$ Taj pojačan nacionalni identitet, tipičan za ljude s granice, kod njege je imao i dodatnu dimenziju, jer je smatrao da je, kao Talijan po izboru, superioran onima koji nemaju nikakvu zaslugu u tome što su Talijani. ${ }^{3}$

Tommaseo se vrlo brzo i javno istaknuo kao talijanski domoljub i borac protiv austrijske dominacije nad talijanskim zemljama. Nakon što je 1834. godine jedan njegov tekst u časopisu Antologia izazvao proteste austrijskih vlasti, Tommaseo odlazi dobrovoljno u progonstvo u Pariz. Upravo tijekom tog, kako ga je sam nazivao „prvog progonstva“, kao već priznat pisac i intelektualac, naknadno i posredno će otkriti „ilirsku“ poeziju i jezik, na koje ranije nikada nije posebno obraćao pozornost.

${ }^{1}$ Jože Pirjevec, Niccolò Tommaseo tra Italia e Slavia, Marsilio Editori, Venecija, 1977., str. 41.

${ }^{2}$ V. Ivan Katušić, Vječno progonstvo Nikole Tommasea, Sveučilišna naklada Liber, Zagreb, 1975., str. 6.

${ }^{3}$ V Oscar Randi, Niccolò Tommaseo nella politica, Tipografia di E. De Schönfeld, Zadar, 1924., str. 9. 
Niccolò Tommaseo i istočna obala Jadrana...

\section{Kasno otkrivanje vrijednosti zavičaja posredovanjem stranaca}

Kulturnu vrijednost svog zavičaja Tommaseo će otkriti znakovito kasno. Ivan Katušić, autor monografske knjige o Tommaseu, u kojoj se posebno bavio njegovom biografijom, ističe da je Tommaseo dugo vremena „o kulturnim vrijednostima svoje rodne grude bio daleko lošije obaviješten nego mnogi kulturni ljudi u Europi. “" $\mathrm{O}$ slabom poznavanju istočne jadranske obale u tadašnjim talijanskim kulturnim krugovima svjedoči i Tommaseov šibenski prijatelj i suradnik Špiro Popović, koji mu 26. 6. 1844. godine piše: „I sami Francezi više poznaju nas nego Talijani; Francezi po Slavjanskim krajevima putuju, uče naš jezik, običaje naše, a Talijani, sa žalošću moram reći, za nas ne mare. “5

Za djelo Alberta Fortisa Put po Dalmaciji (Viaggio in Dalmazia, 1774), koje je imalo priličnog odjeka u europskim intelektualnim krugovima, gdje je čak i potaklo modu „morlakizma“, Tommaseo će saznati vrlo kasno, na Korzici 1838. ili 1839. godine. Zvuči pomalo apsurdno to da je Dalmatincu Tommaseu o znamenitom Fortisovom dalmatinskom putopisu koji mu je proslavio zavičaj, prvi govorio Adolfo Palmedo, britanski konzul u Bastiji. Otprilike $u$ isto vrijeme Tommaseo „otkriva“ i vrijednost južnoslavenske narodne poezije. Jože Pirjevec ističe činjenicu da je Tommaseu bio potreban autoritet velikih njemačkih umova da bi prepoznao vrijednost Hasanaginice ${ }^{6}$. O sličnom posrednom Tommaseovom vrednovanju jezika i pjesništva njegovog zavičaja piše i Ivan Katušić: „Kao svjetskom čovjeku, Tommaseu je neobično važno da evropska kulturna središta blagohotno gledaju prema ilirskom kompleksu iz kojega je niknuo. " ${ }^{\text {“7 }}$ Ono što je dalmatinskim intelektualcima tog vremena značio Tommaseov „blagoslov“, to je njemu bilo mišljenje učene Europe. Katušić na drugom mjestu u pogledu Tomamseovog povratka korijenima uočava: „kao da bijaše najvažnije da kulturni svijet - pred kojim se stidio svog barbarskog porijekla - uviđa da sada imaju riječ slavenski narodi. “8

Nakon te inicijacije, Tommaseo se ne samo počeo zanimati za narodni jezik i poeziju, već je na jesen 1839. godine počeo i pisati na materinskom jeziku.

\footnotetext{
${ }^{4}$ Ivan Katušić, Vječno progonstvo Nikole Tommasea, str. 45.

5 Mate Zorić, „Carteggio Tommaseo-Popović III (1844)“, Studia Romanica et Anglica Zagrabiensia, n. 38, Zagreb, 1974., str. 279-337., str. 314.

${ }^{6}$ Jože Pirjevec, Niccolò Tommaseo tra Italia e Slavia, str. 43.

${ }^{7}$ Ivan Katušić, Vječno progonstvo Nikole Tommasea, str. 46.

${ }^{8}$ Ibidem, str. 44.
} 


\section{Tommaseove Iskrice}

Nakon zavičajnog „obraćenja“ Tommaseo će napisati nekoliko „ilirskih“ djela, među kojima su najznačajnije Iskrice, lirske proze u kojima se obraća slavenskim narodima, a napose stanovništvu svoje rodne Dalmacije i slavi jednostavni i zdravi narod, kojem preporučuje kršćansku poniznost i strpljivost.

O Tommaseovom oduševljenju slavenskim jezicima i narodnom kulturom svjedoči i pismo Špiri Popoviću napisano 30. 5. 1840. u kojem strastveno ističe: „Slavenska rasa uzdići će se samo ako ne bude oponašateljica: a toga se bojim. Ali Dalmacija je podvojena zemlja: trebalo bi objesiti sve koji govore talijanski; mene prvoga."

Iste 1840. godine, kad je napisao hrvatski izvornik Iskrica, Tommaseo je izvršio i talijanski prijevod. ${ }^{10}$ Spremio je hrvatski i talijanski tekst za posebno izdanje, u koje je mislio uključiti i nekoliko tekstova na grčkom jeziku. No austrijska cenzura u Zadru je 1841. godine zabranila tiskanje tog djela, pa je 1841. godine u Veneciji tiskano samo jedanaest neproblematičnih Iskri$c a{ }^{11}$ Prvi put su hrvatske Iskrice tiskane u Zagrebu 1844., a drugo izdanje uslijedilo je 1848. godine. Talijanska verzija je, za razliku od hrvatske, na tisak čekala gotovo trideset godina. Treba napomenuti i to da autor nije bio zadovoljan navedenim hrvatskim izdanjem. U jednom pismu Špiri Popoviću Tommaseo se žali kako su bez njegovog znanja Iskrice tiskane u Hrvatskoj, s promjenama koje kvare „,zvuk i smisao“. ${ }^{12}$

I pored svih tih nedaća Iskrice su se čitale (U Beču je u tri dana prodano petsto primjeraka), čak i učile napamet, kao da se radi o molitvama. Ubrzo su prevedene na njemački, poljski, češki, tiskane u raznim časopisima i oponašane. ${ }^{13} \mathrm{U}$ istom razdoblju Tommaseo je skupljao korzikanske, grčke i ,ilirske“ narodne pjesme. Kao rezultat tog rada je 1842. u Veneciji objavio knjigu Canti popolari toscani, corsi, illiri e greci. Tommaseo je narodne pjesme u prevodio u prozi. Kao izvorima za južnoslavensku narodnu poeziju služio se zbirkama Vuka Stefanovića Karadžića, ali i rezultatima sakupljanja koje su za njega vršili njegovi dalmatinski suradnici. ${ }^{14}$ Pjesme je popratio ko-

\footnotetext{
${ }^{9}$ Mate Zorić, „Carteggio Tommaseo-Popović I (1840-41)“, Studia Romanica et Anglica Zagrabiensia, 24, Zagreb, 1967., str. 169-240., str. 186.

10 Mate Zorić, „Intorno alle 'Scintille' di N. Tommaseo“, Studia Romanica Zagrabiensia, 4, Zagreb, 1957., str. 53-60., str. 53.

${ }^{11}$ Ibidem, str. 54.

${ }^{12}$ Mate Zorić, „Carteggio Tommaseo-Popović III (1844)“, str. 290.

${ }^{13}$ Jože Pirjevec, Niccolò Tommaseo tra Italia e Slavia, str. 75.

${ }^{14}$ Usp. Mate Zorić, ,Talijanski pisci o nama i našim književnostima. Svjedočanstva, odjeci i prijevodi od Dantea do Pasolinija“", Književna smotra, III, 8, Zagreb, 1971, str. 65-81, str. 76.
} 
Niccolò Tommaseo i istočna obala Jadrana...

mentarom i interpretacijom u uvodima u prozi. Nekoliko godina nakon Iskri$c a$, Tommaseo je napisao i osam dvojezičnih proznih tekstova naslovljenih Spisi starog kaluđera / D'un vecchio calogero, koji su objavljeni tek u 20. stoljeću. ${ }^{15}$ Ti tekstovi su imali zanimljivu sudbinu. Najprije su bili objavljeni u talijanskoj varijanti i to samo njih sedam. Kasnije je Franjo Zović dokazao da se niz poslanica koje je priređivač Raffaele Ciampi objavio pod naslovom Ai popoli slavi kao pravi naslov ima D'un vecchio calogero i da se sastoji od osam, a ne od sedam sastavaka kao kod Ciampinija. ${ }^{16}$ Spisi starog kaluđera su, pored Iskrica, najznačajnije Tommaseovo djelo koje se bavi istočnojadranskim temama.

Nakon austrijske amnestije iz 1839. godine Tomamseo se vratio iz Francuske i nastanio u Veneciji, gdje će 1848. godine aktivno sudjelovati u revolucionarnim zbivanjima i pokušaju restauracije Mletačke Republike. Poslije gušenja revolucije, kojem su veliki doprinos dali i hrvatski vojnici u austrijskoj službi, 1849. godine odlazi u „drugo progonstvo“ na Krf, odakle se vraća u Italiju tek 1854. kada se nastanjuje najprije u Torinu, a zatim 1859. prelazi u Firencu, gdje je ostao do smrti 1874. godine. Po povratku u Italiju nakon „drugog progonstva“ Tommaseo će se u još jednom razdoblju javiti oko dalmatinskih tema, pišući šest antiunionističkih brošura protiv ujedinjenja Dalmacije s Hrvatskom 1861. godine. Pred kraj života planirao je napisati i dvije knjige o Dalmaciji, no nije ih uspio realizirati. ${ }^{17}$

Premda se nikada nije izjasnio za priključenje Dalmacije Italiji, Tommaseo je kasnije od strane iredentista bio obilno korišten kao simbol talijanstva Dalmacije, štoviše stvoren je pravi mit o Tommaseu kao najtalijanskijem Talijanu, velikanu talijanskog iredentizma. ${ }^{18} \mathrm{~S}$ druge strane su ga srpske i hrvatske elite nastojale prisvojiti kao „našega čovjeka“ koji je stekao ugled u svijetu. Istina je da je imao nekoliko faza - od mladalačkog hiperidentificiranja s talijanstvom (super-Talijan po izboru), preko faze oduševljenja slavenskom narodnom poezijom i nacionalnim pokretom, do kasnijeg razočaranja i protivljenja ujedinjenju Dalmacije i Hrvatske. Mate Zorić, hrvatski talijanist koji se zadnjih pola stoljeća najsustavnije bavio Tommaseom, ističe da je njegov odnos prema formiranju nacionalne svijesti u Dalmaciji „vrlo slo-

\footnotetext{
${ }^{15}$ Mate Zorić, Italia e Slavia: Contributi sulle relazioni letterarie italo-jugoslave dall'Ariosto al D'Annunzio, Medioevo e Umanesimo - 74, Editrice Antenore, Padova, 1989., str. 316 i dalje.

${ }^{16}$ Ivan Katušić, Vječno progonstvo Nikole Tommasea, str. 215.

${ }^{17}$ Mate Zorić, „Due libri sulla Dalmazia progettati dal Tommaseo e le 'Iskrice,“, (trad. di Ingrid Damiani Einwalter), Ommaggio a Niccolò Tommaseo 1874-1974, The Bridge/Il Ponte - The Association of Croat Writers, Zagreb, 1975, str. 53-111.

${ }^{18}$ Ivan Katušić, Vječno progonstvo Nikole Tommasea, str. 8.
} 
žen i mnogostran i nikako se ne može svesti na polemiku protiv ujedinjenja Dalmacije s Hrvatskom ili protiv definitivne afirmacije hrvatskoga narodnoga imena u primorskim gradovima južno od Velebita." ${ }^{19}$ Ivan Katušić, koji svoju monografsku knjigu o Tommaseo gradi na konceptu njegovog „vječnog progonstva" ističe da su kasniji nacionalistički interpretatori brutalno pojednostavljivali njegovo djelo i uzimali samo neke elemente, zanemarujući ostale: „Nažalost, spomenuti hrvatski, srpski i talijanski rodoljubi nisu imali smisla za pjesnikove intimne rane. Svaki ga je vukao na svoju stranu. Kao da se svakomu od njih činilo da je potreban samo mali napor, još samo jedan citat, da ga konačno dobije u okvir određenog nacionalnog osjećaja. “20

No, na ovom mjestu, ta pitanja su od sekundarne važnosti. Iz perspektive analize prekojadranskog poluorijentalističkog diskursa Tommaseovo nacionalno ili političko svrstavanje i djelovanje manje je značajno od načina na koji je pisao o istočnoj Jadranskoj obali, od njegove retorike, metaforike, općenito „optike“ kojom gleda na zemlju svog porijekla.

\section{Paternalistički sentimentalizam}

Govorimo o Tommaseovom paternalističkom sentimentalizmu, jer je, pored osnovnog tona kršćanskog romantizma, njegov pogled prema istočnoj strani Jadrana prije svega pogled spoznajne nad-moći: on Dalmatincima, i općenito Slavenima, želi dobro, i smatra da to što je za njih dobro zna bolje od njih samih, obraćajući im se tonom i jednostavnim jezikom kojim se obično obraća djeci ili neukima, i to na jeziku kojeg jedva da uspijeva pisati. Utoliko se postavlja pitanje tko je bio pravi adresat Iskrica? To zasigurno nije nepismeni narod, nego čitateljska publika u slavenskim zemljama, dakle elita, ali onda se javlja dodatno pitanje primjerenosti tog paternalističkog tona.

Taj paternalistički, spoznajno i civilizacijski nadređeni stav koji dominira Tommaseovim Iskricama, često se sreće u kolonijalističkoj književnosti. Postkolonijalna kritika ističe kako se, unutar tradicije orijentalizma, o Drugome koji se smatra civilizacijski nižim može govoriti apriori, o njemu se ionako sve zna, on je jednostavan, nepromjenjiv, djeluje iz svoje prirode. Naizgled banalno pitanje o tome tko govori, o čemu govori i čime legitimira svoju kompetenciju za govorenje o toj temi, metodološki je dragocjeno i za analizu prekojadranskog poluorijentalizma. Kao primjer možemo uzeti Tommaseovo izvješće o Dalmaciji iz 1844. godine (koje je djelomično revidirao 1871.), tekst u kojem ,analizira“ stanje u austrijskoj Dalmaciji i u kojem se bavi administracijom, gospodarstvom, školstvom, crkvom, poljoprivredom i broj-

\footnotetext{
${ }^{19}$ Mate Zorić, „Nikola Tommaseo i narodni preporod u Dalmaciji“ (posebni otisak iz Zadarske revije, br. 6/1961), Zadar, 1962., str. 3.

${ }^{20}$ Ivan Katušić, Vječno progonstvo Nikole Tommasea, str. 116. 
Niccolò Tommaseo i istočna obala Jadrana...

nim drugim temama. ${ }^{21}$ Taj tekst je nastao gotovo slučajnim spletom okolnosti. Tajnik potkralja austrijskih pokrajina Lombardije i Venecije zatražio je 1844. godine od državnog savjetnika Angela Fraria, inače rođenog Šibenčanina, da sastavi izvješće koje bi sadržavalo i korisne savjete o stanju i potrebama u Dalmaciji. ${ }^{22}$ Frari je o tome obavijestio svog prijatelja i zemljaka Nikolu Tommasea, koji je pristao napisati to izvješće, koje je Frari, uz njegovu suglasnost, predao pod svojim imenom. U navedenom izvješću Tommaseo ističe kako mnogi koji dolaze vladati Dalmacijom „,nemaju povjerenja u nas, preziru nas". Piše također i kako to nije samo slučaj kod stranaca, nego da i brojni Dalmatinci iz gradova gledaju na siromašnog seljaka „kao na čovjeka druge rase, skoro kao na životinju“‘ ${ }^{23}$

Između ostalog, Tommaseo piše i o problemu pijanstva kod Morlaka i ističe kako su Venecijanci bili zakonom zabranili sađenje vinograda u brdskim krajevima te dodaje: ,Ja ne kažem da snagom zabrana treba učiti narode njihovoj koristi; ali kažem da nije dobro ni ostaviti im samo tu vrstu slobode da škode samima sebi. “24 Pri tom ponavlja kritiku morlačke neekonomičnosti koju je u svom dalmatinskom putopisu ranije iznio Alberto Fortis i spominje već klasični primjer češnjaka i luka (o kojem su već pisali i Alberto Fortis, Ivan Lovrić i Carlo Gozzi) kojeg Morlaci uvoze, umjesto da ga sami proizvode. Navodi kako oni, i u slučajevima kad uzgajaju kupus ili slično povrće, te namirnice ne nose u grad kako bi ih prodali, već ih daju prvome koji ih zatraži. ${ }^{25}$ Kao što je ranije Fortis Dalmatincima spas tražio u stablima kestena, Tommaseo im u tom tekstu preporučuje sađenje badema. ${ }^{26}$

Upravo na takvim primjerima najbolje se vidi neutemeljeni paternalizam. Znajući da su u Dalmaciji, sedamdesetak godina prije tog Tommaseova teksta bile osnovane gospodarske akademije koje su razmatrale ta pitanja, možemo se zapitati na temelju čega autor koji desetljećima nije boravio u Dalmaciji, i koji je za vrijeme druge revizije teksta već odavno bio i slijep, daje za pravo analizirati sve segmente tamošnjeg života, od uzgoja i prodaje

${ }^{21}$ Opširnije o ovom tekstu v. Mate Zorić, „Tommaseovo izvješće o Dalmaciji iz 1844. i 1871. godine“, Hrvatsko-talijanski književni odnosi. Knjiga VIII., Filozofski fakultet Sveučilišta u Zagrebu, Zagreb, 2002., str. 35-124.

${ }^{22}$ V. Mate Zorić, „Tommaseovo izvješće o Dalmaciji iz 1844. i 1871. godine“, str. 35-124.

23 „Del presente governo della Dalmazia“, u Niccolò Tommaseo, Scritti editi e inediti sulla Dalmazia e sui popoli slavi, Volume I, ur. Raffaele Ciampini, Sansoni, Firenca, 1943., str. 175.

${ }^{24}$ Ibidem, str. 186.

${ }^{25}$ Ibidem, str. 188.

${ }^{26}$ Ibidem, str. 185. 
kupusa do školstva i crkvene uprave. Odgovor je vjerojatno isti kao i na pitanje zašto je intelektualcima s istočne obale Jadrana bilo toliko stalo do Tommaseovog mišljenja, premda su bili kompetentniji od njega u pogledu svih pojedinih dalmatinskih tema o kojima je pisao - Tommaseo je bio slavni talijanski pisac. Dakle, oni hegemonijski usvajaju potrebu za legitimacijom zapadnim pogledom, premda im on ne nudi nikakvu novu spoznaju.

Dio „krivice“ za taj podređeni položaj stoga uvijek snose i lokalni intelektualci. O prestižu kojeg je Tommaseo uživao u rodnom kraju svjedoči i jedno pismo koje mu je Špiro Popović napisao 13. 11. 1843. godine i u kojem konstatira: „Mi Dalmatinci malo značimo u svijetu, malo nas poznaju, ali imamo našeg Tommasea koi nas s' velikim narodima upoznaje, i s' njime sve imamo.“27 Hrvatski talijanist Mate Zorić piše da su ,,mnogi skromni književni pregaoci iz Dalmacije“, među kojima navodi Š. Popovića, S. Ivičevića, F. Carraru, M. A. Vidovića, S. Ivačića, M. Kažotića i druge, Tommasea „nekritično smatrali europskom veličinom““. ${ }^{28}$ Tommaseovi sastavi na „ilirskom“ konačni leksički i gramatički oblik dobili su zahvaljujući tuđoj pomoći. ${ }^{29} \mathrm{~A}$ onda su se isti kulturni krugovi iz koje je ta pomoć u pisanju dolazila divili Tommaseovom ,ilirskom“ pisanju o ,ilirskim“ temama.

\section{Topos Dalmacije kao nezaštićene sirotice}

$\mathrm{Na}$ početku svojih Iskrica (koje se u definitivnom izdanju koje je uredio Mate Zorić sastoje od 36 lirskih proza) Tommaseo piše kako se vraća jeziku na kojem mu je majka plačući molila za udaljenog sina. Želi pokazati poštovanje i naklonost narodu kojeg je i sam dio. Obraća se Dalmaciji, ali i slavenskom svijetu općenito. ${ }^{30}$ U drugoj Iskrici zahvaljuje Špiri Popoviću što nakon više od polovice života počinje ,izušćivati“ svoj materinski jezik. ${ }^{31}$ Osnovni Tommaseov paternalistički stav (koji, kako smo već rekli, podrazumijeva apriornu intelektualnu nadmoć nad Drugim, ali i skrb za njegovo dobro) prema Slavenima, a napose prema Dalmaciji, retorički se očitava u sku-

${ }^{27}$ Mate Zorić, „Carteggio Tommaseo-Popović II (1842-43)“, Studia Romanica et Anglica Zagrabiensia, n. 27-28, Zagreb, 1969., str. 207-294., str. 291.

${ }^{28}$ Mate Zorić, ,Talijanski pisci o nama i našim književnostima“, str. 78.

${ }^{29}$ Mate Zorić, „O nekim manjim Tommaseovim 'ilirskim' sastavima“, Hrvatskotalijanski književni odnosi, Zbornik II, ur. Mate Zorić, Zavod za znanost o književnosti, Zagreb, 1990., str. 119-144., str. 119.

${ }^{30}$ Niccolò Tommaseo, Scintille, Redazione definitiva a cura di M. Zorić, Studia Romanica Zagrabiensia, 4, Zagreb, 1957, str. 60-89., str. 60.; Citate iz Iskrica navodit ćemo prema hrvatskoj verziji iz izdanja: Nikola Tommaseo, Iskrice, uvod napisao Ivan Milčetić, Matica Hrvatska, Zagreb, 1888. (1. izd. 1844.). U numeraciji Iskrica slijedit ćemo definitivno Zorićevo izdanje.

${ }^{31}$ Nikola Tommaseo, Iskrice, str. 12. 
Niccolò Tommaseo i istočna obala Jadrana...

pinama metafora koje su vezane za područje nižega - Dalmaciju najčešće prikazuje kao mladu, siromašnu, nezaštićenu, ženu, a pored toga, u pisanju o zavičaju, ali i Slavenima općenito, Tommaseo često koristi i animalne i bolesničke metafore.

Već na samom početku prve Iskrice sebe prikazuje kao odraslu, sposobnu pticu, koja svojim mladima, koji su nepomični u gnijezdu:

Kano što ptica ljubavna pripravlja u proljeće gnijezdašce svojim ptičicama, i kupi perje i slamu, da lakše leže male svoje, koje ona još nije vidjela; tako i ja iz dalekih zemalja, iz stranjskih knjiženstva, iz različitih jezika, kupim ćućenja i glase i skladanja, da bih mogao milu braću nadahnuti plamenom ljubavi. ${ }^{32}$

Dosljedno svom kršćanskom romantizmu koristi i usporedbe s mravima (Iskrica XII.), ovcama (Iskrica XXV i XXIX):

Kano ovce, koje leže u jednoj jari, na jednom polju skaču, a ne misle jedna za drugu, ako padne u dubinu, ako je lupež ukrade, ako je čoban proda oli odere ter izjede; tako i mi u jednom mjestu živimo, a što se od bližnje braće naše radi (slijepi i nemili!) ne marimo. ${ }^{33}$

Pored navedenih, kako bi istaknuo potrebu poniznosti, koristi i sliku konja, koji se malo skupi prije nego što potrči (Iskrica XXXV).

Tommaseo se, prije svega, obraća Dalmaciji kao ženi: „Dalmacijo draga, tebi nije nikada bio život vlastiti; jur od mnogo si vremenâ vučena za kolima drugih naroda“. Želi da ona postane ,prsten zlatnih veriga, koje valja da slobodno svežu sve kćeri slavenske matere naše. "34 Zanimljivo je da Francesco Dall'Ongaro u posveti svoje lirsko-dramske trilogije Marco Cralievic za Tommasea kaže da je ,živa karika između dvije domovine i dvije muze“. ${ }^{35}$

U trećoj Iskrici, Tommaseo piše kako bi želio sa ,slavenskom nacijom“ razgovarati kao čovjek s ,,voljenom ženom“, što je čest motiv u orijentalističkom diskursu. „Voljena žena“ treba pomoć. Tommaseo stoga koristi i medicinske metafore - „Nitko je dobro još ne poznade od onih, koji ti govore; nitko ne mjeri upravo slabosti ni kreposti tvoje; a kako ćemo ti, ne poznajući te, pomoći? Gdje počinje, a gdje dospijeva rana, ne vidimo; kako ćemo je liječiti? ${ }^{36}$ Autor tako promatra istočni narod kao bolesnika, a sebe stavlja u ulogu liječnika. Osim opreke liječnik-pacijent, u istoj Iskrici nalazimo i

\footnotetext{
${ }^{32}$ Nikola Tommaseo, Iskrice, str. 9.

${ }^{33}$ Ibidem, str. 62.

${ }^{34}$ Ibidem, str. 10.

${ }^{35}$ Francesco Dall'Ongaro, Fantasie drammatiche e liriche, Successori Le Monnier, Firenca, 1866., str. 89-98.

${ }^{36}$ Nikola Tommaseo, Iskrice, str. 13.
} 
onu znalac-neuki na mjestu gdje Tommaseo govori narodu (kojeg naziva i „nesretnim narodom“) kako on nije kriv što mu život prolazi u neznanju.

Uz to što ga smješta u semantičko područje infantilnoga i ženskoga, Tommaseo narodu s istočne obale Jadrana učitava (i apriorno ga unutar njega smješta) značenjsko polje neznanja i bijede, ali i izrazito tjelesnog i krepkog jer govori o njegovim lijepim i snažnim udovima koja su dostojni i čistije košulje. Paradoksalno, Tommaseo s jedne strane stoji na poziciji kršćanskog „blago siromašnima“, ističe primjer Kristovog siromaštva, hvali siromaha i preporučuje poniznost i strpljenje (v. Iskrica VIII), a s druge strane žali Dalmaciju zato što je siromašna i jadna. Dakle, dok je s jedne strane siromaštvo nešto moralno poželjno, $s$ druge strane je za Tommasea ono nešto realno negativno, budući da kod njega izaziva empatiju i sažaljenje.

Iskricom IX. dominira metafora rodne zemlje kao majke, kojoj Tommaseo sa žalošću konstatira geo-morfološke osobine: „Da je zemlja tvoja, Dalmacijo žalosna, kao povjetarce tvoje, bile bi u tebi sakupljene ljepote talijanskoga i grčkoga polja. Ali zemlja je tvoja kao glava bez vlasi, kao kosti

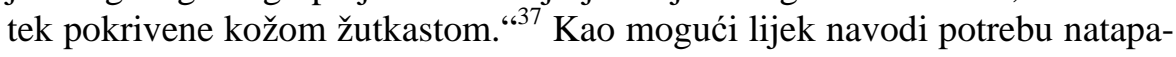
nja tla i pošumljavanja.

U Iskrici XVII Tommaseo, tipično orijentalistički, piše o podređenom narodu kao o narodu bez povijesti: „Puk žalostan povijest svoju oli ništa oli

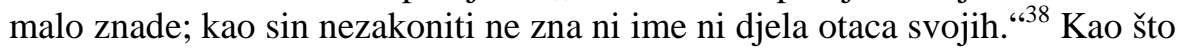
mu je prošlost zatvorena, tako mu je i budućnost prazna i mračna. Stoga ,po svemu svijetu siromah ostaje kao gorostasni slijepac, koji se trudi i spava, ter se tuži i napije“. Optužuje učene ljude koji čitaju i pišu na tuđim jezicima i dodaje: „Domovina njihova dalja im je od srca nego Arapska i Babilonska. Općena je ovo krivina, i moja poveće.“39

U Iskrici XXII Tommaseo piše sljedeće:

Puci, koji su okolo tebe, Dalmacijo mala, nemaju s tobom nego malo podobnosti: ili su mnogo veći, ili mnogo manji od tebe: oli more, oli planina rastavlja te od njih; a više nego more i planina različiti običaji, i razilčita korist. Istrijanska ostrva dalja su od Dalmacije nego London od Malte. Sama si malašna siromašica među vodama i stijenama svojim. ${ }^{40}$

Tommaseove ženske i tjelesne metafore za Dalmaciju, koja navodno vapi za pokroviteljstvom u skladu su s tradicijom europske kolonijalističke književnosti. Feminiziranje koloniziranog teritorija je trop u kolonijalnom

\footnotetext{
${ }^{37}$ Nikola Tommaseo, Iskrice, str. 30.

${ }^{38}$ Ibidem, str. 40.

${ }^{39}$ Ibidem.

${ }^{40}$ Ibidem, str. 46.
} 
Niccolò Tommaseo i istočna obala Jadrana...

mišljenju. ${ }^{41}$ Znakovitu tjelesnu žensku metaforu Tommaseo koristi i u Spisima starog kaluđera - govoreći kako je „,sirota Dalmacija“ na štetu „Nijemcu“ ističe kako „Baš kao star čovjek i u zlu sagnut, kad mladu ženu vjenča, zaludu i sebe i nju muči; tako i vas Nijemac vladanjem dosadnim muči; niti se zadovoljiti može.“42

Iskrica XXVI ključna je za razumijevanje Tommaseovog gledanja na identitet Dalmacije: „Poplave silne sa dugim mukanjem, smućenim vodama, padale su kroz mnogo stoljeća na te, Dalmacijo moja. Različite su vlade u tebe došle, nijedna nije temelj u tvojoj zemlji ukorijenila. Povijest pravu nemaš; sve je razdrto, kao gdje poplava prođe, rupe i dubine razdru svuda planinu. “43 $\mathrm{Na}$ istom mjestu piše i sljedeće: „Mrvice imaš povijesti, mrvice dobra, cijelo tijelo nemaš, nemaš zidanja savršenoga." Dalmacija dakle ima mrvice (u tal. verziji ,frammenti“) povijesti, fragmente dobra, ali nema cjelovitog tijela, nema cjelovitih svojih tradicija ni jedinstvenog identiteta: „Nijesi se nigda dobro ni talijanila ni turčila, slavenska nijesi““44 (,Non sei bene Italia ne bene Turchia: Slavia non sei“). Ovaj zgodni retorički paralelizam, u stvarnosti u kojoj se sve više počeo primjenjivati princip narodnosti, naprosto nije bio istinit, jer je u to vrijeme slavensko stanovništvo činilo preko $96 \%$ ukupnog stanovništva Dalmacije, o čemu će biti više riječi kasnije.

U Iskrici XXVIII Tommaseo ističe: „Nije našeg puka ruho čisto i tanano, ali duša mu je slobodna i u prostoti jaka. Napije se siromah vina i rakije; ali pijanstvo oholosti malodušne, silnoga straha, laži i novaca, gore je i nepoštenije pijanstvo. ${ }^{\text {“45 }}$ Njegova opijenost je dakle uvijek tjelesna, a ne duhovna, čime se ponovo između Zapada i Istoka učitava opreka duh-tijelo. U istom tonu idealiziranja sirotog, nepovijesnog, ali neiskvarenog naroda Tommaseo na istom mjestu piše i sljedeće: „Nema puk dvore, ali nije ni postelju svoju napunio nečistoćama. (...) Nemamo mi uspomena, koje bi nas razveselile, ali nemamo ni onih, koje bi nas zasramile“. Osim što Slavenima opet odriče mogućnost imanja povijesti, na ovom mjestu Tommaseo ponovo prelazi na „mi“. Kulminacija ovog dijela leži u opisu slavenske Vile, koja kao neka amazonka trči bespućima golih grudi (što jako nalikuje na tipične kolonijalne fantazije): „Ne leži naša vila u velikim posteljama, kod gospodskih trpeza ne

${ }^{41}$ Kadiatu Kanneh, „Feminism and the Colonial Body”, The Postcolonial Studies Reader, ur. Bill Ashcroft, Gareth Griffiths, Helen Tiffin, Routledge, London/New York, 1995., str. 346-348., str. 346.

${ }^{42}$ Nikola Tommaseo, ,Spisi starog kaluđera“ u Ivan Katušić, Vječno progonstvo Nikole Tommasea, Sveučilišna naklada Liber, Zagreb, 1975., str. 223-243., str. 232.

${ }^{43}$ Nikola Tommaseo, Iskrice, str. 56.

${ }^{44}$ Ibidem, str. 57.

${ }^{45}$ Ibidem, str. 15. 
sjedi; žedna i gladna trči kroz gore, i što više trpi, sve ljepša postaje, i glas njezin puniji izlazi iz prsiju golih i hlepećih.“446

U istoj Iskrici Tommaseo ističe kako „kuće nemamo, ali imamo porodice; otac i mati nijesu još imena bez znamenja; onaj koji prezire časnost čovječanskih duša, onaj je varvar pravi.“" ${ }^{47}$ Tommaseo tako idealizira siromašno slavensko stanovništvo nasuprot iskvarenosti zapadne civilizacije, a poteže i pitanje o tome tko su pravi barbari. ${ }^{48}$

Sliku Dalmacije kao potpuno bespomoćnog i ubogog toposa nalazimo i u Iskrici XXIX - „Mala brodice, razrušena, bez jedara, bez vesla, kamo ćeš ti sama, koji će te vjetar pomoći? Utisnuti u ovom kraju zemlje, medju planinama i morem, što smo mi, žalosni, gdje možemo protezati krila svoja?‘49

U Iskrici XXX Tommaseo ponavlja opće mjesto o staroj Veneciji kojoj mladi Skjavuni daju tjelesnu snagu: „Bio je odavno lav izgubio bogatu grivu, zube i šape; ali ono nešto nokata strahovitih, što mu bješe ostalo, slavenska sila bijaše. “50

Gledano iz perspektive današnje hrvatske nacije, Tommaseo na različit način govori o dva njezina dijela; s jedne strane s paternalističkom simpatijom govori o slavenskom stanovništvu u Dalmaciji, koje je siromašno, čisto, mlado, neiskvareno, i kao takvo pogodno za izljeve pokroviteljskog sentimentalizma, dok drugačije pristupa tadašnjoj Hrvatskoj, na koju gleda kao na nešto manje siromašno i ubogo, ali zato ponijemčeno, dakle djelomično iskvareno i potencijalno opasno. I u kasnijoj tradiciji prekojadranskog poluorijentalističkog diskursa o širem području Jugo-Istočne Europe „dobri Drugi“ je uvijek onaj nemoćni, koji se promatra kao žrtva pa je pogodan za paternaliziranje, ili pak, onaj dovoljno udaljen i nepoznat, s kojima nema političke kolizije ni potencijalne opasnosti. Po toj osnovi su i za Tommasea „dobri slavenski Drugi“" Srbija, Hercegovina, Bosna i Poljska, dok su loši ili sumnjivi Hrvati, Crnogorci i posebno Rusi, o čemu će biti više riječi kasnije.

\section{Politička strategija ,autonomaškog Tommasea“}

Kao konstanta njegovog političkog promišljanja o rodnom kraju, kod Tommasea se provlači teza, koju smo vidjeli u navedenom odlomku iz Iskrice XXVI., kako Dalmacija podjednako nije ni talijanska ni slavenska. Ivan

${ }^{46}$ Nikola Tommaseo, Iskrice, str. 16.

${ }^{47}$ Ibidem.

${ }^{48} \mathrm{U}$ prethodnim poglavljima smo često susretali taj motiv - kod Marije Todorove je to često Zapad, Larry Wolff piše o Venecijancima koji su barbarski opljačkali Carigrad, a na koncu Drugog svjetskog rata Slobodna Dalmacija naziva talijanske fašiste barbarima.

${ }^{49}$ Nikola Tommaseo, Iskrice, str. 64.

${ }^{50}$ Ibidem, str. 70. 
Niccolò Tommaseo i istočna obala Jadrana...

Katušić ističe, u pogledu Tommaseovog pisanja o 400.000 Slavena nasuprot 20.000 Talijana, kako je točno da je Tommaseo prihvatio svekoliku Dalmaciju - talijansku i slavensku, ali ,njegovo kazivanje vodi prema zabludi (ili dolazi iz zablude) po kojoj su talijanski i slavenski elementi barem podjednako značajni, ako talijanski dio nije značajniji. “51 Golemi nerazmjer između etničke strukture stanovništva Dalmacije i zastupljenosti u vlasti, kulturnim i javnim institucijama ističe i američki povjesničar Larry Wolff u knjizi Venecija i Slaveni, pozivajući se na austrougarski popis iz 19. stoljeća koji pokazuje da 96\% stanovništva Dalmacije čine Slaveni (prema vjerskoj pripadnosti je od tog broja bilo $80 \%$ katolika i $20 \%$ pravoslavaca), a Talijani samo $3 \%{ }^{52}$ Jože Pirjevec u svojoj monografskoj knjizi Niccolò Tommaseo između Italije $i$ Slavije navodi precizne brojke austrijskog popisa, koje pokazuju kako je godine 1846. u Dalmaciji živjelo 395.273. Slavena ili 96,18\% ukupnog broja od 410.988. stanovnika, no navodi i da su oni malo utjecali na javni život, jer je Dalmacija u 19. stoljeću bila pretežno poljoprivredna regija, u kojoj je $90 \%$ populacije činilo seosko, mahom slavensko stanovništvo. ${ }^{53}$ Književni i znanstveni rad u Dalmaciji se u prvoj polovici 19. stoljeća odvija i dalje pretežno na talijanskom jeziku, o čemu svjedoči i podatak da su u prvih tridesetak godina austrijske vlasti dalmatinske tiskare objavile preko 500 talijanskih publikacija, a svega 67 na hrvatskom jeziku. ${ }^{54}$

Ali taj odnos se s vremenom nepovratno mijenjao. Potvrđivanje principa narodnosti i neizbježni dolazak posljedica demokratizacije i industrijske revolucije, od priljeva seoskog stanovništva u gradove do širenje prava glasa i obaveznog školovanja neumoljivo su vodili prema drugačijem političkom i društvenom odnosu snaga koji je išao u korist, dotada u političkom, javnom i kulturnom životu nerazmjerno zastupljenom, hrvatskom (i srpskom) stanovništvu. Premda bi razmatranje Tommaseove političke pozicije sredinom 19. stoljeća, kada je nacionalna polarizacija i konfrontacija Hrvata i Talijana u Dalmaciji bila tek na početku, iz optike naknadnog povijesnog iskustva predstavljalo anakronizam, možemo ustvrditi da je, iz pozicije mudrije i dalekovidnije zaštite talijanstva, logično da Tommaseo umjesto nerealnog iredentističkog stava (za koji je već sredinom 19. stoljeća bilo jasno da je neostvariv) bira autonomističko-jugoslavenski, dakle stav protivljenja ujedinjenju Dalmacije s Hrvatskom i zalaganja za njezino uključivanje u širu i složeniju juž-

${ }^{51}$ Ivan Katušić, Vječno progonstvo Nikole Tommasea, str. 50.

${ }^{52}$ Larry Wolff, Venice and the Slavs: The Discovery of Dalmatia in the Age of Enlightenment, Standford University Press, Standford, California, 2001, str. 332.

${ }^{53}$ Jože Pirjevec, Niccolò Tommaseo tra Italia e Slavia, 1977., str. 24.

${ }^{54}$ Mate Zorić, Književni dodiri hrvatsko-talijanski, Književni krug, Split, 1992, str. 351 . 
noslavensku federalnu cjelinu, unutar koje se moglo očekivati lakše konzerviranje ,prave Dalmacije“, tj. one unutar koje talijanski element zadržava relativnu privilegiranost.

Tommaseo piše Špiri Popoviću iz Pariza 7. rujna 1848.:

i on bi htieo da se Dalmacia žalosna s' Hervatskom sdruži: a kako, molim vas, kad se je Hervatska bezčovječkom silom protiv Italije osramila? A kako će se ipak Hervati s nama ponjeti? Naše je izobraženje plemenitije; jezik čistii, ljepši kip. Dok se ne Ercegovina i Bosna s' nama sjedini, neće za nas dobro biti. Ono je već ponjemčeno, i varvarske oholesti puno. ${ }^{55}$

Jože Pirjevec ističe kako je Tommaseo 1840. godine u pogledu Dalmacije svjestan ,novih etničkih snaga, koje će udaljiti od Italije i približiti susjednim zemljama“, te dodaje kako je „ta svijest pobuđivala u njemu proturječne osjećaje iščekivanja, ali i žaljenja i straha. ${ }^{\text {“56 }}$ Mate Zorić kao jednu od omiljenih Tommaseovih misli ističe onu prema kojoj se „Dalmacija ubraja u

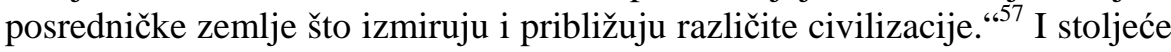
i pol nakon Tommaseo možemo često čuti kako je Dalmacija mjesto koje je sudbinski predodređeno „biti posrednikom između naroda i naroda“. ${ }^{58}$ Uzevši u obzir etnički sastav Dalmacije već u 19. stoljeću, učitavanje neke posredničke uloge (u političkom, a ne samo u kulturnom smislu) toj etnički prilično homogenoj regiji nalikuje na krilaticu - što je naše to je naše, a što nije naše to je zajedničko, tj. posredničko. Dalmacija je, dakle, po Tommasaeu trebala biti most između Italije i slavenskog svijeta, te biti dio šire južnoslavenske zajednice. ${ }^{59} \mathrm{U}$ tom pogledu Tommaseo piše: „Što god da se dogodilo, ne Hrvatska - siromašna zemlja i oskudna kulturom nego plodne slavenske pokrajine koje su podložne Turskoj, a koje su u moralnom pogledu manje zarobljene nego Hrvatska, ujedinjene s Dalmacijom - učinit će je bogatom i posrednicom kulture i bogatstva." (N. Tommaseo, Il Monzmbano e Sebenico, Firenca, 1869) ${ }^{60}$ Pri tome ostaje nejasno što je mogao znati o količini ,,moralne zarobljenosti“" stanovništva s kojim nije imao nikakvu komunikaciju, i kako bi Dalmacija, koju ranije opisuje kao arhaičnu, primitivnu, čistu,

${ }^{55}$ Mate Zorić, „Nikola Tommaseo i narodni preporod u Dalmaciji“, str. 6.

${ }^{56}$ Jože Pirjevec, Niccolò Tommaseo tra Italia e Slavia, str. 51.

${ }^{57}$ Mate Zorić, „Nikola Tommaseo i narodni preporod u Dalmaciji“, str. 10.

${ }^{58}$ Lucio Toth, „I mari di Tommaseo“, I mari di Niccolò Tommaseo e altri mari: Atti del Convegno internazionale di Studi nel bicentennario della nascita di Niccolò Tommaseo, Zagabria, 4-5 ottobre, 2002, ur. M. Čale, S. Roić, I. Jerolimov, FF press, Zagreb, 2004., str. 38-54., str. 54.

${ }^{59}$ V Ivan Katušić, Vječno progonstvo Nikole Tommasea, str. 77.

${ }^{60}$ Navedeno prema Ivan Katušić, Vječno progonstvo Nikole Tommasea, str. 95. 
Niccolò Tommaseo i istočna obala Jadrana...

siromašnu, bez povijesti i sjećanja, odjednom postala ,posrednica kulture i bogatstva“".

Tommaseove političke stavove prema istočnoj jadranskoj obali bi, u posebnom istraživanju, možda bilo korisno razmotriti u sklopu njegovih širih političkih pogleda i lutanja i u pogledu ujedinjenja Italije, gdje je „Tommaseo - uvjereni federalist, municipalist i republikanac - bio otvoreni neprijatelj talijanskog ujedinjenja pod savojskom dinastijom. ${ }^{\text {“61 }} \mathrm{U}$ jednom pismu iz 1859. godine, objavljenom u knjizi Drugo progonstvo (Il secondo esilio, III, str. 376) Tommaseo piše: „Dalmaciji ne bi koristilo jedinstvo s Venecijom. Dalmatinci su u staroj republici bili jedini istinski vojnici. Sada ne bi bilo tih razloga za poštivanje i većina Talijana smatrala bi Dalmatince kao nižu rasu, ne znam da li s pravom. “62. Iz navedenog se može zaključiti da Tommaseo, osim vojne iskoristivosti, ne vidi druge vrline kojom bi Dalmatinci mogli zaslužiti poštovanje u Italiji. Mate Zorić ističe kako se Tommaseo protivio uvlačenju Dalmacije u mletačku revoluciju 1848. godine, između ostalog jer se ,plašio da bi angažiranje Dalmacije na talijanskoj strani ubrzalo unutarnju političku diferencijaciju i pripajanje Hrvatskoj. “63

Tommaseov književni ugled u Dalmaciji je djelovao kao amortizer njegovih političkih stavova. Zanimljivo je da se na Tommaseov polemički spis „Ai Dalmati“ iz 1861. godine u pismima autoru pohvalno osvrću i vođa dalmatinskih autonomaša Antonio Baiamonti i istaknuti pobornik narodnjačke stranke Vid Morpurgo, koji ističe da je tim spisom Tommaseo skrenuo poglede Dalmatinaca s Italije. ${ }^{64}$ Tako su obje suprotstavljene političke stranke u Dalmaciji uzimali u obzir samo onu polovicu Tommaseovog stava koja je odgovarala njihovoj političkoj opciji - autonomaši njegovo protivljenje ujedinjenju s Hrvatskom, a narodnjaci uvjerenje da se Dalmacija ne treba pripojiti Italiji.

\section{6. Želja za konzerviranjem zemlje djetinjstva i njene političke refleksije}

Jedna od konstanti Tommaseovog mišljenja o Dalmaciji, ali i o slavenskim narodima općenito, bilo je protivljenje modernizaciji, urbanizaciji, utjecaju zapada, osim ako se nije radilo o ulozi ,mosta“ koji bi posredovao talijansku kulturu. U Iskrici IX Tommaseo piše kako „mi““(dakle, sada se smatra dijelom Dalmacije) „od tudjinaca uzimljemo cvijeće a ne stabla, haljine a ne

\footnotetext{
${ }^{61}$ Ivan Katušić, Vječno progonstvo Nikole Tommasea, str. 97.

${ }^{62}$ Ibidem, str. 111.

${ }^{63}$ Mate Zorić, ,Nikola Tommaseo i narodni preporod u Dalmaciji“, str. 4.

${ }^{64}$ Ivan Katušić, Vječno progonstvo Nikole Tommasea, str. 116.
} 
plugove, riječi a ne stvari, što je nevaljalo, a ne što je potrebito.“65 Isti ekonomski problemi koji se tiču izvoza sirovina, a uvoza završnih i luksuznih proizvoda u razmjeni istočne jadranske obale sa zapadnom prisutni su i danas, nakon stoljeća i pol.

Dalmaciju i Slavene Tommaseo gotovo opsesivno nastoji držati prikovanima za postojeće stanje. U desetoj Iskrici tako piše: „Kad ti tražiš one radosti koje tvoga stanja nijesu, tada si kao bolestan u svim udima, rana živa grize dušu i ime tvoje." ${ }^{66}$ Time je dakle, njihovo prirodno stanje neka okamenjenost i nepromjenjivost (opreke: povijestan-nepovijestan, dinamičan-nepromjenjiv, moderan-tradicionalan). U navedenom odlomku nalazimo ponovno korištenje medicinske metafore te snažan impuls protiv promjene i pozapadnjenja: „U našim gradovima ima sada više ljudi neg’ prije, koji se bore s gladom, dugom i sa sramotom. Mučeni su od želje svoje, i poruženi od drugih. Hoće da slijede oholost bogatih mjesta, a nemaju od njih nego smrad. Ono, što nije naravno, nije ni dobro. ${ }^{67}$ No pitanje je tko je arbitar prirodnosti? Što je prirodno Slavenu? Da kopa i bude poslušan i strpljiv? Tommaseo u tom pogledu piše: „Prosti budimo i ponizni; radimo i mùčimo, a drugim pustimo veličanstva i ljepote (...) Budimo siromasi, ali čisti; čisti u ruhu, čisti u duši. “68

U trinaestoj Iskrici dolazimo do motiva dobrog divljaka, tj. čistoće iskonskog siromašnog Slavena, koji se kvari ako počne gledati svoje materijalne interese, što je već ranije viđeno kod Fortisa: „Učeni ljudi češće nego siromasi gledaju na korist više nego na dužnost. Umjetnosti njihova čini se kao trgovina; sve misli njihove bojadišu se bojom novaca. Njihovo je srce često u trbuhu, a pamet u kesi““. ${ }^{69}$ Slavenski duh se kod takvih pojava srozava i zatvara u sebi. „Bolje bi im bilo orati i kopati, nego tako narodno svojstvo grditi““ ${ }^{70}$ Tommaseov stav prema očitoj oštroj i nepravednoj društvenoj podjeli u Dalmaciji je krajnje konzervativan - siromašnom slavenskom puku preporuča trpljenje i poslušnost, a nadređenima više obzirnosti:

Dva smo naroda u jednom puku, - kapa i klobuk nijesu ista otadžbina; ljekar i mesar ne govore isti jezik; težak i trgovac su kao neprijatelji. Valja da se klobuk pokloni kapi; u ovoj je osobito narodnost i dostojnost. Popravljajmo pučku neizvjesnost, pučke rane liječimo; nu popravljajuć i vidajuć, počitujmo puk sa svim srcem

\footnotetext{
${ }^{65}$ Nikola Tommaseo, Iskrice, str. 31.

${ }^{66}$ Ibidem, str. 28.

${ }^{67}$ Ibidem.

${ }^{68}$ Ibidem, str. 29.

${ }^{69}$ Ibidem, str. 38.

${ }^{70}$ Ibidem.
} 
Niccolò Tommaseo i istočna obala Jadrana...

svojim. Od njega učimo svoj ljudski jezik, a ne kvarimo ga mudrim svojim varvarstvom. ${ }^{71}$

U navedenom odlomku opet uočavamo medicinsku metaforu (,,pučke rane liječimo“) i znakovito upozorenja da se puk ne kvari „mudrošću“.

Dodatno pojašnjenje ovog stava daje šesnaesta Iskrica:

Nijesmo mi, vrsta učenih, s narodom svojim niti dobro sastavljeni, niti dobro razlučeni; s njime se miješamo, ne da mu dademo štogod od svojeg plemstva, ili da mu štogod od njegove prostote ukrademo. Mi se s narodom miješamo, da budemo i mi i on tužniji i gori. $^{72}$

Tommaseo je opsjednut čistoćom narodnog duha i očuvanjem tog ,prirodnog slavenskog stanja“. Tako se u Iskrici XIX pita kad će prestati to slijeđenje tuđih običaja.

U Iskrici XX spominje kako parobrod sjedinjuje daleke narode (kasnije spominje i telegraf), no ističe kako bi trebao više približavati duše nego tijela. Opet koristi „mi“ (dok je maloprije pripadao „vrsti učenih“) učitavajući ponovo poluorijentalističke opreke duh-tijelo i odrasla osoba-dijete: „Mi smo kano čovjek jak, koji ne zna upotrebiti snagu svoju. Treba da mnoge stvari učimo kao dijete malašno. Što će nam snaga bez poniženja." ${ }^{673}$

U Iskrici XXI Tommaseo poziva slavenske mladiće koji studiraju vani da sačuvaju svoj muževni jezik. „Talijanski ćete duh bolje ćutjeti, kad budete Slaveni ${ }^{74}$ pravi. ${ }^{675}$ Tommaseo se oštro protivi novotarijama sa zapada i bilo kakvoj promjeni i razvoju sirotice Dalmacije. Kao da želi sačuvati svijet svoga djetinjstva na kojem može iskazivati samilost.

Mate Zorić pišući o drami Splićanina Giulia Solitra (1820-1892) I conti di Spalato (Venecija, 1854.) u kojoj autor, premda autonomaš, negativno sudi o venecijanskoj upravi u Dalmaciji u 18. stoljeću, navodi kako je Tommaseo, ,jedan od najvećih propagatora kulta Venecije među domaćim autonomistima“, autoru drame oštro zamjerio antimletačke tendencije. ${ }^{76}$ Tako nastaje svojevrsna polemika u kojoj Solitro piše kako je cilj Venecijanaca bio ostaviti dalmatinsko stanovništvo u stanju neznanja, siromaštva i darežljivog srca u kojem su zatečeni. ${ }^{77}$ No Zorić navodi kako prema Tom-

\footnotetext{
${ }^{71}$ Nikola Tommaseo, Iskrice, str. 38-39.

${ }^{72}$ Ibidem, str. 51.

${ }^{73}$ Ibidem, str. 35.

${ }^{74} \mathrm{U}$ tal. izd. „Illirici siate, e lo sprito italiano sentirete allora viemmeglio“, str. 74.

${ }^{75}$ Nikola Tommaseo, Iskrice, str. 54.

${ }^{76}$ Mate Zorić, Književni dodiri hrvatsko-talijanski, str. 442-444.

${ }^{77}$ Ibidem, str. 444.
} 
maseu „zaslužuje pohvalu i taj 'konzeravtivizam' Mlečića, koji su takvom upravom zaštićivali 'čistoću' dalmatinskog puka i autentičnost njegovih običaja i navika“" ${ }^{78}$ Tako Tommaseo opisuje slično društvo kao i Fortis - iskonsko, čisto, siromašno, snažno, moralno.

Bugarska teoretičarka Marija Todorova, piše kako zapadnjačkom balkanističkom diskursu prijezir prema Balkancima nije izazvala njihova srednjovjekovna, nerazvijena, primitivna priroda, koja je naprotiv, bila izvor „kvazi-romantične privlačnosti kojom je Balkan zračio“. Zapadu nije bilo mrsko vidjeti vlastitu sliku iz praskozorja ljudske povijesti, već svoju sliku od prije samo nekoliko generacija, od prvobitne akumulacije kapitala pa nadalje. ${ }^{79}$ Slično gledanje nalazimo kod Fortisa, kojeg zanima i oduševljava što je moguće primitivnije stanovništvo. Postkolonijalni teoretičar Chinua Achebe sažima na sljedeći način kolonijalističko gledanje na afričko stanovništvo - Da li je obrazovani urođenik jednak svojoj braći u šumi? Ne! On je različit; on je gori. - izgubio je vezu sa svojim ljudima koje više ne razumije i koji zasigurno ne žele njegova nezadovoljstva i pretenzije. ${ }^{80} \mathrm{Na}$ sličan način Tommaseo ističe kako su škole, u koja su prisiljena ići seljačka djeca, povećavaju zlo jer čine seljaka sve više građaninom. On smatra da se prosperitet Dalmacije treba tražiti u suprotnom smjeru od onoga koji je zadnjih pedeset godina bio slijeđen - „Ne seljaka u grad, nego treba građanina pozvati da živi od sela.“ ${ }^{481}$

Iz današnje perspektive gledano, šokantno djeluju Tommaseove teze iznesene u izvješću o Dalmaciji, u kojem piše kako ,jedan od Vladi najtežih, narodu nabeskorisnijih, štoviše često štetnih, troškova je onaj škola“. Ističe kako iz njih nakon tri-četiri godine izlaze bez ikakvog znanja i kako:

(...) ne nauče gramatiku, nego umjesto toga nauče slobodnije ponašanje, skuplje odijevanje, ambiciju da ništa ne rade, ili da budu gospoda, ili da nastave studije; te, nakon što su uništili sirotu obitelj, na koncu da je i preziru. Škole su naročito opasne za seljake koji stanuju u gradu, najopasnije za žene, kojima je, da nema ničega drugog, to šetanje ulicama četiri puta dnevno rasipanje kojeg se više treba bojati nego krajnjeg neznanja. I doista, u našim krajevima, ta-

\footnotetext{
${ }^{78}$ Mate Zorić, Književni dodiri hrvatsko-talijanski, str. 444n.

${ }^{79}$ Marija Todorova, Imaginarni Balkan, prev. s engleskog D. Starčević i A. Bajazetov-Vučen, Biblioteka XX vek, Beograd, 1999., str. 79.

${ }^{80}$ Chinua Achebe, „Colonialist Criticism”, The Postcolonial Studies Reader, ur. Bill Ashcroft, Gareth Griffiths, Helen Tiffin, Routledge, London/New York, 1995., str. 57-61., str. 58.

81 „Del presente governo della Dalmazia“, u Niccolò Tommaseo, Scritti editi e inediti sulla Dalmazia e sui popoli slavi, str. 176.
} 
Niccolò Tommaseo i istočna obala Jadrana...

mo gdje djeca manje idu u školu, ponašanje je zdravije i ljudi više vole rad. ${ }^{82}$

Tommaseo oštro kritizira pojavu luksuza u Dalmaciji. Kaže da se ,prava šteta u Dalmaciji, ne sastoji u tome što vrijednost uvezenih stvari premašuje vrijednost izvezenih; sastoji se u prirodi uvezene robe, jer najviše koštaju one luksuzne (...) svatko zna mogućnosti susjeda, i zna, koliko ga posta košta novi šeširić, i koliko sramote jedan šal." ${ }^{\circ 3}$

Završni dio Iskrice XXX - ,Ne stidi se krvi svoje; pazi samo, da ti čista ostane, da ti kuga gradskih opačina ne ulije u nju slabost, nevolju i sramotu." - ima zanimljiv biografski poticaj. Ivan Katušić spominje kako je ovaj dio podcrtan u drugom izdanju, vjerojatno po Tommaseovoj želji i dodaje: „Pred čitaocem će bljesnuti neočekivano objašnjenje kad se sazna da je Tommaseo iz Pariza donio spolnu zarazu. ${ }^{\text {(884 }}$

U Predgovoru planiranoj knjizi Pjesme puka dalmatinskoga Tommaseo ističe čistoću izoliranih zajednica - kaže da se „u onim častima naroda slavenskoga, koji nisu pokvarene običajma tugjim, porodica zaderži još drage i častive sveze svoje.“ ${ }^{\text {(85 }}$ Tome dodaje i sljedeće: „Al izobrazenje narodah ubija mnogo putah ona ista dobra koja su ga u svjet dovela. Što više raste mekost života, što su lakša ljepa dočekanja, to više ladise prava ljubav.“" ${ }^{\text {‘ }}$

\section{Sukob s Njegošem}

Navedeni Tommaseov paternalistički i konzervativan stav prema slavenskim narodima, prema kojem bi oni trebali izbjegavati modernizaciju i zapadne utjecaje i ostati u svom stanju ,čistoće“, siromaštva i poniznosti, najbolje se očituje u njegovoj netrpeljivosti prema crnogorskom vladaru Petru II Petroviću Njegošu. U skladu s ranije navedenim vrijednostima, Tommaseo Njegoša optužuje zbog luksuznog života, a kao poseban grijeh spočitava mu to što je opjevao jednu glumicu iz tršćanskog kazališta: ,...ti, medju gadnim i gladnim ubožestvom puka tvoga, pokažuješ kao na preziranje, veličanstvo dvornika, i zaljevaš se francuskim vinom u zdravlje svih onih koji kruha nemaju, i slavišs, o vladiko, igračicu Terstinskog kazališta glasom onim kojim neznaš slaviti Mater Božju. “87

82 „Del presente governo della Dalmazia“, str. 204.

${ }^{83}$ Ibidem, str. 196.

${ }^{84}$ Ivan Katušić, Vječno progonstvo Nikole Tommasea, str. 179.

${ }^{85}$ Predgovor-Prefazione ai „Canti del popolo dalmata“, u Mate Zorić, „La prefazione ai 'Canti del popolo Dalmata' di Niccolò Tommaseo“, Studia Romanica et Anglica Zagrabiensia, n. 38, Zagreb, 1974., str. 213-277., str. 238.

${ }^{86}$ Ibidem, str. 244.

${ }^{87}$ Nikola Tommaseo, ,Spisi starog kaluđera“, str. 236. 
U pogledu navedene ,igračice“, treba napomenuti da je Njegoš u tršćanskom kazalištu gledao operu Robert le Diable, Giacoma Meyereera, u kojoj ga je očarao ples Flore Fabri-Bretin, kojoj je posvetio jednu pjesmu. ${ }^{88}$ Tommaseo mu zamjera i podložnost Rusiji pa piše da je Crna Gora postala predgrađe Petrograda i da se Njegoš klanja ruskom caru. ${ }^{89}$ Optužuje ga zbog niza navika zapadnoeuropskog čovjeka, koje je sebi Njegoš dozvolio, a koje Tommaseo valjda smatra nedopustivim luksuzom za Slavena, pa čak ako je riječ o vladaru: „Djeca tvoja grabe za živiti, a ti na biljard igraš; djeca tvoja, kao životinja, u smradu živu a ti francuske romane čitaš..." Optužuje ga da na stare mane svog naroda dodaje nove: ,i na mjesto da njih učiš kako će siromaštvo svoje snositi, budiš želje koje oni nemogu nasititi bez prevarnih nasiljah, bez pobjedah svakog poraza opasnijih.“900

Dok je Njegoš izražavao snažnu želju za „europeiziranjem“ i moderniziranjem Crne Gore, Tommaseo je smatrao da je treba sačuvati tradicionalnu i patrijarhalnu. ${ }^{91}$ Pored tog odudaranja od idealizirane slike dobrog, siromašnog i primitivnog Slavena, razlog Tommaseovog neprijateljstva prema crnogorskom vladaru treba tražiti i na političkom polju. Njegoš je vjerovao u skoro ostvarenje jugoslavenske ideje i protivio se aneksiji Italije Dalmaciji, koju su zahtijevali Venecijanski revolucionari iz 1848., i zalagao se za ujedinjenje Dalmacije s Hrvatskom. U proglasu od 20. 5. 1848. pozvao je Bokelje i Dalmatince obje vjere da podrže bana Josipa Jelačića. ${ }^{92}$ Pored toga, u jednom pismu Špiri Popoviću iz 1845. Tommaseo se žali da mu Njegoš nije poslao neke obećane narodne pjesme. Tu ljutnju koju čovjek sa Zapada osjeća kada mu Orijentalac nije uvijek spremno i oduševljeno na usluzi, nalazimo i kod Alberta Fortisa kad u Putu po Dalmaciji govori o „zlobnoj lijenosti“ stanovnika Vida koji ga nisu htjeli odvesti do nekih kamenih natpisa.

Njegoš, kojeg Tommaseo oštro optužuje pred zapadnoeuropskom javnošću, suprotstavlja se tvrdnjama da su Crnogorci neprijatelji slobode, ističući kako su se oni uvijek morali boriti da bi očuvali neovisnost od Turaka. Naglašava kako su oslobodilački pokreti Slavena ,često promatrani s podozrenjem i klevetani upravo od onih naroda - a tu je mislio i na Talijane - koji su

\footnotetext{
${ }^{88}$ Mate Zorić, Italia e Slavia: Contributi sulle relazioni letterarie italo-jugoslave dall'Ariosto al D'Annunzio, str. 328.

${ }^{89}$ Nikola Tommaseo, ,Spisi starog kaluđera“, str. 236.

${ }^{90}$ Ibidem, str. 237.

${ }^{91}$ Vesna Kilibarda, „Un contributo allo studio dei rapporti tra Tommaseo e Njegoš“, I mari di Niccolò Tommaseo e altri mari: Atti del Convegno internazionale di Studi nel bicentennario della nascita di Niccolò Tommaseo, Zagabria, 4-5 ottobre, 2002, ur. M. Čale, S. Roić, I. Jerolimov, FF press, Zagreb, 2004., str. 202-212., str. 208.

${ }^{92}$ Ibidem, str. 203.
} 
Niccolò Tommaseo i istočna obala Jadrana...

stoljećima bili njihovi gospodari.“93 Uz to, optužuje Tommasea da dijeli svjetske predrasude prema Slavenima te da se suprotstavlja njihovoj emancipaciji. Njegoš zahtijeva za Crnogorce i Slavene ista ona prava na borbu za neovisnost na koja se pozivaju ostale europske nacije. ${ }^{94}$ Oštru polemiku slične inspiracije s Tommaseom je 1862. godine vodio i Natko Nodilo, koji mu spočitava da se postavio na pijedestal i da s visine iznosi sudove o složenim pitanjima Austrije, Mađarske, Dalmacije i Hrvatske, o slavenskoj kulturi i jeziku, a da nema pravog znanja o problemima o kojima govori. ${ }^{95}$

\section{Zauzimanje za ,ilirski jezik“ i narodnu poeziju}

Tommaseo se u Iskrici XI obraća svećenicima i preporučuje im materinski jezik, koji je ,hitar i pun, jak i tih, mlad jošter, ali silne mladosti i vječne“. 96 Time opet ponavlja topos o mladim narodima i mladim jezicima. Stoviše, ,ilirski“ jezik je vječno mlad. Očigledno je na ovom mjestu to izrečeno kao pohvala, ali ona istovremeno slavenskom narodu učitava stanje vječne infantilnosti. U pismu Enricu Stieglitzu Tommaseo spominje Fortisa kao „prijateljskog i milostivog posjetitelja“ Dalmacije koji je prvi Europi pokazao ,ilirski poeziju“. Pored njega navodi i C. Nodiera i Guzlu. Piše kako se u Hrvatskoj obrazovani ljudi i žene, koji su se nekada sramili „ilirskog“ jezika sada su ga se počeli držati. Kaže kako bi se tog srama trebali osloboditi i svi obrazovani ljudi u Dalmaciji. ${ }^{97}$ O Fortisu Tommaseo još navodi i to da je o Dalmaciji pisao s ljubavlju te kako je savjetovao da se iskoriste kamenolomi koje je koristio i stari Rim, kako je preporučivao uzgajanje kestena, navodnjavanje itd. ${ }^{98} \mathrm{Na}$ istom mjestu Tommaseo spominje i Ivana Lovrića. ${ }^{99}$ Pored toga, treba istaknuti da je Tommaseo upoznat i sa djelom Giulia Bajamontija, premda mu nije upamtio ime. Tako piše kako je u jednim novinama u Vicenzi, negdje u drugoj polovici prošlog stoljeća netko njemu nepoznat pisao o Homerovom morlakizmu. ${ }^{100}$

${ }^{93}$ Navedeno prema Jože Pirjevec, Niccolò Tommaseo tra Italia e Slavia, str. 119.

${ }^{94}$ Ibidem, str. 119-120.

${ }^{95}$ Ibidem, str. 208-211.

${ }^{96}$ Nikola Tommaseo, Iskrice, str. 69.

${ }^{97}$ Niccolò Tommaseo, Scritti editi e inediti sulla Dalmazia e sui popoli slavi, 115.

${ }^{98}$ Niccolò Tommaseo, „Anton Maria Lorga: La scienza e la civiltà“, u Scritti editi e inediti sulla Dalmazia e sui popoli slavi, str. 144.

${ }^{99}$ Ibidem, str. 143.

100 Niccolò Tommaseo, „Italia, Grecia, Illirio, la Corsica, le isole Ionie e la Dalmazia“, u Scritti editi e inediti sulla Dalmazia e sui popoli slavi, str. 333. 
U predgovoru „Pjesmama dalmatinskog naroda“ Tommaseo Marka Kraljevića uspoređuje s Homerovim ratnicima. ${ }^{101} \mathrm{U}$ istom tekstu ponavlja još jedno opće mjesto, ono o usnulom Marku Kraljeviću kao metafori Južnih Slavena: „Nije on mertav; nego spava.(...) Usta će Marko pokrepljen od stoljetnog počivanja, pun stoljetnih spomenah; i doći će kano rijeka umnožena vodama dugim putem iz daleka tekućim. “102 Poput Bajamontija i Tommaseo je oduševljeni čitatelj Giambattiste Vica, čije se misaono naslijeđe osjeti i u spisima o Dalmaciji, prije svega stavovima o usmenoj tradiciji općenito. ${ }^{103}$

Treba istaknuti da se Tommaseo zalagao i za akademsko proučavanje jezika i narodnog pjesništva Južnih Slavena. Piše kako „srpski““ (što mu je često sinonim za ,ilirski“) jezik ima svoju katedru u Beču i Parizu i da će biti oslobođen prijezira kojom su ga, u očima uglađena svijeta držali „brkovi i gruba sukna nesretnih Skjavuna“. ${ }^{104}$ Tommaseova velika zasluga je što je, uz pomoć svojih suradnika u Dalmaciji, prikupio 337 narodnih pjesama. ${ }^{105}$ No ne treba zaboraviti ni na to da je njihova vrijednost u Dalmaciji bila prepoznata i znatno ranije. Žarko Muljačić navodi da se Nikola Muljačić, dugogodišnji profesor zadarskog latinskog sjemeništa, još u prvoj polovici 18. stoljeća, dosta prije Fortisa, Bajamontija i Ferića zalagao za sakupljanje i objavljivanje naših narodnih pjesama. ${ }^{106}$ I stotinu godina prije Tommasea kudio gradsku gospodu koja zanemaruju ilirski jezik.

Tommaseo će se pred kraj života, povodom smrti supruge Diamante, opet vratiti ,ilirskom“ jeziku na kojem će napisati jednu dirljivu pjesmu. U pismu kojeg je 12. 1. 1874. godine napisao franjevcu Ivanu Šimunoviću, koji mu je pomogao jezično i stilski dotjerati tu pjesmu, Tommaseo ističe kako je unatoč tome što tridesetak godina nije slušao ni čitao materinski jezik ,želio i na jeziku na kojem je moja sirota majka molila, govoriti svojoj sirotoj mrtvoj

${ }^{101}$ Niccolò Tommaseo, Predgovor-Prefazione ai „Canti del popolo dalmata“, str. 250 .

${ }^{102}$ Ibidem, str. 252.

103 Sanja Roić, „I temi vichiani di Tommaseo“, I mari di Niccolò Tommaseo e altri mari: Atti del Convegno internazionale di Studi nel bicentennario della nascita di Niccolò Tommaseo, Zagabria, 4-5 ottobre, 2002, ur. M. Čale, S. Roić, I. Jerolimov, FF press, Zagreb, 2004., str. 182-201., str. 182.

${ }^{104}$ Niccolò Tommaseo, Scritti editi e inediti sulla Dalmazia e sui popoli slavi, Volume I, str. 118.

${ }^{105}$ Usp. Mate Zorić, Italia e Slavia: Contributi sulle relazioni letterarie italojugoslave dall'Ariosto al D'Annunzio, str. 291.; Sanja Roić, Stranci: Portreti s margine, granice i periferije, str. 101.

106 Žarko Muljačić, „Iz korespondencije zadarskih profesora 18. stoljeća, napose Nikole Muljačića“, Radovi Instituta Jugoslavenske akademije znanosti i umjetnosti u Zadru, sv. XI-XII, Zadar, 1965., str. 545-564., str. 556. 
Niccolò Tommaseo i istočna obala Jadrana...

ženi““ ${ }^{107}$ Mate Zorić piše kako je ,prenaglašena skromnost i poniznost šibenskog fratra spram Tommasea slična stavu većine dalmatinskih suradnika koji su u njemu vidjeli živog velikana kojega nisu smjeli ničim povrijediti. Zato Šimunović umanjuje svoj udio u dotjerivanju pjesme...“"108

\section{Topos razlomljenog slavenskog narodnog tijela}

Tommaseo se u Iskricama ne ograničava samo na rodnu Dalmaciju, već se dotiče i slavenskog pitanja, općenito. Paradoksalno, dok je ranije govorio da Dalmacija nema ništa s narodima oko sebe i isticao njezinu ,čistoću“ i autentičnost, Tommaseo u Iskrici XXXI piše da s Rusijom ,imamo“ zajednički jezik, s Njemačkom zakone, s Grčkom obred, s Italijom običaje i znanost. U Iskrici XXXII piše: „Rastrgnuta su uda tvoja, slavenski narode, ali općen život u njima se miče, svaki dan tvoja krv sve veselije vri. ${ }^{\prime 109}$ Znakovito je da u ovom obraćanju svim Slavenima Tommaseo opet koristi tjelesnu metaforu. Slavensko tijelo prikazuje kao nešto rasuto, nepovezano (kao Lacanov hommelette u stadiju zrcala) što tek treba dobiti cjeloviti oblik, identitet i značenje.

U Iskrici XXXVI. opisuje širenja Slavena kao neku prirodnu stihiju provalili su iz Azije poput rijeka iz dubokog jezera i odijelili se tijekom dugoga putovanja. ${ }^{110}$ Poziva se na jedinstvo Slavena, ističući zajedničke korijene riječi u ruskom, poljskom, češkom i ,ilirskom“ jeziku. Glas slavenske braće koja se vole ,poput električne iskre, tankom žicom prenesene, u bljesku prepisuje od srca srcu svetu riječ novog saveza““. ${ }^{111}$ Zanimljivo je da opis slavenskog jedinstva Tommaseo započinje mitskom slikom rijeka koje se razdvajaju, koju smješta u drevno vrijeme uoči njihovog dolaska u Europu, a ponovno spajanje prikazuje kroz metaforu tada najmodernije tehnike. Promatra slavenske narode kao jednu veliku obitelj. Govori kako se i kod njih javlja plodno sjeme civilizacije i kao primjer ističe Češku koja bi, prema mjerilu broja osoba obuhvaćenih školstvom, bila civiliziranija od Francuske. ${ }^{12}$ Poziva na prevladavanje klasnih, kulturnih i političkih netrpeljivosti među slavenskim narodima: „Dalmatinski gradjanin nek poštuje hrabru prostotu golog seljaka; pisaoc horvatski nek se pokloni pred kapom slobodnog Serbljina; Rus

${ }^{107}$ Mate Zorić, „O nekim manjim Tommaseovim 'ilirskim' sastavima“, str. 137.

${ }^{108}$ Ibidem, str. 139.

${ }^{109}$ Nikola Tommaseo, Iskrice, str. 60.

${ }^{110}$ Niccolò Tommaseo, Scintille, Redazione definitiva a cura di M. Zorić, str. 84.

${ }^{111}$ Ibidem, str. 85.

${ }^{112}$ V. „A Niccolò Giaxich“, u Niccolò Tommaseo, Scritti editi e inediti sulla Dalmazia e sui popoli slavi, str. 28. 
silni, nek se boji, više od topovah, uzdisanja tvoga, Poljače, potlačeni.“113 Nasuprot kršćanskom panslavizmu Iskrica, na drugim mjestima Tommaseo pokazuje izrazitu netrpeljivost prema nekim slavenskim narodima. Srpskom narodu tako poručuje da se čuva pokrovitelja, misleći prije svega na Rusiju. $^{114}$

Tommaseo „orijentalizira“ Slavene pripisujući im neke urođene osobine koje su na prvi pogled pozitivne, ali koje u biti impliciraju izvjesnu intelektualnu ograničenost i prevagu tjelesnosti, strastvenosti i fantazije: „Slavenski rod ne zna raditi zavjere; previše je prostodušan i vatren. “115 U već navedenom izvješću o Dalmaciji piše da je razjedinjenost mana Slavena, kao i „svih naroda maštovitog uma“. ${ }^{116} \mathrm{U}$ pismu Dall'Ongaru izražava sumnju u mogućnost uspjeha Mazzinijevog djelovanja među Slavenima koji su: ,jednostavni ljudi no utoliko teži za razumjeti nekome koji nije jednostavan.“117 U svojoj Književnoj oporuci (Testamento letterario) Tommaseo piše kako je rođen u ,talijanskoj koloniji, kojom su nekada vladali Venecijanci, a ranije Rimljani, u slavenskoj zemlji između Istoka i Zapada..." ${ }^{118}$ Jože Pirjevec piše kako Tommaseo vidi Slavene kao posrednike između Orijenta i Zapada, ali dodaje i kako je važnije to da su „oni bili, i s duhovnog i društvenog aspekta, na pola puta između dva svijeta. “119 Upravo zbog te pozicije „na pola puta između dva svijeta" i govorimo o tradiciji poluorijentalizma u talijanskom prikazivanju istočne jadranske obale. A unutar tog širokog slavenskog spektra, na ljestvici Tommaseovih simpatija, negdje na pola puta između idealizirane sirotice Dalmacije, savršenog objekta sentimentalističkog paternaliziranja i snažne, politički opasne Rusije prema kojoj osjeća odbojnost, nalazi se tadašnja Hrvatska. U Spisima starog kaluđera Tommaseo se sjevernim Hrvatima obraća sljedećim riječima:

Nisu vas poznavali dosada, drugi narodi, o bratjo Hervati, i gledajući vas kao robove pružene pod štap njemački, prezirali su vas bez ikakvog sažaljenja. Vi pak, kao dobar konj pod uzdom ergjavog konjika, zalud hrabrost i kerv trošite; vjernosti vašoj nije sljedovala blagodarnost, niti pobjedi čast, niti smerti uspomena. Poslali su vas

\footnotetext{
${ }^{113}$ Nikola Tommaseo, ,,Spisi starog kaluđera“", str. 240.

${ }^{114}$ V. „Ai popoli slavi“", u Niccolò Tommaseo, Scritti editi e inediti sulla Dalmazia e sui popoli slavi, str. 87.

115 „Italia, Grecia, Illirio, la Corsica, le isole Ionie e la Dalmazia“, u Niccolò Tommaseo, Scritti editi e inediti sulla Dalmazia e sui popoli slavi, str. 247-248.

${ }^{116}$ „Del presente governo della Dalmazia“, u Niccolò Tommaseo, Scritti editi e inediti sulla Dalmazia e sui popoli slavi, str. 182.

${ }^{117}$ Jože Pirjevec, Niccolò Tommaseo tra Italia e Slavia, str. 152.

${ }^{118}$ Ibidem, str. 87.

${ }^{119}$ Ibidem, str. 88-89. 
Niccolò Tommaseo i istočna obala Jadrana...

kao životinju u mesarnicu, na bojna polja Europe; davali su vami, kao čelatima, žalosnu službu da davite perva dviženja talijanske slobode, a sada protivu vas Talijane šalju, koj kao ubice, oružje strano derkjući kervlju vašom polivaju. ${ }^{120}$

Pored toga, poziva Hrvate da očiste „od Njemčadjie jezik i dušu“ te dodaje: ,govor vaš neka slobodan bude od zapletenih izrečenjah, kao od zapletenih načinah djelanje vaše. " ${ }^{121}$ Piše da su mnogo učinili u malo godina, ali da im još mnogo toga ostaje, jer su još dijelom Nijemci. Preporuča im da uče „od prostog Serbljina, siromaha Dalmatinca“ ono što naziva „,̌istotja govora i jakost“. ${ }^{122}$ Promatra Slavene kao jednu cjelinu i dodaje: „u Serbljanskim šumama prebjegla je sloboda sveta i pjesničstvo: iz saborah Hervatskih, iz tiskarnicah českih neg se javlja sloboda sveta i obilnorječje. ${ }^{\text {"123 }}$ Hrvatima poručuje da ne oponašaju narode koji imaju drugačiju civilizaciju, običaje i prirodu. Premda će se u kasnijim antiunionističkim brošurama protiviti ujedinjenju Dalmacije i Hrvatske, u Spisima starog kaluđera Tommaseo ističe njihovo povijesno i etničko jedinstvo: „Ustav i kerv sjedinja vas s'tužnom Dalmacijom: spomenite se i nje; ljubite je bratinskom ljubavlju, i želite nju ne kao podanika, već kao druga“. ${ }^{124}$

\section{Tommaseov polu-mit Venecije}

U tekstu „Italia, Grecia, Illirio, la Corsica, le isole Ionie e la Dalmazia“ iz 1850. godine Tommaseo nastoji pokazati sličnosti između tih zemalja, koristeći povremeno i izrazito nategnute usporedbe. Ostavivši po strani brojne, prije svega historiografske promašaje, pa i besmislice (poput npr. tvrdnje da se još Dioklecijan služio slavenskim trupama), zbog kojih je o tom Tommaseovom tekstu negativan sud dao i Benedetto Croce ${ }^{125}$, zanimljiv nam je svojevrsni polu-mit Venecije izražen u tom spisu. Mletačku Republiku Tommaseo ne prikazuje kao savršenog i prosvijećenog vladara, no inzistira na tome da je njezina vladavina neupitno najmanje zlo koje se moglo dogoditi njezinim bivšim podanicima. Pišući ukratko o povijesti Dalmacije navodi kako su Venecijanci kupili Zadar za sto tisuća dukata i dodaje: „Venecija je barem kupovala u gotovini; i, štogod se govorilo o tome, donosila je civilizaciju, istina nedovoljnu, no takvu kakvu nam austrijska Mađarska ne bi donijela,

\footnotetext{
${ }^{120}$ Nikola Tommaseo, ,Spisi starog kaluđera“, str. 226.

${ }^{121}$ Ibidem.

${ }^{122}$ Ibidem, str. 227.

${ }^{123}$ Ibidem.

${ }^{124}$ Ibidem, str. 228.

${ }^{125}$ Niccolò Tommaseo, Scritti editi e inediti sulla Dalmazia e sui popoli slavi, XL.
} 
nego bi napravila drugu Hrvatsku...“126 U okvir Tommaseovog „polu-mita“ Venecije mogli bismo uvrstiti i njegovu ranije navedenu tezu, iznesenu u polemici sa Solitrom, o tome kako je mletačka vlast ,zaslužna“ za očuvanje čistoće dalmatinskog slavenskog stanovništva tako što ga je držala u zaostalosti, ne kvareći ga školama i luksuzom. Tommaseo izražava paternalistički i utopijski stav da bi Venecija trebala biti most između Italije i slavenskog svijeta, i da ovomu treba pomoći u rastu, a naročito Dalmaciji. ${ }^{127}$

Upravo je od tog polu-mita Venecije u dvadesetom stoljeću najlakše polazilo dnevnopolitičko interpretiranje i instrumentaliziranje Tommaseovog pisanja o Dalmaciji. Oscar Randi, u knjižici o Tommaseu i politici objavljenoj u Zadru u prvim godinama fašističke vladavine piše kako je u Dalmaciji za vrijeme Mletačke Republike ,miroljubiv bio suživot između Talijana i Slavena, no uz apsolutnu superiornost Talijana i ne manje očitu inferiornost Slavena; stanje, dakle više srednjovjekovno, nego moderno". ${ }^{128}$ No nakon propasti Venecije i kasnije tijekom 19. stoljeća stanje se mijenja: „Miroljubivi suživot i tolerancija između Talijana i Slavena, naslijeđeni od Venecije, bili su, pred Tommaseovim očima, poremećeni općim buđenjem nacionalnog osjećaja...“129 Autor moguće proturječje u tvrdnjama o „miroljubivom suživotu i toleranciji između Talijana i Slavena“ $i$ istovremenoj ,,apsolutnoj superiornosti Talijana i ne manje očitoj inferiornosti Slavena" prevladava fašističkom ideologijom o višim i nižim rasama, pri čemu se ,poziva“ na Tommasea, govoreći o njegovoj ,instinktivnoj odbojnosti prema Hrvatima“" koje je uvijek ,prezirao ili je malo držao do njih, kao do niže, nezrele rase. “130

Pišući o „teškoj, herojskoj, uzvišenoj, ponekad očajničkoj“ borbi dalmatinskih Talijana Randi ističe kako je „formula 'autonomije' bila prolazna etiketa koja je trebala poslužiti za dobivanje nekih ustavnih sloboda koje bi trebale poslužiti pripremi odvajanja od Monarhije“. ${ }^{131}$ Iz fašističke perspektive u Dalmaciji se u 19. stoljeću nije radilo o borbi dvije različite nacionalne i političke opcije, već o borbi civilizacije i barbarstva: „Tommaseov glas se diže iznad rasa, zemljopisnih i povijesnih razloga. Braneći talijansko pravo na jadransku obalu, znao je da brani najviše interese ljudske civilizacije.“132 Autor spekulira o tome kako bi se Tommaseo ponio u kasnijim povijesnim događajima i zaključuje da bi u vrijeme Prvoga svjetskoga rata bio interve-

126 „Italia, Grecia, Illirio, la Corsica, le isole Ionie e la Dalmazia“, u Niccolò Tommaseo, Scritti editi e inediti sulla Dalmazia e sui popoli slavi, str. 239.

${ }^{127}$ V Jože Pirjevec, Niccolò Tommaseo tra Italia e Slavia, str. 120.

${ }^{128}$ Oscar Randi, Niccolò Tommaseo nella politica, str. 4.

${ }^{129}$ Ibidem, str. 15.

${ }^{130}$ Ibidem, str. 27.

${ }^{131}$ Ibidem, str. 30.

${ }^{132}$ Ibidem. 
Niccolò Tommaseo i istočna obala Jadrana...

nist, da bi 1920. godine bio uz D'Annunzia protiv Rapalskog ugovora, a da bi 1922. vjerojatno bio fašist, ,ako ni zbog čega drugog, zbog toga što se Mussolini trudi konačno stvoriti Talijane. “133

Kod Tommasea nalazimo i kasnije kanoniziran mit o odanim Skjavunima koji su zadnji branili Veneciju:

Kao nužan uvjet predaje Venecije bilo je postavljeno da se Dalmatinci otjeraju. Jer tim jednostavnim ljudima republika nije bila samo ime, niti im je Sv. Marko bio samo slika utisnuta na loše zarađene i loše utrošene novce. Oni su ostali posljednji Venecijanci i pravi nasljednici Michielia i Dandola: jer Skjavuni imaju, kako kaže poslovica, tvrdu glavu; i tamo gdje drugi završava, oni počinju. ${ }^{134}$

Pišući o Korzici, Dalmaciji i Kefaloniji Tommaseo kaže da strani vladari koji dolaze iz Francuske, Austrije, Engleske procjenjuju tamošnje stanovništvo s predrasudama i prijezirom, te kako dok proklinju svoj boravak u tim regijama istovremeno sasvim dobro vode privatne poslove. Piše i o tome kako Francuzi, Austrijanci i Englezi tretiraju te podanike kao pripadnike niže rase: „Rekli biste, slušajući ih, da su to barbarske zemlje koje drže iz sažaljenja, i kao vojno mjesto, u kojem nema razumnih životinja koje se mogu pripitomiti za bilo koje umijeće. “" 135 Znakovito je da Tommaseo, u tom opravdanom gnjevu, ne spominje bivše venecijanske vladare i pisce koji su o Dalmaciji davali upravo takvu sliku kakvu je opisao, premda spominje kako je Carlo Gozzi proveo u mladosti nekoliko godina u providurovoj službi u Dalmaciji. ${ }^{136} \mathrm{Ne}$ navodi ništa podrobno o Gozzijevom opisu Dalmatinaca, ali zato kao primjer sažetog i točnog opisa navodi Goldonija: „Budući da je pjesnicima dano u jednom potezu oslikati ljude i događaje, Goldoni, koji nije pjesnik stilom, već pojmom, nazivajući Dalmatince hrabrim i osjećajnim narodom, nije ih elegantno, već istinito oslikao.“137

Pišući o tome kako se Dioklecijan služio slavenskim trupama Tommaseo dodaje i sljedeće:

Jer su Slaveni, kao što smo nedavno vidjeli da su od srca postali Venecijanci, i također vjerno služili Austriju, tako u rimskim vremenima bili vjerniji Rimljani od onih rođenih u Italiji. I možda su

${ }^{133}$ Oscar Randi, Niccolò Tommaseo nella politica, str. 33.

${ }^{134}$ Niccolò Tommaseo , „Italia, Grecia, Illirio, la Corsica, le isole Ionie e la Dalmazia“, str. 252.

${ }^{135}$ Ibidem, str. 256.

${ }^{136}$ Ibidem, str. 311.

${ }^{137}$ Ibidem, str. 293. 
Slaveni jedina snaga predodređena spasiti Europu od germanske prevlasti, kao što su već od turske. ${ }^{138}$

Tim ponavlja stariju sliku Skjavuna kao vjernog vojnika, ali i anticipira novu sliku Slavena kao brane, ne više protiv Turaka, već protiv Germana, koja će u većoj mjeri biti prisutna kod Giuseppea Mazzinija.

\section{Tommaseo kao arhetipski Dalmatinac}

Nakon Tommaseove smrti, a pogotovo obnavljanjem talijanskih pretenzija na istočnu jadransku obalu početkom 20. stoljeća, počet će se graditi mit o Tommaseu kao arhetipskom Dalmatincu. U zadarskoj periodici iz dvadesetih godina prošlog stoljeća čitamo o nekoj posebnoj „dalmatinskoj psihi““ čiji je Tommaseo egzemplarni predstavnik. ${ }^{139}$ Lucio Toth početkom 21. stoljeća piše da je Tommaseo bio ,čovjek snažnih građanskih strasti, autentični Dalmatinac, po svojim vrlinama i manama“" ${ }^{140}$ Premda nije sasvim jasno što bi to bio ,autentični Dalmatinac“ i koje se sve informacije prenose kada talijanski autori Tommasea lapidarno nazivaju „Il Dalmata“, to naizgled bezazleno opće mjesto o „dalmatinskoj psihi“ nipošto nije izolirani lokalni slučaj. Edward Said govori o ,upadljivim retoričkim figurama“ koje se stalno ponavljaju unutar kolonijalističkog diskursa, u opisima „tajanstvenog Istoka“ ili u stereotipima o ,afričkom umu“ i sl. ${ }^{141}$ Isto tako se u venecijanskoj/talijanskoj kulturi govori o „dalmatinskom karakteru“, koji umnogome određuje ponašanje njegovog ,nositelja“, reducirajući mu time mogućnost individualnosti. Valja imati na umu da se stereotipi, od strane onih na koje se odnose, često hegemonijski usvajaju i preobražavaju u autostereotipe čijim se interioriziranjem ostvaruje učinak proročanstva koje se samo ispunjava, jer se individua ponaša u skladu s tom slikom o samome sebi i onda kada ni po čemu ne odgovara stereotipu tvrdoglavog kolerika koji identitet temelji na „dišpetu“. Ovaj složeni fenomen bi zahtijevao posebno istraživanje, na ovom mjestu ga samo bilježimo, ostavljajući otvorenu mogućnost da bi korijene (auto)stereotipa o „dalmatinskom karakteru“ možda trebalo tražiti u okviru prekojadranskog poluorijentalističkog diskursa.

${ }^{138}$ Niccolò Tommaseo , „Italia, Grecia, Illirio, la Corsica, le isole Ionie e la Dalmazia“, str. 265.

${ }^{139}$ Nedjeljka Balić-Nižić, „Il cinquantesimo anniversario della morte di Niccolò Tommaseo nei periodici Zaratini“", I mari di Niccolò Tommaseo e altri mari: Atti del Convegno internazionale di Studi nel bicentennario della nascita di Niccolò Tommaseo, Zagabria, 4-5 ottobre, 2002, ur. M. Čale, S. Roić, I. Jerolimov, FF press, Zagreb, 2004., str. 224-239., str. 233.

${ }^{140}$ Lucio Toth, „I mari di Tommaseo“, str. 38.

${ }^{141}$ Edward Said, Kultura i imperijalizam, prev. Vesna Bogojević, Beogradski krug, Beograd, 2002, str. 9. 
Niccolò Tommaseo i istočna obala Jadrana...

Tommaseo je u svoj dnevnik 17. 5. 1846. zapisao: „Žao mi je što sam kasno spoznao koliko sam dobra mogao učiniti pišući za slavenski narod, koji je još mlad i nije tako kukavan i tako nezahvalan kao narod talijanski.“142 Taj stav o mladom istočnom narodu nasuprot „kukavnog“ Zapada u skladu je sa širim romantičarskim stavovima. Edward Said piše o važnoj romantičarskoj zamisli o obnovi Europe uz pomoć Azije. Između ostalog navodi kako su Friedrich Schlegel i Novalis nagovarali Europljane da detaljno proučavaju Indiju jer indijska kultura i vjera može pobijediti materijalizam i mehanizam zapadne kulture. ${ }^{143}$ Analizirajući pisanje T. E. Lawrencea (Lawrencea od Arabije), koji „kao manipulator Arapima sebe stavlja na njihovo čelo“, Said ističe jednu promjenu: „Orijentalist je sada postao reprezentativni orijentalac za razliku od prijašnjih promatrača poput Lanea, za koje je Orijent bio nešto što se brižno drži podalje od sebe. ${ }^{\text {“144 }}$ U ovom novom orijentalističkom stavu „Arapska pobuna ima smisao samo ako joj Lawrence zacrta smisao.“145 Tommaseov odnos prema Dalmaciji i Južnim Slavenima umnogome je sličan kasnijem odnosu Lawrencea prema Arapima.

U Iskrici XXIII Tommaseo napada starost i kukavičluk venecijanskog Lava, koji je propustio priliku proširenja svojih istočnih granica: „Ostala nam je Bosna vavijek tudja radi nemilog zavidjenja i staračkoga mletačkog straha. Mogao je lav s one strane širiti krila svoja; zdravije bi bio spavao i časnije ostario u srpskim planinama nego u talijanskim. “146 Tommaseo optužuje Veneciju što, „kao starci, koj malo mare za tudje velike bolesti, misle samo na svoje; koj se smerti plaše, i boju se i od jakih ljekarijah, s'kim bi mogli život produžiti“, nije pomogla Hercegovini i Bosni protiv Turaka. Zbog istog grijeha optužuje i Austriju, koristeći ponovo metaforu starosti, govoreći da je „omatorila“. ${ }^{147}$

$\mathrm{U}$ boljem razumijevanju ove metaforike mladog, gotovo djetinjastog slavenskog naroda, može nam pomoći i teorija dječje književnost, koja, polazeći od pretpostavke da je ,dijete“ u onom smislu u kojem se rabi u znanosti o dječjoj književnosti, društveni konstrukt, uočava da se na dječji lik projiciraju utopijske čežnje određene društvene zajednice (ideja o dječjoj nevinosti i idealiziranje djeteta kao „graditelja“ bolje budućnosti). ${ }^{148}$ Sličnu projekciju

${ }^{142}$ Ivan Katušić, Vječno progonstvo Nikole Tommasea, str. 71.

${ }^{143}$ Edward W. Said, Orijentalizam, prev. Biljana Romić, Konzor, Zagreb, 1999, 149.

${ }^{144}$ Ibidem, str. 312.

${ }^{145}$ Ibidem.

${ }^{146}$ Nikola Tommaseo, Iskrice, str. 32.

${ }^{147}$ Nikola Tommaseo, ,Spisi starog kaluđera“, str. 230.

148 Dubravka Zima, ,Djetinjstvo i stereotipi: Slika djeteta u hrvatskome dječjem romanu 20. stoljeća“, Kulturni stereotipi: koncepti identiteta u srednjoeuropskim knji- 
utopijskih čežnji nalazimo u Tommaseovom pisanju o Slavenima. Za paternalistički odnos uvijek je potrebno dvoje - simboličko dijete (Dalmacija, Hrvati, Slaveni), koje je nezrelo, nevino, nemoćno, neuko, i s druge strane odrasli subjekt koji posjeduje znanje i moć (u Tommaseovu slučaju kulturnu nad-moć). Problematična točka svakog paternalizma je njegova imanentna sklonost konzerviranju postojećeg stanja. „Djetetu“ se tako ne dozvoljava emancipiranje i osuđuje se svaki doticaj sa svijetom odraslih (modernizacije, „Zapada“), kao što se vidjelo u slučaju Tommaseove žučne kritike Njegoša.

O tome da orijentalistički paternalizam pokazan na Tommaseovu primjeru nije izoliran primjer, koji bi bio vezan isključivo za određeni povijesni kontekst i određene biografske okolnosti, svjedoči poplava slične metaforike u svakodnevnom suvremenom političkom govoru. U vrijeme kad Hrvatska i njeni istočni susjedi prolaze mukotrpan put pristupa Europskoj Uniji, na začuđujući način se opet javio paternalistički diskurs iz zapadnih središta moći, koji, govoreći o europskom jugoistoku rabi fraze poput ,pokazivanje zrelosti“, ,,svladavanje zadataka“, ,polaganje europskih ispita“, „,mlade demokracije“ „,domaće zadaće iz Bruxellesa“ i sl. čime se cijelom nizu zemalja učitava infantilnost, gotovo na tomazeovski način, i još jednom potvrđuje nužnost ponovnog čitanja ,starih“ pisaca i priča iz novih teorijskih uglova.

\section{Literatura}

- Achebe, Chinua: „Colonialist Criticism“, The Postcolonial Studies Reader, ur. Bill Ashcroft, Gareth Griffiths, Helen Tiffin, Routledge, London/New York, 1995., str. 57-61.

- Balić-Nižić, Nedjeljka: „Il cinquantesimo anniversario della morte di Niccolò Tommaseo nei periodici Zaratini“", I mari di Niccolò Tommaseo e altri mari: Atti del Convegno internazionale di Studi nel bicentennario della nascita di Niccolò Tommaseo, Zagabria, 45 ottobre, 2002, ur. M. Čale, S. Roić, I. Jerolimov, FF press, Zagreb, 2004., str. 224-239.

- Dall'Ongaro, Francesco: Fantasie drammatiche e liriche, Successori Le Monnier, Firenca, 1866.

- Kanneh, Kadiatu: „Feminism and the Colonial Body“, The Postcolonial Studies Reader, ur. Bill Ashcroft, Gareth Griffiths, Helen Tiffin, Routledge, London/New York, 1995., str. 346-348.

- Katušić, Ivan: Vječno progonstvo Nikole Tommasea, Sveučilišna naklada Liber, Zagreb, 1975.

ževnostima, ur. Dubravka Oraić Tolić, Erno Kulcsar Szabo, FF press, Zagreb, 2006., str. 253-265, str. 253. 
Niccolò Tommaseo i istočna obala Jadrana...

- Kilibarda, Vesna: „Un contributo allo studio dei rapporti tra Tommaseo e Njegoš“", I mari di Niccolò Tommaseo e altri mari: Atti del Convegno internazionale di Studi nel bicentennario della nascita di Niccolò Tommaseo, Zagabria, 4-5 ottobre, 2002, ur. M. Čale, S. Roić, I. Jerolimov, FF press, Zagreb, 2004., str. 202-212.

- Muljačić, Žarko: „Iz korespondencije zadarskih profesora 18. stoljeća, napose Nikole Muljačića“, Radovi Instituta Jugoslavenske akademije znanosti i umjetnosti u Zadru, sv. XI-XII, Zadar, 1965., str. 545-564.

- Pirjevec, Jože: Niccolò Tommaseo tra Italia e Slavia, Marsilio Editori, Venecija, 1977.

- Randi, Oscar: Niccolò Tommaseo nella politica, Tipografia di E. De Schönfeld, Zadar, 1924.

- Roić, Sanja: „I temi vichiani di Tommaseo“, I mari di Niccolò Tommaseo e altri mari: Atti del Convegno internazionale di Studi nel bicentennario della nascita di Niccolò Tommaseo, Zagabria, 45 ottobre, 2002, ur. M. Čale, S. Roić, I. Jerolimov, FF press, Zagreb, 2004., str. 182-201.

- Said, Edward W.: Orijentalizam, prev. Biljana Romić, Konzor, Zagreb, 1999.

- Said, Edwarad W.: Kultura i imperijalizam, prev. Vesna Bogojević, Beogradski krug, Beograd, 2002.

- Todorova, Marija: Imaginarni Balkan, prev. s engleskog D. Starčević i A. Bajazetov-Vučen, Biblioteka XX vek, Beograd, 1999.

- Tommaseo, Niccolò: Scritti editi e inediti sulla Dalmazia e sui popoli slavi, Volume I, ur. Raffaele Ciampini, Sansoni, Firenca, 1943.

- Tommaseo, Niccolò: Scintille, Redazione definitiva a cura di M. Zorić, Studia Romanica Zagrabiensia, 4, Zagreb, 1957, str. 60-89.

- Tommaseo, Nikola: Iskrice, uvod napisao Ivan Milčetić, Matica Hrvatska, Zagreb, 1888. (1. izd. 1844.)

- Tommaseo, Nikola: „Spisi starog kaluđera“, u Ivan Katušić, Vječno progonstvo Nikole Tommasea, Sveučilišna naklada Liber, Zagreb, 1975., str. 223-243.

- Toth, Lucio: „I mari di Tommaseo“, I mari di Niccolò Tommaseo e altri mari: Atti del Convegno internazionale di Studi nel bicentennario della nascita di Niccolò Tommaseo, Zagabria, 4-5 ottobre, 2002, ur. M. Čale, S. Roić, I. Jerolimov, FF press, Zagreb, 2004., str. 38-54. 
- Wolff, Larry: Venice and the Slavs: The Discovery of Dalmatia in the Age of Enlightenment, Stanford University Press, Stanford, California, 2001.

- Zima, Dubravka: „Djetinjstvo i stereotipi: Slika djeteta u hrvatskome dječjem romanu 20. stoljeća“, Kulturni stereotipi: koncepti identiteta u srednjoeuropskim književnostima, ur. Dubravka Oraić Tolić, Erno Kulcsar Szabo, FF press, Zagreb, 2006., str. 253-265.

- Zorić, Mate: „Intorno alle 'Scintille' di N. Tommaseo“, Studia Romanica Zagrabiensia, 4, Zagreb, 1957., str. 53-60.

- Zorić, Mate: „Nikola Tommaseo i narodni preporod u Dalmaciji“, (posebni otisak iz Zadarske revije, br. 6/1961), Zadar, 1962.

- Zorić, Mate: „Carteggio Tommaseo-Popović I (1840-41)“, Studia Romanica et Anglica Zagrabiensia, 24, Zagreb, 1967., str. 169-240.

- Zorić, Mate: „Carteggio Tommaseo-Popović II (1842-43)“, Studia Romanica et Anglica Zagrabiensia, n. 27-28, Zagreb, 1969., str. 207-294.

- Zorić, Mate: „Talijanski pisci o nama i našim književnostima“, Književna smotra, III, 8, Zagreb, 1971, str. 65-81.

- Zorić, Mate: „Carteggio Tommaseo-Popović III (1844)“, Studia Romanica et Anglica Zagrabiensia, n. 38, Zagreb, 1974.

- Zorić, Mate: „La prefazione ai 'Canti del popolo Dalmata' di Niccolò Tommaseo“, Studia Romanica et Anglica Zagrabiensia, n. 38, Zagreb, 1974., str. 213-277.

- Zorić, Mate: „Due libri sulla Dalmazia progettati dal Tommaseo e le 'Iskrice'", (trad. di Ingrid Damiani Einwalter), Ommaggio a Niccolò Tommaseo 1874-1974, The Bridge/Il Ponte - The Association of Croat Writers, Zagreb, 1975, str. 53-111.

- Zorić, Mate: Italia e Slavia: Contributi sulle relazioni letterarie italo-jugoslave dall'Ariosto al D'Annunzio, Medioevo e Umanesimo - 74, Editrice Antenore, Padova, 1989.

- Zorić, Mate: „O nekim manjim Tommaseovim 'ilirskim' sastavima“, Hrvatsko-talijanski književni odnosi, Zbornik II, ur. Mate Zorić, Zavod za znanost o književnosti, Zagreb, 1990., str. 119-144.

- Zorić, Mate: Književni dodiri hrvatsko-talijanski, Književni krug, Split, 1992.

- Zorić, Mate: „Tommaseovo izvješće o Dalmaciji iz 1844. i 1871. godine“", Hrvatsko-talijanski književni odnosi. Knjiga VIII., Filozofski fakultet Sveučilišta u Zagrebu, Zagreb, 2002., str. 35-124.

- Zorić, Mate: „Hrvatska i Hrvati u talijanskoj lijepoj književnosti: Od baroka do prve polovice 20. stoljeća“, Hrvatsko-talijanski književni odnosi. Zbornik IX, ur. Sanja Roić, Zagreb, 2005., str. 7-135. 
Niccolò Tommaseo i istočna obala Jadrana...

Nino RASPUDIĆ

\section{NICCOLO' TOMMASEO E LA SPONDA ORIENTALE DELL'ADRIATICO - DAL PATERNALISMO SENTIMENTALE FINO AI PROBLEMI CON NJEGOŠ}

Niccolò Tommaseo, grande lessicografo e letterato dell'Ottocento italiano, nato a Sebenico, è una delle figure più importanti nell'ambito delle relazioni culturali e politiche tra le due sponde dell'Adriatico. Analizzando dal punto di vista della critica postcoloniale le sue opere (soprattutto le Scintille/ /Iskrice) in cui parla della Dalmazia e del mondo slavo in generale, si scopre che il suo discorso adriatico è permeato di orientalismo (nel senso in cui lo concepisce E. Said). Le sue rappresentazioni della Dalmazia sono segnate da un forte approccio paternalistico: la osserva con simpatia, però lo fa sempre da un punto di vista gnoseologico e culturale superiore. Nelle Scintille Dalmazia è spesso metaforicamente rappresentata come una donna giovane e indifesa, che ha bisogno di tutela. I Dalmati sono rappresentati come "buoni selvaggi" che non devono lasciarsi "corrompere" dalla civiltà occidentale. Tommaseo condanna modernizzazione, urbanizzazione, istruzione obbligatoria, lusso e altri influssi occidentali (non risparmiando neanche Njegoš, "colpevole" perché leggeva romanzi francesi) e "orientalizza" gli slavi attribuendo loro alcune caratteristiche innate, che a prima vista sembrano positive, ma che implicano una certa limitatezza intellettuale e prevalenza di elemento corporeo, passionale e fantastico (la letteratura coloniale "classica" similmente descriveva gli Africani). Non sorprende perciò il fatto che Tommaseo idealizzi in parte il governo veneziano in Dalmazia. L'approccio paternalistico, analizzato nel caso di Tommaseo, è ancor oggi vivo nel discorso burocratico dell'Unione europea sull'Europa sud-orientale.

Parole chiave: Tommaseo, Dalmazia, Croati, Slavi, paternalismo, orientalismo, critica postcoloniale, Njegoř 

LINGUA MONTENEGRINA, god. III, br. 5, Cetinje, 2010.

Institut za crnogorski jezik i jezikoslovlje „Vojislav P. Nikčević“

UDK 821.163.4.09 Andrić I. 821.163.42.09 Krleža M.

Izvorni naučni rad

\section{Boris ŠKVORC (Split)}

Filozofski fakultet Sveučilišta u Splitu

Macqarie University, Sydney, Australija

\section{KONSTRUKCIJA, PRENOŠENJE I PREOBLIKOVANJE PRIČE(A) O NACIONALNIM IDENTITETIMA: O KRLEŽINOM STARČEVIĆU I ANDRIĆEVOM NJEGOŠU}

Ovaj rad bavi se pripovjedačkim taktikama, autorskim impostacijama i ideologemskim manipulacijama u proznim tekstovima Iva Andrića i Miroslava Krleže, a u svrhu dekodiranja pripovjednih taktika koje pozicioniraju navedene pisce u odnosu prema izvantekstualnom okviru i političkom drugom, kako sugeriraju njihove pripovjedne taktike. U središtu pozornosti je fikcionalizacija prostora koji se diskursivno upisuje kao povijesni, posebno u oblikovanju 'likova' Ante Starčevića u Krležinim esejima i Petra II Petrovića Njegoša u Andrićevim esejima. U radu pokazujemo da se dekodiranjem njihovih taktika u esejima mogu dekodirati oni diskursivni slojevi pripovjednog koji su do sad bili skriveni, a jasnije postaju i impostacije obojice autora u odnosu na prostor u kojem su stvarali, posebice u odnosu na njegov postkolonijalni povijesni status. Tako se središnja pitanja rada vežu uz postkolonijalna čitanja dvojice autora i određivanje upisivanja prostora unutar kojih se vrši identifikacija pojedinaca i grupa (zajednica). U središtu su pitanja identifikacije Nas i Njih u nekim romanima, ali uvijek referirajući prema onom što je napisano u esejima o dvojici značajnih povijesnih ličnosti iz devetnaestog stoljeća. U radu se dolazi do spoznaja da se kod dvojice pisaca odvijaju suprotni naratološki i ideologemski zasićeni procesi. Dok kod Krleže u fikcionalizaciji faktografskog dolazi do fingiranja otklona od srednjoeuropske pripovjedne i impostacijske paradigme i uokviravanja u lokalnu identifikaciju, kod Andrića se upravo ono što je u fikciji prikrivano manipulacijskim narativnim taktikama autorske intencije izravnije izlazi na vidjelo. Tome je tako i kad se radi o odnosu prema priči ali i odnosu prema drugima (kao naciji i hegemonijskoj intenciji).

Ključne riječi: identifikacija, tekstualne manipulacije autorske(ih) intencije(a), narativne taktike, ideologemi, mitologemi, fikcija, kulturalni studij 


\section{Uz impostaciju zadanih metodoloških okvira:}

Kako se fikcija doima udobnijim okolišem nego što je život, nastojimo život tumačiti kao da je fikcija. ${ }^{1}$ (Umberto Eco)

Što će se dogoditi s književnim kanonom ako kulturalni studiji progutaju proučavanje književnosti? Kada je teorija povrh književnih djela ohrabrila čitanje filozofskih i psihonalitičkih tekstova, mogla se čuti (...) optužba - studenti su odvraćeni od klasika. No otvarajući vrata različitim čitanjima 'velikih djela' (...) teorija je oživjela tradicionalni književni kanon. (...) Hoće li kulturalni studiji imati isti učinak - omogućiti nove kontekste i povečati raspon pitanja $(\ldots) ?^{2}$

(...) ja ću - ja istina - biti prema vama velika varalica, jer moji putevi ne prolaze samo kroz laž. ${ }^{3}$ (Jacques Lacan)

Mit se ne može definirati prema predmetu svoje poruke već prema načinu na koji se iskazuje poruka: postoje formalna ograničenja mita, ali nema 'sadržajnih'.

${ }^{1}$ Pogledati poglavlje „Protokoli fikcije“ u hrvatskom prijevodu Ecove knjige: Šest šetnji pripovjednim šumama, Zagreb, Algoritam, 2005.

${ }^{2}$ U poglavlju o kulturalnim studijima i književnosti, v. Jonathan Culler: Književna teorija - vrlo kratak uvod, Zagreb: AGM, 2001, dakle u hrvatskom prijevodu. U dijelu teksta koji prethodi, Culler piše nešto što je posebno važno za ovu našu (post)kolonijalnu analizu: „Rad u kulturalnim studijima osobito je osjetljiv na problematičan značaj identiteta, kao i na višestruke načine njegova oblikovanja, doživljavanja i prijenosa. Osobito je, stoga, važno proučavanje nestabilnih kultura i kulturalnih identiteta koji se javljaju kod grupa - etničkih manjina, imigranta, žena - koje mogu imati poteškoća u identificiranju s većom kulturom u kojoj su se zatekli, kulturom koja je i sama klizni ideološki konstrukt“" (isto, str. 57).

${ }^{3}$ Pogledati poglavlje „Frojdovska stvar“ u srpskom prijevodu Jacquesa Lacana: Lakan, Žak: Spisi, Beograd, Proseveta 1983. U tumačenju tog teksta Kordić (2007) kaže: „Zacelo, putevi književnosti (ni političkog) ne prolaze samo kroz laž, kroz fikciju. Ali i ne zaobilaze laž“. Uostalom na Lacanovu tvrdnju iz seminara „Od Drugog ka drugom“ koja glasi ,ja sam čista artikulacija iznesena poradi vaše pometnje“, Alien Badiou je rekao kako su „Nauka, umetnost i ljubav procedure aristokratske istine“ (Kordić, 2007:21), „Izvan ove istine ostaje istina zajednice (pravo mesto politike, ali i književnosti - i jedinstvenosti jedinke, jedinstvenosti aristokratske istine), društva, duha vremena“ (isto).

${ }^{4}$ Ovo je moj prijevod iz zbornika A Ronald Barthes Reader (v. literaturu), poglavlje „Myth Today“ (iz: Mythologies, Paris, 1957. engl. prijevod 1972). 
Konstrukcija, prenošenje i preoblikovanje priče(a) o nacionalnim identitetima...

\section{Konstrukcije Krleže i Andrića: (krausovska) Srednja Europa i (saidovski) Orijent}

Ovaj rad bavi se pitanjima čitanja stereotipiziranih mitologema u promijenjenom i fikcionaliziranom povijesnom okružju globaliziranog svijeta 'konstruiranih istina' koji se prema lokalnoj identifikaciji postavlja agresivno i (post)kolonijalistički. Otuda upravo ova četiri citata koji su navedeni ispred Uvoda, a čiji autori stoje u temeljima kulturalnog studija koji uvažava autohtonost, društvenu uvjetovanost i intertekstualnost književnog teksta. To čini premještajući ga iz područja zatvorenosti u 'posebno područje' natrag u prostor multidisciplinarne diskursivnosti koja uključuje razne interese, od semiotičkih studija, preko antropologije pa sve do kognitivne psihologije. Pri tom ne želim zaobići činjenicu o ključnoj ulozi kognitivnih procesa i ideje 'podteksta' koji uvjetuje naše čitanje tekstova stvaranjem predodžbi tijekom procesa jezične komunikacije. Samo naglašavam onu drugu, društvenu i ideologijom zasićenu iskustvenu diskursivnu uvjetovanost pojedinaca i grupa koje žive u određenim uvjetima i nameće im se određeni ideološki, ali i jezični obrazac. ${ }^{5} \mathrm{U}$ takvom se diskursivnom okruženju lokalna identifikacija iščitava u odnosu na dominantnu kulturalnu paradigmu zasićenu novim medijima, njihovom konstrukcijom stvarnosti i istine, čitanjem ideologema iz dekonstrukcijske perspektive i „novim jedinstvom“ (medijskim i političkim) na području odnosa između ,sukoba svjetova“, odnosno prostora u kojem je došlo do „eksperimenta“ u obliku sukoba religija, identifikacija i steretipa koji su na temelju njih oživljeni, nerijetko i putem referiranja prema autorima kojima se ovdje bavimo.

Predlažemo da se ovdje na trenutak zamislimo nad načinom na koji takav jedan problem ,izmišljenog (uprizorenog) rata“ (sukoba između ,različitih svijetova" - ovoga puta ne u Bosni nego na Bliskom Istoku) vidi iz suvremene perspektive Jean Baudrillard u svojoj kontroverznoj knjizi o pragmatičnom podsticanju sukoba (konstruiranim i namjerno izazvanim) putem konstrukcije narativa o mogućoj mržnji „,svjetova“ koji nastanjuju suvremeni sukus različitih kulturalnih paradigma. ${ }^{6} \mathrm{U}$ postmodernoj konsolidaciji teksta

${ }^{5}$ O ovom više u M. Biti i D. Marot Kiš (2008:64-66). Knjiga se bavi upravo ,ppoetikom uma“ i opisivanjem procesa stvaranja (metaforičkih) predodžbi. Citira mnoge kognitivne lingviste, uključujući i autore koji su se bavili neuroznanošću. Ali pri tom se, unatoč pozornosti na konsolidaciju, ,čovjeka“ u tekstu, neprekidno naglašava ovaj društveni, politički diskurs ,koji obiluje iskazanim formulama kojima je cilj - a nerijetko i učinak - oblikovanje svijesti koja pogoduje održanju moći ...".

${ }^{6}$ Riječ je o prikazu ,sukoba civilizacija“ u obzorju horizonta očekivanja o kojem u svojoj kontroverznoj knjizi piše Jean Baudrillard. Ovdje citirano izdanje je englesko, u prijevodu Chrisa Turnera. V. Baudrillard, 2005. Posebno inspirativno za raspravu o „krvavom zidu“ u Andrićevim esejima o Njegoševom kosovskom mitu djeluje poglavlje 
koji aludira na razumijevanje drugosti kao vrijednosti, Baudrillard piše o simulakri, simulaciji dakle, sukoba koja je proizvedena medijskom manipulacijom zasnovanom na zaoštravanju retoričkog odnosa suprotstavljenih kvalitativnih (religijskih, kulturoloških) razlika između civilizacija, odnosno ,suprotstavljenih" kulturalnih obrazaca. Takvih je pozicioniranja u povijesnom narativu lokalne identifikacije u odnosu na druge bilo mnogo, daleko prije sukoba u Zaljevu, ali i paralelno s njime. Mnogi se od njih nisu ostvarivali kroz manipuliranje medijskim prividom, nego su svoje uokvirenje i uporište pronalazili u mitu, u predaji i legendi, odnosno u njihovim aproprijacijama i naturalizacijama koje su često imale pragmatički nagovor i politički stav, ili su ih barem podražavale. ${ }^{7}$

Radovi lokalnih, južnoslavenskih autora o kojima će ovdje biti riječi u takvom se kontekstu danas iščitavaju na dvije razine od kojih druga, koja će biti pojašnjena kasnije, bitno utječe na prvu. Najprije, tu je prva razina, ona koja se tiče stereotipizacije mitskog iskustva i pretvaranja mitologemski zasićenog čitanja ,tradicijom“ u čitanje zasićeno ideologemskom razinom nagovora. To se zbiva knjiškom aproprijacijom mitskog iskustva i njegovom naturalizacijom u pragmatičke intencijske svrhe, bilo da su one dio pripovjednog nagovora određenog ideologemskog sloja autorske zasićenosti, ili su uvjetovane diskursivno. U takvom je kontekstu stvaranje imaginarnih zajednica (nacija, etniciteta, kolonijalnih konglomerata i postkololonijalnih urušavanja paradigmi) bitno uvjetovano modelom ideološki impostirane autorske instance u tekstu, odnosno, često, fingiranjem autorske model instance da „misli ono što ne misli“ ili „da hini mišljenje koje nije pravo“. Takav nagovor čitatelj treba prepoznati na trasi razumijevanja teksta. Tradicionalno, riječ je o ironiji, a u ovim konkretnim slučajevima, vidjet ćemo kasnije, o postmodern(ističk)om uokviravanju razlike u odnosu na zadane „velike priče“ unutar kojih se, opet tradicionalno, očekivalo od naratora da ugrade svoj iskaz, ne suprotstavljajući se hegemoniji prevladavajućeg diskursa. Lokalno identificirana, ovakva razina pričanja nacije uglavnom je usmjerena prema vlastitom korpusu, nacionalnom i književnom. To znači da se lokalizira, na-

„Najednostavnije rješenje“ (The Easiest Solution u Turnerovom prijevodu) s dijelovima „Želite li biti slobodni“ i ,Želite li biti netko drugi“. Poglavlja aludiraju na ,pozapadnjivanje“ iračke i općenito srednjoistočne percepcije društva i sustava vrijednosti. Je li diskursivno povezivanje sukoba o kojem je ovdje riječ komplementarno s Andrićevim interpretacijama Njegoševa stiha „Neka bude što biti ne može!““ pokušat ćemo ispitati ovdje. Inače, o istom problemu posvajanja metaforom, ali iz lingvističke, odnosno retoričke perspektive pisao je Lakoff (Metaphor and War: The Metaphor System Used to Justify War in the Gulf. V. i u M. Biti i dr.; 2008)

${ }^{7} \mathrm{O}$ aproprijacijama i naturalizacijama ,zbilje“ određenog povijesnog razdoblja pisao sam u knjizi: Ironija i roman: Krležinim labirintima. Zagreb, Naklada MD, 2003. 
Konstrukcija, prenošenje i preoblikovanje priče(a) o nacionalnim identitetima...

turalizira i vrši aproprijacija lokalnog mitskog iskustva. Drugi pri tom ostaje u multikulturalnom ne-dodirivanju. On je tu, ali ipak „tamo“. Na taj način Miroslav Krleža, na primjer, gradi neke od svojih konstrukcija drugosti u odnosu hrvatskog i mađarskog kompleksa i njihova međusobnog ogledavanja, odnošenjem koloniziranog i kolonizatora kao dva različita agensa. U fikcijskim tekstovima to posebice čini kroz lik Joje u odnosu prema Emeričkom junioru, te $\mathrm{u}$ ispreplitanju rekonstruiranih scena odnosa istog Emeričkog mlađeg i ljubavnice mu Ane Borongay u Zastavama. No sve se to zbiva u okviru jednog kulturalnog modela. Ironični odmak autorske intencije u tom narativnom kompleksu je skokovit i narativna tekstualna ravan neprekidno se bori za izlazak iz teksta u prostor izvantekstualnog okvira, što joj uglavnom ne uspijeva.

Druga se razina odnosi na šire zamišljen prostor uklapanja, bilo da je riječ o uklapanju u književne paradigme (zapadnog književnog kruga, na primjer) ili o uklapanju u mehanizme proizvodnje nacije u širem kontekstu. To je multikulturalističko uokvirenje drugim kao vlastitim odrazom ili, mogli bismo reći da govorimo o uklapanju u šire zadane paradigmatske identifikacijske obrasce koji reflektiraju prema „nama“ kao dijelu cjeline. Takav pokušaj „odmaka“ imamo na primjer ako se usredotočimo najprije na ,pogled izvana" (Said, 1999), ali i razliku koja fingira da je izvanjska dok istovremeno taj konstruirani pogled izvana koristi kao oruđe onog (autorske instance) koja gleda iznutra, što je posebno prisutno u romanu Iva Andrića. Tako bi bilo vrlo zanimljivo detaljnije analizirati i usredotočiti se na razliku u Davilovu (Daville) i Defonseovu (des Fossés) ,čitanju Bosne“ u Travničkoj hronici. Andrić uspostavlja perspektivu fingirane razlike iz dva tipa drugosti koja potpadaju pod isti identifikacijski obrazac, a sve da bi stvorio fikcijsku, romanesknu sliku o Orijentu iz perspektive Zapada, onako kako je on kao instanca najbliža implicitnom autoru vidi. To čini gradeći konstrukciju drugih perspektiva i „hineći mišljenje koje nije pravo“ kroz suprotstavljanje dva konstruirana identifikacijska obrasca. Tako kad je riječ o ovakvim mehanizmima fingiranja drugosti, onda govorimo i o konstrukciji globalne refleksije neke lokalne sredine, odnosno o onoj „situaciji“ koja se proizvodi prikazanim reprezentacijama u tekstu. Riječ je o ideologemskom impostiranju koje se može uklopiti i čitati u imaginarnoj zajednici čitatelja koji izlaze izvan kruga zamišljenog lokalnom identifikacijom i time se tekst otvara za moguća čitanja u drugim jezicima, kulturama i tipovima ideološke impostacije i društvenog uklapanja imaginarne čitateljske (i interpretacijske) instance. Tu je prisutna svijest da osim prešućenog kontekstualnog „ostatka“ proizvedenog tekstom, valja isto tako izreći i ono što se obično prešućuje, samo treba naći načine da se to učini nenametljivo i da se ne prepozna autorstvo koje takvo čitanje sugerira, ili ga ima potenciju sugerirati. 
Drugi dobar primjer razlike prvog i drugog tipa impostiranja autorske instance $u$ čitanju nacije(a) uklopljene $u$ širi kontekst mogao bi se prezentirati kroz zamišljenu (komparativnu) analizu Andrićevih priča „Put Alije Đerzaleza“ i „Mustafa Madžar“ u odnosu prema Krležinim novelama „Hodorlahomor veliki“ i „Veliki meštar sviju hulja“. U analizi impostacije autora prema šire zamišljenom „svijetu stvarnosti“, a u odnosu prema korištenju elemenata onovremene ekspresionističke poetike, možemo naslutiti mogućnosti koje prva dva teksta donose na razini alegorijskog prodiranja u drugo i uokviravanja stanja koja prethode priči i razgrađuju legendu, time otvarajući prostor za fingirani odmak od teksta, likova i sudjelovanja u tekstu. Krležini pak tekstovi ne dekonstruiraju ,junake“, nego „obične“ intelekturalce, čime ne stvaraju alegorijski potencijal jednog mogućeg, drugog i drugačijeg, čitanja nego uvode razgradnju koja se dinamizira i čitatelju ukazuje upravo skokovitošću ironičnog odmaka, posebice u odnosu na izlaz iz zatvorenog opterećujućeg prostora (mađarskog, balkanskog, onog na kojem još uvijek gore ,turski požari“) lokalne identifikacije. Ista se dekonstrukcija zbiva i u odnosu na paradigmu tradicije književnosti koja ju je uobličila kao samostalnu književnu činjenicu, odnosno mogući svijet kojeg nam valja spoznati. Pri tom autorska instanca neprekidno prodire $\mathrm{u}$ tekst i mijenja perspektive unutar stvorenog svijeta.

Izlaskom iz tekstualne analize u područje definiranja intencijskih identifikacijskih obrazaca prema kojima tekstovi referiraju, postat će vidljiviji i načini na koji se stereotipi ograničavajućeg prostora otvaraju prema univerzalnim tumačenjima, ali, što je možda još zanimljivije, istovremeno će se pokazati na koji način impostiranja narativnih instanci doprinose učvršćivanju slike o opstojnosti legendi i predodžbi (autopredodžbi i heteropredodžbi) u odnosu na drugog prema kojem se identifikacijski postavljaju i konstruiraju svijet djela koji proizvodi nagovor na temelju vlastitog aparatorija stereotipa i kognitivnih mogućnosti razumijevanja značenja, jezičnih i društvenih. Upravo u prostoru nikad završena postkolonijalnog sukoba svjetova, ovakva se analiza može usmjeriti na rubne elemente koji uokviruju književno polje i iz takve perspektive otvaraju mogućnost identificiranja pretpostavljanog ideološkog pozicioniranja dviju intencija: pripovjedačke i čitateljske. Pri tom valja naglasiti da su izvanjsko uokviravanje i poniranje u tekst dva različita moguća polazišta analize, $\mathrm{s}$ tim da drugo često strateški proizvodi privid prvog. Kod Andrića riječ je o odnosu prema istoku (Orijentu) koji je zadao prostor vlastitim parametrima ispisivanja i ograničavajućih nametanja moći, te time odredio njihovu disperziju i ,raspored snaga“ u tekstu, a što bismo mogli nazvati tipom impostacije koju je moguće analizirati foucaultovskim pristupom. Kod Krleže to je odnos prema Zapadu kao zajedničkom prostoru susretanja koji je uokvirio prostor intelektualne paradigme, u našem slučaju 
Konstrukcija, prenošenje i preoblikovanje priče(a) o nacionalnim identitetima...

osjećajem nedostižnosti i krivice. Impostacija bi se dakle mogla analizirati freudovskom (čak lacanovskom) metodologijom. ${ }^{8}$ No u oba slučaja intencija modela autora ostaje ukazivati na „drugo“, odnosno na slojeve teksta koji korespondiraju s mitologemskim svijetom koji je na razini ideologije čitanja ostvaren tako da osim na povijesni diskurs često aludira na sadašnjost i čvrsto je politički obilježen zasićenošću su-vremenih značenjskih jezgri.

Problem vezan uz čitanje ovako (politički, ideološki) impostiranih tekstova jest problem iščitavanja autorskih intencija koje referiraju prema mitskom iskustvu i legendi kod Andrića ili urbanoj legendi, odnosno proizvedenom „narativu nacije“ kao europski determirane potencije, što vidimo kod Krleže. Ovdje je istovremeno riječ o problemu odnosa teksta i čitatelja, a ovaj je uvjetovan tekstovim diskursivnim pozicioniranjem ali i obavezujućim okvirom koji je diskurs proizveo svojim konstituiranjem u društvu i jeziku. Tu prije svega mislim na način reprezentacije koji se nadaje kognitivnom potencijalu čitatelja u odnosu prema zamislivim svjetovima $\mathrm{i}$ aparatoriju njihova razumijevanja, bilo da se radi o stereotipiziranju legendi i legendarnih ,junaka" ili o rekonstrukciji priče (stereotipa) o konsolidaciji određenog apstraktnog kulturalnog kruga. Tako jedno od ključnih pitanja koje se postavlja čitanjem tekstova ove dvojice reprezentativnih južnoslavenskih pisaca postaje ovo: kako čitati „okamenjene“ stereotipe koji su se u njihovim djelima iz područja povijesnog pamćenja (naracije nacije kao pri/povijesti u nacionalnoj povijesti, povijesti književnosti i predaji) na razini nagovora za razumijevanje teksta, preselili u fikcionalizirani prostor „svijeta djela“? Ovaj se, pri tom, tek neizravno vraća u područje lokalne identifikacije kao „kosmosa“, nečeg što je zadano i dogovoreno kao „velika priča“ o vlastitoj povijesti. Razgradnja te priče i nagovor na ,čitanje između redaka“, odnosno na autorske iskaze koji govoreći o „onda i ondje“ istovremeno sugeriraju neko „sada i ovdje“, nalazi se u središtu tekstualnog ideološkog zasićenja. Pri tom valja imati na umu da je ta velika priča zadana tradicijom, pričom o toj tradiciji i njezinom simulakrom u tekstu i kontekstualnom govoru koji proizvodi taj privid stvarnosti. Mislim da nije presmjelo reći kako je riječ o manipulacijama građom, odnosno o „zbilji“ koja je uokvirena u prostoru onog što bi Baudrillard nazvao „simulacijom“ a gdje onda dolazi i do njezina repozicioniranja u odnosu na izvanknjiževnu paradigmu. Ako pogledamo gore navedene priče/novele i konstrukcije odnosa u dva navedena romana, sve nam jasni postaju modaliteti na temelju kojih se proizvodi takva manipulacija u

${ }^{8}$ Jest, ovo izgleda nategnuto. Ali ako pomnije čitamo Lacana i njegove ideje o simboličnom jeziku moći i Foucaltove tekstove koji se bave odnosom znanja i moći, možda (čak) i nije tako! U svakom slučaju čitajući na primjer Kordićevu Politiku književnosti ili Stojanovićeve analize Andrićevih proznih tekstova (Lepa bića Ive Andrića) može se reći da ovakva hipoteza ima uporište. 
odnosu na model čitatelja kojem je tekst (teorijski gledano) upućen. Prostor i vrijeme proizvodnje sile kod Andrića zadan je kao lokalni činitelj destabilizacije koji uokviruje krajnje mogućnosti lokalnog djelovanja, identifikacije i odnosa fiktivnih i fakcijskih elemenata u svijesti čitatelja obilježenog lokalnim diskursom. Kod Krleže pak, sila služi kao izvanjski okvir unutarnjem profiliranju diskursivnih potencijala koje bi se, kad bi se reklo ono što se reći ne smije, moglo ostvariti i drugačije.

Ono, međutim, što je posebno zanimljivo kod obojice pisaca, a tiče se upravo ovih problema i njihova daljnjeg osvjetljavanja, zbiva se na razini njihovih ne-fikcijskih tekstova, odnosno onih koji se takvima očituju. Tamo se neke od ovih taktika vide jasnije a neki se ideološki zasićeni elementi poetike autora očituju izravnije, već na površini tekstova. Tako kada govorimo o esejističkim iskaznim intencijama ove dvojice autora, onda vidimo da autorske intencije uočavamo izravnije i prepoznatljive su na razini interpretacijskog konsenzusa. Nagovor se obraća podrazumijevanoj čitateljskoj intenciji ali s drugačijom impostacijom u odnosu na novele i romane, tekstove koji se bore između mimetičke i dijagetičke usmjerenosti vlastita iskaznog nagovora. $\mathrm{U}$ esejima riječ je o izravnom odnosu prema stvarnosti (možda čak i značenjskom potencijalu čitateljevom), onom koji ironičnim odmacima određuje pozicioniranje prema izvanknjiževnom području čitateljske kompetencije (tradicije i nagovora). Za razliku od romana ili novele/priče, gdje se tekstualno odnosi prema tradiciji iskazivanja kao uokvirenoj formi sa svojim potencijalima koji su zadani i dogovoreni, ovdje se na razini automatizma teži za onim što je rečeno, a ne kako je rečeno. Takvo vrijednosno pozicioniranje autora dopunski je moguće pojasniti citatima iz tekstova jer u fikcijskim tekstovima oni, ili ionako umeću slojeve esejističkog koje se prezentira „slobodnim neupravnim govorom" (Krleža), ili se autorska intencija otkriva tako što se pripovjedač pozicionira kao sveznajući arbitar (Andrić) prepuštajući prostor iskazivanja glasu koji hini da nije autorski nego pripovjedačev. Ali, kad govorimo o esejima, tu se stvar na razini odnosa instanci komplicira, premda se čini da je nagovor izravnije usmjeren. Naime, ovakvo impostiranje u prozi i jednom i drugom autoru omogućuje da se u esejističkim tekstovima stvara prostor unutar kojeg je moguće „okretati“ tekstualni nagovor, odnosno fikcionalizirati slojeve esejističkog kako bi se ostvarili intencijski efekt u obliku nametanja intencije reprezentacije koju su navedeni pisci zadali tekstu kao svoj ideološki sloj iskazivanja, upravo onaj kojeg model čitatelj treba iščitati iz teksta. Ali pri tom, tko može biti siguran da treba čitati upravo onako kako su, vokacijski, tekstovi postavili svoj nagovor? Kad Andrić kaže mi, zašto ne bi, kao u fikcijskom tekstu, mogao i dalje biti skriven iza autoriteta neke od instanci koje su u tekstu, a ne ostati, iskoračiti izvan njega? 
Konstrukcija, prenošenje i preoblikovanje priče(a) o nacionalnim identitetima...

Cijeli taj proizvedeni svijet se, $\mathrm{s}$ jedne strane, smješta u vrijednosni sustav ideologema što ih nadaje autorska intencija, a s druge u svijet djela obogaćenih novim fikcionalnim slojem koji uspostavlja odnos prema stvarnosti i to takvoj kakvu se na razini fikcijske impostacije može motivirati samo djelomično. To znači da nagovor autora u ovom slučaju pretendira ne samo na svijet djela, nego i na mitologemsko uokviravanje priče kao diskursivne zadanosti koja se nadaje iz pozicije (kulturalnog) autoriteta, dakle tradicije i povijesti u najšire zamišljenom smislu riječi.

Može se dakle reći kako u tekstovima dvojice autora dolazi do fikcionalizacije povijesnog i do pri/povijesnog uokviravanja pripovjednog kao ideološki profiliranog nagovora. Drugim riječima, povijesne ličnosti koje su obilježile „priču“ o devetnaestom stoljeću (Starčević u narativu o hrvatskoj državnosti i Njegoš u narativu o „refleksu kosovske krvi u pogledu“"9), prvi u esejističkim tekstovima Krležinim a drugi u Andrićevim, polako se kroz tekstualni nagovor fikcionaliziraju i oblikuju sustav ideologema koji prelazi razinu „,trošenja historijskog narativa“ u prijenosu pri/povijesti idućim naraštajima, postajući pri tom čvrstim mjestom ideološkog određivanja autorske instance nagovora koja postaje važna ne samo za eseje, nego i za cijele opuse ovih autora.

Ono što se oblikuje ovim tekstovima može se (pokušati) (pro)tumačiti jedino uključivanjem najšire zamišljena koncepta teorije (sa svim svojim interdisciplinarnim odvojcima, onako kako je prezentira Jonathan Culler) u prostor koji se tradicionalno zvao interpretacijom tekstova i oslanjao se na poetiku i fenomenologiju. ${ }^{10}$ Otuda i metodološke dvojbe, pozivanje na naratologiju i njezina „gramatička“ ograničenja kasnije, tijekom procesa iščitava-

${ }^{9}$ Usp. s Andrićevim esejem „Njegoš kao tragični junak kosovske misli“, I. Andrić: Umetnik i njegovo delo, Sabrana djela Ive Andrića, Knjiga trinaesta (Dopunjeno izdanje), Sarajevo, 1981: 9-10.

${ }^{10}$ Govorimo tu o teoriji onako kako ju je definirao Richard Rorty, a što nam prenosi Culler u svojoj vrlo važnoj knjizi: ona je novi žanr, odnosno ,posebna vrsta pisanja“, a koja nije „ni vrednovanje relativnog značaja književnih proizvoda, ni intelektualna historija, ni moralna filozofija, ni socijalna prognostika, već sve to promišljeno zajedno u jedan novi žanr". Na ove riječi upozorava Jonathan Culler u svojoj Teoriji književnosti vrlo kratki uvod (knjiga je prevedena i objavljena na hrvatskom 2001. godine), a Rortyija navodi i Zdenko Lešić u svojoj Teoriji književnost (Sarajevo, 2005) što ukazuje na prisutnost ovog „,novog žanra“ u hrvatskoj i južnoslavenskoj književnoj teoriji krajem devedesetih i početkom 2000-ih godina. U krajnjoj liniji i diskursivni studiji nastupaju slično, povezujući semiotiku, etnografiju, antropologiju, sociologiju, psiholingvistiku, teoriju sistema i psihologiju s drugim teorijskim disciplinama a kroz medij diskursivnog očitovanja „strukture i procesa“ konsolidacije integracijske paradigme. Ova će tek na presjecištu svih tih disciplina i tako uokvirena „očitovanje subjekta“ dekodirati one intencijske elemente teksta koji izmiču tradicionalnoj interpretaciji. 
nja autorskih i tekstualnih intencija, a time i ukazivanje na njezine ograničene mogućnosti kad govorimo o ideološkim manipulacijama tekstualnim u pragmatične svrhe. ${ }^{11}$ Time pokušavam opravdati ovdje često korištene ekskurze u teorijsko impostiranje šire zamišljenih uokvirenja i prizivanje drugih ideološki zasićenih narativa, odnosno proklizavanje iz usko zadane struke u područje multikulturalne teorije, indvidualistički impostirane interpretacije ideologija i tumačenje kulturalnih paradigmi na razini prerađivanja stereotipa u njihove kognitivne realizacije, a što sve izlazi iz okvira ,tradicionalne" tekstualne analize, onakve kakvu nam je u nasljeđe ostavila naratologija. Otuda i nastojanje da se tumačenje ,,potpomogne“ i kulturalnim studijima i dekonstrukcijskom kritikom. ${ }^{12}$

Pokušat ćemo ovdje pokazati kako Krležin Starčević i Andrićev Njegoš nisu samo teme eseja, već i intertekstualne tvorevine koje su fikcionalizacijom autorskih intencija inicirale narativ lokalne identifikacije i zaživjele u raznim oblicima političkog i kulturnog (na)govora kao paradigme koje su, uz kulturološku, zadobile političku moć nagovora i manipulativnu snagu koja proizlazi iz tekstova (knjiga i priča), ali bez sigurnosti povratka u njih kao jedini tip nagovora koji opstoji u ,priči o naciji“ i biva nam zadan kao moguće čvrsto mjesto analize. Tako zamišljen i proveden narativ svojim se pozicioniranjem u odnosu (književnog) teksta i njegova diskursivnog uvjetovanja podjednako odnosi prema povijesnom prostoru sjećanja koliko i prema fiktivnom prostoru aproprijacije vlastita iskazana svijeta ovih autora. Kakve to posljedice može imati na učitavanje (i iščitavanje) ovih opusa unutar okvira šire zamišljena koncepta intertekstualnosti (književne vrijednosti kao globalnog mitologema), pokušat ću naznačiti u daljnjem dijelu teksta. Drugo je vrlo važno, naratološki i dekonstrukcijski gledano, pitanje koliko fikcionalizacija stereotipa i njezino „re-stereotipiziranje“ obogaćeno (nagovoreno) autorskom intencijom utječe povratno na sam mitologem koji djeluje na konstantiv naracije nacije, pretvarajući ga (povremeno) u performativ spreman na (ideološki markirani) pomak prema pragmatičnoj pozicioniranosti iskoristivosti (i iskorištavanja) u ideološki determirane dnevno-političke svrhe? To smatram onim prostorom ,sivih pjega“" našeg odnošenja prema tekstu gdje iz teorije

${ }^{11}$ Tako ,gramatika teksta“ nije ovdje ta koja zadovoljava interpretacijski potencijal ovih tekstova i iz područja čitanja konstrukta izlazimo u područje dekodiranja stilizacije i „odnosa mentalnih i jezičnih svjetova“ (v. M. Biti, 2008). O tome v. i H. Porter Abbott: The Cambridge Introduction to Narrative. Drugo izdanje, Cambridge University Press, 2008.

${ }^{12}$ Pri tom novohistoricističke slojeve interpretacije i pozivanje na postkolonijalnu kritiku smatram dijelom dekonstrukcijskog ,razgrtavanja površine“ i impostiranja u povijest i odnos moći, uz raskrinkavanje diskursivnih zadatosti hegemonijom čiji jezik, u obliku lacanovskog simboličnog jezika, vlada određenom paradigmom.. 
Konstrukcija, prenošenje i preoblikovanje priče(a) o nacionalnim identitetima...

izlazimo u politiku, iz politike u manipulaciju, a iz manipulacije u interpretaciju mitskog iskustva kao (fingiranog) znanstveno ovjerljivog prostora djelovanja humanistike.

I na kraju ovog prvog dijela teksta u kojem je postavljeno nekoliko ključnih pitanja i gdje je naznačen okvir izlaganja, želimo postaviti možda najvažnije pitanje, ono koje je vezano uz nagovor teksta u zajednici, odnosno želimo upozoriti na činjenicu koja ukazuje na konstataciju da nagovor teksta jednako ovisi o kodiranju književnog teksta u odnosu prema zajednici, koliko i o šire impostiranom društvenom mitologemu (naracije nacije) u odnosu prema književnom tekstu. Pitanje je ovo: koliko taj nagovor djeluje na samu promjenu kulturalne, političke pa čak i ,strateške paradigme“ koja definira i određuje naciju i nacionalno u odnosu na druge? Navest ćemo primjere takvog nagovora. Riječ je, najprije, o slučaju (mogućeg) odnosa kosovskog mita, onako kako ga je impostirao Andrić u navedenom eseju, i to u odnosu prema određenim događajima u Bosni sredinom 1990-ih. Drugi je primjer odnos ideje repozicioniranja ,vertikale Starčevića“ u reafirmaciji performativa malograđanske ideje „elitnog hrvatstva“ u nacionalnoj političkoj paradigmi krajem osamdesetih i početkom devedesetih godina prošlog stoljeća. Pri tom oni (dakle Oni koji djeluju pragmatički prevodeći jezik fikcije u jezik nagovora) ni sami nisu svjesni da se, djelomično, pozivaju i na Krležinog, fiktivnog Starčevića, onako kako su ga u paradigmu prijenosa mitologema ugradile priče. A u tom kulturalnom okružju važno je zapitati se misli li se pri tom na komplicirani odnos fikcijskog i fakcijskog, ili mitsko iskustvo „,zadane paradigme" preuzima primat na temelju kojeg gradi svoju priču koja je podložna aproprijaciji fakcijskog sloja u svrhu konkretnog i jednokratnog političkog nagovora? ${ }^{13}$

\section{2. $O$,postkolonijalnom stanju stvari"‘: suprotstavljanje globalne i lokalne identifikacije u tekstu i diskursivnom okruženju}

Ovdje je dakle riječ o konstrukciji Krležina Starčevića i izravnijoj, s obzirom na impostaciju tekstova, gradbi konstrukta Andrićeva Njegoša koji je iskaz(iv)an u nekoliko eseja skupljenih u istoj knjizi Sabranih d(j)ela. U okviru postkolonijalnog okruženja druge Jugoslavije (u odnosu na austrougarsku i tursku pa onda kraljevsku jugoslavensku kolonijalnu situaciju), rekonstrukcija kolonijalne zbilje i utvrđivanje kolonijalnih odnosa u SFR Jugo-

${ }^{13} \mathrm{U}$ tom je smislu zanimljiv nagovor predsjedničkog kandidata Milana Bandića, bivšeg uglednog člana Socijalno demokratske partije Hrvatske, koji u svom predstavljanju predsjedničke kandidature i programa ne govori o budućnosti zemlje, zdrastvenom osiguranju, mirovinskim fondovima ili pokretanju gospodarstva već o „starčevičevštini i radićeveštini“" kao svom programu. V. Jutarnji list, 5. studenog 2009. 
slaviji dio su taktika na koje treba obatiti pozornost prije svega kod Krleže, ali i kod Andrića, gdje također naslućujemo naznake određenog ,disidentstva" u odnosu na vladajuce paradigme usuprot kojih su tekstualni ideologemi njihovih djela poslije Drugog svjetskog rata zapis(iv)ani. Kod Krleže to se vrlo dobro vidi u Zastavama. Premda taj roman funkcionira na nekoliko ironičnih razina komunikacije (prije svega na onoj gdje se hini mišljenje koje nije pravo, i to na makrostrukturalnoj razini) $)^{14}$, a čak je moguće govoriti i o alegorijskom sloju tog romana, isti je kompleks prisutan i izrican kod Andrića, ali je broj djela koja se mogu čitati „,na trasi i putanji razumijevanja“ manji s obzirom na njegovu impostaciju u prostor i vrijeme. Tako se u ovom drugom slučaju na razini imaginarnog autorstva hini da je čitanje „onog i ondje“" u odnosu prema ,sada i ovdje“ teže ostvarivo.

Da je tome tako, vidimo u romanu Prokleta avlija. Tamo bi se, izgleda, impostacije teksta mogle nategnuti do sinteze u kojoj bi bilo moguće tvrditi da značenjski slojevi teksta sugeriraju kao da se sublimira sve ono što je Cesarec izrekao u Carevoj kraljevini te se, paradigmatski, potpuno neizravno i na razini interpretacije intencijski, može reći kako taj tekst nehotično najavljuje i roman slovenskog pisca Drage Jančara Zujanje u glavi, tekst koji barata sličnim alegorijskim aparatorijem. Premda je odreda riječ o alegorijskim tekstovima, različite razine ironijskih konstrukata $\mathrm{u}$ glasovitom Andrićevom tekstu vrlo su očigledne i funkcioniraju na nivou različitih razina otklona od trase razumijevanja „,doslovnog“ značenja. Kod tekstova iz tog razdoblja postoji element uokviravanja koji djeluje na dvije razine: na razini vremena koje se pripovijeda, ali i odnosa autorske instance s vremenom pripovijedanja kroz neke elemente putanje razumijevanja teksta. Postkolonijalni tekstovi nisu se oslobodili balasta uokviravajuće paradigme kontinuiteta i naslanjaju se na dijakroniju kao na svoju vertikalnu impostaciju. ${ }^{15}$ Istovremeno, povijesni likovi postaju ,junaci“ opstojnosti naroda prema čemu se tekstualno odnosi kao o povijesnoj činjenici, a dekonstrukcija ostvarene situacije samo je jedna opcija u različitim mogućim čitanjima, odnosno postaje izlet u moguće. A onda opet: u takvim se tekstovima izravno impostira misao o linijskom tijeku dijakronije koja je zadana i na razini razumijevanja teksta ovisna o njezinim mogućim ,odrazima“ na druga i drugačija povijesna

${ }^{14} \mathrm{Na}$ drugom mjestu (Škvorc, 2003) pokušavamo pokazati da se neki dijelovi teksta u kojima razgovaraju Emerički Junior i Senior jednako mogu odnositi prema situaciji u tzv. Drugoj Jugoslaviji, kao i u zadnjim dijelovima dvije prethodne kolonijalne tvorevine.

${ }^{15} \mathrm{U}$ drugom izdanju zbornika radova Arama H. Veesera pod naslovom The New Historicism (1994.; prvo izdanje je iz 1989.) u novohistoricističkom se ključu čitaju i tekstovi koji ne pripadaju korpusu renesansne književnosti, a uključene su i suvremene knjige koje se re-konstruiraju iz perspektive „sada i ovdje“. 
Konstrukcija, prenošenje i preoblikovanje priče(a) o nacionalnim identitetima...

očitovanja, a ne o de(kon)strukciji priče o naciji (što se može naslutiti iz pozicioniranja pripovjedača u gornja dva romana). Fra Petrova zatočenost u Prokletoj avliji orijentalnog zatvora jedan je način čitanja tog romana koji ukazuje na povijesnu uvjetovanost ,priče o teškom životu“ franjevaca i raje općenito pod Turcima. Priča o simboličkom zatvoru kao „tamnici naroda“, a koja se ne odnosi samo prema kolonijalnom vremenu nego i prema vremenu „ideološki determinirana zatvora“ kao stvarnog simboličnog potencijala, otvara posve drugačije mogućnosti tumačenja teksta. Uzimajući ozbiljno u obzir ovakvo čitanje „zatvora“ kao paradigme jednog vremena i prostora, odnosno određenog rasporeda moći u okviru jedne političke i kulturalne paradigme, može se onda utjecati na drugačije čitanje drugih tekstova, onih koji nisu programatski i koji impostacijski ne nastupaju tako izravno u odnosima vlasti i moći, odnosno u odnosu diskursivno zadanog „ondje i tada“ prema „ovdje i sada“.

Tako mislim da je moguće reći kako je navedena polazišna postavka o proklizavanju značenjskih paradigmi iz polja u polje i iz jedne ideološke impostacije u drugu, zapravo polazište koje se u odnosu na esejističke tekstove može sažeti u konstataciju da je iz navedenih pripovjednih impostacija moguće dekodirati da oblikovani stereotipi „hrvatstva“ i „kosovskog mita“, odnosno stereotipiziranje i fikcionaliziranje likova Ante Starčevića i Petra II Petrovića Njegoša (Rada Tomova) u esejističkim tekstovima Miroslava Krleže i Iva Andrića pripadaju postkolonijalnom imaginariju pripadajućih lokalnih zajednica, njihovih odnosa prema „stanju stvari“ i njihove pragmatične uloge u svijetu i narodu (nacijama) u kojima su pričani i prema kojima se odnose. Ti imaginariji su utemeljeni na iskustvu kolonijalno zadanog i uokvirenog nacionalnog iskustva, ali istovremeno i njegove (njihove) vremenski sukcesivne negacije iz perspektive drugačijeg tipa aproprijacije i fikcijskih tekstova koji su znakovi oporbe vlastitom glasu pripadanja određenom kompleksu, odnosno njegovoj (njihovoj) potencijalnoj drugosti u odnosu na rekonstruiranu priču „,nacije“ i konstruiranu priču „zajedništva“ koja (koje) se prožima(ju) u povijesnom tekstu.

Oni svoje podvajanje nacionalne priče i stvorenih steretipa crpe, $\mathrm{s}$ jedne strane, iz postojećih snažnih narativa ,naracije nacije“ kao jake povijesne činjenice, tradicije koja se prenosi u mitu, političkom (na)govoru i utvrđenom književnom i politički zasićenom polju lokalne identifikacije. No, istovremeno, to se zbiva iz pozicije i manipulacije koju tako zadana nadređenost govora „snage“ proizvodi svojim nagovorom. S druge pak strane, mislim da je važno reći kako u svojim esejima autorska fikcionalizacija likova dvaju povijesnih ličnosti doprinosi preoblikovanju i regeneriranju stereotipa najprije ih, s jedne strane, učvršćujući u nacionalnom narativu ,pričanja nacije“, odnosno u kontinuitetu koji traje od kolonijalnih do postkolonijalnih vreme- 
na. Ali, također, ona ih potom, s druge strane, odmah dekonstruira u obliku prepoznavanja mogućih fokalizatora alternativnih opcija, odnosno kroz pronalaženje puteva prenošenja konstante predaje i povijesne (ideološke) zadanosti u obliku čvrstog mjesta (orjentacije u prostoru i vremenu).

Kroz fingirani proces fikcionalizacije likova Starčevića, odnosno Njegoša i, na temelju povijesnih predložaka, stvaranje (gotovo) književnih likova od njih, takvih koji se mogu prenositi iz teksta u tekst, dakle intertekstualizirati, otvara se mogućnost ne samo pre/pričavanja pri/povijesti, već i intermedijalizacije, to jest prenošenja ovog imaginarija iz medija u medij, iz teksta u kontekst, iz priče u povijest $\mathrm{i}$ iz povijesti u priču. Pri tom se misli na prijenos imaginarija i mitologemski dogovorenog sloja „istine fikcije“ iz književnog teksta u politički govor, iz političkog govora u pragmatični nagovor a iz pragmatičnog nagovora natrag u ,,̌isto“ mitsko iskustvo koje opravdava počinjeni performativni čin, i to takav koji zadobiva konotativnu ulogu pragmatičnog nagovora. To znači da se situacijski dobiva takav tip uvjeravanja koji se ponaša ne-fikcijski i zadobiva tendenciju da djeluje u „stvarnom svijetu“" ne-fikcije. Upravo otud dolazi do mogućnosti da iz Andrićeve interpretacije Nenadovićeva nagovora o tome kako „su na Kosovu naša prava zakopana“ (a o čemu svjedoče čak i ,namučene žene koje su se odmarale pored bremena drva na kamenoj ivici puta“) ili Krležina nagovora o „krčmarskom hrvatstvu“ s ,figom u džepu“ koje se motivira bidermajerskim pozivom na starčevičanski zamišljeno „državno pravo“ ${ }^{16}$ dolazi do mogućnosti iščitavanja nekih od današnjih paradigmi fiktivne konstante koja se, sublimirana književnim tekstom, vratila u ideologemski život koji oblikuje „naraciju nacije“ ne samo kao „naroda“ nego i u pragmatički nagovor državnih (nacional/ističk/n/ih) elita koje posjeduju istinu moći (novac, političku snagu ili nešto treće). Tako je obrazac, onaj koji je određen racionalizacijom priče, bivajući prenošen iz teksta u tekst, performativno transformiran ili iz (na)govora u (na)govor. Na taj je način on intencijski uvjetovao tip ponašanja postkolonijalnih osloboditelja /oslobođavajućeg narativa/ i činitelja oslobađajuće pa-

${ }^{16}$ Ovdje ne bi bilo na odmet citirati odlomak iz Krležina eseja „Malograđanska historijska shema“ (Odlomci predgovora za studiju o hrvatsko-srpskom problemu): „Nepoznati, prezreni i izrugivani, barbari za Zapad, a Švabe za pravoslavni Istok, Hrvati trče za svojom Modrom Pticom Slobode uvijek u bolećivom zanosu za obmanom i lažima, razdirani poetskom inspiracijom za ostvarenjem svojih ideala, uvijek podjednako ustrajno u nerazmjeru prema stvarnosti“, Eseji i članci IV, Sabrana djela Miroslava Krleže, Sarajevo, 1979, str. 102. Ur. Anđelko Malinar. Ovako sublimiran oživljeni mitologem utemeljen na temelju starčevićanske ideje, kasnije će omogućiti podrivanje paradigme (što kod Andrićevih mitologema iz esejistike obično nije slučaj), ali će istovremeno, u čemu je često bit ironične dinamike Krležinih tekstova, djelovati i doslovno: kao patetični program borbe za bolju prošlost. 
Konstrukcija, prenošenje i preoblikovanje priče(a) o nacionalnim identitetima...

radigme, i (p)ostao mjerilom ,stanja stvari“. On se kretao od priče okovane fiktivnim zajedništvom koja obavezuje, do priče o uvjetovanim okolnostima kao potencijalima za propitivanje mitskog iskustva. Tako je u tom procesu „fluktuacije“ teksta doprinio uslojavanju posebnosti, razlika između naroda, njihovih tradicija i njihovih narativa borbe za vlastito oslobođenje od zadatosti okvirom, Orijentom, kolonizacijom ili samo narativnom taktikom autorovom.

Prije Krležina Starčevića i Andrićeva Njegoša stereotipi „starčevićanstva“ (kao sna o vlastitoj državnosti na temelju povijesnog prava i na temelju mnogobrojnih interpretacija tog ,sna“ koje su često bile dosta antagonističke prema drugom) i „,kosovskog mita“ (u obliku narativnog otpora muslimanskoj dominaciji i „ostvarivanja nemogućeg“, što je upravo andrićevska impostacija do određene mjere, neizravno, naravno, usmjerila prema „krvavom zi$\mathrm{du}^{\text {“ }} \mathrm{u}$ odnosu na druge $)^{17}$, bili su prikraćeni za dimenziju svijesti o intencijskoj i hegemonistički impostiranoj vanknjiževnoj i književno-povijesnoj manipulaciji autorskim tekstom, odnosno onakvim manipulacijama kakve su kasnije ostvar(iv)ena kao pragmatični „nagovor“ navedenih tekstova. Naime, kroz tekstove dvojice autora (u Krležinim esejima, ponajprije u Deset krvavih godina ali i u eseju o Križaniću i Predgovoru podravskim motivima te u Andrićevim tekstovima o Njegošu i Vuku Karadžiću; odnosno posebno u tekstovima Njegoš kao tragični junak kosovske misli, Njegoš u Italiji, Večna prisutnost Njegoševa i Optimizam Vuka Karadžića) „Njegoš“ i „Starčević“" zadobivaju značenje fikcijski zadanih ideologema i nadilaze prostor oblikovanja priče kao fikcije o vlastitoj povijesti. Tako cijeli proces kroz književnu ideološku manipulaciju postaje intelektualno ovjeren i knjiški regeneriran kao ovjera i zaokruživanje priče koja se „ne nadovezuje u povijesni niz“ nego ga svojom snagom istovremeno dopunski oblikuje (s uvjerenjem tumači) i dekonstruira, postajući istovremeno nagovor naracije nacije i činitelj njegovog isključivanja iz sukcesije vremenske diakronije. Tu je važno napomenuti da, paralelno s procesom dekonstrukcije mitologema koji je živio prije, bilježimo i njegovu rekonstrukciju s novom sintezom. Ona je obogaćena ne samo slojem uključivanja predaja i legenda u autorski tekst, već i autorskim fikcij-

${ }^{17}$ Usp. Radovan Vučković: Andrić, istorija i ličnost, Beograd, Gutembergova galaksija, 2002. Na str. 78-80 Vučković komentira Andrićeva Njegoša (iz I. Andrić: Sabrana djela, XIII) i citira: „Ali za Njegoša je veliko i moćno Osmanlijsko Carstvo bilo uistinu oličenje pakla na zemlji, ovaploćen princip zla sa kojim mu dužnost nalaže boriti se bez kolebanja i pomirenja (...)“. Stereotip ovog prostora kao mjesta „,borbe Istoka i Zapada“ podražava se sudbonosnom ulogom „našeg naroda“ koji je, kako Vučković citira iz Andrićeve doktorske dizertacije, tu smješten tako da ,prepolovi i podvoji našu nacionalnu celinu svojim krvavim zidom“. Ovaj će mitologem, moglo bi se izvesti iz navedenog, kasnije izgraditi vrlo snažan narativ imaginarne zajednice koja je u ,stvarnom životu“" postala spremna na radikalne mjere, uključujući etničko čišćenje. 
skim slojem koji re-konstruira ono što je preneseno. Riječ je o sloju nagovora koji su u tekstu različito prepoznavala drugačija čitanja ali i čitanja različito diskursivno uključena, od onog koje je bilo suvremeno autorskom iskazu, do današnjeg koje koristi svoje manipulacijske taktike „novog historicizma“ kako bi vlastitom nagovoru prilagodilo proizvedene mitologeme i ideologeme koji se mogu iščitati iz tekstova prošlosti. Koliko od navedenog ostaje unutar granica književnog iskazivanja, a koliko izlazi iz okvira teksta i prelijeva se u kontekstualno uključenu diskursivnu praksu oblikovanja i preoblikovanja imaginarne zajednice (nacije) kao prostora svjesne manipulacije, pitanje je koje mi se čini najvažnijim u ovoj raspravi o konstrukciji, prenošenju i preoblikovanju priče(a) o nacionalnim identitetima.

Kako se ovdje bavimo tekstom, odnosno pripovješću (story) više nego li povijesnom interpretacijom i re-konstrukcijom (history), mislim da je polazište sad već posve jasno, a ekskurzi iz tekstologije u prostor kulturalnog studija unaprijed opravdani, čak i neophodni, s obzirom na odnos između priče i diskursa (s njegovim tendencijama prema uspostavi hegemonije i ,vladajućeg“ jezika), koji se dinamizira na razini interpretacije tekstova. A što se tiče preplitanja raznih diskursivnih zadanosti, kad govorimo o „korištenjima teksta“ u razne (ideološke, kulturološke, pragmatične) svrhe, proučavanje takvih trošenja teksta i rekonstruiranje raznih tipova nagovora nisu dijelom naših diskursivnih taktika, ukoliko ne reflektiraju prema hegemoniji diskursa koji uokviruje priču (story) i njezine uvjete nastanka (discourse). Ovdje se opravdanje za priču traži u izvornom nagovoru, odnosno nagovorima tekstova o kojima govorimo, onako kako se reflektirala u originalnom okruženju i kako mi danas možemo shvatiti autorsku intenciju i njezinu (njihovu) diskursivnu zadanost. Ali da mnoge stvari ne bi ostale nejasne i izvan „okvira" teme, valja najprije odrediti dominirajuće metodološko polazište iz kojeg ćemo pristupiti ,velikim“ temama Starčevića i Njegoša. To treba učiniti s posebnim naglaskom na promatranje tekstualne prakse kao ishodišta istraživanja i kulturalnih studija, i njihove primjene u zapadnoj književno (i kulturološki) istraživačkoj praksi, kao discipline kojom nam se, na razini prepoznavanja agensa pokretanja određenih procesa koji uokviruju tekst, valja pomoći u procesu rada s tekstovima i njihovim diskrzivnim uokvirenjima. Pri tom problemu uvijek valja prilaziti s prisutnom sviješću o tome da su nam u središtu zanimanja konkretni autori i tekstovi, a da šira slika „stanja stvari“, rekonstrukcije agensa koji pokreću određene procese u odnosima moći i dominaciji priča, može funkcionirati jedino u suodnosu s drugim analizama koje smo poduzeli ranije vezano uz ovu dvojicu autora i postkolonijalno pozicioniranje kulturalnog kompleksa o kojem govorimo.

Stoga na ovom mjestu smatramo opravdanim postaviti pitanje koje će definirati okvire rasprave i zadati njezine izvanjske ograničavajuće činitelje, 
Konstrukcija, prenošenje i preoblikovanje priče(a) o nacionalnim identitetima...

kako se iz pozicioniranja u području teorije i kulturalnog studija ne bismo našli u vrlo nezahvalnoj situaciji da se moramo provlačiti kroz trusno područje oprimjerivanja diskursivnih odnosa dnevno političkim govorom i njegovim učincima na suvremenu stvarnost, onu i onakvu iz pozicija koje o navedenim tekstovima često u pragmatičnom (na)govoru progovaramo i ,trošimo ih“ u pojedinačnim političkim nagovorima. Oni naime na taj način „troše“ test(ove) i pripitomljavaju ih uvlačeći ih u vlastiti hegemonizirajući okvir. To je, dakle pozicionirati se istraživački, potrebno učiniti i s obzirom na redefiniranje polazišta u istraživanju povijesno-književno označenih činjenica unutar književnoznanstvenog diskursa, ali i u odnosu na ostale discipline koje sa znanošću o književnosti graniče i u službi su ovog „probijanja okvira“, a o kojima smo govorili definirajući Rortyjevo polazište u procesu interdisciplinarizacije sustava povijesti i teorije književnosti.

Ponavljamo, to što ovdje u prvom planu neće biti spoznaje tih graničnih disciplina (pogotovo na pragmatičnoj razini nagovora) i rezultati istraživanja koje one postižu u dodiru teksta i konteksta te pozicioniranja individualnog i kolektivnog subjekta u prostoru diskursivnog ostvarivanja, nije posljedica minoriziranja interdisciplinarne teorije i kulturalnih studija kao susretišnog područja raznih sustava znanja i metodologija koje uključuje više tipova različitih diskursivnih praksi i osvjetljava problem nacionalnog pozicioniranja u širem kontekstu iz više perspektiva, pa time i kompleksnije, jasnije i zaokruženije. Razlog je tome činjenica da ovdje u prvom planu imamo određene povijesno determirane tekst(ove), najprije kao književnu(e) činjeni$\mathrm{cu}(\mathrm{e})$ a onda i kao iskaze koji svojim diskursivnim ostvarivanjem od strane čvrsto definiranog ,jakog“ kolektivnog iskaznog subjekta utječu na mogući dogovor o drugačijem shvaćanju originalnog teksta koji se promatra, odnosno prenosi iz naraštaja u naraštaj, reciklirajući mitologeme i proizvodeći uvijek nove ideologeme. Smatramo da bi za rezultate ovog istraživanja proklizavanje u druge discipline, koje bi im donijelo poziciju drugog u odnosu na ishodišnu paradigmu, utjecalo na tumačenje teksta, ali bi istovremeno zakompliciralo početnu postavku i ideju da se ovdje prije svega bavimo rubnim područjem na kojem tekst prelazi u priču o naraciji nacije, ali i obrnuto. Priča bi naime mogla postati potrošena, a pozicioniranje stereotipizirano i uvučeno u hegemoniju odnosa političkog diskursa moći. Pod tim mislim na intertekst naracije nacije i njegovo uključivanje u prostor pričanja koji zadobivaju vlastiti nagovor i postaju ,,jakim mjestom“ kulturalne dijakronije kao sastavnim (neupitnim) dijelom kanona.

Tu je i oprez glede pitanja posljedica koje bi diskursivno uključivanje tekstova i njihova interteksta u širi korpus kulturalne interakcije imalo na narativ nacionalnog korpusa, onako kako se on ostvaruje i kao tekst i kao povijest, odnosno kao predaja i/ili (humanistička) znanstvena ovjerljivost. Naime, 
kada ne bismo odredili granicu kompetencije, ovako impostirana rasprava mogla bi, kao što se to već dogodilo u spominjanju nekih političkih događaja iz 2009., proklizati iz ,sigurnog“" prostora znanstveno ovjerljivog u prostor dnevno političke spekulacije, nagovora, pa čak i simplifikacije u ime tog nagovora, uz razotkrivanje mehanizama hegemonije, načina na koji fatička uloga (politiziranog) diskursa oduzima primat značenjskim konotacijama teksta pa bi došlo i do gubljenje originalnog predmeta iz vida. A to u kontekstu ovog rada nismo spremni riskirati s obzirom na uloženo vrijeme, trud i poštivanje metodološke discipline u najvećem dijelu ovdje iskazanog. ${ }^{18} \mathrm{Mi}$ slimo da pitanje diskursivne refleksije ovakvog teksta i istraženih intencija autorovih može postati dijelom rasprave koja će se (kulturološki) baviti posljedicama pozicioniranja dvojice autora u kasnijoj dnevnoj politici ili politici nagovora svakodnevnice. Ali istražujući ishodišne strukture, uzorke pripovjednih poziciniranja u tekstovima, mi zapravo ovdje samo određujemo okvire iz kojih će i pogled u društveno-političko, nacionalno i nagovorno biti u mogućnosti ovjerenije se pozicionirati u odnosu na hegemoniju diskursivne političke zadanosti i odnose moći u sustavu.

Vantekstualna diskursivna uključivanja ostalih kulturalnih presjecišta, dakle, bit će uzimana u obzir, ali kao „pomoć“ u osvjetljavanju problema kojim se bavimo, onoliko koliko se njihovo oblikovanje u stereotipe i preoblikovanje ideologemske paradigme koju uokviruju tiče tekstova i njihovih manipulativnih taktika kojima su utjecali na druge iskazne prakse te na dosege „fakcionalizacije fiktivnih“ elemenata navedenih priča, novela i eseja. Ostat ćemo dakle uglavnom na području književne teorije, naratologije i nekih metodoloških parametara kulturalnih studija kao interdisciplinarnog uvida u presjecište diskursivnih usjecišta naše suvremenosti kao modelnih svjetova (onih koji se odnose na artikulaciju agensa u tekstu i identifikacijske obrasce), ma koliko izazovno izgledalo u konkretnim situacijama odnosa prema „likovima“ kojima se ovdje bavimo iskoračiti izvan teksta i povijesti poetike kulture u najširem smislu te riječi, te ući u dnevno politički život ,poetike svakodnevnice“" kao ideologemske prakse na koju su zapravo modeli o kojima ovdje govorimo (neizravno) najviše utjecali.

Mislim da su u ovom kontekstu važna dva pitanja od kojih valja početi zaokruživati priču o stereotipiziranju mitskog iskustva i lokalnom pozicioni-

${ }^{18} \mathrm{Uz}$ ovu raspravu riječ je o još dvije rasprave o Andriću i Krleži, najprije jednu o njihovom ,društvenom djelovanju“ i ,,pozicioniranju“, a onda i o raspravi koja se izravno nadovezuje na ovu (bivajući njezinim logičnim nastavkom) a bavi se daljnjim analizama sada vezanim uz lokalnu i globalnu impostaciju autorstva i taktike kojima se to nagovješćuje (skriva). Prva je rasprava objavljena (2005) a treća će biti sastavnim dijelom knjige koja će se baviti postkolonijalnim (re)konstrukcijama hrvatskih (i južnoslavenskih) književnih impostacija. 
Konstrukcija, prenošenje i preoblikovanje priče(a) o nacionalnim identitetima...

ranju problema kojima se autori o kojima ovdje govorim bave. Najprije, tu je pitanje kako dolazi do stereotipiziranja jednom proizvedenog mitskog iskustva kroz njegovo refokusiranje putem preoblikovanja povijesnih i predajnih žarišta, jakih mjesta, u fikcijska? Nastavlja se pitanje vezano uz povratak iz odnosa prema tekstu kao fikciji, nazad, u područje ideologije kao pragmatike, odnosno pitanje koje pokušava naći odgovor vezan uz problem kako se oblikuje takva intencija (tekstualna, čitateljska, diskursivna) koja će fikcijski tekst „preuzeti“" i preoblikovati, vrativši potom žarište intencije ,natrag“ u područje mitskog iskustva, predaje, pragmatičke mogućnosti ideologemskog utjecanja na „stvarnost“ u kulturalnom okruženju povijesne pojedinačnosti? To je ono mjesto s kojeg se, kad govorimo o Andriću i Krleži, istovremeno sublimira do sada skicirano o postkolonijalnoj identifikaciji ali i pričanju priče o naciji koja u obzir uzima zasićenost ovako formuliranim žarišnim polazištem.

Odmah nakon postavljanja ova dva pitanja pitanja, slijedi i treće koje iz njih logički proizilazi. To je ovo: kako se to dvoje zbiva u tekstu, gdje to možemo vidjeti u njegovim interpretacijskim intencijama, refleksijama i utjecajima na druge iskaze u obliku nagovora i interteksta u okviru kojeg dolazi do prijelaza određenog ideološki nabijenog iskaza (ili iskaznanih stereotipiziranih jezgri) iz teksta u tekst, iz jednog tipa diskursivne prakse u drugi? Osim samog utjecaja na ukupnost preformulirane jezične prakse „naracije nacije“, tu je i utjecaj na oblikovanje (stereotipizirane) jezične stvarnosti kao refleksije zadanog neproživljenog iskustva, odnosno na nagovor tekstualnog u odnosu spram kulturološkog i političkog djelovanja. Drugim riječima, govorimo o oblikovanju određene ideologemske paradigme koja u svom praktičkom odvojku ,proizvodi“ takvo djelovanje.

Iz toga slijedi da je fikcionalizacijom stereotipiziranog mitskog iskustva i njegovih pragmatičkih ideologemskih nagovora autorska instanca (Krležina i Andrićeva) refokusirala to mitsko iskustvo, lokalizirala ga u tekstu, vratila natrag u prostor okamenjivanja kontinuiteta (stereotipa) i pokušala uklopiti u vlastite intencijske vizije doprinosa lokalnoj identifikaciji, reinterpretaciji stereotipa i repozicioniranju ideologema, ali također i njihovom pozicioniranju u šire okružje (u procesu objašnjavanja naše situacije drugima). A to pak znači da, s obzirom na autorske intencije ovih pisaca onako kako su ostvarene intencijom tekstualnog (ne obavezno i na razini izvantekstualnog nagovora), ovakvo pozicioniranje želi u njihovim konkretnim slučajevima djelovati i u globalnom okruženju, uz inzistiranje na opstojnosti vlastite imaginarne zajednice (nacije hrvatske, srpske, crnogorske ili ,,jugoslovenske") kao posebnosti u okviru (ili) pored drugih s kojima ili nasuprot kojih zajednice (nacije, vjere, kolonije) pričaju svoju priču.

Pri tom je važno uočiti bitnu impostacijsku razliku između dvojice autora, a o čemu je na razini odnosa autorske intencije prema tekstu već bilo 
riječi ovdje. Ponovimo to, ali sada u odnosu na ne-fikcijske tekstove za koje smo rekli da su jednostavniji za ,iščitavanje“. Krleža od izravnog pokazivanja ovakve intencije bježi u ironični autorski odmak gdje sve „može biti drugačije nego se na prvi pogled čini“. Tako njegov Starčević (ili Križanić) i jest/jesu i nije/nisu povijesna ličnost, i jest i nije ideologem oko kojeg se može graditi priča. U fikcijskim tekstovima njegovim to je još naglašenije, ali i složenije ispričano, re/prezentirano. Čitajući Orlićev ekskurz u „nepoznato“, izvan sigurnog svijeta srednje Europe ${ }^{19}$ u pripovjetki „Hodorlahomor Veliki““ (1918) Krleža se „igra“ s idejom identifikacije i podrijetla. Orlić na putu prema svom fiktivnom Parizu uživa u izgledu vagona gdje ,(...) i presvlaka (je) čipkasta i grimizna, a ne stara izlizana koža kao kod nas u Madžarskoj“ (str. 185). ${ }^{20}$ Samo dvije stranice dalje govori o ,umoru bijedne balkanske raje, provincijalnog jadnog parije, što se izgubio u vrtlogu“ (str.188) da bi svoj san o Parizu prizivao iz prostora „Ondje u maglama gdje se još rumene turski požari, otimaju djevojke..." (str. 189). A prije fikcijskog (ekspresionističkog) zaleta s asirskim kraljem slijedi i udaranje o dno dna: nakon što je uhapšen kao sumnjivo lice od strane nekog "glupana u neobično bijelim hlačama“, „Orlić je počeo da pije. Da se opija temeljito. Horvatcki“ (str. 191). Tako je već u prvim fikcijskim Krležinim tekstovima identitet reprezentiran kao „klizav prostor" nesigurnosti gdje mađarsko postaje tursko koje postaje balkansko, koje postaje hrvatsko, ovisno o opterećenosti drugim, uvjetovano razinom kompetencije, prostornim uokvirenjem, mjestom identifikacije i ucijepljeno u raspoloženju glavnog lika, odnosno intenciji pripovjedača, autora i njihovom nagovoru koji se prenosi tekstualnom intencijom.

Andrić, pak, umjesto u ironičnu impostaciju prividno ne-mitskog, svog pripovjedača skriva u privid mitskog iskustva a kao oruđe (oružje?) mu daje na raspolaganje predaju i priču. $U$ vezi toga najizravnije će se autorska intencija očitovati u „Priči o vezirovom slonu“, a što ćemo detaljnije citirati kasnije. Ovdje samo spominjemo osnovnu misao tog dijela teksta: priče su, smatraju u Bosni (ponajprije Turci, a očito i ostali, op. B. Š.) ,stvarnije od stvarnosti“. To s jedne strane objašnjava zašto se može pričati o toliko nezanimljivim likovima kao što je to slučaj s pričom-dekonstrukcijom o Aliji Đerzalezu. Po tom bi se dakle moglo reći da se na razini tekstualne intencije zbivaju promjene u odnosu na autorsku i to takve u kojima Krležini tekstovi zadobi-

${ }^{19}$ U knjizi Ironija i roman: $u$ Krležinim labirintima pisao sam o tom odnosu „šume i doma“, odnosno srednje Europe i područja koje izlazi iz tog kolonijalnog okruženja kao ,sigurnog doma“. Tamo je bilo riječi o romanu Vražji otok (1924) te pripovjetkama „Kako je doktor Gregor po prvi put u životu sreo Nečastivog“(1929) i „Cvrčak pod vodopadom" (1936). V. Škvorc, 2003: 23-24, 88-93.

${ }^{20}$ Prema izdanju: Miroslav Krleža: Novele koje je pripremio D. Duda, Zagreb: Školska knjiga, 1995. 
Konstrukcija, prenošenje i preoblikovanje priče(a) o nacionalnim identitetima...

vaju dominantnu intenciju uzrokovanu i motiviranu ironičnim odmakom, a Andrićevi tekstovi to čine preuzimanjem kontrole pričanog nad autorskom impostacijom. To se, uostalom, nadovezuje i na tezu o dvije razine kompetencije s kojom sam i započeo ovaj tekst.

Činjenica je međutim da su, ako ove ideološki determirane iskaze malo pomnije pročitamo, obje impostacije fingirane. Niti Krleža prepušta „značenjima koja nisu prava" da preuzmu dominaciju nad njegovim ideologemskim slojem, barem na razini intencije, niti kod Andrića priča dominira nad strukturiranjem tekstualne intencije i ,podmetanjem“ autorske impostacije u onom što je već davno nazvano Andrićevim „gnomskim iskazom“. To znači da obojica autora zadržavaju kontrolu nad svojim tekstovima i njihove intencije dominiraju tekstualnim, premda se često, čak ne samo ni na prvi pogled, čini drugačije. Kad Krleža ironično progovara o srednjoj Europi kao prostoru koji ne postoji kao ispripovijedano mitsko iskustvo zajedništva (dakle ni kao jedinstvena kulturna činjenica), on istovremeno pokušava afirmirati takvo iskustvo kao vlastitu naraciju nacije, odnosno makar i negativnim odnosom proizvesti tip sinergije koji će omogućiti prostor uključivanja i prostor sigurne „kuće“ unutar koje će se kretati likovi njegova fikcijskog svijeta.

U Andrićevom slučaju pričom o Njegošu konkretizira se tip proizvodnje mitskog iskustva iz romana kao što su Na Drini ćuprija i Prokleta avlija, tako da ona dobivaju svoj pragmatični odvojak kao intertekst podložan za moguće novo iščitavanje jake autorske pozicije u tekstu i njegovom oživljavanju tijekom čitanja. Riječ je o onim općim, ,univerzalnim iskazima“ koji na okupu drže priče iz romana o ćupriji i u esejističkim podtekstom podražavaju čitateljski intenciju da se usredotoči na priču. Tako se krug fikcionalizacije nefikcijskog zatvara i kod njega, premda ne ironijom u odnosu na ,stvarnost" već ironičnim odnosom prema intencijama pojedinih tipova uslojavanja vlastitog teksta. To se pogotovo odnosi na sekvence koje na prvi pogled izgledaju samostalnima, zasnovanima na predaji i onima koje izgledaju kao da su se „otele“ kontroli autora. U tom zadržavanju kontrole i manipulaciji „odbjeglim“ dijelovima teksta, posebice u odnosu na identifikacijsku impostaciju, i jest prostor unutar kojeg se može govoriti o Andrićevoj postmodernosti. A proizvodnjom tekstualnih slojeva koji ironiziraju impostiranje pripovjedača $i$ ispričanog kao konstante koja bi trebala proizvoditi tekst, a koja se odnosi upravo prema nekom povijesno zadanom vremenu i prostoru (kod Krleže), i onih koji usložnjavaju pripovjedačke taktike proizvodeći slojeve koji referiraju prema drugim tekstualnim intencijama istovremeno ih relativizirajući (kod Andrića), lokalno usmjereni tekstovi dobivaju univerzalni značaj. Prvi to čine u dekonstruiranju tipične srednjoeuropske modernističke kohezije, a drugi u dekonstruiranju i (zlo)rabljenju mita i predaje u svrhu postizanja dojma koji je, iz zapadne perspektive gledano, proizveo mitski reali- 
zam. Pri tom lokalni tip identifikacije s tekstom može kroz tekstualne nagovore, iza postupaka i tipa mimetizma koje tekstovi proizvode, vidjeti ove tekstove bitno drugačije, „dijagetičnije“ i, na razini mogućnosti dekodiranja „pravih značenja“, onih prema kojima diskursivno, s obzirom na unutarnje konsolidiranje „odnosa između strukture, procesa i društvene interakcije“ (v. Van Dijk, 1997), intencija odnosi kud i kamo složenije no što se na prvi pogled čini. Nije isključeno da ova ,dvostruka igra“, univerzalna i posebna, lokalna i globalna, formalna i sadržajna u stvari i jest dio manipulacijskih taktika dvojice pripovjedača (autora) i njihovih intencijskih tekstualnih slojeva. U tako zadanom „odnosu snaga“ multidisciplinarnost diskursivnih studija koji će povezivati „,sada i ovdje“ $\mathrm{s}$ kolonijalnom impostacijom autora i projekcijom te kolonijalnosti u postkolonijalni prostor i vrijeme „sadašnjosti“ postaje posebno zanimljiva polazna pozicija za čitanje (post)kolonijalnih tekstova. Pri tom ni novohistoricistički nagovor re-konstrukcije „onog i ondje“ teksta u odnosu prema ,onom i ondje“ vremena i prostora impostacije autorske intencije, a u odnosu prema „ovom i ovdje“ našeg vremena čitanja i diskurzivne „društvene interancije“ trenutka čitanja, ne bi trebali biti zanemarivi činitelji daljnjih analiza.

\section{Otpor i podražavanje (postkolonijalnog), ,stanja stvari“": impostacija autorske(ih) intencije(a)}

Upravo je to područje pogodno za dekodiranje i interpretaciju mehanizama „svjesne manipulacije“ na raznim razinama. Mjesto je to na kojemu ćemo pokušati pronaći odgovore na pitanja vezanih uz suprotstavljanja lokalnog i globalnog ideologemskog sloja unutar korpusa dvojice vjerojatno najznačajnijih kanonski verificiranih južnoslavenskih književnika u dvadesetom stoljeću. Već je utvrđeno i da su njihovi opusi i paradigme iskazivanja istovremene, ali dosta različite. Andrićeva i Krležina impostacijska polazišta teško da se mogu dijaloški izravno suprotstaviti s obzirom na prostor koji prisvajaju kao svoj. Usporedivi su samo u strukturiranju odnosa prema drugom i prema nomenklaturi i raspršenom struktuiranju (i dekonstruiranju) mehanizama moći koji uspostavljaju mehanizme hegemonije u određenom vremenu i prostoru. To se pogotovo odnosi na strukturu i disperziju moći koju su dijelili kao njezini agensi i pod kojom (u kojoj) su živjeli uokvireni istim sustavom, unutar iste diskursivne vremensko-prostorne i društvene zadanosti. Riječ je o kontroverznom položaju unutar sustava. Jedan autor, dakle, dok s jedne strane prisvaja prostor Srednje Europe kao kulturološko uporište, istovremeno ironizira njezinu „vatrogasnu kacigu“ ili „pjevanje starinskih vinskih pjesama“, odnoseći se prema tim mikroscenama (narativnim sekvencama) kao primjeru kiča, odnosno lažnih vrijednosti u kojima i po kojima se živjelo. On se ideološki pozicionira kao „dvostruki disident“, istovremeno se rugajući Sred- 
Konstrukcija, prenošenje i preoblikovanje priče(a) o nacionalnim identitetima...

njoj Europi i bivajući njezinim kroničarom. Ta uloga unutarnjeg disitenta posebno će se uočiti kad kroničara Srednje Europe suprotstavimo njegovim ideologemima koji se bave „balkanskim kompleksom“. Izrugujući se bidermajeru kao austrijskom tipu „niveliranja stvarnosti“ i malograđanskoj svijesti kao prostoru bez otpora ideologemu ispraznog podražavanja, pa tako i priznavanja kolonijalnog stanja (što se može prenijeti i na kasnije kolonijalno i kolonizacijsko stanje kraljevske Jugoslavije, posebice ako čitamo Zastave), Krleža u prozi „Ivan Križovec“ (Glembajevi proza, Sarajevo, 1981) piše:

Bolje je putovati u salonskim vagonima, biti presvijetli gospodin, biti pozivan u grofovske i barunske dvorce, vozikati se u karucama, pjevati starinske vinske pjesme iz četrnaestog stoljeća i živjeti gospodski nego pisati nekakve glupe članke o domovini i boriti se za rodoljubne magle (str. 193).

Ironizirajući prostor ne-djelovanja Krleža neće izravno „zauzeti stranu“ u sukobu nas i njih. „Naša stvarnost“ bit će uvijek kulturološki određen, nikad vrijednosno zauzet prostor mitologemskih odjeka, refleksije mitologema. Bit će to gotovo izvrnuta slika u ogledalu. Ideologemski impostiran sukob bit će izravan, čak i podražavan tekstom, ali će mitsko u ovom (inter)tekstu ostati prostorom ironiziranja različitih ,zauzetih pozicija“, više nego li će se njime autorska intencija izravno baviti. Sukob će na ideologemskoj razini često biti klasno motiviran, određen odnosom kolonizirane provincije i bezobrazno (i bezobzirno) bogatog, razuzdanog i „bolesnog“ centra. Dobar je primjer toga sekvenca iz eseja „Evropa danas“. Nakon upoznavanja s mističnim drugim (,Zvao sam se Giordano Bruno, spalili su me na lomači; kad sam izdahnuo u njihovu smislu pristojno, kao ugledan veleposjednik i gavan Voltaire, tri put su me izbacili iz groba ...", str. 29) ${ }^{21}$, dolazi i do određivanja između provincije i centra. Ono je diskursivno kolonijalno uokvireno, te nije samo kulturološki zadano kao odnos središta i kulturno manje vrijedne provincije, a kako se obično misli:

Ovaj staromodni, četrdesetosmaški fantom, koji mi tu govori o nevidljivim sablastima i o evropskim fantomima, zbunio me potpuno. Ja sam oduvijek bio sklon vjerovati da je Evropa prilična ludnica, ali da se njom igraju nevidljivi fantomi kao dječjom igračkom, to mi je izgledalo ipak pretjerano (...).

„Dragi moj, s takvim provincijalnim golubovima (kao vi) prilično je teško inteligentno razgovarati (...)“.

„E vidite! Oni fantomi koji su na svakom evropskom ratnom grobu zaradili dvadeset i šest hiljada franaka, oni svojim matresama

${ }^{21}$ Iz Krležinih Sabranih djela, Eseji i članci, knjiga 3, Zagreb i Sarajevo, 1979. 
kupuju brazilske kolibriće u zlatnim krletkama i ogrlice za sedamstotinasedamdesetsedamhiljada franaka."

To je ta „Evropa“ koja je uokvirila kolonijalni položaj Krležine Hrvatske. A postkolonijalna potencija revolucionarne mogućnosti da se postane drugi neslavno je završila. Ni ovdje nema izravnog zauzimanja strana izvan označavanja nas kao kulturološkog i ideologemskog međuprostora između dviju kolonijalnih opcija:

Naši profesori i političari, naši historici i novinari lažu po novinama i piskaraju kako smo mi imali narodno-revolucionarne pokrete i da je ova država plod naše narodne revolucije, i pošto je tih novinskih heroja palo u ratovima na buljuke, ta nam zabušanska piskarala prijete kao da su i sama poginula na Kajmačkanu.

Ova država sazidana je na kostima junaka od Mačkova kamena do Kajmakčalana i mi ćemo i opet zagaziti u poplavu krvi prije nego što dopustimo propast naših narodnih svetinja.

Ta fraza potpuno je analogna onoj da su se Staleži i Redovi Trojedne Kraljevine borili s narodima Habzburške Monarhije rame o rame u nepokolebljivoj lojalnosti i stoljetnoj vjernosti u smislu stoljetnih tradicija; tu frazu slaboumno melju jedni te isti ljudi već deset godina po novinama i po školskim knjigama, koje se sada zovu udžbenici (...).

Kod nas nije bilo nikakvog revolucionarnog ni iredentističkog gibanja, kao što nije bilo ni stoljetne vjernosti, jer, u sveopćem indiferentizmu i usred potpune apolitičnosti jednog dobrog dijela ,našeg malog čovjeka“, sve što nije „Vesela udovica“ ili „Čar valcera“ nije naročito zanimalo široke slojeve čitača Malog oglasnika ili Sherlocka Holmesa (...). ${ }^{22}$

Krležin narator, onoliko koliko se iskazivač esejističkog teksta naratorom zvati može, množinsko obraćanje s „mi“, odnosno „nas“ pozicionira u kulturološko okružje ironično impostirane i intonirane zajednice koja (ne) pruža aktivni otpor prema drugom, onom koji vrši kolonijalnu, dakle fizičku, i moralnu, kulturološku, agresiju. Istovremeno, jezik koji drugog stavlja izvan prostora tih nas nije obilježen kao nešto što se može stereotipizirati antagonistički u smislu isključivanja iz zajednice nas, već kao preplitanje koje „,nas“ pozicionira kao zajednicu inferiornu u odnosu na „dominanatne njih“. Ti „oni“ su „,nam“ nametnuti „odozgora“, odnosno iz prostora koji pripada nadređenom, globalnijem okruženju u okviru kojeg lokalna zajednica ironizira-

${ }^{22}$ Citirano iz Deset krvavih godina, str. 17-18, izdanje: Miroslav Krleža: Deset krvavih godina i drugi politički eseji, Sarajevo, Veselin Masleša, 1990. Riječ je o tekstu „Prvi dani apokalipse: panika i politika puna rodoljubnih nada“. 
Konstrukcija, prenošenje i preoblikovanje priče(a) o nacionalnim identitetima...

nih živi opisana i opasana, ali pod teretom inferiornosti a koji je položaj, ironični iskaz kaže, sama odabrala kao vlastito nacionalno pozicioniranje. U takav okvir smjestila je navedena (Krležina, fiktivna?!) zajednica svoju priču. Naravno, ovakvo tumačenje prikraćuje čitateljima čitavu jednu dimenziju a to je pozicioniranje njegova iskaznog subjekta unutar uokvirenosti pravilima „klasne borbe“. Takvo se pozicioniranje ostvaruje ideologemom koji će u mnogo čemu korigirati ovakvo impostiranje ideologemski zasićenih „nas“ iz prethodnog citata, a što je naznačeno u eseju „Evropa danas“, ali samo u odnosu na klasnu nejednakost koja se razvija između kolonizatora i koloniziranih, ali ne i unutar istog nacionalnog korpusa. Projekcije prema ,suvremenoj situaciji“ mogu se početi iščitavati na alegoričnoj razini teksta još od objavljivanja prve knjige romana Banket $u$ Blitvi.

Ivo Andrić, s druge strane, prividno ne sudjeluje u pozicioniranju koje određuje odnos koloniziranog i kolonizatora danas. On stoji pred „krvavim zidom" mržnje koji je izgrađen u odnosu presjecišta na prostoru Bosne i Hercegovine, izgrađenog usustavljivanjem turskog kolonijalnog ustrojstva (Carstva), a onda i austrijske kolonijalne uprave, odnosno okupacije. Istovremeno pokušavajući na razini tekstualne intencije graditi presjecišta različitog, Andrićev pripovjedač prisiljen je intencijski podražavati suživot priča i graditi kompleksne međuprostore nepremostivih sukoba i nemogućih suodnosa, ali u prostoru koji je isprepleten. Jer ovdje kolonizator nije negdje drugdje, on je tu, njega se može lokalno identificirati kao jednu od konstanti lokalne uključenosti, kao jednog od glavnih agensa i pokretača radnje, bilo kad se putevi grade ili ruše. ${ }^{23}$ To nije „Evropa“ koja kolonizira administracijom i željeznicom, to je „Azija“ koja je kolonizirala ucjepljivanjem u sredinu, vjeru, kulturu i svakodnevnicu. U takvoj konstelaciji snaga suživot se gradi lokalno, a ne u odnosu na ono što je isključeno i daleko. Uz navedeni primjer iz Travničke hronike, to se dobro vidi u VI. poglavlju romana Na Drini ćuprija gdje, unatoč tome što je počela jedna borba u kojoj se već čuo „Karađorđev top“ $s$ brda preko granice, odnos života, igra noći i dana „u kasabi“ ipak izgleda ovako:

${ }^{23}$ Ovo je aluzija na raspravu dvaju Francuza, likova iz Travničke hronike, konzula i „mladog konzula“ o putevima u Bosni. Na jednom mjestu mladi Defonse (des Fossés) citira fratra iz Doca koji kaže kako im odgovara da se putovi razgrađuju, ruše, da ih nema. Što je manje putova, to je manje veze s njima, s onim drugim s kojim se živi unutar istog svijeta. Istovremeno: „U ovim sredinama sve je povezano, čvrsto uklopljeno jedno u drugo, sve se podržava međusobno i nadzire. Svaki pojedinac pazi na celinu i celina na svakog pojedinca. Kuća posmatra kuću, ulica nadzire ulicu, jer svaki odgovara za svakoga i svi za sve, i svaki je potpuno vezan sa sudbinom ne samo svojih srodnika i ukućana nego svojih komšija, istovernika i sugrađana“ (Travnička hronika, str. 153; izd. Sabrana dela Ive Andrića, Sarajevo, 1981). 
Noći su tada bile pune opreznog i strasnog šaputanja, kroz njih su išli nevidljivi talasi najsmelijih želja i snova, najneverovatnijih misli i planova, i ukrštali se, nadbijali i lomili u modroj tami nad kasabom. A sutra, kad svane dan, odlazili su i Turci i Srbi na svoje poslove, sretali se ugašenih i bezizraznih lica, pozdravljali i razgovarali sa onih stotinjak uobičajenih reči čaršijske učtivosti, koje oduvek kruže po kasabi i pretaču se od jednog drugome kao lažan novac, koji ipak omogućuje i olakšava saobračaj. ${ }^{24}$

No njegova iskazna intencija, nakon što pronalazi u prostoru razdvajanja univerzalne vrijednosti, odbacuje ipak položaj hijerarhijski zadanog i „stanja stvari“ koje uvažava različitost i zatečenu situaciju u prostoru, te se pozicionira u prostoru „njegoševski“ izabranog ideologema vječnog sukoba. Tako impostirani ideologemski sloj izdiže se iz mitskog svijeta susretišta („Kuća posmatra kuću, ulica nadzire ulicu...“, v. bilješku 23) i počinje od razdvajanja. Evo najprije jedan primjer iz ,čiste fikcije“, odnosno iz ,,romana izgrađenog na predajama":

Ali, ako je i moglo biti sporno da li se jeka srpskog ustaničkog topa čula do u kasabu, jer čovek često misli da čuje ono čega se boji ili čemu se nada, nije moglo biti sumnje o vatrama koje su ustanici noću ložili na Panosu, strmoj i goloj kosi između Veletova i Gostilja, na kojoj se osamljeni veliki borovi mogu iz kasabe golim okom prebrojati. Njih su dobro videli i pažljivo posmatrali i Turci i Srbi, iako su se i jedni i drugi pravili da ih ne primećuju (...). (Naše /podvukao au./ su se žene krstile u tami i plakale od nerazumljivog ganuća, a u suzama su im se lomile ove ustaničke vatre kao ovi avetinjski plamenovi koji su nekad padali na Radislavljev grob i koje su njihove šukunbabe, pre gotovo tri veka, isto ovako kroz suze nazirale, sa ovog istog Mejdana) (Isto, str. 91).

Andrić se u fikcijskim tekstovima vrijednosno pozicionira vrlo rijetko. U tako nazivanim ,gnomskim iskazima“"25 (prije smo spomenuli vrijednosno impostirane iskaze sveznajućeg pripovjedača koji nadilaze lokalnu identifikaciju) u kojima njegova autorska intencija izravno preuzima primat pripovjedaču i na temelju ,primjera iz teksta“ uopćava neka iskustvena saznanja o društvu, ljudima i vremenima, jaki fokalizator tekstualnog na razini izravnog obraćanja autorske intencije fingira ulogu objektivnog pripovjedača i tumača ispričanog. On se međutim ne određuje intencijski i izravno prema ideologe-

${ }^{24}$ Citirano prema izdanju Sabrana djela Ive Andrića, Knjiga prva, Zagreb, 1963.

${ }^{25}$ Više autora govori o ovom aspektu impostiranja Andrićeva pripovjedača: Krešimir Nemec, Krunoslav Pranjić, Dragan Stojanović. Riječ je većinom o tekstovima nastalim u zadnjih desetak godina; v. bibliografiju. 
Konstrukcija, prenošenje i preoblikovanje priče(a) o nacionalnim identitetima...

mima koje označava na razini odnosa fikcijskog i faktografskog. Taj dio pozicioniranja u pričanju nacionalne povijesti daje se u obliku ,prenošenja sadržaja“, odnosno povijesti prostora, a u prostor i vrijeme fikcionalnog smješteni su iskazi koji se vrijednosno odnose prema „općim istinama“, onako kako ih konstruiraju ideologemi izravno vezani uz intenciju autorske instance. Nagovor tako impostiranog teksta ne proizvodi kolektivnu svijest već upućuje na onaj sloj književnosti u kojem se ,iz svijeta osjećajnosti i pojedinačnosti“" kroči u „svijet općeg, umjetnički univerzalnog“. U nekim tekstovima međutim koji se svojim tematsko-vremenskim slojem odnose bilo na turska vremena (Na Drini ćuprija, „Za logorovanja“ ili kasniji tekst „Priča o vezirovom slonu“), vremena austrijske okupacije (,Rzavski bregovi“) ili u pričama u kojima se progovara o vremenu takozvane Nezavisne Države Hrvatske, na primjer u manje poznatoj priči „Bife Titanik“ (iz 1950), dolazi do vrijednosnog određivanja s obziroma na fokaliziranje ,narativa nacije“ gdje se neki $M i$ iz pozicije tekstualne intencije odnose prema ostalima, drugima u tekstu. To se zbiva bilo na razini odnosa nacije i reprezentacije kao što je to predočeno odnosom Menta Pape i Sjepana Kovića u uokvirenom prostoru koji je ostalo od bifea Titanik, ili na razini naracije nacionalne (etničko-vjerske) opstojnosti kao u ,velikim povijesnim romanima“. No pitanje koje ostaje otvoreno vezano je uz sloj fikcionalne konvencije u trenutku pozicioniranja narativnog glasa.

Kada kaže naša zemlja, naš narod ili naše žene, misli li Andrićev pripovjedač na kut gledanja teksta ili je ideologemski sloj opisa prostora ušao u tekstualno kao reprezentant određenog svjetonazora, religije, pojedinačnog mita koji dobiva prvenstvo, povlašteno mjesto „znanja“ i autoriteta u tekstu? $\mathrm{Na}$ razini većih tekstualnih cjelina polietničnost prostora je na trenutak stvorila multikulturalni okvir ${ }^{26}$, onako kako ga definira Bhabhino pozicinoranje između, ali vrijednosni sud razlikovnog glasa drugosti ipak zna isplivati iz dubinskih slojeva priče koja pripovijeda prostor. Tako se pripovjedač (ipak) pozicionirao kao reprezent jedne od skupina koje taj prostor nastanjuju. Za razliku od reprezentativnog narativa (polu)kolonijalne hrvatske situacije u kojoj su Mi u odnosu na Njih jasno definirani od Šenoe do Krleže (vidjet ćemo da se u postmoderni taj problem pojavljuje upravo na razini destrukcije reprezentacije), ${ }^{27}$ Andrićevo pozicioniranje nastoji biti postkolonijalno, od-

\footnotetext{
${ }^{26}$ Pharek (2000) navodi razliku između polietničkog i multikulturalnog prostora kao važnu vrijednosno determiranu razliku gdje prva označava suživot, a druga međusobno prepoitanje i uvažavanje.

${ }^{27} \mathrm{O}$ tom pišemo u analizi Ferićeva post-kriminalističkog romana Smrt djevojčice sa žigicama. (V. tekst u Novoj Croatici; 2008). Bilo bi zanimljivo vidjeti kako se u takvom okruženju ponašaju Marinkovićev ili Šegedinom pripovjedač, posebno u Crnom smješku. O Novaku više u istom tekstu iz Nove Croatice.
} 
nosno pokušava dati glas fingiranoj poziciji post-stanja iz kojeg se može „objektivno" pričati a tekstovi mogu, da se ipak na trenutak upustim u dnevnopolitički jezik ,poetike svakodnevnice“ o čijem sam izbjegavanju nekoliko puta govorio a vezano uz „korištenje tekstova“ u okviru kulturalne analize, poslužiti „zapadnim političarima“ da „bolje shvate Bosnu“, kao da je riječ o stručnim knjigama a ne fikcijama. ${ }^{28}$

Upravo zbog mogućeg fingiranja ovakve pozicije upotreba mita, oslanjanje na predaje, reprezentacija nacionalnog i ,globaliziranje“ u obliku težnje prema univerzalnom iskazu ovdje na prvi pogled izgledaju i stvaraju privid kao da su dominantni elementi iskazivanja. Stoga se vrlo jakim iskazima u ovoj prozi čine ona mjesta gdje se progovara iz pozicije nas i njih, neovisno o tome radi li se doista o fingiranom mjestu reprezentativa ili je riječ o vrijednosnom pozicioniranju autorske intencije koja povremeno zauzima i pokazuje svoj stav u odnosu na ispričano, dajući mogućnost interpretatoru da se i sam intencijski odredi. Ali za razliku od dijakronijskog niza od Šenoe do Krleže gdje je pozicija jasno određena kao izvanjska, ispreplitanje kulturoloških paradigmi koje imamo ovdje na prvo čitanje izgleda kao multikulturalni tekst u kojem pripovjedač nivelira i vlada odnosima između različitih zajednica čije priče re-prezentira. Je li tome doista tako, vidjet će se na temelju analize Andrićeve konstrukcije „Njegoša“ kao amblema.

Drugi primjer koji ovdje navodimo je iz priče ${ }^{29}$ koja se zove „Priča o vezirovom slonu“, a riječ je o zrelijoj priči autorovoj. Ona je prvi put objavljena 1947. godine:

U tesnoj travničkoj čaršiji fil je izgledao veći nego što je u stvari bio, a izgledao je i strašniji i glomazniji, jer su svi, gledajući ga, pomišljali više na vezira nego na životinju samu. I mnogi koji su ga samo nazreli u povorci između mladog zelenog granja kojim je bio opkoljen, nadlagivali su se dugo po kafanicama i prelima, pričajući čuda o strašnom izgledu i neobičnim svojstvima „vezirovog živinčeta“. Tome se ne treba čuditi, jer ovdje kao i svuda na svetu, oči lako vide ono čega je duša prepuna. A opet, naš

${ }^{28}$ Danas je već „urbani mit“ to da se ondašnji američki predsjednik Bill Clinton tijekom sukoba u Bosni informirao o „stanju stvari“ iz Anrićevih romana.

${ }^{29}$ Motiviran predgovorom Kruna Pranjića ,pričama“ sabranim u knjizi Priča iz Japana i druge odabrane (Zagreb, Konzor 2003), namjerno umjesto pripovijetka ili novela koristimo termin priča, a na temelju Pranjićeve sugestije vezane uz uvid u Andrićev govor prigodom dobivanja Nobelove nagrade, „O priči i pričanju“. Zato u trenucima $\mathrm{kad}$ se vrši komparativna analiza govorimo o pričama/novelama (pripovjetkama). Više o teorijskoj nomenklaturi Krležinih kraćih proznih tekstova v. u našoj knjizi Gorak okus prešućenog, Zagreb, 2005, poglavlje „O nekim problemima peridizacije Krležine proze“. 
Konstrukcija, prenošenje i preoblikovanje priče(a) o nacionalnim identitetima...

čovek je takav da bolje neguje i više voli svoju priču o stvarnosti nego stvarnost o kojoj priča. ${ }^{30}$

Za razliku od prvog pozicioniranja u tekstu gdje su ,naše žene“ bile vrijednosno obilježene unutar dinamične narativne sekvence koju je kontrolirala unutarnja logika tekstualnog pozicioniranja (onog ,između“, rekao bi Bhabha), ${ }^{31}$ ovdje se ,naš čovjek“" pojavljuje upravo u tipu iskaza koji je kritika označila „gnomskim“, odnosno u trenutku kad se intecija pripovjedača pozicionira najbliže intenciji autorstva i gdje se čini da autor ima potpuni autoritet, da je potpuno ovladao ispripovijedanim svijetom. Ovakvi su slučajevi pozicioniranja u Andrićevoj povijesnoj prozi vrlo česti, ali izravno prema priči i pričanju referiraju najviše u ovdje citiranoj priči i u romanu Prokleta avlija (1954), te se čini kao da autor piše manifest svoje poetike koji je ,podmetnuo“ u fikcijski tekst. Prema „našem čovjeku“ iz ove sekvence ovdje se referira u odnosu na sam početak teksta kao traktata o bosanskoj (izmišljenoj) priči, odnosno pričama, i njihovoj istinitosti (Andrić kaže: ,stvarnosti““) u odnosu na istinu (turska poslovica veli da su ,istinitije od svake istine“, isto, str. 43). Tako taj naš čovjek ovdje predstavlja fluktuirajući slabi subjekt koji priča i pričan je, tako da na prvi pogled izgleda kao da nije ideologemski obilježen već je autorska instanca samo filter, fokalizator kroz koji se pričaju priče drugih. Njegova kolonijalna identifikacija inzistira na lokalnom, nasuprot globalnom prema kojem se veže ili suprotstavlja jedan dio tih izmiješanih (vjerskih, nacionalnih) identiteta. Pogledi u druge uvijek su pogledi u mutnu i nepoznatu daljinu koja je samim time opasna jer je prostor Lotmanove ,šume“ nepoznatog svijeta tuđine i nedohvatljivog. Upravo u tako ostvarenoj „slici“ o vlastitom narodu (autopredodžbi), ali i o drugom koji je taj narod uokvirio (dakle heteropredodžbi) ${ }^{32}$ vlastitom pričom (jer stara poslovica da su priče o stvarnosti stvarnije od stvarnosti ipak je - turska) naziru se napukline u uokvirenju „objektivne pripovjedačke instance“ koja stoji izvan tekstualne intencije i izvana promatra premreženost politetničke zajednice s povremenim intencijskim ekskurzima prema multikulturalnom preplitanju, pri čem mislim na način definiranja razlike koji sam citirao iz Parekha (2000).

\footnotetext{
${ }^{30}$ Prema: Ivo Andrić, Sabrana djela: Nemirna godina, Sarajevo i Beograd, 1988. godine, str. 54.

${ }^{31}$ Dobro objašnjenje ovakve pozicije diseminacije nacionalnog pozicioniranja $u$ prostor ,između“ mogućih čvrstih zauzimanja pozicija pronalazimo u poglavlju iz Bhabhine knjige Location of Culture koje je prevedeno u knjizi Vladimira Bitija Poetika $i$ etika pripovijedanja.

${ }^{32}$ Termini su prilagođeni iz uvodne rasprave Davora Dukića u zbirci tekstova o imagologiji pod naslovom Kako vidimo strane zemlje. Uvod u imagologiju (v. Dukić, 2009). Ovdje v. str. 8 i 9.
} 
Zato mi se čini da upravo u ,priči o priči“ Andrićeva pripovjedačka intencija može ostvariti jedinstvo ispreplitanja različitog, ali istovremeno zadobiva moć, odnosno ukazuje se mogućnost intencijske manipulacije ispričanim. Ali takva povlaštena pozicija uokviravanja različitog $\mathrm{u}$ ispripovijedanom odnosu mitologemskog suživota koloniziranog i kolonizatora raspada se $\mathrm{u}$ trenutku kad se počinju poklapati vrijeme pripovijedanja $\mathrm{i}$ ispripovijedano vrijeme, odnosno u trenutku kad intencija tekstualnog preuzima primat i unutar okvira kojim je zadana identificira se lokalno sa stalnom mišlju o drugom (ali sada ideologemski vrlo zasićenom na razini lokalne identifikacije). Primjer je već s iduće stranice u istoj priči, kad riječ autorskoj instanci preuzima (oduzima) dolački paroh (sic!) fra Mato Mikić:

„Bilo je, kao što znaš, i naših - pisao je fra Mato - koji su, gledajući kako vezir uništava Turke i njihove 'prednje ljude', govorili da iz toga može izići neko dobro za raju. Jer naše budale misle da tuđe zlo mora svakako biti njihovo dobro. Možeš im slobodno kazati, da znaju bar sada kad već ranije nisu mogli znati, da od toga nema ništa“. (Isto, str. 55)

Zanimljiv je način na koji se onda vrši izabir iz tekstualnih mogućnosti, odnosno kako pripovjedačeva intencija ulazi u žarište fra Mata sa čvrstom namjerom da se kroz govor drugog pruži univerzalna istina, dakle izvan gnomskog iskaza, izvan pružene prilike da se otkrije autorska instanca i svojim autoritetom iskaže misao „veću od teksta“ i diskursivno se podvoji ukazujući na relativnost situacije u kojoj su pričani povijest i vrijeme, priča i diskurs. To se čini tako da se još uvijek prepoznaje manipulacija autorstva, i da se gotovo, premda samo neizravno, ukazuje na vremenski raskorak vremena pripovijedanja $\mathrm{i}$ ispripovjedanog vremena. Iz upravnog se govora prelazi u neupravni, vrijeme se ponovo sažima, i tajna identifikacije unutar uokvirenja vremenske (ne i prostorne) dislociranosti prikriva se tajnim jezikom (u kojem se miješaju latinske riječi s našima):

„Et sic Bosna ut antea neuregiena sine lege vagatur et vagabitur forte do sudgnega danka“ (odnosno: I tako Bosna kao i dosada neuređena, bez zakona, luta i lutaće možda do sudnjega dana).

Riječ je o iskazu koji svojom fatalističkom intonacijom iz pozicija autoreferencijalnosti (autopredodžbe) funkcionira na isti način kao mnoge Krležine tekstualne manipulacije iz Banketa u Blitvi i pogotovo Zastava. Podsjetimo se, tamo Krležina pripovjedačka intencija govoreći o prošlom vremenu iz pozicije „unutarnjeg disidenta“ (koju je odredio Stanko Lasić u Kronologiji) zapravo progovara o iskaznom pozicioniranju naspram suvremenoj situaciji vremena u okviru kojega se usložnjavaju ideologemi tekstualnog. Tekstove reference ovdje su dvostruko intencijski intonirane i manipulacija je usmjere- 
Konstrukcija, prenošenje i preoblikovanje priče(a) o nacionalnim identitetima...

na prema dvije različite instance: prema ispripovijedanom vremenu kao povijesnoj zadanosti i novohistoricistički dislociranom drugom koji je zapravo tekstom prezentiran kao autorska intencija koja asocira na ono što je tekstom uokvireno u vrijeme pričanja teksta, i to više nego li na razini ideologemskog odnosa prema ispripovijedanom vremenu. Kod Andrića su takvi ekskurzi u eksplicitno područje ideologema, što se odnose prema izvantekstualnoj uokvirenosti (Culler bi rekao extratextual frame), puno rjeđi i u prvom čitanju teksta daleko slabije vidljivi nego kod Krleže. Dok Krležin pripovjedač još od Hrvatskog boga Marsa zaključuje kako ,nikad tome (nasilju, ubijanju, klanju, op. au.) neće biti kraja“, Andrićev narator u gnomskom iskazu pokušava progovoriti o općim situacijama za koje se čitalačkoj intenciji sugerira čitanje i tumačenje iz pozicije mitologemske zasićenosti uz privid objektivnosti kroz kojeg se tek povremeno nazire ideologemsko pozicioniranje i određivanje prema naciji, nacionalnom pitanju i sugerira se, neizravno, vrijednosno jaki iskaz svrstavanja. Ovaj je, u tekstovima u kojima - kako bi rekao Roman Jakobson - prevladava poetska funkcija jezika, vješto prikriven. U takvim gnomskim iskazima koji, s jedne strane, doista progovaraju o „općim istinama“, ali s druge ipak ulaze u sloj proizvodnje ideologemskog pozicioniranja pripovjedačke intencije, istovremeno se je i lakše i teže sakriti. Pri tom valja primijetiti kako je prijelaz iz svijeta priče, legende i mitologemskog sloja „povišene impostiranosti“ u privid objektivnosti, ideologemski intertekstualno položen u smislu i na način kojeg definiraju Fredric Jameson i Julia Kristeva. ${ }^{33}$ To zapravo znači da se odvija prijelaz iz diskursivnog polja u diskursivno polje (što znači da se radi o metaforičnoj komunikaciji), ali istovremeno predstavlja i pojačavanje ukazivanja na ono što stoji iza površinskog sloja reprezentacije zbilje (legende). Kod Krleže pak, taj je prijelaz jasniji i uvijek se i u fikcijskom sloju suodnošenja prema drugim strukturama može dekodirati i intertekstualnost na ideologemskom planu.

Zanimljivo je međutim to da dok se Krleža u prozi svrastava izravano i jasno, u esejima njegova svijest o kolonijalom stanju stvari, a kasnije i postkolonijalno zauzimanje ,položaja“ u odnosu na srednju Europu, proizvodi iskaz koji je vrlo uslojen i često stoji dijaloški složen, strukturalno izgledajući

${ }^{33}$ Misli se na definiranje ovakvog pozicioniranja u knjizi Fridrica Jamesona The Political Unconscious. Na jednom mjestu Jameson definira ideologem kao ,povijesno determiniranu koncepcijsku ili semičku kompleksnost koja se može projicirati različito u obliku 'sustava vrijednosti' ili 'filozofskog koncepta' ili u obliku protonarativa, privatne ili kolektivne narativne fantazije“ (1981:115). Za Jamesona ideologemi su ,sirov materijal“ kulturalnih produkata koji doprinosi razumijevanju tih projekata kao „kompleksnih rezultata transformacije“. Kasnije, Julia Kristeva ideologeme dovodi u vezu s intertekstualnošću: oni konkretnim strukturama (romanima, na primjer) omogućavaju interakciju s drugim strukturama (diskursima) u intertekstualnom prostoru preplitanja. 
dijaloški gotovo u Bahtinovom smislu opisa dijalogističkog suprotstavljanja „ravnopravnih“ opcija. Tako na primjer kad kritizira lokalnu identifikaciju Starčevićevu, on ga istovremeno mitologizira i uzdiže gotovo na razinu amblema kojeg onda, fingirano ili ne, podražava kao ,jedinu svijetlu točku“, tako reći neko neodređeno svjetlo prema kojem se, eventualno može(mo) orijentirati u priči koju izmišljamo o vlastitoj nacionalnoj veličini i mjestu u prostoru globalne identifikacije. Pokušavajući izgraditi ono što njemačka imagologija u Dukićevoj interpretaciji pozicionira kao autopredodžbu (2009), Krležina se pripovjedna (esejistička) intencija pozicionira kao druga u odnosu na povijesnu ličnost koju je dislocirao u fikcijski sloj tekstualnog. Tako se iz „slike o nama“ prelazi na sklisko područje rekonstrukcije „slike o njima“, odnosno dolazi do svjesne fikcionalizacije vlastite povijesne priče kojoj je svrha proizvođenje slike o sebi kao slike o drugom. Pokušava se dakle pripovjedno pozicionirati prema vlastitom drugom iz pozicije heteropredodžbe. Mi više nismo dislocirani mi, već su to sada neki oni prema kojima se može ideologemski intertekstualno odnositi, nastupajući iz drugačijeg diskursivnog polazišta.

To je moguće samo uz kružnu strukturu „vječitog poniranja“ u dijalogu sa samim sobom, a što je naročito naglašeno u tehnici i impostacijskim slojevima Zastava, teksta koji cijelo vrijeme balansira pozicioniranje pripovjedača, manipulirajući pri tom odnosom romanesknog i esejističkog impostiranja i pretvarajući životnu situaciju (povijesno obilježenu mizanscenu) u fikciju. Ili se zbiva obrnuto pa dolazi do fikcionalizacije koncepata o kojima se polazišno progovara kao o čvrstim mjestima faktografske identifikacije. To se događa, kako sam napisao u motu ovog rada, intencijom usijecanja fakcijskog u okvir ,udobnijeg okoliša“ za pokazivanje mehanizama koji bi u izravnom ne-fikcijskom govoru Krležinu mogao proizvesti izravnu disidentsku poziciju, a time i određene posljedice (v. Eco). Umjesto toga, autor je izabrao poziciju ,unutarnjeg disidenta“ a komocija, udobnost fikcionalizacije činjeničnog pružila je sigurno utočište piscu čija intencija je mogla prouzrokovati destabilizaciju sustava. Tako se u Krležinoj prozi događa esejizacija romanesknog s relativno jasno određenim (dijaloški) zauzetim pozicijama i fikcionalizacija esejističkog u kojoj su stvari manje izravne, a slojevi prijelaza zamućeni odnosom prema povijesno dislociranom drugom kao (fiktivnoj) heteropredodžbi.

Andrić će pak u esejističkom tekstu biti daleko eksplicitniji glede impostacije nego što je to u prozi, a ideologemski sloj potpuno će se oteti mitologemski impostiranom kodiranju tekstualnih poruka, bez obzira na činjenicu da i on želi djelovati mitologemski i „općenito“. Kao i Krleža od Supila ili Križanića, Andrić također želi napraviti od Njegoša lik (premda u eseju koji pretendira na „objektivno zauzimanje stava“ a ne na fikcionalizaciju zbilje, 
Konstrukcija, prenošenje i preoblikovanje priče(a) o nacionalnim identitetima...

kakav slučaj bilježimo kod Krleže). Krleža je to učinio drugačije, impostirajući se do davanja mistificirane neodređene snage Starčeviću u svojim razbacanim odlomcima kroz nekoliko eseja o Supilu, Križaniću, Kranjčeviću i Hegeduševićevim Podravskim motivima, a ne u programatskom eseju o Starčevićevom položaju u prostoru i vremenu. Takva je impostacija sve više raspršivala ali i konsolidirala fiktivnog Starog, sve više i više kroz nova iščitavanja većeg broja različitih tekstova koji su, prvenstveno, bili o nečem drugom. Pri tom kod Andrića snažna izravna ideologemska razina impostiranja onemogućava dijaloški pozicioniranog drugog kao sudionika u ovom tekstu. Sloj odnosa prema totalitetu kulturne proizvodnje prema kojem se umrežavanje ideologema treba odnositi kao prema svom diskursivnom uključenju u šire procese dekodiranja zajednice ovdje se ne ostvaruje kompleksno kao kod Krleže i nije usložnjena fikcijskim su-odnošenjem prema likovima koji izmiču uokviravanju unutar jednog teksta, jedne paradigme. Andrićev Njegoš odražava doduše svoj lik kroz naznake drugog pogleda, odnosno gledanja iz uvijek drugačije perspektive, prije svega tijekom svoga boravka u Italiji, ali je kronika o kojoj Andrić piše (Nenadovićeva) ipak tekst koji prije svega pred očima čitatelja iz ideološki čvrsto zadane pozicije proizvodi mitsko iskustvo i iz autorskog teksta ga „vraća“ natrag u lokalnu zajednicu, više nagovarajući nego pregovarajući s čitateljskom intencijom. Intencija njegova tako predstavlja čvrstu upisanost u tradiciju, njezino obogaćivanje i učvršćivanje, a ne služi se propitivanjem mogućih svjetova kao svojom središnjom snagom, kako je to bio slučaj kod Krležinih autorskih taktika u gore navedenim tekstovima.

Primjer iz Andrićeva niza tekstova o Njegošu koji navodim ovdje vrlo je indikativan. Za razliku od Krležinih, Andrićevi mi puno su bliže ideji imaginarne zajednice kao nacije (u Andersenovom smislu opisa i kvalifikacije nacije i nacionalnog). Ton je ovih zapisa povišen, a tekst zasićen slikama autopredodžbi o veličini nacije, deseterca kao oruđa (oružja) i zvuku poziva na zbijanje redova kojem se valja odazvati u procesu homogenizacije. Kad se takav način oslikavanja Njegoševe „ostavštine“ u esejističkim tekstovima Andrićevim usporedi s fikcijskim tekstovima i impostiranjem problema odnosa prema drugom u tim ,aktualizacijama mita“, dobiva se rezultat u obliku izravnog nagovora koji je potpuno suprotan ustaljenom sterotipu o Andriću kao objektivnom pripovjedaču i kroničaru polietničke sredine iz njegovih povijesnih proza:

Za sve nas koji smo se rodili na tlu nekadašnje osmanlijske ekspanzije ili vladavine, Njegoš je najviši i nama najbliži pesnički izraz svega što pokreće čoveka u njegovoj borbi za slobodu, hleb i prosvećenost, u njegovoj težnji da se oslobodi prokletstva i rđe nedostojna života i robovanja. Ima u nama drhtaj jednog tona koji tačno odgovara specifičnom ritmu Njegoševa deseterca, koji se prema 
njemu odnosi kao kalup prema odlivku i koji se na njegov zvuk uvek odazove, veran i nepogrešan kao lozinka. Možemo trenutno otići u svojim mislima i osećajnim zaletima daleko napred, mi ćemo se uvek vratiti Njegošu; možemo, „zabavljeni o sebi“ zaostati za njim, mi ćemo ga u presudnim trenucima uvek stići. On je uvek prisutan i može samo izgledati odsutan. (str. 59) ${ }^{34}$

Iz ovog je razvidno da se Andrićev pripovjedač drugačije pozicionira u fikciji a drugačije u faktografski (povijesno i iz jake pozicije idologemski) impostiranim tekstovima u kojima fikcijskim elementima naglašava i posreduje ideologemski sloj pripovjedne intencije s pragmatičnim nagovornim slojem, služeći se mitologemskim amblemima okamenjenih predodžbi kao materijalom za uvjerljiv nagovor, odnosno upisujući ih u proces umrežavanja ideologemskih žarišta teksta. U tom nizu tekstova prikupljenih u knjizi Umetnik $i$ njegovo delo, ${ }^{35}$ Andrićev se imaginarni autor postavlja izravno, čvrsto se pozicionirajući kao nastavljač jedne mitologemske tradicije koju mu je zadatak posredovati tako da je potpuno jasno tko su to njegovi mi u ovim tekstovima i kako se njegova naracija ,jugoslovenske nacije“ plete oko narativa Kosova i kosovskog mita. Tako se može reći da dok je u fikcijskim tekstovima njegova pripovjedna intencija fingirala mitologemski sloj kao izvorište pripovjednih sukoba, pri tom se koristeći ideologemski zasićenim naslagama kao dubinskim strukturama teksta, ovdje više nema ironične dvosmislenosti u odnosu na zauzimanje vrijednosno obilježenog pozicioniranja iskaznog subjekta:

(...) Namučene žene koje su se odmarale pored bremena drva na kamenoj ivici puta govorile su mu o Kosovu kao o svojoj osobenoj sudbini i ličnoj tragediji. „Naša je prava na Kosovu zakopana“, govorili su ljudi rezigrirano i ne pomišljajući da je traže drugim putem do onoga koji im kosovski zavet nalaže. Celokupna sudbina ovih ljudi bila je tim zavetom omeđena i upravljana. Kao u najdrevnijim legendama, koje su uvek i najveća ljudska stvarnost ... (...)

(...) Tu je dakle početak i Njegoševe drame. Bez ovoga bi tragika Njegoševa života bila teško razumljiva. Njegoš je prototip kosovskog borca (...). ${ }^{36}$

\footnotetext{
${ }^{34}$ Iz izdanja Sabrana dela, Udruženi izdavači, Sarajevo, Beograd Zagreb, Ljubljana, Skopje i Titograd, 1981. Knjiga trinaesta: Umetnik i njegovo delo. Eseji II.

${ }_{35}$ Ovdje je konkretno riječ o trinaestoj knjizi sabranih djela šest jugoslavenskih izdavača, objavljenoj 1981. godine.

${ }^{36}$ Dijelovi iz eseja „Njegoš kao tragični junak kosovske misli“, I. Andrić: Sabrana dela, Knjiga trinaesta (dopunjeno izdanje), Sarajevo 1981.
} 
Konstrukcija, prenošenje i preoblikovanje priče(a) o nacionalnim identitetima...

Ponovo se pojavljuje ista taktika koju pronalazimo (a ovdje smo je već iznijeli) u dvadeset godina kasnije napisanoj priči o vezirovom slonu, ali ovoga puta bez ukazivanja na tursku poslovicu koja joj je ishodište. Legende su, dakle, najveća ljudska stvarnost, baš kao što su priče o događajima istinitije nego sami događaji. Lokalna identifikacija zasnovana je na legendi, baš kao što je u hrvatskom slučaju kojeg impostira Krleža identifikacija u esejima o Starčeviću bila zasnovana na fikcionalizaciji fakata. Ali i jedno i drugo je učinjeno i upisano u svjesnoj umjetničkoj manipulaciji. Ovdje se radi o dvije tradicije: srednjoeuropskoj i orijentalnoj, dakle, najprije o onoj koja (autorski manipulativno) pretvara povijest u priču, a onda i onoj kojoj je priča zapravo prava povijest. U prvom slučaju bijeg od kolonijalnog jarma moguć je uspostavljanjem (intelektualne) vertikale kao fikcijskog oslonca, a u drugom je priča jača od stvarnosti pa ju je ova i uobličila kao konkretni nagovor ispričanog, onog koje je jasno, jednostavno i izravno. I nema, na kraju krajeva, priče koja može biti tako okrutna kao stvarnost. Zato se utjeha ovdje pronalazi u življenju fikcije, a ne u fikcionalizaciji (zamišljaja) stvarnosti. Upravo je stoga hrvatska (Krležina) priča bidermajerski kićena i neprestano se vrti u ničeanskom krugu ,vječitog kruženja i propadanja“, a srpska (Andrićeva) je sirova i surova, izravna i zaokružena u sebi samoj. Poetički profinjen iskaz tako proizvodi još veći kontrast i doprinosi dinamici tekstualnog. I zato je riječ u dva tipa uklapanja i uklopivosti u globalno okruženje te o dva različita stereotipa heteropredodžbi, odnosno o jednima i drugima nama koje su Andrić i Krleža upisivali u svoje tekstove. Ovo može poslužiti kao dobro polazište odnosa politike i poetike u nagovoru dvojice pisaca, njihovim ideologemskim polazištima, ali i u korištenju mitologema kao „materijala“ na impostaciji tekstualnih taktika. Tu počinje rasprava o odnosu politike i poetike, odnosno lokalnog i globalnog nagovora u pripovjednim taktikama dvojice pisaca.

\section{Literatura}

- Anderson, Benedict (1991): Imagined Communities. Reflections on the Origin and Spread of Nationalism. Revised Edition. London i New York: Verso.

- Baudrillard, Jean (2005): The Intelligence of Evil or the Lucidity Pact. Oxford i New York: Berg (francusko izdanje 2004), prev. Chris Turner.

- Baudrillard, Jean (2001): Simulacija i zbilja. Zagreb: Jesenski i Turk. Predgovor: Rade Kalanj.

- Baudrillard, Jean (1983) Simulations. NewYork: Semiotext(e).

- Barthes, Ronald (1993) : A Ronald Barthes Reader. Ur. i pred.: Susan Sontang. London, Melbourne i Sydney: Vintage. 
- Biti, Marina i Danijela Marot Kiš (2008): Poetika uma. Osvajanje, propitivanje $i$ spašavanje značenja. Zagreb i Rijeka: Hrvatska sveučilišna naklada i Izdavački centar Rijeka.

- Biti, Vladimir (2002) Poetika i etika pripovijedanja. Zagreb: Hrvatska sveučilišna naklada.

- Bhabha, Homi (1993): The Location of Culture. London: Routledge.

- Bogarth, Ralph (1991): The Writer as Naysayer. Miroslav Krleža and the Aesthetic of Interwar Central Europe. Columbus, Ohio: Slavica Publishiers, Inc.

- Bourdieu, Pierre Felix (1987): Distinction: A Social Critique of the Judgement of Taste. Cambridge, Mass.: Harvard University Press.

- Culler, Jonathan (1991): O dekonstrukciji. Zagreb: Nakladni zavod Globus.

- Derrida, Jacques (1991/2004/): Dissemination. London i New York: Continuum. Prijevod na eng. i pred.: Barbara Johnson.

- Dukić, Davor i dr. (2009): Kako nas vide strane zemlje. Uvod u imagologiju. Ur.: Davor Dukić, Zrinka Blažević, Lahorka Pleić Poje i Ivana Brković. Zagreb: Srednja Europa.

- Eagleton, Terry (2002): Ideja kulture. Zagreb: Naklada Jesenski i Turk.

- Eagleton, Terry (2005): Teorija i nakon nje. Zagreb: Algoritam. (After Theory, prev. Darko Polšek).

- Eco, Umberto (2005): Šest šetnji pripovjednim šumama. Zagreb: Algoritam. (Prev.: Tomislav Brlek).

- Falck, Colin (1994): Myth, Truth and Literature. Towards a True Post-modrenism. Cambridge: Cambridge University Press.

- Jameson, Fridric (1981): The Political Unconscious: Narrative as a Socially Symbolic Act. Itacha: Cornell University Press. (Fredrik Džejmson, Političko nesvesno. Beograd: 1984. Prev. Dušan Puhalo).

- Frank, Manfred (1994): „Postoje li u sporazumijevanju racionalno neodlučivi konflikti“. U: Manfried Frank, Kazivo i nekazivo. Ur.: Vladimir Biti. Zagreb: Naklada MD.

- Foucault, Michel (1994): Znanje i moć. Zagreb: Nakladni zavod Globus. Prev. Rade Kalanj.

- Greenblat, Stephen (1991): Shakesperian Negotiations. The Circulation of Social Energy in Renaissance England. Los Angelos: California University Press.

- Kodrić, Radoman (2007): Politika književnosti. Beograd: Filip Višnjić. 
Konstrukcija, prenošenje i preoblikovanje priče(a) o nacionalnim identitetima...

- Lacan, Jacques (1983): „Frojdovska stvar“. U: Žan Lakan: Spisi. Beograd, Prosveta.

- Lasić, Stanko (1982): Krleža. Kronologija života i rada. Zagreb: Grafički zavod Hrvatske.

- Nemec, Krešimir (1995): „Ivo Andrić u procesu razdruživanja“. U: Krešimir Nemec: Tragom tradicije. Zagreb: Matica hrvatska.

- Nemec, Krešimir (1995): „Usmjerena recepcija - Krležino djelo između ideologije i estetike“. U: Krešimir Nemcec: Tragom tradicije. Zagreb: Matica hrvatska.

- Oraić Tolić Dubravka i Erno Kulcsar Szabo (ur.) (2006): Kulturni stereotipi. Koncepti identiteta u srednjoeuropskim književnostima. Zagreb: FF Press.

- Parekh, Bhikhu (2000): Rethinking Multiculturalism: Cultural Diversity and Political Theory. Basingstoke i London: MacMillan.

- Pranjić, Krunoslav (2003): „Proslov“. U: Ivo Andrić: Priča o Japanu i druge odabrane. Zagreb: Konzor.

- Rorty, Richard (1989): Contingency, Irony and Solidarity. Cambridge: Cambridge University Press.

- Sekeruš, Pavle (2002): „Društvene predstavke i proizvodnja značenja: Slike Južnih Slovena u francuskoj kulturi XIX veka“. www.ff.ns.ac.yu/stara/elpub/susretkultura

- Stojanović, Dragan (2003): Lepa bića Ive Andrića. Novi Sad i Podgorica: Platoneum i CID.

- Spivak, Gayatri Chakravorty (1989): „The New Historicism: Political Commitment and the Postmodern Critic". U: Aram Vesser, ur.: The New Historicism. London: Routledge.

- Škvorc, Boris (2003): Ironija i roman. U Krležinim labirintima. Zagreb: Naklada MD.

- Škvorc, Boris (2005): „Neki problemi periodizacije Krležine proze (i proze njemu suvremenih autora)“. U: B. Škvorc: Gorak okus prešućenog. Zagreb: Alfa.

- Škvorc, Boris (2006): „Društveno djelovanje i pozicioniranje autora: Ivo Andrić i Miroslav Krleža“. U: Hrvatska književnost u 20. stoljeću, različite ideje i funkcije književnosti. Ur.: Branimir Bošnjak i Cvjetko Milanja. Zagreb: Altagama.

- Van Dijk, Teun A. (1997): „Discourse as Structure and Process“. U: Teun Van Dijk, ur.: Discourse Studies: A Multidisciplinary Introduction, vol 1. London i Thousand Oaks: Sage Publications.

- Van Dijk, Teun A. (2006): Ideologija. Multidisciplinarni pristup. Zagreb: Golden marketing i Tehnička knjiga. 
- Visković, Velimir (1998): „Predgovor“. U: Ivo Andrić: Prokleta avlija. Zagreb: Konzor.

- Visković, Velimir (2001): Krležološki fragmenti. Krleža između umjetnosti i ideologije. Zagreb: Konzor.

- Vučković, Radovan (2002): Andrić: istorija i ličnost. Beograd: Gutenbergova galaksija.

- Žižek, Slavoj (2009): Paralaksa. Zagreb: Antibarbarus.

\section{Boris ŠKVORC}

\section{CONSTRUCTION, TRANSFERENCE AND RESTRUCTURING OF STORIES ABOUT NATIONAL IDENTITIES: ABOUT KRLEŽA'S STARČEVIĆ AND ANDRIĆ'S NJEGOŠ}

This work explores the narrative tactics, authorial impostations and the manipulations with ideologemes in prose works of two of the most important twentieth century South Slavic authors, Ivo Andrić and Miroslav Krleža. The focus is on their narrative and ideological tactics: fictionalization of factional layers of the text, especially on the processes of fictionalization of historical 'characters' such were Ante Starčević, an important Croatian politician from nineteen century, and Petar Petrović Njegoš, probably the most important historical person in Montenegrian nineteen century history. The postcolonial reading of this work explores the influence of various centres of power to on the readings and intepretation of our authors, their writing as well as the ways and tactics by which Andrić and Krleža are building those two historical persons into their fictional characters. The most important issue is that this is the process happening in a genre of essay, which is not fictional form. Some of the most important novels of two authors are also interpreted and explored with special attention given to the opposite process, that is the factionalisation of fiction and a production of various layers of identification tactics within both, fictional and factional texts. The paper argues that with decoding of the most important layers in factional text the great tool of further exploration in fiction of these two authors is provided.

Key words: identification, textual manipulations of authorial intention(s), narrative tactics, ideologemes, mithologemes, fiction, cultural studies 
LINGUA MONTENEGRINA, god. III, br. 5, Cetinje, 2010.

Institut za crnogorski jezik i jezikoslovlje „Vojislav P. Nikčević“

UDK 821.163.42.09-1

Izvorni naučni rad

\section{Zlata ŠUNDALIĆ (Osijek)}

Filozofski fakultet Sveučilišta J. J. Strossmayera u Osijeku

\section{KONOTACIJE PUTA U VILI SLOVINKI}

U radu je pozornost usmjerena na Vilu Slovinku (1614.), spjev zadarskog pisca Jurja Baraković (1548.-1628.), koji je pjesnik ispjevao u slavu Zadra, s kojim je imao i nekih težih nesuglasica. U kontekstu priče o Pisniku, Vili, Poklisaru (Osinu) i ostalim likovima istražuju se konotacije puta (putovanja, bijega, povratka) i njegovih izvedenica, odnosno istražuju se jezgreni i periferni semantemi na razini priče, lika i kompozicije, te njihovo dovođenje u svezu s poetikom književnosti na prijelazu u 17. stoljeće (manirizam).

Ključne riječi: Vila Slovinka, put, lik, priča, kompozicija, manirizam

\section{Rečeno je o Vili Slovinki}

Prije stotinu i dvadeset godina pojavila su se u sedamnaestoj knjizi edicije Stari pisci hrvatski Djela Jurja Barakovića, koja su za tisak godine 1889. priredili Pero Budmani i Matija Valjavac. ${ }^{1}$ Uz Vilu Slovinku, koja je bila preuzeta prema prvom izdanju iz 1614. godine, u Djela je bila uvrštena i Jarula (1618.), i Draga, rapska pastirica (tiskana tek 1889.), te poslanice. ${ }^{2}$ Kao najbolje i najreprezentativnije Barakovićevo djelo uzima se, i prije i danas,

${ }^{1}$ Riječ je o izdanju Baraković, Juraj (1889). Djela, priredili za štampu P. Budmani i M. Vaĺavac, Stari pisci hrvatski, Kńiga XVII, JAZU, Zagreb.

${ }^{2}$ Barakoviću se pripisuju i tri hrvatska djela (Život Sv. Jeronima, Gramatika hrvatskog jezika i Povijest naroda dalmatinskog i hrvatskog) i jedno talijansko djelo (Život Marka Tulija Cicerona u stihovima), kao i propovijedi na hrvatskom jeziku Sacri sermoni in lingua illirica, koje su i pronađene u galeriji Sotheby u Londonu (Franičević, 1983: 634): „Barakovića je pratio glas dobroga propovjednika, ali i nemarnoga župnika, o čemu govore izvještaji biskupskih vizitatora.“ (Bratulić, 2000: 7) Istog mišljenja nije i Nikica Kolumbić: „Malo je vjerojatno da bi Barakovićeva mogla biti i rukopisna zbirka propovijedi Sacri sermoni in lingua illirica, koja se u novije vrijeme čuva u zagrebačkoj Nacionalnoj sveučilišnoj biblioteci.“ (Kolumbić, 1980: 310) 
upravo Vila Slovinka ${ }^{3}$ (Šafařik, 1865: 168; ${ }^{4}$ Švelec, 2000: 329), koja je do 19. stoljeća doživjela tri izdanja ${ }^{5}$ (Bratulić, 2000: 13), a nakon njega još najmanje tri. ${ }^{6}$ Ono što se prije nije znalo, a danas se s velikom sigurnošću uzima kao dokumentirana činjenica je raznovremenost nastajanja Vile Slovinke, jer je cijelo Petje peto, nastalo prije Vile, kao samostalna pjesma u pohvalu Zadra, te kao takva naknadno umetnuta u spjev (Švelec, 1990: 147-163).

Čitanja Vile Slovinke mijenjala su se tijekom vremena od pozitivističkog biografizma do manirizma (M. Franičević ${ }^{7}$ ), baroka (F. Śvelec $^{8}$ ) i onirizma (Z. Kravar, ${ }^{9}$ S.P. Novak ${ }^{10}$ ) današnjih interpretacija. Tako se u 19. stoljeću, pa i kasnije, ${ }^{11}$ zbog oskudnih podataka o životu i radu sa-

${ }^{3}$ Ovu je misao zapisao još 1889. i Matija Valjavac: ,Slovinka je svakako Barakovićevo najbole djelo i kompozicijom i dikcijom, pa za to nije vjerojatno da je i ńegovo prvo.“(Vaĺavac, 1889: X)

4 Šafařik je o Vili Slovinskoj, kako je on naziva, zapisao ovu rečenicu: „Ausgezeichnet durch Composition, Styl und Versbau." (Šafařik, 1865: 168), a preuzima je u svoje Ogledalo književne poviesti i Šime Ljubić (Ljubić, 1869: 392).

${ }^{5}$ Godine 1614. izašlo je prvo izdanje Vile Slovinke u Veneciji, gdje je tiskano i drugo izdanje 1626. godine, ali i treće izdanje iz 1682. godine.

${ }^{6}$ U ediciji Pet stoljeća hrvatske književnosti (Knjiga 8) tiskana je, ali ne u cijelosti, godine 1964. Vila Slovinka koju je priredio Franjo Švelec; godine 2000. pojavila su se dva nova izdanja - za ediciju Stoljeća hrvatske književnosti priredio ju je Franjo Švelec, a za ediciju Croatica - Hrvatska književnost u 100 knjiga Josip Bratulić. Četiri godine kasnije (2004.) za Matičinu je biblioteku Parnas Slobodan P. Novak napravio izbor iz Vile Slovinke pod nazivom Vila Slovinka - Zučnopojke, izdvojivši iz Vile samo osmeračke sonete (zučnopojke) i objavivši ih kao samostalan kanconijer: „Ali, iako organski uklopljeni u cjelinu, ovi se Barakovićevi soneti mogu čitati i kao zasebna cjelina, kao kanconijer." (Novak, 2004a: 66)

${ }^{7}$ Marin Franičević naziva Barakovića pjesnikom ,,prelaznoga manirističkog razdoblja“ (Franičević, 1983: 645).

${ }^{8}$ Franjo Švelec za Barokovića kaže da je ,barokni čovjek i po svom općem habitusu“ (Švelec, 1974: 194).

${ }^{9}$ Posebnu pozornost snovima u Vili Slovinki posvetio je Zoran Kravar (v. Kravar, Zoran (1991). Das Barock in der kroatischen Literatur, Köln - Weimar - Wien, Böhlau Verlag), jer u priču Pisnik umeće svoje snove, a i spjev kao cjelina doima se kao veliki san, kao ep-san.

${ }^{10}$ Slobodan Prosperov Novak kaže: „Vila Slovinka iz 1614. onirički je ep koji se doima poput prostornoga čudovišta. Nalik je patuljku s udovima diva.“ (Novak, 2004b: 114)

${ }^{11}$ Početkom 20. stoljeća Branko Vodnik piše: „O dogadjajima u životu Barakovićevu ne znamo upravo ništa, ali 'Vila Slovinka' svjedoči, da mu je život bio buran i nesredjen." (Vodnik, 1913: 264) O književnom radu Barakovićevu i Marin Franičević donosi određene zaključke na temelju Vile Slovinke: „Ali potvrdu o književnom radu Jurja Barakovića u XVI stoljeću nalazimo i u samoj Vili Slovinki, odnosno u pohvalnoj pjesmi Osipa Ivetića štampanoj na kraju djela, uz ostale pohvalnice. (...) Nešto bi se biografskih podataka moglo izvući iz njegovih djela, ali ona sama za sebe, bez drugih potvrda, nisu 
mog Barakovića (Plemići, 1548. - Rim, 1628. ${ }^{12}$ ) Vila Slovinka čitala kao djelo s pouzdanim autobiografskim podatcima (o piščevim precima i ženidbama, slavnoj prošlosti, o njihovim posjedima) (Vaĺavac, 1889: V-X). Početkom 20. stoljeća i dalje se vrlo pozorno iščitavala sadržajna razina ${ }^{13}$ Vile i kritizirala kompozicija, kojoj nedostaje jedinstvenost ${ }^{14}$ (M. Medini), koja nema zaokruženi smisao ${ }^{15}$ (B. Vodnik), čije su sastavnice slabo povezane ${ }^{16}$ (S. Ježić), jer je nepovezanost „plod primitivne i neuredne mašte“ (Kombol, 1961: 198).

U interpretacijama Vile Slovinke naglasak je bio stavljan na određene probleme, kao što su na primjer: kako je nastajala konačna inačica Vile (F. Švelec ${ }^{17}$ ), je li Vila jedinstven spjev (B. Vodnik ${ }^{18}$ ), ideja panslavizma (M.

dovoljno pouzdano svjedočanstvo i nikada ne znamo da li potječu iz stvarnosti ili pjesnikove fantazije.“ (Franičević, 1983: 633)

${ }^{12}$ Povijesti stare hrvatske književnosti životopisne podatke svode na sljedeće: rodio se u Plemićima 1548. godine, djetinjstvo i dio školovanja proveo u Zadru. Nakon završenog školovanja, najvjerojatnije u Italiji, postao je klerik, a kasnije kao svećenik (1564. spominje se kao klerik, a 1586. kao svećenik). Zbog nepoznatih razloga (možda zbog ljubavnih avantura?) prognan iz Zadra u Šibenik. Sudjelovao je i u borbi protiv Turaka i bio ranjavan. Umro je za vrijeme svog trećeg boravka u Rimu 1628. godine.

13 „Sve ostalo, osim podataka o njegovu sudjelovanju u borbama protiv Turaka gdje je bio ranjen u prsa, te o njegovoj smrti u Rimu na hodočašćenju 1. kolovoza 1628. što je Ivan Tomko Mrnavić unio u nadgrobnu ploču u rimskoj crkvi sv. Jeronima, doznajemo tek iz posrednih izvora, a većina se može nagađati prema njegovim autobiografskim podacima u Vili Slovinki i Dragi.“ (Kolumbić, 1980: 307)

14 ,Jedinstvenosti Vili nedostaje, i to je glavno, što je grdi.“ (Medini, 1902: 247)

15 ,(...) kompozicije ne odaje nikakve, i na svakom mjestu djela može on govoriti o svemu, što mu na um pada, o prošlosti i sadašnjosti, o sebi i o drugima, tako te je veoma teško naći i omanje mjesto, koje bi imalo zaokruženi smisao, a vrlo su česta mjesta, koja nemaju nikakva smisla." (Vodnik, 1913: 264)

16, „(...) raznolični elementi pjesme vrlo su slabo među sobom povezani; imade i mnogo ponavljanja, a sve skupa kvare pjesnikova mudrovanja, u kojima ima mnogo riječi, a malo misli; (...).“(Ježić, 1993: 114)

${ }^{17}$ Poznato je da je Vila Slovinka tijekom 17. stoljeća tiskana tri puta (1614., 1626., 1682.) i sva su tri izdanja gotovo u cijelosti podudarna (s izuzetkom nekih tiskarskih pogrješaka). Danas se na temelju samoga teksta Vile pretpostavlja da inačica zgotovljena 1613. a tiskana 1614. godine nije podudarna sa svojom tiskanom inačicom. Iz posvetne pjesme An'jelu Justinijanoviću jasno je da je Vila prvotno bila upućena kao pohvala gradu Zadru i njegovim sugrađanima. Ali neharni Zadrani Vilu nisu prihvatili, jer im ili nije ugodila ili im je draži bio latinski jezik (zbog već započetog romaniziranja samih građana): , Znači, pjesnik je prvu verziju morao mijenjati. Danas možemo samo nagađati kakve je izmjene izvršio, no sigurno je da u novoj verziji imamo drugačiji tekst. Zbog 'popravljanja' su po svoj prilici nastale određene neusklađenosti, koje je danas teško objasniti, na primjer, pohvale nekim Zadranima i, poslije, njihovo poricanje." (Švelec, 2000: 20) 
Medini) ${ }^{19}$ borba protiv Turaka, odnos između pučana i plemića (M. Franičević), semantika stiha (F. Švelec ${ }^{20}$ ), strani utjecaji, posebice Vergilija na Vilu Slovinku (V. Dukat, ${ }^{21}$ F. Švelec ${ }^{22}$ ) itd.

Prigovore vezane uz sadržajnu i kompozicijsku nepovezanost Vile Slovinke gotovo su redovito pratila priznanja Barakoviću kao versifikatoru, koji je svoj opsežan spjev ispjevao u različitim metričkostrofičkim oblicima, koje pjesnik naziva: pismi skupne, osmoredke, poluredke, zučnopojke, a kojima se treba pribrojati i osmeračke sestine i bugarštica. Ako im se dodaju i osmeračke i jedanaesteračke oktave iz Jarule i osmeračke oktave i sestine iz Drage, dobije se velika raznovrsnost stiha, što nije bilo uobičajeno za pjesnikovo vrijeme. Sve to ,(...) pokazuje da se Baraković bavio versifikacijom, tražeći svoj izraz i u raznovrsnosti stiha, kao i nešto stariji Dinko Ranjina." (Franičević, 1983: 636)

Što se tiče dijakronijskog smještanja Barakovićeva djela u povijest nacionalne književnosti, mišljenja su različita: Vodnik ga smješta u 17. stoljeće (Vodnik, 1913: 258-267), Ježić u posljednje dvije renesansne generacije u Dalmaciji i Dubrovniku (Ježić, 1993: 103-116), Kombol među epigone (Kombol, 1961: 193-203), Švelec u barok (Švelec, 1974: 193) odnosno u manirizam (Švelec, 2000: 24), Franičević ga smješta na smjenu stoljeća (Franičević, 1974: 184-195), Kolumbić ga imenuje najizrazitijim pjesnikom hr-

Nacionalna i sveučilišna knjižnica u Zagrebu otkupila je, naime, londonski rukopisni zbornik propovijedi Sacrj sermoni in lingua illyrica na čijem se kraju nalazila i pjesma podudarna s pohvalnom pjesmom Zadru iz petog pjevanja Barakovićeve Vile Slovinke. Zbog toga se došlo do pretpostavke ,da je zadarski pjesnik pohvalnu pjesmu Zadru napisao mnogo prije nego što ju je ugradio u svoju poemu zvanu Vila Slovinka.“ (Švelec, 1990: 156)

${ }^{18}$ Ovo su pitanje postavljali stariji povjesničari hrvatske književnosti, pa i Branko Vodnik, a sve je bilo potaknuto činjenicom da nakon sedmog pjevanja Vila nestaje iz samoga teksta.

${ }^{19}$ Već je početkom 20. stoljeća Milorad Medini otvorio temu panslavizma u Barakovićevu spjevu: „U Zoranića opažamo već tragove toga, recimo: panslavizma, a u Barakovića imamo skoro već čitavu zgradu gotovu, pa bi bilo jako lijepo ići dalje, te ispitati sveze ovijeh pjesnika sa starim našim hronografima, koji takodjer bilježe ovakova basnovita rodoslovlja, te sa knjigom Il regno degli Slavi poznatoga Orbinija, gdje je staro izmiješano sa novim te sve prikazano tadanjoj generaciji kao povijesna istina." (Medini, 1902: 253)

${ }^{20}$ „Koliko je pozornosti posvećivao izrazu i osobito samoj organizaciji fabule, očituje se lijepo u njegovu nastojanju da za određene sadržaje nađe adekvatne izražajnostilske, stihovnometričke i strofičke oblike." (Švelec, 2000: 15-16) 44, Zagreb.

${ }^{21}$ Usp. Dukat, Vladoje (1932). Vergilije u Hrvata, Ljetopis JAZU 1930/1931, sv.

${ }^{22}$ Usp. Švelec, Franjo (1990). Odjeci Vergilijeve Eneide u Vili Slovinki J. Barakovića, u: Iz naše književne prošlosti, Split, Književni krug. 
vatskog manirizma (Kolumbić, 1980: 306), kao što ga i već spomenuti Franičević nešto kasnije smiješta u prijelazno manirističko razdoblje (Franičević, 1983: 645), u kasnorenesansnu, odnosno manirističku književnost (Franičević, 1983: 653), a Frangeš u renesansu književnost (Frangeš, 1987: 70-71). Danas se Vila Slovinka češće uzima kao djelo čija poetika predstavlja odmak od renesansne (F. Švelec, S. Petrović, N. Kolumbić, P. Pavličić, M. Peićc ${ }^{23}$ ), ali uz napomenu da Zoran Kravar i takvo mišljenje dovodi u pitanje. ${ }^{24}$

\section{Neželjeno putovanje i sva ostala}

Sve ono što je Baraković mogao poznavati u odnosu na domaću književnu tradiciju, u koju svakako spadaju Zoranićeve Planine (tiskane 1569.), Karnarutićevo Vazetje Sigeta grada tiskano 1584.) i Piram i Tižba (tiskani 1586.), Marulićeva Judita (tiskana 1521., 1522., 1523., 1586.), ali i djela Lucića (Robinja tiskana 1556.), Marina Držića (djela su mu nastajala u vremenu 1548.-1559.), Dinka Ranjine (Pjesni razlike tiskane 1563.), Dominka Zlatarića (Ljubmir tiskan 1580.), Mikše Pelegrinovića (Jeđupka tiskana 1599.) i nekih drugih, u Vili nije neinventivno oponašano, jer nije riječ ni o transformaciji već poznatog predloška (npr. biblijske priče o Juditi, Ovidijeve priče o zaljubljenicima Piramu i Tizbi ili Črnkova zapisa o sigetskoj bitci) ni o zoranićevskom fiktivnom putovanju u planinu zbog ljuvene boli: „Baraković u Vili čini nešto dotada neuobičajeno: otvara spjev pripovijedanjem o svom odlasku u šibensku okolicu s namjerom da je kao pridošlica upozna." (Švelec, 2000: 10) Još se ni danas ne zna zašto je Baraković, veliki zaljubljenik u svoj rodni grad, morao krajem 16. stoljeća ${ }^{25}$ napustiti Zadar i preseliti se u

\footnotetext{
${ }^{23}$ Potvrđuju to sljedeći radovi navedenih autora:

Petrović, Svetozar (1968). „Problem soneta u starijoj hrvatskoj književnosti. Oblik i smisao“, Zagreb, Rad JAZU, knj. 350.

Kolumbić, Nikica (1980). Hrvatska književnost od humanizma do manirizma, Zagreb, Matica hrvatska.

Pavličić, Pavao (1988). Poetika manirizma, Zagreb, August Cesarec. Hrvatske.

Peić, Matko (1989). Barakovićev barok. - Slovo o Rabu, Zagreb, Grafički zavod

Švelec, Franjo (2000). „Juraj Baraković“, u: Juraj Baraković, Vila Slovinka, priredio Franjo Švelec, Stoljeća hrvatske književnosti, Zagreb, Matica hrvatska.

${ }^{24}$ Potvrđuje to knjiga Kravar, Zoran (1991). Das Barock in der kroatischen Literatur, Köln - Weimar - Wien, Böhlau Verlag.

25 „Neki historičari književnosti to njegovo preseljenje stavljaju u 1602, ali na osnovi Ivetićeve pjesme zaključujemo da je to moralo biti nekoliko godina prije." (Franičević, 1983: 634)
} 
Šibenik. ${ }^{26}$ Stvarni je uzrok ovog neželjenog putovanja bez povratka ostao pjesnikova tajna: „Nastanivši se u Šibeniku, više se puta pokušao vratiti u Zadar, ali u tome nije uspio. No Zadar je ostao njegova trajna ljubav i briga." (Bratulić, 2000: 7) I dok je onaj stvarni uzrok odlaska i danas nepoznat, onaj poetski uzrok preseljenja objašnjen je samom Vilom: „Stvar bi bila u neharu prema pjesnikovoj ličnosti, ali i u općem nehaju.“ (Franičević, 1983: 641)

Unutar trinaest petja, odnosno unutar 9345 stihova (Franičević, 1983: 647) Vile Slovinke progovara, direktno ili indirektno čovjek - Pisnik - koji je prognan iz voljenog Zadra, zbog čega sve ispripovijedano i opisano prožima perspektiva ,izgnanca“, odnosno ,čovjeka koji je napustio zavičaj i više ne može naći dom" (Franičević, 1983: 636, 641).

U interpretacijama Vile Slovinke koje su pokušale predočiti sadržaj$\mathrm{nu},{ }^{27}$ kompozicijsku ili metričku razinu, ${ }^{28}$ odnos prema književnom naslje$\mathrm{đu}^{29}$ ili nadnacionalni kontekst, ${ }^{30}$ sve su one gotovo redovito dodirivale i temu putovanja. Tako se izmišljena putovanja dovode u svezu i s hrvatskom renesansnom književnošću, ali i s najvećim književnim putnikom - Danteom, odnosno kaže se da je tematika jednostavne ,strukture (sastoji se od nekoliko međusobno srodnih putničkih epizoda), ali je teška za razumijevanje, jer uključuje nemotivirane prijelaze, skokove i proturječja. Iznosi je prividno autobiografski pripovjedač ('pisnik'), koji izvješćuje o četirima izletima u šibensku okolicu." (Kravar, 2000: 41) Pisnikovo putovanje po šibenskoj kopnenoj i pomorskoj okolici prožima, dakle, sve primarne slojeve tekstualne strukture, od fabule, kompozicije do aktancijalne razine i stiha, a na koji način, pokušat će se odgovoriti u tekstu koji slijedi.

\footnotetext{
${ }^{26}$ Preseljenje je bilo neželjeno putovanje, odnosno progonstvo: „Pretpostavka da je bio prognan iz Zadra zbog ljubavnih avantura nije, u vremenu u kojemu je živio, nevjerojatna." (Franičević, 1983: 634)

27 „Vila Slovinka se ostvaruje opisom pjesnikova putovanja po šibenskoj okolici, gdje se on susreo s Vilom.“" (Švelec, 1974: 191)

28 „Metričke varijacije najvjerojatnije su u svijesti pjesnikovoj trebale imati funkciju razbijanja monotonije i izgrađivanja kompozicije u kojoj će putovanje pjesnikovo biti osnova, a 'osmoretke', 'zučnopojke' i 'poluretke' nešto kao dijelovi, što treba da toj zgradi da raznovrsnost i zanimljivost već i u formalnom pogledu“. (Švelec, 1974: 194)

${ }^{29}$ U Vili se prepoznaje utjecaj domaće književne tradicije, od Marulića, Lucića, Pelegrinovića, Hektorovića, Ranjine, pa do najbližih mu Zadrana, Karnarutića i Zoranića: „Od Zoranića je preuzeo osnovnu koncepciju izleta i dijaloga s vilom, koju je prilagodio svojim potrebama i namjerama (...).“ (Franičević, 1983: 646)

30 „U nadnacionalnom kontekstu Baraković je, kao i njegov neposredni uzor Petar Zoranić, na tragu velikuh književnih putnika, kako po ovom tako i po onom, drugom svijetu, pri čemu osobitu ulogu ima najveći od njih - Dante." (Švelec, 2000: 10)
} 


\subsection{Razina priče}

Kada je riječ o sadržajnoj razini Vile Slovinke, književni povjesničari pokušavaju s različitih uporišta, kako onih tematskih tako i onih aktancijalnih, ispripovijedati njezinu priču. Tako na primjer u odnosu na prvi, tematski sloj Nikica Kolumbić spominje dva bitna doživljajna elementa koja ustrojavaju Vilu, a to su sudbina Barakovićeve domovine i njegove osobne životne patnje (v. Kolumbić, 1980: 317); Zoran Kravar govori o četirima izletima u šibensku okolicu (prvi izlet obuhvaća I.-IX. pjevanje, drugi X. pjevanje, treći XI. pjevanje, četvrti izlet obuhvaća XII.-XIII. pjevanje) (v. Kravar, 2000: 4142), a Josip Bratulić govori o pet putovanja i pet tematskih krugova: „Prvo putovanje u okolicu Šibenskog polja urodilo je susretom s Vilom koja pjesnika upućuje u povijest pjesnikova roda i rodnoga grada. Drugo putovanje - sa Šibenskog polja u Šibenik urodilo je susretom s Poklisarom - to je razina sadašnjosti i suvremenih zbivanja u rodnome gradu, u obitelji i zavičaju. $\mathrm{Na}$ trećem putovanju pjesnik upoznaje pustinjaka koji ga izvještava o šibenskim koludricama i o opatici Rafaeli Ivetić. Četvrto je putovanje vezano za njegovu ljubav u Šibeniku i za ljepoticu koja mu ne uzvraća ljubav te se upućuje u Trogir u uzaludnoj potrazi za ljubavnim lijekom. Peto i posljednje putovanje, u ukradenom čamcu, vodi ga iz Šibenika u oluju i nove doživljaje na otoku Bulkanu gdje su ulazna vrata u Pakao.“ (Bratulić, 2000: 10)

Ako se u Vili Slovinki, koja započinje posvetnom pjesmom An'jelu Justinijanoviću i nastavlja se kroz 13 pjevanja nejednake dužine, kao temeljni kriterij putovanja uzmu dvije uporišne točke, njegov početak i završetak, onda se na pitanje koliko je putovanja/izleta u Vili Slovinki ne može jednoznačno odgovoriti. Nikola Batušić kaže: „Putovanje kao empirijsko-spoznajna kategorija ima u srži svoga pojma dvije bitne odredišne točke. Njegova je vrijednost određena početkom i završetkom.“ (Batušić, 1984: 16) ${ }^{31}$ Ako se za istraživanje kategorije putovanja vezane uz središnji lik Pisnika u Vili kao polazište uzme navedena tvrdnja, onda pojavnost ove kategorije u tekstu nije podudarna ni s već spomenuta četiri izleta, ni s pet putovanja. Situacija je sljedeća:

${ }^{31}$ Spoznajne konotacije puta sadržane su i u Vilinu savjetu Pisniku - ako želi nešto doznati o Šibeniku, mora išetati iz grada i doznati, istražiti ono što ga zanima (v. tablicu na kraju teksta i u njoj Primjer 35):

Zagrusti mi: ,Sam ishodi

ako misliš putovati,

hteć otajna zjiskovati

družbe sobom nigdar vodi. “(225)

(Napomena: Svi citati iz Vile Slovinke donose se prema izdanju Baraković, Juraj (2000). Vila Slovinka, priredio Franjo Švelec, Stoljeća hrvatske književnosti, Zagreb, Matica hrvatska, i to tako da se u zagradu stavlja broj stranice na kojoj se citat nalazi.) 
- prvo putovanje ima svoju polaznu i završnu točku (Zadar - Šibenik), o čemu izvješćuje posvetni tekst Plemenitomu gospodinu An'jelu Justinijanoviću Šibenčaninu rajnoga Frančiska gospodinu momu, Juraj Baraković Zadranin, i ne zna se koliko vremenski traje;

- drugo se putovanje događa na Šibenskom polju, ima svoju početnu i završnu točku (Šibenik - Kamenar-straža - Piska draga - Šibenik), o čemu se govori u Petju parvom, Petju drugom, Petju tretom, Petju četvartom, Petju petom, Petju šestom, Petju sedmom i Petju osmom, a traje jedan dan;

- zatim slijede ponavljanja drugog putovanja Šibenskim poljem u Petju devetom i traju nekoliko dana;

- slijedi putovanje na vrh gore s naznačenom polazišnom i završnom točkom (Šibenik - vrh gore blizu grada - Šibenik) u Petju desetom, i traje jedan dan, sve do večeri;

- $\quad$ u Petju jedinonadesetomu opisano je putovanje u Trogir i Šibenik (neimenovano mjesto - neimenovana gora - hiža ljubaznog pastira - stan vilenika u Trogiru - Šibenik) i traje nešto više od pet dana;

- putovanje se zatim u Petju dvanadesetom premiješta na morsku pučinu, jer Pisnik putuje na otok (Šibenik - otok Bulkan - Šibenik), a samo putovanje traje pet dana;

- da bi na kraju bilo opisano putovanje iz ovostrane konačnosti u onostranu vječnost u Petju trinadesetom (Šibenik - vječnost) i vremenski je neodredivo.

Prvo putovanje. Prigodnost i panegiričnost uvodnih stihova Plemenitomu gospodinu An'jelu Justinijanoviću Šibenčaninu rajnoga Frančiska gospodinu тоти, Juraj Baraković Zadranin određuje i njihov sadržajnostilski izgled. Poznato je još od srednjeg vijeka da su predmet pohvale pored bogova bili i ljudi, ${ }^{32}$ što potvrđuje i Barakovićev pohvalni govor upućen Justinijanoviću, za koji struka kaže da je bio napisan kasnije u odnosu na ostali dio Slovinke, odnosno onog trenutka „kad je odlučio da spjev neće predati Zadranima“" (Kolumbić, 1980: 316). Barakovićeva posveta An'jelu uzima djelomice u obzir retoričko pravilo o trima vremenskim stupnjevima (temporibus tribus): ,hvalimo nekoga po onome što je ispred njega samoga, što je u njemu i poslije njega. Prije njega, kao što je rod i zavičaj ...: u njemu, kao ime, odgoj, obrazovanje, tjelesni lik i red djela; poslije njega, kao što je sam završetak života, kao što mrtvoga vrednuju oni koji ostaju." (Curtius, 1998: 173) Prvom vremenskom stupnju (ispred Justinijanovića) pripadaju podatci: An'jel je u

\footnotetext{
${ }^{32}$ Curtius tomu još dodaje i ,zemlje, gradove, životinje, biljke (lovor, maslinu,
} ružu), godišnja doba, kreposti, umijeća, razne vrste zvanja.“ (Curtius, 1998: 171) 
krvnom srodstvu s carem Justinijanom, hvali se i An'jelov stric, poklisar Otavjan, zatim se spominje životopisni podatak o preseljenju iz Venecije (Bnetke) u Šibenik, navode se imena četvorice braće koja su umrla (Orsat, Frančisko, Otavjan, Belizar); drugom vremenskom stupnju (u Justinijanoviću) pripadaju podatci: pomaže siromašne, častan je, vrijedan i hrabar, čemu je dodan i superlativni prozopografski opis njegova lika od čela, kose, lica, obrva, nosa, zubi, do vrata, pleća, koraka, ruku, prstiju; a u treći vremenski stupanj (poslije Justinijanovića) lirski subjekt uključuje samoga sebe, jer ako će mu Justinijanović biti zaštitnikom, njegova će Vila, koju mu šalje na dar, jer su je neharni Zadrani odbili, biti sigurna i zaštićena od svih otrovnih jezika.

Pohvalni govor primarno ne određuje priča, nego formula laudis. Ipak, u Barakovićevim se stihovima Plemenitomu gospodinu An'jelu Justinijanoviću nalazi zametak priče koju određuje put, i koja će se pokušati ispričati/ /objasniti/opravdati u narednih 13 pjevanja. Iako se sama riječ put bez dopuna i epiteta ovdje pojavljuje tek 4 puta, ${ }^{33} \mathrm{i}$ to ne u značenju putovanja nego u kontekstu slavljenja strica Otavjana (on je slavan posvuda; v. Primjer 1. u tablici na kraju teksta), ipak putovanje realizirano prije početka same Vile (eksterna analepsa) određuje likove, njihove postupke i razmišljanja. Lirski subjekt, čije je ime ovdje Juraj Baraković Zadranin, jer je kao takvo zapisano na margini stihova, objašnjava uzrok svoga putovanja iz Zadra u Šibenik:

Bih vilu odpravi' u Zadar da poje zaradi ljubavi bašćine te moje, hteć da ju posvoje prijamše u Zadar za svoju da broje pokle jim bi na dar, dali ju u nehar neharno pustiše, nikakor imat var varhu nje ne htiše, ali jim ne biše umila ugodit, al' oni voliše Latinki pogodit. Sramni su možebit jazikom svojime Ter vole govorit svaki čas tujime, a ja ću mojime govorit ljudem svim, jer sam ja sasvime po Bogu dičan njim: ja drugim ne umim od moga poroda govorit, neg ovim koji mi Bog poda.

Stihovi potvrđuju da je zadarski nemar (nehar) prema Barakoviću i njegovu djelu natjerao Barakovića kao pisca na odlazak iz Zadra, otvorivši tako pitanje o svrsi književnosti i o odnosu pisca i njegova djela (Pavličić,

${ }^{33}$ Riječ je o stihovima koji o stricu Otavjanu kažu da je na putu i domom priklonit, miran, tih (49), da ga puk cijeni i put mu odapriči pošteno da side. / Gdi ga putom vide plemeniti muži, / ne rekuć beside za njim se množ pruži (...) ter mu put pritiče (51). 
1988: 96): Vilom je hvalio Zadrane, Zadrani su ostali ravnodušni, a pisac i njegovo djelo izgubili smisao te napustili Zadar i smisao potražili na drugom mjestu.

Ovdje se, dakle, na margini jednog panegiričkog žanra - posvete - doznaju dvije bitne točke putovanja, polazište i završetak, i zemljopisno su jasno određene (Zadar - Śibenik), ali bez opisnih detalja; putnik je Baraković, dakle pošiljatelj a ne naslovnik posvete, Justinijanović; što se na samom putovanju dešavalo, ne zna se. Osjećaji koji su prožimali pisca-putnika bili su ljutnja, bijes, razočaranje, a na putovanje se krenulo zbog potrage za izlaskom iz vlastite krize i društva koje nije cijenilo njegov spisateljski rad.

Drugo putovanje. Dok se za prvo putovanje može reći da ga Baraković Zadranin poduzima kako „bi stigao na cilj“ (Anselmo, 2008: 7), a to znači u Šibenik, za drugo bi se moglo reći da se poduzima kako bi se bilo $n a$ pu$t u$. Lirski se subjekt imenuje jednostavno Pisnikom, ,koga donekle možemo identificirati s autorom, premda ne uvijek i ne sasvim“, kaže Pavao Pavličić (Pavličić, 1988: 92). Ipak, u Petju dvanadesetom Pisnik na upit mornara, koji ga izgladnjela i iznemogla spasiše s otoka Bulkana, tko je on, odgovara da je on Juraj Baraković:

„Baraković Ivan“, rekoh, ,je otac moj,

A ja sam Juraj zvan, karstjanin tolikoj.“ (309)

Lirski subjekt, zvao se on Pisnik ili Juraj Baraković, kreće i na svoje drugo putovanje, ali sada zbog želje da upozna Šibensko polje. On kao stranac (jer Šibenik i okolicu ne poznaje!), i to sam, kreće na put koji mu nije poznat:

Stah misleć hoću l' s kim izajti ali sam,

a vele dobro vim da put ne znam.

Na ovo putovanje (Bratulić, 2000: 10) ili izlet (Kravar, 2000: 41) u nedjeljno jutro (Pisnik kreće na put ujutro i ostaje na njemu do zalaska sunca, jer Pisnik kaže dokle na zapadu sunašce vidismo /78/, a nešto slično govori i Vila Pisniku: jur se dan nagiba kud sunce zapada, / a tebi ni treba noćiti van grada /163/) odlazi se da bi se vratilo: iz Šibenika preko Kamenar-straže i Piske drage ponovo u Šibenik, i to kraćim putem. Naglasak nije stavljen na polaznu i završnu točku (kao u prvom putovanju), nego na ono što se dešava između tih dviju točaka, dakle, naglasak se stavlja na ,putovanje kao empirijsko-spoznajnu kategoriju“ (Batušić, 1984: 16), jer Pisnik ide ususret drugima, Vili neposredno nakon odlaska iz Šibenika i Poklisaru s Ostarvice neposredno prije povratka u Šibenik. U spoznavanje novoga maksimalno je angažirana vizualnost (kud oči put kažu /69/), kako u opisu pejzaža tako i u opisu Vile.

Umor, koji gotovo redovito prati putovanje stanovita je prepreka kontinuiranu kretanju, pa tako i Pisnikovu: umoran, znojan, bez kruha i vina za- 
stao je, potražio počinak, ali umjesto odmora za tijelo, doživio je šok, okamenio se (stah, blenuh kako slip, al' stovren u stinu /61/) ugledavši Vilu, neizrecivo lijepu ženu s krilima. Vila mu zna ime, ali bi od njega samog htjela čuti iz kojeg grada dolazi. Pisnik joj udovoljava i kaže da je rođen u Plemićima, da mu je majka Zadranka, da je iz Zadra protiran zbog čega i sada puca od jida, da svoju bašćinu ne može braniti od turske sramote ali ni da bašćina ne pomaže njemu. Vilu ražalosti Pisnikova priča, zaplače i nakon toga mu priča o njegovu pradjedu Bartulu, hrabru ratniku na dvoru kralja Bele, koji njegovo junaštvo nagrađuje trima selima (Plemići, Brus, Oštri Rat). Na ovaj je način početna točka prvoga putovanja (Zadar) došla u prvi plan i ovdje i kao takva ostala u Petju drugom u kojemu Vila opisuje razaranje i izgradnju zadarskih bedema pod vodstvom Sforca Palavicina, arhitekta iz Parme, nakon što se desilo prvo razaranje Zadra pod vodstvom turskog cara Selina, a po lukavu nagovoru Beloninu. Kako bi se Pisnik odmorio od užasnih opisa opsjedanja Kotara i Zadra, Vila mu priča o skupu svih vila na Velebiću (Petje treto, Petje četvarto), donosi mu pjesmu u pohvalu Zadra koju je otpjevala vilama (Petje peto), a na zahtjev Od istoka vile opisuje slavni grad Zadar (Petje šesto), zatim kako je nastao Zadar i rijeka Sava (Petje sedmo), nakon čega Vila nestaje, a Pisnik vraćajući se u sumrak u Šibenik susretne Poklisara, koji od hlivanskog bega nosi pismo šibenskomu knezu i pri tome Pisniku opisuje vjenčanje Grižogonovo (Petje osmo).

Ponavljanja drugog putovanja. Nakon što su u večernje sate uspjeli ući kroz gradska vrata u Šibenik i tako preduhitrili gradskoga ključara, Pisnik i Poklisar odlaze na večeru, a nakon toga na spavanje. Iz košmarnih snova Pisnika ujutro budi Poklisarev glas, koji mora nastaviti prekinuto putovanje. Pisnik je ljut, jer je Poklisar prekinuo lijep san i u njemu susret s Vilom. Nakon Poklisareva odlaska Pisnik opet odlazi u Šibensko polje u nadi da će ponovo susresti Vilu. Ponovio je to više puta, i to bezuspješno, ali ne gubeći nadu: Ako Vile danas ne bi, / zjutra bi mogla biti. (228). Ponovljena Pisnikova putovanja/izleti u Petju devetom identična su putovanju drugom u odnosu na smjer kretanja $^{34}$ (Šibenik - Kamenar-straža - Piska draga - Šibenik), ali ne i sadržajem, jer nije susreo ni Vilu ni Poklisara. Dok je putovanje drugo bilo putovanje u nepoznato, i u odnosu na smjer kretanja i u odnosu na njegov

\footnotetext{
${ }^{34}$ Sam Pisnik priznaje da je na svoje ponovljene izlete odlazio u različito doba dana, i zorom i o podne, da je namjerno hodio na ista ona mjeste gdje je prvi put ugledao Vilu, sve u namjeri da je ponovno sretne:

Tad na ona dojdih mista gdi me parvo srića nani, kad mi zgovor misal zani, svijuć garmje sve do lista. (226)
} 
sadržaj, dotle su ona ponavljena putovanja drugog u Petju devetom putovanja u poznato i s jasno postavljenim ciljem (susresti Vilu), ali ne i ostvarena.

Putovanje na vrh gore. Nakon što je bezuspješno tragao nekoliko dana Šibenskim poljem za Vilom Slovinkom, Pisnik odlučuje promijeti smjer svoga putovanja, te kreće na vrh gore blizu grada, gdje se susretne s Pustinjakom, koji mu priča o Šibeniku, a posebice o šibenskim kolurdricama i o opatici, glavarici samostana sv. Spasa, Rafaeli Ivetić, ponosu grada. Pustinjak svoje pričanje prekida zbog dolaska noći i Pisnika koji se prije mraka ${ }^{35}$ treba vratiti u grad.

Putovanje u Trogir $\boldsymbol{i}$ Šibenik. Pisnik zatim ispovijeda svoju nesretnu, trogodišnju zaljubljenost u okrutnu, neumoljivu ženu, koju jednostavno naziva Vilom, i odluku da bijegom izliječi, ugasi svoj ljuben plam. Odlazi u goru, svjesno se prepušta zvijerima, kao Karnarutićev Piram, ali četvrtog dana iznemogla ga pronalaze lovci, odvedu u kuću gostoljubiva pastira, okrijepe i peti dan krenu prema Trogiru. Tamo biva smješten u stanu vilenika, koji mu savjetuje da ponovo posjeti svoju Vilu, izjavi joj ljubav, što ovaj i učini otputovavši u Šibenik. Vila ga još jedanputa hladno ali kulturno odbije, a Pisnik se oženi drugom, koja mu bi ugodna, ali koja ne uspije izliječiti i njegovo ranjeno srce.

Putovanje na otok Bulkan. Svoja kopnena putovanja Pisnik nastavlja na moru, jer donosi odluku da će se u ukradenu brodu otisnuti na more, iako svjestan vlastite nevještosti mornarskim poslovima. Na putu do otoka Bulkana uhvati ga oluja, ali se ipak spasi. Na otoku susretne Osina, Poklisarevu sjenu, koji otkriva prave razloga svoje kazne i dodijeljena mu mjesta u paklu - glavni je uzrok laž (lagao je i o zadarskoj svadbi, i o viđenijim Zadranima). $\mathrm{S}$ prvim zrakama sunca Osin nestaje u paklenim dubinama, a Pisnik gladan i iznemogao istražuje otok, ne bi li pronašao nešto hrane i prijevoz za povratak na kopno. Spašavaju ga mornari, koji nakon povratka u Šibenik slave Pisnikovo spašavanje još osam dana. Pismo koje je Pisniku predao Osin na Bulkanu, nije uspio pročitati mornarima, jer su isplovili iz šibenske luke, pa je to učinio sam, nakon što je čuo plač s ulice zbog smrti junaka Frane Strižoevića, o kojemu je pismo Osinovo i govorilo.

\footnotetext{
${ }^{35}$ Pustinjak se ovim riječima obraća Pisniku:

Govoren'ja moga jur svarha prihodi, a posluha tvoga vrime odahodi, ustani ter hodi, da te mrak ne stiže, jur sunce zahodi, a noć se približe (237)
} 
Putovanje iz ovostranosti u onostranost. Putovanje opisano u Petju trinadesetomu drugačije je od svih prethodnih Pisnikovih kopnenih i morskih putovanja, i to stoga što putnik nije živa osoba, a putovanje je posljednje, bez mogućnosti povratka na polazišnu točku i bez mogućnosti ponavljanja. Stoga se o sprovodu Frana Strižoevića, o kojemu govori posljednje Petje, može govoriti samo kao o putovanju iz ovostranosti u onostranost, potvrđujući još jedan simbolizam putovanja, a to je potraga za besmrtnošću: „Osobito bogat simbolizam putovanja može se ukratko sažeti u potragu za istinom, mirom, besmrtnošću, u potragu i otkriće duhovnog središta." (Chevalier, Gheerbrant, 2007: 599)

Ovako, dakle, predočena sadržajna razina Vile Slovinke navodi na zaključak da broj putovanja/izleta nije moguće jednoznačno matematički odrediti, jer su se neka putovanja ponavljala neodređeni broj puta (npr. drugo putovanje). Svako putovanje ima svoju polazišnu i završnu točku, bez obzira na to bilo ono smješteno u sižejni okvir priče ili izvan njega kao eksterna analepsa (prvo putovanje) ili kao eksterna prolesa (smještanje Strižoevićeve duše u raj dogodit će se u budućnosti, nakon završetka priče u Vili Slovinki). Sve polazišne točke pripadaju zbiljskoj topografiji (Zadar, Šibenik, neimenovano mjesto), što ne vrijedi i za sve završne točke putovanja, jer se pored Šibenika u toj ulozi pojavljuje i onostrana vječnost. Vremenski gledano putovanja su neujednačena i traju od jednog dana do tri, pet i više dana ili neodređeno nekoliko dana. Dužina trajanja putovanja ne korespondira s obimom ispričane priče, pa je tako za vrijeme jednoga dana, koliko traje na primjer drugo putovanje, ispričano znatno više u odnosu na putovanja koja traju tri ili pet dana.

Tko odlazi na put, zašto i što se na putu dešava - pitanja su kojima se bavi tekst koji slijedi.

\subsection{Razina lika}

Na 284 stranice Vile Slovinke, koju je priredio Franjo Švelec za ediciju Stoljeća hrvatske književnosti (Zagreb, 2000: 41-325), leksem put s nevelikim brojem svojih izvedenica (putovati, stranputica, uputiti, putnik, putnici) pojavljuje se oko 90 puta. Pobližih epitetskih određenja je također malo - put je dug, opačan, ravan, prav, širok, raskošan, dalek, a njime putuje trudan putnik (v. Tablicu - Leksem put u Vili Slovinki). O put-ovanju govore ili su i sami putnici Pisnik, Poklisar/Osin i još neki likovi. Već je u literaturi o Barakoviću konstatirano da se na aktancijalnoj razini priča Vile Slovinke svodi na Pisnikove zgode s Vilom i na zgode s Poklisarom, odnosno Osinom (Švelec, 1964: 188), da se kroz likove i njihove odnose oblikuju temeljni kompozicij- 
ski principi. ${ }^{36}$ Vili i Poklisaru, koji pričaju Pisniku o njegovim precima i Zadru, treba dodati i pustinjaka koji priča o Šibeniku i šibenskim koludricama, te vilenika koji priča o ženi, koju Pisnik jednostavno naziva Vilom, u koju je bio nesretno zaljubljen i zbog koje se oženio drugom, iz ugode ali ne i zaljubljenosti.

Na putovanje se u Vili Slovinki odlazi iz različitih razloga, a najbrojniji su oni vezani uz Pisnika, zatim uz Poklisara/Osina i likove kao što su: ratni profiteri i mitski likovi Sava i Nino.

Na prvo je putovanje Pisnik iz Zadra u Šibenik krenuo zbog neprihvaćenosti, zbog neharnosti samih Zadrana prema njegovu književnu djelu, prema Vili Slovinki, u kojoj hvali upravo njih i njihov grad. Onog trenutka kada zadarska društvena sredina počne negirati važnost i smisao Pisnikove književnosti i književnog stvaranja, on sam gubi ,svoju pravu domovinu, svoj zavičaj i pribježište" (Pavličić, 1988: 95), a to je poezija, odnosno književnost uopće. Navedenu situaciju Pavao Pavličić uzima kao primjer za najopćenitiju razinu manirističke metatekstualnosti „,na kojoj književna djela razmatraju o svrsi i zadacima književnosti uopće“"(Pavličić, 1988: 91).

Na drugo putovanje (i njegova kasnija ponavljanja) Pisnik odlazi iz dokolice i svojevrsnog neznanja - nakon što je kao izgnanik stigao u Šibenik, želi upoznati novi prostor te sam kreće u obilazak Šibenskoga polja. Nedjeljna šetnja pretvara se u pustolovinu, koja je rezultirala novim spoznajama o Pisnikovim precima, o Zadru i njegovim viđenijim građanima. Chevalier i Gheerbrant kažu: „U svim književnostima, dakle, putovanje simbolizira pustolovinu i traganje, bilo da je riječ o blagu ili jednostavno o nekoj spoznaji, materijalnoj ili duhovnoj. Ali to je traganje u biti samo potraga za sobom, a još češće bijeg od sebe.“ (Chevalier, Gheerbrant, 2007: 601) I jedno i drugo (potraga za sobom i bijeg od sebe) primjenjivo je na Pisnika.

Na sljedeća dva putovanja Pisnik odlazi iz duboko emocionalnih razloga - zbog nesretne ljubavi prema ženi (Vili), koju je najprije pokušao okončati smrću otišavši u goru i namjerno prepustivši svoju sudbinu opasnim gorskim zvijerima. Kako se smrt nije desila, ali ni ljubavna nesreća prestala, Pisnik želi pobjeći od svoje bolesti otisnuvši se na nepredvidljivo more. Tako su oba putovanja mogla biti posljednja (smrt), ali nisu, i oba su putovanja trebala kvalitativno promijeniti Pisnikov život (dokinuti ljubavnu patnju), ali nisu. Polazna i završna točka putovanja s emocionalnoga gledišta nalikuju jedna drugoj, jer se nesretna ljubav s početka putovanja potvđuje i na njegovu kraju.

36 „Barakovićevi susreti i razgovori s Vilom i s poklisarom oblikovni su principi komponiranja. U prvome ostavaruje se slika prošlosti Zadra, u drugome slika tadašnjeg Zadra, grada iz kojega je pjesnik, negdje potkraj XVI stoljeća, bio prognan.“ (Švelec, 1977: 210-211) 
Opisana Pisnikova putovanja pokazuju, dakle, da ih je poduzimao iz poetičkih razloga (kada književno djelo izgubi smisao u određenoj sredini), prostornih (upoznati novu sredinu) i privatnih (petrarkistička nesretna zaljubljenost).

Razlozi putovanja drugoga lika, Poklisara/Osina, nisu ni poetičke ni privatne naravi, već društvenojavne. Za života Poklisar, naime, kreće na putovanje zbog diplomatskih razloga, jer prenosi pismo hlivanskoga bega šibenskomu knezu. Posao je nekorektno odrađen, izrečene su laži, počinjen je, dakle, grijeh, koji je u onostranosti sankcioniran putovanjem Karontovom lađom, putovanjem bez povratka, putovanjem u pakao.

Putovanja mogu biti potaknuta i različitim katastrofama na razini društvenog i političkog života, što u Vili potvrđuju, s jedne strane, turska osvajanja Kotara, i babilonska nesreća, s druge strane. Kada je, naime, Pisnik u nedjeljno jutro išetao u šibensku okolicu, susreo je Vilu, koja mu je najprije pričala o turskim napadima na Kotar i o sličnim prijetnjama Zadru. I dok u ratnim vremenima jedni pobjeđuju, drugi stradavaju, treći bivaju zarobljeni, četvrti njima trguju i zarađuju. Upravo stoga Vila naglašava da je razlog putovanja u Obrovac brojnih trgovaca toga vremena bila trgovina robjem.

U Vili Slovinki je opisana još jedna kaotična situacija, i to iz biblijskih vremena, kao razlog odlaska na put. Zbog kaosa koji je nastao nakon babilonske katastrofe, Sava i Nino napuštaju Babel, odlaze prema Lici, a zatim južnije, prema moru, osnovavši tamo grad Nin.

Zaključno bi se, dakle, moglo reći da je najveći putnik u Vili Slovinki Pisnik, zatim slijedi Poklisar/Osin, a pridružuju im se i trgovci, i mitski likovi Sava i Nino. Razlozi njihova putovanja su poetički (Pisnik), privatni (Pisnik), javni (Poklisar), moralni (Osin), profiterski (trgovci) te bijeg iz kaosa (Sava i Nino).

O prijevoznim sredstvima putnika u Vili Slovinki nema previše informacija: kopnom se putuje pješice, a morem se putuje brodom, koji se u dvanaestom pjevanju pojavljuje dva puta. ${ }^{37}$ Pri tome ono uočeno u odnosu na konceptualnu metaforu Život je putovanje u frazeologiji, dobrim je dijelom primjenjivo na kopnena i morska putovanja u Vili Slovinki: „Kroz prizmu frazeologije čovjekov se život sagledava kao stalno putovanje prema različitim odredištima koja zapravo predstavljaju određene životne ciljeve kojima

37 „U cijelom pjevanju dvaput se javlja motiv broda. Funkcija u kojoj se prvi put pojavljuje bitno je različita od funkcije na kraju. Radi se o dijametralno suprotnom odnosu. Barka koju je ukrao trebala je poslužiti ispunjenju transcendentalnoga toposa (odlaska, promjene mjesta, putovanja) dok na kraju motiv broda preuzima isti modus samo različitoga predznaka. I ovaj se put pjesnik upućuje na promjenu mjesta boravka, no novo mjesto je zapravo ono prvo, staro, već poznato. 'Dosadno' i stabilno kopno sada se s nestrpljenjem priželjkuje.“ (Srdoč-Konestra, Lajšić, 2007: 253) 
čovjek tijekom svog života teži. Stoga je svako kretanje prema cilju pozitivno, a negativno je obilježeno sve ono što čovjeka na tom putu ometa, zaustavlja ili vraća natrag.“ (Hrnjak, 2009: 197) Odnosno, moglo bi se reći da se na putu premošćuju prepreke, susreću antagonisti, rješavaju nedoumice (Batušić, 1984: 17), a sigurnost putovanju daju i stanoviti orijentiri, kao što su zvijezde (v. Primjer 70: zvizdu mi starzite, putujte sve po njoj /310/). Ovakvo određenje putovanja navodi na zaključak da su u Vili Slovinki vrlo upitne njegove pozitivne konotacije - ili putovanju nije jasno postavljen cilj, ili je kretanje ometano i zaustavljano. Upitnost postavljena cilja ima i Pisnikovo prvo putovanje iz Zadra u Šibenik (jer iako je jasno određena završna točka putovanja - Šibenik, Pisnik bi se ipak vrlo rado vratio na početnu točku, a to je Zadar), upitno je i njegovo putovanje u šibensku okolicu (jer odlazi se u šetnju bez jasno postavljena cilja ${ }^{38}$ kao i odlazak na more (isplovljava se također bez jasno postavljena cilja). Na putovanjima u Vili Slovinki gotovo su uobičajene prepreke, zaustavljanja koja sobom nose i negativne konotacije. Putnike na njihovu putu ometaju: drugi ljudi (u odnosu na Pisnika to su: Vila Slovinka, Poklisar, pustinjak, vilenik, Vila na prozoru, Osin), događaji (Poklisara zaustavlja svadba, Pisnika lov, oluja i smrtna opasnost), strah (Osin se boji puta u pakao te zbog toga nevoljko kreće naprijed; v. Primjer 62: Trepetah kako prut, prid vrati pakla stah, / otvoren viđah put kim tamo pojti mnjah /296/). Kako u Vili Slovinki gotovo ništa nije jednoznačno i jasno (odnos zbilje i fikcije je problematičan), to se potvrđuje i konotacijama putovanja, na primjer: nakon što je nesretno zaljubljeni Pisnik htio svoje patnje okončati u smrti, u raljama gorskih zvijeri, našli su ga lovci i spasili. Ovo zaustavljanje, ometanje putovanja s čitateljeve točke gledišta ima pozitivne konotacije, jer je izbjegnuta smrt, ali ne i s Pisnikove, koji si je smrt postavio krajnjim ciljem putovanja.

Sve ukazuje na to da od renesansne linearnosti u smislu jasno opisana lika u njegovu izvanjskom izgledu (jer Vila, na primjer, svoju vizualnu ljepotu negira i naziva prividom!), od epskog prostorno-vremenskog kontinuiteta, pravilnosti i tektoničnosti u izgradnji kompozicije, mnoštvenosti u odnosu na motive i epizode, jasnoće u prikazivanju događaja (Pavličić, 1979: 203-236), dakle, da od svega toga u Vili Slovinki nije ostalo gotovo ništa. Tako se renesansna jasnoća i pravilnost ne mogu potvrditi ni u odnosu na putnike, ni u odnosu na njihova putovanja, ni u odnosu na konačna odredišta njihovih putovanja.

${ }^{38}$ Besciljno luta i ožednjela Plankita, progoneći ranjenu košutu, jer umjesto da ona vlada putom, put vlada njome (v. Primjer 19.). 


\subsection{Razina kompozicije}

Kada se govori o komoziciji Vile Slovinke, često se u književnoj historiografiji upotrebljavaju riječi: nejedinstvenost, necjelovitost, zbrkanost (Švelec, 1977: 205), razbarušenost: „Sav se spjev, koji i bez dodatnih pjesama ima više od 9300 stihova, može, dakle, svesti na nekoliko prividno vrlo divergentnih elemenata kao što su dijalog s vilom Slovinkom, pohvala Zadru, priča o majci Margariti, ljubavni zaplet, priča o susretu na vratima pećine paklene i o junaštvu i smrti Frane Strižoevića. Zato je i bilo toliko riječi o razbarušenosti kompozicije.“ (Franičević, 1983: 641) Ipak, Marin Franičević dodaje: „Ali taj je sadržajni element ipak nešto kompleksniji, pa je time i unutarnja kohezija jača.“ (Franičević, 1983: 641) Izgradnju unutarnje kohezivnosti pomaže ne stvarno osobno nego poetsko obrazloženje Pisnikova napuštanja Zadra (Zadrani nisu cijenili njegovo književno djelo, u kojemu je naglašavao svoju zabrinutost za sudbinu bašćine i slovinskoga jezika), ali i način izgradnje sižea, odnosno postupci integracije različitih sadržajnih elemenata u jednu cjelinu. Kada se, naime, promotre završeci i počeci petja, postaje razvidno da je završetkom petja najavljen početak idućega, uz dva izuzetka, što u odnosu na tekst izgleda ovako:

- Petje parvo: na kraju ovoga petja najavljena je Vila kao pripovjedač Petja drugoga, čiji će sadržaj biti bolan za slušatelja Pisnika, jer ona kako britku strilu boleznu spusti rič (79), najavljujući u Drugom petju podizanje turske vojske na Kotar i Zadar, o čemu Drugo petje i govori;

- Petje drugo: na kraju ovoga petja Pisnik najavljuje sadržaj i Vilu kao pripovjedača sljedećega petja, jer nakon što je Vila opisala Belonu i njezino poticanje cara Selina na rat protiv Zadrana i „lava“ (Mlečana), Pisnika zanima kada su se razaranja grada desila (Ti raspi kad bihu, / ovo bih znati rad, ka lita tecihu? / ka doba, ali kad te slave slovihu? (96/) o čemu se onda i govori u Petju tretom;

- Petje treto: Vila na kraju ovoga petja, u kojemu je pričala o ratnim strahotama, odlučuje Pisniku pričati o nešto veselijim sadržajima, jer nakon plača stiže veselje, ${ }^{39}$ što znači ne pričanje o ratu, nego o zboru vila na Velebiću, o čemu se i govori u Petju četvartom;

\footnotetext{
${ }^{39}$ Potvrđuju to stihovi:

Ne veće dresele karvave rati boj neg riči vesele da t' zbraja jazik moj. Za trudom gre pokoj, za plačem veselje, ne može stati toj po sve dni dreselje, mnokrat se namelje po srići od Boga da glavno začelje dopade uboga. 
- Petje četvarto: Vila na kraju ovoga petja najavljuje pjesmu u čast Zadra. Vile na Velebiću povele su tanac i sve su molile Vilu Slovinku da započne pismicu, a njoj na pamet pada ona u kojoj se hvali Zadar (Pade mi na usti od Zadra početi, / častiti i slusti, začinjat $i$ peti, / zač mu se ne grusti slidit zakon sveti."/116/) i koju donosi Petje peto;

- Petje peto: to je prvo pjevanje u kojemu se ne donosi najava sadržaja Petja šestoga.

- Petje šesto: na kraju ovoga petja Vila najavljuje da će u sljedećem petju ostalim vilama govoriti od početak temelja (141) grada Zadra, uz napomenu da sama ništa nije vidjela, jer je bila mlada, ali da im prenosi ono što je čula od drugih vila $i$ može toga bit istina veći dil (142);

- Petje sedmo: Vila govori doista od začetja Zadra grada, ide daleko u prošlost, u vrijeme građenja babilonske kule, nastanka Zadra i rijeke Save. Pisnika na kraju zanima čeka li ga kakav pokoj u životu, a Vila mu odgovara da si je naprtio odviše teško breme na leđa, o čemu i govori naredno petje;

- Petje osmo: teško breme ovdje potvrđuje bugaršćica majke Margarite, Barakovićeve sestre, čijega sina Ivana pogubiše Senjani, a brat Petar pogibe kod Korfa, služeći dužda. Na kraju ovoga petja najavljena je čemerna večera, o kojoj govori sljedeće petje;

- Petje deveto: čemernost se potvrđuje u košmarnim Pisnikovim snovima, u kojima Vila negira istinitost svega ispripovijedanoga u stvarnosti. Ovdje Pisnik najavljuje svoj odlazak na goru, o čemu govori sljedeće petje;

- Petje deseto: opisan je Pisnikov odlazak na goru, susret s pustinjakom, koji mu priča o Šibeniku. Na kraju je najavljena Pisnikova mladenačka nesretna ljubav i putovanje.

- Petje jedinonadeseto: ovdje je doista opisana Pisnikova mladenačka trogodišnja ljubav prema Vili i ženidba drugom iz očaja. Ovo je drugo pjevanje u kojemu nije najavljen sadržaj sljedećega petja.

- Petje dvanadeseto: opisana je Pisnikova plovidba brodom do Bulkana, susret s Osinom i povratak s mornarima. Pismo koje je Pisniku predao Osin na otoku, pročitat će u sljedećem petju, najavljujući tako njegov sadržaj.

- Petje trinadeseto: ovdje Pisnik doista čita Osinovo pismo i kroz prozor promatra sprovod Frane Strižoevića.

Iz ovako opisana sadržaja i njegove sižejne strukturiranosti vidljivo je da je svaka kompozicijska sastavnica najavljena prethodnom, da kraj petja najavljuje sadržaj narednoga, uz dva izuzetka: sadržaji Petja šestoga i Petja 
dvanadesetoga nisu najavljeni prethodnime. U izgradnji sižea dominira, dakle, lančani ili stepenasti način prema ruskim formalistima (Solar, 1979: 171), a u njemu sudjeluju i dva putovanja: u Petju devetome najavljeno je Pisnikovo putovanje na goru u Petju desetomu, a u Petju desetomu najavljeno je Pisnikovo putovanje u Petju jedinonadesetomu u Trogir i Šibenik. Na taj je način tema putovanja funkcionalno uklopljena i u izgradnju sižea, ali ne kao dominantni princip.

\subsection{Aktualizirani periferni semantemi}

Provedeno istraživanje leksema put u Vili Slovinki pokazalo je da se na razini priče, lika i kompozicije iz njegova semantičkoga polja ${ }^{40}$ naglasak stavlja na jezgrena, primarna značenja (Užarević, 1995), a to znači prostornost, koju određuje početna i završna točka čovjekova kretanja, kretanje prema naprijed, čovjek u prostoru (putnik), prepreke na putu i usporavanje kretanja prema naprijed (prepreke mogu biti drugi ljudi, određeni događaji, fizički umor, vrućina, ugodnost krajolika, starost, smrt). Ovakva određenost jezgrenoga značenja riječi put $\mathrm{u}$ tekstu je proširena i nekim periferijskim značenjima uvjetovanim kontekstima u kojima se riječ našla. Tako je istraživanje leksema put u Vili Slovinki potvrdilo i sljedeće semanteme:

- biti poznat po nekoj osobini - kategoriji prostornosti dodaje se informacija o društvenom statusu određenoga lika (Otavjan, stric An'jela Justinijanovića, poznat je i uvažavan posvuda; v. Primjer 1: na putu i domom priklonit, miran, tih /49/; put mu odapriči pošteno da side. / Gdi ga putom vide plemeniti muži, / ne rekuć beside za njim se množ pruži (...) ter mu put pritiče /51/), dodaje se i svojevrsno strahopoštovanje (Sforca Palavicin je cijenjen kao stručnjak, arhitekt; v. Primjer 3: Kad putom grediše, s ponistar odzgora / svud bobot staniše i plačna romora. /82/), zatim moć i strah (onaj tko ima moć, određuje smjer puta, kao što čini božica rata Belona; v. Primjer 5: U ruke vaze prut da ga se pristraše, / kud ona kaže put da bisni usplaše, /87/; I kad se oddili pokle put upravi, / Zavidost posili da se š njom odpravi /88/), ali i slava (jezgrenom značenju ,kretanje naprijed“ dodan je semantem pronošenja slave Zadra; v. Primjer 12: Slavi ga i dvori vas narod $i$ štuje / gdi su Nilu zvori $i$ kuda putuje /121/).

40 „Pod semantičkim poljem riječi razumijem do određenoga stupnja usustavljenu ukupnost aktualnih i potencijalnih značenja (semova, semantema) koja na ovaj ili onaj način ulaze u domenu neke riječi. Semantičko se polje sastoji od jezgrenih (središnjih, osnovnih) i periferijskih (drugotnih, dopunskih) značenja.“ (Užarević, 1995: 105) 
- ponavljanje radnje - kretanje prostorom zbog svoje početne i završne točke može biti i ponovljeno/ponavljano (puk u izgradnji zadarskih zidina poslom putuje, tj. svakodnevno ponavlja određene radnje; v. Primjer 4: Svak poslom putuje dokraj bila danka, / a ništar praznuje, mnju, do vlasa tanka. /86/) ili mora biti ponavljano (bit nekog zanimanja, npr. mornarenja je ponavljanje putovanja; v. Primjer 6: Tko često putuje mornarit nastoji, / on blaga nakuje a pak se pokoji. /93/).

- topos nepravoga puta - kategoriji prostornosti dodaje se informacija o pravom (bez grijeha) i nepravom putu (ispunjen grijesima, ali raskošan i primamljiv), ${ }^{41} \mathrm{~s}$ više naglaska na ovom drugom, kojega se čovjek treba kloniti (v. Primjer 8: a prem od pokore pristupaše vrime / kada grišni more oblahčati brime, / blagoslov da prime pustiv put opačan, / da bude sasvime blaženim pritačan /98/; Primjer 53: Puti su široci, raskošni, i staze, / zač tuda svidoci lažljivi ulaze. 1275/; Primjer 57: Lažljivih ovude prohodi velik broj, / oholi onude, svaki put znade svoj 1283/; Primjer 59: Tko martav gre $k$ vodi, za njim put zatvore, / brodar ga pribrodi, već nazad ne more. /283/).

- stari i novi put - put kojim čovjek prolazi može mu biti poznat, ali i posve nov, nepoznat, što kada se prenese u semantičko polje nacionalnoga identiteta znači da su bašćina, jezik i muza slovinska onaj pouzdan, poznat put, koji treba čuvati, a ne pomodarski ga zamjenjivati novim i nepouzdanim (v. Primjer 23: Tko išće put novi, a stari zapusti, / u raspi gotovi skoro će zablusti. /171/).

- ispravnost smjera - čovjek se može kretati u pravome smjeru, ali i zakoni mogu biti pisani u pravome smjeru, zbog čega se pravome putu dodaju i pravničke konotacije (vile na Velebiću žele napisati zakon, i to dobar; v. Primjer 11: Sve imahu želju i sve potvardiše / o starom temelju zakon da se piše, / sve jedino hotiše da se put upravi / da zakon uskriše koga svit zatravi. /115/), zatim konotacije pravilnosti (u različitim životnim situacijama vrijede određena pravila, pa tako i u plesu, o čemu govori Vila Slovinka u proslavljanju Slovanova rođenja; v. Primjer 20: Na skoke igrahu noseći vrat prignut, / gdi okom smirahu tuj bišse nozi put /152/).

41 „S obzirom da je simbolična slika pravog, ispravnog puta vezana uz kršćanski nadahnuto duhovno pjesništvo, njen praizvor logično je tražiti u Bibliji. U Starom zavjetu vezana je uz nauk o 'dvama putovima', dobrom i lošem. Prvi je put vrline, pravednosti, vjernosti istini, mudrosni ga spisi cijene putom života; on osigurava dug i uspješan ovozemaljski život. Drugi je onaj što ga slijede bezumni, grešnici, zlikovci, on vodi u propast i smrt.“ (Pavešković, 2000: 165-166) 
- psihološka napetost (strah) - prostornost puta konkretizira, osim njegove početne i završne točke, i nazočnost čovjeka u njemu; ako ga nema, on se iščekuje, čak i sa strahom, kao u slučaju pripreme napada Turaka na Zadar (v. Primjer 10: Putnika ni gosta na polju ne bi tad / slobodna ni prosta, ni hiže za priklad /106/).

- neobuzdanost $i$ sloboda - kategoriji prostornosti kao jezgrenom značenju leksema put dodaje se i proizvoljnost u njegovu savladavanju, bez točno određena cilja, što se dovodi u svezu s periferijskim semantemom leksema mladost (v. Primjer 37: zač mladost luduje kako konj prez žvala, / kad hoće putuje nimav strah iz mala. /240/).

Istraživanje semantema riječi put u Vili Slovinki pokazalo je, dakle, da se u ovom spjevu semantičko polje navedena leksema dotiče, isprepliće sa semantemima iz semantičkih polja drugih riječi, kao što su: čovjek (biti poznat po nekoj osobini), mladost (neobuzdanost i sloboda), određena moralna i vrijednosna kategorija (topos nepravoga puta, stari $i$ novi put), zakon (ispravnost smjera). Dok se semantem (ne)pravoga puta vezuje uz kršćanstvo i Bibliju, dotle ostali svojom sadržajnom i idejnom stranom pripadaju uglavnom renesansnome vremenu (biti poznat, slobodan i neobuzdan, imati dobre zakone, uvažavati i nastavljati postojeću književnojezičnu slovinsku baštinu). $\mathrm{Na}$ aktancijalnoj se razini navedeno maniristički problematizira, jer većinu semantema aktualiziraju u svom govoru izrazito nezbiljski, fantazijski likovi (Vila Slovinka, Od istoka vila, Osin; v. Tablicu - Leksem put u Vili Slovinki).

\section{Zaključno}

Usmjereno čitanje Vile Slovinke u odnosu na leksem put i njegove izvedenice (u tekstu su ukupno 92 potvrde puta i njegovih izvedenica!) potvrdilo je neke već poznate tvrdnje, kao na primjer: priču ustrojava nekoliko putničkih epizoda (Z. Kravar), u kojima središnje mjesto pripada i likovima putnika (Pisnik, Poklisar, Osin) (M. Franičević). U literaturi o Vili nije posebno posvećena pozornost sekundarnim žanrovima s tematikom puta uključenim u spjev. Tako je ispisivanje leksema put i njegovih izvedenica u tekstu s naznakom njegove vezanosti uz određeni lik i aktualizirane semanteme, pokazalo da je istraživani leksem uključen i u žanr posvete (i to u panegiričke svrhe), i u pozdrav s dobrim željama (v. Primjer 67), ali i u gnomičke izreke (v. Primjer 23).

Nadalje, podrobnije istraživanje ovog leksema, što je dokumentirano i prilogom na kraju teksta (v. Tablicu - Leksem put u Vili Slovinki), pokazalo je da se u više od pola navedenih primjera riječ put pojavljuje u svom osnovnom značenju, koje podrazumijeva postojanje početne i završne točke kretanja, odnosno prostornost. Ako bi se kao određenje pravoga putnika uzela 
Baudelaireova tvrdnja, koja kaže: „Pravi su putnici samo oni što na put idu radi putovanja“" (citirano prema Chevalier, Gheerbrant, 2007: 601), onda bi u Vili Slovinki bilo malo pravih putnika, jer putovanja Barakovićevih putnika imaju primarno konotacije bijega (Pisnikovo putovanje iz Zadra u Šibenik, iz Šibenika na otok Bulkan, Ninino i Savino putovanje-bijeg zbog babilonske katastrofe), zatim empirijsko-spoznajne konotacije (Pisnikovo putovanje u Šibensko polje i na goru u okolicu Šibenika), te profitabilne konotacije (putovati u ratnim vremenima kako bi se trgovalo ljudima i zarađivalo - trgovci, putovati kako bi se obavio neki diplomatski posao - Poklisar, putovati kako bi se osigurala svakodnevna egzistencija - mornari).

O značajkama putovanja u crkvenoj drami Nikola Batušić kaže: „Putuje se uvijek iz tame prema svjetlu, iz mraka neznanja, od nagovora grijeha i zova iskušenja do svijetlih predjela spoznaje i konačnoga očišćenja, u iznimnim primjerima i do susreta s božanskim prosvjetljenjem." (Batušić, 1984: 19) U Vili Slovinki većina putovanja, od prvog, neželjenog Pisnikovog putovanja do gotovo svih ostalih, završavaju u posve suprotnu ozračju - na kraju puta nije ni svijetlo, ni znanje, ni nada, ni utjeha, nego suprotno - tjeskoba, iščekivanje, maniristička rastrzanost: „Kao pjesnik onog razdoblja koje je bilo raskidano između renesansno-hedonističkog vremena, s kojim je bilo tako čvrsto vezano, s jedne i na silu obnavljane mističko-asketske duhovitosti koja se sve više nametala s druge strane, Baraković u svojoj Vili Slovinki najbolje izražava to vrijeme polariziranih ideja između kojih još nije bilo došlo do kompromisa." (Kolumbić, 1980: 327) Raskidanost, problematičnost između početne točke putovanja i (ne)ostvarenja postavljena cilja odnosno završne točke putovanja, zatim upitnost samog cilja putovanja, prepreke i zaustavljanja na putovanju - sve to potvrđuje pjesnikovu dvojnost: jasno postavljen i ostvaren cilj se ne priželjkuje (nakon bijega iz Zadra u Šibenik cilj je ostvaren, ali on ne usrećuje Pisnika, jer bi prava sreća i smirenje bilo pretvaranje bijega u povratak, što je opet nešto posve suprotno crkvenoj drami u kojoj junak ,na svojoj životnoj putanji predočenoj na pozornici linearno, ne vraća se prema ishodištu.“ /Batušić, 1984: 20/), ili cilj je postavljen ali ne i realiziran (Pisnik odlazi po nagovoru trogirskoga vilenika u Šibenik još jedanputa izjaviti ljubav okrutnoj Vili, koja ga ponovo i konačno odbije; Poklisar želi na bilo koji način ostvariti osobni probitak u Zadru, ali u tome ne uspije, jer se služi lažima; priča o Plankiti, zavjetovanoj Dijani, slijedi ranjenu košutu, ali je umor i žeđ na putu zaustave, ona košutu ne pronađe, ali je Neptun učini ženom), ili cilj jednostavno nije ni postavljen (kao što je slučaj s Pisnikovim odlaskom u Šibensko polje i s njegovim ponavljanjima u narednim danima, te s Pisnikovim odlaskom na otok Bulkan). Navedene situacije pokazuju da Barakovićevim putnicima biti na putu nije osmišljavajući čimbenik njihova života kao što to nije ni (ne)postavljeni cilj putovanja. Ono što je znatno ka- 
snije Vid Došen u Aždaji sedmoglavoj jasno naznačio kao bit putovanja, a o čemu govore stihovi:

što su oči putovanju,

to je razlog dilovanju (Došen, 1969: 48),

u Vili Slovinki ne može naći svoju potvrdu, jer u njoj ono što oči vide, proglašava se prividom, a ono što se sanja, proglašava se zbiljom samom. Putovanja se odvijaju na geografski potvrđenim lokalitetima, ali zapreke i razlozi zaustavljanja putnika na njima su i drugačija bića (Vila, Osin, vilenik), koja na stanovit način problematiziraju zbiljskost i putnika i putovanja, pribavljajući Barakoviću i na razini ove tematski usmjerene analize status pjesnika „,na prijelazu u XVII. stoljeće“, odnosno smještajući ga u „razdoblje manirizma“" (Franičević, 1983: 622).

\section{Literatura i izvori}

- Batušić, Nikola (1984). „Putovanje kao strukturni element srednjovjekovne pozornice“, u: Skrovito kazalište. Ogledi o hrvatskoj dra$m i$, Zagreb, Hrvatsko društvo kazališnih kritičara i teatrologa.

- Bratulić, Josip (2000). „Predgovor“, u: Juraj Baraković, Vila Slovinka, priredio Josip Bratulić, Croatica, Knjiga 78, Vinkovci, Riječ.

- Chevalier, Jean - Gheerbrant, Alain (2007). Rječnik simbola. Mitovi, snovi, običaji, geste. Oblici, likovi, boje, brojevi. Peto, prerađeno i prošireno izdanje, Zagreb, Kulturno-informativni centar - Naklada Jesenski i Turk.

- Curtius, Ernst Robert (1998). Europska književnost i latinsko srednjovjekovlje, s njemačkog preveo Stjepan Markuš, drugo izdanje, Zagreb, Naprijed.

- Došen, Vid (1969). „Aždaja sedmoglava“, u: Djela Vida Došena, Stari pisci hrvatski, Knjiga 34, priredili Tomo Matić i Antun Djamić, Zagreb, JAZU.

- Frangeš, Ivo (1987). Povijest hrvatske književnosti, Zagreb-Ljubljana, Nakladni zavod Matice hrvatske-Cankarjeva založba.

- Franičević, Marin (1983). Povijest hrvatske renesansne književnosti, Zagreb, Školska knjiga.

- Franičević, Marin (1969). „O Vili Slovinki Jurja Barakovića Zadranina“, u: Čakavski pjesnici renesanse, Zagreb, Matica hrvatska.

- Grün, Anselmo (2008). Na putu - teologija putovanja, Zagreb, Teovizija.

- Hrnjak, Anita (2009). Putovanje kroz hrvatsku frazeologiju, http://www.suedslavistik-online.de/01/hrnjak.pdf 
- Ježić, Slavko (1993; prema prvom izdanju iz 1944). Hrvatska književnost od početka do danas (1100-1941.), Zagreb, Grafički zavod Hrvatske.

- Kolumbić, Nikica (1980). „Juraj Baraković (1548-1628) - najizrazitiji pjesnik hrvatskog manirizma“", u: Hrvatska književnost od humanizma do manirizma, Zagreb, Nakladni zavod Matice hrvatske.

- Kombol, Mihovil (1961). Povijest hrvatske književnosti do Narodnog preporoda, Zagreb, Matica hrvatska.

- Kravar, Zoran (2000). „Baraković, Juraj“, u: Leksikon hrvatskih pisaca, urednici: Dunja Fališevac, Krešimir Nemec, Darko Novaković, Zagreb, Školska knjiga.

- Ljubić, Šime (1869). Ogledalo književne poviesti jugoslavjanske na podučavanje mladeži, Knjiga II, Rieka, Riečki Emidija Mohovića Tiskarski Kamen. Zavod.

- Medini, Milorad (1902). Povjest hrvatske književnosti u Dalmaciji i Dubrovniku, Knjiga I. XVI. stoljeće, Zagreb, Matica hrvatska.

- Novak, Slobodan Prosperov (2004a). „Juraj Baraković“, u: Juraj Baraković, Vila Slovinka - Zučnopojke, Zagreb, Matica hrvatska.

- Novak, Slobodan Prosperov (2004b). Povijest hrvatske književnosti, Sv. I. - Raspeta domovina, Split, Marjan tisak.

- Pavešković, Antun (2000). „Topos 'pravoga puta' u duhovnom pjesništvu Vetranovića, Dimitrovića i Nalješkovića“, Anali Dubrovnik 38.

- Pavličić, Pavao (1988). Poetika manirizma (pogl. „Metatekstualnost u manirističkim književnim tekstovima“"), Zagreb, August Cesarec.

- Pavličić, Pavao (1979). Rasprave o hrvatskoj baroknoj književnosti, Split, Čakavski sabor.

- Srdoč-Konestra, Ines - Lajšić, Saša (2007). „Realno i irealno u 12. pjevanju Barakovićeve Vile Slovinke“, u: Zadarski filološki dani 1, urednice Vanda Babić i Zdenka Matek Šmit, Zadar, Sveučilište u Zadru.

- Solar, Milivoj (1979). Teorija književnosti, Zagreb, Školska knjiga.

- Šafařik, Paul Jos. (1865). Geschichte der illirischen und kroatischen Literatur, Prag, Verlag von Friedrich Tempsky.

- Švelec, Franjo (1974). „Hrvatska književnost sedamnaestog stoljeća“, u: Franičević, Marin - Švelec, Franjo - Bogišić, Rafo (1974). Povijest hrvatske književnosti, Kjiga 3 - Od renesanse do prosvjetiteljstva, Zagreb, Liber - Mladost. 
- Švelec, Franjo (1977). „O kompozicijskim osobitostima 'Vile Slovinke"“, u: Po stazi netlačeni (Studije iz starije hrvatske književnosti), Split, Čakavski sabor.

- Švelec, Franjo (1990). „Kako je nastajala Vila Slovinka Jurja Barakovića“, u: Iz naše književne prošlosti, Split, Književni krug.

- Švvelec, Franjo (2000). „Juraj Baraković“ i „Prilozi“, u: Juraj Baraković, Vila Slovinka, priredio Franjo Švelec, Stoljeća hrvatske književnosti, Zagreb, Matica hrvatska.

- Užarević, Josip (1995). „Tropi i jezik. Zapažanja o metafori, metonimiji i sinegdohi“, u: Tropi i figure, uredile Živa Benčić i Dunja Fališevac, Zagreb, Zavod za znanost o književnosti.

- Vaĺavac, Matija (1889). „Juraj Baraković“, u: Djela Jurja Barakovića, priredili za štampu P. Budmani i M. Vaĺavac, Stari pisci hrvatski, Kńiga XVII, JAZU, Zagreb.

- Vodnik, Branko (1913). Povijest hrvatske književnosti, Knjiga I. Od humanizma do potkraj XVIII. stoljeća. S uvodom V. Jagića o hrvatskoj glagolskoj književnosti, Zagreb, Matica hrvatska.

\section{Prilog}

Tablica - Leksem put u Vili Slovinki

\begin{tabular}{|c|c|c|}
\hline $\begin{array}{c}\begin{array}{c}\text { kompozicijske } \\
\text { jedinice }\end{array} \\
\text { primjer }\end{array}$ & navodi iz djela & $\begin{array}{c}\text { - vezanost uz lik, događaj } \\
\text { - semantem }\end{array}$ \\
\hline $\begin{array}{l}\text { Plemenitomu } \\
\text { gospodinu An'jelu } \\
\text { Justinijanoviću } \\
\text { Šibenčaninu } \\
\text { rajnoga Frančiska } \\
\text { gospodinu momu, } \\
\text { Juraj Baraković } \\
\text { Zadranin } \\
\text { Primjer 1. }\end{array}$ & $\begin{array}{l}\text { na putu i domom priklonit, } \\
\text { miran, tih (49); }{ }^{42} \text { put mu } \\
\text { odapriči pošteno da side. / Gdi } \\
\text { ga putom vide plemeniti muži, } \\
\text { / ne rekuć beside za njim se } \\
\text { množ pruži (...) ter mu put } \\
\text { pritiče (51). }\end{array}$ & $\begin{array}{l}\text { - Otavjan, stric An'jela Justinijano- } \\
\text { vića } \\
\text { - prostornost u kontekstu posvete: } \\
\text { biti poznat i uvažavan posvuda na } \\
\text { putu }\end{array}$ \\
\hline $\begin{array}{l}\text { Petje parvo } \\
\text { Primjer } 2 .\end{array}$ & $\begin{array}{l}\text { U svaku priliku kaže plod obi- } \\
\text { lje / i trudnu putniku putovat } \\
\text { udilje. (59); a vele dobro vim } \\
\text { da puta i ne znam (60); Dali } \\
\text { tko putuje po gorah pustošnih / } \\
\text { družba mu tribuje prez ke ja } \\
\text { pojti htih (60); sam pojti odlu- }\end{array}$ & $\begin{array}{l}\text { - Pisnik } \\
\text { - besciljnost } i \text { usamljenost: Pisnik } \\
\text { odlučuje upoznati Šibensko polje, } \\
\text { kreće u obilazak, sam, ne znajući } \\
\text { pravi put ni cilj }\end{array}$ \\
\hline
\end{tabular}

${ }^{42}$ Svi citati iz Vile Slovinke donose se, kako je već i napomenuto u prethodnim bilješkama, prema izdanju Baraković, Juraj (2000). Vila Slovinka, priredio Franjo Švelec, Stoljeća hrvatske književnosti, Zagreb, Matica hrvatska, i to tako da se u zagradu stavlja broj stranice na kojoj se citat nalazi. 


\section{Zlata ŠUNDALIĆ}

\begin{tabular}{|c|c|c|}
\hline & $\begin{array}{l}\text { čih kud viđah bolji put (60); } \\
\text { Prošad van kroz lazi kud oči } \\
\text { put kažu ( } 60 \text { ); ovde mi hotiše } \\
\text { skratiti puta duga ( } 78) \text {; }\end{array}$ & \\
\hline $\begin{array}{l}\text { Petje drugo } \\
\text { Primjer } 3 .\end{array}$ & $\begin{array}{l}\text { Kad putom grediše, s ponistar } \\
\text { odzgora / svud bobot staniše i } \\
\text { plačna romora. }(82)\end{array}$ & $\begin{array}{l}\text { - Sforca Palavicin } \\
\text { - prostornost: u priči o izgradnji } \\
\text { zadarskih zidina posvuda se Palavi- } \\
\text { cin uvažava sa strahopoštovanjem } \\
\text { (narod ga sa strahopoštovanjem } \\
\text { prati kao stručnjaka, arhitektu i } \\
\text { nitko mu ne proturječi) }\end{array}$ \\
\hline Primjer 4. & $\begin{array}{l}\text { Svak poslom putuje dokraj bila } \\
\text { danka, / a ništar praznuje, } \\
\text { mnju, do vlasa tanka. (86) }\end{array}$ & $\begin{array}{l}\text { - Zadrani (puk) } \\
\text { - svakodnevnost: u priči o izgradnji } \\
\text { zadarskih zidina opisuju se radnje } \\
\text { koje se tijekom dana ponavljaju }\end{array}$ \\
\hline Primjer 5. & $\begin{array}{l}\text { U ruke vaze prut da ga se pri- } \\
\text { straše, / kud ona kaže put da } \\
\text { bisni usplaše, }(87) \\
\text { I kad se oddili pokle put upra- } \\
\text { vi, / Zavidost posili da se š } \\
\text { njom odpravi (88) }\end{array}$ & $\begin{array}{l}\text { - Belona, božica rata, u društvu } \\
\text { personificirane Zavidosti } \\
\text { - strah } i \text { moć: kontekstu priče o } \\
\text { Beloni i njezinu poticanju paklenih } \\
\text { sila i Turaka, tj. cara Selina protiv } \\
\text { Zadrana i njegove okolice dominira } \\
\text { moć, jer onaj tko ima moć, izaziva } \\
\text { strah ali određuje i smjer puta } \\
\text { vlada njime }\end{array}$ \\
\hline Primjer 6. & $\begin{array}{l}\text { Tko često putuje mornarit } \\
\text { nastoji, / on blaga nakuje a pak } \\
\text { se pokoji. (93) }\end{array}$ & $\begin{array}{l}\text { - Belona se obraća Karontu koji } \\
\text { brodi rijekom Lete } \\
\text { - gnomičnost: nakon što je Zavidost } \\
\text { po Beloninu nagovoru uvjerila cara } \\
\text { Selina u snu, da mora pokoriti Za- } \\
\text { drane, Belona odlazi do Karonta, } \\
\text { koji nemajući posla još od vremena } \\
\text { bana Zrinskoga, hoda gorom, zbog } \\
\text { čega ga Belona kori i savjetuje } \\
\text { ako je brodar, mora ploviti, a ne } \\
\text { bluditi gorom, i samo će tako biti } \\
\text { bogat, o čemu svjedoče i Belonini } \\
\text { gnomično oblikovani stihovi } \\
\text { leksemom put }\end{array}$ \\
\hline Primjer 7. & $\begin{array}{l}\text { Tad će činit lav putnici da } \\
\text { mnozi / napune tvoju plav ter } \\
\text { brodi i vozi (95); } \\
\text { od zore do noći ni sedi, ni lezi, } \\
\text { / potežuć sve moći putnike } \\
\text { uprezi }\end{array}$ & $\begin{array}{l}\text { - Belona } \\
\text { - mrtve duše kao putnici: Belona se } \\
\text { obraća Karontu i obećaje mu puno } \\
\text { posla (putnika, tj. mrtvih duša) na- } \\
\text { kon što je uzbunila turskog cara } \\
\text { protiv Zadrana }\end{array}$ \\
\hline $\begin{array}{l}\text { Petje treto } \\
\text { Primjer } 8 .\end{array}$ & $\begin{array}{l}\text { a prem od pokore pristupaše } \\
\text { vrime / kada grišni more oblah- } \\
\text { čati brime, / blagoslov da prime } \\
\text { pustiv put opačan, / da bude } \\
\text { sasvime blaženim pritačan (98) }\end{array}$ & $\begin{array}{l}\text { - grješnik u korizmi u ratno vrijeme } \\
\text { - topos nepravog puta: Vila opisuje } \\
\text { početak Ciparskog rata (1570.- } \\
\text { 1573.) u korizmenim danima, kada } \\
\text { kreću turski napadi na Kotar i kada } \\
\text { se javljaju prijetnje Zadru, s poseb- } \\
\text { nim naglaskom na putu ispunjenom } \\
\text { grijesima }\end{array}$ \\
\hline
\end{tabular}




\begin{tabular}{|c|c|c|}
\hline Primjer 9. & $\begin{array}{l}\text { ne osta ni gora prez karvi, ni } \\
\text { dolac, / do sama zatvora pun } \\
\text { robja Obrovac, / gdi biše targo- } \\
\text { vac k Obrovcu putuje, / pote- } \\
\text { žuć tobolac da robje kupuje } \\
\text { (101) }\end{array}$ & $\begin{array}{l}\text { - ratno vrijeme } \\
\text { - putovanje radi trgovine: Vila } \\
\text { Slovinka priča Pisniku kako su Tur- } \\
\text { ci zauzeli Kotar, kako se isto spre- } \\
\text { ma Zadru, kako je puno zarobljeni- } \\
\text { ka i kako se njima trguje, zbog čega } \\
\text { trgovci i kreću na put }\end{array}$ \\
\hline Primjer 10. & $\begin{array}{l}\text { Putnika ni gosta na polju ne bi } \\
\text { tad / slobodna ni prosta, ni hiže } \\
\text { za priklad (106) }\end{array}$ & $\begin{array}{l}\text { - ratno vrijeme } \\
\text { - odsutnost putnika kao izraz } \\
\text { psihološke napetosti: Vila Slovinka } \\
\text { priča Pisniku kako se iščekivao na- } \\
\text { pad Turaka na Zadar, opisuje atmo- } \\
\text { sferu u kojoj se miješao i strah i } \\
\text { hrabrost, što je na prostornom planu } \\
\text { dočarano činjenicom da između dva } \\
\text { tabora nije bilo nikoga, pa čak ni } \\
\text { putnika (odsutnost putnika nagla- } \\
\text { šava napetost i iščekivanje sukoba) }\end{array}$ \\
\hline $\begin{array}{l}\text { Petje četvarto } \\
\text { Primjer } 11 .\end{array}$ & $\begin{array}{l}\text { Sve imahu želju i sve potvardi- } \\
\text { še / o starom temelju zakon da } \\
\text { se piše, / sve jedino hotiše da se } \\
\text { put upravi / da zakon uskriše } \\
\text { koga svit zatravi. (115) }\end{array}$ & $\begin{array}{l}\text { - napisati zakon } \\
\text { - ispravnost: Vila govori Pisniku o } \\
\text { zboru vila na Velebiću koje su, iz- } \\
\text { među ostalog, bile složne i oko za- } \\
\text { kona koji bi se trebao napisati, ali u } \\
\text { pravome smjeru (pravednosti, is- } \\
\text { pravnosti) }\end{array}$ \\
\hline $\begin{array}{l}\text { Petje šesto } \\
\text { Primjer } 12 .\end{array}$ & $\begin{array}{l}\text { Slavi ga i dvori vas narod i } \\
\text { štuje / gdi su Nilu zvori i kuda } \\
\text { putuje (121) }\end{array}$ & $\begin{array}{l}\text { - slava Zadra } \\
\text { - kretanje naprijed } i \text { slava: nakon } \\
\text { što su vile na Velebiću odslušale } \\
\text { Vilinu pohvalnu pjesmu Zadru, jav- } \\
\text { lja se Od istoka vila i kaže da je pu- } \\
\text { no čula o Zadru, da ga slave svi na- } \\
\text { rodi, od izvora Nila pa dalje cijelim } \\
\text { njegovim tokom, ali da ga nije vi- } \\
\text { djela, tj. preko personifikacije rijeke } \\
\text { Nil govori se o širenju, pronošenju } \\
\text { slave grada Zadra }\end{array}$ \\
\hline Primjer 13. & $\begin{array}{l}\text { jer kud sam hodila životom } \\
\text { mojime, / vazdi sam vidila pi- } \\
\text { sano to ime, / putnici, pastiri, } \\
\text { mišćani, vitezi, / svaki ga zami- } \\
\text { ri oštrimi železi: / putnici uz } \\
\text { more na glatku kamenu, / pasti- } \\
\text { ri varh gore, na stupu drivenu, / } \\
\text { u svakom vrimenu to ime slo- } \\
\text { vući, / na svakom slimenu pisa- } \\
\text { no budući.(122) }\end{array}$ & $\begin{array}{l}\text { - Od istoka vila i slava Zadra } \\
\text { - hvala: Od istoka vila se poziva na } \\
\text { vlastito iskustvo, na vlastita puto- } \\
\text { vanja, na kojima je vidjela različite } \\
\text { ljude, putnike, koji su svi redom } \\
\text { slavili ime Zadra }\end{array}$ \\
\hline Primjer 14. & $\begin{array}{l}\text { „Ka vas je mudrija“, rekoh jim, } \\
\text { „ sad hodi / al' umom hitrija ter } \\
\text { meni pogodi; / ov tanac izvodi, } \\
\text { a puta ne griši / i mojoj slobodi } \\
\text { te sumnje odriši. (125) }\end{array}$ & $\begin{array}{l}\text { - Vila Slovinka } \\
\text { - pravilnost kretanja: Vila Slovinka } \\
\text { govori vilama na Velebiću o potrebi } \\
\text { kretanja pravim smjerom, po pravi- } \\
\text { lima, posebice kada je riječ o plesu }\end{array}$ \\
\hline
\end{tabular}




\section{Zlata ŠUNDALIĆ}

\begin{tabular}{|c|c|c|}
\hline Primjer 15. & $\begin{array}{l}\text { Potanko sve sliši steć sa mnom } \\
\text { nabliže, / a pak me ne liši ča } \\
\text { svim znat naliže, / uzmožno } \\
\text { ako je, to čudo učini, / pokaži } \\
\text { put koj 'e na morskoj pučini. } \\
\text { (126) }\end{array}$ & $\begin{array}{l}\text { - Vila Slovinka } \\
\text { - pravi smjer: Vila Slovinka govori } \\
\text { vilama na Velebiću o potrebi } \\
\text { putovanja pravim smjerom i na } \\
\text { morskoj pučini }\end{array}$ \\
\hline Primjer 16. & $\begin{array}{l}\text { to ti je poljanom ravan put uz } \\
\text { more / hoditi građanom pokle } \\
\text { grad otvore, / sam ta put od } \\
\text { gore na kopno izhodi, / u istok } \\
\text { od zore na vrata izvodi. (127) }\end{array}$ & $\begin{array}{l}\text { - građenje Zadra } \\
\text { - smještenost u prostoru: Vila } \\
\text { Slovinka opisuje sagradu (građe- } \\
\text { nje) Zadra vilama na Velebiću } \\
\text { njegovu smještenost u prostoru (na } \\
\text { putu) koja ima i svoje orijentire }\end{array}$ \\
\hline $\begin{array}{l}\text { Petje sedmo } \\
\text { Primjer } 17 .\end{array}$ & $\begin{array}{l}\text { Hti se š njom svitovat da pratež } \\
\text { naprave, / da gredu putovat da } \\
\text { Babel ostave, / da tuje daržave } \\
\text { prišlaci posedu / babelske giz- } \\
\text { dave pustivši odsedu, / puto- } \\
\text { vav da sedu gdi bude prilika / } \\
\text { da sime izvedu našega jazika. / } \\
\text { Tad blaga spraviše putnici za } \\
\text { dosta / ča putom tratiše da jim } \\
\text { ga izosta. (144) }\end{array}$ & $\begin{array}{l}\text { - Sava i Nino } \\
\text { - kretanje naprijed uz moguće } \\
\text { zaustavljanje: Vila Slovinka priča } \\
\text { vilama na Velebiću o Savi i Ninu, } \\
\text { koji nakon babilonske katastrofe } \\
\text { kreću na put, kako bi negdje ostavi- } \\
\text { le sjeme slovinskog jezika }\end{array}$ \\
\hline Primjer 18. & $\begin{array}{l}\text { pusti jih zla volja našad lug ze- } \\
\text { leni / gdi voća najbolja od slat- } \\
\text { ke jeseni, / jur bihu u zameč i } \\
\text { zrilo kogodi, / putnikom izda- } \\
\text { leč na vrime pogodi. (145) }\end{array}$ & $\begin{array}{l}\text { - Sava i Nino } \\
\text { - zaustavljanje na putu (ugodan } \\
\text { krajolik): Vila Slovinka priča kako } \\
\text { su Sava i Nino tražili pogodno mje- } \\
\text { sto za nastaniti se i da su ga prona- } \\
\text { šli uz more, u gradu koji nazvaše } \\
\text { Nin i u kojemu Sava rodi Plankitu }\end{array}$ \\
\hline Primjer 19. & $\begin{array}{l}\text { Plankitu bi želja da usta osladi / } \\
\text { gdi ju put pripelja i lišca da } \\
\text { hladi / zač biše zmučena košutu } \\
\text { slideći, / od zraka sunčana kako } \\
\text { cvit pri peći. (148) }\end{array}$ & $\begin{array}{l}\text { - Plankita } \\
\text { - zaustavljanje na putu (umor, žeđ, } \\
\text { vrućina): Vila Slovinka priča o } \\
\text { Plankiti, zavjetovanoj Dijani, koja } \\
\text { slijedi ranjenu košutu, ali je umor, } \\
\text { žeđ i vrućina na putu zaustave, što } \\
\text { se kasnije pokaže pogubno (bit će } \\
\text { učinjena ženom) }\end{array}$ \\
\hline Primjer 20. & $\begin{array}{l}\text { Na skoke igrahu noseći vrat } \\
\text { prignut, / gdi okom smirahu tuj } \\
\text { biše nozi put (152) }\end{array}$ & $\begin{array}{l}\text { - bogovi } \\
\text { - pravilnost kretnji: Vila Slovinka } \\
\text { priča kako su bogovi došli proslavi- } \\
\text { ti rođenje sina Slovana Plankite i } \\
\text { Neptuna i pri tome opisuje ples } \\
\text { (tance), koji podrazumijeva kretnje } \\
\text { po pravilima }\end{array}$ \\
\hline Primjer 21. & $\begin{array}{l}\text { Pridoše tad k vodi ka bistra } \\
\text { izvire, / na ku prav put vodi da } \\
\text { lasno k njoj smire. (157) }\end{array}$ & $\begin{array}{l}\text { - Plankita } \\
\text { - određenost cilja: Vila Slovinka } \\
\text { priča kako su na proslavljanje Slo- } \\
\text { vanova rođenja Cerere i Bako stigli } \\
\text { nakon ostalih bogova i kako su tra- } \\
\text { žili od Plankite da im ispriča kako } \\
\text { se desila obljuba od strane Neptuna }\end{array}$ \\
\hline
\end{tabular}


Konotacije puta u Vili Slovinki

\begin{tabular}{|c|c|c|}
\hline Primjer 22. & $\begin{array}{l}\text { hodeći nevišće njoj se put } \\
\text { razklopi / da ju most pritišće a } \\
\text { rika utopi (160) }\end{array}$ & $\begin{array}{l}\text { - Sava } \\
\text { - opasan put: Vila Slovinka priča } \\
\text { kako je Sava hodeći preko rijeke, u } \\
\text { već dubokoj starosti, spotakla se i } \\
\text { utopila u rijeci, koja se po njoj zove } \\
\text { Sava }\end{array}$ \\
\hline Primjer 23. & $\begin{array}{l}\text { Tko išće put novi, a stari } \\
\text { zapusti, / u raspi gotovi skoro } \\
\text { ce zablusti. (171) }\end{array}$ & $\begin{array}{l}\text { - Vila Slovinka i Pisnik } \\
\text { - vrijednost staroga puta: Vila Slo- } \\
\text { vinka daje Pisniku mnoštvo kori- } \\
\text { snih gnomično oblikovanih savjeta } \\
\text { (prudni sviti), a među njima je i } \\
\text { ovaj o potrebi čuvanja staroga puta, } \\
\text { što u odnosu na Pisnika znači da se } \\
\text { treba hvaliti vlastiti jezik, njegova } \\
\text { muza (Vila Slovinka) i domovina, a } \\
\text { ne latinksi ili neki drugi tuđi jezik }\end{array}$ \\
\hline Primjer 24. & $\begin{array}{l}\text { Gdi je prudna muka, truda se } \\
\text { ne ćuti, / vazda dobar nuka na } \\
\text { dobro, i puti, / vazda taman } \\
\text { muti, zač kriposti neće, / ter } \\
\text { pomita skuti ča se putom } \\
\text { kreće, (174) }\end{array}$ & $\begin{array}{l}\text { - Vila Slovinka i Pisnik } \\
\text { - upućivanje na dobro: u mnoštvu } \\
\text { Slovinkinih savjeta Pisniku nalazi } \\
\text { se i ovaj - prijatelj se trudi i upućuje } \\
\text { na dobro, a neprijatelj čini suprotno }\end{array}$ \\
\hline $\begin{array}{l}\text { Petje osmo } \\
\text { Primjer } 25 .\end{array}$ & $\begin{array}{l}\text { Idoh ustav iz planine, / naglo } \\
\text { hodeć stranputice / niz visoke } \\
\text { kružne stine, / vred se stanih na } \\
\text { ulice / jer sunašcu morske } \\
\text { tmine / skrivat jaše svitlo lišce. } \\
\text { (181) }\end{array}$ & $\begin{array}{l}\text { - Pisnik } \\
\text { - brzo kretanje naprijed: nakon što } \\
\text { je Vila ostavila u gori Pisnika sa- } \\
\text { mog, on se brzo vraća kući jer stiže } \\
\text { noć }\end{array}$ \\
\hline Primjer 26. & $\begin{array}{l}\text { Sliš' me dobro ča ti reku, / da t' } \\
\text { u kratke riči skažu, / jer zgovo- } \\
\text { ru pridaleku / hoć' posumnjit da } \\
\text { ti lažu, / gdi van puta rič pri- } \\
\text { teku, / pusti marsku, primi dra- } \\
\text { žu. (182) }\end{array}$ & $\begin{array}{l}\text { - Poklisar } \\
\text { - kračina kao argument istinitosti: } \\
\text { Poklisar se obraća Pisniku i kaže } \\
\text { mu da će mu pričati ukratko, kako } \\
\text { Pisnik ne bi pomislio da mu dugim } \\
\text { govorom laže, skreće s puta istine }\end{array}$ \\
\hline Primjer 27. & $\begin{array}{l}\text { Ta gospodin sluge šalje / sve } \\
\text { putnike ke nahode / u polaču } \\
\text { da jih vode, / okol grada i po- } \\
\text { dalje. (184) }\end{array}$ & $\begin{array}{l}\text { - Poklisar } \\
\text { - veselje, brojnost, svečanost, gosto- } \\
\text { ljubivost: Poklisar govori Pisniku } \\
\text { ono što mu je ispričao sluga o uzva- } \\
\text { nicima na vjenčanju Darje i Federi- } \\
\text { ga Grižogona, donosi bugaršticu } \\
\text { koju je pjevalo „niko dite mladolit- } \\
\text { no“, a svatovsko veselje su upotpu- } \\
\text { njavali i slučajni putnici }\end{array}$ \\
\hline Primjer 28. & $\begin{array}{l}\text { Odpravi se put istoka / pustiv } \\
\text { majku da uzdiše, / Senjani ga } \\
\text { pogubiše / pri Korčuli kraj oto- } \\
\text { ka. (207) }\end{array}$ & $\begin{array}{l}\text { - nećak Ivan } \\
\text { - pogubnost zaustavljanja na putu: } \\
\text { Poklisar priča Pisniku kako mu je } \\
\text { nećak Ivan pogubljen kod Korčule }\end{array}$ \\
\hline Primjer 29. & $\begin{array}{l}\text { Za putnikom hodeć zada / pri- } \\
\text { mičući ča se more / dokle vrata } \\
\text { ne zatvore, / da ne spimo van iz } \\
\text { garada. (210) }\end{array}$ & $\begin{array}{l}\text { - Pisnik i Poklisar } \\
\text { - hodanje prema naprijed, u točno } \\
\text { vrijeme: u razgovoru (o vjenčanju } \\
\text { Grižogona, zatim i o Barakovićevoj } \\
\text { sestri Margariti, njezinu sinu Ivanu }\end{array}$ \\
\hline
\end{tabular}




\section{Zlata ŠUNDALIĆ}

\begin{tabular}{|c|c|c|}
\hline & & $\begin{array}{l}\text { i Barakovićevu bratu Petru) Pisnika } \\
\text { i Poklisara polako sustiže noć, a pri- } \\
\text { je mraka i prije zaključavanja grad- } \\
\text { skih vrata treba ući u Šibenik }\end{array}$ \\
\hline $\begin{array}{l}\text { Petje deveto } \\
\text { Primjer } 30 .\end{array}$ & $\begin{array}{l}\text { Uputi se k onoj gori / gdi je } \\
\text { misto od razloga, / da bi do nje } \\
\text { doprit moga', / gdi su vičnje } \\
\text { slave zvori. (218) }\end{array}$ & $\begin{array}{l}\text { - Pisnik i Vila u njegovu snu } \\
\text { - bitnost završne točke putovanja, } \\
\text { jer se u njoj (u onoj gori) nalazi is- } \\
\text { tina: nakon povratka s Poklisarom u } \\
\text { Šibenik, Pisnik usne čudne snove, u } \\
\text { kojima se javlja i Vila, ali tužna } \\
\text { ljuta, te ga savjetuje da pođe u goru } \\
\text { i dozna istinu, jer sve što je čuo u } \\
\text { zbilji, nije istina }\end{array}$ \\
\hline Primjer 31. & $\begin{array}{l}\text { Pohlepna me užga želja / da } \\
\text { put najdu kim se hodi / na pri- } \\
\text { stol'je ki dovodi, / stah zablenut } \\
\text { od veselja, (222) }\end{array}$ & $\begin{array}{l}\text { - Pisnik u svom snu } \\
\text { - izgubljenost (ne-biti-na-putu): na- } \\
\text { kon što mu je Vila rekla da treba } \\
\text { poći na goru, Pisnik kreće i uviđa } \\
\text { da je tamo sve raskošno i složno, jer } \\
\text { svi žele ispuniti kraljev zakon, zbog } \\
\text { čega bi i on htio pronaći put do } \\
\text { prijestolja }\end{array}$ \\
\hline Primjer 32. & $\begin{array}{l}\text { „Grem ja“, reče, „putovati, / } \\
\text { ustanimo, jur je danak, / pospa- } \\
\text { li smo dobro dosti.“ (224) }\end{array}$ & $\begin{array}{l}\text { - Poklisar i Pisnik } \\
\text { - zaustavljanje (zbog spavanja): na- } \\
\text { kon što su navečer zajedno legli, } \\
\text { Poklisar u jutro budi Pisnika, jer } \\
\text { mora poći dalje, mora nastaviti svo- } \\
\text { je putovanje }\end{array}$ \\
\hline Primjer 33. & $\begin{array}{l}\text { Prokleh vrime i namiru / ka me } \\
\text { učer na nj namiri, / kad na putu } \\
\text { na me smiri / noseć glasi s kih } \\
\text { umiru, (224) }\end{array}$ & $\begin{array}{l}\text { - Pisnik } \\
\text { - zaustavljanje (zbog čovjeka): Pi- } \\
\text { snika je iz ugodnog sna probudio } \\
\text { Poklisarev glas, koji mu je jučer do- } \\
\text { nio tragične glase o smrti nećaka } \\
\text { brata }\end{array}$ \\
\hline Primjer 34. & $\begin{array}{l}\text { Tad Poklisar: „,zbogom!“ reče, / } \\
\text { „put me čeka nadaleče, / mnju } \\
\text { da sam se zakasnija.“ (224) }\end{array}$ & $\begin{array}{l}\text {-Poklisar i Pisnik } \\
\text { - cilj putovanja: nakon prespavane } \\
\text { noći Poklisar nastavlja putovanje uz } \\
\text { naglašavanje bitnosti završne točke } \\
\text { putovanja }\end{array}$ \\
\hline Primjer 35. & $\begin{array}{l}\text { Zagrusti mi: „Sam ishodi / ako } \\
\text { misliš putovati, / hteć otajna } \\
\text { zjiskovati / družbe sobom } \\
\text { nigdar vodi.“ }\end{array}$ & $\begin{array}{l}\text { - Vila i Pisnik } \\
\text { - putovanje kao spoznavanje: Vila } \\
\text { govori Pisniku da ako želi doznati } \\
\text { nešto o prošlosti Šibenika, mora } \\
\text { sam išetati iz grada i istražiti ono } \\
\text { što ga zanima }\end{array}$ \\
\hline $\begin{array}{l}\text { Petje deseto } \\
\text { Primjer } 36 .\end{array}$ & $\begin{array}{l}\text { onako kakova dila se diluju, / } \\
\text { plaća je takova kom pak obilu- } \\
\text { ju, / kim putom putuju ljudi } \\
\text { sega svita, / s plaćom se raduju } \\
\text { ka jim se obita, (232) }\end{array}$ & $\begin{array}{l}\text { - Pustinjak i Pisnik } \\
\text { - svakome prema zaslugama: Pisni- } \\
\text { ka zanima kakva je budućnost Šibe- } \\
\text { nika, a Pustinjak mu gnomično od- } \\
\text { govara da svatko dobiva ono što } \\
\text { zaslužuje (kakva djela, takva } \\
\text { nagrada) }\end{array}$ \\
\hline
\end{tabular}




\begin{tabular}{|c|c|c|}
\hline Primjer 37. & $\begin{array}{l}\text { zač mladost luduje kako konj } \\
\text { prez žvala, / kad hoće putuje } \\
\text { nimav strah iz mala. (240) }\end{array}$ & $\begin{array}{l}\text { - Pisnik i čitatelj (obraća se čatniku } \\
\text { koji čte) } \\
\text { - neobvezujuća sloboda: Pisnik se } \\
\text { obraća čitatelju i priča mu na način } \\
\text { mudrih izreka, kako se u mladosti } \\
\text { neobuzdano zaljubio i kako si je } \\
\text { tada naprtio, ne razmišljajući, teško } \\
\text { breme }\end{array}$ \\
\hline $\begin{array}{l}\begin{array}{l}\text { Petje } \\
\text { jedinonadeseto }\end{array} \\
\text { Primjer } 38 .\end{array}$ & $\begin{array}{l}\text { Pripasah svite skut suzeći u } \\
\text { plaču, / van grada vazeh put } \\
\text { kroz bahće vartaču (243) }\end{array}$ & $\begin{array}{l}\text { - Pisnik } \\
\text { - bijeg (od sebe i ljubavnih boli): } \\
\text { Pisnik ispovijeda svoju nesretnu } \\
\text { mladenačku trogodišnju ljubav, } \\
\text { koju je htio zaboraviti, izliječiti } \\
\text { bijegom iz grada }\end{array}$ \\
\hline Primjer 39. & $\begin{array}{l}\text { Ako l' mi zvir prosti ter mi put } \\
\text { ne smarsi, / sam se htih ubosti } \\
\text { na moj mač u parsi, (244) }\end{array}$ & $\begin{array}{l}\text { - Pisnik } \\
\text { - priželjkivanje prepreke na putu } \\
\text { (=smrti): zbog nesretne ljubavi Pi- } \\
\text { snik želi okončati život i nada se da } \\
\text { će mu u tome pomoći zvijeri na pu- } \\
\text { tu, ali ako se to ne dogodi, sam će si } \\
\text { presuditi }\end{array}$ \\
\hline Primjer 40. & $\begin{array}{l}\text { Rekoh mu da strila ljubena } \\
\text { poraza / i žena nemila ta mi put } \\
\text { ukaza. (246) }\end{array}$ & $\begin{array}{l}\text { - Pisnik } \\
\text { - bijeg (od sebe i nje, okrutne vile): } \\
\text { odlazak u goru Pisnik argumentira } \\
\text { okrutnošću Vile }\end{array}$ \\
\hline Primjer 41. & $\begin{array}{l}\text { Ugledah gdi mornar uputi } \\
\text { svoju plav, / šibenski prem } \\
\text { brodar jidarcu daje sprav. (251) }\end{array}$ & $\begin{array}{l}\text { - Pisnik } \\
\text { - imati smjer kretanja: nakon luta- } \\
\text { nja gorom Pisnika su četvrti dan } \\
\text { lovci pronašli u lošem stanju, okri- } \\
\text { jepili ga u pastirevoj kući i poveli u } \\
\text { Trogir, gdje on ulazi u kuću vileni- } \\
\text { ka, koji treba skinuti urok njegove } \\
\text { nesretne ljubavi i koji ga savjetuje } \\
\text { da lijek svojoj ljubavi potraži ne u } \\
\text { gori, nego da pođe na more, u Šibe- } \\
\text { nik s brodarom, kako bi omekšao } \\
\text { svoju okrutnu Vilu; Pisnik ga poslu- } \\
\text { ša i odlazi na put, ali Vila ga pono- } \\
\text { vo odbija, i to na kulturan način }\end{array}$ \\
\hline Primjer 42. & $\begin{array}{l}\text { Znaš da sam kako gost, zabludi } \\
\text { nevišće / tvoga sam puta most, } \\
\text { a stana ognjišće. (256) }\end{array}$ & $\begin{array}{l}\text { - Pisnik } \\
\text { - udovoljiti nečijoj želji: moli Boga } \\
\text { da ga oslobodi ljuvene boli, jer i na- } \\
\text { kon što se oženio ljubom pogod- } \\
\text { nom, nije našao mir }\end{array}$ \\
\hline $\begin{array}{l}\text { Petje } \\
\text { dvanadeseto } \\
\text { Primjer } 43 .\end{array}$ & $\begin{array}{l}\text { Odlučih život moj po moru } \\
\text { provesti, / hteć tilu nepokoj tim } \\
\text { putom odnesti, / jeda bih otre- } \\
\text { sti mogal tim trud visok / i mo- } \\
\text { joj bolesti najti put i uzrok, } \\
\text { (260) }\end{array}$ & $\begin{array}{l}\text { - Pisnik } \\
\text { - bijeg, ali i nada: Pisniku je dosa- } \\
\text { dilo lutanje gorama i poljem zbog } \\
\text { nesretne ljubavi (bolesti) i odlučuje } \\
\text { mir potražiti na moru u ukradenu } \\
\text { brodu, u zoru }\end{array}$ \\
\hline Primjer 44. & $\begin{array}{l}\text { Vidi' sam po ta put oglobje ki- } \\
\text { pu stat, / sveden zad na leut, a }\end{array}$ & $\begin{array}{l}\text { - Pisnik } \\
\text { - onda, onaj put: nakon što je ukrao }\end{array}$ \\
\hline
\end{tabular}




\section{Zlata ŠUNDALIĆ}

\begin{tabular}{|c|c|c|}
\hline & sprida visok rat, (261) & $\begin{array}{l}\text { brod i otisnuo se na pučinu, Pisnika } \\
\text { je zadesila oluja u kojoj brod izgle- } \\
\text { da vrlo krhko }\end{array}$ \\
\hline Primjer 45. & $\begin{array}{l}\text { Malo brod putuje, jur vesla ne } \\
\text { rabe, / more njim vojuje jak ko- } \\
\text { rom od žabe. }(264)\end{array}$ & $\begin{array}{l}\text { - Pisnik } \\
\text { - zaustavljanje (zbog oluje): oluja je } \\
\text { zaustavila napredovanje u putova- } \\
\text { nju }\end{array}$ \\
\hline Primjer 46. & $\begin{array}{l}\text { prolita međami kud sunce } \\
\text { putuje (267) }\end{array}$ & $\begin{array}{l}\text { - Febova sestrica } \\
\text { - pomoć na putu: Pisnik se obaraća } \\
\text { Febovoj sestrici na uzburkanu moru } \\
\text { i moli je da mu pomogne i utiša vje- } \\
\text { trove i oluju }\end{array}$ \\
\hline Primjer 47. & $\begin{array}{l}\text { Vitri su jali put gdi je stat njim } \\
\text { dilo, / i jadna mora mut obuja } \\
\text { bistrilo. (268) }\end{array}$ & $\begin{array}{l}\text { - vrhovno božanstvo } \\
\text { - pomoć na putu: nakon što je boži- } \\
\text { ca zamolila zatišje na moru, vrhov- } \\
\text { ni je bog udovoljio njezinoj zamolbi }\end{array}$ \\
\hline Primjer 48. & $\begin{array}{l}\text { po ki l' put s ovih tmin s } \\
\text { narugom zide sad (272) }\end{array}$ & $\begin{array}{l}\text { - Pisnik } \\
\text { - zaustavljanje (zbog ljudske sjene, } \\
\text { Osina): nakon oluje na otoku Pisnik } \\
\text { susreće Osina i pita ga tko je }\end{array}$ \\
\hline Primjer 49. & $\begin{array}{l}\text { znam tebe i tvoj dom i s tobom } \\
\text { putovah (273) }\end{array}$ & $\begin{array}{l}\text { - Osin } \\
\text { - kretanje prema naprijed: na otoku } \\
\text { Bulkanu Pisnik susreće Poklisarovu } \\
\text { sjenu, Osina, koji mu govori da je } \\
\text { za života putovao s njim }\end{array}$ \\
\hline Primjer 50. & $\begin{array}{l}\text { Nesrićni Poklisar koga ti pošto- } \\
\text { va / kad s tobom kroz kotar } \\
\text { šibenski putova ( } 273)\end{array}$ & $\begin{array}{l}\text { - Osin } \\
\text { - kretanje prema naprijed: u raz- } \\
\text { govoru Pisnika i Osina nastavlja se } \\
\text { prisjećanje na događaje koji su se } \\
\text { zbili za života Osinova (Poklisa- } \\
\text { rova) }\end{array}$ \\
\hline Primjer 51. & $\begin{array}{l}\text { Hoću t' reć srićom kom i kako, } \\
\text { po ki put / sada me silom svom } \\
\text { pokori biča prut (274) }\end{array}$ & $\begin{array}{l}\text { - Osin } \\
\text { - na koji način: Osin pokušava } \\
\text { objasniti Pisniku kako je dospio u } \\
\text { paklenu jamu na otoku Bulkanu }\end{array}$ \\
\hline Primjer 52. & $\begin{array}{l}\text { More me tim putom donese } \\
\text { živa, znaj, / ter živim životom } \\
\text { otrese ovi kraj. (275) }\end{array}$ & $\begin{array}{l}\text { - Osin } \\
\text { - tada, onda: nastavlja se Osinovo } \\
\text { objašnjavanje onoga što se onda, za } \\
\text { života desilo i čime je zalužio } \\
\text { pakao }\end{array}$ \\
\hline Primjer 53. & $\begin{array}{l}\text { Puti su široci, raskošni, i staze, } \\
\text { / zač tuda svidoci lažljivi ulaze. } \\
\text { (275) }\end{array}$ & $\begin{array}{l}\text { - Osin } \\
\text { - topos krivoga puta: na otoku Pi- } \\
\text { snik susreće Poklisarovu sjenu, Osi- } \\
\text { na, koji mu opisuje ulazak u pakao i } \\
\text { laži zbog kojih je tamo dospio (Pi- } \\
\text { snik doznaje da je sve izrečeno o } \\
\text { svadbi i zadarskoj gospodi - laž) }\end{array}$ \\
\hline Primjer 54. & $\begin{array}{l}\text { Iz Hlivna skoro tad pospišno } \\
\text { vazeh tik, / putovah s tobom } \\
\text { kad u slavni Sibenik. (277) }\end{array}$ & $\begin{array}{l}\text { - Osin i Pisnik } \\
\text { - putovanje naprijed: Osin prepri- } \\
\text { čava Pisniku kako je putujući s nji- } \\
\text { me u Šibenik govorio laži o piru u } \\
\text { Zadru }\end{array}$ \\
\hline
\end{tabular}




\begin{tabular}{|c|c|c|}
\hline Primjer 55. & $\begin{array}{l}\text { Po ki put mož' znati ti pirni } \\
\text { obidi, / gospodu i svati, ako jih } \\
\text { ne vidi? (277) }\end{array}$ & $\begin{array}{l}\text { - Pisnik i Osin } \\
\text { - na koji način: Pisnik se čudi Osi- } \\
\text { nu - zašto je lagao, kada ga ništa na } \\
\text { to nije tjeralo i kada je mogao o } \\
\text { svemu jednostavno šutjeti }\end{array}$ \\
\hline Primjer 56. & $\begin{array}{l}\text { Reče: „Znaj, kako bi prijazan } \\
\text { moja k njim: / želja me pridobi } \\
\text { da putom idu tim. (278) }\end{array}$ & $\begin{array}{l}\text { - Osin i Pisnik } \\
\text { - ići putem laži: Osin objašnjava Pi- } \\
\text { sniku kako je dospio u pakao i zašto } \\
\text { je lagao (lažima pridobiti osobnu } \\
\text { korist) }\end{array}$ \\
\hline Primjer 57. & $\begin{array}{l}\text { Lažljivih ovude prohodi velik } \\
\text { broj, / oholi onude, svaki put } \\
\text { znade svoj ( } 283)\end{array}$ & $\begin{array}{l}\text { - Osin i Pisnik } \\
\text { - topos nepravoga puta (grijeha): } \\
\text { Osin opisuje Pisniku pakao i obja- } \\
\text { šnjava kako svaki grješnik ima svoj } \\
\text { put u paklu }\end{array}$ \\
\hline Primjer 58. & $\begin{array}{l}\text { a } \mathrm{z} \text { grihom to umre, vodi ga } \\
\text { silom grih, / od sedam jednim } \\
\text { gre tih putov ke ti rih. (283) }\end{array}$ & $\begin{array}{l}\text { - Osin i Pisnik } \\
\text { - topos nepravoga puta (grijeha): } \\
\text { Osin opisuje Pisniku pakao i pakle- } \\
\text { ne putove grješnika }\end{array}$ \\
\hline Primjer 59. & $\begin{array}{l}\text { Tko martav gre k vodi, za njim } \\
\text { put zatvore, / brodar ga } \\
\text { pribrodi, već nazad ne more. } \\
(283)\end{array}$ & $\begin{array}{l}\text { - Osin i Pisnik } \\
\text { - topos nepravoga puta (odlazak } \\
\text { bez povratka): Osin opisuje Pisniku } \\
\text { pakao u koji se ulazi bez moguć- } \\
\text { nosti povratka, jer koga Katront } \\
\text { preveze preko rijeke, ne vraća se }\end{array}$ \\
\hline Primjer 60. & $\begin{array}{l}\text { i puti i staze nogami kud hode / } \\
\text { i kuda ulaze i opet izhode, / } \\
\text { svud oganj nahode od žive } \\
\text { žerave (288) }\end{array}$ & $\begin{array}{l}\text { - Osin i Pisnik } \\
\text { - kretanje ometano preprekama (že- } \\
\text { ravica): Osin opisuje Pisniku pakao, } \\
\text { a posebice mjesto namijenjeno oni- } \\
\text { ma koji umiru u tašćoj ljubavi (is- } \\
\text { praznoj) }\end{array}$ \\
\hline Primjer 61. & $\begin{array}{l}\text { Ovi su uzmožni ostalim dati } \\
\text { put, / zač su tri svi složni pa- } \\
\text { kleni mutit mut: / ovi su koreni } \\
\text { i žile svakih zlob (293) }\end{array}$ & $\begin{array}{l}\text { - Osin i Pisnik } \\
\text { - biti primjer (negativne konotaci- } \\
\text { je): Osin opisuje Pisniku pakao i tri } \\
\text { glavna grijeha (oholost, lakomost, } \\
\text { bludnost) iz kojih proizlaze svi } \\
\text { ostali }\end{array}$ \\
\hline Primjer 62. & $\begin{array}{l}\text { Trepetah kako prut, prid vrati } \\
\text { pakla stah, / otvoren viđah put } \\
\text { kim tamo pojti mnjah (296) }\end{array}$ & $\begin{array}{l}\text { - Osin i Pisnik } \\
\text { - strah na putu: Osin opisuje Pisni- } \\
\text { ku pakao i put koji vodi u najveće } \\
\text { dubine i užase, gdje je smješten i } \\
\text { Juraj ban smiderski, koji je izdao } \\
\text { one koji su ga ljubili }\end{array}$ \\
\hline Primjer 63. & $\begin{array}{l}\text { Podobno ni reći: po morskoj } \\
\text { pučini, / jedan dan vozeći, tolik } \\
\text { put učini. (302) }\end{array}$ & $\begin{array}{l}\text { - Osin i Pisnik } \\
\text { - velika udaljenost: Osin opisuje se- } \\
\text { be kao sjenu koja živi samo u mra- } \\
\text { ku, koja s prvim zrakama sunca ne- } \\
\text { staje, i koja kao takva može prijeći, } \\
\text { savladati veliki prostor }\end{array}$ \\
\hline Primjer 64. & $\begin{array}{l}\text { zač bo je dalek put a more } \\
\text { sardito, / kad vali dignu mut, } \\
\text { premda je i lito. (302) }\end{array}$ & $\begin{array}{l}\text { - Osin i Pisnik } \\
\text { - opasnost na putu (oluja): Osin sa- } \\
\text { vjetuje Pisnika da na vrijeme krene }\end{array}$ \\
\hline
\end{tabular}




\section{Zlata ŠUNDALIĆ}

\begin{tabular}{|c|c|c|}
\hline & & $\begin{array}{l}\text { prema kopnu, jer i ljeti se događaju } \\
\text { oluje na moru }\end{array}$ \\
\hline Primjer 65. & $\begin{array}{l}\text { Po drugom načinu ne moreš } \\
\text { najti put, / toliku pučinu od } \\
\text { mora priko plut. ( } 302)\end{array}$ & $\begin{array}{l}\text { - Osin i Pisnik } \\
\text { - opasnost na daleku putu: Osin sa- } \\
\text { vjetuje Pisnika za povratak u Šibe- } \\
\text { nik potraži pomoć mornara koji } \\
\text { znaju stat i na ovaj pakleni otok } \\
\text { Bulkan }\end{array}$ \\
\hline Primjer 66. & $\begin{array}{l}\text { Grozi me ježen sarh, trepećuć } \\
\text { kako prut / ostavih gore varh, a } \\
\text { k moru vazeh put. (305) }\end{array}$ & $\begin{array}{l}\text { - Pisnik } \\
\text { - kretanje prema naprijed: na otoku } \\
\text { Bulkanu granulo je sunce, Osin je } \\
\text { nestao, Pisnik je gladan, ali na oto- } \\
\text { ku ništa ne nalazi, odlazi na obalu } \\
\text { ne bi li ugledao kakav brod, tj. spas }\end{array}$ \\
\hline Primjer 67. & $\begin{array}{l}\text { Uzvapih: „Bratjo ma, slišite ča } \\
\text { ću rit, / tako vam svim doma na } \\
\text { zdravju s puta prit.“ (307) }\end{array}$ & $\begin{array}{l}\text { - Pisnik i mornari } \\
\text { - željeti dobru sreću na putu: nako } \\
\text { što je Osin nestao, Pisnik luta Bul- } \\
\text { kanom, umoran i nesretan, u potrazi } \\
\text { za hranom i nekim brodom, koji se } \\
\text { napokon ukaže }\end{array}$ \\
\hline Primjer 68. & $\begin{array}{l}\text { prodaje, kupuje, targ za targ } \\
\text { promini, / kad pravo putuje, } \\
\text { lasno ga ucini, (309) }\end{array}$ & $\begin{array}{l}\text { - Pisnik i mornari } \\
\text { - ispravnost putovanja: Pisnik go- } \\
\text { vori mornarima o sebi, da je on Ju- } \\
\text { raj Baraković, da je odgojen u Zad- } \\
\text { ru, da sada voli Šibenik i da je tamo } \\
\text { razvijena trgovina }\end{array}$ \\
\hline Primjer 69. & $\begin{array}{l}\text { Ne krati zaboga, učini, svi di- } \\
\text { mo, / da puta ovoga Šibenika } \\
\text { vidimo. (310) }\end{array}$ & $\begin{array}{l}\text { - mornari i Pisnik } \\
\text { - cilj putovanja: mornari žele vidjeti } \\
\text { Šibenik, koji je Juraj nahvalio, a bu- } \\
\text { dući su mornari strani trgovci, Juraj } \\
\text { im je navigator }\end{array}$ \\
\hline Primjer 70. & $\begin{array}{l}\text { zvizdu mi starzite, putujte sve } \\
\text { po njoj (310) }\end{array}$ & $\begin{array}{l}\text { - Juraj i mornari } \\
\text { - orijentiri na putu: Juraj je nevješt } \\
\text { navigaciji, pa govori mornarima da } \\
\text { se orijentiraju prema zvijezdama }\end{array}$ \\
\hline Primjer 71. & $\begin{array}{l}\text { Uhitih za timun daržeći grada } \\
\text { put, / veselja svega pun stavih } \\
\text { brod krajem plut, (311) }\end{array}$ & $\begin{array}{l}\text { - Pisnik } \\
\text { - završna točka puta (grad): Pisnik } \\
\text { je sretno nakon oluje doplovio uz } \\
\text { pomoć moranara na kopno }\end{array}$ \\
\hline Primjer 72. & $\begin{array}{l}\text { Putovah u pet dan na jidra } \\
\text { leteći / ča parvo u jedan učinih } \\
\text { ne mneći }(311)\end{array}$ & $\begin{array}{l}\text { - Pisnik } \\
\text { - putovanje kao trajanje: Pisnik je } \\
\text { sretan što je ponovo na kopnu i kaže } \\
\text { da je putovao pet dana u povratku }\end{array}$ \\
\hline Primjer 73. & $\begin{array}{l}\text { jidarce razapam, u svoj put } \\
\text { idoše (314) }\end{array}$ & $\begin{array}{l}\text { - Pisnik } \\
\text { - biti na pravom putu: nakon što je } \\
\text { osam dana slavio s mornarima sre- } \\
\text { tan povratak s Bulkana, mornari od- } \\
\text { laze, ne čekajući da Pisnik pročita } \\
\text { knjigu (pismo) koju mu je dao Osin }\end{array}$ \\
\hline $\begin{array}{l}\text { Petje } \\
\text { trinadeseto }\end{array}$ & $\begin{array}{l}\text { zbi vlaški narodi, ki na zlo us- } \\
\text { kaču / ter putnici brodi ukre- } \\
\text { dom naskaču. ( } 321 \text { ) }\end{array}$ & $\begin{array}{l}\text { - Pisnik } \\
\text { - strah na putu (Turci): nakon što je } \\
\text { Pisnik pročitao pismo i doznao da }\end{array}$ \\
\hline
\end{tabular}


Konotacije puta u Vili Slovinki

\begin{tabular}{|l|l|l|}
\hline Primjer 74. & & $\begin{array}{l}\text { je Strižoević hrabri šibenski junak u } \\
\text { borbi protiv Turaka, kroz prozor } \\
\text { dopire plač, jer sahranjuju tog istog } \\
\text { Strižoevića }\end{array}$ \\
\hline Primjer 75. & $\begin{array}{l}\text { da noge putuju stvorene za } \\
\text { hodit (324) }\end{array}$ & $\begin{array}{l}\text { - Pisnik } \\
- \text { gnomični argument za vlastiti } \\
\text { stav: Pisnik je izišao iz sobe, jer je } \\
\text { čuo veliki plač zbog sprovoda Frane } \\
\text { Strižoevića, ali na kraju ostaje nada } \\
\text { da će očevo junašto nastavit sin } \\
\text { Strižoević Viculin (jer junak porađa } \\
\text { junaka), što Pisnik argumentira pri- } \\
\text { mjerima iz prirode i svakodnevnog } \\
\text { života, među kojima svoje mjesto } \\
\text { ima i leksem put - normalno je da i } \\
\text { Viculin bude junak kao što mu je } \\
\text { bio i otac Frane, isto kao što je } \\
\text { normalno da i noge hodajući putuju. }\end{array}$ \\
\hline
\end{tabular}

\section{Zlata ŠUNDALIĆ}

\section{VARIOUS CONNOTATIONS OF THE WORD WAY IN VILA SLOVINKA}

The paper deals with the poem Vila Slovinka (1614), written by the poet from Zadar, Juraj Baraković (1548-1628). The poem was written in honor of the town Zadar, where he had confronted various problems. The author researches different meanings of the word way (journey, escape, return) within the context of the story about the poet, fair, and other characters as well as meaning of the essential and peripheral meanings of the term and their relationship with the poetics of literature at the very beginning of the $17^{\text {th }}$ century.

Key words: Vila Slovinka, way, character, story, composition, manirism 

LINGUA MONTENEGRINA, god. III, br. 5, Cetinje, 2010.

Institut za crnogorski jezik i jezikoslovlje „Vojislav P. Nikčević“

UDK 93/94(497.5)

Izvorni naučni rad

\section{Marko DRAGIĆ (Split) \& Ivana ODŽA (Split)}

Filozofski fakultet Sveučilišta u Splitu

\section{KLIŠKI KAPETAN PETAR KRUŽIĆ I NJEGOVA SUPRUGA JEROLIMA U KNJIŽEVNOSTI, POVIJESTI I SUVREMENOM NARODNOME PRIPOVIJEDANJU}

Rad počinje povijesnim kontekstom i uzrocima postanka uskoka i hajduka. Potom je riječ o ženi u srednjem i ranom novom vijeku s posebnim obzirom na žene uskokā, poglavito o Jerolimi Kružić, ženi Petra Kružića o kojoj nema preciznijih povijesnih podataka. Tema se obrađuje temeljem dostupnih povijesnih podataka, žive tradicije i romana Presječeni puti Viktora Cara Emina. Koautori, tako, (re)konstruiraju lik Jerolime Kružić rekognoscirajući njezinu ličnost - od podrijetla, preko fizičkog izgleda do životnih nazora žene jednog od najglasovitijih uskočkih vođa.

Jerolima je vrlo vjerojatno bila bliska svjetonazoru svoga muža, a pri tome se osobito misli na bogoljublje i domoljublje, čime se uklapala u opću sliku žene toga vremena. Romansirana verzija Viktora Cara Emina obilno se koristi povijesnom istinom, ali daje naslutiti i oprečnu sliku otkrivajući psihologiju osobe koja se i nije uvijek lako nosila s ulogom žene ratnika.

U članku su poglavlja o Petru Kružiću, njegovim herojskim bitkama protiv turskih osvajača i junačkoj pogibiji 12. ožujka 1537. godine. Turski su vojnici istoga dana pokorili Klis. U radu su i poglavlja u kojima se govori o Franu, sinu Jerolime i Petra Kružića. Neustrašivost, herojstvo, bogoljublje i domoljublje Petra Kružića i danas je prisutno u narodnome pripovijedanju. Bogoljublje i domoljublje resili su i njegovu suprugu Jerolimu, koja ga je svekoliko pomagala i podržavala u borbi protiv tuđinske vlasti.

Ključne riječi: bogoljublje, domoljublje, Jerolima Kružić, Petar Kružić, uskoci, povijest, književnost 
Marko DRAGIĆ \& Ivana ODŽA

\section{Uvod}

Jerolimu Kružić, suprugu slavnoga uskočkog junaka Petra Kružića, povijesni izvori poznaju tek na razini informacije. Nešto je više podataka o Petru Kružiću pa će oni biti polazište u rekonstrukciji života njegove supruge. Podatci o njemu odnose se, uglavnom, na dužnosti kapetana i kneza kliškoga, te na vojne akcije koje je sukladno s tim dužnostima obavljao. Malo je podataka o njegovom privatnom životu. Uz sestre Katarinu i Jelenu, od kojih je Jelena povijesti poznata kao ona koja je od Murat-bega otkupila Petrovu mrtvu glavu, usputno se spominju sin Franjo (Fran) i žena Jerolima.

Život Jerolime i Petra Kružića nadahnuli su Viktora Cara Emina, ${ }^{1}$ koji ih je temeljem povijesnih činjenica literarizirao u romanu Presječeni puti. Bogoljublje, domoljublje i herojstvo Petra Kružića do naših dana sačuvani su u narodnome pamćenju.

\section{Povijesni kontekst}

U 9. i 10. stoljeću bili su mnogobrojni sukobi Mlečana s hrvatskim vladarima. Nakon neuspješnih mletačkih prodora 839., 840., 865. i pogibije dužda Petra Candiana I. kod Makarske 887. godine, Mlečani su plaćali Hrvatima danak kako bi slobodno plovili Jadranskim morem. Od 991. do 1009. godine Mlečani su zauzeli Zadar, Trogir, Split, Dubrovnik, Osor, Krk, Rab, Korčulu i Lastovo. Tada su se mletački duždevi titulirali i kao dux Dalmatiae.

Hrvatska je 1102. godine stupila u državnu zajednicu s Ugarskom. Od tada do XV. st. bili su neprestani sukobi Mlečana i hrvatsko-ugarskih vladara. U drugoj polovici XIII. st. mletačku vlast priznaju: Poreč, Umag, Novigrad, Sveti Lovreć, Motovun i Rovinj. U XV. st. Mlečani su ovladali teritorijem od Istre do Albanije osim Dubrovačke Republike. U to je vrijeme Mletačka Republika brojila 200.000 stanovnika, a vladali su nad 2.500 .000 žitelja.

Turci su, koncem svibnja 1463. godine, prijevarom pokorili nekoć moćno Bosansko kraljevstvo. Nakon pada Bosanskoga kraljevstva Turci često upadaju u hrvatske zemlje te Kranjsku, Korušku i Štajersku razarajući ih i odvodeći mladiće i djevojke u sužanjstvo. Godine 1474. opustošili su Turopolje i okolicu Križevaca a u ropstvo je odvedeno 14.000 stanovnika. ${ }^{2}$ Posljednji slobodan hercegovački teritorij (Herceg) Novi pokorili su 15. prosin-

${ }^{1}$ Viktor CAR EMIN (Kraj kod Lovrana, 1870. - Opatija, 1963.). Bio je učitelj. Uređivao je: Mladog Istranina i Mladog Hrvata. Bio je pročelnikom Narodnog vijeća za Rijeku i Sušak. Od 1951. godine bio je članom Jugoslavenske akademije znanosti i umjetnosti. Uz navedeno, značajna su mu djela: Na uzburkanom moru (1894.), Pusto ognjište (1900.), Zimsko sunce (1903.), Vitez mora (1939.), Na straži (1946.), Udesni dani (1951.), Oj more duboko (1952.), Starci (1917.).

2 Anđelko MIJATOVIĆ, Iz riznice hrvatske povijesti $i$ kulture, Školska knjiga, Zagreb, 1996., 132. 
Kliški kapetan Petar Kružić i njegova supruga Jerolima u književnosti...

ca 1481. godine. (Mnogi povjesničari tu okupaciju datiraju u 1482. godinu.) Hrvatski ban Matija Gereb kod Zrinskog Broda na Uni 1483. godine porazio je tursku vojsku koja se s 10.000 zarobljenika vraćala iz Kranjske i Koruške. ${ }^{3}$

Veliko je hrvatsko stratište na Krbavskom polju pokraj Udbine. Hrvatske snage, predvođene jajačkim banom Emerikom Derenčinom, 9. rujna 1493. godine, nespremno i strateški nesložno, sukobile su se s turskim snagama koje je predvodio Sandžak-beg Hadum Jakub-paša. Derenčin je uoči bitke zagovarao da se Turci dočekaju na polju, a Ivan Cetinski je predlagao da se presretnu na šumskim klancima. Do okršaja je došlo na otvorenom polju. Izginuo je „Cvijet hrvatskoga plemstva“ (Ivan Cetinski, Juraj Vlatković i dr.). Bernardin Frankopan se spasio. Zarobljeni su Karlo Gusić i ban Derenčin koji je usužnjen u Carigradu i nakon tri mjeseca sužanjstva od žalosti umro.

Prema Juraju Rattkayu na Krbavskom je polju izginulo 5.077 Hrvata, a prema drugim povjesničarima, primjerice Anđelku Mijatoviću, izginulo je 13.000 Hrvata. U Mletačko-turskom ratu od 1499.-1503. godine Turci su pustošili splitsko, šibensko i zadarsko područje, a 1500. godine osvojili su Makarsku i luku Busoljinu kraj Trogira. Sljedeće (1501.) godine Turci su osvojili trogirsko i šibensko područje. Čačvinu i Nutijak u Cetinskoj krajini Turci su osvojili 1513. g. Osam godina kasnije (1521.) osvojen je Beograd. Tako je osvajačima otvoren put prema Srijemu, Slavoniji i Ugarskoj.

Turska vojska sa 25.000 vojnika i mnogo topova, koncem svibnja 1522. g. osvanula je pod Kninom. Nije poznato što je nagnalo hrvatskoga plemića i zapovjednika obrane Knina Mihajla Vojkovića da grad uoči Spasova (28. svibnja) preda Turcima. Predaja Knina snažno je odjeknula, te su branitelji Skradina (10. lipnja) pobjegli iz grada nastanivši se u Šibeniku i po otocima. Tako su na jugu Hrvatske ostali slobodni jedino Klis i Ostrovica. U prosincu 1523. godine turska četa je osvanula pod Ostrovicom. Prema mletačkim izvorima neki izdajica Damjan predao je grad Turcima. ${ }^{4}$

Godine 1526. sa dvjesto tisuća vojnika i tri stotine topova osvojili su Srijem i Osijek. Hrvatsko-ugarski kralj Ludovik II. je 29. kolovoza te (1526.) godine na Mohačkom polju s oko 30.000 započeo bitku s Turcima ne čekajući glavninu hrvatske vojske koju je predvodio Krsto Frankopan. Kralj nije čekao ni Erdeljsku vojsku pod zapovjedništvom Ivana Zapolje. U okršaju je poginulo 22.000 vojnika. Kralj se utopio u potoku Čeleju. ${ }^{5}$

Jajce i Banja Luka osvojeni su 1528. g. Sulejman II. Veličanstveni je 29. rujna 1529. g. s oko 100.000 vojnika i 300 topova opkolio Beč.

\footnotetext{
${ }^{3}$ Anđelko MIJATOVIĆ, op. cit., 137.

${ }^{4}$ Vjekoslav KLAIĆ, Povijest Hrvata (knjiga četvrta), MH, Zagreb, 1974., 382.-389.

${ }^{5}$ Anđelko MIJATOVIĆ, op. cit., 167.
} 
Marko DRAGIĆ \& Ivana ODŽA

\section{Uzroci postanka uskoka i hajduka}

Nakon pada Bosanskoga kraljevstva nastupilo je 415 iznimno surovih godina turske vlasti. U prvim je godinama od zuluma turskoga u Hrvatsku i druge zapadnoeuropske zemlje izbjeglo oko 400.000 kršćana. U Bosni i Hercegovini uništena su 444 sakralna katolička objekta, ${ }^{6}$ vršeno je nasilno islamiziranje. Kršćani su bili u stalnoj opasnosti, izloženi progonima, stradanjima i pogibeljima. Gnjusno je bilo tzv. Pravo prve bračne noći po kojem je kršćanka morala prvu bračnu noć provesti s begom, agom ili pašom. ${ }^{7}$ Iznimno je težak bio i Danak u krvi - odvođenje kršćanskih djevojaka u hareme a mladića u janjičare.

Splitski nadbiskup Bernardo Zane 1512. g. zapisao je da je svojim očima gledao kako Turci otimaju djecu s majčinih grudi; siluju žene pred njihovim muževima; starce i starice, kao nepotreban plijen, ubijaju pred djecom i unučadima. $^{8}$

Jedini otpor turskim okupatorima pružali su uskoci i hajduci. Uskoci su bili kršćani koji su iz Bosne i Hercegovine pobjegli od turskoga terora, nastanivši se ponajviše u: Senju, Krku, Omišu, Poljicima, Klisu, Solinu, te Kninu, Ostrovici, Sinju, Skradinu koji su pripadali Hrvatima. Međutim, i u tim krajevima neprestano im je prijetila turska opasnost zahtijevajući stalnu pripravnost. Stoga su uskoci razvili snažan osjećaj osvete nad Turcima, ,stvorili su među sobom neku vrstu saveza za obranu i navalu proti zajedničkom neprijatelju Turčinu. A kao ratna stranka, Uskoci si smatrahu dopuštenim navaliti na neprijatelja iz zasjede, zateći ga nepripravnim, oteti mu imatek, i napokon ga ubiti: to je sve spadalo u ratno pravo". ${ }^{9}$ Na sličan način odnosili su se prema ubijenom prijatelju - međusobna solidarnost te pravo na osvetu prijatelja bili su pitanje časti, a, uz vjeru, čast je temeljna kategorija u vrijednosnom sustavu uskoka. U kontekstu časti, Kerubin Šegvić spominje ženu uskoka - vjerojatno iz usmene predaje stranaca koji su boravili na području Senja: „Sami tuđinci izriču udivljenjem poštenje uskočkih žena. Pišu da u Senju nema za sve zlato ovoga svijeta nepoštene žene. Ako imade koja javna grešnica, ta je

${ }^{6}$ Vidi: Stjepan DUVNJAK, „Sveti Ilija i sveti Juraj - zaštitnici Bosne“, u: Zbornik o Marku Dobretiću, Općina Dobretići, urednik Marko Karamatić, Kulturni povijesni institut Bosne Srebrene Sarajevo, Sarajevo - Dobretići, 2008., 38.-39.

${ }^{7}$ O tomu u svojim djelima između ostalih pišu Pavao Ritter Vitezović, Nikola Lašvanin, Jako Baltić, Bono Benić, Safvet-beg Bašagić, Ivo Andrić, Hamid Dizdar, Husein Đogo, Nedim Filipović, Dominik Mandić, Martin Đurđević, Kasim Gujić, Adem Handžić, Mehmed Handžić, Emile Haumant, Vjekoslav Klaić, Ferdo Šišić, Šukrija Kurtović, Hazim Šabanović, Franjo Šanjek i dr.

${ }^{8}$ Anđelko MIJATOVIĆ, op. cit., 152.-153.

${ }^{9}$ Cherubin ŠEGVIĆ, Junačka djela senjskih uskoka, Tisak i naklada knjižare L. Hartmana, Zagreb (godina izdanja nije navedena), 20. 
Kliški kapetan Petar Kružić i njegova supruga Jerolima u književnosti...

iz vana. Ako bi se slučajno dogodilo, da jedna žena skrene s puta, odmah će je najbliži rod smaknuti kao šugavu ovcu. Nijedna vlast se ne usuđuje takvo ubojstvo kazniti, jer bi se puk pobunio“. ${ }^{10}$ Isti izvor navodi priču o ribaru koji je ubio vlastitu ženu jer je ,zaludila svojom pojavom riječkog plemića“. ${ }^{11}$

Dok Šegvić svojim tvrdnjama objašnjava važnost časti u životu uskoka, Bracewell daje dvostruku mogućnost; bilo je uskoka koji odgovaraju Šegvićevu opisu, dakle, koji su se strogo držali kodeksa časti, a zgode koje nam se iz današnje perspektive čine pretjeranima treba shvatiti u kontekstu njihova moralnog kodeksa, ali gotovo se priklanja drugoj hipotezi prema kojoj su u pozadini uskočkog djelovanja i drugi ciljevi. ${ }^{12}$

U neizvjesnim vremenima uskoci su se snažno utjecali Bogu. Iz toga proizlaze zavjetni darovi crkvama, samostanima, kao i bliski odnosi s vladarima i papama, pa i onda kada su im oni uskraćivali pomoć. I Šegvić i Bracewell u tom se dijelu slažu: vlastito ratovanje uskoci su doživljavali kao rat protiv Turaka s ciljem obrane granica i vlastite vjere.

Na poticaj Mlečana uskakali su u susjedne kršćanske krajeve i borili se protiv Turaka. Hajdučiju i četovanje prvi put 1550. g. spominje putopisac Zeno. Vrhunac djelovanja uskoka i hajduka bio je za vrijeme Kandijskoga rata (1645.-1669.). Uskoci su djelovali u skupinama na poticaj ili sa znanjem vlasti, a hajduci su bili samostalni.

Oprečna su mišljenja i o hajducima. Jedni ih smatraju razbojnicima, a drugi ih mistificiraju i glorificiraju. Do suprotstavljenih mišljenja dolazi jer su postojale četiri kategorije hajduka: Hajduci zulumćari (turski hajduci) činili su strašna zlodjela nad kršćanima. Šeih Gaibija predvodio je ,kupreške turske hajduke“ koji su 4. siječnja 1557. g. u Rami zapalili i opljačkali samostan, a franjevce pobili.

Hajduci osvetnici borili su se protiv turske okupacije. U tim su družinama bili zajedno Hrvati, Crnogorci, Srbi i Muslimani. Od 17. st. snažni su bili muslimanski hajduci osvetnici. Harambaša Abdurahman je 1639. g. u Ravnom (na putu iz Splita preko Duvna, Rame do Visokog) sa svojim hajducima napao karavanu trgovaca od 400 ljudi i ubio 19 trgovaca. ${ }^{13}$

Postojali su i kršćanski hajduci razbojnici. Takav je, primjerice, bio harambaša Nikola Maleta, koji je zaprosio Anđu Bailovu ${ }^{14}$ iz Livna, a kad ga

${ }^{10}$ Cherubin ŠEGVIĆ, op. cit., 78.

${ }^{11}$ Catherine Wendy BRACEWEL, Senjski uskoci, Barbat, Zagreb, 1997., 64.

${ }^{12}$ Isto, 64.

${ }^{13}$ Namik ČEHIĆ, Prozorski kraj u oslobodilačkom ratu i revoluciji, Prozor, 1985., str. 19. Usp. Miroslav DŽAJA - Krunoslav DRAGANOVIĆ, Sa Kupreške visoravni, II. izdanje, Baško Polje - Zagreb, 1994., 54.-56.

${ }^{14}$ Ibro je, također, silno volio Anđu i maštao da će je poturčiti i dovesti u svoj dvor. Turčinu delibaši javio se Mujo i tješio ga da će na megdanu pogubiti Stipana Naki- 
je ona odbila, on joj je zaprijetio da ne će ni drugoga ljubiti i da će je od svatova oteti. Maleta je sa svojim hajducima poubijao dvije stotine i trideset svatova Stjepana i Anđe. ${ }^{15}$

I danas su usmenoj komunikaciji povijesne predaje i epske pjesme o uskocima: Petru Kružiću, Ivi Senjaninu, ${ }^{16}$ Stojanu Jankoviću, ${ }^{17}$ Nakićima, ${ }^{18}$

ća. Delibaša Stipanu Nakiću pripisuje mitsku snagu i junaštvo i upozorava Muju da je pamet izgubio jer da znade Nakića Stjepana ne bi ima ni u glavi sana. Turčin nadalje Muji besjedi o Stipanu koji je prije šest godina porazio dvanaest tisuća Turaka. Mujo sluša kako Stipan s obadvije ruke siječe Turke a ruka mu je deblja u mišici nego ženska noga pri bedrici.

15 Vidi: Dragić, Marko: Književna i povijesna zbilja, HKD Napredak, Split, 2005., 195.-198; 214.-234.

${ }^{16}$ Ivo Senjanin (Ivan Vlatković), uskočki vojvoda (? - Karlovac, poslije 24. VII. 1612.). Kao kapetan ratovao po Albaniji, Bosni i Hercegovini i Hrvatskoj. Istaknuo se u borbama za Klis i Petrinju u Dugom ratu (1593.-1606.). Optužen za krađu žita i pogubljen. Uzalud je senjski kapetan svjedočio da mu je dao žito za njegove vojnike. Pomilovan je nakon pogubljenja!

${ }^{17} \mathrm{Ne}$ zna se točno kada je rođen glasoviti uskok, pravoslavac, Stojan Janković, koji se istaknuo u Kandijskom ratu. Godine 1666. zarobljen je i odveden u Carigrad, odakle nakon 14 mjeseci bježi. Mletačka ga je vlast odlikovala naslovom „kavaliera“ i dodijelila mu u feud imanje u Ravnim Kotarima. U Morejskom ratu uspješno je ratovao u Lici. Godine 1685. protjerao je Turke iz Gračaca, oslobodio Kotare od Turaka (1688.), prodro u Liku do Ribnika i osvojio kulu u Lapcu. Pomažući carsku vojsku, oteo je sa Smiljanićem Zvonigrad i Rakovnik. Sudjelovao je i u oslobađanju Sinja (1686. godine). Opjevan je u mnogim narodnim pjesmama. Pjesmom Ženidba Janković Stojana koristio se francuski pjesnik Lamartine u svojemu spjevu La Chute d' un Ange. Predaja o tome uskoku govori kako ,je poslao nekog Grgu Antunića s vojskom na Gabelu, da je spali i da onda dođe k Mostaru gdje će se ujediniti. Spalivši Antunić Gabelu, krenuo je prema Mostaru, ali ga na putu dočekaše katolici Blaževići i Arapovići, te mu vojsku razbiše tako da se morao vratiti. (...).“

${ }^{18}$ Knez Ivica Vojnić (Nakić) bio je 1551. godine gospodar Vojnića, Rompovića, Buovića, Ovina i drugih sela. Po majci se prozvao Nakić. Imao je pet sinova: Grgura, rođenoga 1590; Mitra, rođenoga 1602; Tomu, koji se rodi 1603; Pavla, koji bi rođen 1605; i Matiju, koji dođe na ovaj svijet 1607. godine. Knez Mitar je, također, imao četiri sina: Matiju, rođenoga 1628; Stipana, koji bi rođen 1629; Martina, koji se rodi 1630. i Ivana, 1633. g. rođenoga. Knez serdar Matija imade šest sinova: fra Antuna, rođenoga 1660. i „bi veliki naučitelj, jubilat i teolog Gonzage“; Antuna, koji se rodi 1652.; Pavla, rođenoga 1665.; Grgura, ,kkolunea, sopraintendanta i kavalira s. Marka“, koji bijaše rođen 1680; Nikolu, serdara i kolunea Krajine, rođenoga 1687., i Iliju, alfira 1689. g. rođenoga. Grgur je imao četiri sina: fra Antuna, rođenoga 1701.; Matiju koji se rodi 1708. i bi kapetan i serdar; Stipana, rođenoga 1710, koji je, također, bio kapetan i serdar; Ivana, koji se rodi 1715. i bi alfir. Knez Nikola je imao pet sinova: Pavla, rođenoga 1750.; Matiju, koji se rodi 1722. i „,bi kapetan tenente od pišaca i mađor od pijace kninske“; Grgura, rođenoga 1724, koji je bio alfir od konjika; Miju, koji se rodi 1728. i Stipana, koji se rodi 1733. i bi kadet od kavalerije (Andrija Kačić Miošić Razgovor ugodni naroda slovinskoga, Ma- 
Kliški kapetan Petar Kružić i njegova supruga Jerolima u književnosti...

Vučkovićima, ${ }^{19}$ te o hajducima Mijatu Tomiću, Muji Hrnjici, Roši harambaši (Ivanu Bušiću), Andrijici Šimiću i drugima. Povijesni događaji i tradicijska kultura u naše se vrijeme iskrivljuju i politiziraju. U tomu kontekstu se interpretiraju i uskoci i hajduci. Pri tome se zaboravljaju činjenice kao što su zajedničko sudjelovanje svih naroda u borbi protiv Turaka, kao i protiv Mlečana, Francuza, Austro-Ugarske i drugih zavojevača. Mijat Tomić je, primjerice, imao utočište kod majke begova Kopčića i nazivao ju je svojom pomajkom. Mijat Tomić je u živoj tradiciji i kod Crnogoraca. Stojan Janković, pravoslavac iz Ravnih Kotara, borio se, ponajviše, za slobodu katolika. U pohodu za oslobađanje ramskoga naroda poginuo je 23. kolovoza 1687. godine na Duvanjskom polju. ${ }^{20}$ Pjesma o pogibiji Stojana Jankovića obuhvaća 285 stihova. ${ }^{21}$

\section{Supruge uskoka}

U ranom srednjem vijeku žene su bile u prilično povoljnom položaju po pitanju nasljeđivanja, sudjelovanja u društvenom životu pa čak i biranja identiteta - identifikacija prezimenom nije postojala, ali je žena imala pravo odabira vlastite identifikacije po bilateralnoj liniji podrijetla, dakle, mogla je odabrati hoće li se identificirati po majci ili po ocu. ${ }^{22}$

U kasnom srednjem vijeku situacija je slična iako ,je od 11. stoljeća kognatski model obitelji organiziran na bilateralnim vezama (...) postupno

tija Antun Reljković Satir iliti divji čovik (priredio Josip Vončina) Zagreb, 1988., str. 521.-522.). Knez Matija Nakić ne htjede podnositi turski zulum te s braćom iz blizu dvije tisuće kuća napusti pradjedovsko ognjište i nastani se u Drnišu i Petrovu polju.

${ }^{19}$ Vučkovići su potomci duvanjske obitelji Nemanović. Spominju se 1506. g. Andrija Kačić Miošić u Razgovoru ugodnomu navodi da su Nakići pod mletačko okrilje, s mnogim kršćanima doveli ,,pridostojnu kuću Vučkovića, iz koje izađoše vrsni na oružju vitezovi“. Petar Bakula piše da Vučkovići nisu mogli podnositi turski zulum te su pribjegli u mjesta pod vlašću Mletačke republike, gdje su postali prvi mletački četovođe, pa su poput pravih vukova junački tukli Turke u više od petnaest okršaja. Potomak Vučkovića je i legendarni fra Pavao Vučković (1658.-1735.), koji je organizirao bijeg Ramljaka i Duvnjaka u Cetinsku krajinu i Dalmaciju 1687. g. kako bi ih spasio od turske odmazde nakon poraza pod Bečom 1684. g. Fra Pavao Vučković bio je jedan od zapovjednika obrane Sinja 1715. g. kada su malobrojni branitelji, uz čudotvornu pomoć Gospe Sinjske, obranili Sinj od mnogobrojnih turskih vojnika. U čast na tu pobjedu od tada se trči Sinjska alka. O fra Pavlu Vučkoviću piše Ivan Aralica u romanu Put bez sna. O Vučkovićima je i sada živa tradicija.

${ }^{20}$ Pogibiju Stojana Jankovića opisao je Ivan Aralica u romanu Put bez sna.

${ }^{21}$ Vidi: Marijan ŠUNJIĆ, Junačke pjesme iz Bosne, II. izd., Sarajevo, 1925., 69.-73.

${ }^{22}$ Andrea FELDMAN, Žene u Hrvatskoj: ženska $i$ kulturna povijest, Ženska infoteka, Zagreb, 2004., 37. 
zamjenjivan agnatskim modelom koji se usredotočuje na očinsku liniju porijekla“. 23

Kasnosrednjovjekovna situacija mogla bi biti relevantna za Jerolimu Kružić iako svojim životom ona zalazi u razdoblje humanizma i renesanse kada se i odnos prema ženi mijenjao. No, uzme li se u obzir postupnost povijesnih mijena, slika žene iz kasnog srednjeg vijeka može biti korisna.

U kasnom srednjem vijeku nastavlja se aktivna uloga žene u poslovnom svijetu. Formiranje građanskog sloja omogućuje ženama sudjelovanje u obiteljskim obrtima; žena u poslu sudjeluje paralelno sa svojim supružnikom i ima puno pravo nasljeđivanja obrta nakon njegove smrti. Ravnopravna je i u imovinsko-pravnim odnosima. Zabilježeni su dokazi o pravu osobnog vlasništva jednog od supružnika, a zajedničko vlasništvo moguće je prodati ili založiti isključivo uz obostran pristanak.

Prilično visok stupanj ženske neovisnosti omogućio je ženama da budu jamci za dugove svojih muževa. Postoje nesuglasice oko prava nasljeđivanja pa dio znanstvenika podržava tezu da nakon smrti jednog od supružnika svu imovinu nasljeđuje živi supružnik, dok drugi drže da se imovina preminulog supružnika vraća u obitelj iz koje je potekla ako u braku nije bilo djece i ako se preminuli supružnik testamentom nije očitovao u korist preživjelog. ${ }^{24}$

U srednjovjekovlju i ranom novovjekovlju, načelno, preljub se jednako tretirao i za žene i za muškarce. Postoje dokumenti u kojima se spominje kažnjavanje preljubnice oduzimanjem imovine u korist muža, čak i gubitkom prava oporučnog iskaza. ${ }^{25}$ Primjer kažnjavanja uskočkih žena preljubnica ubojstvom, svjedoči o posve neliberalnom shvaćanju preljuba koji je u skladu s takvim shvaćanjem bio i sankcioniran. ${ }^{26}$

Nakon opće slike žene kasnog srednjeg vijeka, C. W. Bracewell se svojim člankom u zborniku A. Feldman bavi ženama senjskih uskoka. Ona se oslanja uglavnom na mletačke izvore (Minuccio, Sarpi, Barbaro) smatrajući ih, u odnosu na habsburške iscrpnijima u obradi života uskoka. Odnos prema uskočkim ženama odgovara stavu autorā čijim se izvorima služila, a taj je uglavnom negativan, pa je upitna njegova vjerodostojnost. U uskocima vide pohlepne grabežljivce koji rade isključivo za svoju korist, a takve su im

${ }^{23}$ Andrea FELDMAN, op. cit., 35.

${ }^{24}$ Isto, 67.

${ }^{25}$ Isto, 72.

${ }^{26}$ Spomenute pogodnosti za žene odnose se na žene u gradskim naseljima međurječja Save i Drave, pa nikako ne smiju biti shvaćene kao unificirano pravilo za cjelokupni hrvatski prostor. Navedeni primjeri uzimaju se kao postulat za promatranje Jerolimina položaja jer je pripadala plemstvu, pa bi se prava mogla nje ticati, a osim toga, Petar je držao posjede u neposrednoj blizini spomenutog područja pa je vrlo vjerojatno da spomenuta prava žene Jerolimi nisu bila nepoznata. 
Kliški kapetan Petar Kružić i njegova supruga Jerolima u književnosti...

i žene - one ih čak potiču na takve pothvate kako bi uživale dio plijena: „Te se žene nikad nisu latile vretena, preslice ni bilo kojeg drugog posla, umjesto toga posvetiše se huškanju svojih muževa groznim riječima u pljačku, živeći u iščekivanju plijena..." 27

$\mathrm{Na}$ temelju takvih navoda nastaju i pretpostavke o fizičkom izgledu uskočke žene - jedni je oslikavaju kao muškobanjastu ratnicu, drugi je drže ženstvenijom oslanjajući se na ulogu koju je uskočka žena imala u vjerskim ceremonijama i njen izgled u tim prilikama.

Iako se isticao vjerski karakter srednjovjekovne žene uopće, uz specifičan odnos uskoka prema vjeri, autori neskloni uskocima, u pokušaju da opravdaju Mlečane, odnosno njihove vojne gubitke, a umanje ratničke vještine uskoka, znali su opisivati uskočke žene kao osobe sklone poganskim ritualima, vradžbinama i čaranju, zahvaljujući kojima su uskoci pobjeđivali.

Isti autori smatraju da je dio uskočkih brakova nastao otmicom djevojke i iznuđivanjem pristanka na udaju od njezine obitelji, te da je u pozadini takvog čina bila nakana uskoka da dobiju veću podršku iz naroda s čijim su članovima nakon ženidbe bili u rodbinskoj vezi, pa se očekivalo da rodbina bude njihova podrška.

S druge strane postojali su legitimni brakovi u kojima su žene bile izrazito vjerne, a najvjerojatnije je takav bio brak Petra i Jerolime, jer Jerolima nije bila seoska djevojka čiji je pristanak trebalo izboriti otmicom. Te žene nerijetko su posredovale za zatočene muževe plaćajući mito za njihov otkup. Bit će riječi o Jeroliminom posredništvu u pregovorima s papom, a valja ovdje spomenuti i Petrovu sestru Jelenu, koja nakon smrti obnaša ulogu posrednika pri otkupu Petrove odsječene glave. Vjerojatno bi tu dužnost imala Jerolima da je bila živa.

Spomenuti izvori ni u ovakvoj koncepciji uskočke žene ne vide ništa pozitivno, naprotiv, podržavati odmetnike i razbojnike smatraju još gnjusnijim činom.

Giovanni Fermo brani uskoke i njihove žene potvrđujući pojedine stavove prethodno spomenutih izvora (primjerice, stavku o netipičnoj ulozi uskočkih žena, o njihovom sudjelovanju u ratnim akcijama). Međutim, ne tumači ih na istovjetan način, pa kaže da nije riječ o izvrtanju spolnih uloga što se protivi Božjem zakonu, kako su to tvrdili protivnici uskoka, već o nuždi muževi uskočkih žena često su bili odsutni pa su bile prisiljene na samostalnu obranu.

Uzimajući u obzir takva razilaženja u mišljenjima, s jedne strane „pobožna žena“", s druge „naoružana muškarača“" ${ }^{28}$ zaključuje se da su žene

\footnotetext{
${ }^{27}$ Andrea FELDMAN, op. cit., 127.

${ }^{28}$ Isto, 139.
} 
Marko DRAGIĆ \& Ivana ODŽA

uskoka iz objektivnih razloga (odsutnost muževa, samostalno čuvanje i obrana doma) morale biti hrabre i posjedovati svojevrsni ratnički gard. Ako se i prihvati teza da su fizičkom građom nalikovale muškarcima, to nužno ne isključuje njihovu ženstvenost koju su mogle pokazati u drugim prilikama, primjerice, za crkvenih obreda.

Pomirdbu oprečnih stavova traži i autorica smatrajući najprikladnijim osloncem dokumente mletačkih činovnika koji su, budući je opasnost od uskoka bila sveprisutna, pomno bilježili pojedinosti vezane za njihov život. Njihovi dokumenti tvrde da je iza spomenutih otmica djevojaka mnogo složenija situacija - često je uskok već prije bio u kontaktu s djevojkom koju je oteo, nerijetko su bili zaljubljeni, a otmica je tek predstava izvedena s ciljem da se obitelj djevojke ne nađe u nezgodnoj situaciji tj. da se ne bi morala opravdavati mletačkoj vlasti, što bi se nužno dogodilo kada bi se znalo da je dobrovoljno pristala udati djevojku za uskoka.

Na sličan način ova dokumentacija obračunava se i s prethodnim tvrdnjama o gramzivosti uskočkih žena navodeći da su žene uskoka doista imale pravo na dio plijena, ali su ga ulagale u uskočke ekspedicije i pridruživale se sindikatima privatnih ulagača koji su uskocima davali proviziju očekujući za uzvrat udio od plijena. Značajan dio plijena činili su zarobljenici, a briga oko njihova otkupa, u zamjenu za muževe i sinove, ili kao izvor prihoda, bila je jedan od važnijih financijskih zadaća žena uskokā. Uloga uskočkih žena, dakle, svodila se na posredovanje, preuzimanje otkupnine, čuvanje i trgovinu zarobljenicima, te skupljanje informacija, što svjedoči o njihovoj mobilnosti.

Međutim, podatci su toliko skromni da smo u konačnici najbliži zaključku Anne Marie Gruenfelder, koja je proučavajući žene uskoka navela: „(...) žena uglavnom bila nepostojeća i nevidljiva osim iznimnih predstavnica ženskog spola koje su uspjele pobuditi zanimanje suvremenika i zato ostavile tragove u povijesti“. 29

Spomenute žene uskoka i njihovi pothvati datiraju na kraj 16. st., nakon Jerolimine smrti pa nema tragova o njenom sudjelovanju, ali predstavljena situacija ne baca nikakve sumnje na takvu mogućnost, osobito ako se uzmu u obzir naznake koje postoje o njenom sudjelovanju u Petrovoj korespondenciji s uglednicima od kojih je tražio pomoć.

\section{Jerolima Kružić, supruga Petra Kružića}

Perojević Jerolimu spominje u dva navrata - govoreći o njenom podrijetlu od roda Vragovića, plemića od Maruševca. Smatra se da je ime Vragović obitelj dobila po Ulriku Erdöeghu od Marjaševca, koji je živio u 15. st.

${ }^{29}$ Senjski zbornik, god. 28, 2001., Gradski muzej Senj, 2001., 106. 
Kliški kapetan Petar Kružić i njegova supruga Jerolima u književnosti...

(mađ. erdo $=$ šuma, ordo $=$ vrag).$^{30}$ Od 14. st. obitelj je nasljednica dobara u okolici Maruševca. Grb obitelji (lav u pandžama drži okrenuto drvo jabuke) sačuvan je na pročelju starog župnog dvora crkve Svetog Juraja u Maruševcu. Kao vlasništvo obitelji Vragović spominje se, od 16. stoljeća, i dvorac Maruševec. Danas je dvorac u posjedu austrijske obitelji Pongrac.

Laszowski se u svom članku Povijesni podaci o obitelji Vragovića Maruševačkih bavi nasljeđivanjem posjeda obitelji Vragović te obiteljskim odnosima, ali nigdje nema spomena o Jerolimi Vragović. Zanimljiviji je Perojevićev drugi spomen Jerolime, koji svjedoči o sudjelovanju u korespondenciji s Petrom i u ostvarivanju njegovih interesa:

U kolovozu 1530. Kružić se već nalazi u Klisu i odatle šalje pismo svojoj ženi u Lupoglav, da ga ona pošalje Kacijaneru. Ona ga 28. VIII. i otpremi svom kapelanu Nikoli koji će Kacijaneru služiti za tumača. Jerolima veli u popratnom pismu da Kružić nema odakle da plati tako česte tekliće i preporučuje Kacijaneru svog kapelana za nagradu, te neka ga bez oklijevanja sa željenim odgovorom pošalje natrag, jer se ne može čekati, a neprijatelj ne spava. ${ }^{31}$

To nedvojbeno svjedoči svekoliku Jeroliminu podršku svome mužu Petru. Da je s Jerolimine strane postojala ikakva nesklonost ili ravnodušnost prema Petrovu djelovanju, Petar bi vjerojatno i sam osjećao određenu sumnjičavost te je zasigurno ne bi uključio u politička i društvena zbivanja koja nisu bila jednostavna i bezazlena. Prethodni ulomak svjedoči i o Jeroliminu altruizmu da za svog kapelana izbori status primjeren njegovim zaslugama što se u literaturi često ističe i kao Petrova vrlina, izuzmemo li tumačenja izvora koji su u nekim Petrovim postupcima tražili suprotne karakteristike.

Šanjek ističe i značajnu ulogu žene u vjerskom i obiteljskom životu. Osobito je velik doprinos žene bio na proštenjima, hodočašćima i sličnim vjerskim manifestacijama. ${ }^{32}$ Vrlo je vjerojatno da je Jerolima bila česta sudionica spomenutih zbivanja. Sudjelovanje u političkom i kulturnom životu koji je sam po sebi bio vezan za crkvu također je bio svojstven ženama viših slojeva, kao i obiteljski život i odgoj mnogobrojne djece koja su u bogatijim obiteljima imala i mogućnost školovanja. Kao primjer sudjelovanja u političkom životu Šanjek navodi kraljicu Jelenu, ženu Mihajla Krešimira II., kraljicu Jelenu Lepu, ženu kralja Zvonimira.

${ }^{30}$ Emilije LASZOWSKI, Povijesni podaci o obitelji Vragovića Maruševačkih, Vjesnik hrvatskog arheološkog društva, Nove serije sveska VII., 1903./4., 203.

${ }^{31}$ Marko PEROJEVIĆ, Petar Kružić, kapetan i knez grada Klisa, MH, Zagreb, 1931., 121.

${ }^{32}$ Franjo ŠANJEK, Kršćanstvo na hrvatskom prostoru, Kršćanska sadašnjost, Zagreb, 1991., 176.-190. 
Marko DRAGIĆ \& Ivana ODŽA

Jerolima zasigurno nije bila u rangu kraljevskih žena, ali spomenuta korespondencija s Petrom svjedoči o upućenosti u zbivanja i o potencijalnoj pismenosti. Ukoliko je i bila pismena, je li Jerolima kao plemkinja bila u doticaju s lijepom književnošću, možemo samo nagađati. Činjenica je da su i Petar i sin mu Fran mnogo putovali, bili u doticaju s talijanskim kulturnim središtima, prema Caru Eminu osobito Fran, ${ }^{33}$ pa su vjerojatno mogli informirati i Jerolimu, no s obzirom na teškoće uskočkog života i opću sliku vremena, upitno je jesu li u tome uspijevali.

Ako i nije bila u doticaju s književnosti, moda odijevanja toga vremena zasigurno joj je bila poznata i dostupna jer se, po uzoru na talijansku, proširila Senjom. Za razliku od muške nošnje senjskih uskoka koja je donekle rekonstruirana, o odijevanju senjskih žena nema mnogo sačuvanih podataka, ali su zato sačuvani pabirci maksimalno iskorišteni za rekonstrukciju mode toga vremena.

Kao polazište poslužila su dva sačuvana kamena spomenika sa ženskim likovima - nadgrobna ploča kneginje Ižote Frankopanke iz 1456. te nadgrobna ploča Senjanke Dominike Betričić iz 1509. Odjeću je sačinjavala haljina koja seže od ramena do stopala. Temeljni dio čini okrugla, bogato nabrana suknja (sarza, modrina), skupljena u struku i našivena na opleće, čiji nabori padaju tako da se može zaključiti da je načinjena od fino otkane vunene tkanine. Struk haljine je položen visoko, neposredno pod grudima, što se smatra konzervativnim modnim detaljem koji je u renesansi zamijenjen slobodnijim formama. Pod haljinom je na samo tijelo, bez potkošulje obučena košulja od lanenog platna, tipa tunike, širih rukava s vezom na prsima i oko vratnog izreza koja također seže do nogu. Vez je isprva neznatni ukras, ali s vremenom poprima bogatu razvedenost čipke. Otvoreno opleće na prsima obrubljuju ukrasne trake, tzv. pasamani. Na sastavu suknje i opleća stavljao se pojas. Haljina na opleću može imati rukave, što je slučaj na kamenom reljefu pokojnice Dominke iako su češći oblici bez rukava tako da se ističe bjelina rukava košulje. Taj rukav, ukoliko postoji, u visokom srednjem vijeku i renesansi imao je dekorativnu funkciju, dok je kod nas imao praktičnu ulogu - oblačio se kao zaštita od hladnoće, a kada se ne bi koristio vezao se straga, pod pojasom. Neizostavni dio je pregača, uvijek otkana od vune sa šarama ili prugama različite boje. Drugo je zaslon ili pretpasnik od lagane tkanine koji se koristio pri radu, a prisutan je u pučkih i urbanih djevojaka, dok u visokom društvu za njim nema ni potrebe. Na haljini Dominke Betričić nema traga pretpasniku. Opisana odjeća je skromna, ali s patricijskom crtom domaće

${ }^{33}$ V. Car Emin Kružićeva sina opisuje kao sanjara i potpunu očevu suprotnost što je (u romanu) rezultiralo rezerviranošću oca prema sinu. Frana su, više od vojnih pothvata, zanimale žene i putovanja, što Petar nikada u potpunosti nije prihvatio. 
Kliški kapetan Petar Kružić i njegova supruga Jerolima u književnosti...

plemićke obitelji i dobre kuće. Zanimljiva je zimska haljina, kotiga - okrugla zatvorena suknja od tankih janjećih kožica s krznom na unutarnjoj strani. Vanjsko lice kotige čine bijele kožice, a donji dio opšiven je tankim skrletom. Krznena je suknja našivana na kraći prsluk s naramenicama. Ovaj odjevni predmet skupocjeno je ruho, a izrađivalo se u posebnim radionicama koje su postojale i u Senju. Kameni reljef Dominke Betričić karakterističnog je oglavlja čiji jedan kraj pada na lijevi dio leđa, a na tjemenu tvori dva simetrična izbojka, vjerojatno modelirana čvrstim podloškom, upletenim ili tek postavljenim na kosu dignutu u pletenice. Kosa udate žene se sakrivala, što također upućuje na konzervativni modni element. Na glavi kneginje Ižote Frankopanske kosa je vidljiva, svilena koprena pada na zatiljak tek kao dekorativni simbol udate žene. Udata žena u nas u pravilu je osim pokrivala imala i kapicu (počelicu, skufiju) kao trajno pokrivalo na kosi udatih žena, pa se njen najjednostavniji oblik nije skidao ni na spavanju. U drugoj polovini 16. stoljeća starinski odjevni inventar se gubi; muška nošnja prelazi u vojničku opremu, a u opticaj ulazi dinarska ženska odjeća koja u dotadašnjoj patricijskoj senjskoj odori unosi promjene, primjerice, duže haljetak (sadak), potkošulju (komeš). Na nogama, Senjanke su nosile čvrstu kožnatu obuću bijele boje. U svečanijim prilikama pristajale su papuče u sjevernom primorju poznate kao firale - firule, a na jugu kao kondure, od crvene ili zelene kože sa crnim kožnatim potplatom. Uskokinje u zaleđu imale su dinarsku pletenu obuću, hlače-bječve i nazuvke. Vrlo je vjerojatno da su i Senjanke pri dnevnim poslovima nosile takvu obuću. Popratan pribor uz odjeću dinarskog tipa bio je i nakit - pojasevi, ogrlice, kopče. Postupno, posebnost u odijevanju se zatire kao strani utjecaj te od 19. stoljeća u većem dijelu primorja i unutrašnjosti odjeća postaje monotona crnina.

Maruševačka nošnja, iz kraja odakle Jerolima potječe, nalik je senjskoj, iako je terminologija različita. Dio ženske nošnje bila je robača. To je naborana suknja izrađena od konoplje ili lana, a bila je bogatija što je imala više nabora. Ispod nje nosila se s podnjica istog kroja, ali bez ukrasa. S prednje strane robače bio je bogati ukras koji se sastojao od tri okomite pruge veza u više boja. Između veza je našivena bijela špica, čipka domaće fine izradbe. Rokavci su bili od bijelog kupovnog finog platna i imali su obrub od sitne bijele čipke. Rokavci su završavali rukavima široko nabranima koji su iznad lakta bili stisnuti bijelim uskim vrpcama (dreticama), a završavali bogatom čipkom ili ukrasnim cvjetnim vezom. Sprijeda preko robače nosio se fortuf, pregača izrađena od bijelog domaćeg platna i bogato nabrana na širokoj traci kojom se vezala oko pojasa. Fortuf je bio bogato vezen cvjetnim uzorcima i obrubljen nabranim volanom, koji završava čipkom sa sitnim zupcima. Na glavi su udate žene nosile poculicu, preko koje se nosio rubac krunač od žućkastog brokata koji se vezao ispod vrata. Zimi su se nosili debeli vuneni rup- 
Marko DRAGIĆ \& Ivana ODŽA

ci narančaste boje ili pak crna surka, kratak kaputić od crnog sukna ili samta stegnut u pasu i ukrašen vezenim cvjetićima crvene boje. ${ }^{34}$

Teško je zamisliti Jerolimu za posredovanja ili čuvanja zarobljenika odjevenu prema opisanom predlošku. Vrlo je vjerojatno da je njezina odora, kada ju je bila u prilici nositi (proštenja, svetkovine), nalikovala opisanoj. Zahvaljujući postojećem prikazu moguće je dijelom predočiti Jerolimin fizički lik.

Velika je vjerojatnost da je Jerolima bila sličnog svjetonazora, jer je vrlo teško zamisliti da bi Petar Kružić, uskočki vođa, odabrao ženu suprotnih nazora. Može se, dakle, zaključiti da su temeljne odrednice njene ličnosti bile bogoljublje i domoljublje.

\section{Petar Kružić, kliški kapetan i vođa uskoka}

O podrijetlu Petra Kružića trojako je mišljenje: najvjerojatnija je teorija da potječe iz lapačkoga mjesta Krug. U suvremenom narodnome pripovijedanju Kružić je bio iz Zvečaja kod Karlovca. Toj tezi pridonose i podatci u daljnjem tekstu ovoga rada. Kačić ga u narodnoj pjesmi, vjerojatno zbog sličnosti s toponimom Zvečaj, smješta u poljičko selo Zvečanj pa uslijed toga nastaju teorije o poljičkom podrijetlu Kružića, ali im se priklanja manjina. ${ }^{35}$ Nekolicina Kružiće veže za Lupoglav koji je Petar dobio u zalog od kralja 1527. i gdje je sa svojom obitelji živio i pripremao obranu Klisa. ${ }^{36}$ Postoji i teorija da je bio iz Trsata.

Vojnu karijeru počeo je 1513. godine kada se priključio braniteljima Klisa. U početku je obavljao vojnu dužnost podkaštelana. Ban Petar Berislavić postavio ga je za kapetana Klisa (1518. ili 1519.). Koncem 1521. g. imenovan je Senjskim kapetanom, s Grgurom Orlovčićem, kojega je kralj imenovao sukapetanom Klisa. Te dužnosti obavljali su zajedno sve do pogibije Grgura Orlovčića na Mohačkom polju (1526. g.). U isto vrijeme je zapovjednik i knez kliški. Razlika između te dvije funkcije odnosila se na razliku između vojnog i civilnog sektora. Budući postoje naznake da je Petar tada bio u muževnoj dobi, smatra se da je rođen u posljednjim decenijima 15. stoljeća. To je najprecizniji podatak o njegovu rođenju. Postoje isprave iz 15. stoljeća u kojima se spominju pojedini članovi obitelji Kružić koji su živjeli u okolici Bihaća i Bosiljeva. Prezime Kružić dovodi se u vezu s mjestom Krug

\footnotetext{
${ }^{34}$ Senjski zbornik, god. 5., 1973., Gradski muzej Senj, 1973. Senjski zbornik, god. 28, 2001., Gradski muzej Senj, 2001.

${ }^{35}$ Ta teorija temelji se na velikom broju branitelja Klisa koji su bili iz Poljica.

${ }^{36}$ Anđelko MIJATOVIĆ, Senjski uskoci u narodnoj pjesmi i povijesti, Nakladni zavod MH, Zagreb, 1983., 19.
} 
Kliški kapetan Petar Kružić i njegova supruga Jerolima u književnosti...

u župi Nebljuškoj između gore Plješivice i rijeke Une, ispod grada Ripča i Bihaća. U sastavu djedovine Kružića nalazi se i selo Zvečaj oko Kupe i Korane.

Većina saznanja o Petru Kružiću svodi se na njegov vojnički život, a o privatnom zna se vrlo malo. Osnovne odrednice Petrove ličnosti najbolje je opisao Marko Perojević:

Čedo nižeg hrvatskog plemstva, vatren kršćanin, nesebičan rodoljub, radi samo iz ljubavi prema vjeri i domovini, ne bira sredstva u borbi kao što ih ne biraju njegovi neprijatelji Turci i Mlečani. Prosti plemić bez školskog obrazovanja ne zna čitati ni pisati, ali zato je veliki diplomat koji ima veza s papom i kraljevima. Pun je vjere i bogoljubnosti, gradi zadužbine, polazi na poklonstva i zavjete, a u isti čas nemilosrdno siječe neprijateljske glave, osuđuje na smrt fratre i izdajnike, otima, robi, pali. ${ }^{37}$

Niže plemstvo kojem je pripadao Petar Kružić, Raukar dijeli u dvije skupine - niže plemstvo u širem smislu i ,plemstvo dvanaestero plemena Kraljevine Hrvatske“, ali ističe da se te razlike gube u 15. stoljeću, pa i u Petrovo vrijeme. Prava nižih plemića vidljiva su u nesmetanom uživanju zemljišnih posjeda i oprostu od plaćanja poreza.

Petar Kružić raspolagao je većim brojem posjeda (Brestovica, Lupoglav) koje je uglavnom dobivao od kralja kao dar za vojne uspjehe. O eventualnom bogaćenju kao posljedici privilegije neplaćanja poreza u ovom slučaju ne možemo govoriti zbog specifičnih financijskih okolnosti uskočkog života koje su, u nedostatku podrške papa i vladara, zahtijevale ulaganja samih uskoka. U Lupoglavu je živjela njegova sestra Jelena i žena Ivana, kako je naziva Slaven Bertoša. Od Bertoše saznajemo i o Kružićevim preokupacijama u slobodno vrijeme: „Kružić je u Lupoglavu uzgajao konje, hrtove i sokole za lov, koje je često slao na dar uglednim osobama, vjerojatno i samom kralju Ferdinandu. “38 Osim spomenutih sestara Jelene i Katarine, postoje naznake da bi Petrov brat mogao biti Toma Kružić, službenik bana Ivana Karlovića. ${ }^{39}$

Kako je proteklo Petrovo djetinjstvo i mladost, ne zna se. Velika je vjerojatnost da se kao niži plemić vrlo rano posvetio vojništvu u kojem je napredovao od kaštelana do kapetana i kneza.

${ }^{37}$ Marko PEROJEVIĆ, op. cit., MH, Zagreb, 1931., 10.

${ }^{38}$ Slaven BERTOŠA, Teme iz prošlosti Lupoglava i njegovog područja od 11. do 19. stoljeća, Zbornik Općine Lupoglav, knjiga 4., Lupoglav, 2003., 25.

39 Ivan Karlović, hrvatsko-slavonsko-dalmatinski ban (? 1485. - Medvegrad 1531.), posljednji je potomak Kurjakovića. Cijeli je život posvetio borbi protiv Turaka, za što je zalagao i svoje posjede. U narodnoj je tradiciji hrvatski vitez. U epskoj poeziji opjevani su Karlovića dvori. 
Marko DRAGIĆ \& Ivana ODŽA

Petar se 1513. god. spominje kao kaštelan, vjerojatno zamjenik tadašnjeg kapetana Ivana Križanića. Do 1522. god. vrlo je malo podataka o njegovu napredovanju, da bi se od te godine pa do njegove smrti (1537.) raspolagalo znatnijom količinom podataka o Petrovu vojnom djelovanju. Iako gorljivi kršćanin i rodoljub, pa i nepismen čovjek, Petar je bio očito otvorenih pogleda, nesklon generalizacijama. Tako Turčina Kovačevića u jednom pismu spominje u pozitivnom kontekstu kao čovjeka koji mu je u turskom zarobljeništvu učinio mnoga dobra.

Viktor Car Emin u svojoj romansiranoj izgradnji lika Kružića ističe njegovu otvorenost prema luteranizmu.

\subsection{Vojni pothvati Petra Kružića}

Život Petra Kružića obilovao je vojničkim pothvatima. Ako se uzmu u obzir prostorne distance između gradova i mjesta u kojima je Petar boravio, sigurno je da su njegova izbivanja iz obiteljskog doma bila česta, a dio putovanja bio je posvećen vjerskim hodočašćima.

Nakon zauzimanja Knina i Skradina turske su snage snažno napale Klis, koji je ostao jedinom značajnijom hrvatskom utvrdom na jugu. U veljači 1524. g. Petar Kružić bio je u velikim neprilikama kada je turski vojvoda Mustafa opkolio Klis sa 3000 vojnika. Međutim, usprkos nadmoćnom neprijatelju te nestašici vode i hrane kliški branitelji odolijevali su dva mjeseca. Petar Kružić je prije opsade otišao u Senj, gdje je sa Grgurom Orlovčićem okupio tisuću pet stotina pješaka i šezdeset konjanika. Pri tome im je pomagao Toma Niger, koji je donio Papinu pomoć u novcu, naoružanju i hrani, te sa četrdeset brodova ploveći samo noću stigao do Solina, gdje su se iskrcali 10. travnja, i krenuli prema Klisu, gdje su razbili porazili tursku vojsku. Kralj Ludovik u znak zahvalnosti za taj podvig Kružiću i Orlovčiću darovao kaštel Breznicu. Pobijedio je Turke kod Senja 1525. i doveo pomoć okupiranom Jajcu.

Nakon Mohačke bitke (1526. g.) Turci su zauzeli Obrovac, a Klis se ponovno našao u teškom položaju. Tri godine kasnije (1529.) Kružić se odrekao dužnosti Senjskoga kapetana i posvetio se obrani Klisa. Dok je Kružić izbivao iz grada sakupljajući pomoć, turski su vojnici 4. lipnja 1532. g., pod zapovjedništvom Mlečanina Nikole Querinija uspjeli, preko izdajnika, zauzeti Klis. Kružić je ubrzo sa svojih dvije tisuće vojnika doplovio iz Ancone i oslobodio Klis, a 18. rujna osvojio je tursku utvrdu u Solinu. Tada je Kružić bezuspješno savjetovao kralju Ferdinandu I. da sagradi utvrdu na solinskom polju. Mlečani su željeli zauzeti Klis, ali je Kružić imao pomoć pape Kle- 
Kliški kapetan Petar Kružić i njegova supruga Jerolima u književnosti...

menta VII. kao i njegova nasljednika Pavla III., te je sultan Sulejman I. priznao da je Klis ,„papinski grad“. ${ }^{40}$

Saznanje o tome da, nakon što dobiju novčana sredstva od kralja ili pape, prvo naplaćuju vlastite troškove, stavilo je uskoke i Kružića u nezavidan položaj. Perojević smatra da je takva slika o uskocima iskrivljena i utemeljena na nepoznavanju načina na koji su se gradovi u to vrijeme opskrbljivali hranom. Opskrba se nerijetko morala izvesti skrivečki, daleko od očiju Turaka, pa su tako oni kojima je to bilo u interesu u tom činu nalazili mogućnost za zlobne interpretacije. U negativnom kontekstu Petar Kružić je spomenut i pri smrti bana Petra Berislavića, kojemu je, navodno, uskratio pomoć na samrti, no, teško je potvrditi istinitost spomenute situacije, osobito ako se uzme u obzir cjelokupno Kružićevo djelo koje više karakterizira hrabrost negoli kukavičluk.

Međutim, Turci su i dalje pokušavali osvojiti Klis, 1535. godine pokušali su ga osvojiti izdajom uskoka Mate Tvrdoslavića, kojega su podmitili, te ih pustio u grad na Pokladni utorak. Tvrdoslavić je prethodno o svemu obavijestio svoje uskoke koji su dočekali Turke i zadali im snažan udarac. Koncem kolovoza 1536. g. velika turska vojska, koja je prethodno obnovila utvrdu u Solinu i izgradila još dvije, opkolila je tako potpuno Klis i silovito ga napala. Kliški branitelji su se hrabro i junački borili, ali su bili prisiljeni na predaju.

\subsection{Pogibija Petra Kružića}

U ožujku 1537. god. s mora je stiglo 3.000 njemačkih vojnika kralja Ferdinanda Habsburškog i 700 talijanskih vojnika koje je poslao papa Pavao III. Predvođeni kapetanom Kružićem i njegovom vojskom, uspjeli su razvaliti dvije turske utvrde. Kada su osvajali posljednju utvrdu, iznenada se pojavio Murat-beg sa svojih 2000 vojnika koji su divlje urlajući navalili na osloboditelje, pa su talijanski i njemački vojnici, plašeći se da je turskih vojnika mnogo više, pobjegli prema obali. Uzalud ih je Kružić pokušavao zaustaviti i smiriti. Nemajući drugoga izbora, Kružić i njegovi vojnici bili su prisiljeni na povlačenje. Kružić je među zadnjima došao do obale. Opkolili su ga Turci. Junački se boreći do zadnjega trena, kapetan Kružić je poginuo, od ruke Atliage, na blagdan svetoga Grgura (12. ožujka) te (1537.) godine.

Klišani su toga dana ostali bez svoga kapetana i bez vrela vode. Nije im preostalo ništa drugo nego prihvatiti ponudu Turaka koji su im obećali slobodu ako im mirno prepuste grad. Junačka pogibija Kružića odjeknula je diljem kršćanskoga svijeta. Kružićevi sugrađani bili su prisiljeni raseliti se na

\footnotetext{
${ }^{40}$ Usp. Vjekoslav KLAIĆ, Povijest Hrvata (knjiga četvrta), MH, Zagreb, 1974.,
} 388. -428 
sve strane, a velik broj njegovih suboraca otišao je u Senj i odande su nastavili borbu protiv Turaka. ${ }^{41}$

Kružićevo tijelo je dopremljeno lađom u Senj i odatle u Trsat, poviše Rijeke, gdje je pokopan u crkvi Gospe Trsatske, u kapelici Svetog Petra, koju je sam podigao 1531. godine, kao zavjetnu obvezu koju je Svetom Petru obećao u bitki s Turcima na Duvanjskom polju. ${ }^{42} \mathrm{Na}$ njegovu je grobu mramorna ploča na kojoj je natpis latinskim jezikom, koji u prijevodu znači: „Ova mramorna ploča pokriva kosti Petra Kružića, kojega, jao, pogubiše Turci. Dok je živio, Senj i Klis se nikada nisu bojali Turaka. Smrt je preuzela njegovo tijelo, nebo dušu, a njegovo junačko djelo po svijetu razglasuje vječna slava. ${ }^{443} \mathrm{Nje}$ gova sestra Jelena otkupila je glavu svoga brata i pokopala ju s tijelom. ${ }^{44}$

\section{Nošnja kliških uskoka}

Uskoci imaju nošnju koja se podudara s onom Dalmatinaca u donjoj Dalmaciji. Muškarac, oženjen ili momak, nosi crvenu kapicu od sukna, kosu spletenu u pletenice i punu bradu; vrat i prsa slobodna. Košulja (rubača) na širokim rukavima koji su na rubu i na šavovima na ramenu s ovratnikom i otvorom sprijeda na prsima je izvezena crvenim i modrim turskim koncem (pamukom), na toj (košulji) je ugarski prsluk (lajbec) s dvostrukim redom puceta, opšiven s crvenim uzicama i petljama.

Oko struka je trostruki husarski pojas izrađen od crvenih struka, u koji je utaknut handžar i kubura. Duge nogavice (hlače) od plavog sukna s donjim gaćama, zatim umjesto čarapa nazuvci i opanci ili spletena obuća.

Zimi preko svega gornji kaput (halja) i još jedna crvena kabanica. Kako svi ovi ljudi puše, to uvijek imaju malu zemljanu crvenu lulu zataknutu u košulju na šiji, a na ramenu sjekiricu (čakan), a rijetko su bez prstena na ruci.

Odora uskočkog časnika sastoji se od košulje koja je od tanjeg lanenog platna, kazak - haljetak od fine crvene čoje, seže do koljena i kopča se jednorednim metalnim dugmadima sredinom prsiju, jačerma - od baršuna s aplikacijama od srmene trake i srebrnim filigranskim dugmadima, hlače tipa „benevreka“ od modrog sukna, čarape pletene od bijele domaće vune, opanci pripletaši, pojas levantinski tip istkan svilom, kabanica - s kukuljicom i rukavima od domaćeg „mrkog“ sukna ili fine crvene čoje, kapa - tipravnim

\footnotetext{
${ }^{41}$ Anđelko MIJATOVIĆ, Iz riznice hrvatske povijesti $i$ kulture, 180.-181.

${ }^{42}$ Drago NAKIR, Obrana Klisa, Napredak, Split 2005., str. 22.

${ }^{43}$ Petar KRUŽIĆ, http://hr.wikipedia.org/wiki/Petar_Kru\%C5\%BEi\%C4\%87 (8. ožujka 2009.)

${ }^{44}$ Ta je predaja i sada živa u kliškom kraju. Zapisala ju je Jelena Radić 2009. god. Kazao joj je Joško Valenta, pripadnik udruge kliških uskoka (rođ. 1965. god.) Rkp. FF Split 2009., E.
} 
Kliški kapetan Petar Kružić i njegova supruga Jerolima u književnosti...

tjemenom od crvenog sukna i prevrnutim, krznenim obodom orlovim ili sokolovim perom na čelu. ${ }^{45}$

\section{Franjo, sin Jerolime i Petra Kružića}

Jerolima i Petar imali su, koliko je poznato, samo jednog sina, Franju (Frana) pa joj odgoj i nije morao oduzimati mnogo vremena u odnosu na prosječne obitelji koje su nerijetko imale više od desetero djece. Pitanje Petrova roditeljstva izaziva nejasnoće - Perojević snažno brani stajalište da je Petar imao isključivo jednog sina - Franju, opovrgavajući tako pretpostavke da je postojao nezakoniti sin Ivan, a neki izvori spominju čak i stanovitog trećeg sina Jakova. ${ }^{46}$ Ivan je vjerojatno postojao, štoviše, Makanec se u toj tvrdnji oslanja na čvrste dokaze - povelju na latinskom jeziku iz 1550. godine, a kojom se Ivanu, nezakonitom sinu Petra Kružića (Petar se u spomenutom dokumentu izričito naziva Ivanovim pokojnim ocem $),{ }^{47}$ dijele plemićka prava.

Spominje ga i S. Bertoša kao stanovnika i maloljetnog nasljednika Kružićeva posjeda u Lupoglavu: „Ivan Kružić bio je konjanički kapetan, a potpisivao se kao Hans Crushitz", ${ }^{48}$ te je obnovio kulu i sobe dvorca. Nakon njegove smrti 1576. posjed nasljeđuje njegova sestra ili kći Margarita.

Za konstrukciju Jerolimina profila, postojanje izvanbračnog djeteta bitna je pretpostavka, no problematici se vraćam u sljedećem ulomku jer je fikcija jedino svjedočanstvo o Jeroliminu stavu prema Petrovu nezakonitom sinu.

\section{Literarizirani likovi Jerolime Kružić}

Na značaj usmenih priča ukazivao je najstariji grčki povjesničar Herodot (V. st. prije Krista). Grčki povjesničar i vojskovođa iz Atene Tukidid (r. oko 460. pr. Krista - umro oko 396. prije Krista), u svom djelu Spis o ratu Peloponežana i Atenjana (8 knjiga) navodi velik broj usmenih priča koje je zabilježio kod zaraćenih strana (u to doba i riječ historija znači priča). Usmene priče, među ostalima, spominje Platon (IV. st. prije Krista), a njegov i Zenonov učenik Aristotel (384.-322. prije Krista) istaknuo je da je poezija (podrazumijevajući pod tim nazivom književnost) istinitija i povjesnija od povijesti i da je treba ozbiljnije shvatiti od povijesti.

Suvremena povijest „koja se bavi 20. st. intenzivno je zaokupljena ključnom temom o odnosu historije i memorije, tj. istraživačkih rezultata

\footnotetext{
${ }^{45}$ Isto.

${ }^{46}$ Marko PEROJEVIĆ, 206./7.

${ }^{47}$ Alfred MAKANEC, Pozakonjenje i podijeljenje plemstva nezakonitom sinu kliškog junaka Petra Kružića, u časopisu Obzor, Zagreb, 1934.

${ }^{48}$ Slaven BERTOŠA, Teme iz prošlosti Lupoglava i njegovog područja od 11. do 19. stoljeća, Zbornik Općine Lupoglav, knjiga 4., Lupoglav, 2003., 26.
} 
Marko DRAGIĆ \& Ivana ODŽA

profesionalnih povjesničara o povijesnim kretanjima u 20. st. te različitih, proturječnih sjećanja i pamćenja javnosti, grupa i pojedinaca o tim istim pojavama. “49 Gross naglašava kako sjećanja pojedinaca i grupa nisu beznačajna, štoviše, često su presudna u oblikovanju kolektivnog identiteta, ali istovremeno ističe da je pamćenje vrlo loš vodič u prošlost ako se ne suočava s profesionalnim historijskim istraživanjem. Njena teza mogla bi se protumačiti kao legitimno pravo da se, u nedostatku povijesnog, istraživač osloni na kolektivno pamćenje, ili, u konkretnom slučaju, na književno-umjetničku vizuru, pod uvjetom da se uvijek održava veza s dostupnom povijesnom istinom. Slično je u proučavanju života Petra Kružića učinio i Marko Perojević, napominjući da je njegov prikaz ,više kao filmska slika negoli kao historijsko prikazivanje“. 50

Oslanjajući se na prethodne teze, nameće se mogućnost promatranja Jerolime kao književnog lika u romanu Presječeni puti Viktora Cara Emina, osobito uzme li se u obzir činjenica da se velik dio povijesno potvrđenih podataka poklapa s piščevom romanesknom obradom. Iako su preklapanja povijesnih činjenica velika, Jerolimin karakter kakvim ga prikazuje Car Emin ne odgovara općoj slici uskočke žene. Pisac inzistira na emocionalnoj strani njezina karaktera pa se stječe dojam o osjetljivoj ženskoj osobi, dobroćudnoj i brižnoj prema svojoj obitelji, ali rastrganoj između zahtjeva okoline i vlastite slabosti koja je onemogućavala u svakom djelovanju.

Pri prvom spomenu u romanu Jerolima leži na postelji izmučena bolešću. Nema naznaka o kakvoj je bolesti riječ, ali pogoršanje je dijelom uzrokovano vijestima o turskim osvajanjima. O Jerolimi brine majka Doroteja, „punica kneza Petra, vanredno odrešita žena, pred kojom je služinčad drhtala od straha, a bojali su je se i kaštelani i ostali služenici, a najviše kmetovi prostrane gospoštije lupoglavske“".51

U svom članku o obitelji Vragovića Laszowski spominje Doroteju Gerecijevu, ženu Jurja Vragovića i majku maloljetnih sinova Krstina i Ladislava, umrlu 1547. god. Iako godina njezine smrti upućuje na mogućnost da je ista žena Jerolimina majka (Jerolima je umrla nešto prije muževljeve pogibije, ne prije 1530. g., o čemu svjedoči korespondencija s Petrom), to ničim ne možemo potvrditi jer se Jerolima nigdje ne spominje kao njezina kći, što je, s druge strane, opravdano ako uzmemo u obzir činjenicu da je Jerolima tada već bila pokojna. Doroteja se snažno protivila svim Petrovim pothvatima, smatrajući ih uzaludnima, osobito ako se uzme u obzir trošenje obiteljskih dragocjenosti. Budući nije mogla utjecati na Petra, pokušavala je manipulira-

\footnotetext{
${ }^{49}$ Mirjana GROSS, Memorija i historija, u: Republika, br. 4, 2007., 34.

${ }^{50}$ Marko PEROJEVIĆ, op. cit., 9.

${ }^{51}$ Viktor CAR EMIN, Presječeni puti, 76.
} 
Kliški kapetan Petar Kružić i njegova supruga Jerolima u književnosti...

ti unukom Franom i Jerolimom, zadajući joj dodatne brige. Kada uskok Tomo donosi obavijesti o teškom položaju Klisa, tražeći usput kakav materijalni zalog, Doroteja Frana upozorava: „Pazi da onom šepavcu ne nasjedneš! On bi htio da se pokupe sve dragocjenosti, i one posljednje što se još u kući čuvaju da se iz oka i iz boka izvuče što više dinara, i opet za onaj prokleti Klis, za onu bezdanu jamu koja je već ionako progutala sve naše. A za koje babe dušu, pitam ja tebe? Što će tvome ocu i tebi i ikome ona pećina tamo dolje? ${ }^{* 52}$

Uz etnološka istraživanja o onovremenim Senjankama koja mogu pomoći u oslikavanju fizičkog izgleda Jerolima Kružić, Car Emin prvi put daje obrise njezina fizičkog izgleda kao i njenih intimnih razmišljanja koji su, uzmemo li u obzir nedostatak podataka o njoj, upitne vjerodostojnosti, ali su zanimljivi kao piščeva predodžba nastala ne temelju određenih povijesnih saznanja:

Bit će joj oko pedeset godina, ali joj je lice puno dubokih brazda što joj ih je usjekao život pun vječitog nemira i straha, teških briga i neprekidnih uzrujavanja. Otkad se udala, promijenila je svoje boravište ni sama ne zna koliko puta. Tek bi se negdje namjestili, već bi se u blizini pokazali Turci i trebalo je ponovno nekuda u svijet, u novu postojbinu. I tako iz godine u godinu, dok nisu prije pet godina pali ovamo, u ovu kulu što ju je Ferdinad ustupio Kružiću u zakup. (...) I tu u ovoj zabiti provodi ona svoje tužne dane najčešće sama sa zajedljivom, uvijek natmurenom majkom, daleko od muža koji se neprekidno lomi i ubija, da Bogu i kralju očuva Klis, i od jedinca sina što od grada do grada luta svijetom, čas po jednom čas po drugom poslu ili pak gonjen onim nekim svojim čudnim unutrašnjim nemirom.(...) No sve bi se nekako i pregorjelo da nije one najnovije strahote... Tu se opet pri samoj pomisli na izgubljeni Klis sva ustrese, lice joj se zgrči, dolazilo joj je kao da će je opet ostaviti svijest. Klis izgubljen! A njegov branilac - Bog zna gdje sad očajno luta! ${ }^{53}$

Nema sumnje da je Jerolima osjećala snažnu zabrinutost za muža, privrženost prema sinu vidljiva je na više mjesta u romanu, no u takvoj slici teško je zamisliti Jerolimu kao odlučnu uskočku ženu spremnu na djelovanje, na što aludiraju povijesna istraživanja. Piščev interes na nekoliko mjesta usmjeren je na odnos Jerolime i Petra; Petar je kao literarni lik iznimno pažljiv muž, svjestan Jeroliminih teškoća i spreman joj uvijek pružiti podršku. Petrova prva preokupacija je posjet ženi. Čim dođe u Lupoglav, trči u sobe vidjeti

\footnotetext{
${ }^{52}$ Viktor CAR EMIN, isto.

${ }^{53}$ Isto, 83.
} 
Marko DRAGIĆ \& Ivana ODŽA

Jerolimu, pomaže joj da ustane iz postelje, poljubi je, pomiluje, te, držeći njenu ruku u svojoj, priča joj o njihovu sinu Franu, kojeg su čekali četiri godine i u kojega se puno puta razočarao, ali je sada potvrđivao svoje oduševljenje i vjeru u Franovu preobrazbu. Dobro Petrovo raspoloženje značilo je i dobar ishod za Jerolimu:

Videći ga onako mirna, malone raspoložena, ona se i sama ohrabrila i gledala ga i slušala s udivljanjem i toplom zahvalnosti za one njegove srdačne riječi o Franu, njezinom dragom mezimčetu. Istina, otkad je dečko krenuo u Klis, nije o njemu čula ništa, čak se i boji da se nije što pripetilo, ali opet - već sama misao da je onaj njegov odlučni korak naišao na ovoliko kneževo odobravanje ulijevalo joj je u dušu neku utjehu, a uz to i nadu da će im Bog biti svima milostiv i da će se sve dobro svršiti. ${ }^{54}$

U drugom spomenu odnosa supružnika Petar dolazi u Lupoglav tek u prolazu, između dviju vojnih intervencija, zahtijevajući od nje da mu spremi nešto zlata. U razgovoru o nezakonitom sinu Ivanu, Jerolima nikada ne sudjeluje. Zajedljive primjedbe daje punica Doroteja i brine se za Jerolimine reakcije, ali nije posve jasno je li u pozadini istinska briga za kćer ili zabrinutost za vlastiti ugled.

Po svemu sudeći, veza s izvjesnom Barbarom, sada pokojnom, čiji je plod sin Ivan, Jerolimi je bila poznata, ali očito ne omiljena tema. Iz romansirane predodžbe moguće je pretpostaviti da bi Jerolima, usprkos neslaganju, pristala na gotovo svaki Petrov prijedlog. Povijesni podatci potvrđuju da je Ivan postao nasljednik Lupoglava, no tada su i Fran i Jerolima već bili pokojni.

Jerolimina smrt u romanu je nastupila kao posljedica dugotrajne slabosti i psihičkog opterećenja zbog pretjerane brige za muža i sina, kao i unutarnjeg sukoba želeći izgladiti njihove zategnute odnose, a pri tome istovremeno ugoditi i jednom i drugom:

Knez je opet u Lupoglavu, sasvim povučen, uduben u molitvu i u teške misli. Svaki dan jutrom i večerom silazi u kapelu sv. Rozarija i kleči pred teškim kamenom pod kojim mu je sahranjena žena, gospođa Jerolima. Vijest o njenoj smrti zatekla ga je u Bihaću, odakle se sred najveće žege vrati kući da joj se barem pomoli na grobu kad mu ne bijaše dano da je još jednom vidi živu. ${ }^{55}$ ma Franu.

Posljednja Jerolimina želja bila je upućena Petru - neka bude blag pre-

\footnotetext{
${ }^{54}$ Viktor CAR EMIN, op. cit., 121.

${ }^{55}$ Isto, 442.
} 
Kliški kapetan Petar Kružić i njegova supruga Jerolima u književnosti...

Viktoru Caru Eminu povijesni podatci bili su bliski kao i nastojanje da ih unutar romanesknog tkiva koliko je moguće prikaže zbiljskima. Iako roman Presječeni puti u povijesti hrvatske književnosti ne zauzima značajnije mjesto, zanimljiv je za otkrivanje povijesno neistraženih područja. Ne može se potvrditi vjerodostojnost lika Jerolime kakvim ga opisuje Car Emin. Ona, kao i drugi likovi, nije osobito psihološki produbljena i sva opisana stanja svode se na dvije odrednice - snažna podrška obitelji, ali i otežana mogućnost suočavanja s postojećim stanjem. Usprkos piščevoj pretjeranoj patetici vidljivoj u navedenim ulomcima, roman nudi logičnu predodžbu - Jerolima je podržavala Petra, vjerujući u iste idejne koncepte te je tom stranom svoje ličnosti odgovarala slici uskočke žene. Iako povijesna istraživanja nigdje ne dotiču pitanje odnosa Jerolime i Petrova izvanbračnog sina, realno je očekivanje da nije bila blagonaklona prema postojećoj situaciji kao ni prema netrpeljivosti između Frana i Petra.

\section{Petar Kružić u suvremenom narodnome pripovijedanju}

Petar Kružić ide u red najvećih hrvatskih ratnika protiv turske vojske. O njemu se i danas pripovijeda:

Tamo negdi u petnaestom-šesnaestom stoljeću, dok su Turci tili osvojit Klis, bio je jedan uskok koji je branio naročito Klis i Senj, a zva se Petar Kružić. On je bio od Zvečaja, a to ti je gori u okolici Karlovca, a u Klisu je bio kaštelan i kapetan. Ima je i ženu i sina, ali o njima se ne zna nešto puno. Bio je pao u tursko ropstvo, ne zna se kako, bar ja ne znam to, ni kako se izbavio, ali znam da se nakon toga borio protiv Turaka i posta kliški knez, i kad god bi Turci napali Klis on je uvik sudjelova u njegovoj obrani. Onda je još, nakon toga, posta i senjski kapetan.

Jedan od, ovako, poznatijih turskih napada na Klis bio je onaj 1523., i tada je Petar Kružić zajedno sa drugim senjskim kapetanom Grgurom Orlovčićem, kod Solina pobjedio Turke i onda im je kralj obojici na poklon dao Brezovicu da ih nagradi. Kralj je bio neki od Jagelovića.

A nije samo s njime Kružić surađiva. Pomaga je on i Krsti Frankopanu, kad su Turci napadali Jajce, dok se ovaj borio s Turcima, Kružić je vodio opskrbu hranom i oružjem.

Onda, kad je doša Ferdinand Habsburški na vlast, Kružić je od njega dobio Lupoglav, ali se kralj nije baš iskaza po pitanju pomoći njemu i njegovim uskocima. Oni su tribali dobivat od kralja plaću, a i od pape bi ponešto dobili, jer je i u njihovom interesu bilo da se Turke što dalje od njih zadrži, a za to su imali uskoke.

I onda je Petar Kružić doša u takvu situaciju da on i njegovi ljudi nisu imali od čega živit, pa je tražio pomoć od kralja jer su spali 
Marko DRAGIĆ \& Ivana ODŽA

na prosjački štap, kako je i od pape pomoć rijetko kad pristizala, pa su on i uskoci bili prisiljeni živit od onoga što bi neprijatelju oteli. A kralj bi obeća, samo kako to uvik ide, ništa od tog obećanog nije ostvario, i onda je zbog toga Klis spa na samo pedeset uskoka, dok su se turske vojske brojale u stotinama, pa čak i tisućama! A cilo to vrime borio se Kružić, kako protiv Turaka, tako i protiv Mlečana, jer su i oni tili osvojit dio našeg mora, a kako su živili u lošim uvjetima i broj uskoka se smanjio, i odma to nije ona ista sila koje su se prije Turci bojali. Tako je on jednom prilikom, braneći Klis sa četrdeset konjanika i četrdeset pješaka, pao u mletačko zarobljeništvo, ali se brzo oslobodio zahvaljujući nekom prijatelju.

Eto, toliko o kraljevoj pomoći, a to da su uskoci bili razbojnici, gle, to je, a valjda kako ko na to gleda. Sad se nama čini nevjerojatno to kako su oni morali otimat da bi preživili, i to od toliko moćnijeg neprijatelja ka šta su Turci bili, ali to je tako tada bilo. Ljudi su se manje i bojali ić u rat, jer nije se branila samo zemlja, branilo se i kršćanstvo, a kršćani koji bi pali u turske ruke bili bi ili ubijeni ili prodani u roblje, to se zna.

1530. Turci su napali Klis i Kružić je doša s tri broda vojske koju mu je papa posla da ga oslobodi. Nakon toga znam da je iša u Lorett, kako se zavitova Gospi, a tada je Klis napala turska vojska od deset tisuća. Tražio je on bio pomoć i od pape, i u Rimu je bio di je od pape dobio potporu, i u Ankoni. Za to vrime su Turci i Mlečani na prijevaru zauzeli Klis. I onda je on, kad se vratia, potuka Turke u Bosni i uništio turske utvrde u Solinu.

Onda su 1533. Turci opet počeli napadat na Klis, a samo u proliće 1534. su trideset sedam puta navaljivali na nj da će ga osvojit i ta je opsada tako trajala par godina, pa su Turci u Solinu sagradili dvi kule da im je lakše nadgledat Kliško područje, tako da se on sad moga oslobodit samo s mora, budući da je kopno bilo ili pod Turcima ili pod Mlečanima. Tako da je Kružić napa njihove tri utvrde u Solinu, koje su imali i to pomoću Ferdinandovih i papinih vojnika i svojih ljudi, a kako su Turci bili jači, Kružićeva vojska počela povlačit prema moru, na lađe, i na jednoj od tih lađa je on i poginia.

Turci su mu odrubili glavu, a kad su je njegovi ljudi vidili i sami su se predali.

Njegovo tijelo je onda prevezeno u Senj, a odande u Trsat, di je on sagradio za zavjet crkvu Blažene Djevice Marije u kojoj je na kraju i pokopan. Onda, kako su Turci još uvik imali njegovu glavu, onda je njegova sestra Jelena otkupila njegovu glavu za sto dukata.

Računa se da je Klis pao 12.ožujka 1537., na dan kad je sam Petar Kružić poginuo.

I eto, to je bio slavni uskok Petar Kružić! 
Kliški kapetan Petar Kružić i njegova supruga Jerolima u književnosti...

A imaš i Klišku kulu, a u njoj se rodila ćer Bele četvrtog, Magdalena se zvala. ${ }^{56}$

Kada se usporede podatci iz navedene suvremene predaje, može se ustvrditi kako skoro i nema razlika između književne i povijesne istine. Međutim, književnost ne pripovijeda samo o onome što se dogodilo nego tipski ukazuje na ono što se može dogoditi. Stoga je književnost didaktičnija, edukativnija i utilitarističnija od povijesti.

U živom su narodnome pamćenju i sljedeće povijesne i etiološke predaje:

Narod ga je zavolio ne samo zbog njegovih iznimnih uspjeha odupiranju Turcima već i zbog toga što je pomagao siromašnim. $O$ njegovoj važnosti i nosiocu žara suprotstavljanja i za svoje ljude govori nam predaja po kojoj je u nastojanju da skrši opsadu GaziHusref begove vojske u bitci kraj Solina poginuo, a turski zapovjednik, Murat-beg Tardić njegovu je glavu donio na koplju pod zidine Klisa, a branitelji su se vidjevši to predali. Smatrali su da bez vodstva Petra Kružića nemaju nikakvih izgleda, prihvatili su uvjete predaje, a Klis je pao u ruke Turaka. ${ }^{57}$

\section{$*$}

Megdan je naselje, dio Klisa sa sjeverne strane kliške tvrđave. Prije se to mjesto zvalo Parhna poljana, a naziv Megdan dobiva nakon dvoboja Miloša Pariževića (Parižiovića), kliškog uskoka i Bakote, Turčina koji se zbio pod tvrđavom 1528. Miloš je pobijedio Turčina Bakotu. ${ }^{58}$

O tomu događaju svjedoči i sljedeća pjesma:

Pod Klis tvrdi osmanlije pali ne bi li se grada dokopali,

A ne mogu osvojiti grada od Kružića Petra grofa mlada. Mjesec dana Turci napadaju

${ }^{56}$ Ivana Vukadin zapisala je 2008. godine u Klisu. Kazao joj je Marko Sabljić (rođ. 1958., u mjestu Sabljići kod Imotskog). Živi u Klisu. Rkp. FF Split 2008, E.

${ }^{57}$ Zdravko Milišić zapisao je 2009. g. u Klisu. Kazao mu je Vladimir Kurtović. Rkp. FF Split 2009., E.

${ }^{58}$ Zdravko Milišić zapisao je 2009. g. u Klisu. Kazala mu je Linda Milišić, (rođena 1964.god.), učiteljica. Rkp. FF Split 2009., E. 
Marko DRAGIĆ \& Ivana ODŽA

Klišani se dobro branit znaju.

I po danu i po mrkloj noći

ne daju im ni blizu doći.

$\mathrm{U}$ to turski telal podvikuje,

podvikuje, kamen odjekuje:

„Teško Klisu jer je na kamenu,

a kamenu jer je Klis na njemu

$i$ što nema u njemu junaka

i viteza Bakoti jednaka,

koji bi mu desnom ravan bio

i Bakotu na tle oborio.

Ko Bakotu na mejdanu svali, mi bismo ga pobjednikom zvali i prestali opsjedati grada, pa nek Klisom pobjednik zavlada.“

Klišani se međ' sobom gledaju, svi na noge junačke ustaju.

A pred svima iskočio Mile,

Perisavić Mile, junak dičan,

Ljutu boju i mejdanu vičan.

Družini je svojoj govorio,

dok je jošte golobradac bio:

„Majci Božjoj zavjet sam činio

Meni Turčin, Majci Božjoj svijeća

Od Bakote ni manja, ni veća.“

Na livadu iziđe Bakota,

vidjeti ga, prava je strahota.

Do dva metra bješe u visinu, jedan cijeli metaru širinu.

Kad Bakota Milu ugledao, grohotnim se smijehom nasmijao:

„Je li Vlaše, život omrznuo

Pa na mejdan meni izašao.

Smrvit ću te prstom jedne ruke

Sve bez šale i imalo muke."

Perisavić mu na to odvrati:

„Moja šaka mrvila medvjede

kamol ne će, Golijate tebe!“”

Kopljima se bojnim nabacili jedan drugom koplje izlomili. Sabljama se oštrim sudarili jedan drugom sablje izlomili.

Preostale jošte gole šake, 
Kliški kapetan Petar Kružić i njegova supruga Jerolima u književnosti...

šakama se u koštac uhvate.

Strah obuze Turke i Hrvate

'oće l' Hrvat svladat Golijata,

Il' Bakota okretnog Hrvata.

Kako Turčin Milu uhvatio,

oko pola ga u pasu savio.

Kako Mile stisnuo Turčina

puče nešto Turku u kostima.

Mile steže, a ture rasteže

dok ga Mile zemlji ne poleže.

Pa dohvati noža iz njedara

i Bakotu u prsi udara.

Još dohvati odbačenu ćordu

kida glavu i baca u torbu.

Kad vidješe Turci smrt Bakote

pobjegoše od silne sramote,

a junaci usred Klisa grada

Zagrliše junačinu mlada.

Sto je reko, Mile učinio

baš toliku svijeću načinio

koliki je taj Bakota bio.

Do dva metra cijela u visinu

jedan cili metar u širinu,

pa je nosi put grada Trsata

Dobroj Majci, na dar od Hrvata.

Da bi svijeća trajni svjedok bila

kakva jeste u Hrvata sila.

Kakva sila i vjera je taka

Nad Hrvatom ne ima junaka. ${ }^{59}$

Tri kralja je zdenac zapadno od tvrđave. Tu je u blizini zdenca nekada postojala kapelica posvećena Trima kraljevima. Taj zdenac nosi naziv i Krvava Voda jer su se branitelji Klisa zatočeni u tvrđavi da bi preživjeli morali upuštati u sukobe s čuvarima za vodu, za zdenac. $^{60}$

${ }^{59}$ Zapisala je Marina Kljajo 2005. godine po kazivanju oca Marka Radića, rođenog u Bijelom Polju kod Mostara (1930.-2007.). Pjesma postoji u njegovu rukopisu, a čuo ju je od svoga oca Jure Radića. Rkp. FF Mostar, 2009, E.

${ }^{60}$ Zdravko Milišić zapisao je 2009. g. u Klisu. Kazala mu je Linda Milišić (rođena 1964. god.), učiteljica. Rkp. FF Split 2009., E. 
Marko DRAGIĆ \& Ivana ODŽA

\section{Zaključak}

Polivalentna shvaćanja uskoka i hajduka u povijesti često se jednostrano interpretiraju crno-bijelom tehnikom. Do takvih postupaka često dolazi i iz ideoloških pobuda. Međutim, sagledavanjem relevantnih povijesnih izvora kao i živoga narodnoga pamćenja nedvojbeno se može zaključiti kako su uskoci bili kršćani (katolici i pravoslavci) koji su od turskih progona bili prisiljeni pobjeći iz Bosne i Hercegovine i hrvatskih krajeva koje su Turci okupirali i nastaniti se u krajevima pod kršćanskom vlašću. Uskoci su hrabro branili svoj novi zavičaj i odatle su na poticaj mletačke i drugih kršćanskih vlasti vodili gerilske ratove protiv Turaka nanoseći im velike gubitke u ljudstvu i imovini. (Hajduci su ostajali u okupiranim krajevima i u skupinama napadali Turke. U hajdučkim družinama sudjelovali su i Crnogorci i Hrvati i Muslimani i Srbi.)

Uskoci (kao i hajduci) strogo su se držali kodeksa časti. Bogoljublje i rodoljublje bili su nadahnućem uskocima i hajducima za svoju tešku borbu protiv turskih zala, među kojima su najgnusnija bila pravo prve bračne noći $\mathrm{i}$ danak u krvi. Dakako, pri tome treba imati na umu i sporadične incidente pa i zločine koji su se događali. Međutim, dok drugi narodi, primjerice Englezi, Robinu Hoodu podižu spomenike i slave ga, Hrvati su često skloni jednostrano optuživati i uskoke i hajduke.

Za bolje razumijevanje uskoka bitno je poznavati i njihov obiteljski život. Spomenuti izvori dali su tek obrise o fizičkim, socijalnim, sociološkim i psihološkim karakterima Jerolime i Petra Kružića. Fizički portret najvjernije oslikava Car Eminova literarizacija, kao i etnološka istraživanja o načinu odijevanja senjskih žena. Jerolima se prema rijetkim povijesnim navodima očito uklapala u opću sociološku sliku svoga vremena - javno djelovanje bilo je u skladu s kršćanskom etikom, privatno je slijedilo uskočki kodeks.

Socijalne komponente su jedine na koje upućuje više izvora - potječe iz plemićke obitelji Vragović. Jerolimin psihološki portret može se promatrati iz dva kuta - prvi korelira sa sociološkom slikom prema kojoj je Jerolima hrabra ratnica, snažna muževa podrška, posve netipična žena koja ne preza ni pred čim u ostvarenju ideala svoga muža koji postaju i njezin ideal. U svom romanu Car Emin daje životniju verziju Jerolime.

\section{Izvori i literatura}

- Bertoša, Slaven, Teme iz prošlosti Lupoglava i njegovog područja od 11. do 19. stoljeća, Zbornik Općine Lupoglav, knjiga 4., Lupoglav, 2003.

- Bracewel, Catherine Wendy Senjski uskoci, Barbat, Zagreb, 1997.

- Car Emin, Viktor, Presječeni puti, Pula, Rijeka, 1984. 
Kliški kapetan Petar Kružić i njegova supruga Jerolima u književnosti...

- Čehić, Namik, Prozorski kraj u oslobodilačkom ratu i revoluciji, Prozor, 1985.

- Duvnjak, Stjepan, Sveti Ilija i sveti Juraj - zaštitnici Bosne, u: Zbornik o Marku Dobretiću, Općina Dobretići, urednik Marko Karamatić, Kulturni povijesni institut Bosne Srebrene Sarajevo, Sarajevo - Dobretići, 2008.

- Džaja - Krunoslav Draganović, Miroslav, Sa Kupreške visoravni, II. izdanje, Baško Polje - Zagreb, 1994.

- Feldman, Andrea, Žene u Hrvatskoj: ženska i kulturna povijest, Ženska infoteka, Zagreb, 2004.

- Gross, Mirjana, Memorija i historija, u: Republika, br. 4, 2007.

- Klaić, Vjekoslav, Povijest Hrvata (knjiga četvrta), MH, Zagreb, 1974.

- Kružić,Petar http://hr.wikipedia.org/wiki/Petar_Kru\%C5\%BEi\%C4\%87 (8. ožujka 2009.)

- Laszowski, Emilije, Povijesni podaci o obitelji Vragovića Maruševačkih, Vjesnik hrvatskog arheološkog društva, Nove serije sveska VII., 1903./4.

- Makanec, Alfred, Pozakonjenje i podijeljenje plemstva nezakonitom sinu kliškog junaka Petra Kružića, u časopisu Obzor, Zagreb, 1934.

- Mijatović, Anđelko, Senjski uskoci u narodnoj pjesmi i povijesti, Nakladni zavod MH, Zagreb, 1983.

- Mijatović, Anđelko, Iz riznice hrvatske povijesti i kulture, Školska knjiga, Zagreb, 1996.

- Nakir, Drago, Obrana Klisa, Napredak, Split, 2005.

- Perojević, Marko, Petar Kružić, kapetan i knez grada Klisa, MH, Zagreb, 1931.

- Perojević, Marko, Orao s Klisa, A3 data, Zagreb 1997.

- Senjski zbornik, god. 5., 1973., Gradski muzej Senj, 1973.

- Senjski zbornik, god. 28, 2001., Gradski muzej Senj, 2001.

- Šanjek, Franjo, Kršćanstvo na hrvatskom prostoru, Kršćanska sadašnjost, Zagreb, 1991.

- Šegvić, Cherubin, Junačka djela senjskih uskoka, Tisak i naklada knjižare L. Hartmana, Zagreb, (godina izdanja nije navedena)

- Šunjić, Marijan, Junačke pjesme iz Bosne, II. izd., Sarajevo, 1925.

$* * *$

Rkp. FF Split (Rukopisne zbirke Katedre za Hrvatsku usmenu književnost, Filozofskoga fakulteta Sveučilišta u Splitu). Rkp. FF Mostar, (Rukopisne zbirke Katedre za Hrvatsku usmenu književnost, Filozofskoga fakulteta Sveučilišta u Mostaru). Te su rukopisne zbirke nastale 
Marko DRAGIĆ \& Ivana ODŽA

kao rezultat izvornih terenskih zapisa studenata kojima sam bio mentorom pri izradi preko tisuću seminarskih radova $i$, do sada (8. rujna 2009. god.), 163 diplomska rada iz Hrvatske usmene književnosti. (Oznaka D - znači diplomski rad, Z - znači završni rad, S - označava seminarski rad, a oznaka $\mathrm{E}$ - znači da je rukopis u elektroničkom obliku. Rukopisne zbirke nalaze se kod mene.)

\section{Marko DRAGIĆ Ivana ODŽA}

\section{PETAR KRUŽIĆ, THE CAPTAIN FROM KLIS AND HIS WIFE JEROLIMA IN THE LITERATURE, HISTORY AND CONTEMPORARY FOLK NARRATION}

The article begins with the historical context and causes for formation of uskoks and hajduks. Than it talks about women of Middle Ages and early New Ages, concentrating on uskok wives, especially on Jerolima Kružić, Petar Kružić's wife, about who, when it comes to genuine historical data, we know very little. Analysis of the topic is based on the existing historical data, living tradition and the novel Presječeni puti by Viktor Car Emin. In that way, coauthors are (re)constructing the character of Jerolima Kružić, examining as many different aspects of the persona as possible, such as her heritage, physical appearance and personal believes of one of the most important uskok leader's wife.

Jerolima's personal beleives were probably very close to those of her husband - by that we mean her Godliness and patriotism in particular - and with that she fitted into the image of woman of the time. The romanticised version (by V.Car Emin) uses the historical truth, but also indicates a different perspective as well, introducing a psihological portrait of a woman who occasionaly had difficulties dealing with her husband's line of work.

In the article there are paragraphs about Petar Kružić, about his brave battles against the Ottoman conquerors and his heroic dead on 12 March 1537. On the same day the Ottoman soldiers conquered Klis. There are also some pharagraphs about Franjo (Fran), son of Jerolima and Petar Kružić. Fearlessness, heroism, love of God and patriotism of Petar Kružić are still present in the folk tales. Love of God also adorned his wife Jerolima, who helped and supported her husband in the fight against foreign command.

Key words: godliness, patriotism, Jerolima Kružić, Petar Kružić, uskoks, history, literature 
Kliški kapetan Petar Kružić i njegova supruga Jerolima u književnosti...

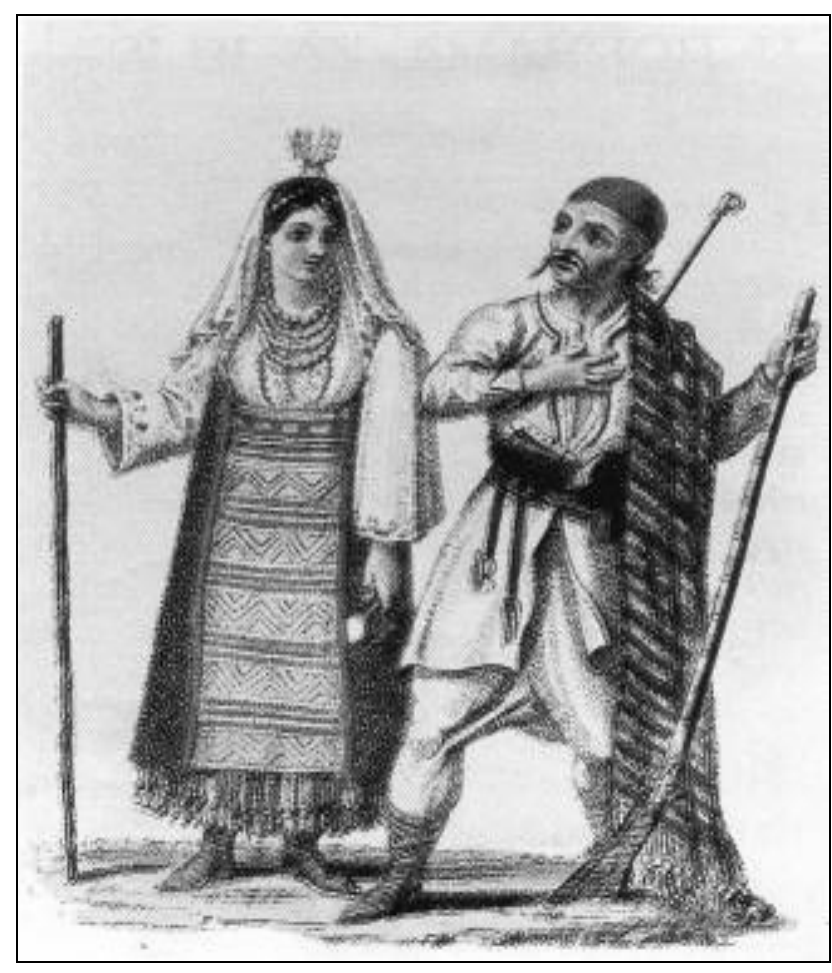

Uskočki par 

LINGUA MONTENEGRINA, god. III, br. 5, Cetinje, 2010.

Institut za crnogorski jezik i jezikoslovlje „Vojislav P. Nikčević“

UDK 398.4(497.13)

Izvorni naučni rad

\title{
Vanda BABIĆ (Zadar) \& Denis VEKIĆ (Zadar)
}

Sveučilište u Zadru

\section{PRETKRŠĆANSKA VJEROVANJA U DOLINI NERETVE}

\begin{abstract}
Vođeni činjenicom da je teritorij doline Neretve posljednji primio kršćanstvo u srednjovjekovnoj Dalmaciji, autori prikupljaju kazivanja o nadnaravnim bićima i događajima koji su obilježili živote Neretvana. Kazivanja su prikupljena i zabilježena u ljeto 2007. godine na nizinskom i brdskom području neretvanskoga kraja. Sva kazivanja su izložena u originalnom dijalekatskom izričaju te su na taj način prvi put prezentirana javnosti. Izložena kazivanja autori valoriziraju te im otkrivaju podrijetlo i mitsku pozadinu. U radu su prezentirana i kazivanja koja su prvi put dokumentirana a govore o demonu crnog ovna koji živi na dnu rijeke. Uz motiv crnog ovna i vilinskih priča u radu se obrađuje i motiv čovjeka-vuka koji se djelovanjem i pojavom razlikuje od vukodlaka.
\end{abstract}

Ključne riječi: lastavica, div, vile, crni ovan, čovjek-vuk, vračanje, vile i konji, kućepazitelj

Promatranje ostataka poganskog vjerskog fenomena u neretvanskoj dolini zanimljivo je upravo zbog raznih miješanja kultura i njihovih stapanja u mediteransku cjelinu vjerovanja prožetu kroz kršćanstvo, koje je, za razliku od drugih dijelova hrvatskog teritorija, na ovaj prostor došlo puno kasnije. Naravno, kršćanstvo kao sustav vjerovanja i kao pokret širilo se ovim krajem i prije njegovog legalnog ustoličenja.

Ovo istraživanje najviše se bavi ostatcima i utjecajima stare slavenske vjere na kršćanstvo na prostorima neretvanske doline s posebnim osvrtom na prodiranje i infiltriranje kršćanskog nauka. Analiziranjem prikupljenih predaja, legendi i vjerovanja stanovništva ovog kraja pokušat će se utvrditi u kolikoj mjeri je stara slavenska vjera ostala ukorijenjena u narodu koji se pokrstio posljednji od hrvatskih plemena.

Prilikom preoblike iz slavenskog u kršćansko vjerovanje zaostali su mnogi elementi poganstava koji su postali i dio lokalne vjere. Posebno je značajno osvijetliti ostatke magije i religijsko praznovjerje budući je proces 
pokrštavanja transformirao neka stara slavenska vjerovanja u kršćanska poradi boljeg prijema kod pokrštenika. Na taj način je često Perun preoblikovan u svetog Iliju Gromovnika, Svantevid u svetog Vida itd. O tom problemu će biti više riječi tijekom ovog istraživanja. Sami značaj preoblike istakao je Jozef Holzner, koji kaže da je ,...pretvaranje antičkoga u kršćanski način života i mišljenja najveći događaj u povijesti ljudskog duha“. ${ }^{1}$ Iako ova izjava djeluje smjelo i pomalo napadno, ne smije se zanemariti njezina vrijednost, a i istinitost. Također su se gradile kršćanske crkve na mjestu poganskih slavenskih svetišta s ciljem preuzimanja uloge i značaja. Posebno se pazilo na nadnevke kako bi se mnoge kršćanske svetkovine poklapale s poganskim svetkovinama.

\section{Naslijeđe}

Nevjerojatna je povezanost predaja sa starim slavenskim vjerovanjima koja su se toliko infiltrirala u današnje stanovništvo da im se i ne zna korijen ni porijeklo. Zanimljivo je da stanovništvo, barem ono starije koje je imalo priliku baštiniti predaje s ognjišta usmenim načinom što se prenosilo $s$ koljena na koljeno, vjeruje u vile i druga mitska bića kao da su to sasvim normalne pojave u svijetu i s tom spoznajom žive kao sustanovnici duhovnih bića. Najčešće se opravdavaju uzrečicom Šta ima imena, ima $i$ simena! te se na taj način mire. Neki stariji stanovnici vjeruju da su vile nastale od Boga te su skoro dužni živjeti s njima, jer kako kazivač Nikola Nikolić ${ }^{2}$ kaže: Ipak ji 'e dragi Bog stvorija, e! Zanimljivo je koliko su neke predaje prožete drevnim vjerovanjima u kojima možemo simbolički pronaći Velesa iako nijedan kazivač nije znao za Peruna, Velesa i Svantevida, ali su jako dobro znali za svetog Iliju Gromoliju što spašava od tuče i suše jer daje kišu. Iako nisu upoznati sa slavenskim poganskim panteonom, dobro znaju za postojanje crnog ovna što odnosi samoubojice utapljanjem u podzemni svijet mrtvih ne sluteći da se iza crnog ovna počesto krije lik Velesa. Da je mitska pozadina neretvanskog kraja bogata i da se iza naizgled običnih priča kriju duboki kozmički sukobi i mitovi, pokazat će se na sljedećim stranicama na kojima će se te teze potkrepljivati pričama kazivača.

Nesvjesnost slavenskog poganstva koje su baštinili od svojih predaka nikako ne umanjuje vrijednost i količinu poganskih vjerovanja koja su se kroz običaje i predaje čuvala u neretvanskom kraju. Zanimljivo je da u predajama starijeg stanovništva postoje drevni mitovi toliko stari da pripovjeda-

${ }^{1}$ Jozef Holzner, Pavao, njegov život i poslanice, hrvatski prijevod Petar Hess, D. I. Zagreb, 1968. predgovor trećem do desetog izdanja.

${ }^{2}$ Nikola Nikolić, kazivač, rođen 1927. u Matijevićima, selu tri kilometra udaljenom od Metkovića. Povremeno živi u Metkoviću iako je cijelo djetinjstvo, mladost i zrelu dob živio u Matijevićima. Radio je kao lučki radnik, sada je u mirovini. Kazivao u lipnju 2007. godine. Zapisao Denis Vekić u lipnju 2007. godine. 
či uopće nisu svjesni te starosti koliko bitnosti čuvanja postojećeg stanja koje ti mitovi poučavaju. Jedan takav primjer je i predaja o lastavici koju je ispričala Draga Vekić, koja je cijeli život živjela u selu Borovci nekoliko kilometara udaljenom od Metkovića:

Nemoj slučajno gađat lastavicu ili joj srušit gnjizdo! Ona je zakrilila repon sunce da ga zmija ne poide pa joj je zato onakav rep jer je sunce opržilo. Da nije nje ni nas ne bi danas bilo! ${ }^{3}$

Ovakvo kazivanje vezuje se za jedan pradavni mit o postojanju dva sunca koja su sjala na nebu u vrijeme kad je zemlja bila „mlada“. Prvo je progutala zmija ili pak zmaj, a drugo nije uspjela pojesti. U ovom slučaju, lastavica je sakrila sunce svojim repom da ga zmija ne nađe i proguta. Kako joj je rep bio blizu sunca, po predaji, opržio ju je tako da je nastala polukružna linija repa koja se i danas može lijepo vidjeti na lastavici. Sličnih kazivanja u različitim varijantama ima i drugdje u Hrvatskoj, posebice u Zagori, Slavoniji, pa i u Vojvodini. Međutim, značajno da je lastavica omogućila opstanak života na Zemlji. ${ }^{4}$ Kazivač Nikola Nikolić napominje kako se priča o lastavici koja spašava sunce pripovijeda još jedino u Dalmatinskoj zagori na prostorima nekadašnje Poljičke Republike.

Postoji također jedna priča koja govori o Mjesecu i drevnim bićima iz osvita vremena koju je kazivao Ilija Klemo Vekić 1994. godine:

To ti div oda noću po svitu sa lampom i skuplja zvizde u vriću. Ma ti je on traljav pa zapne o kakvo brdo ili planinu i padne a sve mu se zvizde prospu iz vriće. Iduće noći on ti opet upali svoju lampu pa opet skuplja zvizde u vriću! I tako ti on svake noći skuplja zvizde jerbo se mora svanit! $!^{5}$

Ova priča o divu koji skuplja zvijezde jedina je priča prikupljena u neretvanskom kraju o divovima uz priču pod imenom $D \not ̌$ ini. ${ }^{6}$ Nazivanje divova imenom $d z ̌$ in potječe od istoimene turske riječi koja ima isto značenje. Ljudi su govorili da su divovi bili veliki i strašni jer kad se kopao kanal, našli su

\footnotetext{
${ }^{3}$ Kazivala: Draga Vekić rođ. Vekić (1928.-2001.), živjela u Borovcima, kazivala 1993. u Borovcima. Draga Vekić je čula ovu priču u svom djetinjstvu (1936.-1940.). Zapisao Denis Vekić god 2007. u Metkoviću.

${ }^{4}$ Jadranka Grbić: Dekodiranje ovozemaljskih čina: vjerovanja o životinjama u hrvatskoj etnografiji - Kulturni bestijarij: II.: iz mitske i etno faune, Biblioteka nova etnografija, Zagreb, 2007.

5 Kazivao Ilija Klemo Vekić (1928.-1997.), cijeli život živio u Borovcima, kazivao god. 1994. u Borovcima. Zapisao Denis Vekić god. 2007. u Metkoviću. Ne zna se iz koje godine priča potječe.

${ }^{6}$ Maja Bošković-Stulli: U kralja od Norina: Priče, pjesme, zagonetke i poslovice s Neretve, Galerija „Stećak“ Klek; Metković - Opuzen, 1987.
} 
Vanda BABIĆ \& Denis VEKIĆ

ljudske kosti koje su bile toliko velike da se pričalo da su to kosti od diva. Priče o divovima u neretvanskoj dolini vežu se za drevna razdoblja, a važno je napomenuti da ih Neretvani spominju kao one „koji su bili tu prije nas“. Priče o divovima vezale su se uz ilirske grobne gomile koje su sadržavale kosti ljudi koji su bili visoki, po procjeni lokalnog stanovništva i do dva metra i četrdeset centimetara. Takvih gomila je velik broj u ovome kraju tako da stanovništvu nisu nepoznanica. Nikada ih nisu rušili nego su se prema njima odnosili s poštovanjem. Iako su se priče o divovima iz grobnica odlikovale poštovanjem prema mrtvima, u ovoj priči Ilije Kleme Vekića, div je zadobio osobine kao što su šeprtljavost i strpljenje koje se očituje u mirnom i uzastopnom sakupljanju zvijezda koje je vršio kao nekakvu dužnost koju je dobio od gospodara. U rečenici u kojoj se kaže: I tako ti on svake noći skuplja zvizde jerbo se mora svanit!, uočava se neumitna sila koja uređuje svijet koji drži u konstantnom poretku. Zora sviće unatoč tome što div pada preko planine i gubi zvijezde. S idejom neumitnog poretka želi se reći da čak ni div, iako je snažan, velik i moćan, ne može utjecati na poredak koji se neprestano ponavlja. Takva verzija priče podsjeća na Regoča, legendarnog diva iz priča. ${ }^{7} \mathrm{U}$ tom fragmentu priče vidi se osjećaj nemoćnosti u kojoj se zauzima stav pomirenja u kojem se ne može promijeniti svjetski poredak jer su ljudi nemoćni učiniti takvo što. Međutim, nihilizam nije bit ove ideje o nemoćnosti malog čovjeka u vječnom poretku, već je zastupljen kao indiferentni stav poslušnosti u kojoj se nalazi smiraj. Priče o divovima ili kako ih puk naziva džinovima poznate su diljem Dalmacije i Zagore.

Nikakva vrijednost nije dana planetarnom sustavu u kojem je Mjesec obično uz Sunce zauzimao važno mjesto. Mjesec se odjednom pretvorio u lampu, svjetiljku kojom se služi div potpuno superiorno. Kretanje Mjeseca podređeno je kretanju diva te je njegova vrijednost podređena u ovoj priči.

Mjesec je u pričama u neretvanskoj dolini simbol i pokretač vukodlaka i vještica, on je magično povezan s vukodlacima te ih može pretvoriti u prave pošasti. Priču o čovjeku-vuku ispričao je kazivač Nikola Nikolić ${ }^{8}$ :

Čovik, kad zaspe, pa kad ne zna šta će diviji kakav je, budi vuk! E! Jer ne zna šta je san, a šta je za stvarno. To ti je kad se čovik noću iznemiri, pa budi vuk! On je zaminija san za stvanost, tu nema normale, on je zaminija san za istinu, njemu je to isto. E, ali to je zlo, to nije dobro da se čoviku desi jer naši kažu: San je lažota, ali je Bog istina!

${ }^{7}$ Ivana Brlić-Mažuranić: Priče iz davnine, Znanje, Zagreb, 1994.

${ }^{8}$ Nikola Nikolić, kazivač, rođen 1927. u Matijevićima. Isto, str. 13.

${ }^{9}$ Kazivao Nikola Nikolić, zapisano u lipnju 2007. godine u Metkoviću. Zapisao Denis Vekić. Kazivač je čuo priču kao mladić, oko 1940. godine. 
Zanimljivo je da pripovjedač ne kaže za ovakvog čovjeka da je vukodlak:

No, no! Ovo ti nije vukodlak, oni plaše i kolju po kućama. Ovo je vuk, razumiš, on je zaminija san za dan!

Ovime se htjelo reći da je on poprimio osobine životinje koja je aktivna noću jer je tada lovac. Poistovjećivanje čovjeka koji izgubi kontrolu nad sobom u snu jako je interesantno budući da opisuje konkretne psihološke pojave koji se manifestiraju dok čovjek mjesečari. Ovdje se najvjerojatnije radi o mjesečarenju budući da kazivač navodi kako je čovjek-vuk zamijenio san za javu u kojoj je taj čovjek aktivan te je moguće vidjeti da spava a ponaša se kao da je budan. I onda, kada u snu djeluju instinkti bez moralnih ograničenja, čovjeka se poistovjećuje sa životinjom koja djeluje po principu instinkta. Zanimljivo je da je mjesečaru dana osobina vuka jer je vuk noćni lovac i nadasve krvoločan tako možemo pretpostaviti da je mjesečar znao biti nasilan te da je mjesečarenje faza prelaska u vukodlaka. Međutim, u pričama vukodlak uvijek nastaje od mrtvaca, za razliku od mjesečara, koji je živ, a poslije se ne sjeća što je radio. Zbog toga su mjesečari u narodnom vjerovanju bili na najboljem putu da postanu vukodlaci kada umru te se na njih prijeko gledalo. Također je važno spomenuti istraživanje Pietera Plasa, koji epileptičke simptome tumači narodnim vjerovanjem da je čovjek dobio „,vučju bolest“. U svom istraživanju tumači vezu vučje naravi sa naravi epileptičara te pučko-etimološkom analizom veže padavicu s ,gorskom bolesti“. „Gorska bolest" navodi kao jedan od naziva za epilepsiju a budući da su vukovi vladari gore i šume, analogno tome je padavičarima pripisana vučja narav. Plas također u istraživanju dolazi do zanimljivih rezultata u kojima kroz recepte pučke medicine otkriva mnoštvo detalja vezanih za pripremanje lijekova za padavicu. Najvažniji su oni koji u svom receptu sadrže vučje organe koji se na razne načine pripremaju i spravljaju ne bi li bolesnik ozdravio. Vuk je ovdje predstavljen kao lijek a i kao uzrok bolesti, odnosno kao asocijativna veza simptoma padavice. Kao zaključak njegova istraživanja i kao jedno od gledišta koje bi moglo objasniti uzrok pretvorbe čovjeka u vuka u spomenutom kazivanju može se izdvojiti Plasova rečenica: „Ovaj drugi aspekt veze 'vuk epilepsije' (...) se sastoji u istovjetnoj pučko-kulturnoj konceptualizaciji simptoma i predikata asociranih s padavicom i vukovima, drugim riječima, $u$ pučkoj sinonimiji koju čini metaforičko izjednačavanje 'vučjih predikata' sa simptomatološkim predikatima epilepsije.“ ${ }^{\text {10 }}$

${ }^{10}$ Pieter Plas: „Ko kurjaka pati, taj će padati s gore: intertekst vuka i epilepsije u tradicijskoj kulturi zapadnojužnoslavenskog areala" - Kulturni bestijarij: II.: iz mitske $i$ etno faune, Biblioteka nova etnografija, Zagreb, 2007., str 135. 
Mjesec nimalo pozitivno ne djeluje na ljude, a najviše utječe na žene, za koje kazivač Nikola Nikolić ${ }^{11}$ kaže: Sve žene kad je pun misec nemaju mira, on im nosi snagu. Zatvaraju oči kad se minja misec. Ovakvo vjerovanje da Mjesec odnosi snagu ženama veže se za drevna lunarna vjerovanja u kojima je Mjesec simbol ženstvenosti i plodnosti. U nekoliko predaja kazivači znaju reći da su sve one žene kojima pun Mjesec oduzima snagu zapravo vještice te da su te noći išle na vještičji sastanak. Na taj način su vještičji običaji magijski povezani s punim Mjesecom, kada su i vukodlaci aktivni.

\section{Kult mrtvih i zagrobni život}

Štovanje predaka i heroja, od pamtivijeka postoji u ljudskom rodu te tako nije izuzetak ni u slavenskom življu. To se štovanje u kršćanstvu obavlja kao religijska dužnost uz ostale obrede. Iz drevne dužnosti obožavanja Boga proizlazi i obaveza štovanja starijih i dužnost iskazivanja počasti i zahvalnosti preminulim precima. ,Smrt je u hrvatskoj tradicijskoj kulturi nešto što je stalno pored čovjeka i memento mori je nešto sasvim prirodno, stvarno i uobičajeno. Štoviše, nema pred njom drhtanja..." ${ }^{\prime 12}$

Kad bi pokojnik umro, slijedeću noć su uz njega bdjeli ukućani sa osobom najstarijom poslije pokojnika te se molilo do zore i prisjećalo se pokojnikovog života. Često bi se na takvim bdijenjima znale pričati priče zastrašujućeg karaktera te mnoge predaje vezane za vukodlake. Jedan od sudionika bdijenja je rekao da se bdije u slučaju da pokojnik postane vukodlak. U slučaju da se to dogodi, svi ukućani ga zaskoče.

U ovom slučaju ukućani ne primjenjuju nasilne metode kojima bi se spriječilo čovjeka da se pretvori u vukodlaka. Da postoji i drugačiji način, spominje Luka Lešo u svom radu $^{13}$ te navodi kako se ljudima, da ne bi postali vukodlaci, režu tetive ispod koljena ili im se zabijaju čavli u pete. To se radilo ne bi li se spriječilo vukodlaka da po noći izlazi iz groba. Ako bi se i otkrilo vukodlaka, ubijalo ga se na razne načine u grobu. Takvo što se radilo uz prisustvo svećenika. Vjerovanje da se duša pokojnika može vratiti na zemlju toliko je često da seljanima to postaje svakodnevica. Ako se nekome u snu javi pokojnik ili ako netko ispripovjedi da ga je sreo na putu, odmah se ide kod svećenika kojemu se obraćaju da plate misu za smiraj pokojnikove duše. Bitno je istaknuti da se ,vukodlačenje“ u predajama neretvanskog kraja pojavljuje češće od pretvorbe u vampira. Znalo je biti slučajeva u kojem seljani

\footnotetext{
${ }^{11}$ Nikola Nikolić, kazivač, rođen 1927. u Matijevićim. Isto, str. 13.

12 Stipe Botica: Biblija i hrvatska kulturna tradicija, vlastita naklada, Zagreb, 1995., str. 26.

${ }^{13}$ Luka Lešo: „Vjerovanja u bića koja se pretvaraju u životinje“ - Kulturni bestijarij: II.: iz mitske i etno faune, Biblioteka nova etnografija, Zagreb, 2007.
} 
Pretkršćanska vjerovanja u dolini Neretve

zovu svećenika da poput vrača istjera zle duhove iz kuće i da umiri dušu pokojnika ili da ih spasi od vukodlaka. Svećenici su znali vršiti službu boraca svjetla protiv sila tame. Još se nijednom nije čulo da neki svećenik nije uspio otjerati zloduha, ubiti vampira ili vukodlaka te da nije uspio dignuti zle čini s osoba i životinja. Takvi slučajevi postoje i dan danas po cijeloj dolini i u ljudima je duboko ukorijenjena ideja da postoje vještice koje bacaju uroke, da postoji crna magija i móre. O takvim kazivanjima bit će riječi u sljedećem poglavlju.

\section{Crna magija}

Vračanje, gatanje, bacanje zlih čini i kletvi te njihovo otklanjanje i detektiranje vještica i danas su dio svakodnevice neretvanskog čovjeka. Iako su žene puno dublje uvučene u ovu problematiku, ni muškarci se ne suzdržavaju od odlazaka svećeniku jer ih je netko ukleja. Kazivači su nadalje podrobno upozorili na neke osobe koje se mogu sresti a da se i ne zna da su vještice. Govorili su da ih se treba kloniti jer Đava nit' ore nit' kopa!, on samo na zlo misli. Bilo je i svjedočenja kako ih je netko prokleo i onda bi se analizirali minuli dani i tjedni i prisjećalo se tko im je ikad kakvu kletvu izrekao. A najčešće su to priče o ukletoj stoci.

Kao zaštitni element koristila se krštena voda, lovorika na okvirima prozora, blagoslovljena sol te posebna biljka zvana kućepazitelj. To je biljka slična kaktusu, zvjezdastog cvata i mesnatih listova. Raste po cijeloj Dalmaciji a ljudi ju sade uvijek blizu kuće i obično od njih stvaraju velike grmove. Ljudi kažu da ih štiti od zla. Kažu da, ako se posadi kućepazitelj, neće Sotona ući u kuću. Kućepazitelj je univerzalni zaštitnik domaćinstava koji tjera od kuće sve zlo koje bi joj jednom moglo zaprijetiti. Svjedoči se za kućepazitelja: Kućepazitelj bija i unda ga se stavlja kod lastavice. I kad bi neko to bacija unda reci: „Sad će Sotona u kuću! “14

Međutim, uvijek nekakva móra, vještica ili štringa, kako ju često nazivaju, proklinje, a to ćemo vidjeti u sljedećim svjedočenjima.

Nikola Nikolić kazivao je jednu priču o naglom nestanku mlijeka kod njegove krave i tvrdi da je to bilo 1994. godine.

Tako se bila u nas otelila krava i ni kapi mlika, a vime gori. Tele gruva a ni kapi mlika. Tako tri dana. Doša i čovik ode popu da kaže šta je. Kad on njima na vratima odma rekne: „Eto mene odma!

${ }^{14}$ Kazivao Nikola Nikolić, rođen 1927. u Matijevićima, selu 3 kilometra udaljenom od Metkovića. Povremeno živi u Metkoviću iako je cijelo djetinjstvo, mladost i zrelu dob živio u Matijevićima. Radio je kao lučki radnik, sada je u mirovini. Zapisano u lipnju 2007. godine u Metkoviću. Zapisao Denis Vekić. Kazivanje čuo u ranom djetinjstvu, do 1937. godine. 
Di ste ima već tri dana!“ Kad šta je? Ta jedna šta se zna da je štringa došla u moji kupit mliko, a oni nisu tili prodat. Sutra, eto ti nema mlika! Doša velečasni i stavija štolu na se, i bacija štolu pod noge i reka Bogu i Kristu: „Ako mi ne uslišite ovu molitvu, ne priznajen te bogon živin, a svaka kap znoja ko krv iz njega!“ To sve za oltaron bilo. Tada zahvali Bogu šta ga je uslišija i unda blagoslovija sol. Sol dali kravi i sutra odma mlika ko vode. Čemu ima ime, ima i sime! ${ }^{15}$

U ovoj priči najinteresantnija je situacija u kojoj svećenik zaziva boga i Krista što se može tumačiti kao da se zove više njih, a Oni su zapravo On jedna božanska osoba. Međutim, već u sljedećim rečenicama vidi se zahvala jednom Bogu, što je i logično. Bio propust kazivača ili ne, zanimljivo je vidjeti da se božanske osobe Otac, Sin i Duh Sveti mogu smatrati kao zasebne božanske osobe. Također je značajno primijetiti da se vidi način na koji se skidaju zle čini. Svećenik je bacio štolu, za narod možda najsvetiji dio svećeničke odjeće, te zaprijetio Bogu što je u ovom slučaju gotovo heretično jer se vjernik, a pogotovo svećenik ne može tako lako odreći Boga. Međutim, tu se vidi i apsolutno povjerenje koje svećenik gaji prema Bogu jer on činom izazivanja uopće ne niječe Boga već ga time i veliča jer on ne sumnja u pomoć. Svejedno, metoda skidanja čini je izrazito magijska jer se vrši posredstvom Boga. Također, svećenik je u ovom kazivanju pokazao sposobnosti vidioca koji može vidjeti a da i ne zna za neki događaj.

Ovo je rijetka situacija u kojoj osoba koja je napastovana odlazi prvo svećeniku jer su ljudi skloni otići prvo lokalnoj vidarici da im spravi kakvi napitak za otklon čini. Međutim, nisu samo svećenik i vidarica oni kojima se seljani obraćaju. Znaju se obratiti i pravim vješticama te zatražiti da se baci kletva na susjeda ili propalu ljubav. Jedan od najtežih zločina bio je traženje smrti netom rođenom neželjenom djetetu. Takvu jednu situaciju ispričao je također Nikola Nikolić.

Tako ti je bila u nas živa štringa! Jedan divojki napravija dite. On govori toj štringi: „Kako ću se ja toga diteta rješit, a neću se ženit za tu divojku.“ Kaže ona: „Želiš li ti to?“ - „Želin.“- „Ujtru neće bit živ!" Tako je i bilo, ujtru dite umrlo! Odma ti je ujtru umrlo! To ti je istina živa. Tako je toj štringi jedan svećenik koji je nikad nije vidija na misi reka kad je donila dite krstit, kaže on njoj s oltara:" Ko ti je da to dite sotono! A ona ga gleda i sve kolači oči. E!“16

Ova priča je svjedočanstvo u kojem je prikazano djelovanje crne magije i vještice. Bez premišljanja, prvo pitanje je postavila mladiću u namjeri da

\footnotetext{
${ }^{15}$ Zapisano u lipnju 2007. godine u Metkoviću. Zapisao Denis Vekić.

${ }^{16}$ Nikola Nikolić tvrdi da se dogodilo osamdesetih godina XX. stoljeća. Zapisano u lipnju 2007. godine u Metkoviću. Zapisao Denis Vekić.
} 
prenese grijeh na njega jer je od nje tražio smrt tek rođenog djeteta. Kada je dobila potvrdu, spremno je odlučila to i napraviti. Iako se u priči ne govori na koji je način vještica djelovala, dijete je umrlo u svojoj kući navodno prirodnom smrću.

Također, postoji jedna priča u selu Borovci koja govori o mladiću koji je išao u vojsku krajem devetnaestog stoljeća. ${ }^{17}$ Noć prije polaska, dok se $\mathrm{s}$ puškom na ramenu vraćao iz polja gdje je čuvao lug, u šumi ga je zatekao gorući grm. Kad je potrčao da ga ugasi, grm se vratio u prvotno stanje, a vatra se pojavila pedeset metara dalje. Kad je iznova potrčao prema vatri, ona je opet misteriozno nestala te se opet negdje u blizini pojavila. Ne želeći riskirati, uzeo je pušku i pucao u grm kad god bi se ovaj zapalio. Tako je radio nekoliko puta te je ujutro došao kući i otišao u vojsku. Nakon tri godine se vratio iz vojske. Međutim, na početku sela su ga zaustavili roditelji jedne djevojke i zamolili ga da svrati kod njih prije nego dođe svojoj kući. Tu su mu objasnili da je djevojka oboljela od strašne bolesti one noći kad se on vraćao kući iz polja. Bila je iz sela blizu mjesta gdje su gorili grmovi. Kad ju je sam posjetio u bolesničkom krevetu, vidio ju je prekrivenu ranama koje ne zacjeljuju. Ona mu je dala terluke ${ }^{18} \mathrm{i}$ istog dana umrla. Mladić se vratio kući. Pričalo se da je djevojka bila vještica te da je vatra služila kao zavođenje, mamac ne bi li te noći došao $\mathrm{k}$ njoj. ${ }^{19}$

U ovoj priči iz Borovaca, vještica je postala žrtvom nesreće i nesporazuma, a služila se magijom u svrhu ljubavi.

Prema predaji, vještica je stvarna osoba koja koristi crnu magiju kao posredsvo svoga djelovanja. To je bezobzirna osoba koja nije tražila naknadu za svoje djelovanje, što će reći da su te žene prožete mržnjom prema svemu živom što podsjeća na Boga.

Svećenikovo prozivanje spomenute žene Sotonom izravni je dokaz da se kršćanstvo ograđuje od crne magije te da je oštro optužuje i odbacuje. Zanimljivo je da se u kazivanju napominje kako je svećenik nije poznavao, ali da je prepoznao njezinu narav i djelovanje. Takav način prepoznavanja naglasio je svećenikovu vrijednost koja djeluje kao dijametralno suprotna vrijednost života koji djeluje u duhu Svjetla i Boga. Iako je magija varljivo područje vjere, a zastranjenja su moguća i kod dogmatičnih vjernika koji magiju doživljavaju kao dio Božje moći, vladanja i djelovanja, gledanje na magiju

\footnotetext{
${ }^{17}$ Smatra da se zbilo oko 1880 . godine.

${ }^{18}$ Terluci - kratke vunene čarape koje dosežu samo do skočnog zgloba, nose se zimi umjesto kućnih papuča ili kao pojačanje za zaštitu od hladnoće.

${ }^{19}$ Kazivao Jure Ante Vekić, rođen 1953. godine u Borovcima, gdje je proveo djetinjstvo i mladost. Živi u Metkoviću i radi kao profesionalni vozač. Zapisano u lipnju 2007. godine u Metkoviću. Zapisao Denis Vekić. Kazivač je čuo priču kad mu je bilo dvadesetak godina, negdje oko 1973. godine.
} 
kao na silu dobra rasprostranjeno je kod seoskog stanovništva i ponekad korelira s bliskošću s Bogom kroz koju se manifestira snaga svećenika koji upravo tom silom pospješuje izlječenje.

U sluge crne magije neretvanskog kraja ubraja se i fenomen móre koja u obliku djevojke napada muškarce a i žene dok spavaju. Najčešće se radi o djevojkama koje su upoznale niže sfere magije te se njome koriste u privatne svrhe. Situacija kod napada od strane móre je situacija gušenja, mučenja i izmaranja osobe dok spava. Metoda je to zastrašivanja, privole i promjene mišljenja. Nisu rijetki slučajevi u kojima djevojka dolazi kao móra mladiću koji joj se sviđa te ga mučenjem nastoji privoljeti da ju on uzme za djevojku. Takav način prisile uopće nije rijedak, ali se također radi i o čistoj mržnji naspram žrtve koju želi mučiti dok ova ne poludi ili umre od nemoći. Ponekada se spominje da se móra pretvara u mačku. To je najčešća pretvorba móre u ovom kraju iako Luka Šešo navodi pretvorbu móre u muhu, kokoš ili pak vola. Obilježja móre su po cijeloj Hrvatskoj uglavnom slična i slično se i manifestiraju mučenja koja one izvode nad mladićima. Jedno od svjedočenja izvrsno opisuje situaciju u kojoj móra muči mladića i jasno se opisuje razrješenje od muka koje je mladić bio prisiljen trpjeti. Ovo svjedočenje govori o tom mladiću, a zbilo se u Borovcima blizu Metkovića četrdesetih godina dvadesetog stoljeća.

Tako ti je jednoga našega u selu mórila móra nekoliko dana! Svako jutro on ti se diza vas satran i taj dan nije moga sobon mrdnit! Sve ga bolilo! Priča je on da ga je to neka divojka iz sela mórila i da zna koja je! Kaže on da mu je sila na kolina i da ne more mrdnit, jedino kad bi prid zoru tila ić ća, on bi se trznija zadnjom snagon da je u bisu uvati! Već je on pokuša prvi par dana nju ulovit, ali čin bi se probudija ona bi ti se nekako iskobeljala i nestala! Ali jednog jutra ju je uspija sčepat za kosu! Ona stala kukat i vikat! Ona njemu stala preklinjat i molit sve umiljatin glason da je pusti da ga više neće morit! Jer ako dočeka jutra i da je svit vidi ubili bi Boga $u$ njoj! On ti tako nju nakon nagovaranja pusti i otad ga nije nikad morilo! Nikad nan nije reka koja je to bila. ${ }^{20}$

Kao što je bilo i za očekivati, u pričama poput ove o móri izrazit je motiv muško-ženskog sukoba. On se nameće kao jedina okosnica ove priče, za koju mještani tvrde da je istinita. U tom slučaju, djevojka na nekakav način ulazi u sobu, paralizira spavača sjedanjem na njegova koljena te u nekakvoj opsesivno-hipnotičkoj maniri daje žrtvu na razne muke. Uspoređujući

${ }^{20}$ Kazivao Ilija Klemo Vekić (1928.-1997.), cijeli život živio u Borovcima, kazivao god. 1994. u Borovcima. Zapisao Denis Vekić god. 2007. u Metkoviću. Kazivač je čuo priču oko 1940. godine. 
ovu priču s grčkim predajama o čudnim nimfama, ženama koje imaju krila i koje dolaze mladiću dok spava te ga napastuju, ne mogu se ne naći poveznice. Naime, u grčkim legendama o nimfama koje napastuju mladiće bilo seksualno, bilo fizički, također je prisutan sukob muško-ženske naravi. Simptomi su isti nakon buđenja mladića te se on nalazi u stanju iscrpljenosti i nemoći. Jedino što mu je ostalo od prethodne noći jesu bol i sjećanje na onu koja ga je mučila. Često puta žrtva o tome ne priča, jer bi móra zaprijetila da će ga nastaviti móriti do smrti ako treba, ali se ne smije saznati što mu je bilo. Neki mladići su propadali po nekoliko tjedana te bi tek pred smrt rekli što je sve bilo. U istočnjačkim vjerovanjima također je prisutna legenda o Succubi. Succubi je bila demon koja je u snu dolazila mladićima te bi ih seksualno iscrpljivala i ponekad bila uzrokom mladićeve impotencije. Međutim, za razliku od Succubi, móre bi mučile mladiće u budnom stanju, ali bi oni bili toliko paralizirani da nisu mogli ni viknuti ni reagirati, kao da ga ih drže u nekakvom hipnotičkom transu iz kojega se mogu izvući tek kada móra otiđe u zoru. Seksualno zlostavljanje ostaje nepoznanica u pričama o mórama jer se isticala samo fizička osnova zlostavljanja u kojoj bi mladići znali dobiti i vidljive znakove nasilja; rane, ogrebotine i ugrize. Suzana Marjanić u svom istraživanju nadalje navodi da se u hrvatskim usmenim predajama: ,u kojima vile i vještice ostvaruju jahanja na muškarcima riječ je o ikonografskom binomu u kojima vješte žene preuzimaju ulogu incubusa, a muškarac, koji pritom ostvaruje pasivnu (femininu) ulogu succubusa, nalazi se u ekstatičnoj obamrlosti svijesti““. ${ }^{21}$ Takva „obamrlost svijesti““ može poslužiti kao osvjetljivač situacije u kojoj mladić ne može učiniti ništa što bi ga spasilo jer je ukočen i umrtvljen.

Može se zaključiti da je móra mogla biti bilo koja djevojka iz sela kojoj je bio poznat način pretvorbe iz djevojke u móru. O pretvorbi se može reći samo to da su očito postojale jer su mladići svjedočili o tome da su zaključavali vrata i prozore od straha da im móre opet ne dođu. U takvim slučajevima one bi se samo stvorile u sobi te bi napale u trenu kad se osoba probudi. Poneke su morile i u snu, a ujutro bi ostali vidljivi znaci mučenja. Po svjedočenjima mnogih mladića, a i starijih ljudi, móre su bile sasvim obične djevojke i često puta uljudne i poželjne u društvu. Selo bi ih znalo cijeniti ne znajući za njihove noćne avanture. Međutim, takve djevojke su koristile razne načine da privole ljubav odabranika ili da mu naprosto napakoste.

Posebno je zanimljiv motiv kose $u$ gore navedenom kazivanju. Rečeno je kako je mladić, u trenutku mórinog odlaska uspio uhvatiti njezinu kosu te

${ }^{21}$ Suzana Marjanić: „Antropopornografija ili životinja kao skopofilijski i seksualni predmet“ - Kulturni bestijarij: IV. „Machina animata“ i prava životinja, Biblioteka nova etnografija, Zagreb, 2007. str. 761. 
je čvrsto sputati prisilivši je da ne pobjegne te da mu više ne naudi. Jedna takva situacija postoji i u predajama o vilama. Ilija Klemo Vekić pripovijeda:

Ma šta! Vilu ako je oćeš imat za sebe, moraš je jamit za kosu i zapritit da ćeš je isčupat! Odma će te molit i kumit, ali ne posustaj nego samo drži. Ona će tvoja bit jerbo kad isčupaš dlaku kose ili ako ju prikineš, to je za nju smrt, ona bi rađe umrla nego bi da joj se to desi! ${ }^{22}$

Jedna takva priča također svjedoči o važnosti kose kod vile. Ilija Klemo Vekić kaže:

Vile, kad bi in se kosa zaplela u draču ili tako nešto onda bi dozivali čobana da in to odriši iz drače. Kad bi čoban, jadan, pristana to one bi ga ucjenile da ako prekine ijednu vlas da će ga ubit na licu mista. A ako bi uspili razdrišit, a da dlaka ne pukne, dat će mu puno sriće! $!^{23}$

Pridavanje važnosti jednom takvom predmetu kao što je kosa povezuje se sa kultom duge kose. Međutim, poštivanje kose kao bitnog dijela tijela nadišlo je svoj početni smisao te je nastalo vjerovanje da u kosi leži snaga i moć. To će izravno podsjetiti na biblijski lik Samsona, čija je snaga počivala u kosi i koju se nije smio ošišati jer će s njome izgubiti i svu snagu. Isto tako, u ranom srednjem vijeku je postojao običaj kod sjevernijih barbarskih naroda po kojem su samo kraljevi i njihove obitelji mogli imati dugu kosu. Duga kosa je tako bila privilegija vladara. Takvo razlikovno odavanje počasti dugoj kosi podsjeća na jedan pradavni iranski običaj koji je postojao na ovim prostorima, kao i u Dalmatinskoj Zagori polovicom dvadesetog stoljeća koje se naziva „šišano kumstvo“. Ne zna se je li taj običaj narod Zagore i neretvanske doline baštinio kroz povijest ili je to bio običaj uveden ,na divlje“ povodom teorija o iranskom podrijetlu Hrvata, koje su nicale za vrijeme Drugog svjetskog rata i nakon njega. Bilo kako bilo, u tom običaju se slavilo prvo šišanje muškog djeteta u kojem bi mu se duga kosa, koja pada već na ramena, šišala. Pritom bi tu bio i djetetov kum šišanja koji se nazivao „,̌išani kum“ a sam običaj „,̌išano kumstvo“.

Kosa, kao osjetljivi dio tijela jedne vile postala je mistificirana te je značila život ili smrt. Kod mladih djevojaka kose su se plele u pletenice vjerujući da tako sputane u sebi kriju snagu. Zanimljivo je promatrati koliko su važnosti najstarije stanovnice sela pridavale kosi i pletenicama. U neretvan-

${ }^{22}$ Kazivač je čuo priču u svom djetinjstvu (tridesetih godina dvadesetog stoljeća), a ispričao ju je 1993. godine u Borovcima. Zapisao Denis Vekić 2007. godine u Metkoviću.

${ }^{23}$ Kazivač je čuo priču u svom djetinjstvu (1930-ih godina) a ispričao ju je 1993. godine u Borovcima. Zapisao Denis Vekić 2007. godine u Metkoviću. 
Pretkršćanska vjerovanja u dolini Neretve

skom kraju ponekad se može čuti i kritika upućena djevojci koja nije splela kosu jer na taj način zavodi mladiće. Smatra se da spletena kosa zrači pozitivnom energijom te da se na taj način djevojka najbolje može predstaviti mladićima.

Zanimljivo je uočiti podudarnost s vilinskim pričama. Podudarnost nije nelogična i nepremostiva stoga što postoje i priče u kojima vile imaju dugu kosu koja je doticala sam pod a znala je biti i duža. Kosa je ponekad vilama bila i oružje.

\section{Vile}

Iako su postojale priče o vilama kao o lijepim ženama u brdima oko Neretve, postojale su i one vile koje su bile sve samo ne lijepe i dobre. Zanimljivo je primijetiti da su lijepe vile obično postojale u onim mjestima koja su daleko u brdima i na višoj nadmorskoj visini, dok su priče o vilama kao zlim i pokvarenim bićima kolale u mjestima smještenim neposredno uz močvare i dolinu. Tako, na primjer u Borovcima, selu 16 kilometara udaljenom od Metkovića, na nadmorskoj razini od 250 metara, mogu se čuti priče o vilama koje su lijepe, ali robuju mani kozjih nogu. Plešu s mladićima i pastirima te ih odvode u svoj svijet. S druge pak strane, u Podrujnici, mjestu 7 kilometara udaljenom od Metkovića i na nadmorskoj visini od 2 metra čuju se priče o vilama tako ružnima i zlima da ih se svi boje i izbjegavaju. Posebno se ističe netrpeljivost djevojaka i vila koje im otimaju zaručnike. Lijeva obala Neretve, koja je pretežito naseljena starosjediocima koji su živjeli u Metkoviću od samog njegovog osnutka, a doselili su se u bježanjima Hrvata pred Turcima iz istočne Hercegovine, sklona je vjerovati da vile vrebaju na mladiće i da se osvećuju djevojkama koje su ljepše od njih. Stav u kojem postoje djevojke ljepše od vila govori o tome kako vile po njihovu vjerovanju nisu bile nadnaravne ljepote te su pribjegle otimanju. Tako, na primjer, postoji brdo iznad Bijelog Vira na lijevoj obali Neretve, čiji se vrh zove Marin vijenac. Predaja kaže da je Mara bila lijepa djevojka koja je pala kao žrtva ljubomore vilâ koje su je jednom zatekle samu te su je ubile. Takvo što se ne može pripisati brdskim selima na desnoj obali Neretve. Očito je da su stanovnici lijeve obale Neretve baštinili mnogo vilinskih osobina iz susjedne Hercegovine.

Vile su, barem u predajama neretvanskog kraja, bez iznimke bile djevojke. Nije poznata ni jedna predaja o vilama iz neretvanskog kraja u kojoj se javlja muški vilenjak ili pak stara vila. Sve su one bile mlade i vezale su se uz priče o zaljubljenima koje su prožete strašću i ljubomorom. To su dva glavna motiva u pričama o vilama te su pokretač i razorna snaga događaja koji često završe smrću i ludilom. Između ljudi i vila u dolini Neretve, nije bilo kompromisa. Ponekad bi mladić pridobio vilu za sebe te se njih dvoje zavole, ali to je toliko rijetko da poprima sfere legendarnog. Postojale su i vi- 
le koje su u dolini i po brdima potajno konjima plele pletenice te su na taj način obilježavale svoje konje miljenike koje su cijelu noć jahale. Jedna takva priča potječe iz Borovaca i ispričao ju je Ilija Klemo Vekić:

Imali ti mi mlada lipa konja. Radija je štono bi se reklo k'o svitlac. Kadno ti jednog jutra mi nađemo njega u štali, a on vas znojan $i$ trzaju mu se mišići od umora. A griva i rep spleteni u sitne uredne pletenice. Nisu ti to one divojačke pletenice već one tanke ko olovka! Bilo i je sam će Bog znat' koliko! A sve svezane konjskon dlakon na kraju. Razdrišili ti mi to, kad, toga jutra u polju on oće da padne s noga, ko nešto umoran. Ajde, taj dan ništa od posla. Ovnoć čuli mi kako nešto klapa u štali, mi tamo, kad konja nema, a svezali ga lipo i zakrakunali ${ }^{24}$ vrata! Šta je sad! U samu zoru, eto ti topota, vraća se konj a jopet pun pletenica! Vas znojan! Toga jutra mi isto razdrišili pletenice, mislili da ga nije ko ureka; ma jopet on neće da vuče u polju, oće da krepa od umora! Treću noć jopet na njemu pletenice! Vidili mi, ima tu nešto više! Ostavili ti mi tako pletenice da stoje na njemu i on radi ko da nikad ništa nije bilo. A cilu noć trča i znojan se vraća u štalu. Tako je sve bilo do jednog dana. Tako ti je to bilo nekoliko godina. Kad više nije bilo pletenica, on ti nakon tri miseca krepa. Stari kažu da tako kad konj ima pletenice da ga to vile vole i da ga one ovnoć jašu a unda ga umorna vrate u štalu. Ma su ti one birale mlade i jake konje da mogu jurcat što brže, e $!^{25}$

Ovakva priča svjedoči o izravnom vjerovanju u povezanost vila i konja, a pogotovo u ljubav za brzim životom i strašću koja je pokretala vile. Priču sličnu ovoj, ali u mnogočemu fantastičnijoj, ispričao je u selu Matijevići Nikola Nikolić. U njoj vile bjesomučno jašu konje i podčinjavaju ih svojoj magiji u tolikoj mjeri da konji lete zrakom bez krila.

One su krale konje i na njima jahale. E, ali je jamila tankovita konja koji može ić brže ća. Ona je činila, on je po zraku iša jer ga je tako stegla da je po zraku iša. Zato su bili znojni. Vile su imale pletenice do šljuka i time konja su vezale, svojon koson.

U prvoj priči vile su voljele konje i posuđivale ih noćima kako bi s njima provodile uzbudljive trenutke $u$ trčanju preko livada i brda. Zahvaljivale su konjima pletenicama i neprestanom brigom o njima. Ako bi se koja pletenica i rasplela, preko noći bi bila ponovno besprijekorno spletena. Takav odnos gorskih vila prema konjima nije bio u drugoj priči u nizinskom dijelu neretvanske doline, u Matijevićima, jer su vile iz doline krale konje i uzimale

\footnotetext{
${ }^{24}$ Zakrakunati - ovdje znači zaključati; zabrtviti.

${ }^{25}$ Događaj se zbio 1988. godine u Borovcima. Kazivač je ispričao priču 1993. godine u Borovcima. Zapisao Denis Vekić 2007. godine u Metkoviću.
} 
one brže. Vila bi ga stegla i njime vladala kosom od koje je pravila uzde. Ovdje se još može izdvojiti dužina vilinske kose koja je sezala do stopala, a bila je spletena u pletenice. U prvoj priči vile su puštale konje da se vrate vlasnicima, a u drugoj priči ne znamo ništa o povratku konja te stoga možemo pretpostaviti da su vile odvodile konje u nepovrat jer su ih ipak krale.

Takvo ponašanje prema konjima jednako je ponašanju s mladićima koje bi zavoljele. Tolika strast je morila vile da su bile spremne sve žrtvovati i sve slomiti da bi dobile što žele. Tako u jednoj priči Nikola Nikolić govori: ...Znali su uništit momka koji in se sviđa. Većinom su lipe cure stradale radi momaka. Znale bi one i unakazit divojki lice, isparat ga dračon ili nečin bodljikavin! Vile su bile gadnije od lipi cura pa su i ništile. Ako je bila lipa divojka, one su je gledale na svaki način uništit da one dobiju te momke.

Ovdje je vidljiva osvetoljubiva narav vila, kao uostalom i njihova strast i tvrdoglavost. Vile, dakle, nisu bile nešto duhovno, poluvidljivo ili prozirno. One su bile dio stare zajednice ljudi i prirode. Nikola Nikolić iz Matijevića o njihovom fizičkom izgledu kaže:

Bilo i je svakakvi, ali bile su većinom crnomoraste i smatrali su ljudi da su one sotone, da nisu to od ljudskoga bića. Dojedna je prkosila! Vile su bile gadnije od ipi cura pa su i ništile. ... Vile su se oblačile u papke ovčije. Nisu one bile gole. Jer su uvik bili sa čobanican, čuvali ovce. One su bile velike ko obično žensko. Vile su imale pletenice do šljuka i time konja su vezale, svojon koson.

Ilija Klemo Vekić iz Borovaca navodi ovakav opis: Ali vile ti imaju kozje noge. One su ti do pasa sa kozjin nogan a gore su ko divojke, samo puno lip̌̌e!

Očita je razlika u poimanju fizičkog izgleda vila. Kod Nikole Nikolića vile su oličenje ružnoće i zla koje proizlazi iz te ružnoće. Imaju dugu kosu i ovčje papke. Kod Ilije Kleme Vekića vile su dvojne prirode; do pasa su životinjskog izgleda, a od pasa su mlade djevojke, samo puno lipše. Pronaći ovakav kontrast u poimanju fizičke i psihičke naravi vila na malom prostoru intrigantna je rijetkost, a time i vrijednost.

Međutim, odnos ljudi i vila ovdje ne prestaje jer su vile bile svakodnevica. Nikola Nikolić ovako opisuje susrete mladića i djevojaka s vilama:

U zoru bi one plesale kolo. Plašile su! Zapriti čobanici. Čobanica ovce čuva i one njoj zapriti da će stado potamanit ako ne otiđe ća. Prkosili su njima čobani i čobanice ali su i' vile potirale jer nisu dale da čobanuju na njiovoj planini. To je bilo po planinan. Vile su se oblačile u papke ovčije. Jer su uvik bili sa čobanican, čuvali ovce. One, ako bi vidile momka, i odnesi ga, momka koga je volila jedna. Ali bi se sukobile za nj! Borile se koja će ga pridobit, ali je on odgovara: „Nijedna, jer ste vi vile, vi ništite!“ Momci su bižali 
Vanda BABIĆ \& Denis VEKIĆ

od nji ko vrag jer su one bile spremne uništit; kad su one pritile ako neš vako, neš nikako, davale su ultimatum. Znale su uništit momka koji in se sviđa. Većinom su lipe cure stradale radi momaka. Znale bi one i unakazit divojki lice, isparat ga dračon ili nečin bodljikavin! Ako divojka momku dođe po vodu njoj ti unda vila zapriti: „Ako nećeš dat da prva poljubin tvoga momka nema ti vode! Zatrovat ću je." Unda divojka dadni da se momak poljubi sa vilon pa uzmu vodu i odoše ća, e. ...Vila, kad bi joj se zamirija kakvi mladić, znala bi zagorkinja vila koson udavit toga momka. Ona je vatala lipe momke, ali momci kažu: „One dave!“ A te su vile bile lipe zdrave divojke, nisu to bile žene, no, nego lipe mlade divojke i unda ona njega zaskoči i sputaj koson i moraš ić. Nema ti druge, mora bi s njon otić. Tada si propa odma. Nema ti povratka! ${ }^{26}$

Ovakvi sukobi s vilama nisu bili rijetkost i često bi loše završili. Posebno je bitno istaknuti kosu kao sredstvo sputavanja i zarobljavanja. Kosa je u zadnjem primjeru krug u koji se zatvara cijeli život. Radi se o starom vjerovanju da, ako se vili kojim slučajem otkine i jedna vlas kose, ona baca prokletstvo na tog zlotvora ili umire. Ubiti vilu je težak zločin koji se nitko nije usudio počiniti. Dakle, ako se mladić bude opirao, vlas kose će negdje puknuti a to znači prokletstvo za njega; ako bi se pak prepustio, vila s njim može raditi što ju je volja. Najčešće je to ljubav ili ženidba, a rjeđe je ples u kolu.

Kosa ima značenje života i spona koje se ne mogu raskinuti bez posljedica. U vilinskim pričama neretvanskog kraja kosa im je sezala do poda te je bila tako bujna da su se vile često zapletale u grmlje ili šumsko granje. Takva jedna situacija dolazi u priči u kojoj je mladić nakon vilinog poziva upomoć pokušao raspetljati zapetljanu vilinu kosu. Obećala mu je sreću i zdravlje ako je raspetlja, a ne prekine niti jednu vlas. Isto tako mu je i zaprijetila, ukoliko tako ne napravi, da će ga učiniti nesretnim čovjekom. U priči mladić uspijeva a vila ga nagrađuje srećom, blagostanjem i naklonošću.

U brdskim dijelovima neretvanskog kraja kolale su priče o dobrim vilama i njihovom povoljnom utjecaju na prirodu. Ilija Klemo Vekić pripovijeda:

Vile ti znaju na lipoj ledini kolo plesat! Di ti one nogon stanu to ti odma tratinčice rastu; zato di vidiš tratinčice di su u krug rasle, tu su ti vile plesale! Ili ako vidiš da je trava ugažena u krug!

Povezivanje vila uz bujanje prirode jako je interesantan motiv, ne toliko zbog vizualnog elementa, koliko zbog kozmičkog obnavljanja prirode. Anđeoska uloga vila se ovdje prekida i počinje se javljati staro vjerovanje u duhove prirode koji pospješuju njen rast. Iako su vile u usmenoj predaji često

${ }^{26}$ Kazivao Nikola Nikolić, rođen 1927. u Matijevićima. Isto, str. 13. Ovo kazivanje je čuo u ranom djetinjstvu, do 1937. godine. 
zamišljane kao anđeoska bića, ovdje se vide tragovi poganskih vjerovanja u prirodu kao Majku svijeta i vile kao duhove prirode. Međutim, vjerovanje u duhove prirode lako možemo pridvojiti bilo kojoj vjerskoj stukturi primitivnijeg karaktera. Gorskim vilama suprotstavljaju se morske i riječne vile. Iako ih se rijetko spominje u usmenoj predaji doline Neretve, postoji kazivač koji tvrdi da one postoje i da nisu nimalo slične onima na kopnu. Evo što je kazivač Nikola Nikolić rekao o njima:

Viđalo se morske vile u riki Neretvi, nego šta! Ona je, ta morska vila, imala rogove! Ali je bila sva runata, nije imala ljuske ko riba, nego runo. Ona izgledala ko divojka. A vile morske i planinke se nisu mogle nikako. Ove su bile u vodi, a ove na brdu, ove ne mogu doli a ni ove iz vode u brdo. Nisu se nikad volile, stalno su se one svađale i nikad se nisu mirile. Ima legenda šta su pričali mornari da bi se one ujtile ankare i uspele se uzanju i unda davi mornara. Ali bi tu bili drugi mornari pa bi je otirali ća. ${ }^{27}$

Morske/riječne vile su, po ovom opisu, davale novu dimenziju duhovnog svijeta u neretvanskoj dolini. Najzanimljiviji je podatak da su morske vile u obliku žene na sebi nosile runo, to jest ovčju dlaku koja ih je štitila od vode. Takvo objašnjenje navodi na zaključak da one nisu voljele vodu iako su bile njezini stanovnici. Samo zaključak da morske vile ne mogu na kopno stavlja ih u sukob s kopnenim, odnosno planinskim vilama. Takav sukob već poprima mitske sfere borbe za prevlast iako ravnoteža ostaje nepovrijeđena zbog nepisanog narodnog zakona da ono što živi u vodi ne može živjeti na kopnu i obrnuto. Iako možemo takvo što smatrati zdravom logikom, nameće se pitanje sukoba gornjeg i donjeg svijeta. U biblijskim parametrima sukobljuju se Život i Smrt, Isus i Sotona. U religijama poput one babilonske, antičke i rimske, sukobljuje se svijet živih predvođen svojim bogovima koji žive na planinama, u dolinama, u morima i rijekama i podzemni svijet koji je ujedno i svijet mrtvih i carstvo boga smrti. U slavenskom sukobu božanstava Peruna i Velesa sukobljuju se planina i voda, svijet živih i svijet mrtvih. Takva jedna paralela s Velesovim podvodnim smrtnim svijetom i s morskim vilama kao predstavnicama vodenog svijeta, može se dovesti u vezu nakon sljedeće priče o biću iz vode što odvodi mrtve umrle nasilnom smrću.

\section{Crni ovan}

Kazivač Nikola Nikolić ispričao je priču: Divojka se bacila $i$ utopila $u$ Norilju. Doša je iz Splita norilac i on je naša. I kaže: „Eto van je tute, ja ne ulazin. Kraj nje stoji crni ovan rogovi mu od metra svaki, jedan s jedne, jedan s druge strane. Ja van doli više ne ulazin." Unda je jedan čovik uzeja

\footnotetext{
${ }^{27}$ Kazivač tvrdi da su se događaji zbili sedamdesetih godina dvadesetog stoljeća.
} 
Vanda BABIĆ \& Denis VEKIĆ

osti, namota joj robu oko ostiju i izvuka je vanka... To ti je bilo šezdeseti godina.

Crni ovan, životinja koja živi pod vodom i prisvaja žrtvu samoubojicu demonsko je biće koje je često poistovjećivano s vragom. U narodu, crni ovan je značio ili skoru smrt onoga tko bi ga vidio ili bi bio vrag koji odnosi duše u pakao. U ovom slučaju, to je demon ili zlo biće koje svojim prisustvom, po narodnom vjerovanju, odnosi dušu osobe koja se ubila, dakle dušu koja nije zaslužila prebivanje u raju.

Poistovjećivanje crnog ovna s vragom, koji je u narodnim predajama također crn i rijetko crven, simptomatično je za cijelo stanovništvo doline Neretve. Isticanje moći crnog ovna/vraga najviše se očituje u mistifikaciji njegovih metarskih rogova. Rog kao simbol moći kod vraga prenesen je u ovom kontekstu na crnog ovna. Najzanimljivije je to što se crni ovan najčešće pojavljuje u pričama gdje se vrhunac razrješava na riječnom dnu. Ta neobičnost u kojoj ovan živ stoji na dnu riječnog korita duboko ispod površine, te se postavlja u ulogu vladara tog područja, ukazuje na nimalo slučajnu poveznicu između crnog ovna i slavenskog boga stoke i podzemlja - Velesa ili Volosa.

Druga priča Nikole Nikolića također svjedoči o crnom ovnu kao o dominantnoj ličnosti koja živi u vodi.

Vozili ti neki gnjoj na svetog Jozipa. I oni mu govore: „Pa danas sveti Jozip...“ A on kaže: „Neka Jozi Jozipa!“ I, ode na Kuli, tu je lađa potonila. I oni se spasili. I unda su zvali iz Splita, danas ti norilac, a unda se je zva šipentaja. I doša on i uša i vidi lađu. A na provi lađe stoji crni ovan sa rogovin. I on kaže: „Ja više ne ulazin! Lađa van je tu, evo tu van je lađa, vi kašnje kako oćete, crni je ovan na provi.“ I odustali. Nisu ni oni ostra tili ništa. Uzeja je sebi lađu i gotovo! ${ }^{28}$

Ovdje se nalazi jedna bitna rečenica koja priznaje crnog ovna kao vladara vodâ koji prisvaja lađu kao znak žrtve ili kazne zbog rada na zapovjedne svetce: Uzeja je sebi lađu i gotovo! Ova rečenica mu priznaje pravo vlasti nad rijekom kao i priznanje njegove kazne za nepoštivanje zakona.

Crni ovan se u simboličkom i značenjskom smislu može povezati s Velesom jer se upravo on po predaji znao preobraziti u životinju. Veles živi u dnu svijeta u vodama, vladar je podzemlja, zaštitnik sve stoke i pastira i njihovog blaga, a prikazivan je u raznim oblicima životinja. Ako usporedimo sliku u kojoj je ovan čuvar, zaštitnik i vođa stada, sliku u kojoj je Veles vladar podzemlja te zaštitnik sve stoke i pastira te sliku u kojoj je vrag crn i vladar zagrobnog života, dolazi se do zanimljive jednadžbe u kojoj je crni ovan

\footnotetext{
${ }^{28}$ Kazivač tvrdi da su se događaji zbili sedamdesetih godina dvadesetog stoljeća.
} 
crn zbog poveznice s vragom, vladar podzemlja i voda u obliku životinje koja je vođa stada daje jasnu poveznicu sa slavenskim božanstvom Velesom. Potrebno je naglasiti da je ovan iz predaja drevni ostatak vjerovanja u Velesa kao boga voda i zagrobnog života koji je s kršćanskim prodorom poistovjećen s vragom. U prije navedenim pričama spomenule su se morske vile koje na sebi nose runo i na glavi rogove. Fizički izgled morskih/riječnih vila, ako ga se stavi u kontest priče o crnom ovnu i Velesu, simbolizira stado koje Veles čuva u podvodnom svijetu. Morske vile su Velesovo stado te ujedno i njegova vojska.

Postoji još jedan zanimljivi trag koji dovodi do ukazanja na sukob dobra i zla i dualizma. Za vrijeme pripovijedanja, kazivač Nikola Nikolić je spomenuo jedan podatak koji ide u prilog činjenici da se na ovim prostorima održala vjera u Peruna i Velesa. Nikola navodi rečenicu u kojoj kaže: Na noć o Božiću nije se išlo nigdi jer je opasno. To se pričalo da sotona vrše, da oće da uništi Gospodina! ${ }^{29}$ Iako bi se ova rečenica mogla lako preobraziti u potpuno biblijsku situaciju, potrebno je pozorno promotriti situaciju u kojoj vrag vreba Boga da bi ga ubio.

To je jedina situacija u kojoj, po predaji, vrag vreba na prevlast nad Bogom. A zanimljivo je primjetiti kako je taj dio godine upravo onaj u kojem je noć najdulja i u kojoj je dan najkraći. Vrag je u vrhuncu moći jer vlada kao noćni gospodar. U tim trenutcima javlja se novorođeni Bog, koji simbolizira povratak svijetla na svijet i na taj način oduzima premoć vragu. Bojeći se za svoju prevlast, vrag ide po svijetu i traži Boga da ga ubije. Upravo ovakva situacija podsjeća na stara slavenska vjerovanja u kojima se bore bog dobra i bog zla. Kršćanstvo je, da bi lakše obratilo pogane, svojim blagdanima i svecima prekrilo poganske svetkovine, gajeve i bogove. Isto tako, Božić pada upravo u one dane kada se slavi pobjeda svjetla nad noći i u kojima su Slaveni udarali u predmete da rastjeraju mrak i pomognu svijetlom bogu da pobijedi tamu i da donese plodnost na svijet. Još se jedino za Božić zadržala tradicija pucanja iz pušaka na neretvanskom području kao i drugdje u Hrvatskoj što možemo tumačiti kao ostatke starih tradicija. Iz svih ovih razloga bi rečenicu: To se pričalo da sotona vrše, da oće da uništi Gospodina!, trebalo protumačiti kao ostatak ruralnog vjerovanja koje je bilo prisutno na ovim prostorima prije dolaska kršćanstva kao službene religije. Dualizam se očitovao i u nekim ostatcima vjerovanja u Iliju Gromovnika ili Gromoliju kao Peruna te crnog ovna ili vraga iz vode kao Velesa. Činjenica da su Neretvani sagradili hramove svojim poganskim bogovima te da su ih pod pritiskom kršćanstva i srušili i činjenica da su ostavili jedino Svantevidov hram u Vidu koji je ka-

${ }^{29}$ Kazivao Nikola Nikolić, rođen 1927. Ovo kazivanje je čuo u ranom djetinjstvu, do 1937. godine. Isto, str. 13. 
Vanda BABIĆ \& Denis VEKIĆ

snije bio posvećen u čast sv. Vita mučenika, daje na znanje da je Svantevidov kult bio snažan i nakon pokrštenja. Svi ovi podatci navode na ideju da su Neretvani istovremeno vjerovali u vrhovnog boga Svantevida i u Peruna i Velesa, koji su također poprimili imena novog sveca i vraga. Posebno je važna rečenica: Uzeja je sebi lađu i gotovo!, koja govori o nekoj vrsti žrtve podvodnom demonu, odnosno Velesu dok su Slaveni prinosili žrtve i darove Velesu, ali i drugim bogovima. U ovom slučaju, lađa je prihvaćena kao žrtva, kao nešto što pripada ovnu jer je on svojim prisustvom označio posjedovanje. Ljudi se nisu usudili usprotiviti njegovoj volji, bojeći se cijele situacije i prikaze, a donekle i da ne bi naljutili demona i oduzeli mu ono što mu pripada. Iz navedenih razloga, a i iz činjenice da je crkva sv. Ilije Gromovnika na brežuljku iznad vode, rijeke Neretve u Metkoviću, proizlazi da je crni ovan upravo Veles u svom životinjskom obliku te da je prastari ostatak slavenskog vjerovanja.

Ovakvo saznanje povezuje se s početkom ovoga rada, gdje se govorilo o postojanosti starih slavenskih vjerovanja u neretvanskoj dolini bez prave svjesnosti stanovnika o njihovom podrijetlu i službi.

\section{Zaključak}

Promatranje vjerskog fenomena u neretvanskoj dolini jako je zanimljivo zbog miješanja raznih kultura i njihovih stapanja u mediteransku cjelinu vjerovanja prožetu kršćanstvom koje je, za razliku od drugih dijelova hrvatskog teritorija, na ovaj prostor došlo puno kasnije. Neretvanska dolina svakako je bogat izvor arheološko-antropološko-kulturalnih podataka te je, za istraživanje, svakako jedan od zanimljivijih krajeva Hrvatske.

Još je mnogo neistraženih i neobrađenih tema vezanih uz Neretvane i njihovu dolinu dok je poganska baština nešto o čemu se znanstveno gotovo i nije pisalo. Specifičan melos koji proizlazi iz ovog hrvatskog kraja odiše tradicijom i starom baštinom koja se u velikoj mjeri čuva gotovo nesvjesno i prihvaća „zdravo za gotovo“ te je na dobrom putu da se izgubi zajedno sa starijim stanovništvom. Svakako je potrebno u Neretvaninu potaknuti svijest o vrijednoj ostavštini predaka.

Iz kazivanja se može zaključiti da su Neretvani nesvjesni ostataka poganske vjere. Priče o nižim mitološkim bićima su za stariji puk svakodnevica. U pričama o vilama su mnoge oscilacije te opisi variraju od lijepih do ružnih vila. Postoje zle i dobre vile koje su unakažene ovčjim ili kozjim nogama. Vile iz priča koje je kazivao Ilija Klemo Vekić su lijepe i dobre. Vole plesati po travi i ispod njihovih stopala rastu tratinčice. Međutim, u kazivanjima Nikole Nikolića iz Matijevića vile su ružne, zlobne i osvetoljubive. Spremne su oteti mladića ili ubiti djevojku. Posebno je istaknuta uloga kose koja je poprimala kozmičke atribute. 
Crna magija također je zastupljena u kazivanjima. Obično je to ona magija kojom se služe vještice i móre za osobnu korist. Vještice su bile odbačene od društva i na njih se gledalo s nepovjerenjem, a obilježene su kao negativne osobe jer su svoju moć, po predaji, dugovale vragu.

U priči o crnom ovnu kazivači vide biće iz priča koje živi u vodama od pamtivijeka. Potrebno je istaknuti moguću poveznicu crnog ovna s Velesom koja je zasnovana na njihovoj zajedničkoj značenjsko-karakternoj osnovici. Iako kazivači nisu poznavali priče o Velesu, Perunu i Svantevidu, ne smiju se zanemariti preoblike mitskih priča koje su se s vremenom preobrazile u sasvim nove priče. Upravo na toj osnovi zasnovana je ideja o crnom ovnu koji je detektiran i u ovom radu prezentiran kao Veles.

Na kraju istraživanja može se zaključiti kako je dolina Neretve zadržala mnoga vjerovanja u niža bića slavenske vjere poput vila, divova, vukodlaka, vještica i móra. Istraživanja ovakvog karaktera na neretvanskom prostoru dosta su rijetka pa postoji opasnost od gubljenja dragocjenih podataka o usmenoj kulturi Neretvana. Iako mlađe generacije ne poznaju mnoge priče, ne smije se izuzeti mogućnost popularizacije neretvanske kulturne tradicije u turističkom smislu. Kazivanja su zabilježena u njihovom izvornom izgovoru s namjerom da se sačuva jedan mali dio govora ovog kraja koji i sada trpi mnoge susjedne utjecaje. Osim što donosi razmatranje o poganskoj slavenskoj vjeri na području neretvanske doline, u ovom radu se iznose i neki novi motivi, poput kose koja znači život i motiv crnog ovna koji u dubljem simboličnom značenju može prikazivati slavenskog boga Velesa.

\section{Literatura}

- Ardalić, Vladimir: Vile i vještice. (Bukovica u Dalmaciji). ZbNŽO, 22:302-311, Zagreb, 1917

- Banović, Stjepan: Vjerovanja (Zaostrog u Dalmaciji). ZbNŽO, 23: [Višćice i višćci: str. 190-194], Zagreb. 1918.

- Belaj, Vitomir: Hod kroz godinu (Mitska pozadina hrvatskih narodnih običaja i vjerovanja), Golden marketing, Zagreb, 1998.

- Bošković-Stulli, Maja: „Splet naših praznovjerja oko vještice i popa“. Bilten Instituta za proučavanje folklora, sv. 2:327-342, Sarajevo, 1953:

- Botica, Stipe: Biblija i hrvatska kulturna tradicija, vlastita naklada, 1995.

- Črnja, Zvane: Kulturna istorija Hrvatske (ideje - ličnosti - djela), Epoha, Zagreb, 1965.

- Gluščević, Smiljan: Donja Neretva u antici, Ogranak Matice hrvatske u Metkoviću, Metković, 1996.

- Grbić, Jadranka: „Dekodiranje ovozemaljskih čina: vjerovanja o ži- 
votinjama u hrvatskoj etnografiji“" - Kulturni bestijarij: II.: iz mitske i etno faune, Biblioteka nova etnografija, Zagreb, 2007.

- Katičić, Radoslav: Literarum studia - književnost i naobrazba ranoga hrvatskog srednjovjekovlja, Matica hrvatska, Zagreb, 1998.

- Katičić, Radoslav: Mitovi naše poganska starine i Natko Nodilo, Filologija 44 (2005)

- Katičić, Radoslav: Na ishodištu - književnost u hrvatskim zemljama od 7. do 12. stoljeća, Matica hrvatska, Zagreb 1994.

- Lešo, Luka: „Vjerovanja u bića koja se pretvaraju u životinje“ Kulturni bestijarij: II.: iz mitske i etno faune, Biblioteka nova etnografija, Zagreb, 2007

- Macan, Trpimir: Povijest hrvatskoga naroda, Nakladni zavod Matice hrvatske, Školska knjiga, Zagreb, 1992., II. izdanje

- Manenica, Lovro: Borovci - prošlost i sadašnjost, Matica hrvatska, ogranak Metković, Metković, 1996.

- Marjanić, Suzana: „Antropopornografija ili životinja kao skopofilijski i seksualni predmet" - Kulturni bestijarij: IV. „Machina animata" i prava životinja, Biblioteka nova etnografija, Zagreb, 2007.

- Marjanić, Suzana: „Vještičje psihonavigacije i astralna metla u svjetovima hrvatskih predaja“ - Stud. ethnol. Croat., vol. 17, str. 111-169, Zagreb, 2005.

- Majnarić, Suzana: (Dyadic) the Goddess and Duotheism in Nodilo's The Ancient Faith of the Serbs and the Croats. Studia mythologica Slavica, 6:183-205, Ljubljana., 2003.

- Majnarić, Suzana: „Životinjsko u vilinskom“. U: ur. Renata Jambrešić Kirin i Tea Škokić, Između roda i naroda: etnološke i folklorističke studije, Institut za etnologiju i folkloristiku, Centar za ženske studije, Zagreb, 231-256, 2004.

- Milčetić, Ivan: Mora i polegač - a) Krk, Kastav, i hrvatski kajkavci. ZbNŽO, I:235-237, Zagreb, 1896.

- Milčetić, Ivan: Vjera u osobita bića. Otok Krk, i kajkavci. ZbNŽO, 1:232-233, Zagreb, 1896.

- Nodilo, Natko (1981/1885-1890): Stara vjera Srba i Hrvata (Religija Srbâ i Hrvatâ, na glavnoj osnovi pjesama, priča i govora narodnog). Logos, Split.

- Plas, Pieter: „Ko kurjaka pati, taj će padati s gore: intertekst vuka i epilepsije u tradicijskoj kulturi zapadnojužnoslavenskog areala“ Kulturni bestijarij: II.: iz mitske i etno faune, Biblioteka nova etnografija, Zagreb, 2007.

- Smoljan, Ivo: Neretva, Nezavisno autorsko izdanje, Zagreb, 1970.

- Škobalj, Ante: Obredne gomile, Zagreb, 1970. 
Pretkršćanska vjerovanja u dolini Neretve

- Vidović, Mile: Don Radovan Jerković život i djelo, Matica hrvatska Metković, Split, 2000.

\section{Vanda BABIĆ Denis VEKIĆ}

\section{PRECHRISTIAN BELIEFS IN NERETVA VALLEY}

Guided by fact that territory of Neretva valley were last to accept Christianity in medieval Dalmatia, authors collect stories about transcendental beings and events that marked lives of Neretva people. Stories are collected and written in summer of year 2007 on lowlands and uplands of Neretva valley. All stories are presented in original dialectical expression and for the first time presented to the public. Presented stories are reviewed by the authors and then there has been unveiled their origin and mythical background. There are stories of black ram demon that lives on the bottom of the river that has been documented for the first time. Besides the motive of black ram and faerie stories, in the research there is motive of wolf-man who is different from werewolf in act and appearance.

Keywords: swallow, giant, faeries, black ram, wolfman, sorcery, faeries and horses, house watch 

LINGUA MONTENEGRINA, god. III, br. 5, Cetinje, 2010.

Institut za crnogorski jezik i jezikoslovlje „Vojislav P. Nikčević“

UDK 821.163.42.09-5"17"

Izvorni naučni rad

\title{
Zlata ŠUNDALIĆ (Osijek)
}

Filozofski fakultet Sveučilišta J. J. Strossmayera

\section{CARSTVO PLANTAE U PROPOVJEDNIČKOME ŽANRU}

\begin{abstract}
U referatu je pozornost usmjerena na proznu dionicu kajkavske književnosti 18. stoljeća. Riječ je o kajkavskim pobožnim pripovjedačima, koji su pišući/govoreći svoje propovijedi postajali i pripovjedači, jer su u svoje duhovne razgovore unosili razne priče, anegdote, bajke, često s fantastičnim elementima. Ovakvu je prozu započeo pisati u 17. stoljeću Juraj Habdelić, a u 18. stoljeću nastavili su je pisati pisci kao što su: Juraj Mulih, Štefan Zagrebec, Štefan Fuček i drugi. U ovom je radu posebna pozornost usmjerena na propovijedi Štefana Zagrepca (Zagreb, 1669. - Zagreb, 1742.), kajkavskog propovjednika i pripovjedača. Kako je njegovo jedino djelo - Pabulum spirituale ovium christianarum... / Hrana duhovna, ovčic kerščanskeh... - objavljeno u pet knjiga (I. svezak u Zagrebu 1715., II. svezak u Klagenfurtu 1718., III. svezak u Zagrebu 1723., IV. svezak u Zagrebu 1727. i V. svezak u Zagrebu 1734.) na više od 3000 stranica, u ovom je radu riječ samo o posljednjoj, petoj knjizi iz 1734. godine. U radu se istražuje poetika Zagrebčevih propovijedi, a posebice uklopljenost i značenje biljnoga svijeta.
\end{abstract}

Ključne riječi: kajkavski pripovjedači, Štefan Zagrebec, Hrana duhovna, propovijed, biljka

U sistematizaciji života na Zemlji naglašava se postojanje dviju skupina živih organizama, carstva Animalia (životinjski svijet) i carstva Plantae (biljni svijet). Moderna znanost (Ernst Haeckel) predlaže uvođenje i trećega carstva - carstva Protista - kao ,polja temeljnog jedinstva biljnog i životinjskog svijeta" (Visković, 1996: 23). U biosferi (biljke i životinje) biljke su ipak ,pretpostavka za svaki drugi život. Kao 'minimum' viših oblika života, one mogu postojati i u odsustvu životinja, dok je postojanje životinja nemoguće bez biljaka“" (Visković, 2001: 51). Na koji način, u kolikoj mjeri i s kojim funkcijama biljke mogu biti uključene i u književni tekst, odnosno u propovijedi 18. stoljeća, istražit ćemo na primjeru kajkavskog pisca Štefana Zagrepca, odnosno svjetovnoga imena Matije Markovića (Zagreb, 1669. - Za- 
greb, 1742.), i njegovih propovijedi iz petog sveska Hrane duhovne, objavljenih 1734. godine.

\section{1.}

O zagrebačkom kapucinu Štefanu Zagrepcu, odnosno o Matiji Markoviću kako mu je bilo pravo ime, propovjedniku i govorniku rođenom 1669. godine u Zagrebu ${ }^{1}$, najopširnije je do danas pisala Olga Šojat. Riječ je o tekstu objavljenom 1978. godine (Šojat 1978: 1091-1121), u kojemu je autorica dala i prikaz literature koja je do navedene godine bila napisana o ovome piscu. Autoričin prikaz pokazuje paradoksalnu situaciju - riječ je o značajnom piscu stare kajkavske književnosti, a naše mu povijesti književnosti dodjeljuju tek redak i pol ili nešto više teksta, a ponekad čak ni toliko. László Hadrovics kaže da je on jedan ,od najvećih a danas najmanje poznatih prozaista hrvatske književnosti“" (Hadrovics 1982: 169), kojemu uz Antuna Vramca, Baltazara Milovca, Jurja Habdelića, Ivana Belostenca, Mihajla Šimunića, pripada vidno mjestu u kajkavskoj propovjedničkoj literaturi. Značajniji je pomak učinjen u radovima Franje Galinca, Nikole Stanka Novaka ${ }^{2}$, Krešimira Georgijevića, dok su izvadke iz Zagrepčeve Hrane duhovne objavili Vladoje Dukat (Sladki naš kaj, 1944), László Hadrovics (Kajkavische Literatur, 1964), Valentin Putanec (u časopisu Kaj, I, br. 7-8, 10 iz 1968. godine i Kaj, II, br. 12 iz 1969. godine), Olga Šojat (u časopisu Forum, br. 6 iz 1978. godine), Josip Bratulić (Hrvatska propovijed od svetoga Metoda do biskupa Strossmayera, 1996), odnosno Hrvojka Mihanović-Salopek (Iz duhovnog perivoja, 2006). Nakon obilježene 330. obljetnice rođenja (1669 - 1999) (Krušelj-Vidas, 1999), pojavio se još jedan izbor, koji je priredila Divna Zečević (Zečević, 2000).

U novije vrijeme Zagrepčeva Hrana duhovna privlači pozornost svojim stilom i kompozicijom ${ }^{3}$ (Hadrovics 1982), žanrovskom pripadnošću, da-

\footnotetext{
${ }^{1}$ Sve do godine 1962. u hrvatskoj se književnopovijesnoj literaturi nije navodilo i svjetovno ime Štefana Zagrepca. Dopunu je unio Nikola Stanko Novak u svojoj seminarskoj radnji pod naslovom „P. Štefan Zagrebec i njegov doprinos za hrvatski jezik i književnost“‘. Druga značajna korekcija, koju je Nikola Stanko Novak unio u životopisne podatke Štefana Zagrepca tiče se godine rođenja. On je otkrio ,(...) da se Matija Marković / Štefan Zagrebec rodio 1669, a ne 1688, kako je to općenito bilo prihvaćeno." (Šojat 1978: 1092). Iako je Novak unio bitne dopune u životopisne podatke patera Zagrepca, oni se u stručnoj literaturi uglavnom ne navode, jer je Novakov rad ostao u rukopisu.

${ }^{2}$ Novak, Nikola Stanko. 1962. P. Štefan Zagrebec i njegov doprinos za hrvatski jezik $i$ književnost (seminarska radnja pohranjena u Nacionalnoj i sveučilišnoj knjižnici u Zagrebu kao rukopis, pod signaturom NSK, R 7706).

${ }^{3}$ Zagrebec u svojim propovijedima nije originalan u današnjem značenju riječi; on je originalan u izboru već postojeće građe, u njezinu komponiranju i stiliziranju. Kompozicija je jednostavna i jasna: uvod (jedna do dvije stranice) započinje razvedenom 428
} 
Carstvo plantae u propovjedničkome žanru

kle kao barokna propovijed (Januš 1994; Pajur 2004), a ne samo kao tekst koji je zanimljiv zbog svoje tematsko-motivske razine (npr. motiv nesretne i gonjene djevojke /Galinec 1936/, edipovski motiv u obliku grješne ljubavi majke sa sinom, Ezopove basne o poljskom i gradskom mišu, o bogatašu i njegovu veselom sustanaru postolaru, kao i neki drugi /Galinec 1934/1935/).

2.

Hrana duhovna je glavno djelo patera Štefana, objavljeno u pet svezaka (ili strana, kako ih sam autor naziva). U ovom je radu pozornost usmjerena samo na jedan, posljednji, peti svezak, koji je objavljen u Zagrebu 1734. godine, i to na njezin prvi dio koji broji 336 stranica. U literaturi se može pročitati da: „Svaki svezak ima pet do šest stotina stranica, tako da čitavo djelo obuhvaća ukupno 3115 stranica. (...) U kajkavskoj ga književnosti po opsegu nadmašuje samo hagiografski zbornik Cvet sveteh (3760 stranica) Hilariona Gašparotija“" (Šojat 1978: 1094). Peti svezak to doista i potvrđuje, jer broji ukupno 664 stranica.

Naslovnica je dvojezična, na latinskom i kajkavskom: PABULUM | SPIRITUALE | ovium christianarum, ..., odnosno HRANA | DUHOUNA, | ovchicz kerschanzkeh...

U literaturi je već zapisano da svaki svezak Zagrepčeve Hrane duhov$n e$, pored ostaloga, ima predgovor, u kojemu treba gledati originalan piščev tekst, u kojemu on iznosi vlastite misli. Peti je svezak u odnosu na rečeno ipak drugačiji, jer ima dva predgovora (o čemu se u literaturi o Hrani duhovnoj nešto manje govori), što nadalje znači i dva zasebna dijela koja su odijeljena i paginacijom, jer svaki dio započinje označenom prvom stranicom. Prvi je predgovor naslovljen kao „Predgovor k pobožnomu štavcu“4 $\left(\mathrm{NT}^{5}\right.$, nepag. 3-4), a drugi ima naslov „Predgovor zverhu desetereh zapovedih Božijeh" (DBZ, 1-4).

pričom iz Biblije, antičke književnosti, svjetske povijesti, svakodnevnog života, vlastitih snova ili meditacijom; slijedi glavna tema propovijedi koja se dijeli na više manjih cjelina, a u završnom se dijelu daju dobri savjeti u svezi s određenim grijehom (v. Hadrovics 1982: 171)

${ }^{4}$ Citate iz djela donosimo kurzivom na način transkripcije (znakovima suvremene hrvatske latinice bilježimo pretpostavljeni izgovor u 18. stoljeću). Istim se načinom poslužila i Olga Šojat, donoseći izbor iz Hrane duhovne (Šojat 1978).

${ }^{5}$ Citate iz Zagrepčevih propovijedi donosimo tako da u zagradu stavljamo skraćenicu naslova i broj stranice na kojoj se citat nalazi. Skraćenicom NT označujem naslov prvog dijela knjige Hrana duhovna, koji glasi „Prodeke zvrhu nedelj Trojačkeh“ (=NT), a skraćenicom DBZ označujemo naslov drugoga dijela, koji glasi „Prodeke zverhu desetereh Božijeh zapovedih“ (=DBZ). Navedeno je potrebno zbog činjenice što se peti svezak Hrane duhovne sastoji, kako je već rečeno, od dva dijela. 
Zlata ŠUNDALIĆ

U prvom je predgovoru objašnjen naslov djela, kompozicija, sadržaj, izvori i situacija u kojoj djelo nastaje. Naslov je objašnjen razvedenom faunsko-florealnom usporedbom: svoje ovčice (vjernike) pastir duhovni (Zagrebec) hrani hranom duhovnom (riječima Božjim) i zbog toga im daje i peto breme svakojakih travica (peti svezak Hrane duhovne). Navedeni je peti svezak komponiran iz dva dijela (travice postavil sem vu dve bremena, NT, nepag. 3): u prvome se nalazi 24 propovijedi, jer je prodeke zverhu tuliko nedelj Trojačkeh (NT, nepag. 3), a u drugome je dijelu samo 21 propovijed na temu Deset Božjih zapovijedi. Sadržajno propovijedi profilira istinitost, pravičnost, korisnost, didaktičnost i jednostavnost, kako bi ih vsaki najpriprosteši mogel razumeti (NT, nepag. 3), a sam autor posebice izdvaja teme u duhu barokne antitetičnosti: smrt tijela i duše, opći i pojedinačni Božji sud, nebeska ljepota i paklenska strahota, muke u purgatoriju, dobra djela kojima su si sveci i svetice zaslužili nebesku diku i grijesi kojima su si grješnici zadobili paklene muke. Navedene su teme potvrđene vsakojačkemi lepemi peldami $i$ hištorijami (NT, nepag. 3), koje svoj izvor, prema Zagrepcu, imaju u Svetom pismu, u djelima svetih naučitelja i pisaca, u djelima rimskih i poganskih pisaca, ali i u nekim drugim područjima, koja on ovdje ne navodi (npr. neke pelde $i$ hištorije zadiru i u područje staroga novca ${ }^{6}$ ). U ovom predgovoru Zagrebec piše i o sebi, o slabljenju vida koji mu sve više ograničava pisanje: Hoču reči, konec je došel jakosti moje, koju je starost potrla $i$ več neg napol slepoga vučinila, ar na levo nikaj, a na desno kruto malo vidim oko. I tako pisanju več knjig pri mene je konec došel. (NT, nepag. 4)

$\mathrm{U}$ drugom je predgovoru samo prepričan onaj dio iz Svetoga pisma u kojemu se objašnjava kako je i zašto Svevišnji obznanio Mojsiju deset Božjih zapovijedi: nakon što je Adam zaboravio veliku čast koju mu je Bog udijelio učinivši ga gospodarom zemaljskoga raja, prvi su ljudi zaboravili svoje naturalske zapovedi i počeli se klanjati mnogim nijemim stvarima (npr. kačama, posojima, bažiliškušima). Da bi se grešno ljuctvo vratilo na pravi put, Bog je svojom božanskom rukom na dvije ploče zapisao Mojsiju deset Božjih zapovijedi, koje postaju perikopama u propovijedima koje slijede.

Nakon prvog, odnosno nakon drugog predgovora slijede glavna poglavlja, koja podrazumijevaju propovijedi za određenu nedjelju tijekom crkvene godine: u prvome su dijelu one eliptično naslovljene pa tako npr. prva glasi „Na dan S.Trojstva“ (NT, 1), što trebamo razumjeti kao Prodeka na dan S.Trojstva, dok su u drugom dijelu naslovi poglavlja cjelovita, pa tako prvi glasi „Od prve Božje zapovedi. Prva prodeka“ (DBZ, 1).

${ }^{6}$ Da bi svojim slušateljima objasnio da se Bog prema nama odnosi onako kako se mi odnosimo prema Njemu, propovjednik donosi priču o penezu (novcu), koji je dao izraditi Maksimilijan Cezar (NT, 71). 
3.

U literaturi o Zagrepčevim propovijedima već je zapisano da: „Postići kompozicijski sklad u tako opsežnu djelu kao što je Hrana duhovna, nije bio ni jednostavan ni lak posao, ali pater Štefan izvršio ga je s uspjehom: svaka je propovijed zaokružena cjelina, u svakoj se pisac strogo pridržava određene teme, a sve zajedno čine jedinstven zbornik propovijedi za sve nedjelje godine.“ (Šojat 1978: 1096) Zbog navedenoga u ovome radu pozornost usmjeravamo na neke druge sastavnice propovijedi, a to je istraživanje biljnog i nešto manje istraživanje životinjskoga svijeta te njegovu funkcionalnu uklopljenost u propovjedničku građu prvoga dijela zbirke. Za navedene potrebe proveli smo istraživanje flore u okviru dvaju tabličnih prikaza: prvim se dokumentira vrstovna raznolikost (Tablica 1 - Biljni svijet u Hrani duhovnoj), a drugim se prikazuje učestalost pojavljivanja florealnih leksema (Tablica 2 Čestotnost pojavljivanja biljaka u Hrani duhovnoj). Na kraju se dobiveni rezultati interpretiraju.

Florealni svijet u Hrani duhovnoj prema našem istraživanju broji preko dvadeset sastavnica, koje u tabličnom prikazu izgledaju ovako:

Tablica 1 - Biljni svijet u Hrani duhovnoj

\begin{tabular}{|c|c|c|c|}
\hline $\begin{array}{c}\text { REDNI } \\
\text { BROJ }\end{array}$ & $\begin{array}{l}\text { NAZIV } \\
\text { BILJKE }\end{array}$ & NAVODI IZ DJELA & UKUPNO \\
\hline 1. & $\begin{array}{l}\text { citronsko } \\
\text { drevo }\end{array}$ & $\begin{array}{l}\text { Videl sem grešnika izvišenoga kakti } \\
\text { citronzka dreva vu Libanu (NT, 189); }\end{array}$ & 1 \\
\hline 2. & cvet & $\begin{array}{l}\text { postavljaju vence vsakojačkoga cvetja } \\
\text { (NT, 21); videči se ada vu pogibeli prelepi } \\
\text { cvet čistoče svoje (NT, 51); kakti vsako } \\
\text { drvo ima svoje korenje, steblo, koru, svrsi?, } \\
\text { listje, cvetje i sad (NT, 83); i cvetjem okin- } \\
\text { čeno (NT, 87); i cvetje koja vsaki veter } \\
\text { lahko otrese (NT, 87); i cvetje rode (NT, } \\
\text { 87); ne mora cvetja vnogo menje sada } \\
\text { pogubiti (NT, 96); cvetje moje je sad } \\
\text { poštenja (NT, 96); pogubivši prelepi cvet } \\
\text { čistoče svoje (NT, 120); sedajuč po } \\
\text { vsakojačkem cvetju (NT, 157); na spodobu } \\
\text { zemlje koja rodi vsakojačke travice, cvetja } \\
\text { i korenja (NT, 160); divojčice cvet čistoče } \\
\text { svoje pogubljati (NT, 218); lepo i vugodno } \\
\text { dišeče cvetje (NT, 244); neg da bi cvet } \\
\text { čistoče svoje pogubil (NT, 264); občuval je } \\
\text { mladi Jožef prelepi cvet čistoče svoje (NT, }\end{array}$ & 14 \\
\hline
\end{tabular}


Zlata ŠUNDALIĆ

\begin{tabular}{|c|c|c|c|}
\hline & & 303); & \\
\hline 3. & črešnja & $\begin{array}{l}\text { i drugo drago kamenje zobali kod črešnje } \\
\text { (NT, 223); }\end{array}$ & 1 \\
\hline 4. & dinja & $\begin{array}{l}\text { zagledavši jednu veliku dinju vu jednom } \\
\text { steklu (NT, 317); kak je ona velika dinja } \\
\text { čez tak malu luknjicu vu ono steklo } \\
\text { dospela (NT, 317); kak je dinja odcvela } \\
\text { (NT, 317); dinja pako greha ne na stol } \\
\text { kralja nebeskoga, nego na gnoj peklenski } \\
\text { hitčena bude (NT, 318); }\end{array}$ & 4 \\
\hline 5. & drevo & $\begin{array}{l}\text { ni list iz dreva opasti ne more (NT, 77); } \\
\text { kod vsako drevo nerodeče (NT, 83); ni } \\
\text { jedna mi se ne vidi priličneša od dreva } \\
\text { (NT, 83); človek je drevo naopak obr- } \\
\text { njeno (NT, 83); kakti vsako drevo ima } \\
\text { svoje korenje (NT, 83); drevje ima ko- } \\
\text { renje (NT, 84); kod drevo od zemlje } \\
\text { hranu svoju primlju (NT, 84); i kakti se } \\
\text { dvoje fele drevja nahađa na zemlje (NT, } \\
\text { 84); kojem drevam prispodobiti se mogu } \\
\text { verni krščeniki (NT, 84); među pitomemi } \\
\text { drevi (NT, 84); i kaj se iz drevja } \\
\text { neplodnoga (NT, 84); vsako drevo koje ne } \\
\text { bude činilo sada dobroga (NT, 84); Ono } \\
\text { drevo je početak zloga dela (NT, 84); Po } \\
\text { drevu onom more se rezumeti (NT ,85); } \\
\text { kaj se pak z podsečenem drevom čini } \\
\text { (NT, 85); Vsako drevo koje ne rodi sada } \\
\text { dobroga (NT, 85); Vsako drevo, budi ono } \\
\text { visoko ali nisko (NT, 85); kod muž } \\
\text { podsečeno drevo (NT, 85); koj želeje } \\
\text { videti jedno takovo drevo (NT, 85); Videl } \\
\text { sem i nut drevo na sredi zemlje (NT, 86); } \\
\text { drevo veliko i jako (NT, 86); lepoga } \\
\text { dreva (NT, 86); podsečete drevo (NT, } \\
\text { 86); po kojem drevu zlamenuval se je on } \\
\text { veliki kralj Nabukodonozor (NT, 86); } \\
\text { Vsako drevo, to je to vsaki živuči človek } \\
\text { (NT, 86); govori od vsako dreva (NT, } \\
\text { 86); vnoga dreva rode lep zvun sad (NT, } \\
\text { 86); da jedno drevo lepo raste (NT, 87); } \\
\text { Vsako drevo koje ne čini sada dobroga } \\
\text { (NT, 87); Drevo koje ne čini (NT, 87); } \\
\text { dosta da je drevo kada rodilo (NT, 88); } \\
\text { kod zločesta dreva bili su podsečena (NT, } \\
\text { 88); kod zločesto drevo (NT, 88); kod se } \\
\text { god drevo debelo silum i teškočum }\end{array}$ & 60 \\
\hline
\end{tabular}




\begin{tabular}{|c|c|c|c|}
\hline & & $\begin{array}{l}\text { podsekuje (NT, 88); kod drevo zločesto } \\
\text { (NT, 89); kod tolika zločesta dreva rodeča } \\
\text { sad (NT, 90); kod od drev svojeh (NT, } \\
\text { 92); niti ne hvali drevo koje lepo visoko i } \\
\text { široko raste (NT, 92); takovo drevo je } \\
\text { hvale i preštimanja vredno (NT, 92); Ne } \\
\text { poznam vas za drevje moje (NT, 94); ovo } \\
\text { zločesto drevo (NT, 95); kakti drevo koje } \\
\text { od mladosti vsigdar je rodilo sad zločest } \\
\text { (NT, 95); Tako i vi o prelepa dreva N.N. } \\
\text { (NT, 95); o prelepa dreva (NT, 96); zmeđ } \\
\text { vsega sadovnega drevja najprvo cvete } \\
\text { (NT, 96); najprvo cvesti među ostalim } \\
\text { drevjem (NT, 96); vsakojačka lepa dreva } \\
\text { (NT, 96); vsako drevo koje ne rodi sada } \\
\text { (NT, 97); kam drevo sliši (NT, 97); obesti } \\
\text { na dreva (NT, 114); ni bilo moči drevja } \\
\text { zmagati (NT, 114); i podignete je na ovo } \\
\text { pres. križno drevo (NT, 120); na ovom } \\
\text { križnom drevu vsega ranjenoga (NT, } \\
\text { 139); nego iz prostoga dreva (NT, 143); } \\
\text { ne more zločesto drevo dobroga sada } \\
\text { roditi (NT, 154); iz vsakoga dreva ... sad } \\
\text { slobodno ješ (NT, 203); Iz dreva pako } \\
\text { znanja dobra i zla naj sada jesti (NT, 203); } \\
\text { sad ovoga prepovedanoga dreva (NT, } \\
\text { 203); dva človeka butore drev na plečah } \\
\text { svojeh noseče (NT, 289); koju oni } \\
\text { obesivši na drevo z paličem preteplju } \\
\text { (NT, 292); i na križnom drevu raspetoga } \\
\text { umoril (NT, 296); }\end{array}$ & \\
\hline 6. & $\begin{array}{l}\text { figovo drevo } \\
\text { (smokva) }\end{array}$ & $\begin{array}{l}\text { nasledujte figovo drevo (NT, 96); da } \mathrm{z} \\
\text { figovem drevom budete od sebe mogli } \\
\text { reči (NT, 96); nadejati se morete kod } \\
\text { figovo drevo sekire smrti (NT, 96); }\end{array}$ & 3 \\
\hline 7. & grmje & ovce pasuče se po grmju (NT, 157); & 1 \\
\hline 8. & $\begin{array}{l}\text { hajda } \\
\text { (heljda) }\end{array}$ & da žito i hajdu mraz opali (NT, 179); & 1 \\
\hline 9. & herš & $\begin{array}{l}\text { da jačmen, herš i pšenica po zime pozebe } \\
(\mathrm{NT}, 179) \text {; }\end{array}$ & 1 \\
\hline 10. & hrast & pod sencum jednoga hrasta (NT, 44); & 1 \\
\hline 11. & hruška & $\begin{array}{l}\text { nekoje divje, kod su hruške i jabuke (NT, } \\
\text { 84); divje hruške i jabuke (NT, 91); }\end{array}$ & 2 \\
\hline 12. & jabuka & $\begin{array}{l}\text { nekoje divje, kod su hruške i jabuke (NT, } \\
\text { 84); divje hruške i jabuke (NT, 91); }\end{array}$ & 2 \\
\hline 13. & jačmen & da jačmen, herš i pšenica po zime pozebe & 1 \\
\hline
\end{tabular}


Zlata ŠUNDALIĆ

\begin{tabular}{|c|c|c|c|}
\hline & & $(\mathrm{NT}, 179)$; & \\
\hline 14. & kupinje & $\begin{array}{l}\text { vide pred sobum ov put zagrađen } \mathrm{z} \text { trnjem } \\
\text { i kupinjem }(\mathrm{NT}, 333) \text {; }\end{array}$ & 1 \\
\hline 15. & $\begin{array}{l}\text { mandala / } \\
\text { mandalsko } \\
\text { drevo } \\
\text { (badem) }\end{array}$ & $\begin{array}{l}\text { na spodobu mandalskoga dreva (NT, } \\
96) ; \text { mandala cvetuča }(\mathrm{NT}, 96) ;\end{array}$ & 2 \\
\hline 16. & $\begin{array}{l}\text { olika } \\
\text { (maslina) }\end{array}$ & $\begin{array}{l}\text { deržečega vu jednom kljunu oliknu } \\
\text { mladicu zlatom obvitu (NT, 71); }\end{array}$ & 1 \\
\hline 17. & palma & $\begin{array}{l}\text { na spodobu jednoga dreva } \\
\text { imenuvanoga }(\mathrm{NT}, 97) ; \text { palma } \\
\text { friškum vodum zalejana }(\mathrm{NT}, 97) ;\end{array}$ & 2 \\
\hline 18. & povertelje & $\begin{array}{l}\text { znal je da voda ... žitek i povertelju } \\
\text { pomuli i pokvari (NT, 160); da povertelje } \\
\text { ali suša posuši (NT, 179); }\end{array}$ & 2 \\
\hline 19. & pšenica & $\begin{array}{l}\text { da jačmen, herš i pšenica po zime pozebe } \\
\text { (NT, 179); }\end{array}$ & 1 \\
\hline 20. & rožica & $\begin{array}{l}\text { da pod zimskem snegom rožice cvetu } \\
(\mathrm{NT}, 57) \text {; iz sebe rodili kod tulike rožice } \\
(\mathrm{NT}, 96) \text {; }\end{array}$ & 2 \\
\hline 21. & $\begin{array}{l}\text { Žitek } \\
\text { (pšenica) }\end{array}$ & $\begin{array}{l}\text { žitek od velikoga deževja bil je poginul } \\
\text { (NT, 219); žitku bude draga cena (NT, } \\
\text { 219); drugo leto on žitek trikrat draže } \\
\text { prodati (NT, 219-220); ves žitek je po- } \\
\text { kupil (NT, 20); svojega žitka nazad ku- } \\
\text { povat (NT, 220); dohađal je žitka k } \\
\text { ovomu skupcu kupuvat (NT, 220); da bi } \\
\text { mu za nje žitka dal (NT, 220); da ako } \\
\text { hoče žitka imati (NT, 220); ni zrna žitka } \\
\text { ne dobe (NT, 220); za kaštigu na žitek } \\
\text { njegov prositi (NT, 220); koji skriva žitek } \\
\text { (NT, 221); koji žitku povečava cenu (NT, } \\
\text { 221); koji skračuje žitek ljuctvu vu } \\
\text { potreboče (NT, 221); da bi mu na žitek } \\
\text { njegov takve kukce poslal (NT, 221); koji } \\
\text { bi mu on žitek ...zkončali (NT, 221); } \\
\text { svojemi velikemi rogmi kupe žitka } \\
\text { raztresaju (NT, 221); ne samo rogati voli } \\
\text { kupe žitka zkončavaju (NT, 222); ves } \\
\text { drugi žitek vse na jagmu zoblju (NT, } \\
\text { 222); komu je draži bil žitek poljski (NT, } \\
\text { 222); da se ne samo voli i kojni s } \\
\text { njegovim žitkom goste (NT, 222); koje } \\
\text { beštije žitek njegov jesu grizle (NT, 222); } \\
\text { zbok pogubljenja žitka svojega (NT, 222); } \\
\text { Kak ovu zapoved obderžavaju oni bogatci, } \\
\text { kojem žužki i štakori žitek kvare (NT, }\end{array}$ & 25 \\
\hline
\end{tabular}


Carstvo plantae u propovjedničkome žanru

\begin{tabular}{|l|l|l|c|}
\hline & & $\begin{array}{l}\text { 237); kakov se žitek vu njega donese (NT, } \\
\text { 244); marofe i štaglje žitkom vkup i z } \\
\text { marhom požgal (NT, 288); }\end{array}$ & \\
\hline 22. & travica & $\begin{array}{l}\text { Peto breme travic (NT, nepag. 3); koje } \\
\text { travice postavil sem vu dve bremena (NT, } \\
\text { nepag. 3); da bi vse ... travice pera (bile) } \\
\text { (NT, 9); iščuči povoljneh travic za hranu } \\
\text { (NT, 157); moraju se suhemi travicami ... } \\
\text { krepit (NT, 157); na spodobu zemlje koja } \\
\text { rodi vsakojačke travice, cvetja i korenja } \\
\text { (NT, 160); dišeče i smrdeče, pekuče i } \\
\text { bodeče travice (NT, 244); }\end{array}$ & \\
\hline 23. & trn & $\begin{array}{l}\text { da se z nogum na trn nabode (NT, 233); } \\
\text { nabode se na trn noga (NT, 234); nabol se } \\
\text { je na trn onoga siromaštva (NT, 234); } \\
\text { najšpičasteše trnje more nogu tvoju mu- } \\
\text { čiti (NT, 234); vide pred sobum ov put } \\
\text { zagrađen z trnjem i kupinjem (NT, 333); }\end{array}$ & \\
\hline & & da trsje tuča skonča (NT, 179); & \\
\hline 24. & trsje & $\begin{array}{l}\text { vušla je pod jeden trs vinike (NT, 138); trs } \\
\text { najmre vinični (NT, 139); }\end{array}$ & \\
\hline 25. & vinika \\
(divlja loza) & da žito i hajdu mraz opali (NT, 179); & \\
\hline 26. & žito & & 1 \\
\hline
\end{tabular}

Na temelju provedenog istraživanja florealnih leksema moguće je napraviti njihovu rang-ljestvicu, odnosno hijerarhiju prema čestotnosti njihova pojavljivanja u prvom dijelu Hrane duhovne, što je i učinjeno u Tablici 2:

Tablica 2 - Čestotnost pojavljivanja biljaka u Hrani duhovnoj

\begin{tabular}{|c|c|l|}
\hline $\begin{array}{l}\text { REDN } \\
\text { I } \\
\text { BROJ }\end{array}$ & $\begin{array}{l}\text { ČESTOTNOST } \\
\text { POJAVLJIVANJA }\end{array}$ & \multicolumn{1}{|c|}{ NAZIV BILJKE } \\
\hline 1. & 60 & drevo \\
\hline 2. & 25 & žitek \\
\hline 3. & 14 & cvet \\
\hline 4. & 7 & travica \\
\hline 5. & 5 & trn \\
\hline 6. & 4 & dinja \\
\hline 7. & 3 & figovo drevo \\
\hline 8. & 2 & $\begin{array}{l}\text { hruška, jabuka, palma, povertlje, rožica, vinika } \\
\text { (divlja loza) }\end{array}$ \\
\hline 9. & 1 & $\begin{array}{l}\text { citronsko drevo, črešnja, grmje, hajda, herš, hrast, } \\
\text { jačmen, kupinje, mandala, olika, pšenica, trsje, žito. }\end{array}$ \\
\hline
\end{tabular}

U interpretaciju dobivenih rezultata može se krenuti od Zagrepčeva poimanja flore (ali i faune), u kojima on vidi nijeme stvari (NT, 135), koje su 
često puta rječitije od samih riječi, zbog čega ih se lijepo može koristiti u propovjedničke svrhe. Koliko se i na koji način Zagrebec koristio ovim mogućnostima, istražujemo u tekstu koji slijedi.

\section{$*$}

Da bi se moglo odgovoriti na pitanje - imaju li sve nijeme stvari (i biljke i životinje) jednako značenje i funkcionalnu iskoristivost u propovjedničke svrhe ili se nekima, i to kojima, dodjeljuje više prostora i zašto - dakle, da bi se moglo što jasnije odgovoriti na postavljena pitanja, donosimo u sažetu obliku spoznaje do kojih se došlo u istraživanju životinjskoga svijeta u Hrani duhovnoj (v. Šundalić, 2008: 171-205).

U Hrani duhovnoj se pojavljuje oko 60 različitih naziva za životinje. Njima se ne potvrđuje temeljni čovjekov odnos spram životinje, onaj materijalno-upotrebni koji podrazumijeva da su životinje čovjeku glavni izvor hrane, odjeće i sirovina (Visković 1996: 11). Životinjsko se ovdje javlja kao potreba „,da bi se definirao čovjek, da bi se odredile unutrašnje granice ljudskoga“ (Visković 1996: 37), uz napomenu da se ovdje pod pojmom čovjek podrazumijeva u prvom redu kršćanin sklon grijehu. Da bi što zornije opisao njegove skrivene psihičke i moralne osobine, Zagrebec je češće posezao za divljim životinjama vlastita podneblja (navodi čak 35 različita naziva: črv, beštija, divji prasec, golub, golubica, gusenica, jastreb, jelen, kača, ašpiš, ljutica, tarantula, gavran, košuta, kragulj, kukac, lastovica, medved, miš, mol, mrcina, muha, mušica, orao, pčela, prepelica, ptica, ptičica, riba, štakor, vrabac, žužki, vučica, vuk, zajec); na drugom su mjestu domaće životinje (navodi 18 naziva: guska, hrt, janac, konj, kokoš, krava, mačka, osel, ovca, ovčica, pas, pišče, svinja, telac, vol, živinče, živina, žrebe), na trećem su mjestu divlje životinje stranih podneblja (navodi 6 naziva: oroslan, pantera, pav, balen, ris, zver), a na četvrtom su mjestu fantastične životinje (bažiliškuš, feniks, posoj).

U odnosu na carstvo Animalia (svijet životinja) u Hrani duhovnoj istraživanje je pokazalo da mu pater Zagrebec vrlo često pripisuje negativne konotacije i njima zornijima čini određene loše, griješne postupke svojih neimenovanih slušatelja. Tako se u usporedbama kao comparandum najčešće pojavljuju divlje životinje vlastita podneblja (beštija, kača, crv, štakor, moljac, miš, jastreb, vuk, itd.), među kojima jedino zmiji (kači) pripisuje isključivo zlo; u odnosu na druge životinje postoji mogućnost da su u određenim situacijama čak i one bolje od griješna čovjeka.

\footnotetext{
${ }^{7}$ Već su se u staroj Grčkoj živa bića dijelila na biljke i životinje „,(..) ali moderna znanost ukazuje na postojanje polja temeljnog jedinstva biljnog i životinjskog svijeta, koje se najlakše vidi kod bičaša i algi, s osnovama u zajedničkom podrijetlu - zbog čega je Ernst Haeckel predlagao uvođenje trećeg carstva Protista u sistematizaciji života.“ (Visković 1996: 23)
} 
Carstvo plantae u propovjedničkome žanru

Životinja se vrlo rijetko pojavljuje u pozitivnim i svojim svakodnevnim primarnim funkcijama (kao npr.u Plutarkusovoj priči, u kojoj se govori o konju koji je za jahanje /NT, 69/). Pozitivna su značenja gotovo podjednako vezana uz domaće i divlje životinje vlastita podneblja (živina, guska, ovca, volovi, osel, golubica, beštija, ptice, ribe, mušica, vuk, pčela, lastavica). Najčešće je riječ o suprotstavljenosti dvaju svjetova - prvi je životinjski, ispunjen dobrim namjerama i dobrim djelima, a drugi je ljudski, ispunjen zlom i lošim djelima. U navedenu kontekstu čak i one životinje uz koje se češće vezuju negativna značenja (beštija, zvijer) postaju pozitivna strana antiteze, jer je grješni čovjek još i od njih gori.

Za stvaranje nerealne zbilje propovjednik spretno koristi životinjski svijet, i to češće divlje životinje vlastita podneblja (golub, muha, vrabac, $m r$ cina, crv, kača, kača ašpiš, medvjed, divlja svinja, jelen, košuta, orao). Nerealna se datost realizira aktiviranjem njihovih i pozitvnih (konj, golub, vrabac) i negativnih osobina (mrcina, crv, kača, medvjed, divlja svinja, jelen, košuta), i to tako da se realno tumači kao privid ili se stvarne životinjske vrste dovode u odnose koje ljudska zbilja ne potvrđuje. A novostvorena zbilja ima samo jednu zadaću - izazvati strah u čovjeku zbog težine ovozemaljskih grijeha. Jezovitost ispričanoga komentirali su već i drugi pozorni čitatelji Zagrepčevih propovijedi: „U Zagrepčevu djelu imamo naime toliko i takvih priča, koje nas svojim sadržajem sjećaju ne samo na naše narodne pripovijetke, nego su one i toliko jezovite, da neke od njih svojim nemilim opisom prelaze svaki prikaz strahota i u Danteovoj 'Komediji'."(Galinec 1935b: 71)

Istraživanje carstva Plantae (svijeta biljaka) u Hrani duhovnoj pokazuju da za Zagrepčeve propovijedi u usporedbi sa životinjskim svijetom biljni nije izrazito razlikovno sredstvo: siromašno je i vrstovno i prema čestotnosti pojavljivanja, a i zastupljenost je neujednačena - u nekim se propovijedima ne pojavljuje niti jedan florealni leksem, dok se u nekima drugim autor njima vrlo obilato služi. ${ }^{8}$

U Hrani duhovnoj pojavljuje se preko dvadeset biljnih naziva (citronsko drevo, cvet, črešnja, dinja, drevo, figovo drevo, grmje, hajda, herš, hrast, hruška, jabuka, jačmen, kupinje, mandal, olika, palma, povertlje, p̌̌enica, rožica, žitek, travica, trn, trsje, vinika, žito), s oko 140 potvrda u tekstu, od kojih gotovo polovica otpada na opću imenicu drvo, koja se stoga i nalazi na prvom mjestu prema čestotnosti pojavljivanja. Navedeno je dobrim dijelom

\footnotetext{
${ }^{8}$ Prvi slučaj potvrđuje propovijed „Na dan S.Trojstva“ (NT, 1-12), a drugi slučaj potvrđuje propovijed „Sedma nedelja po Trojakeh“ (NT,83-97), u kojoj su preko 60 puta ispisani određeni florealni leksemi.
} 
određeno sadržajem perikope, pa tako na primjer nakon uvodnih rečenica za sedmu propovijed - Kod vsako drevo nerodeče dobroga sada podsekuje se $i$ vu ogenj postavlja, tak $i$ G.Bog vsakem grešnikom prez sada dobreh del čini (NT, 83) - slijedi tekst u kojemu se biljni leksemi navode više od 60 puta. Riječ je najčešće o uopćenim nazivima (drevo, znatno manje cvet, travica), na čije pojavljivanje u tekstu otpada gotovo dvije trećine svih potvrda, što znači da se na ostalih dvadesetak biljnih vrsta odnosi nešto manje od 40 potvrda u tekstu.

Zagrepčev biljni svijet pokazuje svoju veliku oslonjenost na biblijsku floru, o kojoj Nikola Visković kaže. „Uistinu, od svih drevnih vjerskih knjiga, Sveto pismo je ono koje najčešće imenuje biljke - oko 110 vrsta, s pedesetak vrsta stabala i grmova. A od svih stabala najviše se spominje velebni i miomirisni cedar, sedamdeset puta, i upravo na tome se temelji trajna karizma toga stabla u zapadnoj simbolici." (Visković 2001: 347) Oslonjenost Zagrepčevih propovijedi na biblijsku floru istražili smo posredno, uspoređujući je s biljnim svijetom u lekcionarima i evanđelistarima Nikole Krajačevića (Sveti evangeliomi, 1651.), Ivana Bandulavića (Pištole i evanđelja priko svega godišta novo istomačena, 1739.), Emerika Pavića (Epistole i evanđelja, 1808.), Kaja Agjića (Štijenja poslanica i evanđelja, 1865.) i Nikole Voršaka (Čitanja i evanđelja, 11878. $)^{9}$. Zajednički su im sljedeći nazivi: drevo, cvet, travica, trn, figovo drevo, palma, povertlje, kupinje, mandala, olika, pšenica, trsje, žito, ${ }^{10}$ dok se Zagrepčev lokalni kolorit može iščitati iz naziva biljaka kao što su: dinja, hruška, jabuka, črešnja, hajda, jačmen.

U usporedbi sa životinjskim svijetom ove propovijedi pokazuju da je biljni svijet korišten gotovo isključivo u prenesenom, i to pozitivnom značenju. Kao primjer uključenosti biljnoga svijeta u tekst u njegovu neprenesenu značenju javlja se tek poneka antiteza (npr. nekada su Židovi okrunili Isusa trnovom krunom, a danas ga slave i kite vjencima cvetja /NT, 21/), a i negativne su konotacije sporadične i jednostavne, bez razvedenih usporedbi homerovskog tipa. Riječ je najčešće o sažetim, poslovičnim rečenicama kojima se naglašava neka loša moralna osobina čovjekova (ne more zločesto drevo dobroga sada roditi, ar sin kaj vidi otca činiti to i on čini /NT, 154/).

Biljka kojom se u prenesenu značenju može najviše govoriti o čovjeku (ne)kršćaninu, prema Zagrepčevu je mišljenju - drvo (drevo) - za što argumentaciju nalazi i u Svetom pismu, i u crkvenih proroka i učitelja, ali i kod filozofa Platona koji, citirano prema Zagrepcu kaže: Homo est arbor inversa.

\footnotetext{
${ }^{9}$ Rezultati istraživanja biljnoga svijeta lekcionara navedenih pisaca nalaze se $\mathrm{u}$ mojoj knjizi Kroz slavonske libarice (Osijek, 2005).

${ }^{10}$ U najzanimljivije i najznačajnije raslinstvo u Bibliji Nigel Hepper navodi: pšenicu, palmu, mirtu, smokvu, badem, maslinu, vinovu lozu, lan, libanski cedar, šipak, hrast, šaš, korijandar, tamjan, rutvicu, trnje i korov (Hepper 1989: 97-100)
} 
Carstvo plantae u propovjedničkome žanru

Človek je drevo naopak obrnjeno, (...). (NT, 83) Nakon ovakve konstatacije slijedi jedna od rijetkih razvedenih usporedbi ${ }^{11}$ u kojoj je $d r v o$ pojam s kojim se uspoređuje (comparand), čovjek kršćanin pojam koji se uspoređuje (compare), a tertium comparationis govori o sličnostima koje propovjednik nalazi među njima:

Jesu vnoge i neizbrojene stvari i stvorenja Božja kojim se more vsaki živuči ter najmre krščeni človek prispodobiti, ali zmeđ vseh stvarih od kojeh sem ja čtel kaj moje žive dni, ni jedna mi se ne vidi priličneša od dreva i to mi potvrđuje na samo $S$. pismo, s. proroki i navučitelji cirkveni, nego i poganinski mudri, kod je bil Plato filosofus, koji veli: Homo est arbor inversa. Človek je drevo naopak obrnjeno, ar kakti vsako drevo ima svoje korenje, steblo, koru, sversi, listje, cvetje i sad; tak more se reči od človeka, kojega glava je koren, steblo je telo, kora je kosa, sversi jesu ruke, listje i sad jesu dobra ali zla dila. Drevje ima korenje vu zemlje, dobri pako ljudi imaju proti nebu obrnjeno, odkud oni kod drevo od zemlje hranu svoju primlju; zločesti pako ljudi obračaju korenje svoje proti zemlje, ne misleč, ne želeč, niti ne iščuč drugo nego veselja i nasladnosti zemeljska, vremenitna i hipna; ne marajuči se, niti ne skrbeči za nebeska vekovečna. I kakti se dvoje fele drevja nahađa na zemlje, nekoje pitomo, nekoje divje kod su hruške i jabuke, pitome koje rode lep, sladek i smahen sad za vsaki gospocki stol, divje pako rode sad žuhek i kisel, ne za ljudi nego za živinu prikladen, kojem drevam prispodobiti se mogu verni krščeniki i krivoverniki. Među pitomemi drevi takaj nahađaju se nekoja plodna, nekoja neplodna. Tak i međ krščeniki nahađaju se nekoji ljudi plodni z dobremi deli, nekoji neplodni, i kaj se iz drevja neplodnoga i divjega čini od gospodara njihovoga, to se čini iz krivovernikov i prez dobreh del krščenikov, da se najmre podsekuju i vu ogenj postavljaju, (...). (NT, 83-84)

U navedenoj razvedenoj usporedbi razvidno je sljedeće: drevo naopak obrnjeno = čovjek; koren = glava; steblo = tijelo; kora = koža; listje $i$ sad $=$ dobra ili zla djela; korenje proti nebu obrnjeno = dobri ljudi; korenje proti zemlje obrnjeno = zločesti ljudi; pitomo $i$ divje drevje kod su hruške $i$ jabuke = vjerni kršćani i krivovjerci; pitoma su drevja plodna $i$ neplodna $=$ ljudi plodni čine dobra djela, a neplodni ne čine; neplodno i divje drevo se podsekuje $i$ u oganj postavlja $=$ kršćanin bez dobrih djela i krivovjerac idu u pakleni oganj; dobar sad = dobro djelo; itd.).

11 O pojmu razvedene usporedbe pisali su posebice Skok (1950), Fališevac (1995), Kravar (1995). 
Na kraju ove propovijedi bogatog herbarija propovjednik određenoj skupini ljudi prispodobljuje određene biljne vrste i to na sljedeći način:

- redovnici (redovne persone) su kao mandalsko drevo, jer ono tj. badem najranije cvjeta, a redovnici moraju biti među prvima koji pronose svijetom istinu o Bogu. Oni su (...) cvetuči svetu i rodni nebu na spodobu mandalskoga dreva koje zmeđ vsega sadovnega drevja najpervo cvete, tak $i$ vaša dužnost je najpervo cvesti međ ostalem drevjem vu ternacu s. cirkve zasajenom. Mandala cvetuča mora jošče veliku zimu, vetre $i$ godine mrzle podnesti, cvetuča vendar ostaje i plemenit sad donaša. Tak $i$ vsaka redovna persona mora vnoge suprotivčine od tela, sveta $i$ vraga pretrpeti, ali zato ne mora cvetja vnogo menje sada pogubiti. (NT, 96);

- bračni drugovi (zakonski ljudi) su kao figovo drevo, jer ono, tj. smokva dva puta donosi dobar plod, kao muž i žena djecu. Zato im propovjednik savjetuje da nasljeduju (...) figovo drevo kojega cvet je prvi sad, potlam pak drugi sad rodi, tak činete i vi (...). (NT, 96);

- mladići i djevojke (mladenci i divojke) su kao mladice vlične, okrenuti prema nebu, a ne prema zemlji, jer trebaju vidjeti samo nebesko veselje. Oni su Kakti mladice vlične vsigdar zelene po letu i po zime, cvetete jošče vu mladosti i rodete sad kod vlične mladice čine, živuči vu pokornosti, pobožnosti, čistoče i poniznosti, ne nagibljete se proti zemlje, nego izraven proti dike nebeske rastete, vsigdar bolje premišljavajuč lepotu i veselje nebesko vekovečno, neg čalarnosti i nasladnosti hipne sveta ovoga. (NT, 97);

- a udovice su kao palme, koje ne smiju biti zalivene svježom vodom, jer će uginuti, a tako se ni udovica ne smije odati nasladnostima, ne smije se „friškati“" zemaljskim ugodama, jer će umrijeti: Palma ako je friškum vodum zalejana, počne pogibati $i$ sušiti se. Tak $i$ vi ako se budete friškale s nasladnostmi sveta ovoga, počnete taki pogibati vu milošče Božje, (...). (NT, 97).

$\mathrm{U}$ ostalim situacijama propovjednik biljne lekseme koristi na manje kompliciran način, što potvrđuju sljedeći primjeri:

- biljni leksem (cvet, olika, trn, dinja) simbolizira određenu vrijednost ili stanje (duševnu čistoću, mir, siromaštvo, rast grijeha). Na primjer: gospodičnu Aleksandru krasi krjepost duševne čistoće, tj. prelepi cvet čistoče (NT, 51), isto kao i Jožefa, sina patrijarka Jakopa, koji bježi iz kraljičine postelje kako ne bi izgubio cvet svoje čistoče (NT, 264); na jednoj strani kovanice Maksimilijana Cezara grančica olike/masline simbolizira mir (NT, 71); trn simbolizira siromaštvo /NT, 234/; rast dinje simbolizira rast grijeha (NT, 317318). 
- propovjednik koristi određeni biljni leksem kako bi svojem slušateljstvu objasnio s kakvim se sve velikim teškoćama susreće u tumačenju kršćanskih istina, pa kaže da bi prije objasnio vjerniku kako pod snijegom rožice cvetu, nego što bi mu objasnio Božju zapovijed o potrebi traženja oprosta od svojih bližnjih.

- biljni leksem može biti sastavnica poslovičnog iskaza, koji je u funkciji tumačenja i približavaja vjernicima određenih kršćanskih istina (npr. o Božjoj sveprisutnosti govori i sintagma u kojoj se kaže da bez Njegova znanja ni list iz drva opasti ne more (NT, 77/).

- biljnim se leksemima ponekad iskazuje i topos neizrecivosti (npr. da su sve travice pera za pisanje, ne bi se mogla opisati ljepota lica Božjega /NT, 9/).

- zatim, propovjednik koristi i postupak nizanja realističkih opisa sporadičnih, ali uobičajenih pojava u prirodi, kako bi pojasnio određene postupke Svevišnjega. Naime, različite vremenske nepogode (suša, tuča, poplava, mraz) mogu ponekad uništiti i biljke i životinje, a čovjek se sjeti zazvati Boga u pomoć tek kada je već za sve kasno, te mu On stoga i ne pomaže. Ako On kroz neko vrijeme čini čovjeku dobro, a on-čovjek $\mathrm{Mu}(\mathrm{Bogu})$ je nezahvalan za to, u određenom će trenutku nastati „nepogoda“, tj. izostat će Njegovo dobročinjenje. Vjerniku se navedena logika i izostanak Božjega dobročinjenja približava domaćim koloritom (jačmen, herš, pšenica, žito, hajda, povertelje):

Pripeti se da letina zmanka, da najmre jačmen, herš i pšenica po zime pozebe, da žito i hajdu mraz opali, da sadovje gusenice pokvare, da trsje tuča zkonča, da povertelje ali suša posuši, ali povodnja pomuli, da na živinu kuga dojde, da očivesti glad postane, od kojega ljuctvo pogibajuč, moli se G.Bogu, hodi po cirkvah na procesijah, kriči na ves glas: Gospone, smiluj se! Kristus, smiluj se! Gospone, vsliši nas! Kristus, vsliši nas! Ali vse zaman, ar prez hasni i prez pomoči čini se G.Bog gluhoga na prošnje. Odkud to, zakaj to? S. Thomas od Aquine tomu daje zrok ovakav (...). Ako Dobročinitelj za dobročinenja večkrat ponovljena nezahvalnost primlje, mora prestati dobročiniti. (NT, 179)

$$
* * *
$$

U pisanju svojih propovijedi Štefan Zagrebec nije, dakle, poklanjao naročitu pozornost biljnome svijetu, ni u odnosu na brojnost, ni u odnosu na čestotnost, ni u odnosu na lokalni kolorit. Autor mu je pristupao jednostrano stavio ga je u funkciju prikazivanja, uglavnom, pozitivnih osobina (duševne 
čistoće, Božje pravednosti), čemu su poslužili i neki poslovični iskazi, odnosno topos neizrecivosti.

\section{4.}

Istraživanje flore (i ovdje nešto manje faune) u propovijedima Štefana Zagrepca pokazalo je da je riječ o žanru u kojemu su životinje znatno više zastupljene (oko 60 naziva za životinje) u odnosu na biljke (preko 20 naziva za biljke), i to kako u odnosu na brojnost vrsta tako i u odnosu na čestotnost pojavljivanja (biljni je svijet upola manje zastupljen). Pri tome dolazi do izražaja propovjednikova sklonost izrazito ozbiljnome diskursu, jer se niti jedan leksem ne pojavljuje u kontekstu smijeha. Florealni se i faunistički leksemi pojavljuju gotovo redovito u prenesenu značenju, a tek sporadično i u svom primarnom, što nalaže poetika propovjedničkoga žanra. Naime, sve priče u kojima se kao glavni akteri pojavljuju određene biljke (i životinje) nemaju smisao unutar granica ispričanoga, nego tek u konteksu propovjednikova tumačenja određenih vjerskih istina. Nakon ispričane pelde ili hištorije slijedi aplikacija, primjena na određeni segment kršćanskoga života i transformaciju neprenesenog u preneseno značenje. U tekstu se ono najjednostavnije ostvaruje dodavanjem pridjeva paklenski (peklenski) određenom biljnom (ili životinjskom) leksemu, odnosno uz pomoć usporedbe, razvedene ili nerazvedene. Tako, na primjer, dinja postaje peklenska dinja (NT, 318), a kača postaje peklenska kača $(\mathrm{NT}, 48)$.

Životinjski svijet osim što vrstovno i čestotno nadmašuje svijet rastlinja u Hrani duhovnoj, on je i značenjski raznovrsniji, jer se uz njega ne vezuju samo pozitivne konotacije, kao što je to u slučaju biljnoga svijeta, nego su vrlo česte i negativne, ali i one kojima se gradi nestvaran svijet. Upravo se stoga uz životinjski svijet češće vezuje nelagoda, prijetnja i strah, te je u njemu vrlo malo umanjenica (susrećemo tek tri faunističke umanjenice: ptičica, ovčica, pišče), dakle onih oblika koji su bili vrlo omiljeni u hrvatskoj renesansnoj pastoralno-idiličnoj drami (u kojoj su upotpunjavali osjećaj ugode), odnosno u komediji (u kojoj su upotpunjavali drugačiju ugodu - hedonizam).

U Hrani duhovnoj propovjednik, nadalje, ne krije svoje sklonosti prema lokalnome. Tako autor na više mjesta u tekstu ističe Horvatcki orsag, zatim njegove običaje (Navada je vu našem najmre Horvatckom orsagu z kraguljem prepelice loviti (...) /NT, 181/), ali i njegove životinje i biljke. Lokalni kolorit otkrivaju posebno imenovane ptice: golub, golubica, jastreb, karvan/ Igavran, kragulj, lastovica, orao, vrabac), odnosno biljke: dinja, hruška, jabuka, črešnja, hajda, vinika, jačmen.

Kada se propovijed kao izrazito poslušan žanr (S. P. Novak), primarno određen izravnim obraćanjem slušateljstvu, usporedi s faunom nekih drugih žanrova 16. i 17. stoljeća (lirika, pastorala, komedija, naracija u stihu, npr.), 
Carstvo plantae u propovjedničkome žanru

onda se uočava da i propovijed pokazuje veću sklonost prema općim nazivima, pa se tako na visoko pozicioniranim mjestima nalazi zvijer ili beštija, koja kontekstom dobiva drugačija značenja. U odnosu na floru situacija je bitno drugačija: u renesansnoj lirici, pastorali, komediji, naraciji u stihu prvo mjesto naizmjenično pripada cvijetu (v. Srdoč-Konestra 2002: 1-16) ili travi, dok se u Zagrepčevoj Hrani duhovnoj kao prvorangirani leksem nalazi drvo, potvrđujući na taj način svoju bitnu oslonjenost na biblijski biljni svijet, u kojemu stabla imaju veliko značenje, odnosno Zagrebec tako pokazuje svoju odmaknutost od petrarkističkog florealnog nasljeđa.

Naše istraživanje flore, i nešto manje faune, u propovijedima prvog dijela Hrane duhovne iz 1734. godine Štefana Zagrepca potvrdilo je, dakle, da ,religioznom čovjeku Priroda nikada nije isključivo 'prirodna' “ (Visković 2001: 294).

\section{Literatura}

- AB. 1985. Evanđelistar, Lekcionar. Leksikon ikonografije, liturgike i simbolike zapadnog kršćanstva [ur. Anđelko Badurina]. Zagreb : Sveučilišna naklada Liber - Kršćanska sadašnjost, 225, 375-376.

- Cansdale, George. 1989. Ptice i druge životinje. Biblijski priručnik. Mala enciklopedija [ur. David i Pat Alexander]. Zagreb : Kršćanska sadašnjost-Grafički zavod Hrvatske, 101-103.

- Delimo, Žan (Jean, Delumeau). 1986. Greh i strah: stvaranje osećanja krivice na Zapadu od XIV do XVIII veka, I [prev. Zoran Stojanović], Novi Sad : Književna zajednica Novoga Sada-Dnevnik, 499 str.

- Dukat, Vladoje. 1944. Sladki naš kaj: ogledi iz stare kajkavske književnosti, Zagreb : Izdanje hrvatskog izdavalačkog bibliografskog zavoda, 309 str.

- Fališevac, Dunja. 1995. „Figura u epu (Na primjeru Marulićeve JUDITE)“. Tropi i figure [ur. Živa Benčić i Dunja Fališevac]. Zagreb : Zavod za znanost o književnosti, 399-425.

- Galinec, Franjo. 1935a. „Ezopova basna u hrvatskoj kajkavskoj književnosti XVII i XVIII stoljeća“, Zbornik za narodni život i običaje Južnih Slavena, Knjiga XXX, Svezak 1, 32-46.

- Galinec, Franjo. 1935b. „J.Habdelić, T.Brezovački, Š.Zagrebec“, Prilozi za književnost, jezik, istoriju i folklor, Knjiga petnaesta, Sveska prva i druga, 64-74.

- Galinec, Franjo. 1936. „Prilozi za motiv 'nesretna i gonjena djevojka' u kajkavskoj književnosti XVIII stoljeća“, Zbornik za narodni život i običaje Južnih Slavena, Knjiga XXX, svezak 2, 1-16. 
- Galinec, Franjo. 1934/1935. „Prilozi za povijest hrvatske književnosti u XVII. i XVIII. stoljeću. 'Loci communes' - u pričanju starijih hrvatskih pisaca“, Nastavni vjesnik, Knj. XLIII, sv. 1. i 2., sv. 3. i 5., 28-37. i 127-142.

- Georgijević, Krešimir. 1969. Hrvatska književnost od XVI do XVIII stoljeća u sjevernoj Hrvatskoj i Bosni, Zagreb : Matica hrvatska, str. 324.

- Hadrovics, László. 1982. „Štefan Zagrebec - kajkavski umjetnik kompozicije i stila“. Hrvatski dijalektološki zbornik, 6, 169-179.

- Hepper, Nigel. 1989. „Raslinstvo u Bibliji“. Biblijski priručnik. Mala enciklopedija [ur. David i Pat Alexander]. Zagreb : Kršćanska sadašnjost-Grafički zavod Hrvatske, 97-100.

- Januš, Ivančica. 1994. „Kajkavska barokna propovijed kapucina Štefana Zagrepca“, Kaj, 27, 2, str. 27-40.

- Kravar, Zoran. 1995. „Estetika tropa“. Tropi i figure [ur. Živa Benčić i Dunja Fališevac]. Zagreb: Zavod za znanost o književnosti, 75-103.

- Krušelj-Vidas, Ines. 1999. „Hrana duhovna Štefana Zagrepca: uz 330. obljetnicu rođenja Matije Markovića poznatijeg kao Štefan Zagrebec", Hrvatsko zagorje: časopis za kulturu, 5, 2, 125-142.

- Pajur, Franjo. 2004. „Štefan Zagrebec i barokna propovjedna književnost“, Kaj, 37, 6, 35-59.

- Skok, Petar. 1950. „O stilu Marulićeve JUDITE“, Zbornik u proslavu petstogodišnjice rođenja Marka Marulića 1450-1950 [ur. Josip Badalić i Nikola Marjanić], Zagreb : Djela JAZU, Knjiga 39, 165-241.

- Srdoč-Konestra, Ines. 2002. Flora Ranjinina zbornika, Fluminensia, 14, 1, 1-16.

- Šojat, Olga. 1978. „Štefan Zagrebec (1669-1734)“, Forum, XVII, 6, 1091-1121.

- Šundalić, Zlata. 2005. Kroz slavonske libarice: rasprave o nabožnoj književnosti u Slavoniji, Osijek : Ogranak Matice hrvatske Osijek, str. 257.

- Šundalić, Zlata. 2005. „Na tragu Rešetarove podjele Držićevih djela“. Zbornik o Milanu Rešetaru književnom kritičaru i filologu [ur. Tihomil Maštrović]. Zagreb : Hrvatski studiji Sveučilišta u Zagrebu, 125-142.

- Šundalić, Zlata. 2003. „Životinja i hrvatska renesansna pastoralnoidilična drama“. Krležini dani u Osijeku 2002: žanrovi u hrvatskoj dramskoj književnosti i struke u hrvatskom kazalištu [ur. Branko 
Carstvo plantae u propovjedničkome žanru

Hećimović]. Zagreb - Osijek : Zavod za povijest hrvatske književnosti, kazališta i glazbe HAZU etc., 18-49.

- Zlata Šundalić. 2008. „Životinjski svijet u propovijedima Štefana Zagrepca“, Bogoslovska smotra, LXXVIII , 1, 171-205.

- Visković, Nikola. 2001. Stablo i čovjek: prilog kulturnoj botanici, Zagreb : AntiBarbarus, str. 848.

- Visković, Nikola. 1996. Životinja i čovjek: prilog kulturnoj zoologiji, Split :Književni krug Split, str. 518.

\section{Zlata ŠUNDALIĆ}

\section{THE EMPIRE OF PLANTAE IN THE NARRATIVE GENRE}

In the focus of interest of this paper is the $18^{\text {th }}$ century kajkavian prose. The authors in question are kajkavian religious storytellers who by writing/telling their sermons also became prose-writers, since in their spiritual conversations they also included various stories, anecdotes and fairytales - frequently with fantastic elements. Such prose was first written in the $17^{\text {th }}$ century by Juraj Habdelić, and in the $18^{\text {th }}$ century it was produced by authors such as: Juraj Mulih, Štefan Zagrebec, Štefan Fuček, and others. In this paper, special attention will be paid to sermons written by Štefan Zagrebec (Zagreb, 1669 - Zagreb, 1742), a kajkavian preacher and storywriter. Since his only work - Pabulum spirituale ovium christianarum... / Hrana duhovna, ovčic kerščanskeh... - was published in 5 books (volume I in Zagreb in 1715, volume II in Klagenfurt in 1718, volume III in Zagreb in 1723, volume IV in Zagreb in 1727 and volume V in Zagreb in 1734) comprising more than 3000 pages, in this paper the author will discuss only the last, fifth book from 1734. In this paper the poetics of sermons written by Zagrebec will also be researched, with a special emphasis on the plant.

Key words: kajkavian storytellers, Štefan Zagrebec, Pabulum spirituale, sermon, a plant 

LINGUA MONTENEGRINA, god. III, br. 5, Cetinje, 2010.

Institut za crnogorski jezik i jezikoslovlje „Vojislav P. Nikčević“

UDK 821.163.42.09-31 Brešan I. Pregledni rad

\title{
Mirna BRKIĆ (Mostar) \\ Filozofski fakultet u Mostaru
}

\section{IGRA NA POZORNICI ŽIVOTA}

\begin{abstract}
Predmet našeg proučavanja su Ispovijedi nekarakternog čovje$k a$ (1996.), drugi roman Ive Brešana. Opsežan pikarski roman, bogate, razgranate fabule i intertekstualnih natuknica, samo je na površini roman o pustolovinama glavnog lika. Posluživši se likom (ne)karakternog čovjeka Fabricija Viskova, Brešan će u romanu iznijeti svoja etička i filozofska promišljanja te književno originalan pogled na problem povijesti i povijesne istine.
\end{abstract}

Ključne riječi: Brešan, Ispovijedi nekarakternog čovjeka, etičko-filozofska promišljanja, pitanje povijesne istine

Ispovijedi nekarakternog čovjeka (1996.) drugi je roman Ive Brešana. Opsežan je (gotovo 500 stranica) i sastoji se od Uvoda i čak 57 poglavlja, raspoređenih u 5 dijelova. Napisan je u prvom licu - pripovjedač i glavni lik romana „nekarakterni čovjek“ Fabricije Viskov pripovijeda svoj život od rođenja do starosti, tj. do one točke u kojoj počinje pripovijedanje. Između prvog Brešanova pikarskog romana Ptice nebeske i Ispovijedi nekarakternog čovjeka razlika je, između ostalog, što bismo prvi Brešanov roman mogli povezati s ranom fazom pikarskog žanra vezanog za španjolsku književnost 16. st. kad ta vrsta romana još nije opterećena etičko-filozofskim promišljanjima pikara, što će biti jedna od karakteristika pikarskih romana od 18. st. nadalje. ${ }^{1}$

Karakteristika suvremenih pikarskih romana poput Ispovijedi jeste da povezuju dvije naoko suprotne karakteristike u formiranju tematske strukture djela: $\mathrm{s}$ jedne strane to je potreba za kretanjem, istraživanjem, za sudjelovanjem, a s druge strane potreba za očuvanjem individualne nezavisnosti pa se, kao logična posljedica sukoba između tih dviju suprotnih sila, javlja izražena sklonost prema intelektualističkoj introspekciji, preispitivanju odnosa između svijeta kakav jest i svijeta u nama.

${ }^{1}$ Usp. V. Visković, „Brešanovo dvadeseto stoljeće“, u knjizi: Umijeće pripovijedanja. Ogledi o hrvatskoj prozi, Znanje, Zagreb, 2000., str. 130. 
Iako je sama Fabricijeva biografija dovoljno bogata doživljajima da privuče pozornost, ipak ono što čini zanimljivim ovaj roman nisu samo zbivanja u kojima sudjeluje, već njegova razmišljanja. Ispovijedi nekarakternog čovjeka samo su na površini roman o pustolovinama glavnog lika. Obrazac pikarskog romana poslužio je Brešanu da na usta Fabricija Viskova iznese svoja filozofska i etička načela te da uobliči književno originalan pogled na problem povijesti i povijesne istine. U skladu je to s Brešanovom poetikom, kako navodi: ,Još uvijek držim da literatura mora sadržavati nešto metafizičko i da je filozofija ono osnovno u njoj. Književno djelo mora biti filozofija, a priča je tu samo zato da tu filozofiju približi čitatelju“. ${ }^{2}$

U Uvodu romana Fabricije kaže da mu je namjera iskreno, bez uljepšavanja iznijeti sve događaje iz svog života. Indikativan je u tom pogledu i naslov romana. Riječ ispovijed(i) referira na katoličku vjersku tradiciju priznavanja grijeha i istina, potpuno iskreno, bez prikrivanja, o sebi pred Bogom.

Već će u Uvodu Fabricije iznijeti svoja filozofska promišljanja o (ne)postojanju morala i karaktera objašnjavajući zašto sam sebe naziva ,nekarakternim čovjekom“. Govoreći iz svog bogatog i često bolnog iskustva, došao je do zaključka da su moral, karakter i načela zapravo samo fikcije. Reći će da su ljudi od početka svijeta na moralno ponašanje motivirani ili strahom od kazne ili željom da budu nagrađeni: $U$ svom dugom i iskustvima bogatom životu nisam nikad sreo ni jednog dobrotvora, donatora, samaritanca, djelitelja pomoći i čovjekoljupca koji u onom što čini nije bio motiviran barem nekom korišću. “3 Odnosno tvrdi: „(...) dobro i zlo ne postoji; oni su samo oznake ili etikete, koje ljudi lijepe tuđem ponašanju, ovisno o tome kako je ono njima u interesu ili od koristi. ${ }^{4}$

Brešan zapravo želi pokazati da su ,ideologizirani modeli samo paravan iza kojeg se najčešće skrivaju sasvim konkretni, pragmatični razlozi te da su njihovi nositelji, neovisno jesu li pripadnici političke ili crkvene vlasti, spremni 'korigirati " vlastite stavove ukoliko u tome vide vlastiti probitak". 5 "

Obrazlažući svoje stajališta u svezi karakternosti, Fabricije kaže i ovo:

Najopasnijom od svih sastavnih osobina karaktera čini mi se kad netko sebi za životni cilj postavi kakav ideal: domovinu, pravednije društvo, slobodu ili jednakost sviju, i spreman je za to na sva moguća odricanja, pa čak i na žrtvu vlastitog života (...) A da ne govorim o tome kako je taj, koji je zbog vlastitih fikcija spreman žrtvovati vlastiti život, to još spremniji kad se radi o tuđem. I što je

${ }^{2}$ Sotona ponovno lik u Brešanovu romanu, www.radio101.hr

${ }^{3}$ I. Brešan, Ispovijedi nekarakternog čovjeka, Znanje, Zagreb, 1996., str. 9.

${ }^{4}$ Isto, str. 10/11.

${ }^{5}$ Milovan Tatarin, „Utvara povijesti, utvara individualnosti“, Dometi, godina 10, broj I-IV, 2000., str. 35. 
Igra na pozornici života

najgore, to ludilo traje koliko i povijest, od srednjovjekovnih asketa (...) pa do suvremenih fanatika koji sjedaju u automobil pun eksploziva i dižu u zrak sebe i druge. A ako biste takvog nekog luđaka pitali što mu je to potrebno i zašto to radi, on bi vam spremno odgovorio: 'Da bi idućim generacijama bilo bolje i da bi živjele u sreći i blagostanju. ' No kakva uistinu sreća i blagostanje čeka iduće generacije od toga, najbolje se vidi ako se neki od tih ideala kojim slučajem ostvari i postane društvena praksa. Ne treba biti vrstan poznavalac povijesti, pa da se zna kakvi su sve monstruozni režimi nastajali na takvim zasadama i kako su u njima nestajale na tisuće ljudi, pa čak i čitavi narodi, ako nisu bili po mjeri tog ostvarenog ideala. ${ }^{6}$

Kao zastupnik antiideološkog pogleda na život Fabricije je sumnjičav prema svakom idealističkom uzletu usamljenog pojedinca. U njegovom se sarkazmu zapravo krije i dio one zdrave plebejske skepse, ona stoljetna eulenspiegelovska sumnja u velike geste i patetičnu retoriku, dakle ona mudrost koja je svojstvena srodnim pučkim likovima u književnosti.

No, pripovjedač nema namjeru čitatelja uvjeriti u svoj način razmišljanja ili mu ponuditi neko svoje rješenje. Naprotiv, on izlaže svoje viđenje stvari, morala i povijesti ostavljajući čitatelju da sam donese svoje sudove i zaključke.

Ispovijedi nekarakternog čovjeka počinju rođenjem glavnog lika Fabricija Viskova 1918. godine u vrijeme propasti Austro-Ugarske i proglašenja nove države, a završavaju prizorom proslave hrvatske neovisnosti 1990. godine tako da se kroz roman događaji ,velike“ povijesti stalno prepliću sa životom ,malog“ čovjeka Fabricija Viskova.

Ako pikarski roman i lik pikara, kako su naglašavali prvi teoretičari toga žanra, nastaje kad je društvo u stanju ,duboke promjene“7 i ovaj pikarski roman i lik pikara Fabricija nastaje kao komentar na važna i dramatična zbivanja u Europi, bivšoj Jugoslaviji, odnosno Hrvatskoj u 20. st. kada se raspada Austro-Ugarska Monarhija te se smjenjuju čak dva revolucionarna, totalitarna koncepta, koja su imala ambiciju uspostaviti novi, bolji poredak - fašizam, a zatim i komunizam, a roman završava prijelomnim trenutkom hrvatske povijesti - stvaranjem neovisne hrvatske države.

Fabricije je, kao i svaki pikaro, putnik kroz vrijeme, prostor i razne slojeve društva, što Brešanu omogućava da prikaže lice i naličje zbilje, socijalne promjene te razne tipove ljudi. Uz to, ovaj roman funkcionira, može se tako reći, i kao „sat političke povijesti Jugoslavije“ - slika je to povijesnih i politi-

${ }^{6}$ Ispovijedi nekarakternog čovjeka, str. 9.

${ }^{7}$ Usp. R. Bjornson, The Picaresque Hero in European Fiction, Madison, Wisconsin, University of Wisconsin Press, 1977., 4. 
čkih mijena na ovim našim prostorima te viđenje povijesti iz perspektive malog čovjeka, sporedne figure povijesti, na kojem se ludilo povijesti najkrvavije očituje.

U prvom poglavlju Fabricije govori o svom rođenju u neimenovanom dalmatinskom mjestu, koje podsjeća na rođenje Rableaisova diva Gargantue. Tom se intertekstualnom natuknicom otvara cijelo polje intertekstualnosti, što je postupak tipičan za sva Brešanova djela. Intertekstualnost u ovom romanu ima i posebno objašnjenje - Fabricije je, iako prezire uređen sustav školovanja, veliki poznavatelji i ljubitelj knjiga te mu se često čini da njegov život poprima karakteristike pročitanih književnih djela, ${ }^{8}$ svjedočeći kako je ponekad tanka granica između zbilje i fikcije.

${ }^{8}$ Intertekstualne opaske u Brešanovim Ispovijedima nekarakternog čovjeka:

Mjesto u Šibeniku gdje Fabricije radi izgleda mu kao neki liliputanski grad iz romana Jonathana Swifta; S konteom, za kojeg se odmah vidi da živi u prošlim vremenima, Fabricije komunicira na način koji konteu odgovara, što mu nije bilo teško zahvaljujući čitanju Šenoinih romana; Za svoju stanodavku kaže da podsjeća na jednu od proročica iz Shakespeareova Machbeta; Razgovori koje Fabricije s prijateljima vodi u kavani Corso postali su toliko dosadni da su se mogli natjecati s fakultetskim predavanjima o Kronici Antuna Vrameca; Kad se jedanput potukao, Fabricije kaže da je protivnika pograbio kao Heraklo Anteja; Kada Adam Lisjak skriva njegove dragulje, učini to kao da je čitao Izgubljeno pismo Edgara Allana Poa; Prilikom zavođenja žena Fabricije se ponaša kao kombinacija Rolanda i Odiseja; Fabricije smatra, parafrazirajući Gogolja, da u svijetu ima takvih zagonetki koje ni čitatelji ni on nikada neće moći odgonetnuti.

Fabricije čak povlači paralele između situacija iz svog života i drugih umjetnosti, najčešće filma, npr. Giulija je odglumila da joj je pozlilo uvjerljivije nego Greta Garbo u Dami s kamelijama. A epizoda u kojoj Fabricije traga za draguljima sakrivenim u jednom od kipića, podsjeća na potragu Ostapa Bendera za draguljima sakrivenim u jednoj od dvanaest stolica iz romana Dvanaest stolica Iljfa i Petrova.

Osim toga, Brešan uspoređuje Điđija, Fabricijeva prijatelja, s Hašekovim dobrim vojakom Švejkom i likovima commedie dell'arte: Po svemu mi se učini da sam se našao u društvu neke suvremene talijanske varijante dobrog vojaka Švejka... (Ispovijedi nekarakternog čovjeka, str. 257.); ili (...) pripadao je onoj vrsti ljudi, koja od svake životne situacije pravi burlesku, te se doimao kao brat likova iz commedia dell'arte (Isto, str. 259.)

Očito je da je Brešan u ovom romanu vođen i danteovskom vizijom svijeta. Intertekstualni odnos s Danteovim Paklom Brešan uspostavlja od svojih prvih radova pa sve do posljednjih romana. Svi likovi u Ispovijedima u danteovskom su smislu grješnici, imaju grijeh, mrlju u svojim biografijama. Često će Fabricije iskustva iz vlastitog života povezivati s Danteovim Paklom, npr. govoreći o iskustvima u ustaškom zatvoru, kaže: Jedino što je iz vanjskog svijeta dopiralo do mene, bili su zvukovi, a ti su bili takvi da sam imao osjećaj da sam u predvorju Pakla. I nehotice se sjetih Danteova stiha. „Sad stanu bolni zvuci da se množe u mojem uhu...", jer ono što sam čitavo vrijeme slušao, bili su sami jauci, cviljenja, tuljenje, zapomaganja, uzdisanja i svi mogući glasovni načini iskazivanja ljudske boli. (Isto, str. 181/182.) 
Igra na pozornici života

Od rođenja Fabriciju je sudbina namijenila da bude drugačiji od drugih. Čak je kršten dva puta. Otac ga je prvo krstio kao katolika, no radi obećane zemlje prelaze na pravoslavnu vjeru kako bi se obitelj spasila bijede. U Ispovijedima nema idealizacije nikoga, pa ni Fabricijeve obitelji. Već na ovom primjeru jasno se očituje Brešanova teza kako čovjek lako odustaje od načela kad se radi o preživljavanju.

Motiv dvostrukog, čak trostrukog krštenja, javlja se u hrvatskoj književnosti i prije i vezan je uz tradiciju lika Petrice Kerempuha. ${ }^{9}$ Matoš u svom

Odnosno, kad opisuje zločine četničkog vojvode Momčila Đujića, kaže da ni Danteova mašta ne bi mogla zamisliti u paklu nešto strašnije. A dospjevši na Goli otok, taj pakao na zemlji, uspoređuje ga s Danteovim paklom.

${ }^{9}$ U 18. stoljeću kajkavski pisac Jakob Lovrenčić (1787. - 1842.) na temelju njemačkih priča o Tillu Eulenspiegelu stvara lik Petrice Kerempuha. Petrica Kerempuh iz njegova djela Petrica Kerempuh iliti Čini $i$ živlenje človeka prokšenoga, koje datira iz 1834. godine, predstavljen je kao lik šaljivčine, ali i varalice, obješenjaka i lukavaca, puna nestašluka, zluradosti, pa i prave pakosti, te su njegovi postupci na granici društveno dopuštenog i često vrijeđaju etičko osjećanje.

Lovrenčićevo djelo u hrvatskoj historiografiji nije dosad dobilo precizniju generičku odrednicu: najčešće se nazivalo samo ,djelo“ ili „djelce“ ili pripovijetka. Na 98 stranica ispričano je 15 kraćih pripovijesti koje kronološki prate Kerempuhove pustolovine od rođenja do smrti. Budući da je Petrica Kerempuh komponiran kao zbirka raznorodnih pripovijedaka ili anegdota koje u cjelinu povezuje naslovni lik i budući da taj lik obilježava strukturu, ton i duh svih pripovijedaka u zbirci, Dunja Fališevac drži da bi Lovrenčićevo djelo najprimjerenije bilo uvrstiti u odvjetak pučkog romana s karakteristično koncipiranim naslovnim junakom. Petrica je, zapravo, svojevrsni antijunak koji život provodi lutajući, boreći se za egzistenciju, pri čemu ne poštuje nikakve društvene ni etičke norme. (Usp. Dunja Fališevac, Kaliopin vrt II., Književni krug, Split, 2003., str. 164.)

Lik Petrice Kerempuha lako se može uklopiti u njegov arhetipski morozofski književni kontekst. Dva su Kerempuhova srodnika koje je Lovrenčić sigurno poznavao. Prvi je Matijaš grabancijaš dijak Tituša Brezovačkog. Drugi je Kerempuhov srodnik, koji ga vezuje uz europsku tradiciju, Till Eulenspiegel. Kajkavski Petrica Kerempuh je sasvim sigurno proizašao iz lika Tilla Eulenspiegela, jer je Lovrenčić svoje djelo napisao na temelju jednog njemačkog izdanja Eulenspiegelovih dogodovština.

No europsku (zapravo indoeuropsku) morozofsku tradiciju (arhetip mudre lude) možemo pratiti još od doba mita, pa se, kao i odrazi svih arhetipova, može pronaći i u ostatcima indoeuropskog pramita i u mitovima mnogih naroda. U hrvatskoj tradiciji su poznata barem dva takva lika koja proizlaze iz europske baštine: jedan domaći morozof, Ero, a drugi dolazi s Orijenta, Nasredin-hodža. Dukat upućuje na još jedan sličan lik iz hrvatske i južnoslavenske tradicije, a to je Domišljan, kome samo ime govori koliko je sličan Kerempuhu. (Usp. o tome: Denis Peričić, Petrica Kerempuh u europskom kontekstu, VALL 042, Varaždin, 1998., str. 78-79.)

Lik Petrice Kerempuha nakon Lovrenčićeva djela javlja se u svim književnim rodovima i vrstama, u djelima poznatih i onih manje poznatih hrvatskih književnika: Augusta Šenoe, Antuna Gustava Matoša, Milana Ogrizovića, Dragutina Domjanića, 
manje poznatom djelu - feljtonističkoj crtici Kod kuće, Plač četvrti, u kojoj je glavni lik Petrica Kerempuh, na početku piše: Tu se rodio moj pobratim, čuveni mudrac Kerempuh (Petrica), naš Nasredin-Hodža, Gil Blas i Eulenspiegel, sin nekog Klauza i Anke Ništarić. Bijaše triput kršten (...) Tako dobi trostruku pamet... ${ }^{10}$

Fabricije, dakle, već na početku života dobiva dvostruki identitet (katolik Fabricije/ pravoslavac Amfilohije), što je samo početak njegovih brojnih promjena identiteta: Eto, tako sam, štovani čitatelju, bio dvaput rođen i dvaput kršten i tako je moj karakter, i prije nego je nastao, dobio sve preduvjete da se po nastanku udvostruči, a onda, samim tim, u daljnjim cijepanjima, kojima ga je život izlagao, učetverostruči te na kraju čak i uvišestruči. ${ }^{11}$

Opisivanje najranijeg djetinjstva ima za cilj pokazati kako „,nekarakterni“" stav Fabricija Viskova nije nastao preko noći. Rezultat je to procesa koji počinje još u djetinjstvu. Još je kao donekle naivno dijete ubačen u okrutan svijet u kojem svatko nosi neku masku kojom skriva svoju pravu prirodu:

Ispričao sam ti sve ovo, štovani čitatelju, da vidiš kako sam u najranijem djetinjstvu SVE što bi mi tko rekao uzimao doslovce, pa čak i onda kad se figurativno izražavao, i kako sam zbog toga uvijek izvukao deblji kraj. Valjda je to bio razlog zašto u kasnijem životu NIŠTA nisam doslovce primao, nego sam, kad god bi mi tko što govorio, uvijek tražio krije li se možda iza toga nešto drugo. ${ }^{12}$

Uvodna poglavlja opisuju Fabricija kao vrlo inteligentnog, snalažljivog dječaka koji uživa u prijevarama (već tada ih naziva predstavama za publiku). Vrlo rano shvaća da nije stvoren za prosječan život koji se od njega očekuje te kao petnaestogodišnjak napušta rodno selo i okrilje obitelji, što je tipičan pikarski obrazac. Vrlo inteligentan i snalažljiv, ali još naivan, upada u okrutan svijet u kojem gotovo svi nose maske. Pod maskom ljubaznosti i očinske brige vrbuje ga pripadnik Orjune te Fabricije upada u mrežu politike iz koje se neće izvući do kraja života. Orjuna je tek prva u nizu okrutnih organizacija koje će ga koristiti kao marionetu u svojim često smrtonosnim igrama. Čini se kao da je politika bolest ili virus koji vlada na ovim našim prostorima i nitko nije imun na nju. Koliko god da joj se čovjek uklanja, ona ga kad-tad nađe i uhvati u svoju mrežu.

Miroslava Krleže, Ivana Gorana Kovačića, Slavka Kolara, Slavka Mihalića i mnogih drugih. A koristeći se likom Petrice Kerempuha autori, zaogrnuti metaforom smijeha, izruguju mane, iskvarenost i licemjerje društva.

${ }^{10}$ Denis Peričić, Kerempuhova čitanka, Antologija tekstova o Petrici Kerempuhu od 1834. do 1999., Vall 042, Varaždin, 2002., str. 36.

${ }^{11}$ Ispovijedi nekarakternog čovjeka, str. 14.

${ }^{12}$ Isto, str. 17. 
Igra na pozornici života

Kao i u ostalim pikarskim romanima, Fortuna upravlja i Fabricijevim životom te je ovo tek početak njenih poigravanja, nevjerojatnih i ponekad fantastičnih situacija u koje ga dovodi, a Fabriciju samo preostaje da se u kaosu snađe kako najbolje zna.

Iako mora da bi preživio sudjelovati u Orjuninim zločinima, u suprotnosti je to s njegovim etičkim osjećajem: Nemoj pomisliti, štovani čitatelju, da sam pri tom počeo osjećati kakvo zadovoljstvo ili užitak. Daleko od toga! Ja sam to jednostavno počeo obavljati više-manje rutinski (...) i shvaćati sve kao nešto što je nužno da bi se preživjelo. ${ }^{13}$

Kao pripadnik Orjune Fabricije je vrlo dobro prozreo narav tzv. političkog teatra. Politika je teatrabilna poput kazališne predstave ili karnevala. Karneval i javni politički skupovi oduvijek se služe istim ili sličnim predstavljačkim sredstvima, posebno lutkom, vatrom, bukom i natpisima (transparentima). Čuvši da je kralj ubijen, orjunaši se odlučuju za krvavu odmazdu, a Fabriciju se čini, a pikaro uvijek ima poziciju ,izvan“ sustava, poziciju onog koji demaskira stvarnost, da svi nose maske i da je cijeli svijet pozornica, a politika tek jedna velika predstava:

(...) ta se tirada izgleda, svih dojmila, osim mene, jer sam na svim licima čitao tugu i žeđ za osvetom, te sam i ja, da ne bih ispao bijela vrana, na sebe navukao masku nalik na one koje sam vidio kod ostalih. Tad mi pade na pamet da možda svatko od nazočnih radi ovog trenutka to isto, naime, svojim licem imitira ono što vidi kod ostalih, i da su čak sve velike i masovne političke strasti jedna vrsta glume, u kojoj svaki pojedinac podešava svoje ponašanje prema ponašanju drugih. Nije li zato sav ovaj emotivni naboj, koji se nadvio nad nama posvuda u zraku, obična scenska iluzija, umjetno stvorena kazališnom intonacijom direktorova glasa? ${ }^{14}$

Krvava odmazda je učinjena kao i obično nad malim ljudima, koji zapravo ništa nisu krivi, ali postaju igračke u rukama povijesti i politike. Orjunaši okrutno ubijaju jednog zagrebačkog odvjetnika, njegovu ženu, a djevojku koja je bila u kući, brutalno siluju. Kako je pikarov svijet, svijet gotovo nevjerojatnih slučajnosti, silovana djevojka je Fabricijeva platonska ljubav i s tom nesretnom djevojkom otvara se cijeli niz nesretnih ženskih sudbina u romanu.

Nakon toga stravičnog događaja, koji funkcionira kao grubo otrježnjenje i zbog kojeg se Fabricije vraća svojoj esencijalno dobroj naravi, ne može više ostati među orjunašima. Kako se ne bi pretvorio u jednu takvu zvijer,

\footnotetext{
${ }^{13}$ Ispovijedi nekarakternog čovjeka, str. 52.

${ }^{14}$ Isto, str. 56.
} 
odnosno kako bi sačuvao netaknutu svoju nutrinu, bježi. Čak razmišlja o samoubojstvu, ali niti jedan pikaro se ne ubija, previše vole život, ma kako bio težak. Bježeći, skriva se u bunar ispred neke šibenske vile.

Fabula je vrlo važna u pikarskim romanima, bogata je, razgranata i maštovita. Često su prisutni trivijalni elementi - skrivanja, prerušavanja, promjene identiteta, neočekivana prepoznavanja, trovanja, otmice i slično, što sve pridonosi dinamičnosti i napetosti radnje. Vlasnik vile je konte Florijan de Draco-Dragojević, posljednji potomak jedne plemićke obitelji. Između njih dvojice vrlo brzo se stvara duboko povjerenje i odnos ,učitelja“ i ,učenika" te oca i sina.

Pikaro nikada ne potječe iz stabilne obitelji pa u njegovu životu tako nikad nema istaknute očinske figure. Otac tradicionalno predstavlja red, rad, poštivanje pravila i tradicije, a sve to kod pikara izostaje. Fabricije kao petnaestogodišnjak odlazi od kuće, a kada kasnije i posjećuje obitelj, otac mu je mrtav. Očinsku ulogu u Fabricijevu životu odigrat će konte koji ga usvaja i ostavlja mu svoje ime i bogatstvo, ali nikad kao autoritativna očinska figura, uvijek više kao prijatelj koji će ga usmjeravati na vlastiti put.

Konte je jedan od najzanimljivijih likova romana. Nikad se ne pere niti mijenja odjeću, zabranjuje bilo kakve radove u dvorcu, ne radi ništa praktično i živi od imetka za koji čak nije ni siguran koliki je. Konteov način života osuda je i ovog našeg materijalističkog svijeta pokretanog novcem. Za kontea je novac izvor Zla, pokretač prelaska iz feudalnog u kapitalistički način života: (...) novac je oduvijek za mene bio najveće zlo, pokretač onog no$\check{z}$ a, koji je presjekao vrat Marije Antoinette i tako srušio moj svijet, da bi uspostavio ovaj novi, prozaičan i bezličan. ${ }^{15}$

Konte ima i osobinu, koju će i Fabricije s vremenom razviti, a to je relativiziranje i nazivanje fikcijama onih kategorija do kojih se u građanskom društvu puno drži: $U$ nacionalnom pogledu on se nije smatrao ničim i tvrdio je za sebe da je kozmopolit, jer aristokracija, po njemu ne poznaje nikakve nacionalne granice, a naciju su izmislile obične ništice, da bi tako gomila došla do kakvog identitete $i$ važnosti. ${ }^{16}$

Svaka osoba koju Fabricije sretne na svom životnom putu, postaje mu svojevrstan ,učitelj“ i ima udjela u formiranju njegova pogleda na svijet i život. I tu je konte odigrao ključnu ulogu. Zahvaljujući njemu, Fabricije završava gimnaziju te vrlo lako nauči nekoliko stranih jezika. No, najvažnije čemu ga je konte naučio je da mora imati vlastiti, kritički stav o svemu, a ne biti netko kome će odrediti što treba misliti, raditi ili govoriti. Zahvaljujući konteu, a to je postojalo u njemu samom kao klica otprije, Fabricije uporište

\footnotetext{
${ }^{15}$ Ispovijedi nekarakternog čovjeka, str. 69.

${ }^{16}$ Isto, str. 69.
} 
Igra na pozornici života

otada za svaki svoj postupak traži samo u sebi, a ne u nečemu izvan sebe kao što to čini većina. Poput većine pikara 20. st. Fabricije je antigrađanin. Dio je sustava, ali nikad pokoren od njega, uvijek čuva svoju unutarnju neovisnost. Jedino se individualizmom pokušava suprotstaviti socijalnim i moralnim kontradikcijama svoga vremena.

Jasno dolazi do izražaja Brešanovo stajalište da čovjek sam sebi treba biti jedino uporište i mjerilo, a ne da se, kao što je čest slučaj na ovim našim prostorima, uporište traži u nečemu izvana, bilo to vjerskog ili svjetovnog karaktera. Istina je, ljudima je u životu potreban neki oslonac, pa ga nalaze ili u vjeri ili u ideologiji ili u mitologiji. Ljudi se boje biti slobodni. Neki filozofi nazvali su to strahom od slobode ${ }^{17}$ navodi Brešan.

Primjećuje tako Fabricije, na tragu Hegelove filozofije, da čak i oni koji se proglašavaju ateistima imaju potrebu da u nešto vjeruju i da ih netko vodi:

(...) središnji predmet cijelog njegova razmatranja bio je Staljin, kom je on malne stao pjevati ditirambe i pridavati svojstva nekog višeg bića božanske provenijencije, citirajući njegove izreke kao Sveto pismo. To me potaknu da pomislim kako i najradikalniji ateisti, kao što su ovi kojima sam okružen, nikada ne gube potrebu za Bogom, pa kad već iz nekog razloga ne mogu vjerovati u onog nebeskog, onda nađu nekog zemaljskog, prema kome se potpuno isto odnose, te mu se, kao ovo sad, na određeni način čak i mile izgovarajući njegove tekstove isključivo iz ritualnih razloga, kao što svećenik na misi čita tekstove iz Evanđelja. Vjerojatno je Hegel bio u pravu kad je rekao da je ateizam samo razočarana religiozna svijest. ${ }^{18}$

Jedna od najzanimljivijih konteovih osobina bila je uživanje u smišljanju i provedbi spletki koje nisu imale za cilj da mu donesu neku materijalnu korist ili drugima nanesu štetu, nego samo da se dobro zabavi na račun bližnjega svoga. I u toj vještini postat će učitelj Fabriciju, s tom razlikom da se konte spletkama služi za zabavu, a Fabriciju su one ne jednom spasile život. Jedanput će Fabricije u konteovoj režiji postati glavni glumac predstave. U cilju nalaženja djevojke smišljaju predstavu u kojoj je Fabricije odglumio grenlandskog princa. Naravno, za ulogu se izvrsno pripremio, od odjeće, kretnji do govora pretvarajući se tako u savršenog glumca na velikoj pozornici života.

U romanu se, kao i u drugim svojim djelima, Brešan pokazuje i kao izvrstan poznavatelj mediteranskog mentaliteta stoga pojašnjava i sklonost mediteranskog mentaliteta prevarama:

17 „Tko se boji Maršala“, Feral Tribune, XVII, 746. Split, 3. siječnja 2000., str. 39.

${ }^{18}$ Ispovijedi nekarakternog čovjeka, str. 150. 
Možda će se ponekom činiti da su nepodopštine koje su izvodili konte i njegovo društvo suviše okrutne i da sadrže čak i ponešto sadizma. No to može zaključiti samo onaj tko ne poznaje mediteranski duh, osobito one njegove oblike koje nalazimo u manjim gradovima. Dobro smišljena i izvedena šala tu se smatra vrhuncem duhovnog umijeća, većim od nekog slikarskog ili književnog djela. ${ }^{19}$

Život Fabricija iz Šibenika vodi u Zagreb, a razlog dolaska je ispunjavanje obećanja danog konteu da će upisati fakultet. Zanimljiv je njegov odabir studija. U skladu sa svojim karakterom, Fabricije odbacuje sve praktično i vezano uz novac te se odlučuje za studij hrvatskog jezika i književnosti: (...) jer to je studij koji ne zahtijeva nikakav drugi napor, osim čitanja literarnih djela, što mi je ionako pasija i užitak. ${ }^{20}$

Ali na fakultetskim predavanjima doživljava potpuno razočaranje. Krutost i nemaštovitost cijelog sustava prešla je i na obrazovanje. Stoga poticajnije intelektualne razgovore i društvo primjerenije sebi i svom svjetonazoru Fabricije nalazi izvan tradicionalnih, formalnih instituciju. Svoje mjesto nalazi u onome što je ,izvan“ sustava priključivši se zagrebačkim boemskim krugovima koji su se okupljali u kavani Corso: Osobito me privuklo to što se u tim komentarima nije osjećalo ni jedno od postojećih političkih stajališta, jer je govornik podjednako ironizirao sve: $i$ hrvatstvo, $i$ jugoslavenstvo, $i$ buržoaziju, i radničku klasu, i vjeru, i ateizam, ili, najkraće rečeno, sprdao se is Bogom is vragom. ${ }^{21}$

Brešan se u romanu pokazuje i kao izniman kroničar društvenog života. Fabricije se kreće i vertikalno kroz sve slojeve tadašnjeg hrvatskog društva. Upoznajemo panoramu društvenog života Hrvatske i reprezentativne tipove: seljake, političare, studente, zagrebačke boeme, a zahvaljujući konteovu bogatstvu, Fabricije ulazi i u elitne zagrebačke krugove.

U spletu nepredvidivih okolnosti Fabricije će dospjeti i u zatvor u kojem upoznaje Hercegovca Jozu Marića, jednog od ključnih likova romana, čiji će se život na najneobičnije načine, kako to obično i biva u pikarskim romanima, ispreplesti s njegovim životom.

Raspravljajući s Jozom, koji je Fabricijeva potpuna suprotnost u odnosu spram idealima, politici i ideologiji, Fabricije iznova ističe svoja stajališta o pojmu slobode, nacije i politike:

Ja, Jozo, nisam zaražen nikakvim idejama, jer uopće ne razmišljam o preuređenju svijeta, pogotovo ne u smislu prekrojavanja državnih granica. Svaka država za mene je samo država i već po sa-

\footnotetext{
${ }^{19}$ Ispovijedi nekarakternog čovjeka, str. 80.

${ }^{20}$ Isto, str. 106.

${ }^{21}$ Isto, str. 125.
} 
Igra na pozornici života

mome pojmu netko tko mi propisuje kako se imam vladati i što mu moram davati da bih imao osnovna građanska prava, pa me se zato sve države ovoga svijeta jednako tiču ili ne tiču, kako hoćeš. Država može prirasti za srce samo onome kome ona osigurava visoki položaj i moć nad drugima. ${ }^{22}$

Fabricije kao suvremeni pikaro kao glavni cilj svoga život postavlja slobodu - slobodu od svih institucija ili autoriteta: Ja se nadam, Jozo, da sada vidiš kako ja nisam čovjek koji bi prionuo uz neku opću ideju i njoj slijepo služio, nego čovjek svojih vlastitih ideja, koje me čine da vrludam sad ovamo, sad onamo, ovisno o situacijama. ${ }^{23}$

Fabricije se u nekoliko navrata vraća rodnoj kući, majci i dvojici braće te se ne samo na njegovu primjeru, nego i na primjeru njegove obitelji uočava kako se povijest i politika poigravaju s malim čovjekom. Fabricije će nemoćno promatrati propast svoje obitelji kao igračke u rukama politike i povijesti. Tri brata Viskov odabrala su tri strane - komunizam, ekstremna hrvatska stajališta te Fabricijev individualizam. Kako u romanu nema idealizacije nikoga, Fabricije ne idealizira ni vlastitu braću. Tvrdnju iz Uvoda romana da je najopasnija osobina karaktera kad netko na prvo mjesto stavi kakav ideal u ime kojeg je spreman žrtvovati i vlastitu obitelj, potkrijepit će ponašanjem vlastite brace. ${ }^{24}$

${ }^{22}$ Ispovijedi nekarakternog čovjeka, str. 141.

${ }^{23}$ Isto, str. 143.

${ }^{24}$ Fabricijev komentar na ponašanje brata Ile: Najneugodnije iznenađenje priredio mi je Ile, koga je položaj gradonačelnika toliko izmijenio, da sam ga jedva prepoznao (...) Ili je druženje s gospodom, posebno onima od vlasti, dalo stanoviti šlif, te više nije bilo ni traga nečemu, što bi upućivalo na nekadašnjeg težaka-nadničara. No sve bi se to moglo uzeti $i$ kao stanoviti napredak, da zajedno s tim nije od tih ljudi poprimio $i$ neki osjećaj moći, a osobito filozofiju uspjeha, po kojoj je pametniji i uopće kao čovjek vredniji onaj tko se više i brže penje po društvenoj ljestvici. To sam osobito osjetio kad sam ga upitao zašto nije pomogao bratu Matku da izbjegne robiju:

- Ja sam učinio sve što je mojoj moći - odgovori mi. Lijepo sam ga nagovarao da nam se pridruži. I da je bio pametan, sad je mogao biti na pristojnom položaju. A ovako, sam je kriv, jer je odabrao pogrě̌an put. (Ispovijedi nekarakternog čovjeka, str. 156.)

Isti obrazac ponašanja primjećuje uskoro i kod drugog brata Matka:

Kad ga upitah, zna li išta o majci ili Ili, kao da sam ga takao u neku bolnu točku, samo mi kratko i hladno odbrusi:

- Ne znam i ne želim o tome misliti. To je cijena koju moramo platiti za ono za što se borimo.

Te riječi me uvjere da je Matko postao fanatik, kome više ni majka ni brat ne znače ništa u odnosu na cilj koji je sebi postavio i da je tom cilju, bude li potrebno, spreman žrtvovati i mene. (Isto, str. 205.) 
Mirna BRKIĆ

Vodeći Fabricija Viskova kroz različita povijesna razdoblja, političke sustave i ideologije, Brešan pokazuje kako slijepo slijeđenje neke političke ideje, čak i kad je zasnovana na u osnovi pozitivnim idejama, uvijek završava u ograničavanju ljudskih sloboda, u zločinu i nasilju u kojem uvijek i iznova najviše stradaju nevini ljudi.

Na početku trećeg dijela romana Fabricije se našao u vrtlogu burnih zbivanja Drugog svjetskog rata. Brešan neprestano postavlja Fabricija pred teške moralne dvojbe kojima se testira njegova „nekarakternost“, a Fabricije se, uvučen u igru života i smrti između Talijana i partizana, u konačnici uvijek odlučuje za konkretnog čovjeka u nevolji. Pikaro Fabricije uspostavlja vrijednost samo osluškujući i prateći vlastite glasove savjesti ne razmišljajući slaže li se njegovo ponašanje s nekim „općim moralnim kodeksom“.

Ljude ne dijeli po pripadnosti određenoj ideologiji, već po onom što čine $u$ ime toga:

(...) što sam duže živio u ovom okružju nepotrebnog ubijanja, sve sam manje ljude dijelio po pripadnosti ili po ideji u koju vjeruju, a sve više po tome što čine uime toga dvoga. Jer luđak je za mene podjednako luđak, bez obzira kome pripadao i u što vjerovao, pa kao što psihijatrija ne pravi razliku između paranoika, opsjednutog idejom da je Isus Krist, i onog koji je umislio da je Napoleon, te obojicu svrstava u istu ustanovu, tako su i za mene komunisti i fašisti bili pripadnici jednog posve drugog soja od onog kome sam ja pripadao ili sam mislio da pripadam. ${ }^{25}$

U ludilu povijesti i politike Fabricije pokušava sačuvati svoju osobnost netaknutu tvrdeći: Boja košulje (...) ne može utjecati na psihu onoga tko je nosi. $^{26}$

Takvu podvojenost pikara još je na primjeru prvih pikarskih romana uočio C. Guillén pri pokušaju definiranja žanra:

(...) ovo razlikovanje bitka i privida, ili između ,unutrašnjeg“ i „spoljašnjeg“ čoveka, naročito je značajno za pikarsku prozu i za izvanredno domišljate primene autobiografske forme u njoj. Dok se pícaro „socijalizuje“, dok preuzima, sasvim svesno, društvenu ulogu, događa se i izvestan proces ,interiorizacije“. Unutrašnji čovek (koji se odlikuje svekolikim bogatstvom i pretanjenošću čovekovih skrovitih misli i sudova) potvrđuje svoju nezavisnost od spoljašnjeg čoveka (obrazaca ponašanja, jednostavnosti društvene uloge). Ova duboka podvojenost junaka je, mislim, jedna od značajnih tekovina

\footnotetext{
${ }^{25}$ Ispovijedi nekarakternog čovjeka, str. 278.

${ }^{26}$ Isto, str. 230.
} 
Igra na pozornici života

pikarske proze i njen suštastven doprinos tematici modernog romana... $^{27}$

Uočeno je da je moralno načelo koje primjećujemo u Fabricijevu ponašanju najbliže kršćanskom moralnom principu ljubavi prema bližnjemu, ali sam lik odbija mogućnost da tu etičku poziciju jasno artikulira kao osviješteno religijsku.

U razgovoru s vojnim kapelanom prije smrtne kazne u talijanskom zatvoru Fabricije:

(...) ironizira klerikaliziran koncept vjere koji se zadovoljava ispraznim, formalnim ritualima. Ne bi trebalo iz svega toga izvući pogrešan zaključak kako Brešan zagovara potpuni moralni relativizam, čak svojevrsni amoralizam. On samo kao deklarirani racionalist izražava skepsu prema svim dogmatskim sustavima koji opravdavaju u ime općeg dobra nasilje nad pojedincem. Premda neprekidno raspravlja o moralnosti, on se trudi da nigdje ne ponudi svoje recepte i dogme o tome što moral jest, jer je svjestan semantičke ispražnjenosti velikih riječi (koje su prečesto u našem stoljeću bivale pokrićem za zločinačku praksu vladavine). Ali, ipak, implicitno se, kao duboko osobna, nenametljivo moralistična pouka piščeva da očitati ideja o tome da nema moralnosti ondje gdje se ne poštuje svaki pojedinačni ljudski život, da nema te političke ideje koja zaslužuje biti utemeljena na ljudskoj krvi. ${ }^{28}$

Fabricijev identitet se u stalno promjenljivom svijetu, kojem se uvijek iznova mora prilagođavati, multiplicirao te ni sam više nije siguran koji je njegov identitet pravi, odnosno postoji li uopće identitet kao nepromjenljiva kategorija. Brešanov roman je tako i na tragu Pirandella. Koristeći se likom pikara, koji je od ustanovljavanja žanra netko tko je mnogostruk, tko stalno mijenja identitete, Brešan problematizira (ne)postojanje identiteta u kaotičnom, stalno promjenljivom svijetu. Temeljni problem suvremenog čovjeka najviše je gubitak vlastite osobnosti, jer ga život stalno sili da se prilagođava trenutku i tako postaje tud samom sebi $i$ drugi u odnosu na sebe, ${ }^{29}$ navodi Brešan.

Dani su tekli, a ja sam nastavio igrati dvostruku ulogu, u koju sam se toliko uživio da sam se sam u sebi podvostručio, te sam postao jedna osoba za javnost, a druga skrivena u vlastitoj intimi. Pre-

${ }^{27}$ C. Guillén, „Ka definiciji pikarskog“, u knjizi: Književnost kao sistem, preveo Tihomir Vučković, Nolit, Beograd, 1982?, str. 88.

${ }^{28}$ V. Visković, Brešanovo dvadeseto stoljeće, str. 136/137.

${ }^{29}$ Andrija Tunjić, Razgovori u Hrvatskoj, AGM, Zagreb, 2001., str. 85. 
varit ćeš se, dragi čitatelju, ako pomisliš da je jedna od tih osoba bila prava, a druga lažna. Ne, ja sam zaista, dok sam izvršavao zapovijedi svojih nalogodavaca s jedne ili s druge strane, počeo raditi to ne razmišljajući slažu li se ili ne slažu one s nekim općim moralnim kodeksom i nalazeći svaki put za njih čak i neko opravdanje. I kao što su strane, kojima su te dvije moje osobe pripadale, bile u međusobnom ratu, tako su i same osobe u meni jedne s drugom ratovale (...) Ukratko, ako bi se i dogodilo da se u tom krvavom vrtlogu tu i tamo probudi neko treće moje ,ja“, koje bi se izdiglo iznad svega i pobunilo protiv svakog prolijevanja krvi i nasilja, nisam bio siguran da sam taj ,ja“ doista ,,ja“, a ne netko tko pripada jednoj ili drugoj strani. ${ }^{30}$

U petom poglavlju trećeg dijela, O uzaludnosti i lažnosti svakog herojskog čina i o susretu s Giulijom, Fabricije iznosi svoja razmišljanja o herojstvu te ga demistificira nalazeći u podlozi svakog herojskog čina sebične razloge. Čini to na primjeru stvarne povijesne ličnosti - Rade Končara. Fabricije se ne može diviti nekome: (...) tko gubitak života nadoknađuje stjecanjem slave, kao što ne mogu cijeniti ni dobročinitelja, koji otkida sebi iz usta, samo zato da bi pobrao pohvale sredine. ${ }^{31}$

Osim toga, ljudima su potrebni heroji, netko u koga će se ugledati, kome će se diviti i tko će ih voditi, a taj čovjek prestaje biti vlasnik sebe i svojih postupaka, postaje mit koji se po potrebi mase gradi i prekraja.

Fabricije se ne ustručava demistificirati i još jedan veliki mit prošloga stoljeća - mit o Titu i najvećem uspjehu njegove politike - bloku nesvrstanih zemalja:

Naime, „blok nesvrstanih“ bio je zaista u sebi nešto kontradiktorno, kao i kvadratura kruga, jer je već samo stvaranje bloka značilo ujedno i stanovito svrstavanje, ma kakvim se imenom to nazivalo. No taj je prekršaj logičkih zakona Tita digao na visok politički pijedestal, jer su tzv. nesvrstane zemlje, iako bez ikakve ekonomske i vojne moći, bile svaka jedan glas u Ujedinjenim narodima. A ,vlastiti put u socijalizam“ pak bio je manje no vlastiti put u ništa, ali taj je blef Titu opet osiguravao distancu od Sovjetskog Saveza, a time i američku pomoć. ${ }^{32}$

Ono što se dogodilo Radi Končaru, dogodit će se uskoro i Fabriciju. Preko noći partizani ga proglašavaju narodnim herojem. No, njegova osobnost i osjećaj nepripadnosti, usprkos svemu, ostali su isti. Mijenjaju se samo

\footnotetext{
${ }^{30}$ Ispovijedi nekarakternog čovjeka, str. 216.

${ }^{31}$ Isto, str. 225.

${ }^{32}$ Isto, str. 463.
} 
Igra na pozornici života

etikete koje društvo lijepi na njega - od državnog neprijatelja postaje heroj, a crnu košulju zamjenjuje partizanskom odjećom. Ljudima su potrebne legende, kao i neprijatelji, kako bi se održala krhka ravnoteža u sustavu.

Brešan u ratnom ludilu nalazi arhetipske oblike ponašanja, dokaz o vječnoj prisutnosti Zla u svijetu. Čini se kao da je cijela povijest ljudskog roda vječito generiranje i ponavljanje zla. (Naznaka teme koju će Brešan detaljnije razraditi u svojim kasnijim romanima: Astarothu, Vražjoj utrobi i Državi Božjoj 2053.)

Spletom okolnosti Fabricije dospijeva među četnike zloglasnog prote Momčila Đujića kojeg Fabricije smatra psihički poremećenom osobom jer nikako drugačije ne može objasniti stravične zločine koje čini. Ali tragično je da iste oblike ponašanja u ratu pokazuju i četnici i partizani, zaključujući: Ubija se, očito, samo zbog ubijanja i zato što je to nekome užitak... ${ }^{33}$

U ratnom ludilu Brešan detektira još jedan arhetipski oblik ljudskog ponašanja - lov na vještice kao vječnu metodu ideologije i vlasti u kojoj uglavnom stradaju nevini. Fabricije će tako biti svjedok strašne scene egzekucije u kojoj bijesni građani traže krv. Kao žrtve, kao Krnjo na karnevalu koji se simbolično spaljuje kako bi se spalilo sve negativno, strada Pavica Žepina, nesuđena Fabricijeva ljubav, i njeni roditelji:

Zapovjednik ne reče ni riječi, nego naredi paljbu i u tren oka se sve troje svali u jamu. Okrenem se i udaljim odatle, jer me uhvatila muka i slabost od toga što sam vidio. Pomislih kako ima nešto mnoge gore i od fašističke i od komunističke diktature, a to je potpuno bezvlašće, u kome se oslobađa slijepi bijes gomile, koja bez ikakvog stupnjevanja traži krivca za ono što je propatila. I pri tom žrtva može postati bilo tko, ako se makar nečim u svom ponašanju razlikuje od ostalih. Ili ne mora se ni razlikovati; dovoljno je da se po nečemu može uvesti kao zamjena za krivca, onako kako se u karnevalu uzima lutka zvana „Krnjo“ i spaljuje kao uzročnik svih nevolja, koje su ljude zadesile tijekom godine. ${ }^{34}$

Jedan od ključnih likova Brešanova romana je talijanski vojnik Điđi, još jedna od inačica lika pikara. Nalik je dobrom vojaku Švejku, vojnik koji sve čini kako bi potkopao instituciju vojske: Ро svemu mi se učini da sam se našao u društvu neke suvremene talijanske varijante dobrog vojaka Švej-

\footnotetext{
${ }^{33}$ Ispovijedi nekarakternog čovjeka, str. 296.

${ }^{34}$ Isto, str. 272/273.
} 
Mirna BRKIĆ

ka... ${ }^{35} ;$ (...) pripadao je onoj vrsti ljudi, koja od svake životne situacije pravi burlesku, te se doimao kao brat likova iz commedia dell'arte. ${ }^{36}$

Od cjelokupnog roka službe dvije je trećine proveo u zatvoru, a teške kazne izbjegava pretvarajući se da je mentalno retardiran. Điđi, naravno, nije retardiran te se razvija iskreno prijateljstvo između njega i Fabricija.

U četvrtom dijelu romana Fabricije prelazi granicu bivše Jugoslavije. Sredina je 1944. godine te se priključuje izbjeglicama koje odlaze u Italiju, a potom u izbjeglički kamp u Egiptu.

U izbjegličkom logoru Fabricija, jer je među najobrazovanijima, postavljaju za učitelja partizanske ideologije. Ulogu prihvaća, kao i sve što mu sudbina servira, ali postavlja se kao opozicija vladajućem poretku, kao netko tko potkopava sustav. Fabricije se samo prividno priklanja mišljenju većine, ali pretjerujući u vjerovanju, cijeli sustav zapravo dovodi do apsurda: (...) odlučih se i ovdje poigrati s cijelom tom stvari, i to tako što ću braneći tu doktrinu, istodobno je i rušiti. Drugim riječima, htio sam, crtajući taj svijet budućnosti onako kako ga prikazuju njegovi zagovornici, svoje slušatelje dovesti dotle da sami posumnjaju u njega. ${ }^{37}$

No, borba protiv korumpiranosti i nepravde u izbjegličkom logoru uzaludna je te Fabricije dolazi do zaključka da su nastupila neka nova vremena u kojima se više ne može razlikovati pošten čovjek od prevaranta: Postalo mi je jasno (...) da se ne radi samo o pojedinačnom slučaju korupcije, nego o čitavom sustavu kriminala, koji seže do samog vrha (...) Mučilo me jedino pitanje kakvo će biti to novo društvo, u kome mi je ubuduće suđeno živjeti, ako je istina ono da se po zori vidi kakav će biti dan. ${ }^{38}$

Početkom 1945. godine Fabricije se vraća u Hrvatsku i rodno selo, ali njegova obitelj je pometena vihorom povijesti. Put ga ponovno vodi u Zagreb gdje sreće neke svoje stare poznanike. Kao i s njegovom obitelji povijest i politika su se $s$ većinom tih malih ljudi okrutno poigrale. Npr. nekadašnji ugledni HSS-ovac Sedak na tržnici prodaje povrće: (...) kao još jedan dokaz da seljaka svaka politika iskoristi koliko može, a kad joj pođe po zlu, ostavi ga na cjedilu i na milost i nemilost neprijatelju, ${ }^{39}$ a u uličnom prosjaku prepoznaje svog nekadašnjeg prijatelja iz boemskih krugova.

Ni ovaj put politika ne zaobilazi Fabricija te će spletom okolnosti postati član Partije, a potom major Udbe. Brešan, posluživši se likom Fabricija, iznova otkriva iste oblike ponašanja u svim organiziranim sustavima, najčešće politici i vjeri. U skladu s tim je i Fabricijevo viđenje čina njegova ulaska

${ }^{35}$ Ispovijedi nekarakternog čovjeka, str. 257.

${ }^{36}$ Isto, str. 259.

${ }^{37}$ Isto, str. 332.

${ }^{38}$ Isto, str. 329.

${ }^{39}$ Isto, str. 352. 
Igra na pozornici života

u Komunističku partiju: Kad sam tako priznao svoje grijehe i sam se s njima obračunao, bio sam, kao i vjernik nakon ispovijedi, spreman za svetu pričest, te sam jednoglasnom odlukom svih blaženika ušao u carstvo nebesko, naime, bio primljen u Partiju. ${ }^{40}$

Komunizam, kao i svaka religija, traži samo vjernike, a kako su vjera $i$ pamet obrnuto proporcionalni i što je više jednog, manje je drugog, u njemu kao i u kršćanskom Raju, mogu biti blaženi samo oni siromašni duhom, a oni koji razmišljaju unaprijed su predodređeni za osudu. ${ }^{41}$

Kako ništa nije jednostavno u Fabricijevu svijetu, ispostavlja se da je Zorman, kojeg mora eliminirati po naredbi Udbe, zapravo Jozo Marić, Fabricijev prijatelj i čovjek koji mu je nekoć spasio život. Ponovno će se Fabricije naći u strašnoj moralnoj dvojbi - izdati prijatelja ili ne te se i ovaj put odlučuje za konkretnog čovjeka, a ne za neku ideologiju ili ideju. No, sve loše završava. Optužen je za izdaju i nakon mučenja priznaje sve izmišljene optužbe, što je ključan trenutak u romanu za Fabricijevu ličnost - postaje tek marioneta u tuđim rukama. Dotad je on uvijek bio taj koji je samostalno odlučivao o svojim postupcima. Individualnost i njegova nutrina ostali su nepromijenjeni usprkos stalnim promjenama identiteta te neprestanom pritisku na konformizam.

Ali u tom trenutku Fabriciju su drugi odredili što treba biti te gubi svoje ,ja“ i postaje sredstvo u tuđim rukama: Nisam li ja samo običan mali pijun drvene glave, koji ništa ne razumije i koga na šahovskoj ploči međunarodne politike pomiču ruke nekih nevidljivih igrača $?^{42}$

Potpisavši lažno priznanje, Fabricije se odriče sebe: Bez ikakva dvoumljenja odrekoh se tako samog sebe i postadoh ono što oni hoće... ${ }^{43}$

Pakao na zemlji u koji dospijeva je Goli otok, koji uspoređuje s Danteovim Paklom. Zatvorenici su povrgnuti neljudskim postupcima, uništavaju im identitet pretvarajući ih u brojeve. U takvom svijetu Fabricije konačno gubi sebe te poglavlje završava apsurdom - pitanjem tko je on zapravo:

(...) sva moja prošlost do trenutka kada sam tu došao bila je puka zabluda, koju sada odbacujem s gnušanjem, pa sam u smislu osobe opet nešto poput novorođenčeta, živa stvar pod registarskim brojem C 47532, jednom riječi nitko i ništa. Drugo, polazeći tako od nulte točke, nastojat ću postati druga osoba, bez ikakve veze s onim prije, izgrađujući sebe prema uzorku novog, socijalističkog čovjeka. (...) Tako sam se ponovo našao na takozvanoj slobodi, ali

\footnotetext{
${ }^{40}$ Ispovijedi nekarakternog čovjeka, str. 344.

${ }^{41}$ Isto, str. 394.

${ }^{42}$ Isto, str. 390.

${ }^{43}$ Isto, str. 392.
} 
bez ikakva znanja što zapravo podrazumijevam pod tim kad izgovorim riječ „Ja“. Uostalom, što je to uopće „Ja“" ${ }^{44}$

$\mathrm{U}$ petom dijelu romana nakon iskustva Golog otoka Fabricije se ponovno vraća u Šibenik. Nekadašnji partizanski heroj sada je u poziciji koju su imali gubavci u srednjem vijeku, dokazujući još jedanput kako vlast i ideologija lako pretvaraju neprijatelja u heroja i obratno ako to odgovara njihovim nakanama. No, iznova Fortuna upleće svoje prste u njegov život. Vraćajući se u rodno selo, doživi automobilsku nesreću u kojoj svi osim njega poginu te Fabricije uzima dokumente jednog od suputnika, Crnogorca Milana Đurovića. Kao Feniks iz vatre rađa se novi Fabricije ispunivši na apsurdan način ono što je Partija od njega zahtijevala - potpunu promjenu identiteta. Kako ne bi došao u opasnost da ga netko prepozna, odlazi u Beograd. Ipak, politika nikad ne zaobilazi Fabricija te će se naći u središtu najveće političke afere. Naime, Đurović je trebao biti jedan od povjerljivih tjelohranitelja Milovana Đilasa. Roman iznova funkcionira kao „,sat političke povijesti Jugoslavije“ - upoznaje nas Brešan sa zakulisnim igrama koje su se vodile na jugoslavenskom političkom vrhu između Tita i Đilasa. Fabricije se uskoro toliko uživio u ulogu beogradskog studenta oduševljena komunizmom te će postati jedan od najutjecajnijih govornika i miljenik Aleksandra Rankovića.

No, posljedice ispiranja mozga na Golom otoku i Fabricijeva gubljenja svijesti o vlastitom identitetu nisu nestale. On koji nikad nije pristajao ni uz jednu ideologiju te imao svoj vlastiti, kritički stav prema svemu, kao da počinje vjerovati u besmislice koje govori. Ali u trenutku kad počinje gubiti etički osjećaj i kritičku poziciju, dolazi do grubog otrježnjenja. Vlast otkriva njegov pravi identitet $\mathrm{i}$ ako želi preživjeti, morat će odigrati ulogu špijuna. Otrježnjenje od ideološke opijenosti pomaže Fabriciju da se vrati svojoj pravoj naravi: Ponovno sam postao stari Fabricije Viskov, koji ne vjeruje nikome i ničemu i kome ništa na ovom svijetu nije sveto. ${ }^{45}$

Špijunski zadatak koji mu dodjeljuju je da pod Đurovićevim imenom bude kulturni ataše u Rimu kako bi raskrinkao veleposlanika za kojeg se sumnja da radi protiv države. U Rimu sreće osobu kojoj se najmanje nada, svoju ljubav Giuliju. Ponovno je Fabricije na moralnoj kušnji - raditi protiv Giulije i veleposlanika, za kojeg uviđa da nije nikakav neprijatelj države, ili ne. U konačnici će se, kao i uvijek, odlučiti za konkretnog čovjeka.

Fabricije će i ovaj put izvući živu glavu, ali Giulija smrtno strada. Nakon punih dvadeset godina u kojima su svi vjerovali da je mrtav, Fabricije se vraća u Šibenik, gdje pronalazi suprugu Cvitu i odraslu kćer za koju nije ni znao. No, ne može vratiti svoj identitet jer službeno više ne postoji. Fabrici-

${ }^{44}$ Ispovijedi nekarakternog čovjeka, str. 400/441.

${ }^{45}$ Isto, str. 451. 
Igra na pozornici života

jevi problemi s dokazivanjem identiteta na tragu su Pirandella i njegova romana Pokojni Mattia Pascal. ${ }^{46}$

Može se zaposliti jedino kao Milan Đurović, nevjenčano živi sa Cvitom, a pojavljuje se i bivša žena pravog Đurovića. Prvotno komična situacija pretvara se u tragičnu. Zahvaljujući pomoći veleposlanika kojem je pomogao u Rimu, identitet mu je vraćen i napokon se Fabricije uspijeva istrgnuti iz mreže politike te pada u potpunu anonimnost: Ovo je bila, dragi čitatelju, ujedno i moja posljednja rotacija u vrtlogu života, nakon koje sam nastavio tiho $i$ anonimno tavoriti u njegovim mirnim vodama. ${ }^{47}$

Rijetki su događaji koje Fabricije otada komentira. Ipak, morao je dati svoj osvrt na Hrvatsko proljeće nalazeći i u tim događajima arhetipske oblike ljudskog ponašanja. Ljudi su uvijek isti, skloni su brzo mijenjati strane i izdavati ideje u koje su se do jučer kleli, u prvom redu zato što su u vječnom strahu za vlastitu egzistenciju. Takav je bio i njegov otac kada je, kako bi prehranio obitelj, s katoličke prešao na pravoslavnu vjeru. Takvi su ljudi i sada, a takvi su bili i prije dvije tisuće godina:

Premda to nigdje nije zapisano, uvjeren sam da je ista ona masa, koja je išla za Isusom vičući: „Hosana, sine Davidov!“ kasnije vikala: „Raspni ga!“. Jer, ako je čak sveti Petar, najbliži Isusov sljedbenik, triput došao u iskušenje da ga se odrekne, što je očekivati od onog običnog malog čovjeka, koji ga je slijedio i ne razumijevajući sasvim što govori. ${ }^{48}$

Prokomentirat će Fabricije još jedan veliki povijesni događaj - Titovu smrt, tj. sprovod, demistificirajući i taj veliki trenutak: (...) bio je to za mene najobičniji sprovod jedne osobe, koju sam znao samo po imenu... ${ }^{49}$

${ }^{46}$ Prvi put prepoznajemo takav lik u protagonistu Pirandellova romana Pokojni Mattia Pascal (1904.). Budući da je iz novina doznao da je pronađen leš za koji drže da je on, dakle da je službeno mrtav, Mattia Pascal to iskorištava kako bi nestao iz javnog i društvenog života. Preuzima novi identitet, ali i tada društvo plete oko njega neizbježnu mrežu, pa kada Mattia otkrije da je pravi identitet onaj koji daje građanski status i da, u takvu stanju u kakvu jest, ne postoji, razočaran odluči otkriti istinu, da bi, vrativši se kući, s gorčinom opazio kako se sredina u kojoj živi već naviknula na njegovu odsutnost, kako za njega više nema mjesta, kako je još jedna od individua koje nisu izmaknule težnji društva da je umrtvi u masku, da joj ubije duh, da je liši mogućnosti ljudske komunikacije. (Usp. o tome: Frano Čale, „Pirandello kao dramatičar i njegovi odjeci u Hrvata“, predgovor knjizi: Šest osoba traži autora, ABC naklada, Zagreb, 1995.)

${ }^{47}$ Ispovijedi nekarakternog čovjeka, str. 484.

${ }^{48}$ Isto, str. 485/486.

${ }^{49}$ Isto, str. 486. 
Sprovod će iznijeti na površinu snažnu potrebu ljudi na ovim prostorima za mitom, što Brešan ističe u nekoliko navrata u romanu:

Kad je vlak ušao na stanicu, nastupila je sakralna tišina, svi su se ukočili u obrednoj pozi, po brojnim obrazima tekle su suze, a cijela atmosfera ispunila se nečim mističnim. Ovom biblijskom prizoru pridonosilo je i intoniranje poznate pjesme „Fala“, u kojoj se pokojniku lirskom tankoćutnošću zahvaljivalo na svakoj izgovorenoj riječi, bez obzira što u masi nije bilo nikoga, tko nije od njega, dok je bio živ, čuo i bezbroj gluposti. Postalo mi je jasno da ova tuga svemirskih razmjera nije izazvana njegovom osobnom smrću, nego gašenjem jednog mita, čijim nestankom se svi osjećaju obezglavljeni i prestrašeni za svoju sudbinu. Jer mi još uvijek nismo sposobni, kao ostali civilizirani narodi Europe, imati na čelu običnog čovjeka (...) Mi još uvijek patimo od kroničnog pomanjkanja razuma, da bi nas mogao voditi netko tko je samo čovjek, pogotovo još i običan; to mora biti polubog. Naša svijest je još uvijek mitološka, kao kod starih Egipćana i Babilonaca, i nas može držati u zajedništvu i opstojnosti samo neko nadnaravno biće, obavijeno legendom, čiji bi nestanak ili demistifikacija značio ujedno i naše rasulo. ${ }^{50}$

U opreci s tom velikom, mitskom smrću događa se istovremeno i smrt običnog malog čovjeka kojeg je pomela povijest i čija smrt neće biti zabilježena u niti jednoj knjizi. A smrt malog čovjeka više se dojmila Fabricija, kao što ga je uvijek više zanimao konkretan čovjek od „velikih“ ideja, ideologije ili utopije. Dakle, pod tramvajem umire pijana starica. Bila je to Zora Gorički, nekoć ljepotica, pripadnica uglednog zagrebačkog društva, nekadašnja Fabricijeva zaručnica, ali i zaručnica fašističkog časnika i supruga uglednog partijca, a završava život tragično kao pijana starica. Sve povijesne i političke mijene zemlje koja se raspadala, kao da su se odrazile na njenoj sudbini.

Nakon uzbudljiva života i brojnih ljudi koji su ostavili traga u njemu, Fabricije ostaje potpuno sam. Budući da više nije aktivni sudionik u zbivanjima, sređuje autobiografske zapise koje je pisao cijeloga života, što je čest postupak u pikarskim romanima.

Godine teku, a povijest i politika prolaze mimo Fabricija tako da ih ni ne osjeti. Ponovno će na trenutak iskrsnuti iz anonimnosti važne 1990. godine. Jedno burno stoljeće, koje su obilježile velike ideje i ideali, ali i brojna stradanja malih ljudi i užasi, prošlo je. Fabricija zatičemo kako sjedi u Gradskoj kavani na Jelačićevu trgu u Zagrebu i iz svoje trenutne pozicije promatrača promatra rađanje novog doba za Hrvatsku. Ali, opet, kao da se ništa nije promijenilo. Povijest se iznova ponavlja: Na dan proglašenja neovisnosti,

${ }^{50}$ Ispovijedi nekarakternog čovjeka, str. 487. 
Igra na pozornici života

na Jelačićevu trgu okupilo se nepregledno mnoštvo, koje je u starozavjetnoj maniri upućivalo riječi obožavanja novom vodstvu, što ga je preko Crvenog mora povelo u Obećanu zemlju. ${ }^{51}$

Neočekivano, kao što to uvijek biva u pikarskom romanu, u Gradskoj kavani sjedi i njegov stari prijatelj Jozo Marić. Jozo je razočaran jer nakon cijelog njegovog života, obilježenog stalnom borbom za neovisnu Hrvatsku, nitko ne mari za njega i njegov trud. To će Fabricija ponukati da mu izloži, još jedanput, svoje viđenje povijesti. Smatra da su pojedinci svojom pojedinačnom ulogom zapravo malo pridonijeli rađanju novog doba, jednostavno svi su se našli u vihoru povijesti i politike radeći ono što su morali, a krajnji rezultat je posljedica povijesnog procesa. Stoga u novom vremenu njih dvojica nemaju što tražiti. Povijest se ponavlja, oni su zatvorili svoj krug, a sad je na drugima red da ponavljaju njihove pogreške: Tko ništa nije naučio iz povijesti, osuđen je da mu se ona ponavlja. Zato se sad otvara novi kružni tok, tako da se sve vraća tamo odakle je i počelo. ${ }^{52}$

Predlaže Jozi da i on zauzme poziciju pasivnog promatrača, s čime se Jozo ne može pomiriti. Njihova mišljenja često su se razilazila, ali to im nije smetalo da budu prijatelji i da riskiraju život za onog drugog. I to je jedna nenametljiva, čini se, Brešanova poruka - da se može biti prijatelj i s onim tko je drugačiji od tebe i ima drugačije mišljenje. Jedini spas iz ludila povijesti i politike, kao i mogućnost očuvanja vlastite individualnosti nalazi se u pridržavanju osnovnih humanih načela poštivanja svakog čovjeka.

Jozo će ipak napustiti Hrvatsku i otići u Njemačku, a Fabricije gubi jedinu vezu sa životom kakav je dotad vodio te tone u potpunu anonimnost.

\section{Izvori i literatura}

- Bjornson, Richard, The Picaresque Hero in European Fiction, Madison, Wisconsin, University of Wisconsin Press, 1977.

- Brešan, Ivo, Ispovijedi nekarakternog čovjeka, Znanje, Zagreb, 1996.

- Brkić, Mirna, Pikarski roman - od kanonizacije do transformacije u 18. st., „Mostariensia“, Mostar, 2008.

- Brkić, Mirna, „Ptice nebeske - pikarski roman Ive Brešana“, Riječ, god. 12., sv. 3., Rijeka, 2006.

- Čale, Frano, „Pirandello kao dramatičar i njegovi odjeci u Hrvata“, predgovor knjizi: Šest osoba traži autora, ABC naklada, Zagreb, 1995.

\footnotetext{
${ }^{51}$ Ispovijedi nekarakternog čovjeka, str. 490.

${ }^{52}$ Isto, str. 492/493.
} 
- Fališevac, Dunja, Kaliopin vrt II., Književni krug, Split, 2003.

- Guillén, Claudio, Književnost kao sistem, preveo Tihomir Vučković, Nolit, Beograd,1982?

- Lever, Maurice, Povijest dvorskih luda, prevela Gordana V. Popović, Grafički zavod Hrvatske, Zagreb, 1986.

- Peričić, Denis, Kerempuhova čitanka. Antologija tekstova o Petrici Kerempuhu od 1834. do 1999., Vall 042, Varaždin, 2002.

- Peričić, Denis, Petrica Kerempuh u europskom kontekstu, Vall 042, Varaždin, 1998.

- Sotona ponovno lik u Brešanovu romanu, www.radio101.hr

- Tatarin, Milovan, „Utvara povijesti, utvara individualnosti“, Dome$t i$, godina 10, broj I-IV, 2000.

- „Tko se boji Maršala“, Feral Tribune, XVII, 746. Split, 3. siječnja 2000.

- Tunjić, Andrija, Razgovori u Hrvatskoj, AGM, Zagreb, 2001.

- Visković, Velimir, „Brešanovo dvadeseto stoljeće“, u knjizi: Umijeće pripovijedanja. Ogledi o hrvatskoj prozi, Znanje, Zagreb, 2000.

\section{Mirna BRKIĆ}

\section{A PLAY ON THE STAGE OF LIFE}

The subject of our interest is The Confessions of a Characterless Man (1996), Ivo Bresan's second novel. This comprehensive picaresque novel, with rich and extended plot and intertextual entries, is only at the surface a novel about the main character's adventures. Through the characterless figure of Fabricio Viskov, Bresan will present his personal ethical and philosophical reflexions as well as an original literary view of the problem of history and historical truth.

Key words: Bresan, Confessions of a Characterless Man, ethicalphilosophical reflexions; issue of historical truth 
LINGUA MONTENEGRINA, god. III, br. 5, Cetinje, 2010.

Institut za crnogorski jezik i jezikoslovlje „Vojislav P. Nikčević“

UDK 141.72:821.111.09 Šo Dž. B. Izvorni naučni rad

\section{Olivera KUSOVAC (Podgorica)}

\section{ČOVJEK I NATČOVJEK: DVOSTRUKO LICE ŠOOVOG FEMINIZMA}

Kroz analizu dva strukturalna dijela Šoovog komada Čovjek $i$ natčovjek, u radu se istražuje uloga žene kao sile života koja usmjerava evoluciju ka krajnjem savršenstvu. Usredsređujući se na odnose između likova, brojne aspekte glavnih protagonistkinja i glavnu ideju komada, rad dovodi u pitanje diskurs Šoovog proklamovanog feminizma. U njemu se preispituje stanovište takozvanog prvog talasa feminističkih književnih kritičara kao generatora diskursa koji predstavlja Šoa kao nedvosmislenog feministu, privlačeći čitaočevu pažnju na suptilne, ranije zanemarivane mehanizme koji, kako se čini, izokreću njegove feminističke namjere, ukazujući tako na ambivalentnost kao dominantnu crtu u njegovoj predstavi žene.

Ključne riječi: Šo, Čovjek $i$ natčovjek, feminizam, sila života, ambivalentnost

Šoova fasciniranost vizijom žene kao figure majke, odnosno one koju prirodni instinkt nagoni da ispoljava osobine koje, na ovaj ili onaj način, održavaju njenu arhetipsku sliku zemlje-majke, čini se da nije jenjavala. Ideje koje u sebi nose ovu viziju u raznim njenim formama prisutne su u mnogim, kako ranim tako i onim poznijim, komadima ovog neumornog dramskog pisca. Međutim, dok je u većini njegovih dramskih djela, koja stoje kao bezmalo školski reprezentativan primjer onog što se u teoriji književnosti naziva dramom ideja, takav sadržaj ipak samo dio jednog šireg i slobodnijeg strukturalnog korpusa, u komadu Čovjek $i$ natčovjek ideje sa strukturom drame toliko su podređene glavnom argumentu da je drama ideja dobila rigoroznu formu drame sa tezom. A teza koja dominira ovim komadom, dakako, ponovo u središte stavlja ženu koja je u svojoj biti majka.

U drami Čovjek $i$ natčovjek autor je, na izvjestan način, podigao svoje posmatranje uloge žene na suštinski viši nivo. Razmatranjima njene uloge $u$ porodici i društvu dao je jedan drugačiji kontekst i stavio ih u funkciju esencijalnih sila čovječanstva, pokušavajući tako da svom komadu dâ kako mitski 
tako i kosmički naboj. Preispitujući uloge polova u tom kontekstu, razvio je teoriju o ženi kao pokretaču sile života i, šire, ključnom faktoru kreativne evolucije koja vodi stvaranju boljeg čovjeka, to jest natčovjeka. Veliki je broj književnih kritičara koji u ovakvom postavljanju stvari vide srećnu reafirmaciju položaja žene, odnosno pokušaj da se ženi i muškarcu u evoluciji društva dâ ravnopravan odnos, ili odnos koji, može biti, naizgled čak favorizuje ženu, a koji, na kraju, u harmoniji izvojevanoj ženskim instinktom, energijom i upornošću, vodi zajedničkom napretku. Neradi da prihvatimo ovakvo stanovište, pokušaćemo da pokažemo da ono, u biti, počiva na osnovama grube i nadasve tradicionalne podjele uloga, te da, stoga, ni u kom slučaju ne doprinosi afirmaciji uloge žene u realnoj sferi svakodnevnog života, u porodici i društvu.

Svoju teoriju o sili života Šo dosljedno provlači kroz dvije različite strukture radnje koje se, dajući komadu na površini defektnu formu, vrlo lako uočavaju. Dramska površina koja se odmah zapaža i koja je, prividno, u I, II i IV činu gotovo lišena druge strukture, otkriva poznati obrazac komične romanse sa likovima koji, stereotipno, progone ili bivaju progonjeni. Ovo, s druge strane, izranja iz konceptualne dubinske strukture, mitske po sadržaju i porijeklu, čiji zamah, eksplicitno predstavljen u neskladno razvučenom III činu, upravlja površinskom radnjom. Ove dvije strukture, koje, dakle, nijesu u pukom odnosu koegzistencije već u odnosu hijerarhije, sredstvo su koje autor koristi da bi izložio svoju tezu.

U površinskom sloju radnje, koji ujedno služi kao okvir komada, čitalac/gledalac susrijeće se sa ljubavnom igrom osvajanja, karakterističnom za komične romanse. Iako u osnovi stereotipan, ovaj obrazac pokazuje se kao odraz u ogledalu u kome lijeva i desna strana zamjenjuju mjesto. U ovoj romansi, naime, namjesto uobičajene slike u kojoj muškarac proganja, a žena biva progonjena, nudi nam se njen obrnuti odraz. Mlada i sočna heroina En Vajtfild, pritajeno ali neumoljivo, stremi ka svojoj izabranoj meti, ljevičarskom političkom propagatoru Džonu Taneru, koji, predstavljajući se kao tvrdokorni neženja, isto toliko neumoljivo uzmiče. Ovim je autor, očito, izokrenuo viktorijansku koncepciju pasivne žene naspram aktivnog muškarca i smjelo otvorio pitanje ženske seksualnosti, stavljajući ga prividno u prvi plan. Jednom prilikom izjavio je čak da je ovo „komad koji se u cjelosti bavi seksom... a upravo neodoljiva novina toga donijela mu je takav uspjeh“. ${ }^{1} \mathrm{~A}$ novina o kojoj je riječ, dakako, odnosi se na činjenicu da je upravo žena ta kojoj je u komadu dao pokretačku seksualnu energiju.

\footnotetext{
${ }^{1}$ Nav. prema: Mary Bryden, „Coils of the Cobra: The Predatory Woman of Shaw and Beckett", New Comparison: A Journal of Comparative and General Literary Studies, 1989, br. 7, 162. Sve citate u radu preuzete iz djela objavljenih na engleskom jeziku prevela je autorka rada.
} 
Nadmoćnost te energije u formi ženske dominacije pokazaće se kao jedna od najočiglednijih karakteristika površinske strukture, što predstavlja istinski paradoks jer žene u komadu koje pośeduju tu energiju (pored En, tu je i sporedni, ali ne manje odlučni lik Vajolet) van usko i tradicionalno definisanih društvenih i bioloških uloga nemaju apsolutno nikakvog oduška za nju. Ipak, u granicama svojih uloga, ove žene ispoljavaju moćnu, ali uvijek doličnu silu. Kao posljedica, stiče se utisak da se muškarci definišu upravo kroz njihov odnos sa ženama. ${ }^{2}$ Tako, uprkos Tanerovim protestima protiv braka i njegovim pretenzijama da predstavlja filozofa utopistu, mi ga posmatramo kao prestrašenog mužjaka koji bježi od En. Nadalje, Robak Ramzden, može biti, uistinu jeste ,,predśednik veoma uvaženih ljudi“, ${ }^{3}$ kako nas autor informiše uvodeći ovaj lik u dramu, ali slika koju vidimo zapravo je ono što En naziva „Enin deka“, 4 to jest slika jednog pompeznog i nesposobnog čovjeka. A zanesenog Oktavijusa, opet, viđećemo paralisanog romantiziranom vizijom En, koja prožima sve njegove govore i djela. Čak i odmetnika Mendozu sagledaćemo kroz prizmu njegove neuzvraćene ljubavi prema ženi koja u komadu uopšte nije prisutna.

Pošto žene u drami imaju tako snažan uticaj na samo definisanje uloga, ne iznenađuje činjenica da je i djelovanje muškaraca podstaknuto i usmjereno djelovanjem ženskih likova. Žene su preduzimljive, odvažne, agresivne i samouvjerene, i upravo one su te koje svojom domišljatošću i smjelošću osiguravaju željeni ishod. Vajolet odnosi prevagu i nad svojim mužem i nad njegovim ocem obezbjeđujući brak pod svojim uslovima, sa neophodnim prihodom. En, opet, odnosi prevagu i nad muškarcem koji želi da se oženi njome i nad onim koji to ne želi, obezbjeđujući rješenje koje je najbolje za sve troje. U tom kontekstu, kao sasvim prirodna nameće se i činjenica da je svako, kako fizičko tako i diskurzivno djelovanje Tanera, kao glavnog muškog lika u komadu, gotovo u cjelosti određeno radnjama i zamislima koje je inicirala En, kao glavni ženski lik. Tako, zapravo, kroz dramu pratimo niz Eninih akcija i prateću seriju Tanerovih reakcija. A Taner, iako će tvrdoglavo bježati od braka sve do samog kraja komada, ipak će govoriti o neizbježnosti svoje reakcije, aludirajući, u šopenhauerovskim terminima, na neopipljivu silu koja upravlja životima muškaraca: „Mi ne sprovodimo vlastitu volju, već volju svijeta." ${ }^{\text {"5 }}$ Kulminacija njegovih reakcija, tako, biće njegova vjeridba sa En, jer, kako on to deterministički kaže, ,volja je svijeta da (En) treba da ima

${ }^{2}$ Sally Peters Vogt, „Ann and Superman: Type and Archetype“, u: Harold Bloom i drugi, George Bernard Shaw, London, Chelsea House, 1993, 217.

${ }^{3}$ Bernard Shaw, Man and Superman, u: B. Shaw, The Complete Plays of Bernard Shaw, London, Paul Hamlyn, 1965, 332.

${ }^{4}$ Ibid, 338-9.

${ }^{5} \mathrm{Ibid}, 402$. 
muža“. ${ }^{6}$ U svojoj reaktivnoj ulozi, Taner ima dosta zajedničkoga sa pasivnim herojem melodrame. Ali, paradoksalno, plitki konvencionalizam melodramskog heroja pretvoren je kod njega u nedokučivu oštroumnost tobožnjeg revolucionara koji izgovara panegirike sili života. $^{7}$

Već prva Tanerova reakcija, kada će, unezvijeren, ulećeti kod Ramzdena sa testamentom tek preminuloga Eninog oca u kojem se on, uz Ramzdena, navodi kao njen drugi staratelj, pokazaće da Taner, iako na svjesnom planu ubijeđen da je meta njegov prijatelj Oktavijus, podsvjesno ośeća da se, zapravo, u ulozi progonjenog nalazi on sam. U tom trenutku neće znati da iza želje pokojnog gospodina Vajtfilda stoji upravo En, kojoj je to samo okvir za klopku koju mu je postavila, ali će se žestoko koprcati na njeno lukavo insistiranje da želja njenog oca bude ispoštovana. A upravo način na koji će ih En obojicu naćerati da zanemare svoje primjedbe i, mada nevoljno, prihvate naturenu ulogu staratelja, pokazaće se kao ustaljeni obrazac koji ona koristi da bi, manipulišući ljudima, okretala neumoljivu društvenu omču oko ženinog vrata u svoju korist.

Budući da je rastao dijeleći svoje dječačke nestašluke $\mathrm{s}$ En, Taner je, očito, odavno bio u prilici da pronikne u njenu sklonost manipulisanju ljudima i okolnostima, te je, stoga, mogao predviđeti šta starateljstvo nad njom može da znači: „Izvršiće svaki zločin koji ugledna žena može da izvrši, i opravdaće svaki od njih tako što će reći da je to bila želja njenih staratelja. Sve će prebaciti na nas, a mi ćemo moći da je kontrolišemo taman onoliko

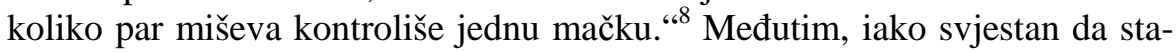
ratelji ne mogu kontrolisati nekog poput En, on ni u jednom trenutku nije postavio pitanje samog starateljstva kao takvog. A mora se priznati da je situacija u kojoj su se glavni akteri našli zaista vrlo apsurdna. Ona predstavlja ekstreman primjer inferiornog položaja koje je viktorijansko društvo nametalo ženi. Naime, preminuli otac, pored žive i zdrave majke, prepušta starateljstvo svojih kćeri, dvaju odraslih đevojaka, dvojici muškaraca, od kojih je jedan (Taner) približno istih godina kao starija ćerka En. Taner želi da pobjegne od te odgovornosti, jer je svjestan Enine manipulativne prirode, ali, istovremeno, misli da mu sasvim pristoji da unapređuje Enin um, što je, inače, prvobitno bila uloga oca. On objašnjava svoje ubjeđenje u vlastitu moralnu i obrazovnu superiornost u odnosu na En: „Voditi računa o tebi... znači zamijeniti svoju volju tvojom. Šta ako je ona nižeg reda od moje? Jesu li žene potkovane bolje ili gore od muškaraca? Jesu li gomile glasača potkovane bolje ili gore od državnika? Gore, naravno, u oba slučaja. " 9 Na taj način stavlja

${ }^{6}$ Bernard Shaw, Man and Superman, 1965, 402.

${ }^{7}$ Sally Peters Vogt, Ann and Superman: Type and Archetype, 1993, 218.

${ }^{8}$ Bernard Shaw, Man and Superman, 1965, 335.

${ }^{9} \mathrm{Ibid}, 347$. 
Čovjek i natčovjek: Dvostruko lice Šoovog feminizma

sebe u poziciju onog koji zna bolje i više, te, stoga, može da poučava, implicirajući potrebu da njen um približi svom, promijeni žensku volju i učini je što sličnijom muškoj.

Ne samo da i svi ostali likovi u komadu smatraju da je takvo stanje stvari posve prirodno, ispravno i pravedno, jer, kako će Ramzden u jednom trenutku reći, „ona (En) je samo žena, uz to još mlada i neiskusna žena“, ${ }^{10}$ već i sami lik majke, čiji je autoritet ovim starateljstvom u potpunosti anuliran, pojavljuje se u svijetlu koje će, čini se, sasvim opravdati takvo ustrojstvo. Marginalnost i beznačajnost koje definišu njen karakter naglasiće se već u njenom, kako ćemo viđeti, ,uzgrednom“ opisu:

Gospođa Vajtfild je, uzgred, jedna sićušna žena, čija izblijeđela kosa boje lana izgleda kao slama na jajetu... Čovjek bi pretpostavio da je jedna od onih žena koje su svjesne da ih tretiraju kao glupave i beznačajne, a koje se, ne pośedujući dovoljno snage da valjano afirmišu sebe, ipak nikada ne mire sa svojom sudbinom. ${ }^{11}$

Odgovornost za njenu nedjelotvornost temelji se na dva osnova: s jedne strane, ono što je čini nemoćnom je ophođenje drugih prema njoj, dok se, s druge strane, takvo stanje pospješuje vlastitim odricanjem roditeljskog autoriteta i odgovornosti. U svom djelovanju, gospođa Vajtfild samo potvrđuje svoju nesposobnost, iako možda i tendencioznu nevoljnost, da prihvati na sebe teret odgovornosti za vaspitanje svojih kćeri. Ona će čak apsolutno odbiti da uzme ikakva učešća u raspravi o njihovom starateljstvu jer, kako kaže, ,nema nikakvog mišljenja po tom pitanju““. ${ }^{12}$ En je, s druge strane, sasvim svjesna majčine nemoći da ispolji bilo kakav uticaj na nju, što će pokazati njena izjava da bi bez njih dvojice bila ,posve prepuštena svom vlastitom nadzoru“. ${ }^{13}$ Ono što će još više omalovažiti ulogu njene majke je činjenica da En izvlači korist iz svoga novog statusa „,siročeta“"14 - termin koji tehnički precizno označava dijete bez jednog roditelja, ali koji se mnogo više koristi za đecu kojima nedostaju oba roditelja. ${ }^{15}$

Upravo ovaj ekstremni primjer nepravednih i za ženu ponižavajućih društvenih okolnosti Šo će postaviti kao okvir u kojem će En moći na najbolji način da demonstrira neumoljivu snagu sile života. A ona će se, ironično, ispoljiti u formi laži i lukavstava kojima se En neprestano služi kako bi postigla svoj cilj. U takvom ponašanju pristojnost i doličnost nikada joj neće

${ }^{10}$ Bernard Shaw, Man and Superman, 1965, 336.

${ }^{11}$ Ibid, 338.

${ }^{12}$ Ibid.

${ }^{13}$ Ibid.

${ }^{14}$ Ibid, 335.

${ }^{15}$ J. Ellen Gainor, Shaw’s Daughters, 1991, 203. 
manjkati, jer je vještinu skrivanja iza paravana poslušnosti i dužnosti dovela do savršenstva. Ne možemo se oteti utisku da kroz ovakav obrazac ponašanja Šo, istovremeno, izražava kritiku licemjernog viktorijanskog društva, koje podstiče i njeguje takvu prepredenost i dvoličnost nudeći ih, osobito ženama, kao jedino sredstvo za ostvarivanje njihovih ciljeva. Paradoksalno, Enina poslušnost i dužnost odnose se na oca, koji nije više među živima, i majku, čija je beznačajnost dovedena do apsurda. Upravo tom njenom osobinom Ramzden će biti potpuno zaveden, što će ovog iskusnog i starog čovjeka izvrgnuti ruglu, jer će se čitalac, ubrzo nakon njegovih prvih, izuzetno pohvalnih komentara u vezi s En, susresti s njom i spoznati besmislenost njegovih riječi: ,,...ona je zadivljujuće poslušna đevojka... Uvijek je to 'Očeva je želja', ili 'Majci se to ne bi sviđelo'. To, zaista, gotovo da je mana kod nje. Često sam joj govorio da mora naučiti da misli svojom glavom. “16

Međutim, najveća potvrda o tome koliko je En uspješna u svojoj igri ne leži u tome što većina likova biva zavedena, već u činjenici da čak i oni rijetki koji su prozreli njeno lukavstvo apsolutno nimalo ne utiču na ishod situacije. Enina majka, kojoj je autor velikodušno podario malo zdrave pameti zahvaljujući kojoj shvata šta njena ćerka radi, nije u stanju, niti ima volje, da vrši bilo kakav uticaj na nju. Taner, s druge strane, i te kako ima i volje i snage da se suprotstavi, ali će se njegovi napori, na kraju, pokazati jednako jalovim. A njegova borba, kako je već rečeno, otpočela je prije nego što je postao svjestan da je En izabrala baš njega i nijednog drugog.

Taneru je sasvim jasno da je konačni cilj kojem En stremi udaja. Svjestan je i niti koje ona ispreda pletući, polako ali sigurno, mrežu u kojoj će na kraju uhvatiti svoj plijen. $\mathrm{O}$ tome da je doživljava u ulozi predatora govori i izuzetno raznovrsni, svrsishodno odabrani, ali ne uvijek i prećerano originalni niz životinja s kojima je poistovjećuje. Ona je u jednom trenutku „mačka“, u drugom ,piton“, u trećem, opet, „lavica“, da bi, potom, naizmjenice postajala „,bengalski tigar“, „,medvjed“, ,pauk“, ,pčela“ i, konačno, ,,slon“. ${ }^{17} \mathrm{~A}$ dok En bude razdragano slušala kako Taner neumorno dodaje nove i nove primjerke za arsenal životinja koje njegove oči vide u njoj, nama će se sve slikovitije dočaravati predstava o ogromnom strahu koji leži iza toga. Ali i bez ovih tako izražajnih verbalnih ispoljenja njegovog straha, čitaocu ne bi moglo lako da promakne kako se on ne ośeća nimalo bezbjedno sa njom, kako zbog, tako i uprkos njezinu đavolskom šarmu. ${ }^{18}$ Taj strah, međutim, nije samo iracionalna i instinktivna reakcija na ono što doživljava kao potencijalnu opasnost, već je i vrlo određeno teorijski zasnovan. A Tanerova teorija,

\footnotetext{
${ }^{16}$ Bernard Shaw, Man and Superman, 1965, 333.

${ }^{17}$ Ibid, 335, 336, 340, 341, 354, 356.

${ }^{18}$ Rhoda B. Nathan, The Shavian Sphinx, The Shaw Review, 1974, XVII, br.1, 49.
} 
Čovjek i natčovjek: Dvostruko lice Šoovog feminizma

koju će nam ovaj salonski orator tokom čitave drame tako razložno izlagati, samo je gruba verzija sveobuhvatnije autorove teze o sili života, data iz jednostrane perspektive preplašene strane u duelu između muškarca i žene.

Dualizam koji, po Tanerovom ubjeđenju, postoji zasniva se na strogoj podjeli uloga: muškarac je umjetnik koji stvara novi um, a žena majka koja stvara nove ljude, pri čemu je muškarac, zapravo, samo instrument pomoću kojeg žena ostvaruje svoj cilj. Mimo toga, on za nju ne predstavlja apsolutno ništa. Da nije njegove finansijske moći, nakon obavljanja svoje nužne uloge u oplodnji bio bi, čak, u potpunosti odbačen: „Kad bi žene mogle bez našeg rada, i kad bismo mi jeli hljeb njihove đece umjesto što ga pravimo, one bi nas ubile kao što pauk ubija svog parnjaka ili kao što pčele ubijaju trutove." ${ }^{\prime 19}$ Ostvarujući svoj cilj, međutim, žena žrtvuje kako njegovu, tako i svoju sreću. Jer, njen cilj podudara se sa ciljem prirode, i tu sreća nije bitna. Ali, u svojoj anksioznosti Taner ostvarenje ženinog cilja posmatra, ujedno, i kao destrukciju muškarca, koju ovaj u svojoj nemoći, ironično, čak i priželjkuje. „To je vražja strana fascinacije jedne žene: ona te naćera da želiš svoje vlastito uništenje“ “ ${ }^{20}$ reći će opčinjenom Oktavijusu, tumačeći njegovu želju da mu En bude žena. Ali, njegov će se strah, možda, najbolje očitovati u završnoj sceni kada ni sam neće više moći da se odupre želji za samouništenjem: ,,zgrabivši je u svoje naručje)... Sila života me začarala: kad te zagrlim, držim čitav svijet u rukama. Ali ja se borim za svoju slobodu, svoju čast, svoje vlastito biće, jedno i nerazdjeljivo.“21 Dakle, sloboda, čast i vlastito biće vrijednosti su koje, približivši se jednoj ženi, to jest oženivši se njome, muškarac gubi. On ne treba da se plaši ljubavi kao takve, jer je ona sa distance ne samo bezopasna, već i svrsishodna kao inspiracija za umjetnika; ono od čega treba bježati jesu brak, porodica i domaćinstvo. Kada se Oktavijus, kojem je želja da postane pjesnik, pozove na inspiraciju koju mu, kako kaže, samo En može dati, Taner, neodoljivo nam prizivajući u śećanje Kandidinog mladog poetu Judžina i njegovu tajnu koju će ovaj, spoznavši je, zauvijek nositi u srcu, reći će:

$\mathrm{Pa}$, nije li bolje da to dobiješ od nje sa bezbjedne distance? Petrarka nije viđao Lauru, ni Dante Beatrisu ni upola onoliko koliko ti sada viđaš En; a ipak su pisali prvoklasnu poeziju... Oni nikada nijesu izložili svoje obožavanje testu domaće familijarnosti, i ono im je trajalo do groba. ${ }^{22}$

\footnotetext{
${ }^{19}$ Bernard Shaw, Man and Superman, 1965, 354.

${ }^{20}$ Ibid, 340.

${ }^{21}$ Ibid, 403.

${ }^{22}$ Ibid, 354.
} 
Ružnoća domaće familijarnosti, dakako, otrijeznila bi Oktavijusa u neđelju dana i, ubrzo, namjesto anđeoske inspiracije vidio bi pred sobom samo jednu debelu ženu. Međutim, kako je Taneru sasvim jasno da žena ima isuviše veliku moć da bi za muškarca bilo moguće da odista zadrži tu distancu, ono što je za njega, na kraju, bitno jeste da on sam ne postane izabrana meta.

Iako je, sasvim u skladu sa svojom teorijom, svjestan da žena u svojoj ulozi lovca (na muža, svakako) vrši vrlo pažljiv odabir, njegova pronicljivost, ipak, omanula je u procjeni toga ko je Enin odabrani plijen. Ona ga je iznenadila, i prenerazila, svojim neočekivanim gestom da pored u nju zaljubljenog Oktavijusa, kojeg nam je autor uveo kao nekog ko bi morao biti glavni junak jer ,nije razumno pretpostaviti da će se još jedna tako privlačna muška figura pojaviti u priči““, ${ }^{23}$ izabere upravo njega koji je ne želi, ili, bar, neće to sebi da prizna. Međutim, da En nije stvorila komplikacije time što je odbila ovog romantičnog i gorljivog udvarača, a izabrala teškog i nepristupačnog Tanera, komada ne bi ni bilo. ${ }^{24}$ Upravo zahvaljujući činjenici da je za nju bio mnogo veći izazov i satisfakcija da od muškarca koji ne obećava mnogo napravi svog obožavaoca nego da pasivno odgovara na udvaranje onog koji je to već postao, pred nama je djelo u kojem se izvrtanjem uloga razbio stereotip. A autoru je, čini se, to bilo potrebno da bi mogao još jednom da pokuša da nas uvjeri da pred sobom nemamo heroinu sazdanu od posve ženskog mesa i kaprica, već individuu s idejama i svjesnim izborom, odnosno modernu ženu. Ova Šoova „moderna“ žena, dakle, odbija konvencionalnog čežnjivog udvarača Oktavijusa, čije će nekritično obožavanje konačno dovesti do naprasnog i otresitog odbacivanja, a bira opasniji i teži, ali vredniji ulov, da bi, uhvativši ga, izjavila: ,Jedina zaista prosta stvar jeste otići pravo za onim što želiš i ščepati ga.“ ${ }^{25}$ A njena poćera za Tanerom, koja se može nazvati seksualnim lovom, kao u nekom začaranom krugu, počinje u viktorijanskoj Engleskoj, nastavlja se tokom neobuzdane vožnje kolima do kontinenta, ostaje aktuelna kroz cijelu epizodu sa Don Žuanom u paklu, i dostiže vrhunac natrag u naturalističkom ambijentu jedne španske vile. ${ }^{26}$

Ironično, Taneru, koji je zahvaljujući svojoj prilično mizoginističkoj verziji teorije o sili života bio stalno na oprezu, biće potrebno da mu drugi kažu da se En nije ustremila na njegovog zaljubljenog druga, već na njega. Spoznavši, u neviđenom očajanju, da je upravo on ,pčela, pauk, obilježena žrtva“ i ,predodređeni plijen““, ${ }^{27}$ u naletu pomamnog straha naložiće svom

${ }^{23}$ Bernard Shaw, Man and Superman, 1965, 332.

${ }^{24}$ Barbara Bellow Watson, The New Woman and the New Comedy, 1974, 8.

${ }^{25}$ Bernard Shaw, Man and Superman, 1965, 399.

${ }^{26}$ Mary Bryden, Coils of the Cobra: The Predatory Woman of Shaw and Beckett, 1989, 163.

${ }^{27}$ Bernard Shaw, Man and Superman, 1965, 360. 
Čovjek i natčovjek: Dvostruko lice Šoovog feminizma

vozaču Strejkeru, koji mu je otvorio oči, da smjesta krene i, u vratolomnoj vožnji, obarajući sve rekorde, odvede ga do „Marselja, Gibraltara, Đenove, bilo koje luke iz koje možemo otploviti ka nekoj muhamedanskoj zemlji đe su muškarci zaštićeni od žena““ ${ }^{28}$ A taj put odvešće ga do sna o nadrealističkom putovanju kroz začuđujući svijet pakla u kojem ćemo, uranjajući u dubinsku strukturu komada, umjesto Tanera viđeti njegovog legendarnog pretka Don Žuana, a umjesto vraške, lukave En arhetipsku figuru Done Ane, kroz koje ovi likovi doživljavaju fizičku i duhovnu metamorfozu.

Upravo kao što se površinska struktura romantične komedije pokazala kao komična inverzija lova na heroinu, tako je i dramski krhki okvir sna koncipiran kao komična inverzije donžuanovske teme. Don Žuan, raskalašnik nad raskalašnicima, postaje progonjeni plijen koji traži jedino misaoni odmor od neumoljivosti vječito proganjajućih žena. Uz ostale likove u snu smješten je u praznom prostoru koji je nastanjen bestjelesnim stvorenjima kao što je $\mathrm{i}$ on sam. Ovo svjesno pomjeranje od konkretnih pojedinosti određene scene predstavlja metod univerzalizacije, jer je radnja apstrahovana iz konkretnog vremena i mjesta, čime je kreirana zona u kojoj ona postaje ceremonija, a glumci arhetipovi. ${ }^{29}$ Pakao, iz kojeg se može tako lako stići i do zemlje i do neba, postaje Šoova satirična verzija svetog središta univerzuma. Koristeći ritualne tehnike, Šo izražava filozofiju kreativne evolucije, a da bi je učinio dramski održivom, koristi legendu o Don Žuanu kao nadmoćno sredstvo. Često tretirana u muzici i književnosti, ova legenda, kroz svoje pojavljivanje van svakog istorijskog konteksta, podignuta je do nivoa mita. Tematski, fluidni mit o Don Žuanu postaje pogodan milje za kreativnu evoluciju: evoluirajuća forma mita o Don Žuanu, zasnovanog na seksualnosti, postaje blisko povezana sa Šoovim evolutivnim mitom, čiji je konačni trijumf zavisan od moći seksualne energije. Tako, ova legenda postaje sredstvo kojim autor saopštava svoju kosmičku filozofiju. A lik Don Žuana postaje prirodna komplementarna dopuna neuhvatljivoj i raznolikoj En. ${ }^{30}$

Šo je znao da je originalni Don Žuan najprije bio seksualni avanturista koji je, zbog svog promiskuiteta, na kraju postao pobunjenik. Šoov Don Žuan, koji predstavlja originalnog Don Žuana sazrelog do punoljetstva, takođe je prvo bio seksualni avanturista, ali koji je, kako kaže, kasnije postao pobunjenik zbog dosade koju je trpio u paklu. On izlaže filozofiju kreativne evolucije jer je spoznao da je njegov mladalački promiskuitet, iako zabavan i poučan, ipak jalov i nesvrsishodan. Puritanac Šo, dakle, želio je da romantičnog ljubavnika preobrati u ličnost koja će biti u službi čovječanstva i krea-

\footnotetext{
${ }^{28}$ Bernard Shaw, Man and Superman, 1965, 361.

${ }^{29}$ Vidi Sally Peters Vogt, Ann and Superman: Type and Archetype, 1993, 220.

${ }^{30}$ Ibid, 221.
} 
tivne evolucije. ${ }^{31}$ Pred kraj diskusije sa Dona Anom, Statuom i Đavolom, on daje obrise svog novog viđenja svrhe života:

...dok god mogu da zamislim nešto bolje od sebe, ne mogu da budem miran sem ako ne težim da to i stvorim ili, pak, otvaram put za to... To u meni radi neprestana težnja života ka višoj organizaciji, široj, dubljoj, intenzivnijoj samosvjesnosti, i jasnijem samopoimanju. Upravo nadmoć ovog cilja svela je, u mojim očima, ljubav na puko zadovoljstvo trenutka, umjetnost na puko uvježbavanje mojih sposobnosti, religiju na puki izgovor za ljenost, pošto je postavila Boga koji je bacio pogled na svijet i vidio da je on dobar, nasuprot instinktu u meni koji je kroz moje oči pogledao svijet i vidio da se on može popraviti. ${ }^{32}$

Svom Don Žuanu Šo je dao zreli cilj u životu na kojem će njegova energija i vitalnost cvjetati. On je ozbiljno usredsrijeđen na život u kome će služiti čovječanstvu, duboko vjeruje u snagu sile života i arogantno prkosi konvencijama društva koje je osujećuju i razaraju.

Don Žuan, kao nadrealistični lik iz III čina ovog komada, suprotstavlja se romanticizmu, slobodnjaštvu i ljubavništvu svojih prethodnika, jer su to zaludne vrijednosti koje mogu dovesti isključivo do isfrustriranosti i nezadovoljstva. U drami Čovjek $i$ natčovjek, on nije heroj zato što uspijeva da pobjegne od žena, jer, očito, ni Taneru ni Don Žuanu to ne polazi za rukom; heroj je jer je njegov novi raison d'etre, služenje sili života, jači od želje da juri za ženama ili, pak, bude njihov plijen. ${ }^{33}$

Šo je, čini se, u svom komadu o Don Žuanu okrenuo ljubavne uloge jer je pretpostavio da, kada se seksualni odabir oslobodi stega tradicije i konvencije, žena, a ne muškarac, postaje ta koja progoni, uprkos romantičnom duhu kojim je legenda o Don Žuanu obavijena. A u svijetlu te pretpostavke, njegov Don Žuan zamišljen je kao filozof jer je čitava civilizacija sagledana kao ,pokušaj muškarca da od sebe napravi nešto više od pukog sredstva koje služi ženinu cilju“. ${ }^{34}$

Filozofija Don Žuana samo je jedan segment kompletne šoovske filozofije, izložene kroz iscrpne i elaborirane diskusije kojima mistični san III čina obiluje. Za razliku od površinskog okvira drame koji je prožet dubokom ironijom, ovaj sloj drame daje sliku života, odnosno ljudskog postojanja, s aspekta dualizma duha i tijela, Pakla i Raja, stvarnog i mogućeg, čovjeka i

\footnotetext{
${ }^{31}$ Carl Henry Mills, Man and Superman and the Don Juan Legend, Comparative Literature, 1967, XIX, br.3, 220.

${ }^{32}$ Bernard Shaw, Man and Superman, 1965, 385-6.

${ }^{33}$ Carl Henry Mills, Man and Superman and the Don Juan Legend, 1967, 225.

${ }^{34}$ Bernard Shaw, Man and Superman, 1965, 378.
} 
Čovjek i natčovjek: Dvostruko lice Šoovog feminizma

natčovjeka, čime drama dobija univerzalno značenje. Don Žuan, koji brani život, suprotstavljen je Đavolu, koji slavi smrt. Budući oličenje intelektualne filozofije razuma, Don Žuan u životu vidi mogućnost da čovjek bolje upozna samoga sebe, da bolje shvati život i da ga na taj način obnavlja na sve višem nivou. Buneći se protiv društvenih normi, smatra da je raj apsolutan, idealistički realitet u kojem su stvari priznate u svojoj suštini i da zato pripada ljudima odanim filozofskoj kontemplaciji. On otkriva Dona Ani da je pakao mjesto đe se nalaze mnogi ,dobri“ ljudi, jer zlo se na svijetu događa u njihovo ime, pa je pakao najprikladnije mjesto da prime svoju nagradu. Đavo, s druge strane, tvrdi da je čovjek opśednut idejom smrti, jer uz nju i u njoj mjeri svoju snagu destrukcijom, podešavajući po njoj svoje moralne, religiozne, društvene i ekonomske norme. Po njemu, svijet nije doživio nikakav bitan napredak i nema svoje svrhe. Istovremeno, on zastupa Ničeovu ideju o natčovjeku, koji će stvarati sopstveni moral i odbaciti okove prividnog, licemjernog morala koji se zasniva na normama hrišćanske civilizacije. Dona Ani još ne može da pokaže takvog natčovjeka ali, zahvaljujući njemu, ona doživi duhovni preobražaj, nalazeći smisao svog života u razvoju i produžetku čovječanstva.

Na mitskoj i filozofskoj pozadini, djelovanje kojim dominira žena postaje, ujedno, i komičnije i nužnije, jer kretanje sile života prema razvijenijem ljudskom biću zahtijeva aktivno učešće žene u hvatanju muškarca. Međutim, pokazuje se da je En više od instrumenta sile života; ona se identifikuje sa suštinom same kreativne evolucije. Njena neuhvatljiva priroda, stalno mijenjajuća i uvijek drugačija, simbolizuje vječiti proces koji podrazumijeva kreativna evolucija. Takav proces opire se jednostavnom definisanju i stoga su likovi koji okružuju En u stanju da razluče isključivo one karakteristike koje priželjkuju kod jedne žene ili koje očekuju da vide. Ironično, upravo ono što ona predstavlja za zavedenog Oktavijusa sintetizuje sve njene osobine i odnosi se na mitsko porijeklo. Za njega, kako će nas autor izvijestiti u didaskalijama,

ona je jedna očaravajuće lijepa žena u čijem prisustvu svijet doživljava preobraženje, a slabašna ograničenja pojedinačne svijesti, kroz mistično śećanje na cjelokupni život rase sve do njegovih početaka na istoku, ili čak natrag do raja odakle je pao, postaju iznenada beskonačna. ${ }^{35}$

Paradoksalno, zaslijepljeni Oktavijus vidi više od cjelokupnog obrasca koji okružuje En nego Taner, koji se razmeće svojom percepcijom poretka stvari. Taj obrazac obuhvata začuđujući niz uloga: ulogu ćerke, sestre, djevice, zavodnice, nevjeste i majke, a sve to unutar mitološke uloge kraljice bo-

${ }^{35}$ Bernard Shaw, Man and Superman, 1965, 337. 
ginje svijeta, arhetipske boginje koja i proždire i uzgaja. Ona je arhetipska Žena, nosilac sile života, Šoovo otjelovljenje blejkovskog kreda slave: „Energija je vječita radost.“36

U simboličnoj interpretaciji koja daje značenje dubinskoj strukturi komada, i životinje sa kojima Taner povezuje En dobijaju novi smisao. Između ostalog, pokazuje se da se uglavnom radi o lunarnim bićima. Mačka, medvjed i tigar, na primjer, dovode se u vezu sa mjesecom u raznim mitologijama. Uz to, postoji i posredna veza između ovih životinja i osnovnih nagona koji isključuju spiritualnost. Enine moćne instinkte i ravnodušnost prema određenim intelektualnim i duhovnim osobinama trebalo bi, stoga, posmatrati unutar implicirane metaforične okosnice mjeseca, koji je trajna evokacija želje. Prikladnost lunarne metafore očita je: budući da je doživljavan kao pasivan jer reflektuje sunčevu svjetlost, mjesec se tradicionalno povezuje sa ženskim principom. Ženske osobine materinske ljubavi i zaštite pripisuju se mjesecu, iako njegova polusvjetlost stvara auru koja sugeriše opasnost i nesvjesnost. Ove lunarne osobine ispoljavaju se u Eninoj nesposobnosti da svjesno rastumači svoje motive. Ipak, ona žrtvuje sve da bi bila supruga i majka. Pored toga, odraz mjesečevih mijena, koje doživljavamo kao neprestano modifikovanje njegove forme, nalazimo u Eninoj kameleonskoj prirodi sa njenim stalnim mijenjanjem uloga.

U čudnovatom svijetu pakla, koji dominira III činom ovog komada, kroz proces samoponištenja i metamorfoze dolazi do ponovnog rađanja, čime se tema kreativne evolucije još više potkrepljuje. U procesu metamorfoze likovi gube sve nebitne lične osobenosti prezentirane u romantičnoj komediji, ostavljajući samo kvintesencijalne osobine neophodne za stvaranje natčovjeka: plodnost i energiju kod Dona Ane, i intelektualnu i duhovnu težnju kod Don Žuana. Nakon te metamorfoze, ishod romantične komedije u kojem se Taner predaje dolazi kao prirodan i logičan. Iako ce na verbalnom nivou ostati pri istom negodovanju zbog neminovnog braka, konstatujući da je ,u kandžama sile života“", ${ }^{37}$ on će, priśećajući se sna u kojem je i došlo do nje-

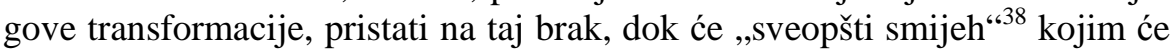
se komad završiti pokazati bezazlenost njegove priče i konačni trijumf te neumoljive sile.

U terminima dubinske strukture komada, brak koji je na pomolu postaje mistični brak koji sjedinjuje suprotstavljene osobine neba i zemlje, sunca i mjeseca, predstavljajući Tanerovo razumijevanje života kroz En, koja je sami život. A priželjkivano rođenje natčovjeka, koje treba da proizađe iz sjedinje-

\footnotetext{
${ }^{36}$ Vidi: Sally Peters Vogt, Ann and Superman: Type and Archetype, 1993, 224.

${ }^{37}$ Bernard Shaw, Man and Superman, 1965, 402.

${ }^{38}$ Ibid, 405.
} 
nja Tanera i En, obećava stvaranje jednog novog društva koje će se uzdići nad postojećim. Tako dolazimo do cilja koji je, čini se, jedini bitan i koji opravdava sve ono što se, u romantičnoj komediji, u formi tipično ženskih lukavstava ispoljilo kod En. Njoj je, velikodušno, sve oprošteno, jer služi višem cilju. Kao čuvar budućnosti, ona ispunjava benevolentnu svrhu nužno nemilosrdnom taktikom. ${ }^{39}$ Tako, ona postaje ništa manje nego uzdanica rase u kretanju prema natčovjeku.

Početkom dvadesetog stoljeća, kada je pisao ovaj komad, Šo je privremeno bio izgubio vjeru u materijalizam. Ośećaj da je fabijanizam marginalizovan stvaranjem prve parlamentarne socijalističke partije, doveo ga je do dijagnoze očaja koja je glasila da demokratija ,ne može da se uzdigne iznad nivoa ljudskog materijala od kojeg su glasači napravljeni““. ${ }^{40}$ Stoga mu se, kao prirodna, nametnula ideja o demokratiji natčovjeka, odnosno uzgajanju novog ljudskog materijala. Kako natčovjek, dakako, može proizaći isključivo iz tijela žene, u djelu Čovjek i natčovjek ona je, neminovno, morala zauzeti središnje mjesto. Jednako neminovno, moralo se pokazati da ona instinktivno teži ciljevima eugenike, što je autora naćeralo da pribjegne esencijalizmu i strogoj biološkoj podjeli uloga, reafirmišući suprotstavljenost, ali i jedinstvo, odnosno paralelno postojanje duha i tijela, produkcije i reprodukcije, razvijanja i ponavljanja.

Dosljedan svom paradoksalnom načinu razmišljanja (ali i podsvjesnom strahu od žena), Šo je morao izvjesnim aspektima dati izokrenutu sliku. Tradicionalno pasivna žena postala je aktivna, a tradicionalno aktivan muškarac ogrnuo se pasivnošću. Njena aktivnost proizvod je ogromne (i zastrašujuće) seksualne energije koju joj je autor pripisao kao inherentnu, pretendujući da prevazilazi stereotipe svog vremena. Međutim, ta energija, sasvim bezbjedno, preusmjerena je, u cjelosti, na nagon za rađanje, koji, ponovo uzimajući formu naprednosti, podstiče ženu na samostalni, svjesni i aktivni izbor partnera, što će se, opet, pokazati kao njen jedini cilj. Ali, ironično, prividno dajući ženi da svojom aktivnošću uspostavi kontrolu nad situacijom, ovako strukturisan komad, zapravo, samo pojačava granice odavno omeđenog prostora ženskog djelovanja. Tako se vizija ženine aktivne seksualnosti izvrće u svoju suprotnost: umjesto da predstavlja izvjesno oslobađanje za ženu, ona je vraća na njeno tradicionalno polje djelovanja.

$\mathrm{Na}$ feministički prigovor da žene u ovom komadu prirodno vide udaju kao krajnji cilj, često se daje odgovor da i muškarci, izuzimajući Tanera, streme ka istome. ${ }^{41}$ Kao potvrda navode se primjeri Oktavijusa i mladog

\footnotetext{
${ }^{39}$ Rhoda B. Nathan, The Shavian Sphinx, 1974, 49.

${ }^{40}$ Nav. prema: Jill Davis, The New Woman and the New Life, 1992, 25.

${ }^{41}$ Vidi: Barbara Bellow Watson, The New Woman and the New Comedy, 1974, 7-8.
} 
Hektora, uz opasku da se, u krajnjoj liniji, ne može u potpunosti vjerovati ni $\mathrm{u}$ iskrenost Tanerovog negodovanja. Čini se da zagovornici takvog stava prenebregavaju činjenicu da su tim istim muškarcima koji žele da se ožene date i druge preokupacije i sfere interesovanja, dok je žene, nažalost, autor lišio toga. Stoga, koliko god nam se grubima i prenaglašenima činile neke od Tanerovih samouvjereno izloženih konstatacija, istinitost njegove sljedeće izjave ne dovodi se u pitanje: „Pobogu, čovječe, kakvog drugog posla ona u životu ima osim da nađe muža?... Ti imaš svoje poeme i tragedije da se njima baviš; En nema ništa. “" ${ }^{\text {‘2 }}$ Ovo je, u krajnjoj liniji, samo karikatura stanovišta koje izbija iz drame i po kojem žena ima isključivo biološku, a muškarac i reproduktivnu i kulturalnu funkciju.

Ono na čemu se zasnivaju kako romantična komedija tako i filozofija drame Čovjek $i$ natčovjek jeste antagonizam polova, upravo ono što današnji feminizam nastoji da dekonstruiše. Volja prirode može se sprovesti isključivo kroz konflikt između muškarca, koji pośeduje um, i žene, koja je nosilac seksualnog/prokreativnog nagona. Don Žuan će elaborirati ovu tezu vraćajući se na istoriju civilizacije i pokazujući, zapravo, da je patrijarhat biološki neminovan:

Kako je samo nepromišljeno i opasno bilo stvoriti zasebno biće čija je isključiva funkcija bila njena vlastita oplodnja! Jer, gledajte šta se dogodilo. Najprije se muškarac množio na njenim rukama sve dok nije bilo jednako muškaraca koliko i žena; tako ona nije bila u stanju da u svoje svrhe upotrijebi više od djelića ogromne energije koju je ostavila njemu na raspolaganje pošteđevši ga iscrpljujućeg napora trudnoće. Ta suvišna energija otišla je u njegov mozak i njegove mišiće. Postao je isuviše jak da bi ga ona mogla fizički kontrolisati, i isuviše kreativan i mentalno krepak da bi se zadovoljio pukom samoreprodukcijom. Stvorio je civilizaciju ne konsultujući se sa njom, uzimajući zdravo za gotovo da je njen rad u kući temelj te civilizacije. $^{43}$

Kako Šo u komadu ne daje nijedan drugi glas koji bi opovrgao Don Žuanovo čitanje istorije civilizacije i uloge polova, stiče se utisak izvjesnog apsolutizma u viđenju ženine funkcije kao isključivo reproduktivne, naspram funkcije muškarca koja je i reproduktivna i kulturalna. Dona Ana složiće se s ovakvim tumačenjem, a njen poznati uzvik prema univerzumu koji glasi: „Oca! Oca za natčovjeka!““44 svojim eugeničkim žarom nagovijestiće spremnost da se ovjekovječe uloge polova, kao i istorija društva koju je Don Žuan

\footnotetext{
${ }^{42}$ Bernard Shaw, Man and Superman, 1965, 353.

${ }^{43}$ Ibid, 378.

${ }^{44}$ Ibid, 389.
} 
Čovjek i natčovjek: Dvostruko lice Šoovog feminizma

predložio. Ironično, Šoova snažna odanost eugenici dovela ga je u vezu sa zagovornicima viktorijanskog ideala ženstvenosti, koji su, takođe, podržavali taj pokret. Kako je Dajhaus zabilježio:

Samožrtvovanje, koje su Sara Elis, Raskin, Koventri Patmore i ostali hvalili kao kvintesencijalno svojstvo žene, sada je moglo da se smatra da ima biološku, funkcionalnu osnovu: žene se žrtvuju, i bilo je bitno da one treba da se žrtvuju, zarad evolucije društva i 'napretka rase '. 45

I zaista, uprkos činjenici da svojom nepopustljivom željom da sprovede svoju volju En predstavlja antitezu duboko ukorijenjenoj viziji žene kao bića koje se mučenički povinuje željama i zahtjevima drugih, njena spremnost da žrtvuje čak i vlastiti život zarad ispunjenja svoje materinske dužnosti ocrtava emocionalnost sličnu onoj koja karakteriše najpopustljivije viktorijanske žene.

Na filozofskom nivou, esencijalne uloge muškarca i žene Šo je prepoznao kao podjelu na Duh i Materiju. Jedno od sredstava u službi demonstriranja vjerodostojnosti ove suštinske podjele je i njegovo sistematsko nastojanje da žene u ovom komadu predstavi kao nesposobne za poimanje bilo kakvih apstraktnih, intelektualnih koncepata. One, kako se pokazuje, u stanju su da razumiju isključivo pojmove koji mogu da se konkretizuju, odnosno povežu sa nečim opipljivim. Taner, na primjer, pokušaće u jednom trenutku da objasni En svoj prelazak sa vandalizma na ikonoklazam: „Ja ne lomim više staklenike, niti palim grmlje štipavca: ja razbijam vjerovanja i rušim idole“ ${ }^{46}$ En je, međutim, nesposobna da prati taj metaforički pomak i, sasvim nezainteresovano, odgovoriće: „Bojim se da sam isuviše žena da bih viđela bilo kakav smisao u destrukciji. Destrukcija može samo da razara. “47 Ovo, pak, ne znači da je Šo ženske likove lišio inteligencije; on je bio odviše promućuran da bi to napravio. Kao zamjenu za to, dao im je praktičnu životnu inteligenciju, koja je odraz iskonske životne energije, energije Materije, koja ima moć da neumitno sprovodi svoju volju. A njenu volju, opet, poistovjetio je sa voljom prirode da stvara savršenije tvorevine i tako, tendenciozno, stavio u službu eugenike.

Prividno, u toj borbi između muškarca-mislioca i žene-majke, arhetipska vizija majke odnosi pobjedu. Enini instinkti prevazilaze njeno ograničeno poimanje i pokazuju se kao superiorni u odnosu na Tanerov intelekt. No, u borbi između viktorijanskog muškarca i viktorijanske žene, ovako strukturi-

\footnotetext{
${ }^{45}$ Nav. prema: J. Ellen Gainor, Shaw's Daughters, 1991, 211.

${ }^{46}$ Bernard Shaw, Man and Superman, 1965, 346.

${ }^{47} \mathrm{Ibid}$, 346: "I am afraid I am too feminine to see any sense in destruction. Destruction can only destroy."
} 
san komad, sa tezom koja se zasniva na strogoj podjeli uloga i antagonizmu polova, pobjedu donosi muškarcu koji, u strahu za sopstvene pozicije, teži da očuva postojeće stanje u kome za ženu koja ne služi isključivo njegovim potrebama i potrebama rase naprosto nema mjesta.

\section{Bibliografija}

- Bryden, Mary, „Coils of the Cobra: The Predatory Woman of Shaw and Beckett", New Comparison: A Journal of Comparative and General Literary Studies, 1989, br.7.

- Davis, Jill, The New Woman and the New Life, Gardner, V., Rutherford, S. i drugi, "The New Woman and Her Sisters: Feminism and Theatre 1850-1914," London, Harvester Wheatsheaf, 1992, $17-33$.

- Gainor, J. Ellen, Shaw's Daughters: Dramatic and Narrative Constructions of Gender, Ann Arbor, University of Michigan Press, 1991.

- Mills, Carl Henry, "Man and Superman" and The Don Juan Legend, Comparative Literature, 1967, XIX, br.3.

- Nathan, Rhoda B., The Shavian Sphinx, The Shaw Review, 1974, XVII, br.1.

- Peters Vogt, Sally, Ann and Superman: Type and Archetype, Bloom, Harold i drugi, "George Bernard Shaw", London, Chelsea House, 1993, 215-232.

- Shaw, George Bernard, The Complete Plays of Bernard Shaw, London, Paul Hamlyn, 1965.

- Watson, Barbara Bellow, The New Woman and the New Comedy, The Shaw Review, 1974, XVII, br. 1.

\section{Olivera KUSOVAC}

\section{MAN AND SUPERMAN: THE TWO FACES OF SHAW'S FEMINISM}

Analysing the two structural parts of G. B. Shaw's play Man and Superman, the paper explores the role of the woman as the Life Force directing evolution towards ultimate perfection. Focusing on the intricate relations between the characters, multiple aspects of the main female protagonists and the main idea of the play, the paper questions the discourse of the author's proclaimed feminism. It re-examines the views of the socalled first wave of feminist literary critics as generators of the discourse 
Čovjek i natčovjek: Dvostruko lice Šoovog feminizma

regarding Shaw as an indisputable pro-feminist, drawing the reader's attention to the subtle, previously unnoticed mechanisms which seem to reverse his feminist intentions, thus revealing the prevailing ambiguity underyling his representation of woman.

Key words: Shaw, Man and Superman, feminism, Life Force, ambiguity 

LINGUA MONTENEGRINA, god. III, br. 5, Cetinje, 2010.

Institut za crnogorski jezik i jezikoslovlje „Vojislav P. Nikčević“

UDK 821.161.1.09-31 Peljevin V. Stručni rad

\author{
Miomir ABOVIĆ (Tivat) \\ Univerzitet Mediteran - Podgorica
}

\title{
MISTIČNO-IRONIJSKA PONIRANJA VIKTORA PELJEVINA (poetske odrednice romana „Čapajev i Praznina“)
}

\begin{abstract}
Predmet rada je analiza romana „Čapajev i Praznina“ ruskog pisca Viktora Peljevina. Ukazaćemo na temeljne poetske značajke ovoga djela i pokušati da u najkraćim crtama ukažemo na visoke umjetničke domete ovoga romana.

Ključne riječi: roman, Viktor Peljevin, Čapajev i Praznina, budizam, kompozicija, humor, ironija
\end{abstract}

Roman „Čapajev i Praznina“ Viktora Peljevina, trenutno najpopularnijega ruskog pisca mlađe generacije, nije uzalud, odmah po objavljivanju, proglašen najboljim romanesknim ostvarenjem te (sad već pomalo davne) 1996. godine. U ovom radu pokušaćemo ukazati na vanrednu slojevitost i razuđenost umjetničkih kvaliteta navedenoga romana i pokazati zašto bi (u poplavi osrednje i loše prevodne beletristike) baš ovaj roman valjalo pročitati.

Peljevin se, koristeći poznati postupak fikcije o pripovjedaču, pojavljuje u funkciji urednika koji je pripremio rukopis za štampu i dao mu naziv „Čapajev i Praznina“ dok nam ime navodnog pravog autora ovog rukopisa ostaje skriveno. „Izvesna grčevitost u pripovedanju“, kaže urednik Peljevin, „može se objasniti činjenicom da cilj pisanja ovog teksta nije bilo stvaranje 'književnog dela', već beleženje mehaničkih ciklusa svesti u cilju konačnog izlečenja od takozvanog unutrašnjeg života. “1 Dalje naglašava da autor ,,...na dva ili tri mesta ... više pokušava da neposredno ukaže na čitaočev um, nego da ga natera da vidi još jedan u nizu fantoma satkanih od reči. “2 Peljevin, odnosno njegov fiktivni pripovjedač, zaista će se potruditi da nas svojim rukopisom naćera na (možda ponovno) i dublje promišljanje suštine i smisla života i svijeta u kome živimo. Kompozicija romana zasniva se na paralelizmu

\footnotetext{
${ }^{1}$ Viktor Peljevin, Čapajev i Praznina, Plato, Beograd, 2002, 7.

${ }^{2}$ Isto, 7-8.
} 
dviju radnji - jedan fabularni tok vremenski je situiran u doba Oktobarske revolucije, a drugi u društvenu zbilju savremene Rusije, Rusije kraja XX vijeka. Oba fabularna toka u romanesknu cjelinu sjedinjuje lik Petra Praznine, dekadentnog petrogradskog pjesnika iz godina pred Prvi svjetski rat i monarhiste po ubjeđenju koji igrom slučaja postaje komandir u diviziji Crvene Armije, a koji u svojim košmarima (ako to stanje u okviru idejne potke ovoga romana možemo tako nazvati) u snu vidi sebe kao jednog od pacijenata moskovske psihijatrijske klinike s kraja dvadesetoga vijeka. Ovim postupkom pisac na efektan način dovodi u neposrednu vezu dva udaljena toka povijesnih zbivanja sjedinjujući ih u cjelovitu sliku lomova i traganja jedne velike kulture i nacije za istorijskim pozicioniranjem. Prvi fabularni tok smješten, kako rekosmo, u vrijeme Oktobarske revolucije, prati pustolovine Petra Praznine i njegovog vojnog zapovjednika Vasilija Čapajeva, lika izrazito mistične i ezoterične profilacije. Njih dvojica vode brojne rasprave o filozofiji, strukturi svijeta i mjestu čovjeka u svijetu, rasprave u kojima Čapajev, naizgled sofistički umješno, a zapravo veoma ubjedljivo, dekonstruiše postavke o apsolutnosti važenja činjenice da stvarnost i ono što nazivamo čovjekovom ličnošću imaju čvrsto ontološko utemeljenje. Evo jednog od tih sjajnih dijaloga:

- Ti, Pećka, pre no što počneš da pričaš o komplikovanim stvarima, najpre nauči jednostavne. Pa „mi““ je složenije od ,ja“, je l' tako?

- Tako je, rekoh.

- Šta ti nazivaš ,ja“?

- Očigledno sebe.

- Možeš li da mi kažeš ko si ti?

- Petar Praznina.

- To ti je ime. A ko je onaj koji to ime nosi?

- Pa - rekoh - može se reći da sam ja - psihička ličnost. Zbir navika, iskustva... I znanja, ukusa.

- Čije su to navike, Pećka? - sugestivno upita Čapajev.

- Moje - slegoh ramenima.

- Pa ti tek što si rekao, Pećka, da si ti zbir navika. Ako su to tvoje navike, ispada da su to navike zbira navika?

- Zvuči smešno - rekoh - ali u suštini je tako.

- A kakve navike imaju navike?

Osetio sam bes.

- Čitav ovaj razgovor je prilično primitivan. Počeli smo od toga ko sam ja po svojoj prirodi. Ako hoćete, mislim da sam... Recimo, monada. U Lajbnicovom smislu.

- Ali ko je taj ko sebe smatra monadom?

- Monada i smatra - odgovorih - čvrsto odlučivši da se kontrolišem. 
- Dobro - reče Čapajev lukavo priškiljivši - o tome „ko“ ćemo porazgovarati kasnije. Reci mi gde ta monada živi?

- U mojoj svesti.

- A gde ti je svest?

- Evo ovde - rekoh kucnuvši se po glavi.

- A gde je tvoja glava?

- Na ramenima.

- A gde su tebi ramena?

- U sobi.

- A gde je soba?

- U kući.

- A kuća?

- U Rusiji.

- A gde je Rusija?

- U nevolji, Vasilije Ivanoviču.

- Mani se toga - viknu on strogo. - Šalićeš se kad ti komandir naredi. Govori.

- Kako gde. Na Zemlji.

Kucnuli smo se i popili.

- A gde je Zemlja?

- U vasioni.

- A vasiona?

Trenutak sam razmišljao.

- Sama u sebi.

- A gde je ta „sama u sebi“"?

- U mojoj svesti.

- Znači, Pećka, ispada da je tvoja svest - u tvojoj svesti?

- Tako ispada.

- Tako - reče Čapajev i ispravi brkove. - A sada me slušaj pažljivo. Na kakvom se mestu ona nalazi?

- Ne razumem, Vasilije Ivanoviču. Pojam mesta jeste jedna od kategorija svesti, tako da...

- Gde je to mesto? Na kom mestu se nalazi pojam mesta?

- Pa recimo da to uopšte nije mesto. Može se reći da je to stva...

Prekidoh se. Da, pomislio sam, evo kuda navodi. Ako upotrebim reč „stvarnost“, on će ponovo sve svesti na moje misli. A onda će pitati gde se one nalaze. Reći ću - u mojoj glavi, i... Gambit. Mogu naravno da upotrebim citate, ali bilo koji od sistema na koji mogu da se pozovem, pomislio sam odjednom sa zaprepašćiva- 
njem, ili zaobilazi ovu smisaonu pukotinu, ili je pokriva sa par sumnjivih latinizama. Da, Čapajev uopšte nije prost. $^{3}$

Čapajev dijalog poentira sljedećim riječima: „Sve što vidimo nalazi se u našoj svesti, Pećka. Zato se ne može reći da se naša svest negde nalazi. Mi se nalazimo nigde prosto zato što ne postoji mesto za koje se može reći da se mi u njemu nalazimo. Eto zato smo mi nigde. ${ }^{\text {"4 }}$ Budistička misao u ovom romanu nije vanjski sistem umjetno inkorporiran u strukturu djela ili proizvod mogućeg intelektualnoga pomodarstva, nego neizbježna posljedica zaključaka do kojih dolazimo u dodiru s realnošću. „U životu postoji apsolutno nepomična tačka prema kojoj je čitav život san. Sve na svetu je prosto vrtlog misli i svet oko nas biva stvaran samo zato što ti i sam postaješ taj vrtlog" ", Čapajev. „Ničeg nema“, kaže još Čapajev, slijedeći poznatu Nagarđuninu doktrinu o sveopštoj praznini i lišenosti stvari vlastite prirode, ,i čak i toga nema takođe nema. "6 Čapajev, koji je u romanu zapravo jedan od avatara Buddhe, i Praznina (prezime veoma indikativno u misaonom obzorju romana) na kraju svog puta u okružju haotične ali uzbudljive atmosfere Oktobarske revolucije skaču u vode rijeke Urala, uslovne rijeke apsolutne ljubavi koja ih oslobađa od vječnoga cikličnog kretanja duše.

Druga fabularna linija romana vodi nas u rusku svakodnevicu kraja dvadesetoga vijeka u kojoj, kako dobro primjećuje jedan kritičar, ništa nije i sve jeste. Poligon dešavanja je psihijatrijska klinika čiji upravnik Timur Timurovič drži da se ozdravljenje bolesnika sastoji u preorijentaciji svijesti na realni svijet, puštanja metaforičkog bika na slobodu tj. usmjeravanja psihičke energije na objekte spoljašnjega svijeta i prihvatanja poza koje vrijeme traži da se zauzmu. On pokušava da svoje pacijente izliječi od sindroma tzv. lažne ličnosti. Životne storije bolesnika zapravo su snovni košmari Petra Praznine i svaka od tih storija nosi izuzetnu značenjsku dubinu, bilo da je riječ o mladiću Mariji i alhemijskom braku Rusije sa zapadom, alkoholičaru Serdjuku koji odlazi na razgovor o poslu sa predstavnikom japanske firme u Moskvi Kavabatom, inače samurajem, ili o razgovoru trojice ruskih mafijaša o vječnom kuliranju tj. nirvani. Smisao za sjajnu ironiju i humorne epizode kroz koje se provlače dublji misaoni sadržaji konstanta su Peljevinova romana. Takva je scena upravo pomenuti razgovor u kojem jedan mafijaš objašnjava dvojici drugih suštinu pojma nirvane upodobljavajući i jezički to objašnjavanje njihovim mogućnostima saznanja. Takva je i scena u kojoj Petar Praznina, dok

\footnotetext{
${ }^{3}$ Viktor Peljevin, Čapajev i Praznina, 161-163.

${ }^{4}$ Isto, 166.

${ }^{5}$ Isto, 326.

${ }^{6}$ Isto, 329.
} 
Mistično-ironijska poniranja Viktora Peljevina

vodi ljubav sa revolucionarkom Anom, razmišlja o ženskoj ljepoti kao zlatnoj etiketi na praznoj flaši, ljepoti iza koje nema ničeg naročitog. I pronicljive psihološke samoanalize junaka nalaze svoje mjesto u značenjskoj slojevitosti ovoga djela. Upravo u tom sjajnom spoju ezoterijske i ironijske komponente udruženim sa misaonom dubinom, sa jedne strane, i kompozicionim postupkom usaglašenim sa idejnom suštinom djela, sa druge, i leži snaga ovoga romana. „Čapajev i Praznina“ spada, bez prećerivanja, u ne tako brojna romaneskna ostvarenja (takav su roman, recimo, i „Školice“ Hulia Kortasara) svjetske književnosti koja su u stanju da dovedu (makar neke) čitaoce u stanje duboke zapitanosti nad nekim temeljnim ,životnim istinama“ i efektivno promijene njihov život. „Šta da se radi, Pećka“, kaže Čapajev, ,takav je ovaj svet - na pitanja treba odgovarati usred kuće u plamenu. ${ }^{\text {"7 }}$ Na pitanje da li pročitati ovaj roman odgovor je svakako potvrdan, doduše u mnogo opuštenijoj atmosferi od one o kojoj govori Čapajev.

Miomir ABOVIĆ

\section{MYSTICAL AND IRONICAL DUBITATIONS OF VICTOR PELEVIN (Poetic determinants in the novel Chapayev and Void)}

This essay covers issues of thematic and compositional characteristics of the novel Chapayev and Void by contemporary Russian writer Victor Pelevin. We have tried to give at least a hint of thematic richness and compositional complexity of this novel and the way in which these two interwined in the writer's attempt to create a novel of the upmost artistic quality.

Key words: novel, Victor Pelevin, Chapayev and Void, Buddhism, composition, humour, irony

\footnotetext{
${ }^{7}$ Viktor Peljevin, Čapajev i Praznina, 326.
} 

LINGUA MONTENEGRINA, god. III, br. 5, Cetinje, 2010.

Institut za crnogorski jezik i jezikoslovlje „Vojislav P. Nikčević“

UDK 792(497.16):821.161.1

Pregledni rad

\title{
Dragana KALEZIĆ (Podgorica)
}

Institut za crnogorski jezik i jezikoslovlje „Vojislav P. Nikčević“

\section{RUSKI PISCI NA SCENI CRNOGORSKOG NARODNOG POZORIŠTA (I)}

\begin{abstract}
Ovaj rad ima za cilj da prikaže i analizira djelovanje Crnogorskog narodnog pozorišta (1953-2003) s aspekta recepcije ruskih pisaca naročito u prvoj deceniji rada Pozorišta.

Prema broju izvedenih djela i autora i kritici koja je propratila te postavke, može se zaključiti da su ruski pisci imali značajno mjesto u repertoaru ovog pozorišta. Naročito je važna bila uloga djelā ruskih pisaca kao što su Gogolj i Ostrovski na samom početku stvaranja repertoara CNP. Od sveukupne inostrane literature najviše su izvođena djela iz ruske književnosti. Crnogorsko narodno pozorište imalo je značajnu ulogu u popularisanju ruske književnosti u kulturnoj javnosti Crne Gore.

Ključne riječi: Crnogorsko narodno pozorište (CNP), ruski pisci, drama, pozorišna kritika, recepcija
\end{abstract}

Sudeći prema bibliografskim podacima na repertoaru crnogorskog pozorišta, ruski pisci uvijek su imali značajno mjesto, uvijek su bili, manje ili više, izvođeni. Još od samih početaka aktivnosti pozorišnih društava u Crnoj Gori, krajem XIX i početkom XX vijeka na Cetinju i u Nikšiću izvođena su djela ruskih pisaca (Gogolj, Čehov) i ta tradicija nastavljena je i njegovana u daljem razvoju pozorišnih prilika u zavisnosti od toga kako se mijenjala pozorišna ideološka orijentacija.

\section{Kratak pregled istorije pozorišnog života u CNP u Podgorici 1953-2003.}

Pozorište je vrlo značajan segment kulture svakog društva i njegova organizacija umnogome svjedoči o kulturnome nivou društva. Da bi se formirala potpunija slika o uslovima i okolnostima rada Crnogorskog narodnog pozorišta, koji su u velikoj mjeri određivali repertoarsku politiku, zastupljenost pojedinih pisaca, dramskih vrsta i sam život pozorišta, ali i zbog njegove 
važne kulturne uloge i misije na ovom prostoru, napravićemo osvrt na istorijske prilike formiranja ovog pozorišta.

\section{Istorijski uslovi formiranja CNP}

Potreba za pozorišnom organizacijom, sam naziv Crnogorsko narodno pozorište i počeci ovog pozorišta vezani su za prve godine poslije Drugog svjetskog rata. Juna 1946. godine u Beogradu je održan sastanak pozorišnih radnika nove Jugoslavije sa predstavnicima iz centara svih republika (izuzev Sarajeva) koji je označio prvi korak u stvaranju pozorišnog sistema novog, socijalističkog društvenog poretka. Na sastanku je odlučeno da svaka republika u glavnom gradu formira centralno, republičko pozorište i da se odatle pomaže razvoj ostalih oblika pozorišne djelatnosti. Ujedno je utvrđena funkcija pozorišta kao prosvjetne, kulturne, filozofsko-estetske i političke institucije. U Izvještaju Centralnom komitetu KPJ od 1949. javni i kulturni poslenik Miladin Perović navodi da je Crnogorsko narodno pozorište jedino koje je postojalo u Crnoj Gori prije rata i da ponovo počinje da radi na oslobođenoj teritoriji 1943. godine, kao pozorišna ekipa pri CASNO (Crnogorskoj antifašističkoj skupštini narodnog oslobođenja). Ime tog pozorišta ubrzo se pojavljuje na plakatu prve predstave u oslobođenome Cetinju - „Najezda“ Leonida Leonova, održane u jesen 1944. godine, u čast II kongresa Narodne omladine Crne Gore i Boke. ${ }^{1}$ Dramu je, prema prijevodu Radovana Lalića i Radovana Zogovića sa ruskog jezika, režirao Dušan Popović.

U Crnoj Gori sredinom dvadesetog vijeka u Nikšiću, Kotoru, Cetinju, Titogradu i Pljevljima radila su pozorišta koja su se razvila iz partizanskih pozorišnih grupa i kulturno-umjetničkih družina. Prvo je nastalo u Nikšiću (1944), a prelaskom te trupe na Cetinje ubrzo je formirano Narodno pozorište Crne Gore. ${ }^{2}$ Godine 1953. Podgorica (tada Titograd) političkom odlukom o preseljenju administrativnoga centra Republike Crne Gore sa Cetinja, dobija svoje stalno profesionalno pozorište, koje prvu sezonu otvara predstavom „Ugašeno ognjište“ Petra-Pecije Petrović.

Što se tiče rusko-crnogorskih kulturnih veza, interesantno je pomenuti da je prvi upravnik novoformiranoga pozorišta u Titogradu od 1953. do 1955. godine bio režiser ruskoga porijekla Vasilij Ivanovič Šćukin (18961969). Śćukinov otac imao je putujuće pozorište koje je gostovalo po Rusiji i van nje i koje je njegovalo burleske i komediju. U tom pozorištu radio je i Sćukin i tako je, kada je stigao u Jugoslaviju (početkom dvadesetih godina XX vijeka), već imao značajno iskustvo. Poslije nekoliko gradova u Vojvodi-

${ }^{1}$ Dr Olga Brajičić, Zapis o crnogorskom narodnom pozorištu 1943-1946, CNP, Podgorica, 2002, str. 17.

${ }^{2}$ O tome vidi: Ratko Đurović, „Pozorište“, Teatrološki spisi, CNP, Podgorica, 2006. 
Ruski pisci na sceni Crnogorskog narodnog pozorišta (I)

ni, zaustavio se u Beogradu. U tom periodu u prijestonici je, sve do II svjetskog rata, radilo nekoliko ruskih grupa i ansambala, u kojima je Šćukin igrao i režirao. ${ }^{3}$ U Crnu Goru Šćukin je prvi put stigao 1920. godine, a od 1936. u njoj stalno boravi i radi. Za Crnu Goru značajan je kao prvi profesionalni organizator, koji je 1939. godine osnovao Dječje pozorište, 1944. Crnogorsko omladinsko pozorište na Cetinju i Dramski studio, koji je bio svojevrsna škola za pripremu glumaca. Vasilij Šćukin i Ananije Verbicki, čuveni scenograf, takođe Rus, izbjeglica, bili su zaduženi za osnivanje profesionalnog pozorišta u Kotoru, đe je Šćukin režirao svoje prve predstave u Crnoj Gori. Godine 1951. osnovao je Pionirsko pozorište, u kome je bio stalno angažovan kao reditelj i upravnik 1952-1953. i 1955-1961. Ipak, najznačajnija zasluga Śćukina vezana je za osnivanje gradskog Narodnog pozorišta u Titogradu. Śćukin je na našoj sceni najviše režirao djela ruskih autora, a naročito se istakao postavljanjem djela Gogolja, Ostrovskog, Katajeva.

Narodno pozorište bilo je prvo profesionalno pozorište u Podgorici, koje će privremeno, do završetka svoje zgrade, biti smješteno u zgradu Doma kulture. Do tada su pozorišni život Titograda činile aktivnosti lokalnih amaterskih dramskih društava i gostujuće pozorišne grupe.

$\mathrm{Na}$ samom početku svog rada Narodno pozorište u Titogradu suočilo se sa nizom problema. Ni prve kritike kvaliteta predstava ni ocjene stanja pozorišta u Titogradu nijesu bile pozitivne. Pred tim mladim pozorištem bio je zadatak da odredi kako i sa čime krenuti. Pozorište se suočilo s problemima koje je trebalo riješiti: malobrojnost glumačkog kadra i potreba za njegovim usavršavanjem, nedostatak garderobe i ostalih pozorišnih rekvizita, određenje repertoara.

Sa sličnim problemima sretala su se i pozorišta u ostalim gradovima, koji su uz to bili slabije razvijeni od Titograda. Potreba da se kvalitet predstava podigne na veći umjetnički nivo, da se osnuje teatar koji će okupiti kvalitetan glumački, rediteljski i tehnički kadar, postaje očigledna. Težnja da se pozorište bolje organizuje, da Republika Crna Gora, poput ostalih federalnih jedinica, ima reprezentativni teatar, sazrijevanje političkih i kulturnih uslova, koji doprinose osnivanju jedinstvenog, stalnog pozorišta u glavnom gradu te činjenica da pozorišta nijesu naročito profitabilne institucije (ekonomističke teorije) dovešće, 1958. godine, do reorganizacije, odnosno redukcije pozorišta u Crnoj Gori.

Pozorišta u Nikšiću, Cetinju, Kotoru dobijaju status poluprofesionalnih, u Pljevljima, Bijelom Polju, Ivangradu i Tivtu ostaju samo amaterska

${ }^{3}$ Pobjeda, Titograd, 15. 12. 2001. 
pozorišta ili dramske sekcije, ${ }^{4}$ a do 1962 . godine i oni bivaju ukinuti. Nakon toga, Narodno pozorište u Titogradu postalo je jedino profesionalno pozorište u Republici. Time njegova uloga dobija širi značaj, ozbiljnije pozorišne, kulturne, pa i nacionalne zadatke. Naime, trebalo je održati se, ali uz to i odgovoriti na sve estetske, kulturno-prosvjetiteljske zahtjeve, napraviti repertoar i izgraditi jaku kulturnu instituciju. Takvo pozorište je, pisao je Sreten Perović, imalo obavezu da ,animira međusobno različitu i teatarskom životu nedovoljno vičnu, mladu publiku, da bude znatno više od pukog zabavnog igrališta, da aktivno utiče na kulturno-nacionalnu emancipaciju crnogorskog naroda i da istovremeno bude, svojim programskim djelovanjem - u saglasnosti s intencijama sveukupnog društvenog razvoja“.5 Tek 1969. godine, to jedino profesionalno pozorište u Crnoj Gori dobiće i zvaničan naziv Crnogorsko narodno pozorište i postati ,reprezentativno pozorište nacije“.

\section{Pozorišne prilike u CNP}

Na svom razvojnom putu Crnogorsko narodno pozorište u Podgorici preživjelo je dosta teških faza. Na samom početku suočilo se sa mnoštvom kadrovskih i materijalnih problema. Po ukidanju profesionalnih pozorišta u drugim crnogorskim gradovima poboljšava se kadrovska situacija, zahvaljujući glumcima koji prelaze u Titograd.

Kao jedino profesionalno pozorište u Republici, titogradsko Narodno pozorište, opštinskog karaktera a republičkog značaja, dobija nove, veće obaveze prema široj publici i na širem području, što ograničava njegove mogućnosti da se razvija kao moderno eksperimentalno pozorište. Milovan Radojević skreće pažnju da je ukidanjem četiri profesionalna gradska pozorišta, Crnogorskom narodnom pozorištu nametan karakter ,putujućeg“. To je uslovilo strah od inovacija i ograničavalo kreativna istraživanja, jer je repertoar trebalo prilagoditi onom dijelu publike „koji nije navikao na recepciju pozorišne umjetnosti “. ${ }^{6}$ Politika titogradskog Narodnog pozorišta težila je repertoaru koji će biti prihvatljiv za sve. Naročito je njegovana nacionalna drama i podstican njen razvoj. U cilju obezbjeđivanja kvalitetnog repertoara djelā nacionalne književnosti, raspisivani su konkursi za dramu iz crnogorskoga života ili su, pak, dramatizovani romani iz nacionalne književnosti, poput

\footnotetext{
${ }^{4}$ Alojz Ujez, „Razvoj pozorišnog sistema u CG u periodu 1944-1999“, Pozorište u Crnoj Gori u drugoj polovini XX vijeka : radovi sa naučnog skupa: Podgorica, 23. jun 2006. godine, Crnogorska akademija nauka i umjetnosti, Podgorica, 2007, str. 28.

${ }_{5}^{5}$ Sreten Perović, Darovi scene, knj. I, Studije i kritike, Univerzitetska riječ : Leksikografski zavod Crne Gore, Titograd, 1986, str. 403.

${ }^{6}$ Crnogorsko narodno pozorište 1953-2003, priredio Milovan Radojević, CNP, Podgorica, 2003, str. XXXIX.
} 
Ruski pisci na sceni Crnogorskog narodnog pozorišta (I)

„Hajke“ Mihaila Lalića (premijera održana 24. II 1962) i „Mrtvog Dubokog“ Čeda Vukovića (premijera 28. II 1963).

Usljed tendencije da se prave kompromisi sa gledaocima, insistira se i na vodviljskoj literaturi, što je imalo samo jedan pozitivan elemenat - ,omasovljavalo je gledalište“. ${ }^{7}$ Postojalo je i mišljenje da je pozorište, s obzirom na mali broj stanovnika grada u kojem je djelovalo, pa samim tim i mali broj gledalaca, bilo prinuđeno da sprema veći broj premijera, kako se reprize ne bi igrale pred polupraznom ili gotovo praznom salom. Repertoarska politika pozorišta, koja se tek počela formirati, nastojala je da uključi i proprati evropsku i svjetsku dramu, jer je ipak trebalo napraviti repertoar dostojan jednog reprezentativnog pozorišta, uprkos limitiranim sredstvima za finansiranje i odlivu kadrova. „Repertoar se prilagođava finansijskim mogućnostima. Izbacuje se iz njega sve što zahtijeva veća sredstva. Znači li to tehničko osiromašenje predstava? Kažu i to“, navodi Milovan Radojević iz članka K. Čakića „Titograd - bez mladih glumaca“, koji je objavio zagrebački Vjesnik, 11. X 1967. Stampa je ne samo u Crnoj Gori, nego i u Srbiji i Hrvatskoj pratila probleme ,u jedinom crnogorskom talijinom hramu“. 8

Kada su sumirani statistički rezultati o radu pozorišta za njegove prve decenije, zaključeno je da je najgledaniji „Gorski vijenac“, što ide u prilog politici njegovanja nacionalnoga repertoara, dok su od 32 izvedena djela stranih autora najviše uspjeha imali: Šekspirovi „Otelo“ i „Mletački trgovac“, Molijerov „Žorž Danden“, Gogoljeva „Ženidba“, Šilerova „Spletka i ljubav“, Goldonijev „Lažljivac“, Rasinova „Fedra“.9 Taj period karakterisao je nedovoljan broj kvalifikovanih i mladih glumaca, što će dugo biti veliki problem. Zabilježen je i podatak da je 1964. najmlađi glumac u Narodnom pozorištu imao više od 30 godina.

Povodom prve decenije zaključeno je i da je dobijena nova pozorišna zgrada, 20-ak stanova za pozorišne umjetnike, ostvarene su dobre predstave, relativno uspjela gostovanja u Republici i vani, na festivalima i na proslavama drugih pozorišnih kuća, dobijena je i nova pozorišna publika iz svih slojeva građanstva. „Učinjeno je mnogo, ali nije učinjeno dovoljno, ne onoliko koliko se moglo učiniti. Komuna je od pozorišta dobila više: niz uspjelih umjetničkih ostvarenja, kolektivnih i ličnih rezultata..."“10

List Pobjeda, koji je uvijek pratio zbivanja u CNP, u pet brojeva u februaru i martu 1965. godine posvetio je znatan prostor problemima i perspektivi razvoja Narodnog pozorišta u Titogradu, organizovavši anketu o problemima pozorišne kuće, za koju je svoja mišljenja poslao veliki broj pozorišnih

\footnotetext{
${ }^{7}$ Crnogorsko narodno pozorište 1953-2003, str. IX.

${ }^{8}$ Isto, str. XIV.

${ }^{9}$ Isto, str. XI.

${ }^{10}$ Sreten Perović, op. cit., str. 394.
} 
kritičara, književnika, novinara, ekonomista, društvenih i javnih radnika. Zabilježeno je da nikad toliko učesnika nije tako spremno učestvovalo u raspravi o jednom kulturnom problemu. Situacija je bila takva da niko nije bio zadovoljan postojećim repertoarom i kvalitetom predstava, pa ni članovi kolektiva pozorišta. Zanimljivo je da je 1963/64. godine, u namjeri da se na scenu postave djela koja će najviše zainteresovati publiku, među građanima sprovedena anketa o ponuđenim djelima za repertoar u sljedećoj godini, ali na nju nije bilo odziva. U anketi iz 1965. ocijenjeno je, između ostaloga, i da su teškoće pozorišta dijelom proisticale iz opštih teškoća u oblasti kulture, ali da nije bilo ni entuzijazma za više i bolje. I kritika je kritikovana kao preslaba ili preoštra. „Lako je pisati dobre kritike ako postoje dobre predstave. Ali ako su predstave slabe, često se pođe linijom manjeg otpora i piše kompromisna kritika upravo da se ne bi demoralisale pozorišne snage. Mnogi od kritike baš to i traže. “11 Interesantno je i što se kroz decenije rada pozorišta može primijetiti kako se uz predstave, koje postaju sve bolje, razvija kritika koja je pratila pozorišne predstave. Ilustrativno bi bilo pogledati i porediti kritiku koja je pratila prve predstave (pa i sa samih pozorišnih početaka) s onom koja je uslijedila kasnije, na predstave poput „Oblomova“, „Gorskog vijenca“ i mnogo drugih.

Bilo je i mišljenja da za neuspjehe pozorišta nijesu krivi samo materijalni razlozi već i nedostatak strasnog umjetničkog nestrpljenja i entuzijazma među pozorišnim stvaraocima. Između ostalog, zahtijevalo se da se preuredi repertoarska politika. „Na repertoaru su se nalazila djela koja su odgovarala afinitetima reditelja koji su radili u Pozorištu. Oni su predlagali određenim umjetničkim tijelima dramske tekstove koji će se uobličavati na sceni. Reditelji su, opet, shodno mogućnostima glumaca angažovanih u Pozorištu dolazili do toga što treba igrati.“"12 Pogledi na repertoarsku politiku pozorišta bili su podijeljeni, što je izazivalo žučne polemike, u koje se nerijetko uključivala i javnost. Široko zauzimanje društvene zajednice za prevazilaženje stanja u Narodnom pozorištu bilo je od velikoga značaja, jer je ukazalo na bitne momente koje treba ispraviti, da bi se poboljšala pozorišna klima i pozorište učinilo atraktivnijim, i rezultiralo je izdvajanjem većih finansijskih sredstava SRCG za dalje aktivnosti Pozorišta.

Sezonu 1969/70. titogradsko pozorište otpočelo je u obnovljenom zdanju, a Narodno pozorište „Zetski dom“ sa Cetinja integrisano je sa Crnogorskim narodnim pozorištem iz Titograda u Crnogorsko narodno pozorište „Zetski dom“, koje je trajalo svega 18 mjeseci. ${ }^{13}$ Uprkos stalnim finansijskim

${ }^{11}$ Pobjeda, Titograd, 11. 3. 1965.

${ }^{12}$ Srđan Vukadinović, Organizacija nacionalnog teatra, Kulturno-prosvjetna zajednica Podgorica, Podgorica, 1995, str. 34.

${ }^{13}$ Isto, str. 44. 
Ruski pisci na sceni Crnogorskog narodnog pozorišta (I)

problemima, Pozorište je prilično uspješno realizovalo svoju repertoarsku politiku i jačalo međurepubličku saradnju sa pozorištima iz Beograda, Ljubljane, Novog Sada, Skoplja i Zagreba. Ta saradnja podrazumijevala je razmjenu što većeg broja predstava radi upoznavanja pojedinih sredina s ostvarenjima pozorišnih kuća iz republičkih i pokrajinskih centara. Osim toga, CNP počinje da učestvuje na pozorišnim festivalima i da izlazi i na inostranu pozorišnu scenu, u SSSR, Rumuniju, Ukrajinu... Dobija priznanja, nagrade te se i sud javnosti o CNP mijenja. Sve je više pozitivnih ocjena. Smatralo se da je Crnogorsko narodno pozorište opravdalo svoje ime, jer „više od polovine predstava igra van Titograda“. ${ }^{14}$ Godine 1979. CNP osniva „Jugoslovenske pozorišne susrete“, koji su okupili najbolja ostvarenja jugoslovenskih teatara, ali se manifestacija iz materijalnih razloga održala tek tri godine.

U narednim godinama rješavani su novi problemi. Zgrada je bila u lošem stanju pa je javnost i putem štampe opominjana ,da i malo duži rad reflektora može da je zapali““. ${ }^{15}$ Kritikovan je nemaran odnos društva prema pozorištu. Blagota Eraković polemiše sa mišljenjem ,po kome je pozorište luksuz, parada, a ne nasušna potreba društva, sredstvo kojim se vaspitava sredina“, a gašenje „Jugoslovenskih pozorišnih susreta“ uzima kao svjedočanstvo da ,društvo nije blagonaklono prema pozorištu“. ${ }^{16}$ Zgrada CNP stradala je u požaru 9. novembra 1989. Konstatovana je velika materijalna šteta (uništena je brojna pozorišna dokumentacija i brojni tekstovi izvođenih drama) i istaknuto da je požar „na najbolniji način“ podśetio da je krajnje vrijeme da se nešto preduzme za pozorišnu djelatnost. Opšte stanje bilo je tragično i svi su bili svjesni da teško može biti stvaralačkog izazova u ruiniranoj zgradi i sa malo novca, pa glumcu ostaje jedino da vegetira.

Naročito se ističe potreba za otvaranjem Fakulteta dramskih umjetnosti i trajnim rješenjem kadrovskog pitanja od strane Univerziteta, jer je situacija bila takva da se umjetnički ansambl godinama nije „osjetnije podmlađivao“. Godine 1984. Pozorište ima dvadeset tri, ,a trebalo bi da ima minimum četrdesetak glumaca“. ${ }^{17}$ Krajem 1991. godine CNP je spalo na 15 glumaca i predstave su se odlagale. Intelektualci su neumorno ukazivali na potrebu stvaranja nacionalne glumačke škole. Još je Miladin Perović u pominjanom izvještaju Centralnom komitetu KPJ 1949. godine izrazio potrebu stvaranja nacionalnog kadra u Crnoj Gori, što je realizovano tek krajem dvadesetoga vijeka. Predavanja na Fakultetu na Cetinju počela su 1995. godine, a studenti su već u aprilu 1996. imali prvi javni čas glume.

${ }^{14}$ Crnogorsko narodno pozorište: $1953-2003$, str. XX.

${ }^{15}$ S. Popović, R. Jovanović, „Kako se može živjeti u snu“, Pobjeda, Titograd, 15. XII 1984.

${ }^{16}$ Crnogorsko narodno pozorište 1953-2003, str. XXVI.

${ }^{17}$ Isto. 
Devedesetih godina vršila se dogradnja i rekonstrukcija pozorišne zgrade. Pozorište nije odustajalo od svoje kulturno-prosvjetiteljske misije. U znak zahvalnosti za razumijevanje i solidarnost koju su građani Podgorice pokazali u vezi sa problemima oko izgradnje nove zgrade CNP, pozorište je 1992. godine predstave igralo besplatno. Građani su davali simbolične doprinose za izgradnju pozorišne zgrade. Odluka da predstave igra besplatno obrazložena je komentarom ,da jedino umjetnički čin, posebno u nesretnim vremenima, može vratiti vjeru da je čovjek sposoban za stvaranje, a ne samo za razaranje..."“18

Pozorišna zgrada završena je do januara 1997. i novi život CNP počeo je 25. maja 1997. godine premijernim izvođenjem „Gorskog vijenca“, što je ujedno bio i jubilej 150 godina od prvog izdanja ovoga djela. Reditelj Branislav Mićunović skrenuo je pažnju na to da se i Njegoš mora čitati na drugačiji način, „,mora biti prigušeno ono što je folklorno i deseteračko, a afirmisano ono što je dramsko i antičko", ${ }^{19}$ što svjedoči da je CNP bilo spremno za otkrivanje novih puteva umjetničkog izražavanja.

Povodom proglašenja Dana Crnogorskoga narodnog pozorišta - 1. novembra 1998. godine, Upravni odbor ustanovio je nekoliko nagrada, koje su se počele dodjeljivati od 1 . novembra 1999 , za najviša i najznačajnija umjetnička ostvarenja u godini. Konačno je decembra 2001. usvojen i stupio na snagu Zakon o pozorišnoj djelatnosti Crne Gore.

Od 1997. i useljenja u novu zgradu CNP do 2003. godine realizovano je 1200 projekata. CNP je učestvovalo na brojnim festivalima, gostovalo po Makedoniji, Srbiji, Sloveniji, Hrvatskoj, Bosni i Hercegovini, Italiji, Austriji, Njemačkoj, Albaniji, Bugarskoj, Kolumbiji, bilo domaćin mnogim istaknutim teatrima i potpisalo protokole o saradnji sa svim nacionalnim pozorištima sa prostora bivše Jugoslavije. Pokrenuta je i izdavačka djelatnost i bioskop „Art cinema“.

Kroz 50 godina postojanja i rada CNP zapaža se ,proces otrzanja od tradicionalističkih oblika svijesti i palanačkog, provincijskog mentaliteta koji ne izlazi iz dometa imitacije drugih centara“. ${ }^{20} \mathrm{CNP}$ je bitno unaprijedilo kulturni život i stvaralački polet u Podgorici, pa i u drugim sredinama u Crnoj Gori, u saradnji s umjetnicima i umjetničkim institucijama iz drugih država i kulturnih sredina, što je uticalo da ostali crnogorski gradovi ponovo upale svoja ,svjetla pozornice“.

CNP je, njegujući tradicionalne duhovne vrijednosti, istražujući i težeći modernizaciji i novom umjetničkom izrazu, u svom repertoaru imalo djela

\footnotetext{
${ }^{18}$ Crnogorsko narodno pozorište 1953-2003, str. XXXI.

${ }^{19}$ Isto, str. XXXV.

${ }^{20}$ Isto, str. XXXIX.
} 
Ruski pisci na sceni Crnogorskog narodnog pozorišta (I)

domaćih i stranih autora iz raznih perioda. Milovan Radojević zapaža opadanje broja izvođenih premijera iz decenije u deceniju i zaključuje da je razlog u tome što se ranije težilo da se publici ponudi što više programa i najšire prezentira svjetska i domaća dramska produkcija, dok se danas više pažnje poklanja umjetničkom nivou, pa predstave duže traju na repertoaru.

„U ne mnogo razvijenom kulturnom životu Crne Gore pozorište je, u stvari, najsigurnija i najplodnija baza za potporu i razvoj ostalih formi kulturnog života i institucija." ${ }^{21}$ CNP se afirmisalo kao ,kulturni animator i ambasador, kao središte umjetničkih zbivanja i promotor aktuelnih kretanja u svjetskom teatru“'22 i kreće se progresivnim putem. Opstanak kroz buran period rada i egzistencije označio je njegovu afirmaciju i Crnogorsko narodno pozorište danas , jedan je od vodećih stubova kulture i emancipator ove vrste umjetnosti, na širem prostoru Balkana“. ${ }^{23}$

\section{Ruski pisci u CNP u periodu 1953-1963}

U prvoj deceniji rada CNP je spremilo i izvodilo 6 djela ruskih autora: „Šuma“ i „Bez krivice krivi“ Ostrovskog, ,Ženidba“ Gogolja, „Neprijatelji“ Gorkog, „Dom zaljubljenih“ Mjasnickog i „Dan odmora“ Katajeva.

\section{„ک̌́uma““}

Prva drama ruskog autora izvedena u Gradskom narodnom pozorištu u Titogradu bila je „Šuma“ Aleksandra Nikolajeviča Ostrovskog, komedija u pet činova. Reditelj predstave bio je Vasilije Śćukin, a predstava, čija je premijera održana 16. XII 1953. godine, rađena je po prijevodu Kirila Taranovskog. Scenograf je bio Ananije Verbicki, a uloge su, prema plakatu, bile podijeljene na sljedeći način: Gurmišska, Raisa Pavlovna, bogata pośednica Julka Cvejanov; Aksjuša, njena rođaka - Marica Stilinović, Marija Jovanović; Milonov, Jevgenije Apolonovič, bogati pośednik - Miloš Mošorinac; Bodajev, Uar Kirilovič, oficir u penziji, bogati pośednik - Dušan Baltić; Vosmibratov, Ivan Petrov, drvarski trgovac - Milan Cvejanov; Petar, njegov sin - Oliver Novaković; Bulanov, Aleksije Sergijevič, nedovršeni gimnazijalac Milan Budimirović; Genadije Nesrećković, putujući glumac - Mirko Ristić; Arkadije Srećković, putujući glumac - Vlado Sušić; Karp, lakej kod Gurmišske - Selimir Simić; Ulita, ključarka - Kosara Marković, Ljubica Vukčević.

Predstava „Šuma“ ujedno je prvo izvođeno djelo inostranog autora u Narodnom pozorištu u Titogradu. Međutim, kritika se nije oglašavala, a u

${ }^{21}$ Alojz Ujez, op. cit., str. 29.

${ }^{22}$ Crnogorsko narodno pozorište: $1953-2003$, str. XXXVI.

${ }^{23} \mathrm{http}$ ///www.zid.cg.yu/adp-zid/casopis/zid41-42/kultura41-42_1.htm - 29. oktobra 2007. 
štampi je propraćena samo najavom, tako da nemamo podataka kako je drama realizovana i koliko je uspješno prenesena njena dramska autentičnost. Ostao je zabilježen podatak da je prikazivana 7 puta, što ne svjedoči o njenoj naročitoj popularnosti u tome periodu. Drame Ostrovskog nijesu bile nepoznate crnogorskoj pozorišnoj publici, jer su i ranije bile izvođene: „Šuma“ je izvođena još 1926. godine. ${ }^{24}$ U periodu do 1953. „Šuma“ je već bila prešla ,preko mnogo pozornica u našoj zemlji. Bila je predmet ozbiljne studije nekolicine reditelja i mnogih komentara njihovih postavki.“25

Ostrovski je kod nas smatran značajnim dramskim piscem i jednim od „omiljenih““26 pozorišnih pisaca. Upravo stoga je na sceni Narodnoga pozorišta u Titogradu izvođen prije drugih inostranih pisaca, i to sa dvije drame, „Šumom” i „Bez krivice krivi”, u periodu kada se naročito insistira na raznovrsnosti autora.

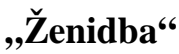

Sljedeće pozorišne sezone, 20. IV 1954. godine, u Gradskom narodnom pozorištu održana je premijera „Ženidbe“, Nikolaja Vasiljeviča Gogolja, u režiji Vasilija Šćukina. Uloge u predstavi bile su sljedeće: Agafja Tihonovna, nevjesta - Ljubica Vukčević; Arina Pantjeljejmonovna, njena tetka - Julka Cvejanov; Fjokla Ivanovna, provodažika - Kosara Marković; Ivan Kuzmič Potkoljesin, dvorski savjetnik - Vlado Sušić; Ilija Fomič Kočkarjov, njegov prijatelj - Milan Budimirović; Ivan Pavlovič Kajgana, egzekutor - Milorad Spasojević; Nikanor Ivanovič Obojak, oficir u penziji - Selimir Simić; Baltazar Baltazarovič Žvakalo, pomorski oficir u penziji - Blažo Milonjić; Aleksej Dimitrijevič Starikov, trgovac - Dušan Baltić; Dunjaška, služavka Marica Stilinović; Stjepan, sluga Potkoljesina - Miloš Mošorinac.

„Ženidba“ je izvođena i u drugim pozorištima, pa čak i u režiji istoga Vasilija Śćukina i bila je vrlo popularna. Naime, Narodno pozorište iz Kotora pozorišne 1949/50. sezone izvodilo je predstave „Sirotinja nije grijeh“ Ostrovskog i Gogoljevu „Ženidbu“. Zabilježeno je da je ta „Ženidba“ bila vrlo pośećena i da je Šćukin sa njom imao više uspjeha nego sa dramom

${ }^{24}$ Ljiljana Milunović, Pozorište u crnogorskoj periodici (1916-1944), CNP, Podgorica, 2003, str. 43-44.

${ }^{25}$ Ratko Đurović, ,'Šuma‘ Ostrovskog“, Teatrološki spisi, Crnogorsko narodno pozorište, Podgorica, 2006, str. 275.

${ }^{26}$ Radoslav Rotković, „Kotorsko pozorište“, Savremena drama i pozoršte u Crnoj Gori, Novi Sad: Sterijino pozorje, 1987, str. 38. 
Ruski pisci na sceni Crnogorskog narodnog pozorišta (I)

Ostrovskog. ${ }^{27}$ Izvođenja „Ženidbe“ na crnogorskoj sceni datiraju još od ranije, od 1910. godine. ${ }^{28}$

A zašto baš ova komedija, nije pojašnjavano. Da li zato što ju je Vasilije Šćukin već ranije režirao? To bi mogao biti razlog, jer je bilo lakše ponoviti predstavu nego raditi oko nove, naročito kada je pozorište radilo u teškim materijalnim uslovima i bez strogo definisane repertoarske politike. Sreten Perović skreće pažnju na uslovljenost izborom repertoara i ekonomske razloge i prilike u kojima radi pozorište. On negoduje što se u repertoarskom planu Narodnog pozorišta u Titogradu nalaze drame poput Roksandićeve „Andree“, Mijuškovićevih „Đetića“, pa dijelom i Gogoljeve „Ženidbe“ i Manijeova „Oskara“, jer smatra da se ovim djelima mogla naći vrednija, adekvatnija zamjena čak i u našoj tadašnjoj, tekućoj dramskoj produkciji i zaključuje da oštrica naše kritike postaje manje opravdana „,kada se sazna da taj ansambl ,ni gradski ni republički', uz krajnja snalaženja uspijeva da obezbijedi samo osnovna lična primanja svojih članova (ne da obezbijedi zakonska povećanja tih primanja), kada sprema svoje predstave u neugrijanim salama, kada nema sredstava da angažuje dobre glumce, nužna rediteljska gostovanja, kada nije u mogućnosti da solidno opremi značajnije, veće predstave““. ${ }^{29}$ Možemo zaključiti da su u prilog Gogolju išli i žanr komedije, jednostavnost teme i dopadljivost sadržine, koji su sigurno morali biti uzeti u obzir u toj pozorišnoj fazi, zbog računice da se privuče što više publike.

Milorad Stojović je povodom te predstave objavio članak u Susretima, ocijenivši je uspješnom. Njegova je ocjena kritički prikaz i glume i režije, ali ipak nije oslobođena ni one doze blagonaklonosti i familijarnosti karakteristične za taj period, kada se smatralo da bi negativna ili stroža kritika, s obzirom na uslove u kojima je pozorišne egzistiralo, ozbiljno ugrozila, demoralisala pozorišne poslenike. Tako dio toga teksta o izvođenju ,Ženidbe“ čini i napomena da je predstava stvarana u teškim uslovima. „Da zalaganje ovog glumačkog kolektiva, koji se bori sa tehničkim, materijalnim i drugim teškoćama, nije u ovoj sezoni ostalo bez rezultata dokaz je i 'Ženidba', predstava

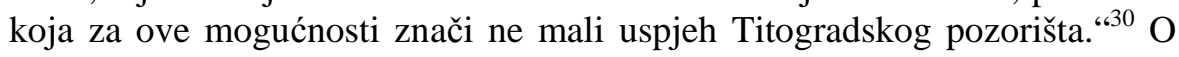
uspjehu komedije može da posvjedoči podatak da je izvođena 14 puta, što je solidno ako se uporedi sa brojem izvođenja ostalih predstava u to vrijeme.

${ }^{27}$ O tome vidi: Darko Antonović, „Narodno pozorište Kotor (1948-1958)“, Pozorište u Crnoj Gori u drugoj polovini XX vijeka : radovi sa naučnog skupa, Podgorica, 23. jun 2006. godine, Crnogorska akademija nauka i umjetnosti, Podgorica, 2007, str. 73-76.

${ }^{28}$ Ljiljana Milunović, Pozorište u crnogorskoj periodici (1909-1915), CNP, Podgorica, 2004, str. 39.

${ }^{29}$ Sreten Perović, op.cit., str. 390.

${ }^{30}$ M. Stojović, „Gogoljeva 'Ženidba“ na sceni Titogradskog pozorišta“, Susreti, Titograd, 1954, VIII-IX, str. 673-674. 
O samome djelu Stojović je pisao da je to komedija u kojoj je Gogolj dao sliku plemstva početkom XIX vijeka i da je u njoj, kao i u „Revizoru“, smijeh ,jedina poštena i blagorodna ličnost“. Zaključuje da je, zahvaljujući homogenoj igri ansambla, pozorište u Titogradu uspjelo da sačuva autentičnost čitave galerije šarolikih tipova u komadu koji svoje porodične odnose zasnivaju na grubom računu. Stojović ocjenjuje da je Šćukin svojom režijom uspio da prikaže Gogoljevo djelo, mada zamjera što nije izrazitije postavio trgovca Starikova, čiji je lik ostao ,površno shvaćen i epizodno dat, iako mu u komadu pripada daleko važnije mjesto“. ${ }^{31} \mathrm{O}$ ostalim ulogama kaže da su gotovo sve pogođene, proučene i približno ostvarene. Glumac Vlado Sušić je u Potkoljesinu, odigravši svoju ulogu živo i efektno, naročito u ,zabavnom“ dijalogu sa nevjestom, dao karakter čovjeka čiji život teče skučeno i ograničeno, bez ikakve dinamike i smisla. M. Budimirović je bio ubjedljiv u prikazivanju Kočkarjeva. B. Milonjić je u liku Žvakala postigao zavidan umjetnički nivo, „davši bez pretjerivanja grotesknu pojavu penzionisanog 'mladoženje“ koji kao davljenik spasioca čeka koju utješnu riječ od bogate udavače“ “. ${ }^{32}$ M. Spasojević je bio vješt u isticanju ,ćiftinskog duha egzekutora Kajgane“, kao i S. Simić u interpretaciji lika kočopernog oficira u penziji. M. Stilinović nije izbjegla scenski kliše u ulozi priproste ruske služavke. L. Vukčević je bila veoma sugestivna u ulozi glupe nevjeste i dala je ,skladan i ubjedljiv psihološki izraz ograničene žene, koja ni sama ne zna šta hoće, naprimjer u sceni kada, po ko zna koji put, vrši smotru svojih prosilaca koji su bili kao marionete poređani ispred nje“. ${ }^{33}$

\section{„Bez krivice krivi““}

Drama „Bez krivice krivi“ A. N. Ostrovskog premijerno je izvedena 1. X 1954. godine. Predstava je urađena prema prijevodu Kirila Taranovskog, a u režiji Ilije Nikolića. Scenograf je bio A. Verbicki. Plakat je sadržao sljedeću raspodjelu uloga: Ljubav Ivanovna Otradina, đevojka iz dobre kuće - Ana Nikolić-Kačanik; Taisa Ilinišna Šelavina, njena drugarica - Ljubica Vukčević; Grigorije Lavović Murov, gubernijski činovnik - Milan Budimirović; Anuška, služavka kod Otradine - Ružica Ikonov; Arina Galčiha, njegovateljica đece - Julka Cvejanov; Jelena Ivanovna Kručinina, poznata glumica Ana Nikolić-Kačanik; Nil Stratovič Dudukin, pozorišni mecena - Milan Cvejanov; Nina Pavlovna Korinkina, Šmaga, Grigorije Neznamov, Peća Milovzorov (glumci) - Marica Stilinović, Lazar Brusin, Sabrija Biser, Enes Por-

${ }^{31}$ M. Stojović, „Gogoljeva 'Ženidba“ na sceni Titogradskog pozorišta“, str. 673674.

${ }^{32}$ Isto, str. 673.

${ }^{33}$ Isto, str. 674. 
Ruski pisci na sceni Crnogorskog narodnog pozorišta (I)

čić; Ivan, sluga u hotelu - Blažo Milonjić. Na plakatu je stajala i odrednica mjesta: jedan gubernijski grad, i vremena: druga polovina XIX vijeka.

Kritičkog odziva na predstavu nije bilo mnogo, premda je izbor ove drame Ostrovskog ocijenjen kao dobar, i to, kako se može zaključiti iz postojećih članaka, prvenstveno zbog teme. Milorad Stojović ističe da je izbor ove drame ,nesumljivo dobar“, budući da Ostrovski interpretira jednu ,opšteljudsku temu“", pitanje sudbine vanbračne đece, kojemu se prilazi i koje se rješava s izvjesnim predrasudama, a drama je sadržajno obogaćena i time što je Ostrovski za osnovnu ideju vezao još neke važne momente iz ruskoga života u drugoj polovini XIX vijeka: odnose prema umjetnicima, glumcima, porodične odnose, sklapanje brakova iz računa...

Pohvaljena je Nikolićeva režija i originalna rješenja nekih momenata, tačno izražena piščeva misao. „Iako neke scene i njihova obrada prividno ostavljaju utisak preslobodne režije, on je ipak uspio da dovede u sklad sa piscem, da opravda postupke glumaca i da liši scenu neopravdane suvišne aktivnosti. “34 Kao karakteristično u ocjeni drame izdvaja se to da je ona teška za izvođenje jer se njena dramatičnost ,ne sastoji u spoljnom scenskom efektu nego u potresnim unutrašnjim sukobima osjećanja glavnih junaka, koji strpljivo snose nepravde i tegobu života“" ${ }^{35}$

Što se ostvarenih uloga tiče, Stojović ocjenjuje da su one, premda na nekim mjestima nedovršene i neuigrane, uglavnom pogođene i shvaćene. Smatra da su gotovo sve uloge u drami složene i zahtijevaju od glumaca velike izražajne mogućnosti, kakve reditelj u siromašnom ansamblu ovog pozorišta nije mogao naći. Ipak izdvaja se uloga glavne junakinje, koju je realizovala Ana Nikolić: ona je u prirodnoj i iskrenoj igri od svoje uloge uspjela da stvori dovršenu, realistički uvjerljivu ,psihološku studiju“ sudbine dobre đevojke, majke i glumice, koja 20 godina u malograđanskom okruženju potajno pati za izgubljenim sinom. S druge strane, glumac Sabrija Biser nije naročito dobro odigrao lik Neznamova. Stojović smatra da bi komad bio veliko pozorišno ostvarenje da je Biser imao dovoljno zamaha, snage i rutine za složenu, tragičnu „hamletovsku ulogu Neznamova“. Sabrija Biser „,neposredan je u ispovijesti sa Kručininom, a suviše teatralan u sceni u garderobi. Za završnu scenu, gdje je trebalo dati najviše života i preživljavanja, nije imao dovoljno izražajnih moći. ${ }^{* 36}$ Drama je izvedena 8 puta i nije se duže održala na pozorišnoj sceni CNP.

\footnotetext{
${ }^{34}$ M. Stojović, „Bez krivice krivi“, Pobjeda, Titograd, 7. XI 1954.

${ }^{35}$ Isto.

${ }^{36}$ Isto.
} 


\section{„Neprijatelji“‘}

Tri godine po izvođenju „Bez krivice krivi“, u toku kojih su počela češće da se izvode djela Šekspira, Molijera i drugih stranih autora, na pozornicu je, naročitim povodom, postavljeno djelo Maksima Gorkog, koji je u pozorišnom životu poslijeratne Crne Gore bio popularan, posebno sa djelima „Mati“ i „Vasja Željeznova“. Ovog puta u Titogradu su, 29. XI 1957, premijerno izvedeni „Neprijatelji“, drama u tri čina, u režiji Milana Popovića. Scenografiju predstave potpisuje Gojko Berkuljan. Uloge su podijeljene na sljedeći način: Bardin Zahar - Ante Kraljević; Polina, njegova žena - Nataša Nešović; Bardin Jakov - Milan Popović; Tatjana, njegova žena, gumica Ljubica Popović-Janićijević; Nađa, Polinina sestričina - Ljubica Šarkić, Marijana Bujišić; Pečenjegov, general u ostavci - Živojin Tomić; Skrobotov Mihailo, ortak Bardinih - Petar Begović; Kleopatra, njegova žena - Darinka Petrović; Skrobotov Nikolaj, njegov brat - Marko Martinović; Sincov, pisar Miloš Petrović; Pologij, pisar - Alojz Ujez; Konj, isluženi vojnik - Branko Obradović; Grekov, Lješvin, Jagodin, Rjapcov, Akimov (radnici) - Vlado Stojanović, Desimir Perišić, Nedeljko Pajević, Dobrica Stefanović, Danilo Radulović; Agrafena, domaćica - Natalija Rončević; Bobojedov, žandarmerijski kapetan - Petar Perišić; Kvač, žandarmerijski narednik - Stevo Matović; Poručnik - Đokica Popović; sreski načelnik - Boško Filipović; Policijski pisar - Čedo Vukanović; Žandarmi, Vojnici, Radnici, Namještenici.

Predstava je priređena povodom 40-godišnjice Oktobarske revolucije, u čijem su obilježavanju uzela učešća gotovo sva pozorišta u zemlji djelima iz klasične ili moderne ruske sovjetske literature. U štampi je propraćeno interesovanje koje je vladalo za izvođenje ove predstave u Titogradu i tokom njenih priprema. Više od mjesec dana prije premijere beogradska Borba najavljuje da pozorište u Titogradu sprema „Narodnog poslanika“ i „Neprijatelje“. Ipak, to interesovanje bilo je više informativnoga karaktera. U jedinom kritičkom osvrtu na pozorišnu predstavu „Neprijatelji“ Sreten Perović piše da se Narodno pozorište u Titogradu opredijelilo za ,ne baš najznačajnije i najbolje djelo Maksima Gorkog s temom iz praskozorja Revolucije“. ${ }^{37}$ Perović zaključuje da snagu i životnost opusa Gorkog ne čini prevashodno progresivna piščeva orijentacija koliko umjetničko hrabro konfrontiranje ,sjenki i svjetlosti jedne natrule atmosfere spahijskog gospodstva $\mathrm{i}$ istodobnog sve jačeg buđenja i jačanja klase potlačenih“. ${ }^{38}$ Kao zamjerka samome djelu navodi se što politička tendencija na više mjesta potpuno nadrasta literarne okvire drame, što u novijim vremenima utiče na ośetno smanjenje afiniteta gledaoca

\footnotetext{
${ }^{37}$ Sreten Perović, ,Slikar predrevolucionarne epohe - 'Neprijatelji ‘ Gorkog u režiji Milana Popovića“, Darovi scene I, str. 234-235.

${ }^{38}$ Isto, str. 234. 
Ruski pisci na sceni Crnogorskog narodnog pozorišta (I)

prema takvom tretmanu materije. Momenti „apolitičnosti““, zatim „diskretno serviranje bogatog piščevog (i ne samo njegovog) iskustva kroz, po pravilu, starije ličnosti drame, trenuci galgen-humora, intimne opšteljudske boljke, ne suviše zavisne od društveno-političkih uslova, svjesnost vlastite efemernosti (kod izvjesnih ličnosti), elementi su koji natkriljuju literarne efemernosti djela“. ${ }^{39}$ Režija Milana Popovića kritikovana je jer je išao više za osnovnom, „ondašnjom“" piščevom idejom-vodiljom, koja nije najdublja, posebno naglašavajući atmosferu vremena u kojoj se radnja događa i specifični karakter likova koji izrastaju iz takve atmosfere, na uštrb prikazivanja djela s onog univerzalnog, opšteljudskog aspekta. Perović zauzima stav da reditelj ,nije išao ka sintezi, kao opšteljudskim elementima drame, čija okosnica može zgodno da posluži kao ilustracija ljudskih stremljenja u jednom istorijski značajnom trenutku; njegova osnovna ideja bila je da dâ adekvatnu sliku predzorja revolucije, te je, insistirajući u tom smislu suviše analitičkim metodom, pojednostavio glavnu umjetnikovu misao o zakonima života uopšte“ ${ }^{40}$ U scenografiji je Gojko Berkuljan išao za idejom reditelja, što je predstavu lišilo poetske simbolike i piščeve vizionarske snage.

Perović je dao podroban prikaz glumačkih ostvarenja u predstavi, pri čemu je izdvojio uloge koje su ostvarili Milan Popović i Nataša Nešović. „Narcisoidno-boemski lik Jakova Bardina, čovjeka koji je, budući izgubljen i za sebe i za druge, jednako udaljen od siromašnih i od bogatih, ali sa primjetnim simpatijama za one koji se bune" u interpretaciji Milana Popovića, Perović je ocijenio kao najzanimljiviju ulogu, dok Nataša Nešović u ulozi Poline „djelovala je od prve do posljednje izgovorene fraze ljudski toplo i psihološki proosjećano“, što njenu ulogu čini najboljom. ${ }^{41}$ To se naročito ističe u poređenju sa drugim ulogama u predstavi, jer ih je isti reflektor jednako osvjetljavao. Stoga je ocijenjeno da je Ljubica Janićijević, tumačeći glumicu Tatjanu, ,ambiciozno-šarmantnu preciozu“, ,,pomodnu provincijsku kurtizanu“, ljupko klizila po površini, dok je „,neobuzdano eksplikativna“ Ljubica Šarkić, u ulozi Nađe, poneđe suviše potencirala idejno-socijalnu razliku između sebe i svojih patrona. U izvođenju Petra Begovića, i pored njegovih napora u ostvarenju uloge ,poslodavca bez kompromisa“ i ,gospodara čvrste ruke“, ostala je „,disonanca između želja i ostvarenja“, kao i kod Darinke Petrović u ulozi Kleopatre. Ante Kraljević je s finim razumijevanjem tumačio lik Bardina Zahara, gospodara-intelektualca, bez spahijske britkosti, kapitalistu koji ima apstraktnog razumijevanja za čovjeka. Isluženoga Konja tumačio

\footnotetext{
${ }^{39}$ Sreten Perović, „Slikar predrevolucionarne epohe - 'Neprijatelji‘ Gorkog u režiji Milana Popovića“", str. 234.

${ }^{40}$ Isto.

${ }^{41}$ Isto, str. 235.
} 
je Branko Obradović sa više uspjeha nego Živojin Tomić Pečenjegova, poblesavljelog generala u penziji.

Svejedno, opšta ocjena je da, i pored toga što je u predstavi bio angažovan gotovo čitav ansambl, pravih i nezaboravnih kreacija nije bilo. Predstava je izvođena svega 5 puta i više nije ponavljana ni u drugim postavkama, što opet ne govori o njenom uspjehu na sceni Crnogorskog narodnog pozorišta.

\section{„Dom zaljubljenih“،}

U repertoar Narodnog pozorišta 1959. godine ušao je ruski pisac Ježi Mjasnicki, čije je pravo ime zapravo Ivan Iljič Barišev (1854-1911). Krajem 70-ih godina XIX vijeka Mjasnicki je objavljivao humorističku poeziju i priče u raznim časopisima, ali je poznatiji kao autor komedija-farsi. Najpopularnije mu je bilo djelo „Dom zaljubljenih“ („Čikina kuća“), koje je i ekranizovano. Ta komedija u tri čina izvedena je premijerno 8. XI 1959. u Pljevljima. Predstavu je režirao Ilija Nikolić, prema prijevodu Milovana Glišića. Uloge su igrali: Ivan Savić - Mirko Simić; Agnija - Mira Simić; Nataša - Milka Filipović; Mića - Slobodan Matić; Fića - Branko Obradović; Književnik - Stevo Matović; Trubač - Mladen Branđolica, Pjevačica - Nada Blažević; Ipsilon - Boro Begović; Stepan - Petar Spaić, Nasta - Milica Petrović; Marica Dragica Davidović; Sudski izvršitelj - Predrag Stojković, Posrednik - Petar Perišić; Petar - Čedo Vukanović. Komedija „Dom zaljubljenih“ izvođena je u Crnoj Gori i ranije, još od 1910. godine. ${ }^{42}$

Ova komedija samo je informativno propraćena u štampi. Jedini kritički prikaz dao je i ovoga puta Sreten Perović, koji ni predstavu ni djelo nije afirmativno ocijenio. U samom djelu Perović kritikuje trivijalnost zapleta i obrade, koja nije nadoknađena literarnom vrijednošću dijaloga niti bilo kakvom ljudskom porukom, idejom, koja bi imala etičko-estetsku vrijednost. „Sumnje i sumnjičenja zbog navodne supružanske nevjere, zbog kombinatorike kojom se služi relativno mlada majka da bi pronašla muža svojoj kćeri koja ništa drugo od života i ne traži, 'tragika' prevarenog (u bolesnoj slutnji) muža kome ne ide u glavu da i on može biti 'rogonja', nespretna i poprilično naivna ,trgovina' tuđom svojinom od strane njihovog nećaka, i arhipoznati sveopšti bračni hepiend - eto sadržine Doma zaljubljenih. “"43 Prema Perovićevu mišljenju, takva literarna podloga djela nije mnogo pružala ni reditelju Iliji Nikoliću, koji je radio u ovom pozorištu od njegovog osnivanja i koji se afirmisao napravivši u njemu veliki broj veoma uspjelih predstava iz oblasti

${ }^{42}$ Ljiljana Milunović, Pozorište u crnogorskoj periodici (1909-1915), CNP, Podgorica, 2004, str. 39.

${ }^{43}$ Sreten Perović, ,'Dom zaljubljenih“ Ježi Mjasnickog“, Darovi scene I, str. 244246. 
Ruski pisci na sceni Crnogorskog narodnog pozorišta (I)

savremene svjetske drame. Reditelj Nikolić je u nastojanju da delokalizuje djelo, da mu dâ nove misaone dimenzije i svježije vrijednosti koautorski dogradio tekst Mjasnickog i izmijenio imena ličnosti komedije, čime je stvorena komedija koja se može odnositi na bilo koju sredinu i društvo. Perović za tekst komedije kaže da je suhoparan i postavlja pitanje da li je to bio tekst samo Mjasnickog i odakle uopšte potiče, ,jer taj tekst dolazi iz ko zna koje ruke“. ${ }^{44}$ Nažalost, tekst po kojem je rađena predstava nije sačuvan, tako da je sad teško bilo šta određivati po tom pitanju.

Perović pohvaljuje glumački ansambl, koji je vrlo spretno obavio svoj zadatak i ostavio lijep utisak, iako sámo djelo glumcima nije davalo mnogo mogućnosti. Slobodan Matić je u ulozi Miće gradio lik nestašnog i nedovoljno spretnog mladića koji, zbog „vazdušastih snova“, zapada u nezgode. Ostali glumci nosili su konkretne likove „neusiljeno i svježe“, osim Milice Petrović u ulozi Naste, koja svoje izrazite humorističke kvalitete nije uspjela da otrgne od nušićevskog stila. „Ako se od nje nije tražilo da izvaja lik džandrljive Ruskinje (shodno rediteljskim intencijama da delokalizuje Mjasnickog), nije se tražilo ni da miriše na srpsku čaršiju“" 45 mada se navodi da je ipak ostvarila niz uspjelih scena. Scenografija i kostimografija Vojislava Žižića ocijenjeni su kao korektni.

Sreten Perović smatra da Mjasnicki nije naročito poznat i vrijedan ruski komediograf i da je izbor i stavljanje „Doma zaljubljenih“ u program Male scene značilo povlađivanje ukusu onog dijela publike koji, umjesto umjetničkog doživljaja, od pozorišta traži zabavu, dva sata lakog i ,rijetko neukusnog humora“. Ipak, zaključak u vezi sa predstavom bio je da je reditelj uspio da predstavu, ,uz dobru dozu trpeljivosti prema djelu“, i rafiniraniji gledalac može gledati i čak da mu se „dogodi“ da se nasmije. Predstava je doživjela 29 izvođenja, dakle, više u odnosu na prethodna djela, što govori o dobroj prihvaćenosti komedije od strane publike.

\section{„Dan odmora“"}

Komedija „Dan odmora“ Valentina Petroviča Katajeva izvedena je premijerno 1. X 1960. godine, u režiji Nikole Vavića i Petra Vujovića. Podjela uloga bila je sljedeća: Zajcev, agent za snabdijevanje - Petar Vujović; Klava Ignjatjuk, studentkinja - Dragica Davidović-Tomas; Kostja Galuškin, njen muž - Petar Tomas; Domaćica odmarališta - Milica Petrović; Mijusov, načelnik centralne baze - Predrag Stojković; Dudkin, profesor - Stevo Matović; Dudkina, njegova žena - Nataša Nešović; Roza Jeremjejevna, žena Zajceva - Mira Simić, Ljekar - Milorad Majić; Vratar - Petar Begović; Šura -

\footnotetext{
${ }^{44}$ Sreten Perović, ,’'Dom zaljubljenih“ Ježi Mjasnickog“, str. 245.

${ }^{45}$ Isto, str. 246.
} 
Ljubica Šarkić; Kuvar - Čedo Vukanović; Bolničar - Vasko Miletić; Šofer Todor Dulović. Na plakatu je pisalo i da se komedija događa u omanjem odmaralištu Siroješki, bez odrednice vremena.

Valentin Katajev već od ranije bio je poznat pozorišnoj publici u Crnoj Gori. Njegova „Kvadratura kruga“ uspješno je izvođena 1931. godine u Narodnom pozorištu Zetske banovine na Cetinju, te naredne godine na gostovanju toga pozorišta u Nikšiću. Pozorišne 1949/50. sezone Narodno pozorište iz Kotora izvodilo je „Roditeljski dom“ Katajeva u režiji Vasilija Šćukina.

Komedija „Dan odmora“ napisana je 1940. godine. U maju te, 1946. godine premijerno je izvedena u Moskovskom pozorištu satire i pozitivno je ocijenjena, a Katajev hvaljen što je krenuo novim putem komedije-šale. Prema njoj je 1956. godine snimljen film, za koji je scenario pisao sam Katajev. Nakon toga, sredinom šezdesetih godina ova se komedija našla na repertoaru i scenama svjetskih pozorišta: u Engleskoj, Belgiji, Švajcarskoj, Francuskoj. ${ }^{46} \mathrm{U}$ slučaju ovoga pisca CNP se može pohvaliti za upućenost u svjetske pozorišne tokove i što je među pozorištima koja prednjače u izvođenju njegovih djela. Ipak, Katajeva i njegovu komediju „Dan odmora“, ionako malobrojna, kritika u Crnoj Gori 1960. godine nije pohvalila. Kritičar Stojović, kao jedini koji se oglasio povodom te predstave, u Pobjedi piše da komedija Katajeva nije djelo od većega umjetničkog značaja, niti ima dublji i misaoniji literarni podtekst. „Pravljena na spoljašnjim sukobima, krcata jevtinim i lakim zapletima, više vješto konstruisanim nego dramskim, ona nema kvalitete pravog humora, životno i psihološki motivisanog i iznijansiranog. “47 Stojović smatra da je Katajev samo periferno zahvatio probleme, koji ni izdaleka nijesu bezazleni kakvim ih on predstavlja. „Umjesto duhovite i oštre satire kakvu stvarno zaslužuje Zajcevljeva odiseja, on je pošao linijom dobroćudnog karikiranja i smijeha, dovodeći svoje junake u nemoguće groteskne situacije, a ne vodeći pritom računa o uvjerljivosti i autentičnosti tih situacija." ${ }^{48}$ Ocijenjeno je da je radnja komedije površna i pravolinijska, te sama po sebi ne omogućava da se u scenskom izvođenju ode daleko, što opravdava sve falinke ili promašaje u režiji i izvođenju komada. Kao glavnu zamjerku predstavi, za koju ipak kaže da je dobro iscenirana i da „ostavlja utisak“, Stojović navodi to što je nedovoljno „ruski“ obojena, „,bez specifičnosti jednog ambijenta i humora“. Zamjera i što je ipak pređena dozvoljena mjera karikiranja u interpretaciji piščevih intencija, što se naročito tiče Dudkina i Dudkine, pa je predstava dobrim dijelom „odvučena u lakrdijašenje“.

${ }^{46}$ O tome vidi: http://www.allbooks.su/chr_235/txt_author_id_1941/

txt_book_id_5285/md_1/index_txt.html

${ }^{47}$ M. Stojović, „Dan odmora“, Pobjeda, Titograd, 9. 10. 1960.

${ }^{48}$ Isto. 
Ruski pisci na sceni Crnogorskog narodnog pozorišta (I)

Jedini lik koji nosi neku psihološku individualnost i određenost jeste Zajcev, a hvaljena je i igra Petra Vujovića, koji je tu ulogu tumačio. On je dobro shvatio i istakao karakter dobronamjernog i slijepo poslušnog činovnika koji se, kako zapaža Stojović, ,kao pijan plota, drži datuma i naređenja ('Danas je ponedeljak - osmi, sjutra je utorak - deveti... ja moram...' itd)“"49 s tim da je i u njegovoj glumi na momente bilo prećerivanja i karikiranja Zajceva više nego što je potrebno. Negativnu kritiku pretrpjeli su i uloga Dragice Davidović-Tomas i njen lik studentkinje, opštepriznate umjetnice Klave Ignjatuk. Taj lik okarakterisan je kao najneubjedljiviji, literarno nedorađen i nepotpun, pa i na sceni djeluje neuvjerljivo.

U zaključku o djelu „Dan odmora“ izražena je sumnja da li je takvo djelo vrijedno izvođenja, što je još jednom nametnulo pitanje repertoara i repertoarske politike CNP. Komedija je izvedena 13 puta i više nije ponavljana, ni ona ni neko drugo djelo Katajeva.

$$
* * *
$$

Primjećuje se da su od 6 predstava rađenih u ovom periodu prema djelima ruskih autora četiri komedije, a dvije drame, od kojih je jedna - „Neprijatelji“ - izvođena posebnim povodom i zadržala se kraće od svih na titogradskoj sceni, ne duže od povoda kojim je postavljena. U prvoj deceniji rada Narodnoga pozorišta u Titogradu bile su brojnije komedije i komadi sa pjevanjem, šale u odnosu na dramu u užem smislu i tragediju. Moguće je da je bilo tako organizovano da bi pozorište privuklo i zadobilo što više publike, koja mu je bila od presudnog značaja, naročito na početku rada. Tezi da se repertoarskom politikom u to vrijeme više teži pridobijanju širih masa publike u prilog ide činjenica da je od djela ruskih pisaca, sudeći po broju repriza predstave, najbolje prošla „Dom zaljubljenih“ - komedija, iako ju je stručna kritika, koja je uticala na usmjeravanje repertoarske politike ka realizaciji viših estetskih nivoa, kritikovala i ocijenila kao djelo manjeg umjetničkog značaja, kao puko povlađivanje ukusu publike koja od pozorišta traži samo laku zabavu. Ruski pisci su u žanru komedije bili najzastupljeniji, a i ukupno zauzimaju značajno mjesto. Najviše su izvođena djela domaćih pisaca. U prvoj deceniji rada Narodnog pozorišta, kada je repertoar bio najraznovrsniji, budući da se insistiralo na kvantitetu, izvedene su ukupno 73 predstave, od čega je bilo više od 40 djela domaćih autora (iz republika bivše SFRJ), a zatim su najčešće izvođena djela američkih i francuskih pisaca sa po 8 predstava, ruskih 6, engleskih 5, italijanskih 2.

Za prve dvije godine rada ovog pozorišta iz stranog dramskog stvaralaštva ruski pisci imali su primat. Oni su bili zastupljeni na crnogorskoj pozori-

\footnotetext{
${ }^{49}$ M. Stojović, ,Dan odmora“.
} 
šnoj sceni i znatno prije II svjetskog rata. Popularni su bili naročito Gogolj i Ostrovski. Stoga se na njih računalo prilikom kreiranja repertoara novoformirane pozorišne kuće u Podgorici (nekadašnjem Titogradu), kada je trebalo napraviti prikladan repertoar, kako bi se raznovrsna publika privukla u pozorište i to upravo djelima na koje je ova sredina bila naviknuta i koja su bila dobro prihvaćena. U periodu 1953-2003. ruski pisci čija su djela najizvođenija u Crnogorskom narodnom pozorištu bili su Ostrovski, Gogolj i Čehov.

\section{Literatura}

- Božović, Zoran - Čehov kao dramski pisac kod Srba, Filološki fakultet beogradskog univerziteta, Beograd, 1985.

- Borba, Beograd, 22. IV 1964 - Svetozar Piletić, „Deset godina rada pozorišta“.

- Brajičić, Olga - Zapis o crnogorskom narodnom pozorištu 19431946, CNP, Podgorica, 2002.

- Crnogorsko narodno pozorište: 1953-1998, edicija „Zetski dom“, priredio Milovan Radojević, Crnogorsko narodno pozorište, Podgorica, 1998.

- Crnogorsko narodno pozorište: 1953-2003, edicija „Zetski dom“, priredio Milovan Radojević; CNP, Podgorica, 2003.

- Đurović, Ratko - Teatrološki spisi, Crnogorsko narodno pozorište, Podgorica, 2006.

- Koprivica, Dragan - „Drame A. P. Čehova na sceni crnogorskog narodnog pozorišta u Podgorici”, Slavistika, XII, Beograd, 2008.

- Kosanović, Bogdan - „Dostojevski na sceni srpskog narodnog pozorišta u Novom Sadu“, Slavističke komparativne teme, Old Commerce, Novi Sad, 2006.

- Kritika i Crnogorsko narodno pozorište, Tom I (1953-1978) / izbor i uvodna riječ Milovan Radojević, Crnogorsko narodno pozorište, Podgorica, 2001.

- Kritika i crnogorsko narodno pozorište, Tom II (1978-2003) / izbor i uvodna riječ Milovan Radojević, Crnogorsko narodno pozorište, Podgorica, 2004.

- Milunović, Ljiljana - Pozorište u crnogorskoj periodici (18841908), CNP, Podgorica, 2002.

- Milunović, Ljiljana - Pozorište u crnogorskoj periodici (19161944), CNP, Podgorica, 2003.

- Milunović, Ljiljana - Pozorište u crnogorskoj periodici (19091915), CNP, Podgorica, 2004.

- Milunović, Ljiljana - Pozorište u crnogorskoj periodici (19441953), CNP, Podgorica, 2006. 
Ruski pisci na sceni Crnogorskog narodnog pozorišta (I)

- Monitor, Podgorica, 25. 10. 2002 - Sreten Perović, „Ruska čežnja u modernom ruhu".

- Nikšićke novine, Nikšić, 16. IV 1974 - R. Krunić, „Predstava vanredne poetske snage".

- Ovdje, Titograd, IV, 1974 - S. Kalezić, „Kako obožavati netalentovanu predstavu“.

- Ovdje, Titograd, I, 1982 - Budimir Dubak, „Čulimsk ili lavirint“.

- Ovdje, Titograd, I, 1989 - Veselin Radunović, „Umjetnost ili imitacija života“.

- Perović, Sreten - Darovi scene, Knjige 1 i 2, Studije i kritike, Univerzitetska riječ, Leksikografski zavod Crne Gore, Pobjeda, Titograd, 1986.

- Pobjeda, Titograd, 7. XI 1954 - M. Stojović, „Bez krivice krivi“.

- Pobjeda, Titograd, 9. X 1960 - M. Stojović, „Dan odmora“.

- Pobjeda, Titograd, 11. III 1965.

- Pobjeda, Titograd, 15. IV 1965 - K. Č., „Dvije premijere u Titogradskom pozorištu“.

- Pobjeda, Titograd, 8. IX 1966 - P. Ćetković, „Repertoar prilagođen publici“.

- Pobjeda, Titograd, 15. XII 1984 - S. Popović, R. Jovanović, „Kako se može živjeti u snu“".

- Pobjeda, Titograd, 28. XII 1988 - Sn. P., „Premijera ,Revizora““.

- Pobjeda, Podgorica, 11. III 2000 - Jovan Ćirilov, „Oblomovština danas i ovdje“.

- Pobjeda, Podgorica, 8. XI 2001 - Snežana Ražnatović, „Malograđani“" (intervju sa Metom Jovanovskim).

- Pobjeda, Podgorica, 15. XII 2001.

- Pobjeda, Podgorica, 20. V 2002 - S. Miletić, „Malograđani ili aplauz bivšem životu“.

- Pobjeda, Podgorica, 5. X 2002 - Rosanda Mučalica, „Život nema reprizu, već samo premijeru“.

- Politika, Beograd, 11. X 1966 - B. Pušonjić, „,Titograd: jedna siromašna nedelja“".

- Politika, Beograd, 9. I 1967 - B. Pušonjić, „Prvo izvođenje Majakovskog u Crnoj Gori“".

- Politika, Beograd, 4. 11. 1975 - A., „Prva premijera u Crnogorskom pozorištu“.

- Prosvjetni rad, Titograd, 15. V 1963 - Radoslav Đukić, „Gogoljeva 'Ženidba' na sceni CNP-a“.

- Prosvjetni rad, Titograd, 15. X 1966 - R. Đukić, „Ostrovski : 'Šuma““. 
- Prosvjetni rad, Titograd, 1-15. I 1967 - R. Đukić, „Majakovski, 'Hladan tuš“".

- Publika, Podgorica, 8. 10. 2002 - Jovanka Kovačević Đuranović, „Praznina prostora, duše, nada, iluzija“.

- Pozorište u Crnoj Gori u drugoj polovini XX vijeka, radovi sa naučnog skupa, Podgorica, 23. jun 2006. godine, Crnogorska akademija nauka i umjetnosti, Podgorica, 2007.

- Savremena drama i pozorište u Crnoj Gori, priredili Sreten Perović i Radoslav Rotković, Sterijino pozorje, Novi Sad, 1987.

- Scena, Novi Sad, IX-X 1974 - S. Piletić, „Minula sezona je bila uspješna“.

- Susreti, Titograd, 1954. VIII-IX - M. Stojović, „Gogoljeva 'Ženidba' na sceni Titogradskog pozorišta“".

- Titogradska tribina, Titograd, 31. X 1963 - S. Piletić, „Osrednja predstava“.

- Titogradska tribina, Titograd, 1. I 1967 - S. Piletić, „Hladan tuš”.

- Titogradska tribina, Titograd, 21. X 1970 - Svetozar Piletić, „Piter Ustinov, 'Kraj trke'".

- Titogradska tribina, Titograd, 29. XI 1972 - S. Piletić, „Čehov, 'Tri sestre“"..

- Titogradska tribina, Titograd, 12. 1. 1990 - L. Brković, „Bogato i uspješno - pet premijera CNP“.

- Vijesti, Podgorica, 5. X 1998 - Balša Brković, „Mit o novom čovjeku“ i „Prvi utisci...".

- Vijesti, Podgorica, 12. X 1999 - Danica Nikolić, „Vrijeme kada se Oblomovi umnožavaju“.

- Vijesti, Podgorica, 14. X 1999 - D. Nikolić, „Hiperekskluzivno pozorište".

- Vijesti, Podgorica, 18. X 1999 - Balša Brković, „Život kao odsustvo postojanja“.

- Vijesti, Podgorica, 29. V 2001 - R. Mučalica, „Svjetionik svjetske dramaturgije“.

- Vijesti, Podgorica, 14. V 2002 - R. V., „Četiri nagrade i ovacije za Mađelijeve 'Malograđane“"..

- Volk, Petar - Pozorišni život u Srbiji : 1944-1986, Institut za pozorište, film, radio i televiziju Fakulteta dramskih umetnosti, Beograd, 1990.

- Vukadinović, Srđan - Organizacija nacionalnog teatra, Kulturno-prosvjetna zajednica Podgorica, Podgorica, 1995. 
Ruski pisci na sceni Crnogorskog narodnog pozorišta (I)

Dragana KALEZIĆ

\section{РУССКИЕ ПИСАТЕЛИ НА СЦЕНЕ ЧЕРНОГОРСКОГО НАРОДНОГО ТЕАТРА (I)}

Цель настоящей работы выявить работу Черногорского народного театра (1953-2003), с точки зрения рецепции русских писателей, особенно в течение первого десятилетия деятельности театра.

На основании числа поставленных произведений и авторов, а также и на основании критики, проследившей за постановками произведений русских писателей, можно сделать вывод, что русские писатели занимали значительное место в репертуаре этого театра. Особенно важной была роль произведений русских писателей, как например Гоголя и Островского, в самом начале создания репертуара ЦНП. Среди совокупной зарубежной литературы чаще всего поставляли произведения русской литературы. Черногорский народный театр сыграл значительную роль в популяризации русской литературы в культурной общественности Черногории.

Ключевые слова: Черногорский народный театр (ЦНП), русские писатели, драма, театральная критика, рецепция 

LINGUA MONTENEGRINA, god. III, br. 5, Cetinje, 2010.

Institut za crnogorski jezik i jezikoslovlje „Vojislav P. Nikčević“

UDK 930.85(497.16)

Stručni rad

\title{
Helena DRAGIĆ (Mostar)
}

Filozofski fakultet Sveučilišta u Mostaru

\section{DUKLJANSKI KRALJ SVETI VLADIMIR U HRVATSKOJ KNJIŽEVNOSTI I CRNOGORSKOJ TRADICIJI}

\begin{abstract}
Rad obuhvaća deset poglavlja: 1. Podrijetlo Vladimira, 2. Napad cara Samuila na Vladimirovo kraljevstvo, 3. Županova izdaja Vladimira, 4. Vladimirovo sužanjstvo, 5. Vladimir i Kosara, 6. Pogubljenje Vladimira, 7. Vladimir u hrvatskoj usmenoj književnosti, 8. Smrt Vladislava, 9. Duklja nakon Vladimirove smrti, 10. Crnogorska tradicija o Vladimiru.
\end{abstract}

Ključne riječi: Vladimir, Kosara, prijevara, mučeništvo, pogubljenje

\section{Uvod}

Duklja je najstariji naziv za oblast oko Skadarskoga jezera. Naziv baštini po ilirskom plemenu Dokleata. ${ }^{1}$ Iliri su indoeuropskoga podrijetla, a u prapovijesnoj i antičkoj epohi živjeli su na zapadnomu Balkanu: područja iznad Makedonije i Tracije do Dunava. Zbog zemljopisne udaljenosti i vanjskih utjecaja ilirska su plemena razvila različite kulture. Vjerovali su u različite bogove. Govorili su sličnim jezicima. Najveći su utjecaj na Ilire imali Kelti i Grci. Iliri su bili razjedinjeni. Međusobno su ratovali. Ratovali i s Grcima, Makedoncima i Rimljanima. Grci su u 8. st. prije Krista osnovali svoje kolonije na ilirskoj obali (Epidamnos), a u 4. st. prije Krista osnovali su kolonije na istočnoj Jadranskoj obali (Issa, Pharos). Enheleji su stvorili moćnu državu u južnoj Iliriji koja je na vrhuncu moći bila u 8./7. st. pr. Krista. Državu su stvorili i Taulanti i Dardanci. Nakon toga stvorena je moćna ilirska država koja se prostirala od srednjodalmatinskih otoka na sjeveru do Epira na jugu te Dardanije i Makedonije na istoku. Česti su ratovi uništili moćnu ilirsku državu 168. godine prije Krista. Podgorice).

${ }^{1}$ Srušeni rimski grad Doclea nalazio se u slijevu Zete i Morače (kraj današnje 
Brojne grandiozne ilirske gradine do naših dana nijemo svjedoče o ilirskoj materijalnoj kulturi. Mnogobrojne su povijesne predaje koje se i danas, nakon dvije tisuće i dvjesto godina. Pripovijedaju o kraljici Teuti. ${ }^{2}$ Ilirskoga su podrijetla rimski carevi, primjerice: Aurelijan, Prob, Dioklecijan, Konstantin. Sveti Jeronim je Ilirac iz Stridona.Godine 620. Duklju su osvojili Slaveni. Stalno je bila izložena pretenzijama Bugara, Saracena ${ }^{3}$ i Mlečana.

Godine 1089. papa Klement III. osnovao je Dukljansko-barsku nadbiskupiju sa sjedištem u Baru. Grgur (Zadar, prva polovica 12. st. - Zadar, 1198 ?) bio je dukljanskim nadbiskupom sa sjedištem u Baru (1173.-1195). ${ }^{4}$ Poznat je pod nazivom pop ${ }^{5}$ Dukljanin. Napisao književno-povijesno djelo koje se, po Dubrovčaninu Ludoviku Tuberonu, prozvalo Ljetopisom. Prema Ferdi Šišiću, u 14. stoljeću to se djelo nazivalo Hrvatska kronika. U njemu Dukljanin piše o dukljanskoj povijesti od 5. do 12. stoljeća. Dukljanin navodi i neke događaje iz Hrvatske i Raške. ${ }^{6}$ Posebno mjesto u Ljetopisu zauzima dukljanski kralj Vladimir.

Mavro Orbini (Dubrovnik, vjerojatno pol. 16. st. - Dubrovnik, 1611.), bio je protureformator, povjesničar, panslavist, benediktinac na Mljetu, Stonu i Braču. Kraljevstvo Slavena ili Povijest dom Mavra Orbinija Dubrovčanina, opata mljetskog nastalo je temeljem Dukljaninova Ljetopisa, usmenih predaja i drugih vrela, posvećena je gosparu Marinu, gospara Andrije Bobaljevića, po čijem je nalogu knjiga i napisana. Knjiga počinje Orbinijevim obraćanjem

\footnotetext{
${ }^{2}$ Nedostatni su povijesni podatci o podrijetlu najljepše kraljice Teute. Na prijestolje je stupila 231. g. prije Krista nakon smrti supruga Agrona. Po nekim suvremenim predajama u Boko-kotorskom zaljevu Agrona je otrovao njegov vojskovođa Demetrije Hvaranin, koji mu je u znak dobrodošlice nakon izvršene pobjedonosne vojne akcije dao ispiti vrč vina u koje je usuo otrov. Po povijesnim izvorima kraljica Teuta vladala je u ime svoga malodobnoga pastorka Pinesa. U to vrijeme moćna ilirska država prostirala se od lijeve obale Neretve do Epira obuhvaćajući sve otoke osim Visa. Nakon pokušaja da zavlada Visom zaratila je s Grcima koji su u pomoć pozvali Rimljane 229. g. pr. Krista. U tomu ratu (229. pr. Kr. - 228. pr. Kr.) Teuta je poražena. Povukla se u Rhizon (Risan, mjesto u današnjoj Crnoj Gori i bila prisiljena plaćati ratnu odštetu i danak te ograničiti kretanje naoružanih brodova. Rimljanima je pripao prostor do ušća Drima, a Hvarom i susjednim otocima zavladao je rimski vazal Demetrije Hvaranin. Vidi: Marko Dragić, Ilirske teme u suvremenom narodnome pripovijedanju, „Osmišljavanja“, Zbornik u čast 80. rođendana akademika Miroslava Šicela, Sveučilište u Zagrebu, Filozofski fakultet, FF-Press, priredio Vinko Brešić, Zagreb, 2007., str. 153-171.

${ }^{3}$ Saraceni je bizantski i latinski naziv kojim su u ranom srednjovjekovlju nazivani sredozemni arapski islamizirani narodi. Iz sjeverne Afrike su prodrli i osvojili: Maltu, Siciliju, Korziku, Sardiniju i Kalabriju, te se učvrstili u Ulcinju.

${ }^{4}$ Papa Aleksandar III. dodijelio mu je nadbiskupski naslov.

${ }^{5}$ Pop je skraćenica od pater omnium pauperum (otac svih siromaha).

${ }^{6}$ Hrvatski leksikon, II. svezak, L-Ž, glavni urednik Antun Vujić, Naklada Leksikon d. o. o., Zagreb, 1997, str. 43.
} 
Dukljanski kralj sveti Vladimir u hrvatskoj književnosti i crnogorskoj tradiciji

čitateljima u kojem je ustvrdio kako su slavna djela Slavena pomračena gustom magluštinom i gotovo pokopana u vječnoj noći zaborava jer naši pređi nisu imali učenih muževa koji bi svojim djelima prenosili slavu roda slavenskoga. ${ }^{7}$ Godine 1601. objavio je Kraljevstvo Slavena. Djelo je napisano u duhu katoličke obnove, ${ }^{8}$ težnji za ujedinjenjem Slavena i njihovim oslobađanjem od osmanskoga ropstva. U trećem dijelu Kraljevstva Slavena (1601.) koji je nazvan Povijest kraljeva Dalmacije i drugih okolnih ilirskih krajeva. Od ljeta Gospodnjega 495. do 1161. U tom je dijelu i legenda o kralju Vladimiru. Kraljevstvo Slavena najviše je osporavao Ivan Lučić.

Međutim, to su Orbinijevo djelo koristili Ivan Gundulić, Junije Džono Palmotić, Jerolim Kavanjin, Juraj Rattkay, Pavao Ritter Vitezović, Filip Grabovac, Andrija Kačić Miošić, Ivo Andrić i mnogi drugi. Orbinijevo Kraljevstvo Slavena bitno je utjecalo na početke srpske i bugarske historiografije, a 1723. godine prevedeno je i na ruski jezik. (Neki Mavra Orbinija nazivaju ocem srpske povijesti.) Napisao je i Zrcalo duhovno od početka i svrhe života čovičanskoga (Mleci, 1630. $)^{9}$

\section{Podrijetlo Vladimira}

Kralja Hvalimira naslijedio je sin Miroslav, koji je brodicom krenuo u posjet starijem bratu Petrislavu. Međutim, podigla se velika oluja u kojoj je Miroslav nastradao. Budući nije imao nasljednika, naslijedio ga je brat Petrislav, koji je dobio sina Vladimira. ${ }^{10}$ Kada je Petrislav preminuo, sahranjen je u crkvi Svete Marije u Gazenima.

\footnotetext{
${ }^{7}$ Navodim prema: Marko Dragić, Književnost katoličke obnove i prvoga prosvjetiteljstva (Hrvatska barokna književnost), Filozofski fakultet Sveučilišta u Splitu, Split, 2006., www.ffst.hr, str. 32-34.

${ }^{8}$ Do katoličke obnove dolazi nakon Tridentskoga sabora, koji je djelovao s prekidima 1545.-1548, 1551.-1552., 1562.-1563. a sazvao ga je papa Pavao III. s podrškom cara Karla V. Svega je nekoliko biskupa sudjelovalo na 1. i 2. dijelu Sabora, a na 3. dijelu gotovo svi dalmatinski biskupi. Zapaženu ulogu imali su Juraj Drašković i Andrija Dudić. Biskupi u domovini provode odredbe Tridentskoga sabora te osnivaju sjemeništa, pučke i srednje škole.

${ }^{9}$ Navodim prema: Marko Dragić, Književnost katoličke obnove..., str. 31.

${ }^{10}$ Pavao Ritter Vitezović piše da je to ime dobio prema miroljubivi vladar. Vidi: Pavao Ritter Vitezović, Život $i$ mučeništvo blaženog Vladimira, hrvatskog kralja, u: Hrvatski latinisti II, Pisci 17.-19. Stoljeća, (ur. Rafo Bogišić), Zora i Matica Hrvatska, PSHK, Zagreb, 1970., str. 156.
} 
Helena DRAGIĆ

Naslijedio ga je sin Ivan ${ }^{11}$ Vladimir (oko 978. - 1016.), mučenik, bio je dukljanskim kraljem. Stolovao je u Krajini kod crkve Prečiste Krajinske, na zapadnoj obali Skadarskoga jezera. Isticao se ljepotom, dobrotom, mudrošću i svetošću. Vitezović piše: „Mir, naime, koji je Krist, Spasitelj ljudskoga roda, preporučio apostolima, on (Vladimir) je uvijek njegovao da, neokaljanih ruku i srca, nije pružao oružan otpor čak ni žestokom neprijatelju. “12

\section{Napad cara Samuila na Vladimirovo kraljevstvo}

Bugarski car Samuilo (oko 938.? - 1014.), doznavši da je dukljanski kralj Vladimir još uvijek momčić i odan pobožnosti i miru, ${ }^{13}$ sa svojom vojskom provalio je u Dalmaciju. Suočen s mnogo jačom silom Vladimir je želio sačuvati vojsku od pogibelji te se s vojskom povukao na planinu Oblik. (Pavao Ritter Vitezović u navedenome djelu (str. 158.) piše da se Vladimir sa svojim prvacima, dvorjanicima i pukom povukao u klanac brda Taraboš.) ${ }^{14}$ Međutim, ondje je bilo mnoštvo zmija otrovnica koje su ubijale ljude i životinje. Vladimir se molitvom obratio Bogu da ga oslobodi od zmija. Bog je uslišao njegovu molitvu, te ondje više nema zmija otrovnica. ${ }^{15}$

Konstantin VII. Porfirogenet (905.-957.) u svom znamenitom djelu $O$ upravljanju carstvom (oko 950. godine) navodi i legendu o sv. Pavlu koji je na Mljetu oduzeo otrov zmijama. Katolički biskup iz Bara, pop Dukljanin, ${ }^{16}$ u svom Ljetopisu (12. st.) ${ }^{17}$ donosi slično predanje za brdo Oblik. Na Cresu je živa tradicija po kojoj je na tom otoku Osorski biskup Gaudencije ${ }^{18}$ protjerao otrovne zmije. Isto je učinio i sveti Dominik u Južnoj Italiji. ${ }^{19}$

${ }^{11}$ Vidi: Leksikon ikonografije, liturgike i simbolike zapadnog kršćanstva i Uvod u ikonologiju Radovana Ivančevića, priredio Anđelko Badurina, Kršćanska sadašnjost, Zagreb, 1990, str. 284-285.

${ }^{12}$ Isto.

${ }^{13}$ Isto.

${ }^{14}$ Isto, str. 158.

${ }^{15}$ Mavro Orbini, Kraljevstvo Slavena (priredio Franjo Šanjek), Zagreb, 1999, str. 285.

${ }^{16}$ Hrvatski leksikon, II. svezak, L-Ž, gl. ur. Antun Vujić, Naklada Leksikon d. o. o. Zagreb, 1997, str. 415.

${ }^{17}$ Vidi: Ivan Mužić, Hrvatska kronika 547-1089, V izdanje (preveo s latinskoga prof. Hraste Nečas Danijel - Filozofski fakultet Zadar), Marjan tisak, Split, 2002., str. 192-206.

${ }^{18}$ Vidi: Hrvoje Hitrec, Hrvatske legende, Školska knjiga, Zagreb, 2007, str. 1719. Hitrec Gaudencija naziva Gaudentom.

19 Vidi: Povijest hrvatske književnosti, knj. 1, napisale Maja Bošković-Stulli i Divna Zečević, Liber, Mladost, Zagreb, 1978., str. 72. 
Dukljanski kralj sveti Vladimir u hrvatskoj književnosti i crnogorskoj tradiciji

\section{3. Županova izdaja Vladimira}

Samuilo je s dijelom vojske zauzeo podnožje planine Oblik, a s drugim dijelom vojske opsjedao je grad Ulcinj. ${ }^{20}$ Shvatio da se ne može domaći Vladimira te ga je počeo mamiti da dođe do njega, čvrsto mu obećavši da mu neće naškoditi. Kad Vladimir to nije prihvatio, župan toga mjesta kojega je Samuilo obećao nagraditi, počeo je nagovarati Vladimira da ode k Samuilu.

Vladimir je želio spasiti vojsku, te im je okupivši ih rekao:

Nužda me sili (kako mi se čini), predraga braćo moja, da u ovom trenutku udovoljim onoj evanđeoskoj izreci koja kaže: „Dobrom se pastiru pristoji založiti dušu za spas svoga stada.“ (Iv. 10,11.) Bugarin obećaje sve vas pustiti neozlijeđene ako ja siđem i odem porazgovarati s njime; ako pak ne učinim tako, prijeti da neće napustiti položaj sve dok svi ne izginemo od gladi. Bolje je, dakle, da se predam u njegove ruke na milost i nemilost nego li da vas sve odvedem u velike patnje i nevolje. ${ }^{21}$

Potom se uputio Samuilu koji je pak pogazio obećanje te ga je utamničio u Prespu kod Ohrida. Samuilo je nastavio pustošiti Dalmaciju. Poharao je sve do Zadra; spalio Kotor i Lauzij, te se preko Bosne i Raške vratio u Bugarsku. $^{22}$

\section{Vladimirovo sužanjstvo}

Sve to vrijeme Vladimir je u okovima dostojanstveno podnosio sva mučenja u tamnici, posteći i moleći Boga da mu se smiluje. Jedne noći Vladimiru se u snu ukazao anđeo i navijestio mu da će biti oslobođen; da će ga Gospodin izbaviti iz zatočeništva i da će mu mučeništvo osigurati kraljevstvo nebesko. To je Vladimiru vratilo snagu, te se još zdušnije posvetio postu i molitvama. ${ }^{23}$

U hrvatskoj je tradicijskoj kulturi kao i u Bibliji načelo dobra i zla „neprijeporna konstanta“. ${ }^{24}$

\section{Vladimir i Kosara}

Kosara (oko 978. - ?), kći kralja Samuila, zatražila je od oca dopuštenje da zatočenicima umije glavu i opere noge. ${ }^{25}$ Vidjevši Vladimira, blaga,

${ }^{20}$ Ivan Mužić, op. cit., str. 192.

${ }^{21}$ Mavro Orbini, op. cit., str. 286.

${ }^{22}$ Ivan Mužić, op. cit., str. 192.

${ }^{23}$ Mavro Orbini, op. cit., str. 287.

${ }^{24}$ Stipe Botica, Biblija $i$ hrvatska kulturna tradicija, Vlastita naklada, Zagreb 1995, str. 76. 
čedna, puna božanske mudrosti i razboritosti, te veoma dostojanstvena, zadrži se i porazgovara s njim: ,činilo joj se da mu je govor slađi od meda i saća. ${ }^{26}$ Stoga se Kosara sažali nad njim i, zadivljena njegovom ljepotom i svetošću, zavoli ga. Otišla je ocu, klekla pred njim i rekla mu: „Moj oče i gospodaru, znam da mi kaniš dati muža kako je običaj, a sada ako tvoje veličanstvo hoće, ili mi daj za muža kralja Vladimira, kojega držiš u okovima, ili znaj da ću prije umrijeti nego uzeti za muža drugoga.“27

Samuilo je mnogo volio kćerku te je uslišio njezinu molbu. Oslobodio je Vladimira i kad je po kraljevskom običaju proslavio svadbu, zagrnuo ga je kraljevskom odorom i povratio mu kraljevstvo kojemu je pridodao Drač, a Vladimirovu stricu Dragimiru vratio je Trebinje i sve što mu je bio oduzeo. ${ }^{28}$

Vladimir je suprugu Kosaru poveo sa sobom i u svetosti nastavio kraljevati. Nakon Samuilove smrti naslijedio ga je njegov sin Radomir koji je zauzeo sve grčke zemlje do Konstantinopola. Car Bazilije se uplašio da će ostati bez carstva, te je potajno poslao izaslanike Radomirovu bratiću Vladislavu, poručivši mu: ,Zašto ne osvetiš krv svojega oca? Primi od mene zlata i srebra koliko budeš htio i budi s nama u miru, te primi kraljevstvo Samuela, koji je ubio tvojeg oca i svojeg brata. A ako možeš ubij njegova sina Radomira, koji sada drži kraljevstvo.“29

Kad je to čuo, Vladislav je jednoga dana bio u lovu s Radomirom i, dok su jahali na konjima, udario je i ubio Radomira.

Vladislav je mislio kako njegovo kraljevstvo neće biti mirno dok je Radomirov svak (zet) Vladimir živ, te ga je počeo mamiti sebi. ${ }^{30}$ Kosara nije dopustila Vladimiru da ide Vladislavu, govoreći mu: „Moj gospodaru, nemoj ići, da ti se - ne bilo tako! - ne dogodi isto što mom bratu, nego pusti mene da pođem, vidim i čujem kako je kralj. Ako me želi uništiti, neka uništi; samo da ti ne nastradaš. ${ }^{311}$ Vladislav je Kosaru dočekao sa svim počastima i brojnom pratnjom. Ponovno je poslao svoje ljude sa zlatnim križem zaklinjući se: „Zašto oklijevaš doći? Evo, tvoja je žena kod mene i nikakvo zlo nije pretrpjela, nego uživa počasti od mene i mojih. Primi vjeru križa i dođi, da te vidim pa da se sa svojom ženom vratiš u svoj kraj s počastima i darovima. ${ }^{332}$

${ }^{25}$ Ivan Mužić, op. cit., str. 193.

${ }^{26}$ Pavao Ritter Vitezović piše da je to ime dobio prema miroljubivi vladar. Vidi: Pavao Ritter Vitezović, Život i mučeništvo..., str. 156.

${ }^{27}$ Ivan Mužić, op. cit., str. 193.

${ }^{28}$ Isto, str. 193.

${ }^{29}$ Isto, str. 193.

${ }^{30}$ Mavro Orbini, op. cit., str. 286.

${ }^{31}$ Ivan Mužić, op. cit., str. 194.

${ }^{32}$ Isto, str. 194. 
Dukljanski kralj sveti Vladimir u hrvatskoj književnosti i crnogorskoj tradiciji

Vladimir mu je odgovorio: „Znamo da naš Gospodin Isus Krist, koji je trpio za nas, nije pribijen na zlatan ili srebren križ, nego na drven; zato, ako je tvoja vjera istinita $\mathrm{i}$ istinite tvoje riječi, pošalji mi drven križ po rukama pobožnih ljudi, a ja ću doći vjerom i vrlinom našega Isusa Krista uzdajući se u životvorni križ i skupocjeno drvo.“33

Vladislav je dva biskupa i pustinjaka s drvenim raspelom uputio s riječima: „Otiđite k Vladimiru, pokažite mu križ ovi i recite da sam se na njemu zakleo da mu neću nikakve privare učiniti. ${ }^{\text {“34 }}$ Došli su k Vladimiru sa drvenim raspelom nad kojim su se zakleli da se Vladimiru neće dogoditi nikakvo zlo.

Vladimir je, primivši križ, poklonio se do zemlje, poljubio ga i spremio u njedra i sa šačicom svojih ljudi krenuo Vladislavu. Međutim, Vladislav je poslao zasjedu da ubije Vladimira. Oni koje je Vladislav poslao da ubiju Vladimira vidješe da je uz njega mnoštvo vojske s krilima i kopljem u ruci. Bijahu to anđeli.

Oni koji su poslani da ubiju Vladimira, vidjevši anđele Božje, pobjegoše.

\section{Pogubljenje Vladimira}

Vladimir je sretno stigao u Preslav Vladislavu, koji je bio za objedom. Vidjevši da Vladimir nije ubijen, naljutio se i zapovijedio da mu odrube glavu.

Kad je Vladimir vidio da je prevaren, okrenuo se biskupima i rekao: „O časni ljudi, zašto me izdaste? Što Vas je nagnalo da prisegnete nad križem Gospodnjim, što ga donijeste sa sobom, da mi nećete nanijeti nikakva zla? Zar mislite da će Bog trpjeti takva zlodjela? ${ }^{635}$ Biskupi su stajali pognute glave. Vladimir ishodi pričest prije nego mu odrube glavu. Poljubi križ rekavši: „Prečasni ovaj križ nek' mi zajedno s vama bude svjedokom u ovaj dan Gospodnji da ću umrijeti nevin. ${ }^{\text {“36 }}$ Potom je poljubio križ i uz plač svih prisutnih izišao pred crkvu, a pred crkvenim vratima odmah su ga ubili i odrubili mu glavu. Bilo je to 22 . svibnja 1016. godine.

Biskupi mu, uz himne i hvalospjeve, tijelo pokopaše u crkvi, a na grobu njegovu mnogi bolesni ozdraviše. Noću se na grobu ukazivalo svjetlo i mnoštvo gorućih svijeća. ${ }^{37}$ Vidjevši to, Vladislav ostane zgranut i dopusti Kosari da muža danonoćno oplakuje i da ga pokopa gdje god hoće. ${ }^{38}$

\footnotetext{
${ }^{33}$ Ivan Mužić, op. cit., str. 194.

${ }^{35}$ Mavro Orbini, op. cit., str. 288.

${ }^{36}$ Isto, 289.

${ }^{37}$ Ivan Mužić, op. cit., str. 195.

${ }^{38}$ Mavro Orbini, op. cit., str. 289.
}

${ }^{34}$ Andrija, Kačić Miošić, Razgovor ugodni naroda slovinskoga, Matija Antun Reljković, Satir iliti divji čovik, (priredio Josip Vončina), Sveučilišna naklada Liber, Zagreb, 1988., str. 180. 
Helena DRAGIĆ

Prema Ljetopisu popa Dukljanina, Vladimirovo je tijelo preneseno, najkasnije u proljeće 1018. godine, u crkvu Svete Marije u Krajini. Njegovo tijelo je i dan danas neraspadnuto i iz njega isparava blag miris, a u rukama drži onaj križ koji mu bješe poslao bugarski car. Na dan njegova blagdana mnoštvo hodočasnika hodočasti njegovu grobu. Kosara je prezrela ovaj svijet i u istoj se crkvi zaredila. Kada je umrla, pokopana je u istoj crkvi do nogu svoga muža. ${ }^{39}$

Prema suvremenim povijesnim vrelima, Vladimirovo je tijelo 1215. godine preneseno u manastirsku crkvu kod Elbasana u Albaniji. Od katoličke Crkve nije kanoniziran, a u pravoslavnoj se štuje od 1861. godine. ${ }^{40}$

\section{Vladimir u hrvatskoj usmenoj književnosti}

Fra Andrija Kačić Miošić (Brist kraj Makarske, 1704. - Zaostrog, 1760.) u Razgovoru ugodnomu naroda slovinskoga (1756., 1759.) navodi proznu i versificiranu legendu o kralju Vladimiru. ${ }^{41}$ Stipe Botica u Hrvatskoj usmenoknjiževnoj čitanci navodi stihovanu legendu zapisanu u Smokvici na Korčuli:

\section{VLADIMIR I KOSARA}

Procmili' je sužanj Vladimire u tamnici krája bugarskoga; cmili teško i nevolja mu je. Začula ga Kosara divojka, lipa ćerca kraja bugarskoga. Ona mu je besidila mlada:

,Što ti mi je, moj sužnji nevojni?

Što niz obraz grozne suze ronišs?

Oli ti je stanje dodijalo

u tamnici lošoj kući mojoj?“

Odgovara sužanj Vladimire:

„Duše moja, Kosara divojka, stanje mi je dodijalo teško u tamnici lošoj kući tvojoj.

${ }^{39}$ Ivan Mužić, op. cit., str. 195.

${ }^{40}$ Leksikon ikonografije, liturgike i simbolike zapadnog kršćanstva i Uvod u ikonologiju Radovana Ivančevića, priredio Anđelko Badurina, Kršćanska sadašnjost, Zagreb 1990, str. 284-285.

${ }^{41}$ Vidi: Andrija, Kačić Miošić, Razgovor ugodni naroda slovinskoga, Matija Antun Reljković, Satir iliti divji čovik, (priredio Josip Vončina), Sveučilišna naklada Liber, Zagreb, 1988., str. 178-185. 
Dukljanski kralj sveti Vladimir u hrvatskoj književnosti i crnogorskoj tradiciji

Jur je ovo devet godinica, nisam vidi' mile majke moje, ja se nisam junak oženio; Od tega mi ni na pamet nije, nego sam se majke uželio i mojega dvora bijeloga. Moli babu tvoga velikoga, da me pusti do dvora mojega, a na viru opet ću mu doći." Besidi mu Kosara divojka: „Spovidi se, moj sužnji nevojni, tiho zboriš, ponizno govoriš, rek bi da si roda gosposkoga?" Govori joj sužanj Vladimire: „Ma ja nisam roda gosposkoga, neg sam sinac kraja slovinskoga, a sužanj sam starca babe tvoga Samojila, da ga bor ubije! $\mathrm{Na}$ božju me viru privario, u tamnicu mene postavio.“ Kad to čula Kosara divojka, mili Bože, ža' ti joj je bilo, i šeta se babi u kamari, i njemu je tiho besidila: „O moj babo, velo dobro moje, svi ti sužnji u tamnici cmile, ma najveće sužanj Vladimire. Pusti mi ga, babo dobro moje, za mojega draga zaručnika!“ - „Vele luda Kosara divojko, ti vazimaj ključe od tamnice, i pusti mi sužnja do jednoga ma ne sužnja moga Vladimira!“ - „O tako ti, babo dobro moje, ja ti ne ću od krajestva ništa, neg mi pusti sužnja Vladimira za mojega draga virenika!“

Više mu se s manjim ne mogaše, jer se babi vije o grjavce, on joj dade ključe od tamnice, da pušćiva sužnja Vladimira, a za nje je draga virenika. 
Helena DRAGIĆ

Ona pojde tamnici na vrata, u tamnicu nogom udarila: „Ustani se, sužanj Vladimire, i otari grozne suze tvoje, jer te draga zaručnica zove!“ Muči sužanj, kako da ne čuje. Opet mu je mlada govorila: „Ustani se, moj sužnji nevojni, i izajdi tamnici na vrata, jer te zove Kosara divojka, lipa ćerca kraja bugarskoga." Kad izajde tamnici na vrata, hitila ga za bijele ruke, i vodi ga u kamare svoje. Mili Bože, velika ti hvala, tri barbira ona nahodila; jedan brije, a drugi ga striže, a treći mu nojte obrižuje. Žuta mu je do pojasa brada, žuti su mu brci do za uho, kraj mu dava ćercu jedinicu za njegovu dragu zaručnicu. I dava mu po krajestva svoga, pa ga šaje dvoru bijelomu, da pozdravi milu majku svoju. ${ }^{42}$

Usmeno-književni žanrovi se pokatkad preoblikuju. Legendu o kralju Vladimiru fra Andrija Kačić Miošić u Razgovoru ugodnomu navodi i u proznom i versificiranom obliku. Kačićeva pjesma obuhvaća 150 stihova.

Navedena lirska pjesma Vladimir i Kosara nalazi se i u Hrvatskim narodnim pjesmama, knj. VI. 1914. g. Ta pjesma ima 81 stih, dakle, skoro upola manje od Kačićeve pjesme. Usmeno-stihovane legende o kralju Vladimiru obuhvaćaju epizode: usužnjenoga Vladimira, susreta s Kosarom, oslobađanje Vladimira i njegovu ženidbu s Kosarom. ${ }^{43}$

${ }^{42}$ Stipe Botica, Hrvatska usmenoknjiževna čitanka, Školska knjiga, Zagreb, 1995, str. 119-120.

Vidi i: Stipe, Botica, Narodni život, običaji i kultura Hrvata do svršetka srednjega vijeka, u: Lijepa naša baština, Portreti, Hrvatska sveučilišna naklada, Zagreb 1998, str. 7-22.

43 Marko Dragić, Poetika i povijest hrvatske usmene književnosti (Fakultetski udžbenik) Filozofski fakultet Sveučilišta u Splitu, Split 2008., www.ffst.hr, str. 194. 
Dukljanski kralj sveti Vladimir u hrvatskoj književnosti i crnogorskoj tradiciji

„Usmenu legendu o kralju Vladimiru, dakle, prvi je zapisao pop Dukljanin. Ta je legenda nadahnula Kačića Miošića da narodnim stilom spjeva Pismu od kralja Vladimira. (Nema podataka da li je pjesma o kralju Vladimiru bila u usmenoj komunikaciji prije Kačića.) Vjerojatno je Kačićeva pjesma prešla u usmenu komunikaciju, kako to navodi Maja Bošković-Stulli."

Tomislav Đurić je napisao i 2005. godine publicirao Legende puka hrvatskoga (Sto najljepših legendi i povijesnih priča iz hrvatske prošlosti) među kojima je predaja:

\section{KRALJ VLADIMIR I PRINCEZA KOSARA}

Počinjalo je deveto stoljeće od Kristova rođenja kada, nakon smrti oca Petrislava, sin njegov Vladimir, čije ime znači ,,miroljubivi vladar", preuzme po baštinskom pravu kraljevstvo Crvene Hrvatske. Mladi kralj držao se evanđeoskih riječi da neokaljanih ruku i srca ne pruža oružani otpor čak ni žestokom neprijatelju.

I dok je Vladimir uz odobrenje cijelog naroda mirno sjedio na svojem prijestolju, navali jedne godine bugarski car Samuel s velikom vojskom na Vladimirovu državu - Crvenu Hrvatsku, da bi podvrgao svojoj vlasti ove krajeve Dalmacije. Ali, kralj koji je bio svet čovjek i koji nije htio da itko od njegovih pogine u ratu čedno se ukloni i popne sa svim svojim narodom na brdo Oblik u njegov klanac Taraboš. Ali i tu ga zatekoše jadi. Na brdu bijaše ognjenih zmija od čijeg se ujeda odmah umiralo. Tad se kralj Vladimir pomoli Gospodinu Bogu sa suzama i Bog odagne zmije.

Car Samuel pošalje Vladimiru glasnike da sa svima svojima siđe s brda, ali kralj Vladimir ne pristade, zbog čega župan toga kraja u kraljevoj pratnji, poput izdajice Jude, pošalje Samuelu poruku da će mu predati Vladimira, car mu obeća veliko bogatstvo. Tada Vladimir odluči sam se predati i rekavši svojima: „Bolje je braćo da ja položim dušu svoju za sve vas i predam tijelo svoje da ga posijeku i ubiju, nego da se vi izvrgavate pogibli od mača i gladi." Sve ih pozdravi pozdravi i predade se caru koji ga pošalje u progonstvo i utamnjiči u svoj carski grad Prespu. Nakon toga car počne rušiti i paliti Dalmaciju te zapali gradove Dubrovnik i Kotor.

Kralj Vladimir je uzničke dane provodio u okovima posteći i moleći se Svevišnjem. Jedne noći pokaže mu se anđeo Gospodnji javljajući mu da će uskoro doći vrijeme njegove slobode.

${ }^{44}$ Marko Dragić, op. cit. Usp. Povijest hrvatske književnosti, knj. 1., napisale Maja Bošković-Stulli i Divna Zečević, Liber, Mladost, Zagreb, 1978., str. 72-74. 
Helena DRAGIĆ

I tako jednog dana kći cara Samuela, potaknuta i nadahnuta Duhom Svetim, pristupi ocu i zatraži od njega da siđe sa svojim služavkama i opere glavu i noge okovanim i zarobljenim, što joj otac dopusti. Gledajući tako i Vladimira i vidjevši da je lijep po izgledu, ponizan, blag i čedan, pun božanske mudrosti i veoma dostojanstven, zadrža se i porazgovara s njim. Činilo joj se da mu je govor slađi od meda i saća. Stoga, sažalivši se nad sudbinom tako vrijedna zarobljenika zavolje Vladimira i zažuđe ga tajnom pomisli sebi za muža.

Kada se Kosara vratila iz tamnice, baci se ocu pred noge i stane ga moliti: „Oče moj i gospodaru, znam da ćeš mi dati muža, kako je običaj. Stoga sada, ako je po volji tvome veličanstvu, ili mi daj za muža kralja Vladimira, koga držiš u okovima, ili znaj da ću prije umrijeti, nego se udati za drugoga." Samuel pristane na zamolbu svoje jedinice princeze Kosare to veselije što je znao da je Vladimir kralj i da je potekao od kraljevskog roda.

Oslobodi ga iz okova, odjene ga u kraljevske haljine, dobrostivo ga pogleda i zagrli u očinski poljubac. Tada mu pred svim dvorjanicima obeća kćer Kosaru za ženu i proglasi ga kraljem i svojim zetom vrativši mu njegovo kraljevstvo.

I tako je kralj Vladimir živio sa svojim ženom Kosarom u svetosti i čistoći te vladao narodom u Božjoj pravednosti i strahu, sve dok ga na prevaru ne domami Samuelov nasljednik Vladislav. Vladimir sam izađe pred vojnike koji ga ubiše.

Ubrzo crkva proglasi Vladimira blaženim, a njegova žena Kosara, postavši redovnica, završi život kasnije - i sahraniše je do nogu muža njezinoga. ${ }^{45}$

\section{Smrt Vladislava}

Vladislav je zauzeo Vladimirovo kraljevstvo. Dok je jedne noći kod Drača objedovao za stolom, pojavi se pred njim čovjek nalik Vladimiru i s mačem u ruci. Vladislav se poplaši, stane dozivati vojsku: „Dotrčite, moji vojnici, dotrčite, i branite me, jer me Vladimir hoće ubiti.“ Rekavši to, ustao je sa stolice i htio pobjeći, ,ali odmah udaren od anđela pao je na zemlju i umro tijelom i dušom". Svi su se njegovi prvaci i vojnici preplašili i odmah zapalili vatru po šatorima i razbježali se. ${ }^{46}$

${ }^{45}$ Tomislav Đurić, Legende puka hrvatskoga (Sto najljepših legendi i povijesnih priča iz hrvatske prošlosti), Meridijani, Samobor, 2005, str. 18-19.

${ }^{46}$ Ivan Mužić, op. cit., str. 195. 
Dukljanski kralj sveti Vladimir u hrvatskoj književnosti i crnogorskoj tradiciji

\section{Duklja nakon Vladimirove smrti}

Kad je za to čuo Vladimirov stric Dragimir, s mnoštvom vojske krenuo je povratiti staro kraljevstvo. Stigao je u Kotorski zaljev, te naredio narod prebaciti preko tjesnaca. Kotorani su pripremili čamce i u znak gostoprimstva donijeli mu u izobilju kruha, vina i svakojake hrane, te su ga čamcem prebacili na otok Sveti Gabrijel. Dok se pripremala gozba, Kotorani su vidjeli da je njih mnogo, a sa carem je malobrojna vojska i da mu nitko s kopna ne može doći u pomoć. Međusobno su razgovarali: „Bugarski je car mrtav, i mrtvi su kraljevi ove zemlje; on je jedini preostao od njihove loze. Ako on poživi i dobije zemlju, neće nam biti dobro, jer će nas tlačiti kao što su nas tlačili drugi kraljevi koji su bili njegovi očevi i braća. Ubijmo ga dakle i više neće biti nikoga iz njihove loze koji bi tlačio i mučio nas i našu djecu. “47

Dok su sjedili gosteći se i napivši se vina skočili da ubiju cara, a on je ušao u crkvu i branio se mačem. Neki su se popeli na krov i, gađajući ga kamenjem i drvima, ubili ga. Potom su ušli u čamce i pobjegli, a narod, vidjevši što se dogodilo, vratio se svojim domovima.

Dragimirova žena nakon muževljeve pogibije s dvjema kćerima vraćala se svome ocu Ljutomiru, glavnom raškom županu. ${ }^{48}$ Budući je bila trudna, u Drinskoj županiji u mjestu Brusno rodila je sina Dobroslava, koji je odgajan u Bosni, te u Dubrovniku i ondje oženio nećakinju negdanjega bugarskoga cara Samuila, s kojom je izrodio pet sinova po imenu: Gojslav, Mihala, Saganek, Radoslav i Predimir. ${ }^{49}$

Doznavši za smrt bugarskoga cara Vladislava, grčki car Bazilije s mnogobrojnom vojskom pokori Bugarsku, Rašku, Bosnu, ${ }^{50}$ čitavu Dalmaciju i sve primorske oblasti. Dobroslav je bio mudar i snalažljiv i ponašao se kao grčki saveznik, a potajno im je davao savjete da prema narodu budu okrutni. Narodu je, pak, govorio: ,Zašto podnosite tako veliko zlo od Grka? Nepravedno vam sude, ali odnose vam dobra, obljubljuju žene, vaše kćeri djevice obeščašćuju i sramote. Nikad vam nisu moji očevi, koji su bili kraljevi prije mene, činili takve stvari. To je veliko i teško zlo." Zbog toga ga je narod zavolio, a Grke žestoko zamrzio. Jednoga dana narod se dogovorio i pobunio pobivši sve grčke velikaše. Potom su poručili Dobroslavu da dođe i preuzme kraljevstvo svojih očeva. Dobroslav je došao sa svojim sinovima i počeo ratovati s Grcima, osvojivši zemlju sve do Aplize. To je ražestilo grčkoga cara, koji je pozvao svoga vojvodu Armenopola, i zapovijedio mu da napadne Dobroslava i njegove sinove. Grčka je vojska uspjela prodrijeti do zetske granice.

${ }^{47}$ Ivan Mužić, op. cit., str. 196.

${ }^{48}$ Mavro Orbini, op. cit., str. 290.

${ }^{49}$ Ivan Mužić, op. cit., str. 196.

${ }^{50}$ Mavro Orbini, op. cit., str. 288. 
Helena DRAGIĆ

Kralj Dobroslav je četvoricu sinova poslao u Vranje da ondje dočekaju grčku vojsku, a sa sinom Radoslavom sa zapada je napao Grke. Moćan i vješt Radoslav došao je do grčkoga zapovjednika, udario ga mačem i zbacio s konja. To je Grke uplašilo te su se nagnali u bijeg, pri čemu su mnogi izginuli. One koji su mislili da su spašeni, dočekali su kraljevi sinovi na istoku i poubijali ih. Tako je Dobroslavljevo kraljevstvo svakodnevno raslo. Kralj je sinu Radoslavu u znak njegovih zasluga dao županiju Gacko. ${ }^{51}$

Grčki car je raškom županu, bosanskom banu i helmanskom prvaku poslao izaslanike s mnogo zlata i srebra kako bi udarili na Dobroslavljevo kraljevstvo. Car je, također skupio mnogobrojnu vojsku kod Skadra i uputio ih prema kraljevstvu Dobroslavljevu. Prešli su rijeku i stigli na ravnicu kod Bara.

Dobroslav je vidio nadmoćnu vojsku, okupio je sinove i rekao im: „Vidite, najdraži sinovi, da je grčka vojska velika, a nas je u usporedbi s njima vrlo malo; oduprijeti im se bitkom, čini mi se nikako nismo u stanju. Zato ćemo postupiti ovako: dvojica od vas Gojslav i Radoslav, neka ostanu, a ostala trojica uzmite po desetoricu vještih s trubama i rogovima i uspnite se na brda i raširite po vrhovima brda, tako da se učini da su Grci u sredini. A ja ću s onima koji budu sa mnom usred noći navaliti na njihov tabor. A kad začujete zvuk trube i roga, vi slično tomu okolo s brda podignite buku iz truba i rogova i vičite iz sveg glasa. Poslije toga postupno siđite i približite se njihovu taboru, a kad budete blizu, nemojte se bojati, nego budite hrabri i muški se borite, jer će nam ih svemogući Bog predati u ruke. ${ }^{\text {“52 }}$

U Baru je živio prijatelj kralja Dobroslava i, htijući prestrašiti Grke, prišao grčkom zapovjedniku Kurziliju i rekao mu da pazi kako će se izvući jer je sa svih strana opkoljen mnoštvom. To se pročulo među grčkom vojskom i počela je vladati panika. Kralj je noću krenuo sa dogovorenim planom. Usred noći stigao je do grčkoga tabora i navalio na njih. To je Grke zbunilo, a kada su se začule trube, rogovi i galama sa svih strana, grčka je vojska bježala. Kralj i njegovi sinovi silno su udarili na Grke, pobivši ih i zarobivši mnogo. Gojslav u šumi nije od prašine i krvi prepoznao oca, udario ga je, ali ga nije ozlijedio jer ga je po glasu prepoznao. Tada je kralj stao na to mjesto i prozvao ga Božja Milost. ${ }^{53}$

Kurzilije je u bitci teško ranjen, ali je uspio doći u ravnicu grada Skadra, gdje je i umro. Na tom je mjestu postavljen križ koji se zove Kurzilijev križ.

\footnotetext{
${ }^{51}$ Ivan Mužić, op. cit., str. 196.

${ }^{52}$ Isto, str. 197. Usp. Mavro Orbini, op. cit., str. 293.

${ }^{53}$ Ivan Mužić, op. cit., str. 198.
} 
Dukljanski kralj sveti Vladimir u hrvatskoj književnosti i crnogorskoj tradiciji

Dobroslav je onom Baraninu dao veliku nagradu jer je uplašio Grke. Vladao je dvadeset pet godina. Umro je u Prapratni, u svojemu dvoru. Njegovi su se sinovi okupili, oplakali ga i pokopali u crkvi svetoga Andrije u njegovoj kapeli uz veliku čast i slavu.

Potom su se kraljevi sinovi sastali s majkom kraljicom i međusobno podijelili zemlje i oblasti svojih predaka. Poslije toga kraljica je s najstarijim sinom Gojslavom i ostalim sinovima vladala, ali se od njih nitko nije nazivao kraljem, nego su se nazivali knezovima. Međutim, kad je Gojslav ležao na bolesničkoj postelji, neki su ljudi iz Tribunije došli i ubili ga. Njegova brata Predimira uhvatili su i ubili, a za svojega poglavara izabrali su Domaneka.

Kad su za to čula preostala trojica braće otišli su u Tribuniju, uhvatili ubojice i pogubili ih najgorom smrću. Međutim, Domanek se uspio spasiti. U to je vrijeme kraljica umrla, a naslijedio ju je sin Mihala, koji je imao sedam sinova. $^{54}$

\section{Crnogorska tradicija o Vladimiru}

Mnogi su starozavjetni pisci ukazivali na značaj tradicijske kulture. Poticajne su poruke svetoga Pavla: „Prema tome, dakle, braćo, budite postojani i držite predaje kojima smo vas poučili bilo usmeno, bilo pismom! Naređujemo vam, braćo, u ime Gospodina, Isusa Krista, da se klonite svakoga brata koji neuredno živi i ne drži se predaje koju ste od nas primili.“ $\left(2\right.$ Sol 2, 15) ${ }^{55}$

Godine 2003. UNESCO je donio Povelju kojom se ukazuje na nužnost čuvanja nematerijalne baštine koja je osobito ugrožena i iznimno je važan čimbenik u očuvanju identiteta naroda.

Paradigmatske su i riječi Pape Ivana Pavla II.: „U ovim je krajevima, u kojima su se stoljećima susretali različiti svjetonazori, potrebno nastaviti zajedničko zalaganje za kulturu, ne upadajući u neplodna suočavanja, nego gajeći poštivanje i pomirbu. To pak ne znači da se zbog toga valja odreći vlastitog identiteta i kulture. Korijeni, baština i identitet svakog naroda, u svemu što im je istinski ljudsko predstavljaju bogatstvo za međunarodnu zajednicu.“

Život i djelo kneza Vladimira nedostatno su istraženi od strane povjesničara (neki ga u svojim djelima i ne spominju), ipak njegov kult među narodom i danas živi. Tomu svjedoče i predaje koje su i danas u usmenoj komunikaciji. Crnogorci i danas, gotovo tisuću godina nakon Vladimirove smrti, na Duhove ${ }^{56}$ iznose relikviju sv. Vladimira na vrh Rumije.

${ }^{54}$ Vidi: Ivan Mužić, op. cit., str. 197-201.

${ }^{55}$ Navodim prema: Marko Dragić, Poetika i povijest..., str. 7.

${ }^{56} \mathrm{Na}$ taj je dan Isus Krist svojim učenicima podario Duha Svetoga i tako im dao moć govora na više jezika kako bi mogli po svijetu propovijedati Kristovu vjeru. Duh Sveti je u središtu kršćanskoga postojanja. Po Ivanovu evanđelju „Duh je onaj koji oživ- 


\section{Zaključak}

Krajem 10. i početkom 11. stoljeća područje nekadašnje Duklje predmetom je stalnih pretenzija bugarske vojske. Dukljom je tada vladao mladi knez Vladimir, kojeg je bugarski car Samuilo na prijevaru pobijedio i zatočio u sužanjstvo. Samuilov je cilj bio prodor ka zapadu te pokoravanje Dalmacije i Duklje. Pohod bugarskog cara, te njegovo osvajanje Dalmacije i Duklje zapisao je svećenik iz Bara (Grgur Zadranin), poznat pod nazivom pop Dukljanin. On je u svome Ljetopisu iz 12. stoljeća, u kojem navodi kako je Vladimir bio hrabar i častan vladar, koji se zbog ljubavi prema svom narodu, ali i u želji da ga spasi, dobrovoljno predao neprijateljskoj vojsci cara Samuila.

Kralj Vladimir i njegova sudbina ostavili su dubok trag u narodnome pamćenju, a o čemu svjedoči i zapis lirske pjesme u Smokvici na Korčuli, kojom je narodni pjevač opjevao Vladimirovo sužanjstvo, njegovu ljubav sa Samuilovom kćeri Kosarom.

U njoj se spominje Vladimirovo sužanjstvo, vapaj nesretnoga kneza upućen majci, upoznavanje s Kosarom i na koncu Vladimir biva oslobođen tamnice, nakon punih devet godina. Zajedničko svim zapisima koji govore o Vladimiru jeste da se u svim spominje kako se Kosara, posjećujući tamnicu zaljubila u njega, te je molila Samuila, svojega oca da im dopusti brak. Samuilo je na to i pristao, te povratio Vladimiru upravu nad Dukljom.

Bitno je istaknuti kako je Vladimir i za života pokazivao svetačke moći. Katolička crkva Vladimira smatra blaženikom, dok ga je Pravoslavna crkva tek 1861. proglasila svetcem.

\section{Literatura}

- Botica, Stipe, Hrvatska usmenoknjiževna čitanka, Školska knjiga, Zagreb, 1995.

- Botica, Stipe, Narodni život, običaji i kultura Hrvata do svršetka srednjega vijeka, u: Lijepa naša baština, Portreti, Hrvatska sveučilišna naklada, Zagreb, 1998.

- Botica, Stipe, Biblija i hrvatska kulturna tradicija, Vlastita naklada, Zagreb, 1995.

- Dragić, Marko, Poetika i povijest hrvatske usmene književnosti (Fakultetski udžbenik) Filozofski fakultet Sveučilišta u Splitu, Split 2008. www.ffst.hr.

ljuje, a tijelo ne koristi ništa“. (Ivan, 6, 63) Po Duhu Uskrsloga Gospodina ,vjernici postaju jedno tijelo, jedan Duh u Kristu“. (Suvremena katolička enciklopedija, A-E, priredili Michael Glazier i Monika K. Helwing, Slobodna Dalmacija, Split., 2005., str. 244245.) 
Dukljanski kralj sveti Vladimir u hrvatskoj književnosti i crnogorskoj tradiciji

- Dragić, Marko, Književnost katoličke obnove i prvoga prosvjetiteljstva (Hrvatska barokna književnost), Filozofski fakultet Sveučilišta u Splitu, Split, 2006. www.ffst.hr

- Dragić, Marko, Ilirske teme u suvremenom narodnome pripovijedanju, „Osmišljavanja“ Zbornik u čast 80. rođendana akademika Miroslava Šicela, Sveučilište u Zagrebu, Filozofski fakultet, FF Press, priredio Vinko Brešić, Zagreb, 2007., 153-171.

- Đurić, Tomislav, Legende puka hrvatskoga (Sto najljepših legendi $i$ povijesnih priča iz hrvatske prošlosti), Meridijani, Samobor, 2005.

- Hitrec, Hrvoje, Hrvatske legende, Školska knjiga, Zagreb, 2007.

- Hrvatski leksikon, II. svezak, L-Ž, glavni urednik Antun Vujić, Naklada Leksikon d. o. o. Zagreb, 1997.

- Kačić Miošić, Andrija, Razgovor ugodni naroda slovinskoga, Matija Antun Reljković, Satir iliti divji čovik, (priredio Josip Vončina), Sveučilišna naklada Liber, Zagreb, 1988.

- Kekez, Josip, Usmena književnost, u: Škreb - Stamać Uvod u književnost, IV . poboljšano izdanje, Globus, Zagreb, 1986.

- Leksikon hrvatskih pisaca, autor koncepcije Krešimir Nemec, urednici: Dunja Fališevac (Starija hrvatska književnost), Krešimir Nemec (Novija hrvatska književnost), Darko Novaković (Hrvatski latinizam), Školska knjiga Zagreb, Zagreb, 2000.

- Leksikon ikonografije, liturgike i simbolike zapadnog kršćanstva $i$ Uvod u ikonologiju Radovana Ivančevića, priredio Anđelko Badurina, Kršćanska sadašnjost, Zagreb, 1990.

- Mužić, Ivan, Hrvatska kronika 547-1089, V izdanje, (preveo s latinskoga prof. Hraste Nečas Danijel - Filozofski fakultet Zadar), Marjan tisak, Split, 2002.

- Orbini, Mavro, Kraljevstvo Slavena, (priredio Franjo Šanjek), Zagreb, 1999.

- Povijest hrvatske književnosti, knj. 1, napisale Maja Bošković Stulli i Divna Zečević, Liber, Mladost, Zagreb, 1978.

- Suvremena katolička enciklopedija, A-E, priredili Michael Glazier i Monika K. Helwing, Slobodna Dalmacija, Split, 2005.

- Vitezović, Pavao Ritter, Život i mučeništvo blaženog Vladimira, hrvatskog kralja, u: Hrvatski latinisti II, Pisci 17.-19. Stoljeća, (ur. Rafo Bogišić), Zora i Matica Hrvatska, PSHK, Zagreb, 1970. 
Helena DRAGIĆ

\section{Helena DRAGIĆ}

\section{DOCLEAN KING ST. VLADIMIR IN THE CROATIAN LITERATURE AND MONTENEGRIN TRADITION}

The paper consists of ten chapters: 1. The Origin of the King Vladimir, 2. The Attack of the Tsar Samuilo on the Kingdom of the King Vladimir, 3. The Country Head's Betrayal of Vladimir, 4. The Slavery of Vladimir, 5. Vladimir and Kosara, 6. The Execution of Vladimir, 7. Vladimir in the Croatian Folk Literature, 8.The Death of Vladislav, 9. Doclea After the Death of Vladimir, 10. The Montenegrin Tradition About Vladimir.

Key words: Vladimir, Kosara, betrayal, slavery, execution 


\section{GRAĐA}



LINGUA MONTENEGRINA, god. III, br. 5, Cetinje, 2010.

Institut za crnogorski jezik i jezikoslovlje „Vojislav P. Nikčević“

UDK 821.163.4'373:21

821.163.4'373.22:58

Preliminarno saopštenje

\section{Vukić PULEVIĆ (Podgorica)}

Institut za crnogorski jezik i jezikoslovlje „Vojislav P. Nikčević“

\section{PRVA DOPUNA FITOTOPONIMIJI I ZOOTOPONIMIJI CRNE GORE}

Prilog sadrži fitotoponimsku i zootoponimsku građu (blizu 1000 toponima) sabranu nakon izlaska knjige Fitonimi $i$ zoonimi u toponimiji Crne Gore (PULEVIĆ V. \& SAMARDŽIĆ N. 2003). Korišćeni su literaturni izvori (dati u spisku literature) i podaci sakupljeni neposredno na terenu (posredstvom saradnika - informatora).

Ključne riječi: toponimija, fitotoponimija, zootoponimija, crnogorski jezik

Nakon izlaska knjige Fitonimi $i$ zoonimi u toponimiji Crne Gore (PULEVIĆ V. \& SAMARDŽIĆ N. 2003) pojavilo se nekoliko radova s bogatom toponomastičkom građom, na koje se mora skrenuti pažnja. Od njih je svakako najznačajniji Toponimija durmitorskog sela Crne Gore (CICMIL-REMETIĆ R. 2003).

Selo Crna Gora, u nekim slučajevima nazivaju ga i Mala Crna Gora, geografski je izrazito omeđeno. Smješteno je na „trouglastome platou“ koji zatvaraju kanjonske doline rijeka Tare i Sušice s dvije strane, a s treće ogranci Durmitora i Štuoca. Nalazi se na nadmorskoj visini od preko $1500 \mathrm{~m}$, a naseljeno je stanovništvom čiji su preci doseljavani iz drugih, obično bližih krajeva. Vjerovatno je to u početku bilo katunsko naselje, a tek poslije formiralo se selo u kojemu se živjelo cijele godine.

Značajno je da je toponime toga sela izučavala lingvistkinja Radojka Cicmil-Remetić, tako da se njena terenska istraživanja i naučna interpretacija sabrane građe moraju visoko vrednovati. Toponimske kategorije, prikazane u radu, obilježene su rednim brojevima od 1 do 663, ali je broj toponimskih jedinica znatno veći (date su zbirne kategorije: usov 11 toponima, pećina 10, dô $31 \mathrm{i}$ dr.).

Selo Crna Gora ima vrlo bogatu floru i vegetaciju, kao i faunu, na kojima je bazirana čitava privredna djelatnost tamošnjih stanovnika. Sve se to 
odrazilo i na toponimiju, na što je autorka u studijskome dijelu obratila posebnu pažnju izdvajajući poglavlja: Fitonimi, Zoonimi i Kulturni mikrotoponimi. Zanimljivo je i to da je prilog o toponimiji sela Crna Gora, drugi specijalistički rad te vrste iz śevernoga dijela Crne Gore, koji je napisao neki lingvista. Prije toga je objavljena studija MILIJE STANIĆA Uskočka toponimija (1988).

CICMIL-REMETIĆ R. 2003:326 konstatovala je ,visok stepen izvršenosti jekavskog i novog jotovanja“. Kao egzaktne dokaze navodi brojne primjere: Jovove ljestvi, Ljetnja ramena, Vrlino ljetište, Zvljerišta, Đević kamen, Međeđe ždrijelo, Gornji Međeđi dô, Donji Međeđi dô, Siđelica, Ćetkova ograda, Ćetkova ornica, Proćepovi, Beśedni dô, Śutraskal/Śstreska i dr. Autorka nije našla nijedan toponim koji bi, bilo na početku ili u sredini riječi, imao grupe $s j$ ili $z j$, čime je potvrđena apsolutnost jotovanja na području koje je istraživala. Ali kako je selo Crna Gora imigrantsko i predstavlja dio Pive (u širem smislu), a uz to se dugom veoma komunikativnom linijom graniči s Drobnjakom i pljevaljskim područjem, te činjenice idu u prilog kompaktnosti jekavskoga jotovanja na čitavome śevernom području države Crne Gore. Ta najbitnija karakteristika crnogorskoga jezika najbolje je potvrđena u toponimima kao fiksiranim dokazima. Zbog toga i pripada velika zasluga lingvistkinji RADOJKI CICMIL-REMETIĆ, koja je te zakonitosti objasnila i potvrdila na primjeru sela Mala Crna Gora, koje zauzima veoma izraženu geografsku, etničku i jezičku poziciju u koine sistemu crnogorskoga jezika.

CICMIL-REMETIĆ R. 2003:326 preko toponima Optovača indicirala je i jedan novi fitonim u crnogorskoj onomastici. Naglašava da je biljka ,ime

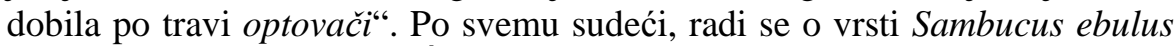
L., za koju je SIMONOVIĆ D. 1959:417 naveo narodni naziv optovina (za Kosovo i Metohiju, prema G. Elezoviću, 1932, 1933). U Crnoj Gori bili su poznati nazivi: aptovina, haptovina, aptovina, artovina, oftovina, rtovina, ali i ne optovača.

CICMIL-REMETIĆ R. 2003:326 pravi jedan samo na prvi pogled formalni propust, a koji je bitan sa stanovišta cjelovitoga objašnjavanja fitonima i fitotoponima. Ona koristi laički naziv trava za različite biljke: siljevina, čemerika, crijemuša, pa čak i za drvenastu vrstu somina. Nijedna od tih vrsta ne pripada familiji trava (Poaceae) u botaničkome smislu. Ti primjeri jasno pokazuju u kojoj mjeri toponomastika treba da ima multidisciplinarni prilaz, kako pri sabiranju građe tako i u interpretacijama

U uvodnome dijelu studije o toponimiji durmitorskoga sela Crna Gora CICMIL-REMETIĆ R. 2003:323\&328, bez povoda i potrebe ulazi u neka etnogenetska i konfesijska domišljanja. Ističe da u selu koje je izučavala ,žive pravoslavni Srbi“, zatim naglašava ulogu svetosavlja „,̌irom Srpstva“ ističući da mu je ,ishodište i žarište bilo na području Hercegovine i Crne Gore i 
Prva dopuna fitotoponimiji i zootoponimiji Crne Gore

da se ono širilo naporedo sa seobama“ (prema Ivanu Božiću, 1979). Da su lamentiranja te vrste bila suvišna, potvrđuje činjenica da autorka, u materijalu sabranome na terenu, kao i u naučnim interpretacijama, nije navela nijedan primjer koji bi potvrdio navedene konstatacije. No i takvi iskazi poslužiće kao svjedočanstvo o zlome vremenu kad je taj rad pripreman i publikovan (1998-2003), kao i o političkim koncepcijama izdavača koji je omogućio njegovo objavljivanje (SANU).

Etnogeografsku i istoriografsku monografiju sela Smriječno, koje se nalazi u Župi Pivi blizu Plužina, objavio je 2004. BOŽIDAR TADIĆ. U sastavu knjige nalazi se i respektabilna toponomastička građa, s preciznom ubikacijom toponima, a đe je to bilo moguće i etimologijom. Na primjeru toponima Koźakinje (Kođakinje - Kozjakinje) TADIĆ je preko glasa ź ukazao na tipično crnogorsko jotovanje i na probleme njegova grafemskog predstavljana u uslovima tada važećih jezičkih standarda.

Godine 2003. ĐORĐIJE M. OSTOJIĆ publikuje obimno djelo Toponimija Drobnjaka, u kojemu smo se sreli sa značajnom fitotoponimskom i zootoponimskom građom. Kako je pisac po struci geograf, to se nije bavio lingvističkim etimološkim tumačenjima, ali je zato dao precizne geografske odrednice, brojne legende, laička tumačenja i pretpostavke. Svi pomenuti parametri dobro će poslužiti lingvistima za dalju analizu te obimne građe, koju je OSTOJIĆ strpljivo sakupljao i tako spasio od zaborava i propadanja.

Značajnu onomastičku studiju jednoga dijela Vasojevića objavio je BOŽIDAR ŠEKULARAC 2008. Istraživanjima je obuhvatio područje Gornjih Sela, smješteno na istočnim ograncima planine Bjelasice, na prostoru oko planinskih rijeka Jelovice, Suvodola i Gunjare, koje su formirale rijeku Bistricu. Obuhvaćena su sela: Lubnice, Kurikuće, Glavaca, Bastahe, Vuča, Praćevac i Zagrad.

U Šekularčevoj knjizi kao posebna poglavlja prikazani su Toponimi Gornjih Sela i Antroponimi Gornjih Sela, a kao dopuna onomastičkoj građi dat je prilično opširan Leksikon starih i rijetkih riječi. Ukupno je navedeno više od 800 toponima, od kojih se nešto oko 200 može svrstati u grupu fitotoponima i zootoponima, računajući i one koji uopšteno oslikavaju stanje vegetacije ili njenu degradaciju (Gora, Rašće, Šuma, Lugovi, Lazina, Paljevina, Trebljevi i dr.).

Kako se toponomastička građa koju je B. ŠEKULARAC sabrao u Gornjim Selima od poodavno nalazi u kartoteci Onomastičkoga fonda Crnogorske akademije nauka i umjetnosti, to su njen fitonimski i zoonimski dio koristili PULEVIĆ V. \& SAMARDŽIĆ N. pri sastavljanju leksikona Fitonimi $i$ zoonimi u toponimiji Crne Gore (,003). I Pored toga u Šekularčevoj knjizi nađeno je 49 novih toponima koje kao dopunu unosimo u ovaj prilog. 
Da su glasovi ś i ź suštinska karakteristika crnogorskoga jezika i na prostoru Vasojevića potvrdio je ŠEKULARAC B. 2008:154. Za predio Gornjih Sela zabilježio je 39 riječi u kojima se nalazi glas ś (19 na početku riječi i 20 u sredini). Naveo je 6 riječi s glasom ź (jednom na početku riječi i 5 sredini). U Šekularčevu rječniku ne srijeće se nijedna riječ koja bi počinjala ,srpsko-hrvatskim“ dvoglaśem sj i zj. Na stranama 23, 28 i 30 ŠEKULARAC navodi toponime Sjenokos (2x) i Pajove sječine, ali to se može smatrati autorovim previdom, što potvrđuju izvorne riječi śenokos i śečivo, prikazane na str. 154 .

Onomastiku Vasojevića proučava i OSTOJIĆ M. 2001. Studija je sveobuhvatna i obimna, pisana s velikim multidisciplinarnim pretenzijama. Preko etimoloških i semantičkih objašnjenja, autor zalazi osim u jezičke još i u geografske, istorijske, etnogenetske i druge sadržaje. Iako ima dosta proizvoljnih i olakih zaključivanja, knjiga će za dugo predstavljati nezaobilaznu literaturu, ne samo za izučavanje crnogorskoga jezika, već i za niz drugih disciplina. Tako je zanimljivo tumačenje toponima Andrijevica, za koji M. OSTOJIĆ smatra da ima fitonimsku osnovu (od drijevo). Zanimljiv je navod toponima Hrast (u selu Petnjica), čime potvrđuje da je fitonim hrast zastupljen samo u śevernome dijelu Crne Gore. PULEVIĆ V. \& SAMARDŽIĆ N. 2003:165 naveli su 9 toponima s osnovom hrast (Hrast, Hrastova kosa, Hrastovača, Hrašće i dr.), zastupljenih u okolini Bijeloga Polja, Pljevalja i Rožaja, i dva na jugu Crne Gore: Podhrastić (Stanjevići iznad Budve) i Debeli hrast (Buronje u Lješanskoj Nahiji). Ostalo je da se prouči da nekim slučajem ti posljednji toponimi nijesu sekundarsnoga imenovanja, jer se radi o pojedinačnim stablima. Svojevremeno je lingvista Mitar Pešikan zapisao da riječ hrast nije karakteristika za Katunsku Nahiju. Da bi se taj problem do kraja izučio treba komparativno izučiti i brojne toponime tipa: Rast, Rastići, Rastovi doci, Rastovac i dr. U Crnoj Gori za neke vrste iz roda Quercus uobičajen je narodni naziv $d u b$, što potvrđuju hiljade toponima tipa: Dub, Dubrava, Dublje, Dubova gora, Dubovik i dr.

ALIJA DŽOGOVIĆ je prvi lingvista koji je ušao u onomastičke probleme svestrano složenoga plavsko-gusinjskog područja. Prvo je to uradio djelimično $(1983,1984,1986)$, kad je izučavajući toponimiju jugoslovenskoga dijela Prokletija zahvatio i područja Gusinja, Plava i Rožaja, da bi potom pripremio i 2009. publikovao kapitalno djelo Onomastika plavsko-gusinjske dijalekatske oblasti. Djelo je onomastički cjelovito - obuhvaćena je kako toponimija tako i antroponimija, i to za svako selo pojedinačno. Slično je za Gornja Sela u Vasojevićima uradio BOŽIDAR ŠEKULARAC (2008).

Toponime smo preuzimali i iz niza drugih knjiga i radova: DAŠIĆ M. 2008, ČIRGIĆ A. 2009, PELIČIĆ J. I.P. 1997, PEROČEVIĆ E. 2003, 
Prva dopuna fitotoponimiji i zootoponimiji Crne Gore

PEROVIĆ N.Đ. 2003, RAOSAVLJEVIĆ R. 1990 i dr. Značajnu građu dobili smo i posredstvom informatora, čiji je spisak priložen na kraju priloga.

$\mathrm{Ni}$ u ovome prilogu, kao ni u knjizi Fitonimi i zoonimi u toponimiji $\mathrm{Cr}$ ne Gore (PULEVIĆ V. \& SAMARDŽIĆ N. 2003), nijesmo se mogli upuštati u fitonimsku i zoonimsku identifikaciju preko latinskih naziva biljaka i životinja, po kojima su toponimi dobijali imena. Kao prepreka stoje brojni homonimi i sinonimi. Kao ilustraciju navodimo samo nekoliko fitonimskih primjera. Narodni naziv kukurijek u Crnoj Gori se veže za dvije vrste: Papaver rhoeas i Helleborus sp. Pa ako bi se sudilo po nekim fitoarealskim parametrima toponimi Kukurijek dolina (Jezera - Durmitor) i Kukurijekova dolina (Goranjsko - Piva) mogli bi se povezati s biljnom vrstom Helleborus odorus, a lokalitet Kukurijek (Donji Zagarač) za vrstu Papaver rhoeas.

Terenskim istraživanjima utvrđeno je da se fitonim kostrika u Crnoj Gori veže za dvije vrste: Ruscus aculeatus i Sesleria robusta, pa s te osnove treba razdvajati i toponime tipa: Kostrike, Kostrikova prodo, Kostrikovača i dr. U crnogorskoj flori ima 8 vrsta iz roda javor (Acer), a više stotina lokaliteta tipa: Javor, Javoprci, Javorak, Javorje i dr. S nazivom rakita na jugu Crne Gore (naročito u priobalnome slivu Skadarskoga jezera) označava se žbun Vitex agnus castus, a na śeveru naziv rakita se veže za neke vrste iz roda vrba (Salix sp.). Primjeri su zaista brojni, i fitogeografski se mogu raščišćavati samo strpljivim radom na terenu.

Na kraju da kažemo da autor ovog priloga ulaže velike istraživačke napore da spasi od zaborava nešto od crnogorske fitonimije i da izradi makar i redukovani rječnik narodnih naziva biljaka. Problemi su brojni, često i nepremostivi, na što je ukazano u jednome od prethodnih saopštenja (PULEVIĆ V. 2009:65-80).

Aluge - zaselak Oraha, Šekular. Vasojevići. (KASTRATOVIĆ R. 1966).

Aluge (Kao: Dô od Aluge) - u Obljaju. Banjani. (PEROVIĆ N. Đ. 2003:21). Aluge - u Obljaju. Banjani. (PEROVIĆ N.Đ. 2003:16).

Aluge kod Kaočine - u Brezovom dolu, Macavare. Banjani. (PEROVIĆ N. Đ. 2003:30).

Andrijevica - gradić u dolini Lima. Vasojevići. NAPOMENA: OSTOJIĆ M. 2001:209 tumači da je toponim Andrijevica složenica bazirana na „drijevo (= drvo)“.

Badljivi dô - pašnjak, Majstori. Njeguši. (ČIRGIĆ A. 2009:20).

Bak - zaravan, selo Rasova. Šaranci. „Nazvano po bukanju goveda“. (OSTOJIĆ M. Đ. 2003:179).

Baljin potok dio Međukuća, selo Dajbabe. Zeta. (I.: M. Knežević).

Bedevina bara - dolina, selo Vrela, jezera. Durmitor. „Najčešće je posjećuju konji kad su u sampasu“. (OSTOJIĆ M. Đ. 2003:312). 
Bedevina dolina - na dijelu Jezera koji pripada Komarskom kraju. Durmitor. (OSTOJIĆ M. Đ. 2003:179).

Bikova rupa - u Cucama. Katunska Nahija. (I: B. Jovanović).

Bjelostavica - u selu Srpska. Zeta. (PELIČIĆ J. I.-P. 1997).

Bobanovac - ,jedan vrh u planinskim prostranstvima Sinjajevine nazvat je Bobanovac. Kažu da je tu u travnatome dijelu uzvišenja rasla neka biljka koja je imala plodove bobičaste, kao plod boba“. Planina Sinjajevina. (OSTOJIĆ M. Đ. 2003:58).

Borak - u selu Petnjica. Vasojevići. (OSTOJIĆ M. 2001:308).

Boričke luke - u selu Glavaca, Gornja Sela. Vasojevići. (ŠEKULARAC B. 2008:26).

Borje - ,to je jedna, erozijom oplakana, okomita strana iznad Vajmeškog naselja i između Brda, Kremenjače, Konačina i Emirovića njiva. Toponim asocira na imenicu bor i svjedoči o nekadašnjoj borovoj šumi, koja je iskrčena, a zemlja privedena oranicama, gdje je najviše sijan ovas...“, selo Rovca, kod Berana. Vasojevići. (DAŠIĆ M. 2008:348). NAPOMENA: PULEVIĆ V. \& SAMARDŽIĆ N. 2003:43 za sliv Kaludarske rijeke i selo Rovca navode tri toponima: Borja $(1 \mathrm{x})$ i Borje $(2 \mathrm{x})$, te je moguća podudarnost naziva. Toponim Borje, predstavljen u ovom pregledu, dat je zbog Dašićeva prikaza degradacije vegetacije na imenovanom lokalitetu.

Borje ravno (kao: Ravno borje) - široka površ između Paljevina, Borovite ravni, Strana, Strančice i Krčevina, s livadama, gajevima, pasištima i oranicama. „Ime je dobila po borovoj šumi koja je davno iskrčena na širokoj zaravni“", selo Rovca, kod Berana. Vasojevići. (DAŠIĆ M. 2008:341).

Bljušturac Trivunov (kao: Trivunov bljušturac) - „dolina (u Gornjem selu) u kojoj raste bljuštur", selo Crna Gora. Durmitor. (CICMIL-REMETIĆ R. 2003:349).

Bor - „brdo na kome dominira stablo bora“, selo Crna Gora. Durmitor. (CICMIL-REMETIĆ R. 2003:349).

Borje aluško (kao: Aluško borje) - iznad sela Aluge. Šaranci. (OSTOJIĆ M. Đ. 2003:40).

Bornato ramo - ,izbočina obrasla borom (kanjon Tare)“, selo Crna Gora. Durmitor. (CICMIL-REMETIĆ R. 2003:366).

Borotulja - livada, selo Glavaca, Gornja Sela. Vasojevići. (ŠEKULARAC B. 2008:26. (Toponim neproziran).

Borovci - buk, selo Brijeg. Piva. (I).

Borove glave - ,predio dva brda, međusobno povezana jednom oranicom, obrasla borovom šumom... Borovi i sada dominiraju na prostoru oba brda“, selo Rovca, kod Berana. Vasojevići. (DAŠIĆ M. 2008:347). 
Prva dopuna fitotoponimiji i zootoponimiji Crne Gore

Borovi buk (kao: Buk Borovi) - u kanjonu Tare. (I).

Borovi//Borovi na Skiću - ,potesi na južnoj strani brda Skić (visoka borova šuma)“. Plav. (DŽOGOVIĆ A. 2009:348).

Borovi Ilije Radunovića na putu Dajbabe - Podgorica. (I: M. Knežević).

Borovi vrt - „teren prilično krševit, ali se ipak kosi“", selo Crna Gora. Durmitor. (CICMIL-REMETIĆ R. 2003:251).

Borovita ravan - ,plato iznad Strana. Nekada je tu bila borova šuma pa je iskrčena, najvjerovatnije za luč koji je služio za potpalu vatre i osvjetljavanja u domaćinstvu“, selo Rovca, kod Berana. Vasojevići. (DAŠIĆ M. 2008:341).

Borovlje - „predio više naselja Kućište (šuma u strani)““, selo Brezojevica. Plav. (A. DŽOGOVIĆ 2009:60).

Borovnički brijeg - na području sela Glavaca, Gornja Sela. Vasojevići. (ŠEKULARAC B. 2008:26).

Borovnjaci - na katunu Ravni. Komovi. (IBLB. 1966:25).

Borovo - u produžetku od područja Ivovca, selo Nedajno. Pivska Planina. (ŽARKOVIĆ LJ. 1999:18: ,područje je dobilo naziv po tome što je bilo obraslo borovom šumom koju su stanovnici postepeno iskrčili, i šumsko zemljište pretvorili u oranice").

Božurno brdo - ,jedno veće uzvišenje na lijevoj strani tarskog kanjona... O porijeklu imena brda nije ustanovljeno tačno, ali se pretpostavlja da je rastao božur, čiji se tragovi naziru, pa je to bio razlog što je narod brdu dao ime Božurno brdo“. Region Durmitora. (OSTOJIĆ M. Đ. 2003:41).

Brđanka - ,mikrotoponim ispod Mandića ... po legendi na tom mjestu je od groma poginula žena koja je bila iz crnogorskih brda“. Šaranci. (OSTOJIĆ M. Đ. 2003:80). NAPOMENA: brđanka je u nekim krajevima naziv za biljku Arnica montana L., koja u Crnoj Gori raste na padinama planine Ljubišnje. Ukoliko toponim Brđanka bude indikacija o zastupljenosti vrste brđanka, onda bi to predstavljalo i značajnu biljnogeografsku činjenicu.

Brestički dô - između sela Radeća i sela Ožezi. Piperi. (I: V. Filipović).

Brestova strana - ,jedna strana koja je eksponirana prema istoku i rijeci Tari ... obrasla je stablima brijesta“. Durmitor. (OSTOJIĆ M. Đ. 2003:104).

Brestovi - na Dajbapskoj gori, dio Stare gore, selo Dajbabe. Zeta. (I: M. Knežević).

Breza - zaselak sela Trepča. Vasojevići. (I: V. Novović).

Breze - u selu Petnjica. Vasojevići. (OSTOJIĆ M. 2001:308).

Breze - „potesi više sela (brezovik, brežđe)“, selo Budovice. Plav. (DŽOGOVIĆ A. 2009:114).

Brezova usov - „točilo oko kojega ima brezove šume“, selo Crna Gora. Durmitor. (CICMIL-REMETIĆ R. 2003:369). 
Brezovci - u selu Zagrađe. Vasojevići. (OSTOJIĆ M. 2001:286).

Brezovi dô - u selu Perovići. Banjani. (PEROVIĆ N.Đ. 2003:9).

Brezoviti laz - livadak opkoljen brezom i bukovinom u okviru šume zvane Buče, selo Rovca, kod Berana. Vasojevići. (DAŠIĆ M. 2008:339).

Brežđe - „,̌umoviti predio u strani više Lijevog Meteha“, selo Meteh. Plav. (DŽOGOVIĆ A. 2009:211).

Brijest Mučića (kao: Mučića briijest) - u selu Mataguži. Zeta. (PELIČIĆ J. I.-P. 1997).

Brijest Otašev (kao: Otašev brijest) - Lipovo, kod Kolašina. (RAOSAVLJEVIĆ R. 1990:328).

Brinje - kod Kolašina, „označava kleku (Juniperus communis)“. (RAOSAVLJEVIĆ R. 1990:328). NAPOMENA: ŚULEK B. 1879:32: „Brinje 1) Juniperus communis L. ... 2) Juniperus oxycedrus L...“. Simonović D. 1959:252 navodi još: brika, brin, brina i dr.

Brnjaševa dolina - u Mrčajevcu, Jezera. Durmitor. U dvije legende toponim se veže za konja brnjaša (jedan brnjaš mještanina Jakšića, a drugi brnjaš Smail-age Čengića). (OSTOJIĆ M. Đ. 2003:142).

Broćanac - livada, ravan teren, selo Crna Gora. Durmitor. (OSTOJIĆ M. Đ. 2003:350).

Brojila - ,jedan tjesnac na padinama Durmitora, vezano za izlazak na katun nazvat je Brojila ... čobani stoku prebrojavaju“. Durmitor. (OSTOJIĆ M. Đ. 2003:203).

Bršljan pećina - ,u tarskim vrletima ispod sela Šljivansko redaju se mnoge pećine i zapećci. Jedna od njih je nazvana Bršljan pećina. Obrasla je rastinjem bršljanom, zimzelenom, što je povod nazivu“. Šaranci. (OSTOJIĆ M. Đ. 2003:220).

Brštanovački buk - u kanjonu Tare. (I).

Buče - ,potes bukovih šuma od Potoka do Ravnog borja na lijevoj strani Rovačkog potoka. Toponim je izveden od imenice bukva. Ovaj oronim se javlja na više mjesta u seoskom ataru“, selo Rovca, kod Berana. Vasojevići. (DAŠIĆ M. 2008:341).

Buče - „predio više sela (šuma)“, selo Koljenoviće. Gusinje. (DŽOGOVIĆ A. 2009:487).

Buče - ,strane više sela (šuma)“, selo Hakanje. Plav. (DŽOGOVIĆ A. 2009: 370).

Buče - veliki kompleks bukove šume od Đorđijevića doline do Laza, selo Rovca, kod Berana. Vasojevići. (DAŠIĆ M. 2008:337).

Buče - u selu Petnjica. Vasojevići. (OSTOJIĆ M. 2001:308).

Bukova rupa - u selu Obljaj. Banjani. (PEROVIĆ B. Đ. 2003:21).

Bukova vlaka - vlaka koja se spušta od Crnog vrha prema rijeci Tari, obrasla bukvom. Durmitor. (OSTOJIĆ M. Đ. 2003:189). 
Prva dopuna fitotoponimiji i zootoponimiji Crne Gore

Bukovac - katun na planini Vučje. Kolašin. (KUJOVIĆ D. 2002).

Bukovac - izvor, selo Pitomine, Jezera. Durmitor. „Kako je došlo do naziva Bukovac nije sačuvano predanje, a vjerovatno je nekada izvirao ispod bukovih stabala“. (OSTOJIĆ M. Đ. 2003:285).

Bukove pećine - „više pećina na manjem prostoru u kanjonu Tare“, selo Crna Gora. Durmitor. (CICMIL-REMETIĆ R. 2003:363).

Bukovi dô - „to je stari naziv za gornji dio Smriječna koji se sad, kao zaselak, zove Dolovima. Odavno tu nema ni bukve, koja je, međutim, svuda iznad sela“, selo Smriječno. Piva. (TADIĆ B. 2004:291).

Bukovi gaj (Gaj bukovi) - ,potesi u strani na istočnom kraju sela (bukova šuma)“", selo Jesenica. Plav. (DŽOGOVIĆ A. 2009:166).

Bukovi izvor - izvor u katunu Krlje, selo Vrela, Jezera. Durmitor. „Izvor je izvirao ispod korijena stare debele bukve“. Durmitor. (OSTOJIĆ M. Đ. 2003:256).

Bukovi omar - lokalitet s bukovom šumom, selo Studenci. Šaranci. (OSTOJIĆ M. Đ. 2003:178).

Bukovice - šuma, Bostur (Lovćen). Njeguši. (ČIRGIĆ A. 2009:34).

Bukovo ramo - ,izbočina u obliku ramena, ravna, obrasla bukvom i sitnim rastinjem u kanjonu Tare", selo Crna Gora. Durmitor. (CICMIL-REMETIĆ R. 2003:366).

Bukva - „relativno ravan teren 'ograđen' gredama, ima poneko bukovo drvo“, selo Crna Gora. Durmitor. (CICMIL-REMETIĆ R. 2003:350).

Bukva - ,vrletan teren pod Crvenom stijenom, pogodan za ispašu koza“, selo Crna Gora. Durmitor. (CICMIL-REMETIĆ R. 2003:350).

Bukva debela (kao: Debela bukva) - izvor, selo Tepca. Durmitor. (OSTOJIĆ M. Đ. 2003:269).

Bukva crkovna (kao: Crkovna bukva) - u selu Kralje, Andrijevica. Vasojevići. Po legendi Kraljani su crkvene knjige, nakon paljenja crkve, smjestili u jednu staru bukvu. (OSTOJIĆ M. 2001:415).

Bukva Gajova (kao: Gajova bukva) - u Tisovcu, Macavare. Banjani. (PEROVIĆ N.Đ. 2003:23).

Bukva vodena (kao: Vodena bukva) - ,strana i veliko drvo (u kanjonu Sušice) koje je zadržalo vodu“, selo Crna Gora. Durmitor. (CICMIL-REMETIĆ R. 2003:350).

Bukve (kao: Podbukve) - ,strmina u kanjonu Sušice, potes do Široke usovi“, selo Crna Gora. Durmitor. (CICMIL-REMETIĆ R. 2003:364).

Buren (1785) - vrh iznad sela Bobovo. Pljevlja. (Tk-stara). NAPOMENA: PULEVIĆ V. \& SAMARDŽIĆ N. 2003:80 navode toponime: Burenj, Burenjski dô, Burev dô, Burjanik. (Toponimi su neprozirni - prikazani su radi komparacije). 
Busika - mikrolokalitet nedaleko od škole u selu Podgora. Durmitor. „Po njemu raste gusta trava koju narod naziva busika“. (OSTOJIĆ M. Đ. 2003:189).

Busnata kosa - kosa obrasla travom, uz Palež, Durmitor. (OSTOJIĆ M. Đ. 2003:98).

Busnati tok - „vrletan potes: u donjem delu usov, a u gornjem - borovina“, selo Crna Gora. Durmitor. (CICMIL-REMETIĆ R. 2003:369).

Ceransko - lokalitet na planini Zeletinu. Vasojevići. (OSTOJIĆ M. 2001: 339 ).

Cerova glavica - Cuce. Katunska Nahija. (I: B. Jovanović).

Cerova prodo - Gornje Koprivice. Banjani. (I: B. Koprivica).

Cikavac - velika i široka udolina, ostatak nekadašnjega cirka, selo Komarnica. Drobnjak. „Dobilo je naziv što rano niče trava, sa pojavom prvih kopnina ... Dakle, trava 'cikne' čim zemlja ugrije, okopni od snijega“". (OSTOJIĆ M. Đ. 2003:168).

Crijemuša - „strana obrasla travom 'crijemušom', reč je o travi koja likom podseća na divlje zelje, a mirisom na beli luk. Jede se kao salata“, selo Crna Gora. Durmitor. (CICMIL-REMETIĆ R. 2003:369). NAPOMENA: PULEVIĆ V. \& SAMARDŽIĆ N. 2003:87 navode toponim „Crijemuše - uz lijevu obalu rijeke Tare“. Vjerovatno se radi o istome lokalitetu, pa je toponim ponovljen radi izvornoga opisa biljke po kojoj je isti imenovan.

Crijemuša - pećina, prije Sige Jovovića, s lijeve strane. Kanjon Tare. (I).

Čajetina - „narod je nazvao zaselak zbog bogatstva trava i cvijeća. Brao je razne čajeve koje je koristio za liječenje“, zaselak, Gornja Bukovica. Drobnjak. (OSTOJIĆ M. Đ. 2003:333).

Čavkača - ,jedan od više vrhova na Visitoru (stijene u kojima ima čavki)“, selo Martinoviće. Gusinje. (DŽOGOVIĆ A. 2009:501).

Čečari Đuričini (kao: Đuričini čečari) - kosa iznad sela, selo Ninkovići, Jezera, Durmitor. (OSTOJIĆ M. Đ. 2003:91).

Čečarje (kao: Podčečarje) - ,grupa kuća naseljenim bratstvom Stevovića je locirana ispod padina koje su pokrivene čečarima“, Jezera. Durmitor. (OSTOJIĆ M. Đ. 2003:323).

Čečarje (kao: Podčečarje) - jedan od zaselaka sela Vrela, Jezera. Durmitor. „Zbog glavica koje su obrasle čečarima naziva se Podčečarje“. (OSTOJIĆ M. Đ. 2003:315). NAPOMENA: možda se radi o ponovljenom toponimu.

Čekale - iznad sela Ninkovića. Durmitor. (Mjesto đe je sačekivana divljač). (OSTOJIĆ M. Đ. 2003:192).

Čelina - ,gola litica, greda u kanjonu Tare“. Čeline - ,veliko kamenje, 'valovlje'. Tu ponovo 'izbija' ranije 'presušena' Sušica“, selo Crna Gora. 
Prva dopuna fitotoponimiji i zootoponimiji Crne Gore

Durmitor. (CICMIL-REMETIĆ R. 2003:370). NAPOMENA: zanimljivo je da autorka na str. 337 te toponime svrstava u grupu 'toponomastičke metafore': „Čelina - metafora po izgledu: čeona strana gole okomite litice“".

Čelina - ,,izvor između Paleža i susjedstva. Javlja se u čistom travnatom pristranku, istureno kao 'čelo čovjeka“, Jezera. Durmitor. (OSTOJIĆ M. Đ. 2003:291).

Čemernati pod - ,pod i lokva u Štuocu“, selo Crna Gora. Durmitor. (CICMIL-REMETIĆ R. 2003:364).

Čemernatice - ,doline u kojima raste trava 'čemerika', biljka širokog lista i gorkog ukusa, koju stoka ne jede", selo Crna Gora. Durmitor. (CICMIL-REMETIĆ R. 2003:370).

Česta - „ravna strana Golog vrga. Nekada je tu bila šuma, a sada - golet“, selo Crna Gora. Durmitor. (CICMIL-REMETIĆ R. 2003:370).

Čubrin krš - u Ozrinićima. Nikšićko polje. (PETROVIĆ D. 1966). NAPOMENA: PULEVIĆ V. \& SAMARDŽIĆ N. 2003:96 navode toponime: Čubra, Čubrača, Čubrin krš, Čubrice. Problemi ostaju otvoreni za dalja istraživanja.

Čučkuša - brijeg, zna se da je tu nekad bilo staro naselje, danas čak i bez ozidine. Risan. (SUBOTIĆ J. 1972). (Toponim nije objašnjen).

Čumna gora - ,u prošlosti su se dešavale čudne i čudnovate pojave. Naime, nestajali su čobani i stoka, često iznenada. Kažu da se javljala bolest kuga, ili kako se kaže čuma. To je bio povod da se šuma nazove Čumna gora“, u Gornjim Šarancima, pravcem prema kanjonu Tare. (OSTOJIĆ M. Đ. 2003:42).

Ćetna dola - „','razvaljena' dolina sa dosta 'dolaca' u planini sela Trse)“, Pivska planina. Trsa. (CICMIL-REMETIĆ R. 2003:327).

Ćetna poda - ,(nekoliko podova, pašnjak u Nedajnom)“", Pivska planina. Piva. (CICMIL-REMETIĆ R. 2003:327). NAPOMENA: za selo Nedajno PULEVIĆ V. \& SAMARDŽIĆ N. 2003:97 naveli su toponim Ćetna polja, što treba provjeriti na terenu (možda je u pitanju pogrešno upisani naziv).

Ćiperovo brdo - iznad Ćiperovače, Jezera. Durmitor. (OSTOJIĆ M. Đ. 2003:322).

Ćipur veli (kao: Veli Ćipur) (418 m) - u selu Grbavci. Zeta. (PELIČIĆ J. I.P. 1997:178).

Dafina - izvor, selo Lubnice, Gornja Sela. Vasojevići. „Dafina tur. drvo sa cvetom jakog mirisa " (cit. lit.). (ŠEKULARAC B. 2008:17\&56).

Dinjišta - u selu Ponari. Zeta. (PELIČIĆ J. I.-P. 1997).

Divl'aka - ,potes pored Lima (ovdje je dubok vir na vodi, vrtlog)“", selo Nokšiće. Plav. (DŽOGOVIĆ A. 2009:244). 
Drača - u selu Gostilje. Zeta. (PELIČIĆ J. I.-P. 1997).

Dračeva njiva - „u orahovskom distriktu“, selo Orahovac. Boka Kotorska. (ANTOLJAK S. 1979).

Dračevice - dio imanja sela Srpska (lokalitet devastirao Aluminijski kombinat). Zeta. (I: M. Knežević). NAPOMENA: PULEVIĆ V. \& SAMARDŽIĆ N. 2003:104 navode toponim Dračevice kao „pašnjak (sada vlasništvo KAP-a, selo Botun“. Treba provjeriti na terenu da li se radi o jednome ili dva lokaliteta (sela Botun i Srpska se graniče).

Drenova - ,potes u Pepićkom polju (livada pored rijeke)“, selo Pepiće. Plav. (DŽOGOVIĆ A. 2009:251).

Drenova gradina - u selu Obljaj. Banjani. (PEROVIĆ N.Đ. 2003:21).

Drenovi - ,potes na predjelu Dubrave (šuma)“, selo Nokšiće. Plav. (DŽOGOVIĆ A. 2009:244).

Drenovi dô - ,dolina u kojoj ima drenovog drveća“, selo Crna Gora. Durmitor. (CICMIL-REMETIĆ R. 2003:353).

Drenovice - na području današnjih Bratonožića. (Sa karte: ŠKRIVANIĆ G.: „Srednjovekovna Zeta“, 1952).

Drijenka - u Mrtvom dolu, selo Perovići, Macavare. Banjani. (PEROVIĆ N. Đ. 2003:10).

Drijenke - zaselak u Cucama. Katunska Nahija. (I: B. Jovanović).

Dub - iznad sela Previš. Drobnjak. „Radi se o brdu koje je karakteristično što se izdvaja usamljeno kao da stoji dupke ili uspravno i osmatra“" (OSTOJIĆ M. Đ. 2003:70).

Dub - brdašce u Donjem selu, ispod Pomoziboga, selo Smriječno. Piva. (TADIĆ B. 2004:298).

Dub - u selu Petnjica. Vasojevići. (OSTOJIĆ M. 2001:308).

Dub Ćetkov (kao: Ćetkov dub) - po legendi star je preko 500 godina. „Iz priča najstarijih stanovnika sela za ovo drvo vezane su brojne legende i pripovijedanja, poput one da je u njegovim čarima često uživao 'sveti' čovjek nastanjen u pećini na domak sela“, u selu Zagreda. Kuči. (Dan, Podgorica, br. 1693, 19. oktobar 2003, str. 24, Ćetkov dub - u selu Zagreda - fotografija: Mycologia Montenegrina, Podgorica, 5:211, 2002).

Dub šuti (kao: Šuti dub) - na Bjeloglavu, selo Radeća. Piperi. (I: V. Filipović).

Dublje - ispod Mramora, Obljaj. Banjani. (PEROVIĆ N.Đ. 2003:18).

Dubovici - u dolini Kraštice (lijeva pritoka Lima), selo Kralje. Vasojevići. (OSTOJIĆ M. 2001:101).

Dubranica - dubravice podno Laza, nekada obrađivane njivice, selo Mikulići. Bar. (PEROČEVIĆ E. 2003).

Dubrava (kao: Korjen Dubrava) - poviše Bijelog polja, Crmnička planina. Crnica. (I). 
Prva dopuna fitotoponimiji i zootoponimiji Crne Gore

Dubrave - ispod sela Šljivansko. Šaranci. (OSTOJIĆ M. Đ. 2003:156).

Dubrave - „veći predio istočno od naselja (šuma i utrina oko potoka - suhovare)“", selo Nokšiće. Plav. (DŽOGOVIĆ A. 2009:244).

Dubravice - Donja i Gornja Gorica. Lješkopolje. (PELIČIĆ J. I.-P. 1997).

Dubravice - stari naziv za lokalitet Stari śen, đe je bila crkva i veliko groblje, selo Balabani. Zeta. (PELIČIĆ J. I.-P. 1997).

Dumača - zaselak, selo Donja Bukovica. Drobnjak. (OSTOJIĆ M. Đ. 2003: $335)$.

Dumače - u selu Petnjica. Vasojevići. (OSTOJIĆ M. 2001:308).

Dupče - „kraj“ u selu Bukovica. Rožaje. (LUTOVAC M. 1960).

Duvaništa - strma i dosta pitoma uvlaka, u ataru Kupinjaka, na lijevoj padini rijeke Tare (predio Durmitora). „Nazvat po tom što se nekada u ovoj uvali sijao duvan i uspješno davao rod““. (OSTOJIĆ M. Đ. 2003:94).

Džanjevina - u selu Ponari. Zeta. (PELIČIĆ J. I.-P. 1997).

Džardin - dvorište ispred kuće Petrovića. Njeguši. (ČIRGIĆ A. 2009:57).

Džudžovača - u selu Lagatori. Vasojevići. (OSTOJIĆ M. 2001:327). NAPOMENA: PULEVIĆ V. \& SAMARDŽIĆ N. 2003:127 navode lokalitet: „Džudžova jama - u selu Stijena. Piperi. (džudžo=tvor). (I: R.J. Bracanović)“.

Eldovište - padine, Kovačev panj, Jezera. Durmitor. „Zbog oranja i sijanja elde (heljde) gdje je izuzetno dobro rađala, narod je mjesto nazvao Eldište“. (OSTOJIĆ M. Đ. 2003:396).

Encijan - kamp u kanjonu Tare. (I). NAPOMENA: toponim je novog imenovanja, nazvan od strane kampera, po biljkama iz roda Gentiana, koje u nekim alpskim zemljama imaju naziv encian.

Fijurina ,potes na predjelu sela (orničina, pašnjak na kojem raste paprat alb. fir)“", selo Nokšiće. Plav. (DŽOGOVIĆ A. 2009:247).

Fjerisht (kao: Gurra e Fjerisht) - ,izvor više zaseoka Gropa (u šumi, na potesu gdje raste paprat)“", selo Martinoviće. Gusinje. (DŽOGOVIĆ A. 2009:498).

Frba - izvor u selu Brijestovo. Bjelopavlići. (I: D. Kalezić).

Frba - „veći potes u zaseoku Zagrađe (livade i mjestimično šumica u kojoj rastu vrbe)“, selo Dosuđe. Gusinje. (DŽOGOVIĆ A. 2009:483).

Gačina prodo - „,duga usekotina i uvala u stenama u Štuocu“, selo Crna Gora. Durmitor. (CICMIL-REMETIĆ R. 2003:365). NAPOMENA: PULEVIĆ V. \& SAMARDŽIĆ N. 2003:129 navode toponime Gač polje (Banjani) i Gačkovica (Bajkove Kruševice na padinama Orjena). Toponimi su neprozirni ali navode na mogućnost ornitonimske osnove (gač = vrsta ptice).

Gaj (kao: Podgaj) - u ataru sela Šljivansko. Šaranci. (OSTOJIĆ M. Đ. 2003: 157). 
Gaj cerovi - ,potes 'niže Jerine mal'e' (Cerova šuma)“, selo Dosuđe. Gusinje. (DŽOGOVIĆ A. 2009:479).

Gaj Jakupovića (kao: Jakupovića gaj) - u selu Tucanje. Vasojevići. (OSTOJIĆ M. 2001:310).

Gaj veliki (kao: Veliki gaj) - u selu Petnjica. Vasojevići. (OSTOJIĆ M. 2001:308).

Gaja - ,(potes na Bezuju, nekada obrastao šumom. Tu je pradeda Bogdana Bajovića rođenog 1922. godine, našao 'lučevu krlju')“, selo Bezuje. Piva. (CICMIL-REMETIĆ R. 2003:327).

Gajevi - ,potesi niže Jerine male (šuma)“, selo Dosuđe. Gusinje. (DŽOGOVIĆ A. 2009:479).

Gajevi - ,potesi od zaseoka Derviševići do državne granice (šuma)“, selo Grnčar. Gusinje. (DŽOGOVIĆ A. 2009:393).

Gajevi - ,predjeli niže Crnog vrha (šuma)“", selo Jesenica. Plav. (DŽOGOVIĆ A. 2009:166).

Gajevi Sal'ića (kao: Sal'ića gajevi) - ,potesi više sela (šuma)“, selo Komarača. Plav. (DŽOGOVIĆ A. 2009:174).

Gajevi Tošića (kao: Tošića gajevi) - ,potesi u strani više sela (šuma)“, selo Komarača. Plav. (DŽOGOVIĆ A. 2009:174).

Gajevi (kao: Zagajevi) - u selu Tucanje. Vasojevići. (OSTOJIĆ M. 2001:309).

Gamarić - brdašce iznad mosta, na putu od sela Godinje prema selu Seoca. Crmnica. (na albanskom gamr=magare) (I: D. Leković).

Garišta - široki prostor u ataru Rta, Jezera. Durmitor. (OSTOJIĆ M. Đ. 2003:184).

Garištine - prostrana livada, selo Vrela, Jezera. Durmitor. „Često su stočari izazivali požare da bi sagorjela stara i ostarjela trava i rastinje ...". (OSTOJIĆ M. Đ. 2003:175).

Garištine - livade, selo Virak. Durmitor. „Naziv je vezan za paljenje trave pod jesen koje su ostale neopasene, da bi sljedećeg proljeća uzrasla gušća i pitomija trava“. (OSTOJIĆ M. Đ. 2003:153).

Garištine - dio sela Petnjica. Drobnjak. (OSTOJIĆ M. Đ. 2003:346).

Golubac - u reonu Savina Bora. Vasojevići. (OSTOJIĆ M. 2001:296).

Golubijerna - kula u staroj hercegnovskoj tvrđavi. Herceg Novi. (Republika, Podgorica, 22-24 jun, 2007, str. 9).

Golubnjača - česma, selo Previš. Drobnjak. Brdo iznad česme takođe se naziva Golubnjača. (OSTOJIĆ M. Đ. 2003:291).

Golubov izvor - u selu Bastahe. Vasojevići. (OSTOJIĆ M. 2001:439).

Golužba - Donja i Gornja Gorica. Lješkopolje. (PELIČIĆ J. I.-P. 1997).

Gora - više lokaliteta u selu Crna Gora na padinama Durmitora: Gornja Peradova gora, Jezička gora, (Jezič gora), Kusonjina gora, Pera- 
Prva dopuna fitotoponimiji i zootoponimiji Crne Gore

dova gora, Sirova gora, Stublinska gora. (CICMIL-REMETIĆ R. 2003:352).

Gora (kao: Crna Gora) - selo na padinama Durmitora. „Crna Gora je ime dobila po nekada gustoj, crnoj četinarskoj šumi. Valja istaći da okolina sela ni danas ne oskudeva u crnogorici“. (CICMIL-REMETIĆ R. 2003:323).

Gora čumna - v. Čumna gora.

Gora gusta (kao: Gusta gora) - na području Čifčija, Jezera. Durmitor. (OSTOJIĆ M. Đ. 2003:182).

Gora hotska (kao: Hotska gora) - ,potesi u strani više sela (šuma)“, selo Dosuđe. Gusinje. (DŽOGOVIĆ A. 2009:479).

Gora suha (kao: Suha gora) - „,brdo više sela (šuma)“, selo Jara. Plav. (DŽOGOVIĆ A. 2009:149).

Gora vel'ika - ,predjeli na planini više sela (šuma i livade)“", selo Budovice. Plav. (DŽOGOVIĆ A. 2009:114).

Gorje (kao: Nadgorje) - ,veći potes livada i dolina ispod Štuoca“ (sastoji se iz nekolika dijela: Veliko Nadgorje, Malo Nadgorje, Đokovo Nadgorje i Ivanovo Nadgorje), selo Crna Gora. Durmitor. (CICMIL-REMETIĆ R. 2003:361).

Gora (kao: Pod gorom) - u selu Srpska. Zeta. (PELIČĆIĆ J. I.-P. 1997).

Gora (kao: Sirova gora) - „i ovaj mikrotoponim je vezan za prostranstva Durmitora“. (OSTOJIĆ M. Đ. 2003:58).

Gora baračka (kao: Baračka gora) - katunište i četinarska šuma na śevernoj strani Barica ispod Javorka, Rovačka planina, selo Rovca, kod Berana. Vasojevići. (DAŠIĆ M. 2008:349).

Gora Radojeva (kao: Radojeva gora). - u selu Opasanica, ispod Komova. (IBLB. 1966:25).

Gora ravna (kao: Ravna gora) - uzvišenje između sela Bosače i Crnoga jezera, Durmitor. „Zbog zaravnjenosti i pokrivenosti gorom, narod je lokalitet nazvao Ravna gora“. (OSTOJIĆ M. Đ. 2003:62).

Gora sirovačka (kao: Sirovačka gora) - južne padine prema selu Sirovcu. Uskoci. (OSTOJIĆ M. Đ. 2003:398).

Gora stara (kao: Stara gora) - lokalitet u Dajbapskoj gori, Dajbabe. Zeta. (I: M. Knežević).

Gora srpska (kao: Srpska gora) - u selu Srpska. Zeta. (PELIČIĆ J. I.-P. 1997).

Gora vaganička (kao: Vaganička gora) - u selu Velika. Plav. (OSTOJIĆ M. 2001:471).

Gora velika (kao: Velika gora) - ,pretežno bukova šuma ispod Jastrebine, jugoistočno od glavnog smrčanskog izvora Korita“, selo Smriječno. Piva. (TADIĆ B. 2004:292). 
Gora Vučinića (kao: Vučinića gora) - „na prostorima Donje Bijele jedna šuma, ili gora, se naziva Vučinića“. Drobnjak. (OSTOJIĆ M. Đ. 2003:391).

Gore - ,gusta bukova šuma podno Ljute, što se spušta do desne obale Bukovičkog potoka od Bezdana do lučice Lug“, selo Smriječno. Piva. (TADIĆ B. 2004:295).

Gore ravne (kao: Ravne gore) - u selu Kurikuće, Gornja Sela. Vasojevići. (ŠEKULARAC. B. 2008:23).

Gorica - ,jedan od krajeva prostranog i lijepog sela Pošćenja se naziva Gorica ... porijeklo toponima je vezano za goru, lišćarsku šumu koja se nadurila iznad sela. Ona je uglavnom posječena ili zapaljena i pretvorena je u obradivo zemljište. Narod je na goru koja je nekada postojala sačuvao uspomenu preko naziva kraja Gorica“, selo Pošćenje. Drobnjak. (OSTOJIĆ M. Đ. 2003:348).

Gorilovac - šumovite kose. „Po kazivanju nekih mještana ime je uslijedilo po prostiranju ogromnih šuma ili gore, a po drugima po tom što su se javljali požari koji su uništavali šumu, gorele, to je logičnije“. selo Šljivansko. Šaranci. (OSTOJIĆ M. Đ. 2003:362).

Gorje (kao: Međugorje) - u selu Lagatori. Vasojevići. (OSTOJIĆ M. 2001: $327)$.

Govedarica - pećina u klisuri Ibra u kojoj goveda planduju („od Govedarice do Zel'enskog mosta sve sam išo uz Ibar"). Rožaje. (HADŽIĆ I. 2003:59). NAPOMENA: PULEVIĆ V. \& SAMARDŽIĆ N. 2003:144 naveli su toponim „Govedarica - vir u rijeci Ibru. Rožaje. (I)“. Vjerovatno se radi o istom lokalitetu s pećinom i virom.

Goveđa usov - „točila u pašnjaku“, selo Crna Gora. Durmitor. (CICMIL-REMETIĆ R. 2003:369). NAPOMENA: PULEVIĆ V. \& SAMARDŽIĆ N. 2003:147, za kanjon Sušice navode toponim Goveđi usov, vjerovatno s greškom, jer treba da stoji Goveđa usov, kako je to na terenu zabilježila R. Cicmil-Remetić.

Goveđac - u selu Mahala. Zeta. (PELIČIĆ J. I.-P. 1997).

Goveđac - lokalitet đe su napasali stoku, selo Mojanovići. Zeta. (PELIČIĆ J. I.-P. 1997).

Goveđaća - prostrani i dosta pitomi pašnjak (vlasništvo sela Previš), planina Ivica. Drobnjak. (OSTOJIĆ M. Đ. 2003:172).

Goveđe brdo - „,na nepreglednim prostranstvima Sinjajevine, u šaranskom dijelu, jedan lokalitet je nazvan Goveđe brdo“, Šaranci. (OSTOJIĆ M. Đ. 2003:56).

Goveđi bogaz - suženi, otežani prolaz od Jablan bare na Crvenu gredu (tuda su jedino mogla proći goveda). Durmitor. (OSTOJIĆ M. Đ. 2003:202). 
Prva dopuna fitotoponimiji i zootoponimiji Crne Gore

Goveđi laz - šumovito brdo iznad sela Murino. (Rodno mjesto književnika Radovana Zogovića). Vasojevići. (Jevrem Brković: Dnevnički zapisi, Vijesti, Podgorica, 7. januar, 2007, str. 15).

Grabi Stefanove (kao: Stefanove grabi) - ima graba. Iz te šume su se brali badnjaci. Brao se i zdravac, selo Ubli. Kuči. (I: B. Radonjić \& M. Rajković).

Grablje - „strane zarasle u grabovu šumu“, selo Crna Gora. Durmitor. (CICMIL-REMETIĆ R. 2003:353).

Grablje - u selu Petnjica. Vasojevići. (OSTOJIĆ M. 2001:308).

Grablje malo (kao: Malo grablje) - ,strane u kanjonu Tare ispod Muminske pržine i Muminske usovi“", selo Crna Gora. Durmitor. (CICMIL-REMETIĆ R. 2003:353).

Grablje veliko (kao: Veliko grablje) - ,strane u kanjonu Tare obrasle šumom (niže Božova ramena)“, selo Crna Gora. Durmitor. (CICMIL-REMETIĆ R. 2003:353).

Grabova prodo - ,po grabovima“, selo Obljaj. Banjani. (PEROVIĆ N. Đ. 2003:20).

Grabova ravan - u selu Lagatori. Vasojevići. (OSTOJIĆ M. 2001:327).

Grabovački most - blizu Rijeke Crnojevića. Ceklin. (Preuzeto iz TV serije).

Grabovi - lokalitet, Seoca kod Andrijevice. Vasojevići. (OSTOJIĆ M. 2001:214).

Grabovica - zaselak sela Trepča. Vasojevići. (I: V. Novović).

Gračevi - ,potesi na predjelu sela (livade, mještani kažu da su ime dobili po istoimenim pticama, kojih ovdje ima, a može biti i onomatopejskog porijekla i semiotike)“, selo Budovice. Plav. (DŽOGOVIĆ A. 2009:114).

Grahorica - u selu Petnjica. Vasojevići. (OSTOJIĆ M. 2001:308).

Graovina - prostrani lokalitet u ataru sela Šljivansko. Šaranci. (OSTOJIĆ M. Đ. 2003:182).

Grašište - u Starom Selu, Macavare. Banjani. (PEROVIĆ N. Đ. 2003:12).

Grkovača - kosa u širem području sela. „Postoji mišljenje da je naziv došao po tome što je trava koja raste po obroncima i padinama neukusna za pašu stoke, kako narod kaže da je grka“, selo Dubrovsko. Drobnjak. (OSTOJIĆ M. Đ. 2003:109).

Grkovo - katun na planini Sinjavini. Kolašin. (KUJOVIĆ D. 2002).

Grmočica - u selu Kurikuće. Vasojevići. (OSTOJIĆ M. 2001:450).

Grmožur - u selu Kurikuće. Vasojevići. (OSTOJIĆ M. 2001:450).

Gubavac - jedno od manjih uzvišenja, selo Donja Bukovica. Drobnjak. Dvije legende: 1) na tom mjestu su kupali oboljele od bolesti gube, krasta i 2) po uzvišenju je poslije kiša rasla vrsta pečurke koja je prekrivala travu (,,u ovom kraju se pečurka naziva guba“). (OSTOJIĆ M. Đ. 2003:75). 
Gubavičin dô - u Stubičkom Kraju, selo Stubica. Pješivci. (PETROVIĆ D. 1972).

Gubavički potok - kod Brštanovice, kanjon Tare. (I).

Gugutni dô - ,veća dolina, pašnjak sa malo kosanice“, selo Crna Gora. Durmitor. (CICMIL-REMETIĆ R. 2003:353).

Gvozd - ,prostrana, šumovita padina ispod Zabrđa, što se spušta do rječice Orašnice, desne pritoke Vbnice“, selo Smriječno. Piva. (TADIĆ B. 2004:294)

Gvozd (kao: Potok od Gvozda) - „veći potok i šumoviti predio oko njega više sela (šuma)“, selo Meteh. Plav. (DŽOGOVIĆ A. 2009:215-216).

Gvozdenače - u selu Bistrice. Zeta. (PELIČIĆ J. I.-P. 1997).

Hel'dine - ,potesi niže sela (livade; ovdje su nekada sijali heljdu, bile su livade $i$ hel'dišta)“", selo Kruševo. Gusinje. (DŽOGOVIĆ A. 2009:494).

Hrast - u selu Petnjica. Vasojevići. (OSTOJIĆ M. 2001:308). NAPOMENA: moguće je da je pomenuti toponim Hrast novijeg imenovanja. Naziv hrast za biljke iz roda Quercus je u Crnoj Gori veoma rijedak, a u južnom i srednjem dijelu čak i ne postoji. (Problem se može izučiti samo terenskim istraživanjima).

Ispašine - livade, selo Lubnice, Gornja Sela. Vasojevići. (ŠEKULARAC B. 2008:18).

Ive - „strana i ivova šuma u gornjem delu sela“, selo Crna Gora. Durmitor. (CICMIL-REMETIĆ R. 2003:355).

Ive - ,dolina u donjem delu sela“, selo Crna Gora. Durmitor. (CICMIL-REMETIĆ R. 2003:355).

Ive - lokalitet obrastao stablima ivova drveta. Šaranci. (OSTOJIĆ M. Đ. 2003:144).

Ivičje - „strane u Širokoj usovi obrasle šumom“, selo Crna Gora. Durmitor. (CICMIL-REMETIĆ R. 2003:355).

Ivov krš - kamenito uzvišenje blizu Gornjih poda, ispod Trogrle, selo Smriječno. Piva. (TADIĆ B. 2004:301).

Ivovac - izvor, selo Tepca. Durmitor. (OSTOJIĆ M. Đ. 2003:272).

Ivove strane - ,veći potes u kanjonu Tare, teren obrastao ivom i drugom belogoricom“", selo Crna Gora. Durmitor. (CICMIL-REMETIĆ R. 2003: 368).

Izgorela dola - ,(potes u planini Dondića i Vojinovića: 'kleka bila pa izgorela')“, Pivska planina. Piva. (CICMIL-REMETIĆ R. 2003:327).

Izjetnjak - „,danas su to prostrane livade i njive od nekoliko hektara i izuzetno plodne zemlje ...Ranije imanje u posjedu bratstva Simunovića kojega su kasnije zamijenili sa Manastirom za Bostane (Suvodanj)“, Goransko. Piva. (TADIĆ B. 2004:103). Informator Vukosav Dobrilović kaže da se naziv izgovara kao Izijetnjak. 
Prva dopuna fitotoponimiji i zootoponimiji Crne Gore

Jablan - „pećina“, na obali rijeke Moprače. Podgorica. (IČEVIĆ D. 2007:164). Jablan bara - bara kraj Sušičkoga jezera, selo Crna Gora. Durmitor. (CICMIL-REMETIĆ R. 2003:349).

Jablan dola - ,(dva potesa: više dolina kod Jablan vrga u Ercegovoj strani i tri doline na Trsi)“, Pivska planina. Piva. (CICMIL-REMETIĆ R. 2003:327). NAPOMENA: dopuna i ispravka toponima ,Jablan doli““ (PULEVIĆ V. \& SAMARDŽIĆ N. 2003:168).

Jablan dolina - travnata i prostrana dolina, selo Ninkovići. Durmitor. (OSTOJIĆ M. Đ. 2003:127).

Jablan mali (kao: Mali jablan) - ,pećina“ (=potkapina) uz obalu rijeke Morače. Podgorica. (IČEVIĆ D. 2007:164).

Jablanica - ,veći predio na planini više sela (smrčeva šuma, dio je i atara Budovice)“, selo Hakanje. Plav. (DŽOGOVIĆ A. 2009:370).

Jablanica (x2) - ,planinska kosa više sela; izvor na ovom predjelu“, selo Budovice. Plav. (DŽOGOVIĆ A. 2009:115).

Jabučnjak - u selu Šušunja. Zeta. (PELIČIĆ J. I.-P. 1997).

Jabuka - livada u Muratovici. „Priča se da je tu nekada davno rasla nekakva pitoma jabuka ispod koje su se okupljali kosci da u hladovini otkivaju kose“, selo Smriječno. Piva. (TADIĆ B. 2004:302).

Jabuka - glavica istočno od Dodoša, na kojoj su Dodošani držali stražu. Ceklin. (PELIČIĆ J. I.-P. 1997).

Jabuka - u selu Tucanje. Vasojevići. (OSTOJIĆ M. 2001:309).

Jabuka u Starom Selu, Macavare. Banjani. (PEROVIĆ N.Đ. 2003:11).

Jabukovci - u selu Perovići, Macavare. Banjani. (PEROVIĆ N.Đ. 2003:14).

Jagenčar - u regionu vrha Asanec, Andrijevica. Vasojevići. (IPLB 1966:25).

Jaginčar - ,potesi niže Konjskog krša (šuma)“, selo Grnčar. Gusinje. (DŽOGOVIĆ A. 2009:394).

Jaginice - u selu Gostilje. Zeta. (PELIČIĆ J. I.-P. 1997).

Jagnjila - mala zaravan s ostacima zidina na zapadnoj strani Koźaka, selo Mikulići. Bar. (PEROČEVIĆ E. 2003).

Jagnječar - „ravan predio na Visitoru (pašnjaci i šuma; ovdje su se jagnjile mal'isorske ovce prije doseljavanja današnjih stanovnika Brezojevice)“, selo Brezojevice. Plav. (DŽOGOVIĆ A. 2009:62). NAPOMENA: PULEVIĆ V. \& SAMARDŽIĆ N. 2003:177 taj toponim su označili kao Jagnjičar (1885).

Jagnjila u selu Lagatori. Vasojevići. (OSTOJIĆ M. 2001:327).

Jagnjilo - u selu Vrbica. Vasojević (OSTOJIĆ M. 2001:314).

Jagodljiva greda - na području sela Ośečenica. Grahovo. (I: Z. Vučurović).

Jagodnja dola - „(dve manje doline u Podmilogori)“. Pivska planina. Piva. (CICMIL-REMETIĆ R. 2003:327). 
Jagodnja dolina - „u Kovačevu Panju, gdje rađaju divlje jagode“, Njegovuđe. Šaranci. (OSTOJIĆ M. Đ. 2003:194).

Jagodnja dolina - ulegnuće između Rudanaca i Gomila. „Nekada je zemljište bilo pod šumom koja je sagorjela u požaru, a potom se javljaju bujne trave i šumske jagode. Ponovo je tlo obraslo šumom, ali je ostao naziv Jagodnja dolina“. Šaranci. (OSTOJIĆ M. Đ. 2003:126).

Jagodnjak - katun na planini Vučje, Donja Morača. Kolašin. (KUJOVIĆ D. 2002).

Jagodnjak - ,potesi više sela (livade i pašnjak; ima i divljih jagoda)“, selo Budovice. Plav. (DŽOGOVIĆ A. 2009:115).

Jajevac - nadomak sela Kovčice, Jezera. Durmitor. (OSTOJIĆ M. Đ. 2003: 111).

Jajevac - u ataru sela Godijelje. „oblik brda je jajast“. Drobnjak. (OSTOJIĆ M. Đ. 2003:37).

Jajna livada - u selu Glavaca, Gornja Sela. Vasojevići. (ŠEKULARAC B. 2008:27).

Jablanov dô - u Ravnoj Gori, Macavare. Banjani. (PEROVIĆ N. Đ. 2003:27).

Jalovina - u selu Bistrice. Zeta. (PELIČIĆ J. I.-P. 1997).

Jalovine - u selu Šušunja. Zeta. (PELIČIĆ J. I.-P. 1997).

Jančine - vrh iznad Zlatarica, Kuk (na Lovćenu). Njeguši. (ČIRGIĆ A. 2009:90). NAPOMENA: toponim Jančina postoji u selu Goranjsko, Piva (PULEVIĆ V. \& SAMARDŽIĆ N. 2003:182).

Japijska usov - strana u kanjonu Tare kuda se spuštala „građa“ ili ,japija“. (OSTOJIĆ M. Đ. 2003:210).

Jaradarica - „dobila je ime po jaradima, jer su ona u njoj zatvarana“, Tisovac, Macavare. Banjani. (PEROVIĆ N.M. 2003:24).

Jarčev dô - u selu Lagatori. Vasojevići. (OSTOJIĆ M. 2001:327).

Jareća pećina - u Krljama, Vrela. Durmitor. (OSTOJIĆ M. Đ. 2003:220).

Jarećak - jama, ,dobila ime po jaradima koja krepaju - uginu, pa se tu ubacuju“, selo Perovići, Macavare. Banjani. (PEROVIĆ N.Đ. 2003:15).

Jasen - „pećina“, na obali rijeke Morače. Podgorica. (IČEVIĆ D. 2007:164).

Jasen - prostrana travna oblast, selo Previš. Drobnjak. (OSTOJIĆ M. Đ. 2003:172).

Jasen Đuretića (kao: Đuretića jasen) - u Goveđem brodu, selo Mojanovići. Zeta. (PELIČIĆ J. I.-P. 1997).

Jasenica - njive i livade oko izvora Jasenica. „Po šumicama oko Jasenice još ima jasenova“, selo Smriječno. Piva. (TADIĆ B. 2004:302).

Jasenovi dô - „u orahovskom distriktu“, selo Orahovac. Boka Kotorska. (ANTOLJAK S. 1979).

Jasici - na južnim padinama prema selu i rijeci Tušinji. Uskoci. (OSTOJIĆ M. Đ. 2003:101). 
Prva dopuna fitotoponimiji i zootoponimiji Crne Gore

Jasik - na istočnim padinama Ćiperovače, Jezera. Durmitor. (OSTOJIĆ M. Đ. 2003:105).

Jasika//Jasike -,,strane obrasle šumom i jasikom i jelom“, selo Crna Gora. Durmitor. (CICMIL-REMETIĆ R. 2003:356).

Jasike - zaselak sela Vrela, ispod padina Kovačeva panja, Jezera. Durmitor. (OSTOJIĆ M. Đ. 2003:314).

Jasike - u najnižem dijelu Krlja prema Orašcu, kompleks pasišta obrastao jasikom, Jezera. Durmitor. (OSTOJIĆ M. Đ. 2003:381).

Jasikovac - jedan od rijetkih izvora na području pasišta Krlje, selo Vrela, Jezera. Durmitor. (OSTOJIĆ M. Đ. 2003:267).

Jasikovica - u selu Petnjici. Vasojevići. (OSTOJIĆ M. 2001:308).

Jaslišta - u selu Kurikuće, Gornja Sela. Vasojevići. (ŠEKULARAC B. 2008:21).

Jastrebova kosa - ,Jastrebova kosa se nazvala po tome što se na njoj sreću ptice jastrebovi“, selo Rasova. Šaranci. (OSTOJIĆ M. Đ. 2003:91).

Jastrebova ravan - šumoviti i stjenoviti prostor, podno šaranskih sela, prema rijeci Tari. ,Zbog okruženja i čestih pojava jastrebova koji su kružili i vrebali da se približe selu, udare u kokoši, narod je mikrotoponim nazvao Jastrebova ravan“. Šaranci. (OSTOJIĆ M. Đ. 2003:174).

Javor - ,ravniji teren, pašnjak na kome rastu javor, bor, smrče. Tu izvire Sušički potok na kome je nekada bilo dvanaest vodenica, a sada - jedna“, selo Crna Gora. Durmitor. (CICMIL-REMETIĆ R. 2003:356. NAPOMENA: dopuna opisa toponima ,Javor - izvor u kanjonu Sušice, ispod Sušičkog jezera. Durmitor. (L.)“ (PULEVIĆ V. \& SAMARDŽIĆ N. 2003:199).

Javor - ,potesi na predjelu sela (livade i šuma u kojoj raste drvo javor)“, selo Budovice. Plav. (DŽOGOVIĆ A. 2009:115).

Javor Raonića (kao: Raonića javor) - u selu Gornja Vrela, Jezera. Durmitor. (OSTOJIĆ M. Đ. 2003:133).

Javoračka dolina - na jugoistočnoj strani Javorka-planine. „Danas tu gotovo i nema javora ...", Rovačka planina, selo Rovca, kod Berana. Vasojevići. (DAŠIĆ M. 2008:331).

Javorak - „planinski predjeli prema mjestu Kuti (šuma i pašnjaci)“, selo Grnčar. Gusinje. (DŽOGOVIĆ A. 2009:394).

Javorci - na padinama uz rijeku Tušinju. Uskoci. (OSTOJIĆ M. Đ. 2003: 101).

Javori - lokalitet orijentisan prema rijeci Tari, s debelim i razvijenim stablima javora. Šaranci. (OSTOJIĆ M. Đ. 2003:99).

Javorike - ,potesi više sela (šuma)“, selo Budovice. Plav. (DŽOGOVIĆ A. 2009:115). 
Javorke - katun iznad Crne Rupe, prema Crnoj planini. Kuči. (I: D. Vuksanović). NAPOMENA: Dopuna sinonimnom toponimu: PULEVIĆ V. \& SAMARDŽIĆ N. 2003:202: „Javorci - brijeg na planini Mokroj. Kuči. (I,L)“.

Javorje - ,predjeli niže planinskog vrha Starac (zapadna ekspozicija; visoka šuma)“, selo Meteh. Plav. (DŽOGOVIĆ A. 2009:213).

Javorovi dô - u selu Obljaju. Banjani. „Dobio ime po javorovoj šumi koja je tu rasla“. (PEROVIĆ N.Đ. 2003:18).

Javorovice - ,velika strana u kanjonu Sušice obrasla borovom šumom“, selo Crna Gora. Durmitor. (CICMIL-REMETIĆ R. 2003:356).

Javorovice (kao: Vrata od Javorovica) - ,uzak prolaz, ulaz u Javorovice; tuda se ujavljuju ovce u kanjon Sušice“, selo Crna Gora. Durmitor. (CICMIL-REMETIĆ R. 2003:351).

Javorska gora - ,veći predio istočno od Desnog Meteha (šuma po brdu; dio potesa pripada i susjednom selu Jara)“, selo Meteh. Plav. (DŽUDOVIĆ A. 2009:212).

Ječmine u selu Ośečenica. Grahovo. (I: Z. Vučurović).

Jela - ,prostor oranica okružen bukovom šumom. Odavno tu jele nema, ali se zna da je u ranijoj prošlosti bilo ovdje jelove šume koja je iskrčena“, selo Rovca, kod Berana. Vasojevići. (DAŠIĆ M. 2008:337).

Jela krnja (kao: Krnja jela) - ,travnato točilo, a pri vrhu - pločast teren“, selo Crna Gora. Durmitor. (CICMIL-REMETIĆ R. 2003:356).

Jela suva (kao: Suva jela) - jedno neveliko uzvišenje u šumovitom dijelu Ledenice, ispod Trogrle, selo Smriječno. Piva. (TADIĆ B. 2004:333).

Jelav - katun na planini Bjelasici (izdižu iz sela Podbišća i Bjelojevića). (KUJOVIĆ D. 2002:98).

Jele - u selu Zagrađe. Vasojevići. (OSTOJIĆ M. 2001:286).

Jelen dô - u Paštrovskoj planini. (I).

Jelenča - u selu Tucanje. Vasojevići. (OSTOJIĆ M. 2001:309).

Jeleni krš - u selu Tucanje. Vasojevići. (OSTOJIĆ M. 2001:309).

Jelice - „veći potes, strane u kanjonu Tare obrasle jelovom šumom“, selo Crna Gora. Durmitor. (CICMIL-REMETIĆ R. 2003:356).

Jelići - „potes, glavica poviše kuće Mumina. Sada tu nema nikakve šume“, selo Crna Gora. Durmitor. (CICMIL-REMETIĆ R. 2003:356).

Jeliča - pašnjak i livada. „Toponim Jeliče izveden je od četinarskog drveća jele, koje je vremenom iskrčeno, ali tragova jele i danas ima na ovom terenu“", Rovačka planina, selo Rovca, kod Berana. Vasojevići. (DAŠIĆ M. 2008:354).

Jelin smet - ,strane obrasle četinarskom šumom“, selo Crna Gora. Durmitor. (CICMIL-REMETIĆ R. 2003:367). 
Jelovačka glava - ,na domak Konata“. Šaranci. Pokriveno jelovom šumom. (OSTOJIĆ M. Đ. 2003:59).

Jelovina mala (kao: Mala jelovina) - ,šumski pojas iznad smrčanskog dijela Ljuti, prema Jarčištima. Nekada je to bila čista jelova šuma, a sada je izmiješana sa bukovinom i drugim listopadnim drvećem“, selo Smriječno. Piva. (TADIĆ B. 2004:313). NAPOMENA: Dopuna toponima „Jelovina (Mala i Velika) - šuma obrasla jelovinom, selo Smrijećno. Piva. (I)“ (PULEVIĆ V. \& SAMARDŽIĆ N. 2003:219).

Jerebice - „strane, veći potes, livade“, selo Crna Gora. Durmitor. (CICMIL-REMETIĆ R. 2003:357). NAPOMENA: PULEVIĆ V. \& SAMARDŽIĆ N. 2003:184 toponim su označili kao ,Jarebice - lokalitet istočno od Male Crne Gore. Durmitor. (Tk)“ Treba uvažiti naziv Jerebice koji je na terenu zabilježila R. Cicmil-Remetić. Inače, na nekim prostorima južnoga dijela Crne Gore, npr. u Piperima, dominantan je naziv jerebica (vrsta ptice).

Ješevik - „gornji dio sela Završ (ovdje rastu johe, johovo drveće)“. Plav. (DŽOGOVIĆ A. 2009:126).

Joe - ,potes na predjelu sela pored Lima (ovdje rastu johe, johovo drveće; u govoru ovog mjesta fonema $h$ se gubi u svim pozicijama, nije karakteristika lokalnog govora pravoslavnih stanovnika)“, selo Nokšiće. Plav. (DŽOGOVIĆ A. 2009:244).

Jofita dol'ina - ,predio istočno od Desnog Meteha (lazina u većoj uvali)“, selo Meteh. Plav. (DŽOGOVIĆ A. 2009:212).

Johe - ,potesi na predjelu sela (šumica)“, selo Kruševo. Gusinje. (DŽOGOVIĆ A. 2009:492).

Joša - ,potesi više naselja (istočno; pašnjaci)“, Malo Selo. Plav. (DŽOGOVIĆ A. 2009:208).

Joše - u selu Lagatori. Vasojevići. (OSTOJIĆ M. 2001:327).

Jova voda - izvor s koritom, na putu Rovca - Donja Ržanica, Berane. Vasojevići. (DAŠIĆ M. 2009:337).

Kalačka glavica (kao: Velja Kalačka glavica) - vis na brdu Kaznovica, iznad Mataruga. Piperi. Mala Kalačka glavica - ispod Velje Kalačke glavice, Kaznovica. Piperi. (I).

Kaloperov val - izvor, selo Komarnica. Drobnjak. „Val se nalazi gdje raste cvijeće, a vjerovatno je rastao i kaloper, pa se po njemu nazvao val i izvor“. (OSTOJIĆ M. Đ. 2003:258).

Kaludra - zaselak, selo Zagrad, Gornja Sela. Vasojevići. (ŠEKULARAC B. 2008:32).

Kaluđerovača - ,jedna od brojnih udolina koja je zatvorena okolnim vrhovima ... Po njoj raste cvijeće plave boje, javlja se rano u proljeće koje 
narod naziva 'kaluđer' pa je tako i dobila ime“. Drobnjak. (OSTOJIĆ M. Đ. 2003:173).

Kamenjača - u selu Lubnice, Gornja Sela. Vasojevići. Kamenjače - u selu Kurikuće. Vasojevići. (ŠEKULARAC B. 2008:18\&21). NAPOMENA: Toponimi nijesu objašnjeni. U literaturi postoji naziv kamenjača za vrstu paprati - Asplenium ruta muraria L. (SIMONOVIĆ D. 1959:57, prema Karlu Malyju - Bosna).

Kerina usov - „veliki odron u Javorovicama (do same reke Sušice)“, selo Crna Gora. Durmitor. (CICMIL-REMETIĆ R. 2003:369). NAPOMENA: PULEVIĆ V. \& SAMARDŽIĆ N. 2003:227 prikazuju toponim „Keranski vrt - na području katastarske opštine Vrbica (po kerovima). Oputna Rudina (Ko)“. Toponimi su neprozirni ali upućuju na mogućnost zoonimske osnove.

Kerovina - livada istočno od Dajbapske gpore. Podgorica (I: M. Knežević).

Klada prijeka (kao: Prijeka klada) - „strma strana obrasla klekom, tu je nekada bila šuma“, selo Crna Gora. Durmitor. (CICMIL-REMETIĆ R. 2003:357).

Kleče - u selu Tucanje. Vasojevići. (OSTOJIĆ M. 2001:309).

Klek crveni (kao: Crveni klek) - „dosta rasprostranjen lokalitet pokriven drvetom klekom“ (izostala preciznija ubikacija). Durmitor. (OSTOJIĆ M. Đ. 2003:74).

Klek veliki (kao: Veliki klek) - „veća strana ispod Velikog Štuoca, strana obrasla klekom“, selo Crna Gora. Durmitor. (CICMIL-REMETIĆ R. 2003:357).

Kleka - ,strm teren pod Jelicama“, selo Crna Gora. Durmitor. (CICMIL-REMETIĆ R. 2003:357).

Kleke - ,veći potes, strane po kojima ima kleke“, selo Crna Gora. Durmitor. (CICMIL-REMETIĆ R. 2003:357).

Klekovi pod - ,prostrana zaravan na ne baš ravnom zemljištu u ataru sela Tušinje, obraslo je zemljište klekom toliko da je skoro nemoguće proći“. Uskoci. (OSTOJIĆ M. Đ. 2003:185).

Kl'eča - „strana više sela (pašnjak)“, selo Bogajiće. Plav. (DŽOGOVIĆ A. 2009:29).

Kl'eča barice - „barljiv predio više sela (po stranama predjela rastu kleke)“, selo Bogajiće. Plav. (DŽOGOVIĆ A. 2009:27).

Kl'eka - ,potesi na planini Bor (pašnjaci)“, selo Kruševo. Gusinje. (DŽOGOVIĆ A. 2009:492).

Kl'eke - „potes na predjelu zaseoka (mahale) Bojovići (l'edine niže puta)“, selo Grnčar. Gusinje. (DŽOGOVIĆ A. 2009:394). 
Prva dopuna fitotoponimiji i zootoponimiji Crne Gore

Kl'ekoviti las (kao: Las kl'ekoviti) - „potes niže Trojana (blizu državne granice; pašnjak i kljeka)“, selo Grnčar. Gusinje. (DŽOGOVIĆ A. 2009:395).

Klen - u Mrtvom dolu, selo Perovići, Macavare. Banjani. (PEROVIĆ N.Đ. 2003:11).

Kobila - na području sela Vusanje. Gusinje. (OSTOJIĆ M. 2001:504).

Kobilara//Kobileća glava - v. Kobileća glava//Kobilara

Kobileća glava//Kobilara - „brdo i strana u Štuocu“, selo Crna Gora. Durmitor. (CICMIL-REMETIĆ R. 2003:352).

Kobileća vlaka - strana na Kobilari, selo Crna Gora. Durmitor. (CICMIL-REMETIĆ R. 2003:351).

Kobilovac - brdo, planina Ivica iznad Šavnika. Drobnjak. (OSTOJIĆ M. Đ. 2003:61).

Kočine - baština, livade, selo Dugi Dô. Njeguši. Kočine - kamenjar, pašnjak, selo Erakovići. Njeguši. (ČIRGIĆ A. 2009:104). NAPOMENA: PULEVIĆ V. \& SAMARDŽIĆ N. 2003:234 navode toponim „Kočine - zapadno od Koljena i Bogaje. Rožaje. (Tk)“. Toponimi su neprozirni.

Kočište - u selu Paprati (Cerovo). Pješivci. (I: B. Nikčević).

Kođa glava - u Pošćenskom kraju ispod Durmitora. (OSTOJIĆ M. Đ. 2003:48).

Kođača - „mikrotoponim je vezan za naselje Stijena, povrh kojeg se pruža prostrani udut nazvan Kođača“. (Vjerovatno u Šarancima ?). (OSTOJIĆ M. Đ. 2003:80).

Kokošiji pod - „manja zaravan na Kljunku“, selo Crna Gora. Durmitor. (CICMIL-REMETIĆ R. 2003:364).

Kolovozi - ,ime je dobilo po stazama kuda je za vrijeme kiše tekla voda i ostavljala duboke tragove. Tuda se provozilo (vuklo) i ogrijevno drvo“, selo Rovca, kod Berana. Vasojevići. (DAŠIĆ M. 2008:337).

Koljenac (945) - istočno od sela Glisnice. Pljevlja. (Tk). NAPOMENA: Toponim nije objašnjen. U literaturi se srijeću (sa širega područja) narodni nazivi nekih biljnih vrsta: koljenka, kolenac, kolenka i dr, tako da se može pretpostaviti i mogućnost fitonimske osnove toponima Koljenac.

Konopljište Šerovo (kao: Šerovo konopljište) - na istočnim padinama $\mathrm{Cr}$ noga vrha, Jezera. Durmitor. (OSTOJIĆ M. Đ. 2003:82). (Na drugom mjestu iste knjige, str. 53, stoji ubikacija: ,ispod Pilitora“).

Konski ulaz - na rijeci Morači, između Ljubovića i Kruševca. Podgorica. (I: M. Knežević).

Konj (kao: Podkonj) - dosta prostrana zaravan livadskog tipa ispod sela Palež, Jezera. Durmitor. „Zbog položaja livade, jer je niže kose gdje su konji pripinjati, nazvana je Pod konj“. (OSTOJIĆ M. Đ. 2003:124). NAPOMENA: PULEVIĆ V. \& SAMARDŽIĆ N. 2003:240 navode to- 
ponim „Konj (1390) - uz Tepačko polje, na pravcu Žabljak - Ninkovići, Jezera. Durmitor. (I,Tk)“. Vjerovatno su pomenuti toponimi povezani (Konj i Podkonj).

Konjoder - na Veljem Rebrčniku, iznad Vukotica. Bjelopavlići. (I). NAPOMENA: PULEVIĆ V. \& SAMARDŽIĆ N. 2003:241 navode toponim „Konjoder - zabran, livada, selo Gostilje. Bjelopavlići. (L)“. Pošto se planina Rebrčnik i selo Gostilje nalaze u suśedstvu, treba na samome terenu provjeriti da li se radi o jednome ili dva lokaliteta.

Konjska stopa - u selu Obljaj. Banjani. („Poneko kaže i Konjska ploča“). (PEROVIĆ N.Đ. 2004:20).

Konjska stopa - omanji izvor „u ataru“ Surdupa. Drobnjak. (OSTOJIĆ M. Đ. 2003:276).

Konjski vrh//Konjski krš - ,vrh na planini Trojan (stijene, jugozapadno od sela Grnčar)“. Gusinje. (DŽOGOVIĆ A. 2009:392).

Konjsko polje - na Jezerima. Durmitor. (OSTOJIĆ M. Đ. 2003:173).

Kopriva - ,pećina“ na obali rijeke Morače. Podgorica. (IČEVIĆ D. 2007: 164).

Koprivna ravan - livade opkoljene šumom. Ime nastalo po koprivi koje je tu bilo u izobilju u 19. vijeku, uz katun Tomovića, selo Rovca, kod Berana. Vasojevići. (DAŠIĆ M. 2008:343).

Koprivnjaci - ,potesi više predjela Nagrad (livade i šuma)“, selo Brezojevica. Plav. (DŽOGOVIĆ A. 2009:63).

Kornjača - ribolov na Skadarskome jezeru. (PELIČIĆ J. I.-P. 1997:162).

Kos - selo u Prekobrđu „,nazvano je po slovenskoj riječi kos što znači šuma“. Donja Morača. (RAOSAVLJEVIĆ R. 1990:329). NAPOMENA: PULEVIĆ V. \& SAMARDŽIĆ N. 2003:247 naveli su toponim „Kos - selo (i željezn. stanica) na prilazu Kolašinu iz pravca Podgorice. (I, L).

Kosanica - livada, pašnjak, selo Dugi Dô. Njeguši. (ČIRGIĆ A. 2009:109).

Kosišta - „brdo u kanjonu Sušice obraslo šumom“, selo Crna Gora. Durmitor. (CICMIL-REMETIĆ R. 2003:358).

Kosmata glavica - (Ispravka: PULEVIĆ V. \& SAMARDŽIĆ N. 2003:249 greškom su stavili da se navedeni toponim nalazi u Bijeloj Rudini, a treba - u Oputnoj Rudini).

Košćela - u selu Mahala. Zeta. (PELIČIĆ J. I.-P. 1997).

Košćela Simonova - u selu Dahna. Zeta. (I: M. Knežević).

Košutin dô - šumoviti dio iznad mjesta Provalije. Durmitor. „Uslijedio je naziv Košutin dô po tome što je po njoj bilo srneće divljači, koju je često narod miješao sa jelenima“. (OSTOJIĆ M. Đ. 2003:182).

Košenjača - u selu Glavaca, Gornja Sela. Vasojevići. (OSTOJIĆ M. 2001: 453).

Kotarine - u selu Vukovci. Zeta. (PELIČIĆ J. I.-P. 1997). 
Prva dopuna fitotoponimiji i zootoponimiji Crne Gore

Kovačica - u selu Lipovo. Kolašin. „,kovačica - kozji list (Lonicera caprifolium)“. (RAOSAVLJEVIĆ 1990:328). NAPOMENA: ŠULEK B. 1879:165 bilježi naziv kovačnik za Lonicera caprifolium. Ostalo je da se provjeri da li je R. Raosavljević naziv kovačica zabilježio na terenu (u Lipovu) ili ga je preuzeo iz literature.

Kovilovača - prostrani šaranski udut. „Po stjenovitim dijelovima ima zelene busike i rijetkog rastinja“. Šaranci. (OSTOJIĆ M. Đ. 2003:88). NAPOMENA: OSTOJIĆ M. Đ. 2003:88 iznosi laičko tumačenje: „Lijepog je izgleda po svojim sektorima, pa je narod za povod mikrotoponimu dao naziv Kovilovača, što je došlo od složenice ko i vila“. Treba uzeti u obzir i mogućnost fitonimske osnove - npr. od kovilje (Stipa pennata L.).

Kovrag - lokalitet na području sela Donja Bukovica. „Tu raste bilje koje neće da pase stoka, otpadna trava, koju narod naziva kovrag“. Drobnjak. (OSTOJIĆ M. Đ. 2003:336).

Kozdovača - iznad Đurđrvića Tare. (I).

Koźa pećina - u Tisovcu, Macavare. Banjani. „Vele da su u njoj preko zime zatvarali koze, pa po tome joj i dali takvo ime“. (PEROVIĆ N.Đ. 2003:24).

Koźakinje - „,dio Ljuti od Čistine za Bezdanom pa do Lijepe glavice, veoma krševit, nekada obrastao sitnim rastinjem, a sada i on pod gustom visokom šumom. Usljed kamenitosti i sitnog rastinja ovo je bio izvanredan pašnjak za koze, prekriven čitavom mrežom tananih kozjih staza. U Pivi se pridjev kozji obično izgovara koz' $i$, dakle sa umekšanim $z$ ' koga nema u književnom jeziku, otuda Koz'akinje (kozje staze). U novije vrijeme čuje se i Kođakinje (svakako kao saobražavanje sa književnim jezikom), ali ne i Kozjakinje“, Smriječno. Piva. (TADIĆ B. 2004:309).

Kozine - prvo ime sela Tepca (najstarije selo na drobnjačkim Jezerima, a među najstarijim u Drobnjaku). Durmitor. (OSTOJIĆ M. Đ. 2003:318).

Kozja voda - izvor na strminama ispod sela Tepca. Durmitor. (OSTOJIĆ M. Đ. 2003:279). NAPOMENA: Toponim Kozja voda zadržan je u obliku kako ga je zapisao M. Đ. Ostojić, a na samome terenu treba provjeriti da li mu je izvorni oblik Koźa voda ili Kođa voda.

Koźačišta - u selu Rujišta, Gornja Sela. Vasojevići. (OSTOJIĆ M. 2001:444 toponim je zapisao kao „Kozjačišta“).

Kragujeva lastva - stjenovita strana iznad Kragujeva dola, tek s ponekim rijetkim drvetom, prema površi Volodera, selo Smriječno. Piva. (TADIĆ B. 2004:309).

Kravički izvor - na Kravici, iznad sela Malinsko. Drobnjak. (OSTOJIĆ M. Đ. 2003:250).

Kravujevac - ,južno od sela Smoljana uzdižu se naporedno dva brda Mali i Veliki Kravujevac ... Dogodilo se da su u tom lokalitetu vuci poklali 
krdo krava, otuda je naziv Kravujevac. Drugo predanje kaže da je naziv nastao po gajenju krava, napasanju po brdu i okolini“. Drobnjak. (OSTOJIĆ M. Đ. 2003:42. NAPOMENA: PULEVIĆ V. \& SAMARDŽIĆ N. 2003:259 navode toponime „Kraljevac (Veliki i Mali) - iznad sela zvanoga Paśi Nugo. Jezera. (I: Dragutin Nedić: 'Ime prema biljci kraljevac'). Na Tk toponim je označen kao Mali (1629) i Veliki (1713) Krauljevac“.

Krčevina - „krčen teren, strane i njive“, selo Crna Gora. Durmitor. (CICMIL-REMETIĆ R. 2003:358).

Krčevina - u selu Perovići, Macavare. Banjani. (PEROVIĆ N.Đ. 2003:15).

Krčevina - ,potesi više sela (livade)“, selo Koljenoviće. Gusinje. (DŽOGOVIĆ A. 2009:488).

Krčevina - ,predio više Bregova (pašnjaci i livade), selo Brezojevica. Plav. (DŽOGOVIĆ A. 2009:63).

Krčevina - ,potes na brdu više sela, selo Pepiće. Plav. (DŽOGOVIĆ A. 2009:251).

Krčevina - ,potesi više sela (pašnjak i šuma)“, selo Jara. Plav. (DŽOGOVIĆ A. 2009:150).

Krčevina Banjova (kao: Banjova krčevina) - ,predio niže Martinovića laza (sada je ovdje šuma)“, selo Brezojevica. Plav. (DŽOGOVIĆ A. 2009:63).

Krčevine - „potes na predjelu Lazi“, selo Nokšiće. Plav. (DŽOGOVIĆ A. 2009:245).

Krčevine - potes više puta u zaseoku (mahali) Bojovići (livade)“, selo Grnčar. Gusinje. (DŽOGOVIĆ A. 2009:394).

Krčevina Lalova (kao: Lalova Krčevina) - oveća njiva ispod Bijeloga puta, a iznad Aništa. To je bio komun koji je Lale Cicmil iskrčio tridesetih godina dvadesetog vijeka“, selo Smriječno. Piva. (TADIĆ B. 2004:311).

Krčevina Savina (kao: Savina Krčevina) - na lijevoj strani Rovačkoga potoka, selo Rovca, kod Berana. Vasojevići. (DAŠIĆ M. 2008:341).

Krčevine - potes livada, oranica i listopadne šume na lijevoj strani Potoka, između Strančice i izvora Lješnica, selo Rovca, kod Berana. Vasojevići. (DAŠIĆ M. 2008:342).

Krčevine - u kanjonu Tare, zapadno od Kupinjaka. (OSTOJIĆ M. Đ. 2003: 153).

Krčevine Karadžića - poznata komunica stvorena krčenjem, Jezera. Durmitor. (OSTOJIĆ M. Đ. 2003:159).

Krečana//Ornica - ,potes na zapadnom kraju sela (ledine, mještani ovdje prave kreč)“, Skić. Plav. (DŽOGOVIĆ A. 2009:348). 
Prva dopuna fitotoponimiji i zootoponimiji Crne Gore

Krekavac - izvor u ataru sela Palež, Jezera. Durmitor. „Za veliku kleku se često kaže kreknjava, pa je tako moglo doći do naziva izvora Krekavac". (OSTOJIĆ M. Đ. 2003:288).

Krilonjin dô - ,veća dolina, kosanica“, selo Crna Gora. Durmitor. (CICMIL-REMETIĆ R. 2003:353).

Krkoče - u selu Lagatori. Vasojevići. (OSTOJIĆ M. 2001:327).

Krl'e - ,potesi na predjelu sela (šuma)“, selo Nokšiće. Plav. (DŽOGOVIĆ A. 2009:245).

Krl'e - „potesi na predjelu zaseoka (mahale) Bojovići (sada su ovdje livade)“, selo Grnčar. Gusinje. (DŽOGOVIĆ A. 2009:394).

Krlja preśečena (kao: Preśečena krlja) - u selu Rasova. Šaranci. (OSTOJIĆ M. Đ. 2003:96).

Krlja prijeka (kao: Prijeka krlja) - na stazi prema Lokvicama. „Tu je bilo presječeno stablo koje je vjetar oborio. Na njemu se sjedilo i osmatralo“. Durmitor. (OSTOJIĆ M. Đ. 2003:92).

Krlje - iznad sela Ninkovića, na obroncima Malog Crnog vrha. Naziv po panjevima istrulih stabala, Jezera. Durmitor. (OSTOJIĆ M. Đ. 2003:192).

Krlje - katun śeveroistočno od sela Vrela, Jezera. Durmitor. (OSTOJIĆ M. Đ. 2003:368).

Krlje Blagojevića - zaravan iznad Tještine. „Nekada je bila pod šumom koja je nestala u požaru, ali su ostali panjevi koji se u narodu nazivaju krlje“, selo Vrela. Durmitor. (OSTOJIĆ M. Đ. 2003:139).

Krljice - u selu Zagrad, Gornja Sela. Vasojevići. (ŠEKULARAC B. 2008:32).

Krmačina njiva - u selu Lagatori. Vasojevići. (OSTOJIĆ M. 2001:327).

Krmska bara - ,samo ime kazuje da se radi o izvoru vode koji nije jak, ali koji su rado posjećivale divlje i pitome svinje (krmad), jer se razlivao u baru“, selo Rovca, kod Berana. Vasojevići. (DAŠIĆ M. 2008:377).

Krstati dô - u selu Obljaj. Banjani. „Dobio je ime po jednom velikom ceru, koji je bio u prisoju pored Rajkove Dubrave. Taj cer je bio razgranat i ličio je na krst i po njemu se naziva Krstati dô i Krstato prisoje. Taj cer sam ja zapamtio“. (PEROVIĆ N.Đ. 2003:18).

Kruševice - prostorno rasturen lokalitet iznad sela Tušinja. Uskoci. (OSTOJIĆ M. Đ. 2003:102).

Kruševo ždrijelo - iznad Dobrskoga Sela prema Belvederu. Ceklin. (I: Martinović).

Kruška - livada (nekad njiva) iznad Pržuljice, na Crvenim brdima, selo Smriječno. Piva. (TADIĆ B. 2004:310).

Kruška - u selu Krilo. Zeta. (PELIČIĆ J. I.-P. 1997).

Kruška - ,potes više sela“, Brezojevica. Plav. (DŽOGOVIĆ A: 2009:63). 
Kruška čobanska (kao: Čobanska kruška) - u selu Rovca, kod Berana. Vasojevići. (DAŠIĆ M. 2008:342).

Kruška popova (kao: Popova kruška) - ,potes u Donjoj Brezojevici“. Plav. (DŽOGOVIĆ A. 2009:63).

Kruškavice - „potesi u strani istočno od naselja (pašnjaci)“, Malo Selo. Plav. (DŽOGOVIĆ A. 2009:209).

Kruške - u selu Lagatori. Vasojevići. (OSTOJIĆ M. 2001:327).

Kruške Bil'ove (kao: Bil'ove kruške) - ,potes na predjelu sela“, selo Završ. Plav. (DŽOGOVIĆ A. 2009:126).

Kruške Ferove - ,potesi na planini Bor (pašnjak)“, selo Kruševo. Gusinje. (DŽOGOVIĆ A. 2009:492).

Kukavica - zaselak, Cuce, Katunska Nahija. (I: B. Jovanović).

Kukavica - u selu Lipovo. Kolašin. „Kukavica - cvijet kaćun (Orchis morio)“. (RAOSAVLJEVIĆ R. 1990:328). NAPOMENA: ŠULEK B. 1879:181 narodni naziv kukavica veže za tri vrste biljaka, od kojih je jedna rod Orchis L. Slično prikazuje i Gilić S. 2004:308. Ostalo je da se na terenu provjeri da li je RAOSAVLJEVIĆ R. 1990:328 fitonim kukavica zabilježio u Lipovu ili ga je preuzeo iz literature.

Kukavica - nekadašnji jaz na rijeci Sitnici iznad Donjih Kokota i Lekića. Lješkopolje. (I: M. Knežević).

Kukavice - ,predio više sela (šuma)“, selo Đurička Rijeka. Plav. (DŽOGOVIĆ A. 2009:123).

Kukavički brijeg - „uzvišenje u lokalitetu Bogomolje nazvano je Kukavičji brijeg. Porijeklo toponima je vezano za pojavu kukavice u proljeće da kuka. Drugi govore da je u selu živio mještanin koji ništa nikome nije znao posuditi, pomoći, otuda naziv". Šaranci. (OSTOJIĆ M. Đ. 2003:51\& 69).

Kukrice - u selu Stabna. Piva. (I: M. Tijanić).

Kukurijek dolina - ,zbog velikog kukurijeka koji se javlja u proljeće i ljeti, narod je lokalitet nazvao Kukurijek dolina“, selo Kovčice, Jezera. Durmitor. (OSTOJIĆ M. Đ. 2003:136).

Kulaševa dolina - u Mrtvom dolu, selo Perovići, Macavare. Banjani. (PEROVIĆ N.Đ. 2003:11).

Kulin krš - listopadna šuma između Rašća i Devića imanja. „Naziv dolazi po stijeni usred šume u koju su ranije ljudi bacali ubijene pse, kule (kučke) u kamenjar", selo Rovca, kod Berana. Vasojevići. (DAŠIĆ M. 2008:339).

Kumanice - ,zaselak Vojnog Sela (desetak kuća; kazuju da na ovim predjelima ima lasica koje ovdje nazivaju kuma, kumačica ...)“, Vojno Selo. Plav. (DŽOGOVIĆ A. 2009:119). 
Prva dopuna fitotoponimiji i zootoponimiji Crne Gore

Kupjenska glavica - kamenjar, pašnjak, selo Erakovići. Njeguši. (ČIRGIĆ A. 2009:115).

Kupjenski dô - baština, livada, selo Erakovići. Njeguši. (ČIRGIĆ A. 2009:115).

Kusonjin dô - „ravna dolina, kosanica“, selo Crna Gora. Durmitor. (CICMIL-REMETIĆ R. 2003:353).

Kužna dolina - udolina u kompleksu Tmora (tepački atar). Ime dolazi zbog guste šume, neprohodnosti i nedovoljne vidljivosti, Tepca. Durmitor. (OSTOJIĆ M. Đ. 2003:187).

Laneni vrt - u selu Obljaj. Banjani. (PEROVIĆ N.Đ. 2003:21).

Laništa - u selu Bijelo Polje. Zeta. (PELIČIĆ J. I.-P. 1997).

Laništa - „livada pri brdu, veći potes na kome se nalazi i jedna kuća“, selo Crna Gora. Durmitor. (CICMIL-REMETIĆ R. 2003:359).

Laništa - ,pitoma dolina u ataru sela Pobrežđa“. Šaranci. (OSTOJIĆ M. Đ. 2003:175).

Laništa - zaselak sela Orah, Šekular. Vasojevići. KASTRATOVIĆ R. 1966).

Lanište - u Starom Selu, Macavare. Banjani. (PEROVIĆ N.Đ. 2003:12).

L'anište - ,potes na južnom kraju sela (pašnjak)“, selo Bogajiće. Plav. (DŽOGOVIĆ A. 2009:30).

Lanište//Vrtići - „ravan teren, nekada oran, manji potes“, selo Crna Gora. Durmitor. (CICMIL-REMETIĆ R. 2003:359).

Las - na širokom području Plava i Gusinja česti su toponimi s osnovom las: Las, Begov las, Magarev las, Okrugli las i dr. (DŽOGOVIĆ A. 2009).

Lastavica - ,,potes pored rijeke (livade)“, selo Đurička Rijeka. Plav. (DŽOGOVIĆ A. 2009:123).

Laz - na području sela Gračanica. Vasojevići: Konjski laz, Dugi laz, Debeli laz. (I).

Laz, Laze, Lazina - (česti toponimi na području Zagarača, Katunska nahija). ĆUPIĆ D.\& ĆUPIĆ Ž. 1997:205).

$\mathbf{L a z}$ - na širokom području Plava i Gusinja veoma su česti toponimi sa osnovom laz: Laz, Laze, Lazi, Lazurce, Laščić, Dugački laz, Okrugli laz, Mujovi lazi, Beširovića lazi i dr.

Laz (kao: Đuče laz) - šumarak na padinama Sredilja, selo Mikulići. Bar. (PEROČEVIĆ E. 2003).

Laz Adžijin (kao: Adžijin laz) - u selu Mataguži. Zeta. (PELIČIĆ J. I.-P. 1997).

Laz Begov (kao: Begov laz) - u selu Gostilj. Zeta. (PELIČIĆ J. I.-P. 1997).

Laz Dinov (kao: Dinov laz) - u Babinom polju. Prokletije. (IPLB. 1966:24).

Laz dugi (kao: Dugi laz) - u selu Lagatori. Vasojevići. (OSTOJIĆ M. 2001:327). 
Laz đedov (kao: Đedov laz) - u selu Đulići, Andrijevica. Vasojevići. (OSTOJIĆ M. 2001:171).

Laz Đukov (kao: Đukov laz) - Grnčar. Prokletije. (IPLB. 1966:25).

Laz Ivezin - šumarak na istočnoj strani Kunteljata, padine Rumije, selo Mikulići. Bar. (PEROČEVIĆ E. 2003).

Laz Kukića - šuma podno Srednjega vrha, selo Mikulići. Bar. (PEROČEVIĆ E. 2003).

Laz Šabov - pašnjak u podnožju južne strane Kunteljata, selo Mikulići. Bar. (PEROČEVIĆ E. 2003).

Laz (Veliki i Mali) - zaobljeni plato u Zaruđu, selo Rovca, kod Berana. Vasojevići. (DAŠIĆ M. 2008:336).

Laz (kao: Grumen/Grumač laz) - u selu Tucanje. Vasojevići. (OSTOJIĆ M. 2001:309).

Laz Milošev (kao: Milošev laz) - u selu Petnjica. Vasojevići. (U selu Petnjici nalaze se još: Bogićev laz, Brajkov laz, Dugi laz, Hurov laz, Okrugli laz). (OSTOJIĆ M. 2001:380).

Laz Omerov (kao: Omerov laz) - u selu Gračanica. Vasojevići. (OSTOJIĆ M. 2001:465).

Laz Otašev (kao: Otašev laz) - u selu Vinicka. Vasojevići. (OSTOJIĆ M. 2001:425).

Laz Ričev (kao: Ričev laz) - u selu Lagatori. Vasojevići. (OSTOJIĆ M. 2001:327).

Laze - južni pojas planine Rumije koji se proteže od Perova brijega do Paštrovca, dužine oko 3 km, selo Mikulići. Bar. (PEROČEVIĆ E. 2003).

Laze - „toponim Laze dobio naziv po iskrčenoj šumi, lazovima. Obuhvata livade između Male ploče, Savine ravni i Skokove doline ...livade su prošarane mahom bukovom, a ima na prostoru Laza i nešto jelove i smrčeve šume“, selo Rovca, kod Berana. Vasojevići. (DAŠIĆ M. 2008:347).

Laze - širok potes na lijevoj strani Potoka do ispred Crnog vrha. „U Rovcima ima više toponima Laz, Lazine. Nastali su krčenjem šuma ...“, selo Rovca, kod Berana. Vasojevići. (DAŠIĆ M. 2008:342).

Laze (ili: Prijeka brda) - oranice, livade i bukova šuma, selo Rovca, kod Berana. Vasojevići. (DAŠIĆ M. 2008:339).

Lazi - u selu Grbavci. Zeta. (PELIĆIĆ J. I.-P. 1997:178).

Lazi (kao: Rados lazi) - u selu Gostilj. Zeta. (PELIČIĆ J. I.-P. 1997).

Lazi (kao: Zalazi: Velji Zalazi i Mali Zalazi ) - sela na Njegušima. (L, Tk).

Lazi Pajovića (kao: Pajovića lazi) - u selu Mataguži. Zeta. (PELIČIĆ J. I.P. 1997).

Lazina - (dosta toponima na prostoru Bjelopavlića). (ĆUPIĆ D. 1970:305). 
Prva dopuna fitotoponimiji i zootoponimiji Crne Gore

Lazina - manja livada u šumi, selo Osreci. Donja Morača. (SIMONOVIĆ A. 1998).

Lazina ciganska (kao: Ciganska lazina) - u selu Glavaca, Gornja Sela. Vasojevići. (ŠEKULARAC B. 2008:28).

Lazine - u selu Obljaj. Banjani. (PEROVIĆ N.Đ. 2003:21).

Lazine - u selu Bijelo Polje. Zeta (PELIČIĆ J. I.-P. 1997).

Lazine - prostrani proplanak, selo Sirovac. Drobnjak. (OSTOJIĆ M. Đ. 2003:83).

Lazovi Đolja Joka (kao: Đolja Joka Lazovi) - u selu Goričani. Zeta. (PELIČIĆ J. I.-P. 1997).

Lazovi Jahovića (kao: Jahovića lazovi) - u selu Tucanje. Vasojevići. (OSTOJIĆ M. 2001:310).

Lijeska Raškovića (kao: Raškovića lijeska) - stara lijeska (koja je isčezla), Gornja Bijela. Drobnjak. (OSTOJIĆ M. Đ. 2003).

Liješće Luburića (kao: Luburića liješće) - njiva ispod Postolača, selo Smriječno. Piva. (TADIĆ B. 2004:312).

L'iska - ,strane niže Zabodišta (sjeverne strane seoskog atara, zapadna ekspozicija; ljeskova šuma i druga sitnogorica; ikavski refleks starog glasa jat u leksemi l'iska)“, selo Grnčar. Gusinje. (DŽOGOVIĆ A. 2009: 396).

L'iske Šaćove - „potesi na ataru zaseoka Zagrađe (ikavizam u leksemi l'iske)“, selo Dosuđe. Gusinje. (DŽOGOVIĆ A. 2009:481).

L’iješće - ,predio niže sela (lugovi i sitnogorica pored Lima)“, selo Brezojevica. Plav. (DŽOGOVIĆ A. 2009:64).

Lipa - „strane u kanjonu Tare; tu je nekada bilo lipove šume“, selo Crna Gora. Durmitor. (CICMIL-REMETIĆ R. 2003:359).

Lipa - velika kosa jugozapadno od Tušinje, a ispod sela Malinsko. Drobnjak. (OSTOJIĆ M. Đ. 2003:103).

L'ipa - ,potes kod Groblja (ovdje je jedna velika lipa)“, Skić. Plav. (DŽOGOVIĆ A. 2009:348).

Lisičac - manji vrh u Aluškom gorju. Durmitor. „Svojim izgledom kad se posmatra iz daljine asocira na glavu lisice“. (OSTOJIĆ M. Đ. 2003:77).

Lisičina - „gusta šuma sa škripom u kome se legu lisice“, selo Crna Gora. Durmitor. (CICMIL-REMETIĆ R. 2003:359).

Lisovci - u selu Gostilj. Zeta. (PELIČIĆ J. I.-P. 1997). NAPOMENA: u Crnoj Gori česti su toponimi Lisac, Lisinj, Lisa i dr. Izučavanje njihove osnove i semantike zaslužuje posebnu pažnju.

Loboder - iznad Rudanaca. Šaranci. „Nema konkretnih podataka kako je došlo do naziva, mada je zemljište na mjestima podbarno gdje raste lisnata loboda, po čemu je narod cijeli lokalitet nazvao Loboder". (OSTOJIĆ M. Đ. 2003:83). NAPOMENA: Za isti lokalitet PULEVIĆ V. \& SAMARDŽIĆ N. 2003:319 zabilježii su, prema topografskoj karti, to- 
ponim „Luboder (1684) - zapadno od Rudanaca, Šaranci. Planina Sinjavina. (Tk)“.

Loboder (kao: Izvor u Loboderu) - ,blizu Studenaca, u lokalitetu Loboder nalazi se izvor kojim se služe okolni stanovnici, čobani i prolaznici“". Šaranci. (OSTOJIĆ M. Đ. 2003:292).

Lom - ,velika strana obrasla bukovom šumom“, selo Crna Gora. Durmitor. (CICMIL-REMETIĆ R. 2003:359).

Lom - u selu Zagrad, Gornja Sela. Vasojevići. (ŠEKULARAC B. 2008:32).

Lom - ,potesi više sela (zapadno; livade)“, selo Pepiće. Plav. (DŽOGOVIĆ A. 2009:251).

Lom Panov (kao: Panov lom) - u selu Novšići. Plav. (IPLB. 1966:24).

Lom Šorov (kao: Šorov lom) - u selu Glavaca, Gornja Sela. Vasojevići. (ŠEKULARAC B. 2008:28).

Lom Vunov (kao: Vunov lom) - u selu Glavaca, Gornja Sela. Vasojevići. (ŠEKULARAC B. 2008:26).

Lomovi - u selu Kurikuće, Gornja Sela. Vasojevići. (ŠEKULARAC B. 2008:22).

Lomovi - livade, selo Zagrad, Gornja Sela. Vasojevići. (ŠEKULARAC B. 2008:32).

Lomovi - „potes na predjelu Lazi (drače, lomovi i šuma)“, selo Nokšiće. Plav. (DŽOGOVIĆ A. 2009:245).

Lomovi - ,potesi više sela (livade)“, selo Budovice. Plav. (DŽOGOVIĆ A: 2009:115).

Lopari - u selu Bor. Vasojevići. (OSTOJIĆ M. 2001:298).

Lovorike (Lorike) - ,u orahovskom distriktu“, selo Orahovac. Boka Kotorska. (ANTOLJAK S. 1979). NAPOMENA: toponim Lorike (Lovorike) zabilježen je i za Škaljare kod Kotora. (PULEVIĆ V. \& SAMARDŽIĆ N. 2003:317).

Lučeva glavica - zaobljena glavica na prostranstvima Trgilja. Nekad je glavica bila pod crnim borom. Durmitor. (OSTOJIĆ M. Đ. 2003:191).

Lučevača - kosa iznad Junča Dola, Jezera. Durmitor. (OSTOJIĆ M. Đ. 2003:107).

Lučevo brdo - , ,iako nema borovih šuma koje bi asocirale na naziv lokaliteta, nekada su izgleda bila velika borova stabla puna smole, po čemu je brdo i nazvano Lučevo“, selo Previš. Drobnjak. (OSTOJIĆ M. Đ. 2003:61).

Lug - pokraj rijeke Bukovice, selo Bukovica. Drobnjak. (OSTOJIĆ M. 2003:139).

Lug - omanja zaravan s nekoliko bukava iznad mosta pod Preśekom, na desnoj obali Bukovičkoga potoka, ispod Ljuti, na putu Smriječno - Goransko, selo Smriječno. Piva. (TADIĆ B. 2004:312). 
Prva dopuna fitotoponimiji i zootoponimiji Crne Gore

Lug - na području Plava i Gusinja veoma su česti toponimi s osnovom lug:

Lug, L'ug, Lugovi, Lugove, Dabov lug, Popov lug i dr.

Lug manastirski (kao: Manastirski lug) - u selu Bistrice. Zeta. (PELIČIĆ J. I.-P. 1997).

Lug - glavica, pašnjak, u selu Zalazi. Njeguši. (ČIRGIĆ A. 2009:123). Postoji i Pod lug - pašnjak, selo Zalazi. Njeguši. (Čirgić A. 2009:175).

Lug (kao: Romač lug) - ispod sela Seljani. Piva. BLEČIĆ V. 1958:44 zabilježio je da se tu na početku 20. stoljeća nalazila ,gusta bukova šuma sa stablima visokim do 30 metara, a u prečniku od 50 do $70 \mathrm{~cm}$. Danas (1958. - prim. V.P.) je to sve pretvoreno u njive i zasađeno voćkama. Ni po čemu se ne bi reklo da je tu postojala gusta bukova šuma, ne pre tri decenije, nego ni dva stoleća unazad“.

Lug široki (kao: Široki lug) - u selu Praćevac, Gornja Sela. Vasojevići. (ŠEKULARAC B. 2008:31).

Lug Vukov (kao: Vukov lug) - u Lješkopoljskom lugu (Tološki lug). Lješkopolje. Podgorica. (I: R. Mugoša).

Luge selo u dolini Lima, kod Andrijevice. Vasojevići. (I,Tk).

Lugovi - u selu Tucanje. Vasojevići. (OSTOJIĆ M. 2001:309).

Lugovi - u selu Lubnice, Gornja Sela. Vasojevići. (ŠEKULARAC B. 2008:18).

Lugovi zorički (kao: Zorički lugovi) - u selu Gračanica. Vasojevići. (OSTOJIĆ M. 2001).

Lužnica - brdo u Lješkopoljskom lugu, Lješkopolje. Podgorica. (I: R. Mugoša).

Lupoglava - ,jedan od visova u starom Drobnjaku dobio je interesantan naziv Lupoglava. Brdo je dosta veliko (1599 m), okruženo zelenim pašnjacima i livadama. Brdo je poznato po vjetrovitosti, pa je zbog toga i nazvano Lupoglava. Dakle, vjetrovi udaraju o glavu, što je poznato, pa se narod stara da se uz nošnju obavezno koristi šal“ (OSTOJIĆ M. Đ. 2003:38).

Lužak - u selu Lagatori. Vasojevići. (OSTOJIĆ M. 2001:327).

Ljaljevac - Gradac. Drobnjak. (OSTOJIĆ M. Đ. 2003:374). NAPOMENA: PULEVIĆ V. \& SAMARDŽIĆ N. 2003:323 naveli su toponime: Ljaljak (2x), Ljaljka, Ljaljkov kuk, Ljaljkovac i Ljaljkuša. Iako se nekima od njih daje mogućnost fitonimske osnove, problem ostaje otvoren za dalja komparativna izučavanja.

Ljeljenak - Međužvalje, Jezera. Durmitor. (OSTOJIĆ M. Đ. 2003:81-82).

Ljeskovci - u Ravnom dolu, Macavare. Banjani. (PEROVIĆ N.Đ. 2003:25).

Mačkov dô - velika udolina. „Nazvata je Mačkova dolina jer su se tuda pojavljivale mačke iz sela uz veljaču. Na tom prostoru se uspješno lovilo, 
jer je prolazila divljač“, selo Podgora, Jezera. Durmitor. (OSTOJIĆ M. Đ. 2003:186).

Mačkof(v) krš - „krševito brdo više sela (ovdje raste drvo mačkovina)“, selo Budovice. Plav. (DŽOGOVIĆ A. 2009:115).

Magareća stopa - na planini Ivici. Drobnjak. (OSTOJIĆ M. Đ. 2003:180).

Makovac - izvor, selo Previš. Drobnjak. (OSTOJIĆ M. Đ. 2003:262).

Makva - „potes pored jezera (brkl'a, podvodno zemljište)“, Vojno Selo. Plav. (DŽOGOVIĆ A. 2009:119).

Mal'ina (x2) - ,livade u selu (ovdje su rasle divlje maline); izvor na ovom potesu“, selo Kruševo. Gusinje. (DŽOGOVIĆ A. 2009:493).

Manati dô - u Ravnoj gori. „Podložan je padanju slane i maće, a mana mu je i to što su ga često orala macavarska goveda i konji, kao i divlje svinje koje su dolazile iz takozvanih Krmećih kosa“, Macavare. Banjani. (PEROVIĆ N. Đ. 2003:27). NAPOMENA: ako se radi o lokalitetu koji je śenovit i vlažan, moguće je da ga naseljavaju mahovine i lišaji, pa da mu je to uslovilo naziv Manati dô.

Manati vrg - „brdo poviše od Lučevog brda, vetroviti teren; duva sa svije strana“, selo Crna Gora. Durmitor. (CICMIL-REMETIĆ R. 2003:351). NAPOMENA: PULEVIĆ V. \& SAMARDŽIĆ N. 2003:338 navode srodne toponime: Manato počivalo (Ugnji kod Cetinja) i Manatovo vrelo (Orah u Pivi).

Margita - „naziv margita na Sinjavini je turskog porijekla, označava lijep pašnjak“. RAOSAVLJEVIĆ R. 1990:329).

Maske - kamenjar - prevoj između Dahne i Međukuća, Dajbapska gora. Zeta. (I: M. Knežević).

Mečkina hrupa - ,uvala više sela (šuma)“, selo Budovice. Plav. (DŽOGOVIĆ A. 2009:116).

Mečkine rupe - Treskavica , Prokletije. (IPLB. 1966:24).

Mečja glava - „brežuljak više sela (pašnjak)“, selo Brezojevica. Plav. (DŽOGOVIĆ A. 2009:61).

Mečkin las - „potes na planini više sela (pašnjak)“, selo Hakanje. Plav. (DŽOGOVIĆ A. 2009:370).

Medeni dočići//Medeni sat - ,veći dô, ravan teren dobrog zemljišta na kome dobro uspevaju svi usevi“, selo Crna Gora. Durmitor. (CICMILREMETIĆ R. 2003:354).

Medeni sat . v. Medeni dočići.

Medinovača - katun, zapadno od sela Šumanovci. Legenda: „Zbog pojave rojeva pčela i pronalasku u drveću meda, nazvata je Medinovača“., Jezera. Durmitor. (OSTOJIĆ M. Đ. 2003:379). 
Prva dopuna fitotoponimiji i zootoponimiji Crne Gore

Medlja//Mednja - „ravan teren, kosanica, kvalitetan teren, kao sat meda (dobar kao mes)“", selo Crna Gora. Durmitor. (CICMIL-REMETIĆ R. 2003:360).

Medljica//Meljica - „vala i proplanci u kanjonu Sušice. Tu je nekada kresan brst za stoku“, selo Crna Gora. Durmitor. (CICMIL-REMETIĆ R. 2003:360).

Mednja - v. Medlja//Mednja.

Medonjino ramo - ,ogromna izbočina u kanjonu Tare, pogodna za boravak čobana“, selo Crna Gora. Durmitor. (CICMIL-REMETIĆ R. 2003:366).

Međeđa glava - lokalitet na kojemu se danas nalazi grad Plav. (GUŠIĆ B. 1974:23).

Međeđa - Cuce. Katunska Nahija. (I: B. Jovanović).

Međeđak - na području sela Murino. Plav. (OSTOJIĆ M. 2001:461).

Međeđi dô donji (kao: Donji Međeđi dô) - selo Crna Gora. Durmitor. (CICMIL-REMETIĆ R. 2003:353).

Međeđi dô gornji (kao: Gornji Međeđi dô) - „ogromna dolina u Durmitoru“, selo Crna Gora. Durmitor. (CICMIL-REMETIĆ R. 2003:353). NAPOMENA: PULEVIĆ V. \& SAMARDŽIĆ N. 2003:346 naveli su za masiv Durmitora toponim Međeđi dô, ali bez diobe na Donji i Gornji.

Meki dô - katun. ,Zbog rude i meke planinske trave koja izrasta dosta visoko, ulegnuće je nazvato Meki dô“, selo Timar. Drobnjak. (OSTOJIĆ M. Đ. 2003:381).

Meki dolovi - iznad sela Miloševići prema Krnovu. Naziv po bujnoj i mekoj travi. Drobnjak. (OSTOJIĆ M. Đ. 2003:176).

Meljica - v. Medljica (CICMIL-REMETIĆ R. 2003).

Mesne glave - „,na prostranstvima Sinjajevine jedno od imena je Mesne glave. Radi se o brdu koje je visoko i travnato. Korišćeno je za napasanje stoke. Često bi dolazilo do šteta u stoci, pojavom vuka koji bi zaklao po neku ovcu“. (OSTOJIĆ M. Đ. 2003:56).

Migalica - „topola (migalovica)“, Lipovo. Kolašin. (RAOSAVLJEVIĆ R. 1990:328).

Mioljica - malo naselje u selu Vlahovići. Rovca. „Ima značenje kruška“. (RAOSAVLJEVIĆ R. 1990:329).

Miševa dolina - šuma, pašnjak, katun Bostur, Lovćen. Njeguši. (ČIRGIĆ A. 2009:134).

Močalina - 1. izvor pod Rumijom; 2. njive u podnožju Srednjeg vrha, sa zapadne strane, selo Mkulići. Bar. (PEROČEVIĆ E. 2003).

Močilo - ,zaravan, sada tu nema vode“, selo Crna Gora. Durmitor. (CICMIL-REMETIĆ R. 2003:361).

Močilo - stajaća voda; bara đe se moči trska od konoplje. (Čest toponim u Vasojevićima). (BORIČIĆ TIVRANSKI V. 2002:160). 
Močilo - dio potoka ispod česme Korita, na gornjem dijelu Smriječna. Piva. (TADIĆ B. 2004:317).

Močilo (x2) - „barljiv potes na predjelu sela, česma na ovom potesu“, selo Bogajiće. Plav. (DŽOGOVIĆ A. 2009:30).

Močilo//Ustava - ,potes u naselju pored Lima (ovdje je i močilo za kvašenje konoplje i lana)“, selo Nokšiće. Plav. (DŽOGOVIĆ A. 2009:245).

Močilo Bjeloševo (kao: Bjeloševo močilo) - ,veća dolina i strana (ime dobijeno po nekadašnjem vlasniku)“, selo Crna Gora. Durmitor. (CICMIL-REMETIĆ R. 2003:361).

Močilo Kučanovića (kao: Kučanovića močilo) - „barljiv predio na jugozapadnom kraju sela (mještani ovdje miče konoplju i lan)“, selo Bogajiće. Plav. (DŽOGOVIĆ A. 2009:30).

Močnica - staro ime za površ Muratovice, selo Smriječno. Piva. (TADIĆ B. 2004:316).

Morava - ,jedan među brojnim izvorima u niskom Drobnjaku, koji se javlja ispod Đedove gore i formira potok, što se kasnije uliva u Grabovačku rijeku ....“. Drobnjak. (OSTOJIĆ M. Đ. 2003:255).

Moravac - ,selo je imalo svoj senat (atar), koji se nalazio u Ćemovskom polju i zvao se Moravac“, selo Mojanovići. Zeta. (PELIČIĆ J. I.-P. 1997).

Mravlje polje - u selu Bijelo Polje. Zeta. (PELIČIĆ J. I.-P. 1997).

Mrčajevac (kao: Katun Mrtčajevac) - śeveroistočno od sela Rudinovače. (Katun dijela bratstva Ostojića - Ramovića), Jezera. Durmitor. (OSTOJIĆ M. Đ. 2003:375).

Mrčajevac - „Mrčajevac je pod crnogoričkim šumama i, kad se posmatra iz daljine, vidi se šumska oaza na ravnim Jezerima, koji izgleda tmuran, mračan, nevidljiv“. Na granici Jezerske visoravni i Šaranaca. Durmitor. (OSTOJIĆ M. Đ. 2003:46).

Mrkaljica - brdo na izmaku Sinjajevine prema Jezerima. Brdo je gusto obraslo šumom, tako da vlada neviđelica“. (OSTOJIĆ M. Đ. 2003:46).

Mrkulja - ,južno od Smoljina i Pasjega Nugla uzdiže se Mala i Velika Mrkulja. Obrasle su gustim stablima smrče, jele i nešto ređe bora ...". Šaranci. (OSTOJIĆ M. Đ. 2003:47).

Mrkušina dolina - „dolina, kosanica“, selo Crna Gora. Durmitor. (CICMIL-REMETIĆ R. 2003:354).

Mrsna lastva - ,zbog stoke koja je tu zaskakala, otiskivala se niz litice i lomila, zbog ugojenosti stoke i dobre paše, lastva se nazvala Mrsna Lastva“. (Negđe u blizini Velike Kalice). Durmitor. (OSTOJIĆ M. Đ. 2003:87).

Murovac „korijen toponima murovec upućuje na sočnu travu“, selo blizu Javorove. Bihor. Gornji Bihor. (OSTOJIĆ M. 2001:329). 
Prva dopuna fitotoponimiji i zootoponimiji Crne Gore

Mužice - pasište, selo Kurikuće, Gornja Sela. Vasojevići. (ŠEKULARAC. B. 2008:22). NAPOMENA: PULEVIĆ V. \& SAMARDŽIĆ N. 2003: 355 navode toponim „Mužnica - stari katun, selo Kurikuće, Gornja Sela. VAsojevići (I)“.

Mužnjaci - pašnjak, Gornja Vrela, Jezera. Durmitor. (OSTOJIĆ M. Đ. 2003: 376).

Neviđen - lokalitet je obrastao šumom, dosta zgusnutom i teško prohodnom, s oslabljenom vidljivošću, Jezera. Durmitor. (OSTOJIĆ M. Đ. 2003:188).

Nježin lug - kod Kolašina, ,dobio je naziv od slovenske riječi nježje sa značenjem vražja ruža (Carlina acaulis)“. (L). Pjesnik Ranko R. Radović (rođen u Brezi kod Bijelog Polja), ima zbirku pjesama Nježje (2007), na str. 96 tumači: „Nježje - vilino sito, ljubotrn, blažena boca, fig. ljubav“. NAPOMENA: toponim Nježin lug je neproziran, a moguća fitonimska osnova je samo jedna od pretpostavki.

Ogorelica - u selu Kurikuće, Gornja Sela. Vasojevići. (ŠEKULARAC B. 2008:22).

Ogorilovac - ,zbog požara, koji se često javljaju u šaranskim šumama, bila je izgorela i ogoljela, ali se ponovo pošumila sa bujnom šumom“, iznad sela Šljivansko. Šaranci. (OSTOJIĆ M. Đ. 2003:69).

Oman - „Oman je izvor koji je nekada bez vode, usahne tokom sušnih ljetnjih dana zbog čega narod kaže omanuo ...", selo Grabovica. Drobnjak. (OSTOJIĆ M. Đ. 2003:266).

Omaništa - „potoci više Desnog Meteha (Livade)“, selo Meteh. Plav. (DŽOGOVIĆ A. 2009:215).

Omanovina - kompleks livada, selo Trebaljevo. Kolašin. (I: M. Bulatović). NAPOMENA: PULEVIĆ V. \& SAMARDĐIĆ N. 2003:357 navode toponime: „Omanovac - više Rovačkog Trebaljeva. Kolašin. (I). (Na istom mjestu pominje se toponim Omanovci, kao kmpleks livada)“.

Omar//Homar - ,predio u strani više Visitorskog jezera (četinarska šuma)“. Plav. (DŽOGOVIĆ A. 2009:66).

Omar Asanov (kao: Asanov omar) - (ispuštena ubikacija). Vasojevići. (OSTOJIĆ M. 2001:320).

Omarići - iznad sela Tepca. Durmitor. (OSTOJIĆ M. Đ. 2003:322).

Omarska kosa - u selu Praćevac, Gornja Sela. Vasojevići. (ŠEKULARAC B. 2008:30).

Omarski potok - ispod sela Šljivansko, nazvan po bukovu omaru koji se prostire blizu izvorišta i na jednom većem dijelu vodotoka. Šaranci. (OSTOJIĆ M. Đ. 2003:232).

Omorika (Homorika) - u selu Lagatori. Vasojevići. (OSTOJIĆ M. 2001: 327). 
Omora kriva (kao: Kriva omora) - ,dolina obrasla crnogoricom“, selo Crna Gora. Durmitor. (CICMIL-REMETIĆ R. 2003:362).

Omore - „deo kanjona Tare, obrastao šumom, šibljem i kupinom“, selo Crna Gora. Durmitor. (CICMIL-REMETIĆ R. 2003:362).

Omore sirove (kao: Sirove omore) - ,potes obrastao šumom na terenu Rupina“, selo Crna Gora. Durmitor. (REMETIĆ R. 2003:362).

Optovača - „livada na brdu iznad kanjona Sušice. Ime dobila po tavi optovači“, selo Crna Gora. Durmitor. (CICMIL-REMETIĆ R. 2003:362).

Oraovice - u Komanima. Katunska Nahija. (Geogr. karta).

Orasi Kneževića (kao: Kneževića orasi) - uz rijeku Moraču, ispod sela Dajbabe. Zeta. (I: M. Knežević).

Oraovo - u selu Tucanje. Vasojevići. (OSTOJIĆ M. 2001:309). NAPOMENA. PULEVIĆ V. \& SAMARDŽIĆ N. 2003:363 naveli su toponim „Orahovo - selo između Crniša i Tucanja. Bijelo Polje. (I, L, Tk).“.

Orli krši - u selu Lubnice, Gornja Sela. Vasojevići. (ŠEKULARAC B. 2008:18).

Orlof(v) krš - ,visok vrh na planini Horolac“, Hote. Plav. (DŽOGOVIĆ A. 2009:376).

Orlošin - katun Mojanska rijeka. Komovi. (IPLB. 1966:25).

Orlov krš - ,iznad kuća Čupića jedno uzvišenje se naziva Orlov krš“. Drobnjak. (OSTOJIĆ M. Đ. 2003:50).

Orlova greda - śeveroistočno od sela Bukovica, iznad kuća Čupića. Drobnjak. (OSTOJIĆ M. Đ. 2003:315).

Orlova strana - strana ispod sela Šljivansko, prema rijeci Tari. Šaranci. (OSTOJIĆ M. Đ. 2003:104).

Orlovo brdo - „u širem prostoru sela Virka jedno brdo je nazvano Orlovo“, Jezera. Durmitor. (OSTOJIĆ M. Đ. 2003:63).

Ostrikovača - u selu Podgora. Durmitor. (OSTOJIĆ M. Đ. 2003:141).

Ośe - u selu Tucanje. Vasojevići. (OSTOJIĆ M. 2001:309).

Ostrikovac - u selu Kurikuće, Gornja Sela. Vasojevići. (OSTOJIĆ M. 2001: 450).

Ošlje - naziv može doći po trnju koje je visoko izrastalo i zahvatilo zemljište. Uskoci. (OSTOJIĆ M. Đ. 2003:83).

Ošlje polje - u selu Kržanja. Kuči. (I: M Rajković).

Ošnja lokva - bistijerna, Majstori (na Lovćenu). Njeguši. (ČIRGIĆ A. 2009: 169).

Oštenci - pašnjak, selo Vraćenovići. Oputna Rudina. (PERUĆICA R.K. 1989:350).

Oštrikovac - „dolina, kosanica“, selo Crna Gora. Durmitor. (CICMIL-REMETIĆ R. 2003:362). 
Prva dopuna fitotoponimiji i zootoponimiji Crne Gore

Oštriković - „nekolike doline, kosanica“, selo Crna Gora. Durmitor. (CICMIL-REMETIĆ R. 2003:362).

Ovči bogaz - ,postoje strmine i neprohodi u durmitorskim vrletima, koje su karakteristične. Jedna staza dosta priprta i karakteristična, kojom se izdušuje s ovcama od Jablan brda na povoljnije tlo za putovanje nazvat je Ovči bogaz“. Durmitor. (OSTOJIĆ M. Đ. 2003:206).

Ovči brod - na rijeci Tari, nedaleko od mosta na Budečevici (prijelaz za ovce). Šaranci. (OSTOJIĆ M. Đ. 2003:230).

Ovsište - ,zaravan, nekada je tu sijan ovas“, selo Crna Gora. Durmitor. (CICMIL-REMETIĆ R. 2003:362).

Palež - selo blizu Šljivanska. Šaranci. (OSTOJIĆ M. Đ. 2003:359).

Palež - niže Vukodola i njegova katuna u podnožju Ranisave. Drobnjak. (OSTOJIĆ M. Đ. 2003:163).

Paleža (Velika Paleža, Mala Paleža) - ,potes u Pirnom Dolu; u Nedajnom je zapisan lik Palež: Rajski Palež“, Pivska planina. Piva. (CICMIL-REMETIĆ R. 2003:327).

Paleži - šumovita padina ispod Tvrdih stijena, sve do Mekog dola i Poljanica, selo Smriječno. Piva. (TADIĆ B. 2004:321).

Paležine - širi prostor, selo Virak, Jezera. Durmitor. (OSTOJIĆ M. Đ. 2003:197).

Pal' - ,potes više sela (istočno; livade)“, selo Pepiće. Plav. (DŽOGOVIĆ A. 2009:252).

Pal' Ahmetagića (kao: Ahmetagića pal') - ,potes na predjelu južno od sela (pašnjak)“", selo Bogajiće. Plav. (DŽOGOVIĆ A. 2009:30).

Pal'.l'al'ića (kao: L'al'ića) - ,potes na predjelu sela (livada)“, selo Bogajiće. Plav. (DŽOGOVIĆ A. 2009:30).

Pal' Prel'in - ,potesi više sela (̌̌uma)“, selo Pepiće. Plav. (DŽOGOVIĆ A. 2009:252).

Pal'evi - „livade jugoistočno od sela“, selo Bogajiće. Plav. (DŽOGOVIĆ A. 2009:30).

Pal'evi//Pal'ovi - ,potesi više Desnog Meteha (ledine i šuma), selo Meteh. Plav. (DŽOGOVIĆ A. 2009:215).

Pal'evi Musića (kao: Musića pal'evi) - ,potes na predjelu sela (pašnjak)“, selo Bogajiće. Plav. (DŽOGOVIĆ A. 2009:30).

Pal'evine - ,predjeli u strani više zaseoka Gropa (podnožje Visitora)“, selo Martinoviće. Gusinje. (DŽOGOVIĆ A. 2009:500).

Pal'evine - „strana na predjelu seoskog atara (pašnjak)“, selo Budovice. Plav. (DŽOGOVIĆ A. 2009:116).

Pal'evine - predio više Desnog Meteha (šume i lazine)“, selo Meteh. Plav. DŽOGOVIĆ A. 2009:215). 
Palj Đurov (kao: Đurov palj)- u selu Bastahe. Vasojevići. (OSTOJIĆ M. Đ. 2001:439).

Palj Preljin (kao: Preljin palj) - ,šuma više sela (ranije pripadala nekom katoliku Prelji)“, selo Brezojevica. Plav. (DŽOGOVIĆ A. 2009:66).

Palj suvi (kao: Suvi palj) - „strane u gornjoj zoni Visitora“. Plav. (DŽOGOVIĆ A. 2009:66).

Paljevine - u selu Petnjica. Vasojevići. (OSTOJIĆ M. 2001:308).

Paljevine (x2) - ,strane i dio naselja na predjelu Nagrad; veći predio na Visitoru (strane, istočna ekspozicija)“", selo Brezojevica. Plav. (DŽOGOVIĆ A. 2009:66).

Palj (kao: Katun Suvi Palj) - katun na Visitoru. Plav. (DŽOGOVIĆ A. 2009:63).

Paljevine - lokalitet u selu Gradac kod Šavnika. Drobnjak. (OSTOJIĆ M. Đ. 2003:400).

Panja - ,prostrana kosanica iznad Timara ... Tu su panjevi starih isječenih stabala“. Drobnjak. (OSTOJIĆ M. Đ. 2003).

Panjevi - „više dolina i strana, tu sada nema šume“, selo Crna Gora. Durmitor. (CICMIL-REMETIĆ R. 2003:363).

Panjevi - travna pasišta po kojima se srijeću istruli panjevi i iśečena stabla bijeloga bora, selo Ninkovići, Jezera. Durmitor. (OSTOJIĆ M. Đ. 2003:192).

Papradl'ivi las (kao: Las papradl'ivi), ,veći potes na planini Lipovica (ovdje raste visoka i gusta paprat, informator je kazao visok $i$ gust paprat - u njegovom jezičkom osjećanju paprat je muškog roda“, selo Grnčar. Gusinje. (DŽOGOVIĆ A. 2009:395).

Paprađe - ,potesi više naselja (istočno; livade po kojima raste paprat)“, Malo Selo. Plav. (DŽOGOVIĆ A. 2009:209).

Papratna strana - strma stana eksponirana prema rijeci Tari obrasla bujnom i visokom paprati, selo Palež. Durmitor. (OSTOJIĆ M. Đ. 2003:90).

Paśa rupa - Cuce. Katunska Nahija. (I: B. Jovanović).

Paśi prijelaz - ispod Grbajskog Zastana. Prokletije. (GUŠIĆ B. 1974:45).

Peca - potkapina na obali rijeke Morače (u njoj može stati 20-30 ljudi), selo Donja Gorica. Lješkopolje. (I: R. Mugoša).

Peca - strmina s nekolika konglomeratna bloka (ispod nekih nalaze se manje potkapine), zaselak Bošnjan Brijeg, selo Gornji Crnci. Piperi. (I: V. Pulević). NAPOMENA: laička etimologija objašnjava toponim po bodljikavim biljkama koje su česte na lokalitetu (Cirsium, Carduus, Centaurea i dr.). Drugo laičko objašnjenje (koje je bliže vjerovatnoći) toponim Peca tumači kao mala pećina, potkapina (veza: Peca - na obali Morače u Donjoj Gorici, Lješkopolje). 
Prva dopuna fitotoponimiji i zootoponimiji Crne Gore

Pelim - pašnjak na Srpskoj gori, selo Srpska. Zeta. (Lokalitet je devastirao Kombinat aluminijuma). (I: M. Knežević).

Pelim - ispod Đurđevića Tare. (I).

Pelimača (Pelimače) - lokalitet na ostrvu Vranjina. Skadarsko jezero. (Po biljci Phlomis fruticosa). (I: V. Bušković).

Pelimova glavica - zapadni dio Dajbapske gore. Zeta. (I: M. Knežević).

Pelin - iznad Nozdruća s lijeve strane prema Crkvičkom polju. Pivska planina. (I).

Pelinov dô - dolina u Poljanicama, do česme Asanovice, selo Smriječno. Piva. „Pelin ili divlji pelin (Artemisia vulgaris L.) je dosta rasprostranjena biljka po čitavoj Pivi, a u smrečanskozabrđanskom ataru je najviše ima po pjeskovitim prisojima gdje raste kao korov. Međutim pravog ili bijelog pelina, odnosno pelena (Artemisia absinthium L.), po Poljanicama nema, iako se i on po Pivi sreta, ali na nižim predjelima“. (TADIĆ B. 2004:324). NAPOMENA: u kanjonu Pive, na toplim prisojnim staništima srijeće se, ali rijetko, vrsta Salvia officinalis L., koja je u južnome dijelu Crne Gore veoma česta i poznata pod imenom pelin/ /pelim. Ostalo je da se provjeri kakvo je njeno narodno ime u Pivi.

Pelinova dolina - ,veća dolina, kosanica“, selo Crna Gora. Durmitor. (CICMIL-REMETIĆ R. 2003:354).

Pelinovac//Pelinovci - ,pod, ravan teren, kosanica“, selo Crna Gora. Durmitor. (CICMIL-REMETIĆ R. 2003:363).

Pelinovci - v. Pelinovac (Selo Crna Gora. Durmitor)

Pešeljevac - dvije uzdužne kose iznad Žugića Bara, Jezera. Durmitor. (OSTOJIĆ M. Đ. 2003:82: tumači da se radi o lokalitetima s izobiljnom travom i dobrom pašom, tj. ispašom - otuda i ime).

Pine - dio grada u Tivtu; prema it. pino (bor, pinija). - Živi na Pine. Imaju ti kuću na Pine, baš na lijepu poziciju. Boka Kotorska. (LIPOVAC-RADULOVIĆ V. 1981:264).

Pirne doline - ,više dolina na Durmitoru, pašnjak“, selo Crna Gora. Durmitor. (CICMIL-REMETIĆ R. 2003:354). NAPOMENA: u Pivi postoji Pirni dô (dio sela Boričje), za koje i informator iz toga kraja ne dovodi naziv u vezu s biljkom pirevinom, već ga tumači kao mjesto đe piri vjetar (PULEVIĆ V. \& SAMARDŽIĆ N. 2003:394).

Piskavci - livade i šume, selo Rovca, kod Berana. Vasojevići. „Nije jasno kakvo je značenje ovog toponima. U narodu Šekulara i Rovaca se za čovjeka koji piskavo (tanko) govori kaže piskavac“. (DAŠIĆ M. 2008: 344).

Piskavi dô - „veća dolina u selu, obrasla sitnom travom“, selo Crna Gora. Durmitor. (CICMIL-REMETIĆ R. 2003:353).

Piskavice - u selu Petnjica. Vasojevići. (OSTOJIĆ M. 2001:308). 
Pitomi dô - „dolina, kosanica“, selo Crna Gora. Durmitor. (CICMIL-REMETIĆ R. 2003:354).

Pitomi dô - u ataru sela Brajkovača. Nazvan po kvalitetu trave i roda. Šaranci. (OSTOJIĆ M. Đ. 2003:171).

Pitomi dô - prostrana travnata udolina, iznad sela Kovčice. Durmitor. (OSTOJIĆ M. Đ. 2003:186).

Plani - u selu Lipovo. Kolašim. „Plani - ispaša bez vlasnika“. (RAOSAVLJEVIĆ R. 1990:328).

Plastovine - na prostoru Brajkovače. „Na lokalitetu se dosta ukosi sijena i potrpa u plašće“. Šaranci. (OSTOJIĆ M. Đ. 2003:124).

Pliješ - u Šestanima. (JOVIĆEVIĆ A. 1922). NAPOMENA: postoje slični toponim: Pliješa i Pliješe Prorokovića (na Lovćenu), Mala pliješa (šuma u Žanjevu Dolu, Njeguši), Velika Pliješ (u dolini Ćehotine, Pljevlja), Pješivci i dr. (Moguće je da toponimi oslikavaju morfologiju terena; preostalo je da se sakupe u svim formama i u što većem broju i lingvistički objasne).

Plješčate grede - stjenoviti predio kod sela Gradac, kod Šavnika. Obrasle su lišajevima „,popješnjivile“. Drobnjak. (OSTOJIĆ M. Đ. 2003:164).

Popovina - mikrotoponim ,u travnatim i prostranim livadama u sinjajevinskom udutu“. (OSTOJIĆ M. Đ. 2003:129 pretpostavlja da ime može doći po biljci plavih cvjetova koju ,narod naziva popac, pop ili kaluđer“).

Poprađe - ,potesi na predjelu zaseoka Zagrađe (pašnjak i šuma, ovdje raste visoka i gusta paprat)“, selo Dosuđe. Gusinje. (DŽOGOVIĆ A. 2009: 482).

Pośečenjak - u selu Krčevo. Vasojevići. (OSTOJIĆ M. 2001:403).

Pośečeni dô - u selu Perovići, Macavare. Banjani (PEROVIĆ N.Đ. 2003:14).

Požarnice - katun. „Nekada su lokalitet zahvatale ogromne četinarske šume koje su uništetme pojavom požara“. Šaranci. (OSTOJIĆ M. Đ. 2003: 373).

Požarnice - pasište i livade, istočno od sela Strug, prema Javorju. Uskoci. (OSTOJIĆ M. Đ. 2003:134).

Požnja - kod Kolašina, ,lan (Linum usitatissimum). (RAOSAVLJEVIĆ R. 1990:328). NAPOMENA: ŠULEK B. 1879:307 ,požnjak, jesenski lan“. SIMONOVIĆ D. 1959 nije prenio Šulekov podatak. Ostalo je da se provjeri da li je narodni naziv za biljku Linum us. zabilježio kod Kolašina ili ga je preuzeo iz literature.

Prapratni dô - ispod Kokota, selo Klenak. Banjani. (I).

Praščeva glavica - „brežuljak više sela (šuma)“, selo Komorača. Plav. (DŽOGOVIĆ A. 2009:174). 
Prva dopuna fitotoponimiji i zootoponimiji Crne Gore

Prepelica - „na Suvopoljici se jedna livada naziva Prepelica. To je uzano zemljište, travnato i ravno koje se kosi. Prepelica je vezana za ovaj mikrotoponim po narodnom izgovoru za uzani dugački prostor. To ga je podsjećalo na vrstu ptice koja je često padala na pomenuto zemljište i nalazila hranu kupeći crviće i ostalo. Pomenuti lokalitet je jedan od mnogih koje je narod nazvao Prepelica“. Jezera. (OSTOJIĆ M. Đ. 2003:121).

Priljepak - katun na ograncima Komova prema Opasanici (blizu Kukuraja). Vasojevići. (Tk, IPLB. 1966:25). NAPOMENA: PULEVIĆ V. \& SAMARDŽIĆ N. 2003:400-401 navode lokalitete: Prilip, Priljep, Priljepe Priljepske strane i dr.

Progoni - na izmaku iz sela Šljivansko prema Kršu (tuda se projavljuje stoka). Šaranci. (OSTOJIĆ M. Đ. 2003:193).

Prokos - dio sela, Gornja Bukovica. Drobnjak. (OSTOJIĆ M. Đ. 2003:333).

Prosište - u selu Vrbica. Vasojevići. (OSTOJIĆ M. 2001:314).

Prośečenica - na padinama Magliča. Kučke planine. (IPLB. 1966:25).

Pupavac - u selu Vukovci. Zeta. (PELIČIĆ J. I.-P. 1997).

Rađevina - istočno od sela Novakovići. „Zbog bogatstva travama, i povoljnostima za stočarenjima, te rađanju usjeva i svega što se sije ...", Jezera. Durmitor. (OSTOJIĆ M. Đ. 2003:36).

Rakitine grede - u selu Previšs. „Tu se, po predanju slomio mještanin sa nadimkom Rakita“. Drobnjak. (OSTOJIĆ M. Đ. 2003:79).

Rakitnica - „vodeni tok“ u Rakitovim barama; vodotok koji teče kroz rakite i na izlazu iz rakita ponire, Jezera. Durmitor. (OSTOJIĆ M. Đ. 2003: 237).

Rasadi - livada i oranice s obje strane Potoka, između Lučice Vuka Vulevića i Čobanske kruške. „Toponim je dobio ime po šljivovim sadnicama i prvom voćnjaku podignutom u Rovcima“, selo Rovca, kod Berana. Vasojevići. (DAŠIĆ M. 2008:342).

Rasadi - livade, selo Kurikuće. Vasojevići. (ŠEKULARAC B. 2008:23).

Rasadišta - u selu Zagrad, Gornja Sela. Vasojevići. (ŠEKULARAC B. 2008:33).

Rasadnivi - u selu Bastahe, Gornja Sela. Vasojevići. (ŠEKULARAC B. 2008:25).

Rastiš (723) - iznad sela Leskovac. Mrkojevići. (Tk).

Rašće - potes hrastovih i cerovih gajeva između Točka i Kulin krša, selo Rovca, kod Berana. Vasojevići. (DAŠIĆ M. 2008:339).

Rašće - u selu Tucanje Vasojevići: (OSTOJIĆ M. 2001:309)

Rašće - lokalitet u selu Seoca kod Andrijevice. (OSTOJIĆ M. 2001:214).

Rašće - „strane više Desnog Meteha (šuma, njive, livade i nekolike kuće; forma toponima bez foneme $h$ u početnoj poziciji, kod muslimanskog 
stanovništva očekivala bi se morfološka struktura Hrašće, ali je moguć uticaj izgovora pravoslavnih susjeda)“, selo Meteh. Plav. (DŽOGOVIĆ A. 2009:216).

Ražana glava (1862) - kod Jablan jezera. Durmitor. (Tk karta Nac. parka Durmitor). NAPOMENA: PULEVIĆ V. \& SAMARDŽIĆ N. 2003: 410 isti toponim zabilježili su kao Ražena glavica. (Na terenu treba provjeriti da li je izvorno glava ili glavica).

Ražišta - „dolina, kosanica, tu su nekada bile kuće“, selo Crna Gora. Durmitor. (CICMIL-REMETIĆ R. 2003:366).

Ražište - ,pristranci, manje strane uz Manati vrg“, selo Crna Gora. Durmitor. (CICMIL-REMETIĆ R. 2003:366).

Ražovište - lokalitet đe je sijana raž, selo Šljivansko. Šaranci. (OSTOJIĆ M. Đ. 2001:309).

Ribarska - „dio naselja u Gornjoj Brezojevici“. Plav. (DŽOGOVIĆ A. 2009:67).

Rikavac (Rikavako jezero) - jezero u Prokletijama. LEGENDA: noću oko jezera boravio je bik, imao je crnu boju i ličio na zmaja. Čuvajući jezero plašio je ljude i stoku. (OSTOJIĆ M. Đ. 2001:112).

Rosulja - „na pravcu Mrkulje i Kravujevca...“. Drobnjak. (OSTOJIĆ M. Đ. 2003:68).

Ruda dola - „dva potesa: više dolina na Trsi, kosanica; više dolinica na Pišču“, Pivska planina. Piva. (CICMIL-REMETIĆ R. 2003:327).

Rudi brijeg - travnato i šumovito brdo, Brajkovača. Šaranci. (OSTOJIĆ M. Đ. 2003:73). NAPOMENA: pominje se i Rudi brijeg - uzvišenje kod sela Šljivansko. Moguće je da se radi o istom lokalitetu, pošto su sela Brajkovača i Šljivsko u neposrednom suśedstvu.

Rudi brijeg - u selu Vuča, Gornja Sela. Vasojevići. (ŠEKULARAC B. 2008:26).

Rudi brijeg - u selu Zagrad, Gornja Sela. Vasojevići. (ŠEKULARAC B. 2008:33).

Rudine - u selu Bastahe, Gornja Sela. Vasojevići. (ŠEKULARAC B. 2008:25).

Rudine - ,dio naselja sela Hakanje (ovdje je ranije bila čistina, utrge, nanosi)“, selo Hakanje. Plav. (DŽOGOVIĆ A. 2009:371).

Rudo brdo - na planini Gradišnica. Bjelasica. (Raste tipac/čipac/jarac). (I: Vulević).

Rudo pol'e - ,veći predio na zapadnoj periferiji Plava (ranije je ovdje bilo selo sa nekoliko kuća, njive, livade, bašte, voćnjaci; sada je ovdje veće i novo gradsko naselje Rudo pol'e)“. Plav. (DŽOGOVIĆ A. 2009: 256).

Rujeva glavica - brdo, glavica, Cuce. Katunska Nahija. (I: B. Jovanović). Rujevi strug - u selu Trebaljeve. Kolašin. (I: M. Bulatović). 
Runjevica - jedno od uzvišenja, selo Donja Bukovica.Drobnjak. (OSTOJIĆ M. Đ. 2003:75)

Rutulja - „lokalitet na Durmitoru, veći potes u kome se izdvajaju dve celine: Velika Rutulja - dubodolina i grede; Mala Rutulja - manja dolina i grede“. Uz ove toponime CICMIL-REMETIĆ R. 2003:366 navodi za Durmitor još: Rutuša//Rutušina peć - ,prolaz sličan tunelu u steni na Durmitoru“. Toponimi su neprozirni, ali donekle upućuju na mogućnost fitonimske osnove.

Ržišta - u selu Bor. Vasojevići. (OSTOJIĆ M. 2001:298).

Ržište - Cuce. Katunska Nahija. (I: B. Jovanović).

Sagoreljak - na padinama Čakora. Prokletije. (IPLB. 1966:24).

Sečine - u selu Vrbica. Vasojevići. (OSTOJIĆ M. 2001:314). NAPOMENA: o mogućnosti da se toponim izgovara i piše kao Śečine treba provjeriti na terenu.

Sijeračko brdo - u selu Petnjica. Vasojevići. (OSTOJIĆ M. 2001:308 smatra da ime dolazi od serv $=$ rob).

Sijerak - na izmaku iz sela Palež. „Ovaj mikrolokalitet je vezan za bogatstvo trave koji narod naziva srijemuša. ...“. Šaranci. (OSTOJIĆ M. Đ. 2003:97). NAPOMENA: vjerovatno je da toponim Sijerak ima fitonimsku osnovu, ali ne po „travi ... srijemuši“.

Siljev krš - „krševiti i kameniti predio na padinama Štuoca nazvat je Siljev krš. Nalazi se nedaleko od Jablan bare. Toponim je vezan za travu siljevicu koja raste u ataru pomenutog krša. Pošto je siljevica rijetka trava, a ljekovita, narod je mikrolokalitet nazvao Siljev krš““. (OSTOJIĆ M. Đ. 2003:76).

Siljevac - između Duži i Dubrovskog, južne padine Durmitora. Drobnjak. Tu je i Siljeva glava (=Siljeva glavica). (I. R. Todorović).

Siljevače - ,strane u koanjonu Sušice. Teren obrastao siljevinom ('ćubasta trava')“", selo Crna Gora. Duirmitor. (CICMIL-REMETIĆ R. 2003:367).

Siljevica - na desnoj strani rijeke Šekularske, iznad Dašića luke, selo Rovca, kod Berana. Vasojevići. DAŠIĆ M. 2008:355).

Sirni dô - „veliki dô pun škripova i jama u Durmitoru“, selo Crna Gora. Durmitor. (CICMIL-REMETIĆ R. 2003:345).

Slamove bare - u selu Glavaca, Gornja Sela. Vasojevići. (ŠEKULARAC B. 2008:28).

Śenička kosa - travnata kosa, pogodna za stočarenje, Jezera. Durmitor. „A tako je nazvata po tome što se tu najčešće javlja ptica sjenica“. (OSTOJIĆ M. Đ. 2003:93). NAPOMENA: tumačenje je dato proizvoljno. Toponim treba objašnjavati u sklopu srodnih toponama, kojih je veliki broj u Crnoj Gori. (PULEVIĆ V. \& SAMARDŽIĆ N. 2003:437 \& 442-443). 
Slamnice - u Lješkopoljskom lugu, Lješkopolje. Podgorica. (I: R. Mugoša).

Smiljača $(1800 \mathrm{~m})$ - lokalitet na planini Bjelasici (đe je planirana izgradnja planinarskoga doma). (Vijesti, Podgorica, 19. jul 2005, str. 21).

Smiljevica - (u Prokletijama, region Vusanja). (GUŠIĆ B. 1974:3 kaže za stanovnike sela Vusanja: „Oni su tako uspjeli i da zadrže svoje planine Bor, Bjelič i dio Smiljevice, pa im je stoka do nedavno predstavljala glavno imane").

Smokve Begove (kao: Begove smokve) - poveća njiva, selo Dajbabe. Zeta. (I: M. Knežević).

Smokve gurkine - na putu Dajbabe - Podgorica. (I: M. Knežević).

Smokvice - selo Grbavci. Zeta. (PELIČIĆ J. I.-P. 1997:178).

Smrče (kao: Izvor u Smrčama) - izvor, selo Vrela (nalazi se u Smrčama Ćorovića), Jezera. Durmitor. (OSTOJIĆ M. Đ. 2003:292).

Smrče Ćorovića (Ćorovića smrče) - jedan kompleks šuma u ataru sela Vrela, Jezera. Durmitor. (OSTOJIĆ M. Đ. 2003:154).

Smrdan - katun na planini Sinjavini. Kolašin. (KUJOVIĆ D. 2002).

Smrdan - na padinama prema rijeci Tari. (Durmitorsko područje). (OSTOJIĆ M. Đ. 2003:102).

Smrdan - izvor, Kovačka dolina, Jezera. Durmitor. (OSTOJIĆ M. Đ. 2003: 272).

Smrdan pećina - ,ispod Uskočkih mlina jedna pećina u Šiljatoj glavici se naziva Smrdan pećina ... Na njenom ulazu je obrasla neka visoka lisnata trava koja se naziva smrdljika, što je bio povod da se pećini dade ime Smrdan pećina“. Drobnjak. (OSTOJIĆ M. Đ. 2003:213).

Smrdanj - u selu Krčevo. Vasojevići. (OSTOJIĆ M. 2001:403).

Smrdivljana - prostrana livada i pašnjak, selo Previš. „U tom dijelu se javlja rastinje koje narod naziva smrdljik ...“. Drobnjak. (OSTOJIĆ M. Đ. 2003:172).

Smrekova strana - padina ispod Lokve, obrasla smrekovinom. Spušta se do samoga sela, selo Smriječno. Piva. (TADIĆ B. 2004:330).

Smrekovac - brdo iznad Smrekove strane, selo Smriječno. Piva. (TADIĆ B. 2004:331).

Smrekovac - u selu Petnjica. Vasojevići. (OSTOJIĆ M. 2001:308).

Somina - „strana i velika stena. Tu raste trava somina“, selo Crna Gora. Durmitor. (CICMIL-REMETIĆ R. 2003:367).

Somina (kao: Potok od Somine) - ,veći potok na predjelu Somina (teče prema zaseoku Vrela)“", selo Dosuđe. Gusinje. (DŽOGOVIĆ A. 2009: 482).

Somina (kao: Put za Sominu) - put od Dosuđa prema predjelu Somina, selo Dosuđe. Gusinje. (DŽOGOVIĆ A. 2009:482).

Spindiruša - „u Gornjim Šarancima, negdje na izlazu od Dobrilovine, vodi strmi i uski puteljak, pješačka staza, skoro neprohodna. Nagib je veliki 
Prva dopuna fitotoponimiji i zootoponimiji Crne Gore

da je narod nazvao Spindiruša, a kažu da se u kamenjaru javlja neka rijetka trava koja je ljekovita, naziva se spindiruša, pa da je po njoj došlo do naziva“. (OSTOJIĆ M. Đ. 2003:84).

Srijensla Jolovića - u Mrtvom dolu, selo Perovići, Macavare. Banjani. (PEROVIĆ N.Đ. 2003:10).

Srneća dola - „tako meštani Kneževića zovu potes na zajedničkoj planini; za stanovnike susednih Šarića to su Srndaćevića doline“, Pivska planina. Piva. (CICMIL-REMETIĆ R. 2003:327).

Srnetiće - „ravan predio podno Barica, kod rijeke (livade)“, selo Meteh. Plav. (DŽOGOVIĆ A. 2009:217).

Striješin dô - u regionu katuna Račama, padine planine Žijevo. Kuči. (I: M. Rajković). NAPOMENA: PULEVIĆ V. \& SAMARDŽIĆ N. 2003:440 navode toponime: Striješev kamen, Striješin dô. U literaturi je zabilježeno da strijež i striješ označavaju inje, mraz, bijele iglice (KOVAČEVIĆ N.S. 2007:156 \& RAOSAVLJEVIĆ R. 1990:412).

Striježevina - iznad sela Kovčice, Jezera. Durmitor. „Narod je lokalitet nazvao tako jer za vrijeme hladnoća i kad padnu velike slane, trava i drugo rastinje nakostriješi se, podigne, stoji dupke smrzlo ...“.(OSTOJIĆ M. Đ. 2003:110).

Strn - u selu Lagatori. Vasojevići. (OSTOJIĆ M. 2001:327).

Svinjač - u selu Mojanovići. Zeta. (PELIČIĆ J. I.-P. 1997).

Śečina - u selu Kovčice. Durmitor. (OSTOJIĆ M. Đ. 2003:66-67).

Śečina - u selu Gradac, Šavnik. Drobnjak. „,Radi se o prostoru koji izgleda da je zasjekom odsječen od cjeline, od susjednog prostora“. (OSTOJIĆ M. Đ. 2003:164).

Śekelj - lokalitet na vrhu Crne planine, iznad Veruše. (I: V. Vujotić).

Śeme (kao: Gubiśema) - ,potes u naselju (livada; ovdje je bila njiva gubila je śeme; u ovoj leksemi evidentirana je fonema $\left.s^{\prime}\right)^{\text {“, }}$, selo Vojno Selo. Plav. (DŽOGOVIĆ A. 2009:118).

Śenokos - ovalni brežuljak na lijevoj obali Radanske rijeke, selo Mikulić. Bar. (PEROČEVIĆ E. 2003).

Śenokos - livade prošarane četinarima između Koprivne ravni i prevoja Śekira, selo Rovca, kod Berana. Vasojevići. (DAŠIĆ M. 2008:344).

Śenokos Pavlov (kao: Pavlov śenokos) - šumovita uvala ispod vrova, prema Jarčištima, selo Smriječno. Piva. (TADIĆ B. 2004:320).

Śenokośe - u selu Glavaca, Gornja Sela. Vasojevići. (OSTOJIĆ M. 2001:453).

Śenokosi - u selu Vukovci. Zeta. (PELIČIĆ J. I.-P. 1997).

Śenokosna strana - ,jedna strmina podno sela Ninkovića travna je i kosa“. Durmitor. (OSTOJIĆ M. Đ. 2003:54).

Śerave - u Golubovcima. Zeta. (PELIČIĆ J. I.-P. 1997).

Śrave - u selu Balabani. Zeta. (PELIČIĆ J. I.-P. 1997). 
Vukić PULEVIĆ

Šarike - u selu Balabani. Zeta. (PELIČIĆ J. I.-P. 1997).

Šaronjina glavica - „brdo pored Čaira“, selo Crna Gora. Durmitor. (CICMIL-REMETIĆ R. 2003:352).

Šarulje - u Golubovcima. Zeta. (PELIČIĆ J. I.-P. 1997).

Šaruljina Jama - u Cucama. Katunska Nahija. (I: B. Jovanović).

Ševar - izvor u Pržića brijegu, selo Jasenova. Donja Morača. (SIMONOVIĆ A. 2000).

Ševar - „potesi pored jezera (močvarne livade, voda se tokom ljeta povlači pa ovdje raste ševar)“, Vojno Selo. Plav. DŽOGOVIĆ A. 2009:120).

Ševar brdo - ,predio na Visitoru (močvarni potesi, ima ševara), selo Brezojevica. Plav. (DŽOGOVIĆ A. 2009:60).

Ševari - „močvarni potesi pored rijeke Ljuče (kada se tokom ljeta voda povuče prema svojoj sredini, na ovim potesima raste visok gust ševar, trska i travul'ina), selo Višnjevo. Gusinje. (DŽOGOVIĆ A. 2009).

Šipak - od sela Kovčice prema Banskim kućama, Jezera. Durmitor. (OSTOJIĆ M. Đ. 2003:135).

Šipčanički potok - u slivu Tare (kanjon Tare). (I).

Šipovac - u Mrtvom dolu, selo Perovići, Macavare. Banjani. (PEROVIĆ N. Đ. 2003:11).

Šipovlje - u selu Radmanci. Vasojevići. (OSTOJIĆ M. 2001:324).

Šljepur - pored Zete, Pažićko polje - kod Željezničke stanice. Danilovgrad. (I: M. Vulikić \& Z. Mrvaljević). NAPOMENA: PULEVIĆ V. \& SAMARDŽIĆ N. 2003:488 zabilježili su toponim „Višljepura - mjesto u brdu Tarašu, Pažići. Bjelopavlići (L: Šobajić P. 1923:53)“.

Šljive Malovića (kao: Malovića šljive) - u selu Dubrovsko. „Radi se i šljiviku koji je već uništen, ali se tako naziva zemljište“. Drobnjak. (OSTOJIĆ M. Đ. 2003:392).

Špate - u selu Berislavci. Zeta. (PELIČIĆ J. I.-P. 1997).

Štavanjske glave - ,na Štavnu-Štavnju u katun Štavanjske glave izdižu stanovnici sela Sretuške gore“. Kolašin. (KUJOVIĆ D. 2002:97).

Šuma - „teren između Dolova i Nadgorja obrastao šumom“, selo Crna Gora. Durmitor. (CICMIL-REMETIĆ R. 2003:370).

Šuma - „veći predio niže Jarine male (šuma)“, selo Dosuđe. Gusinje. (DŽOGOVIĆ A. 2009:484).

Šuma Ćosovića (kao: Ćosovića šuma) u selu Vusanje. Gusinje. (IPLB. 1966:25).

Šuma krstata (kao: Krstata šuma) - „planinska kosa više sela, jugoistočno (visoka, četinarska šuma)“, selo Bogajiće. Plav. (DŽOGOVIĆ A. 2009:32).

Šuma novšićka (kao: Novšićka šuma) - ,gajevi više sela (informator je upotrijebio leksemu novšićka umjesto nokšićka, a tako je od admini- 
Prva dopuna fitotoponimiji i zootoponimiji Crne Gore

strativne promjene ranije forme imena ovog sela)“, selo Nokšiće. Plav. (DŽOGOVIĆ A. 3009:247).

Šuma od Hurvale - predio niže Strane Nikočevića (sek. fonema $h$ u leksemi hurvale//Hurvale)“, selo Dosuđe. Gusinje. (DŽOGOVIĆ A. 2009:484).

Šuma Rustova (kao: Rustova šuma) - ,potes više puta u selu (hrastova šuma)“, selo Komarača. Plav. (DŽOGOVIĆ A. 2009:177).

Šumarci - ,planinska kosa pravcem Pršov krš - Kodra (mjestimično ima šume, sitnogorica)“, selo Nokšiće. Plav. (DŽOGOVIĆ A. 2009:248).

Šume - ,teren obrastao zakržljalom bukovinom“, selo Crna Gora. Durmitor. (CICMIL-REMETIĆ R. 2003:370).

Šume - „šumoviti predio više Dolje (sjeverozapadno, brda)“, selo Dolja. Gusinje. (DŽOGOVIĆ A. 2009:476).

Šume - „,brdoviti potesi na predjelu sela (šuma, njive, livade i nekolike kuće)“", selo Meteh. Plav. (DŽOGOVIĆ A. 2009:217).

Šume l'evoške (kao: L'evoške šume) - ,potesi na predjelu Ljevoša (veće brdo, šuma)“, selo Komarača. Plav. (DŽOGOVIĆ A. 2009:177).

Šumarci - u selu Velika. Vasojevići. (OSTOJIĆ M. 2001:471).

Šume - u selu Gračanica. Vasojevići. (OSTOJIĆ M. 2001:465).

Šumljakica - „,predio u strani više sela (šuma)“, selo Brezojevica. Plav. (DŽOGOVIĆ A. 2009:68).

Šumnata glavica - kod Podbožura. Nikšićke Rudine. (Tk).

Teleća ograda - „strana, nekada zagrađivano zemljište za telad“, selo Crna Gora. Durmitor. (CICMIL-REMETIĆ R. 2003:362).

Teleća prodo - „strančica koja je nekad bila ograđena“, selo Crna Gora. Durmitor. (CICMIL-REMETIĆ R. 2003:365).

Tetrijebovo osoje - u Brezovom dolu, Macavare. Banjani. „Dobilo je ime po ptici, koja se zove tetrijeb. Vjerovatno ih je ranije tu bilo, a danas, koliko ja znam nema ih“. (PEROVIĆ N.Đ. 2003:29).

Tisa - iznad Brezojevice, Stravče. Kuči. (I: Z. Rajković).

Tisovac - ,jedna od strmina obrasla je tisom, koja je u narodu poznata kao drvo zaštite čovjeka...", po tome je nazvan lokalitet Tisovac, kanjon Tare. (OSTOJIĆ M. Đ. 2003:205).

Tisovac (kao: Kita Tisovca) - glavica na Tisovcu, Macavare. Banjani. (Jedan lokalitet zove se Grad na Tisovcu, nazvan po građevini koju su Austrijanci gradili 1917. i 1918). (PEROVIĆ N.Đ. 2003:24).

Tmora - prostrani kompleks šuma u Tepačkom kraju. Iznad se nalazi Tmorska glavica. ,Zbog gustine debelih i visokih stabala četinara u gustišu šuma je neviđelica, tmina, tama, po čemu je šumski kompleks dobio ime Tmora“. Isto: „Tmora su gusti nepregledni kompleksi tepčkih šuma, poznati po kvalitetnom i dobrom drvetu“, Jezera. Durmitor. (OSTOJIĆ M. Đ. 2003:86). 
Vukić PULEVIĆ

Tmušice - ,preko Malog Crnog vrha prema rijeci Tari, prostirala se šuma borovih stabala“, Jezera. Durmitor. (OSTOJIĆ M. Đ. 2003:192).

Trava bijela (kao: Bijela trava) - pašnjaci i njive podno Srednjega vrha, selo Mikulići. Bar. (PEROČEVIĆ E. 2003). NAPOMENA: PULEVIĆ V. \& SAMARDŽIĆ N. 2003:466 navode toponim Bijela trava za dva lokaliteta: u Gornjoj Lastvi (iznad Tivta) i u Čelobrdu (Paštrovići).

Trebljevina - širi lokalitet, selo Virak. Prostor je bio nekada kamenit „pa su mještani trijebili (micali) kamen i sabijali ga u gomile i pozide“. Durmitor. (OSTOJIĆ M. Đ. 2003:147).

Trebljevina - voda, selo Lubnice, Gornja Sela. Vasojevići. (ŠEKULARAC B. 2008:19).

Trebljevina - izvor u selu Komarnica. Drobnjak. (OSTOJIĆ M. Đ. 2003:258).

Trebljevina - izvor u Pošćenskom kraju. „Nazvat je Trebljevina po tom što je narod uređivao okolinu izvora mičući ili trijebljeći kamen i druge otpadne materije“, Jezera. Durmitor. (OSTOJIĆ M. Đ. 2003:280).

Trešnja - u selu Gostilj. Zeta. (PELIČIĆ J. I. -P. 1997).

Trešnje brojanske - ,potes više Česme velike (više brojanskih kuća - katoličkih doseljenika iz Albanije; livade na kojima ima i divljih trešanja)“, selo Grnčar. Gusinje. (DŽOGOVIĆ A. 2009:398).

Trešnjički mlini - na putu Lastva - Radanovići. Grbalj. (I).

Trnovače - u selu Tucanje. Vasojevići. (OSTOJIĆ M. 2001:309).

Trnovci - „dolina i strane obrasle travom i velikim, konjskim trnjem“, selo Crna Gora. Durmitor. (CICMIL-REMETIĆ R. 2003:369).

Trnoviti pod - ,zemljište koje je ravno, bez posebnih oblika reljefa, nazvan je Trnoviti pod. Obradivo je zemljište, travnato i pogodno za život ljudi“ i da nije nazvano zbog trnja, već ,zbog trave koja je bila po livadama zvene trn“. (Bez konkretne ubikacije). Drobnjak. (OSTOJIĆ M. Đ. 2003:164).

Trnje - u selu Petnjica. Vasojevići. (OSTOJIĆ M. 2001:308).

Trševina - ,potesi pored rijeke (livade; oko rijeke raste ševar i visoka trska)“, selo Đurička Rijeka. Plav. (DŽOGOVIĆ A. 2009:123).

Tršl'evina - potes zapadno od Jare (livada na kojoj raste nekakva trska)“. Plav. (DŽOGOVIĆ A. 2009:151).

Turuntaš - izvor, selo Mirac. Njeguši. (ČIRGIĆ A. 2009:228).

Tusta - katun, selo Lubnice, Gornja Sela. Vasojevići. (ŠEKULARAC B. 2008:19). NAPOMENA: toponim Tusta je neproziran. U botaničkim rječnicima srijeću se fitonimi: tust, tust divlji, tustenjača, tusti bob, tusti koren, tustika i dr.

Udljikova prodo - u selu Smriječno. Piva. (TADIĆ B. 2004:324). 
Prva dopuna fitotoponimiji i zootoponimiji Crne Gore

Ulj - ,vjeruje se da je od povike vlasnika zemlje, kad uđe stoka u zabran, pa je kratko govoreno ulj(eze) stoka u štetu“, selo Donja Bukovica. Drobnjak. (OSTOJIĆ M. Đ. 2003:75).

Uljanik tepački (kao: Tepački uljanik) - ,negdje na obroncima sela Tepaca ispod strmih stijena, javljaju se pčele koje su umjesto košnica pravile medišta u krošnjama drveća“, selo Tepca. Durmitor. (OSTOJIĆ M. Đ. 2003:54).

Usovine - na prostoru sela Kurikuće, Gornja Sela. Vasojevići. (ŠEKULARAC B. 2008:24).

Usovišta - ispaša, selo Zagrad, Gornja Sela. Vasojevići. (ŠEKULARAC B. 2008:33).

Usovište - na prostoru sela Kurikuće, Gornja Sela. Vasojevići. (ŠEKULARAC B. 2008:24).

Ušl'ivi potok - ,veći potok na predjelu sela (teče niz strane i dalje kroz seoski atar, nosi pijesak i kamenje pa ga po tome ovako nazivaju)“", selo Kruševo. Gusinje. (DŽOGOVIĆ A. 2009:493).

Ušljivac - vrelo, Rovačka planina, selo Rovca, kod Berana. Vasojevića. (DAŠIĆ M. 2008:352).

Uzgorica - „to je jedna omanja livada ispod Crvenih brda. Toponim je od sintagme uz goru: Uzgorica - livada uz goru“, selo Smriječno. Piva. (TADIĆ B. 2004:335).

Vekljevac - ,jedna livada u obliku terase na padinama Sinjavine zove se i danas Vekljevac, što znači kožđarnik. I zaista njena okolina obrasla je sitnogoricom pogodnom za gajenje koza. Stari Sloveni zvali su kozu veka, a ovcu beka. Otuda su se i do današnjih dana očuvali i izrazi: večati i blejati“. Sinjavina. (RAOSAVLJEVIĆ R. 1990:327).

Vidrenjak - ,,potesi pored Plavskog jezera (sjeveroistočna ivica jezera). Plav. (DŽOGOVIĆ A. 2009:255).

Vidrica - „Vidrica - ogromna okomita stena, ravna i glatka; U narodu: tako se zove jer je lijepa kao vidra", selo Crna Gora. Durmitor. (CICMIL-REMETIĆ R. 2003:351). NAPOMENA: Dopuna toponimu kojeg su naveli PULEVIĆ V.\& SAMARDŽIĆ N. 2003:483. „Vidrica (2037) na śeverozapadnim ograncima planine Durmitor prema Sušičkom jezeru. $(\mathrm{L}, \mathrm{Tk})$ “.

Vila - oronim iznad Kralja. Vasojevići. (OSTOJIĆ M. 2001:101).

Vilin izvor - na Komovima. (OSTOJIĆ M. 2001:101)

Vilina pećina (kao: Pećina vilina) - u selu Śenica. Kuči. (PETROVIĆ D. 1988).

Vilina pećina - na području Brskut - Korijen. Kuči. (PETROVIĆ D. 1988).

Vilina pećina - u Bijelim vodama. Kuči. (PETROVIĆ D. 1988).

Vilino kolo - na Komovima. (OSTOJIĆ M. 2001:101). 
Vil'in izvor - veći izvor u predjelu Liješće niže sela (po predanju ovdje su se kupile vile)“, selo Brezojevica. Plav. (DŽOGOVIĆ A. 2009:62).

Vinograd kaluđerov (kao: Kaluđerov vinograd) - svojina Manastira Dajbabe. (Tu je i toponim Kaluđerova bašta). Zeta. (I: M. Knežević).

Voćnjak - (dosta toponima imenovano je po voću ili povrću; iako su danas degradirali i na njima rastu autohtone vrste spontane flore oni su zadržali ime. Takvi su: „Vinograd“, „,Voćnjak“, „Šljivik“, „Lučnjak“, „Bostan“ i dr.).

Votnjak - zaselak, selo Glavaca, Gornja Sela. Vasojevići. (ŠEKULARAC B. 2008:26).

Voznik - u selu Perovići, Macavare. Banjani. (PEROVIĆ N.Đ. 2003:15).

Voznik - ,potes na predjelu sela (strana za liferovanje trupaca)“, selo Jesenica. Plav. (DŽOGOVIĆ A. 2009:166).

Voznik - ,potes u strani više sela (šuma; niz ovaj voznik mještani spuštaju drvenu građu prema selu)“, selo Kruševo. Gusinje. (DŽOGOVIĆ A. 2009:491).

Voznik pašin - ,potesi u strani više naselja Dolja (zapadno; pripada Ali-paši Gusinjskom)“, selo Dolja. Gusinje. (DŽOGOVIĆ A. 2009:473).

Voznik: Val'ski voznik, Vel'iki voznik, Mali voznik - na području sela Martinoviće. Gusinje. (DŽOGOVIĆ A. 2009:497).

Voznik vlačegov (kao: Vlačegov voznik) - stari prokrčeni voznik, koji je „povezivao Žagricu sa starim naseljenim djelovima Smriječna i vjerovatno je služio za dovoz luča i lučeve daske“, selo Smriječno. Piva. (TADIĆ B. 2004:293).

Vranići - u selu Gostilj. Zeta. (PELIČIĆ J. I.-P. 1997).

Vranina - brdo, Cuce. Katunska Nahija. (I: B. Jovanović).

Vranjina - ,veći potes, doline i strane, livade“, selo Crna Gora. Durmitor. (CICMIL-REMETIĆ R. 2003:351).

Vražje vođenice - ,stijene i pećine između Duljeva katuna i Šticke rijeke (pripovijedaju da ovdje žive vragovi)“, selo Grnčar. Gusinje. (DŽOGOVIĆ A. 2009:392).

Vražji virovi - kod Đalovića pećine u Đalovića klisuri. Bijelo Polje. (Tk).

Vrba Nuhova (kao: Nuhova vrba) - u selu Dašča Rijeka. Vasojevići. (OSTOJIĆ M. 2001:320).

Vrbe - u Lješkopoljskom lugu, Lješkopolje. Podgorica. (I: R. Mugoša).

Vrbe - u selu Lagatori. Vasojevići. (OSTOJIĆ M. 2001:327).

Vrbe Mitrove (kao: Mitrove vrbe) - na rijeci Morači, ispod sela Dajbabe. Zeta. (I: M. Knežević).

Vrbica - u selu Gostilj. Zeta. (PELIČIĆ J. I.-P. 1997). 
Prva dopuna fitotoponimiji i zootoponimiji Crne Gore

Vrbica - izvor pitke vode u selu Gradac kod Šavnika. „Toponim je nazvat po tom što su se na Vrbicu, proljećni praznik okupljali mladi i služili vodom“. Drobnjak. (OSTOJIĆ M. Đ. 2003:243).

Vrbica - ,potesi na planini Lipovici (šuma i pašnjak)“, selo Grnčar. Gusinje. (DŽOGOVIĆ A. 2009:392).

Vrbić - u selu Vukovci. Zeta. (PELIČIĆ J. I.-P. 1997).

Vrbič - njiva u zaseoku Androvići, selo Mikulići. Bar. (PEROČEVIĆ E. 2003). NAPOMENA: PULEVIĆ V. \& SAMARDŽIĆ N. 2003:502 navode: „Vrbič - izvor, Mikulići. Bar.(L)“.

Vrbiš debeli (kao: Debeli vrbiš) - u selu Ponari. Zeta. (PELIČIĆ J. I.-P. 1997).

Vrbljak - jedan od zapuštenih i rijetko korištenih izvora, selo Vrela, Jezera. Durmitor. (OSTOJIĆ M. Đ. 2003:267).

Vrbovac - u selu Mataguži. Zeta. (PELIČIĆ J. I.-P. 1997).

Vrbovac - u Golubovcima. Zeta. (PELIČ́Ć J. I.-P. 1997).

Vrtići - v. Lanište (CICMIL-REMETIĆ R. 2003).

Vuča legla - lokalitet na planini Zeletin. Vasojevići. (OSTOJIĆ M. 2001: 339).

Vučje jame - kod Kovačeva panja. Šaranci. (OSTOJIĆ M. Đ. 2003:217).

Vučje jame - u kanjonu rijeke Tare. One su tako nazvate što su se često oko jama sretala vučad. Šaranci. (OSTOJIĆ M. Đ. 2003:216).

Vučja jama - na putnom pravcu prema katunu Lokvice. „Do naziva je došlo zbog česte pojave vučice i vučadi što se sklanjaju u jami ...“. Durmitor. (OSTOJIĆ M. Đ. 2003:191).

Vučja lokva - u selu Glavaca, Gornja Sela. Vasojevići. (ŠEKULARAC B. 2008:26).

Vukotinac - uz selo Vuča, Gornja Sela. Vasojevići. (OSTOJIĆ M. 2001:441).

Vukov brijeg - u selu Bastahe, Gornja Sela. Vasojevići. (ŠEKULARAC B. 2008:25).

Vuznik//Vuznici - ,planinski (pješački) put prema Kofiljači (ovim putem mještani dovoze drva i građu sa planine; vuznici-voznici)“", Malo Selo. Plav. (DŽOGOVIĆ A. 2009:208).

Zabel' - „zaselak sela Hote (livade, pašnjaci, šume, katuništa ...)“仿, selo Hote. Plav. (DŽOGOVIĆ A. 2009:375)

Zabel' - ,potesi na predjelu Čardak (šuma)“, selo Dosuđe. Gusinje. (DŽOGOVIĆ A. 2009:480).

Zabio - brdo, selo Majstori, Lovćen. Njeguši. (ČIRGIĆ A. 2009:252).

Zabio - u selu Lagatore. „Zabjel je granica“. Vasojevići. (OSTOJIĆ M. 2001:327).

Zabio velji (kao: Velji Zabio) - brdo, selo Majtori, Lovćen. Njeguši. (ČIRGIĆ A. 2009:242). 
Zabjela - u selu Radmanci. Vasojevići. (OSTOJIĆ M. 2001:324).

Zadubljica - velika i prostana njiva, ispod uzvišenja Dub, Previš. Drobnjak. (OSTOJIĆ M. Đ. 2003:112).

Zabravlje - prostrana uvala u podnožju velike Orujice (sa dobrim ukosom sijena), Jezera. Durmitor. (OSTOJIĆ M. Đ. 2003:158).

Zaruđe - brdo i padine između Dašića Mahale i Bijedanjske strane. „Izvedeno od glagola zaruditi ... u Zaruđu ima ruja što je rjetkost u čitavom Beranskom kraju“, selo Rovca, kod Berana. Vasojevići. (DAŠIĆ M. 2008:336).

Zasada - „ravan predio više Nikšića laza (livada)“, selo Brezojevica. Plav. (DŽOGOVIĆ A. 2009:62).

Zec kamen - između Kaluđerovače i Previje, Jezersko polje. (Po usamljenom kamenu koji asocira na zeca u travi). Durmitor. (OSTOJIĆ M. Đ. 2003:97).

Zečevo ždrijelo - „tijesnac kroz koji se mora proći“, selo Brajkovača. Šaranci. (OSTOJIĆ M. Đ. 2003:98).

Zečica - zaravan ispod sela Junča. „Tu su Turci podignuli karaule za čuvanje posjeda i granica. Zečica se nije nazvala zbog kretanja zeca, već što su često vršilči napade na Turke, pa su se oni od Drobnjaka plašili, zbog čega se nazvala Zečica“, Jezera. Durmitor. (OSTOJIĆ M. Đ. 2003:175).

Zečica - na prostoru sela Tušinja. „Predanje kaže da su tim lokalitetom prolazili, igrali se i pasli zečevi koji su iz šume prolazili da piju vode na rijeci Tušinji“. Uskoci. (OSTOJIĆ M. Đ. 2003:100).

Zečja glava - u selu Kovači. Oputna Rudina. (I: B. Koprivica).

Zečji brk - glavica, između Vraćenovića i velimlja. Banjani. (I: B. Koprivica).

Zečke bare - lokalitet u selu Slatina. (Tu je nekada živjela porodica Zečevi). Tu su još lokaliteti: Zečke lazi i Zečke poljane. Drobnja. (OSTOJIĆ M. Đ. 2003:390).

Zečkovina - u Cucama. Katunska Nahija. (I: B. Jovanović).

Zelena glavica - u selu Njegovuđe. Šaranci. (OSTOJIĆ M. Đ. 2003:69).

Zelena gora - u Donjim Šarancima, neđe iznad sela Krš. ,Zelena Gora je tako nazvana po tom što se prostiru šume zaista uvijek zelene“. (OSTOJIĆ M. Đ. 2003:39).

Zeleni dô - ,velika dolina u selu“, selo Crna Gora. Durmitor. (CICMIL-REMETIĆ R. 2003:353).

Zeleni pasovi - „potes u Škrci prema Žabljaku i Drobnjacima“. Durmitor. (CICMIL-REMETIĆ R. 2003:363).

Zeleno ramo - ,poveća izbočina obrasla listopadnom šumom i borovima, teren pored Jatara (kanjon Tare)", selo Crna Gora. Durmitor. (CICMIL-REMETIĆ R. 2003:366). 
Prva dopuna fitotoponimiji i zootoponimiji Crne Gore

Zeretino polje - ,podno sjevernih padina Kovačeva panja u ataru Vrela, jedna prostrana zaravan je nazvata Zeretino ili često izgovarano Zvjeretino polje“. Po legendi tuda se ,zvijerinje spuštalo vodopojima“.Durmitor. (OSTOJIĆ M. Đ. 2003:123-124).

Zlatna dolina - dolina, selo Gradac kod Šavnika. ,Zbog roda i izgleda (cvijeće žute boje), narod je dolinu nazvao Zlatna dolina“. Drobnjak. (OSTOJIĆ M. Đ. 2003:400).

Zlatna strana - u Banjanima. (Možda je nazvana po nekoj gusto nastanjenoj biljci žutih cvjetova, npr.: Genista, Petteria i dr.). (L, I).

Zlogorica - u selu Srpska. Zeta. (PELIČIĆ J. I.-P. 1997).

Zmajevac - izvor, Jezera. Durmitor. (OSTOJIĆ M. Đ. 2003:277).

Zmijanovica - u selu Vranj. Zeta. (PELIČIĆ J. I.-P. 1997).

Zmijanac - izvor, Morinj. Boka Kotorska. (NAKIĆENOVIĆ S. 1913:525).

Zminja krša//Zminji krši - ,krševit i strm teren koji ulazi u brijeg na Bezuju“. Pivska planina. Piva. (CICMIL-REMETIĆ R. 2003:327).

Zminje brdo - brdo, Cuce. Katunska Nahija. (I: B. Jovanović).

Zminje ramo - ,izbočina i vala obrasla šumom (kanjon Sušice)“, selo Crna Gora. Durmitor. (REMETIĆ R. 2003:366).

Zogajsko blato - mjesto kod Ulcinja (Ulcinjska solana). Zog na albanskom ptica. (SAVELJIĆ D. 2008. Tra terra e Mare. Universita del Salento).

Zukvanjsko polje - $u$ ataru sela Bukovica. „Narod kaže da je naziv došao po divljim jabukama koje narod naziva zukve ....". Drobnjak. (OSTOJIĆ M. Đ. 2003:124).

Zvjerinak - u Cucama. Katunska Nahija. (I: B. Jovanović).

Zvjerišta//Zvljerišta - ,veći potes u kanjonu Tare, teren bogat divokozama“, selo Crna Gora. Durmitor. (CICMIL-REMETIĆ R. 2003:355). NAPOMENA: Možda se radi o istom lokalitetu kojega su prikazali PULEVIĆ V. \& SAMARDŽIĆ N. 2003:525: „Zvjerište (Malo i Veliko) - na lijevoj obali rijeke Tare (u kanjonu), nizvodno od Tepaca. (L: Brajović M.B. 1984)“.

Žaborovo - livade i močvare pri Skadarskom jezeru, blizu sela Gostilj. Zeta. (I: M. Knežević \& V. Bušković). NAPOMENA: PULEVIĆ V. \& SAMARDŽIĆ N. 2003:526 naveli su lokalitet „Žabarevo“ - između Mataguža i Gošića. zeta. (I)“. (Ovim se vrši dopuna i ispravka naziva).

Žar Averića (kao: Averića žar) - u reonu sela Žabljak. Ceklin. (PELIČIĆ J. I.-P. 1997).

Žar Dokof(v) - „malo brdo više sela (zapadno; šuma)“, selo Pepiće. Plav. (DŽOGOVIĆ A. 2009:251).

Žar međedof(v) - „potes više sela (šuma i pašnjak)“, selo Kruševo. Gusinje. (DŽOGOVIĆ A. 2009:491). 
Vukić PULEVIĆ

Žar Rekovića - ,potes više sela (livada)“, selo Pepiće. Plav. (DŽOGOVIĆ A. 2009:251).

Žarevi - ,planinski predjeli zapadno od sela Grnčar (na međi atara sela Grnčar i atara naselja Kuti)“, selo Grnčar. Gusinje. (DŽOGOVIĆ A. 2009:393).

Žarevi - ,potes više sela (livade)“, selo Budovice. Plav. (DŽOGOVIĆ A. 2009:114).

Žarevi murinski (kao: Murinski žarevi) - ,,predjeli na zapadnoj strani Visitora (prema selu Murina)“. Plav. (DŽOGOVIĆ A. 2009:62).

Žarovi - ,,potes na planini Bor (pašnjaci)“, selo Kruševo. Gusinje. (DŽOGOVIĆ A. 2009:491).

Žarovica - na području sela Vusanje. Gusinje. (OSTOJIĆ M. 2001:504).

Žestičje (Žeštičje) - predio iza Ledenice, između vrha Kuletine i česme Kalanjuše. Prvo navodi da se po Tucakvu veže za Ramnus falax. „No u Pivi se žestikom zove i jedna vrsta javora, što navodi i Vuk u rječniku. U svakom slučaju jasno je da je toponim došao po vrsti rastinja na tom lokalitetu“, selo Smriječno. (TADIĆ B. 2004:299).

Žirna dolina - lokalitet prekriven bukovim stablima koja bogato rađaju žir. Jezera. Durmitor. (OSOJIĆ M. Đ. 2003:131).

Žitnica (kao: Bežitnica) - u Jezero-šaranskom području. Durmitor. (OSTOJIĆ B. 1998:14).

Živci//Živčići//Živići - ,,veći potes šume u Štuocu“, selo Crna Gora. Durmitor. „Onim nastao u vreme kada je označavao mladu goru, šumu u začetku“. (CICMIL-REMETIĆ R. 2003:338\&355).

\section{Literatura}

- ANTOLJAK S. 1979: Orahovac (Boka Kotorska). Boka, 11:53198. Herceg Novi.

- BLEĆIĆ V. 1958: Šumska vegetacija i vegetacija stena i točila doline reke Pive. Glasn. Prir. Muzeja, Ser. B, 11:5-101. Beograd.

- BORIČIĆ TIVRANSKI V. 2002: Rječnik vasojevićkog gvora. Prosveta. Beograd.

- CICMIL-REMETIĆ R. 2003: Toponimija durmitorskog sela Crne Gore. SANU - Onomatološki prilozi, 16:323-375. Beograd.

- ĆUPIĆ D. 1970: Mikrotoponimija sa sufiksom -ina u Bjelopavlićima. Prilozi proučavanju jezika, 5:303-307. Novi Sad.

- ĆUPIĆ D. \& ĆUPIĆ Ž. 1997: Rečnik govora Zagarača. Srpski dijalektološki zbornik, XLIV, str. IX-XX \& 1-615. Beograd.

- ČIRGIĆ A. 2009: Rječnik njeguškog govora. Matica crnogorska Biblioteka Crnogorski jezik. Cetinje - Podgorica. 
Prva dopuna fitotoponimiji i zootoponimiji Crne Gore

- DAŠIĆ M. 2008: Rovca kod Berana. CANU - Odjeljenje društvenih nauka, 61(17). Podgorica.

- DOŠLJAK D. 2009: Onomastikon Crne Gore u Onomatološkim prilozima. Riječ, Nov. ser., 1:31-42. Nikšić.

- DŽOGOVIĆ A. 2009: Onomastikon plavsko-gusinjske dijalekatske oblasti. ALMANAH - posebna izdanja. Podgorica.

- GILIĆ S. 2004: Rječnik bilja - Građa za hrvatsku fitonimiju. Rijeka

- GUŠIĆ B.1974: Po Prokletijama kroz pola stoljeća. Tokovi, 9. Ivangrad.

- IČEVIĆ D.2007: Podgorički govor. Društvo prijatelja stare Podgorice. Podgorica.

- IPLB (=Institut za proučavanje lekovitog bilja). Beograd, 1966: Elaborat o proučavanju lekovitog bilja na području Komova i Prokletija. Beograd).

- JOVIĆEVIĆ A. 1922: Crnogorsko primorje i Krajina. Srp. Etn. Zbor. Knj. XXIII. Naselja i poreklo stanovništva, knj. II. 1-171. Beograd.

- KASTRATOVIĆ R. 1966: Šekular i Šekularci u narodnoj priči i tradiciji. Cetinje.

- KOVAČEVIĆ N.S. 2007: Nijesmo od juče. (Zapadni dio Crne Gore: Banjani, Rudine, Grahovsko viluski kraj, pa preko Krivošija do mora). Izdavač: Galerija Most). Podgorica - Herceg Novi).

- KUJOVIĆ D. 2002: Kulturno nasljeđe Kolašina. ITP Umireks. Podgorica.

- LIPOVAC-RADULOVIĆ V. 1981: Romanizmi u Crnoj Gori, jugoistočni dio Boke Kotorske. Cetinje - Titograd.

- LUTOVAC: M. 1960: Rožaje i Štavica. Srp. Etn. Zbor., Knj. LXXV. Beograd.

- NAKIĆENOVIĆ S. 1913: Boka - antropogeografska studija. Srp. Etn. Zbor., knj. 20. Beograd. (Reprint: Herceg Novi, 1982).

- OSTOJIĆ B. 1998: O toponimima u onomastici jezero-šaranskog područja. Soa Nebeska, 23:14. Žabljak.

- OSTOJIĆ M. 2001: Vasojevići u svijetlu onomastike. Stupovi. Podgorica.

- OSTOJIĆ M. Đ. 2003: Toponimija Drobnjaka. Izdavačka kuća Draganić. Beograd.

- PELIČIĆ J. I.-P. 1997: Zapisi o Zeti. Naselja - stanovništvo - tradicija. Sabor Zete. Golubovci - Beograd.

- PEROČEVIĆ E. 2003: Mikulići na kraju vijeka. Bar. (Poglavlje Toponimija područja Mikulića, str. 145-148). 
- PEROVIĆ N. Đ. 2003: Moje kratke priče o Macavarama i Macavaranima. Nikšić.

- PERUĆICA R. K. 1989: Oputna Rudina - Građa za proučavanje mog zavičaja. ITP Trag. Beograd.

- PETROVIĆ D. 1972: Mikrotoponimija Gornjih Pješivaca i Broćanca. Prilozi proučavanju jezika, 8:47-70. Novi Sad.

- PETROVIĆ D. 1988: Toponimija Kuča. Onomatološki prilozi, 9:1-163. Beograd.

- PULEVIĆ V. \& SAMARDŽIĆ N. 2003: Fitonimi i zoonimi u toponimiji Crne Gore. DANU - Posebna izdanja. Podgorica.

- PULEVIĆ V. 2009: Osvrt na probleme crnogorske fitonimije. Lingua Montenegrina, 3:65-80. Cetinje.

- RAOSAVLJEVIĆ R.1990: Morača, Rovca, Kolašin. Beograd.

- SIMONOVIĆ A. 1998: Osreci - selo u Donjoj Morači. Podgorica.

- SIMONOVIĆ A. 2000: Jasenova i Jasenovci of Šćepana do naših dana. Podgorica.

- SIMONOVIĆ D. 1959: Botanički rečnik imena biljaka. SANU Posebna izdanja, Knj. CCCXVIII. Institut za srpskohrvatski jezik, Knj. 3. Beograd.

- ŠEKULARAC B.2008: Onomastikon Gornjih Sela. Crnogorski P.E.N. centar. Cetinje.

- ŠULEK B. 1879: Jugoslavenski imenik bilja. Zagreb.

- TADIĆ B. 2004: Smriječno - selo u Pivi. Cetinje, 2004.

- ŽARKOVIĆ LJ. 1999: Nedajno u Pivi na Durmitoru. Podgorica.

\section{Informatori (I)}

- Bulatović M. (Trebaljevo - Kolašin)

- Bušković Vasilije (Vranjina, Zeta)

- Filipović Veselin (Piperi)

- Jovanović Boško (Cuce)

- Kalezić Dejan (Bjelopavlići)

- Knežević Milorad (Dajbabe - Zeta)

- Koprivica Božidar (Banjani)

- Leković Drago (Godinje - Crmnica)

- Mrvaljević Zorica (Bjelopavlići)

- Mugoša Rade (Lješkopolje)

- Nikčević Božo (Pješivci)

- Novović Velimir (Trepča - Vasojevići)

- Radonjić Brano (Kuči)

- Rajković Milenko (Kuči) 
Prva dopuna fitotoponimiji i zootoponimiji Crne Gore

- Rajković Zdravko (Kuči)

- Vučurović Zoran (Nikšić)

- Vujotić Vidak (Kuči)

- Vuksanović Danilo (Kuči)

- Vulević (Kolašin)

- Vulikić Marina (Bjelopavlići)

- Tijanić Mara (Piva)

\section{Vukić PULEVIĆ}

\section{THE FIRST ADDITION TO THE FITOTOPONYMY AND ZOOTOPONYMY OF MONTENEGRO}

The addition consists of the material related to the fitotoponymy and zootoponymy (near 1000 toponyms) collected after the publishing of the book entitled Fitonimi i zoonimi u toponimiji Crne Gore (PULEVIĆ V. AND SAMARDŽIĆ N. 2003). The author has used literary sources (which are given in the list of literature) as well as the data collected by the fellowworkers.

Key words: toponymy, fitotoponymy, zootoponymy, Montenegrin language 

LINGUA MONTENEGRINA, god. III, br. 5, Cetinje, 2010.

Institut za crnogorski jezik i jezikoslovlje „Vojislav P. Nikčević“

UDK 801.83:821.163.4

Preliminarno saopštenje

Adnan ČIRGIĆ (Podgorica)

Institut za crnogorski jezik i jezikoslovlje „Vojislav P. Nikčević“

\section{GRAĐA ZA IZUČAVANJE NJEGUŠKOGA GOVORA}

U radu se prezentuje građa za izučavanje njeguškoga govora, tj. transkribovani i akcentovani razgovori s tipičnim govornim predstavnicima Njeguša. Ispitivanje su obavili Adnan Čirgić i Aleksandar Radoman u ljeto 2008. i 2009. godine, u okviru projekta Matice crnogorske - Izučavanje crnogorskih govora.

„Njeguški je jezik udrobljen od bokeljskoga i katunskoga govora.“ Ova laička definicija jednoga od informatora možda najbolje pokazuje stvarnu sliku njeguškoga govora. Nalazeći se na istorijskom prijelazu Katunske nahije i Boke, Njeguši su vremenom usvojili neke karakteristične bokeljske jezičke odlike, a svakako se skladno uklapaju u podlovćensku granu crnogorskih govora. Njeguši su danas, kao uostalom i većina crnogorskih ruralnih oblasti, nažalost najvećim dijelom raseljeni. Nekoliko sela čak je sasvim napušteno; nove generacije govorno su prilagođene gradovima u kojima žive, pa samo možemo slutiti koliko je obilje jezičkoga materijala nestalo s posljednjim tipičnim govornim predstavnicima. U selima Velji Zalazi, Mali Zalazi, Gačevići, Knež Do, Žanjev Do više nema stanovnika (u posljednja dva boravi se jedino vikendom i djelimično ljeti); selo Vrba još uvijek ima stalno naseljenih žitelja, ali nema nijednoga tipičnog govornoga predstavnika (mlađi su uglavnom vezani za Kotor, što je svakako uticalo na promjenu govora, a dvije starice iz toga sela nijesu s Njeguša); na Krscu, u Veljemu Kraju i u Dugome Dolu nema tipičnih govornih predstavnika. Ni na katunima Bižaljevac i Vuči Do nema žitelja. 
Adnan ČIRGIĆ

Međutim, u Erakovićima i Raićevićima i danas je priličan broj onih koji su vezani za njeguško tlo, pa se na tome području najlakše mogu obaviti jezička ispitivanja i tu je, prirodno, snimljen najveći broj razgovora. Pored toga, do značajnih podataka došli smo u selu Kopito, kao i na katunu Kuk i Međuvršje, te na sadašnjem „,izdigu“ (nekadašnjem selu) Majstori. Iako, kako smo rekli, na Vrbi nema tipičnih predstavnika, od značaja je što smo uspjeli snimiti poduži razgovor s 85 -godišnjom informatorkom iz toga sela koja živi u zaseoku Džupani (Župani).

Sav materijal prikupljen je u ljeto 2008. i 2009. godine. Ispitivanja su obavili Adnan Čirgić i Aleksandar Radoman. Obišli smo sva (naseljena) njeguška sela osim Mirca, zbog požara koji je onđe harao. Za ispitivanja su birani relevantni govorni predstavnici, čiji jezik nije poremećen uticajem školstva ili okolnih govora. Riječ je uglavnom o starijim osobama, čiji je život vezan za njeguški predio, a kojima su bliži preci takođe Njeguši (kako se u njihov govor ne bi provukla neka atipična osobina). Razgovor je sniman diktafonom, a i u svemu ostalom primijenjena je ustaljena dijalektološka metodologija.

Njeguškim govorom dosad se gotovo niko nije bavio. Izuzetak predstavljaju onomastička ispitivanja Rada Ljesara. Vršena kad je u Njegušima živio priličan broj stanovnika, ta su ispitivanja danas od nemjerljivoga značaja jer, usljed raseljavanja stanovništva, današnja onomastička ispitivanja ne bi mogla dati ni približno iste rezultate. Materijal Rada Ljesara nalazi se u rukopisnoj ostavštini Crnogorske akademije nauka i umjetnosti - Onomastička građa Njeguša, koju ta institucija nažalost do danas nije publikovala (kao ni brojne druge onomastičke zbirke). No najveći dio Ljesareva onomastičkog materijala publikovan je u radu Anđelke Martinović: „O etnološkoj, etimološkoj i toponomastičkoj karti Njeguša (s korišćenom onomastičkom građom prof. Rada Ljesara)“, Bibliografski vjesnik, br. 1-2-3, Cetinje, 2004, str. 174 205, čime je postao dostupan stručnoj javnosti. Pored toga, vrijedi pomenuti i onomastičku građu koju je publikovao Mitar Pešikan („Imena iz lovćenskog sela Majstori“, Onomatološki prilozi, VI, Srpska akademija nauka i umetnosti, Beograd, 1985, str. 2-5). Glavna mana te građe jeste u tome što nije prikupljena terenskim ispitivanjem, već na osnovu razgovora s jednim iseljenim informatorom. Osim Ljesara i Pešikana, njeguškim se govorom bavio i Adnan Čirgić (Rječnik njeguškoga govora, Matica crnogorska, Cetinje - Podgorica, 2009). 
Glasovni sistem njeguškoga govora „proširen“ je suglasnikom $3(d z)$, koji se u nekim leksemima javlja bez alternative sa $z$. Taj suglasnik označen je kao 3. Takođe, ovaj govor karakteriše i specifični alternant nekadašnjega poluglasnika. Nije riječ o sačuvanome poluglasniku već o vokalu koji stoji na granici između $a$ i $e$, kao npr. u grbaljskome ili crmničkom govoru. Poslužimo se objašnjenjem Branka Miletića („Crmnički govor“, Srpski dijalektološki zbornik, knj. IX, Srpska kraljevska akademija, Beograd 1940, str. 17), koji zamjenu crmničkoga poluglasnika objašnjava kao vokal „koji je vrlo nalik na englesko 'prednje' $a(c)$ u man (low-front-wide), samo što je malo zatvoreni$\mathrm{ji}$, dakle, bliži otvorenom $e^{\text {“ }}$. Ta je pojava u današnjem njeguškome govoru u procesu iščezavanja i zabilježili smo je uglavnom samo kod starijega stanovništva, ali i kod njih nedosljedno. Taj glas obilježen je kao $\propto$. Još jedna glasovna karakteristika ovaj govor izdvaja iz crnogorske standardnojezičke slike. To je postojanje labijalizovanoga $a$ s elementima nazalnosti, što je opet odlika primorskih i crmničkih govora. Javlja se samo u dugome slogu, akcentovanom ili neakcentovanom i označeno je kao $q$.

Pored toga, napominjemo da smo, u skladu s ustaljenom dijalektolo-

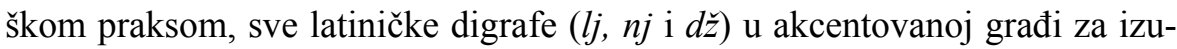
čavanje govora Njeguša označili kao monografe, i to: $l(=l j), \dot{n}(=n j)$ i $\breve{z}(=d \check{z})$ kako bi se izbjegle eventualne zabune o prirodi tih glasova.

Posebnu zahvalnost na gostoprimstvu prilikom terenskih ispitivanja dugujemo Milu Kadiji, koji nam je pomogao i u odabiru tipičnih govornih predstavnika. Zahvalnost dugujemo i informatorima za izučavanje njeguškoga govora, pa samim tim i njeguške leksike: Dragoljubu Mirkoviću (Kopito), Pavlu Bogdanoviću (Kopito), Blažu Popoviću (Erakovići), Stani Stanišić (Župani), Ilinki Kustudiji (Majstori), Vidosavi Popović (Erakovići), Milici Ševaljević (Raićevići), Iki Popović (Erakovići), Muju Popoviću (Erakovići), Senki Čavor (Župani), Andriji Ševaljeviću (Navrhpolja), Mili Ševaljević (Raićevići), Dušanu Otaševiću (Dugi Do), Luki Peroviću (Žanjev Do), Iliji Ćutku (Kuk), Belu Radnjiću (Kuk), Veśu Kustudiću (Majstori), Jovu Kustudiji (Majstori), Radovanu Popoviću (Erakovići) i Stevu Popoviću (Erakovići).

Rezultati detaljne analize prikupljenoga materijala biće objavljeni posebno. Osim dijalektološkoga doprinosa, oni će poslužiti i kao građa na osnovu koje će se moći utvrditi koliko je narodni govor Njeguša prisutan i u djelima naših klasičnih pisaca koji su potekli s toga terena, u prvom redu mislimo 
Adnan ČIRGIĆ

na Petra I i Petra II Petrovića Njegoša. Do tada, nadamo se, ona će i u ovom vidu biti od koristi zainteresovanim jezikoslovcima i drugim proučavaocima.

Në, bôgami, ne prekîdāte nïšta. A štö trëbāte? Ne smêtāte mi bögami nǐšta. Jâ në znām štö ću vi rèć. Jedîno štö je glậmnō i döbro ë se nïjesmo iskläli među söbōm. A käko je bîlo krēnülo - döbro je. Ïzvūkli smo se, döbīli smo držävu näpokōn. Nëko zädovōlan, nëko në. Nëko bi da je oburdâ, nëko da je obdiržī. Ovömē se kräja në znā, möji mômci, po mojêmu.

Äh, käd bi pöčēo prǐčăt käkāv je živöt bỉjo u möje đetîństvo i käd ${ }^{t}$ sam mladî́ bï̀o... Ovô je sæ̈d përo za käpu. Jädan je živöt bï̀o. Rakïju möžēte... Odïlo se i glą̂dno i gölo i böso, čūväla se stöka od mậle šäkē. Glą̣mno je bîlo da dïjete zavřš̄ četìri rāzrëda škōlê i uzīmäli su ga kā rą̂dnīka da čûvā stöku. I täko je ï bīlo. A päre - têško se doläzīlo za vrïjeme kraĺevìnē, da bôk sačüvā, nïkāko. Bīvälo je ōdën da žêna (trî paząra su bîla: utôrnīk, četvrtäk i subötōm) zâmī tovär krtôlē i trî päzāra idê da ga prodâ. Îstī tovär. Têžak je živöt bị o. Porödice su bîle mälo jäčē, tädēr su žěne rāđäĺle - nëkā trî, nëkā pêt, a nëkā sedam-ösam i dö desēt člänōvā. Odìli su lûdi pö svijētu da zarađüjū, da jâdē, da se müčē. Danäs lûdi nêće da râdē. Öće kafićc, öće provöđēne, öće zvêk, öće kästīg...

Držăli smo i žîvō do ëvo dvïje gödine dok je bäba mögla müs. Ranïjē smo držäli nëšto övācāh i pö dvije kräve i müč̄ili se dok su đëca učilla. Pöslije ${ }^{d}$ pö dvije kräve i köńa. Pā sam mäkæ köńa. Vìdīo sam da ne mögu za ńîm odït i da se böle isplą̂tī kupovät dřva nego držăt köńa. Pā pö dvije kräve, pa pö jednu, pā säd nïjednu. Ne möže se. Đëca su pöšla za lëbom. Jëdan mi sîn u Cetîne îmā küću. Žìîi. A jëdan je žīivìo u Tìvat. Pröšlē gödinē, èvo säd je gödina pröšla, üm ${ }^{a}$ ro je. Famëĺa mu je döĺe. Sîn mu plövī. Snäha i unüče i šcêr i žëna su döĺe. Jëdan mi je unük pö svijetu. Râdī u Ämeriku. Raštr̂̀āni su, ma böĺe nō da su näjedno. Bārek ako se rïjetko vïdīmo, bäre se ižlúûīmo i progovôrīmo jëdno z drügijēm. A ōdën da smo, möžda bismo se i köškąli. Sâmi smo mî dvöje, a doläzēe öni. Pośéćaū ne. I nêmā štö, nō doläzē. Nïjesu kā drügī, nō smo bîli zädovốni ot porödicē ka ïjeni dvơìica u Cr̂nū Göru, da mi ne ümrije ovî sîn lą̂nîk. U trî mjësēca ga räk öčisti. Në bī lïjeka nìđe ù svijēt. Täko. 
A ôđe se iselîlo. Mlögo je prąznijeh kûcāah. Ne vräćū se mläđī da odřžē küce i starevìnu. İmā ih kơî se küćé, a ïmā i onïjeh štö im se në znā kräja. O čèm žĩvî i käko žīvî - tô sämo ön znâ. Äj, žīvjëli mi, mônci! A dvānäes sêlāh je bîlo ōdën. Jâ mìslīm, kölko se śęćām kao dījete, käd su sämo lûdi glasäli, bîlo je nëšto preko čětiri stötine gläsāčā. Ovô sëlo näše je imälo oko četrës i nëšto porödīcāh. I säd ìmā nëšto stärācā. Ōđë, da se zapâli kôme küća, nêmā kö gāsït.

Ovî je pût Aüstrija naprävīla za planìnu. Näma je planìna preko tïje br̂dā göre, Vršäń. Tämo je žīvjëlo trīdēs porödīcǣh ĺêti sa stökōm. Nïje zīmïlo bez dvïje porödice kojê nïjesu imäle küću ōdën. A ovô je izdìzālo o Đûrđevu-dne sa stökōm. Göre ìmā päšē, göre, bîle su nāpôjnice (ovî üblovi vëlikī za nāpôjnicu stökē) i tû su lêtovāli bögomi i po hilädu î pō övācā i kôzāh i vǐše, i ponëšto krąvāh. Kräve su se pöčèle držät poslije räta. Do räta nïje bīlo u näše sëlo dvïje-trī kräve. Većìnōm su se bazīräli nä ôvce i köze e i je läkše držät. Trëba krävi dät zîmi ilädu î pō kîlā sîjena sämo, a tûn je mögao petnäes övācā ili dvādës kôzǣ izazīmìt so tìjēm. Zborìli su prïje: ako mi döđē prïjateĺ, jâ ne mögu ot košëta krävina okìnūt, a jägńe ili järe mögu zaklät i da se ne zacrvënīm da dočěkām prïjateĺa. Släbo je bîlo za vrïjeme kralevìnē i nädnīcāh. Nìje se imälo đë zarādìt. Tô što je bîlo, tô su prïjateĺi svöje namiještäli. A täko je i danäs.

Komïte nïjesam zapāntî̀o, a bîlo ih je. Bîlo ig je dösta. Ovô ti je bîlo u ovô sëlo möje - dvïje-trī porödice su bîli bjëlāši, a štö se tîče Popövíćá, Bôžovićá i drügijeh - tô je svë bî̀o zelenâš i za Cr̂nū Göru. Bîlo je kömītā, äma tî nïjesam zapântijo. Tô sam čùo od ${ }^{t}$ stậrijek i kao dïjete. Pā ćâgu döđi, a nïje bîlo đävola i televîzijē i râdija, nō se sküpi l̂udi starî, pā zapöčnū prîču od ovömē, od onömē, a jâ prisluškû̉. Strādälo je tô, da Bôk sačüvā, äpšeno, prebîjano. Iz ovögā sëla su dvâ-trī pogìnūli. Zakr̈vīlo se, zajādìlo se, müka je bîla. A bjëlāšā je mälo bîlo. Jâ mïslīm is svïjeh Ńëgūšāh nïje bîlo ogôrčenijeh bjëlāšā dvādëstoro, nō je svë pomāgälo komïte. I mögli su komìtovāt dok ig je nāröd pomāgäo...

Ôvđe je bîlo sëlo Vëíī Krâj. Tô su bîli starośedịjoci. Pozādi onê küćē je bỉ o ${ }^{\mathrm{v}}$ lädika Rufîm, čūjäli ste. Tämo mu je bì̀o manastîr nëđe. Pā kät smo mî döšli prije trī-četìri stötine gödīnæ, mälo-pomälo, te nêmā nāko ovâ jëdna küća te su Batrìćevīći od niỉh. Tô su starośedîjoci kojî su prijed näs döšli ōdën i bîli su ōdën sëlo. A ovî dvâ sëla nâjvišā, Ërākovići i Raìćevići, mî smo dose- 
lilli - velê - nèokle od Zenìce, pā u Bäńāne, pa od Bàńānā ōdèn, dvâ bräta Ërāk i Raìć. Öni su podijēlìli ovô. Raïć je üzēo Lôvćen i tô göre kako pût stojî, a Ërāk Vršäń i ovû bäru ōdën. I zborìli su svë käko je Ërāk prevärījo bräta. Üzēo je bölé. A säd vǐše valâ Lôvćen nō svë ovô drügō. Mïjenā se vrïjeme.

Danäs su têškē prīlïke döšle. Jâ nëkē lûde ne mögu da razumïjēm: öće prâvdu da pretvörē u nëprāvdu, a nëprāvdu u ìstinu... Küj su krēnüli nëkī, štö mìslē nëkī lûdi - jâ në znām. Në jā zatô štö sam simpatizêr Crìnē Gorê i štö sam Crnogōràc; nêću se odrīcät od moïjeh jer sam čūjâ da su döbri bîli, siromäšni ma pöšteni. Da nïjesmo imäli držăvu, da nïjesmo imäli jezïka, da nïjesmo imäli cr̂kvu, da nïjesmo imäli nǐšta - kö tô möže vjërovāt?! Jâ nêmām nâko čětiri rāzrèda, mä sam čùo nëšto, a nëšto $i$ vìdî̉o...

U Zāläze nêmāte kot kôga. Tî dvâ sëla su pötpuno iselïli. Tô vi jâ garantîrąm. Ni u Knêž-dō nêmā nïkōga. Ni Vâso vǐše ne izläzī. A jâ mïslīm da u Žānéëv-dō ìmā nëko. Ne zîmī nìko, činî mi se, ali lêtti izîdū nëkī tûn što držê nëšto kôzǣ. A i ĺêše im je za čobą̂nstvo. Möže i püštīt. Ëvo säd otolên do Grähova nêmaū štö poärāt...

Tû u sredìnu, pošto je podvödno, ako se usïjāla šenìca, iźëla je vöda zîmi. A ovô u ökolinu - tô sē svë örālo i kopälo, tô su svë môbe kopäle rumetîn, žěne ù mōbu žńële šenìcu. Jâ sam udîjoničār u tô gûmno möjēga brästva, pā sam čëkao rêd kät će me dopänūt da ovr̂̌šēm šenìcu, a säd nêće nïko da kopâ. Jâ mìslīm čöeka ispod ${ }^{t}$ četrdës-pedesêt ${ }^{d}$ gödīnā u Nëgūše nêmā kojî znậ krtôlu oprāšìt. Nêće ü zemju, pā nêće. Zä nešto drügō bi mögao nâj râdnīka, a za tô - në. Nêće da se glîbā. A läko mu se glībät. Sväkā küća ïmā kupatìlo. A jâ ü planinu, da sam imâ ûjtro vodê da öči otvörīm, kā dä bih se okūpâ. A ovô je bezvödno. Poslije räta lûdi nekolicìna su naprä $̂$ îli svöje vöde i möglo se böle nō ranìjēe I käd ${ }^{t}$ su naprävīli vöde, ostäla je i vöda i küća i svë je đäo pönīo.

Ne kösī nïko nïšta göre. A lânīk je i opậleno i izgorëlo svë. Vëlikā je sûša bîla. A prïje su bîle nëkolike bistïjerńē prìvātnē, a bîlo je i nëkoliko vôdāk nārödnijeh, pā su ĺûdi odìli s barëlima s końîma, žène nä pleći nosìle $\mathrm{i}$ donosïlo sē. Svë u svëmu, živöt je bî̀o têžak i nïkakav. A danäs ü pleme ńëgūšsō nêmą porödicē kojâ îěše ne žĩvî nō im je îkad îko žīiïjo. Ali motìku nïkāko...

A prïje se zborïlo: Kö se räno öženi - në kaja se. A danäs öće da se provödī po trìes i pet ${ }^{\mathrm{d}}$ gödīnā - četrdës. Jëdno dïjete ili nïjedno, nïje mu stälo 
ni do porödicē... I jëdan môj unük zakäsnīo je, bögami. Tries-trèćā gödina. Nêce strankïńu nō b' ovämo, a ovämo rïjetko doläzī. I käd döđē, nâjviše dväez dæenā. - „Štô je, Lûka?“ - „Đëde, pösao se môrā päzīt. Nïje tämo kā ovämo." Ma nâd ü Boga, dâko döđē ovô lêto säd. Mâjka mu je pöšla kod ńëga, dâko nešto učìnīmo. A jâ nêću da mi đëca në znāu näški, da mi đëca në znaū kö su. Zadržäo je ôn svë. Döbar je, prîčaū mi. Bäš mu je bïjo jëdan drûgk prïje dvâ-trī dâna ōdën. Bäranin jëdan. Zäjedno su sväkī dân kad' su slöbodni. A rëkli su mi i prïjed nëkī kojî su doläzīli da je za prīmjèr. A rëkli su mi dostìńa privē gödinē käd je pošào - ovî te su odîli da üčē jezïke tämo i tô - kö je do ńëga došào, pomögao ga je, nïje mögao drükče. Bîvalo je i kod ńëga da ig uzîmā nä stān po nëkolka mjësēca dok se snäđū. Jâko je döbar. I mïlo mi je tô...

Odolên ćemo. İmām jâ cigārâh. Ïmām rezêrvē dōsta. Svì mi donēsū, a šćêr öbavezno...

Prïjed je bîla vëlikā slöga kod lúdîh. Ako je nëko bîjo inokösan, da nïje imào nìkōga, üvečē se dogovōrìlo, pā mu se pokosìlo, pā môba. Sküpījo je čöek môbu - četvorìcu, petïńu, šestînu, käko je kö imäo - kukurùze da oprậ-

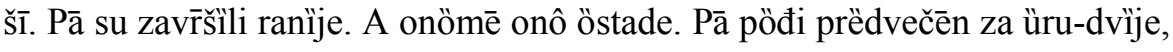
pā oprâ̧ši onömē te mu nêmā kö. Pā pomözi, pā vìđi ko nêmā köńa - uzą̂mi mu köńa da sörē. A säd nêmā kö. Stârī izümrli, a mląâ̄ nêce da rabötaū ni döma, a ne da ìdū drügōme. A štö ćemo im, nëka ih Bôg žīivî.

Bîlo je ü planinu nëšto pïtomē šùmē, jäsēna i dübovine, pā se śëklo. Śëklo se lîsta. Tô se dijelïlo pêtē gödinē. Ali nïjesmo imäli mî kā po Katûnskōj nāhïji göre da se sväkē gödinē sečû lìstovi, sadïjevaū stogövi. A bükva se i drügā göra ne upotrebläjē za tô. Nō sväkē pêtē gödinē, kad nastänē jäsēn i ovô, dijēlïla se göra.

Pedesē trëćē gödinē su köze dïgnūte ōdëna. Bögami, nïjesam se slāgäo. A i ù selo većîna se nîje slāgäla. Ma nëkōme je bîlo do tögā. Dïgoše se köze. Pöčěše da se nabâvlaū kräve. Läkše $\mathrm{i}^{\mathrm{m}}$ je bîlo kräve držät. A köze su valäle dösta. Komunīsti su bîli da se dïžū, pā sam jâ i ü šālu, a i u îstinu - dìgoše se köze, ostäde se be stökē, bez svëga: - „Äjte, rëko, säd u partizäne, äjte u Vršàn. Četrez drügē gödinē näšli ste, rëkoh, träpove krtôlē, stöka bîla, nïje se poznāvälo e se kölē. A danäs..."

Manastîr je bịjo tämo. Zärāslo je tô. Ödmā je bịjo pozādi küćē, tûn u tê mëđe. Tô su mëđe bîle ovïjeh starośedîōcā Nikölíçā, a od niỉh nêmā nïko. Tûn ti je lädika Rufîm bî̀o. Tâ cr̂kva tämo të je u tô borôvle te se vïdī, đë e tâ pro- 
plänæk prośečèn, tû su dvïje Svetê Neđëĺe. Za ńû në znā nïko kö je grādịjo. Tämo su se sahrańīväli öni, Nikölići i Batrìćevići, tî starośedîjoci kojî su bîli. A bögami je nägnūta gädno. Jëdna rëbra su i zïdovi iskočilli. Ne vödī račûna nïko. A plöča je göre. Metäli su lûdi plöču, u möje đetînstvo održāväli je. Tâ Batrïćević stậrī, Mậrko, đëd ovögā te je säd, ön je čūvâ i grôbje i nïje smìjo čobän nïđe da püštī. A ëvo ovâ cr̂̉kva ōdën, Svetî Đôrđe, četrës pêtē-šêstē, në znām ni käd, tâbla na ńu - „zākönom zaštî́ena“, a ëto pō neê raskrivëno. Öće da pänē. Odvoịjo se prëdńi dịjo öd vōlta. Nìko ni â. A tûn je sahrânen i otæ̈c i mâjka Ńëgoševi. İmā još gröbōvāh, nō su zärāsli. Tûn su se sahrańĩväli Ërākovići do Grähovskē bìtke, dok smo ogrādïli onû onämo säd tê oprävíāmo. Ne vïdīte je pros tû jäbuku. Tämo je näše grôbje ërākovickō. Tûn su sahranî́vāni. Kostûrnica je bîla jëdna e je üsko bîlo. Svë näjedno. Prïje nëkolike gödine smo podüprli zîd da se ne pröspē i kostûrnica i kösti. Poslïje je tâ tämo cr̂̀vva ogrâđena. S nêe su pöšli rą̂dnīci na Grähovskū bïtku. I nëkāko smo je održāväli. A säd smo se nëkāko složǐli, pözvāli onögā Frânovića i stvậrno će je urēdït. Stīđëli smo se kad nëkōga sahrańüēmo da kö ûđē unûtra...

A o jädu su u Mâjsstore žīvjëli, bögami. Dalëko od grädōvāh. Prodāväli ćumüre i zagrädnice po Kotöru. Zagrädnice su dr̀va iśceëpkāna tänko, pā naprävíeno poviše ogniišsta da s' osûšĩ i da zadìmē, pā nä końa ćërāno u Kotör i prodâvāno Kotörānima. Tädēr nïje bîlo strûjēe. Bögami, döbrā žèna i döbrā mäska zarađīväla je na tô. Tovär na mäsku i brëme nä pleći, pā onê dvïje te je na mäsku sagnäla - naprävi čètiri i onô nêezino brëme, pā prodâj. Müke...

U Dügī Dô nêmā nïko. Žìvî zîmi jëdna udovìca i jëdan s famëlōm i jëdna bäba ćôrā... Tô je bäba ćôrā. Öna je odolên iz möjēga sëla, a üdāta za Pâjovića. Nïjesu imäli đecê, a đëver joj se nïje ženî̀o. I täko otolên nêmā nïko bez öna. E në znām je li Düka Ötāšević tûn došăo i ${ }^{\mathrm{s}}$ Saräjeva. Ôn je istorìčậr. A u Kopïto ìmāte Mîla Bogdānövića. Ôn je môj savremenîk. Kopìto vi je đê onâ šušära Čavörova...

Nêmā ovögā nïđe. Döbro mi je ōdën. Ladovìna mi je. Ōdë lêti do dëvet ûrā śedîm. Stâlno t' oväko pìrkā do pêt sātî. Ot pêt sātî prigriije i do dēvēt. Ōđë je râj nebëskī. Nêmā ovögā nïđe. Ovô da je imälo kôga izā räta, i od räta, i danäs, da ìmā vodê, pā da pogrâdī hotël i da je uspińäča mëtnūta döĺe kûpleš ga ù mōre, a üvečēn ga jorgänom pokrïjevāš. Ovô bi Bëčiće ušìlo. Ukïnūla je uspińäču Itâlija. A kämi je i rādïla. Vôjska je bîla na štaciône ot Kr̈sca na dvâ mjësta do Kotöra. Po nekölka vojnîka su čūväli tô. Itâlija, käd 
je döšla, dïgla je želêzo svë. Svë je želëzo doćërāno bîlo s Kr̈sca do Cetîna i rasporêđeno. Sämo da se montîrā. Šćëli su do Cetîna da je sprovëdū. I säd ${ }^{t}$ se poznâjē đë su šarâfi u betôn mëtnūti...

Nïjeste mi pösao izgubïli nō sam se tamän fîno isprīčào - ako vi tô štö büdē valälo. I büdite mi zdrävo. A äko vi je štö korìstīlo, vî ćete tô fîno sprovës. Nëka ste mi zdrävo i da me poslüšāte da se ožènīte...

Blažo Popović (85 godina)

Erakovići

A nemôte mi prīčăt nïšta. Vìdīte li ovû škôlu ōvđën? Nëkad je bîlo ösam râzrēdā. U sväkī rāzrëd je bîlo oko trīdës üčenīkā. Da bi danäs döšlo da u tê čètiri rāzrëda nêmā nāko pe-šez đâkā. Svë pöšlo u grädove. Nëko trčî da bi škölovao đëcu, nëko völī gräckī živöt, nëko oväkō - nëko onäkō...

...Talijâni su za vrïjeme räta u ovû küću näšu bîli. I tû su imäli kühinu. Pa ćâhu fätāt mäčke. I ćâhu mäčku odëri, pā vïsī mäčka o prōzöru. Ē, da jëdū mäčke. A i jëlo je tô sväšto. Pā sam glëdao: uhvätē jêža, pā š ńîm u vrëlū vödu da se otvörī onî jêž, pā klijēštìma mäknū bôdĺe. Pïh!

...Uspinääča je bîla ot Kotöra do Ńëgūšāh. Tô su Austrijąanci rādïli. Tô je na drvënē stübove bîlo. Pöslijed ${ }^{t}$ pâda Aüstrije mî smo svë tô pokìdāli, polomïli. Nëka tô, nō za vrïjeme okupâcije Itậlijē. Öni su šceeli da naprävē uspińäču. I bjëše tû nä vr Kr̈ca. Naprävīše küću i od želëza i onî zupčanîk vëlikī. I đäo i ńỉh pönese. I pöslije okupậcije, partizäni svë pokïdāli i dâli u stârō gvöžđe. A i za vrïjeme Kralevìnē Jugoslâvije, i öni su šceeli da naprävē uspińäču čak ${ }^{g}$ do Cetìna. Čak se i jâ seécāam - hr̈pe su gvöžđa bîle štö su šceëli da muntîrajū. Pā i tô smo räznijeli... A tû nä vr Kr̈̀ca su Austrijânci bîli naprävīli dvâ ögrōmnā rezervâra po dvïje hiläde kûbīkā vodê. Öni su imäli nëkakav plân da snabdïjevaū Kotör väĺda. Ni tô nïjesu uspjëli da zavřšēe pā i dân danäs stojê tî rezervâri nì za što. Pā se jâ pîtām, käd ${ }^{t}$ su sköro za Ńëgūše prävīli tê rezervâre göre i na Korìtńik, zäšto nïjesu tô upotrijebïli tämo jer tô je bîlo povêzāno s cijēvìma is tìjeh rezervârā sköro do na pöla pûta ovämo. I zatëklo ih je štö ih je zatëklo, vrātïli se öklē su döšli, a tô je täkō ostälo...

...Mônci möi döbrī, da vi prîčām da ne vjërujēte. Śëćām se döbro. Môj otäc imäo je čètiri bräta. Nỉh pêt je bîlo. I säd tî lûdi su odìli većìnōm... o tê pêt, niỉh četvorìca su bîli u ämeričkē rûdnīke da zarađüjū päre. I dvâ strîca su 
Adnan ČIRGIĆ

bîli nëšto düže u Ämeriku. I u onô döba käd je bîjo zābrän älkohola u Ämeriku, držäli su nëkū kafänicu, švërcovāli. I zarađīväli lïjepē päre. I o tïjeh pârā pöslijē nëkolike gödine su dönijeli lïjepē päre i ovämo su kupoväli zëmju. Jëdan mi je strîc pošào u Bëogrād so tìjem pärāma i lïjepo je žīiìjo. İmāše šêz dućânā u jëdan rêd i pozâdi küću na sprät. Ovî drügī je došào tû, kupoväo zëmju, stöku... E lïjepo ih je zarādîjo... A käkvē su bîle küce i poküćstvo u ovâ sëla. Küće su bîle pokrivëne slämōm, a čêsto i u suhomëđu. A jëdan mi je strîc siromäšno živiìo. I śéćām se ko tögā strîca - nïje bỉjo nëkī râdnīk vëlikī, siromäšan. Imäo je nëkakvū küćicu, pā tû je bîlo ogńïšte, pā vǐše ogniništa nëkē žìce da se sûšē dr̈va da ih śütrī dân u Kotör prodäjū - onäkō käko sam vi prǐčào. A u dỉjo küćē tämo, stajäo je tâ köń, stajälo nëkō prâse štô su kūpïli... E käko je tô bîlo. Tô prâse smo kupoväli u onê kotarìce, u onê košìne. Ovî Zagârčāni i ovî tämo od Danïlova grâda döđū i prodäjū ni tû präsād. A tâ präsād ${ }^{t}$ su bîla mâlā, po pe-šes kîla u onô jädo-prâse. I öndā tô kûpi i podižzi. I kâžēm vi: tû mu je bîjo krevët i köń ili magärac, a tû mu je jöš i tô prâse ležälo. Svë üjedno. Tô je strašnî sûd bìjo. Da Bôk sačûvā...

...Mî smo Šèvālevići, na prêzime. A postồ ${ }^{\overline{1}}$ vêrzija i za tô näše prêzime. Nāvödno, ali öpēt bez nëkē dokumentâcije, bez nëčesa, - dä li je tô täčno në znām - bîlo je dösta brästāvā neëguškijeh koî su se prezīväli Petrövići. I jëdno o ${ }^{t}$ tïjeh je bîlo i näše brästvo. Po nëkakvōme Pëtru - Petrövići. A Petrövići kät su döšli nä vlās, në znām za vrïjeme kojëgā ot Petròvícaá, zabrānïše da bi öni sämo ostäli Petrövići: Mïjeńāte prêzime käko znâte i umïjēte. I nāvödno za ovô näše prêzime postöī legênda da nëkakav potömak ot tïjeh näšs̄h tädašńīh Petrövīćā rādî̀o je na nëkakvū kumpanïju fräncuskū. A tâ kumpanïja bîla je pomörskā. A ôn je bỉjo pomörac. I tâ se kumpanïja zvâla Ševalijê. A tô u prēvödu znâči vìtēz, štö li. Nëšto täkō. I sät käd su se dogovāräli tädašńī näši prëci: käko ćemo promijēnìt prêzime? Aj da dodâmo tömē Ševalijëu onô ié, pā se täkō prözvāli Šèvalević. Tô sam čùo od ${ }^{\mathrm{t}}$ strìčèvā.

Andrija Ševaljević (77 godina)

Navrhpolja

Dvānâs gödīnǣ sam zîmi odìla u Nôvī Sâd. Tämo sam pö dvā mjësēca ostāväla i tämo sam... na proléće jöpe döđēm, a säd otkâ ne ïdēm tämo, ïdēm u Böku ko ${ }^{\mathrm{d}}$ šćerê, tûn pö dvā mjësēca i näzād. 
Jâ za vrïeme Kralevìne Jugosląvije, znâm Jugoslą̂viju, mî smo žĩvëli ù rōd mi bäš döbro, držäli smo kafầnu na Lôvćen i žīvjëli smo süper. I pöslijē räta bî onô, zäratī Jugosląvija bîvšāă, onâ Kralevìna Jugoslâvija zärati, pöslijē nästūpi onâ revolûcija, rätovi, müke, čùda, svë sam tô prežīijëla. I öndār jöpe dôđe oslobođêńe. Kao omladînka îšla sam na râdnē äkcije, nä prūge i na tâ dôm, tûn smo rādïli i sređīväli. Pjëvāsmo tûn, ovî: „Ōj zâdružnī pored mösta, dào si mi znöja dösta“. Kao omladînka mōräla sam petnâ ${ }^{\mathrm{z}} \mathrm{z}$ dậā da rąadīm, a plüs kät su svëčevi bîli, neđêle i drügī svëčevi äkcijōm ìsto da ïdēm. Döbro e bîlo. Pöslijēd, ëto, rästade se i žälosno je štö püštīše onû držävu da se rastänē. Onô je lïjepa držäva bîla, nō ëto. Nïje bîlo čvr̂stē rukê ni rukovöstva da onô ustävī...

Në, në, jâ ne pijêm nïšta, böže sačûvā... İmām ovî prìtisak i izbäčila $\mathrm{sa}^{\mathrm{m}}$ svë jâ... jâ ne gäzīm rïječ, jâ sam odrêđena u hrậnu, u svë. Dvâ-pūt su me hïtno odolên povëli, pā mi e rëkla döktorica: „Nìje tô ni zbok hrānê, nï zbog... “ Jâ se päzīm stvậrno. Nösīm, nösīm ovê gödine, mäda, đäoli ga znäli, nïje glätak živöt bïjo, küćo möja. Jès ù rōd mi, a kät sa se ùdāla - në, bögami, nō tệžak. E öndār käd mi je mûž prīmïjo pênziju, e tädar smo žīvjëli bäš lïjepo, sölīdno, fîno. I jâ se säd ne žälīm nïšta, užîāàm tû pênziju. Nêmā da se razbâcām, ali mögu onäkō sölidnō, küćo möja. Ne držîm nïšta, nêmām ni mäčkē ni kökoškē.

Rôd mi je u tô drügō sëlo, Šèvālevićāa a ovämo sam za Popövićem. Pjëvāč onî je od röđąka mi. Ńegöv otæè $i$ jâ $-o^{d}$ dvą röđenē bräta. Ëto, brät mu nësta - Râde jädan...

A onê promôcije ako ste glëāli, onô mi ${ }^{\mathrm{j} e}$ sëstra izläzīla na promôcije prïjed nō smo držàvu döbīli. Öna je mläđā, küćo, jâ sa ${ }^{\mathrm{m}}$ dëvēt gödinā starïja od ńê. İmāmo jënu sëstru, têško bölesna je öna. Tû mi e žào ńû. Öna svë têškō snösī. Jâ, da mögu, jâ bi je pomögla. Ali jâ nêmām mogûćnōsti, küćo. Nō, öna okô ńē. Jëno trìes èūrā su jo dāväli. Jëdan röđāk ni je u Bëogrād, pomāgäo je stvârno döbro. Ali otkä-smo döbīli držävu, në. Nō jo-e spüštî̄o i slüšalicu, vìdījo e na onê jädo-promôcije, a u küću jo ëto i säd zą̂stava crnogörskāa. I ovî velî: ogädīla je küću, i vî̌se se ne čüjē. A öna döđē, pā velî: „Ëvo jâ i bez Jôca žĩvîm, īsto se snavödim, ïsto se snaödim“, velî.

A mëne je otæ̈c sämopēti bïjo, čëtiri bräta i ön-pēti. I nïje mi sramöta rèć, otæ̈c mi je bïjo kao u näjprvū vrsstu Neëgūšāo, i kao selâk pämētan. Dōdîli su kod ńëga i od istôriji da prîčă. A bî̀o mi je ōdën i jëdan komšïja. A mögla 
sam dösta od ńëga naučìt, a nïjesam ni imäla kæ̈d. A mögla sam čüti i od pröšlosti i od istôriji. Ön je za Cr̂nu Göru bïjo. Crnogörac. Pā je na onê crnogörskē käpe, nosïjo je onô dnö cr̂nō. Metäla se onâ körota. E ön je s tîm cr̂nijem pošào u cr̂nū zëmĺu. Pā ga ćâhū pītät: „Mârko, zäšto na käpu nösǐš tô cr̂nō?"“ A ön je ćâše skïni: „Sînko, za Cr̂nom Gorôm“. A näši stậrī säd u gröb će se previrćát od rädosti štô smo döbīli držävu. Jâ pöštujēm i ovô sa strąnê. Möžemo mî sa svïjema u okružêne bït lïjepo, ali nïje rêd da se brät z brätom ili svôjta jëdna z drügījem da se razdvâjēmo radi pölitikē. Tô mi se ne svîđā.

A zborìli smo väzdæ, küćo möja, crnogörski. Äda nïjesmo koźâčkī jezïk imäli. A štö su ni onî osamnäestē pönijeli, ama ne uspjëše säd da dobïjū. A onädār su ni pönijēli i cr̂kvu i jezïk i držävu. Jâ në znām, ne mïslīm da ću nëkōga uvriēdìt, ali znâm ovô: nïkad ni nïjesu Srbijąnci bîli bräća. A po čèmu? Pokāzäli su osamnäestē. Säd, döbīla sam držàvu, jâ sam zädovōína. Da i se podié, ovïjema stârijema, ǐś! Pokāzäli su svè osamnäestē tô brästvo i jedînstvo...

A në, fậla, ne püšīm... Säd ïmāš tańîr, vilúšška, kašìka, a prïje nïje nō ožìca, dâj mi tâ pjät, tigân - dâ tū prosülíu. A štö ćemo, jädan, a nïje ni bîlo kā ovô säd, küćo möja. Ōđën se ìsto žĩvjëlo, ovî, têško. Pöslije oslobođêńa je drükče, već säd je drükče. Jâ mìslīm da se nïgđe ne živî štö se ōđën u ovô mjësto žĩvî, pa iäko se žälē. Ëo ti prīmjër: käd se dāväo hlëb svináäma i krävąama? Pā ëo ti möbilnō - onô đäola mąlo ōlìko, pa möbīlnī nösī. Döbro e Mîlo rëkǣ: „Jâ ne vildīm da smo glâdni ni na müku käd đëca nösē möbīlnī'. Ëvo jâ stậrā, pā sam ga nabävīla. A nüžda mē nagnäla, küćo, bögami. Vìđi, sväšta se dogâđē. Onî fỉksnī râdī nëkæd, nëkad në. Ne-dâj-bože mükē, na onô bi dözvāla. Ëto rā ${ }^{\mathrm{d}}$ tòga sa ga ùzēla. Jâ nêmām nāko jëdnu šćêrku. Tû su säd òna $i$ zët mi. Jâ sam s niïma lïjepo. Jâ pöđēm - öni döđū. Odïla sam zîmi u Nôvī Sâd ko-sestrê i sestrìca. Tämo mi e i svâk bìjo, pa je nestäo. I tô sâma, näjprvī pût ti jâ sâma zagärīla, niìh zvậla da me čëkaū na stänicu. I ëvo säd da ödēm u Nôvī Sâd, svë bi ti jâ pokāzäla, a u Cetìne - kā da bi me s Märsa bäcīo.

Žìvîm bögami lïjepo i sa sväkīm völīm lïjepo. Štö vïdīm - ne vìdīm, štö čüjēm - ne čüjēm. Svôj pösā. Ëvo säd u ovô vrïjeme bi pöšla kod sestrê u Raïćevīée. Pośêdīm do dësēt, dēsēt ì pō, i vrâtīm se. Ne völīm ogovārät nïkōga. Näīću naćäs jer su mi tû döšli šćêr i zët... İdēm pjëškī, äda sü što ću... Prëkśutra ćemo, näleše bi bîlo prëdvečē e u töku dậna jâ môrām šeširìć e mi pûstā vrućìna šködī, a i rëkli su mi döktori... 
İmā ōđën i starìjēh liūdî, nō su pöšli. İmā i jëdan mi đeverǐčić, Blâžo Lûkīn, ön je starî od mëne, nō säd në znām jë li mu nëzgodno e je neêmu sîn nestäo, ümro...

E, bögami, nëko je jëo i zlâtnijem i srëbrnijem ožìcāma, ma mî nïjesmo mögli ni drvënijema okūčìt. Nō je srëća e se mî razdvojīsmo. E tô je srëća. E vïđi säd ${ }^{t}$ kojê gödine ìmām - bögami sam zaigräla kolïko mi ${ }^{\mathrm{j}} \mathrm{e}$ rädosno bîlo e sam döbīla držävu i onô zä što su se möji prëci borìli...

Nemôte zamjërìt štö, möžda bäba i pobr̂kā. Jöpet oväkō mölīm Böga da mi Bôg ovô mälo pämēti sačûvā dok pöđēm i da mi dâ läkū smr̀t, ëto tô...

Ike Popović, rođ. Ševaljević (80 godina)

Erakovići, rođ. u Raićevićima

Izvölte, izvölte. Jâ sam tûn ëvo dvïje-trī gödine. Držîm tâ štänd tûn, ali ovê gödinē je nëšto pedesêt pösto lošỉjē nego prïje... Jậ pijêm kąafu, a vî štö ćete popìt? Prehlādî̀o sam. Imào sam üpalu plūćą prïjed dväez dậnā, pā sam îšā na kontrôlu. Prīmìjo sam sedam-ösam inëkcỉjā i nëšto i nëkakvē antibiötike i tô i bögami se pövūklo bîlo. I jöpēt sam säd ${ }^{t}$ prehląăîjo. Ōdën je đaolê mjësto za prëhladu. Üvijēk nëkī vjëtar, ili jüg ili śëvēr, ali stą̂lno dûvą. I śë-

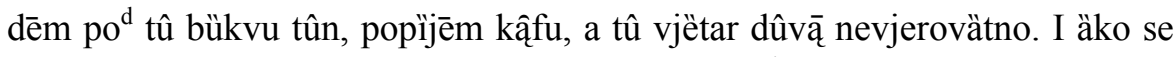
izậđē is kôlā il döđē sä sūnca, ma nêmā - prehlādîjo si ödmā. Ma döbro, mëne je läko vǐše obạ̄lìt. Sedamdesêt i trî gödine sam säd napünìjo prïje desê dạ̄nâ. Nêcu ją nï̌ta, nego štö ćete vî popìt? Ëvo ją pijêm ką̧fu.

Jestë li pjëški döšli? A trëbā vi prëśeka da są̂đēte pjëški? Nëkad je bîjo pût ${ }^{\mathrm{d}}$ dök je planìna bîla püna nạ̄röda, pā je tô zärąaslo, nego ovî planinậri proläzē čêsto, pā öni su i viěni. A ìnāče, obilëženo je tô. İmā jëdan izvör tûn i pored neèga ćete prôć. Pogrijēšit ne möžete. Prävo ve pût vödī na äsvạ̄lt döĺe, na Vûči Dô, a öndā vi se nïje prōblëm snậ́... Žīvjëli!

Žīvîm u Raïceviće, blīzu küćé Bêlovē, nêmā sto mëtārā. Žīvîm döle, a i rödījo sam se döĺe. Döĺe sam i pênziju stëkæ. Rāilìo sam u ugostitếlstvo jëdno dvaëz gödīnæ. Öndā sam rādìjo u mjësnū kanceląriju osamnäez gödīnæ $i$ ötolē sam u pênziju pošào, u mirovìnu. Pa nêmąmm štö rādìt. A imäo bih štö, nō gödine činê svöe. A tû îmām jëdnu krävu küći. Prodâjēm mälo sìra, pomälo pršüta. A ìnąče, küća mi je ovämo, na ovî katûn đê Bêlova küća, blîzo. A öndā ti döđēm kölima tûn ${ }^{n}$ nëšto, a bögami sämo da mi proläzī vrïjeme. I nêću 
štëtu naprävīt tûn. A jë li vrûće u Podgöricu? Strąšno. Pā vïđi tî Lôvćen käko ga sûnce pečê. A svë je cr̈klo. Nêmā nï-o-čega srëćē. Kät sē bükva pöčēla sūšìt, stậrī su prǐčäli: kät se tô ośëtī, röda nêmā. A öna je ëvo pöčēla. Poglëdāte tû strąnu tämo. E täko vi je tô.

A döbro, jësam li jâ nëđe väs glëdao? Mä, jèsam, bögami. Čìm sam ve vildî̀o tûn, upälo mi je ù oko da sam ve nëđe vïdīo. İdēte li po terênu svüđ? A jë li Dušän göre, na küću? Zną̧čĩ, došào je is Saräjeva. Na Knêž-dō vi nêmā nïko. A na Žąnéëv-dō vi je Lûka Pērövić. İmā Lûka sedamdèset i sedam-ösam gödīnāh. Ako nïje u bôlnicu, trëbao bi u Žąanèv-dō dä je. Nêmā đë drügō zašto nïje pošäo ni ù drva ni u rabötu. A jestë-l bîli kod Märkovićá? Kod Đûra? Ôn je starî od mëne, triestrëćē godǐšte. A žèna mu je triespêtō. Öna je s Vrbê. Pasäli ste mu poret küćē. Ôn je prïjed Mìlicē jëno četres-mëtąrāă, pot sâmī pût. Îmā jëna taräca i stëpenice đë se uläzī. Jëdna küća je zatvörena ispre ńegövē. Tô je ìsto Märkovićā, Pâvla nëkōga. Jâ në znām jestë li slüšąli - dvą sîna je izgubïjo: jëdan o ${ }^{d}$ dväez gödīnæ, üm ${ }^{a}$ ro je käd je pošäo na sähranu ovömē prijäteĺu ü Vr̉bu. Izjāvìjo saučěšće i vrą̄tịjo se. Käd je preko präga ìzīšæ, nämjesto mr̄tàv. Nïje se bîjo ženì o, mä nïje ni imäo käd - dväez gödīnæ. $\mathrm{A}$ drügī - üvečēn je lëgā, a nïkad nïje ośëtî̄o nëkū bölijēs il nëšto. U Cetïńe su žīvjëli. Dväes i òsam gödīnæ. Üjtro su ga näšli mîtvōga. E täko sē tą küća zatvorìla. A stậrī je tû na Bostûr. Sämo je tô porödica poköšenā da Bök sačûvā. Tô ne dâj böže ni krmnîku. Tô se rïjetko dešąvā. A jës se dësîlo Pą̂vlu Đönoviću. Vî ste znäli Pą̂vla? E täko je i ôn izgubîjo dvą sîna. Jëdan onämo prema Kr̈scu, niz onê grêde. Nöću odìjo prema Kotöru i käko je odìjo niz onê grêde, täko se omäknē i sîšao je mr̂tav döĺe. A drügī mu sē sîn prìpēo nä vr küćē da poprävī nëšto oko kamîna. Sklizâ sē i pänē mr̂tav. Tô su tî dvą slücăāja. Mî smo bîli vršńâci i fîno smo se držăli. A kao čöek je bij̀ döbar. Bịjo je i spösoban i vïlo pämētan. Ali kät će baksüz, ôn ìdē po svojêmu...

Kod näs je prētëžno bîla kostrìka, a vîša je mälo kod näs. Tô je tämo u ovê nïžē prēdjële, a ïnąče u Lôvćen vülo mälo je vîša nego svë kostrïka. I tô su žěne brą̂le prìjed, žène i lûdi, bögami. Tô je bîlo püno nāröda, püno stökē. Nïje se kosïlo nïšta niti se imälo đë kosìt, nego sē svë örąlo. Nïje bîlo nïđe livädicē. Kät sē pöčēlo kosït kod näs - kät se pöčēlo napūštät sëlo, pā se zalivädīlo i tädār su se pöčēli liûdi čăk i učìt kosìt pomälo. Mî kät smo pöčēli kosìt, näma sē čineëlo da îmāmo i kosačìce i nëšto näjsavremenijē za poĺoprîvredu. Nëgo smo prïje svë sr̂pom. Îšlo se u Štirôvnik ${ }^{g}$ göre, pā sr̂pom, pā öndā 
ga nösi na katûn döĺe, pā se tô sûšī, pā öndār köńima tô sagöni döĺe u Ńëgūše. Täko je tô bîlo. A ìnąče, kö je imäo mälo vïše stöke dạväo ih je na zimnïcu döle u Böku. Pā öndậr ovî koî ih je dāvào na zimnìcu u Böku, ôn je niīhovu stöku öpēt izagonìio preko lêta. Dậvälo se po kìlo sìra nä ōvcu kojâ se mūzê. A tô je bỉo müčenī živöt. Brâlo sē śekïrāma, pā prigöni pri küći tûn, pā otolên - dešāvälo se pö trī pûta odolên pjëški da se ìdē s köńem u Nëgūše döĺe da se priprêmaū dr̀va, pā sē sādìla vëlikā krtôla tûn, prodąvaälo se po Böki. A säd, säd je napüšteno svë. Ovô mläđē nêće da rậdī. I tô štö je ostälo - još ëto nëkē jäde. A bögami je mälo tïjeh koî su ponešëni za nëkīm pöslom. Nō, đäoli ih znäli, a jâ në zną̄m štö mïslē käko će käd ostäraū, käd žīvê od rodìtēlá još üvijēk. Jậ sam pöčeo da örēm i da izagönīm volöve, a nïjesam imäo četrnäez gödīnæ. Pā käd zavr̂̌ši svöju imovìnu, òndā îšlo se po nädnīcāh da se örē, da se kopâ, da se o jädu rậdī. A danäs në, nō: äko sam se jâ müč̉íjo, nêce möje dïjete. A i tô će dïjete da dožîvī stậrē dậne, jë-1, pā će pö ${ }^{\mathrm{d}}$ starōs da se üčī käko trëbā do lëba doläzīt. Mî grëšku činîmo u ödnosu na drügē zëmĺe. Mëne prîčaū Slovênci nëkī: döđē mu dỉjete osamnäez-dväez gödīnæ, äjde za pöslom, snaläzi se. I naüčī ga da žīîi živötom, pā zną da cïjenī svë tô. Jâ ìmām sîna i unüka öt sīna. I ôn: ako sam se jâ müčījo s töbōm zäjedno, nêću da se ôn müčì. A i ne ïdē mu bäš tâ škôla, a ëto proläzī nëkāko. A da ìdē tâ škôla käko trëbā, pā ga nëka. Ali oväkō, jâ mïslīm da je tô grëška. Trëbā ih učìt da stïječū rą̂dnē nąvike. Bes pösla nêmā živöta. E, đäoli ga znäli...

...A jë li vi Bêlo prīčào štö? Jë li ležêći prǐčào? A ôn je srčanî bolesnîk odậvno, pā sät käko je ìzǐšæ na Kük täko je i pänūo i nïje se ni dìzao o tâ dæ̂n. Ôn je bî̀o humorìsta vëlikī. Žèna mu je iz Bökē. A jë-1 mu sëstra bîla tûn? Öna se nïje udąväla. Öna je starìjā od mëne jëdno gödinu dậnā. A nïje ni öna nëšto zdrästveno döbro...

Jâ, käko sam rādịjo u tû mjësnū kanceląrriju, ìmām tïjeh podậtą̄ā dösta. Nëđe četrdëstē gödinē bîlo je oko dvïje î pō hilädē stanovnikâ u Neëgūše. Održąväle se güslarskē vëčeri, pā prîredbe, pā śëdnīci üvečēn po kûcāàh, ïgrajū se onê stàračkē ìgre. Pā se tô nïje razdvājäla mläđā i onâ starìjā generąacija. Na ovî katûn đë ste bîli kod Bêla, jâ se döbro tögā seécām, po trî hiläde ôvā̄cāh je bîlo i kôzāh. Trīdës i pêt porödīcāh je žīvjëlo. A säd nêmā bez Bêlo, Mą̂rko - jëdan röđāk mu, ovâj Ilïja i jậ. Četvorìca smo. Nego nêmą svïjetla pûstōga, a đë nêmā svïjetla - nêmą živöta. Ne möž nǐšta imät u küću. Jâ sam jütros ${ }^{z}$ bị̀o u Cetìne. Üzēo sam nëkē ćevâpe i nëšto. Bögami, dok sam došâ i 
ponì'o mi ih unük odolên do onämo, tô se usmr̄đëlo. E, nëkad se računälo kä döđē pût da je svë rïješeno. Al öpēt bës svijētla têško. Ëvo Bostûr ōdën, nêmā čêtrsto mëtārā, öni otkäd ìmaū strûju, odậvno, a Kük je blîzu, nêmā sëdamsto-ösamsto mëtārā oväkō prïjeko, prëčicōm, ali nêmą svïjetla. A bögami da je bîlo štö od näs, möglo se tô rijēešit...

Nêmā, nêmā nïko. Planìne su opūšćële. Rëcimo, onô sëlo Žānéëv-dō, öno je imälo svôj katûn. Bižāéèvac se zovê. Nỉko žîvī nïje izläzīo ìmā dvądëz gödīnā. Nìti je kosîjo imovìnu, nïti örāo štö... nïko nïšta. Öni su prētëžno preselïli u tû Böku, ogrạ̄dilli küće i tô mläđē rậdī tämo. A sköro sväkō sëlo je imälo svôj katûn nëkad... Jë li vi rûće bîlo pûtem ot Küka ovämo, jës? E täko vi je tô.

...Odïle su žëne od mükē, po šēsët-sedamdesêt gödīnæ, pā žńële kostrìku, sväko kö se mögæ dìzật. Mōräo je stöki sprēmït zimnïcu e se nïje imälo đë kosìt. Sväkā bäština se rądiìla, kopäla i örāla. Jemjēš - zną̂te štö je? Mōräo je i ôn zadïrąt ü među da në bi ostälo pậrče zemjê neobrą̧đeno. Vülo mälo je krûpnē stökē tädēr bîlo u möje đetîństvo. Prētëžno su se ôvce držäle i köze i sprēmäla se tâ zimnìca otolên. Kät sē pröbî̀o pût ${ }^{\mathrm{d}}$ za televîziju, mî smo srèćnī nāröd bîli - da tovärīmo nä końe tû kostrìku, da je gönīmo na katûne, pā da je sûšīmo, pā käd s' osûšī, vêžēmo je u onê - mî tô zovêmo kašûni, kašěte. Tô je bîlo o däskē napräĺeno, pa sē vēzälo u žìce, pā s' öndār gonïlo nä końe u Nëgūše. Tô je bîla zimnìca. A köńima dạvälo se vülo mälo kostrìkē. Tô je gospockô bîlo, nego sē brąla ovâ br̂s ${ }^{t}$ käd opänē lîšce, da glöđū. I svë onô odërū bez onî tapälak debëlī...

Dâ mi tî jëdnu kïśelū vödu i kâfu. Štö ćete vî popìt? Ē täko vi je tô. Primijētïlo se säd ${ }^{t}$ prilïkōm ovögā pöžāra, a i glëdāli su ga tüdā - velê da ìmā mëđēdāh. Primijētìli su ga i nöću. Jëdan otolên, ù mrāk, käd je krēnùo za Böku, primijêtìjo je međëda da je preko žąâe preskočịjo. Öndā prilìkōm ovögā pöžāa naodìli su onô đë su ležäli i onê br̉löge. Ôn ïdē da trąžĩ vödu u ovû sûšu - i međëd i dîvlēe prą̧se, svë tô lûtā da trąž̃i vödu...

Jëdan dịjo Ërākovićāh i Raïćevići čìtāvo sëlo - slävē Svetôga Đôrđa. Kopìto slävī Svetôga Nikölu. Dügī Dô Svetôga Nikölu. Rbläni Svetû Pêtku. Žańedölâni Svetôga Jeremïju. Täko sköro sväkō sëlo ìmąa svöju slävu. Neegūšš su dösta vëlikī bîli po bröju stanovnīkâ, a i po prostrąnstvu. Nëgūši su se računäli Mīrčäni, Čavöri, Pôda, Zāläzi, i jöš kolïko jöš... 
Îmām sîna i dvïje šceêrke. Jëdna mi je ùdạta za jednïjem Šèvālevićem, näšijem Ńëgūšom. Ôn je pōmörac, komadänt bröda, a plövī već trïez gödīnā. A sîn mi ìmą sîna, ovögā unüka möjēga štö je tû. A drügā je šceêrka üdậta u Podgöricu, u Gölubōvce. A i sîn mi îmā dvïje šćêrke. A imäo sam čëtiri strîca. Nïjedan nïje dočëkāo da se ožênī, nego svë pömrlo i izgìnūlo u rät. I otæ̈c mi sē oženìjo i bîli smo nàz dvā bräta. Brät mi se öženi i nïje imäo đecê. Nïje imào pōröda i ümrijē i ôn prije čẹtiri gödine. I täkō nêmą nāko tâ jëdna küća i ovâ snäha mi...

...Tâ vöda se zovê Studēnæ̈c. A tô je tämo döĺe bîla küća nëkōga Šèvāĺevića, Mîća Šëvālevića. Lïjepa je bîla i ot käkvōga kämena. Tû nïje nïkad nïko zīmî̀o. Tô su vëlikī šńëgovi znäli da pänū, zną da pänē po dvâ mëtra snïjega. Tâ je Mîćo bî̀o bez vîda. Ništa nïje vïdîjo. I bïjo se oženiijo bäš sa tëtkōm ovögā mậlōga štö rą̣dī tûn. I ìmā dvâ sîna. Nïjesu žëńeni. A onô đê tâ küća zovê se Stârī Stänovi. E öni su nëkad döbro žīvjëli. Öni su imäli stöku vëlikū, ôvce, köze, volöve. I päzite kakvä je prîča ostäla: Öni su tolïkō bogäto žīvjëli i imäli su vëlikū stöku i jednê prilïkē jëdan vô bî̀o se pöpēo iznad Studënæcāhh, iznad onê vodê, u vurh onê glavìcē göre Bäbĺak te se zovê. İmā jëdna grêda pri vr̈h göre i tâ vô ûšą u tû grêdu i päsā. I nïje mögæ da izą̂đē. I tâ vô se niz onû grêdu nëkāko opüštī i slömī se i döle mr̄täv. Ovâj gàzda ńegöv rëkæ je: $\mathrm{O}^{\mathrm{d}}$ danäs mi je pükla pögibija. I otädā je svë pöšlo näopą̄ko u tû küću. Jë li tô slučâjnōs bîla, jë li tô nëkī baksüz bỉjo, štö li je tô bîlo... Ali je ostäla tâ prîča. A čùli su ĺûdi da je rëkǣ: $\overline{\mathrm{E}} \mathrm{o}^{\mathrm{d}}$ danäs mi je pükla pögibija u küću. I o tädā, zbîla, svë je pöšlo näopą̄ko. Südbine su ĺuckê čüdo.

Ilija Ćutko (73 godine)

Kuk, raićevićki katun

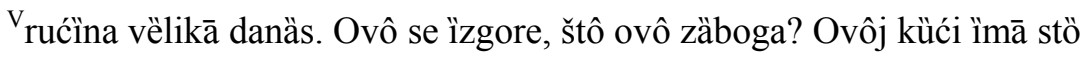
gödīnæ... Vìđi, svë je izgorëlo. Ne mögū ovê kräve ni sïjeno da ïjū kolïko je sûho...

Jâ sam i rödom i dömom Kustudìja. A säd ne nêmā u cìjelē Mâjstore bes troïca. Vrućìna je, ne möžemo rādìti nïšta, pā mälo odmąrāmo, àda štö ćemo čińët. A nïjesmo vǐše za nëku rabötu, pā mlögo i ne žûrīmo. Držîmo dvïje kräve, ne vǐše đäoĺōm, i tô dok ih sîdēmo, pā önda sämo jëdnu. A prïje pē-šez gödīnæ, kææd smo onô mögli, držäli smo i kôzæ i övæc $\bar{c}$, a säd ne đào- 
Íōm vǐše. Näma je döle famëĺa. Ne mögu vǐše đäolómm. A i mögla bih nō nêću. Dösta je i bîlo. Säd će ni vodê fälīt. Nêmā üslōvā. Ëto pût käkav je löš, nêmā strūjê, nêmā žîvē vodê. Vodê nêmā, jök, nêmā ni za dëse dâna jöš, e nïje päla kiša ìmā prëko dvâ mjësēcā, a sväki dân pûhā nëkakvī vlëtar. Svüđe je pädālo bez ōdën. A nêce vödu da doždënē nïko, ni päre ne pomąą̌ū.

Mî smo ōdënake svì jëdno brästvo, nō su jëdni Kustudîci a drügī Kustudïje. A svì smo Kustudïje bîli do sköro, pā se öndā nëko prözva Kustudîć, a nëko Kustudïja, pā je tô mälo i löšo. İstī, a dōđösmo do dvâ prëzimena. Nïje tô ügodno. A prą̂vō ni je prëzime Kustudīja, nō ëto säd nëko ìmā i tâ pridodātäk. Jâ se zovêm Îlīnka, a môj se mûž zovê Jôvo. Jâ sam röđena tûn, a akobôgdā tûn ću i zav̄ršìt.

Izvöra nêmą nīđe ōdën. A svë su izvöri döĺe. Svë je tô pöšlo döle pu ${ }^{t}$ Pöbōrā. Nỉje ih ni bîlo nïkad. Sühopąrno je, zną̂te, kao onô kako ne välā. A sàd vìše nêmā vodê ni za stöku ni za nàs. Bögami sûjmām da ćemo još dèse dậnā sastävìt. A nêće da ni doćêrajū cistïjernū, velê da im je öpāsno radi vöžńē. Ništa ne möžemo da urêdīmo käko trëbā, ni sìr nïje kā štö je bỉjo e je vüća vëlikā... Štö vi je, lûdi? Štö nǐšta nêćete, zäboga? Äda prôvājte!

Mëne đëca svë isprävlaū: Tî, mâjjko, prîčăš po onömē stąrōmē. A jâ nêću da lömīm jazïk nō ću onäkō käko sam se rödīla. Äjd ùzmite o ${ }^{d}$ tögā sìra. Öćete li lëba? Äjd ùzmite mr̀vicu sìra... Näši su lûdi izgìnūli za ovû danäšńicu. Vìđite tâ spömenīk - svë su tô näši lûdi te su izgìnūli. Strijēläli svë. Pā su se näši raselïli, čētres sëdmē gödinē pöšli su za Vöjvodinu, u Lôvćenac, u Nìšiće prïje räta, a näs šès porödīcā na Tröicu. Täko smo se svì raselïli. Tîho je ōdën. Mîrno je. A famëĺa ni je döĺe. Döĺe ìmāmo jëdnu küću. Mûž mi je u pênziju. Mî smo navìkli ōdën, pā čim döđē pr̈vī mäja, ödmāh bjēžîmo za Mâjstore. Sämo je ovâ gödina näjgorā.

Bîli su novinâri prvê neđëĺe, pā su me sìlōm slikäli. Pā ću bït kā karikatûra u növine. A na sïlu su me nagnäli, a nïjesam jâ ščèla. A käd ni porödica büde vïđela dä smo se slikäli, polūđëće. Käko smo lïjepi kā lütke, a ìmā ne pëtoro u cïjelō sëlo. A nêmā ōdë nāčìna za živöt. Da je bâr strūjê ili vodê izöbīla. Al nêmā nǐšta. A sïgūrno nïje nïjedno sëlo postrādälo kā ovô näše nïkæd. Mäńēga sëla a vǐše strādäńa - tô nïje bîlo nïkæd, a jäda vìšēga nïje od neèga ostälo. Nîko nïšta nïje pomögao, olìkō, olǐčkō. A svë sū dōdïli - töboš öće dät pût, öće dät strûju, a nïkad nïšta. Svë su obećäli i nïkad nïjesu dâli nï- 
šta. Dōdịo je ovî minìstar, Sīmövić je doläzī̄o, bịjo je tû ko tôgā spömenīka dvâ mïnūta i doviđêńa. Ni vodê ni nǐšta.

Dr̂vā ima zaìsto. A bîlo je ōdën svë zelëno prïje u ovâj-doba. Znâš käkvā ötava fînā. A ovê gödinē nïšta. A öklē kät kâpi kìšē nêmā. Svüđ ökolo döđē, a ôđe ni kâpi nêmā. Nō jâ prîčām, ne patǐšēm, imäćeš štö pīsät. Za ovô mi nïje žào, ali onô da me slikäū - e tô mi je mr̂zno bîlo. A mî dvojìca smo ti ōdën sâmi, pā se tamän fîno posvädīmo. Tô da döđēš ìzdaleka da čüjēšs, mïslijo bi kö znâ kolicìńa su tämo. A käd smo döĺe kod famëlée, öndā se nêmāmo oko čěga svädīt. Nō tô je mậlā sväđa.

Jâ zbörīm cükær, a möže i šećër, ma në na Neëgūše. İmāmo i sūdâh: jâ zbörīm plät, ćîkara, prosüĺa i täkō. Pā vǐzân - öklē pijêmo kâvu, pā suprëš i

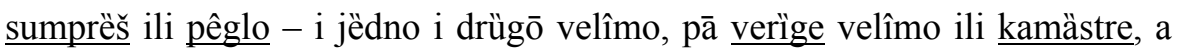
ëno ti ih vìse onämo u ćöšak... İmāmo i crïjepńu i säč štö sē lëb ${ }^{p}$ pëkæ. Ovô naviše se zovê pëtar ili šuvìt. Ovâ grêda te držî ovô svë - tô je nāšlëdnica, na nû se klúčevi povezüjū. Äj popî tû čäšu rakïjē, ne bôj se, đäole. Śëdi, đäole, ne bôj se, ne zadržâjēš me. Nêmaū mi kräve štö povärāt.

Nō mi zböri käko tô nêće da uvëdu tô slövo ś. Mî ne möžemo bež ńë-

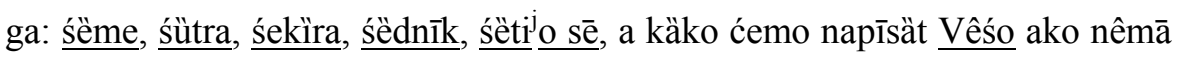
seê, ili śekirâm se - kâ jâ od neëga, te bi se kńïga napīsäla. Pā i onô zë : brozîn i bronzîn, ozovìna, 3ìpa i štö jâ zną̂m, pā źë - velîmo köźī sìr, äda tô je prīrödno - köza i köźīi.

Üzmi, ne bôj se, nêćeš se oplänīt. Da si osläbīio, ne bi ovudijên pjëški odî̀. Śëdi, mî smo ōdën žěĺni mälo nāröda. Mî smo držäli dösta stökē, i övācææ i kôzæ, nō nïje ni vïše prèša. E täko vi je tô.

A nëkæd, tô je bîlo ranïjē, bîlo je i žănāgo i žnâm i në žnām, šnâga, šnïjevām, tô je täko möja mâjka zborìla. Täko ti je bîlo nëkæd, täko su näše mâjike zborìle. I šńëgovi i vršnîk i naüžnāk, a tô ìmā i danäs. A mî smo ti ìsto s Ńëgūšāh, još prïđe stö pedesêt gödīnæ krâl Niköla nē ôvđe namlêstījo, näše stậrē. A mî smo u Ńëgūše na nälešē mjësto žīvjëli, đë je onâ bära ńëguškā, ako znąte. I danäs su tämo küćīšta đë sū näši stậrī žīilëli. I otolên ne krâí Niköla poćërao e su näši stậri lûti bîli, pā se zakřvīli. Pā je stîjo u Itąliju da ih zâmī, ali ni je öndā cr̂̀kvu tûn ogrādìjo i näše lû́de ōdën preselî̀o. A cr̂̀kva, srüšîla se öna. Päla je. Za vrïjeme räta je bîla püna munîcije, pā sē tô zapālìlo, a öndā je zëmĺotres dokrājčìì. Pöslijē smo je oprävīli, pā je öpēt päla. E 
Adnan ČIRGIĆ

bögami će se döckæn tô naprävīti... Tî mi sväkū fätāš, mëne će dä-ti cìjelā kniìga ìzāć.

Jâ nïjesam rādïla, pā nïjesam štëtîla jezïk. Nïjesam ga šceèla kvārìt. Mî ôvđe velîmo müha i büha, a ne müva i büva. Nō bûhā, bögu fâla, nêmā vïše. Nêmā ih odąmno, bögu fâla. Mëne se famëĺa svë smījê käko zbörīm. Jâ rëčēm mnïjeko, a öni: „Nïje täkō“, nō drükše, në znām ni käko. Jâ nêću zänāgo säd mijēnät jazïk. Štö mē stälo za tô. Zną̂m prïje kæ̈d su zborìli ovî näši stậrīnō sam se jâ zaprǐčăla mlögo - zną̂m kææ ${ }^{d}$ su zborìli da bi radî bîli da $i^{(m)}$ je tô dījete izìjo pæ̈s nō da ga kr̈stī Grōbjänin, a vëć Škälar nïje dōdî̀o u öbzīr.

İmā ōdën i vükōvāh, nō nêmā sìtnē stökē, pā ih ne ośêćāmo. A velê ìmā i mëđēdāh, ma ih jâ nïjesam vïđela. A dök je bîlo sìtnē stökē, tädēr je sìr bïjo döbar, míešavìna, köźí i övčī sìr i ot krâvāh. Mnïjeko ot kôzǣ, od övācāh i ot krâvāh, pā se smïješā i tâ mĺešävina se öndā usìrī i tô je öndā nälešī sìr ńëguškī štö möže bït. Vìđi käko mi se smijê käko zbörīm. A mî smo döĺe sîšli dâmno. Jâ sam mögla zborìt i drükče, ali jâ nïjesam nïjednu rïječ primïla od '̌ Škälārā ni ot Kotörānā, nō käko sam od mâjkē i od öca naučìla. A mögla bih i jâ progovōrìt po bokêški, dä-ti në bih lûdo prozborìla, ali nêću. Prīröda je tô väĺda. Käko se kö ròdī. A nëko ödmā promïjēnī, mînē nëđe gödinu dânā i nïšta mu vǐše razumjët ne möžeš...

Ilinka Kustudija, rođ. Kustudija (65 godina)

Majstori

Šćer: Ëvo vi. Ovô je ōdën po stärački äko ćete ko dëda. Ôn se ne dïžē.

Belo: Pädoh jedan dân tûn. Ëvo petnâz dą̂nā danäs käko sam povrijēdì ${ }^{j}$ kük. Mä nïjesam slomìjo nïšta. Mögu da se skìnēm i da śëdēm. Nëgo sam tô nätuk̄̄, pā me tô bolî. Ne mögu se öprijēt nä nogu. Počàsti tê lûde, Rädmila.

Šćer: Sä ću, sä ću, nō mi èvo kräve ïdū, pā da ih povêžēm. Nêće säd bjēžät.

Belo: Mî döĺe žĩvîmo, ali izîdēmo ōdën po jëdno trî mjësēca lêtti te pokösīmo trâvu, ubërēmo mälo dr̂vā i täko, i kràve izaždënēmo.

Šćer: Îmāmo jëdan übao tû, pā smo pûmpu stävīli i agregât i täko îmāmo vodê ōdën. A i göre ìmāmo iznad ${ }^{t}$ cèstē nō ni sē jëdan prikäčíí, pā ni je prësūši. 
Belo: A đë râdīte, opröstite? A i mëne jèna mậla pöčēla ovê gödinē göre u Nišiće za učìtelicu. Ïdē is Podgöricē.

Šćer: A štö ćete popït, mônci? Ïmā rakïjē, kokakölē, fânntē. Öćete nëšto. Käko ste döšli? Pjëški? A đê Mậrko? Ïmā i pîva. Štö ćete pìt? Bögami nïje vöda prëstudena - izvör mi je pödaleko.

Belo: Ōdën je izläzīlo za vrìjeme onê krālêvskē Jugoslą̂vijē po trīdēs i šês porödīcæ na ovî katûn ōdën. A säd ${ }^{t}$ čětiri. Pö trī î pō iläde övācæ i kôzæ je bîlo ōdënak, a säd nïšta. Nêce ovô mläđē nō pöđi ü grād, starìje nïje kâdro.... A kö pöđē ü grād, në bi ga vrātìjo da bi ga konöpom mìcæ. Sväko glëdā da mu je läkše, da l̂́ěš žīvî.

Šćer: Nëka nêće, bögami. Nëka se nïko ne vräcée... Ā, ëvo kräve.

Belo: Svë kükaū - nêmā se. A nêmā küćé kojâ köla nêmā. A štö da ti kâžēm: za mëne lïčno ovô je Ämerika. Jâ žīvîm döbro. İmām ōdën tû küćicu, ìmām u Nëgūšse küću nôvū i stą̂rū. İmām cëntrālnō grìjāńe u Neègūše u nôvū küću. I̋māmo dvöje kôlā, sîn mi i unük. Öni u Podgöricu rą̂ēe tämo, a tâ mi je sîn na Štirômnīk, a unük mi ìdē po tïjeh relējâh po Cr̈nōj Göri. Ïmaū köla öba, a ìmą̄mo i nëkā stậrā köla ovüdije po planìni te tranaąmo š niìma. Ïmą̄mo dvâ träktora onê mậlē, ìmą̄mo dvïje mašîne onê za dìva, ìmāmo - në znām telefonæ̂ sëdam-ösam. E jâ tô nïjesam mögæ nïkæd ni môj nïko mïslīt da ja mögu täkō žīvjët. A säd ${ }^{t}$ se krîvā sväkōme. Krîv ovî - krîv onî, a nêće nïko da rabötā nïšta.

Nêmām bez dvïje kràve, i tô zä doma. Bäba za ńïma ìdē. A jâ sam nëpismen. Nïjesam ü škōlu odìjo bës trī gödine, i tô za vrïjeme Itậlijē. A ëto čîtao sam pönešto i z drûštvom se sastälao, ëto täkō. Jâ sa ${ }^{\mathrm{m}}$ se bävījo pölitikōm jëdno petnâz gödīnæ, onäko ä. Tô su bîla drügā vrëmena. Přvo poslijē räta otäc mi je pogìnūo u rät, brät mi je pogìnūo u rät, $i$ öndā smo mî kā đëca ńïhova bîli privilëgovāni od vląstî. Jâ sam mögæ odìt da üčīm kojî göđ öću fakultêt i đë göđ öću u onû zäjedničkū držävu. Ali bäba i đëd ostärāli, nïje imào kö da ih pridřžĩ i jâ sam ostào. I ne käjēm se. Ne käjēm se štö nïjesam ni naučìio e èvo naüčenijeh dòsta, pā zälūdu...

Ovô je raïćevickō: Kük, Mậlī Bostûr i Vëlíi Bostûr, a Vûčĩ Dô i Bižālēvac - tô je žańedöĺskō i kopīckō. A tûn Dolövi - tô vi je mìračkō i pöđanskō. Tô su vi sëla, pā po katūnâ se tô dijēlïlo. A lïjepo je ōdën ĺëti... A jâ sam zapāntìjo krālêvvskū Jugoslâviju. A käko je tô bîlo, üh. Žändāri, finą̂nci, polîcija, cärina - ne dâ ti nïšta, nïšta. Nïje se möglo zarąąìt nïšta. Pā rëcimo ako ïdēš 
Adnan ČIRGIĆ

ko döktora, pā prezìrā tê. Trčîš za niîm, pā: „Gospodìn döktore, sämo da pîtām...“, a ôn nêće ni da progovôrī s töbōm. A säd... mlậdī su lûdi bölí od näs stârijeh. Mî smo zadržäli i nēmäštinu i osküdicu i bïjedu, pā svë ni je mälo. Nëkako smo interežžǐje. A mlâdi su lûdi kömotni. Imäo sam prīlïku da se s Íūdìma srïjećēm $\mathrm{i}^{\mathrm{z}}$ svïjeh onïjeh repüblikāh. Jâ sam dosäd dëvet pûtāh s Mîlom Đukänovićem śedịjo kā säd ${ }^{t} s$ töbōm. Prävo ti rëć - mëne je čâs bîlo śeđët š ńîm. Tô je pämētan mömak, döbar Crnogörac. I jâ ńëmu vëĺu: „Znâš štô, Mîlo, volïjo bi dôć kod tëbe prìjed nō ümrēm da se poprīcâmo." Kâžē ôn: „Döđi käd göđ öćeš‘. Jâ nïjesam odịjo, a žào mi je štö nïjesam. Lïjepo je imät svöju držävu, ali vjërūjte me - da nïje bîlo Mîla Đukänovića, në bismo je nïkad döbīli.

Ovô mi je bäba. Öna je s Östrva cvïjeća. Oženìjo sam se o ${ }^{\mathrm{d}}$ šesnäez gödīnæ i trî mjësēcā. Ëvo šēsët i drügā gödina käko smo se üzēli. Öna je zgödna bîla, ovâ lìgunica.

Baba: O đäole, lëzi, štö ti svë nâmpadā. Da si odìjo za tïjema krävāma, në bi ti nä ūm pälo.

Belo: Bögami je zgödna bîla, a jâ nïjesam nō klepëtina. Nïjesam bịjo ĺêši nō säd tô đäolóm. Gô, bôs, glïbāv - onô izā räta. Čëtres sëdmē sam se oženìjo. Müka vëlikā, nêmāš nïšta.

Baba: Bögami je mälo kö bìjo obūčèn. Čüjēš tögā đëda - sväšta zbörī... Bögami je rûće näpoĺe.

Belo: Türite im pö kāvu. Äjte vârite tû kâvu.

Baba: Sä ćemo, sä ćemo i kāvê.

Šćer: Doväti o ${ }^{\mathrm{d}}$ tögā sìra. Okïni.

Belo: Bîlo je ovudijên i kömītāh. Rëcimo, ovî žândāri srbiją̂nskī pālìli su küce po Cûcāh, po Nǐšicáh, pālïli su porödice cïjelē, tô je bîlo röstvo vëlikō. Üzmi rëcimo krấl Aleksą̂ndar, ôn se rödījo na Nëgūše, mâjka mu ümrla mlą̂da, Zôrka, i öndā ga podìgla bäba - kralíca Milëna, i đëd i tëtke. I käko je bîlo pöslijēd... Ôn je ujčevìnu prognäo u inostrąnstvo, konfïskovao imovìnu i zabrānìjo povrätak... Ëto, a ne mrzîm jâ Srbijąance. Za mëne ste i vî svì jëdnāci - i da ste Podgorïčāni i Nišićāni il da ste Albą̂nci, Hrvâti - ako si čợek. Sväkōga je mâjka rödīla. Al su onî Srbijąnci lukävi. I tô nïko në bi od ujčevïnē naprävījo štö je ôn naprävì-jo. Pā onâ sküpština osamnäestē - üzēli ni cr̂̀kvu, üzēli ni držävu, tô je nagr̄̄illo Cr̈nū Göru. I säd se tâ Amfilôhije uplekäo da posvöī svë. A öklē kæ̈d tô nïje ńïhovo. Îmāmo mî u Nëgūše petnäes cr̂̀ā- 
vāh. Tê su cr̂kve svë Neegūšs rādìli, a Amfilôhije se na ńîh möštī kā da su tô Srbiją̂nci rādïli. E svë je tô osamnäestā učińëla... A käd ${ }^{t}$ su döšli Taliją̂ni, öni su mälo privilëgovāli i Cetïńe i Ńëgūše jer je kralî̀ca Jelëna bîla otolên. Mïslīli su da mëtnū na čëlo Cetìna öca ovögā prìnca Nikölē, te mu je žëna ümrla prëkjučēn, Mihaïla ńegöva öca mïslīli su da büdē glâmnī u Cr̀nu Göru. Ali ôn niije stìjo prifâtît se da slûžī okupą̂tora, pā su ga u rōstvo zāmīli, u Némačkū. A Jelëna mu je tëtka bîla... Sämo štö kod näs u Nëgūše nïko nïkōme nïje zlö käkvō naprävījo kā štö je bîlo po Zagàrāčāh i tämo-ovämo po drügijeh mjêstāh đë su se lûdi međusöbno ubījäli, a na Neègūše nïje nō su sačûvāni tî komšînskī odnösi. Jâ zną̂m - jëdan Čavör käd je čětres pr̈vē ustänak bïjo, zarobïše ga Talijąani. I säd vödē ga Taliją̂ni, a jâ ìzī̌̌æ slüčăjno - mâlī đetīćäk. A tàmo se sküpīlo jëdno trìez drūgæ̂h. Nösī püšku näopāko, cïjev döĺe okrēnüo, a jëdan garabinér ìzāđe, pā kâžē ńëmu - a bîjo je nëšto naučịio da prî̌ā näški: „Tî Pêro Čavör?“, a ôn velî: „Jësam“. Te öni donësū odlüku da ga strïjeĺaū. A bî̀o nëkī Vâso Bećîr i nëkī Nîko Kašćelän - öni su bîli tî nacijonalìsti štö sū sarađīväli s Talijąnīma. I öni dvâ rëkū: Në! A odrēdïli bjëhū i mjësto đë će ga strijēêät pod nëkē boröve tämo oko tr̂ga. I öni kâžū: „Në, strijēelät ${ }^{d}$ ga nêćete!“ I pöšĺlu ga u röstvo. I ôn je preživiìo. Pöslijed je bìjo i na Göli ötōk. Ali nïjesu šćëli dozvolìt, bez öbzīra štö su bîli protîmnīci, i nïjesu šćëli dozvolït da pänē kr̂v u svöje mjësto. Täko su Nëgūši ostäli slöžni i jedinstvëni, pā bez öbzīra kö je bî̀o u partizäne, u nacijonalìste, u čètnīke, ali ostäli smo slöžni.

A mälo je bîlo i škrìpārā ōdën. Jës tû nëšto u Mīràc, više Radänovīćāh, tûn je bîlo nëkoliko ńîh, al tō su bîli bëzopąsni. Jâ bäš täda bjëh đetīćäk i ödēmo u pöćeru za škrìpārima. I obîđēmo svë, al ne möš tî tô nâć. Jëdan komšìja môj i grüpica jëdna - öni su se krïli u tê křše göre. I pöslijed käd se prëdāo, velî: „Vìđeli smo mî väs küđ ìdēte“, ali ne möš ih tî nâć. I pöslijē su nëkoliko ńïh s Nëgūšāh osūdīli na zātvör, ali nïko nïje ostào düže o dvïje gödine.

A Talijąni su bîli blagorödni. Jâ dïjete. I nêmām nïšta da izìjēm i ìdēm kod ńîh sväkō jütro da mi nêćē dät štö da iźëdēm. A ìmāhū jëdnu kužînu, pā jâ kod niỉh. Jednôga oficîra zvâhū Mậrijo, a jâ kao dïjete naučijo bjëh pönešto da prîčām. Jâ čīm döđēm göre, öni kæ̋ me vìdē - ödmā se smijû. A jâ trâžīm mälo lëba. A jednôm dìnstāhū nëkō mêso, a jâ se primäkǣ, a onô mêso od mäčkē... A Nêmci në. Tô su psìne bîle. A Talijąni në. Blagorödni bjëhū. Jâ dïjete, pā sam se mögǣ najës da mi nïšta ne brânē. A pöneko od Neëgūšāh je 
Adnan ČIRGIĆ

bịjo osamnäestē s krâlem Nikölōm u Gaëtu. E öni su znäli taliją̂nskī, kā môj strîc. Đûro Alëksīn je prīčào talijąnnski kā näški.

Baba: E jâ tô nïjesam znäla.

Belo: Pā nïje stîjo s töbōm zborìt taliją̂nski... Näĺleše se žĩvëlo u Dügī Dô, u jëdno mâlō sëlo, iz Bükovice kad ${ }^{t}$ släzīšs, tû je dëse-petnâs kûćāh. Näĺeše se tämo žĩvjëlo, lïjepo, gospöcki. Pā i Petrövići su žīvjëli lïjepo. A u sväkō sëlo je bîlo po jëdno dvâ čöeka te su lïjepo žĩvjëli, s mükōm vëlikōm i s vëlikijēm rą̂dom, mä lïjepo. Bîlo je nāröda dōsta. U sväkū küću po pē-šèstoro đecê. U onögā Čavöra, te sam ti prīčào, bîlo je u ńîh ü trī küće dvādès i tröje đecê. A säd nêmāš u cïjelē Neëgūše tolïkō. Prëtprošlē gödinē na Neëgūše je bî̀o jëdan đậk. Tô se iselïlo svë. Mî smo čëtres ösmē imäli ilädu i čëtrsto stanôvnīkā, a säd nêmāmo nëpunē trìsta. Tû ti je bîlo u Neëgūše Ötāševići, Vrbīce, Petrövići - tô su ti bîli dvâ-trī brästva te su mälo böle žīvjëli. Ovî Ötāševići i Vrbìce su pämētni lûdi. Mî kậžēmo - lukävi lûdi, ali në da su nêlúdi ili büdale ili nëšto. Nō pämētni lûdi. E čöek ako je büdala, ôn ne möže lukäv bït...

E käko je säd. Pöla trąvvê ostänē nepoköšeno. A prïje nïje se imälo štö pokosït. Svë sē rądillo. Nō se ovô raselïlo, näviše u Böku. Säd ti dâjē da kösīš క̌äbē, al nêće nïko da kösī.

Baba: A prïje nïje, nō se i u ovâj vr̂h brąla kostrïka.

Šćer: Svë žēne sr̂pom, pā nä lēđa, pā sûššš, pā nä końe u Neegūšse dvāpût nä dān, svë pjëški...

Baba: Üzmite o tögā, jädni, štö ste se stìsnūli? Käko se säd grâdī Podgörica. A pô Cr̂nē Gorê se u nuû spüšstīlo.

Belo: A râdī Mügoša Podgöricu, sväkā mu čâs. Spösoban je.

Baba: Spösoban. Zmïja je...

Šćer: İmāmo mî i žîvū vödu, izvör jëdan.

Belo: Tô je nälešā vöda u Cr̂nū Göru. Leèšā od Vidrovąna. Zovê se Studênca. Tô su stậrī näši rạ̄dìli, pā je tô bîlo svöltāno. Mî kąažēmo völat. Möžda prïje dvjësta gödīnāh. Pā je bîlo döšlo da pänē. Jâ ovömē Sīmöviću, ovömē minìstru, jâ mu trâži päre ovû vödu da poprävīm. Ôn bögami däde te ga poprävīsmo. Tô je säd da vìdîš kā manastîr. Tô vi je tamän tûn.

Šćer: Möžete i pjëški äko ćete.

Baba: Jès nō nêće potrëfìt.

Šćer: Käko nêcee. Preo vodê ìmāte pût, prävo göre izîdēte na izvör. Äko ćeš vodê, ïmāte lämicu tämo unûtra. A kakvä je vöda, vïđećeš, îh... Sämo säd 
je sûša, pā je mâlā vöda, a käd su kǐše - da vïdīš... Nō sàd je sûša, i Ivänova su korìta presūšilla. Đävolā kâp ne vrê.

Baba: A štö su präsād učińëla na onî nägorńī übā...

Belo: Dîvlā präsād. Bîlo ih je jedno-vrïjeme ōdën. Tô je svë prekopälo preo zîmē, onô käko nêmā nïko. I nïje ih bîlo odâmno, ìmā dä-ti pê-šez gödīnāh, i jöpēt se säd pojâvē.

Baba: Svë je ödrto. Svë pläse dïgnūte, kā da je träktor odịjo.

Belo: Vükōvā nêmā e nêmaū štö čineèt.

Šćer: A öklē. Nêmā nāko pê-šes krâvāh, a tô se čûvā il vêžēe pri küći, pa nêmā ni vükōvāh. A dä je övācāh, pojāivìio bi se ôn.

Baba: Bögme ih je i bîlo dok je bîlo övācāh.

Belo: Öćete li ko ${ }^{d}$ Cütka säd? Äko ćete na Ńëgūše skrāj Cüütka, ìmāte prijēěàc jëdan i sîdēte na Vûčì Dô döĺe, ödmā tû pöviše Kr̈̀sca. Tüdije se koniìma odïlo väzda. Nō në znām je 1 tô zärāslo. A nïje dalëko. Tô ti je ĺepöta. Premda je zärą̧slo, ali ti möžeš pasät. A svë ti je nanïžica.

Šćer: Sät ću jâ s väma do Turuntâša pā ću vi kāzät pût.

Belo: Äjte, srëća vi nä pūt...

Jovan Belo Radnjić (78 godina) (i šćer mu i žena)

Kuk, raićevićki katun

Döbar dân. Äjt ${ }^{\mathrm{e}}$ ovämo. Ne smêtạ̄te nïšta. Śëdite. Izvölte. A vî mômci, käko ste? Pîtā ih štö će da popïu? Öćete, käko ne. Jë li rûće? Jestë li pjëški ili kolìma? Pjëški idête? Ǟū, döbro bögami, mômci ste, mlâdi ste. Ovô mi je zët i šćêr mi je ovô. A jâ sam jučê odî̀o bäš, pā sam kolìma, öbīšæ sam Lôvćen e odâmno nïjesam odîjo. A ödolēn sam rādî̀o - trî gödine sam izläzî̉o göre. Tämo mi je diönica bîla. Pütār sam bî̀o.

U Škälāre žīvîmo säd. A ĺêti izîdēmo. A bögami sam ōđën žīiìjo. Jâ sam držäo ōđën po pêt krâvæ. Ali gödine su vǐše. I dőšlo je... Äjte žīvjëli! İmāmo göre na Bižălêvac planìnu, nō ne izläzīmo mî đäolóm. Jâ i bäba stäri - žìvîmo ōđën po dvâ mjësēca.

A štö da ti prîčām? Ïma tïje prîča, ali štö ću jâ bez da pogrïješīm nëšto, pā da pöslijēe rëčē nëko: Viđđi ga đë baglačâ sväšta. U Žāneèv-dô su ti bîli Pērövići, Ĺësāri i Vûlovići. Trî brästva. A ranïjē, prïjed... mî smo is Cûcā Pērö- 
Adnan ČIRGIĆ

vići, sa İzvōrāk tûn. Ötolēn smo prïješli ovämo, ìmā prëko stö gödīnā. A Ĺësāri i Vûlovići - öni su mlögo prïje ${ }^{\mathrm{d}}$ döšli.

A jestë li vî sa Cetîna ili is Podgöricēe A kot Kadïjē ste smjëšteni... İmaū tämo Mâjstori. Tämo nïjeste odìli. A ìmā dvâ sâta gotövo da ìdēte do Mâjstōrā. Na Vûčì Dô - nêmā tûn nïko. Ranïje smo na Bižāálèvac izläzīli svì. A säd nêmā nïko. Päle küće. Nïko. A na Mīràc jöšt ìmā pöneko. I na Bostûr ìmā pöneko. A i na Dolöve ìmā. Bîli su tämo i dvöje Zâlāzāh - Mâlī i Vëlí. $\mathrm{Ne}$ živîi vǐše nïko tämo. Tô su tâ sëla ńëguškā. Mälo je ostälo, nǐšta. Nïđe nïko, štö ću vi prīčăt.

Mögu da vi kâžēm da je ōđën bîlo zä vrijēme Aüstrijē, bîle su ođđënake dvïje žičäre is Kotöra. Jë li pöznāto vi tô? Jëdna ${ }^{\mathrm{j}} \mathrm{e}$ ođë bäš pot küćom bîla, a jëna je na Krštäc bîla. A jëdnu su bîli pöčēli Talijąni, ali je onô stälo kät su kapitulīräli i nïje se zavřšìla. I säd ëvo nëkī Austrijąanci kojî su rādïli ovô, ńïgovi stậrī, säd òn öće da üzmē da pràvī Lôvćen - Cetìńe žičàru. Čitäo sam tô nëšto. A oćê li tô bït... dosäd nêmā nïšta.

Göre ïmāš tunël, ōđënake bäš više Čëla. Tûn je dvâ rezervậra. Pedësēt mëtārā je dügačak, pêt visök, pêt širök. Jëdan je pötpuno zavirššn, a ovî je u završêtku. Öni su izvëli vödu bîli is Kotöra, sa Gûrdića, cijēvìma, i vëć su bîli na Krstäc vödu döbīli za onê dvïje gödine. Tô je svë dïgnūto pöslijed. Svë se tô razrūšǐlo i pönijēelo i tô. Mî ne umïjēmo sačūvät onô bogästvo štö ostänē iza nëkōga. E tô su grëške vëlikē kod näs. Tûn ìmāmo cr̂̀kvu i grôbĺe. Popräviāli smo dösta. Štö da vi prîčām drügō...

Äjte, opröstite. Srëćan vi pût. Zdräo bîli. Äjte prävo pûtom, pā ćete izbït na Ńëgūše.

Luka Perović (80 godina)

Žanjev Do

Ike: Sëstre mi žīvê èvo ōvdën, u Raïćeviće. A tämo je Kopïto, tämo Dügī Dô, öndār Vr̂́ba, Žānéëv Dô, Krstëc, ìmā dösta. Düka će väma tô näleše kāzät. A onô je näša cr̂̀kva ërākovickā, Svetî Säva. Ëvo smo rijēšìli säd, oprälāmo je. Jëdva smo se složìli, küćo möja. Svì smo dậli jëdną̣ko. Jâ sam dậla od ovô mälo tamän kā ovîzi te prîmaū dösta. A onô su tämo dvïje Svetê Nëđeĺe, tämo Svetî Säva i ōđën Svetî Đôrđe i Svetâ Göspođa, pā Svetî Arąndiijo... 
Pîtaū me svë đë ću, küj ću - ovî prozä selo. E nêću vi kązät... Tû ti ìmā Màrkovíćā, ìmā Bëćîrāh, ìmā Mäštrāpāh, ìmā Cütko, ìmā Räūtāh, mî Šèvaĺevići, Rädoníći, Perünovići. Ëto täkō...

Ëvo väma stolìca. Ōdën ću jâ. Śëte tûn. Öh, stärōs... A môrā da je nëđe ìzāšla kot konšìje. Ëvo jo jahvą̂lnica. İmām i jâ. Znâ se kôme su je sprävīli.

Nìje ovô dalëko, vïdīš. Jâ s krivìnē sväkū vëčēen döđēm ōdën, śedîm do dësēt, dësēt ì pō. Otolên jöpēt nàzād. Pjëški svë. Ali je ladìna i odgovąara mi tô. Täko ti je tô, dûšo. A jë li vi Mąšse što prīčăla, bögoti? Nïje öna s Négūšāh. A Gospäva je kükālā slïjepa. Jâdi ōeënak. A jë 1 Danïca bîla više küćé? A nïjeste kod Mâšē bîli nō ko ${ }^{d}$ Danìcēe Öna je z Botûna. Danìca je pämētnā žèna, fînā žëna...

A ne držî Mîle nïšta, ni mäčkē ni küčkē. Üh, a kakvä jo e pênzija. Jâ se š nôm svë krïtikujēm. Mâla jo e pênzija.

A bîli ste kod Andrìjēe. Kod Âśa näšēga. Âśo je döbar, döbar čợek, döbar domaćîn. A i kod Bêla ćete još da ïdēte. I kot Ćütka, kod Ilïjē Cuütka. Döbro bi bîlo da ve nëko prebäčī. A svë smo pjëški prïje odîli, i ü planinu i is planìnē, sagonïli dr̀va i sïjeno. I svë se prïje rādïlo, bögami, i nïje tô nǐšta dalëko bîlo... A nêćete vî ovô u növine, në li? A në, zäboga. Në bi räda bîla îme u növine da mi se mëćé...

Nêmą vǐše da zną̂m starî nìko tàmo. A ìmaū na Vûčĩ Dô onî Peškîri te su se sät prözvāli Petrövići, a öni su Peškîri. Otæèc im je ostào ovōdënake od vōjskê austrîskē. Ôn je tämo is Pëtrińe, is Hrväckē. A đë Petrövići? Petròvīćā nêmā nāko ovê dvïje küće tûn u näše sëlo. Za mëne su Peškîri öni, a mögū mi rëć da su Drëkalovići, al za mëne su Peškîri. Od Aüstrijē su öni tûn. Brânko ostào, otäc im. A fîn je bịjo i kao čǒek i kao komšìja i kao selậk. Nỉje se zamjërijo nïkōme.

...Ovô su mi rodïteĺi, otæec i mâjka. Ovô ti je bïtka na Vûčī Dô... A Dušàn sprêmā jöš ednu kńìgu. A ovû je sprēmäo od Vëlēemu Kräju, ot küćé näšēe pā do onê cr̄kvê. Tô se zovê Vëíi Krâj. Tûn su bîli, dûšo, starośedịjoci. Bịjo je cär Rufîm. Bij̀ je u onî potök. Nïje vi tô Düka rëkǣ? Rëće vi. Bịjo je manastîr cära Rufîma. I bîlo je ńïh sedandesêt kûcāh, domaćînstą̄vāh. A ovî Ërāk i Raiič döšli su i žĩvëli su nëđe tûn, u jënu Zaüglinu. Tûn su žĩvjëli. Pöslijēd ${ }^{t}$ su... Jëste li odìli đê onâ vöda? A në. Tû ìmā vöda te su ogrąaìli. Pîšè: ovû vödu podïgoše bräća Raîćevići. I öni su doläzīli i pojîli - ovî iz Vëléga Kräja. A ovî - niîh je bîlo sëdam - dä-ti bräcée i štö jâ zną̂m. I öni se š niìma bïli i gā- 
Adnan ČIRGIĆ

đäli ih kamēńîma. I öni pöšli u Cetìne i žälīli se. Koî je bịjo lädika në znām. Në znām koî je bî̀o. I öndạ̄a rëkā: „A kölko ńïh ïmā?“ - „A ńïh - velî - sëdam.“ - „A väs?“ - „Sedandesêt domaćînstāvāh.“ - „Znâš štö je, - velî - níì bîlo sëdam i sëdam i sedandesêt i sëdam, a väs nïjedno." I täkō je bîlo. Nêmā tïjeh starośedīōcā bes tâ Batrïćević. Pröklēo ih je. Tô će vi Düka svë fîno obją̧snìt...

A jë li Stâne tûn? Üh, Stâne ìmā gödīnā dösta. Öna pậntī dösta. Zną Stâne. Čủäla je od öca, o strǐčēvāh i tô. Znâš štô je - kö je bị̀o zaìnteresovān mögæ je... Štö je zborìjo jëdan môj komšìja: „A, sînko, nïjesam jâ ovû istôriju is kńîgā naučìjo nō sam svë od Zêka Mašänova, od Jôva Sâvova, od ovïjeh stârijeh slüšāo. Ovî starî su śeđëli oväkō oko ögńa i pjëvāli uz güsli. I öndār öni prîčaū od istôriji, ot pröšlosti, a mlädōs - velî - ovämo ìgrā kölo. E otolên ti jâ, - velî - sînko, tô zną̂m.“

...Korïtńík je vöda. Vöda ù planinu. Tô je prīrödno täkō. Aüstrija je naprävīla ovê rezervâre i obr̄nüla vödu ovämo. A ëto säd. I zagrādìla bîla dô $\mathrm{i}$ tô urēdïla. Sedamdësēt ösmē inžinêr koî je projëktovao doläzī'o je ìz Bēča sa ženôm. Vozịjo ga je nëkī Dušàn Milōšèvić, taksīsta. Ön mi se s mûžem poznāvào döbro. I ôn pîtā ńëga: „A, Dûle, kôga tô vözīš?“ Ôn kažūè. A në stade trën, ëvo se vräcúu. Kâžēe „Dûle, štö ovô bî, zäboga?“ - „Polūdījo je - velî -

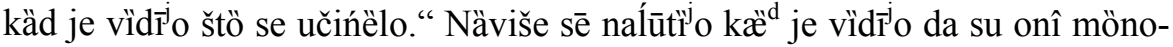
gram Frâńa Jösifa izbrìsąali. A vìdījo da je svë upropą̧śćeno. E, đäolu fâla, da städe jož gödinu dậnāh, da prödūži Aüstrija, në bi Nëgūši bîli bez vodê. Në bi sìgūrno jer su śceëli spoìt Grëbēí tàmo pūd Žāneèva Döla. Jer ìmā tämo oväko tūnël. Odovüd uĺěžěš, a izâđēš na vr Žāneëva Döla. Uläzīla sam kao dïjete. Tunël naprälen i unûtra pod zemjôm rëzervār. I öni su šćëli tô dä-ti iz Böke vûć vödu, te në bismo danäs bîli bez vodê. A mî smo tô svë fîno srēdìli i očūväli. Kā mî. Mî ne lîčìmo nāko sëbe. I tô täkō stoî. A tô döĺe svë plìvā kad vöda ustänē. Da ìmāmo lą̣đe, mögli bismo plovìt. İmā porön kot küćé Petrövića. I tâ porön izläzī na Crnogörskī pazậr. A onî ù Dō porön, kæ̋' Dô ustänē, izläzī na Ĺûtū. A znâš po čèmu znâmo da e tô täkō? Prōväli su, böje onê sìpāli, pā böja đê ìzāšla. Ô da je Aüstrija ostäla... A ōdën èvo vìdīš kölko je kûcāh, a ëvo nêmā bez öna ōdën. Säd ĺëti i ìmā, a zîmi nïđe nïko. Böže ni pomözi...

Mile: A jâ sam do mälo prijed ōdën śeđëla. Döbar dān. Käko ste? Jeste döbro? Äj śëdite.

Ike: Öni su bîli kod Âśa näšēga. 
Mile: Ê. Štö ćete popìt? Oćëte 1 po jëno mąllo pîvo? Ma öćete öndā po jëdan slädolēd. Mä käko nêćete nïšta, za Svêtoga Pëtra? Ne möže. Môrąate nëšto. ...Nêmā tû kartìca da se kûpī bez nülā šêz dëvēt, mëne je nülā šē sëdam...

Ike: A rëkla sam, Cvïjetu sam zvậla i rëkla je da öće. Üh, đë si bîla? U Vôja sìgūrno.

Mile: A đë ću drügō bït? Ōdë nêmąž đë. Nìđe nïko. Ovô je svë opūšćëlo. Ovô je prīzör. Ovô ne lîči nïčemu. Oväkvō mjësto, ovâ ĺepöta. Tô je sväko zaborävījo käko se podìzālo. A säd tô se izobälo, pomąąìlo i jöpēt im se krîvā. Äjde säd mi tî objâsni, mölīm te lïjepo. Da jâ nëkōme mläđēmu obją̂snīm käko sa ${ }^{\mathrm{m}}$ jâ rą̂sla. Imäla sam petnäez gödīnæ - böle smo žīvjëli nō drügī - üh, pā da mi je bîlo prëpreke... Tô su se tädē zvą̂le prëpreke - güma döĺe, käkvā güma bîlo, ot käkvē jädo-köžē onô ispreplìjeći i ëto prëpreke. Žìcōm svêži ili brökvicāma, pā käko ìdēš - täkō ti nöge nagîdī. Jâ jöš ìmą̄m srästākǣ. A mälo smo böle žīvjëli. A imäla sam dä-ti jëno petnâjz gödīnæ, u šesnâjstu, kūpïli su mëne sandälice. E jâ sa ${ }^{\mathrm{m}}$ se svë oglēdäla. Čineẻlo mi sē tô nïko nêmā. A ovô danäs sē svë pomąmïlo, ozobälo i jöpē im se krîvā. Krîvi im ovî, krîvi im onî, kao da će pänūt štö ìz neba. Böže sačùvā... Štö je, Mâše?

Maše: Öću da se dïgnēm.

Mile: Pā äjde. Dâ jo rûku, Îke... I täko, hä. Nïkæ ${ }^{d}$ se nïje böle živjëlo nō danäs, küćo möja. Nō vî ne möžete tô znät. Nïkæ nä svijet böĺe.

Ike: Äjde, dïgni se, Mâše. Äj dìk se.

Mile: Dâ jo ${ }^{j}$ rûku, dâ, da ne pänē... E täkō, küćo möja. Ëma je prïje bîlo svë poštenïjēe Jâ pą̂ntīm svë ovô kæ̋ je bîlo püno ovô. Svë küća do kücée, svë porödica do porödicē. Nỉko nïkōme nïje smētào. Svë fîno. Svë se slą̧z̄è. A säd, ovô je nënormą̄lno. Välā vìđećete, a jâ nêću vìđet, a vî bîli zdrävo, pā ćete vïđet. Ovô ne vödī döbru. A öndā velê - porëdak je krîv. A štö ti porëdak smêtā. Prüžīla ti se šą̂nsa da prävīš bìznis, da rậdīš, da pönešto mälo i zarądī̌s. Mëne je otäc bîjo dvādèz gòdīnā u Ämeriku. I došào ōdèn i štô je činìjo - kupoväo imovìnu. Pô Lôvćena je möje. A štö će mi kad jâ ne döđēm do ńëga. I naprävījo küću - tädēr, u tâ döba, näĺešā u Nègūše. A säd? Svê se mïjeńā, küćo möja. Nêmāmo bräćē, svë sëstre.

Ike: Imäle smo jednôga bräta, nō tô je...

Mile: Äh, tô je mâlo ugìnūlo, ot pe-šes mjësēcā, gödinu - në znām. Ëto, živöt je takäv. Ńëgoš velî: Nêmā vïšē brükē od ${ }^{t}$ stärosti.“

Ike: E në, bögami. 
Mile: E velî ti nëko: Žīvìjo stö gödīnæ. A käkvē sto gödīnā, đëtiću drâgī? Žīììjo dok čöek möže sä sobōm. A živöt je prölazan. Pïh. Kad je zborìjo Tômo Mârkov, otæ̈c Nëgošev, a ôn žīvìjo stö sedam gödīnæ, je 1?

Ike: Sto jedanäes.

Mile: I velî: Käko ti se učińëo ovî živöt? Velî: Kao dä sam na ovâ vrâta ûšā, a na tâ îzāšæ. A ovî näš nāröd bi sämo da im je äm, da im je žăbē. Nêmā, bögomi, žäbē nïšta. Ëvo vïđi, jâ sâma s ovïjem bolesnîkom, pā sam sâma srēdïla zìmnicu. A štô ću. Ëh, kæ̈ bi držäla žîvō. Äma se jâ vǐše ne mögu sekät. Püšti, gödine svöje činê. Tries ôsmō sam godǐšte. I tô sam röđena na Cär Kostadìn. Čèkāli svë da nêće bït müškō. Što će bìt? Đevôjka. Jëdan mi röđāk $^{\mathrm{g}}$ da ponësē vïjes na Lôvćen e se rödīla đevôjka, napïjē se kā... nāko štö nïje cr̈kæ. Näpīio se e sam bîla žënskō.

...Ëvo vïđi, öce sä ${ }^{d}$ da dokąažū da ne postöî crnogörskī jezïk. Ma nïje täčno. Ëvo sä̀ da öce svì svjëckī pröfesori i näučnīci da dokąžñu da nïje postojäo crnogörskī jezïk - nïje täčno. Pā ovî l̂udi stąrīi, öni nïjesu jädni odìli ü škōlu. Ali su imäli prīròdnī fakultêt, küćo möja. Äda nïje se prīčälo fräncuski no crnogörski. Znälo sē svë käko se štö zovê. A säd su svë izmijēnïli. Ožìca, pïrūn, pjät, nožǐć - tô je po näšēmu. Šêrpa - tëća, korâć, klïjēšti. A säd nêće nō klïjēšta. Öće svë da izmïjenē. Öni srbüjū, küćo. A bîli su nekäd komïti i bjëląši - izdâjnīci svojê mâle zemjê, jädnē, dîvnē. I tô je pöšlo, tîzi, tî gêni tô vūčû.

Dok nïjesu pöčēli na televîziju ovîzi kalendâri, mî od Sr̈bijē nïjesmo nǐšta smjëli - ni pokāzät näše. Osamnäestē, vî zną̂te fî̀no, srēdīli su te käko. Svë sū üzēli. Ëh, väzda je bîlo izdâjstva u ovû näšu držävu. Ne mögu välā bïti Srpkìńa, Srbijąanka. Zną̧š käko su se prïje öni glëdāli - bâr kölko jâ pântīm - ćâhū ovī stârī Crnogôrci väzda: Tâ ciganïja. Ê, küćo. Öni za ńïh nïjesu drügōga ìmena imäli. Në, bögami. Äh, kæ̈ sam čüla onögā Šëšeĺa i kæ̈ sam čüla onögā ńegöva Nikölićca, dä-ti zą̂mjenika, štö li, da kâžū da nïje postojäla Cr̈nā Göra.

Ike: Ëh, a nâjprvā na Balką̂n - Cr̈nā Göra.

Mile: A jë li prìznāta i na Berlînskī kôngres? Je lï, küćo? Tô znąte.

Ike: Düka će ńïma fîno objāsnït svë. Düka Jovänov.

Mile: A onâ sküpština osamnäestē - pönijēli ni svë, öh, svë. I velê da smo bräća. A öklēn bräća, đëtiću, kat su ni čùda čineelli?

Ike: Öh, jēsu, čùda po Cr̈nōj Göri. 
Mile: Žène su u bunâr bāčäli. Tô ti je žîvā ìstina. Pā pod onô jädo-sükńē, käko su stärice nosïle onê sükńe širökē, mäčku ubäči. Pā svêži döle, pā i po ńôj i po mäčki. Pā im ubî famëĺu. Bräća Sr̈bi. E tô ti ne möže brät bït, küćo, nî na jedan nąčìn. Ali vìdīš, tî od domąćijeh izdâjnikǣ ne möžeš ostät.

Ike: Znâte li štô je? Näjprijed ovî škölovąni zaglîbē. Öni në znaū däle nāko onô što pročîtaū.

Mile: Öni sàmo bûpaū onô is kńïgē. A mëne je ìnteresovālo da čüjēm ot stârijeh. Väzda sē küpīlo, śêdnīci. Nïje bîlo televîzijē. Pā ovô mläđē na jënu strą̂nu, a ovô starìjē ovämo i prîčaū i gusläū. A mëne je înteresovālo da čüjēm što öni prîčajū. Ma milïjē mi je bîlo ńïh čüt od ǐčesa, mä.

Ike: Düku vi śütra ufätite. Ôn će dösta da vi pokąžē.

Mile: Mâjka ni je prīčlala - në đê möja mäma, nō döbra je žěna bîla kǣd su bîli bjëlạšsi, odïli su ovämo niz ovî vïh i doläz̄ili ōdën. Bjëlāši. Négūši. I döšli: „Mî smo žêdni, al nemôte ne otrövāt.“ Bräću da trüjēš, üh. Bîlo je svëga. Ne povrātìlo se.

Ike: Në, nï da jậki Bôg.

Mile: A višāā slöga i vǐšã ĺubàv je vlādäla. A danäs nïko nïkōga. Onô štö rödīš - onô će ti se ödrijēt dok mu je ìnteres ot tëbe nëkī. Zäšto se dozvolîlo da se uvą̂lī drôga, što je nāröd cìjelī polūdîjo? Në valâa zą̄kön. Znâš koî je zākön bîjo döbar? Kńąza Danìla. Kat su tû jednôga ubïli za glavìcu zëĺa. Äda nô nō ga mušketäli. A zäšto je übrāo? Što nïje pītäo? Što nïje trāžịjo? E tô je bîlo. Stävi zlätnīke nä pūt, pā äjd. Öće, nō savî se. Kako në, nō proläzī. A danäs nëko da döđē da me ubïjē e mìslī da îmą̄m pą̂rā, a jâ preživläjēm. Üh...

Znâš käko. Jâ sam bîla näjmlađā u porödicu. Ali mi narêdē mälo krtôlē i mälo zëla u onî sakečìć i upr̈tīm se i nizä strāne. Dïjete. Ali trëbā nizä strāne sîs na Crnogörskī pazậr u Kotör. Nösīm nëšto mälo lểše što ìmām da se obüjēm, ali upřćena kröz grād do nä Rīvu. Ô, đäola. Dïjete. Pā öndār prodâ onô i ùzmi pönešto i öndār uzä strāne.

Ike: Jöpē upr̈ćena...

Mile: Nëko ìdē s köńima, pā ti onô što nösīš stàvī nä końa. A jedapût, a živāa ìstina. Bîla ovâ küća svë üjedno. A bî̀o jëdan stârī šporët, pā jëna klûpa izā šporëta. Nïje se imälo könfōra. Nō došâ nëkī pöp ${ }^{b}$ Böško Radusìnović i ostäo na konäk u näs. Mëne mäma nëšto pröstrē $i$ jâ trëbām ûjtro räno da ïdēm u mlïn s drûštvom. Dä-ti nêmā štô vïše nō dëset kîlæ mi stävīli e nêmā štö vǐše od mëne nosìt. I jâ lëgla na tû klûpu. A tô je humör, jädna. I dä-ti zä- 
spāla. Da opröstīte, jâ se izgörīm. Vìdīm ûjtro jëdan vëlikī šklöpac. Ô, nïšta jâ. Upr̈tīm se. Bäš je Ilïja Ćütko tàdār odìjo i ovâ Mîle Jovana Pêrova i onâ Đur-Ilîna i bîlo je näs jëno pē-šëstoro. A snïjeg, štö ću ti prīčät. Äjde mî pöđi, vrâti se, tô ni döle u Odoĺën samëli i mî se u onâ ûža - upïti se, a onî muškậrci u rüsāk. Döđi u Krstäc. A, mâjčīn sîne, käko ćeš. Äjde, bögami, onî Ćütko - momæ̈k, a ôn je i starî od mëne nëkolko gödīnā - ôn pìtī, a mî svë za nî̂m. Ako mälo onû stöpu... üh, zlôga pûta... A, bögami, vjëšto se jâ držîm svë dësnē strânē. Nō pasâj Krstäc, döđi đê Svetâ Pêtka, ovâ cr̂̀kva. Döđi pre cr̂̀kvōm, ali vǐše se në znā ni đê potök, nō pälo... Ilïja ìdē nâjprvī. Nösī rüsāk. Dok jedapût Ilïja svë četìri, pôđe u potök. Hâj, da ne doskočìsmo, jâdo, ügūšsi se. Ôn je dä-ti nosìjo sìgūrno i dväes kîlæ i vîše i täko ga izvûci is potöka. Döđi döma. Đäola. Ali je bîlo da si imäo nëkū čvrsstū obüću, ali nëšto. A öklē, nāko onäkō onô...

Äh, käko lömē säd jezïk i svë mïjeńaū, böže jëdan.

Ike: A štö ćeš? Neka mïjeńaū.

Mile: A nëka ih. Ma jâ ne mögu säd rëj bêlo bez bïjelo, Svetōgä mi Joväna. Bêlo, äh ovô, äh onô. Jâdi, jâdi, pïh. Ma ovô nïje döbro. Nïje döbro do ${ }^{g}$ göj ne döđē zākön Danïlov. Vìđi, sa ${ }^{\mathrm{t}}$ slüšam nä vijēsti... Üh.

Ike: E täko vi je tô. Ëvo čüli ste i ńû.

Mile: Aj žīijëli! Starìjēga vàzda poslüšā, sämo ne ïdi za ńîm. Üh, käko je ovô säd. Bï za prijeśêdnīka da ti döđē onî što śedî kæ̋̀ je hîmna, što bûcā Ustäv... Da Bôk sačûvā.

Ike: E ne möže tô bït...

Mile: Nïjeste me slöbodno zadržäli. Nō vi želîm uspjëh. Poküpite svë prąvēe îstine. Äjte, sväkū srëću i da vi čüjēm döbrō zdrâvĺe.

Ike: Äjte, srëća vi nä pūt.

Mile: Sväkū srëću i sväkō döbro. Da vi čüjēm döbrō zdrävĺe. Da odřž̄̄te ovû näšu držävu, ne dâte je vï̌̌e da je härčĩ nïko. Në, küćo möja...

Ike Popović, rođ. Ševaljević (80 godina)

Mile Švaljević (70 godina)

Maše Ševaljević (85 godina)

Raićevići 
Građa za izučavanje njeguškoga govora

Milo Kadija: Surütkē ìmā li?

Mujo Popović: A öklē surütkēe Ovâ je möja kïśelīla, pā je prosîpā tüda.

Milo Kadija: Kö je prosîpā?

Mujo Popović: Zôrka.

Milo Kadija: A zäšto je prosîpā?

Mujo Popović: Zatô štö tëbe nêmā.

Milo Kadija: Nïje täčno. Jâ döđēm ōdën, pā nêmā nïko. Äj müč!

Mujo Popović: Nemô tî mëne mučǐkāt....

Mujo Popović: Tûn je bäba stâlno, tû je do käsnē zīmê i öndā idê po jëdno dvā mjësēca oko Növe gödinē i oko Böžićā kod šćerê, a nïđe jo ńôjzi nïje liêpše nō tû.

Mëne je otäc pīsâ drämu Batrïć Pērövić, otäc môj. Solomün su ga zvậli, razumïjēš. Jâ sam pošâ vǐše po ujčevïni, po nëkōme Pêru Növākovu. I u ujčevìnu ih je bîlo pämētnijeh, Mihaïlo Iličcković i kumpanïja, ali jâ sam po Pêru pošæ̂. I ön je napīsäo ovû kniïgu Batrïć Pērövić, tô je möno-dräma. Tô je objâvĺeno, a ìmām i originâl. Kńïga je štàmpana i öna je dâvāta, i ōđë je dâvāta na Nëgūše i pö Mīrcu i po Cetìnu. Ïmām jâ slïke ńêne iz Ämerikē đë su je dāväli, i ńû i Kńâza Arvanïta, Balkânskū cäricu, ìmām slïke vëlike ńïhove i plakâte osamdesêt sa šēêtt sa mëtar.

Milo Kadija: Ovî dvoïca, Mûjo, pî̌ū stûdiju o neëguškōme jezïku, prâvōme selâčkōme neëguškōme jezìku. Nêmā selâǎčī - nō ńëguškī. Pā nemô

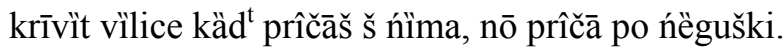

Mujo Popović: Jâ nïjesam umjëtnīk, ma đë sam göđ đé pošào, jâ garäntu däjēm da nijëdno slövo $i^{\mathrm{s}}$ svojêga rëčnika nïjesam izbäč̄ijo. Ovô štô se danäs prävī gospodìn - Jânko, Mârko i pêtī i devêtī: „Oväko se prīčălo nëkada“; mìslīm se: Äjde, đäole, tû seẻdi. Näjprostijē štö je rečëno, tô je näš jezïk, razumïjēš. Ne möžeš tî istēzäti näš gövōr. Bäre na ovê kräjeve Katûnskē nāhïjēē ne möže se istēzäti gövōr, ne möže.

Na Nëgūše nïje vi ostälo nǐšta bez ovô stârō, ovô štö je preko pedesêt gödīnæ pā navïše. Pā se škôla zatvorïla tû. Svë se raselïlo. Ü škōlu râdē čêtiri rāzrëda ösnōvnē. Jâ mìs'īm da ìmā sedamdesêt mömǣkā kô̂ je pasäo dväez dvije-trī gödine.

Pölitika je pölitika, bräte, stî̀ tî tô - ne stî̀ o, ali tô ti je tô. Čìm se škôla ukìnūla, sëla su izümrla tötālno. Kojâ sëla?! Käd jâ nêmām kâpi vodê, svä- 
kī lìtar môrām is Cetìna plātìt ōdè da mi döđē cistìjernā vodê. I tô da držî sëlo? A ëvo ti, bôg i böžijā ìstina, pîtā ga kölko je cistïjernā vodê. Pîtā ga. Ëvo ga, vïđi ga. U Cüce, u Ćëklīće, u Bjelīce - pedesêt ëūrā cistïjernā, a ōđën je stötinu, a düplo blïže. I ôn danäs, gëjāk, $o^{t}$ šêsët gödinā sü dvije kräve i sü dvije-trî köze us tê glavïce da ïdē i o tömē da žīvî?!

Jâ sam naprävījo bistïjerńū prije triez gödīnā, sedamdesêt kûbīkǣ, mậla je, ne valâ nïšta. Držîm jëdnu krävu. Pröšlē gödinē sam dvïje imäo. Dogödinē nêću nïjednu nō ću krepāvät oväkō. Štö je onî zborìjo: Crnogôrci ìjū u prösijēk sârmu - nëko zële, nëko mêso, i ëto ti sârma.

Radovan Popović: Döbro, mômci, jâ bi ve sämo jëdnu stvąr pītäo. Kojïjem ste vî rëcimo pûtom döšli? Štö ve înteresujēe Vìđi, jünāče, nïjesam stîjo da se ukíûčīm uöpštē dosäd u ovî räzgovōr, vïđeli ste. Ovô svë štö je Mûjo Popövić rëkao - ìzā togā jâ stojîm. Jâ sam - ë sa ${ }^{\mathrm{m}}$ se rödî̀o - na Neëgūše sam cìjo vïjek ëvo do säd. Provëo sam vïjek kao čợ ek selâk. Nì dā Bôg, ne ogovârām. Mî smo svì ōvđën bräća, komšǐje, kümovi, drügovi, prïjatelí. Tô je svë povêzāno. Intervenïsao sam nëkolka pûta - ovô me ôn po śëtîjo - zbog ovê bälijerkē štö mi je sîn trëbao da üzmē. Jâ se ìstinōm slûžīm. Stìjo je da je üzmē za sëbe, a da je kôme rādìjo - në bi mu žäbē rādîjo. Sät, käko ćete vî mëne svätìt, jâ në znām, ali ôn se bì̀o preokupīrào - täko da rëčēm - da üzmē bälērku. Trâži, düpa, sëka, tämo-ovämo... E jâ ve säd, mômci, pîtām je-l tô u rêdu da jâ säd o ${ }^{\mathrm{d}}$ šêsêt $\mathrm{i}$ kusûr gödīnæ ćërām us tô br̈do dvïje kräve i dä li jâ mögu od ösam ëūrā, jâ i žèna, da pasâmo danäs? Ösam ëūrā računâm kïlo sïra, onî môj pröizvod, ne računäūći onô što zbörī Mûjo Popövić - rāshödi, nego sämo prīhödi, a štö ìdēm u mînus - käko bi rëkā - e stvârno je žälosno. Šês pûtæ ìdēm na komîsiju i zbörī: „Kot pacijênta se ne navödī nïkakvī gubītäk, nego je pacijênt i däle spösoban“. A jâ, da sam znäo käko će šêstī pût ${ }^{\mathrm{d}}$

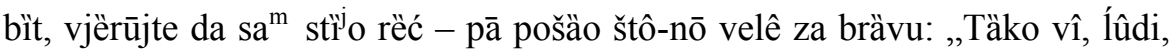
bîli spösobni“. Kük sam lomìjo - ôn znâ da nïjesam u stânu bìjo da ìdēm da se lïječīm pošto nêmām osigurąnna. Mômci, opröstite e ve opterećüjēm s ovïjem. Jâ nïjesam stïjo da se umëćēm ü rijēči ńegöve. A bögami dösta pântīm. Äjte, zdräo bîli.

Mujo Popović: Jâ o svôme živötu brìnēm ot četrnäestē gödinē. Ëto, Mârko, otäc mi, bịjo je oglâšen̄̄ ,izdâjnīk“ nâjstrašnī, protiv držävē, us krâla Nikölu je bî̀o. A krâla Nikölu - nïjesi smî̀ pomēnüt mu ìme do osamdesê šēstē kät su ga krēnüli donosït. Znâčī, svì tî lûdi koî su bîli okô ńega - tô su 
bîli nâjgorī. Ön je döbīio prâvo glâsa šēse četvirtē. E säd znädi. Kæ̈d ${ }^{\mathrm{j}}$ sa se jâ zaposlî̉ o, môj dirëktor je odì ${ }^{j}$ trī pût na saslušâne i trëbao je da se skìnē $s$ mjësta dirëktora štö je üzēo sîna Mârka ,izdâjnīka“. A otæec mi se dvâ pûta ženì'o. Pr̛̀vī pût $o^{t}$ četrdës i dvïje gödine. I ümrē mu žèna i ostänē mu dvöjēe đecê, dvïje sëstre mởe. I ot pedesêt ösam se ožênī drügī pût. I dvâ bräta prëda mnōm ümrū. Jâ trëćí. Zatô mëne tëpajū Mûjo. Nïje mëne Mûjo ìme prâvō. Pöslijē mëne jöpēt još jëdan brät ümrē i sëstra ovâ nâjmlađā. Ovô imâne krâĺa Niköle ot četrnäēz gödinæ sam jâ sâm kosiijo s röđākom. Nêmā pênsije, nêmā plātê, nêmā nïšta, a nïđe nïjesi döbro došào. Tî si sîn Mârka zelenâša, ëto ti krâí Niköla, ëto ti ga, äjde u Itâliju za nî̀m pā nëka ve ön pomögnēe pā ovô, pā onô. I öndā râdi, näjgorē raböte kojê su bîle mōrào si da râdīs. Mâjka, i öna u gödine döšla. I öna se öndā ùdāla $o^{t}$ trìes i dvïje-trī gödine. A čàvā ü grēdu ni nïje ostâ. Koî je tô nāčìn živöta bỉjo, kojê je tô päćēńe bîlo. Odolên jâdi, čìsti snïjeg da kräve ti pasäjū, da izâđū göre ù planinu, da ti ne pokrepäū ōđën. A šêz gödīnā po dvānäes kïlometārā, tolìkō je odolên do göre, do küće mojê ù planinu. A dïjete u privī rāzrëd, tô je planìna, tô je pustära göre, tû ne žīvî vǐše nïko. Nïko, ïmā trīdêz gödīnæ. A sämo se izdìzālo göre. Ali se izdïzālo ösam mjësēcā. Ösam mjësēcā je göre bỉjo, a čètiri ơđën. Sämo kät pänē snïjeg i kät pöčnē da köpnī snïjeg. Znâčī, u äprīl mjësēc si odịjo, a u novêmbar mjèsēc, kät kölêš kr̀mād, si se vräcáa. Zaköléš kr̀mād göre i izaždënēš ih. Kö će sagnät kr̈mād. Tô bi krepälo da ih ćêrāš dvānäes kïlometārā, prâse užîrenō. Zäklāne smo ih ovämo donosïli. Znâčī, čětiri mjësēca si bî̀o ōđën, a ösam ü planinu. I sväkō jütro ozgôr. Döbro je bîlo dok sam ûjtro odîjo ü škōlu. Ali pöpōdnē, u oktôbar mjësēc - prìje nō se püštīmo i $i^{\mathrm{s}}$ škôle mr̈knē. A jâ môrām odìti još sât ì pō vrëmena göre. Pā ćâše mi otäc izâđi kā nä vr tê glavìcē i öndā me zovê üvečēn: Ëvo jâ te čëkām - da me nïje strâh. Tû su karijäpi, jäme. A öndā se đëca prepädāla da se në bi nakviječäla na jäme - käko su đäoli skākäli, käko ovô, käko onô... Pā, kükāvče cr̀n̄̄, izâđi odovüd, pā stäni za kakvïjem křšem, pā glëdāj onû jämu. Pā stàni döĺe. Nêmā nìkōga. Pā sküpi snâgē, pā třči da đäo ne isköčī, da te ne uvätī, pā pröđi, pā se obřći izâ sebe, pā mälo-mälo pröđi, pā se spotäkni, pā päni. Udäri se, nagr̈di se, ôh, ôh, ôh, jäda i nesrëćē, kükū, kükū...

$A$ jâ sa ${ }^{m}$ po jëdno trî mjësēca, od Ilîna dnê, od drügī ävgusta, pöčnē da se korubą dûb, tô je cër, pöčnū da se lömē grâne da se korubậ tô. Za stöku, jünāče, nïjesi imäo nǐšta da joj dâš. Përa o ${ }^{d}$ dūba su se ĺūštïla. Objësi jëdnu 
Adnan ČIRGIĆ

kësu okô pāsa, svêži je za onê dvā kräja i öndā üzmēš i korubậšs, skîdąšs grančìce i stävlấš u vrëću lîs. A öndā, pöslije ${ }^{d}$ tögā čëkāla se pr̀vā kïša, säd pöslijed ovâj-doba, a öndā se korubäo jäsēn, pā ubäči po dvâ křša u vrëću da tëglī i öndā se pëńi uz onî jäsēn. Savî grânu vrëcóm jer od šümāra je nïjesi smìjo ubrät da je posïječēš. Imäo sam jâ kosïjer da je okìnēm, ali nïjesi smî̀o. Dāväli su da se korubâ, ali da se sïječe - në. Tô su öndā käzne bîle, mōrào si odìt u zātvör. Śëdi, śëdi, tögā zlä i tê mükē...

Mujo Popović (56 godina); Radovan Popović (64 godine);

Milo Kadija (57 godina)

Erakovići

Tû žīvîm. Jësa ${ }^{\mathrm{m}}$, röđena sa ${ }^{\mathrm{m}}$ na Ńëgūše, u tô sëlo tämo, u Ërākoviće, a ōeèn üdąta, u Raïćeviće. Ot Popövićā sa ${ }^{\mathrm{m}}$ rödom, a dömom Šëvālević. Čūjäli ste za Lûba Šèvālevića. E tô mi je sîn. A jëdæn mi je ümanro štö je u Podgöricu bïjo... više manastîra... Ako ste čūjäli e je üm ${ }^{a}$ ro, e ga je sìce okìnūlo. Pā mi je Ĺûbo osläbīio, u Brèzovīk je... Möžēte kâvu popït. Ne remëtīte me slöbodno, ne smêtā me raböta.

Po cïjelū gödinu smo mî ođđën stojäli. Jesenäs mi je üma ro đëde, pa nìjesam šceèla odìt nïđe, a prolietōs mi ümrije i tâ sîn. Bäš je jučêr godǐšnica bîla đëdu. Nïje mi nïđe ĺěše nō ōđën. Ne râdīm nïšta. A držäli smo i müčili se kǣ İsus, a säd në. A Blą̂žo, onî stậrī, štö mu je sîn ümaro, tô mi je brät. Brät ö strīca, nêmām bräćē bež ńëga... Ĺ ûbova mi je famëla u Kotör, a ovögā u Podgöricu. I šceêr mi je u Kotör. Ne däjū me, nō bïše da me vödē, al nêću. Näĺeše mi je ōđën. Tû mi je i đëvēr. Ovî svì zimüjū ōđë štö su. Döbro je, ìmā dr̀vā... Sramöta da nëšto ne üzmēte... Säd je lïjep živöt na Neègūše, a bögami bîla je müka. Rādìlo se, nēmäština bîla, a säd nïje nō döbro... Jâ ìmām osamdesêt i dvïje gödine. Bögme me dösta jäda ubïlo. Đäo me držî zä đavola. Ëvo vïđi: Imäla sam jëdnu sëstru. Öna je ümrla dâmno. Otæ̈c ni üma ro, a mâjka ni se prëudāla, pā nê öndā onî otæ̈c Bląžov podìzao. Strîc nê podìzao. Tôj sëstri mi niije ostälo đecê, a mëne jès. I jöš ìmām desëtoro unüčādī, tröje präunučādī, sä tögā sîna i šcêrrku. Nō mi je i ôn bôn... Ma möžēte nëšto popït. E ne valâ tô täkō... E ôđë nêmāte štö mląadō, nâko sämo ovê babetìne... A jë li vi lïjepo kot Kadìjē? Jê li tô naprävījo?... 
E nêmā dä-ti stârijeh vìše, nō sam jâ näjstarijā u ovô sëlo. A öklē ste vî rödom?... Mî smo izdīzāli na Lôvćen e smo držäli stöku. İmāmo göre imąnée i küću, a ìmāmo i tûn zemíê dösta. Svë smo kupoväli. Nïje ne od đëda dopälo, nō smo svë kupoväli. E, i säd mi je bịjo jädo-sîn küću naprävî̀o na Lôvćen. Da je u srëd Bëogrāda, nêmā jo mânē. Ovî sîn is Podgöricē štö je nestäo...

Iza tïjeh börōvāh je Vrrba. Ïdēte krajem hotèla, onämo onâ cr̂̀kva prvâ štö je, ülica je kräjem crkvē i sëlo je ödmā ${ }^{\mathrm{h}}$.

Milica Ševaljević, rođ. Popović (82 godine)

Raićevići, rođ. u Erakovićima

Fâla Bögu, bögami ōđën kö göđ döđē möže pö slobodi, ako će nörmālno, kā domąaći. Ëto täkō. Väzda su mu vrâta otvörena, onô štö je Bôg däo $i$ vodê bìstrē... A ovî su mi bîli dese-dąanā döle na kūpäńe. Ôn ih dovèo, pā se vrātījo na rabötu... Rädośnica, rädośnica bäbina! Jëśi tî bäbīn śîn?... Ne püšìm, sîne, fālä ti. Ëvo päsa lêto. Popî tû rakïju...

Jâ sam s Vrbê, od Vûjkovićā. Tô je dâmno bîlo. Svë sam zaborävīla... E, bäba - źäba... A Mîlica vi je, ńêzina bäba, ali je bölesna, öna će vi näjbole kāzät. Jâ sam ovōđën ot pedesët pētē, ëto tolikô. Ïmām trî šceëri i sîna. Šćëri üdāte, sîn ožëńen... Päpi, śîne, päpi... Püši tî, püši, ne smêta ńëmu, ôn je vǐśe vëjikī... Bîlo je sväšta, siromäština. Bîlo je rabötē da sam i zaborävîla, da se mïslīm käko sam svë tô pasäla, ali štö ćeš. Täkō je mōrälo. Sväk je täkō rādìjo. Nïje se odīlo na raböte, nïje platæ̂ bîlo, žīivëlo se o ${ }^{\mathrm{d}}$ stöke. Mî smo imäli vödu väzdæ, a dostìna su na müku bîli. Odïlo se ù drva. Prodāväla su se dr̀va, kostrïka brâla. Täko. A svë je pröšlo. A kostrìka se dāväla žîvōme. A brâlo se i ü goru, ali se pasälo. A ōđënake nêmā vîša nō tämo po Ćëklīćāh. A ōđën se brào lîs i slāgäo u stogöve. A planìna ni je bîla na Bostûr. A uzìmāli smo i tûđu stöku s prīmöra za pö pō kïla sìra. Svë je tô zaühārno bîlo öndā...

Nä Vr̉bu vi je näjstarijā onâ Bôse Kînova... Mögli smo sküvāt pö kāvu... A đë mi je onâ mühalica?... Nêmā ovudijên u ovû ökolinu bäš nïko pöstarī. E ìmā Stâne. Mögli bi bögami kod neê pôć. Öna znâ istôriju döbro. Tûn je ödmāh. Nïje dalëko. E öna je pasäla tērët vëlikī...

Senka Čavor, rođ. Vujković (72 godine)

Raićevići (Džupani), rođ. u Vrbi 
Śëdi, śëdi. Śëte vî slöbodno. İmām jâ đë, ìma stölicāh nō jâ donësēm tê mą̂le. A vî käko ste? Nỉjesam od rabötē nïkakvē, đäolí zälogāj. A vî? Štö ćete popït? Dâj, čästi ih bâre ${ }^{\mathrm{m}}$ po koląač... Käko se žĩvjëlo prïje? Bögami siromäšno. Nïje se trāžìlo prïje o držävē nïšta nō: „Štö nïjesi zarādìjo döma?“ A danäs kæ̈ čüjēm e svë môrā držăva dät... jâ ne znâm. Prïjed je bîlo - svë se ćërāle zagrädnice i müčījo se nāröd i svekolïko. A danäs: Döđē Dîśo tûn, pā zbörī: Käko se žīvî?! Müči, rëko, tûn, Dîśo, bögoti, nemô prǐčät. Danäs äjde näđi dvā köńa u Nëgūše da ćëraū i dr̀va dogönē iz Lôvćena. Vì kakvä je šüma. A danäs nïđe nïko ne ïdē, nō kupüjēe. I köla, svë jëdno iza drügōga. I käko se ne živîi döbro? Nêće nïko nïšta da rą̂dī, bjëž đäole tämo. A nïje nō smo bezobräzni kölko smo têški, özbîĺno vi kâžēm. Üzmite. Äjde, štö ćete pït? Ne zajebâjte, bögovi. Donësi o tïjeh kolāčâh, đevôjko! E täkō ti je tô. Zagrädnice štö su? Dr̈va se ćërāla nis Kotörskē strą̂ne. Mälo kö nïje. E döbro, mî smo nä Vr̉bu - rëcimo - drükče žīijëli. Näma su l̂udi trgoväli; te kastradînu üjesēn köli, dogöni š Čèva - bîlo je prïjed onîjeh trgövācāh, pā dožëni, pā nävr petnās dânā jöpêt drügē - pā prodâj... Pā smo imäli i dröba i glâvu i utröbicu i nëšto ni ostänē, bögami. I mî smo žĩvjëli döbro. Üjesēn su trgoväli s rïbōm. Nä Vr̉bu se žīijëlo döbro naspram ovîjeh drügijēh sêla. A ovâ drügā sëla - jâ sam mìslîla da su öni bogäti - a väzda su jādìli u Lôvćen. Svë sa ${ }^{\mathrm{m}}$ zborìla: nïkat se nêću tämo udät. Pā ëvo vìđi. Südbina, Böže sačûvā! A sväki me đävo đäolu dödāo. Sväki. Đûko, ovî pröfesor, tô mi je brät štö je üm ${ }^{a}$ ro èvo pê-šes mjësēcā... Äjde üzmite! Ovô mi je sprävīla šceêr, a ovô mi je unüka. Jâ ti žīvîm sậma. Ïmām dvïje šceèri. Jëdna mi je üdāta u Bär, a ovâ u Kotör ê ovâ đevôjka ńôjzina.

I jâ sam ti ostäla mlą̂da udovìca, trīdës i nëšto gödīnāh. Mûž mi je ümªro. Ûjtro sagnâ ōđën krtôlu, üjesēn, i pöpodnē jâ sîšla - đëca mi tûn ü škōlu odìla, i da sažēnēm jöpēt ûjtro... Onô ûjtro jâ öbično ostänēm döma da srêdīm, i jâ su ovôm starîjōm štö je u Bär, pričëkā je mälo da izîđē is škôle i da îdē sà mnōm göre, e s Vrbê mi je nûko dāväo jëdno magàre, pā mi je zaühār dvâ tovära sagnäti, dvâ ûjtro - dvâ pöpōdnēe tô je dösta. Kä ${ }^{d}$ smo döšli göre, nêmā ńëga. Mî zövi, ovämo - onämo. Imäli smo tädā trî kräve. Mî ìmāmo planìnu tämo vëlikū. Tëk da öće kö dôj da tô prodâm. Štö će mi? A ìmāmo da se vïdī cïjelā Böka, od ̌̌âdē ovämo, ot Ćütka (znâte li đê ${ }^{j}$ e Ćütko?), đë se skrêćē na Lôvćen, tämo ni je plänina. I ön - kâp ${ }^{b}$ ga gāđäla. I mî glëdā- 
mo đê je. Jâ sam ödmāh vìđela da je nëšto š nîm käd ${ }^{t}$ su kräve okō žìta i okō krtôlē. Öh, ne dâj böže, zbïla, izneną̂dnē! Onâ mąlā pôđe da zovê. Tô je blîzu svë. Sväko se žîvī začùdījo: üjutro ù poĺe, a pöpōdnē mr̀tav. I täko, ostäla sam su tô dvöje đecê, müčīla se... Ovâ mläđā ösam gödīnā, ovâ starïja u desêtū. I öndār... Nō imäla sam döbar rôd i täko smo jëdno z drügījem, i valäli su mi. Döle su öni stojäli, a jâ se ōđën müčīla i rādïla. Öne su ü rōd mi na Prčäń odìle ü škōlu, döĺe. Ovâ mi je starìjā učìla gimnâziju döĺe. I jöpēt u Nǐšice za nāstąvnicu. I slüšāle su me, bögami. I kæ̈d döđū, svë su mi rabötāle. I ëto täkō. A säd sam döbīla, nïjesam säd nō îmā dväez gödīnā - jâ sam ti nëkī bōràc läžavī - döbīla sam na Prčän ot Sāvëza bôrācā mälo stâna i säd ti tûn su mi bräća i sëstra jëdna i sestrìći i svî smo blîzu. A ovâ mi je jöpēt u Kotör, mâjka ovê, i blîzu mi je i tämo. A ōđën izîđēm prëo ĺeta. Žäo mi je ovû jädnū ĺepötu i ovû müku. Ovô je svë ön ogrādî̀o, domaćîn mi. Svë, poglêdāj. Svë je ovô ńegövōm rukôm ogrâđeno i käd je mögā žīvjët, pükla mu je pögibija. I ëto täkō. Pā mi je žào ovô napüštīt. Izläzē, pā äko tē držät, nëka držê, a ako në - nëka püštē. Ōđë je prèo ĺta lïjepo. Ëto täko vi je tô, möji mônci. A i ön je bî̀o po rôstvu, po zlôme pûtu. Täkva su tô bîla vrëmena. Bịjo je u röstvo. Kö nïje stïjo üzēt püšku talijânskū - svïjeh su pozatvärāli. Stö tries Négūšāh nïjesu šceêli üzēt püške i svë su ih tû vëčēn ovî näši špïjūni prošpijäli đê ${ }^{j}$ e kö stajäo, svë su ih poäpsīli i sprävīli u lôgor u Albâniju, pā otolên u Itâliju, pā u Nëmačkū, do ${ }^{k}$ göđ se rät zavř̌šìjo. A ne znâm ni kolicìńa nïjesu ni döšli žîvi, nō su ostäli tämo u Neèmačku. Bîla je müka i rät. Ne dâj böže rät. Lïjepo ni je s mîrom, s ânđelom. Rät ne dâj böže. A štö petläū ovê pârtije, izazîvaū nëkojēga đàola, a lïjepo li je dök je mîrno. Üzmi, küćo möja, äjde. Täko vi je tô.

$\mathrm{Ne}$ držîm nǐšta to-đäoĺōm. İmām tû pênziju, a i da mi fäli štö, në bi me dä-ti püštīli ovî möi. A ìmāmo döbra kolïko öćeš. İmāmo ôđe pe-šes rą̂la zemíê, ìmā tû i jëdno küćǐšte, nïje jë no nō dvâ. Tô je od zëmĺotresa vrâg ${ }^{k}$ pönījo i ne stoî tämo nïko. I ìmā šùmē stö mëtārā dr̈vā ödmā tûn. Tô bi prödāla da ïmām köme. A štö će mi? Jâ ne mögu vïše ni dotolên. Äjd üzmi, mômče, bögoti.

A žěne su prìje bîle čvr̂ste i rą̂dne i bîle pögodne i slüšāle, a danäs nêće nō käko im je drâgo, i zatô i rāzdvöj brâka i đävoli i sväšto. Nêmā be slögē nïšta, môrā nëko popüštīt. Viéte da vi nëšto kâžēm. Mlädōs je čüdo. Käd mi ną̂mpanē: Në bih danäs jëdnu stvâr učineella da bi mi cïjelē Ńëgūše potpīsäo štö sam prïje činëla. Između Talijānâh u Kotör poküpi bômbe, orûže i čüdo, 
pā u onê gâjbe talijânskē bjëše onô vîno u onê böčice ökrūglē. A dvâ sträžāra - jëdan na jënu, a drügī na drügū strânu, pā izmëđu ńih svë bômbe i munîcije i čùdo, pā usûdǐš se da ìdēš, pā käko ti büdē. Pā čëkāj nôć tämo, pā ubäči tô u nëkakvī... bjëše nëkakvē šùmē, ma smrdelävo tô bjëše, pā tûn ubäči, pā üvečè, käd mrâk döđē, upr̈ti tô pā us tê strąne zaläškē, pā da iznësēš u Zāläze tô, onô brëme i drügō, mah... A jöpēt si nëkāko se provūkäo, nō nïjesi mögao od näšijeh. Niđđe nïjesi mögao od näšijeh. Znäli su e râdīš za partizäne, e si komunìsta, i näši te za onî pańök prätē tûn. Tätu su mi zatvärāli. Vr̈ba je bîla za komunïste. Dvïje küce nïjesu, a svë drügō za komunïste. Tätu su mi zatvärāli, e je komunïsta, u Cetìne i da će ga strijēlät, objësīt käd i Krüšku. Ön je bỉo u Ämeriku, pā je došâ iz Ämerikē, pā je znâ jezïke, pā je krâl Niköla zvào da döđū näši da brânē ovämo... Ovolïko su bîli napäkovāli za nî̂m. A ôn, bögami, pämētan je bî̀o čöjek, a i vîše starî. Pā ga pîtā ovî Nēmäc i ön mu svë prīčào käko je, štö je. „Ïmāš-i, stârī, kôga u partizäne?“ „Në jâ, bögami, nïkōga. Sìnovi su mi mąali, a đevôjke još mą̂le. Nō da ti jâ - zbörī - nëšto rëčēm (ovömē glâmnōme): Ovî näši, äko te mrzê, sväšto ti napäkujū, sämo za onî pańök. I öni su mëne napokövāli, a vî vìđite, pā äko ćete me objësīt sät käd i Krüšku - bjëšāte, prösto vi bîlo.“ A nëkakvī držâ onû žlilu da ga šibiką̧, znậšs, pā mu rëkā: „Prîčāš kā grämofōn.“ „Jâ - zbörī - prîčām onô štö j' ìstina.“ I mî mìslīmo täta gotöv, öće ga objësīt. A ńëga, môj sökole, ovî näjstarī püšti. Snïjeg vëlikī, a ujčevìna mu u Bäice, od Martìnovićā mu je bîla. Ôn ńëmu: „Äjde tî, stričăne, tî si döbar i poštën čöek. Svë štö si prǐčào tô j' ìstina. Stvą̂rno - zbörī - čöjek ako mrzî sväšto će rëć i za pańök i za svë.“ I püštē öni pokôjńéga tätu. Mî ûjtro se dǐžēmo, mìslīm da je bịjo Bäníi dân, nëšto snïjeg bjëše, i ëto täta ispot kûćā... I täko vi je tô, möja đëco. Rät nïje döbar. Nêmci su bîli zlïce. Käkvī su tô mônci bîli, tô je bîlo zvïjerād. A Talijäni su bîli povūčěni onäkō. A mëne su bîli jedapût učińëli Talijâni da mögu pôć. A käko sam odìla - nösǐš đäola i vïjesti i öćeš da ponësēš do u Bäice, do u Cetîne, pā ne smïjēš preo Nëgūšā nō oköli preo tïjeh rûpāh, pā do Svetê Pêtkē. Ne smïješ dôć preo Nëgūšāh od izdâjnikāh i čûdā e te znäjū. I jedapût döšli Talijâni i bïjo nëkī, Pâjo Tupažî́ se zväo, ôn ${ }^{j}$ e bî̀o kā milicijonêr säd, žändār. I döšli ovî i prîčā, prîčā... A bî̀o je tâ faraôn od Talijânā tolïko pogàn i öndār täta š niìma prîčā i jâ zbörīm da ne mögu dobïti bësu nìkāko da pöđēm u Cetìńe. Mârko Jôšov i tîzi ne däjū: „Mřšs, mâla Mìtra Mârkova, ne möžeš dobïti.“ Jâ ûjtro podräni, dâjū dëse pâsōšā. Ma käkvi da te dopänē. I mî prî̌āmo. I svë isprîča käko bih 
odïla i käko ne mögu. I öni vïđeli da ïmā i poštènōga nāröda. Ôn zbörī mëne: „Döđi tî ûjtro. Dobïćeš tî bilëte, nêću jâ pītät níîh.“ Jâ ûjtro jädo-pöđi, jâ pret hotël, a ovî faraôn nösī onê bilëte. Vëć ôn napīsäo. „Čëkā tî mëne tûn.“ Ôn mi näpīsa $i$ jâ sa ${ }^{m}$ so tïjem permëzom proläzīla gödinu dậnā. A bịjo je jëdan B. - nǐšta i nïđe - da ne prebërē näs žënskē...

Ma ùzmite $o^{d}$ tïjeh kolāčąh... A imäla bi vi jâ štö prīčät nō öćete vî za pöslom. Bîli mî na Lôvćen, bregâde iz cìjelijeh nâhījāh i otüd se poküpīlo da se berû dr̀vva za Cetìne. Oslobodìlo se, nêmā se pậrā. Tämo se mî poküpīli na onô gûmno na Lôvćen da se odabërē kö će prīmät hrąnu, kö će odïti u dr̀va, štö jâ znąm. Đë cee mëne, zä vrāga? Izabëri me da prîmām hrą̂nu i da päzīm hrą̂nu. A u tû küću na Lôvćen nïje tvr̂̀do nïšta da zatvörīš u mägazīn. A ja ìmām sëstru na Dolöve, jâ bih odïla üvečē s ovïjema rödicāma tämo. Izabërū öni mëne da jâ môrąąm prīmät hrąnu. Döbro. Nō bögomi su bîli döbri ovî rukovodîjoci. Öni su ostāväli üvečēn u onî mägazīn da në bi kö štö pökrao. Nō dôdē brigâde dvöje pö dvoje i îmāš da im dâš štö ih šlëdujē - lëb i onô i tämo se vârī süpa i pönešto, kölko se möglo. Siromäšno je bîlo. Nō jëdan dân nêmā lëb jëdan ili dvâ. Käko ćemo säd? Käko je fälī̉o? Jâ ovïjema zbörīm šöferima: „Rëcite i brôite tâ lëb. Ovâ je mlädōs döšla da râdī žäbē i da je glą̂dna.“ „Bögami - zbörī - zaìsto mî bröīmo.“ Drügī dân nêmā trî-čětir. A jâ - bîla sam mlą̂da, nïjesam se bojäla dvâ öka ü glāvu - e jâ ti pöđi u onî kömbī, pā rëko: „Öklē si tî došâ, pîčka ti mäterina, fukäro, bîjo si na blök i špijāväo ne i nïjesi ni dào pasät i kö tē püštī̄o rëci e jâ bi im öca svïjema jebäla!“ Käd su ńëga püštīli štö je sväšto činìjo. „Mřšs, - rëko - fukäro, i sät ću te prijāvïti e si tî došâ säd da ovôj ömladini krādêš lëb ${ }^{p}$, fukäro jëdna. " I jâ ga izasramöti i rëc onôme da napî̌šē i tô. Višs käko se čöjek probïjēe, đë je došâ jöpēt, jünāče. Čùdo je činìjo, nïje nïko smìjo pasät i došâ ovämo... A zbî́la, svaštočińna e svaštočǐńa. E täko ti je ön činìjo. Ëma nïje vǐše došâ.

Vr̂́ba nïje selîla nìđe. Pā smo znäli - äko je neđëĺa, da se počìnē. Pā lûudi ûjtro Navr̄pöĺa, a pöpōdnē šêtā se dö vr Kr̈ca - väzda su slöžno žīvjëli. A mî, mlädōs, nëko će da čûvą ôvce, pā nëko preo Pǐštētā s ōvcäma, nëko nä poĺe s krävāma, pā na onê rāźđële seêdi. A Raîcevīći, èvo ih ïdū s onïjema końîma po jädo-mälo trāvê, po mälo dr̀vā, a ìmali su töbož ođđën zemí̂ i planïnu. Ali đäola. A znâš, jâ sam ùzēla onî riêd... - Jâ pr̀vē gödinē käd sam s' üdāla... Äda nïjesam śćëla nō me nagnäše döma. Imäla sam dvïje zâve - jëdna mi je bîla strîna, a jëdna ûjna. I da môrām üzēt Nîka, môrām. A küj ću u 
Adnan ČIRGIĆ

Raïćevīée. A mögla sam se, böžā ti vjëra, udät kā ïjedna, i trāžlili su me, ali bîla su ni đëca sìtna, poumìrālo đecê, sëstra mi se üdāla u Miräc mlą̂da, pa

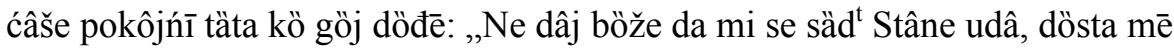
zmîjā zaklälo. Küj će đëca i tô...“ Nijje mi nâmpadālo za üdaju. A đë ću? U Raïćeviće. - Äh, pr̀vē gödinē: ïdēš u čopjän preo Lôvćena, tämo put Mậjstōrāh... Odïla sam jedapût jedìnō na Mâjstore kät su prenosìli onê kösti Kustudîjāa... Trâžīšs, trâžǐš koprìve. Jâ ti drügē gödinē kā Vrbjäni štö žīvê - da sâdīm blïtvu. Mî smo sādìli blïtvē da ìmāmo pêrāh i onû glavìcu da se zöbī kr̈mādima. Lïjepo ti jâ u Mečēòv brïjeg u Kotör sedam-ösam stötīnā strūkâh blïtvē, pā donësi, pā posâdi, pā jâ prëo ĺeta vǐše ne ìdēm ni u čopjän ni u koprïve, nō od onïjeh pêrāh i nëšto još sastävi u onî kazän i üjesēn, käd zavìjē, od onê blïtvē. Nïkad nïjesam viiše pöšla ni u čopjän ni u koprïve. Nāčìn je čüdo. Su mälo, a ïmāš zemíê. Äjde đäole, käd mē povëla đeverǐčna po onïje rûpāh po planìni tämo, iz jäme u jämu da näđēm koprìve. Takvôga zlôga pûta, da se slömīšs. Tô vi je prâvā ìstina. Pa pöđi vräńonogē da ubërēš, ćâhū präsad svë pücāt $o^{\mathrm{d}}$ tê trąvvē, pā iäko je sûva. Nïje im bîla döbra nō ëto, nïje se ìmalo štö sküvặt, pā se tô küvąlo. A blïtva je čùdo. I käd ïmaš zemjê, pā odvöjīš jëdan komatïć za blïtvu... A Pïštetti su vöda, vöda tâ glą̂mnā više Vr̉bê göre. I danäs je tâ žîvā vöda. Tûn se po četrdesêt... bîlo je po četrdesêt porödīcāh u Vr̈bu, a sväk mäne-vǐše imào je övācāh. I ćâsmo preo tögā brìjega i tämo u tô zabr̈đe vëlikō, tämo čûvāj ôvce i ùveče ìgrāj špänée, klîsa, löptē, kā mlädōs. Pā öndā polûči ôvce, pā öndā tî ceèrā pr̀vī tvöje ôvce, a ìmā korìta göre, korìto vëlikō je bîlo ot cimênta da mögū ôvce pït. Pā napôj jëdne, pā öndār onî drügī, pā svë täko jëdno za drügījem. I danäs je tâ vöda.

A käd ${ }^{t}$ su pobïli onê Kustudìje, znâš, na Lôvćen, käd je bî̀o ovî rät. Pā su döšli Kustudïje i pomögli te su ubïli nëkolka Talijâna. I, bögami, ovî ih Talijâni dovëdi i ovî Talijâni te su ostäli - da poznädū. I kâžū: ovî, ovî, ovî, i öni ih poküpi, povëdi u Cetìne. I đë ce da ih povëdū? Na vödu Lậza Andrîna. Svë ih pobïjū. I ìzā oslobođêńa në znā nïko đë su tî Kustudïje. A bîla je nëkā žêna z Dubovîka ź đetëtom u onû strânu göre i vĩđela da su dovëli lû́de i da su izvädīli onû rüpu u onû polänu döĺe. Döbro zbörē: zäklēla se zëmĺa räju da se sväkē tâjne znäjū. Öna se zabî i öni ih tûn pobìi $\bar{u}$ i svë ih u tû jämu, u tû grobnìcu stävē. I në znā se đë su Kustudìje. Nō öna se nïje bojäla i rëkla: ,Jâ ću vi kāzät." I täko su se näšli tûn i öndār iza oslobođêńa üzēle se kösti. Bîlo 
Građa za izučavanje njeguškoga govora

je öndār sa sväkē strąanê nāröda dösta. I tê kösti su se pönijēeli na Mâjstore. E täko vi je tô.

A u möje vrïjeme nïje bîlo ni zelenąş̌ā ni bjëlāšā. E jës, sūjmäli smo za dvïje küće e su vǐše za Talijâne nō za partizäne, a mî svì smo bîli - zvâla se Mậlā Möskva. Bîlo je u Ërākoviće ne zną̂m kojëgā đäola, nacijonalïsti vëlikī, od niỉh nïjesi mögā žīijët. A u ìme Talijânā, da nïje bîlo näšijeh špìjunā, mögæ si odïti, nosìti štö göj öćeš, nïka te në bi öni... nō näši špïjūni svë: đë je, štö je, što činî? Väzda je bîlo špìjūnā i bïće. E rät je đào. A ovî Bokêli su bîli poštëni i valäli su ni dösta, a i mî niìma i svë su ni prìznāli i böli su nō ovî näši...

Mâjka mi je iz Zâlāzǣ, ot Pejätovīéā, u Mâle Zạläze. Nêmā vïše nïko göre. A znąš käko je tämo krûpan nāröd bïjo i zgödni mônci i đevôjke. A u Vëlé Zāläze svë jädno, žûto, nesrëtńo. Sämo dvïje porödice su bîle da valâ vīđet. A tämo svë delïje, i mômci i đevôjke, a ovämo sämo Sâvo Bögdānov je bịjo da nëšto vìdīš i ovî Zêkovići pe-šes brâtā i čëtiri sëstre, desëtoro $i^{\text {h }}$ je bîlo. Öni su bîli odvöjeni, a ovô drùgō sìtno, žûto... Äjde ùzmite, ùzmite da jâ vïđu...

Năjvišē je zlö, pa nëka je näjboĺa zą̂va. Kät se ožëni brät, ôn bögami môrā prema žëni, a öne lübomōrne. Ôn môrā sa ženôm. Tô je prīrödno, a zâve pûstē lúbomōrne. I käd îmāš pe-šěs zāvâh, lïjepo ćeš od niỉh pasät. Jâ sam imäla čëtiri: jëdnu na Bjelöše, a dvïje nä Vr̄bu, a jëdna je bîla nëudāta. Vìše mi je ją̂dā zädāla nō mi je kosê nà glāvu. Nō säd mi je opäla kösa. Svë mi je jäde čińëla. Nëka joj ${ }^{\mathrm{j}} \mathrm{e}$ tämo läka zëmja. A nïkad nïjesam pöšla u pazâr da joj nïjesam dönijēla mïlōs. A mäma: „Nemô, möje dïjete, rïječi su vöda. Näma ne möže nïko nïšta. Sväko sväkōga znâ.“ Üh... A ovê su mi nä Vr̄bu bîle döbre, a osobïto Sênkina mâjka... Äma tê štö su üdāte, pā i da döđū jednôm da ti učìnē sväđu, pā fâla Bögu. Nō käd ti je sväki dân, tô je müka. Näjbolé je čīm se ožënīš odvojït se, pā u košäricu - u košäricu. Pā svojôm ženôm i đecôm lïjepo s ânđelom, pā se svê stēčē. Sämo käd je ĺūbäv i ìskrenōs. A käd ga ž đäolom ïješs, đäo ga i izìjo...

Stane Stanišić, rođ. Vujković (81 godina) Raićevići (Džupani), rođ. u Vrbi

A štö ćete popìt? A jestë li bîli ko ${ }^{\mathrm{d}}$ Stêva Mî́cova, ko ${ }^{\mathrm{d}}$ Stêva stârōga? A jë li Düka pošäo otolên? Äjte popîte nëšto. Öćete, bräte. Röđena sam ōđën. 
Adnan ČIRGIĆ

Ëto mi rôd ${ }^{t}$ tamän tûn, ìsto ot Popövićā. Al mî smo vëlikō brästvo. Na ogrą̂nke se dïjelīmo i täko möžemo se među söbōm uzïmāt. Mî smo i Petrövići od ïstōga. Ovî po nëkōme se pöpu prözvāli. Onî ostäli Petrövići i täko. Ërāk i Raîc polovìnōm petnâjstōga vïjeka döšli su nâjprijed ödnekud iz Hercëgovine, pod Neègoš planinôm, pā su öndā döšli ōđën i tû su se u jëdnu pećînu bîli uselîli, ödmā tû đê onâ küća Andrî-Ilîna, ovämo na ūläs sëla. Tämo je tâ pećîna i tû su öni doselîli i öndār su se öni razdvoïli. Raić je pasâ tämo, a Ërāk ovämo. I zatô se zovû ovô Ërākovići, a onô Raïćevići tämo, po ńïma. Tô đê pećìna zovêmo Zaüglina, za üglom, za onî ćöšak tämo. Naselïlo se ovô od Ërāka i Raïća dösta. Svä su ovâ brästva od ńîh. Bîli su starośedîjoci sämo u ovî krâj. Tô se zvâlo Vëíī Krâj - Nikölići i Batrïćevići. Batrïćevīcaa ìmā ëto jëdna küća, a ovî su izümrli. Nêmā vïše tïjeh Nikölićāh.

Stêvo Mîćov i Blâžo su näjstarī ōdën. Strîc mi je znäo istôriju Cr̈ne Gorê. Tô je bîla žîvā istôrija, pā smo mî mläđī dösta pönešto naučìli täkō, mäda se nïjesmo mlögo ni înteresovāli dok je žîv bïjo stậrī. A pöslijed nêmāš ot kôga. Popîte nëšto...

Držăli smo i pö trī kràve do sköro, a säd nïjesmo nō pö jednu, pā ùmrijē mi mûž prolêtōos i öndā ne dädoše öni vìše...

Möji su bîli učêtnīci na Balkânskē rätove. I na Môjkovac mi je strîc bị ${ }^{\mathrm{j}}$, onô šesnäestē käd je bîlo. Nêmā vìše. Tô nïko ne pântī. Nìko ne vödī račûna ni od ovïje mlâdijeh da saznâ štò. Kämi studënī. E bỉjo je na Môjkovac i prǐčào je, velî: Äko čětres ösam sātî odřžē Môjkovac, da su se vàzda sìpstvu odūžìli. A öni su ösam dânā držäli Môjkovac, a... Da nïjeste vî Srbijânci? Držäli su im ostüpnicu na Môjkovac, te su öni pasäli za Albąaniju... I käko im tô virćū, i vřćāli su dösta pûtā i Petrövićima i svïjema... Ëto täko je tô. Pā su bîli i na Skädar näši svì ovî. Đëd mi je pogìnūo na Skädar käd su Skädar zauzīmäli Crnogôrci. Tädēr je pogìnūlo dvanäes hî́ādā Crnogörācāh.

Mî se dïjelimo na ogrą̂nke. Jâ sam od Ardänovića, a oni su Grûjovići. Pa ìmā: Jašärovići, Bijelövići, Serdārēvići, Vūjövići, Späsojevići, Toromäni. Ëto täkōn.

Ōđë se žīijëlo dösta lïjepo. Ńëgūši su između Kotöra i Cetìna. I tô ti sē vàzda pazārïlo. Štö sē imälo - tô sē prödālo. Mäda je ovüdijē is Katûnskē nāhïjē i skrôz odozgôr - nāröd je proläzījo u Böku na pazậr, pā ti je ōdë väzda bîlo da se konäčĩ. I täkō. Nä pūt su bîli Négūši. Bës końa se zä dvā sâta möglo sâć u Kotör, a ako je köńče ćërao, öndā je tô sporìjēe Ćâsmo ü trī üre po 
pōnöći podräni, zâmi krtôlu, pā ù šes ûræ smo bîli nä Rīvu kotörskū. Ćâsmo krtôlu, zële, sìr, pā prodâj, pā üzbrdo naviiše. Ōđën ïmā dösta riječî talijânskijeh zäšto smo bîli blīzu Bökē. I ōđën se žīvjëlo znâš-i käko: göre u Katûnskū nāhïju käd su svädbe, nïje bîlo pašâdē da se stävī i tańîri i tô na trpëzu, nō onäkō. A kod näs - jâ mïslīm i näši präđedovi su to imäli. Ovô käko smo blīzu Bökē bîli, pā se nëkāko tô nabāvjälo böle. A ōđë je bîlo na svädbu kā i danäs. A ovämo göre... Sëstra mi pöšla jedapût u Broćänæc kod röđāka i öndār tämo nëkī ńîhovi blîžńí svädbu čineelli, pā da idê i öna. Käd öna, käd je vïđela mêso oväkō na onû trìpezu kā skubicîrāno, ńố je tô bîlo za čùdo... E, jâ në znām, möžda su od räta na ovämo pöčēli postävjāt... A bäš sam čūjäla od stârijeh da se ōđën ìpāk živjëlo lïjepo, dösta lïjepo u ōdnösu na drügē.

Möji su izvozïli kaštradînu u Itâliju. Pā su jenôm izgubïli imąnée zbok tögā. Brôd ${ }^{t}$ se pokvārîjo i dok se poprävījo, kaštradîna pövūkla vlägu i bäčĩli je ü mōre, à. A öni su bîli zadūžìli päre tê sū kūpïli brą̂ve i štö jā zną̂m i pöslije ${ }^{d}$ tô propälo i nïjesu mögli tô vrātìt. A îšla kämata na kämatu i öndā propälo im imą̂ne, znâte käko. Möžda e tô prïje sto gödīnā bîlo, pöšto je đedeJôšo na Täraboš pogìnūo. Đëde je bî̀o döbar trgövac i kūpì̀o je bî̀o vëlikō imâne ōđë ù poĺe zä trī sîna da se podỉjēli. I òndā, ôn je pogìnūo, öni su se podijēlïli. Ovî su dvâ bîli ožëńeni. Käko täta još nïje bî̀o punolëtan, öndā ńegövo imâne još nïjesu zadūžìli. A öni su izgubïli imą̂ne, üh vëlikō, i jëdan i drügī strîc, svë na trgovìnu. A đëde je trgoväo i ńëmu je îšlo za rukôm. Kâžūu, üvečē bi rādîjo, vädîjo krtôlu dok mr̈knē, i sämo döđē, večèrā, möžda sât vrëmena zäspī i ne zäspī i na Danïlov grâd dok svänē döđi. Prīčäli su, tô je bịjo râdnīk i šćëlo mu sē u tû trgovìnu. Đëd mi tô. A pogìnūo je, nïje imäo nō čëtres ï trī gödine, na Skädar, na Täraboš.

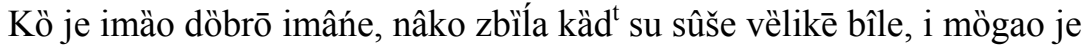
žīvjët. Lëba sē imälo, tû se sîjāla šenìca. Znâte käko je rāđäla. Plödno je ovô pöle, nō säd ëto nïko ne rậdī. Öbično se ōđën rumetîn i šenïca siijāli, a ù planinu ćâsmo krtôlu i onû râž. Tâ se râž viiše sỉjāla da se küce pokrïjevajū s onôm slämōm. A ćâše se i räžānī lëb umïjesi. Nïje ni ôn bï̀o rûžan. Onô je bỉjo cr̂n. A käko je onî šenǐčnī lëb bî̀o slädak, pā kät se ispëčē pot säč...

Odâmno ne zdïžēmo na Vršâń, ni ovîzi đê sam se üdāla ni ovîzi möji. Onô sē bîlo porazmäklo, po räbōtā pöšlo. A bîlo je u Vršăń pöneđe žîvā vöda, ali lûdi ćâhū nëkāko bistïjernē naprävi. İ̀mā sät tämo jëdan odolên, Rädo$v \overline{\mathrm{a}}^{\mathrm{n}}$ Nîkov. A u Lôvćen i Štirômnik - tämo svë su kostrìku brâli. A mî smo, 
na prīmjër ù planinu näšu - jâ zaìsto nïjesam - žńëli je, pā svêži u onû rukövēt, pā upïti i donësi döma žène kojê su žńële. A tämo nïjesu, nō je tâ kostrïka nëkā čvîsta trâva. Nỉje se mögla vēzät i öndār naprävi oväkō od onê vrëćé, täko nëkāko, te tô svêži. I öndār, käko žńēvê, täko stälā u vrëću i öndā tämo izäspi na jëno mjësto dvâ-trī tê korëta, ubëri, pā öndār tô döbro naslâži da ga uprìtī i donësē döma. Üh, đaolî živöt. A već prïjed mëne, mâjike näše i bäbe, üh. A danäs, nì će kö da rą̂dī ni ìmā kǐšè.

Mlögo su se sporïli guvernadûri i Petrövići. Jedapût sam čūjäla ô strīca: Posläli, velî... ma käko će, velî, da ubïju Đüzu - täko se zväo nëkī níihov stậrī guvernadûr. I štö će? Pöšlú đëcu da čûvaū i öndār da se pobìjū čobäni. Onîzi otüd, a onî otüd - pobî̀ū se đëca. Do sköro je bîlo da se ni đëca ne podnösē. I öni pöđi. Đëca se pobî, a sköčī Đüza i trčî da se đëca ne pobìjū. A skočìli i nëkakvī mončići i štö jâ znąm. A skậče Đüza niz onê mëđe, a düšąñku öbūkā i skâčū mu, velî, onî rukąvi: „A në, zäboga! Nemôte se pobït.“ A onî nëko ödonud nanišâni i ubî Đüzu. A käko je tämo bîla još jëna bäba - në znām jë li Kadîna - i öna dä-ti pöšla tàmo. Käd onô pogìni i bäba. Te štö će. Đüzu ubïli. A öni tô svë smïslīli. Öni käko će. Oküpi se kmëtovi - tädēr su se zvậli kmëtovi. Velî: „Käko?“ - „Glâvu zä glāvu.“ Bäbu za guvernadûra! Tô je bîlo za vrïjeme vlädike Väsilijē ili Danïla, në znām...

İmaū ōdën dvā-trî prèzimena čùdnā: Mašträpi, Cuütko, Raüt, Čavöri. Mî smo mìslīli e će ovî stậrī žĩvíêt jöšs, pā smo dösta stvārî propüštīli. Öćāh jâ pošto mi je strîc üm ${ }^{a}$ ro: Üh, mögla sam i ovô strîka pītät; e säd vǐše nêmām kôga pītät. Öćāsmo mî kā mlâdī, dìgni se odolên, pā pöđi, kö znā u kojâ döba, da izâđēmo u Kapëlu ü trī üre po pōnöći käd je onô rāsvìt ${ }^{\mathrm{d}}$ zorê na trinäestī jûl, pā vïdīš lïjepo Skädar i talijânskū öbalu. Br̈zo se izîde göre pot Kapëlu. Tô je tädēr mlą̂dō bîlo, naučìlo trčät za brāvìma. İmām se čèga seécáat...

Vidosava Popović, rođ. Popović (71 god.) Erakovići 
Građa za izučavanje njeguškoga govora

Adnan ČIRGIĆ

THE MATERIAL FOR THE RESEARCH OF THE SPEECH OF THE PEOPLE FROM NJEGUŠI

The author of the paper presents the material for the research of the speech of the people from Njeguši (the transcribed and accented dialogues with the typical representatives of this Montenegrin area). The research, which was a part of the project of Matica crnogorska, entitled The Research of the Speeches of Montenegro, was completed by Adnan Čirgić and Aleksandar Radoman in the summer of 2008 and 2009. 

LINGUA MONTENEGRINA, god. III, br. 5, Cetinje, 2010.

Institut za crnogorski jezik i jezikoslovlje „Vojislav P. Nikčević“

UDK 003.349(497.6)

Preliminarno saopštenje

\section{Amira TURBIĆ-HADŽAGIĆ}

Filozofski fakultet Univerziteta u Tuzli

\section{PRILOG KULTURNOJ BAŠTINI: DVA KRAJIŠNIČKA PISMA IZ 17. STOLJEĆA (II)}

Dva pisma: Pismo Hadžagić bega iz 17. st.; sign. $1984^{\mathrm{a}}$, br. $81^{\mathrm{a}}$ i Pismo hercegovačkoga Ibrahim paše iz 17. st.; sign. $1984^{\mathrm{a}}$, br. $72^{\mathrm{a}}$ pisana su na bosanskome književnome jeziku brzopisnom bosančicom. Latinična transliteracija obavljena je prema vlastitome čitanju autorice originalnih pisama koja se danas nalaze u Državnome arhivu u Dubrovniku.

Ključne riječi: krajišničko pismo, transliteracija, bosančica

\section{Uvod}

Dva pisma iz 17. st.: Pismo Hadžagić bega i Pismo hercegovačkoga Ibrahim paše nisu do sada transliterirana. Imamo objavljenih i naučnoj javnosti prezentiranih tek pet originalnih i latinicom transliteriranih krajišničkih pisama $^{1}$ u različitim časopisima i zbornicima radova, iako "uzbaštinjena bosanična krajišnička pisma 17. st. od iznimnoga su značaja u književnopovijesnim, kulturnopovijesnim i jezikoslovnopovijesnim relacijama“ (Turbić-Hadžagić 2006:285) i ostavila su neizbrisiv trag u bosanskohercegovačkoj prošlosti. Pisana su bosančicom, latinicim i arebicom, prema tome jasnije nam je i Jahićevo zaključivanje da "u pisanom naslijeđu na bosanskohercegovačkom

${ }^{1}$ Prema Neziroviću krajišnička "pisma najvećim dijelom daju pisati carski namjesnici, beglerbezi, sandžakbezi, paše, muselimi, kapetani pojedinih kapetanija, dizdari utvrđenih gradova, nazori, emini - tj. nadzornici javnih dobara, pojedini bezi, age i bajraktari, gdjekad i poneki učitelj i nevoljni sužanj i tužni zatočenik koji u tuđoj zemlji moli za svoju slobodu. Ova pisma dolaze najčešće iz krajeva koje su turske vlasti držale u Slavoniji, Dalmaciji, Boki Kotorskoj kao i iz unutrašnjosti Bosne i Hercegovine i ona se upućuju odgovarajućim ličnostima na područja koja su bila i ostala pod mletačkom i austrijskom upravom, kao i ona što su bila turska a koja su poslije od njih nanovo osvojena. Ova pisma se naslovljuju na banove, pa čak i na kraljeve, providure, porkolabe (suce) kapetane hrvatskih gradova, na kneza i vlastelu dubrovačku, na gvardijane franjevačkih samostana, na kneževe iz Poljica, na vladiku crnogorskog..." (Nezirović 2004:6). 
tlu aktivnu ulogu igraju bosančica i arebica. Ta dva pisma daju osoben pečat razvoju pisanih formi bosanskog jezika. Kad je riječ o književnom jeziku, na prvome mjestu vazda se postavlja pitanje njegove literarne tradicije. Jer svaki jezik kao kulturna tekovina naroda svoj autentični razvoj pokazuje u pisanim formama, kao sredstvo šireg sporazumijevanja i vid očuvanja kulturnoga kontinuiteta” (Jahić 1999: 25-26). Istina, najznačajniji je i najobimniji „korpus pisane građe na rukopisnoj bosančici sačuvane u krajišničkim pismima 17. st., koji je nastao u komunikaciji Krajišnika sa Dubrovnikom, Herceg Novim te Makarskim primorjem i zaleđem” (Turbić-Hadžagić 2006:293).

\section{Latinična tranliteracija tekstova}

Pismo Hadžagić bega iz 17. st.; sign. 1984, br. $81^{a}$

1) $\hat{o}(\mathrm{~d})^{2}$ mene $\cdot$ bega $\cdot$ alage $\cdot$ hačagîja $\cdot$ gospodinu

2) knezu $\cdot$ dubrovackome $\cdot$ i ostaloe $\cdot$ gospodi $\cdot$ vlas-

3) telom $\cdot$ dubrovackieme $\cdot$ v.d.p.

4) a potom $\cdot$ razumiesmo $\cdot \hat{\mathbf{c} o ~ n a m} \cdot \operatorname{pišet}(\mathrm{e})$ izra-

5) di $\cdot$ vašieh $\cdot$ podložnnika $\cdot$ konavilana $\cdot$ bog zna

6) ĉo budemo $\cdot$ eaci $\cdot$ biĵe $\cdot$ vaše $\cdot$ gospostvo .

7) posluženo $\cdot \mathrm{i}$ činiĵemo $\cdot$ za rečene $\cdot$ konavla-

8) ne $\cdot \operatorname{sv}[$ a]ko dobro $\cdot$ zaĉo bismo $\cdot$ vas $\cdot$ radi $\cdot$ poslu-

9) žiti · svakieme $\cdot$ dobrieme $\cdot$ načinome $\cdot$ ne dru-

10) go $\cdot$ i bog vas veseli ô $\cdot$ molimo vas $\cdot$ nemoe vi žo

11) biti $\cdot$ zaco smo $\cdot$ na malo $\cdot$ knige $\cdot$ upisali $\cdot$ na

12) putu se $\cdot$ namierismo

\footnotetext{
${ }^{2}$ Latinična transliteracija krajišničkih pisama obavljena je prema vlastitome čitanju autorice originalnih krajišničkih pisama 17. st. Autorica je pri transliteraciji koristila tabelu S. Damjanovića, pa je transliterirana slova obilježavala na slijedeći način: omega $(w)$ kao $o$ sa kapicom $(\hat{o})$ : $(\mathrm{w}=\hat{\mathrm{o}})$. Nadredno ispisana slova koja nisu znak kraćenja spušta u redak, a title rješava u malim okruglim zagradama. Velika slova i znakove interpunkcije prenosi tačno onako kako su upotrijebljeni u originalu. (Isp.: Damjanović 2002: 48-49).
} 
Prilog kulturnoj baštini: Dva krajišnička pisma iz 17. stoljeća (II)

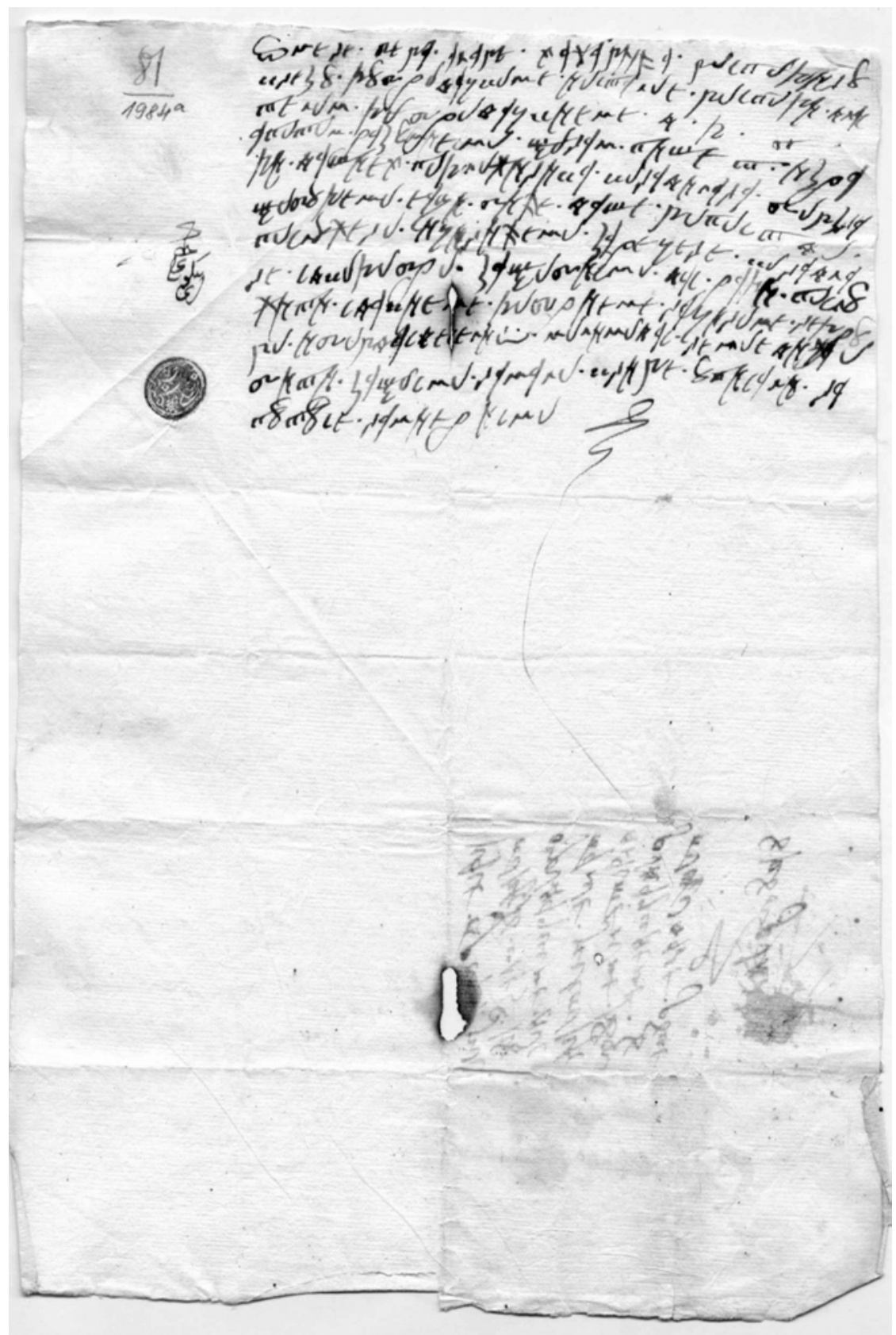


Pismo hercegovačkoga Ibrahim paše iz 17. st.; sign. 1984a ${ }^{a}$ br. $72^{a}$

1) ôt mene $\cdot$ ibrahim $\cdot$ paše $\cdot$ zapoviednika $\cdot$ ôt hercegovine

2) našiema $\cdot$ priatelima $\cdot \mathrm{knez} \cdot \mathrm{begu} \cdot \mathrm{i}$ ostaliema $\cdot$ begovi-

3) ma $\cdot v($ (ele). d(ragom). p(resvietlome) a potle $\cdot$ toga $\cdot$ doje mi $\cdot$ vaša . kniga $\cdot$ i razumleh .

4) ĉ mi pišite $\cdot$ da e moj · čovik $\cdot$ omer $\cdot$ aga $\cdot$ vašemu $\cdot$ pod-

5) lošniku $\cdot$ čelepčie $\cdot$ petra $\cdot$ na planinu $\cdot$ čobana $\cdot$ uhitio $\cdot$ i da ga e $\cdot$

6) uhapsio $\cdot$ i da mu e pet dukatih $\cdot$ na silu $\cdot$ uzeo $\cdot$ u dinariĵe $\cdot$ a

7) ja vam · pišem $\cdot$ da znate $\cdot$ da ja $\cdot$ na ime $\cdot$ omer $\cdot$ age $\cdot$ nikakva

8) neima $\cdot$ nego $\cdot$ neka $\cdot$ doĵe $\cdot$ oni $\cdot$ vlah $\cdot$ i neka $\cdot$ poznae $\cdot$ toga $\cdot$ čojka

9) a koi e $\cdot$ to uzeo $\cdot \mathbf{j a}$ ju $\cdot$ to $\cdot$ aliverisat $\cdot$ i tomu $\cdot$ momu $\cdot$ čoiku

10) ôt haka $\cdot$ dôji $\cdot$ ere ja $\cdot$ nikako $\cdot$ niesam $\cdot$ kail $\cdot$ da moj čovik

11) putove razbija $\cdot$ i zulum $\cdot$ da čini

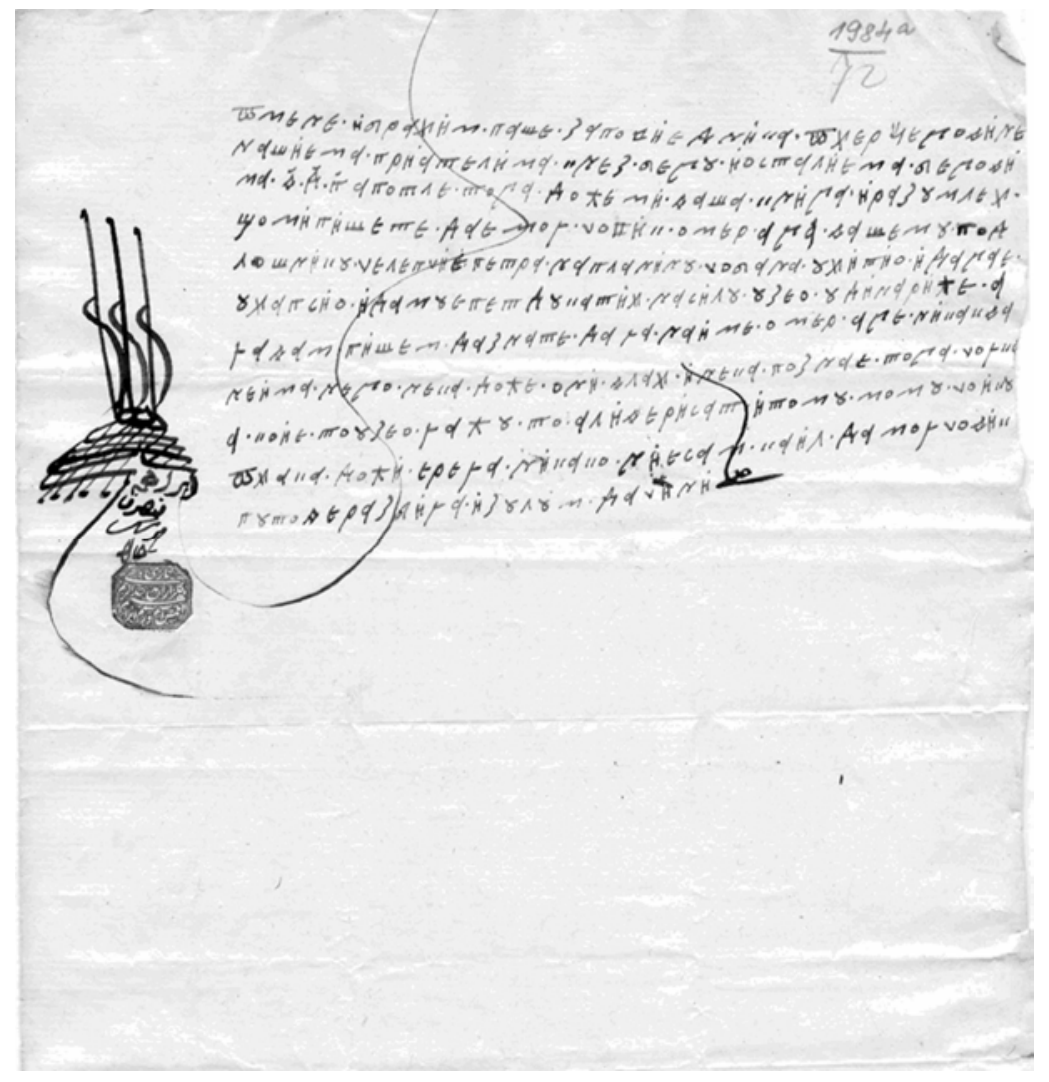


Prilog kulturnoj baštini: Dva krajišnička pisma iz 17. stoljeća (II)

\section{Zaključak}

U ovome smo radu pokazali da su originalna krajišnička pisma: Pismo Hadžagić bega i Pismo hercegovačkoga Ibrahim paše iz 17. st. napisana bosančicom, starim pismom Bosanskoga kraljevstva srednjovjekovne Bosne. Ona na osoben način svjedoče o načinu života vremena u kojem su nastajala, te su ostavila neizbrisiv trag u bosanskohercegovačkoj kulturnoj prošlosti. Važna sastavnica krajišničkih pisama, između ostaloga, jest onimija - antroponimi (Hadžagić, dubrovački, Čelepčija, Petar, Omer-aga) i toponimi (Hercegovina).

\section{Izvori:}

- Pismo Hadžagić bega iz 17. st.; sign. $1984^{\mathrm{a}}$, br. $81^{\mathrm{a}}$

- Pismo hercegovačkoga Ibrahim paše iz 17. st.; sign. $1984^{\mathrm{a}}$, br. $72^{\mathrm{a}}$

\section{Literatura:}

- DAMJANOVIĆ, Stjepan (2002): Slovo iskona. Staroslavenska/starohrvatska čitanka, Matica hrvatska, Zagreb.

- JAHIĆ, Dževad (1999): Trilogija o bosanskom jeziku, Knj. Bosanski jezik u 100 pitanja i 100 odgovora, Sarajevo: Liljan.

- KRAJIŠNIČKA pisma (2004): Odabrao i priredio Muhamed Nezirović, BZK Preporod, Sarajevo.

- TURBIĆ-HADŽAGIĆ, Amira (2004): Paleografske osobitosti ktitorsko-nadgrobnog natpisa sudije Gradiše, Zbornik radova, Tuzla, Vol. 31, br. 5, 85-93.

- TURBIĆ-HADŽAGIĆ, Amira (2005): Latinična transliteracija krajišničkih pisama, Gradovrh, Časopis za književno-jezična, društvena i prirodoznanstvena pitanja, Tuzla, Matica hrvatska, 115-121.

- TURBIĆ-HADŽAGIĆ, Amira, KASUMOVIĆ, Ahmet, IMAMOVIĆ, Adisa (2005): Latinična transliteracija i transkripcija Pisma Omer-age Sulejmanagića Dubrovniku (krajiško pismo), Zbornik radova, Tuzla, Vol. 31, br. 6, 429-433.

- TURBIĆ-HADŽAGIĆ, Amira (2006): Jezične osobitosti krajišničkih pisama 17. stoljeća, Riječki filološki dani, knj. 6, (Zbornik radova s Međunarodnoga znanstvenog skupa Riječki filološki dani održanoga u Rijeci od 18. do 20. studenoga 2004), Rijeka, 285-296.

- TURBIĆ-HADŽAGIĆ, Amira (2009): Prilog kulturnoj baštini: dva krajišnička pisma iz 17. stoljeća, LINGUA MONTENEGRINA, Časopis za jezikoslovna, književna i kulturna pitanja, Cetinje, br. 4, 61-68. 
Amira TURBIĆ-HADŽAGIĆ

- TURBIĆ-HADŽAGIĆ, Amira (2009): Paleografske osobitosti Povelje Kulina bana, Bosanski jezik. Časopis za kulturu bosanskoga književnog jezika, Filozofski fakultet Univerziteta u Tuzli, Tuzla, br. 6, 25-36.

\section{Amira TURBIĆ-HADŽAGIĆ}

\section{A SUPPLEMENT TO THE CULTURAL LEGACY: TWO LETTERS FROM KRAJINA FROM THE $17^{\text {TH }}$ CENTURY (II)}

Two letters: the letter of Hadzagic beg from $17^{\text {th }}$ century, sign. 1984a, number $81^{\mathrm{a}}$ and the letter written by Ibrahim pasa from $17^{\text {th }}$ century, sign. 1984a, number $72^{\mathrm{a}}$ were written in the literary Bosnian language in the bosancica alphabet. The author made the Latin transliteration of the original letters which are now stored in the State Archive in Dubrovnik.

Key words: A letter of Krajina, transliteration, Bosančica 


\section{PORTRETI}



LINGUA MONTENEGRINA, god. III, br. 5, Cetinje, 2010.

Institut za crnogorski jezik i jezikoslovlje „Vojislav P. Nikčević“

UDK 811.163.42'28

Pregledni rad

\section{Adnan ČIRGIĆ (Podgorica)}

\section{MILAN REŠETAR KAO MONTENEGRIST}

Ovaj prilog predstavlja osvrt na doprinos Milana Rešetara montenegristici, posebno njegošologiji i dijalektologiji. Njegov dijalektološki doprinos došao je do izražaja u dvijema njegovim studijama - Der štokavische Dialekt (Štokavski dijalekat), koja je ove godine objavljena u Matici crnogorskoj u prijevodu na crnogorski jezik, i još uvijek neprevedenoj studiji o akcentima jugozapadnih štokavskih govora Die serbokroatische Betonung südwestlicher Mundarten (Wien, 1900). Ovim radom se, u povodu 150-godišnjice Rešetarova rođenja, želi sintetički istaći veliki doprinos nauci o crnogorskome jeziku Milana Rešetara, kao prvoga školovanog filologa koji se bavio crnogorskim jezikom.

Ključne riječi: Milan Rešetar, montenegristika, njegošologija, štokavski govori

Crnogorsko književno-jezičko nasljeđe, iako bez profesionalnih domaćih proučavalaca za cijeloga 19. i prvih decenija 20. vijeka, pratila je srećna okolnost da su za nj bila zainteresovana renomirana naučna imena širom slovenskoga svijeta. Svojom vrijednošću, značajem i ljepotom to je nasljeđe privuklo velikane poput Vuka Stefanovića Karadžića, koji se bavio proučavanjem i prikupljanjem crnogorskoga usmenog blaga i ostavio prve napomene o pojedinim specifičnostima crnogorskoga jezika u predgovoru Srpskim narodnim poslovicama (Cetinje, 1836), slavnoga slavista Vatroslava Jagića, koji je 1883. godine u Berlinu priredio ćirilično izdanje Marijinskoga jevanđelja, Alekseja Aleksandroviča Šahmatova, koji se zanimao i za porijeklo i stanje crnogorskih akcenata (1898) i dr. No po zaslugama za crnogorsku dijalektologiju, a posebno za njegošologiju, u cijelome tom nizu slavista proučavalaca crnogorskoga književno-jezičkog blaga prednjači Milan Rešetar.

Milan Rešetar rođen je u Dubrovniku, 1. februara 1860. godine. Potekavši iz obrazovane porodice (još mu je otac Pavo bio bečki student), u kojoj se govorilo i njemačkim i talijanskim jezikom, Milan Rešetar imao je dobre osnove za obrazovanje i usavršavanje. U kasnijim danima objavljivaće svoje 
radove i na njemačkome i talijanskome jeziku. „Od 1865. do 1869. pohađao je I. R. Capopscuola Maggiore (C. K. osnovnu školu), gdje je nastavni jezik bio talijanski, a već od 1870. i u osnovnoj školi i u gimnaziji predavalo se na narodnom jeziku. " ${ }^{\text {1 }}$ Osim dobre osnove u porodici, imao je sreće i s učiteljima. Još u ranoj mladosti ,imao je dobre učitelje, a među njima svakako valja izdvojiti Pera Budmanija, jednoga od najvažnijih hrvatskih filologa druge polovice 19. stoljeća i početka 20., gramatičara, proučavatelja dubrovačkoga govora, tekstologa, prevoditelja i urednika Akademijina Rječnika“. ${ }^{2}$ Upravo je Budmani presudno uticao na njega da, poslije uspješno položene mature 1877. godine, krene u Beč na studije slovenske i klasične filologije, đe je predavao tada već stari F. Miklošič. Finansijski će razlozi usloviti da u Beču ostane svega jednu školsku godinu, nakon čega je prešao u Grac (đe je njegov stariji brat Jozo studirao pravo). U Gracu su mu profesori bili Gregor Krek, Gustav Meyer i Hugo Schuchardt. Nakon završenih studija Rešetar započinje svoje učiteljevanje u Kopru (1882) i profesuru u Zadru (1884) i Splitu (1884-1891). Već na početku istakao se kao vrstan jezikoslovac, a jedna od novina u splitskoj gimnaziji bila su njegova predavanja o hrvatskim akcentima. Godina 1891. biće prijelomna za dalji rad Rešetarov. Naime, na Jagićevu preporuku on postaje urednik hrvatskoga izdanja Lista državnih zakona (Reichsgesetzblatt) i seli u Beč, đe započinje prijateljstvo s Jagićem, čiji će Rešetar postati zet oženivši Jagićevu šćer Stanku ljeta 1892. U Beču započinje univerzitetska karijera Milana Rešetara: godine 1895. postaje docent za slovensku filologiju, 1904. izabran je za vanrednoga profesora, a Jagićevim odlaskom u penziju 1908. godine Rešetar preuzima njegovu katedru i postaje redovni profesor, sve do 1919. godine, kad, nakon sloma Austrije, gubi službu i s porodicom seli u Zagreb, đe ostaje do 1928, kad, star i gotovo slijep, seli u Firencu. Kao i njegov tast Vatroslav Jagić, a i brojni drugi slavni slavisti, Milan Rešetar ni pred kraj svojega života nije filološkim radom mogao sebi obezbijediti ugodan život. Naprotiv, njegove su posljednje godine bile prilično teške. O tome naročito svjedoči podatak da je svoju izuzetno bogatu biblioteku i kolekciju dubrovačkoga novca (naslijeđenu od oca i dopunjavanu cijeloga života) morao prodati Pragu, u kome se one i danas čuvaju. Umro je u Firenci, 14. januara 1942. godine. Želja da bude sahranjen u porodičnoj grobnici u Dubrovniku ispunjena mu je tek prenošenjem pepela 1965. godine.

Za svoj rad Milan Rešetar dobio je brojna priznanja. Bio je član Jugoslavenske akademije znanosti i umjetnosti u Zagrebu, Srpske kraljevske akademije u Beogradu, Ruske akademije u Petrogradu, Češkoga društva nauka u

\footnotetext{
${ }^{1}$ Maria Rita Leto, Milan Rešetar, Zavod za znanost o književnosti Filozofskog fakulteta u Zagrebu, Zagreb, 1989, str. 9.

2 Josip Lisac, „Milan Rešetar“, In: Hrvatski profesori na Bečkoj slavistici, priredila Truda Stamać, Erasmus naklada, Zagreb, 2005, str. 29.
} 
Milan Rešetar kao montenegrist

Pragu, Slovenskoga instituta Londonskoga univerziteta, Ševčenkova naučnog društva u Lavovu, Slovenskoga instituta u Pragu, a na Filozofskome fakultetu Kraljevskoga univerziteta u Firenci jednoglasno mu je dodijeljen počasni doktorat. $^{3}$

U ideološkom smislu Rešetar je platio dug vremenu kojemu je pripadao. Iako sin autonomaša i učenik autonomaša, on će još kao dijete postati predvodnik narodnjaka u IV razredu muške pučke škole u Dubrovniku. ${ }^{4} \mathrm{Ne}$ što kasnije, najvjerovatnije pod uticajem svojega učitelja Pera Budmanija, Rešetar postaje izraziti predstavnik ideologije Vuka Karadžića i Frana Miklošiča (o pradavnoj odvojenosti Srba i Hrvata, pri čemu je štokavce smatrao Srbima, a čakavce Hrvatima). „Izjasnio se kao Srbin. I nije u tome bio sam među dubrovačkim intelektualcima svojega vremena. Ali na tome nije inzistirao i prema svemu hrvatskome odnosio se dobrohotno i otvoreno. (...) No nikada ne bi dozvolio da se o jeziku novoštokavskih dijalektalnih obilježja govori kao o jeziku hrvatskome. “5 Rešetarovo kasnije odricanje od Miklošičevih stavova nije označilo nikakav napredak u pogledu nacionalne i jezičke identifikacije na prostoru kojim se bavio. Umjesto prihvatanja Bošnjaka, Crnogoraca, Hrvata i Srba kao zasebnih naroda (i njihovih jezika) na tome terenu, on će do kraja života ostati vjeran ideji da su Srbi i Hrvati jedan narod (Srbohrvati) i da je njihov jezik jedan - srpskohrvatski. To je i bio razlog njegova kasnijega (i današnjega) svojatanja kao predstavnika srpske filologije. No danas možemo s distance reći da je Rešetar u svojemu naučnome radu gotovo potpuno zanemario srpski jezik, odnosno da je gotovo cio svoj naučni opus posvetio hrvatskome jeziku i hrvatskoj kulturi (naročito dubrovačkoj), a da je u velikoj mjeri doprinio razvoju crnogorske (i donekle bosanske) dijalektologije i filologije uopšte.

Posebno je značajan doprinos Milana Rešetara razvoju njegošologije. Taj njegov rad podrobno je opisan u dvijema studijama, ${ }^{6}$ pa ćemo se ovđe na

\footnotetext{
${ }^{3}$ Biografski podaci o Milanu Rešetaru preuzeti su iz: Maria Rita Leto, $n$. $d$., str. $7-32$.

${ }^{4}$ Autonomaši su zagovarali autonomiju Dalmacije, a narodnjaci su se zalagali za ujedinjenje Dalmacije s ostalim hrvatskim krajevima.

${ }^{5}$ Radoslav Katičić, ,Milan Rešetar i hrvatski književni jezik“, In: Zbornik o Milanu Rešetaru, Hrvatski studiji Sveučilišta u Zagrebu, Zagreb, 2005, str. 10.

${ }^{6}$ Vojislav P. Nikčević, „Milan Rešetar kao njegošolog“, In: Zbornik o Milanu Rešetaru, Hrvatski studiji Sveučilišta u Zagrebu, Zagreb, 2005, str. 193-212, i u knjizi: Jezičke i književne teme, Institut za crnogorski jezik i jezikoslovlje, Cetinje, 2006, str. 287310. U toj studiji Rešetarov doprinos njegošologiji obrađen je u ovim poglavljima: „Uvod, Rešetar kao Njegošev bio-bibliograf“, „Rešetar kao njegošolog vukovske škole“, „Rešetar kao Njegošev tekstolog“, „Rešetar kao Njegošev književni istoričar“, „,Rešetar kao Njegošev filolog i jezikoslovac“, „Rešetar kao Njegošev leksikograf i leksikolog“, „Rešetar kao komentator Gorskoga vijenca“, „Zaključak“.
} 
njega samo kratko osvrnuti. Duže od 50 godina Njegoševo je djelo bilo predmet Rešetarovih naučnih interesovanja. „Sa sigurnošću se može reći da je bio utemeljivač naučne filološke njegošologije, najveći njegošolog svojega doba

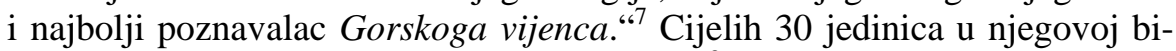
bliografiji posevećeno je Njegoševim djelima. ${ }^{8}$ Iako je tačno znao primijetiti npr. da je Simo Milutinović ,,bez sumnje učinio od mladog Crnogorca (Njegoša - prim. A. Č.) vatrena Srbina i Slavena“", ipak je i sâm Njegoša određivao kao srpskoga pjesnika (kao što su i njega kasnije određivali kao srpskoga filologa): „Iako M. Rešetar redovno upotrebljava etnonim Crnogorci, atribut crnogorski, crnogorski govor i dijalekat (djalekat) pa čak i termin crnogorski jezik, protivurječno tome oni su mu po štokavskoj teoriji 'Srbi/Srbohrvati', maternji im je jezik 'srpski/srpskohrvatski', pa śljedstveno tome i Njegoš 'Srbin/Srbohrvat', pripadnik 'srpskoga/srpskohrvatskog' kao maternjeg mu jezika i 'srpske" književnosti." "10 Povodeći se za tada aktuelnim vukovskim stavovima o jeziku, Rešetar je iznio i neke neprihvatljive i pogrešne teze o jeziku Njegoševu, poput one da je Njegoš napisao Gorski vijenac čistim narodnim jezikom u skladu s Vukovim zahtjevom o uvođenju narodnoga jezika u književnost. No s obzirom na ondašnje stanje u filologiji, naročito crnogorskoj, teško bi se danas moglo zamjeriti Rešetaru što nije znao da je već vjekovima prije toga narodni jezik bio u upotrebi u crnogorskoj književnosti. Takve su njegove greške zanemarljive u odnosu na doprinos koji je njegošologiji dao. Naročito je značajno što je Njegošev jezik rekonstruisao u skladu s narodnim izgovorom, koji mu je kao dijalektologu bio itekako poznat, a ne prema ruskoslovenskome pisanju autorovu. Tako je Rešetar pravilno odredio pojedine Njegoševe oblike, koji se i danas nerijetko pogrešno predstavljaju. ${ }^{11}$ On je, na primjer, suglasničke grupe $t s$ i $d s$ i pravopisno prilagodio narodno-

Milorad Nikčević, „Komentari Gorskoga vijenca (1847.) Stefana Mitrova Ljubiše i Milana Rešetara“, In: Zbornik o Milanu Rešetaru, Hrvatski studiji Sveučilišta u Zagrebu, Zagreb, 2005, str. 305-326.

${ }^{7}$ Vojislav P. Nikčević, „Milan Rešetar kao njegošolog“, In: Jezičke i književne teme, Institut za crnogorski jezik i jezikoslovlje, Cetinje, 2006, str. 287.

${ }^{8}$ Isto, str. 290.

${ }^{9}$ Gorski Vijenac vladike crnogorskoga Petra Petrovića Njegoša, peto izdanje s komentarom Milana Rešetara. U Biogradu, 1909. - Citirano prema Vojislav P. Nikčević, n. $d$. , str. 291.

${ }^{10}$ Vojislav P. Nikčević, $n$. d., str. 295.

${ }^{11}$ U usklađivanju jezika Gorskoga vijenca sa stvarnim izgovom u crnogorskome narodnom jeziku najdalje su pošli Vojislav P. Nikčević (Petar II. Petrović Njegoš, Gorski vijenac, Jubilarno izdanje povodom 150. godišnjice prvog izdanja s predgovorom priredio Vojislav P. Nikčević, Crnogorski PEN centar, Cetinje, 1997) i Radmilo Marojević (Petar II Petrović Njegoš, Gorski vijenac, Kritičko izdanje. Tekstologija. Redakcija i komentar Radmila Marojevića, CID, Podgorica, 2005). 
Milan Rešetar kao montenegrist

me izgovoru: ljucki, bracki < ljudski, bratski; bogastvo, gospostvo < bogatstvo, gospodstvo; ekavizme tipa kolevka, vreme, koji se decenijama pripisuju Njegošu, u skladu sa zahtjevima stiha ispravno je označio kao stvarne ijekavizme: kol'jevka, vr'jeme, dok je - opet kao vrstan dijalektolog i poznavalac crnogorskih govora - ostavio u Njegoševu jeziku stvarne ekavizme koji se javljaju u govoru Njeguša (odakle Njegoš potiče) poput ovde, celiva i sl.

Cijeloga života bavio se Rešetar Njegoševim djelom, naročito Gorskim vijencem. To izučavanje započeo je još kao profesor gimnazije u Splitu, a i u poznim godinama skupljao je literaturu koja je objavljivana o Njegošu, o čemu svjedoči njegova firentinska biblioteka. Prvu raspravu u Jagićevu Archivu (1888) Rešetar je napisao upravo povodom njemačkoga prijevoda Gorskoga vijenca. „Uvidjevši odavna potrebu kritičkoga izdanja Gorskog vijenca, Rešetar već 1883. počinje sastavljati komentar (...). Rešetarovo izdanje, objavljeno 1890, bilo je deveto izdanje Gorskog vijenca, ali prvo s opširnim komentarom (uvod od 80 stranica), s oko 450 napomena i rječnikom s više od 500 riječi“"12 koji obuhvata riječi koje su uglavnom nepoznate čitaocima izvan Crne Gore. Smatrajući ga prvim naučnim tekstologom Njegoševim, Vojislav P. Nikčević ističe kako je Rešetar tekstološki priredio i objavio cjelokupna Njegoševa djela nastojeći da poprime kritički karakter. Taj posao posebno je otežavala činjenica da su nedostajali mnogi pjesnikovi autografi, pa se priređivač umjesto njih morao koristiti prvim njihovim izdanjima, pri čemu treba naglasiti da su pojedini tekstovi u pogledu autorstva i do danas ostali sporni. ${ }^{13}$ Pitanjem autorstva nekih Njegoševih djela bavio se Rešetar i prilikom priređivanja kritičkoga izdanja njegovih „,manjih pjesama““ ${ }^{14}$ Osim toga treba istaći i njegovu sumnjičavost u pogledu istoričnosti „,istrage poturica“, što je pohvale vrijedno kad se zna da je i danas pojedini književni istoričari i istoriografi smatraju istorijskim činom iako je u nauci odbačena kao mit. ${ }^{15} \mathrm{O}$ književnoistorijskome doprinosu Rešetarova bavljenja njegošologijom pisao je i slovenački njegošolog Vladimir Osolnik. ${ }^{16}$

Za pedesetogodišnjega bavljenja Gorskim vijencem Rešetar je objavio 10 njegovih izdanja (prvo 1890, a posljednje 1940) - osam ćiriličnih i dva latinična. Po svojim komentarima toga djela on je ,najviše poznat u našem narodu, jer je to njegovo najčitanije djelo. Učinio je pristupačnim svakome naj-

\footnotetext{
${ }^{12}$ Maria Rita Leto, $n . d$. ., str. 59-60.

${ }^{13}$ Vojislav P. Nikčević, $n$. d., str. 295-296.

${ }^{14}$ Manje pjesme vladike crnogorskoga Petra II Petrovića Njegoša, Izdao Milan Rešetar, Srpska književna zadruga, Biograd, 1912.

${ }^{15}$ Viđi: Vojislav P. Nikčević, Istraga poturica - mit ili stvarnost, Almanah, Podgorica, 2001.

${ }^{16}$ Viđi: Vladimir Osolnik, Istorija književnosti o Petru II Petroviću Njegošu, Crnogorska akademija nauka i umjetnosti, Podgorica, 1999, str. 75, 84-87.
} 
dublje djelo naše muze, dotad više hvaljeno negoli čitano. Njegovim su se komentarom koristili i drugi izdavači toga djela, i oni izvan Jugoslavije (u Čikagu 1915., u Ženevi 1917.), a neki su ga prevodioci spjeva također i prevodili (na slovenski R. Perušek 1907., na talijanski U. Urbani 1939.)“ ${ }^{17}$ Prirodno, za sve to vrijeme pratile su ga brojne kritike i polemike vezane za njegov način priređivanja Njegoševih djela, posebno vezane za pojedina njegova objašnjenja. Ta rasprava svakako je pozitivno uticala na razvoj njegošologije u Crnoj Gori i izvan nje. Pozitivno je uticala i na samoga Rešetara, koji je svako naredno izdanje dopunjavao i mijenjao usvajajući ili odbacujući primjedbe koje su mu davali razni prikazivači njegovi. Već uz prvo svoje izdanje on je istakao: „Ja sam se najviše trsio da ovo moje izdanje sasvim vjerno kaže, kako je baš sam pjesnik naštampao svoju pjesmu, a nijesam ni u čemu mijenjao ni popravljao osim ortografije i interpunkcije. “18 Naravno da je među brojnim prikazivačima i polemičarima bilo i onih koji su davali neprimjerene sugestije i komentare, pa i takvih koji su tvrdili da je Rešetarov komentar suhoparan i da ubija poeziju, te da bi pjesnike trebalo da proučavaju pjesnici. U vezi s time je interesantan Rešetarov odgovor u njegovu posljednjem izdanju Gorskoga vijenca: „Već otprije željkovano izdanje s 'pjesničkim“ komentarom nije se još pojavilo - kao da je zadaća komentatora da o pjesmi pjesmu pjeva, a ne da, što je moguće jasnije, pa makar katkad i 'prozaički', protumači, što je baš sam pjesnik htio da reče ondje, gdje to nije jasno kazano", čime je završio svoju polemiku povodom toga. Antun Barac ističe da je Rešetar bio spreman da objavi takav komentar Gorskoga vijenca u kojemu bi obuhvatio sva tumačenja pojedinih Njegoševih stihova, ali takvo izdanje nikad nije objavljeno jer za tako obimnu knjigu nije mogao pronaći izdavača. ${ }^{19}$

Interesantno je pomenuti da je zbog ugleda Milana Rešetara u njegošologiji Odbor za prijenos Njegoševih ostataka na Lovćen 1925. godine odlučio da mu povjeri uredništvo cjelokupnih djela Njegoševih kao državnoga izdanja. Celokupna dela Petra II Petrovića Njegoša objavljena su u dvije knjige (u Beogradu, prva 1926, druga 1927). Prva knjiga obuhvata Gorski vijenac, Luču mikrokozma i Šćepana Maloga, s propratnim tekstovima, a drugu knjigu čine: Svobodijada, Manje pjesme i Proza.

Govoreći o Rešetarovu doprinosu njegošologiji, Vojislav P. Nikčević je rezimirao: ,(...) bio je Njegošev bio-bibliograf, kritički usmjeren tekstolog svijeh njegovih literarnijeh tvorevina, književni povjesničar, filolog i jezikoslovac, leksikograf i leksikolog, priređivač, interpretator i komentator Gorskog vi-

${ }^{17}$ Dr. Mirko Deanović, Milan Rešetar (1. II. 1860. - 14. I. 1942.), Ljetopis Jugoslavenske akademije znanosti i umjetnosti za godine 1946.-1948., knj. 54, Zagreb, 1949, str. 349-350.

${ }^{18}$ Maria Rita Leto, $n$. $d$. , str. 60.

${ }^{19}$ Isto, str. 61 . 
Milan Rešetar kao montenegrist

jenca, njegov revnosni popularizator i afirmator. Niko od dosadašnjijeh njegošologa nije dao takvi i toliki doprinos njegošologiji kao Milan Rešetar.“'20

Iako je manje poznat kao proučavalac crnogorskih govora nego kao njegošolog, Rešetar je dao izuzetan doprinos crnogorskoj dijalektologiji. Veliki dio njegovih dviju obimnih studija o štokavskome sistemu posvećen je podacima o osobinama crnogorskih govora. Zahvaljujući projektima Balkanske komisije ${ }^{21}$ Austrijske akademije nauka, Rešetar je uz Jagićevu preporuku već 1897. godine ,krenuo po nalogu Komisije na svoje prvo istraživačko putovanje i obilazio terene, što je u kasnijim godinama nastavio (...) i njihove je bogate rezultate predočio znanstvenoj javnosti u publikacijama Komisije i u Jagićevu Arhivu za slavensku filologiju. To su prije svega temeljne monografije o štokavskom narječju (...) na temelju Rešetarovih terenskih istraživanja u godinama 1897., 1898. i 1901...“22 Ako se uzme u obzir činjenica da je Milan Rešetar prvi školovani dijalektolog koji je izučavao crnogorske govore, kao i prvi „koji je koristio fonograf u dijalektologiji“ ${ }^{23}$ postaje jasno kakav značaj u današnjoj montenegristici, posebno dijalektologiji, imaju podaci koje je on publikovao o crnogorskim govorima. Kao saradnik Balkanske komisije Rešetar ,,je mnogo dao Beču gdje je dugo radio, poglavito pak hrvatskoj i crnogorskoj filologiji, najviše Dubrovniku, svom rodnom gradu“ “. ${ }^{24} \mathrm{Za}$ nas je posebno značajan njegov doprinos izučavanju crnogorskih narodnih govora, posebno kad se zna da se prije Rešetara, ali i pune dvije decenije poslije njega, tim govorima niko sistematski nije bavio. ${ }^{25}$ Rešetarov doprinos

${ }^{20}$ Vojislav P. Nikčević, n. d., str. 305.

${ }^{21}$ Formirao ju je Vatroslav Jagić 1897. kao Komisiju za istorijsko-arheološko $i$ filološko-etnografsko ispitivanje Balkanskoga poluostrva, a 1948. preimenovana je u Balkansku komisiju. - Radoslav Katičić, „Milan Rešetar und die Balkan-komission der Weiner Akademie“, In: Zbornik o Milanu Rešetaru, Hrvatski studiji Sveučilišta u Zagrebu, Zagreb, 2005, str. 167.

${ }^{22}$ Radoslav Katičić, $n$. d., str. 167.

${ }^{23}$ Gerhard Neweklowsky, „Milan Rešetar als Dialektologe“, In: Zbornik o Milanu Rešetaru, Hrvatski studiji Sveučilišta u Zagrebu, Zagreb, 2005, str. 29.

${ }^{24}$ Josip Lisac, $n$. $d$., str. 35.

${ }^{25} \mathrm{Ne}$ treba zanemariti teškoće s kojima su se ondašnji dijalektolozi srijetali prilikom terenskih ispitivanja, naročito u krševitim i često besputnim crnogorskim predjelima koje je Rešetar obišao. Uza sve to, Rešetar je sa sobom nosio teške i glomazne sprave koje su danas zamijenili diktafoni. Govoreći o njegovu nastojanju da unaprijedi tehnička sredstva za svoja dijalektološka ispitivanja, Radoslav Katičić naglašava: „U vrijeme prije Prvoga svjetskog rata Akademija (Austrijska - prim. A. Č.) je upravo razvijala fonografiju, mogućnost zvučnoga snimanja pri terenskim istraživanjima, u prvom redu dijalektološkim i folklorističkim. Poznato je da je Matija Murko s tehničkim sredstvima koja mu je stavila na raspolaganje Balkanska komisija u Akademijin fonetski arhiv donio prve snimke epskog pjevanja muslimanskih Bošnjaka. Oni su i danas ponos toga arhiva. Tada 
crnogorskoj dijalektologiji do punoga je izražaja došao u dvijema njegovim obimnim studijama: Die serbokroatische Betonung südwestlicher Mundarten (Wien, 1900) i Der štokavische Dialekt (Wien, 1907). I jedna i druga studija, kao i ispitivanja koja su im prethodila, nastale su zahvaljujući njegovu članstvu u Balkanskoj komisiji Carske akademije u Beču. Prva studija (o akcentima jugozapadnih štokavskih govora) nažalost još uvijek nije prevedena na crnogorski jezik, niti na neki od ostalih štokavskih standardnih jezika. U njoj je Rešetar dao veliki doprinos hrvatskoj i crnogorskoj akcentologiji i dijalektologiji. Prikazao je detaljno akcenatski sistem Dubrovnika, Prčanja i Ozrinića, a „ta se tri sustava, među kojima su dva zetskoga tipa, prčanjski i ozrinićki, uspoređuju s Karadžić-Daničićevim sustavom. Osobito u metodološkom smislu to je veliko djelo (...). ${ }^{\text {‘26 }}$ Ta tri akcenatska sistema nijesu slučajno uzeta u razmatranje. Na osnovu njih ulazio je u razmatranja o različitim stepenima razvoja akcenata na štokavskome i širem terenu. Od tri akcenatska sistema koja je uzeo u razmatranje dva su četvoročlana (dubrovački i ozrinićki prelazni govor s djelimično izmijenjenim akcentima i akcenatskim mjestima) i jedan dvočlani (prčanjski silazni akcenti), a svaki od njih razlikovao se od Karadžićeve i Daničićeve akcentuacije, u čemu je Rešetar i vidio njihov poseban značaj. „I u tom je radu Rešetar veoma pouzdan, jer njegovo muzikalno i izvježbano uho dobro razlikuje i najmanje nijanse melodije glasa. ${ }^{\text {“27 } \mathrm{Kad}}$ se to uzme u obzir, kao i činjenica da je usljed ubrzanoga procesa urbanizacije koji je zahvatio Crnu Goru u posljednjih nekoliko decenija nestalo mnoštvo tipičnih osobina narodnih govora, nije potrebno isticati značaj podataka o crnogorskim (i hrvatskim) akcenatskim specifičnostima koje je Rešetar skupio. No značaj te studije za crnogorsku dijalektologiju moći će se u potpunosti sagledati tek onda kad i ona bude objavljena u prijevodu na crnogorski jezik.

se još moglo snimati samo na gramofonske ploče, za magnetofonske vrpce još se nije znalo. Tako je i Rešetar od Komisije dobio zadatak da na svoje dijalektološko terensko istraživanje ponese fonograf i da snimi svoje kazivače. On je taj zadatak izvršio, vrlo požrtvovano, pa čak dijelom i na uštrb istraživačkih rezultata, jer je fonograf bio teška i glomazna naprava za koju je morao unajmljivati nosače, pa i kola s kočijašem ako bi se imao udaljiti od kolodvora. Akademija je gotovo na silu htjela prevladati teškoće koje su pri ondašnjem stanju tehničkog razvoja stajale na putu terenskim fonografskim zapisima i time bitno osuvremeniti istraživačku dokumentaciju. I Rešetar je u Akademijim Arhiv donio ploče sa snimcima i oni se i danas mogu odslušati, a priprema se i njihovo izdavanje, pri čemu sam i ja sudjelovao. S jedne se ploče može čuti i Rešetar kako pjeva. Imao je vrlo zvonak glas." In: Hrvatski profesori na Bečkoj slavistici, priredila Truda Stamać, Erasmus naklada, Zagreb, 2005, str. 37.

${ }^{26}$ Josip Lisac, $n$. $d$., str. 32.

${ }^{27}$ Dr. Mirko Deanović, $n$. d., str. 347. 
Milan Rešetar kao montenegrist

Studija Der štokavische Dialekte obuhvata podatke i objašnjenja osobina različitih štokavskih dijalekata, ponajviše iz Dubrovnika i Crne Gore. Od crnogorskih govora najpodrobniji podaci dati su iz Prčanja i Ozrinića, koje je - kako je već rečeno - i akcentološki obradio u prethodnoj studiji, ali i iz nekih drugih govora. Kad se zna u kakvim je uslovima Rešetar obavljao svoja dijalektološka ispitivanja, bez prećerivanja se može reći da impozantno zvuči podatak da je on na početku 20. vijeka stigao da prikupi podatke i iz Zete (Mahala, Golubovci, Berislavci...), Podgorice, Bjelopavlića, Danilovgrada, Pive, Drobnjaka, Spuža, Pipera (Stijena, Zavala), Bratonožića, Kuča (Ubli), Morače, Vasojevića (Budimlja, Lijeva Rijeka, Kučele), Gusinja, Crmnice (Podgor), Bara s okolinom (Tuđemili, Zupci, Mrkovići), Paštrovića, Grblja, Riječke nahije (Rijeka, Ceklin, Ljubotin), Lješkopolja, Cetinja, Katunske nahije (Bajice, Njeguši, Cuce, Komana, Pješivci), Nikšića, Banjana, Risna, Mula, Dobrote, Tivta, kao i iz brojnih manjih bokeških naselja (Kavač, Mrčevac, Dub, Strp, Đurići, Bogdašić, Luštica, Stanišići, Pelinovo, Prijevor, Gošić), te objedinio i vrlo oskudne podatke koji su do tada publikovani o crnogorskim govorima (npr. Vuk Karadžić, Tomo Brajković). Pri tome treba naglasiti da on vrlo često nije ni navodio ime sela ili zaseoka iz kojega je crpio podatke, već je to označavao širom oblašću, npr. Piperi, Zeta, Crmnica i sl.

Pavle Ivić je iznio prilično oštar sud o Rešetarovu Štokavskom dijalek$t u$, označivši ga uglavnom kao studiju od kulturnoistorijskoga značaja ${ }^{28}$ jer „,rad ne daje potpuniju sliku nijednog lokalnog govornog tipa, niti ocrtava precizno ijednu izoglosu“. ${ }^{29}$ Takav se stav mora odbaciti iz više razloga. U vrijeme kad je Rešetar započeo svoja izučavanja štokavskoga jezičkog sistema o štokavskim osobinama vrlo se malo znalo. Literatura koju je Rešetar koristio bila je više nego oskudna. Osim toga, među dijalektolozima koji su izučavali štokavske govore nema nijednoga koji je svojim ispitivanjima obuhvatio ni približno široku teritoriju koju je obuhvatio Rešetar. Pa i sâm Ivić svoju Dijalektologiju srpskohrvatskog jezika. Uvod i štokavsko narečje nije bazirao na sopstvenim terenskim ispitivanjima, već je napravio sintezu rezultata do kojih su došli dijalektolozi prije njega. Među njima svakako značajno (ako ne i najznačajnije) mjesto zauzima Rešetar. No ključni razlog za odbacivanje takvoga Ivićeva stava kao neutemeljenog jeste činjenica da sâm Rešetar u predgovoru studije Štokavski dijalekat ističe da mu je namjera bila samo da odredi granice štokavštine, naročito prema kajkavskome sistemu, i da dâ grafički prikaz njihova prostiranja, a da je onda gotovo usput ,objedinio sve

${ }^{28}$ „U svakom slučaju ovaj rad koji je u svoje vreme značio ogroman napredak u nauci, zadržaće svoju vrednost kao ilustracija tadašnjeg stanja nauke i kao repertorij problema.“ - Pavle Ivić, Dijalektologija srpskohrvatskog jezika. Uvod i štokavsko narečje. Matica srpska, Novi Sad, 1956, str. 39.

${ }^{29}$ Pavle Ivić, $n$. $d$., str. 39. 
svoje zabilješke o štokavskome dijalektu koje su mogle biti od koristi za srpskohrvatsku dijalektologiju“. Rešetar stoga naglašava: „Naslov ove rasprave treba dakle shvatiti u tom smislu, a ne kao moju namjeru da njime označim iscrpno obrađen rad kojim su obuhvaćena i sva štokavska narječja." O značaju Rešetarove studije svjedoči i rasprava koja je izbila odmah po njezinu objavljivanju. Budući da dobrim dijelom Rešetar u njoj polemiše s Belićevim zaključcima i materijalom koji je on publikovao, Belić je već sljedeće godine publikovao opsežnu polemičku studiju pod naslovom $O$ srpskim ili hrvatskim dijalektima ${ }^{30}$ a polemika između njih teći će zatim u nekoliko nastavaka u Brankovu kolu (1909). ${ }^{31}$

Teško se može prihvatiti konstatacija Pavla Ivića da Rešetarova podjela štokavskih dijalekata ne predstavlja napredak u odnosu na Belićevu. Takav se stav mora odbaciti prije svega kad su u pitanju crnogorski govori. Belić crnogorske govore smješta u zetsko-bosanske (jekavsko-ikavske) govore ili ih kao odvojene iz te skupine definiše kao zetsko-sjeničke. Na neutemeljenost toga naziva svojevremeno je skrenuo pažnju i sâm Ivić, koji ga je na početku upotrebljavao, ,zato što se pokazalo da Sjenica ne leži na području tog dijalekta“. ${ }^{32}$ Za razliku od Belića, Rešetar sve štokavske govore dijeli na dvije grupe: one koji su poslužili kao osnova ,srpskohrvatskoga književnog jezika“ i kosovsko-resavski dijalekat. Zatim skreće pažnju na klasifikaciju ,južnoga dijalekta“" koju je izvršio njegov učitelj Pero Budmani na 4 poddijalekta: crnogorski (kojim se govori u Crnoj Gori, Boki i śevernoj Albaniji), $d u$ brovački, hercegovački i bosanski. I Rešetar, poput Budmanija, iz prve svoje grupe izdvaja samo zetski ili, kako ga još naziva, crnogorski dijalekat. Iako je poznato da se nije bavio teorijskim pitanjima u jezikoslovlju, ovđe treba istaći da je Rešetar nekoliko značajnih zapažanja o prenaglašenome značaju alternanata jata i akcenatskoga sistema pri podjeli štokavskih dijalekata. No i

\footnotetext{
${ }^{30}$ Aleksandar Belić, O srpskim ili hrvatskim dijalektima, Glas Srpske kraljevske akademije, LXXVIII, Drugi razred, 47, U Beogradu, 1908, str. 160-164.

${ }^{31} \mathrm{Tu}$ je polemiku prikazao i Pavle Ivić u svojem kratkom osvrtu na Rešetarov Štokavski dijalekat: „U uvodu (knjige - prim. A. Č.) diskusija o grupisanju srpskohrvatskih dijalekata, većim delom uz polemiku s Belićem (kojemu prebacuje izlučivanje kajkavštine, način podele čakavštine, davanje posebnog mesta kosovsko-resavskom dijalektu, pripisivanje čakavskog porekla štokavskim ikavcima, tumačenje geneze šumadiskovojvođanskog dijalekta mešavinom ekavaca i jekavaca i poricanje prelaznog karaktera prizrensko-timočkim govorima). Zamerke su nejednako opravdane (...). Rešetarovo grupisanje štokavskih govora ne znači napredak prema Belićevom iz 1905.“ - Pavle Ivić, $n$. d., str. 38-39.

${ }^{32}$ Pavle Ivić, Osvrt na lingvističke metode dosadašnjih proučavanja crnogorskih narodnih govora, Crnogorski govori. Rezultati dosadašnjih ispitivanja i dalji rad na njihovom proučavanju, Zbornik radova, Crnogorska akademija nauka i umjetnosti, Titograd, 1984, str. 32.
} 
Milan Rešetar kao montenegrist

pored toga i sâm je podlegao metodologiji koju kritikuju, pa tako - zbog akcenatskih razlika - pod crnogorskim govorima podrazumijeva samo govore ,zetskoga“ tipa, ali ne i śeverozapadne crnogorske govore, koje nerijetko prilikom ocrtavanja izoglosa pojedinih pojava ili poređenja materijala pridružuje tim prvim, naglašavajući da su u pitanju hercegovački govori koji su pripojeni Crnoj Gori poslije Berlinskoga govora. No na tome mu se ne može mnogo zamjeriti ako se zna da po tome pitanju ni do danas nema saglasnosti među dijalektolozima. ${ }^{33}$

Gotovo da nema stranice u Štokavskome dijalektu koja ne sadrži i neki podatak o crnogorskim govorima. Pritom ne treba zaboraviti da Rešetarov cilj ni izdaleka nije bio da izuči crnogorske govore, već samo da ukaže na pojedine osobine štokavskih govora, želeći da obuhvati samo one osobine koje nijesu odlika ,srpskohrvatskoga književnoga jezika“. Jedna od vrlo značajnih osobina njegove studije jeste to što je gotovo za svaku osobinu naznačio i lokalitet na kojemu je čuo. To naravno ne treba shvatiti tako kao da je ta osobina karakteristična samo za taj lokalitet, osim u slučajevima kad sâm autor to naglašava.

Ako se zna da je Rešetar svoja ispitivanja obavio prije više od sto godina, nije potrebno isticati značaj podataka koje je on širom Crne Gore sakupio. To tim prije što mnoge osobine koje je on opisao ili objasnio danas usljed ubrzanoga procesa urbanizacije sve više nestaju ili su već u potpunosti iščezle. No njegovo precizno lociranje pojedinih pojava danas nam (uz pomoć literature koja je nastala poslije Rešetara) može pomoći da ocrtamo precizne izoglose pojedinih jezičkih pojava u Crnoj Gori. Naročito je značajan odjeljak o alternantima jata, u kojemu nije propuštio da popiše i objasni sve rijetke ekavizme u Crnoj Gori, pojave sekundarne ijekavice tipa poštijer, manijer, kosijer, pastijer, špijerlica ili ijekavizme tipa pokrijevat, umijevat, izbijevat i sl. Posebno je dobar njegov opis i objašnjenje ikavizma u govoru podgoričkih muslimana, za koji kaže da se razvio glasovnim putem a ne doseljavanjem stanovništva, kako su i poslije njega tvrdili pojedini istraživači. Ništa manje nije značajan ni opis izgovora i prostiranja alternanta poluglasnika u pojedinim crnogorskim govorima, specifičnoga izgovora glasa $a$ i brojnih drugih (naročito glasovnih) pojava. O nekim podacima o crnogorskim govorima danas ne bismo gotovo ništa znali da nije Rešetarova opisa. Takvi su npr. grupe śj i źj nastale kao produkt jotacije sj i zj ili podatak o uzlaznim

${ }^{33}$ Reviziju podjele crnogorskih govora dao je Adnan Čirgić u ovim radovima: „O klasifikaciji crnogorskih govora“, Lingua Montenegrina, br. 2, Institut za crnogorski jezik i jezikoslovlje, Cetinje, 2008, str. 109-128, i „Revizija podjele crnogorskih govora“, Lingua Montenegrina, br. 3, Institut za crnogorski jezik i jezikoslovlje, Cetinje, 2009, str. 253-266. 
akcentima u govoru Podgorice (što se vidi iz primjera koje on daje) jer danas ni kod najstarijih tipičnih govornih predstavnika takvih osobina nema.

Treba istaći još i značajno njegovo zapažanje o uticaju religijske pripadnosti na govorne osobine. Neke je jezičke osobine Rešetar identifikovao kao karakteristične samo za određene konfesionalne skupine. Izuzetak u tome predstavljaju uglavnom samo neke zajedničke osobine katolika dubrovačkoga govora i predstavnika crnogorskih govora (svih konfesija), što pri njihovu navođenju Rešetar nekoliko puta ističe.

Ne ulazeći u detaljan opis osobina koje Rešetar iznosi o crnogorskim govorima, ovđe ćemo navesti samo još njegovo oduševljenje stanjem u crnogorskim govorima, koje je iskazao prilikom opisa glagolskih oblika: „No za sam jezik najvažnije je da li su imperfekat i aorist sačuvani ili ne (...). Od štokavskih dijalekata koji su mi bliže poznati crnogorski najistrajnije ostaje pri tim lijepim glagolskim oblicima i bio sam prijatno iznenađen kad sam onđe oko sebe čuo čiste imperfekte i aoriste! Da bi se moje oduševljenje shvatilo, mora se naime znati da u dubrovačkome dijalektu nema ni aorista ni imperfekta, koje je - kao i u jeziku obrazovanih štokavaca - potpuno zamijenio perfekat svršenih odnosno nesvršenih glagola.“

Studijom Štokavski dijalekat Milan Rešetar dao je veliki doprinos i crnogorskoj i hrvatskoj i bosanskoj dijalektologiji, i jezikoslovlju uopšte. Posebno ističemo doprinos crnogorskoj dijalektologiji jer u to doba, a ni pune dvije decenije poslije toga, nije bilo nijednoga školovanog dijalektologa koji bi se tim govorima mogao baviti. Kao prvi školovani dijalektolog koji je dao dobar opis pojedinih crnogorskih jezičkih osobina, Milan Rešetar zauzima jedno od čelnih mjesta u montenegristici. Kad bi se iz njegove knjige izdvojili podaci koji se samo odnose na te osobine, to bi opet bila jedna opsežna studija. Prevođenjem knjige Štokavski dijalekat olakšan je i pristup izradi Dijalektologije crnogorskoga jezika, pri čemu će Rešetarova studija poslužiti kao primarna i nezaobilazna literatura.

\section{Literatura}

Belić, Aleksandar, „O srpskim ili hrvatskim dijalektima“, Glas Srpske kraljevske akademije, LXXVIII, Drugi razred, 47, U Beogradu, 1908, str. 160-164.

- Čirgić, Adnan, „O klasifikaciji crnogorskih govora“, Lingua Montenegrina, br. 2, Institut za crnogorski jezik i jezikoslovlje, Cetinje, 2008, str. 109-128.

- Čirgić, Adnan, „Revizija podjele crnogorskih govora“, Lingua Montenegrina, br. 3, Institut za crnogorski jezik i jezikoslovlje, Cetinje, 2009, str. 253-266. 
Milan Rešetar kao montenegrist

- Deanović, Dr. Mirko, Milan Rešetar (1. II. 1860. - 14. I. 1942.), Ljetopis Jugoslavenske akademije znanosti i umjetnosti za godine 1946.-1948., knj. 54, Zagreb, 1949.

- Hrvatski profesori na Bečkoj slavistici, priredila Truda Stamać, Erasmus naklada, Zagreb, 2005.

- Ivić, Pavle, Dijalektologija srpskohrvatskog jezika. Uvod i štokavsko narečje. Matica srpska, Novi Sad, 1956.

- Ivić, Pavle, „Osvrt na lingvističke metode dosadašnjih proučavanja crnogorskih narodnih govora“, Crnogorski govori. Rezultati dosadašnjih ispitivanja i dalji rad na njihovom proučavanju, Zbornik radova, Crnogorska akademija nauka i umjetnosti, Titograd, 1984.

- Katičić, Radoslav, „Milan Rešetar i hrvatski književni jezik“, In: Zbornik o Milanu Rešetaru, Hrvatski studiji Sveučilišta u Zagrebu, Zagreb, 2005.

- Katičić, Radoslav, „Milan Rešetar und die Balkan-komission der Weiner Akademie“", In: Zbornik o Milanu Rešetaru, Hrvatski studiji Sveučilišta u Zagrebu, Zagreb, 2005.

- Leto, Maria Rita, Milan Rešetar, Zavod za znanost o književnosti Filozofskog fakulteta u Zagrebu, Zagreb, 1989.

- Lisac, Josip, „Milan Rešetar“, In: Hrvatski profesori na Bečkoj slavistici, priredila Truda Stamać, Erasmus naklada, Zagreb, 2005, str. 29.

- Manje pjesme vladike crnogorskoga Petra II Petrovića Njegoša, Izdao Milan Rešetar, Srpska književna zadruga, Biograd, 1912.

- Neweklowsky, Gerhard, „Milan Rešetar als Dialektologe“, In: Zbornik o Milanu Rešetaru, Hrvatski studiji Sveučilišta u Zagrebu, Zagreb, 2005.

- Nikčević, Milorad, „Komentari Gorskoga vijenca (1847.) Stefana Mitrova Ljubiše i Milana Rešetara“, In: Zbornik o Milanu Rešetaru, Hrvatski studiji Sveučilišta u Zagrebu, Zagreb, 2005, str. 305-326.

- Nikčević, Vojislav P., Istraga poturica - mit ili stvarnost, Almanah, Podgorica, 2001.

- Nikčević, Vojislav P., „Milan Rešetar kao njegošolog“, In: Zbornik o Milanu Rešetaru, Hrvatski studiji Sveučilišta u Zagrebu, Zagreb, 2005, str. 193-212, i u knjizi: Jezičke i književne teme, Institut za crnogorski jezik i jezikoslovlje, Cetinje, 2006, str. 287-310.

- Osolnik, Vladimir, Istorija književnosti o Petru II Petroviću Njegošu, Crnogorska akademija nauka i umjetnosti, Podgorica, 1999, str. 75.

- Petrović Njegoš, Petar II., Gorski vijenac, Jubilarno izdanje povodom 150. godišnjice prvog izdanja s predgovorom priredio Vojislav P. Nikčević, Crnogorski PEN centar, Cetinje, 1997. 
Adnan ČIRGIĆ

- Petrović Njegoš, Petar II, Gorski vijenac, Kritičko izdanje. Tekstologija. Redakcija i komentar Radmila Marojevića, CID, Podgorica, 2005.

\section{Adnan ČIRGIĆ}

\section{MILAN REŠETAR AS A MONTENEGRIST}

This paper represents a review of the contribution of Milan Rešetar to the Montenegristics, especially to its dialectology and njegosology. His contribution has been pointed out in two of his papers- Der stokavische Dialekt (the Stokavian Dialect) which has been published this year by Matica crnogorska, translated into the Montenegrin language, and a non-translated paper about the stress within the south-west stokavian speech entitled Die serbocroatische Betonung sudwestlicher Mundarten (Wien 1900). The author wants to point out a great contribution of Milan Rešetar, who was the first educated philologist interested in the Montenegrin language.

Key words: Milan Rešetar, montenegristics, njegosology, stokavian speech 
LINGUA MONTENEGRINA, god. III, br. 5, Cetinje, 2010.

Institut za crnogorski jezik i jezikoslovlje „Vojislav P. Nikčević“

UDK 82:929 Rotković R. Pregledni rad

\author{
Aleksandar RADOMAN (Podgorica) \\ Institut za crnogorski jezik i jezikoslovlje „Vojislav P. Nikčević“ - Cetinje
}

\title{
RADOSLAV ROTKOVIĆ KAO ISTORIČAR KNJIŽEVNOSTI
}

U ovom radu dat je pregled djelatnosti Radoslava Rotkovića iz oblasti istorije književnosti. Radoslav Rotković osobena je pojava u crnogorskoj nauci i kulturi. Već više od šezdeset godina prisutan je kao autor u nekoliko disciplina: književnoj kritici, istoriji književnosti, istoriji i jezikoslovlju. Pored toga, Rotković je i značajan prozni i dramski pisac. U svojim radovima iz istorije književnosti uglavnom se bavio starijim, neistraženim periodima crnogorske književnosti - srednjim vijekom, renesansom, barokom i prosvjetiteljstvom. Od velikog je značaja i njegov rad na otkrivanju i priređivanju djela starih pisaca. Pored toga, autor je monografija o Stefanu Mitrovu Ljubiši, crkvenoj drami u Boki Kotorskoj, te prvog pregleda crnogorske književnosti. Njegov pristup karakteriše sveobuhvatan uvid u društveno-političke okolnosti epohe, kao i precizne analize konkretnih tekstova i lucidna zapažanja o piscima i njihovim djelima.

Ključne riječi: Radoslav Rotković, istorija književnosti, crnogorska književnost, srednji vijek, crkvena drama, Stefan Mitrov Ljubiša

I površan uvid u bibliografiju dr Radoslava Rotkovića ${ }^{1}$ (Mojdež, Herceg Novi, 1928) jasno upućuje na zaključak da je riječ o posve osobenoj ličnosti savremene crnogorske kulture i nauke. Od prve objavljene pjesme, $J u$ tro u Duklji, 1948. godine, Rotković je ispisao na desetine tomova - romana, pripovjedaka, drama, pjesama, književnih i pozorišnih kritika, scenarija, komentara, osvrta, reagovanja, eseja, enciklopedijskih jedinica, te istoriografskih, književnoistorijskih i jezikoslovnih studija. ${ }^{2} \mathrm{U}$ ovome radu ograničiće-

\footnotetext{
${ }^{1}$ V. Ljiljana Lipovina, Radoslav Rotković: bio-bibliografija, DANU, Podgorica, 2009.

${ }^{2}$ V. Adnan Čirgić, „Radoslav Rotković kao jezikoslovac“, Lingua Montenegrina, broj 4, Cetinje, 2009, 471-488.
} 
mo se samo na jedan segment opusa ovoga našeg posljednjeg klasičnog polihistora. Riječ je o radovima iz oblasti istorije književnosti.

Ako se ostavi po strani njegov beletristički opus, Rotkovićev angažman mogao bi se hronološki, u grubim potezima, podijeliti na tri faze. $\mathrm{U}$ prvom periodu, koji obuhvata pedesete i šezdesete godine dvadesetog vijeka, on, u prvom redu, djeluje kao književni kritičar. Štaviše, Radoslav Rotković, uz Boža Bulatovića i Milorada Stojovića, slovi za utemeljivača moderne novinske kritike u Crnoj Gori. Smjelih zapažanja i lucidno formulisanih ocjena recentnih tekstova domaće i strane provenijencije, Rotkovićeve kritike obezbijedile su mu status pouzdanog i uvijek osluškivanog analitičara savremenih književnih tokova. Za drugog perioda, koji se, okvirno, proteže na sedamdesete i osamdesete godine, Rotković je sve prisutniji kao istoričar književnosti: objavljuje studije i monografije, priređuje brojna izdanja i antologije: nameće se kao prvorazredni autoritet za ovu oblast, značajno proširujući saznanja o crnogorskom književnom nasljeđu. U trećem, pak, periodu, posljednje decenije dvadesetog i prve decenije dvadeset prvog vijeka, Rotković se mahom bavi istoriografskim temama. Ne treba, ipak, smetnuti s uma da se $\mathrm{u}$ Rotkovićevu slučaju, ma u kojoj disciplini se ogledao, uvijek mora računati sa nesputanom erudicijom, nerazlučivom karakteristikom njegova života i stila. Stoga, njegovi tekstovi uvijek nude mnogo više od očekivanog i zadatog određenim žanrovskim obrascem, te funkcionišu kao specifični polimorfni prostor ispunjen atmosferom i duhom brodelovske - totalne istorije.

Crna Gora, njena kulturna, književna i politička povijest, za svih šest decenija Rotkovićeva stvaralaštva, centralna su preokupacija njegova ,,pjevanja i mišljenja“. Uz brojne književne, pozorišne i filmske kritike, potpisane Rotkovićevim imenom, koje srijećemo u jugoslovenskoj periodici prvih decenija nakon Drugog svjetskog rata posebnu pažnju danas izazivaju njegove polemike i reagovanja na pokušaje negiranja ili posvajanja crnogorske kulture i temeljnih identitetskih vrijednosti. Tako već 1956. godine u tekstu Razgovor neugodni kritikuje praksu svrstavanja crnogorskih pisaca u srpske antologije. ${ }^{3}$ Deceniju kasnije, 1967, reaguje na izjavu sekretara Matice srpske Živana Milisavca da je postojanje crnogorske književnosti politički a ne naučni problem. ${ }^{4}$ Rotković, istina, nije bio sasvim usamljen, pripadao je grupi crnogorskih intelektualaca (braća Radojević - Radoje i Danilo, Vojislav P. Nikčević, Dragoje Živković...) koji su od kraja šezdesetih godina snažnije afirmisali posebnost crnogorskog nacionalnog identiteta, no ta je borba bila osuđena na izvaninstitucionalno djelovanje, a njeni protagonisti proskribova-

${ }^{3}$ Radoslav Rotković, „Razgovor neugodni“, Pobjeda, god. 13, br. 12, 18. 3. 1956, 9.

${ }^{4}$ Radoslav Rotković, „Privremeno rješenje“, Pobjeda, god. 24, br. 2603, 30. 3. 1967,9 . 
ni i sumnjičeni za ,nacionalističke tendencije“. Činjenica da su naučne koncepcije ove grupe kulturnih radnika danas postale dio oficijelne crnogorske istoriografije, književne istoriografije i jezikoslovlja, nije bitnije uticala na tretman njihovih kreatora.

Cjelovitije i svestranije crnogorskom književnom dijahronijom Rotković će se pozabaviti sedamdesetih godina. Dvjema studijama o Ljetopisu Popa Dukljanina, objavljenim u reviji Ovdje 1971. godine, ${ }^{5}$ otpočinje period Rotkovićeva intenzivnog i plodonosnoga bavljenja našim književnim nasljeđem. I već u tim tekstovima očituju se sve bitne osobine njegova postupka polemičnost, besprijekorno poznavanje literature i duha epohe, analitički, multidisciplinarni pristup materiji i umijeće sintetičkog zaokruživanja problema. Nastalim kao reakcija na knjigu Nikole Banaševića, Letopis popa Dukljanina i narodna predanja, u ovim dvjema studijama raspravlja se o gotovo svim važnijim pitanjima koje u nauci izaziva ova zagonetna i dragocjena srednjovjekovna hronika. U prvoj studiji, „Da li je Dukljanin bio Roman“, Rotković se upušta u analizu nekih teza Nikole Banaševića ali i cijelog niza autora koji su se bavili pitanjem autora Ljetopisa Popa Dukljanina. Na Banaševićevo potcjenjivanje razvijenosti pismenosti u srednjovjekovnoj Duklji i zaključke da je Ljetopis djelo nekog učenog benediktinca romanskog porijekla, te da nije postojao slovenski original hronike, Rotković odgovara nizom sugestivnih pitanja kojima potcrtava nedostatnost Banaševićeve argumentacije. U zaključku naglašava: „U svakom slučaju rizično je proglasiti nepostojećim sve ono što se nije sačuvalo, jer naučnici najbolje znaju koliko je djela za koje se zna da su postojala, pa ih danas nema!“ U drugoj studiji, ,Izvori i uzori Ljetopisa Popa Dukljanina“", Rotković problematizuje Banaševićevu tezu da u ovoj srednjovjekovnoj hronici nema baš nikakvog odjeka usmene tradicije. Dajući pregled ranijih izučavanja ovoga problema (Jagić, Šišić, N. Radojčić, Kovačević) i kritički analizirajući i komentarišući jedan po jedan primjer iz Banaševićeve monografije, Rotković zaključuje: „Studija N. Banaševića je iscrpna i korisna. On je prikupio i obradio sve ono što bi moglo imati veze bilo sa manirom bilo sa sadržajem Ljetopisa i ta su istraživanja za dogledno vrijeme konačna, jer nema izgleda da se otkrije neko novo staro djelo koje je moglo da posluži Dukljaninu. Ali isključivost u negiranju uticaja narodne pjesme ili prozne legende je nepotrebna. Ne treba ići dalje od vladike Vasilija i Petra I pa utvrditi da su oni čitali i koristili Orbinovo Kraljevstvo Slovena (prema ruskom prevodu) a pisali su i pjesme. U njihovim istorijama Crne Gore pomiješana je pjesma i istorija jednako kao i u Ljetopisu Popa

${ }^{5}$ Radoslav Rotković, „Da li je Dukljanin bio Roman“, Ovdje, br. 29, Titograd, 1971, 15; Radoslav Rotković, „Izvori i uzori Ljetopisa Popa Dukljanina“, Ovdje, br. 30, Titograd, 1971, 15. 
Dukljanina." Premda se u potonje četiri decenije bibliografija o Kraljevstvu Slovena Popa Dukljanina značajno uvećala objavljivanjem nekoliko novih izdanja, vrijednih monografija i brojnih studija, osnovni zaključci iznešeni u tim dvjema Rotkovićevim studijama - o autoru, kompoziciji, izvorima i uzorima ove srednjovjekovne hronike, i dalje su aktuelni.

Uslijedili su, u prvoj polovini sedamdesetih, radovi o Ivanu Antunu Nenadiću, Stefanu Mitrovu Ljubiši, Antunu Kojoviću, Ljudevitu Paskoviću, Vuku Vrčeviću... Posebna vrijednost Rotkovićevih istraživanja ogleda se u činjenici da je za predmet svojih studija uzimao manje poznate i slabo proučene pisce, pa su njegovi tekstovi često imali karakter otkrića zaboravljenih slojeva baštine. To osobito dobija na vrijednosti ako se zna da se sistematičnija ispitivanja starijih segmenata književnoga nasljeđa u Crnoj Gori začinju tek pojavom biblioteke „Luča“, 1963. godine, biblioteke koja će desetak godina kasnije dobiti i određenje - antologija crnogorske književnosti. Početni koraci u pravcu revalorizacije starije literarne baštine učinjeni su priređivanjem antologije Prednjegoševsko doba i publikovanjem prvog crnogorskoga izdanja Ljetopisa Popa Dukljanina, upravo u okviru biblioteke „Luča“. Za tu biblioteku Radoslav Rotković je od 1967. do 1987. godine priredio čak sedam izdanja. Pored antologijskoga izbora iz stvaralaštva savremenika, Čeda Vukovića i Janka Đonovića, tu su se našla izdanja pisaca koji do tada u Crnoj Gori nijesu nikada publikovani ili prevedeni - izbori iz stvaralaštva Ivana Antuna Nenadića, Vuka Vrčevića, Krsta Ivanovića, Stefana Zanovića i Ljudevita Paskovića.

Važnije radove iz ovog perioda Rotković je uvrstio u knjigu Crnogorsko književno nasljeđe I, za koju je dobio nagradu Udruženja književnika Crne Gore i prvi put bio kandidovan za Trinaestojulsku nagradu (na prijedlog pisca Čeda Vukovića). Iako će za ovo najveće državno priznanje biti predlagan još nekoliko puta narednih decenija, Trinaestojulsku nagradu Rotković nikada nije dobio. Pored već ranije objavljenih priloga, „Humanista Ljudevit Pasković Kotoranin“, „Ivan Antun Nenadić“, „Djelo Antuna Kojovića“ i „Vrčevićeva proza“, knjiga Crnogorsko književno nasljeđe I donosi i obimnu studiju „Književnost dukljansko-zetskog perioda (IX-XII vijek)“. Prvi je to pokušaj sinteze najstarijeg i najslabije izučenoga perioda crnogorske književnosti u našoj književnoj istoriografiji. Polazna premisa Rotkovićevih istraživanja je da ,dukljansku književnost čini ono što je ona naslijedila od drugih i ono što je ona ostavila drugima“". ${ }^{6}$ Upuštajući se u multidisciplinarno čitanje društveno-političkih odnosa u dukljanskoj srednjovjekovnoj državi, te posebne analize ključnih spomenika ove epohe - Andreacijeve povelje, barskih

${ }^{6}$ Radoslav Rotković, Crnogorsko književno nasljeđe I, Pobjeda, Titograd, 1976, 19. 
Radoslav Rotković kao istoričar književnosti

epitafa, legende o Vladimiru i Kosari, te Kraljevstva Slovena, Rotković ne zaobilazi ni ona u nauci „tamna“ mjesta kakva su pitanje prisustva glagoljice, bogumilskih uticaja, narodnoga stvaralaštva te epohe i postojanja zetskohumske redakcije staroslovenskoga jezika. Ovom periodu Rotković će se vratiti dvadesetak godina kasnije u knjizi Kraljevina Vojislavljevića XI-XII vijeka. ${ }^{7}$ Radom „Humanista Ljudevit Pasković Kotoranin“ Rotković u matičnu literaturu vraća čuvenoga latinistu koji je ,jedan od prvih naših pjesnika uvrštenih u strane zbornike i antologije, i jedan od posljednjih koji je tu počast doživio u svojoj zemlji““. ${ }^{8}$ Rekonstruišući pjesnikovo doba i biografiju, raspravljajući o sačuvanim knjigama i rukopisima, mogućim uzorima i uticajima (Pasković je snažno uticao na engleskoga pjesnika Tomasa Lodža), te dajući preśek tematsko-motivskih dominanti poezije ovog u svoje doba izuzetno cijenjenoga pjesnika, Rotković nam ponovo nudi na uvid cijeli jedan ,zatureni“" fragment naše literature. Opsežan izbor iz stvaralaštva Ljudevita Paskovića Rotković je objavio 1987. godine. ${ }^{9}$ Tu su se prvi put, među koricama jedne knjige, našle objedinjene pjesme prevedene sa latinskog i italijanskog jezika. Prilog „Ivan Antun Nenadić“ predstavlja djelimično izmijenjen predgovor objavljen uz izbor iz Nenadićeva djela. ${ }^{10}$ Rotković daje cjelovit pregled Nenadićeva djela, posebno skrećući pažnju na fenomen bokokotorske crkvene drame, što će kasnije postati i predmetom njegove doktorske disertacije. Pored analize Nenadićeva epskog i dramskog stvaralaštva, Rotković apostrofira Nenadićev Nauk krstjanski u čijem je predgovoru još 1768. godine istakao da se trudi pisati tako da bi bolje bio ,razumjen od naše čeljadi, i da se lašnje može štjeti kako se govori i da se izgovara onako kako se šti$j e$ ", formulišući tako, četrnaest godina prije Adelunga, osnovna načela fonetskoga pravopisa. Novi izbor iz Nenadićeva djela Rotković je priredio 1996. godine. ${ }^{11}$ Tekst „Djelo Antuna Kojovića“ posvećen je ovom značajnom budvanskom analisti, pjesniku i komediografu. Rotković oprezno iznosi ocjenu njegova djela smještajući ga u konkretni društveni kontekst: „Kojović, kao ni Andrija Zmajević, ne može da se procjenjuje samo po estetskim valerima svojega djela, jer on nije stvarao samo sebe i za sebe, već je odmagao sebi uzdižući grad, njegujući u njemu učenike, buduće glumce i pisce, pozorišnu publiku... (...) Kao i mnogi drugi pregaoci u skromnim, nepovoljnim prilika-

${ }^{7}$ Dr Radoslav Rotković, Kraljevina Vojislavljevića XI-XII vijeka, Print, Podgorica, 1999, 337-406.

${ }^{8}$ Radoslav Rotković, Crnogorsko književno nasljeđe I, Pobjeda, Titograd, 1976, 105.

${ }^{9}$ Ljudevit Pasković, Sveti plamen, biblioteka „Luča“, Pobjeda, Titograd, 1987.

${ }^{10}$ Ivan Antun Nenadić, Slijepa pravda, biblioteka „Luča“, Pobjeda, Titograd, 1975.

${ }^{11}$ Ivan Antun Nenadić, Drame, „Književnost Crne Gore od XII do XIX vijeka“, Obod, Cetinje, 1996. 
ma i Kojović je krčio nove puteve i ostao zatrpan pod izbačenom zemljom.“12 Studija „Vrčevićeva proza“ takođe predstavlja predgovor objavljen uz izbor iz narodne pripovjedačke proze koju je sakupio Vuk Vrčević. ${ }^{13}$ Djelatnost ovog agilnoga sakupljača narodnih umotvorina, saradnika Vuka Karadžića, bila je u velikoj mjeri zanemarena, te su ovaj Rotkovićev izbor i propratna studija uveliko doprinijeli Vrčevićevoj književnoj reafirmaciji. Pa iako je u izboru zastupljen samo dio narodnog proznog materijala koje je Vrčević sakupio (bajke, basne, priče, podrugačice), Rotković se u studiji ne zadržava samo na tome materijalu već upućuje i na Vrčevića kao originalnoga proznog pisca, analizirajući njegove pripovijetke i memoarsku i putopisnu prozu, konstatujući kako je i taj segment Vrčevićeva opusa obiman i značajan ,i tek očekuje podrobnu analizu. “14 U prikazu ove knjige dr Danilo Radojević je zapisao: „Rotkovićeva knjiga Crnogorsko književno nasljeđe, zahvaljujući analitičkom pristupu veoma značajnim književnim i kulturnim pojavama i temama, iz raznih epoha, imaće poseban značaj pri budućoj sistematizaciji i valorizaciji crnogorske literature. Osnovni utisak dok se čita ova knjiga je mirnoća i preciznost kazivanja, argumentativnost. On uvijek saopšti i osnovne stavove kritike s kojom se ne slaže, ali se ne gubi u direktnom konfrontiranju, već svoju koncepciju argumentuje književno-istorijskim, estetskim i drugim analizama." ${ }^{15}$

Iste godine kad i Nasljeđe, 1976, u časopisu Stvaranje publikovana je Antologija crnogorske književnosti IX-XX vijek, priređivača Branka Banjevića, Radoslava Rotkovića, Čeda Vukovića, Sretena Perovića i Milorada Stojovića. ${ }^{16}$ Izbor tekstova iz IX-XVIII vijeka sačinili su Branko Banjević i Radoslav Rotković. Značaj ovoga kapitalnog poduhvata ogleda se, prije svega, u tome što je tu prvi put crnogorska književnost sagledana integralno, in continuo, od samih početaka do savremenoga doba. No, upravo je to i bio povod za napade koji su uslijedili. Na strukturu Antologije i njene priređivače oštro se ustremio u zagrebačkom Oku pjesnik Jevrem Brković. Kritikujući koncepciju antologije „koja počinje sa Andreacijem a završava se sa Zuvdijom Hodžićem“, Brković nudi svoj nacrt crnogorske literature: „Iznenadio me onaj

${ }^{12}$ Radoslav Rotković, Crnogorsko književno nasljeđe I, Pobjeda, Titograd, 1976, 210.

${ }^{13}$ Vuk Vrčević, Maštanija, biblioteka „Luča“, Pobjeda, Titograd, 1975.

263.

${ }^{14}$ Radoslav Rotković, Crnogorsko književno nasljeđe I, Pobjeda, Titograd, 1976,

15 Danilo Radojević, Istraživanja crnogorske književnosti, Stvaranje, br. 7-8, Titograd, 1977, 1143.

${ }^{16}$ Antologija crnogorske književnosti IX $-X X$ vijek, Stvaranje, br. 10, Titograd, 1976. 
deveti vijek i svi oni vjekovi do početka devetnaestog. Po meni crnogorska književnost počinje od Petra Prvog Petrovića Njegoša i njegovih Poslanica. “17 Na Brkovićevu paskvilu odgovorili su Milorad Stojović i Radoslav Rotković. Polemiku koja se razvila i poprimila i lične tonove Rotković lucidno rezimira usmjeravajući je na osnovni problem: „Po njemu, crnogorska književnost počinje od Petra I. Kojoj književnosti pripada onaj raniji period, on izričito ne kaže, ali iz brojnih napomena se vidi da bi on želio da se to književno nasljeđe 'vrati' Srbima i Hrvatima. Na taj način on će sigurno zadovoljiti dvije čaršije, ali narodi s time nemaju nikakve veze. Svaki narod ima neotuđivo pravo da prihvati kao svoje nasljeđe ono što je sam, na svome tlu, bez obzira na okupacije i režime, stvarao u toku stoljeća. Ako bi se pojam crnogorske književnosti vezivao za naziv Crna Gora, i tada bi trebao 'sići‘ do XIV vijeka. U čemu je principijelna razlika između odvojenosti Dalmacije od zaleđa, na jednoj strani, i Boke i prirodnog, ekonomskog, etničkog zaleđa na drugoj strani?“"18

Do kraja sedamdesetih Rotković je u periodici objavio nekoliko značajnih studija (,Petrarkista Đorđe Bizanti Kotoranin“, „Počeci crkvene drame u Boki“, „Misli i popjevke Miroslava Zanovića“, „O nekim 'prazninama“ u crnogorskom nasljeđu srednjega vijeka“...) i za biblioteku „Luča“ priredio još dva izdanja izabranih djela naših starih pisaca - Krsta Ivanovića i Stefana Zanovića. Prilogom o Đorđu Bizantiju ${ }^{19}$ Rotković je vratio dug zaboravljenome kotorskom pjesniku iz prve polovine XVI stoljeća za kojega je hrvatski istoričar književnosti Josip Torbarina ustvrdio da mu ,jamačno pripada skromno mjesto u razvitku evropskoga petrarkizma, ako ne kao prvom, a ono bez sumnje jednom od najranijih sljedbenika Bembove reforme“". ${ }^{20}$ Bavljenje kotorskim renesansnim pjesničkim krugom Rotković će zaokružiti deceniju kasnije studijom „Ivan Bona Boliris, kotorski humanista“, đe instruktivno zaključuje: „U Paskoviću i Bolirisu doživio je kotorski humanistički krug vrhunske poetske domete, kao dokaz da nijesmo samo uzimali od svijeta, nego mu i davali“. ${ }^{21}$ Radom o Miroslavu Zanoviću, ${ }^{22}$ manje poznatom bratu

\footnotetext{
${ }^{17}$ Jevrem Brković, ,Ako se rodilo zdravo dijete zašto ćutimo ili o jednoj antilogičnoj antologiji““, Oko, Zagreb, br. 126, 13-27. siječnja 1977, 4.

${ }^{18}$ Radoslav Rotković, „Ništa nije opasnije od neznanja kad je aktivno“, Oko, Zagreb, br. 127, 27. siječnja - 10. veljače 1977, 5.

${ }^{19}$ Radoslav Rotković, „Petrarkista Đorđe Bizanti Kotoranin“, Stvaranje, br. 4, Titograd, 1977, 675-680.

${ }^{20}$ Josip Torbarina, „Naš prilog evropskom petrarkizmu“, Forum, br. 4-5, Zagreb, 1974.

${ }^{21}$ Radoslav Rotković, „Ivan Bona Boliris, kotorski humanista“, Ars, br. 1, Cetinje, 1987,50 .
} 
budvanskog alazona Stefana Zanovića, Rotković podśeća na još jednu zanimljivu ličnost naše književnosti. U nevelikome korpusu sačuvanih djela, koji se svodi na jednu objavljenu i fragmentarno sačuvanu knjigu i jedan rukopis, nahode se misli, popijevke i počasnice Miroslava Zanovića. Rotković ukazuje na stepen (ne)originalnosti Zanovićevih misli, te na problem nemogućnosti utvrđivanja što je u njegovim pjesmama narodno a što autentično. U dodatku studije Rotković je objavio Zanovićeve popijeke i počasnice a tu, pored ostalog, srijećemo pjesmu Još ne sviće bijela zora danas poznatu narodnu pjesmu Još ne sviće rujna zora. U raspravi „O nekim 'prazninama“ u crnogorskom nasljeđu srednjega vijeka“"23 Rotković se usredsređuje na tri važna, nerazriješena problema našega srednjovjekovlja - pitanje prisustva glagoljice, apokrifa i bogumilske jeresi u dukljanskoj/zetskoj državi. Polazeći od Vodnikove teze da je Zeta bila rasadnik glagoljice i približavajući društveno-političke okolnosti epohe, Rotković usmjerava pažnju na Marijinsko jevanđelje, jedan od spisa iz najužeg kanona staroslovenskih spomenika. Rotković, zapravo, ovđe Jagićevu pretpostavku da je rukopis nastao , južno od Bosne, ali ne u Dalmaciji, u svakom slučaju u štokavskom kraju“ dovodi do logičnog zaključka - Marijinsko jevanđelje nastalo je u srednjovjekovnoj Zeti! Ovu smjelu Rotkovićevu hipotezu, poduprtu i analizom leksike spomenika, afirmisali su docnije, dopunjujući je novim argumentima, u posebnim studijama crnogorski filolozi dr Vojislav P. Nikčević i dr Milorad Nikčević. ${ }^{24}$ Slijedeći poglede Račkog o apokrifima i bogumilskoj jeresi, o čemu je opširnije pisao u Crnogorskom književnom nasljeđu I, Rotković se fokusira na još jedan „zaboravljeni“" spomenik nastao na prostoru srednjovjekovne Zete - Zbornik popa Dragolja. Jer upravo u ovom zagonetnom rukopisu, po svemu sudeći iz treće četvrtine XIII vijeka, srijeću se obje tradicije. Zbornik, naime, pored Kozmine beśede protiv bogumila i drugih kraćih prerada, sadrži i bogat izbor rijetkih apokrifa (Viđenje proroka Danila, Viđenje Isaijino, Pandehovo proročko skazanije...). Rotković ne propušta priliku da upozori i na razloge što su ova dva dragocjena rukopisa u nauci ostala nedovoljno proučena: „Kao i 'Marijinsko jevanđelje' i 'Zbornik popa Dragolja' je zapostavljen zato što su ispitivači ovih tekstova osjećali da je on nastao negdje između Makedonije i Srbi-

${ }^{22}$ Radoslav Rotković, „Misli i popijevke Miroslava Zanovića“, Stvaranje, br. 6, Titograd, 1978, 781-789.

${ }^{23}$ Radoslav Rotković, „O nekim ,prazninama“ u crnogorskom nasljeđu srednjega vijeka“, Stvaranje, br. 3, Titograd, 1978, 343-362.

${ }^{24}$ Dr. Vojislav P. Nikčević, Crnogorska književna raskršća, Matica crnogorska, Cetinje, 1996, 169-179; Milorad Nikčević, „Jagićevo izdanje Marijinskog evanđelja (Berlin, 1883)“", u knjizi: Komparativna filološka odmjeravanja, Osijek - Cetinje, 2006, 313-336. 
je, južno od Bosne ali ne u Dalmaciji a nijesu mogli da se sjete šta bi se to moglo nalaziti između ovih krajeva.“25

Izborom iz djela Krsta Ivanovića, ${ }^{26}$ znamenitoga Budvanina, analiste, pjesnika, dramskog pisca, istoriografa i teatrologa, koji je slavu stekao daleko od zavičaja, u Veneciji, Rotković je ovog zaboravljenoga kanonika predstavio u svim žanrovima u kojima se ogledao. I osmišljen da ukaže na raznovrsnost Ivanovićevih interesovanja i da podstakne na nove prijevode i priređivanja, ovaj izbor sadrži prijevode odlomaka iz obimnijih Ivanovićevih djela - Budvanskih anala, Istorije rata svete lige protiv Turaka i Pozorišnih uspomena iz Venecije - kao i epske i lirske pjesme, pisma i drame. Znatan dio tekstova preveo je sam Rotković a istraživanja o ovome piscu obavio je uglavnom u Veneciji. Za Ivanovića Rotković konstatuje: „On je bio čovjek čiji se glas čuo i slušao. Trebalo je objasniti da li je taj njegov uspjeh bio posljedica nesposobnosti onoga doba da shvati što je umjetnost ili zasluga njegova talenta koji je kroz mnoga ograničenja, i lična i društvena, uspio da prodre svojom vizijom svijeta, poklanjajući, kao i Minerva, jednaku pažnju i peru i maču, sreći i stradanju. “27 Slično kao i Ivanović, ni drugi slavni Budvanin, Stefan Zanović, sve do pojave Rotkovićeva izbora, ${ }^{28}$ u svojoj domovini nije bio zastupljen knjigom. Istina, o Zanoviću se dosta pisalo, ponajviše zbog avanturističkoga duha i živopisne biografije, no njegov literarni rad nije bio naročito poznat. Nešto njegovih tekstova bilo je razasuto po periodici i antologijama, ponešto je publikovao i zaslužni Mirko Brajer u, do danas najcjelovitijoj, monografiji o Zanovićima, ${ }^{29}$ no svoju prvu knjigu objavljenu u Crnoj Gori ovaj avanturista dobio je tek 1978. godine, sa cijela dva vijeka zakašnjenja. Kao i u Ivanovićevu slučaju, Rotković je posegao za što širim izborom iz stvaralaštva pa se u ovom izboru mogu naći - misli, politički, istoriografski i prozni tekstovi, pisma, drame i pjesme Stefana Zanovića. Do dijela građe Rotković je došao u Amsterdamu, gradu u kojem je Zanović oduzeo sebi život, a dio tekstova je sam preveo.

Godina 1979. od posebnog je značaja iz dva razloga. Naime, 28. februara te godine Rotković je u Zagrebu odbranio doktorsku disertaciju Oblici $i$ dometi bokokotorskih prikazanja. Prilog istoriji drame XVII i XVIII vijeka,

\footnotetext{
${ }^{25}$ Radoslav Rotković, „O nekim „,prazninama“ u crnogorskom nasljeđu srednjega vijeka“, Stvaranje, br. 3, Titograd, 1978, 359.

${ }^{26}$ Krsto Ivanović, Minerva za stolom, biblioteka „Luča“, Pobjeda, Titograd, 1978.

${ }^{27}$ Radoslav Rotković, predgovor u knjizi: Krsto Ivanović, Minerva za stolom, biblioteka „Luča“, Pobjeda, Titograd, 1978, 38.

${ }^{28}$ Stefan Zanović, Pakao ili nebo, biblioteka „Luča“, Pobjeda, Titograd, 1979.

${ }^{29}$ Mirko Breyer, Antun conte Zanović i njegovi sinovi, Roman života jedne paštrovsko-budljanske porodice u pretprošlom i prošlom vijeku (1720-1834), Zagreb, 1928.
} 
pred komisijom koju su činili prof. dr Rafael Bogišić, prof. dr Eduard Hercigonja i prof. dr Franjo Švelec. I drugo, u časopisu Stvaranje Rotković je objavio studiju „Pregled crnogorske literature. Od najstarijih vremena do 1918“.

Kao posebna knjiga Rotkovićeva disertacija objavljena je tek 2000. godine. ${ }^{30}$ Ovom monografijom Rotković je zaokružio svoje višedecenijsko bavljenje fenomenom crkvene drame u Boki Kotorskoj. Sveobuhvatan je to pregled porijekla, postanka, dosadašnjih proučavanja, te komparativni preśek - $\mathrm{s}$ posebnim osvrtom na najviše domete ostvarene u djelu Ivana Antuna Nenadića - crnogorske pasionske baštine. Rotković opisuje 24 teksta i jedan prijevod koji pripadaju ovom korpusu, od monologa do razvijene dramske radnje, vrši njihovu klasifikaciju i nudi poredbenu analizu. Više prostora posvećuje umjetnički uspjelijem ostvarenju Ivana Antuna Nenadića Prikazanje Muke Jezusove, te u završnom dijelu monografije raspravlja o pravopisnim, prozodijskim, fonetskim, morfološkim i sintaksičkim osobinama jezika bokokotorskih prikazanja. U rezimeu ističe: „S obzirom na nizak umjetnički nivo svih bokokotorskih prikazanja, sem Nenadićevog, treba da zaključimo da je ovaj rad brojnih prepisivača, od kojih mnogi nijesu imali nikakve veze sa bogosluženjem, prvenstveno značajan za čuvanje narodnog jezika u vrijeme mletačke okupacije. A podržavanje pozorišne tradicije olakšalo je prodor svjetovnog pozorišta i svjetovne drame. ${ }^{\text {“31 }} \mathrm{U}$ prikazu ove studije književni kritičar Borislav Jovanović naglašava: „Rotković je kroz istraživanje prikazanja, odnosno, crkvenog života na Crnogorskom primorju kroz 17. i 18. vijek izvršio i hronološko-sintetičan uvid u književna, kulturna i politička obilježja perioda, spajajući poznato sa novootkrivenim. I što je najbitnije, proučen je zaobilaženi ili manje fokusirani segment barokne književnosti, nastale na ovom području. Zbog toga je ova knjiga, kako u njenom podnaslovu stoji, i prilog istoriji drame 17. i 18. vijeka.“32

Pojava „Pregleda crnogorske literature. Od najstarijih vremena do 1918. ${ }^{\text {‘33 }}$ krupan je događaj za modernu crnogorsku književnu istoriografiju. Prethodni radovi koji su imali za cilj dijahronijski opis književnosti u Crnoj Gori, Pregled književnog rada Crne Gore od vladike Vasilija do 1918. Trifuna Đukića i enciklopedijska jedinica Crna Gora - Književnost iz prvog izdanja Enciklopedije Jugoslavije čiji je autor Vido Latković, tretirale su crno-

${ }^{30}$ Radoslav Rotković, Oblici $i$ dometi bokokotorskih prikazanja. Prilog istoriji drame XVII i XVIII vijeka, CNP, Podgorica, 2000.

${ }^{31}$ Isto, 237.

${ }^{32}$ Borislav Jovanović, „Pozorišne i jezičke spone“, Pobjeda, br. 12554, Podgorica, 25. XI 2000, 30.

${ }^{33}$ Dr Radoslav Rotković, „Pregled crnogorske literature. Od najstarijih vremena do 1918“, Stvaranje, br. 4, Titograd, 1979, 587-654.

678 
gorsku književnost kao regionalnu, a njene početke vezivali za pojavu vladike Vasilija Petrovića i njegove Istorije o Crnoj Gori. Tek je radovima Milorada Stojovića ${ }^{34}$ i Vojislava P. Nikčevića ${ }^{35}$ krajem šezdesetih godina ponuđena jedna drugačija paradigma crnogorske literarne povijesti. Tu se, naime, crnogorska književnost decidirano određuje kao nacionalna, a njeni počeci vezuju za epohu srednjega vijeka. No, tek je Rotkovićev Pregled donio cjelovit, sistematičan i sveobuhvatan uvid u crnogorsko književno nasljeđe, u kontinuitetu, od početaka pismenosti do 1918. godine. Rotković je svoj Pregled podijelio u petnaest poglavlja, time grubo skicirajući i nacrt jedne moguće književne periodizacije: I Književnost dukljansko-zetskog perioda (IXXII vijek); II Nemanjićki intermeco; III Obnova Zete; IV Humanizam i renesansa; V Barok; VI Prelazno doba Petra I Petrovića; VII Petar II Petrović Njegoš; VIII Vukovi saradnici; IX Stefan Mitrov Ljubiša; X Crnogorska poezija od Njegoša do 1918; XI Marko Miljanov i drugi pripovjedači do 1918; XII Dramska književnost do 1918; XIII Putopisi i memoari; XIV Kritika i nauka i XV Crnogorska književnost prema drugima. Premda neka novija saznanja - prije svega ona vezana za problem periodizacije - nijesu u svemu podudarna sa njenom osnovnom shemom, ova je obuhvatna sinteza do danas ostala najpouzdaniji vodič kroz vjekove trajanja crnogorske književnosti. Uostalom, sam Rotković u radu „Stara crnogorska književnost. Periodizacija“ djelimično modifikuje koncept ranije periodizacije, predlažući da se za prednjegoševsko doba usvoji ,naziv Stara crnogorska književnost, a unutrašnje strukturiranje toga dugog perioda od možda 10 vjekova treba izvesti u tri etape: Srednji vijek, Humanizam i renesansa i Barok i prosvjetiteljstvo“. ${ }^{36} \mathrm{Za}$ drugo izdanje Enciklopedije Jugoslavije Rotković je, u okviru jedinice Crnogorci - Književnost, napisao djelove o usmenoj književnosti te najveći dio odrednice Pisana književnost (samo je dio o književnosti XIX vijeka obradio dr Božidar Pejović). Kontinuirano i plodotvorno bavljenje crnogorskom književnošću preporučilo je Rotkovića da se nađe u timu autora (uz dr Jovana Čađenovića, dr Slobodana Vujačića, dr Radomira Ivanovića i dr Novaka Kilibardu) koje je početkom osamdesetih godina Crnogorska akademija nauka i umjetnosti okupila s ciljem izrade prve cjelovite istorije crnogorske književ-

${ }^{34}$ Milorad Stojović, „O periodizaciji crnogorske književnosti“", Stvaranje, br. 2-3, Titograd. 1968.

${ }^{35}$ Vojislav Nikčević, „Narodni jezik u crnogorskoj književnosti prednjegoševskog doba“, Jezik, br. 1, 19-22. i br. 2, 41-52, Zagreb, 1968/69.

${ }^{36}$ Dr Radoslav Rotković, „Stara crnogorska književnost. Periodizacija“, Zbornik radova profesora i saradnika Nastavničkog fakulteta, br. 5-6, Nikšić, 1982, 309. 
nosti. ${ }^{37}$ Prema Rotkovićevim riječima, on je svoj dio posla obavio predavši Akademiji rukopis dijela istorije koji obuhvata razdoblje od početaka pismenosti do Njegoša, no što se dalje desilo s tim rukopisom, ostaje nepoznanica.

Monografijom Tragajući za Ljubišom ${ }^{38}$ Rotković je zaokružio još jedan važan segment svojih višegodišnjih istraživanja. Interesovanje za Stefana Mitrova Ljubišu posebno je naraslo od sredine sedamdesetih. Nakon velikoga naučnog skupa posvećenoga njegovome životu i djelu (CANU, 1976) pojavile su se dvije dragocjene monografije o njegovu stvaralaštvu - Književno djelo Stefana Mitrova Ljubiše dr Božidara Pejovića, 1977. godine, i Pripovijedanje kao opsesija dr Nova Vukovića, 1980. godine. Ovim dvjema izuzetnim književnoistorijskim studijama Ljubišino djelo nanovo je aktuelizovano i približeno savremenome čitaocu, no tek sa Rotkovićevom knjigom Ljubiša nam je predstavljen u totalu - i kao homo politicus i kao homo poeticus. Pažljivo uronivši u arhivsku građu Rotković je minuciozno rekonstruisao Ljubišin životopis, posebno njegovu političku djelatnost, a na samom početku razriješio i dva sporna mjesta - pitanje imena i godine rođenja. Na osnovu budvanskih matičnih knjiga Rotković je, naime, ustanovio da je pisac rođen 1822. godine, a ne 1824. kako se vjerovalo ranije. Takođe, analizom izvornih dokumenata konačno je utvrđeno da je pjesnikovo ime Stefan a ne Stjepan! Težište prvog dijela knjige je na Ljubišinoj biografiji i političkoj djelatnosti, dok nam u drugom dijelu Rotković, na unekoliko nov način, približava Ljubišu-pisca. U poglavlju „Politika Ljubišine poetike“ Rotković analizira neke elemente Ljubišine proze - „namjerne“ anahronizme, socijalni stav, hrišćanski moral i antireligiozni humor, motiv sloge... - identifikujući njihovu funkciju u samome tekstu. U „Pogledu u majstorsku radionicu“, s osloncem na Pejovića, upoređuju se neke verzije i prati geneza tekstova. „Otkrivanje lika“ je poglavlje u kojemu se kroz niz fragmenata upućuje na različite pripovjedačke postupke u uvođenju i građenju likova, kompoziciju i sl. „Matica i kovnica jezika“" posvećena je Ljubišinoj leksici i odnosu prema njenome nepresušnom vrelu - narodnim govorima. Posebno je originalna Rotkovićeva analiza oblika govora, u istoimenom poglavlju. Polemišući sa postavkama koje Ljubišu svode na status narodskog pričaoca, Rotković u njegovoj prozi prepoznaje razuđen repertoar oblika govora: pripovjedni; ispovjedni; razgovorni; agonalni; pregovorni, nagovorni ili dogovorni; raspravni; suparnički ili prepirni i oratorski. Poglavljem o funkciji stilskih figura u Ljubišinoj prozi Rotković zatvara dio knjige posvećen Ljubišinu književnom djelu. Svodeći re-

${ }^{37}$ Viđi o tome: Dr Radoslav Rotković, „Prva Istorija crnogorske književnosti“, Pobjeda, br. 6106, Titograd, 4. XII 1982, 9.

${ }^{38}$ Radoslav Rotković, Tragajući za Ljubišom, Pobjeda, Titograd, 1980. 
zultate svojih sveobuhvatnih istraživanja Ljubiše, Rotković lucidno poentira: „Imao je on tanke prste za filigranski rad ali je zbog nesrećnog stanja primorskog dijela svoje otadžbine i potrebe njenog buđenja iz srednjevjekovnog sna bio prinuđen da lije zvona i kuje mačeve. I dobro ih je kovao. ${ }^{\text {39 }} \mathrm{U}$ prikazu ove monografije dr Krsto Pižurica ističe: „Jedna od novina u Rotkovićevom pristupu Ljubišinom djelu je u tome da on naglašenije od drugih njegovo djelo povezuje sa njegovom političkom aktivnošću. Jedno poglavlje ove monografije, kao što smo vidjeli je pod naslovom Politika Ljubišine poetike i nije posrijedi igra riječi, već je naslov osmišljen, sadržajem opravdan. Rotković ne misli da je Ljubiša svoju umjetničku prozu podredio potrebi dnevne, tekuće politike, već da je to djelo angažovano u širem značenju, upotrebom simbola, aluzija i reminiscencija, angažovano je, dakle, umjetničkim iskazom. “40 Rotković će se Ljubiši vratiti 1988. godine, kada će za potrebe kritičkog izdanja Sabranih djela prirediti dva toma Ljubišinih prijevoda, članaka, govora i pisama. ${ }^{41}$ Pored toga, Rotković je osamdesetih priredio dvije antologije, ${ }^{42}$ jednu hrestomatiju (sa Sretenom Perovićem), ${ }^{43}$ jedan izbor izvora i legendi ${ }^{44}$ i učestvovao u priređivanju kritičkoga izdanja Istorije o Crnoj Gori vladike Vasilija Petrovića. ${ }^{45}$

Srednjovjekovnom književnom nasljeđu Radoslav Rotković se vratio knjigom Kraljevina Vojislavljevića XI-XII vijeka: izvori i legende, 1999. godine. ${ }^{46} \mathrm{U}$ ovoj kapitalnoj knjizi Rotković je sabrao izvore za najstariji period, od doseljenja Slovena na ove prostore do pada Duklje pod Rašku krajem XII vijeka. Proprativši izvore instruktivnim studijama i komentarima, Rotković je građu podijelio na nekoliko poglavlja obuhvativši političku, crkvenu i knji-

${ }^{39}$ Isto, 236.

${ }^{40}$ Krsto Pižurica, „Dvije studije o Ljubiši“, Stvaranje, br. 5, Titograd, 1985, 638.

${ }^{41}$ Stjepan Mitrov Ljubiša, Boj na Visu: prevodi, članci, govori, Sabrana djela, knj. III, Crnogorska akademija nauka i umjetnosti, Titograd; Univerzitetska riječ, Nikšić; Istorijski arhiv, Budva, 1988; Stjepan Mitrov Ljubiša, Pisma, Sabrana djela, knj. IV, Crnogorska akademija nauka i umjetnosti, Titograd; Univerzitetska riječ, Nikšić; Istorijski arhiv, Budva, 1988.

${ }^{42}$ Antologija crnogorske kratke priče 1944-1984, Stvaranje, br. 12, Titograd, 1984, 1445-1638; Antologija crnogorske poezije 1945-1985, Stvaranje, br. 12, Titograd, $1985,1417-1500$.

${ }^{43}$ Savremena drama i pozorište u Crnoj Gori, Sterijino pozorje, Novi Sad, 1987.

${ }^{44}$ Sazdanje Cetinja: izvori i legende, Leksikografski zavod Crne Gore, Titograd, 1984.

${ }^{45}$ Vasilije Petrović, Istorija o Crnoj Gori, Leksikografski zavod Crne Gore, Tito$\operatorname{grad}, 1985$.

${ }^{46}$ Dr Radoslav Rotković, Kraljevina Vojislavljevića XI-XII vijeka: izvori i legende, Print, Podgorica, 1999. 
ževnu povijest ove epohe. Posebno valja naglasiti činjenicu da je u ovoj knjizi prvi put prevedena najstarija nama poznata verzija Kraljevstva Slovena Popa Dukljanina, ona koju je Mavro Orbin publikovao na italijanskom, 1601. godine. Kraljevstvu Slovena Popa Dukljanina Rotković je posvetio znatan dio knjige, argumentovano komentarišući iznova i na osnovu najnovijih saznanja brojna otvorena pitanja vezana za autorstvo, vrijeme, okolnosti ili pojedina sporna mjesta iz samog spisa. Prijevod Orbina Rotković je opremio komentarima i tekstološkim poređenjima sa drugim verzijama hronike. U poglavlju „Pismenost i književnost“ data je sveobuhvatna slika književnih prilika ovog perioda: od rasprave o paleoslovenskoj pismenosti - crtama i rezama, te slovenskim runama, do pregleda prepisivačke i prijevodne djelatnosti, s posebnim osvrtom na odjeke narodnoga stvaralaštva. Na kraju, Rotković donosi izbor tekstova propraćenih komentarima i objašnjenjima, malu antologiju crnogorske književnosti dukljanskog perioda. Ovu antologiju čine: Andreacijeva povelja, Legenda o svetom Tripunu, barski epitafi, Muka gospoda Isusa Hrista (iz Pontifikala Kotorske biskupije), te odlomci iz Knjige o čudima blaženog Vladimira Zećanina iz Krajine, Kraljevstva Slovena Popa Dukljanina i Čuda blaženog Mikule. Poglavlje o književnosti i pismenosti Rotković je, u proširenoj verziji, objavio i u Ilustrovanoj istoriji crnogorskog naroda I, dodavši tom korpusu i legendu o bokeljskim mučenicima Petrilovrijencima. ${ }^{47} \mathrm{U}$ drugoj knjizi ove edicije nalazi se poglavlje o prepisivačkoj djelatnosti u Zeti pod Nemanjićima. Ovim naslovom obuhvaćeni su skriptoriji, Vukanovo jevanđelje, Ilovička krmčija, Divoševo jevanđelje, natpisi (ćirilski i latinski), zavještanja, hronograf Vasilija zovom Zlodjeja, povelje, te apokrifi u Zborniku prezvitera Vasilija zovom Dragolja. ${ }^{48}$

Kada je 1990. godine dr Slobodan Kalezić objavio prvi tom hrestomatije Crnogorska književnost u književnoj kritici, koji se odnosio na tzv. staru književnost, u ovoj se knjizi našlo čak devet tekstova Radoslava Rotkovića. ${ }^{49}$ Takođe, Rotković je najcitiraniji autor i u posthumno objavljenoj knjizi dr Vojislava P. Nikčevića Istorija crnogorske književnosti od početaka pisme-

${ }^{47}$ Radoslav Rotković, Ilustrovana istorija crnogorskog naroda I, Pomorje zetsko, Pomorje zapadno, Kraljevina Vojislavljevića, Crnogorska izdanja, Podgorica, 2003, 163-213.

${ }^{48}$ Radoslav Rotković, Ilustrovana istorija crnogorskog naroda II, Zeta u državi Nemanjića (1186-1356), Crnogorska izdanja, Podgorica, 2003, 240-259.

${ }^{49}$ Ovđe bi valjalo podśetiti da je prijedlog za izradu jedne ovakve hrestomatije prvi formulisao baš Rotković, i to još 1971. godine. Viđi: Radoslav Rotković, „Istorija crnogorske književnosti je gotova, treba je samo ukoričiti“, Ovdje, br. 28, Titograd, $1971,7$. 
Radoslav Rotković kao istoričar književnosti

nosti do XIII. vijeka ${ }^{50}$ koju je i recenzirao. No, njegov doprinos konstituisanju moderne crnogorske književne istoriografije neuporediv je. Ipak, ne umanjujući značaj brojnih drugih istoričara književnosti i publicista koji su u potonje četiri decenije značajno doprinijeli stvaranju nove, modernom dobu primjerene, recepcije crnogorske književnosti u njenom milenijumskom trajanju, a imajući u vidu obim i domete njegova djela, bez i malo prećerivanja moglo bi se zaključiti, kroz parafrazu jednog Kišova iskaza izrečenog povodom Borhesa, da se crnogorska književna istoriografija dijeli na onu do Radoslava Rotkovića i na onu poslije njega.

\section{Bibliografija}

- Antologija crnogorske književnosti IX-XX vijek, Stvaranje, br. 10, Titograd, 1976.

- Antologija crnogorske kratke priče 1944-1984, Stvaranje, br. 12, Titograd, 1984.

- Antologija crnogorske poezije 1945-1985, Stvaranje, br. 12, Titograd, 1985.

- Breyer, Mirko, Antun conte Zanović i njegovi sinovi. Roman života jedne paštrovsko-budljanske porodice u pretprošlom i prošlom vijeku (1720-1834), Zagreb, 1928.

- Brković, Jevrem, „Ako se rodilo zdravo dijete zašto ćutimo ili o jednoj antilogičnoj antologiji“, Oko, Zagreb, br. 126, 13-27. siječnja 1977.

- Čirgić, Adnan, „Radoslav Rotković kao jezikoslovac“, Lingua Montenegrina, broj 4, Cetinje, 2009.

- Ivanović, Krsto, Minerva za stolom, biblioteka „Luča“, Pobjeda, Titograd, 1978.

- Jovanović, Borislav, „Pozorišne i jezičke spone“, Pobjeda, br. 12554, Podgorica, 25. XI 2000.

- Lipovina, Ljiljana, Radoslav Rotković: bio-bibliografija, Dukljanska akademija nauka i umjetnosti, Podgorica, 2009.

- Ljubiša, Stjepan Mitrov, Boj na Visu: prevodi, članci, govori, Sabrana djela, knj. III, Crnogorska akademija nauka i umjetnosti, Titograd; Univerzitetska riječ, Nikšić; Istorijski arhiv, Budva, 1988.

${ }^{50}$ Vojislav P. Nikčević, Istorija crnogorske književnosti od početaka pismenosti do XIII. vijeka, priredili Adnan Čirgić i Aleksandar Radoman, Institut za crnogorski jezik i jezikoslovlje „, Vojislav P. Nikčević“", Cetinje, 2009. 
- Ljubiša, Stjepan Mitrov, Pisma, Sabrana djela, knj. IV, Crnogorska akademija nauka i umjetnosti, Titograd; Univerzitetska riječ, Nikšić; Istorijski arhiv, Budva, 1988.

- Nenadić, Ivan Antun, Slijepa pravda, biblioteka „Luča“, Pobjeda, Titograd, 1975.

- Nenadić, Ivan Antun, Drame, „Književnost Crne Gore od XII do XIX vijeka“, Obod, Cetinje, 1996.

- Nikčević, Vojislav, „Narodni jezik u crnogorskoj književnosti prednjegoševskog doba“, Jezik, br. 1, 19-22. i br. 2, 41-52, Zagreb, $1968 / 69$.

- Nikčević, Vojislav P., Crnogorska književna raskršća, Matica crnogorska, Cetinje, 1996.

- Nikčević Vojislav P., Istorija crnogorske književnosti od početaka pismenosti do XIII. vijeka, priredili Adnan Čirgić i Aleksandar Radoman, Institut za crnogorski jezik i jezikoslovlje „, Vojislav P. Nikčević“", Cetinje, 2009.

- Nikčević, Milorad, „Jagićevo izdanje Marijinskog evanđelja (Berlin, 1883)“, u knjizi: Komparativna filološka odmjeravanja, Osijek - Cetinje, 2006.

- Pasković, Ljudevit, Sveti plamen, biblioteka „Luča“, Pobjeda, Titograd, 1987.

- Petrović, Vasilije, Istorija o Crnoj Gori, Leksikografski zavod Crne Gore, Titograd, 1985.

- Pižurica, Krsto, „Dvije studije o Ljubiši“, Stvaranje, br. 5, Titograd, 1985.

- Radojević, Danilo, „Istraživanja crnogorske književnosti“, Stvaranje, br. 7-8, Titograd, 1977.

- Rotković, Radoslav, „Razgovor neugodni“, Pobjeda, god. 13, br. 12, 18. 3. 1956.

- Rotković, Radoslav, „Privremeno rješenje“, Pobjeda, god. 24, br. 2603, 30. 3. 1967.

- Rotković, Radoslav, „Da li je Dukljanin bio Roman“, Ovdje, br. 29, Titograd, 1971.

- Rotković, Radoslav, „Izvori i uzori Ljetopisa Popa Dukljanina“, Ovdje, br. 30, Titograd, 1971.

- Rotković, Radoslav, „Istorija crnogorske književnosti je gotova, treba je samo ukoričiti“, Ovdje, br. 28, Titograd, 1971.

- Rotković, Radoslav, Crnogorsko književno nasljeđe I, Pobjeda, Titograd, 1976. 
Radoslav Rotković kao istoričar književnosti

- Rotković, Radoslav, „Ništa nije opasnije od neznanja kad je aktivno“, Oko, Zagreb, br. 127, 27. siječnja - 10. veljače 1977.

- Rotković, Radoslav, „Petrarkista Đorđe Bizanti Kotoranin“, Stvaranje, br. 4, Titograd, 1977.

- Rotković, Radoslav, „O nekim 'prazninama“ u crnogorskom nasljeđu srednjega vijeka“, Stvaranje, br. 3, Titograd, 1978.

- Rotković, Radoslav, „Misli i popijevke Miroslava Zanovića“, Stvaranje, br. 6, Titograd, 1978.

- Rotković, Radoslav, „Pregled crnogorske literature. Od najstarijih vremena do 1918“, Stvaranje, br. 4, Titograd, 1979.

- Rotković, Radoslav, Tragajući za Ljubišom, Pobjeda, Titograd, 1980.

- Rotković, Radoslav, „Stara crnogorska književnost. Periodizacija“, Zbornik radova profesora i saradnika Nastavničkog fakulteta, br. 5-6, Nikšić 1982.

- Rotković, Radoslav, „Prva Istorija crnogorske književnosti“, Pobjeda, br. 6106, Titograd, 4. XII 1982.

- Rotković, Radoslav, „Ivan Bona Boliris, kotorski humanista“, Ars, br. 1, Cetinje, 1987.

- Rotković, Radoslav, Kraljevina Vojislavljevića XI-XII vijeka: izvori i legende, Print, Podgorica, 1999.

- Rotković, Radoslav, Oblici i dometi bokokotorskih prikazanja. Prilog istoriji drame XVII i XVIII vijeka, Crnogorsko narodno pozorište, Podgorica, 2000.

- Rotković, Radoslav, Ilustrovana istorija crnogorskog naroda I, Pomorje zetsko, Pomorje zapadno, Kraljevina Vojislavljevića, Crnogorska izdanja, Podgorica, 2003.

- Rotković, Radoslav, Ilustrovana istorija crnogorskog naroda II, Zeta u državi Nemanjića (1186-1356), Crnogorska izdanja, Podgorica, 2003.

- Savremena drama i pozorište u Crnoj Gori, Sterijino pozorje, Novi Sad, 1987.

- Sazdanje Cetinja: izvori i legende, Leksikografski zavod Crne Gore, Titograd, 1984.

- Stojović, Milorad, „O periodizaciji crnogorske književnosti““, Stvaranje, br. 2-3, Titograd, 1968.

- Torbarina, Josip, „Naš prilog evropskom petrarkizmu“, Forum, br. 4-5, Zagreb, 1974.

- Vrčević, Vuk, Maštanija, biblioteka „Luča“, Pobjeda, Titograd, 1975.

- Zanović Stefan, Pakao ili nebo, biblioteka „Luča“, Pobjeda, Titograd, 1979. 


\section{Aleksandar RADOMAN}

\section{RADOSLAV ROTKOVIĆ AS A HISTORIAN OF LITERATURE}

This article gives an overview of Radoslav Rotković's work in the area of history of literature. Radoslav Rotković is an extremely important figure in Montenegrin science and culture, present for more than sixty years as an author in several disciplines: literary criticism, history of literature, history and linguistics. Apart from that, Rotković is also a significant writer. In his works from the area of history of literature he mainly dealt with older, unexplored periods of Montenegrin literature - Middle Ages, Renaissance, Baroque, and Enlightenment. His work on discovering and collecting works of old writers is also of great importance. He is also the author of monographs on Stefan Mitrov Ljubiša, ecclesiastical drama in Boka Kotorska, as well as the first review of Montenegrin literature. His approach is characterized by a comprehensive insight into socio-political circumstances of an epoch, as well as by precise analyses of texts and sharp observations on writers and their works.

Keywords: Radoslav Rotkovic, history of literature, Montenegrin literature, Middle Ages, ecclesiastical drama, Stefan Mitrov Ljubiša 
LINGUA MONTENEGRINA, god. III, br. 5, Cetinje, 2010.

Institut za crnogorski jezik i jezikoslovlje „Vojislav P. Nikčević“

UDK 82:929 Lisac J.

In memoriam

Josip LISAC (Zadar)

Sveučilište u Zadru

\section{ŽARKU MULJAČIĆU U SPOMEN}

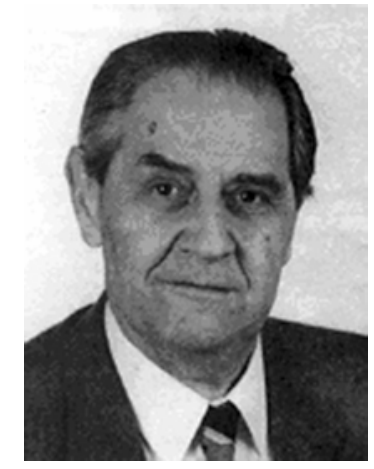

Hrvatski lingvist Žarko Muljačić, rođen 2. listopada 1922. u Splitu, preminuo je 6. kolovoza 2009. u Zagrebu. U svom je bogatu i znanstveno razvedenu životu ostvario mnogo, kao malo koji drugi hrvatski učenjak humanističkog usmjerenja. Nakon kraćega profesorskog srednjoškolskog rada u Puli i Splitu radio je u Dubrovniku (1950.-1953.) i u Zagrebu (1953.-1956.), potpuno sazrio i doživio punu afirmaciju u Zadru (1956.-1972.), krunu karijere dosegao u Berlinu (1972.-1988.) gdje je bio do 1997. otkad je živio u Zagrebu, gdje je u mirovini nastavio svoj neumorni rad. U tim je sredinama djelovao veliki naš znanstvenik, uvijek sređen i plodan, sav u nalaženju znanstvene istine te u obogaćivanju kolegijalne suradnje. I taj ritam zadržavanja u pojedinim gradovima - po tri godine u Dubrovniku i u Zagrebu, po šesnaest godina u Zadru i u Berlinu - makar za Muljačića i ne bio najsretniji, kao da govori o marljivu počinjanju znanstvenoga života i o kasnijem punom proplamsaju talenta i kapaciteta. Bio je arhivist u Dubrovniku, sveučilišni nastavnik u Zagrebu, u Zadru i u Berlinu, gdje je, nakon Jagića, bio prvi Hrvat sveučilišni profesor i gdje je razvio jagićevsku aktivnost, iako su se vremena promijenila u svemu, pa i u filologiji. Bio je istaknuti fonolog, proučavatelj 
Josip LISAC

dalmatskoga u Dubrovniku i dalmatskoga općenito, fonolog koji se zanima i za hrvatsku fonologiju i za fonologiju romanskih jezika, pa i za fonologiju općenito. Autorom je svjetski glasovite Opće fonologije i fonologije suvremenoga talijanskog jezika. Talijansko izdanje objavljeno u Bologni 1969., hrvatsko u Zagrebu 1964. i 1972; knjiga o općoj fonologiji tiskana je i u Barceloni na španjolskom. Objavio je i druga važna izdanja o talijanskom jeziku, npr. Introduzione allo studio della lingua italiana, Torino, 1971, 1982. Muljačić se bavio Tomom Basiljevićem, predstavnikom prosvjetiteljstva u Dubrovniku, poglavito pak Albertom Fortisom. O obojici je objavio knjige: Tomo Basiljević-Bassegli, predstavnik prosvjećenja u Dubrovniku, Beograd, 1958; Putovanja Alberta Fortisa po Hrvatskoj i Sloveniji (1765-1791), Split, 1996. Talijanskom jeziku među romanskim jezicima u Muljačićevu znanstvenom interesu pripada prvo mjesto, no svi su romanski i drugi jezici promatrani teoretskim očima; otuda npr. relativistički pristup u proučavanju geneze i povijesti romanskih jezika u novije vrijeme; tu je bitno razlikovanje viših, srednjih i nižih jezika. Obogaćujući hrvatsku lingvistiku ujedno je mnogo pridonosio i poznavanju hrvatskoga jezika; spominjem npr. njegove prinose o čakavizmu, o Petru Zoraniću i o Bartolu Kašiću. Jezična pitanja jadramske orijentacije proučavao je minuciozno dajući vrsne priloge o vezama hrvatskoga i romanskih jezika, gdje je vrlo znatno mjesto imao dalmatski jezik. O njemu je objavio i posebnu knjigu, Das Dalmatische iz 2000; uz dalmatski npr. Krka, Zadra, Dubrovnika, tu se obrađuje i dalmatski u Kotoru, Budvi, Baru, Ulcinju, Skadru itd. Knjiga Problemi manjinskih jezika u romanskim državama u Europi, publicirana 2007. u Rijeci, nagrađena je Nagradom ,Josipa Jurja Strossmayera“ 2008. godine. Dobitnikom je i nekih drugih važnih nagrada i odličja, poglavito u Italiji. U Matici hrvatskoj u Zagrebu objavljena mu je knjiga Iz dubrovačke prošlosti (2006.). Prevodio je glasovitoga ekonomskog pisca 15. stoljeća, Dubrovčanina Benedikta Kotruljevića. Bio je dopisni član HAZU, a i član drugih znanstvenih ustanova, npr. akademija u Firenci i u Rimu. Literaturu je pratio neutrudljivo iz dana u dan, njegove su bibliografije redovito izvrsne, a svoju je misao modernizirao i metodološki usklađivao. Raniji su radovi pretežno strukturalistički, noviji sociolingvistički i pragmalingvistički. U vremenu od 1940. kad je u skromnim Pregnućima objavio članak „Selo kao predmet realističkih opisivanja“ do smrti objavio je stotine bibliografskih jedinica, među njima i mnogo prikaza. Od tinejdžerskih do veteranskih godina radio je sustavno i zaneseno, pisao dobronamjerno i kritički, stvorio opus iz kojega se jasno razabire da je znanost prije svega traženje i otkrivanje istine. Od splitskih početaka do svjetskih uspjeha, uz bok Matteu Giuliju Bartoliju, Petru Skoku i Romanu Jakobsonu. 
Žarku Muljačiću u spomen

Crnogorsku problematiku obrađivao je u neveliku dijelu svoga opusa. Npr. u radu o našim pejorativima romanskoga podrijetla (Radovi Filozofskog fakulteta u Zadru, 3, 1962.) navodi mnoge dijalekatne podatke i iz Crne Gore (Banjani, Njeguši, Risan, Perast, Dobrota, Prčanj, Tivat, Grbalj itd.). Objavio je također radove „Dubrovnik i prva faza austrijske akcije u Crnoj Gori 1788. god.“ (Istorijski zapisi, 14, 1958, 1-2, 94-112), „Boravak Alberta Fortisa u Boki Kotorskoj“ (Boka, 8, 1976, 287-290). Tu je i poticaj za ovo sjećanje na velikoga jezikoslovca i filologa, nezaboravnoga Žarka Muljačića. 



\section{PRIKAZI}



LINGUA MONTENEGRINA, god. III, br. 5, Cetinje, 2010.

Institut za crnogorski jezik i jezikoslovlje „Vojislav P. Nikčević“

UDK 811.163.4'373

\author{
Milica LUKIĆ (Osijek) \\ Filozofski fakultet Sveučilišta J. J. Strossmayera
}

\title{
GOVORITI PO NJEGUŠKI
}

Adnan Čirgić, Rječnik njeguškoga govora, Biblioteka Crnogorski jezik Matice crnogorske (urednik Branko Banjević), Cetinje - Podgorica, 2009, 263. str.

Nakon smrti barda crnogorske jezične, književne i kulturne povijesti Vojislava P. Nikčevića 2007. godine Institut za crnogorski jezik i jezikoslovlje koji nosi njegovo ime dobio je dostojna zamjenika toga vrhunskog i svestranog filologa u osobi njegova učenika - mladog Adnana Čirgića, koji vjerno ide stopama svoga učitelja. Pokazuje to već sada zavidna bibliografija njegovih radova, odskora obogaćena novim naslovom iz biblioteke Matice crnogorske Crnogorski jezik - Rječnik njeguškoga govora. Već je svojom doktorskom disertacijom, koja je zaživjela i u knjigovnom izdanju, Govor podgoričkih muslimana (Sinhrona i dijahrona perspektiva) (Institut za crnogorski jezik i jezikoslovlje „Vojislav P. Nikčević“, Podgorica, 2007), Adnan Čirgić najavio kako je primarnim svojim usmjerenjem u jezikoslovnoj znanosti dijalektolog, ali i leksikograf jer je dijelom toga rada i rječnik govora podgoričkih muslimana.

Znanje o nekom jeziku kao sustavu nepotpuno je bez dobrog poznavanja njegovih organskih idioma, tako da je i ovaj leksikološki rad koji se tiče njeguškoga govora prilog boljem i potpunijem poznavanju crnogorskog jezika općenito.

Terenska istraživanja u kojima je prikupljena građa za rječnik autor je obavio uz pomoć Aleksandra Radomana u ljeto 2008. i 2009. godine, i to uglavnom u Erakovićima i Raićevićima, u selu Kopito, na katunu Kuk i Međuvršje i u nekadašnjem selu Majstori. Prema dijalektološkim klasifikacijama, njeguški govor pripada podlovćenskoj grani crnogorskih govora, a prema laičkoj je definiciji, koju i sam autor spominje u Uvodnim napomenama svomu rječniku, „udrobljen od bokeljskoga i katunskoga govora“ s obzirom na to da se Njeguši i nalaze na povijesnom prijelazu između Katunske nahije 
Milica LUKIĆ

i Boke. Leksik ovoga govora obilježen je brojnim romanizmima (adio, akomodat se, bagabunda, beštija, cukar, fljaka, forca, gradela, kuražan, kužina, lumbrela, mobilje, mušketat, na atento, pamidora, profundat, provat, vadžola itd.), što bi se moglo tumačiti utjecajem bokeljskoga govora, ali je, prema istraživanjima koja je proveo autor, evidentno da neki romanizmi uopće nemaju svojih slavenskih zamjena. Jednako je tako njeguški govor obilježen i brojnim turcizmima (adet, ajvan/hajvan, avlija, besa, čakija, džomba, fukara, fukarluk, meteh, obojak, odžaklija, pašaluk; prezimena: Kadija, Belegija, Peškiri itd.), koji su svakako svjedok društveno-povijesne situacije na tomu području. Iz leksika je njeguškoga govora evidentno kako je riječ o ruralnoj sredini obilježenoj patrijarhalnim odnosima u kojoj je napose izražena povezanost čovjeka s prirodom, dakle s biljnim i životinjskim svijetom. U prilog tomu govore brojni mikrotoponimi zastupljeni u rječniku, a koji se odnose na imena livada, šuma, pašnjaka, njiva, voda, potoka, brda, putova, putljaga, staza, baština, kamenjara, serpentina, pećina, jama, uzbrdica, glavica i sl. Kotorske strane, Kršljivi Babljak, Pod Babinom glavom, Niz Trešnju, Popova pećina, Simov laz, Žanjev do, Ždrijela samo su neki od njih. Taj je dio leksika u njeguškom rječniku najzastupljeniji, a pri njegovu oblikovanju, kako bi bio što precizniji, autor je osim vlastita istraživanja u obzir uzeo i rezultate istraživanja Anđelke Martinović prema njezinu radu $O$ etnološkoj, etimološkoj $i$ toponomastičkoj karti Njeguša (s korišćenom onomastičkom građom prof. Rada Ljesara) (Bibliografski vjesnik, br. 1-2-3, Cetinje, 2004, str. 174205) te onomastičku građu Mitra Pešikana objavljenu pod nazivom Imena iz lovćenskog sela Majstori (Onomatološki prilozi, VI, Srpska akademija nauka i umetnosti, Beograd, 1985, str. 2-5).

Napomenuti je još kako su leksičke jedinice, kojih je s toponimima 4.200, složene abecednim redom natuknica, slijed natuknica je okomit; leksičke su jedinice obilježene naglascima i temeljnim gramatičkim znakama. Kada je riječ o imenskim riječima, uz njih kao gramatička oznaka stoji rod te nastavak za genitiv jednine kod imenica, dok se nepromjenjive riječi imenuju. Uz glagole stoji vidska oznaka te nastavak za prvo lice prezenta. Primjeri kontekstualne upotrebe navode se uz gotovo svaku natuknicu (osim uz one koje su značenjski potpuno prozirne), što je još jedan prilog preciznosti odčitavanja leksičko-semantičkog ekvivalenta svake riječi njeguškoga govora koji se donosi u crnogorskom književnom jeziku. Glasovni je sustav njeguškoga govora upotpunjen i suglasnikom $3(d z)$, koji doduše nije zabilježen u inicijalnoj poziciji, ali ga se nalazi primjerice u riječima biзa (kučka), bisak i bisin (pas), magaзin (ostava), maзija (momak), oзovina (zova - Sambucus racemosa i Sambucus nigra) i sl. U rječniku se ne donose posebne oznake koje bi upućivale na podrijetlo pojedinih riječi, što bi svakako dalo doprinos ko- 
munikativnosti rječnika u odnosu na one potencijalne recipijente kojima jezikoslovlje nije strukom.

Ostaje nam zaključiti kako je Rječnik njeguškoga govora Adnana Čirgića važno dijalektološko djelo za crnogorski jezik i jezikoslovlje u cjelini, koje će zasigurno svojim punim životom zaživjeti kada bude dovršena najavljena monografska studija o tomu govoru koja će uključiti i fonetsku, morfonološku, morfološku i sintaktičku obradu te da je A. Čirgić talentirani mladi jezikoslovac koji je, krenuvši putem svoga učitelja Vojislava P. Nikčevića, nastavio crnogorskome jeziku vraćati zasluženi dignitet. 

LINGUA MONTENEGRINA, god. III, br. 5, Cetinje, 2010.

Institut za crnogorski jezik i jezikoslovlje „Vojislav P. Nikčević“

UDK 821.163.4.09

\section{Vladan LALOVIĆ (Podgorica)}

\section{Milorad Nikčević, JOSIP JURAJ STROSSMAYER I NIKOLA I. PETROVIĆ NEGOŠ - u korespondenciji i dokumentima, Osijek, 2009.}

U okviru manifestacije „Dani Ivana Mažuranića (1814-1890) u Crnoj Gori 2009“, održane na Cetinju od 27. 9. do 01. 10. 2009, upriličena je promocija knjige Josip Juraj Štrosmajer i Nikola I. Petrović Njegoš - u korespondenciji i dokumentima, koja predstavlja još jedan prilog plodnom naučnom radu prof. dr Milorada Nikčevića. Ona, pored njegovih brojnih radova, osvjetljava jedan period (drugu polovinu 19. vijeka) crnogorsko-hrvatskih političkih, kulturnih i duhovnih veza, kroz korespondenciju eminentnih ličnosti crnogorske i hrvatske povjesnice: knjaza Nikole Petrovića Njegoša i biskupa bosansko-đakovačkog i srijemskog Josipa Jurja Štrosmajera.

Pored uvodnog slova, u kome nam autor koncizno i pregledno izlaže strukturu i sadržaj knjige, ona se kompoziciono sastoji iz tri dijela.

Prvi dio čine naučne studije (njih ukupno 6): Nad povijesnim tokovima i izvorima korespondencije J. J. Strossmayera i Nikole I Petrovića Njegoša; Prinosi J. J. Strossmayera i Nikole I Petrovića Njegoša na uspostavljanju Konkordata (1886); Staroslavenski jezik u funkciji bogosluženja katolika Barske nadbiskupije i o ne/riješenim pitanjima Parčićeva „Misala“ (1893.) $i$ Strossmayerova ćirilometodska djelatnost pretočena u pjesmu i priču na prostoru Crne Gore i Hrvatske, čiji je I i II dio napisao prof. dr Nikčević, a III i IV dr Milica Lukić. Studije su nastale na temelju prepiske, koju je đakovački biskup vodio, sa knjazom Nikolom i drugim crnogorskim zvaničnicima. Razvrstane su po tematskim cjelinama i oslonjene na relevantnu građu i izvore, koje je autor pažljivo obradio i raščlanio, te iznova objavio u ovom izdanju. U njima znalački analizira, preko brojnih pisama, karakter odnosa korespondenata, pružajući nam jasan uvid u ondašnju društvenu-političku stvarnost, kulturne i duhovne veze, na slovenskom jugu i šire. U ovom dijelu knjige nalaze se još dvije studije: dr Milice Lukić, Uloga Šimuna Milinovića barskog biskupa glagoljaša u oživljavanju ćirilometodske ideje u I polovici 19. stoljeća u Crnoj Gori, i referat dr Dima Vujovića Štrosmajer i Crna Gora u prepi- 
Vladan LALOVIĆ

sci i dokumentima, sa Međunarodnog naučnog skupa održanog 1990. godine posvećenog biskupu Štrosmajeru; a koje se organski uklapaju u korpus predmetne teme.

U drugom dijelu knjige sabran je veći broj pisama naslovljenih na dvije visoke adrese - Cetinju i Đakovu, kao i na druge značajne ličnosti iz političkog, kulturnog i duhovnog miljea ondašnjeg vremena, poput arcibiskupa barskog Šimuna Milinovića, Jovana Sundečića, F. Račkog i državnog sekretara Svete Stolice kardinala Rampolu. Ova pisma je dr Vladimir Košćak naznačio u svom radu Izvori, bibliografija i literatura o J. J. Strossmayeru. Tu su još i neobjavljena pisma nadbiskupa Milinovića prosvjetnim i drugim čelnicima cetinjske Vlade, koja se čuvaju u Državnom arhivu Crne Gore. Kako i sam autor navodi, ova priložena pisma poslužila su mu kao dopuna svojim analizama ilustracije radi, bez pretenzije na njihovo sistematizovanje.

U trećem dijelu knjige, odnosno njezinu dodatku, priložen je integralni tekst Konkordata, uporedo na latinskom i crnogorskom jeziku, kao i Ustav Svetoga Sinoda u Knjaževini Crnoj Gori iz 1904. godine.

U 19. i početkom 20. stoljeća Crnu Goru su pośećivale, duže ili kraće boravile u njoj, brojne istaknute ličnosti iz drugih krajeva, zemalja i naroda. Izvanjci (kako su kod nas obično nazivani) dali su značajan doprinos razvoju crnogorske kulture, prosvjete, prava, arhitekture i drugih oblasti, od kojih je nemali broj bio sa prostora današnje Hrvatske. Za Crnu Goru su se interesovali eminentni predstavnici hrvatskog prosvjetiteljstva i nosioci narodnog i kulturnog preporoda/ilirizma: Ljudevit Gaj, Ivan Kukuljević-Sakcinski, ban Josip Jelačić, Mate Topalović, Ivan i Antun Mažuranić, Fridrih Orešković i dr. Crnogorske vladike Petar I i Petar II Petrović Njegoš stvaraju pogodnu duhovnu klimu, otvarajući vrata svima onima koji su Crnu Goru doživljavali sa romantičarskim zanosom, kao zemlju koju je providencija odredila da udahne slavu slobode i snage posustaloj slovenskoj mišci širom Balkanskoga poluostrva. Kulturno-prosvjetiteljski zamah sa jačim intezitetom nastavlja se za vrijeme njihovih nasljednika knjaza Danila i osobito knjaza Nikole, pod čijom je dugom vladavinom petrovićevska Crna Gora doživjela najveći uspon na državnom, političkom, ekonomskom i kulturnom planu, uzdignuta na rang kraljevine, da bi, desetkovana u vihoru I svjetskog rata, bila likvidirana 1918. kao međunarodnopravni subjekt, odlukama nelegalne i nelegitimne Podgoričke skupštine. Upravo u Nikolino doba, pored Mažuranića, kojega je već ranije crnogorska viševjekovna herojska borba za slobodu i pravo na postojanje nadahnula da napiše svoj veliki ep, još par hrvatskih velikana ostavilo je i posvetilo svoja monumentalna djela Crnoj Gori, od kojih treba posebno izdvojiti: Valtazara Bogišića i njegov Imovinski zakonik; Trogranina Josipa Šilovića-Sladea, koji je ovđe utisnuo svoj prepoznatljivi graditeljski pečat i osigurao sebi trajno mjesto u istoriji crnogorskog urbanizma i arhitekture; i 
Milorad Nikčević, JOSIP JURAJ STROSSMAYER I NIKOLA I. PETROVIĆ NEGOŠ...

slikara Vlaha Bukovca, koji je na svojim platnima ovjekovječio značajne istorijske ličnosti i etnografske motive Crne Gore.

Osoben doprinos jačanju crnogorsko-hrvatskih veza dao je biskup Štrosmajer, čijoj je prepisci sa knjazom Nikolom autor na stranicama ove knjige posvetio posebnu pažnju ukazujući na brojne lične detalje, očekivanja i ciljeve iz njihove korespondencije. Strosmajer se nadaleko pročuo po svojim briljantnim nastupima na generalnim zasijedanjima Prvoga vatikanskog sabora. Spoljašnjom retorskom formom i sadržajem saborskih govora skrenuo je znatnu pažnju ondašnje evropske javnosti. Naročito je ostao upamćen njegov peti govor od 2. juna 1870. na raspravi teksta konstitucije De ecclesia Christi, u kome je kritikovao dogmu o infalibilitetu, odnosno papskoj nezabludivosti. Njegova oratorska sposobnost odisala je klasičnom elegancijom i lakoćom izražavanja u latinštini, otkrivajući biskupovo enciklopedijsko poznavanje teologije i filozofije, erudiciju i njegov renesansni duh.

Osim toga, Štrosmajer je energično djelovao na društveno-političkom planu. S padom apsolutizma 1860. godine kao duhovni vođa Narodne stranke, uz Franju Račkoga, razvija jugoslovensku ideju, u kojoj je Crna Gora svakako imala zaslužno mjesto, inspirišući biskupa svojom viševjekovnom epopejom. Markantnu ličnost đakovačkoga velikodostojnika, katoličkoga panslaviste, mecene, kulturnog pregaoca, osnivača i pokrovitelja Jugoslavenske akademije znanosti i umjetnosti i ambicioznoga crnogorskog knjaza, zaokupljala su razna pitanja: od sklapanja Konkordata sa Svetom Stolicom, oživljavanja ćirilometodijevske ideje i štampanja Misala na staroslovenskom jeziku za potrebe katolika na prostoru Crne Gore, do ujedinjenja južnoslovenskih naroda i pomirenja dvaju crkava unutar slovenskog svijeta.

Prema sačuvanim pismima koja je Štrosmajer slao knjazu Nikoli, autor je uspio da rekonstruiše dio njihovih prijateljskih odnosa i veza. I u korespondenciji sa drugim crnogorskim zvaničnicima, a posebno sa Jovanom Sundečićem, biskup ističe da je sa knjazom „familijarno općio“, što se da zaključiti iz preambule njegovih pisama u kojima crnogorskog vladara oslovljava sa: „Slavni (sjajni) kneže Nikola; Veleljubljeni i veličanstveni prijatelju; Veličanstveni i cijenjeni prijatelju“ i sl. Dakle, njih dvojicu je vezivalo čvrsto prijateljstvo, zasnovano na sveslovenskoj solidarnosti i ideološki podudarnim koncepcijama o budućnosti balkanskog prostora i ujedinjenju Južnih Slovena. Naklonost biskupa Štrosmajera knjazu Nikoli i crnogorskom narodu, nije bila samo verbalne prirode, nego se konkretizovala i kroz razmjenu knjiga, slanje vrijednih umjetnina, novčanu pomoć za pokretanje štamparske djelatnosti na Cetinju i sl. Njihova prisnost i bliskost stavova, nije bila po volji političkih krugova u Beču i Pešti, o čemu je Štrosmajer više puta obavještavao knjaza Nikolu. Naime, u jednom pismu Jovanu Sundečiću Štrosmajer ističe da crnogorskome knjazu šalje poruku iz Osijeka, jer iz svoga Đakova 
ne može zametnuti tragove njihove korespondencije. I zaista, crnogorski suveren dobijao je pisma iz različitih destinacija Đakova, Osijeka, Rogaške Slatine, Beča i dr. mjesta.

Ipak, najveći biskupov doprinos, kako Nikčević s pravom naglašava, odnosi se na potpisivanje Konkordata Crne Gore i Svete Stolice 1886. godine. Njegovo posredovanje u čitavoj stvari bilo je od krucijalnoga značaja, a svojim mudrim savjetima knjazu Nikoli i crnogorskoj vladi dao je važne smjernice i olakšao pregovore oko potpisivanja ovoga sporazuma. Prvi potpisani konkordat sa jednom slovenskom, pravoslavnom zemljom treba posmatrati u kontekstu istočne politike Svete Stolice i pape Lava XIII. Sa njegovim pontifikatom započela je nova faza odnosa između Rima i istočnopravoslavnih hrišćanskih crkava. Njihovo sjedinjenje sa Rimskom stolicom bila je jedna od glavnih papinih briga, kojoj je posvetio 6 enciklika, 7 apostolskih pisama, 14 nagovora i 5 govora. U svojoj enciklici Grande munus christiani nominis propagandi, od 30. septembra 1880, posvećenoj slovenskim apostolima Ćirilu i Metodiju, ukazao je na njihove bliske veze s Apostolskom Stolicom i na brigu pape za položaj slovenskih naroda. Tu se dalje kaže da papu posebno zaokuplja postizanje crkvenog jedinstva sa pravoslavnima. Štrosmajer je među katoličkim velikodostojnicima uz vrhbosanskog nadbiskupa Josipa Štadlera, od koga se u mnogo čemu razlikovao, bio onaj na kojega se Lav XIII najviše oslanjao u pokušajima ostvarivanja crkvene unije sa pravoslavnim crkvama na Balkanu. Iz Beča se na Štrosmajerova i papina proslovenska nastojanja nije blagonaklono gledalo, zbog bojazni da njihov krajnji cilj nije pronalaženje optimalnog rješenja za položaj rimokatolika u Austrougarskoj monarhiji, već Rusija i njeno približavanje Svetoj Stolici. S druge strane, biskupov panslavizam s nevjericom je priman u Rusiji, koja se pribojavala da on može doprinijeti smanjenju njezina uticaja na Slovene u Dunavskoj monarhiji i na balkanskom području. Najveću senzaciju i zaprepašćenje bečkih krugova izazvao je telegram koji je Štrosmajer uputio rektoru Kijevskog univerziteta 27. jula 1888, povodom obilježavanja 900-godišnjice pokrštavanja kijevskih Rusa. U njemu doslovno stoji sljedeće: „,...) Bog blagoslovio Rusiju i dao joj da živom vjerom, uzoritim životom, višom pomoću i kršćanskim heroizmom, pored svojih ostalih zadaća, i onu veličajnu svesvjetsku zadaću, koju joj Promisao božija opredijeli, sretno, spasonosno i slavodobitno ispuni“", što je izazvalo buru negodovanja i osude širom Monarhije. Svjestan reakcija koje će uslijediti, biskup Štrosmajer je svom prijatelju Račkom, uz kopiju telegrama napisao i ovo: „Ljutit će se na to i u Zagrebu i u Pešti i u Beču, a možebit i kratkoumnici i kratkovici i u Rimu, ali je zabadava“. Telegram u Rusiji primljen je sa razumljivim zadovoljstvom, čak i kod predstavnika desnog krila slovenofila, koji su ga od tada počeli drugačije doživljavati. 
Milorad Nikčević, JOSIP JURAJ STROSSMAYER I NIKOLA I. PETROVIĆ NEGOŠ...

Svjestan da Konkordat sa Crnom Gorom kao pravoslavnom zemljom predstavlja na indirektan način i korak bliže Rusiji, biskup Štrosmajer je sa velikom pažnjom i interesovanjem pratio cijeli tok pregovora oko njegova sklapanja. I ne samo to, kako autor s pravom zaključuje, poslije iscrpne analize u svojoj studiji posvećene ovome važnom dokumentu, on je aktivno učestvovao u njegovu koncipiranju i preko svojih veza uveliko doprinio konačnom potpisivanju istog, što je bitno uticalo na obnovu rada Barske nadbiskupije. Za nadbiskupa barskog izabran je dalmatinski franjevac Šimun Milinović, kao najprihvatljiviji kandidat, iza koga su stali Sundečić i Štrosmajer, što se da jasno razumjeti iz njihove prepiske proljeća 1886. godine, kojoj primarni cilj nije bio usaglašavanje stavova oko sporazuma sa Svetom Stolicom, nego izbor budućeg čelnika katoličke crkve u Crnoj Gori. Značajan uspjeh u pregovorima sa Svetom Stolicom postignut je uvođenjem staroslovenskoga kao liturgijskog jezika za katoličke vjernike u Knjaževini. Naime, papskim kodicilom Lava XIII od 29. marta 1887. dozvoljena je upotreba staroslovenskog jezika u bogoslužbenim obredima na području barske dijeceze. U tu je svrhu 1893. godine u Vatikanu štampan glagoljski Misal, da bi prva liturgija na staroslovenskom jeziku bila održana u barskoj katedralnoj crkvi 1895, u prisustvu visokih crnogorskih zvaničnika.

I na kraju treba istaći da ova knjiga predstavlja skladnu sintezu više studija u kojima je autor pažljivo opservirao i interpretirao brojnu prepisku, što predstavlja sublimaciju dosadašnjeg istraživanja ove problematike. Ona se odlikuje koherentnom strukturom u dijalektičkom jedinstvu i uzajamnoj vezi njenih djelova, što je bilo zahtjevno metodološki postaviti, naročito zbog multidisciplinarnog pristupa ovoj temi. Osoben senzibilitet i istančan naučnoistraživački nerv autora, izražen kroz sadržajan, prijemčiv i stilski skladno uobličen pisani iskaz, preporučuju ovu knjigu kako stručnoj tako i široj čitalačkoj publici. 

LINGUA MONTENEGRINA, god. III, br. 5, Cetinje, 2010.

Institut za crnogorski jezik i jezikoslovlje „Vojislav P. Nikčević“

UDK 82.0:141.72

\title{
Aleksandra NIKČEVIĆ-BATRIĆEVIĆ (Podgorica) \\ Filozofski fakultet - Nikšić
}

\section{OPIRANJE GENERALIZACIJI: JOŠ JEDNOM O FEMINISTIČKOJ KNJIŽEVNOJ TEORIJI}

\begin{abstract}
U pitanju je kratak prikaz zbornika tekstova koje je pod naslovom Kembridžov priručnik za feminističku književnu teoriju objavila izdavačka kuća Kembridž juniversiti pres. Knjigu je priredila Elen Runi, profesorka sa Univerziteta Braun, dok su ostali saradnici poznata imena u oblasti teorije o kojoj je riječ. Knjiga je podijeljena na tri dijela u kojima su analizirani različiti aspekti ove teorije.
\end{abstract}

Ključne riječi: tekst, tradicija, feministička književna teorija, generalizacija

U izdanju Kembridž juniversiti presa (Cambridge University Press) objavljen je Kembridžov priručnik za feminističku književnu teoriju, zbornik tekstova koji je priredila Elen Runi, profesorka književnosti s Univerziteta Braun (SAD) i autorka velikoga broja studija iz domena književne teorije. Ovom prilikom Runijeva je za prestižno Kembridžovo izdanje okupila zavidan broj saradnika koji su svojim dosadašnjim radom značajno uticali na razvoj feminističke književne teorije. „Feminizam je“, kako Runijeva piše u predgovoru, „dramatično uticao na način na koji čitamo, predajemo i ocjenjujemo književne tekstove. Feministička književna teorija promišljeno krši tradicionalne granice između književnosti, filosofije i ostalih društvenih nauka, pomažući nam tako da na najbolji način razumijemo konstruisanje roda i njegovo predstavljanje kroz jezik."

Zbornik je podijeljen u tri segmenta koji nose sljedeće naslove: „Pojava problematike“, „U osvit feminizma: žanr, period, forma“" i „Primjena feminističke teorije“, u okviru kojih se problematizuju sljedeća pitanja: pitanje kanona i pojava feminizma Afroamerikanki, feministička estetika čitanja, od-

${ }^{1}$ Svi su citati i parafraze u ovom tekstu iz knjige The Cambridge Companion to Feminist Literary Theory, ed. Ellen Rooney, Cambridge University Press, Cambridge, 2006. 
nos feminizma i romana kao žanra, odnos autobiografije i feminističkoga subjekta, pitanje modernizama i feminizama, žensko pismo (ecriture feminine) francuskoga feminizma, odnos feminizma i popularne kulture. U trećem dijelu zbornika preispituje se primjena feminističke teorije u doba poststrukturalizma, feministička teoretizacija kolonijalne/postkolonijalne književnosti, feminističko razmatranje rasnoga pitanja, psihoanalitička književna kritika, kvir politika, kvir teorija i budućnost „,identiteta“.

U do sada objavljenim kritičkim osvrtima na ovu knjigu afirmisan je naučni diskurs u kome je napisana, živ stil i efektno oblikovan izraz, izvanredna argumentacija i diverzitet po pitanju pristupa problematici feminističke književne teorije. Neki od tekstova jasan su pokazatelj feminističkih kritičkih principa u primjeni u analizi književnoga teksta, dok se u drugima autorke vraćaju korak unazad kako bi reartikulisale razvoj pojedinih feminističkih književnih metoda i ,interakciju feminizma, književne kritike i književnosti““2 Zbornik predstavlja svojevrsan napor da se u okviru teorije koja je raskošnoga hronološkoga zamaha i stalno otvorenih i novih izražajnih mogućnosti, drsko okrenuta isprobavanju glinenih nogu maskulinoga društvenog i književnog koncepta, izdvoje esencijalni elementi koji je čine. Runijeva piše da i kratak osvrt na istoriju nastojanja feminističkih književnih teoretičarki da sumiraju kolektivni projekat i otkriju izrazito i rastuće zanimanje prema samoj mogućnosti takvoga sinoptičkog pogleda jeste pokušaj koji se najbolje prepoznaje u pitanjima o uslovima inkluzije i ekskluzije koji su u središtu svakoga nastojanja da se definišu granice feminizma. Na tom fonu „napor da se predloži definicija, genealogija ili istorija feminističke književne teorije, iz pedagoških razloga, razloga političke jasnosti ili čak iz razloga intelektualne razumnosti za ovu oblast kao cjelinu, prijeti da pojednostavi ono što je na nepromjenjiv, možda neiskorjenjiv način, kompleksno“.

U otkrivanju unutrašnjih veza, simetrija i opozicija u okviru viševjekovne feminističke priče, Runijeva i saradnici nerijetko zastaju i idu unazad ne bi li, iz perspektive nekih ranijih talasa feminističke teorije i prakse, saznali na kakve nas je staze početak dvadeset prvoga vijeka u preplitanju ove priče odnio. Vraćamo se tako na već izrečenu konstataciju kako nije teško primijetiti da su feminističke književne teorije varijeteti, da su heterogene i konfliktne: „feminističke književne teorije jesu kolektivne konverzacije (često kontradiktorne i uzrujane) feminističkih čitalaca koje se odnose na značenje i praksu čitanja, intersekcije subjekatskih formacija kakve su rasa, klasa, seksualnost, rod i književno djelo. Feministička književna teorija uspješno je

\footnotetext{
${ }^{2}$ Nerijetko se u razmatranju individualnih poetika insistiralo na ovoj vrsti interakcije. Adrien Rič napisala je u jednom eseju da je neminovno da, ukoliko želite da naučite nešto o poetici Mjurijel Rukejser, pažljivo analizirate interakciju poezije, politike, seksualnosti i nauke.
} 
Opiranje generalizaciji: još jednom o feminističkoj književnoj teoriji

intervenisala u književnim studijama u cjelini, iznova promišljajući pitanje roda, kanona i estetike; u ovom smislu, ona više nije radikalna jer je transformisala sopstveni djelokrug". Ipak, radikalno teorijsko promišljanje o onome što su feministkinje ,uradile“ izučavanju romana nudi Nensi Armstrong, koja piše o romanu kao o ,žanru čija je kritička percepcija najradikalnije modifikovana feminističkim pitanjima“. U priči o feminizmu koji je preorijentisao „klasično“ čitanje romana, Armstrongova se direktno bavi ovom transformacijom pomjerajući fokus kritičke pažnje od „,nedostatka“ koji karakteriše muškoga protagonistu do pitanja što je to protagonistkinji nedostajalo. Ona ispituje razlike do kojih je ova promjena dovela i postavlja pitanje što je zapravo nedostatak: „Feministička književna teorija načinila je brzu i efektnu intervenciju u čitanju proze, kada je ubijedila čitavu generaciju čitalaca da razmotri što to nedostaje protagonistkinjama a ne njihovim muškim pandanima. Osamdesetih godina ovaj način čitanja promijenio je ne samo izbor romana koji su čitani i predavani u učionicama već i zamišljeni odnos između individue i nacije koji je podsticao identifikaciju čitalaca s protagonistom. Feminističke kritičarke počele su da čitaju Defoovu Mol Flanders umjesto Robinzona Krusoa, Pamelu Semjuela Ričardsona umjesto Toma Džounsa Henrija Fildinga, i Emu Džejn Ostin umjesto Veverlija Voltera Skota“.

Ketrin Mulin pokušava da dokuči složen odnos između dvije „kompleksne ideološke formacije“, modernizma i feminizma, i u tom kontekstu potencira pitanje revizije kanona i tradicionalnih koncepcija modernizma kao perioda kojim je dominirao trijumvirat Eliota, Paunda i Džojsa, a u okviru koga su autorke poput Virdžinije Vulf, Gertrud Stajn ili Nele Larsen stvarale svoje sopstvene modernizme. Ona navodi da postoje mnogi feminizmi, ali i mnogi modernizmi: ,niz diverzitetnih i čak nekompatibilnih estetskih praksi obično se označava terminom modernistički i on uključuje futurizam, simbolizam, imažizam, vorticizam, ekspresionizam i nadrealizam. Svi pokušaji definisanja modernizma uglavnom su opštega tipa, a uobičajena definicija modernizma kao umjetnosti specifičnog istorijskoga perioda naglašava i istorijsku podudarnost sa feminizmom“. U hronološkom smislu, period od 1890. do 1930. godine bio je, simultano, vrijeme pojačane feminističke agitacije jer su žene u raznim zemljama ,počele da se obrazuju na univerzitetima, da rade u neuobičajeno velikom broju, da se bore za pravo glasa“. U domenu politike postavljale su i pitanja o rodu i seksualnosti. Osim toga, književna kritika bila je, prema riječima Mulinove, svjesna uspona „,nove žen“i krize u seksualnoj politici koju je ona personifikovala - završna decenija devetnaestoga vijeka dovela je do povećane feminizacije književnoga tržišta jer je objavljeno više od stotinu romana u kojima je predstavljena „,nova žena“ i koji su preispitivali konvencionalni viktorijanski zaplet o braku. Estetski radikalizam modernizma počeo je da se razvija uz politički radikalizam „prvoga talasa“ 
feminizma, zaključuje autorka i navodi riječi Džejn Eldridž Miler, koja smatra da romansijerke eksplicitnoga feminističkog stava (kakve su bile Roda Barton i Oliv Šrajner) nije bilo lako uključiti u modernistički kanon. Umjesto toga, ova vrsta feminizma često je bila konstruisana kao jedna od ideologija protiv kojih je trebalo da se pobune modernistički poslenici.

Rej Čou napisala je tekst u kome razmatra pitanje spornog odnosa između feminističke teorije i poststrukturalizma. „Čou čita taj odnos kroz problem subjekta, što je tema kojoj se feministička književna teorija neprestano vraća, bilo u formi 'dekonstrukcije ' žene ili statusa 'lične kritike' ili žanrova kakvi su autobiografija i memoari. U Deridinom radu ona prepoznaje „,napor da se radikalizuju (značenje) značenja na način na koji se konvencionalno izvode iz različitih postojanih formi identiteta, uključujući tekst, istoriju, misao, kao i sam subjekat“. U tekstu o autobiografiji i feminističkom subjektu navodi se da je feminizam oduvijek imao gotovo simbiotsku vezu s autobiografijom. Linda Anderson piše da, ako se osvrnemo na rane stadijume ovog odnosa, možemo primijetiti kako je šezdesetih i sedamdesetih godina dvadesetoga vijeka, za trajanja drugoga talasa feminizma, autobiografija obezbjeđivala privilegovan prostor za žene u okviru kojega su mogle da otkriju nove forme subjektiviteta kroz čitanje autobiografskih napisa iz pera žena i kroz produkciju tekstova koji su istraživali ženski subjekat na iskreniji i inventivniji način. Kasnije, pak, ,kada je poststrukturalistička teorija počela da transformiše feminističko mišljenje, autobiografija je postala poprište za glavne teorijske debate o subjektu“.

U uvodu teksta o francuskom feminizmu Kari Veil piše da se francuski feminizam uglavnom povezuje sa grupom spisateljki koje su stekle reputaciju u Francuskoj sedamdesetih i osamdesetih godina dvadesetoga stoljeća. Iako sebe nijesu smatrale grupom, one su na nov način promovisale razmišljanja o ženama, njihovim tijelima i žudnjama, čime su znatno uticale na lokus feminističkoga razmišljanja u američkoj sredini. Elen Siksu, Lis Irigaraj i Julija Kristeva, za čije su djelovanje suštinske Sosirova lingvistika i Lakanova teorija subjekta, razvile su sistem analize koje je bio radikalno različit od onoga koji je praktikovan u anglo-američkom svijetu. Kroz discipline kao što su lingvistika, psihoanaliza i filosofija, svaka od teoretičarki kretala se ka dekonstrukciji maskulinoga načina pisanja koji teži da poveže feminino s iracionalnim, dezorganizovanim načinima pisanja: jezik je, tvrde one, potisnuo ono što je feminino, ,potčinjavajući ga simbolizaciji patrijarhalnoga sistema imenovanja i kategorizacije“. U praksi je njihovo pisanje težilo da postojeće binarne opozicije (muško/žensko, racionalno/iracionalno itd.) dekonstruiše koristeći simbolizam fluidnosti i ženske seksualnosti u suočavanju sa falogocentrizmom zapadnoga filosofskog pisanja. Ono što je francuski feminizam učinilo tako popularnim, navodi Veilova, ima veze sa tradicionalnom zavod- 
Opiranje generalizaciji: još jednom o feminističkoj književnoj teoriji

ljivošću „francuskih stvari“ i kompleksom niže vrijednosti koji su Amerikanke ośetile u odnosu na sofisticiran stil njihovih sestara sa Kontinenta. Zavodljivost je predstavljala dio te priče, potvrđuje ona: to su bili tekstovi koji su, pored sveg intelektualizma koji ih je karakterisao, govorili o žudnji i tijelu, o erogenim zonama žene i o mogućnostima otpuštanja njihove libidalne snage u pisanju. Za francuske feministkinje, ženska žudnja najviše je potiskivana i obuzdavana od strane patrijarhata-jouissance, francuska riječ za „orgazam ili za zadovoljstvo tako intenzivno da je u isto vrijeme u tijelu i van njega, postalo je pomodan termin književne teorije za intenzitet koji, poput ženskoga zadovoljstva, jeste izvan jezika, zaključuje Veilova.

U ovim tekstovima autorke se pozivaju na mnoga uticajna imena, kakvo je, na primjer, ime Barbare Džonson, čiju studiju Kritička razlika citiraju u pokušaju definisanja kompleksnog odnosa između teorije i književnosti. Džonsonova tvrdi da feminističku teoretizaciju treba održavati usklađenom sa tekućim izazovima književnoga teksta; da treba obratiti pažnju na vezu između različitosti i tekstualnosti koja ima posebnu rezonantnost za feminističku teoriju; na čitav raspon tema koje jasno odgovaraju stavu prema kome feministička književna teorija potvrđuje tezu da žensko čitanje ima posebne posljedice i da donosi značenje koje je intelektualno, politički i poetički novo; da čitateljke raznolikošću svojih čitanja i interpretacija, izlažu na svijetlo dana maskulinizam nekadašnjih čitalaca i čitanja; da imaju aktivan odnos prema tekstu, odnos koji blisko prati djelovanje označitelja, njegovih kontradiktornih pokreta i sposobnosti da iznenadi. Sagledano kroz ovu perspektivu, kako navodi Runijeva, čitanje je tranzitivno: čitanjem mijenjamo tekst, a žensko čitalačko iskustvo je drugačije zbog toga što žene čitaju kako bi razvrgnule prethodne falusne paradigme i kako bi nagovijestile još uvijek zamislive tekstualne mogućnosti koje obeskrepljuju „raspoložive paradigme“ i ostavljaju nam istraživanje koje karakterišu ambivalentnost, kontradiktornost i konfliktnost.

U knjizi se apostrofira i stav da se „ono što je već poznato ne može uzeti zdravo za gotovo“. Feminističku književnu teoriju u svim fazama razvoja posebno interesuje samoispitivanje i nevoljnost da se pristane na jednu lokaciju, ističe priređivačica ove knjige. Preispitivanje tradicije i reevaluacija estetike važni su za ovaj intelektualni tok, jer je takva vrsta preispitivanja dobila mnogostruke forme. Strategije im, da parafraziram Runijevu, nijesu uvijek kompatibilne. Ona se priśeća teksta objavljenoga 1987. godine pod naslovom „Feministička kritika: Kako znamo kada smo pobijedile?“ u kojem Lilian Robinson, piše da objektivno gledano, bilo koje djelo koje u središte svog interesovanja stavlja izučavanje stvaralaštva kakve spisateljke, ima feministički efekat. Proširenje kanona ima feministički efekat gotovo bez obzira na prirodu argumenata i veza koje se djelom uspostavljaju ili ignorišu. 
Intelektualni izazov koji su žene postavljale sebi još od vremena Meri Vulstonkraft, ${ }^{3}$ koja je svoja rana feministička razmišljanja zasnovala na pretpostavkama liberalnog individualizma i materijalizma, sačinjen je od radikalnih evolucija i isprepletan, u postmoderno doba, sa raznim drugim teorijama, pa se opire svakoj generalizaciji. Idiosinkrazija prema generalizaciji manifestuje se i kroz pitanja u rasponu od onih koja se odnose na analizu društvenih formacija koje imaju praktične i psihičke efekte na svoje subjekte, preko kritike slika, posebno stereotipnih slika feminiteta na koje nailazimo u književnim tekstovima, krivotvorenja ženske tradicije (śetimo se potrebe za novom mapom ili, još značajnije, različitom koncepcijom kritičke prakse kojom je pol autora svakako trebalo uzeti u obzir, o čemu je pisala Rut Robins) do stava koji je u fokusu ginokritike u čijem je središtu žena kao stvarateljka tekstualnoga značenja, sa istorijom, žanrovima i strukturama književnih tekstova koje su ispisale žene i temama koje ,uključuju psihodinamiku ženske kreativnosti, lingvistiku i problem ženskoga jezika, književnu istoriju i izučavanje pojedinih spisateljki i njihovih djela“.

Ovo su tek neke od pretpostavki na kojima počiva ovo Kembridžovo izdanje. Druge, koje ovom prilikom nijesu eksplicitno navedene, samo potvrđuju neke od stavova koje je jednom davno, u prvoj priređenoj antologiji feminističkih eseja, ${ }^{4}$ ispisala Ilejn Šouvolter: feministička kritika cvjeta u kombinaciji sa različitim kritičkim pristupima, u dvadeset prvom vijeku čak i sa semiotikom i naratologijom. ${ }^{5}$ Dalje, razbijanje teorije književnosti kao muškoga bastiona otvorilo je prostor za pojavu teoretičarki koje su preispitale književnoteorijsko nasljeđe. Još jedna od pretpostavki na kojima insistira Šouvolterova, a koju u ovoj knjizi potvrđuju Runijeva i saradnici, jeste ona prema kojoj se feministička književna kritika ne oslanja na jednu autoritativnu figuru ili na korpus svetih tekstova, jer one nemaju ,'majku svih nas“ ili jedinstveni sistem iz kojega bi crpile fundamentalne ideje“. Izvori su im različiti i ekstenzivni, ali one pišu jednako dobro kao muškarci, mada drugačije, kako je to u jednom prikazu napisala Džordž Eliot. U traganju za sopstvenim

\footnotetext{
${ }^{3}$ Erika Džong napisala je u Zavođenju demona da upravo Vulstonkraftova pripada ili predstavlja prvi talas feminizma.

${ }^{4}$ Feministička kritika: Eseji o ženama, književosti i teoriji iz 1985. godine.

${ }^{5}$ Suzan Lanser, najznačajnija feministička naratološkinja, navela je kako je spoj između feminizma i naratologije čudan: feminizam je, ističe ona, impresionistički, evolutivan i političan, dok je naratologija naučna, deskriptivna i neideološka. Zaista, ,nijedna od savremenih teorija nije izvršila manje uticaja na feminističku teoriju od formalističke strukturalističke naratologije“. Ona navodi da postoji više razloga za nepovjerenje naratologije prema feminizmu: njena kompleksna terminologija, skepticizam prema binarističkom načinu razmišljanja kome je strukturalizam sklon, činjenica da nijedna od naratoloških teorija ne uzima u obzir rod.
} 
Opiranje generalizaciji: još jednom o feminističkoj književnoj teoriji

glasom, stilom i strukturom, detaljno i u naučnom diskursu, Runijeva i saradnici značajno su ovom knjigom uticali na mapu dosadašnjih feminističkih književnoteorijskih postignuća.

\section{Literatura}

- Mills, Sara, Lynne Pearce, Sue Spaull, and Ellen Millard, eds. Feminist Readings, University Press of Virginia, Charlottesville 1989.

- Rooney, Ellen, ed. The Cambridge Companion to Feminist Literary Theory, Cambridge University Press, Cambridge 2006.

- Robins, Ruth: Literary Feminisms, Palgrave Macmillan 2000.

\section{Aleksandra NIKČEVIĆ-BATRIĆEVIĆ \\ THE RESISTANCE TO GENERALIZATION: FEMINIST LITERARY THEORY REVISITED}

This is a short review of the collection of texts published by Cambridge University Press under the title The Cambridge Companion to Feminist Literary Theory. Editor of the book is Ellen Rooney, while the other contributors are prominent scholars in the field of feminist literary criticism. The book is divided into three sections in which different aspects of the theory are analyzed.

Key words: text, tradition, feminist literary criticism, generalization 

LINGUA MONTENEGRINA, god. III, br. 5, Cetinje, 2010.

Institut za crnogorski jezik i jezikoslovlje „Vojislav P. Nikčević“

UDK 821.163.42.09-31

Milica LUKIĆ (Osijek)

Filozofski fakultet Sveučilišta J. J. Strossmayera

\section{ROMAN U ČAST SV. KONSTANTINU-ĆIRILU I NJEGOVU PISMU \\ Jasna Horvat, $A z$, Biblioteka Otvorena knjiga, Naklada Ljevak, Zagreb, 2009.}

Ja koji poznajem slova (Boga) kažem da je dobro živjeti na zemlji veo$m a$ - poruka je to koja je putujući kroz vrijeme ostala aktualnom do naših dana jer ukazuje na čovjekove mogućnosti i dosege njegova razvoja kao intelektualnog i duhovnog bića preko dara koji je primio izumom pisma. Poruka je to koju je Konstantin-Ćiril, Solunjanin, u 9. stoljeću prepoznao i ugradio u novi pismovni sustav namijenjen Slavenima, danas poznat pod nazivom glagoljica, i na koncu, poruka je to što ju je autorica Jasna Horvat prepoznala kao romanesknu temu koja ima snagu promovirati navedene vrijednosti u okviru hrvatske kulture koja je postala dionicom Konstantinova dara i vjernom čuvaricom glagoljskoga pisma već više od tisuću godina. Tako su Konstantin-Ćiril i njegovo pismo postali ne samo temom nego i glavnim likovima njezina romana $A z$ jer je kao i Konstantin, od kojega je dijeli cijelo tisućljeće, shvatila da je $u$ iskonu istina o biću.

Struktura je romana $A z$ vrlo promišljena i nesvakidašnja, prvenstveno uvjetovana i inspirirana rasporedom pismena (slova) u azbučnome nizu glagoljice (jer glagoljica kao pismo u paradigmatskome smislu pripada azbukama) te njihovom znakovnom i simboličnom prirodom koju određuje filozofsko-teološka šifra (teologija Sv. Pavla) ugrađena u svako pojedino slovo. Danas se sve teorije o podrijetlu glagoljice mogu svrstati u tri velike skupine: egzogene, endogene i tzv. egzogeno-endogene. Jasna se Horvat odlučila za neke iz skupine endogenih koje čvrsto stoje uz Konstantinovo autorstvo glagoljice i pismo nastoje objasniti i interpretirati unutar vlastita zatvorenoga sustava, ne tražeći uzore izvana, u nekom drugom pismu. Takve su teorije ujedno i najzanimljivije, posebice onima koji nisu filolozi, jer svako pojedino slovo u takvu načinu promatranja može postati jedna nova priča - a upravo je priča ono što je trebalo Jasni Horvat. Jedna je od tih teorija i ona koju je ute- 
Milica LUKIĆ

meljio finski slavist Georg Černohvostov sredinom 20. st. i ona kaže kako je Konstantinova protoglagoljica sastavljena od triju temeljnih kršćanskih simbola: križa kao simbola kršćanstva, Krista, njegove muke i smrti (križ je ujedno u protoglagoljici prvo slovo - ,az“, što je leksičkim svojim značenjem zapravo lična zamjenica ,ja“ - po čemu je roman i dobio ime), kruga kao simbola savršenstva, odnosno Boga, i trokuta kao simbola Svetoga Trojstva. Njoj vrlo bliska je i teorija bugarskoga slavista V. Jončeva, prema kojoj se oko svakoga glagoljskog slova može opisati kružnicu koju četiri dijametra dijele na osam jednakih dijelova; svako je slovo samo neki dio predstavljenog modela i svaki takav dio može se poistovjetiti s kružnim isječcima dakle, glagoljsko je slovo izlučeno iz rozete odnosno mandale. Takav način gledanja na glagoljicu i njezin nastanak inspirirao je i ovaj književni tekst. Osim toga, glagoljica je pismo u kojemu slovima nisu pridružene samo glasovne vrijednosti nego i brojčane oznake te imena koja poredana u nizu oblikuju tzv. azbučnu molitvu funkcija koje je mnemotehnička, dakle lakše pamćenje i usvajanje pisma. Upravo takvo stanje vrlo vjerno prati struktura romana $A z$ u kojoj je svako glagoljsko slovo poglavlje unutar pet cjelina od kojih su četiri dnevnički zapisi četiriju pripovjedača, povijesno ovjerenih likova povezanih na različite načine s Konstantinom-Ćirilom i njegovom misijom (stariji brat Konstantinov - Sv. Metod, bizantska carica Teodora, Konstantinova zaštitnica i pokroviteljica, Anastazije Knjižničar - pisac jednoga od važnih izvora za povijest ćirilometodske misije, tzv. Italske legende, te hrvatski knez Mutimir, otac kralja Tomislava), dok je peta cjelina odijeljena od ovih četiriju intermezzom i kratkim izravnim autoričinim uplitanjem u radnju, čime i sama postaje lik vlastita romana. Peti je dio zapravo ključ za dekodiranje romana u cjelini - to je pravi mali leksikon glagoljice u kojemu glavni lik postaje glagoljica koja se predstavlja u svoj svojoj složenosti i ljepoti svoga simboličkoga ustroja koji i eksplicitno i implicitno sugerira udjel pojedinca, onoga koji se u jeziku izražava ličnom zamjenicom ja (az), u oblikovanju svijeta kroz spoznavanje samoga sebe u Bogu - Logosu - Sofiji Mudrosti.

Četiri navedena pripovjedača prate Konstantinov život kroz različite njegove faze (djetinjstvo u Solunu, posvećenost filozofiji Sv. Grgura Nazijanskoga, školovanje na bizantskom dvoru, mistične zaruke sa Sofijom, misije Saracenima, Kazarima, i Slavenima, dispute s vrhunskim intelektualcima njegova vremena poput svrgnutoga patrijarha Ivana VII. Gramatika, prolazak kroz hrvatske zemlje na putu u Rim...) i iz pozicije uključenosti u njegov život, tako da su priče njegova brata Metoda i ona carice Teodore priče neposrednih svjedoka, onih koji polažu veliko pravo na Konstantinov život i govore o njemu onako kako ga u ljubavi doživljavaju - muškom (bratskom) i ženskom (majčinskom i ljubavničkom) energijom, a priče Anastazija Knjiž- 
Roman u čast Konstantinu-Ćirilu i njegovu pismu

ničara i hrvatskoga kneza Mutimira priče su onih koji su primorani vjerovati povijesnom dokumentu, dakle posredne.

Roman $A z$ nastao je zapravo prelijevanjem brojnih sekundarnih žanrova, njihovom vrlo lucidnom i vještom transformacijom u jedan novi sustav: isprepliću se tu povijesni dokumenti - životopisi Sv. Braće, tzv. žitija, legende, apokrifni tekstovi, azbučne molitve, rodoslovlja, igre, posebice drevna igra mlina koju je autorica iskoristila kao funkcionalnu motivaciju za nastanak glagoljskih slova i tako izgradila strukturu novopovijesnoga postmodernističkog romana. Upravo je začuđujuće s kakvom lakoćom u svoje tekstovno tkanje autorica upliće sve odreda povijesne ličnosti iz bizantskoga i slavenskoga kulturnog kruga druge polovice 9. st. čiji je povijesni identitet postao književnim, izmaštanim upravo na onim mjestima o kojima povijest šuti i s koliko vjerodostojnosti, a na temelju povijesnih dokumenata, oživljava atmosferu u kojoj se odvijao društveni i kulturni život u drugoj polovici 9. st. na bizantskome dvoru i u slavenskim pokrajinama koje su neposredno baštinile rezultate Konstantinove genijalnosti: Velika Moravska, današnje Češka i Slovačka, i Hrvatska. Upravo se na hrvatskom nacionalnom prostoru ćirilometodska baština najduže zadržala u upotrebi, pa je glagoljica, iako pismo jednoga Grka namijenjeno moravskim Slavenima, postala simbolom hrvatskoga nacionalnog identiteta od 9. stoljeća do naših dana te je danas doživljavamo kao nacionalno pismo.

Gledajući iz te perspektive, roman $A z$ vrijedan je spomenik hrvatskoj kulturi kroz povijest i onomu što je bitno obilježuje i čini jedinstvenom među europskim kulturama te nadasve njezin promicatelj jer je otvoren za čitanje na različitim razinama i za vrlo širok krug recipijenata - od onih koji su zainteresirani za dobru priču do onih koji od teksta traže i neke druge dimenzije, primjerice duhovnu i intelektualnu nadgradnju, jer to ovaj hibridni žanr - romaneskno-znanstveni - omogućuje. Ne treba zaboraviti da su Konstantin-Ćiril i njegov brat Metod svecima i Katoličke i Pravoslavne crkve, da su ekumenski simboli i uz Sv. Benedikta suzaštitnici Europe, da je u glagoljsko pismo utkana kršćanska teološka misao, što knjigu čini poželjnom i na policama onih koji žele produbiti znanja o kršćanskoj vjeri i kulturi, to više što je posljednji roman s tom tematikom objelodanjen davne 1927. godine (Velimir Deželić ml., Sofiju odabra-Roman iz 9. stoljeća).

$\mathrm{Na}$ koncu, ovaj je roman namijenjen svim onima koji u vlastitu iskustvu žele potvrditi misao vodilju glagoljskoga pisma: Ja koji poznajem slova (Boga) kažem da je dobro živjeti na zemlji veoma. 

LINGUA MONTENEGRINA, god. III, br. 5, Cetinje, 2010.

Institut za crnogorski jezik i jezikoslovlje „Vojislav P. Nikčević“

$811.163(497.16)$

\section{Adnan ČIRGIĆ (Podgorica)}

Institut za crnogorski jezik i jezikoslovlje „Vojislav P. Nikčević“

\section{POVODOM JEDNOGA FALSIFIKATA*}

Ovaj članak predstavlja odgovor na tekst Boška Mijanovića Dvorac Crnojevića nije prikazan na graviri u Oktoihu (Matica, br. 39, Podgorica, 2009, str. 159-180) u kojemu se iznosi netačan podatak o jeziku testamenta Đurđa Crnojevića. Mijanović u tome tekstu optužuje autora ovoga priloga da je neosnovano ,napao“ Jelicu Stojanović, koja je ustvrdila da je pomenuti testament pisan ,,jezikom i pismom srpskim“, te da je autor ovoga priloga selektivno iznosio činjenice o toj problematici.

Crnogorski jezik dugo je i u Crnoj Gori i izvan nje bio tabu. A zatim se zahvaljujući angažmanu nekolicine intelektualaca montenegrista krajem 60ih godina minuloga vijeka počela probijati svijest o njemu, prvo u inostranstvu pa tek onda u samoj Crnoj Gori. I to je danas opštepoznata činjenica kod nas. Ono što bi začudilo prosvijećeni svijet jesu otvorena i prikrivena negiranja, falsifikovanja, podmetanja i slična nepočinstva raznoraznih profesora i profesoresa, novinara, pjesnika, predstavnika različitih struka, a posebno pojedinih jezikoslovaca i književnih teoretičara i istoričara s Filozofskoga fakulteta u Nikšiću ${ }^{1}$ u vrijeme kad je država Crna Gora svojim Ustavom crnogorski jezik proglasila za službeni. U posljednjem broju časopisa Matica pridružio im se i penzionisani matematičar s Cetinja - Boško Mijanović. ${ }^{2}$

U radu Dvorac Crnojevića nije prikazan na graviri u Oktoihu, koji vrlo malo veze ima s naslovom koji mu je autor nađenuo, matematičar Boško Mijanović dao se u kulturološke, književne, jezičke, slikarske, istoriografske

* Ovaj prilog objavljen je u časopisu Matica, br. 40, Matica crnogorska, Podgorica - Cetinje, 2010, str. 221-226. Budući da su se prilikom objavljivanja potkrale nekolike tehničke greške, ovđe ga objavljujemo u ispravljenoj verziji. Prim. autora.

${ }^{1} \mathrm{O}$ tome viđeti više u: Adnan Čirgić: „Aktuelna jezička politika u Crnoj Gori“, Matica, br. 37/38, Matica crnogorska, Podgorica - Cetinje, 2009, str. 17-90.

${ }^{2}$ Viđeti: Boško Mijanović: „Dvorac Crnojevića nije prikazan na graviri u Oktoihu“, Matica, br. 39, Matica crnogorska, Podgorica - Cetinje, 2009, str. 159-180. 
Adnan ČIRGIĆ

i ine kritike i analize. Svojim kritizerskim perom obrušio se i na žive i mrtve, na: Marka Dragovića - crnogorskoga kulturnog stvaraoca na razmeđu XIX i XX vijeka, književnika Momira Markovića, jezikoslovca Adnana Čirgića, istoričara Radoslava Raspopovića, istoričara umjetnosti Pavla Mijovića, istoričara umjetnosti Rajka Vujičića, istoričara književnosti Đorđa Sp. Radojičića, bibliografa Dušana Martinovića i druge. Da je Crna Gora rasadnik ,eksperata opšte prakse“, pasioniranih ,polihistora“ spremnih da u svakome trenutku i na svaku temu - od problema istorije umjetnosti, prirode književnoga teksta ili metodologije naučnoga rada - s podjednakom kompetencijom, autoritativno prosuđuju i presuđuju, nije nepoznat fenomen. Pomenutim je pamfletom i Boško Mijanović na velika vrata ušao u to probrano, „sveznadarsko" društvo.

Danas je i laicima poznato da je još Aristotel prije dvije hiljade i trista godina definisao razliku između istorije i književnosti, odnosno ,pjesništva“. Još u antičko doba postalo je jasno da istorijska istina ne obavezuje pjesnike. Iako taj podatak nije neophodan u matematici, ipak bi i matematičari morali znati, kad se počnu upuštati u neke izvanmatematičke vode, kao što to čini npr. Boško Mijanović kritikujući Marka Dragovića, a povodom jednoga fikcijskog a ne istoriografskoga teksta, što pod terminom ,oganj“ možda nije podrazumijevao samo „,artiljerijski oganj“ nego i „oganj iz pušaka“ i sl. ili, kritikujući književnika Momira Markovića, što u svojoj knjizi upotrebljava termin „vadžola" u vrijeme kad se u Crnoj Gori nije ni znalo za njega... Da je bio malo dosljedniji, Mijanović je kritiku mogao uputiti i Šekspiru lično - avaj, kako to da najslavniji kraljević svjetske književnosti - ne govori danski!?

Ipak, predmet ovoga teksta nijesu ni fadžola ni oganj, nego tendencioznost Boška Mijanovića u dijelu koji se odnosi na imenovanje jezika u testamentu Đurđa Crnojevića. Mijanović kaže: „Kada se piše naučni ili stručni tekst, ne bi se smjele iz poznatih činjenica uzimati samo one koje služe da opovrgnu neku tvrdnju, a izostaviti one koje tu tvrdnju potvrđuju, već iz svih njih treba da se izvuče zaključak. Adnan Čirgić napada Jelicu Stojanović zato što 's pozivom na udovicu Đurđa Crnojevića utvrđuje kako je testament ovoga vladara pisan srpskim jezikom iako se u sačuvanom prijepisu na talijanskom jeziku kaže da je testament pisan jezikom i pismom slavenskim' (...). Ali Adnan Čirgić nije htio da napiše da zvanični organi u Veneciji kažu da je Đurđev testament pisan na srpskom jeziku. Navešću ih onako kako ih je Miloš Milošević preveo u svojoj knjizi Testament Đurđa Crnojevića (kritičko izdanje sa komentarom, Cetinje 1994): (...) testamentarni zapis spomenutog njenog pokojnog muža, pisan njegovom vlastitom rukom, na srpskom jeziku, (...) uputiti rečeni testamentarni zapis, pa da se sa srpskog na latinski jezik, kao što je gore rečeno, prevede (...) To traženje je procijenjeno pravednim $i$ ostvareno preko vjerodostojnog prevodioca, sa spomenutog jezika srpskog 
na latinski, jer je taj testamentarni zapis bio i jeste napisan na spomenutom jeziku srpskom. (...) rukom istog gospodina Đurđa, na jeziku i slovima srpskim napisan i potpisan (...) testamentarni zapis sa srpskog jezika na latinski jezik od stručnih lica redigovati... (str. 49-53).

Zar srpski jezik nije slovenski jezik? “3 - Mijanović završava svoju „odbranu“ Jelice Stojanović.

Zaista je u najmanju ruku neobično da onaj koji spočitava nekome da selektivno iznosi činjenice i sâm nekoliko redaka poslije toga izbjegne da spomene ključnu činjenicu u problematici kojom se bavi, kao što to radi Boško Mijanović u pomenutome slučaju. Naime, mi nijesmo „,napadali“ Jelicu Stojanoviću, već smo skrenuli čitaocu pažnju na njezina krivotvorenja istine o crnogorskoj jezičkoj prošlosti i sadašnjosti. Da podśetimo, tada samo napisali: „Osnovna je namjera ove autorke (Jelice Stojanović - prim. A. Č.) da po svaku cijenu, služeći se čak i falsifikatima, pokaže kontinuitet srpskoga jezika u Crnoj Gori od početaka pismenosti (reklo bi se čak i u onom periodu kad se o srpskome jeziku ni u Srbiji ne može govoriti). Umjesto detaljnijega osvrta na sve omaške ovoga rada, zadržimo se samo na nekim. Autorka je svoj rad koncipirala kao kakvu brošuru Srpske radikalne stranke, pa će u skladu s tim konstatovati: 'U granicama današnje Crne Gore, kao što je poznato, nalaze se teritorije koje su nekad pripadale različitim formacijama srpskih zemalja ““, ${ }^{4}$ te „No njoj (Jelici Stojanović - prim. A. Č.) je draža 'istina“ Ljubomira Durkovića-Jakšića, čijih se metoda pridržava, pa s pozivom na udovicu Đurđa Crnojevića utvrđuje kako je testament ovoga vladara pisan srpskim jezikom iako se u sačuvanom prijepisu na talijanskom jeziku jasno kaže da je testament pisan jezikom i pismom slavenskim (lingua et lettera schiava)." ${ }^{\circ 5}$ Naravno, i dalje smatramo isto! A budući da Boško Mijanović tvrdi kako je pomene srpskoga jezika preuzeo iz kritičkoga izdanja Testamenta Đurđa Crnojevića, čiji je priređivač Miloš Milošević, ${ }^{6}$ sasvim je jasna njegova tendencija da odbrani falsifikat Jelice Stojanović kako je taj testament pisan srpskim jezikom. Da je Bošku Mijanoviću bilo stalo do naučne istine na koju se poziva u polemici s nama, ne bi preskočio ključnu činjenicu da u dijelu testamenta koji je pisao Đurđe Crnojević, odnosno preveo pisar Stjepan Paskvali, nigđe nema pomena o srpskome jeziku i pismu. Naprotiv, onđe jasno stoji da je riječ o jeziku i pismu slovenskome, kako smo naveli i u osvrtu na tekst Jelice Stojanović. A u prijevodu testamenta Đurđa Crnojevića, koji je sačinio Miloš Milošević, kaže se ovo: „Ja, Stjepan Paskvali pok.

\footnotetext{
${ }^{3}$ Boško Mijanović, n. d., str. 165-166.

${ }^{4}$ Adnan Čirgić, $n$. d., str. 77.

${ }^{5}$ Isto, str. 79

${ }^{6}$ Miloš Milošević: Testament Đurđa Crnojevića. Kritičko izdanje s komentarom, Podgorica - Cetinje, 1994.
} 
gospodina Nikole, došao sam u kancelariju presjajne gospode Sopragastalda i svjedočim da sam gore napisani testament, ili zapis (testamentarni), pisan mojom vlastitom rukom, preveo sa jezika i pisma slavenskoga, (pisanog) rukom pokojnog presvijetlog gospodina Đurđa Crnojevića, pokojnog presvijet$\log$ gospodina Ivana, i to vjerno od riječi do riječi, kao što se u onom sadrži, ne mijenjajući ili iskrivljujući smisao bilo koje stvari, sa vlastitim potpisima svjedoka (...)“. ${ }^{7}$ Kao potvrdu toga citata donosimo preslik stranice testamenta Đurđa Crnojevića iz pomenute knjige.

$82 \mathrm{Al}$ qual ricomando ta mia peccatrice anima, de mi Zorzi, ed a ti, consorte mia, con li filioleti mei. Nel millesimo qua-

83 dringentesimo nonagesimo nono dela natività de Christo. Et de Adamo sette mille et octo, nel mese de octobre, adi 22 ,

84 in Milano. lo Zorzi Cernovich ho scripto de mia mano, presenti li testimonil infrascritti. Et sigillai con lo mio sigillo grande per

85 mazor fede. Io Triphon Buchia da Catharo, nepote da parte di sorella del signor Zorzi Cernovich, son testimonio del soprascritto.

86 lo Frano Mednich, son testimonio del soprascritto, essendo servidor del signor Zorzi Cernovich. Io Laicho Stanissalich, servidor del signor

87 Zorzi Cernovich, son testimonio del soprascritto. 1514, adi 20 april, Io Stephano de Pasquali, quondam messer Nicolo, constituido nel officio

88 di Magnifici Signori Sopragastaldi, fazo fede qualiter el sopraseritto testamento, overo cedula, scripta de mia man propria, ho transducta de lingua et lette-

89 ra Illustre Signor Zuane: questo fidelissimamente de verbo ad verbum, como in quello

90 se contien, senza mudar, over alterar, el sentimento de cosa alguna, con le sue sottoscription di testimonii, come in esso. Et in fidem

91 me subscripsi etiam propria manu. Hic finis. Volentes et firmiter statuentes quod suprascripta Helisabet, relicta suprascripti quondam domini Georgii Cerno-

82 Нсму прспоручујсм моју грсшиу душт, мене Ђурһа и тсбе, жсно моја, са дјсчицом мојом. Хиљалу

83 четиристоте дсвсдесет дсветс од рођсыь Христова, а од Адама ссдам хиљада и осмс, мјсссиа октобра, дана 22.

84 у Милану. Ја, Ђурђе Црнојсвиһ, написао сам својсручно, у присуству дољьсспомснутих свјсдока и псчатах својим всликим Псчатом за

85 всһу вјсродостојност. Ја Трипун Буһа из Котора исһак од странс сестре господина Ђурһа Црнојевиһа, свјелок сам горе написаног:

86 Ја, Франо Медниһ, свједох сам горе написаног, као слуга господина Ђурһа Црнојевиһа Ја, Лајко Сташисалиһ, слуга господина

87 Ђурһа ІІршојевиһа, свједок сам горс иаписаног. 1514, дана 20. априла. Ја Стјспан Пасквали пок. господиша Пиколе, дошао сам у каниеларију

88 пресјајне господе Сопрагасталда и свједочим да сам горе написани тестамснт, или запис (тсстамснтарни), писан мојом властитом руком, превео са језика и писма

89 славснскога (писаног) руком покојног прссвијстлог господиша Ђурhа Шрнојсвиhа, покојно пресвијетлог господина Ивана и то вјсрНо од ријечи до ријечи, као ІІто се у оном

90 садржи, не мијењајуһи, или искривљујуһи смисао било које ствари, са властитим потписима свједока, као што (стоји) у ьему, и за овјсру

91 се и потнисах властитом руком. Ту је крај. Хтијуһи и чврсто утврһу. јуһи да се гореспоменута Елизабста улова гореспоменутог господина Ђypha

\footnotetext{
${ }^{7}$ Miloš Milošević, $n . d .$, str. 65.
} 
Boško Mijanović je u svojoj „odbrani“ Jelice Stojanović, odnosno u đerićevskoj odbrani pojave srpskoga imena u Crnoj Gori preskočio da spomene krucijalni podatak da svi spomeni srpskoga jezika i pisma u testamentu o kojemu je riječ potiču zapravo od mletačke administracije. Na to je skrenuo pažnju Miloš Milošević u predgovoru izdanja koje je i sâm Mijanović koristio. Naime, Milošević objašnjava kako je svaki testament, pa i Đurđev, bio pravno nevalidan u originalu. Da bi stekao pravnu validnost, testament je morao biti podvrgnut pravilima mletačke administracije, ,,morao je prije svega biti preveden i, sa uvodnim i završnim klauzulama, prepisan u zvanične spise, rukom duždeva notara. Prevodilac je bio Kotoranin Stjepan Paskvali pok. Nikole i on je izvršio prevod na italijanski jezik, možda još 1503 . godine, a 1514. pred vlastima potvrdio autentičnost tog prevoda. Notar Đakomo Grasolari (Giacomo Grassolari) dao je zvaničnu redakciju teksta, a cjelokupna procedura je dovršena 4. januara 1517. godine“. ${ }^{8}$ Poslije toga postupka original Đurđeva testamenta nije imao pravnu snagu, pa je tako i zagubljen. „Zna se samo pouzdano da je postojao, jer sam prevodilac Paskvali svjedoči da ga je prevodio 'sa jezika i pisma slavenskoga', a mletačka administracija u Senatu navodi u svom uvodnom tekstu na više mjesta da je original pisan svojeručno 'na srpskom jeziku i pismu' pa ga treba prevesti na latinski jezik." ${ }^{\text {"9 }}$ Navedeni Miloševićev citat nalazi se na samome početku knjige, pa je teško povjerovati da ga je Mijanović previdio kad se zna da je dobro iščitao cijelu knjigu da bi u njoj našao svih šest potvrda imena srpskoga jezika, koje je i naveo. Ali nije naveo da nijedan od tih pomena ne potiče iz pera Đurđa Crnojevića niti njegova prevodioca Kotoranina Stjepana Nikolina Paskvalija, kao što nije spomenuo da svi ti pomeni srpskoga jezika i pisma potiču od mletačke administracije. A bio je dužan to naglasiti jer se u Miloševićevoj knjizi kojom se koristio to na više mjesta decidno kaže!

Podmetanje srpskoga jezika Đurđu Crnojeviću starije je od Jelice Stojanović i Boška Mijanovića. Danilo Radojević skrenuo je na taj problem pažnju u knjizi Crnogorci na limesu, ${ }^{10}$ a Vojislav P. Nikčević u knjizi Crnogorski jezik, tom II. ${ }^{11}$ Riječ je o falsifikatu Vasilija Đerića, ${ }^{12}$ koji, baš kao i Jelica Stojanović i Boško Mijanović, navodi sintagmu srpski jezik u tome testamentu, bez naznake da je riječ o napomeni duždeva notara i kancelara Đakoma Grasolarija, a ne o tekstu Đurđa Crnojevića ili njegova prevodioca Stjepana Kotoranina.

\footnotetext{
${ }^{8}$ Miloš Milošević, $n$. $d$., str. 5.

${ }^{9}$ Isto.

${ }^{10}$ Danilo Radojević: Crnogorci na limesu, Podgorica, 1999, str. 61.

${ }^{11}$ Vojislav P. Nikčević: Crnogorski jezik, tom II, Cetinje, 1997, str. 58-59.

12 Vasilije Đerić: O srpskom imenu po zapadnijem krajevima našega naroda, Beograd, 1900. Drugo „vrlo povećano izdanje“ objavljeno je 1914.
} 
Nema sumnje - Boško Mijanović pažljivo je pročitao knjigu Miloša Miloševića Testament Đurđa Crnojevića. O tome svjedoče brižljivo odabrani pomeni srpskoga jezika u njoj. Isto tako nema sumnje - Boško Mijanović je u njoj morao pročitati objašnjenje Miloša Miloševića o toj sintagmi. A da nema sumnje u to da je Boško Mijanović prećutkivanjem ključnih činjenica koje objašnjavaju porijeklo te sintagme želio podržati i osnažiti falsifikat Jelice Stojanović o srpskoj jezičkoj tradiciji u Crnoj Gori - svjedoči i posljednja rečenica njegove polemike s nama: „Zar srpski jezik nije slovenski jezik?“. Srpski jezik jeste slovenski, ali matematičar Boško Mijanović ipak nije Pitagora.

\section{Citirana literatura:}

- Črirgić, Adnan: Aktuelna jezička politika u Crnoj Gori, Matica, br. 37/38, Matica crnogorska, Podgorica - Cetinje, 2009, str. 17-90.

- Đerić, Vasilije: O srpskom imenu po zapadnijem krajevima našega naroda, Beograd, 1900. Drugo „vrlo povećano izdanje“ u Beogradu 1914.

- Mijanović, Boško: Dvorac Crnojevića nije prikazan na graviri u Oktoihu, Matica, br. 39, Matica crnogorska, Podgorica - Cetinje, 2009, str. 159-180.

- Milošević, Miloš: Testament Đurđa Crnojevića. Kritičko izdanje s komentarom, Podgorica - Cetinje, 1994.

- Nikčević, Vojislav P.: Crnogorski jezik, tom II, Cetinje, 1997.

- Radojević, Danilo: Crnogorci na limesu, Podgorica, 1999.

\section{Adnan ČIRGIĆ}

\section{IN THE GROUND OF ONE FORGERY}

The paper represents the answer to the paper written by Bosko Mijanović, entitled Dvorac Crnojevića nije prikazan na graviri u Oktoihu (Matica, no. 39, Podgorica, 2009, pp. 159-180) where is given a false piece of information about the language of the will of Đurađ Crnojević. Mijanović makes an accusation against the author of the text, who, in his opinion, had attacked Jelica Stojanović without a palpable reason and that the fact of the problem were only partially true. Jelica Stojanović claimed that the will had been written in the Serbian language. 
ARHIVA 

LINGUA MONTENEGRINA, god. III, br. 5, Cetinje, 2010.

Institut za crnogorski jezik i jezikoslovlje „Vojislav P. Nikčević“

UDK 811.163.4'28

\section{Bogić NOVELJIĆ}

\section{NAŠ KNJIŽEVNI DIJALEKAT*}

Ulaskom naše pokrajine u današnju državnu zajednicu naš južni književni dijalekat je, izgleda ostao ,ni nam ni vam“. I zaista, on odaje izgled potpuno zapuštenog, skoro zaboravljenog gazdinstva. Dovoljno je samo baciti pogled kamo god gdje naše književno narječje dolazi u pitanje, pa da se odmah uoči kakva pometnja vlada u oblasti književnoga dijalekta naše pokrajine.

Primjera radi pogledajmo našu štampu koja nam pruža vjernu sliku toga haosa. Dopise koje je možda autor napisao čistim ekavskim dijalektom nije slovoslagač uspio da „ekavski složi“, dok druge koje je, opet možda, autor uspio napisati u pokrajinskom književnom narječju, ovaj posljednji je „ekavski pokvario“. Dalji pak napisi, koji su istovremeno i najbrojniji, sami sobom ne uspijevaju da se orijentišu između dva književna dijalekta, te oni logično, ispadaju trostruka mješavina. Najzad i gotovo u svakom slučaju, i naš tipični folklor, naše narodne pjesme, tužbalice, anegdote i t d žrtve su toga haosa. U koliko pak ima porodičnih edicija ili knjiga koje pretendiraju na upotrebu čistog književnog dijalekta naše pokrajine, ove su malo popularne te tako veoma slabo uticajne na narodni književni govor i književno obrazovanje uopšte.

Nepotrebno bi bilo iznositi mnogo toga; pomenućemo još samo stanje u našim školama. Svršetkom svjetskoga rata, udžbenici pisani pokrajinskim dijalektom završili su svoje dalje izdavanje. Nabavljaju se udžbenici od brojnih izdavača te iz raznih književnih centara, svi, dakako, sa oznakom raznih književnih izgovora, što sve u pogledu upoznavanja čistog književnog dijalekta na školsku omladinu utiče tako negativno, da je to kod nje odmah i veoma lako uočljivo. Poseban primjer za ovo pružaju osnovne škole u kojima, počevši od bukvara, ne postoji ni jedan udžbenik pisan pokrajinskim književnim dijalektom...

* Rad je objavljen u: Slobodna misao, br. 35, god. XIV, Nikšić, nedjelja, 23. septembra 1934, str. 4. Priredila ga i prilagodila strukturi časopisa Tamara Krivokapić. 
Naš književni dijalekat sastavni je dio našega književnog jezika. Da li će se on i dalje razvijati ili pak izumirati, pitanje je koje spada u kompetenciju stručnjaka. Tako isto i ovih nekoliko redaka o tome pitanju najmanje plediraju za neko oživljavanje pokrajinskog književnog dijalekta; iznesena je samo pogreška činjenica uočljivih svakom laiku, isključivo sa ciljem, da potsjeti odgovorne na metež i potpuno otsustvo opredjeljenja o upotrebi našeg književnog dijalekta, te da ukaže na neophodnost potrebe orijentisanja: ili kultivisati pokrajinsko narečje u njegovom čistom književnom obliku, ili smatrati da je njegovo razvijanje prestalo te uputiti svoja nastojanja onom književnom dijalektu koji ima najviše izgleda da vremenom postane književnim jezikom cijeloga našega naroda. Ova orijentacija nije potrebna samo nastavnicima, već svima onima koji svojim položajem utiču ili su u mogućnosti da utiču na širenje i razvoj književnoga jezika kod drugih.

Jer, naposljetku, sopstvenik bilo čega, ako nije sposoban dati računa svome vlasništvu, nije dostojan da mu to bude. 
LINGUA MONTENEGRINA, god. III, br. 5, Cetinje, 2010.

Institut za crnogorski jezik i jezikoslovlje „Vojislav P. Nikčević“

UDK 37.016(497.16)

\section{Bogić NOVELJIĆ}

\section{CRNA GORA U ŠKOLSKIM UDŽBENICIMA*}

„Zeta“ je, tu skoro u dva navrata, dotakla ovo pitanje. Osim toga u još jednom, uvijek vladinom listu, vodi se polemika po predmetu koji dijelom spada u ovo pitanje, a koja - uzgred budi rečeno - jednom od polemičara nimalo ne služi na čast. Sasvim je razumljivo zašto je ovo pitanje već izbilo i u javnost; nama se, štaviše, čini da u ovome ima mnogo zakašnjenja: da je, dakle, to pitanje trebalo istaviti još davno. U navedenim slučajevima, pokretači ovoga pitanja dotakli su isto tek djelimično [prvenstveno u pitanju istorijskog gradiva]. Smatramo potrebnim ovoga puta dodirnuti to pitanje u cjelosti onako kako je postavljeno, tj. baciti jedan opšti pogled na sve školske udžbenike s obzirom na zastupljenost naše pokrajine u njima. Ograničavamo se na narodne osnovne škole.

Počnimo s udžbenicima narodnoga jezika. Ako dohvatimo ma koji od tih udžbenika (bukvar, čitanku, gramatiku) vidjećemo na prvi pogled da Crne Gore nema u njima. Ni po čemu. Iako sva pozitivna vaspitna načela kategorički zahtijevaju da se, čim je moguće više, jaz koji postoji između roditeljske kuće i škole otkloni i učini neprimijetnim, na njih se kod nas niko ne osvrće. Umjesto toga naše osnovne škole, poglavito zbog udžbenika koji se u njima upotrebljavaju, toliko su daleko od naroda da je to „divljenja“ dostojno. A i kako ne bi, kad toga naroda gotovo uopšte i nema u njima. Skoro ni po čemu. Prije svega, a i najglavnije od svega: po narodnu govoru. Već od prvih dana škole nastavnici moraju djeci prevoditi izraze sa istočnog narodnog izgovora (ekavskog) na naš narodni (ijekavski) izgovor. Bukvari prosto kipte takvim izrazima i pola vremena se utroši na njihovo objašnjavanje. Evo vam nekoliko izraza o kojima možete još odmah pitati djecu koju u idućoj godini namjeravate upisati u prvi razred, pa ćete se, vjerujemo, prijatno iznenaditi dobijenim odgovorima. Šta naprimjer, znače ovi izrazi: uja, sêlo (sijelo ili sélo), bes, meh, svet (svijet ili svetac), jege, vrg, šarage, dada, đevđir? itd, itd. Oče-

* Rad je objavljen u dva nastavka u časopisu Zeta, br. 47, str. 3 i 48, str. 3, god. 1937. Priredio ga i strukturi časopisa prilagodio Adnan Čirgić. 
vidno je da ih ima koje ni nastavnici ne znaju rastumačiti, a šta tek onda znače za djecu? Osobna imena, naprimjer, zvuče prosto neshvatljivo. Tako: Isa (Isidor?), Vaja (?), Mlađa (Mladež?), Tima (Timotije?), Sreta (Sreten?) i sl. Za mnoga se ne zna da li su muškoga ili ženskoga roda, kao: Vida, Pera, Mita, Đura (Đurđina?), Vasa itd. Nego, neka to. Važno je da mi (osim, možda, 2-3 zagrebačkog izdanja), u našoj državi, uopšte nemamo bukvara napisana ćirilicom, u ijekavskom izgovoru. A zaključak je: Crne Gore nema čak ni u bukvarima!

O gramatikama (za sve razrede) ne zaslužuje uopšte govoriti više nego to: da Crne Gore nema ni u njima. Apsolutno. Ali u njima ima nešto što ne znaju ni višeškolci naši. Na primjer, da je od osobne imenice Mile (m. rod) 2-gi padež - Mileta! Hajde, što i to ne znamo, neka ga! Ali smijemo pretpostaviti da nove generacije i naših profesora [domorodaca] već nijesu načisto da li je ono po našoj gramatici pravilno, naprimjer, reći: riješenje, rješenje ili rešenje; slijedeće, sljedeće ili sledeće; odjeljenje, odeljenje ili odelenje i slično. Ne zbog čega drugog već samo zato što od Ujedinjenja pa naovamo uopšte nema: ili Crne Gore u gramatikama ili gramatika (njenih) u Crnoj Gori - uzmite kako hoćete!

Čitanke za III i IV razred, u normalnim prilikama, treba da pruže učenicima, pored pretežno ostalog poučnog štiva, još i pojedine odabrane spise iz istorijskog, zemljopisnog, prirodopisnog i dr. gradiva, ono, dakle, što i pojedini predmetni udžbenici nemaju mogućnosti da obuhvate u potankostima. Međutim izuzev par članka iz zemljopisnog gradiva na pr. o Lovćenu, Boki Kotorskoj, Cetinju i sl., o svemu ostalom nema ni pomena. Nije pitanje kakvo će poznavanje o Crnoj Gori da steku školska djeca drugih pokrajina, nego je riječ o tome kako je učenicima iz našeg kraja predočeno nastavno gradivo iz kojeg imaju da steku osnovno znanje o svojoj zavičajnoj pokrajini. Ali da ne govorimo autoritativno, potrebno je malo brojeva. Pregledaćemo dvije vrste čitanka za III i IV razred (od g.g. Jovića i Jovanovića) koje su najviše (gotovo isključivo) u upotrebi u našoj pokrajini. Broj štiva (članaka) iz pojedinih nastavnih predmeta pripadnih sadržajem pojedinim pokrajinama izgleda ovako: Jović, čit. III razr.: Srbija (26), Crna Gora (0), sve ostale pokrajine (2). Moramo ovdje napomenuti da u 6 članaka (od onih 26) i Crna Gora ima dijela pošto su to: četiri pjesme iz kosovskog ciklusa, zatim „Marko kazuje na kome je carstvo“ i pjesma „Rastko“. Jović, čit. IV razr.: Srbija (14), Crna Gora (2), sve ostale pokr. (18). Ona dva članka o Crnoj Gori su: „Kotor“ i „Klima u Crnoj Gori“, oba iz zemljopisne nastave; iz istorije, dakle, u oba udžbenika niti jedno štivo. - Jovanović, čit. III razr.: Srbija (13), Crna Gora (0), sve ostale pokr. (0). Ima, doduše, i još jedan članak „Hajduci i uskoci“, ali je ovaj opšteg značenja. Crna Gora ima dijela opet u 3 kosovske pjesme i pjesmu o Sv. Savi, - Jovanović, čit. IV razr.: Srbija (32), Crna Gora (5), sve 
ostale pokr. (18). Članci o Crnoj Gori nose naslove: „Stara Zeta“, „Lovćen“, „Na izvoru Beloga Drima“, „Boka i Bokelji“ i „Voka“ (pjesmica); 4, dakle, iz zemljopisne a jedan jedini iz istorijske nastave.

Daleko smo i od pomisli da kritikujemo spomenute udžbenike. Naprotiv, oni su vrlo lijepo udešeni, ali za one pokrajinske zavičajnosti kojima pripadaju sami autori udžbenika. Naše je pitanje, kako je Crna Gora zastupljena u današnjim školskim udžbenicima za osn. škole, a brojevi su dali najrječitije odgovore. Slično navedenim udžbenicima, stvar stoji (i još u jačoj mjeri) sa svima udžbenicima beogradskog izdanja.

O udžbenicima iz istorije bilo je riječi u ranijim dopisima o ovom pitanju u „Zeti“", kao što je spomenuto. Zato nećemo ponavljati. Spomenućemo ipak jednu značajnu stvar. Istorija se, u osnovnoj školi, uči u III i IV razredu. Da se ne pozivamo na vaspitne principe, već prema najobičnijem laičkom shvatanju, red bi bio da se u III razr. upozna svoja istorijska zavičajnost (kao najbliža te time i najlakša za upoznavanje), a zatim u IV r. istorija ostalih pokrajina, kako bi učenici, napuštajući osnovnu školu, imali bar ono najneophodnije osnovno znanje o prošlosti našega čitavog ujedinjenog naroda. Dosljedno tome, učenici naših škola trebalo bi da izučavaju u III razr. samo istoriju Crne Gore, a u IV razr. istoriju svih ostalih bivših istorijskih pokrajina u našoj državi. Jer, istorija se bar ne može prikazivati onakvom kakva bi mi željeli da je bila, već tačno onako kako je tekla. Međutim, šta se dešava? Nastavni program za III razred predviđa iz istorije izučavanje samo devet istorijskih ličnosti, a to su: Ćirilo i Metodije, Sveti Sava, Knez Lazar, Kraljević Marko, Nikola Šubić - Zrinjski, Karađorđe, Štrosmajer, Kralj Petar Veliki i Kralj Aleksandar. Odredbom, dakle, samog nastavnog programa u svima udžbenicima za III razred osn. škola u našoj državi ne može biti i nema o Crnoj Gori niti jedne riječi. U IV pak razredu učenicima se može prikazati istor. gradivo naše pokrajine preko ovih naslova: „Kraljevina u Zeti“, [,Nemanjići“], „Turska osvajanja jugoslovenskih zemalja“, „Oslobođenje Crne Gore“, „Ratovi za nezavisnost Srbije i Crne Gore (1876-1878) i njihove posljedice“, „Balkanski ratovi“ i „Svjetski rat“. - Pitanje je, dakle, kako će pojedini sastavljač udžbenika, u gornjem djelokrugu, iznijeti istorijsko gradivo što pravednije.

Samo na dvama glavnim škol. predmetima (ostali su za ovo pitanje manje važni) prikazali smo činjenicama da više-manje Crne Gore stvarno nema u udžbenicima za osnovne škole. Ko dokaže protivno bićemo mu zahvalni. Krivicu za to nedostojno je baciti ma na koga drugoga već na sebe lično. Jer, ako čovjek neće sam da povede računa o svojoj materijalnoj ili duhovnoj imovini, od koga drugoga može to tražiti? Povoljno riješenje pitanja udžbenika za osnovne škole, s obzirom na naše pokrajinske prilike, nije imalo težak problem; ali o tome drugom prilikom. 

LINGUA MONTENEGRINA, god. III, br. 5, Cetinje, 2010.

Institut za crnogorski jezik i jezikoslovlje „Vojislav P. Nikčević“

UDK 323.1(497.16):316.7

\section{Radoje RADOJEVIĆ}

\section{DISKUSIJE NA SIMPOZIJUMU CRNOGORSKA KULTURA I PUTEVI NJENOG RAZVOJA*}

Prethodno ću nešto reći o nekim stavovima iz saopštenja prof. dr Vuka Pavićevića i iz prvih izlaganja koja smo ovdje čuli.

Kategorički odbijam, ne samo ovdje nego bilo gdje, da raspravljam o tome da li postoji ili ne postoji crnogorska nacija i nacionalna kultura. Smatram da to ni u kom slučaju ne može biti ni predmet rasprave na ovome skupu. Isto tako odbacujem, kao nenaučne, buržoasko-idealističke terminološke špekulacije sa „nacionalnim osobenostima”, ,individualnostima” i sličnim terminološkim zaobilaženjima, pomoću kojih se želi produžiti tretman crnogorske nacije i nacionalne kulture u skladu sa starim buržoasko-nacionalističkim i hegemonističkim interesima pojedinih društvenih grupacija u Jugoslaviji. Kad se opšti pojam „nacionalna osobenost”, koji označava nacionalne razlike među nacijama uopšte, primjenjuje na Crnogorce tako da se ne kaže „,crnogorska nacija” već „,crnogorska nacionalna osobenost”, onda je očito da se iza toga krije težnja za indirektnom negacijom crnogorske nacije. Takvim se postupkom crnogorsko nacionalno biće ograničava i svodi na nepotpuno izražene nacionalne „osobenosti”, ,posebnosti”, „specifičnosti” itd., na neke regionalne karakteristike po kojima se Crnogorci razlikuju od „matične” nacije kojoj „,pripadaju” u ,širem” smislu. Simplifikacije o „dvonacionalnosti” crnogorske nacionalne kulture imaju isti smisao i ne mogu izdržati ni najblaži naučni kriterijum. Ako se ni za jednu nacionalnu kulturu u Jugoslaviji, ili bilo gdje u svijetu, ne postavlja problem njenoga „dvonacionalnog” karaktera, zašto se to čini u odnosu na crnogorsku nacionalnu kulturu? Kad postoji nacija, postoji i nacionalna kultura kao osnovni element nacionalnog bića, kao neotuđivo kulturno nasljeđe i bogatstvo nacije. Opšti značaj crnogorske nacionalne kulture za sve narode Jugoslavije, pa i za druge ukoliko njeni

* Tekstovi su objavljeni u: Crnogorska kultura i putevi njenog razvoja, druga knjiga, Kulturno prosvjetna zajednica Crne Gore, Titograd, 1968, str. 40-46. i 204-207. Priredio ih i prilagodio strukturi časopisa Aleksandar Radoman. 
dometi dosežu, ničim nije umanjen ako se ona smatra onim sto jeste: crnogorskom, ako se u školskim programima, antologijama, udžbenicima i svim mogućim drugim vidovima ne tretira kao sastavni dio neke druge nacionalne kulture. Međusobni kulturni uticaji i prožimanja nacionalnih kultura su opšta pojava, čime se ne umanjuje nacionalni karakter pojedinih kultura. Sa tog stanovišta su neprihvatljive i neke teze dr Pavla Mijovića.

Saopštenje prof. dr Vuka Pavićevića smatram nenaučnom improvizacijom. Pavićević i sam više puta ističe da nije dublje proučavao probleme o kojima piše. Iz te činjenice je trebalo da izvuče konsekvence prije nego što se prihvatio toga posla. Sam naslov saopštenja („O nacionalnoj kulturi i etosu Crne Gore") pokazuje kako je autor pristupio ovoj temi. Crna Gora kao geografsko-politički i državno-pravni pojam nema svojega etosa, pa ni nacionalne kulture. Subjekt je crnogorski narod, koji je stvorio svoju nacionalnu kulturu. I Pavićević govori o etničkim grupama u nacionalnom smislu, tj. o naciji kao etničkoj grupi kod koje je manje ili više izražena ,nacionalna osobenost" (kao da nacije postaju samo od kompaktnih etničkih grupa!), zamjenjujući naciju etničkom grupom, i o sličnim besmislicama. Pavićevićevo „,sociološko” i „karakterološko” posmatranje Crnogoraca podsjeća na „naučni” postupak Sima Šobajića i Vladimira Dvonikovića. Nije čudo što su neki listovi pohitali da prikažu Pavićevićevo saopštenje, objavljeno u „Praksi”, i to baš citiranjem njegovog završnog dijela gdje se govori o crtama u etosu i mentalitetu crnogorskog naroda koje su mu zajedničke „sa ostalim srpskim” narodom. Pogotovo je nerazumljivo zašto je organizacioni odbor prihvatio ovo saopštenje, kad je već postojao onako dobar rad magistra Vidaka Vujačića na istu temu.

Sada ću nešto da kažem na temu: crnogorska nacionalna kultura - izraz ostvarivanja slobodne ličnosti.

Crnogorska nacionalna kultura, kao i nacija, nastala je kroz mnogovjekovne permanentne borbe protiv političkog i ekonomskog porobljavanja, odnarođavanja i kulturnog potčinjavanja. Ona je izraz ostvarivanja slobodne ličnosti, te ima karakteristike koje proističu iz crnogorske istorije, emotivnog i etničkog ostvarivanja crnogorskog naroda. Za bolje razumijevanje tih nacionalnih karakteristika moramo imati u vidu i specifičnosti razvojnog puta crnogorskog naroda, često zanemarivane ili nenaučno prikazivane.

Crnogorci su etnički jednako srodni svim slovenskim narodima, ali ih je istorijski proces posebno zbližio s jugoslovenskim narodima, politički, ekonomski i kulturno. Osim toga, slovenska plemena koja su naselila područje današnje Crne Gore asimilirala su romansko i mnogobrojno ilirsko stanovništvo, što se odrazilo i na antropološke i duhovne osobine Crnogoraca. Razvijena privreda i kultura starosjedilaca, Romana i romanizovanih Ilira, koju su primili preci Crnogoraca, uslovila je brz ekonomski, politički i kulturni 
napredak slovenskih plemena u Duklji, docnijoj Zeti odnosnoj Crnoj Gori, tako da su moćni zetski kneževi već 1077. stvorili prvo zetsko kraljevstvo. Međutim, proces feudalizacije nije uništio plemensku strukturu, niti je, po svemu sudeći, bio dovršen u brđanskim stočarskim plemenima.

Relativna potčinjenost zetskih feudalaca feudalnim vladarima iz države Nemanjića, u trajanju od oko sto sedamdeset godina, nije mogla skrenuti istorijski proces autohtonog prerastanja zetskog stanovništva u crnogorski narod, od kojega je postala crnogorska nacija. Otpor feudalnom potčinjavanju, naročito poslije raspada državne organizacije, jačao je plemensku i međuplemensku koheziju. U tome jedinstvu, koje izrasta iz otpora, nalazimo korijen stvaranja crnogorskog naroda i izgradnje svijesti o jedinstvu interesa, iz čega slijedi i svijest o narodnosti.

Za formiranje etosa Crnogoraca, bila je presudna činjenica što su se prvi od evropskih naroda oslobodili feudalnog jarma. Padom feudalne države Crnojevića raspao se i domaći feudalizam. Turski feudalci nikad nijesu uspjeli potčiniti i počiftlučiti većinu crnogorskih plemena. Pokušaj indirektnog potčinjavanja uvođenjem filurije, u početku šesnaestog vijeka, dok se crnogorska plemena nijesu ojačala i sjedinila u otporu, nije imao osjetnijeg uspjeha, jer crnogorski slobodni seljaci ni u kom obliku nijesu htjeli da prihvate nove gospodare. Stara plemenska struktura, prilično očuvana u feudalizmu, obnavlja se u modificiranom obliku unutrašnjeg jedinstva bratstveničkih, plemenskih i međuplemenskih interesa u borbi protiv turskog feudalizma.

Sa stanovišta istorijskog ostvarivanja crnogorskog naroda, progresivna je istorijska činjenica: poraz feudalne države Crnojevića. Iz te nove istorijske situacije rezultirao je viševjekovni direktni sukob slobodnih crnogorskih seljaka i primorskih građana s turskim feudalizmom i aristokratskom Mletačkom Republikom. Crnogorci su na taj način ,,preskočili” dugi period feudalnog kmetstva kroz koji je prošla Evropa. Slobodni crnogorski seljaci, klasno slabije izdiferencirani, i pored neminovnih međuplemenskih sukoba, branili su nezavisnost. Primorski građani su bili snažan oslonac njihovoj borbi, a i sami često aktivni učesnici oružanih sukoba. Velika potvrda jedinstva svijesti crnogorskog naroda snažno je izražena već u istrazi poturica. U svijetlu toga saznanja treba gledati i na kontinuitet crnogorske slobode od kraja petnaestog vijeka na ovamo, a ne po tome koliko je cetinjska mitropolija u šesnaestom i sedamnaestom vijeku imala atributa državne vlasti u odnosu na spoljne sile i unutrašnji život crnogorskih plemena.

Institucija „opšteg zbora naroda Crne Gore”, pored skupova plemenskih glavara, bila je ustaljena još početkom sedamnaestog vijeka. 1660. godine 39 crnogorskih plemenskih glavara, u ime „opšteg zbora”, potpisuju s predstavnicima Mletačke Republike ugovor o nenapadanju i zajedničkoj borbi protiv Turaka. 
Pleme, taj specifični oblik političke samouprave u crnogorskom društvu i jedinica borbenog saveza crnogorskog naroda, pretvorilo se u sopstvenu suprotnost onda kad je postalo smetnja ubrzanom razvoju nacionalne svijesti i stvaranju savremene državne organizacije. Pleme je u osnovnoj društvenoj funkciji prevaziđeno već u prvoj polovini devetnaestog vijeka, u sklopu opšteg društvenog razvoja. U gradovima Crnogorskog primorja bila je razvijena građanska klasa. U slobodnoj Crnoj Gori je, povezano s ovom, izrastala još u prvoj polovini devetnaestog vijeka osobena građanska klasa iz redova glavara i imućnijih seljaka, koji su se bavili i trgovinom, i nekim drugim vidovima robno-novčanog privređivanja, pa su bili nosioci privrednog, političkog i kulturnog života. Ubrzanim prerastanjem crnogorskog naroda u naciju, apsolutnom pobjedom jedinstva interesa crnogorskog naroda, uništen je i plemenski partikularizam još za vlade knjaza Danila. Sličan proces zbivao se u Norveškoj, pa Engels u pismu Paulu Ernestu, 1890. govoreći o razvoju norveške nacije i nacionalnog duha, kaže: „Norveški seljak nikad nije bio u kmetskoj potčinjenosti, a ta činjenica, slično kao u Kastilji, daje sasvim drugu pozadinu. (...) Ova je zemlja, doduše, uslijed odvojenosti i prirodnih uslova zaostala, ali njeno stanje je uvijek bilo primjerno njenim proizvodnim uslovima i stoga normalno." Ima i drugih primjera koji pokazuju koliko je nenaučno shematsko shvatanje da se nacionalna svijest može razviti samo u društvu koje se nalazi u razvijenim kapitalističkim odnosima.

Primivši hrišćanstvo i pismo od Romana, preci Crnogoraca su rano ušli u krug uticaja latinske kulture, ali se među njima širio i vizantijski kulturni uticaj, te se kroz sve sinteze činilaca i uticaja uobličuje specifična kolotečina kulturnog i književnog nasljeđa što u devetnaestom vijeku služi kao temelj daljega razvoja crnogorske nacionalne kulture.

Kulturni i književni rad u crnogorskom plemenskom društvu stagnira od početka šesnaestog do potkraj osamnaestog vijeka, ali se ne gasi. Pritom narodni jezik ostaje neprekidno kao književni, nasuprot crkvenoslovenskom jeziku koji je uglavnom egzistirao u crkvenim tekstovima. Ako pažljivije oslušnemo jezik tekstova iz toga vremena koji imaju djelimično književno-umjetnički karakter, možemo utvrditi da je on izvorno narodni, uvijek živ, sa vrlo neznatnim primjesama dikcije i leksike crkvenoslovenskog jezika. Vještačke jezičke tvorevine u osamnaestom i devetnaestom vijeku nijesu bile potrebne Crnogorcima, niti su služile kao književni jezik u crnogorskoj književnosti. Crnogorski glavari, vladike i drugi pismeni ljudi redovno pišu dobrim narodnim jezikom, koji tako postepeno dobija specifičnosti književnog jezika, koji je u djelu Petra Prvog dobio najbolji izraz. U Crnogorskom primorju kontinuirano se razvijao narodni slovenski jezik kao književni; tu je napredovala pisana književnost, unapređivana prosvjeta, umjetnost i nauka. Vukova reforma nije imala značaja za crnogorsku književnost osim u pogledu pisma i pravopisa. 
Slobodni crnogorski čovjek utemeljio je slobodu u svoj etos, u svoju kulturu, a posebno u književnost kao najstariji i najrazvijeniji oblik svojega umjetničkog stvaralaštva, koja ima za osnovni podsticaj i predmet slobodno ostvarivanje čovjekove ličnosti u stremljenju opštemu dobru. Prihvatajući, u borbi za opstanak, smrt kao realnu alternativu slobodnom ostvarivanju čovjeka, plemensko društvo je izgradilo surove moralne norme, ali je i pored toga u njemu moralo dolaziti i do pojava moralnog klonuća, razdora, izdaje, međusobnog krvoprolića i drugih opačila. Crnogorski narod je prebrodio strašne polome i mnogo puta se potvrdio u sudbonosnim trenucima istorije, posebno u narodnooslobodilačkoj borbi i revoluciji. Crnogorska nacionalna kultura vjerno je odrazila ,strašne ure” Crnogoraca.

Crnogorci su svoju borbu za održanje slobode shvatili kao dio opšte borbe za slobodu. Tako u crnogorskoj nacionalnoj kulturi nema izraženog nacionalizma, šovinizma i hegemonizma, tih strašnih otrova buržoaskog klasnog poretka. Crnogorci su i u kulturi kao i u borbi sjedinjavali posebno i opšte. Razni paraziti na zdravom tijelu nacionalne kulture, koji su „u ime crnogorskog naroda" ispoljavali druge i suprotne ideje i interese, nemaju mjesta u crnogorskoj kulturi ni po „djelu” ni po ,idejama”.

Revolucionarni crnogorski pisci između dva rata umjetnički su snažno izrazili jedinstvo revolucionarne borbe crnogorskog naroda za nacionalno i socijalno oslobođenje, s težnjama jugoslovenskog i svjetskog revolucionarnog poretka. Kad je Radovan Zogović gledao, u „Internaciji Crne Gore”, kako „svezana Crna Gora ide preko Crne Gore”, vidio je hod stotina miliona potlačenih radnika i seljaka širom svijeta, kao što je gledao i Mirko Banjević u „Brijestu” i „Tužbi svetom Vasiliju Ostroškom”, ili Janko Đonović u „Morači” i „Crncima i Crnogorcima”. Zato je nepojmljivo prazno estetičarsko pobijanje umjetničke vrijednosti književnosti koja održava socijalna previranja i revolucionarni pokret između dva svjetska rata.

Danas crnogorska nacionalna kultura ne samo najboljim ostvarenjima, daje svoj doprinos kulturnoj riznici jugoslovenskih naroda i opštoj kulturi.

$$
* * *
$$

Nije nam bio cilj, a to nijesmo ni činili, da dokazujemo nespornu istorijsku činjenicu - crnogorsku naciju i nacionalnu kulturu (Još 1857. godine Anri Delari, učeni Francuz, dobar poznavalac crnogorskog naroda, napisao je o Crnogorcima: „Veoma razvijene socijalne svijesti, oni pomažu danas, kad prelaze iz stanja plemena u stanje nacije, svoju narodnu upravu sa svom onom ljubavlju sa kakvom su nekad pomagali svoje pleme!"). Pa ipak je moralo biti riječi o pojavama nacionalizma i hegemonizma prema crnogorskom narodu, o nekim velikosrpskim koncepcijama i nastojanjima da se crnogor- 
ska nacija i nacionalna kultura prikažu kao djelovi srpske nacije i nacionalne kulture.

U gledanju na ove probleme za mene je bitna jedna stvar: onaj ko je marksist, komunist, revolucionar, koji ima razvijenu socijalističku društvenu svijest, ne može biti nacionalist. Marks, u jednome pismu Engelsu, piše da je upoznao Lopatina, ruskog revolucionara-narodnjaka, i kaže za njega - slobodno interpretiram - da je to divan revolucionar ali da mu je slaba tačka Poljska... Kao velikorus, Lopatin nije mogao da prevaziđe hegemonistički odnos prema poljskom narodu. Nacionalizam je plod klasnih buržoaskih shvatanja; on se manje ili više javlja među svim narodima, pa ni mi Crnogorci ne možemo reći da smo potpuno čisti od njega. Zato je revolucionisanje naše društvene svijesti, borba za pobjedu komunističkih društvenih ideala i za jačanje Socijalističke Federativne Republike Jugoslavije kao zajednice slobodnih i ravnopravnih naroda i narodnosti, put koji vodi ka potiranju ostataka klasnog društva iz društvene svijesti i društvenih odnosa.

I ovi naši razgovori moraju ličiti na pravdanje pred sopstvenim narodom. Crnogorski naučni i drugi kulturni radnici su za posljednje 22 godine malo uradili na naučnom izučavanju i osvjetljavanju prošlosti i sadašnjosti crnogorskog naroda. Tako je ostala ,važećom” sva ona po obimu ogromna literatura, koja s buržoasko-idealističkih, nacionalno-romantičarskih i velikosrpskih pozicija, neistorijski i nenaučno govori o crnogorskom narodu i njegovoj kulturi. Istina, ekonomske teškoće su dosta ometale rad na istinski naučnom raspravljanju ovih pitanja u redovima crnogorskih kulturnih radnika. Tome su pružale otpor i određene unitarističke i hegemonističke snage u našoj zemlji, koristeći se snažnim pozicijama u naučnim i kulturnim institucijama, na univerzitetima, u izdavačkoj djelatnosti itd. Te snage, naročito u toku posljednjih desetak godina, nastoje da „ovjekovječe” takvo naslijeđeno stanje, da ,naučno fundiraju” one „međe” prema kojima se crnogorska nacionalna istorija i kultura, a time i nacija, uključuje u srpsku. U ovome se jasno vidi i tendencija da se u socijalističkoj epohi našeg društvenog života stvori za buduće generacije „,naučni” oslonac hegemonizmu. Stoga se svakodnevno pojavljuju razne istorije, enciklopedije, monografije, rječnici, edicije književnih djela, studije, rasprave i mnogi drugi radovi u kojima se crnogorska nacionalna istorija i kultura tretira kao srpska. Međutim, sada su drugovi srpski komunisti poveli borbu protiv tih decenija, i mi treba da im u tome pomognemo. Suprotstavljajući se pojavama nacionalizma i nacionalne romantike u sopstvenoj sredini, crnogorski kulturni radnici imaju zadaću da crnogorskoj nacionalnoj kulturi pruže onaj naučni aparat koji druge nacionalne kulture već odavno imaju, čime će se efikasno dezavuisati sva ona „literatura” o kojoj sam govorio.

U nekim saopštenjima i izlaganjima bilo je govora o pojedinim poduhvatima od bitnog značaja za crnogorsku nacionalnu kulturu (pretvaranje 
Diskusije na simpozijumu Crnogorska kultura i putevi njenog razvoja

„Pobjede” u dnevni list, ostvarenje započetog programa na izgradnji televizijskog studija, ponovno osnivanje crnogorskog naučnog društva itd.). Razumije se da pritom moramo voditi računa o realnim ekonomskim mogućnostima, da je beskorisno govoriti o zamislima koje se ne mogu ostvariti, ali se moraju ostvariti neke bitne pretpostavke za unapređenje naše kulture. Jedna od najprečih potreba naše kulture je, na primjer, pisanje istorije crnogorske književnosti. S obzirom da je za stvaranje takvoga kapitalnog djela nužan dug prethodni istraživački rad, valjalo bi ga uskoro organizovati i postupno pružati materijalnu pomoć naučnim radnicima kojima bi bio povjeren taj posao. Isto tako bi valjalo raditi na pisanju monografija iz pojedinih oblasti nacionalne kulture, koje bi u budućnosti poslužile kao osnov za izradu kulturne istorije Crne Gore. Mislim da se i problem udžbenika može bolje riješiti. Pošto nije moguće ekonomski rentabilno izdavati sve udžbenike, a nema dovoljno sredstava za subvenciju, trebalo bi ispitati mogućnost da se u Crnoj Gori izdaju bar oni najnužniji udžbenici iz humanističkih nauka, iz nastave pismenosti, jezika, književnosti, istorije itd. Zapravo, prethodno obezbijediti izdavanje onih udžbenika gdje se u programu nastave polazi od posebnog, nacionalnog, ka opštem. Moguće je u tom pogledu ostvariti dobru saradnju i sa zavodima za izdavanje udžbenika iz drugih socijalističkih republika, radi smanjenja troškova, ali bi ti udžbenici morali u potpunosti odgovarati, jezički i programski, nacionalnom karakteru crnogorskog školstva, kao što je slučaj i u školstvu drugih socijalističkih republika u Jugoslaviji. Postoje i mnoge druge oblasti gdje se i sada može dosta učiniti na poboljšanju postojećeg stanja.

Ovdje je dosta govoreno o etosu i tradicionalizmu. Razumije se da nijedan narod, pa ni crnogorski, nema jedinstven moral, jer moral ima klasnu suštinu i kao takav je podložan promjenama u skladu s mijenjanjem društveno-ekonomskih odnosa. Riječ je o onim elementima duhovne nadgradnje društva, psihičke konstitucije, koji posebno karakterišu većinu članova toga društva, iako ne sve podjednako. Zajedničke crte u sistemu vrijednosti, mentalitetu, načinu mišljenja, socijalnom aktivitetu i drugim osobinama u duhovnom biću Crnogoraca, čine onu nacionalnu karakteristiku koju uslovno nazivamo etosom. U tome etosu imaju trajnijih vrijednosti, koje se obogaćuju novim vrijednostima socijalističkog humanizma, transformišu u kvalitativno novim uslovima i predstavljaju novu društvenu vrijednost. Revolucionisanjem društvene svijesti, društvo potiskuje neodgovarajuće oblike moralnih shvatanja i tradicija. Prema tradicijama moramo biti obazrivi, boriti se za sintezu starih i novih vrijednosti u novim uslovima, a potiskivati sve ono što koči duhovni i materijalni napredak. Naša borbena, revolucionarna marksističko-komunistička opredijeljenost, mora voditi, kroz sve sinteze i preobražaje, ka izgradnji novog socijalističkog morala. 



\section{UPUTSTVA SARADNICIMA}

Časopis Lingua Montenegrina prvjenstveno objavljuje originalne rezultate filoloških i kulturoloških naučnih ispitivanja, i to one radove koji se publikuju prvi put, ali i preliminarna saopštenja, pregledne naučne radove i stručne radove.

Pored toga, Redakcija objavljuje i recenzije i prikaze knjiga, časopisa, naučnih i stručnih skupova. Odabir ponuđenih rukopisa za objavljivanje te klasifikaciju odabranih radova Redakcija časopisa zasniva na ocjeni recenzenata.

C̆asopis Lingua Montenegrina izlazi na crnogorskome ili nekom drugom slovenskome jeziku, kao i na engleskome jeziku.

1. Izvorni naučni rad (Original scientific paper) sadrži neobjavljivane rezultate izvornih teorijskih ili praktičnih ispitivanja koje je autor korektno naveo tako da se mogu provjeriti njihova tačnost i tačnost analiza.

2. Preliminarno saopštenje (Preliminary communication) sadrži građu ili naučne podatke koji zahtijevaju brzo objavljivanje.

3. Pregledni rad (Review) jeste kritički i analitički pregled nekog područja ispitivanja ili jednog njegova dijela. U članku treba biti vidan autorov doprinos izučavanju izabrane problematike, a citirana literatura mora biti cjelovita.

4. Stručni rad (Professional paper) informiše i uvodi u problematiku struke bez pretenzija da bude plod naučnoga istraživanja.

U gornjem lijevom uglu potrebno je istaći: ime i prezime autora, titulu, instituciju u kojoj je zapošljen, grad i e-mail adresu.

Naslov rada mora biti kratak i jasan.

Rad treba da ima sažetak od oko 250 riječi i ključne riječi. Naslov rada, sažetak i ključne riječi potrebno je prevesti na engleski jezik.

Autor predlaže kategorizaciju rada, a konačnu odluku, nakon recenzentskoga postupka, donosi Redakcija časopisa.

Rukopisi i CD se ne vraćaju.

Redakcija 



\section{SADRŽAJ}

Jelena ŠUŠANJ:

Dekomponovanje leksema i birokratizacija jezika na primjerima

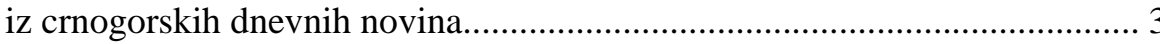

Miomir ABOVIĆ:

O prirodi veznika $a$ i mogućnosti komutabilne upotrebe veznika $a$ i $i \ldots \ldots . . .47$

Miloš KRIVOKAPIĆ:

Frekvencija glagolskih oblika u Ljubišinu jeziku ........................................ 61

Branko KUNA:

Kvalitativni genitiv u hrvatskome jeziku .................................................... 67

Milica LUKIĆ:

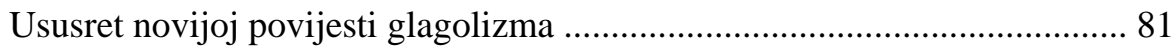

Loretana FARKAŠ:

Oblikovanje stručnoga nazivlja u hrvatskom jeziku 18. stoljeća

Lilianna MIODOŃSKA:

Czy obecna serbska polityka językowa to już językowy lapot?

Sandra VUJOVIĆ:

Funkcija prozodijskih elemenata $\mathrm{u}$ televizijskim emisijama razgovor-

noga tipa na engleskom jeziku

Irineusz KIDA:

Metalanguage in English and Spanish Classroom Instruction -

How Much of Transparency?

Ivana KOVAČ-BARRETT:

Istorijski, pravni i sociolingvistički kontekst jezičke situacije u Španiji ... 157

Milorad NIKČEVIĆ:

Poezija druge polovine XIX i početka XX vijeka

Marjana ĐUKIĆ:

Sentimentalizam Turskih pisama Stjepana Zanovića 
Jakov SABLJIĆ:

Prva crnogorska književna antiutopija

Vesna KILIBARDA:

Lazar Tomanović kao italijanista

Nino RASPUDIĆ:

Niccolò Tommaseo i istočna obala Jadrana

- Od sentimentalističkog paternalizma do nevolja s Njegošem

Boris ŠKVORC:

Konstrukcija, prenošenje i preoblikovanje priče(a) o nacionalnim identitetima: O Krležinom Starčeviću i Andrićevom Njegošu .

Zlata ŠUNDALIĆ:

Konotacije puta u Vili Slovinki

Marko DRAGIĆ \& Ivana ODŽA:

Kliški kapetan Petar Kružić i njegova supruga Jerolima u književnosti, povijesti i suvremenom narodnome pripovijedanju

Vanda BABIĆ \& Denis VEKIĆ:

Pretkršćanska vjerovanja u dolini Neretve 403

Zlata ŠUNDALIĆ:

Carstvo plantae u propovjedničkome žanru 427

Mirna BRKIĆ:

Igra na pozornici života

Olivera KUSOVAC:

Čovjek i natčovjek: Dvostruko lice Šoovog feminizma

Miomir ABOVIĆ:

Mistično-ironijska poniranja Viktora Peljevina

Dragana Kalezić:

Ruski pisci na sceni Crnogorskog narodnog pozorišta (I)

Helena DRAGIĆ:

Dukljanski kralj sveti Vladimir u hrvatskoj književnosti i crnogorskoj tradiciji

\section{GRAĐA}

Vukić PULEVIĆ:

Prva dopuna fitotoponimiji i zootoponimiji Crne Gore 537 
Adnan ČIRGIĆ:

Građa za izučavanje njeguškoga govora 599

Amira TURBIĆ-HADŽAGIĆ:

Prilog kulturnoj baštini: Dva krajišnička pisma iz 17. stoljeća (II)

\section{PORTRETI}

Adnan ČIRGIĆ:

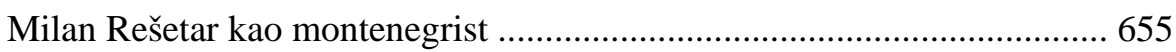

Aleksandar RADOMAN:

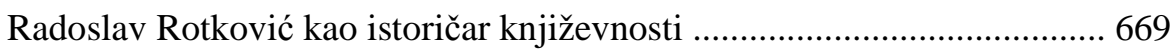

Josip LISAC:

Žarku Muljačiću u spomen

\section{PRIKAZI}

Milica LUKIĆ:

Govoriti po njeguški 693

Vladan LALOVIĆ:

Milorad Nikčević, Josip Juraj Strossmayer i Nikola I. Petrović Njegoš

- u korespondenciji i dokumentima, Osijek, 2009.

Aleksandra NIKČEVIĆ-BATRIĆEVIĆ:

Opiranje generalizaciji: Još jednom o feminističkoj književnoj teoriji ..... 703

Milica LUKIĆ:

Roman u čast sv. Konstantinu-Ćirilu i njegovu pismu

Adnan ČIRGIĆ:

Povodom jednoga falsifikata

\section{ARHIVA}

Bogić NOVELJIĆ:

Naš književni dijalekat

Bogić NOVELJIĆ:

Crna Gora u školskim udžbenicima

Radoje RADOJEVIĆ:

Diskusije na simpozijumu Crnogorska kultura i putevi njenog razvoja .... 



\section{TABLE OF CONTENTS}

Jelena ŠUŠANJ:

Lexical Decomposition and Language Bureaucratization on Examples

Taken from the Montenegrin Newspapers ..................................................... 3

Miomir ABOVIĆ:

On the Nature of the Connective $a$ and Commutation Possibilities of the Connectives $a$ and $i$

Miloš KRIVOKAPIĆ:

Frequency of the Verb Form in the Language of Stefan Mitrov Ljubiša ..... 61

Branko KUNA:

The Question of the Qualitative Genitive in the Croatian Language

Milica LUKIĆ:

Towards Recent History of Glagolitism

Loretana FARKAŠ:

Developing Technical Vocabulary in the Croatian Language in the $18^{\text {th }}$

Century

Lilianna MIODOŃSKA:

Has the Current Serbian Language Politics Already Become a Language

Lapot?

Sandra VUJOVIĆ:

The Functions of Prosodic Elements in TV Talk Shows in English

Irineusz KIDA:

Metalanguage in English and Spanish Classroom Instruction -

How Much of Transparency?

Ivana KOVAČ-BARRETT:

Historical, Legal and Sociolinguistic Context of the Language Situation in Spain

Milorad NIKČEVIĆ:

Late $19^{\text {th }}$ and Early $20^{\text {th }}$ Century Poetry 
Marjana ĐUKIĆ:

Sentimantalism Of The Turkish Letters By Stjepan Zainović

Jakov SABLJIĆ:

First Montenegrin Literary Dystopia

Vesna KILIBARDA:

Lazar Tomanović as an Italianist

Nino RASPUDIĆ:

Nicollo' Tomasseo And The East Coast Of The Adriatic Sea -

From The Sentimentalistic Paternalism To The Troubles With Njegoš .... 263

Boris ŠKVORC:

Construction, Transference and Restructuring of Stories about National

Identities: About Krleža's Starčević and Andrić's Njegoš

Zlata ŠUNDALIĆ:

Various Connotations of the Word Way in Vila Slovinka

Marko DRAGIĆ \& Ivana ODŽA:

Petar Kružić, the Captain from Klis and His Wife Jerolima in the

Literature, History and Contemporary Folk Narration

Vanda BABIĆ \& Denis VEKIĆ:

Prechristian Beliefs in Neretva Valley 403

Zlata ŠUNDALIĆ:

The Empire of Plantae in the Narrative Genre

Mirna BRKIĆ:

A Play on the Stage of Life

Olivera KUSOVAC:

Man and Superman: The Two Faces of Shaw's Feminism

Miomir ABOVIĆ:

Mystical and Ironical Dubitations of Victor Pelevin

Dragana KALEZIĆ:

The Russian Writers on the Scene of Montenegrin National Theatre (I) .. 493

Helena DRAGIĆ:

Doclean King St. Vladimir in the Croatian Literature and Montenegrin

Tradition 


\section{MATERIAL}

Vukić PULEVIĆ:

The First Addition to the Fitotoponymy and Zootoponymy

of Montenegro

Adnan ČIRGIĆ:

The Material for the Research of the Speech of the People from

Njeguši

Amira TURBIĆ-HADŽAGIĆ:

A Supplement to the Cultural Legacy: Two Letters from Krajina from the $17^{\text {th }}$ Century (II)

\section{PORTRAITS}

Adnan ČIRGIĆ:

Milan Rešetar as a Montenegrist

Aleksandar RADOMAN:

Radoslav Rotković as a Historian of Literature 686

Josip LISAC:

In Memoriam of Žarko Muljačić

\section{REVIEWS}

Milica LUKIĆ:

Speaking as the People from Njeguši Do

Vladan LALOVIĆ:

Milorad Nikčević, Josip Juraj Strossmayer and Nikola I Petrović Njegoš

in the Letters and Documents, Osijek, 2009

Aleksandra NIKČEVIĆ-BATRIĆEVIĆ:

The Resistance to Generalization: Feminist Literary Theory Revisited .... 703

Milica LUKIĆ:

The Novel Written in Honour of St. Constantin-Ciril and His Work

Adnan ČIRGIĆ:

In the Ground of One Forgery

\section{ARCHIVE}

Bogić NOVELJIĆ:

Our Literary Dialect 
LINGUA MONTENEGRINA 5/2010.

Bogić NOVELJIĆ:

Montenegro in the Schoolbooks

Radoje RADOJEVIĆ:

Various Discussions Held During the Conference Entitled

Crnogorska kultura i putevi njenog razvoja ... 




\title{
Lingua Montenegrina \\ časopis za jezikoslovna, književna i kulturna pitanja \\ icjj@t-com.me \\ Izdavač \\ Institut za crnogorski jezik i jezikoslovlje „Vojislav P. Nikčevič“ - Cetinje
}

\author{
Glavni i odgovorni urednik \\ Adnan Čirgić \\ Za izdavača \\ Aleksandar Radoman
Lektura i korektura
Jelena Šušanj \\ Prijelom \\ Sonja Asović \\ Štampa \\ IVPE - Cetinje
}

Tiraž

500 
Objavljivanje časopisa Lingua Montenegrina pomoglo je Ministarstvo kulture, sporta i medija Crne Gore

*CIP - Каталогизација у публикацији

Централна народна библиотека Црне Горе, Цетиње

81(497.16)

*LINGUA Montenegrina : časopis za jezikoslovna, književna i kulturna pitanja / urednik Adnan

Čirgić . - God. 3, br. 5 (2010) - . - Cetinje

(Ivanbegova 57) : Institut za crnogorski jezik i

jezikoslovlje „Vojislav P. Nikčević“, 2010 (Cetinje

: IVPE), - $24 \mathrm{~cm}$

Dva puta godišnje.

ISSN 1800-7007 = Lingua Montenegrina (Cetinje)

COBISS.CG-ID 12545808

Časopis je registrovan u Ministarstvu kulture, sporta i medija Crne Gore (br. 05 - 2951/2) 